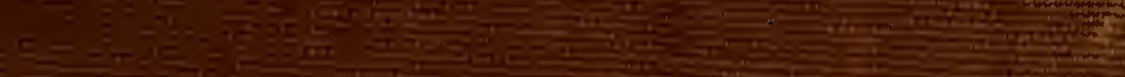

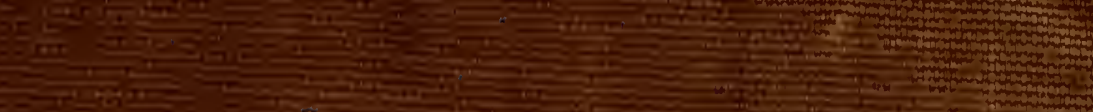

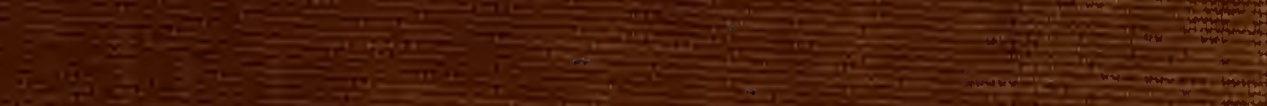
\begin{tabular}{ll}
\hline \\
\hline
\end{tabular}

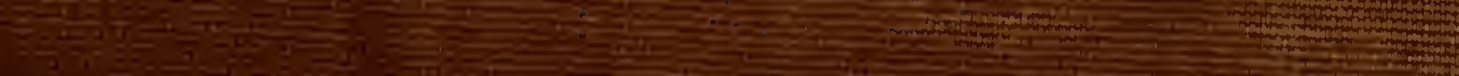

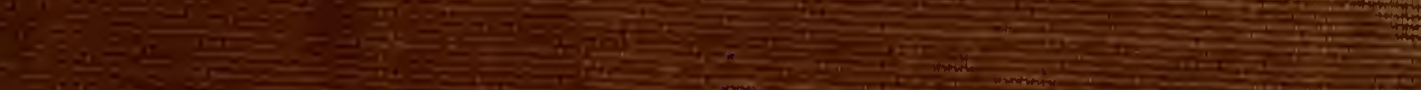

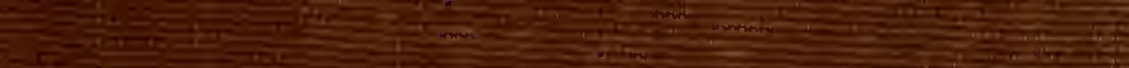

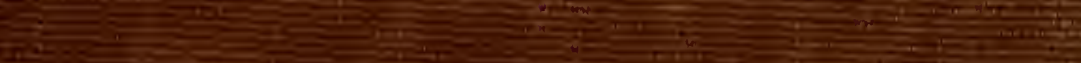

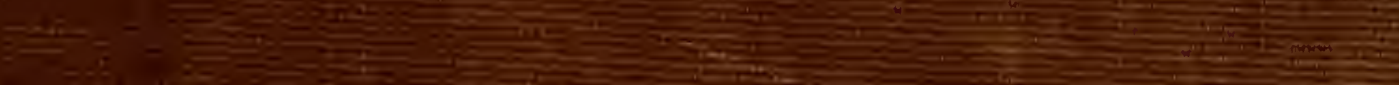

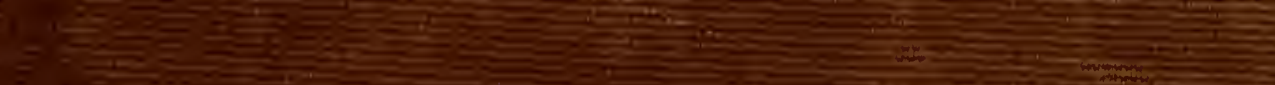

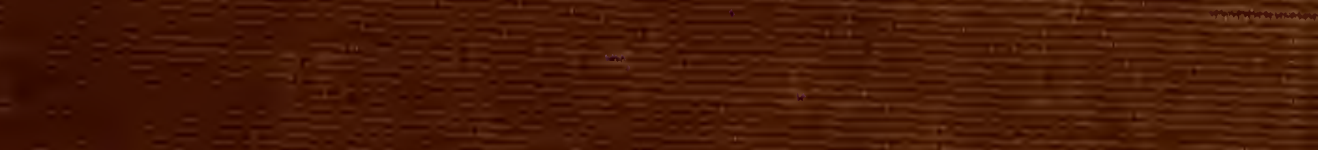

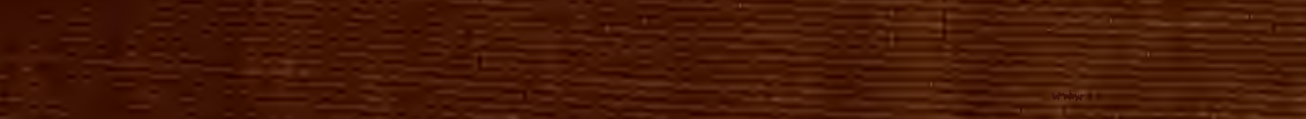

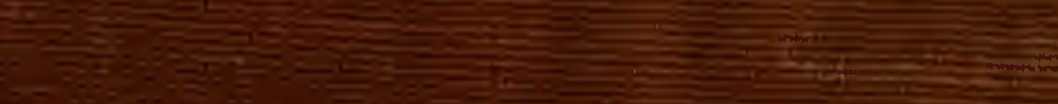

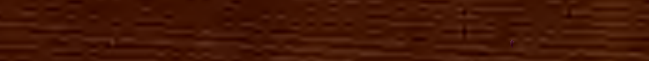

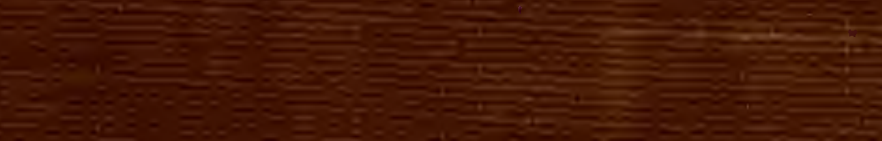




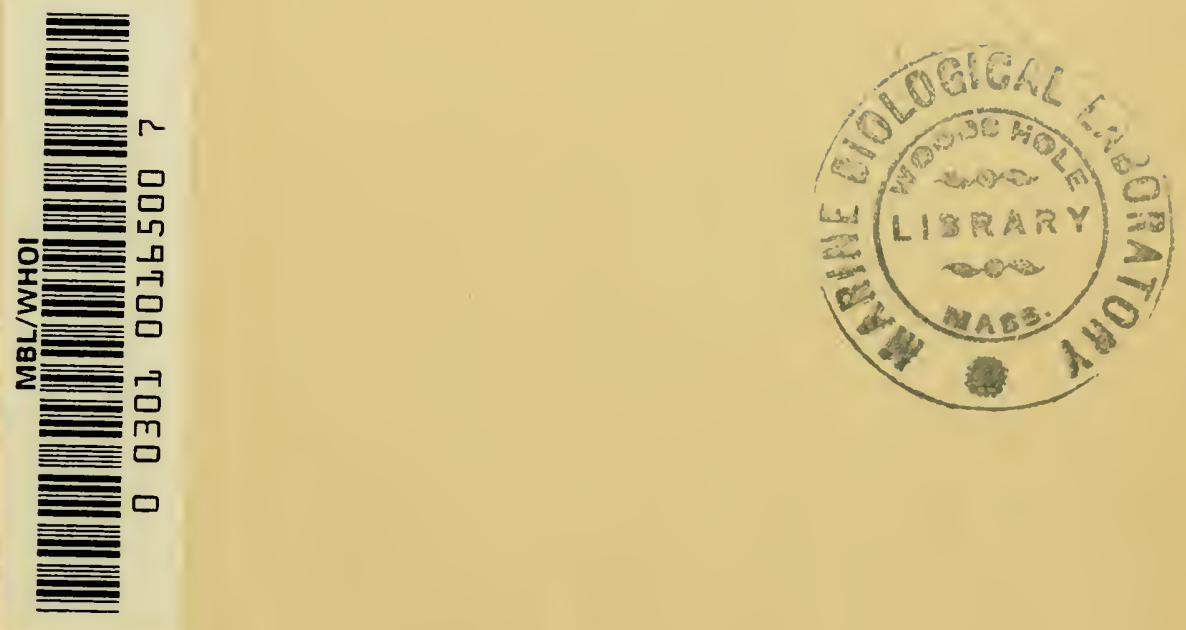



THE MOLLUSCAN FAMILY PLANORBIDAE 



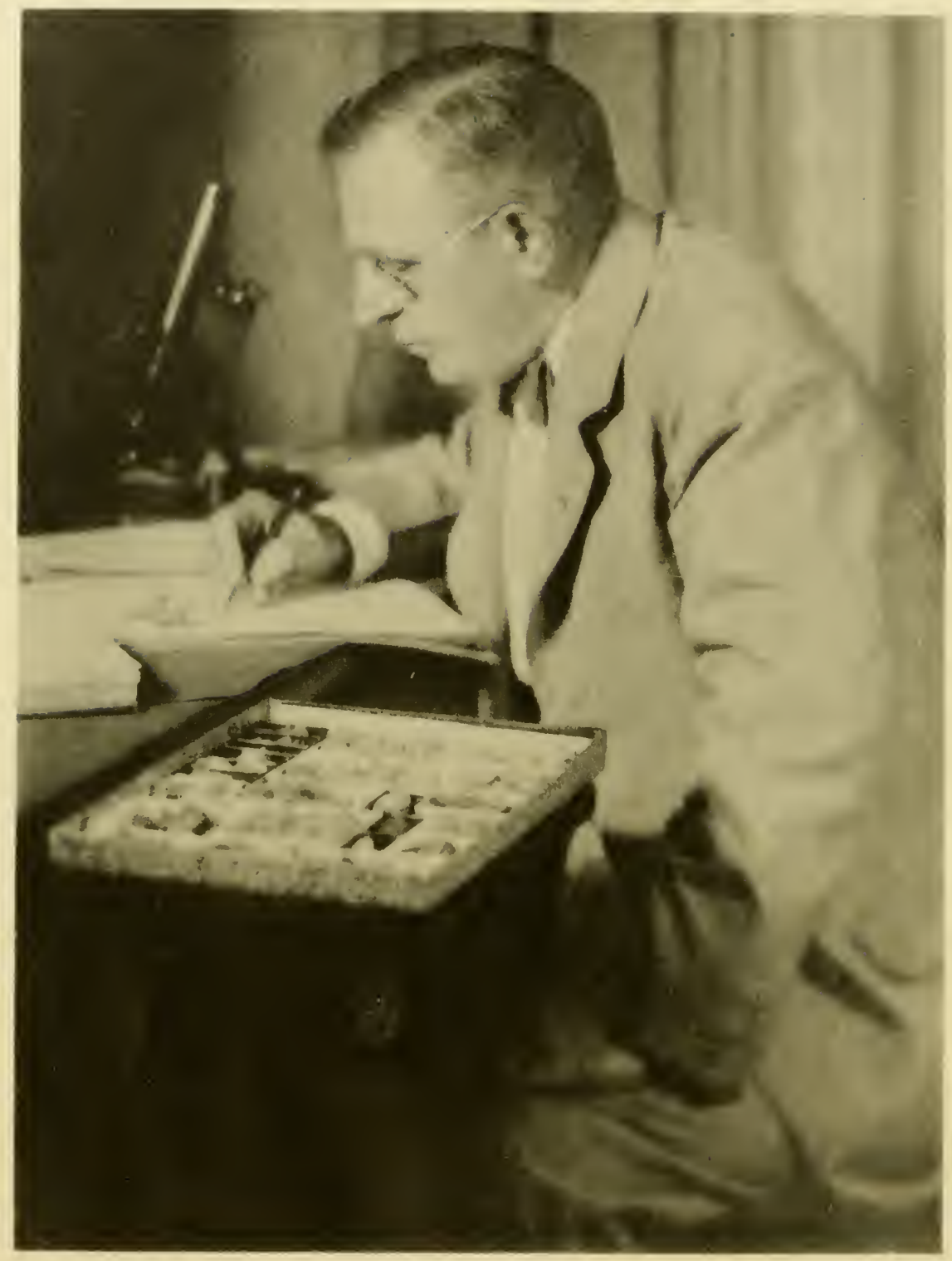

IrankCBbatew 


\title{
THE MOLLUSCAN FAMILY PLANORBIDAE
}

\author{
By \\ FRANK COLLINS BAKER \\ Curator, Museum of Natural History, Emeritus \\ University of Illinois
}

Collation, Revision, and Additions

By

HARLEY JONES VAN CLEAVE

THE UNIVERSITY OF ILLINOIS PRESS

URBANA : 1945 
Published by the University of Illinois Press under the auspices of the Graduate School.

Copyright, 1945, by the University of Illinois Press. Permission for reproduction in any form may be obtained from the Publisher.

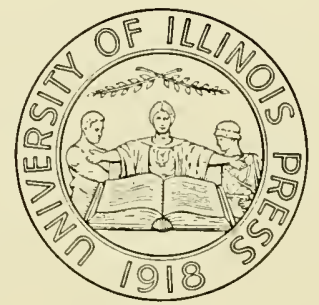




\section{PREFACE}

$\mathrm{T}$

HE WIDE DISTRIBUTION, large number of species represented, and the economic significance from a medical standpoint, as intermediate hosts of flukes or trematode worms, constitute the family Planorbidae as one of the most important groups of fresh-water Mollusca. It is the largest and most conspicuous of the families of Basommatophorous pulmonate snails.

Unlike the terrestrial pulmonates (Stylommatophora Pulmonata) which have been brought to a high state of precise classification from the anatomical studies of Dr. Henry A. Pilsbry and his co-workers, the Basommatophora are still in a condition of more or less chaos as regards classification, all of the monographs and many of the local studies being based wholly or partly on characteristics of the shell with little regard for relationships which might be gained by a study of the organization of the animal. The condition of this large group as far as classification is concerned is little better than that of the land snails seventy-five years ago.

In 1911 the writer published a monograph of the Lymnaeidae of North and Middle America, basing the classification on characteristics of the genitalia and radula. In that work it was suggested that studies on Planorbis, Physa, and other groups might follow the publication of the Lymnaeidae volume if it should meet with the approval of the conchological public. That it is still in general use after an interval of more than thirty rears is evidence that its reception has been, on the whole, of a favorable nature.

The present rolume on the Planorbidae was begun some twenty-five years ago and has been in active preparation for the past ten years. As the work progressed it became evident that adequate treatment of the subject could not be given in a volume similar to that on the Lymnaeidae and so the work has been divided into two parts, part I on the anatomy and classification of the family, and part $I^{*}$ on descriptions of the species of the family inhabiting North and South America and the West Indies.

The study of the internal organization of the family Planorbidae has shown that, as in the case of the land snails, the anatomy gives the only true key to a natural classification. The shell alone camnot be relicd upon for this purpose because some of the characteristies are often misleading, affording many cases of parallel development, as the presence of lamellae within the aperture, which feature is found in a number of groups which are unrelated anatomically. There are some shell characteristics, however, which are of value in classification when used in conjunction with anatomical features.

For the anatomical studies recorded in this volume, eighty species and races of the family have been examined, represented by more than 725 specimens. The anatomy of six additional species has been taken from the literature. The number of species examined has been divided among the four subfamilies as follows: Planorbinae 19; Segmentininae 11; Helisomatinae 41; Planorbulinae 10. A large majority of the known genera and subgenera are represented and it is confidently believed that additional anatomical study will not greatly alter the classification herein set forth.

* See title page of Part II (page 213) for statement regarling change in scope of this part. 
The anatomical drawings in this work have all been made by the author with the aid of the camera lucida, and the outlines and much of the detail of the figures are eorreet from the standpoint of dimensions. Some of the finer cletails have been filled in by hand on the camera lucida figure. All dissections were macle with a Spencer binoeular microscope with magnification up to serenty-five diameters. The radulae have all been examined under a Zeiss microscope with magnification up to about 1000 diameters.

In order that the features of the different organs might be fully known they have been separated and otherwise dissected to bring out all relationships. In many cases sections have been made through organs or groups of organs the better to show structural conditions. Some of the figures are cliagrammatic, but in the majority of the figures the author has endeavored to portray the form of the organs as they appeared to him under the microscope. Only the shells of the trpe species of the different genera and subgenera are figured in the plates prepared for Part I.

In the matter of bibliographic citations it has not been deemed necessary to include all references to works in which a genus or other group is listed or described. To have done this would have lengthened the work to a large degree without adding greatly to its value. Only the most important eitations, including the first one in which the generic name appears, are included. It will be noted that many groups, which have been ignored or placed in the synonymy by previous authors, have been recognized in this work. This is particularly true of Asiatic groups which have been little known anatomieally. Every generic or group name has been given eareful study to ascertain its true relationship.

All groups deseribed in this work are arranged under the heading of a genus or of a subgenus, none as sections. Until a greater number of species have been examined for the internal organization this division appears best. Some of the groups herein considered genera may later be placed as subgenera. It does not at present appear to be of any adrantage to recognize the terms section or subsection for any of the groupings.

The list of species ineluded in each genus or subgenus has no pretension to eompleteness, only those species being listed which have either been examined anatomically or appear from the form of the shell to be related. As additional material is examined some of the species listed may be shifted to other groups and additional species may be included.

January, 1942 


\section{ACKNOWLEDGMENTS}

TN IARGE MEASURE the successful preparation of this work has been due to the help and encouragement of many American conchologists and zoologists. The authorities of the United States National Museum at Washington, through the interest of Dr. Paul Bartsch, Curator of Recent and Cenozoic Invertebrates, have freely lent the collections of Planorbidae for study. Without this magnificent material, probably the largest assemblage of species of this family extant, it would have been impossible to understand the relationships of the American species of the family. Mr. William J. Clench, Curator of the Department of Mollusca, Muscum of Comparative Zoology of Harvard University, supplemented the National Museum material by the loan of thousands of specimens, many of the series of species being incomparable in size and completeness. Both of these gentlemen have also contributed much anatomical material. Other individuals and institutions have lent or given specimens for both anatomical and dry study. To all of these the writer is uncler the greatest obligation. The list of those rendering assistance is given below:

Dr. C. C. Adans, Director, State Museum of New York, Albany

Dr. E. A. ANdrews, Professor of Zoology (Retired), Johns Hopkins University, Baltimore

Dr. H. Burrington Baker, Professor of Zoology, University of Pennsylvania, Philarlelphia

Dr. John C. Bequaert, Professor, Harvard University Medical School, Cambridge

Dr. Edward W. Berry, Professor of Paleontology, Jolms Hopkins University, Baltimore

Dr. S. Stillaian Berry, Redlands, California

Dr. Stanley T. Brooks, Curator of Lower Invertebrates, Carnegie Museum, Pittsburgh

Dr. A. R. CAHN, formerly Associate Professor of Zoology, University of Illinois, Urbana

Dr. E. P. Cheatum, Professor of Zoology, Southern Methodist University, Dallas

Dr. Williali A. Clemens, formerly of the Pacific Biological Station, Nanaimo, B.C. Now Professor of Zoology, University of British Columbia, Vancouver, B.C.

Miss Ruth E. Coats, Tellamoole, Oregon

Dr. Ernest C. Faust, School of Tropical Medicine, Tulane University, New Orleans

Mr. C. J. Firkins, Edwardsville, Illinois

Dr. Thural Dale Foster, ${ }^{*}$ University of Illinois, Urbana

Mr. Calvin Goodrich, Curator of Mollusca, University of Michigan Museum, Ann Arbor

Dr. G. D. Havna, Curator of Paleontology, California Academy of Science, San Francisco

Professor Junius Henderson,* Curator Emeritus, University Museum, University of Colorado, Boulder

Dr. L. G. Hertuein, Assistant Curator of Paleontology, California Academy of Science, San Francisco

Mr. Shintoro Hirase, Z Zoological Institute, Tokyo, Japan

Dr. William A. Hoffman, * School of Tropical Medicine, San Juan, Puerto Rico

Mr. Lessie Hubricht, St. Louis Botanical Gardens, St. Louis, Missouri

Mr. A. Jankowski, Warsaw, Poland

Mr. A. LaRoceue, Canadian Geological Survey, Ottawa, Canada

Mr. Johx B. Litsey, Dallas, Texas

*Deceased. 
Mr. Paul McGinty, Boynton, Florida

Dr. Roy W. Miner, Curator, Department of Living Invertebrates, American Museum of Natural History, New York City

Mr. William B. Marshall, formerly Assistant Curator of Mollusea (Retired), U.S.N.M., Washington, D.C.

Dr. Paul R. Needhan, Associate in Aquatic Biology, U.S. Bureall of Fisheries

Mr. Olof O. Nylander, Caribou, Maine

Dr. Henry A. Pilsbry, Curator of Mollusca, Academy of Natural Sciences, Philadelphia

Dr. C. Ping, Fan Menorial Institute, Peiping, China

Dr. Baini Prashad, Zoological Survey of India, Indian Museum, Calcutta, India

Dr. H. S. Rao, Zoological Survey of India, Indian MIuseum, Calcutta, India

Dr. D. S. Rawsox, Professor of Zoology, University of Saskatchewan, Canada

Dr. Harold A. Rehder, Assistant Curator, Division of Mollusca, U.S.N.M., Washington, D.C.

Dr. Horace G. Richards, Academy of Natural Sciences, Philadelphia

Mrs. Imogene C. Pobertinon, Buffalo Museum of Science, Buffalo

Dr. Hugo G. Rodeck, Curator, University of Colorado Museum, Boulder

Mr. W. F. Shay, Department of Science, Normandy High School, St. Louis

Miss Elberta C. Sinth, University of Colorado Museum, Boulder

Mr. H. W. Smith, Atlantic Coast Biological Station, St. Andrews, New Brunswick

Dr. Harley J. Van Cleave, Professor of Zoology, University of Illinois, Urbana

Dr. Henry Vax der Schalie, University of Michigan Mnweum, Anu Arbor

Mr. T. van Hrning, Curator, State Museum, Gainsville, Floridla

Dr. BRYANT WALKER, * Detroit

Dr. Alexander WetMore, Assistant Secretary, Smithsonian Institution, in charge of U.S.N.M., Washington, D.C.

Mr. Berlin H. Wright, * Penn Yan, N.Y., and Lakeland, Florida

The writer is highly appreciative of the help given him by the University of Illinois Library, not only for the volumes consulted in its stacks, but also for its aid in securing through the interlibrary loan system many rare volumes not in our own library. To Miss Fanny Dunlap the author is deeply indebted for this help. The libraries lending these books include the John Crerar Library, Chicago; Columbia University of New York; Johns Hopkins University, Baltimore; Harvard University, Cambridge; University of Michigan, Ann Arbor; Iowa State College, Iowa City; The U.S. Geological Survey, Washington, D.C.; and the Congressional Library of Washington, D.C.

The photographs of the shells and the copies from author's works were all made in the Photographic Laboratory of the University of Illinois, under the direction of Mr. Ray R. Hamm, Manager of the Laboratory.

The author desires to express his deep appreciation of the help given by Dean R. D. Carmichael, of the Graduate School of the University of Illinois, who has greatly aided in the preparation of the work by providing several grants of funds for the making of the photographic plates. Without this assistance this volume could not have becn completed. $\dagger$

\section{Frank Collins Baker}

\footnotetext{
*Deceased.
}

$\dagger$ The University of Illinois Press here records its appreciation of the assistance of Professor Harley J. Van Cleave, who, in addition to writing the 'Memorial' and compiling the bibliography attached thereto, has carefully checked the copy and the plates, including the legends, and has given many helpful suggestions on the typographical and scientific arrangement of the data. Mrs. Katharine Hill Paul, artist in the Department of Zoology, has rendered valued service in making numerous alter:ations of the original drawings to ensure satisfactory engravings.-H.E.C. 


\section{CONTENTS}

Preface . . . . . . . . . . . . . . . i

ACKNoWledgheNTS . . . . . . . . . . . . . . . . xi

A Menorial to Frank Collins Baker (1867-1942) . . . xvii

A Chroxological list of the Scientific Plblications

of Frank Collins Baker. . . . . . . . . xxv

Original Articles and Books. . . . . . . . . . . . . . . xxv

Biographical Contributions. . . . . . . . . . . . . . xxxv

Book Notices and Reviews. . . . . . . . . . . . xxxv

\section{PART I \\ Classification and Gexeral Morphology}

I. General \Iorphologr . . . . . . . . . . 3

A. External Appearance of the Animal . . . . . . . . 3

B. General Internal Anatomy . . . . . . . . . . . 4

(a) The Reproductive System . . . . . . . . . . . . . 4

(b) The Digestive System . . . . . . . . . . . . . . 9

(1) The Jaw .

(2) The Radula . . . . . . . . . . . 11

(c) The Renal System . . . . . . . . . . . . . 12

(d) The Circulatory System . . . . . . . . . . 13

(e) The Respiratory System . . . . . . . . . . . . . 14

(f) The Nervous System . . . . . . . . . . . . . 14

(g) The Muscular System . . . . . . . . . . 15

C. The Shell . . . . . . . . . . . 15

II. Geveral Ecology . . . . . . . . . . 17

General Environmental Conditions. . . . . . . . 17

Variations in Different Environments. . . . . . . 18

Locomotion . . . . . . . . . . . . . 19

Food . . . . . . . . . . . . . . . 19

Food for Other Animals . . . . . . . . . . . . . . . . 19

Length of Life . . . . . . . . . . . 20

The Planorbidae as Hosts for Parasitic Worms . . . . . . . 21

III. Nidification and Embryological Developaext . . . . 25

A. Development of Helisoma scalare (Jay) . . . . . . . 25

B. Nidification and Development in Other Species of Helisoma 28

(a) Self-fertilization or Aut ofecundation . . . . . . . . 29

(b) The Development of Helisoma. . . . . . . . . . 31

(1) Helisoma trivolvis lentum (Say) . . . . . . . . 31

(2) Helisoma trivolvis fallax (Haldeman) . . . . . . 32

(3) Helisoma duryi normale Pilsbry . . . . . . . . . 33

(4) Helisoma duryi eudiscus Pilsbry . . . . . . . . 34

(5) Helisoma tenue californiense F. C. Baker . . . 34

(6) Other Records of Egg Laying . . . . . . . . 35 
IV. Distribution in Tine and Space . . . . . . . 37

A. Geological History and Distribution . . . . . . . . 37

B. Geographical Distribution . . . . . . . . . 38

Dispersal of Species . . . . . . . . . . . . . 39

V. Historical Sketch of Classifications . . . . . 41

Vi. A New Classification of the Family Planorbidae 45

General Discussion . . . . . . . . . . 45

Anatomical Keys to Groups . . . . . . . . . . . . . . 46

Systematic List of Genera and Subgenera Recognized in

This Work............... 48

ViI. Systematic Accolnt of the Subfamlies, Gexera, axd

Subgenera - Recent and Fossil . . . . . . 50

Subfamily Planorbinae H. A. Pilsbry, 1934 . . . . . . . . 50

Genus Planorbis Geoffroy, 1767 . . . . . . . 51

Genus Anisus Studer, 1820 (Gray, 1847) . . . . . . 55

Subgenus Anisus SS. . . . . . . . . . . . . . . 57

Subgenus Costorbis Lindholm, $1926 \ldots$. . . . . . 61

Subgenus Bathyomphalus (Ag.) Charp., 1837 . . . 62

Genus Odontogyrorbis Lörenthey, 1906 . . . . . . . 64

Genus Gyraulus (Ag.) Charp., 1837 . . . . . . . . . . 65

Subgenus Gyraulus SS. . . . . . . . . . . . 66

Subgenus Torquis" Dall, 1905 . . . . . . . . . 72

Genus Armiger Hartmann, 1840 . . . . . . . . . . . 75

Genus Taphius H. and A. Adams, 1855 . . . . . . . . 79

Genus Tropicorbis Pilsbry and Brown, 1914 . . . . . 80

Subgenus Tropicorbis SS. . . . . . . . . . . . . 85

Subgenus Obstructio Haas, 1939 . . . . . . . . . . 85

Subgenus Lateorbis F. C. Baker, New Subgenus . . . 85

Genus Afroplanorbis Thiele, 1931 . . . . . . . . . . 86

Genus Syrioplanorbis F. C. Baker, new name for

Heterodiscus West. . . . . . . . . . . S8

Genus Biomphalaria Preston, 1910 . . . . . . . . . . 89

Genus Australorbis Pilsbry, 1934 . . . . . . . . . 90

Genus Anisopsis Sandberger, 1875 . . . . . . . . . . . 94

Subfamily Segmentininae F. C. Baker, New Subfamily . . . 96

Genus Segmentina Fleming, 1817 . . . . . . . . . . . 96

Genus Hippeutis (Ag.) Charp., 1837 . . . . . . . . . . 100

Genus Polypylis Pilsbry, 1906 . . . . . . . 104

Genus Helicorbis Benson, 1855 . . . . . . . . . . . 106

Genus Trochorbis Benson, 1855 . . . . . . 108 
VII. Systenatic AccocNt of the Scbfanilies-continued Subfamily Segmentininae F. C. Baker, New Subfanily-continued

Genus Pingiella F. C. Baker, New Genus . . . . . . . . 109

Genus Intha Amnandale, 1922 . . . . . . . . . . . . 112

Genus Drepanotrema Fischer and Crosse, 1S80 . . . . . 114

Subgenus Drepanotrema SS. . . . . . . . . . 118

Subgenus Fossulorbis Pilsbry, 1934 . . . . . . . . 118

Genus Paraplanorbis Hanna, 1922 . . . . . . . . . . . 119

Genus Platytaphius Pilsbry, 1924 . . . . . . . 120

Genus Acrorbis Odhner, 1937 . . . . . . . . . . . . . 121

Subfamily Helisomatinae F. C. Baker, 1928 . . . . . . . . 123

Genus Helisoma Swainson, $18 t 0$. . . . . . . . . . . 123

Subgenus Helisoma SS. . . . . . . . . . . . . 124

Subgenus Seminolina Pilsbry, 1934 . . . . . . . . . 129

Subgenus Pierosoma Dall, 1905 . . . . . . . . 134

Subgenus Planorbella Haldeman, 1842 . . . . . 150

Genus Carinifex IT. G. Binney, 1863 . . . . . . . . 154

Genus Torticifex Meek, 1870 . . . . . . . . . . 159

Genus Perrinilla Hannibal, 1912 . . . . . . . . . . . 160

Genus Parapholyx Hanna, 1922 . . . . . . . . . . 161

Genus Pompholopsis Call, 18ss . . . . . . . . . 165

Genus Planorbarius Froriep, 1806 . . . . . . . . 166

Subfamily Planorbulinae Pilsbry, 1934 . . . . . . . . . 172

Genus Planorbula Haldeman, 1840 . . . . . . . . . . 172

Subgenus Planorbula SS. . . . . . . . . . . . 173

Subgenus Haldemanina Dall, 1905 . . . . . . . . 177

Genus Promenetus F. C. Baker, 1935 . . . . . . . . 178

Genus Menetus H. and A. Adams, 1855 . . . . . . . 182

Subgenus Menetus SS. . . . . . . . . . 183

Subgenus Micromenetus F. C. Baker, New Subgenus . 187

Genus Planorbifex Pilsbry, 1934. . . . . . . . . . 190

TIII. Groles of Uxcertain Affinities. . . . . . . . . . 192

Subfamily Choanomphalinae Germain, 1923 . . . . . . . 192

Genus Choanomphalus Gerstfeldt, 1859 . . . . . . . . 192

Genus Poecilospira Mörch, 1853 . . . . . . . . . . . 194

IX. Fhalli Bulinide . . . . . . . . . . . 196

Genus Indoplanorbis Annandale and Prashad, 1920 . . . 196

X. Genera Wrongly Referred to Playorbidae. . . . 202

Genus Nautilinus Mousson, 1872 . . . . . . . . . . 202

Genus Palacorbis Beneden and Coemans, 1867 . . . . 202

NI. Bibliographi . . . . . . . . . . . 204 


\section{PART II}

The Planorbidae Inhabiting North and South America And The West INdes

XII. Foreword. . . . . . . . . . . . . 215

XiII. Descriptions of New Species and New Varieties. . 218 Genus Tropicorbis . . . . . . . . . . . . . 218

Tropicorbis shimeki, New Species . . . . . . 218

Genus Helisoma . . . . . . . . . . . . . . . . . . . 219

Helisoma anceps anticostianum, New Variety . . . . 219

Helisoma anceps bartschi, New Variety . . . . . . . 219

Helisoma anceps idahoense, New Variety . . . . . . 220

Helisoma anceps politum, New Variety . . . . . . 221

IIelisoma binneyi randolphi, New Variety . . . . . . 221

Helisoma caribaeum cubense, New Variety . . . . . . . 222

Helisoma columbiense, New Species. . . . . . . . . 222

Helisoma kennicotti, New Species . . . . . . . . . 223

Helisoma pilsbryi preblei, New Variety . . . . . . . 224

Helisoma subcrenatum perdisjunctum, New Variety . . . 224

Helisoma trivolvis marshalli, New Variety . . . . . . . 225

Helisoma campanulatum dalli, New Variety . . . . . . 226

Helisona campanulatum pleistocenicum, New Variety . . 226

Helisoma campanulatum rideauense, New Variety . . . 227

Genus Parapholyx . . . . . . . . . . . . . . . . . 227

Parapholyx effusa dalli, New Variety . . . . . . . 227

Parapholyx klamathensis sinitsini, New Variety . . . 228

Parapholyx pusilla, New Species . . . . . . . . . . . 229

Genus Planorbula . . . . . . . . . . . . . . . . . . . 229

Planorbula smithii, New Species . . . . . . . . . 229

Genus Menetus . . . . . . . . . . . . . . . . . . . 230

Menetus coloradoensis, New Species. . . . . . . 230

Menetus cooperi crassilabris, New Variety . . . . . . 230

Menetus cooperi planospirus, New Variety . . . . 231

Menetus dalli, New Species . . . . . . . . . . 231

Menetus dilatatus floridensis, New Variety . . . . . . 232

Menetus labiatus, New Species . . . . . . . . . . 232

Menetus portlandensis, New Species . . . . . . . 233

Illustrations of the Anatomy and of Shells . . . . . 235

Index to Text . . . . . . . . . . . . . . . . 521

Index to Illutstrations . . . . . . . . . . . . . . . . . 527 


\section{A MEMORIAL TO FRANK COLLINS BAKER (1867 to 1942$)$}

$\mathrm{F}$ RANK COLLINS BAKER became Curator of the Museum of Natural History in the University of Illinois on January 1,

191S. From that date onward until his death on May 7, 1942, his chief interests centered around his work and his associations on the Urbana campus. Though he carried on extensive field studies during these years, they were chiefly summer vacation employment, and Urbana remained the focal point of his attention and activity. His appointment as Curator of the University Museum gave him the opportunity to cooperate in the development of a museum devoted primarily to teaching. To this work he brought a broad background of professional experience in every aspect of museum work and at the same time drew freely from his research experiences to create on the Urbana campus a series of collections and exhibits the prime purpose of which was ever that of aiding in student instruction. As in all good teaching one of the first requisites is that of enlisting responsive interest by attractive presentation of fact or material, so likewise in his displays interest was always sought though it was never purchased by cheapening spectacular showmanship. In his synoptic display of the animal series, the dry framework of classification became clothed by artistic and balanced organization of his materials. Groups represented only by fossil remains were treated as integrated with modern expressions of life, not as isolated representations of a dead past.

For one whose career never placed him before classes for delivering formal instruction, he gave evidence of keen appreciation of the museum as a supplement to laboratory and classroom teaching. and at all times offered hearty cooperation to the teaching faculty in creating habitat groups and other exhibits embodying both specific detail and broad principle. Under his curatorship the Museum of Natural History became utilized by diverse student groups. Biology, geology, and geography students found the displays meaningful; students in agriculture came to study the well-organized habitat groups of pests of farm crops, and art students frequented the exhibition halls for sketching.

Mr. Baker's concept of the functions of a museum combined not alone the aspects of display and instruction but a third objective as well, namely, that of research. Throughout his curatorship, he labored to establish and organize research collections. Naturally, the fields of his own interests were most emphasized and these included such diverse interests as the Mollusca, archeology, and paleontology. 
In certain specialized areas of these three fields, the University collections have assumed a significance greater than might be expected in a small museum. The collections of Mollusca are especially rich in representatives of the fresh-water and land Mollusca, the direct result of Mr. Baker's active research program. Extensive field collecting was particularly stimulated by his association with the Natural History Survey of Wisconsin in the preparation of his exhaustive two-volume work on the Mollusca of Wisconsin (1928). His long association and collaboration with the Illinois State Natural History Survey gave him access to extensive collections, especially in late years when he was engaged in an intensive field study of the land snails of Illinois which culminated in the Fieldbook of Illinois Land Snails published (1939) by the State Natural History Survey. A revival of interest in researches on the archeology of the State by the University resulted in amassing within the Natural History Museum huge quantities of pottery and artifacts for the care of which Mr. Baker became responsible.

His early interest in the Pleistocene fauna was revived and stimulated by a cooperative program of studies inaugurated by the State Geological Survey. Enormous series of Pleistocene material in quantitative samples were studied by Mr. Baker, whose services in cooperation with the State Geological Survey were recognized by his appointment to the position of Consultant in Pleistocene Paleontology on its staff (1919). The Pleistocene collections under this joint arrangement between Museum and Survey assumed great importance and wide reputation as repository of critical materials, and numerous collectors throughout the country sent samples for critical determination. Thus, at the time of Mr. Baker's death, the Pleistocene collections, which are now deposited in the State Geological Survey, had become one of the significant study collections in this field.

Mr. Baker's interest in research was deep and genuine, and the esteem with which his results are held gives evidence of the effectiveness of his activities in scholarly pursuits. His earliest studies on Mollusca were, in keeping with that period, restricted largely to the study of the shells but he early became an advocate of the study of the soft parts of the living animal which produces the shell and the volume which this sketch accompanies is the culmination of his program of anatomical studies. New apparatus and improved optical equipment made him often express the regret that he could not go back and do again all the earlier studies which he carried on with less adequate laboratory equipment.

Early in his career as a student of Mollusca, Mr. Baker by his own collecting and by personal exchange, began amassing a private collection of fresh-water Mollusca. This collection centered around his chief interest, the fresh-water pulmonate snails. The operation of the old adage, 'To him who hath shall be given,' here finds exemplification, for students of Mollusca regularly sent doubtful specimens 
to him for classification or verification, and samples of those submitted were added to his cabinet. At the time of his death, the two families Lymmaeidae and Planorbidae were particularly well represented in the Baker Collection, which, as indicated elsewhere in this volume, was presented to the United States National Museum.

A member of many scientific societies, he cherished particularly the election as Corresponding Member of the Zoological society of London. He was a fellow of the Geological Society of America and likewise of the Paleontological Society of America. At the time of his death he was president of the American Malacological Union. Other societies in which he held membership include: American Association of Museums, Museum Association of Great Britain. Ecological Society of America, American Linmological Society, Ottawa Field Naturalist's Club, and Sigma Xi. He was a fellow of the American Association for the Advancement of Science and held life membership in the Chicago Academy of Sciences and in the Illinois State Academy of Science.

With the years, his zeal for research never waned. In fact, gradually increasing deafness which tended to shut him off from an earlier appreciation of music and from easy communication with his friencls gave him opportunity for uninterrupted study in which he could become so completely immersed as to ignore surromding distractions entirely and to forget adversities, even when he faced some of life's greatest tragedies.

These statements regarding Mr. Baker, as a man and a scientist. would not be complete without some narration of his early years and background.

Frank Collins Baker, son of Francis Edwin and Anna Collins Baker, was born in Warren, Rhode Island, on December 14, 1867. His family later moved to Providence, and there the boy received his early education and for a time attended a business college. Still struggling between the alternatives of business and science as a career, he was for a time employed by the Gorham Silversmiths, and there he learned the techniques of exactness and accuracy which he later maintained were of value in his scientific work.

He attended Brown University for one year (1SSS-S9). Even before this time he had developed a consuming interest in shells which he often remarked were the favorite childhood toys brought to him from distant oceans by a seafaring grandfather. He left Brown to accept the Jessup Scholarship (1SS9-91) in the Philadelphia Academy of Sciences and there, at the fountainhead of molluscan studies, the die was cast for his scientific career. In later years he often referred to the inspiration which he obtained from mere proximity to Joseph Leidy and other notables in the library and in the programs of the Academy. There likewise he became associated with H. A. Pilsbry, and the tradition for sound molluscan studies, which has always been an important aspect of the Academy program, gripped him. 
In 1890, Mr. Baker, as zoologist, was a member of an exploring party from the Philadelphia Academy into Mexico. The travels in Cuba, Yucatan, and Mexico afforded by this expedition had on him the same broadening influence which travel has brought to all the great naturalists and inspired him to consider natural famal areas instead of political units in subsequent programs of comprehensive taxonomic studies. Thus his monograph on the Lymnaeidae (1911) was not confined to the boundaries of the United States but encompassed a more natural zoogeographical scope of 'North and Middle America, and the program on the Planorbidae, results of which are embodied in this volume, was extended to include even broader scope in order to secure comprehensive treatment of a taxonomic unit without reference to political subdivisions. After his return from Mexico, Mr. Baker published his first separate book (1895), a small popular work entitled 'A Naturalist in Mexico.' which wove together a narrative of the trip, a description of the country, and scientific observations.

An intimate correspondence with Henry A. Ward of Rochester, part of which has been available to the present writer, ended in an arrangement wherein Mr. Baker was to become associated (1S91) as Invertebrate Zoologist with the influential Ward's Natural Science Establishment. Few strictly educational institutions in the early history of this country have wielded the influence exerted by this private concern in the training of natural scientists, especially those headed toward museum work as a profession. While residing in Rochester, he became a frequent visitor in the home of John Hall. On June 12, 1892, he married Lillian May Hall who was his constant companion until her death in 1934.

While his employment by the Ward Establishment was primarily for the identification and organization of the Ward collections of Mollusca, Mr. Baker at the same time selected and organized an extensive synoptic display of museum specimens representing all the groups of the invertebrates, which was being prepared for exhibition at the Chicago World's Columbian Exposition in 1S93. Tpon completion of this task. Mr. Baker accompanied the exhibit to Chicago where he supervised its installation. At the close of the Exposition, the Ward exhibit was purchased by Marshall Field as part of the nucleus for the beginning of the Field Columbian Museum, and Mr. Baker was engaged as curator in the newly established museum (1S94). But that same year he was chosen curator of the old. long established Chicago Academy of Science. where he succeeded and had association with men of the calibre of Robert Iiennicott. William Stimpson, and T. C. Chamberlin. It was here that he perfected the techniques of museum display and administration and for the first time had opportunity to develop an intensive program of research, integrated with his professional work. Unfortunately, after about two decades with the Academy, a change in administration placed 
the Academy in the hands of an individual who acrimoniously opposed the place of research as a museum function. Even this adverse atmosphere brought no reduction in the research program which $\mathrm{Mr}$. Baker had embarked upon, for nights and holidays were free from dictatorial domination. Some measure of his accomplishment during the Chicago period is available in the larger monographs which punctuated the continuous stream of smaller contributions from his desk. Three of his outstanding volumes were published during the twenty-one years of Mr. Baker's association with the Chicago Academy. These are: two volumes on the Mollusca of the Chicago Area (1S9S and 1902) and the monograph on the Lymnaeidae (1911). Another undertaking of particular importance-The Life of the Pleistocene-was virtually completed during the years with the Chicago Academy. However, publication of this volume was not afforded until after Mr. Baker came to the University of Illinois (1920), and it was then published by the University Press. The work on this volume marked a new epoch in his research program. Stimulated by an intimate and cordial relation with Professor T. C. Chamberlin of the University of Chicago, Mrr. Baker's personal interest in research swung toward the study of faunas of the past and interpretation and reconstruction of envirommental conditions under which they existed. The material which served as the original basis for this study was made available in unusual quantity by construction of the Chicago Drainage Canal. Apparently endless material was exposed by the dredging operations, but much of this opportunity for research would have been lost had it not been for Mr. Baker's close personal attention to the dredging as it proceeded. Exposure which he experienced at that time led to infections which affected his hearing. Conditions there established became progressively worse until in later life his hearing was very seriously impaired.

While with the Chicago Academy, Mr. Baker developed a service feature which has become an important aspect of most public museums today and links them closely with the educational program. He began the construction of small portable displays of habitat groups for loan to public schools, thus taking the educational influence of the museum into the schools rather than depending wholly on the unilateral relation of expecting the schools to send their pupils to the museum. The interest in children, and in education, developed by these contacts always remained with him. In the museums under Mr. Baker's direction, the urchin was as welcome a visitor and was as thoughtfully treated as the scholar. Thus, though he never held formal appointment as instructor in any educational institution, he exerted marked influence, and a number of present-day scientists trace the awaking of their interest to his kindly encouragement and enthusiastic attitude toward the field of science. Graduate students in the University of Illinois always found him inspiring and helpful when they approached him with their problems. 
Mr. Baker found deep satisfaction in following the careers of men who attributed part of their early zeal for science to boyhood contacts with him and to inspiration growing out of his enthusiasm and kindly interest in their personal problems. One instance of an influence of which he was personally unaware stands out prominently. A mother called at his office in Urbana to present him with a copy of a scientific book written by her son. She explained that the son, who had died while on archeological explorations in a foreign land, definitely attributed his aspiration in the field of science to the benevolent and gracious attention of Mr. Baker to the queries of an unknown and apparently unpromising urchin frequenting the museum of the Chicago Academy.

Mr. Baker resigned from his position with the Chicago Academy in 1915. In that same year, he embarked on a new phase of his career in which his time was given over entirely to field study and research. The newly established New York State College of Forestry, on the campus of Syracus University, employed him as an investigator. For two years he carried on a comprehensive evaluation of the relations of bottom fauna to fish life in Oneida Lake. This program culminated in two rolumes of distinctive contributions which were published by the New York State College of Forestry.

Ever since the founding of the University of Illinois, the Museum of Natural History had been in charge of members of the faculty whose foremost obligation had been that of teaching or administration. Under wise guidance of men such as S. A. Forbes and Frank Smith, the Museum had prospered and was able to secure the services of very unusual collectors and competent preparators who added materially to its development. Toward the end of President James's administration, a renewed interest in archeology and in natural resources together with rapid increase in University enrollment led to consideration of the problem of securing a full-time curator for the Museum of Natural History. The position was offered to Mr. Baker who, at the height of his professional career, entered upon his duties in January. 1918.

In 1936 Mr. Baker reached the age established by the University for retirement from active service but his good health and vigor and the best interests of the University combined to bring about postponement of his retirement for three additional years. In 1939 , in his seventy-second year, his colleagues helped him celebrate entrance upon status as Curator Emeritus, which permitted him to devote his entire time to completion of researches in progress. Letters of congratulation and appreciation from colleagues and from fellow scientists throughout the country were assembled, bound, and presented to him at a dimner in his honor. The esteem with which he was held as an individual and acknowledgments of personal debts of gratitude were as sincely expressed as was the evaluation of his scientific work. 
Soon thereafter, illness impaired his opportunity for continuous work in the laboratory, but even under this physical handicap he continued to devote all the time that his strength would allow to the final studies for and preparation of the manuscript for his magmum opus - - the monograph on The Molluscan Family Planorbidae. Volume I, based on exhaustive anatomical researches, was ready for the editor and work was progressing on Volume II when he was taken critically ill and hospitalization for surgery was unavoidable. Following the operation he never regained his health but became rapidly weaker and died on May 7,1942 .

Slight in stature, unpretentious in attitude, mild in disposition, and kindly, charitable, and unbiased in all of his personal and professional relations, Mr. Baker has left an undying impression of honesty, integrity, and genuineness in the memories of his many friends and associates.

For more than half a century (18s9-1942) Mr. Baker continued to publish the results of his researches and observations. Aside from purely incidental notes and compilations, which he continued to publish throughout his career, his early publications dealt largely with distributional studies and problems of taxonomy of the Mollusca. Relatively early he began to shift his interest in Mollusca from purely conchological to malacological lines (about 1897) when he began to study the radulae and anatomy of the soft parts of the molluses. The interest in Pleistocene paleontology first found expression in a paper published in 1898 and continued through the rest of his life with two posthumous papers on this subject.

Faunal studies with considerable attention to ecological relations of the molluses began early and found particular expression in his monograph on the Lymnaeidae (1911) and in his ecological studies on the fauna of Oneida Lake. These studies stand as background to the interest which found final expression in his contributions as associate editor of Naturalist's Guide to the Americas (1926).

His long identification with the program of molluscan studies. kindly personal qualifications, and familiarity with the history of the subject led to his being commissioned to prepare biographical sketches for five of the distinguished students of Mollusca in the Dictionary of American Biography (Gould, 1929; Kennicott, 1930; Stimpson, 1932; Tryon, 1933; and Sterki, 1933).

Interest in museum administration found expression in a series of papers issued during his years with the Chicago Academy and was revived when he became established in the museum at the University of Illinois.

His publications in archeology were stimulated by his responsibility for the University collections and were concerned largely with analysis of shells and other remains of animal life encountered in excavations of Indian village sites in the Middle IVest. In this aspect 
of his work, he collaborated with various specialists but had closest relations with the late $\mathrm{W}$. K. Moorehead whose reports on studies conducted for the University of Illinois were edited by Mr. Baker.

To supplement this analysis it should be recorded that in the period from 1900 to 1915 , Mr. Baker edited the Bulletins and other publications of the Chicago Academy of Sciences. From 1913 to 1915 he was assistant editor of Home and School Reference Work, published in Chicago in seven volumes, to which he personally contributed 125 articles on birds. Earlier (1900) he prepared a one-page article on Mollusca for the United Editors Encyclopedia published in New York. In 1926, in addition to serving as associate editor of Naturalist's Guide to the Americas, he prepared the references therein to molluscan distribution. From 1921 to 1926. Mr. Baker wrote numerous reviews of current works on Mollusca for Ecology.

In his total contributions, exceeding 350 original articles, more than 250 deal entirely or largely with his chosen field of research, the Mollusca. While many of these are but short. minor notes, some quantitative evaluation of Mr. Baker's productivity may be reflected in the fact that more than a dozen of these works enumerated are of such size as to merit classification as separate books.

Throughout his active career Mr. Baker kept a carefully compiled record of his publications, a copy of which was in his desk at the time of his death. This list, which he prepared, is here published in full with but few slight editorial changes and corrections.

Harley Jones Man Cleave 


\title{
A CHRONOLOGICAL LIST OF THE SCIENTIFIC PUBLICATIONS OF FRANK COLLINS BAKER
}

\author{
ORIGINAL ARTICLES AND BOOKS
}

\section{9}

1. Conchology department in 'The Old Curiosity Shop' (of which department the writer was editor). Cillifornia.

2. Notes on Florida shells. Nautilus, 3:53-54.

3. Description of a new species of Ocinebra. Op. cit., 3:80-81.

4. A few notes on ornithological collecting. Oologists Exchange, New York, $2(9)$.

5. Notes on the food of birds. Proc. Acad. Nat. Sci. Philadelphia, 1889:266-270.

6. Remarks upon the round-tailed muskiat, Neofiber alleni True. Op. cit., 1889: $271-273$.

\section{0}

7. On the Indian River, Floricla. Oologists Exchange, 3(11).

8. Directions for collecting alcoholic specimens of the Mollusea. Old Curiosity Shop, $9(3)$.

9. Remarks on Urosalpinx perrugatus Conrad. Nautilus, 4:29-30. Also in Proc. Acad. Nat. Sci. Philadelphia, 1890:46-47.

10. On the modification of the apex of Murcx. Proc. Acad. Nat. Sci. Philadelphia, $1890: 66-72$.

11. A catalogue of conchological abbreviations. Nautilus, 4:89-91, 115-117.

1891

12. Notes on a collection of shells from southern Mexico. Proc. Acad. Nat. Sci. Philadelphia, $1891: 45-55$.

13. Descriptions of new species of Muricidae, with remarks on the apices of certain forms. Proc. Rochester Acad. Sci., 1:129-137.

14. Remarks on the Muricidae with descriptions of new species of shells. Proc. Acad. Nat. Sci. Philadelphia, 1891:56-61.

15. Catalogue and synonymy of the recent species of the family Muricidae. Proc. Rochester Acad. Sci., 1:153-172.

16. The caves of Yicatan. Op. cit., $2: 2$.

17. Notes on a collection of shells from the Mauritius; with a consideration of the Genus Magilus of Montfort. Op. cit., 2:19-40.

18. Catalogue of specimens of Echinodermata, corals, gorgonians, and sponges. Ward's Natural Science Establishment, Rochester, N.Y., iv + 82 pages.

\section{4}

19. Further notes on embryonic whorls of the Muricidae. Proc. Acad. Nat. Sci. Philadelphia, $1894: 223-224$.

\section{5}

20. A glance at the Chicago Academy of Sciences. Nautilus, $8: 109-111$.

21. The geographic distribution of the Mollusca. Science (n.s.), 2:179-183.

22. Preliminary outline of a new classification of the Muricidae. Bull. Chicago Acad. Sci., $2: 169-189$.

23. Syllabus of biological lectures. (Delivered before the North Side Science Section of the Chicago Institute of Education). Chicago.

24. A naturalist in Mexico: being a visit to Cuba, northern Yucatan, and Mexico. Chicago, 1895: viii + 145 pages.

25. Thirty-eighth annual report of the Chicago Academy of Sciences. For the year 1895. 16 pages.

26. On the correct position of the aperture in Planorbis. Jour. Cincinnati Soc. Nat. Hist., 19(1):45-48.

27. Notes on the mental development and intelligence in animals. The Observer, $1896: 680-682$. 
28. Thirty-ninth annual report of the Chicago Acarlemy of sciences. For the year 1896. 26 pages.

29. On the pulsations of the molluscan heart. Jour. Cincinnati Soc. Nat. Hist., 19(2): 73-78.

30. Note on Natrix grahami B. and G. (With F. M. Woodruff). Science (n.s.), $5: 447$.

31. On the effect of music on caged aninals. Amer. Nat., 1897:460-463.

32. Critical notes on the Muricidae. Trans. Acad. Sei. St. Louis, 7:371-391.

33. On the modification of the apex in gastropod mollusks. Ann. New York Acad. Sei., $9: 685-704$.

34. On a collection of mollusks from Grand Tower, Illinois. Nautilus, 11(3):28-30.

35. Further notes on animal intelligence. The Observer, S:193-194.

36. Collecting about Chicago. Sports Afield, 19(2):112-113.

37. Reason among animals. Op. cit., $19: 276-278$.

38. Notes on Radulae. Jour. Cincinnati Soc. Nat. Hist., 19(3):81-93.

\section{8}

39. Do cats remember? Sports Afield, 20:215.

40. The molluscan fama of western New York. Trans, Acad. Sci. St. Louis, S(5): $71-94$.

41. Collecting in Florida. Sports Afield, $20: 314-316$.

42. Totes on mollusks from Acadia, Missouri. Nautilus, $11: 36$.

43. Fortieth annual report of the Chicago Academy of Sciences. For the year 1897. 27 pages.

44. The Mollusca of the Chicago area. Part I. The Pelecypoda. Chicago Acad. Sci., Nit. Hist. Survey Bull., 3(1) :1-130.

45. A day on the C'hicago drainage cunal. Nautilus, $12(6): 63-65$.

46. A new Sphaerium. Op. cit., $12: 65-66$.

\section{9}

47. Collecting fresh-water shells. Popular Sci., 33(5):99-100.

48. Notes on the mollusks of Lilycush Creek. Nautilus, 13(3):30-31.

49. Study of fresh-water mussels. Popular Sci., 33:194-197.

50. Notes on the Mollusca of Owasco Lake, New York. Nautilus, 13:57-59.

\section{0}

51. Notes on a collection of Pleistocene shells from Milwaukee, Wisconsin. Jour. Cincinnati soc. Nit. Hist., 19:175-177.

52. On a collection of fresh-water shells from Rhode Island. Nautilus, 13:112-113.

53. A new museum tablet. Amer. Nat., 34:283-284.

54. The rock shells. Birds and Nature, $7: 191-192$.

55. The gross anatomy of Limmaea cmarginata Say, variety Mighelsi Binney. Bull. Chicago Acad. Sci., 2(3):191-211.

56. A revision of the Physae of northeastern Illinois. Nautilus, 14(2):16-24.

57. The teeth of snails. Popular Sci., 34:187-188.

58. Shell collecting near Rochester, New York. Nautilus, $14: 69-71$.

59. Mollusks in grass. Op. cit., 14:93.

\section{1}

60. The oyster and its relatives. Birds and Nature, 9:26-31.

61. A revision of the Limmaeas of northern Illinois. Trans. Acad. Sci. St. Louis, $9(1): 1-24$.

62. Snails of the forest and field. Birds and Nature, $9: 74-79$.

63. Snails of pond, river, and brook. Op. cit., $9: 128-133$.

64. Snails of the ocean. Op. cit., 9:176-181.

65. The Nautilus and other cephalopods. Op. cit., $9: 222-227$.

66. New varieties of fresh-water shells. Nautilus, 15(2):17-18.

67. The digitations of the mantle in Physa. Bull. Chicago Acad. Sci., 2(4):225-228.

68. Description of a new species of Limnaea. Op. cit., 2(4):229-230.

69. The molluscan fauna of the Genessee River. Aner. Nat., 35:659-664.

70. The prong-horned antelope. Birds and Nature, 8:179-181.

71. Limnaea auricularia in America. Nautilus, 15(5):59.

72. The educational value of natural history museums. Review of Education, Chicago, $7: 155-157$.

73. Some interesting molluscan monstrosities. Trans. Acad. Sci. St. Louis, 11:143-146. 
1902

74. Planorbis bicarinatus striatus, n. var. Nautilus, 15(10):120.

75. Editorial on museum articles. Review of Education, Chicago, $7: 361$.

76. The Mollusca of the Chicago area. Part I1. Gastropoda. Chicago Acad. Sci., Nit. Hist. Surver Bull., 3(2):131-410.

77. Startishes. Birds and Nature, $12: 35-37$.

7S. The cowries and shell money. Op. cit., $12: 86-90$.

79. Some snails of the ocean. Op. cit., $12: 134-139$.

so. The descriptive arrangement of museum collections. Museum Jour., (England), $2: 106-110$.

\section{3}

81. Shell collecting on the Mississippi. Natutus, $16: 102-105$.

82. Corals, sea-fans, and sea-whips. Birds and Nature, 13:83-85.

83. The stony corals. Op. cit., 13:131-133.

S4. Coral reefs. Op. cit., 13:179-181.

S5. The hydroid corals. Op. cit., $13: 225-227$.

86. Shells of land and water. A familiar introduction to the study of the mollusks. A. W. Munford and Co., Chicago. xvi +175 pages.

87. Pleistocene mollusks of White Pond, New Jersey. Nautilus, 17:38-39.

S8. A partial list of the marine mollusks of San Salvador, Bahamas. Op. cit., 17:57.

89. Rib vilriation in Cardium. Amer. Nat., $37(439): 481-488$.

90. Sea urchins and sand dollars. Birds and Nature, 14:179-181.

91. Notes on Hurcx marcoensis Sowerby. Nautilus, 17-88.

\section{4}

92. The mollusks of Cedar Lake, Indiana. Op. cit., 17:112-113.

93. Some American grasshoppers. Birds and Nature, 15:131-133. (Nom de plume, Collins Thurber)

94. New varieties of American Limnaeas. Nautilus, 18:10-12.

95. The molluscan fauna of the Dells of Wisconsin. Trans. Acad. Sci. St. Louis, $14(2): 99-105$.

96. Note on Planorbis truncatus Miles. Op. cit., 14(2):107-110.

97. The arrangement of the collections of Mollusea in the Chicago Academy of Sciences. Museums Journal (England), 2:354-360.

98. Spire variation in Pyramidula alternata. Amer. Nat., 38(453):661-668.

99. New American Lymnaeas, II. Nautilus, 18:62-63.

100. The bluebird. Birds and Nature, 16:15S-161. (Nom de plume, Collins Thurber)

101. The bald eagle. Op. cit., 16:232-236. (Nom de plume, Collins Thurber)

\section{5}

102. The belted kingfisher. Op. cit., 17:50-51. (Nom de plume, Collins Thurber)

103. The flicker. Op. cit., $17: 131-132$. (Nom de plume, Collins Thurber')

104. Critical notes on the smaller Lymnaeas. Nautilus, 18:125-127.

105. The long-billed marsh wren. Birds and Nature, 17:179-180. (Nom de plume, Collins Thurber)

106. New species of Lymnate. Nautilus, 18:141-142.

107. The marsh hawk. Birds and Nature, 17:201-202. (Nom de plume, Collins Thurber)

108. The molluscan fauna of McGregor, Iowa. Trans. Acad. Sci. St. Louis, 15(3): 249-258.

109. Notes on a collection of shells from Bass Lake, Indiana. Nautilus, 19:27-28.

110. The inuseum and the public school. Nuseums Journal (England), 5:50-55.

111. A new species of Lymnaca from Ohio, with notes on Lymnaea parva Lea. Nantilus, 19:51-53.

112. The loggerhead shrike. Bircts and Nature, 18:23-24. (Nom de plume, Collins Thurber)

113. The hermit thrush. Op. cit., 18:50-51. (Nom de plume, Collins Thurber)

114. Notes on the genitalia of Lymnaea. Amer. Nat., 39:665-679.

115. The rellow-bellied sapsucker. Birds and Nature, 18:119-121. (Nom de plume, Collins Thurber)

116. The cerulian warbler. Op. cit., 18:167-168. (Nom de plume, Collins Thurber)

117. The American flamingo. Op. cit., 18:213-214. (Nom de plume, Collins Thurber) 
118. The bob-white or quail. Op. cit., 19:23-24. (Nom de plume, Collins Thuber)

119. The least bittem. Op. cit., 19:71-72. (Nom de plume, Collins Thurber)

120. The blue-gray gnatcatcher. Op. cit., 19:110-111. (Nom de plume, Collins Thurber)

121. A new variety of Plunorbis nautileus Linn. Nautilus, 19:120.

122. Lymaea hinkleyi 11. sp. Op. cit., 19:142-143.

123. Application of De Vries's mutation theory to the molluses. Amer. Nat., 40: $327-334$.

124. Notes on a collection of mollusks from the vicinity of Alpena, Michigan. Trans. Acad. Sci. St. Lonis, 16(2):1-15.

125. A new Sphacrium from Illinois. Nautilus, 20(2):21.

126. The dickcissel. Birds and Nature, 19:146-147. (Nom de plume, Collins Thurber)

127. The great blue heron. Op. cit., 19:213-214. (Nom de plume, Collins Thuber)

12S. Lymnaca danielsi n. sp. Nautilus, 20:55.

129. A catalogue of the Mollusea of Illinois. Bull. Illinois State Lab. Nat. Hist.. 7(6): $53-136$.

\section{7}

130. Descriptions of new species of Lymnaca. Nautilus, 20:125-127.

131. The camera in seience. Photo Eru, 18:185-186.

132. Two new species of Lymnaca. Nautilus, 21:52-55.

133. Some observations on museum administration. Science, 26:666-669.

\section{8}

134. Some instructive methods of bird installation. Proc. Amer. Mus. Assoc., 1:52-57.

135. The Chicago Academy of Sciences. Science, 27:423-424.

136. The Chicago Academy of Sciences: its past history and present collections. Chicago Acad. Sci., special publ., 2:1-7.

137. Note on Lymnaca desidiosa Say. Nantilus, 22:20-23.

138. Suggestions for a naturul classification of the family Iymnaeidae. Science, 27 : 942-943.

139. The Chicago Academy of Sciences. Op. cit., 2S:13S-140.

140. A new American Planorbis. Nautilus, 22:45.

141. A small collection of shells from Texas. science, 28:531-535.

142. Provincial museums. Op. cit., 28:684-685.

143. The relation of the State Acarlemy of science to the Natural History Survey of the Chicago Academy of Sciences. Trans. Illinois State Acarl. Sei., 1:68-69.

144. The Natural History Survey of the Chicago Acadeny of Sciences. Proc. Amer. Assoc. Mus., 2:15-19.

\section{9}

145. Annual report of the Chicago Acadeny of Sciences. For the year 1908. Bull. Chicago Acad. Sci., 3:1-21.

146. A new species of Lymnaca. Nautilus, $22: 140-141$

147. Description of a new fossil Lymmaea. Op. cit., 23:19-21.

148. Note on Planorbis binneyi Tryon. Op cit., 23:41-42.

149. The Chicago Academy of Sciences: Its past history and present collections. Museums Jour. (England), 8:423-428.

150. Range of Lymnaca umbilicata. Nautilıs, $23: 80$

151. Report on the educational work of some east American museums. Bull. Chicago Acad. Sci., 3:26-34.

152. Mollusks from Kiansas and Oklahoma. Nautilus, 23:91-94.

153. Suggestions for an educational exhibit of mollusks. Proc. Amer. Assoc. Mus., $3: 56-59$.

154. Exhibition cases without shelves. Op. cit., 3:128-130.

\section{0}

155. A new variety of Lymnaea stagnalis. Nautilus, 23:112-113; 125-126.

156. Note on free public museums. Science, $31: 221$.

157. Annual report of the curator. Bull. Chicago Acarl. Sci., 3:26-45.

15S. Annual report of the librarian. Op. cit., $3: 45-46$.

159. The ecology of the Skokie Marsh area, with special reference to the Mollusca. Bull. Illinois State Lab. Nat. Hist., 8:437-499.

160. Preliminary note on the life of Glacial Lake Chicago. Science, $31: 715-717$. 
161. Suggestions for an educational exhibit of mollusks. Museums Jour. (England), $9: 394-397$.

162. The ecology of the Skokie Marsh area with special reference to the mollusks. Trans. Illinois State Acad. Sci., 3:106-108.

163. Description of a new Lymnaca. Nautilus, 24:58-60.

164. Mollusks of Unionville, Connecticut. Op. cit., 24:68-69.

1911

165. The Lymnacidae of North and Middle America, recent and fossil, Chicago Acad. Sci., Special Publ., 3:xvi + 539.

166. Annual report of the curator. Bull. Chicago Acad. Sci., 3:137-150.

167. Annual report of the librarian. Op. cit., 3:151-152.

168. A method of exhibiting large descriptive labels on the outside of musem cases. Proc. Amer. Assoc. M1us., 4:21-23.

169. School loan collections as prepared by the Chicago Academy of Sciences. Op. cit., $4: 36-40$.

170. Mollusks of Wellesley Island and vicinity, St. Lawrence River. Nantilus, 25:66-67.

171. The molluscan fauma of Tomahawk Lake, Wisconsin. Trans. Wisconsin Acad. Sci., Arts, and Lett., 17(1):200-246.

\section{2}

172. A new Planorbis from Michigan. Nautihs, 25:118-120.

173. Post-glacial life of Wilmette Bay, Glacial Lake Chicago. Trans. Illinois State Acad. Sci., 5:108-116.

174. A method of exhibiting insect collections. Proc. Amer. Assoc. Mus., 6:108-111.

175. Recent additions to the catalog of Illinois Mollusea. Trans. Illinois State Acad. Sci., $5: 143-145$.

\section{3}

176. A new Lymnaca from Montana. Nautilus, 26:115-116.

177. Psendogalba, new name for Simpsonia. Op. cit., 26:120.

178. Interglacial records in New York. Science, $36: 523-524$.

179. Notes on post-glacial Mollusca. I. Emmet County, Michigan. Nautilus, $27: 7-8$.

180. Galba ferruginea in Oregon. Op. cit., $27: 24$.

181. Mollusca of Wyoming County, New York. Op. cit., $27: 54$.

182. Notes on post-glacial Mollusca. II. Waukesha County, Wisconsin. Op. cit., $27: 68$.

183. Interglacial mollusks from South Dakota. Science, 38:858-859.

\section{4}

184. Northern Idaho shells. Nautilus, 27:104-106.

185. Mollusks from Magician Lake, Cass and Van Buren Counties, Michigan. Op. cit., $28: 8-10$.

186. Use of enlarged photographs in museum groups. Proc. Amer. Assoc. Mus., 8: 89-91.

187. An evening with the aquarium and snailery. Nature Study Rev., 10:315-320.

1915

188. On the classification of the Iymnaeidae. Nautilus, 29:20-24.

189. Campeloma leuisii Walker in Illinois. Op. cit., 29:36.

190. Mollusks from Berrien County, Michigan. Op. cit., 29:47.

191. Pleistocene mollusks from Illinois. Op. cit., 29:87-88.

\section{6}

192. A mollusk injurious to garden regetables. Science, $43: 136$.

193. The fresh-water Mollusea of Oneida Lake, New York. Nautilus, 30:5-9.

194. North American faunal areas. Science, $44: 273-275$.

195. The relation of mollusks to fish in Oneida Lake. New York State Coll. For., Technical Publ., 4:1-366.

196. The auroral display of August 26. Science, $44: 568$.

197. A new rariety of Lampsitis from Oneida Lake with notes on the luteola group. Niatilus, $30: 74-77$.

198. Further notes on the post-glacial biota of Glacial Lake Chicago. Trans. Illinois State Acad. Sci., $7: 74-78$.

199. The relation of the Mollusks of Oneida Lake to the basin of lower South Bay. (Abstruct). Ecol. Soc. Amer., 1916. 
1917

200. Notes on Acella haldcmani (Desh.) Binney. Nautilus, 20:135-138.

1918

201. Further notes on the Mollusca of Oneida Lake, New York; the mollusks of lower South Bay. Op. cit., 31:81-93.

202. A molluscan garden pest. Science, $47: 391-392$.

203. The animal world in a handful of algae. The Guide to Nature, $10: 376-380$.

204. Notes on nidification in Gillia and Ammicola. Nautilus, 32:19-23.

205. Description of a new variety of fresh-water mussel from Oneida Lake, New York. Appendix to New York State Coll. For., Technical Publ., 9:247-248.

206. The productivity of invertebrate fish food on the bottom of the Oneida Lake, with special reference to mollusks. Op. cit.. 9:1-264.

207. Post-glacial Mollusea from the marls of Central Illinois. Jour. Geol., 26( 7$)$ : 659-671.

208. The relation of shellfish to fish in Oneida Lake, New York. New York State Coll. For., Circular, $21: 1-34$.

\section{9}

209. Description of a new species and variety of Planorbis from post-glacial deposits. Nitutilus, $32(3): 94-97$.

210. Mollusks infested with parasitic worms. Op. cit., 32(3):97-98.

211. The ecology of North American Lymnacidae. Science, 49:519-521.

212. A new species of Physa from New; York State. Nautilus, 33:11-13.

213. Studies in aquiculture or fresh-water farming. Nat. Hist., 19:478-48s.

214. Molluska of the Crocker-Iand Expedition to northwest Greenland and Grinnell Land. Bull. Amer. Mus. Nat. Hist., 41(11):479-517.

215. Fresh-water Mollusca from Colorado and Alberta. Op. cit., 41(13):527-539.

216. The Musem of Natural History of the Tniversity of Illinois. Trans. Illinois State Acad. Sci., 12:57-63.

\section{0}

217. Animal life and sewage in the Genessee River, New York. Amer. Nat., 54:152-161.

218. A new Planorbis from Illinois. Nantilus, $33: 123-125$.

219. A new form of Amnicola from the Olio Pleistocene deposits, with notes on a Physa from the same formation. Op. cit., 33:125-127.

220. Physa smithiana, new name for Physa smithii. Op. cit., 33:142.

221. The life of the Pleistocene or glacial period, as recorded in the deposits haid down by the great ice sheets. Univ. Illinois Bull., 17(41): iv +476 pages. Trbana, Illinois.

222. Pleistocene Mollusca from Indiana and Ohio. Jour. Geol., 28(5):439-457.

223. Animal life in loess deposits near Alton, Illinois, with descriptions of two new varieties of land shells from the same deposits. Nantilus, 34:61-66.

224. Notes on a small collection of shells from Alaskit. Op. cit., 34:67-6s.

225. The Musemm of Natural History. In 'Sixteen Years at the Eniversity of Illinois,' a statistical study of the administration of President Edmund J. Janes. University of Illinois, Urbana, pages 119-121.

226. A mussel survey of the upper waters of the Vermilion River with special reference to the Salt Fork. (With Frank Smith). Trans. Illinois State Acad. Sci., $12: 129-131$.

227. Effect of sewage and other pollution on animal life of rivers and streams. Op. cit., $13: 271-279$.

\section{1}

228. The value of ecology in the interpretation of fossil faunas. School Sci. and Math., $21: 323-327$.

229. Baker's 'Life of the Pleistocene' (reply to eriticism by Dr. Shufeldt). The Auk, $38: 155-156$.

230. Preparing collections of the Mollusen for exhibition and study. Trans. Amer. Micros. Soc., 40(1):31-46.

231. New forms of Pleistocene mollusks from Illinois. Nautilus, 35:22-24.

232. The importance of ecology in the interpretation of fossil faunas. Ecology, 2: 277-280. 
233. Pleistocene Molluska from northwestern and central Illinois. Jour. Geol., 30(1): 43-62.

234. Fhake infections and the destruction of the invertebrate host. Jour. Parasitol, $8: 145-147$.

235. New species and varieties of Mollusea from Lake Winnebago, Wisconsin, with new records for this state. Nautilus, $35: 130-133 ; 36: 19-21$.

236. New Lymmaeas from Wisconsin and Minnesota, with notes on shells from the latter state. Op. cit., $36: 22-25$.

237. The molluscan fauna of the Big Vermilion River, Illinois, with special reference to its modification as the result of pollution by sewage and manufacturing wastes. Illinois Biol. Monogr., 7(2):1-127.

238. The musemu, the original exponent of visual education. School Sci. and Math., $22: 651-655$.

1923

239. The Pleistocene Millusca from the vicinity of Joliet, Illinois. Trans. Illinois State Acad. Sci., 15:408-420.

240. A new Anodontoides from Wisconsin. Nantilus, 36:123-125.

241. Description of a new Lymmaca flom Yellowstone Park. Op. cit., 36:125-126.

242. The educational value of a university natural history musem. Science, 58 : $55-57$.

243. Some problems of a university curator. Museum Work, 5:92-94.

244. The use of molluscan shells by the Cahokia mound builders. Trans. Illinois State Acad. Sci., $16: 328-334$.

245. A new Physa from California. Nautilus, 3s:15.

246. Report of curator, the Museum of Natural History. In 'President's Report,' University of Illinois, 1922-1923:159-162.

1924

247. The place of the museum in university instuction. Museum Work, $7: 81-87$. (Reprinted in School Life, $10: 33-35$ ).

248. The fauna of the Lake Winnebago region. A quantitative and qualitative survey with special reference to the Mollusca. Trans. Wisconsin Acad. Sci., Arts, and Lett., $21: 109-146$.

1925

249. Report of curator, Museum of Natural History. In 'President's Report,' University of Illinois, $1924-1925: 117-119$.

\section{6}

250. Museums and nature. Naturalist's Guide to the Americas, 27-29.

251. The effects of pollution on animal life. Op. cit., 38-41.

252. Nomenclatorial notes on American fresh-water Mollusca. Trans. Wisconsin Acad. Sci., Arts, and Lett., $22: 192-205$.

253. Bowmanville low water stage of Glacial Lake Chicago. Science, 64:249.

254. Fresh-water Mollusca from White Lake, Oakland County, Michigan. Nautilus, $40: 49-52$.

255. New forms of Planorbis and Lymnaea with notes on other forms. Op. cit., 41: 23-24.

256. Report of curator, Museum of Natural History. In 'President's Report, Unirersity of Illinois, 1925-1926:145-149.

1927

257. Description of a new species of Lymnaea from British Columbia. Nautilus, 41 : 23-24.

258. Description of a new species of Somatogyrus from Wisconsin. (With H. A. Pilsbry). Op. cit., $41: 24-26$.

259. The naiad fauna of the Rock River System; a study of the law of stream distribution. Trans. Illinois State Acad. Sci., 19:103-112.

260. New varieties of Stagnicola from Wisconsin and Wroming. Nautilus, 40(3) : 85-87.

261. New rarieties of Helisoma antrosa from Wisconsin and Minnesota. Op. cit., 40: 82-85. 
262. On the division of the Sphaeriidae into two subfamilies; and the description of a new species and genus of Unionidae, with descriptions of new rarieties. Amer. Midl. Nat., 10(7):220-223.

263. Descriptions of new forms of Pleistocene land mollusks from Illinois, with remarks on other species. Nautilus, $40: 114-120$.

264. Molluscan associations of White Lake, Michigan; a study of a small inland lake from an ecological and systematic riewpoint. Ecology, S(3):353-370.

265. A new rariety of Hclisoma campanulata from Michigan. Nautilus, 41:49-51.

266. Reprort of curator, Museum of Natural History. In 'President's Report,' University of Illinois, 1926-1927:129-132.

1928

267. Descriptions of new varieties of land and fresh-water mollusks from Pleistocene deposits in Illinois. Nautilus, 41:132-137.

268. The American Bythinia not wholly an introduced species. Trans. Illinois State Acad. of Sci., 20:56-63.

269. Mollusean life of the loess deposits of Illinois. Op. cit., 20:269-292.

270. Influence of a changed enrironment in the formation of new species and varieties. Ecologry, $9: 271-283$.

271. The fresh-water Mollusea of Wisconsin. Part I. Gastropoda. Wisconsin Acad. Sci.. Arts, and Lett., $1928: \mathrm{i}-\mathrm{xx}+50 \mathrm{~T}$ pages.

272. The fresh-water Mollusca of Wisconsin. Part II. Pelecypoda. Bull. Univ. Wisconsin, $1527: \mathrm{vi}+495$ pages.

273. The Mollusea of Chautauqua Lake, New York, with descriptions of a new variety of Ptychobranchus and of Hclisoma. Nautilus, 42:48-60.

274. Report of curator, Museum of Natural History. In 'President's Report,' University of Illinois, 1927-1928:124-127.

1929

275. Fossaria perplexa F. C. Baker and Junius Henderson. Nautilus, 42:103-104.

276. Certain anatomical features of the fresh-water molluse, Helisoma corpulenta Say. Truns. Aner. Micros. Soc., 4S(1):44-47.

277. Vermont shells. Nautilus, $41: 108$.

278. Mollusea from Vernilion and Pelican Lakes, Minnesota, with the description of a new rariety of Helisoma corpulenta. Op. cit., 42:95-97; 131-136.

279. A study of the Pleistocene Mollusea collected in 1927 from deposits in Fulton County, Illinois. Trans. Illinois State Acad. Sci., $21: 285-312$.

280. The nse of molluscan shells by the Cahokia mound builders. The Cahokia Mounds, Bull. Univ. Illinois, 26(4):147-154.

281. Stagnicola coulecnsis F. C. Baker. In Henderson, 'Some Fresh-water Mollusca from Washington and Oregon,' Nautilus, 41:118-120.

282. 'The European starling in Illinois. Science, $69: 521-522$.

283. Report of curator, Museum of Natural History. In 'President's Report,' University of Illinois, 1928-1929:140-146.

1930

284. A new record of Castoroides ohioensis from Illinois. Science, 71:389.

285. On genus and species making. Op. cit., 72:37-39.

285a. Iniversity museum exhibition cases. Museum News, 7(19):11-12.

286. The use of animal life by the mound-building Indians of Illinois. Trans. Illinois State Acad. Sci., 22:41-64.

287. The molluscan fauna of the southern part of Lake Michigan and its relationship to old Glacial Lake Chicago. Op. cit., $22: 186-194$.

288. A review of our present knowledge concerning the character and distribution of the Pleistocene aquatic molluscan life of Illinois. Op. cit., 22:411-434.

289. Influence of the glacial period in changing the character of the molluscan fauna of North America. Ecology, $11(3): 469-480$.

290. The variation of mollusean life during the Pleistocene and recent time. Nautilus, $44(1): 21-24$.

291. Notes on Professor Shinek's paper on land snails as indicators of Ecological conditions. Ecology, 11(4):788-789.

292. Report of curator, Museum of Natural History. In 'President's Report,' University of Illinois, $1929-1930: 164-169$. 
1931

293. Description of a new rariety of Valvatr lewisii Currier. Niuttilus, 44(4):119-121.

294. Additional notes on animal life associated with the mound builders of Illinois. Trans. Illinois Acad. Sci, 33:231-235.

295. A restudy of the interglacial molluscan fauna of Toronto, Canadit. Op. cit., 33 : $358-366$

296. Ecologicul relationship of the gemus Pomatiopsis with special reference to Pomatiopsis lapidaria. Ecology, 12(3) :389-396.

297. The classification of the large planorboid snails of Europe and America. Proc. Zool. Soc. London, 1931 (2):575-592.

298. Fresh-water Mollusca from central Ontario. (With A. R. Cahn). Ann. Rept., 1929, Natl. Mus. Canada, pp. 41-64.

299. Pulmonate Mollusea peculiar to the Pleistocene period, particularly the loess deposits. Jour. Paleontol., 5(3):270-292.

300. Pleistocene history of the terrestrial Mollusea of Fulton County, Illinois. Trans. Illinois State Acad. Sci., 24(2) :149-155.

\section{2}

301. Stagnicola apicina and Stagnicola walkeriane. Nantilus, 45:139-140.

302. Mollusean shells from Etowah Mounds. Chapter V', in WV. K. Moorehead's 'Exploration of the Etowah Site in Georgia.' Department of Archeology, Phillips Academy, Andover, Massachusetts, pp. 145-149.

303. The ecology of Say's Limnaeus elodes. Ecology, 13:286-289.

304. New species and varieties of Helisoma and Gyraulus from Canada. Nautilus, $46(1): 6-9$.

305. A new race of Polygyra appressa from Illinois. Op. cit., 46(2):48-49.

\section{3}

306. Polygyra dorfeuilliana and Bulimoides dealbatus in Hllinois. Op. cit., 47:4-7.

307. A new Stagnicola from Montana. (With Junius Henderson). Op. cit., 47:30-32.

308. Self fertilization and nidification in Physa halei. Op. eit., $47: 35$.

309. Studies on the bottom fauna of fresh-water lakes. Science, 78:190-191.

310. The genitalia of the Indian mollusk, Indoplanorbis exustus. Jour. Morphol., $55(1): 1-13$

311. A new form of Polygyra tridentata from Illinois. Nautilus, $47(2): 59$.

312. New species of Lymnaeidae from British America. Jour. Washington Acad. Sci., $23(11): 520-523$.

\section{4}

313. Description of a new snecies of Gyraulus. Canadian Field-Nat., 48-27.

314. The rariation and distribution, recent and fossil, of the snail Polygyra profunda, in Illinois. Amer. Midl. Nat., 15(2):178-186.

315. The rariation and distribution, recent and fossil, of the snail Polygyra profunda, in Illinois. (Abstract). Trans. Illinois State Acad. Sci., 25:189.

316. New Canadian Lrnnaeas. Canadian Field-Nat., 48:69-70.

317. Two new races and a new species of Helisoma from California. Nautilus, 47: 140-142.

318. The molluscan fauna of the great river valleys of Illinois. Trans. Illinois State Acad. Sci., $26: 129$.

319. New Lymnaeidae from the United States and Canada: 1. California, Oregon, and other western states. Nautilus, $4 S(1): 17-20$.

320. A new mammoth record for Illinois. Science (n.s.), $80: 118$

321. A new species of Gyraulus from Canada. Canadian Field-Nat., 48:135.

\section{5}

322. Mollusea from Turker Run State Park. Indiana. Nautilus, 48(3):105-106.

323. Land and fresh-water molluses from North Star Lake and ricinity, Itasca County, Minnesota. Amer. Midl. Nat., 16(3):257-272.

324. Stratiographic sequence of mollusean fossils in loess deposits. (Abstract). Proc. Geol. Soc. Amer. for $1934: 372-373$

325. New species and races of Iymnaeidae from Newfoundland. (With Stanley T. Brooks). Nautilus, 49:10-13.

326. The generic position of Planorbis umbilicatcllus with the description of a new group of Planorbidae. Op. cit., 49(2):46-48.

327. Stagnicola elrodiana, new name for Limnaea montana Elrod. Op. eit., 49:60. 


\section{6}

328. The generic position of Planorbis obstructus Morelet. Op. cit., 49(3):104.

329. Quantitative examination of molluscan fossils in two sections of Pleistocene loess in Illinois. Jour. Paleontol., 10(1):72-76.

330. The fresh-water molluse Helisoma corpulentum and its relatives in Canada. Natl. Mus. Canada Bull., $79: 1-37$.

331. Paleontology. In A. L. Lugn's 'The Pleistocene Geology of Nebraska.' Nebraska Geol. Surv. Bull., 10:1-223. (Identifications and comments on pages 122, 123, $183-187,190,194,195,210-212)$.

332. New Lymnaeidae from the United States and Canada, 11. Michigan, Minnesota, and Montana. Nautilus, 49(4):127-140.

333. The relationship of Parapholy.x. Op. Cit., $50: 30-31$.

334. Remains of animal life from the Kingston kitchen midden site near Peoria, Illinois. Trans. Illinois State Acad. Sci., 29:243-246.

\section{7}

335. Identification of shells. In Cole and Denel, 'Rediscorering Illinois.' Appendix VI, 'Explorations in and around Fulton County,' pages 269-270.

336. Mollusca from the Prince Albert Nitional Park, Saskiltchewan. Nilutilus, 50(4): $113-117$.

337. An Illinois record for the little brown crine. The Auk, 54:388.

338. A new Pleistocene race of Polygyra appressa. Nautilus, 51(1):22-23.

339. Pleistocene land and fresh-water Mollusea as inclicators of time and ecological conditions. In 'Symposium on Early Man,' held at Academy of Natural Sciences, Philadelphia, March, 1937. J. B. Lippincott, 1937:67-74.

340. Abundance of the European starling in Illinois. Science, $85: 564$.

\section{8}

341. New land and fresh-water Mollusca from the Upper Pliocene of Kinsas and a new species of Gyraulus from Early Pleistocene strata. Nautilus, 51(4):126-131.

342. The Mollusea of the shell heaps or escargotieres of northern Africa. Purt III of 'Prehistoric habitation sites in the Sahara and North Africa.' Logan Mus. Bull., 5:185-225.

\section{9}

343. Original copies of Say's 'American conchology' Nautilus, 52:106.

344. Stagnicola bulimoides vancouverensis nov. Var. Op. cit., 52:144.

345. Remains of animal life from the Kingston kitchen midden site near Peoria, Illinois. 'The Kingston Site' by A. M. Simpson. Peoria Acad. Sci., 1939:13-15.

346. Land and fresh-water Mollusea from western Ontario. Canadian Jour. Research, D. $17: 87-102$.

347. Fieldbook of Illinois land snails. Illinois Nat. Hist. Surv. Manual 2, 166 pages.

\section{0}

348. South American species referred to Planorbula. Nautilus, 53:106.

349. The case of Limnacus sordidus Kuster. Op. cit., 53:138-141.

350. A new Hclisoma from the Pliocene of Florida. Op. cit., 54:17.

351. A new anatomical classification of the Planorbidae. Tenth Ann. Rept. Amer. Malacol. Union, Philadelphia, 1940:4-5.

\section{1}

352. A new species of Drepanotrema and some preoccupied planorboid names. Nautilus, 54:96-97.

353. A new race of Parapholyx effusa. Op. cit., 55:16-17.

354. A study in ethnology of the prehistoric Indians of Illinois. Part II. Contributions to the archaeology of the Illinois River valley. Trans. Amer. Philos. Soc. (n.s.), $32(1): 51-67$.

1942

355. Lymnaca stagnalis and Lymnaea (Radix) auricularia. Nautilus, 55:105-106.

356. Land and fresh-water Mollusea of New Hampshire. Amer. Midl. Nat, 27:74-85. 
357. Collecting and preserving fresh-water snails. Ann. Rept. Amer. Malacol. Union, Philadelphia, $1941: 5-9$.

358. A new Gyraulus from the Pleistocene of California and a new Parapholyx from a supposed Pliocene deposit in Oregon. Nautilus, 55:130-132.

\title{
1943
}

359. Mollusea contained in the test pit deposits. Cannegie Inst. of Washington, Publ. $538: 117-119$.

1945

360. The Molluscan Fanily Planorbidae. The University of Illinois Press, Urbana.

\section{BIOGRAPHICAL CONTRIBUTIONS}

\author{
(In Dictionary of American Biography)
}

1929. Augustus Addison Gould.

1932. George Washington Tryon.

1930. Robert Fiennicott.

1933. Victor Sterki.

1932. William Stimpson.

\section{BOOK NOTICES AND REVIEWS}

\author{
(In Ecology)
}

1921

The fresh-water Mollusca of the Parish of Aldenham, by A. E. Boycott. $2: 230$.

Correlation of shape and station in fresh-water mussels, by A. E. Ortmann. 2:231.

Nitural history and propagation of fresh-water mussels, by Shira, Coker, Clark, and Howard. $2: 314$.

\section{2}

The Mollusca collected by the University of Michigan-Walker expedition in southern Vera Cruz, Mexico. by H. B. Baker. 3:342.

Final report on the study and appraisal of mussel resources in selected areas of the upper Mississippi River, by N. M. Grier. 3:343.

The edible clams, nussels, and scallops of Cilifornia, by F. W. Weymouth. 3:344-345.

Molluscal of North Dakota, by Mina L. Winslow. 3:345.

Stream pollution. A review of 'Stream pollution studies,' by Russel Suter and Emmeline Moore. $3: 340-341$.

\section{3}

On the effect of salinity on Teredo navalis, by H. F. Blum. $3: 318$.

The Mollusea of Dickinson County, by H. B. Baker. 4:318.

The Clamplain Sea, by Winifred Colding. $4: 318$.

The Mollusea of Oundle, by Rev. C. E. Y. Kendall. 4:319.

Variations in the shell of Teredo navalis, by R. C. Miller. 4:319.

\section{4}

The Kentucky River and its mussel resoures, by E. Danglade. 4:431.

Studies of the biology of fresh-water muscels. III. Distribution and movenents of Winona Lake mussels, by W. R. Allen. 5:220.

The Mollusca collected by the University of Mieligan-Williamson expedition in Venezuela, by H. B. Baker. $5: 221$.

Biology and economic value of the sea mussel, Wytitus rdulis, by I. A. Field. 5:306. Mollusea of the southwestern states. XI. From the Tueson Range to Ajo, and mountain ranges between the San Pedio and Santa Cruz rivers, Arizona, by H. A. Pjlsbry and J. H. Feniss. $5: 222$. 
The small bottom and shore fauna of the middle and lower Illinois River and its connecting lakes, Chillicothe to Grafton: Its valuation, its resources of food supply, and its relation to the fishery, by R. E. Richardson. 5:416-41S.

\section{5}

Land and fresh-water Mollusea of the Dutch Leeward Islands, by H. B. Baker. 6:193. Conditions under which Goniobasis livescene oceurs in the island region of Lake Erie, by F. H. Krecker. $6: 320$.

1926

Changes in the small bottom fauna of Peoria Lake, 1920 and 1922, by R. E. Richardson. $7: 229-230$.

Illinois River bottom fauna in 1923, by R. E. Richardson. $7: 230$. 
THE MOLLUSCAN FAMILY PLANORBIDAE

\author{
PART I \\ CLASSIFICATION AND GENERAL MORPHOLOGY
}



I.

\section{GENERAL MORPHOLOGY}

\section{A. EXTERNAL APPEARANCE OF THE ANIMAL}

$\mathrm{C}$ ONTRARY TO GENERAL CUSTOM, the characteristies of the animal and its gross anatomy will be considered before taking up the shell and its rariations. This procedure seems more logical since it is the animal which secretes and builds up the shell or ealcareous covering (sce plate 70, fig. 1).

The head and foot protrude from the shell and bear several important organs. The foot is long and variably narrow, broadly rounded in front, and usually tapering to a point behind. There is a large velar area above and in front of the foot which is retained from the embryonic animal, as in Lymnaea, and bears the head, eyes, and tentaeles. This relum is broad and short and is capable of great extension and retraction; it is usually somewhat semieireular in shape.

The tentacles are very long and filiform, varying from one-half to the whole length of the foot, and are placed at about the junction of the relum with the foot. The eyes are placed on swellings at the inner base of the tentacles. The mantle collar does not extend beyond the edge of the aperture of the shell. The texture of the foot is smooth, not granular as in some of the land snails, and there are no grooves on the body, the animals resembling the Lymmaeas in this respect.

The Planorbidae differ from the related family Lymnaeidae in having certain of the organs on the left side (sinistral), the organs in Lymnaeidae being on the right side (dextral). In this respeet the Planorbidae resemble the families Plyysidae and Bulinidae. The tentacles of the Planorbidae, Physidae, and Bulinidae are also similar and differ from the Lrmnaeidae and Ancyliclae, in which the tentacles are flattened and triangular.

The breathing organ of the Planorbidae, a modified lung as in the family Lymmaeidae, is supplemented by a prolongation of the anal region (auriform lobe), ealled the pseudobranch or false gill, which may take over the function of breathing when the animal is submerged and can not obtain free air. This organ is highly vascular, many blood ressels entering it from the lower part of the lung carity. It is comparatively a recent organ, being post-natal in origin, not having been observed in embryological development.

The pseudobranch raries greatly in shape, being long and narrow, wide, leaf-like, or rounded in different genera. It always bears a portion of the rectum and the anus opens at the upper right side. There is usually a ridge. more or less heavy and clistinet, which begins on the upper part of the rectum and ends in the middle or at the base of the pseudobranch. The variations of the pseudobranch are shown on the plates illustrating the anatomy of each genus. A siphon-like extension of the mantle, called the pneumostome or respiratory opening, which may be greatly expanded, provides a tube-like conduit for free air to reach the lung. The pseurlobranch is on the left side of the body and the pneumostome is to the right of this organ nearer the median line of the neck. 
The genital outlets are on the left side of the neck, the male opening just behind the left tentacle and the female opening a short distance behind the male opening in the side of the neck. In many individuals the penial complex has been observed protruding from the male opening (plate 29 , figs. $6,7,11,12)$, the animal having been killed while in breeding condition. That self-impregnation of the female system by sperm from the extended penial complex is possible is easily believed when the closeness of the two sex outlets is observed.

The body above the foot may be flatly rounded or it may be rounded above and flattened on both sides of the foot (plate 70, fig. 10). Good figures of the animal of Tropicorbis are shown on plate 78 .

The color of the animal differs in the various genera. Mostly it is bluish-slate or blackish, grayish, or brownish, the color being lighter on the base of the foot and on the tentacles. In some species the color is yellowish. There are often flecks or spots of white on the foot and tentacles. The mantle, especially over the lung and kidney, is in many groups heavily blotched with black or brown.

The shell may be carried perpendicularly, as in Helisoma (plate 70, fig. 7), or it may lean to the left side, eausing the shell to be pscudodextral or ultradextral, as in Gyraulus and Menetus (plate 70, fig. 9).

\section{B. GENERAL INTERNAL ANATOMY}

The internal anatomy includes the following systems: Reproduetive, Digestive, Respiratory, Renal, Circulatory, Museular, and Nervous. The most important internal strueture for classification purposes is the reproduetive system and this will be first eonsidered.

\section{[a] The Reproductive System}

Like other Basommatophora, the Planorbidae are hermaphroditic with the organs of the two sexes mostly separated. The different organs may be tabulated as follows:

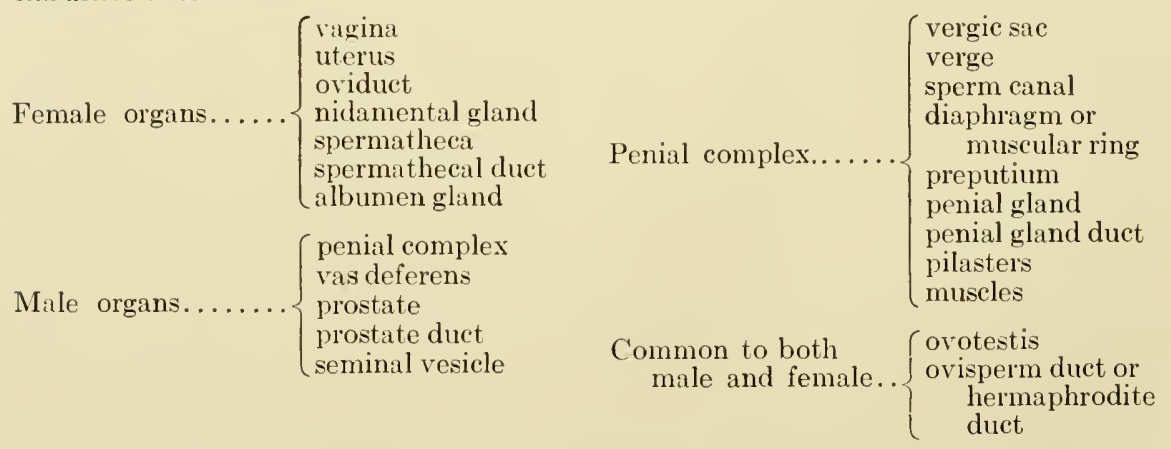

Male Organs. External form. In the natural position the penial complex lies over the vagina and uterus (plate 39 , fig. 3 ). When pulled away from this position its form is seen to be more or less cylindrical and to consist of a large bulbous lower portion, preputium (PR) and a smaller pyriform portion, the vergic sac (VS, plate 24, fig. 11). A narrow tube, the vas deferens (VD) is inserted at the summit of the vergic sac. This descends to 
near the male opening where it is eoneealed in the muscular tissue of the neck of the animal and appears again near the female opening (plate 24 , fig. 15). In some species the vas deferens is enlarged as it enter the vergic sac, the enlargenent being similar to the epiphallus of the land snails pliate 39, fig. 7, Menetus).

In one group of species (the Helisomatinae) there is usually a duct (penial gland duet, plate 24 , fig. 11 , DC) which normally lies coiled at a point between the vergie sac and the preputium (plate 27, fig. 9, DCO). This may be very long, as in Helisoma trivolits (plate 24. fig. 11) or short, as in Helisoma anceps (plate 23, fig. 3, DC). In another subfamily (Planorbinace) there is no penial gland duet exeept in two or three genera.

There are one or two retractor museles of the penial complex (plate 24 , fig. 11, RM ; pilate 39, fig. 9, RM ; plate 34, fig. 2 ) and a number of muscles believed to be supporting museles to retain the penial complex in position. The retrictor museles enter the rolumellar musele but the supporting muscles are attached to the museular wall of the forepart of the body. The supporting museles may in a measure perform the office of additional retractor muscles in some genera, especially in helping to retract the preputium after eversion. There do not appear to be any protractor museles; the penial eomplex becomes turgid by blood pressure.

The penial complex assumes many shapes in the genera belonging to the subfamily Helisomatinae. The preputium may be pushed upward and the rergie sac may oceupy a position on the side of the preputium as in Helisoma campanulatum (plate 27, figs. 5-8).

The vas deferens is continued near the female complex and borders the uterus and oviduet where it is a small tube (plate 24 , fig. 15 , Helisoma trivolvis). Just above the spermatheea the prostate appears. This organ varies greatly in the different genera. In Helisoma (plate 24, fig. 15, PRS) it is somewhat elongated and fan-shaped and the compound diverticula empty directly into the sperm duct along a very small portion of that tube. A cross section of the prostate in Helisoma trivolvis illustrates this condition (plate 24, fig. 13 ; see also plate 27 , figs. 4 and 12 , eross sections of Helisoma campanulatum). The section is seen to be distinctly fanshaped. In some other genera the prostate duet is separated from the sperm duet and ras deferens and the prostate is greatly lengthened. The prostate is composed of many or few diverticula arranged in a single series, each diverticulum being attached to and emptying into the separate prostate duct, which in turn empties into the vas deferens below the prostate (plate 14 , figs. 7,9 ; plate 1 , figs. 1,7 ).

Beyond the prostate the vas deferens is continued as a somewhat larger tube, the sperm duet (plate 27, fig. 14 , SPD; plate 24 , fig. 15). At its distal end the sperm duct unites with the oviduet to form the ovisperm duct or hermaphrodite duct (plate 27 , fig. 14 ; plate 34 , fig. 6 ).

About midway of the ovisperm duct is a glandular enlargement which has been called the seminal resicle (ST). Many students of both freshwater and land pulmonates simply eall this region an enlargement of the ovisperm duet, but it is distinetly glandular and different from the orisperm duct in structure. It also oecupies the position above the prostate. where it lies in other animals. It is recognized as the seminal vesiele by Simroth (1912, p. 501) and by Larambergue (1939, p. 94). Taylor (1900, p. 359) calls the small sac-like organ into which the duct of the albumen 
gland enters, the seminal vesicle, but as this organ is an adjunet of the male system in all animals it could scarcely be located in an organ of the female system. The swelling near the albumen gland is the carrefour. The seminal vesicle is variable in form in the different species and genera and provides another feature for classifieation purposes tsee plate 35 , fig. 5 , Carinifex jacksonensis; plate 1, fig. 1, Planorbis planorbis; plate 14, fig. 7 , Gyraulus albus).

Female Organs. The ragina (VG), nsually a thick walled, wide tube, passes imperceptibly into the uterus (U) which is usually much enlarged. A large saceulated body, the nidamental gland (NG, sometimes ealled egg gland) follows the uterus and is usually placed over the uterus and the oviduct. The oviduet (OD) lies back of the gland and is much narrowed as it passes backward to join the ovisperm duet. The method of junetion of the oviduct and sperm duct with the ovisperm duct varies in different genera.

The albumen gland (AL) is a large, more or less elongated organ, eomposed of many small alveoli. In its natural position it lies over the stomach and a loop of the intestine passes under it causing a chamnel to be formed on the under side of the albumen gland (plate 38, fig. 9, Wenetus opercularis; plate 15, fig. 1. Gyraulus hirsutus). The organic relations between the albumen gland and the oviduct are somewhat complieated. A small duet extends from the albumen gland and enters a large bulbous swelling which is attached to the end of the oviduct before that organ combines with the sperm duet to form the ovisperm duet. This gland or bulb is the earrefour which reeeives the products of the albumen gland and from which they enter the oriduct see plate 34 , fig. 6 , Carinifex ponsonbyi; plate 35 , figs. 6, 7, Carinifex jacksonensis). Taylor (1900, p. 359) erroneously ealls the carrefour the seminal vesicle.

The spermatheca or receptaculum seminis (S) is a bulbous or pearshaped organ with a narrow durt of variable length which enters the vagina at its jumetion with the uterus. Its function is said to be that of receiving the sperm (in the form of a spermatophore) during copulation and to store it safely until the eggs descend from the ovotestis, at which time they are fertilized by the stored sperm. The vagina is usually very short but may be of consiclerable length in some species.

Organs Common to Both Systems. The ovotestis (OT) is embedded in the liver and fills about one whorl of the shell. It varies in form much as cloes the prostate, the two organs being more or less synehronous in this respect, a valuable feature in classification. In the Helisomatinae it is many-lobed, the diverticula branching fan-wise from the ovisperm duct (plate 27, fig. 4, Helisoma campanulatum; plate 34, fig. 9, Carinifex ponsonbyi). In the Planorbinae and Segmentininae the divertieula are in pairs; the two divertieula are attached direetly to the ovisperm duct plate 16, fig. 9, Gyraulus deflectus obliquus). During the breeding season the diverticula may be filled with both ova and sperm, the ova either ripe for expulsion or dereloping (plate 10, fig. 2, OT, Drepanotrema hoffmani). The orisperm duct is a small tube of variable length, enlarged near the middle to form the seminal vesicle.

Both ova and sperm are produced in the same divertieulum. They are said to arise simultaneously from indifferent epithelial substance and may 
be found developing together in a single diverticulum (see Crabb, 1927, 1). 75). It is thought by most malacologists that the spermatozoa ripen first, descend during eopulation, and are stored in the spermatheea of the fenale system until the ova ripen and deseend through the oriduet, and that fertilization occurs when the ova and sperm meet in the lower part of the uterus or vagina, just before the depositing of the egg capsule. Some retologists declare that fertilization occurs in the orotestis diverticulum and that the fertilized egg descends and is deposited without the neecsity for copulation. See Clappl 1927 for a discussion of this subject. Typical eupyrene spernatozoa and nueleated ovum of cryraulus circumstriatus (Tryon) are shown on plate 52, figs. 14-16.

The Penial Complex. The male organ, which I have called the penial complex, contains a number of features which are of great value in systematic diagnosis. The whole organ is divisible into two parts, a lower swollen or bulbous portion called the preputium (PR) and an upper portion ealled the vergie sae (VS). The latter contains the penis proper or verge (V). which may be short and fat (plate 1, fig. 5, Plunorbis planorbis or very long and narrow (plate 10, fig. 6, Dreparotrema hoffmani). All grades of length and diameter between these extremes are to be found in the different genera.

The rerge may be modified at its extremity by the presence of a daggerlike object called a stylet (plate 16, fig. 6. s'i Giyraulus deflectus obliqums: plate 14, fig. 1 and fig. 6 (ryroulus albus). In these examples the outlet canal for the passage of the spermatozoa is at the side. In other genera there may be a fleshy papilla or appendage at the end of the verge (PA) with the outlet of the canal in the middle at the base of the papilla (plate 2, figs. 5, 6, segmentina nitida). In still other genera the temination of the rerge is simply rounded with the eanal outlet in the center (plate 38 , fig. 15 , Menetus cooperi calioglyptus). Other slight modifications are found in some genera.

Between the vergic sac and the preputium there is an organ which I have ealled the diaphragm (D). This is a muscular ring which separates the two parts of the penial complex. This may be a simple ring with a central perforation (plate 39, fig. 7, Wenetus cooperi) or it may be a dependent papilla (plate 23, fig. 6, Helisoma anceps: plate 24, fig. 10, Hclisoma trivolvis; plate 16, fig. 5, Gyraulus deflectus obliquus). The preputium always has several vertical ridges on the inside ealled pilasters (PL) which may serve to guide the verge or the penial gland during protrusion.

In 1926 (Trans. Wis. Acad., V. 22, pp. 200, 201) the writer called attention to a peculiar gland found in the preputiun of the genus Helisoma. Subsequent study has shown that this organ is found in several other groups or genera of American, European, and Asiatie planorbids. This gland is of variable shape, prriform, rounded, or elongated tplate 23, fig. 2, Helisoma anceps: plate 24 , figs. 8 and 14 , Helisoma trizolvis). In seetion it is seen to be eup-shaped, to be lined on the sides with folds and to have many small folds in the bottom of the eup. The gland is attached to the inner wall of the preputiun either midway between the male opening and the muscular ring (diaphragm), or somewhat nearer this ring in some species. 
From the base of the eup, and piercing the integument of the preputium, is a duet of variable length (DC), which, if long, is folded on the outsicle of the preputium (plate 27, fig. 9, Helisoma campanulatum); or. if short, simply lies on the surface of the preputium (plate 23, fig. 2, Helisoma anceps). When coiled on the outside of the preputium it is bound to that organ by short museles. Sections through the cup are shown on plate 23 , fig. 1 , plate 24 , fig. 1 , and plate 27 , fig. 1 . The duet terminates at the muscular ring or diaphragm (D), pierees the wall of the lower part of the vergic sac, and terminates just above the ring (plate 23, fig. 6 . Helisoma anceps; plate 24. fig. 10. Helisoma trivolvis), or in a groove in the ring iplate 36, fig. 9, Parapholyx effusai).

The function of the penial gland is at present insufficiently known. It was once thought by the writer to be connected with the formation of the spermatophore and was called the spermatophore gland (Baker, 1931. p. 581), but this belief scarcely agrees with the structure of the gland. In section this organ is seen to have two parts, each of which may have a different function. In Helisoma tricolvis (plate 24, fig. 4) the gland shows a large cup-shaped eavity, the walls of which are lined with vertical folds (GF). The bottom of this cup is.lined with folds laid crosswise. The long duct begins at the bottom of the cup and terminates in the rergic space (DC) of the rergic sac (TS) just above the muscular ring or diaphragm (D).

In some species, as Helisoma duryi and its varieties, the duct begins in a small cavity or eup at the end of the gland (plate 33, figs. 3,10 ), the walls of which have vertical folds. The larger cup-shaped eavity has no connection with the smaller earity or its cluct. In some species, notably in the genus Menetus, there is no external duct, comection with the vergie space being effected by an open channel (plate 42, figs. 3, 4). Another group of Menetus has a short duct on the inside of the preputium (plate 39, fig. 7). In Menetus and some other groups there is a small channel in the muscular ring (plate 39, fig. 7. D). Helisoma anceps shows this feature well (plate 23, figs. 2, 6). Parapholy $x$ effusa lilamathensis (plate 36, figs. 9. 10 ) also shows the eanal in the muscular ring.

It appears possible that one of the functions of the penial gland might be to expand the opening in the muscular ring or diaphragm whieh is normally nearly or quite elosed, and prepare it for the protrusion of the verge. The penial gland duct possibly earries a fluid, secreted by the vertieal folds in the gland cup, to the diaphragm to facilitate the passage of the rerge.

But there is another function of the gland. It has been observed that during copulation not only is the verge extruded from the male opening, but also the whole penial gland. This has been observed in many species of Helisoma ( $H$. duryi normale, plate 33 , fig. $16 ; H$. trivoliz lentum, plate 29 , figs. 7, 11, 12; Promenetus exacuous, plate 41, fig. 9). In all species of Planorbidae the verge is extrucled during eopulation. In a specimen of Drepanotrema lucidum examined (plate 11, figs. 1, 2, 6, 7) the verge and penial gland protruded together from the male opening. It is probable that the gland portion with the cup-like cavity lined with vertieal folds is an excitatory organ or sarcobelum, for in the species possessing this gland there is no special apparatus for this purpose such as oecurs in other speeies 
which have a horny stylet or fleshy papilla at the end of the rerge (Gyraulus, Anisus, and other genera).

Another feature observed in connection with the penial gland is that the penial complex is often seen in a bilobed condition, the gland being pusbed upward in the preputium causing the vergic sac to appear as though attached to the side of the preputimm. This condition oecurs mostly in Helisoma (plate 25, figs. 1, 6, 7, 9; plate 24. figs. 1, 2). The evolution of this feature was observed in specimens of Helisoma campamulatum and is show on plate 27 , fig. 7 being the normal form and figs. 6,5 , and 8 showing the gradual change to the bilobed condition.

Much remains to be learned about the function of the penial gland. Observations of the living snail in aquaria should help to solve some of the questions. It may be observed, howerer, that this is not so easily accomplished as might be supposerl. Nore than a dozen aquaria were kept under observation by the writer for several years, and while the animals were seen in apparent coitus on sereral occasions, the protrusion of the gland was not seen. Perhaps histological studies would help, especially before and after breeding. The subject is worthy of a doctor's thesis.

As was recorded in the study of the family Lymnaeidae (Baker, 1911), there is great variation in the form of the genitalia of the genera of the family Planorbidae. As in the Lymnaeidae, also, this modification oceurs mostly in the male organs, principally the penial complex, but includes also the prostate and seminal vesicle. The female organs are uniform in position and shape, only the spermatheea and its luet vary in form and length to any degree. The male organs, therefore, afford useful features upon which to base a natural classification of the family, since the characters of the different groups are constant and uniform.

\section{[b] The Digestive System}

The digestive system of the Planorbiclae is similar in many respects to that of the family Lymnacidae. The system naturally divides into three parts, the first consisting of the buceal sac, the ocsophagus, and the salivary glands, the second part the region of the stomach with the liver connections, and the third part the intestine and rectum (see fig. 1, plate 48).

The buecal sac is usually pear-shaped, the oesophagus entering it at the upper middle portion. There are retractor and protractor muscles and nerves received from the buceal ganglia. The salivary glands are paired, a duct entering the buceal sac on each side near the oesophageal connection. The salivary glands, usually erlindrieal and elongated, are composed of many small lobules. The two glands are joined behind and form a continuous loop or ring. These organs are very uniform in the different speeies of the family (see plate 70 , figs. 12,13 ). The oesophagus is usually rather long (about one-fourth as long as the intestine), beginning as a tube of small diameter and enlarging as it approaches the stomach region.

The stomach is a large muscular body composed of three parts, first the crop, which is an enlarged portion of the oesophagus, then the gizzard, which is an indistinctly bilobed body of large diameter, and third the pyloris, or opening into the intestine. The gizzard is not as distinetly bilobed as in Lymnaea but is of the same nature. When opened it is found 
to contain small particles of siliccous matter, ericlently sand taken in with the food to serve for the breaking up of the ingested food.

On the under side of the pyloris, near the duct of the liver, there is a finger-like process or blind sac which appears to be the stylotheca containing the crystalline style. This blind sac is present in all species of the family examined. Internally the sac contained a gelatinous substance or was empty. The liver or digestive gland covers the posterior part of the stomach region in its natural position. It has two unequal lobes which form the posterior part of the animal and in which the orotestis is concealed. The liver is composed of a great number of small lobules, more or less digitiform. It is well supplied with blood ressels which form a plexus on and in the organ. A large duct enters the prloric portion of the stonach at the point of junction with the blind sac.

The intestine is very long. It bends around the stomach from the end of the pyloris and passes backward for a distance. It then forms a single loop which bends forward and extends to the fore part of the animal on the left side (the right side in the Lrmmacidae). The rectum, the greatly enlarged portion of the intestine, supports a central ridge or erest on the upper side which extends to and over the pseudobranch. The anal opening is always near this ridge on the pseudobranch, to the right and above this organ.

Tariation in the digestive system is noted only in the form of the stomach region, short and rotund in some species (plate 48, fig. 1, Helisoma trivoleis) or elongated and narrow in other species rplate 48, fig. 8 , Bathyomphalus contortus). The loop of the intestine sharply borters the stomach in some species (fig. 1) though in some species it extends forward without a loop (fig. 8).

\section{[1] The Jaw}

The mouth of the Planorbidae is provided with two important nrgans which afford characteristics for classification, the jaw and the radula. The horny jaw lies in the upper part of the mouth at the fore end of the buceal sac (plate 70, fig. 13). As in Lymnaea, the mouth is somewhat T-shaped in repose. In the upper part of the $T$ lies the superior jaw, which is wide and low, of a bromish color, striated rertically on its front part, the striations producing a saw-like condition on its lower, cutting edge (plate 49, fig. 1, Helisoma anceps). The lateral jaws, two narrow, brown, horny ribbons, emargin the lips or sides of the mouth. They are connected with the lateral margins of the superior jaw by a narrow projection from the upper part of the lateral jaws. These side jaws form a question-mark figure, as will be noted in the figures on plate 70. The jaws, superior and lateral, are attached to a cartilage which in turn is attached to the roof of the mouth. The jaws are moved by several distinct muscles.

The jaws of the Planorbidae fall into two principal types or variations. The most conmon is the group described above, with large superior jaw and two smaller lateral jars. Another type is horseshoe-shaped and in this there is but one division which appears to represent the fusion of the lateral and superior jaws of the first type. The striations of the superior jaw of the first group become separate vertical plates in the second group, producing a segmented jaw. This segmentation extends to the lower part 
of the side of the horseshoe, showing that the lateral jaws are included in the segmentation (see plate 50, fig. 16, Gyraulus parrus).

A peculiar jaw, not included in the usual segmented type of the family, is that of Carinifex in which the jaw is bow-shaped (or roundly horseshoeshaped and is composed of many narrow plates fastened to a heary cartilage (plate 49, fig. 19, Carinife $x$ ponsonbyi; fig. 18, Carimifex jacksonchsis). Although belonging to the subfamily Helisomatinae the jaw is praetieally of the Planorbinae type. Figure 17 on plate 49 shows the latrge size of the eartilage in this genus (C. jacksonensis).

This type of segmented jaw is suggestive of the polyplacognath group of land snails. It is said to be a very aneient type of jaw which would seem to indieate that the Planorbinae group of the family is more ancient than the Helisomatinae group (except Carimifex which has the prinitive form of jaw). The marginals of the radula also indicate a primitire form of radula.

\section{[2] The Radula}

The radula of the Planorbidac is ribbon-like as in the Lrmmaeirlae. It lies on a subquadrate cartilage near the rear end of the buceal sac. The front end of the radula extends toward the moutl of the snail and the rear end is bent downward into a radular sae which forms a rounded protrusion or bump at the back of the buecal sac (see plate 70 , figs. 12,13 ). The radula grows forward from this sae as the functional teeth at the front end of the ribbon become worn by use. There are protractor and retractor muscles which pull the radula backward and forward, over its cartilage, during the act of eutting up food particles. In use, the rarlula is moved from behind forward, like the tongue of a cat lapping food from a plate. as described by Sterki many years ago.

The lingual ribbon of the Planorbidae earries many teeth in transverse rows as in the family Lymnaeidae. There may be as many as 200 rows with 85 teeth in a row or a total of 17,000 teeth in one ribbon. The central tooth is always bicuspicl and in some groups (as in Drepanotrema) there are one or more accessory eusps on either side of the rentral eusps. There is a series of duplicating teeth on each side of the central tooth. This row is divisible, as in the Ixmmaeidae, into lateral, intermediate, and marginal teeth. The lateral tecth are usually tricuspid and comprise an inner, short entocone, a large median mesocone, and a smaller outer ectocone see plate 57, fig. 1). The cusps are usually dagger-like and may be wide or narrow. The intermediates are those teeth between the typical lateral and marginal teeth which show certain modifications, as splitting of the ectocone or entocone into smaller cusps. The marginals are usually somewhat claw-like with a variable number of small eusps. The mesocone usually persists in the earlier marginal teeth and may be recognized by its large size and central position.

The law of mesometamorphosis applies to the Planorbidae as well as to the Lymnaeidae. As stated by Pilsbry this law is as follows:

All modifications of the teeth proceed from the median line of the radula outwards toward the edges, the outer marginal teeth being the last to be modified (Guide to Study of Helices, p. xiii).

The marginals of the Planorbidae are of the same primitive type as are those of the Lymnaeidae, showing a close relationship between these two 
families and also their common descent from the tectibranchiate stock of marine mollusks. The lateral teeth of the Planorbidae show a wider degree of variation than do the lateral teeth of the Lymnaeidae, inclicating, perhaps, that the Planorbidae may be somewhat younger in development.

In studying the teeth of the Planorbidae it must be remembered that only the unworn teeth show the true characteristics of the radula. Also the teeth must be in their natural position on the radula ribbon and not tilted or otherwise disturbed.

The Planorbidae are divisible into two groups by the form of the marginal teeth. One group, including the genus Helisoma and other divisions of the subfamily Helisomatinae, have long and narrow reflections reaching far below the base of attachment and with the distal end and the outer margin multiserrate (see plate 57). The other group, including the genus Planorbis and other divisions of the subfamily Planorbinae as well as some of the subfamily Segmentininae, have short, wicte reflections high up on the base of attachment and only a few serrations or cusps on the lower margins (see plate 69 ).

The lateral teeth are very uniform in both groups, these being mostly tricuspid, the cusps rounded or sharp and dagger-like. In several groups (as Drepanotrema and Segmentina) the laterals are modified by the addition of several cusps, causing the teeth to be 6 or 7 cuspid. These exceptions appear to be due to a splitting of the three cusps of the normal lateral teeth (entocone, mesocone, ectocone) foumd in the majority of planorbid genera. As with the other organs, the radulae offer sound criteria for classification purposes.

\section{[c] The Renal System}

The kidney or renal organ (nephridium) of the fanily Planorbidae is a large and conspicuous part of the snail's anatomy, occupying a considerable portion of the body whorl of the animal. It lies to the left of the lung cavity, the genitalia being between the kidney and the ureter (see plate 14, fig. 4, U, NG). Viewed from the rentral side, the kirlney consists of two parts, a small upper saccular portion with the pericardium at the right (SK) and an elongated lower portion (TK). A section through the midclle of this portion of the kidney (plate 44, fig. 9) shows a central tube or lumen flanked on each side by a large vein, the pulmonary vein on the right side (AP) and the renal vein on the left side (RA). The central tube, the tubular portion of the kidney, is regularly marked by internal septa which project into the lumen for a greater or less distance. The tubular portion is surrounded by thick walls of spongy tissue, the most conspicuous part being a distinet ridge (RK). To the left of this ridge (in the section) there is another conspicuous ridge on the roof of the mantle.

At the lower end of the tubular portion is the short ureter (UR). This is a small tube which turns to the left, usually more or less upward, and discharges into the mantle cavity. The figures on plates 44 to 47 show the various forms of ureter and the relationships of the different parts of the kidney. In 1940, Mattox, working on another group of snails, pointed out the fact that the kidney may reflect specific character's.

A series of sections through the kidney of Australorbis glabratus (plate 45 , figs. 7 to 11 ) show the internal form of the kidney at different points in its length. In fig. 1, plate 45 , an arrow indicates the place where each 
section is made. Figure $7(\mathrm{E})$ is a section through the sacculate part of the kidney below the perieardium, and shows the lumen partly filled with folds extending from the walls of the kidney. In fig. 8 (D) the section shows the tubular portion of the kidney with a few folds extending from the walls, also the large pulmonary vein at the right and the smaller renal rein at the left. In figs. 9 and $10^{\circ}(\mathrm{C}, \mathrm{B})$ the same features are shown. In fig. 11, near the lower part (A), the lidney is flattened and broadened and the veins are smaller. All figures show the rariation in the form of the ridge in different portions of the kidney. The blood ressels (reins) lie in close proximity to the tubular part of the kidney and pick up the blood to be earried to the heart.

The folds in the tubular portion of the kidney are metaneric in their presenee and one section may pass through a portion of the kidney where these are present, or it may pass between two sets of folds, as shown in figs. 16 and 17 on plate 45 , as well as on other plates. The ridge on the kidney is mostly confined to members of the subfamily Helisomatinae and offers a valuable eriterion for the separation of this planorbid group. The Planorbinae are mostly without this ridge.

The ureter of the Planorbidae is described as straight, but no exit of this nature was found in any species exanined. All had a short ureter, partly reflexed, as shown in the figures on the plates.

\section{[d] The Circulatory System}

The circulatory system of the Planorbidae is similar to that of the Lymnaeidae and other Basommatophorous Pulmonata. The heart lies to the right of the kidney (instearl of to the left as in Lymnaea) and consists of a ventricle and an auricle enclosed in an oval pericardium (plate 44, fig. 2 , PC, $A U, Y T)$. The aorta $(\mathrm{AO})$ extends backward from the rentricle and divides into two branches or arteries, the visceral artery which supplies the digestive. genital, and other systems in the posterior part of the body. and the cephalic artery which bends around and forward, earrying blood to the organs in the head, foot, ete. These arteries branch frequently, the branches becoming smaller, and terminate in contact with the venous system either by small arterioles or through lacunae or blood sinuses which connect the arterial system with the renous systen.

The renous system consists of blood ressels which eonver the blood back to the heart after eirculation through the kidneys, lung, and other parts of the srstem. A large branchial vein borders the kidney on the right side, earrying blood to the auricle. A large renal vein also borders the left side of the kidney, entering the saccular portion (see plate 44, fig. 2. AP, RA). Tenous sinuses are present and store the blood after circulation to be carrier to the renal and respiratory systems for purification.

In the Planorbidae the blood (haemolymph) contains a substance (haemoglobin) which gives it a pinkish or red color. This is an active substance occurring abundantly in the respiratory system and differs from the bluish blood (haemocyanin) which oceurs in most mollusks. Its presence in Planorbis is said to be associated with the poorly oxygenated habitat occupied by most species of this group in stagnant pools or lakes and ponds poorly supplied with oxygen. This statement, however, is open to question, since many species of the Planorbidae live in habitats abundantly 
supplied with oxygen, in company with Lymnacas and other fresh water pulmonates. The pseudobranch is probably helpful in supplying oxygen to the blood, as it is highly vascular (plate 14 , fig. $4, \mathrm{P}$ ).

\section{[e] The Respiratory System}

Respiration in the Planorbidae is effected as in the Lymnaeidae and other aquatic pulmonate mollusks. Free air is admitted into a large mantle carity abundantly lined with blood ressels forming a plexus on the dorsal wall of the mantle cavity. This lung cavity lies on the right side of the mollusk, next to the kidney, and is bordered on the left by the pulmonary vein (plate 44 , fig. 2 , L). The lung eavity is placed on the right side of the body in sinistral species (Planorbis, Physa) but on the left side in dextral species (Lymnaea).

In the Planorbidae the presence of the secondary branchium, the pseudobranch, enables the animal to respire without eoming to the surface. This organ is of various shapes, but is always an outgrowth of the branchial cavity walls and lies to the left of the pulmonary siphon to which it is attached (plate 14 , figs. 3,4 , Pl. It may be a simple rounded fold or it may be flat with a distinet ridge down its center. It is abundantly supplied with a plexus of blood ressels which absorb oxygen from the water.

The reetum passes through the pseutobranch and its outlet (anus, A) is usually above and about at the middle of the pseudobranch. The rectum usually has a large erest or ridge on its upper surface which diminishes in size at the lower part where it extends over and to the edge of the pseudobranch (see plate 25, fig. 3, Helisoma pilsbryi; plate 28, fig. 8, Helisoma scalare; plate 35, fig. 4, Carinifex jachsonensis).

The breathing orifice or pulmonary siphon (pneumostome) is an outgrowth of the mantle which is eapable of forming a tubular conduit or siphon through which free air may be admitted to the lung (see the plates mentioned above). The respiratory, renal, and circulatory systems are intimately comneted and should be considered together to understand the conditions governing the respiration and blood circulation of the animal.

\section{[f] The Nervous System}

The nervous system of the family Planorbidae differs little from that of the family Lymnaeidae (see Baker, 1911, plates 1 and 5). A nerve ring surrounds the oesophagus posterior to the buceal sac (plate 48, fig. 18). There are two cerebral ganglia above the oesophagus (CG). Below the oesophagus there are two pectal ganglia (PG), two buceal ganglia (BG), two visceral ganglia, and a single abdominal ganglion. Two pleural ganglia are connected with the risceral, pedal, and ablominal ganglia. The left cerebral ganglion sends nerves to the penial complex (plate 48, fig. 17, Helisoma anceps), which divide to send branches to the vergic sae, penial gland duct region, and retractor muscle, as well as to other parts of this complex.

In the Planorbidae these nerves are sent off from the left instead of the right ganglia, becanse the group is sinistral. In the Lymnaeidae, a dextral group, the nerves arise from the right ganglia (see Baker, 1911, plate 5). 


\section{[g] The Muscular System}

The muscular system of the family Planorbiclae does not differ from that of the family Lymnaeidae except in positions due to the sinistrality of the animal. The most important muscles for elassification purposes are those of the male generative system.

\section{THE SHELL}

The shells of the Planorbidae are mostly orb-shaped, wheel-shaped, or dise-shaped, rarely becoming a conical spiral as in Lymnaea and Physa. Several physoid types oceur, as the Helisoma scalare of Florida. Such types sometimes occur in other species of the family as abnormal or pathologie forms, and have been noted in the genera Helisoma and Carinifex. Sealariform individuals may also oecur in any speeies and have been noted particularly in the smaller species of the genus Gyraulus.

The shell may be elosely coiled, like a wateh spring, or loosely coiled. and of few or many whorls. It may be so flat that one wonders how an animal ean find enough room to function in so small a space. as Drepanotrema cultratum, or it may be almost globose, as Helisoma pilsbryi. It may be as thin as paper or thick and very solid.

The shells of the larger species, especially in Helisoma, are earried ahmost perpendieularly as in Helisoma trivoli is macrostomum (shown on plate 70, fig. 7), or it may lie almost flat as in Planorbula jentisi (shown on plate 70 , fig. 11 ). In all species of the family Planorbidae the genital organs are on the left side and the animal is sinistral. But the shells are not all strikingly sinistral. Such large groups as Helisoma, Planorbarines, and Indoplanorbis are obviously sinistral, usually exhibiting a distinet right and left side when in locomotion. But the smaller species are tipped to one side. to the left, and are apparently dextral and are usually described as pseudodextral or ultradextral. In such species the upper side (right) is umbilical and the lower side (left) is apical. These shells, while truly sinistral, appear as dextral. In most works on this family the shells have all been considered dextral and figurect as such. Quite a literature has developed in the controversy as to whether the shells of Planorbis are dextral or sinistral isee Baker, 1896. Jour. C'ineimnati soe. Nat. Hist., 19. 1. 451 .

In size the planorbids range from the tiny Armiger crista, less than $2 \mathrm{~mm}$. in diameter, to the large Helisoma trivolvis macrostomum, which attains a diameter of $30 \mathrm{~mm}$. The whorls may be rounded on the periphery or this region may be sharply earinated or squarely flattened. The lower (umbilical) surface may be so flattened that no umbilical opening is indieated, or it may be deeply indented forming a distinet umbilieus. Sutures may be deeply indented or seareely visible. The aperture is most frequently rounded, orate, or half-moon shaped. It may be armed with lamellae or entirely free from such obstructions. The outer lip may be thin and sharp or it may be strengthened by a heary ridge or callus. There may be, also, more or less of a callus on the parietal wall. As most species are planorboid in form there are fer modifications of the columella, as are found in the family Lymnaeidae. 
The sculpture of the planorbid shell consists mostly of growth lines which may be very fine and thread-like or coarse and rib-like. In some species there have been developed costae or ribs more or less erenly distributed. In a fer species the epidermis forms paper-like crests or frills, as in Helisoma anceps royalense. Spiral impressed lines are found in most of the species of the family. These are usually rather heary and conspicuous but in some species they are very fine. In a few species the spiral lines are very faint or absent, as in Menetus opercularis. Malleated individuals are comparatively rare in the Planorbidae although they are common in the Lrmnaeidae. The epidermis or periostracum of the planorbids is nsually rather thick and heary. In some groups the shell appears devoid of an epidermis, the surface being shining and waxy. The remarks on sculpture in the Lymnacidae Monograph (pp. 3, 4) apply equally well to the Planorbidae.

The color of the shells of the family Planorbidae is usually some varicty of horn color, light or dark. In some groups, as Australorbis, the color is rich brown or eliestnut. Some shells are light milky in color. A few species border on red, others are ashy. The range of color is about like that in the family Lymmaeidae, but there are no species known comparable to the greenish shell and purplish aperture of Bulimnea magasoma, the handsomest of the fresh water pulmonates. Zebra markings occur among the planorbids as among the lymmaeids. 
II.

\section{GENERAL ECOLOGY}

$\mathrm{E}$ COLOGY now has such a wide signifieance and includes so many diverse subjects that it is necessary to define what is embraced under this term in this chapter. It is here made to include everything that affects the animal either from extemal or internal sources, including such subjects as the habitat, climate, altitude, chemical conditions of the water body, pollution, parasites, relations in food chains, reprochuction, development, ete.

\section{GENERAL ENVIRONMENTAL CONDITIONS}

Representatives of the family Planorbidae may be found in almost any body of fresh water, from the largest lakes to the sumallest pools. Streams of all sizes harbor one or more species of the family. Certain groups, as Menetus, Planorbula, Tropicorbis, and some Gyraulus, are abundant in small pools which may become wholly or partially dry during dry seasons. Many of the large forms, such as Helisoma campanulatum, Helisoma corpulentum, Helisoma pilsbryi, and some varieties of Helisoma anceps, prefer larger bodies of water like the larger lakes. Helisoma trivolvis is common in small lakes or bays of larger lakes, in shallow areas where the shore is bordered by Typha and sedge. where food in the form of algae and other vegetation is abundant. In such habitats the snails may be seen with the foot attached to the under side of the surface film, the shell hanging downward, the animal busily eating such small organisms as may lie on the surface. In Floricta, members of the subgenus Seminolina live in limestone pools of limited size.

Almost all of the members of the family Planorbidae are littoral animals and are not usually found in water deeper than fifteen feet, the usual limit of rooted regetation in water bodies. The maximum numbers oceur in shallow areas not exceeding six feet in depth. A few inhabit deeper water and in the deep lakes of Europe and Asia, as lakes Genera. Constance, and Léman in Switzerland, Lake Balaton in Hungary, and Lake Baikal in Siberia, they may oceur in abysmal depths of from forty to 350 meters. In our own lakes. deep dredgings have produeed no members of the family Planorbiclae. The family is on the whole a distinctly shallowwater group.

The Planorbicke are able to withstand unfavorable features of their environment better than most groups of mollusks, owing to their ability to breathe free air. Thus water of some alkalinity and salinity, as well as water containing sewage. may be used by these animals successfully as habitats. The Lymnaeas also share this ability to live under unfarorable conditions. It has been observed, howerer, that chemicals and oil, also wood wastes from factories, are inimical to the Planorbiclae and Lymnaeiclae and none have been seen which could resist this deadly type of habitat. Clear, cold mountain streams, especially if rapid, contain no planorbids, and usually no other mollusks, as far as personal observations have indieated. Many such in New England have been examined and a few in Idlaho and Montana. 
Altitude does not seriously affect the distribution of the members of the family Planorbidae. In the Rocky Mountains they occur in lakes at altitudes of from 9,000 to 10,000 feet. Lake Titicaea, in Peru, which contains many mollusks, including a peculiar grouj of Planorbidae (Taphius) is at an altitude of 12,846 feet. The Swiss lakes are at comparatively high altitudes as are also some of the lakes of Asia which eontain mollusk faunas of some size.

Quite a literature has accumulated on the general ecology and particular habitat relationship of the Planorbidae and other fresh-water mollusks. The remarks on the lymnaeas in the 1911 monograph on that family may be consulted with adrantage. A number of special papers and books have been published which bear on this subject. These are listed in the bibliography and may be consulted uncler the following names: Adams, 1909; Baker, F. C., 1910, 1911, 1916, 1918, 1920, 1922, 1924 ; Dybowski, 1875; Forel, 1869, 1874; Lindholm, 1909, Taylor, J. W., 18941900.

\section{VARIATIONS IN DIFFERENT ENVIRONMENTS}

The planorhid snails do not exhibit as mueh variation due to differences in the environment as do the Lymmaeidae (see Baker, 1911, pp. 29-32). The shell aperture often increases in size in large lake localities where the animal is subject to heary ware action. This may be observed in Helisoma anceps percarinatum and in Helisoma anceps sayi which are lake dwellers in contrast with typical Helisoma anceps which is usually a river or creek inhabitant. Helisoma campanulatum darisi is a small pool or swamp dweller while typical Helisoma campamulatum is a lake inhabitant and usually las a larger, more expanded aperture. Some species of this family show preferences for particular types of liabitat. Thus Planorbula armigera is usually found in ephemeral pools or small bodies of water, or in protected places in larger ponds and lakes. Planorbula crassilabris may often be found on a lake shore fully exposed to the waves. Promenetus umbilicatellus is an inhabitant of ditehes, pools, and swampy places, while Promenetus exacuous is usually found in larger bodies of water.

Great variation is often seen in specimens of the same species from one habitat. Thus Helisoma duryi seminole, in Lake Eustis and Lake Griffin, Florida, varies from a typieal planorboid form to a distinet physoid form by the elongation of the spire. In Lake Titicaca, in Peru, Taphius andecolus exhibits many rariations in the form of the aperture, the whorls, and the condition of the umbilical region. In Carimifex the individual variations are numerous among specimens of one speeies from the same habitat. Among some of the species of the genus Australorbis of South America and the West Indies there is often great variation in the axial height of the shell.

These examples might be greatly multiplied but enough have been presented to show that variation is the rule among individuals of the family Planorbidae and that this variation may not be due alone to conditions of the enviromment but rather to the inherent 'law to vary' which is found in all living things. The family Planorbidae does not appear to offer as good a field for the distinguishing of the so-called habitat or ecological variations as does the family Lymnaeidae. 


\section{LOCOMOTION}

Locomotion in the family Planorbidae is accomplished by the same means as in the family Lrmmacidae (see Baker, 1911, p. 32). The method most usually observed is that of gliding. The planorbids have been observed to rise suddenly and descend abruptly, as do the lymmaeids, by varying the anount of air in or on the body or shell. The members of the family are usually very active, crawhing about on acuarium walls quite rapidly, eating everything in their path. In locomotion the planorbids resemble the physas more than the lymmaeids, the latter usually being rather sluggish in motion. Young and immature planorbids are usually very active, much more so than fully mature indiriduals.

\section{FOOD}

Like the lrmnaeids the food of the planorbids is largely regetal. Little is known, however, concerning the food supply of this family. They have been observed eating pond-lily leaves (prineipally Castalia). Potamogeton, both the large floating leaf species and the submerged leaf speeies, and algae of various kinds. Both old and young snails will eat avidly of the algal scum which collects on the glass sides of an aquarium. The radula can be plainly seen, the animal using it from behind forward as described by Dr. T. Sterki many years ago.

Stomachs and crops that have been opened and examined have usually contained a quantity of fine sand (especially in the erop) which probably helps in grinding the food before it enters the intestine. Ostracods (six in one specimen of Helisoma subcrenatum from Pass Lake, Fidalgo Island, Washington), distomids, vegetable fibers, and a quantity of flocculent undigested animal matter have been noted in the stomach. Specimens of Helisoma duryi seminole from Florida had the stomach and gizzard filled with small grains of sand and nothing else. Some planorbids are scavengers, though not to the extent observed among the lymnaeids. No eridenees have come under observation indicating that the group is carnivorous (see Baker, 1911, p. 42 for notes on the food of lymnaeas).

\section{FOOD FOR OTHER ANIMALS}

Together with other fresh-water mollusks, the family Planorbidae furnishes food for a large number of other forms of animal life. Chief among the animal groups feeding on mollusks are certain species of fish isee F. C. Baker, 1916). Fresh-water snails, including planorbids, have been found in the stomachs of the following food and game fish:

Whitefish (Coregonus clupeaformis (Mitchill))

Small Mouth Buffalo (Ictiobus bubalus (Raf.))

Common Sucker (Catostomus commersonii (Lacépède))

Yellow Bullhead (Ameiurus natalis (LeSueur))

Common Bullhead (Ameiurus nebulosus (LeSueur))

Freshwater Drum (Aplodinotus grunniens Raf.)

Pumpkinseed (Lepomis gibbosus (Linn.))

Bluegill (Lepomis macrochirus Raf.) 
Many smaller fish, not of direct value as food or game fish, are yet of great value as food for the larger food fish. Many of these include the planorbids and other fresh-water snails in their diet. Such small fish known to cat snails are:

Fresh Water Killy (Fundulus diaphanus (LeSueur))

Killifish (Fundulus dispar (Agussiz))

Viriparous Top Minnow (Gambusia affinis (Baird \& (iirard) )

Manitou Darter (Percina caprodes zebra (Agassiz))

Five species of the planorbids have been specifically identified in the stomach contents of fish. These are:

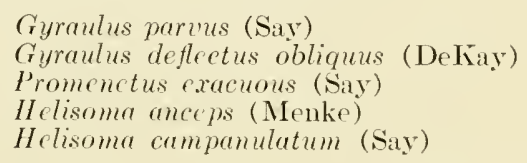

Many species of birds, especially water birds, consume some mollusks in their iliet. Ducks, such as the Lesser Scaup (Nyroca affinis (Evt.)) and others feeding in shallow water, eat fresh-water snails. The waders, such as the Tpland Plover (Bartramia longicauda (Bechst.)) and the Killdeer (Oxyechus vociferus (Linn.)), feed on snails. The Red-winged Blackbird (Agelaius phoeniceus (Limn.)) has been known to feed on a planorbid (probably a Gyraulus).

Other groups of animals which inclucle fresh-water snails in their diet are turtles, frogs, newts and salamanders, erayfish, lecehes, and dragonfly nymphs. It is quite probable that many other animals which frecuent fresh-water snail habitats feed on the smaller species or the young of larger species. The stomach contents of many fish and birds have been listed as simply snails or Planorbis without identification of the species involved. It is obvious that the planorbids, and other snails of the fresh waters, are a raluable food source for the larger animals.

\section{LENGTH OF LIFE}

The life span of the members of the family Planorbidae is not definitely known. Specimens of Helisoma trivolvis lentum were hatched in an aquarium and lived sixteen months. At this time they were about $8 \mathrm{~mm}$. in diameter and had four whorls. An adult lentum has five whorls and is about $20 \mathrm{~mm}$. in diameter. It appears possible that these specinens would have attained full maturity in another year, or two and a half years from time of hatching. Helisoma duryi normale has been hatched in an aquarium and has lived for over a year. An adult Planorbarius corneus the red snail) has been kept alive with goldfish for two years. Mature individuals of Helisoma trivolvis have remained alive for nearly two years in a wellbalanced aquarium.

Just how long any of the planorbids live in their natural habitat is not known, four or five years it is probable. The lymnacids are said to live for three or four years. Experiments with the larger snails of the family Planorbidae, Helisoma particularly, would be of value. 


\section{THE PLANORBIDAE AS HOSTS FOR PARASITIC WORMS}

The fanily Planorbidae furnishes some of the best examples of the rôle of snails in the life history of eertain trematode worms known as flukes. A group of worms known as blood flukes (Schistosoma) cause serions disturbances in man. Three speeies are known from different parts of the world. These parasites require a mollusk as the hust of the parthenogenetie generations of their life eyele. In this life cyele the schistosoma in the human host lays eggs which are roided in the faeces or the urine. Erentually the larvae in the eggs become clothed with a ciliated epithelimm, and. on coming into water, the eg shell bursts and the miracidium ereapes. whereupon it begins to swim about rapidly (Faust, 1932, p. 350).

These miracidia are adapted to specifie groups of snails. When in their swimming they reach the proximity of certain snails they show a specific response to that specics of mollusk, probably due to a mucous secretion of the animal. In most eases they readily attack, and, in the course of half an hour or an hour, penetrate the soft tissues of the snail. In certain rases of other trematodes (Clonorchis and Metagonimus), however, it is neeessary for the embryonated eggs to be swallowed by the snail, wherempon they hatch in the limen of the oesophagus, bore their way through the wall, and gradually migrate through lymph channels into the lymph spaces bathing the hepatic glands. In the meantime, they have metanorphosed into the simple saceulate sporoeysts. These first generation sporoeysts give rise to a parthogenetic progeny reither seeond generation sporoessts or rediae). From this seeond generation there develops (also parthogenetieally), a progeny of larrae known as eereariae. Thus, from the penetration of a single miracidium there may be developed as many as ten thousand or more cereariae. Then later, on reaching maturity, they erupt from the tissues of the snail, and, either by direet or indirect routes, produce infection in human or reservoir hosts (from Faust, 1932, pp. 350-351).

Although the three human species of blood flukes (Schistosoma) are closely related, they utilize entirely different speeies of mollusks for the parthenogenetie stages. Thus, Schistosoma haematobium, with a distribution in northern Afriea, the Congo Basin, the Sudan, Mesopotamia. Palestine. Sicily, Corsica, and possibly southem Franee, parasitizes speeies of the genera Bulimus and Physopsis. Schistosoma japonicum, with a distribution in China, Japan, Formosa, and the Philippine Islands, uses members of the genus Oncomelania.

The third species, Schistosoma mansoni, occurring in the same loealities in Africa as S. haematobium, is also found in northern South America and many of the West Indian islands whither it was brought from Africa by slaves during the days of the slave traffie. This speeies originally parasitized small planorbids belonging to the genus now known as Afroplanorbis. In the West Indies a genus of large snails known as Australorbis is parasitized by the Schistosoma mansoni, which has become a serious pest in these regions. A genus of smaller snails, Tropicorbis, related to the African group Afroplanorbis, is also used as intermediate host. The small snails of the genus Drepanotrema have also been found with cercariae. Attempts to use the genus Helisoma as a host for Schistosoma mansoni 
were unsuccesful, although species of this genus are parasitized by other forms of trematode worms.

Aguayo (1938, p. 210) has summarized the species of snails used as intermediate hosts by Schistosoma and other trematodes. Schistosoma haematobium is shown to use a species of planorbid, 'Planorbis dufuorii' as well as Bulinus and Physopsis. The Schistosoma mansoni intermediate hosts include Afroplanorbis boissyi, A. pfeifferi, A. sudanicus, Australorbis glabratus, A. olivaceus, A. antiguensis, Tropicorbis centimetralis, and Drepanotrema cultratus.

The liver flukes of the genus Fasciola parasitize certain genera of Lymnaeidae (Radix, Pscudosuccinea, Fossaria, and Stagnicola) as well as one Physa, P. cubensis. The large fluke of the Orient, Fasciolopsis bushi, which is elosely related to Fasciola, uses only the small planorbids belonging to the old genus Segmentina which now includes the groups Polypylis, Helicorbis, and Pingiella, true Segmentina not being found in the East. Four speeies are listerl as intermediate hosts, Planorbis cocnosus (=Helicorbis), Segmentina hemaesphaemula $1=$ Polypylis), and "Segmentina schmakeri" and 'S nitidclla' which have not yet been exammed for their anatomy and hence their position is doubtful (probably Polypylis). The value of correct specific identifications of the intermediate liosts of these trematode worms is of the first importance as has been elearly indieated by Ingles (1933) in a study of the parasites of frogs.

Elaborate studies have been made by Dr. E. C. Faust of the Department of Tropical Medieine in Tulane University, New Orleans, and by the late Dr. William A. Hoffman of the School of Tropical Medicine of the University of Puerto Rico, on various phases of the Sehistosomiasis mansoni problem in Puerto Rico, where the mollusk Australorbis glabratus (Say) (=Planorbis guadeloupensis somb.) is the intermediate host. For these studies see Faust, 1933; Hoffman and Faust, 1934; and Faust, Jones, and Hoffman, 1934.

Papers by parasitologists in which mollusean hosts are mentioned are numerous. A few are here indicated. Faust (1918) has observed cereariae of four species in Helisoma trivolvis in Illinois and one species in Helisoma subcrenatum (not trivolvis, as stated) in Montana (Faust 1917). In a list of the described cereariae of the United States (1919) Faust mentions two speeies of the family Planorbidae, Planorbis parn's (Gyraulus) and Planorbis trizoleis (Helisoma), as well as several Physidae and Lymnaeidae which are known hosts. Fourteen species of cereariae infest Helisoma trivolvis and three speeies oeeur in Gyraulus parvus. Miller (1936) found Helisoma trivolvis from Illinois and Helisoma trivolvis lentum (not lantum, trpographical error) from Louisiana to be hosts of many Ameriean cereariae. O'Roke (1917) found Helisoma trivolvis (probably the race lentum) carrying cereariae in Kansas, and McCormick (1923) found Helisoma trivolvis and Gyraulus parves to be infested in Ohio. Ward (1918), in Ward and Whipple's Fresh-water Biology (pp. 365424), summarizes the cercarial stages of parasitie flatworms, gives keys for the determination of the larval stages and indicates the species of mollusks which have served as intermediate hosts. Physa, Lymnaca, and Planorbis are listed, including many of the Planorbidae. However, this text was compiled at the very beginning of studies on trematode life histories on this continent. More recently there have been numerous de- 
tailed studies on the stages in fresh-water snails. Many other works might be quoted but a suffieient number lave been indicated to show the rôle played by the fresh-mater snails, partieularly the Planorbidae, in the life rycle of the trematode worms. Some additional titles are listed in the bibliographies accompanying the papers mentioned in this ehapter.

During the anatomical investigations marle for this work eareful note was made of the presence of larvae of trematode worms, prineipally cereariae and a few rediae. Over a thousand specimens of mollusks were examined but only a few contained parasitic worms. The following species, arrangerl under subfamilies, were observed to be infested.

subfamily Planorbinae

No specimens of this subfanily were found with cercariae or rediae.

\section{Subfamily Segmentininae}

Segmentina nitida from marshes in a meadow in Czneriakow, a suburb of Warsaw, Poland. Sent by Mr. A. Jankowski. Cereariae were abundant; mainly in the orotestis which was almost destroyed. All specimens examined were infested.

Drepanotrema hoffmani from pond near Isabela, Puerto Rico. Sent by Dr. WilIiam A. Hoffman. Heavily infested with stylet cercariae.

Australorbis glabratus from near San Juan, Puerto Rico. Sent by Dr. Hoffman. Various degrees of infestation.

\section{Subfamily Helisomatinae}

Helisoma anceps, from Unionville. Connecticut. Collected by F. C. Baker. One specimen with lung carity filled with rediae and one specimen with cercariae in liver and genitalia.

Ifelisoma trivolvis lentum, from near Urbana, Peoria, and St. Joseph, Illinois. Cercariae in liver and orotestis.

Helisoma subcrenatum fron Cottonwood Pass, near Gypsum, Colorado. Sent by Junius Henderson. Four out of six specimens with cercariae in different parts of the body, mostly the liver. Some specimens from a sluggish creek one nile west of Devon, Montana, collected by J. Henderson and Hugo Rodeck, contained cercariae, mostly in the liver.

Helisoma plexatum, from Teton River, north of Rexburg, Idaho, collected by J. Henderson; one out of six infected.

Helisoma homii, from Paul Lake, Kamloops District, British Columbia. Sent by Dr. D. S. Rawson, University of Saskatchewan. About one-third were affected by cercariae.

In lisoma pilsbryi from Chetek Lake, Barron Co., Wisconsin. Collected by F. C. Baker. Cercariae in eight specimens with the liver and orotestis mostly affected.

Helisoma corpulentum from Miles Bay, Lake of the Woods, Canada, Fall Lake, Ontario, Canada, and Knife Lake, St. Louis Co., Minnesota. Collected by Dr. A. R. Cahn. Many infested with cercariae.

II clisoma corpulentum multicostatum, from Lake Kahnipiminanikok, Ontario, Cinnada. Collected by Dr. A. R. Cahn. One out of six with cercariae.

IIclisoma whiteavesi from Kashabowie Lake, Ontario, Canada. Collected by Dr. Cahn. One out of four infested with cercariae.

Helisoma campanulatum wisconsinense from Pirate Island, Lake Nipissing, Ontario. Canada. From the Biological Board of Canada. One out of five specimens with cercariae.

\section{Subfamily Planorbulinae}

Menetus cooperi callioglyptus from Quatana, Vancouser Island, British Columbia. Received from D1. WT. A. Clemens. Two-thirds of the specimens cxamined (about at dozen) were infested with cercariae, in several examples almost consuning the liver, albumen gland, and ovotestis. In sereral specimens the cercariae were nost numerous about the stomach. Several hundred were observed in some specimens.

Ifenctus cooperi from small lakes on Mt. Constitution, Orcas Island, Puget Sound, Washington. Collected by Dr. Dale Foster. Of fifteen specimens examined, one contained cercariae.

Menctus dilatatus from Unionville, Connecticut, fourteen miles west of Hartford. Collected by F. C. Baker. One specimen in sixteen contained cercariae. 
Menetus sampsomi from slough of Meramec River east of Stanton, Franklin Co., Missouri. Collected by Leslie Hubricht. Twelve out of fourteen specimens were infested with cercariae, the liver and genitalia being principally affected. In several specimens nearly all of the internal organs had been destroyed.

Same species from small lake near Hutchins, Dallas Co., Texas, collected by Dr. E. P. Cheatum. Fifty per cent of specimens examined were affected by cercariae.

Promenetus exacuous from small lake in Wainwright Park. Alberta, Canada. Receised from A. LaRocque, Canadian National Museum, Ottawa. Nearly all specimens examined were infested with celcariae, some in the fore part of the body, many about the stomach, but mostly confined to the liver and genitalia. Specimens of exacuous from Maine, Wisconsin, Michigan, New York, and Ontario did not contain larral worms.

It is unfortunate that parasitological assistance was not available when these anatomical studies were in progress in order that the particular species of parasitic trematode worms involved might have been ascertained. Many species of cercariae remain to be discovered from the tissues of planorbid and other fresh-water mollusks.

The effect of fluke infestation on the anatomy of the snail is variable. The cercariae may infest only the liver, in which case, often, the cercariae finally leave the snail which recovers from the damage inflicted by the parasite. In many other cases, however, the liver, genitalia, and stomach are affected and in large measure destroyed. Specimens have been cxamined in which the genitalia were completely destroyed or the genitalia and liver obliterated. In one case (Menetus cooperi), almost the whole snail was so filled with cercariae (several thousand) that the normal organization could not be distinguished, the cercariae being packed in the space oceupied by the organs and in aggregation taking their form. This was particularly true of the genitalia. Faust (1920, p. 79) has given a good account of the pathologieal changes in the gastropod liver due to fluke infestation. Wesenberg-Lund (1934) and Miriam Rothschild (1936) have recorded instances of gigantism in snails apparently attributable to trematode infections.

Several parasitologists have essayed the rôle of conchologists in an cndeavor to understand the specific limitations of the groups of molluscan species acting as hosts for parasitic trematode worms. Among these are the late Dr. Adolpho Lutz (1918) of the Instituto Oswaldo Cruz and Dr. A. Tianna Martins (1938) of the Laboratorio do Instituto Biologico Ezequiel Dias. Dr. Lutz describes all species under the common generic name Planorbis, the modern genera Australorbis and Tropicorbis being the principal groups discussed. In the main, the work of Dr. Lutz is good and the species have been carcfully distinguished. The work of Dr. Martins is a study of the genus Australorbis of Pilsbry, based in part on the earlier work of Dr. Lutz. Unfortmately the two genera Tropicorbis and Australorbis have been confused by this author and many species lumped under Australorbis, to which they have little relation anatomically. It is obvious that specific identifications must be accurately made if any value is to be attached to these forms as intermediate hosts of parasitic worms.

In Part II of this work the recognized species, and also the synonyms, of species of both Australorbis and Tropicorbis, as well as of other groups, will be discussed and the species figured.*

*The author's death came before he could finish Part II. Howerer, 60 plates made for Part II are printed as an Appendix to this work (see page 213 et seq.). H.E.C. 
III.

\section{NIDIFICATION AND EMBRYOLOGICAL DEVELOPMENT}

$\mathrm{T}$ HE EARLY STAGES of cell growth and derelopment in the planorbids (Helisoma trivolvis) have been well described and figured by Holmes (1900, pp. 369-458). Crabb (1927, pp. 67-108) has described and figured the early stages of Lymnaea stagnalis appressa (= jugularis) and Lankester (1874) has given us the full development of the European Lymnaca stagnalis. More reently (1934) Lomrance has rery fully described the early development of Stagnicola kingi. Little work has been done, however, on the embryonic development of the different species of the family Planorbidae and espeeially on their nidifieation. period of development, and the time element in the growth of the young animal in its shell."

A dozen or more aquaria were operated during the years 1930 to 1934 and careful data were gathered concerning the period of egg deposition, number of eapsules laid, ehanges taking place within the egg eapsule, and growth of the young snails within the egg and after hatching.

\section{A. DEVELOPMENT OF Helisoma scalare (JAY)}

In 1932. Dr. E. A. Andrews, of the Johns Hopkins University, sent the writer a piece of pond lily leaf upon which was a large egg capsule of Helisoma (Seminolina) scalare (Jay), containing twenty-eight eggs in rarious stages of development. This capsule was deposited in an aquarium but the parent came from Lake Butler, Florida. This egg eapsule was observed as opportunity afforded until all of the embryos were hatehed or had died. From this capsule a fairly good idea of the development of this planorbid was obtained. Observations began when the speeimen was reeeived on Mareh 2 and the last speeimen was hatehed on Mareh 17. The different stages are figured on plate 51 and are described in the explanation of that plate.

Development was observed to be sporadic in many of the eggs. There were resting stages between periods of great activity of rotation about the interior of the egg, the rotation beginning in this species the latter part of the gastrula stage, the second day of development, and becoming marked from the early trochophore stage. This rotation is caused by the vibration of the numerous eilia attached to the foot of the embryo (CL in figures).

Observations on the egg capsule began on Marel 2. when twenty-eight fertile eggs were counted. The observations, made several times a day, showed the following degrees of development:

March 2-3. 24 eggs in segmentation stages. 4 in early trochophore stage.

4. Same condition as on March 3.

5. 20 eggs in gastrula stage; 4 in trochophore stage; 4 in preveliger stage.

7. 18 in gastrula stage; 5 in trochophore stage; 3 in veliger stage; 2 postveliger.

8.18 in gastrula stage; 4 trochophore; 3 veliger; 3 embryos with shell.

* After this manuscript was in press, a rery significant experimental study, by H. B. Roney, on the development of Helisoma eggs, under controlled conditions, appeared in Ecology, v. 24, Pp. 21S-243.-H.J.V-C. 
March 10. 18 in gastrula stage: 4 trochophore: 3 veliger: 3 embryos with shell.

11. 18 in gastrula stage ; 4 veliger; 3 post veliger ; 3 embryos with shell.

12. 18 in gastrula stage; 3 veliger; 4 postveliger; 3 embryos with shell.

13. 18 in gastrula stage; 3 veliger; 3 postveliger; 3 embryos with shell; 1 hatched.

14. 18 in gastrula stage; 3 veliger; 3 post veliger; 2 embryos with shell; 1 hatched.

15. 18 in gastrula stage; 2 veliger; 2 postreliger; 2 embryos with shell $; 2$ hatched.

16. 18 in gastrula stage: 2 postveliger; 3 embryos with shell; 1 hat ched.

17. All hatched or dead, many of the gastrula stage filled with Protozoa.

In the above table it will be observed that only ten embryos completed their development. Eighteen embryos did not continue their growth after reaching the gastrula stage, for what reason is not apparent. In the stage shown in fig. 9 on plate 51 the snail is very active, moving about in the egg and grazing like the adult snail. The radula ean be seen working with its peculiar lapping motion, the heart is beating regularly, and the pulmonary siphon is functioning, for it can be seen to emit bubbles. One young snail four days out of the egg was transferred to an aquarium. This speeimen was very active, erawling about the glass sides of the jar. The eyes were black and very conspicuous.

Several of the embryos that completed their development showed the following history.

\section{EGG NLYBER 1}

March 2-3. Segmentation and gastrula. Like fig. 2, 3.

4. Early trochophore stage.

5. Trochophore stage.

7. Posttrochophore stage. Like figs. 4, 5 .

8. Veliger stage, Like figs. 6,7 .

9. Veliger stage. Like fig. 9.
March 10. Embryo stage. Like fig. 10 . 11. Embryo stage. Like fig. 10. 12. Embryo stage. Like fig. 11. 13. Young snail. Like fig. 12.

14. Young snail. Like fig. 12. 15. Young snail. Like fig. 12. 16. Hatched from egg. Like fig. 13.

\section{EGG NUMBER $s$}

March 2-4. Early segmentation and gas. trula stages. Like figs. 2,3 .

5. Posttrochophore stage. Like figs. 4,5 .

7. Veliger stage. Like fig. 6 .

8. Veliger stage. Like fig. 6 .

9. Veliger stage. Like figs. 7,8 .
March 10. Veliger stage. Like fig. 9.

11. Embryo stage. Like fig. 10.

12. Embryo stage. Like fig. 10.

13. Young snail. Like fig. 12.

14. Young snail. Like fig. 13.

15. Young snail. Like fig. 13.

16. Hatched. Like figs. 13, 14.

Both of the above embryos completed their development in fifteen days. Probably some early cell divisions took place the day before observations began, which would inerease the development period to sixteen days. The temperature of the room was 70-75 degrees Fahrenheit. The other eggs in this eapsule showed approximately the same development. The embryo in egg number 5 migrated to egg number 6 at the late embryo stage and hoth embryos oceupied the same chamber until they were hatched, three days later.

Several adult Helisoma scalare received from Dr. Andrews, collected in Lake Butler, Florida, were placed in an aquarium where they bred and laid eggs which successfully completed their development. Eggs were first observed on March 13 (see plate 52, fig. 1). The egg capsules were deposited on the glass sides of the aquarium and were numbered so that development could be easily and accurately observed. Thirteen egg capsules were deposited early in March: 
No. 1. 10 eggs, capsule 3.5 by $2.5 \mathrm{~mm}$.

2. 6 eggs, capsule 3.5 by $2.5 \mathrm{~mm}$.

3 . 8 eggs, capsule 3.0 by $3.0 \mathrm{~mm}$.

4. 10 eggs, capsule 5.0 by $3.0 \mathrm{~mm}$.

5 . 4 eggs, capsule 3.5 by $2.5 \mathrm{~mm}$.

6. 10 eggs, capsule 4.5 by $3.5 \mathrm{~mm}$.

7. 10 eggs, capsule 5.0 by $3.0 \mathrm{~mm}$.
No. S. 11 eggs, capsule 4.5 by $3.5 \mathrm{~mm}$.

9. 2 eggs, capsule 4.5 by $2.5 \mathrm{~mm}$.

10. 9 eggs, capsule 5.0 by $3.5 \mathrm{~mm}$.

11. 5 eggs, capsule 4.5 by $3.5 \mathrm{~mm}$.

12. 13 eggs, capsule 5.0 by $4.0 \mathrm{~mm}$.

13. 14 eggs, citpsule 5.0 by $3.5 \mathrm{~mm}$.

Egg capsule No. 3 with eight eggs developed as follows:

March 13. Freshly deposited capsule.

14. Early segmentation.

15. Gastrula stage.

16. Gastrula and trochophore stages.

17. Castrula and trochophore stages.

18. Trochophore and preveliger stages.

19. Veliger stage.

20. Early embryo stage.

21. Embryo stage.
March 22. Embryo with shell of about one whorl.

23. Embryo with shell half filling c cgg.

24. Enbryo with shell threefourths filling egg.

25. Embryo with shell almost filling egg.

26. Embryo with shell filling egg.

27. Four embryos hatched.

28. Last embryo hatched.

The period of development was fifteen days.

Capsule No. 6, with ten eggs, oceupied a longer period (18 days) in hatching.

Capsule No. 8, with eleven eggs, had all embryos hatched in seventeen dars, from March 15 to March 31. Capsule No. 11, with five eggs, dereloped and hatched the young snails in thirteen days, from March 15 to March 27. All other capsules oceupied fifteen to eighteen days. The shell when the young are hatched measures about $1.0 \mathrm{by} 0.7 \mathrm{~mm}$.

About two weeks later (April 2) six eapsules were deposited measuring as follows (see plate 52, figs. 2,3 ) :

Capsule 4.5 by $3.0 \mathrm{~mm}$. with 10 eggs.

Capsule 5.5 by $3.0 \mathrm{~mm}$. with 7 eggs.

Capsule 6.0 by $4.0 \mathrm{~mm}$, with 14 eggs.

Capsule 5.0 by $3.0 \mathrm{~mm}$. with 9 eggs.

Capsule 5.0 by $3.0 \mathrm{~mm}$. with 19 eggs.

Capsule 5.0 by $3.0 \mathrm{~mm}$. with 9 eggs.

One capsule with nine eggs developed as follows, the process occupying but twelve days:

April 2. Freshly deposited eggs.

3. Segmentation.

4. Segmentation and gastrula stages.

5. Crastrula and trochophore stages.

6. Posttrochophore and preveliger stages.

7. Preveliger and veliger stages.

On May 22 the aquarium was examined for its entire contents. There were ninety-six young snails of scalare only sixteen of which were living. There were three adult speeimens measuring 8 to $10 \mathrm{~mm}$. in length. These, curiously enough, wele in shape more like Helisoma duryi seminole than typical scalare. The shells were very wide with broad spire and decided umbilicus. The young snails in the aquarium were approximately seren and one-half weeks old. A few of these were measured and the number of whorls was counted:

Height 2.0 ; diameter $2.5 \mathrm{~mm}$. Whorls 2 .

Height 3.0 ; diameter $3.0 \mathrm{~mm}$. Whorls $21 \%$.

Height 2.5 ; diameter $2.5 \mathrm{~mm}$. Whorls $21 \%$.

Height 2.5; diameter $2.5 \mathrm{~mm}$. Whorls $2 \frac{1}{4}$. 
When hatched the shells usually measure $1 \mathrm{~mm}$. in height and $0.7 \mathrm{~mm}$. in diameter and lave a trifle more than one whorl. The young scalare, therefore, had more than doubled in size in less than eight weeks. On August 15, after a hot summer, seren specimens remained in the aquarium. Five of these measured as follows:

\section{Height 4.7; diameter $5.0 \mathrm{~mm}$. Whorls $31 \%$. \\ Height 4.0 ; diameter $4.1 \mathrm{~mm}$. Whorls 3 . \\ Height 5.0 ; diameter $5.1 \mathrm{~mm}$. Whorls 3 . \\ Height 6.0 ; diameter $5.0 \mathrm{~mm}$. Whorls $3 \%$. \\ Height 6.0 ; diameter $6.0 \mathrm{~mm}$. Whorls $3 \frac{1}{2}$.}

These measurements indicate that the shells had almost trebled in size in about twelve weeks, although but one more whorl was added.

On June 26, during a hot period of weather, two adult snails of this species died, leaving one adult, which lived over winter isolated in a small aquarium. On March 5, 1933, several egg capsules were laid by this individual approximately nine months after its isolation. Two empty egg eapsules were observed on the side of the aquarimm and twenty-one young snails were erawhing about. The young shells measured $2 \mathrm{~mm}$. in height and $2.5 \mathrm{~mm}$. in diameter and had two whorls. All lived from March 5 to May 21 when three died. On June 25 the last adult died but nine of the young remained alive.

On September 3, 1933, four of the young scalare were living. The young snails at this time, about twenty-three weeks old (160 days) measured 5.0 $\mathrm{mm}$. in height and $4.5 \mathrm{~mm}$. in diameter and had three and one-half whorls. Between September 3 and September 17 these young snails formed eighteen egg eapsules containing the following number of eggs: $6,11,13,9,10,5,7$, $7,12,11,2,5,9,10,10,7,9,7$. Embryos in but two of the eapsules completed their development. The parent snails of this last brood, it will be noted, were the offspring of an isolated adult scalare. The young snails lived until January, 1934.

The derelopment of Helisome scalare is similar in many respects to that deseribed by Lankester for Lymnaca stagnalis $(1874)$ and by Lowrance (1934) for Stagnicola kingi. There are, of course, differences in the form of the embryos as would be expected in two such diverse families. Lowrance found that young snails of Stagnicola kingi hatehed in from fourteen to sixteen days (p. 10) but that with increased temperature $(26$ degrees centigrade) this period was cut to from nine to eleven days. Lymmaca stagnalis may require as mueh as twenty days or more for development.

\section{B. NIDIFICATION AND DEVELOPMENT IN OTHER SPECIES OF Helisoma}

\section{Plates 51 and 52}

Living material belonging to five additional species and races of Helisoma was studied in aquaria during the years 1931,1932 , and 1933 . The species included were:

Helisoma trivolvis lentum ( Say)

Helisoma trivolvis fallax (Haldeman)

Helisoma duryi normale Pilsbry

Helisoma duryi eudiseus Pilsbry

Helisoma tenue californiense F. C. Baker 
Several species were from different localities and these as well as each race were kept in separate aquaria. Observations were made several times each day at intervals of three or four hours. Each jar was labeled and the egg capsules lettered or numbered as they were deposited by the animals. Notes were kept of developments in each capsule. The data which follow have been condensed from the original notes.

The information sought in these studies was to ascertain the time required for development and the rate of growth of the shells of the young snails during their life in the aquaria.

\section{[a] Self-fertilization or Autofecundation}

That self-fertilization or autofecundation is possible among the freshwater pulmonates has been suggested by several zoologists during the past hundred years or more, but until comparatively recent time few experiments have been earried on to test the reality of this inethor of reproduction. Colton (1912, p. 173; 1918, p. 48) has shown that Lymnaea, Physa, and several groups of Planorbidae (Gyraulus, Menetus) lay fertile eggs by this method when isolated. Crabb (1927) has presented elaborate data on this subject, and more recently Larambergue (1939) has issued an elaborate monograph particularly relating to Bulimus contortus. On pages 541-543 he presented a list which includes all of the authentic examples of autofecundation. This list includes all families of Basommatophora as well as a few among the Stylommatophora. Crabb (1927) studied Lymnaea stagnalis appressa (= jugularis) to determine whether snails kept in striet isolation reproduced by self-fertilization or by parthenogenesis. His conelusions were that there was no eridence of parthenogenesis in this snail.

It is to be noted, howerer, that reproduction by parthenogenesis does oceur in some groups of snails. Boycott (1919) has asserted that Paludestrina jentinsi develops by this method. More recently Yan Cleave (1937) and Mattox $(1937,1938)$ have shown that the viriparoid snail Campeloma mufum develops solely by parthenogenesis although other species of the genus have been found to be bisexual. The reproductive method in Campeloma was observed by morphological and histological studies and there is no question concerning the parthenogenetic method of reproduction in the species examined.

Some years ago, Chadwick (1903, p. 265) conducted some interesting experiments on Planorbis i'ortex, a common English planorbid. On February 2, 1901, he isolated an adult specimen in a jar three-fourths filled with boiled water, a small quantity of weed was introduced, the rest of the jar was filled with pure oxygen and the ressel was perfectly sealed. It remained in this condition for eighteen months, or until August, 1902. In June, 1902, aften sixteen months of complete isolation, the snail deposited some eggs which were hatehed in early July, producing twenty-seven young snails, many of which were still thriving under these confined conditions on December 10, 1902. In evaluating this set of observations, and many others along this line. it should be remarked that only those experiments in which individual eggs were isolated have any conclusive value in establishing the occurrence of self-fertilization. This is especially true when forms are considered for which there are no observations as to the length of time the spermatozoa remain viable following copulation. 
Crabb states $(1927$, p. 91) that self-fertilization is the normal method of reproduction in Lymnaea and other fresh-water pulmonates and that eross-fertilization seldom or never occurs. With this general statement the writer can not fully concur. It is doubtless true in many cases of reproduction during isolation but that it is the ehief method anong free snails when in aggregation in their native environment or even in the laboratory is scarcely possible. The writer has observed many species of Lymnaea, Physa, and the planorbids in coitu. If the method of reproduction mentioned by Crabb is the elief or possibly the only method, why should the male portion of the genitalia be so elaborately developed with prostate and the penial complex provided with such diverse accessories in its makeup? The spermatheca has been found to contain a spermatophore containing sperm which was obviously deposited during copulation. Self-copulation probably occurs when a snail is isolated, at least in those species having a penial complex of sufficient length to reach the female opening, which is the case in many species of the Planorbidae.

Crabb states that he was unable to raise progeny from isolated Planorbis trivolvis (Hclisoma), four individuals being carefully reared in isolation for 377 days without the laying of a single egg capsule. Ten to fifteen small empty egg masses were deposited. Even the control culture. consisting of two smails, formed no capsules. Lymnaca stagnalis, on the contrary, was very prolific.

My isolated laboratory stock lays about every third day for a period of about twentyfive days, rests a few days, then begins another cycle of laying. This is continued throughout the year. Of fifty-four L.s.appressa isolated from the same egg mass. seven laid their first eggs fifty-eight days after hatching. However, they do not reach their maximum laying capacity until they are about one hundred diys old (Crabb, p. 73).

Colton's experiments on Lymmaca (Pseudosuccinea) columella indieated that the interval between hatching and egg laving was widely variable (1912, ). 175). Thirteen isolated individuals had the following interval between hatching and egg laying: $32,26,35,49,58,92,50,50,56,57,63$, 74 , and 74 days. Twenty-six days was the shortest interval and ninety-two days the longest interval.

In the family Planorbidae the intervals are much longer, not only of the specimens placel in isolation, but for those in aggregation. Helisoma scalare laid thirteen egg capsules in early March, 1932. In early April, six additional capsules were produced. An isolated individual which lived over winter (nine months) without egg laying, deposited two fertile egg capsules on March 5, 1933. Between September 3 and September 17 the young snails, 160 days old, laid eighteen egg capsules containing from six to thirteen eggs in each capsule.

Specimens of Helisoma trivolvis lentum were placed in aquaria in 1930. On February 16, 1931, a capsule was laid, on February 22 four capsules were deposited and on March 7 two capsules were laid. No other eggs were laid by these specimens which lived until September 17, 1933, or a period of 943 days. A young specimen from the parent lentum was isolated January 16, 1932. It was about 325 days old. Between May 27 and June 9 , 1932 , this individual, after inhabiting the aquarium for 132 days, laid twenty egg capsules aggregating 325 eggs. On .June 20, 1932, the parent snail was removed to another aquarim and on .June 22 laid two egg eap- 
sules and on June 27 deposited two more capsules. These capsules were laid fifteen and twenty days after the large laying period in the first aquarium. Two-thirds of the eggs laid completed their development. A few of the second generation remained alive for about two years but laid no egg capsules.

These examples seem to indicate that the large planorbids do not breed as often as do the lymmacids and are not as available for studies in development as are members of the Lymmaeidae. Just how the smaller species of the genera Menetus, Gyraulus, and Tropicorbis would react to such investigations is not known." It is probable that had Crabb kept his Helisoma trivolic longer they might ultimately have laid eggs.

\section{[b] The Development of Helisoma}

The notes that follow describe some of the results of aquarium observations on a few of the species of the genus Helisoma. No attempt has been made to go into the finer details of embryological development. This has been done by Holmes (1900) and others.

\section{[1] Helisoma trivolvis lentum (Say)}

Several specimens of the lentum race were received in 1930 from Dr. E. C. Fanst of the Tulane Medical School, New Orleans. They were collected from the canal at New Orleans. This city is also Say's original locality for this species. The snails were placed in aquaria and kept under observation for several years. On February 16, 1931, an egg capsule was observed, apparently freshly laid, with twenty-five eggs. It measured 7.5 by $6.0 \mathrm{~mm}$. On February 22 four additional egg capsules were laid, one 4 by $3.5 \mathrm{~mm}$. with nine eggs, one 7 by $4 \mathrm{~mm}$. with fourteen eggs, one 9 by $4.5 \mathrm{~mm}$. with nineteen eggs, and one 10 by $4.5 \mathrm{~mm}$. with twenty-four eggs. On March 7 , two other egg capsules were observed, one with fifteen eggs and the other with nineteen eggs. All eggs were fertile and contained embryos in the early stages of development.

On September 12, 1931, twenty-five young snails were counted, ranging in diameter from $4.5 \mathrm{~mm}$. with two and one-fourtl whorls to $16 \mathrm{~mm}$. with four whorls. On Norember 2S, 1931, nineteen specimens were counted ranging in size from $5.5 \mathrm{~mm}$. in diameter with three whorls to $14 \mathrm{~mm}$. with four and one-fourth whorls. On January 16, 1932, the nineteen specinens were again measured, the smallest being $5.5 \mathrm{~mm}$. in diameter with three whorls and the largest $14 \mathrm{~mm}$. with four and one-fourth whorls. On March 19,1932, the same number of specimens remained in the aquarium, the smallest being $6 \mathrm{~mm}$. in diameter with three and one-fourth whorls and the largest $14.5 \mathrm{~mm}$. with four and one-fourth whork. On June 10, 1932, only fourteen specimens remained in the aquarim, five having died. The smallest was $6.5 \mathrm{~mm}$. in diameter and had three and one-fourth whorls and the largest was $12.5 \mathrm{~mm}$. with four whorls. August 15,1932 , only six specimens were alive, the smallest $6.5 \mathrm{~mm}$. in diameter and the largest $10 \mathrm{~mm}$. in diameter. On October 23 and December 26 the six specinens were still alive. The ir size had not increased.

On March 5, 1933, five specimens were living, the largest $10.5 \mathrm{~mm}$. in diameter with four whorls. On June 25, 1933, three were living, the largest being $11 \mathrm{~mm}$, in diameter with four and one-fourth whorls. On September 17, 1933, two specimens were living. These two specimens had lived orer two years in the aquarium. Of the original 125 eggs laid in February and March, 1931, only 25 young snails survired until September, 1931, and only two snails were alive two and one-half years later. Mortality among the young snails appears to be heary in their early postenbryonic life.

*Rearing methods for securing uninfected snails to be used in life history studies on parasitic worms have been practiced in many parasitological laboratories. W. H. Krull (1931) has published the jrocedure for successul rearing of Gyraulus parves and found that this species ma be reared to full size in from four to five weeks under laboratory conditions (Occis. Pap. Mus. Zool., Uni. Michigan, Yo. 226).-H.J.V-C. 


\section{[2] Helisoma trivolvis fallax (Haldeman)}

October 2, 1931, fifteen specimens of this race, collected near Cambridge, Massachusetts, were received from Dr. Harold A. Rehder, then in Harvard University (now Assistant Curator of Mollusea, United States National Musemm). Egg capsules were observed February 6, 1932, one measuling 4.5 by $3.5 \mathrm{~mm}$. and containing six eggs, and one 5.6 by $7 \mathrm{~mm}$. with thirteen eggs. The egus of both capsules pissed through their derelopment and were hatched by February 12. On February 28 another capsule was laid measuring 5.2 by $4 \mathrm{~mm}$., containing ten eggs, but was eaten by Protozoa after three days of development. March 4 a capsule was laid measuring 5 by $6 \mathrm{~mm}$. with twelve eggs, and on March 10 another capsule was laid, 3.5 by $5.5 \mathrm{~min}$. , containing eleven eggs. On March 13 a cajsule containing nine eggs was observed. On March 19 , twenty-two young and five adult snails were counted in the aquarium, the young ranging in size from $1.8 \mathrm{~mm}$. to $3 \mathrm{~mm}$. in diameter.

An examination on May 22 revealed seventeen young snails living. All of the adult snails were clead. The living young snails measured as follows:
2 specimens $2.5 \mathrm{~mm}$. in diameter with 2 whorls.
3 specimens $2.5 \mathrm{~mm}$. in diameter with $21 / 2$ whorts.
1 specimen $2.8 \mathrm{~mm}$. in diameter with $2 \frac{1}{4}$ whorls.
3 specimens $3 \mathrm{~mm}$. in diameter with $21 / 2$ whorls.
1 specimen $3.2 \mathrm{~mm}$. in dianeter with $2 \frac{1}{2}$ whorls.
4 specimens $3.5 \mathrm{~mm}$. in diameter with 3 whorls.
1 specimen $3.8 \mathrm{~mm}$. in diameter with 3 whorls.
2 specimens $4 \mathrm{~mm}$. in diameter with 3 whorls.

On June 26, 1932, the seventeen young fallax were still alive. On August 15 there were fourteen living young suails which measured as follows:

1 specimen $2 \mathrm{~mm}$. in diameter with 2 whorls.

1 specimen $3 \mathrm{~mm}$. in diameter with 2 whorls.

1 specimen $3.5 \mathrm{~mm}$. in liameter with $21 / 2$ whorls.

2 specimens $4 \mathrm{~mm}$. in diameter with $21 / 2$ whorls.

5 specimens $4.5 \mathrm{~mm}$. in diameter with 3 whorls.

2 specimens $5 \mathrm{~mm}$. in diameter with 3 whork.

2 specimens $5 \mathrm{~mm}$. in diameter with $3 \frac{1}{4}$ whorls.

On October 23, 1932, only four young fallax remained living:

1 specimen $3.5 \mathrm{~mm}$. in diameter with $2 \frac{1}{2}$ whorls.

1 slecimen $4.5 \mathrm{~mm}$. in diameter with 3 whorls.

1 specimen $5 \mathrm{~mm}$. in diameter with 3 whorls.

1 sjecimen $5 \mathrm{~mm}$. in diameter with $3 \frac{1}{4}$ whorls.

On March 1, 1933, these four snails were still living and measured as follows:

1 specimen $4 \mathrm{~mm}$, in diameter with $2 \frac{1}{2}$ whorls.

1 specimen $5 \mathrm{~mm}$. in diameter with 3 whorls.

1 specimen $5.2 \mathrm{~mm}$. in diameter with $3 \frac{1}{2}$ whorls.

1 specimen $5.5 \mathrm{~mm}$. in dianeter with $3 \frac{1}{4}$ whorls.

On May 1, 1933, only three liring snails remained:

1 specimen $4.9 \mathrm{~mm}$. in diameter with 3 whorls.

1 specimen $5.5 \mathrm{~mm}$. in diameter with $31 \frac{1}{2}$ whorls.

1 specimen $5.6 \mathrm{~mm}$. in diameter with $3 \frac{1}{2}$ whorls.

On June 25 one young snail remained which measured $6 \mathrm{~mm}$. in diameter and had three and one-half whorls.

This small subspecies of IIctisoma trivolvis lived in the aquarim 495 days or about seventeen months. It grew from a size of $1.5 \mathrm{~mm}$. in liameter when hatched to $6 \mathrm{~mm}$. when it died, and increased from one and one-fourth to three and one-half whorls. Adult fallax measures $15 \mathrm{~mm}$, in diameter and has five full whorls. The last remaining young was, therefore, somewhat more than one-third grown. Full maturity would probably have been attained the third year after hatching.

Conclusions of this sort, in which length of life span is estimated from growth rates in aquaria, are only tentative and are possibly subject to considerable error. Very early experiments on snitil development tended to show that the size of reared snails is influenced by the volume of the water and the container in which they grew. Conclusive pridence of rate of growth in nature could be determined by measuring representative samples, from normal habitats, taken periodically as practiced by Van Cleave (1932) and his students in the interpretation of life history data. 


\section{[3] Helisoma duryi normale Pilsbry}

Specimens of this planorbid, collected on the Tamiani Truil, forty miles west of Miami, Floricla, were sent to the writer by Mr. W. F. Shay of the Department of Science, Nommaly High School, St. Lours. They were placed in aquaria in January, 1931. On January 31 several egg capsules were observed, one containing fifteen embryos in various stages of development, thee in veliger stage and twelve with wellformed shells. By February 2, eleven snails had been hatched and were crawling on the glass sides of the aquarium. By February 6 most of the veliger larvae had been hatched. Another calsule contained fifteen eggs with one veliger stage, one gastrula stage and thirteen embryos with well-formed shells. These latter hatched on February 4. Another capsule contained ten eggs, five embryos with partly formed shells and five embryos with fully formed shells. These were hatehed by Febriary 5.

On September 1, 1931, three capsules were observed on the side of the aquarium, one with nine eggs, 7 by $4.5 \mathrm{~mm}$. in area, one with ten eggs, 6 by $5 \mathrm{~mm}$. and one with eight eggs. 5.7 by $3.2 \mathrm{~mm}$. On September 12 , two adclitional capsules were deposited, one with seren eggs ( 6 by $3.2 \mathrm{~mm}$. in area) and one with fou eggs (4.7 by $2.7 \mathrm{~mm}$.). Of the first series of three capsules, two died and were eaten by Protozoa and one completed its development. Of the second set, one capsule carried out its full development. In this capsule, the veliger stage was reached on September 15 and the embryo with a well-formed shell on September 19. On September 20, the four snails were actively feeding in the egg capsule, the walls of the egr capsules were broken, and the snails were crawling about in the broken interior. On September 21, the snails had left the egg capsule and were feeding on the side of the aguarium. It is probable that this capsule had been laid for a day or two before first observed because the interval of nine or ten days seems too short for complete development.

On January 17, 1932, a recently laid capsule containing sixteen eggs was discovered and was observed until all of the embryos had been hatched (see plate 42, fig. 12). In this capsule fifteen days elapsed between early segmentation and exit from the egg. $\mathrm{By}$ the middle of February the young snails measured $1.1 \mathrm{by} 1 \mathrm{~mm}$. and actively glided about the aquarium. The body in the shell is pinkish, the foot hyaline, slightly yellowish, the liver brownish, and the eyes black and prominent. The tentacles are long and mobile. The radula can be plainly seen at work and the jaw appears blackish through the translucent head.

From the above capsule and from several others hatehed at about the same time, forty young snails were released in February. Observations were made on the shells several times in March and April. On May 22 there were seven living snails and thirty-three empty shells, indicating that mortality had been heary, principally during the month of May. The seven living snails had the following shell measurements:

1 specimen $1.5 \mathrm{~mm}$. in diameter with 2 whorls.

1 specimen $2.5 \mathrm{~mm}$. in diameter with $21 \%$ whorls.

1 specimen $2.8 \mathrm{~mm}$. in diameter with 3 whorls.

1 specimen $3.4 \mathrm{~mm}$. in diameter with $2 \% 4$ whorls.

2 specimens $3.5 \mathrm{~mm}$. in diameter with 3 whorls.

1 specimen $4 \mathrm{~mm}$. in diameter with $3 \frac{1}{2}$ whorls.

On June 26 the seven snails were still alive. By August 15 one had dier. The six snails gave the following measurements:

2 specimens $4 \mathrm{~mm}$. in diameter with 3 whorls.

2 specimens $4.5 \mathrm{~mm}$. in diameter with $3 \frac{1}{4}$ whorls.

1 specimen $5 \mathrm{~mm}$, in diameter with $3 \frac{1}{4}$ whorls.

1 specimen $5.5 \mathrm{~mm}$. in diameter with $3 \frac{1}{4}$ whorls.

On December 26. 1932, but four snails remained alive. These showed the measurements below:

1 specimen $4 \mathrm{~mm}$. in diameter with 3 whorls.

1 specimen $5 \mathrm{~mm}$. in dianeter with $3 \frac{1}{4}$ whorls.

1 suecimen $5.2 \mathrm{~mm}$. in cliameter with $3 \frac{1}{4}$ whorls.

1 specimen $6 \mathrm{~mm}$. in diameter with $3 \frac{1}{2}$ whorls.

On March 12, 1933, three snails were living which measured as follows:

1 specimen $4.8 \mathrm{~mm}$. in riameter with 3 whorls.

1 specimen $5.7 \mathrm{~mm}$. in diameter with $3 \frac{1}{4}$ whorls.

1 specimen $6.1 \mathrm{~mm}$. in clinmeter with $3 \frac{1 / 2}{3}$ whorls. 
On June 25, 1933, the same three snails showed some growth:

1 specimen $5.5 \mathrm{~mm}$, in diameter with $33 / 4$ whorls.

1 specimen $6.5 \mathrm{~mm}$. in diameter with $31 / 2$ whorls.

1 specimen $6.5 \mathrm{~mm}$. in diameter with $31 / 2$ whorls.

On August 6, 1933, but two snails remained alive. These neasured:

1 specinen $6 \mathrm{~mm}$. in diameter with $31 / 2$ whorls.

1 specimen $6.8 \mathrm{~mm}$. in diameter with $3 \frac{1}{2}$ whorls.

These young snails lived 570 to 580 dits after hatching and increased in diameter from $1.1 \mathrm{~mm}$, to $6.8 \mathrm{~mm}$. and in number of whorls from one to three and a half. An adult normale measures about $20 \mathrm{~mm}$. in diameter and has five whorls, so that the young snails were about one-third grown after a development period of one year and seven months. If this growth is normal, it must require three or four years for this race to attain maturity, unless there is considerable arceleration in growth during the second or third years. The temperature in which the young snails were reared was ordinary room heat between 70 and 75 degrees F. This temperature reached 90 degrees or more in the hot summer montls. The matter of food is also important since only filamentous algae were flaced in the aquaria, the snails feeding mostly, however, on the green algal deposit which formed on the grass sides of the aquaria.

\section{[4] Helisoma duryi eudiscus Pilsbry}

Specinens of this race of duryi were received from Mr. T. Tan Hyning, of the Florida State Museum, collected at Silver Springs, Marion County. They were received at the laboratory on October 2, 1931. On December 13 an egg capsule was laid measuring 2 by $2.5 \mathrm{~mm}$. in area with five eggs. ()n February 6, 1932, another capsule was laid measuring 2 by 4 mm. with nine eggs, and on February 12 a capsule with seven eggs. On February 10 a large capsule measuring 5 by 4 mm. was deposited containing twelve eggs. One capsule (Feb. 10) developed to the gastrula stage and then ceased growth. Another was disintegrated and the slace was filled by Protozoa. A third capsule (Feb. 12) completed its development, all of the embryos being hatehed.

A single adult cudiscus was left in the aquarium and on June 11, 119 days after the laying of the last egg capsules, egg laying began again with the deposition of a capsule measuring 4 by $3.5 \mathrm{~mm}$. and containing two eggs, each cog $1 \mathrm{~mm}$. in diameter. On June 13 the eggs had reached the gastrula stage. From June 14 to June 26 the egg: remained in the same stage and at the last date the cogs appeared to disintegrate.

\section{[5] Helisoma tenue californiense F. C. Baker}

Specimens of this race were received from Dr. S. S. Berry, collected from Prospect Park, near Redlands, San Bernardino Mts., California. They were placed in an aquarium ou February 12, 1932, and laid nine exg cupsules on the next day. The nine capsules contained 199 egrgs as noted below:

No. 1. 4 by $4 \mathrm{~mm}$. in diameter containing $15 \mathrm{eggs}$.

2. 5 by $3.5 \mathrm{~mm}$. in diameter containing 18 eggs.

3. 4 by $7 \mathrm{~mm}$. in diameter containing 21 eggs.

4. 6 by $3.5 \mathrm{~mm}$. in diameter containing 28 eggs.

5.4 by $5 \mathrm{~mm}$. in diameter containing 15 eggs.

6 . 4 by $4 \mathrm{~mm}$. in diameter containing 11 eggs.

7.4 by $7.5 \mathrm{~mm}$. in diameter containing 27 eggs.

8. 4.5 by $7 \mathrm{~mm}$. in diameter containing 26 eggs.

9 . 5 by $8 \mathrm{~mm}$. in cliameter containing 38 eggs.

Development was fairly regular and occupied fifteen days, from February 13 until February 28. A typical development is indicated below:

Feb. 14. Segmentation begun.

15. Segmentation and gastrula stages.

16. Gastrulia and trochopliore stages.

17. Trochophore and preveliger stages.

18. Early veliger stages.

19. Teliger stages.

20. Early embryo stages.

21. Farly embryo stages.

22. Embryos with shell forming.
Feb. 23. Embryos with shell forming.

24. Embryos with shell $1 / 3$ filling membrane.

25. Embryos with shell filling $1 / 3$ and $1 / 2$ of membrane.

26. Embryos with shell filling $3 / 4$ of membrane.

27. Embryos with shell completely filling membrane.

28. All hatehed. 
On February 15 three capsules were laid by the adult snails. They contained three, eleven, and thirteen eags respectively and development oceupied thirteen to fifteen days, from February $2 S$ until March 12. On February 18 a capsule 9 by $6 \mathrm{~mm}$. was laid containing forty exgs, and on Februar 20 four capsules were deposited measuring 6 by 5,9 by $6,6 \mathrm{by} 5$, and 6 by $4.5 \mathrm{~mm}$. They contained thirty-five, thirty-thrce, twenty-eight, and twenty eggs respectively. On March 1 and 2, two capsules were laid containing thirty-one and twenty-three eggs. All of these eggs completed their derelopment in from twelve to fourteen days.

On June 5, 1932, the aquarium was cramined and the shells counted and measurerl. There were ninety-six living young snails and forty-five empty shells, 141 specimens in all which had liatched from the capsules enumerated above. The living young snails gave the following measurements:

Sspecimens $1.5 \mathrm{~mm}$. in diameter with $11 \%$ whorls.

18 specimens $2.0 \mathrm{~mm}$. in dianeter with 2 whorls.

3 specinens $2.311 \mathrm{~m}$, in diameter with 2 whorls.

40 specimens $2.5 \mathrm{~mm}$. in diameter with 2 whorls.

20 specimens $3.0 \mathrm{~mm}$. in diameter with 2 whorls.

6 specimens $3.0 \mathrm{~mm}$. in diameter with $21 / 2$ whorls.

1 specimen $4.0 \mathrm{~mm}$. in dianet er witl 21 , whorls.

Between June 5 and June 26, fifty-four roung snails died, leaving forty-two active roung and three adult snails. On August 15, only fourteen young snails were alive. the great mortality being largely due to the very hot sumner. The measurements of these survivors are shown below:

1 specimen $2.1 \mathrm{~mm}$. in dianeter with 2 whosls.

2 specimens $2.5 \mathrm{~mm}$. in diameter with 2 whorls.

3 specimens $3.0 \mathrm{~mm}$. in diameter witl $21 / 2$ whorls.

6 specimens $3.5 \mathrm{~mm}$. in diameter with $21 / 2$ whorls.

2 specimens $4.0 \mathrm{~mm}$. in diameter with $2 \frac{1}{2}$ whorls.

On October 23, 1932, two roung snails died leaving twelve active young. On December 2S, 1932, four additional snails died leaving eight young which gave the following measurements:

1 specimen $3.5 \mathrm{~mm}$. in diameter with $21 / 2$ whorls.

1 specimen $4.0 \mathrm{~mm}$. in diameter with $2 \frac{1}{2}$ whorls.

1 specimen $4.0 \mathrm{~mm}$. in diameter with 3 whorls.

1 specimen $4.2 \mathrm{~mm}$. in dianeter with 3 whorls.

3 specimens $4.5 \mathrm{~mm}$. in diameter with 3 whorls.

1 specimen $4.9 \mathrm{~mm}$. in diameter with 3 whorls.

On March 12. 1933, only five young snails remained alive, as noted below:

1 specinien $4.0 \mathrm{~mm}$. in diameter with $21 / 2$ whorls.

1 specimen $3.5 \mathrm{~mm}$. in diameter with 3 whorls.

2 specimens $5.0 \mathrm{~mm}$. in diameter with 3 whorls.

1 specimen $5.0 \mathrm{~mm}$, in diameter with $3 \frac{1}{4}$ whorls.

On May 1, 1933, but two specimens remaned alive, meusuring:

1 specimen $4.0 \mathrm{~mm}$. in diameter with 3 whorls.

1 specimen $5.2 \mathrm{~mm}$. in diameter with $3 \frac{1}{4}$ whorls.

On Junc 25, 1933, one specimen only remained, measuring $6.1 \mathrm{~mm}$. in diameter with three and one-half whorls. This specimen had lived from February 28, 1932, until June 25. 1933, an interval of 482 days or sixteen months. It had grown from a diameter of $0.8 \mathrm{~mm}$. to $6.1 \mathrm{~mm}$. and the whorls increased from one to three and one-half. Adult califormiense measures $20 \mathrm{~mm}$. in diameter and has five whorls which would indicate that the young specimen sixteen months old had made about one-third of its growth. $A=$ in the cases of the other species described in this chapter, factors of volume of water, food. and temperature nay have retarded the normal growth of the young of this race. At this ratio full maturity would be attiined between the third and fourth years of life.

\section{[6] Other Records of Egg Laying}

IIclisoma pilsbryi infracrinatum F. C. Baker. Specimens of this species were received from Mr. A. LaRocque of the Canadian National Muscum. They were collected in tle Rideau River near Ottawa, Canada. On June 20 two egg capsules were deposited each measuring 6 by $4.5 \mathrm{~mm}$. in size and containing eighteen and twenty eggs. On 
May 7 a capsule was laid which measured 7 by $4.5 \mathrm{~mm}$. in area and contained twentytwo eggs. Development was not observed.

Helisoma traskii (Lea). Six shells of this species, preserved in alcohol, received from Mr. Stanley Siegfus of Bakersfield, California, had eleven egg capsules on the shells, containing 394 eggs. A capsule containing fifty eggs is figured (13) on plate 52. The specimens were from the Buena Vista Canal, outlet of Kern Lake, California, near the type locality for traskii. The capsules and eggs are noted below:

1 shell with 2 capsules containing 16 and $24 \mathrm{eggs}$.

1 shell with 2 capsules containing 45 and 42 eggs.

1 shell with 1 capsule containing 10 eggs.

1 shell with 2 capsules containing 35 and 85 eggs.

1 shell with 3 capsules containing 35.22 , and 20 eggs.

1 shell with 1 eapsule containing 50 eggs.

Moquin-Tandon (1855, pr. 425-439) collected egg capsules from water bodies in the environs of Toulouse, France, and observed the development of some of the embryos. Some of his observations are recorded below:

Segmentina nitida (Müller). Nine egg capsules containing $3,4,5,6,7$, and 8 eggs, the capsules measuring 0.25 to $1.5 \mathrm{~mm}$. in diameter. Development occupied ten to twelve days.

Hippcutis fontanus (Lightfoot). Several capsules with 3, 4, 5, and rarely 6 eggs in each capsule.

Gyrobis complanatus (Linn.) (= Planorbis planorbis (Linn.)). Eight capsules containing $10,11,13,16,17$, and 21 eggs.

Gyrorbis carinatus (Beck in Möller) ( = Planorbis carinatus). Capsules containing ten to twenty eggs each. Development occupied ten to fifteen days.

Gyrorbis vortcx (Linn.) (= Anisus vortex (Linn.)). Ten to twelve eggs in a capsule which were $4 \mathrm{~mm}$. in diameter. Development required ten to twelve days.

Planorbis albus Mïller (=Gyraulus albus (Mïller)). Capsules 3 to $4 \mathrm{~mm}$. in diameter containing four to ten eggs.

Planorbis contortus Linn. (= Bathyomphahes contortus (Linn.)). Capsules $3 \mathrm{~mm}$. in diameter containing six to eight eggs. Development occupied ten to twelve days.

Planorbis corneus (Linn.) (= Planorbarius corneus (Linn.)). Egg capsules 9, $11,12,13$, and $15 \mathrm{~mm}$. in diameter containing twelve to forty eggs each. Development required fifteen to sixteen days.

Brooks (18s0) has recorded the early stages in the derelopment of the small snail Gyraulus parvus (Say) (= Planorbis parvus Say). 


\section{IV. \\ DISTRIBUTION IN TIME AND SPACE}

\section{A. GEOLOGICAL HISTORY AND DISTRIBUTION}

$\mathrm{T}$ HE ANCESTRY of the Planorbidae, as of other members of the pulmonate mollusks, is shrouded in mystery. It is said that the ancestors of the Planorbidae, as of other groups of the Basommatophora, were originally aquatic, then migrated to the land and finally again returned to aquatic habitats. Perhaps this was aceomplished through such groups as the Auriculidae (Carychium for cxample) which have the Basommatophorous organization but inhabit the land.

In America the family apparently first appears in the Morrison formation which is considered of Jurassic or Early Cretaceous age, probably Jurassic. In Europe, a species, Planorbis mendipensis Moore, is known from the Liassic of England. The family is not uncommon in the Bear River formation, believed to be at the top of the Lower Cretaceous (Comanchean), or at the base of the Upper Cretaceous, and also in the several divisions known to belong to the Upper Cretaceous, as Judith River, Belly River, and others. During Tertiary time the family was well represented. Eocene, Miocene, Oligocene, and Pliocene formations have viclded many characteristic species. The Pleistocene planorbid fauna is practically the same as the recent fauma.

As the few specimens of planorbid shells from Jurassie or Lower Cretaceous time are not notably different in general characteristics from those of later geological periods or from the modern fauna, it is obvious that the family in some form must have existed in earlier strata. Triassic and Carboniferous (Pennsylyanian and Mississippian). A Physa (prisca Wolcott) and other fresh-water groups are reported from the Mississippian of Nerada and fresh-water and land mollusks are known from various localitics from strata of Pennsylvanian age. Planorbids, however, have not yet been reported from these older geological periods.

In Europe this family is fairly common in roeks of Mesozoic and Cenozoic age, but earlier records are very few in number. A Triassic planorbid has already been mentioned. In the Upper Oolite another species appears, Planorbis fisheri Forbes. In the Eocene a number of species of this family occur, and in the Oligocene more than eleven species are known. The family is not uncommon in later periods. On the continent a large number of species and races of this family have been recorded from nearly all of the latel geologieal periods. Wenz (1923) has listed all of these but many of the species have obviously been placed in the wrong genera, especially some of the large forms which are listed under the genus Planorbina, for it does not oceur in Europe. It is quite probable that these large species are members of the genus Planorbarius and are related to the large Planorbarius corneus so common in the recent fauna.

In America (see Henderson, 1935) sixty-three species of fossil planorbids have been described. Of these two are of Jurassic or Comanchean age, 
two from Comanchean, five from Upper Cretaceous, eight from Eocene, six from Oligocene, five from Miocene, thirty from Pliocene, and five simply described as 'Tertiary.'

It is obviously very difficult to place fossil mollusks in appropriate genera in a classification based on anatomieal characteristics. Nearly all of the fossil planorbids of America and Europe have been described as 'Planorbis.' With the greatest of care it is possible to place some of these species in their correct genera as unclerstood at the present time. Some forms, however, can only be tentatively placed, basing the decision on the similarity of the fossil species to some known living species of which the anatomy is known. Even among modern speeies this method is fraught with danger because of similar resemblances of the shells of several genera, as in Planorbula and Tropicorbis, where some species of the latter genus have internal lamellae in the aperture similar to species of the genus Planorbula. The two genera are far apart anatomically.

Among American fossils the following genera are known to be represented by several species and races:

Tropicorbis, 1 species; Paraplanorbis, 1 suecies: Platytaphius, 2 species; Gyraulus, 6 species; Helisoma, S species; Carinifex, 2 species; Torticifex, 8 species; Perrinilla, 2 species; Parapholyx, 2 species; Pompholopsis, 1 species; Menetus, 5 species; Planorbifex, 1 species.

Many of the species now known as Planorbis may later be placed in more appropriate genera. It is proposed in Part II of this work to review critically all of the American fossil Planorbidate, including several from the West Indies and Central America, and to endeavor to place each speeies in its correct genus.*

The geographical distribution of the extinet species of the family Planorbiclae is not very different from that of the recent species of the family. Fossil speeies of the family have been recorded from Europe, Asia, Africa, Australia, some of the islands of the Pacific Ocean, North and South America, and the islands of the West Indies.

\section{B. GEOGRAPHICAL DISTRIBUTION}

Like the Lymnaeidae, the Planorbidae are world-wisle in their geographic distribution. There is searcely a known region in which some of the planorbid snails do not live. The distribution by genera, however, is more or less linited. Trpical Planorbis and Planorbarius are mostly confined to Europe and western Asia, with possibly some forms of eireum-Mediterranean distribution. Helisoma is wholly American but is known from both North and South America and from some of the West Indies. A fossil species has been reported from northeast Siberia (Lindholm, 1933). This genus is numerous in North America, prineipally the northern part of the United States and Canada. Planorbula is found only in eastern North America from Alabama northward. Carinifex and Parapholyx are west American in distribution. Menetus is American and does not extend south of the United States. A small group of Helisoma (Seminolina) occurs only in the peninsula of Florida.

*As explained elsewhere, Mr. Baker's death prevented him from completing Part II of this monograph. 
Australorbis is known from South America and the West Inrlies but is not found north of the Isthmus of Panama. Tropicorbis occurs in South and Central America, in Mexico, the West Indies, and in the southern part of the United States bordering the Gulf of Mexico. Curiously enough, a closcly related group, known as Afroplanorbis, is found in northern and central Africa and resembles Tropicorbis so closely, in both shell and anatomy, that it is a question whether the two groups are not iclentical generically. Anisus is mostly European and Asiatic. Segmentina is typically European, west Asian, and north African. Several groups related to Segmentina, as Polypylis, Helicorbis, Pingiella, and Intha, are confined to eastern Asia and some of the Pacific islancls. Taphizs occurs only in Central America and in northern South America. Gyranlus is the most widely distributed of any of the genera of Planorbidae, being known from North America, Europe, Asia, Africa, and some of the islands of the Pacific as well as from the West Indies. It is typically a northern group (palacarctic) but a few species extend southward into the tropical regions.

The present study of the distribution of the members of the family Planorbidae shows conclusively the value of the anatomy in the classification of the species. It is of interest to note that in consictering the distribution of the genera, details of the anatomy have been the only means by which the different groupings could be made with certainty. Hence our knowledge of distribution has become more definite and better understood than was possible when shell characters were given chief taxonomic value. The shell alone is not sufficient to distinguish groups because there are parallels in growth tendency which render shells of widely separated genera confusingly simitar in appearance. Instances of this are found in the species of Tropicorbis and Planorbula, Australorbis and Helisoma, Segmentina and Polypylis, ete.

\section{Dispersal of Species}

The presence of species of mollusks in isolated places has been somewhat of a puzzle to many zoologists. How, for example, are ponds without inlet or outlet and more or less widely separated, populated by one or more species of planorbick or other fresh-water species? In what manner have the same species of Tropicorbis, Australorbis, or Drepanotrema found their way to so many of the islands of the West Indies, isolated by large and deep areas of salt water? Examining the distribution of Australorbis, for example, we find it occurring in eastern and northern South America and also in many of the groups of islands-the Lesser Antilles, the Creater Antilles, Puerto Rico, and Jamaica. Some species of Tropicorbis have the same distribution.

Natural dispersal by migration is out of the question. Driftwood might answer for land snails (at least to a limited degree) but not for fresh-water forms. A former connection with South America occurred too remotely to answer satisfactorily the question. When we examine the migration routes of the migrating birds, especially the wading birds and chucks, we are struck by the similarity of the geographic routes of the birds with the geographic distribution of the snails. One route is from Venezuela, South America, through the Caribbean and West Indian islands as follows: Trinidad, Cirenada, St. Vincent, St. Lucia, Martinique, Dominica, Marie 
Galente, Antigua, St. Christopher, St. Thomas, Puerto Rico, Haiti, Jamaica, and Cuba. The three genera Australorbis, Tropicorbis, and Drepanotrema inlabit most of the islands mentioned. Another route is from Venezuela northward up the eastern coast of Panama, close to Costa Rica, Nicaragua, Honduras, Guatemala, eastern Mexico to the gulf coast of the United States. The genus Tropicorbis has this distribution and many of its species are widely distributed. Some migrant birds pass up the west coast of Central America and Mexico.

It is the writer's belicf that the populating of many if not all of the islands of the West Indies with planorbid and other fresh-water mollusks has been brought about through the ageney of migrating birds. They stop at these islands to feed and rest, the snails become attached to the feet or other parts of the bodies of the birds, to be liberated when the birds make other stops. Young snails have been found attached to the feet of many birds. In the case of the Basommatophorous mollusks a single snail introduced into a pond would be sufficient to insure population since selffertilization is easily accomplished. By this means in a few years a body of water would be a prolific habitat for the species. Aquatic insects, especially beetles, would perform the same service, especially in populating closely associated ponds or streanis. Young snails have been found attached to the wings (elytra) of beetles.

Natural migration doubtless takes place in connected streams and other bodies of water and will account for the dispersal of related species within the drainage of a water system. Floods often carry species of snails over natural divides. In the distribution and dispersal of the Mollusea, all agencies must be taken into account. The scareity of records of snails on the bodies of migrating birds is primarily due to the fact that those who kill the birds, sportsmen and liunters, pay no attention to what may be attached to the fect of their victims. Ornithologists, too, do not carefully examine the bodies of the specimens and the snails fall off or are brushed off during the preparation of the skin for the cabinet. Careful examination of the bodies of birds would doubtless provide many valuable evidences for arian dispersal of fresh-water and other mollusks. 


\section{V. \\ HISTORICAL SKETCH OF CLASSIFICATIONS}

$\mathrm{I}$ N THE EARLY TOLUMES on the Mollusea, the planorbids, as well as other genera, were largely elassified by the shells and were placed in families witl wide limits as to the genera involved. Thus in 18511856, in S. P. Woodward's Mamal of the Mollusca, nearly all of the genera of fresh-water pulmonates-Limnaea, (hilina, Physa, Planorbis, and Ancylus-appear in the family Limnaeidae. In A History of British Mollusea, by Forbes and Hanley, in 1853 (rolume iv) the fresh-water pulmonates of the genera Limnaea, Planorbis, Physa, and Ancylus are all placed in the family Limnaeidae.

II. G. Binney, in 1865, published a work on The Land and Fresh-Water Shells of North America, in which the fresh-water pulmonates are all placed in the family Limmaeidae with Limmaeinae, Planorbinae, and Ancylinae as subfamilies. Physa being included in the subfamily Limmaeinae.

In $1870, \mathbb{W} . \mathrm{H}$. Dall proposed a classification in which four subfamilies were recognized: Limnaeinae, Planorbinae, Camptocercinae, and Pompholiginae. In 1872, Creorge W. Tryon, Jr., in a Monograph of the Freshuater Cnivalie Mollusea of the Únited States, placed all groups under the family Physidae, but separated the principal groups as subfamilies: Limnaeinae, Pompholiginae, Megasystrophinae, Planorbinae, and Anerlinae. In this grouping he was following Haldeman (1842-184t) who placed Planorbis and other groups in the family Physidae.

Paul Fischer, in the Manuel de Conchyliologie (1883), listed most of the fresh-water pulmonates under the family Limnaeidae, within which he recognized Anerlinae, Limnaeinae, and Planorbinae as subfamilies. Physa he relegated to a separate family. Tryon, a year later (1884), in the third volume of his Structural and Systematic Conchology, placed all of the fresh-water pulmonates under the family Limnaeidae with subfamilies Limnaeinae (including Physa, Aplexa, Bulinus, ete.). Pompholiginae, Planorbinae, and Ancylinae. A. H. Cooke, in 1895, evidently following Paul Fiseher, separated Physidae as a family but places the subfamilies Limnaeinae, Planorhinae, and Ancrlinae in the Limnaeidae. F. C. Baker in 1902 and Dall in 1905 separated Physa and Aplexa to form the family Physidae but placed Limnaed (Lymnaea). Planorbis, and allied genera in the family Limnaeidae. Ancylus was made a separate family. Ancrlidae, by Baker.

In 1902. Westerlund placed all of the Basommatophorous mollusks in the family Limnaeidae with four subfamilies, Limnaeinae. Physinae. Planorbinae, and Aneylinae. Dybowski (1903) proposed a classification of the Basommatophora in which six families were recognized, Limnaeidae, Limnophysidae, Amphipeplidae, Planorbidae, Aneylidae, and Plysidae. Bryant Walker (1918) in his 'Synopsis' reeognized four families. Lymnaeidae, Planorbidae, Phrsidae, and Ancylidae.

From 1920 onward, most of the important monographs and lists have accepted the four-family dirision of the Basommatophora, Lymnaeidae. Planorbidae, Physidae, and Anerlidae (Germain, 1921-23; Kennard and 
Woodward, 1926; Pilsbry and Bequaert, 1927; F. C. Baker, 1928; Haas, 1929; Lindhohm, 1926; Thiele, 1931; and others). Germain (1931), in his Mollushs of France, recognized five families, the four previously alluded to and Bulinidae, the groups of which were thought to constitute a family. Many other works might be listed, especially by European writers, as Lindholm, Westerlund, Clessin, Dybowski, Odhner, Pallery, Preston, Soos, and other's. The most important of these are listed in the synonymy under the different genera. The large monographs, such as Clessin (1886) and Sowerby (Reeve, 1872), do not help much in family distinetions and the lesser faunal lists of both continents, of which there are many, simply copy the elassification as published in some of the works mentioned above.

In the matter of generie distinetions among the planorbids there is little of note in the carlier works. In 1884, Tryon listed most of the group names as subgenera of Planorbis, recognizing Segmentina as a distinct genus. Pompholyx, Carinifex, and Choanomphalus are listed as genera with some subgenera, mostly fossil groups. In 1905. Dall eonsidered all groups but Segmentina as subgenera of Planorbis. Germain, 1921, followed Dall. Kennard and Woodward (1926) did likewise. In 1926, F. C. Baker reoognized the groups Helisoma, Planorbula, Menetus, and Gyraulus as being of generic rank and in 1928 fully deseribed these groups, giving anatomical reasons for their distinetion. Among European works, Linchohm in 1926 recognized as of generic rank Planorbis, Tropidiscus, Spiralina, Anisus, Gyraulus, Bathyomphalus, Armiger, Hippeutis, and Segmentina, a great step in advancement over previous works as regards elassification. Thiele in his Handbuch (1931) was too conservative, listing all groups as sections under the genera Planorbis and Anisus. Mori (1938) in his elassification of Japanese Planorbidae followed Thiele. It is to be observed, however, that all of these genera or subgenera as treated by early authors, were diagnosed from shell characters for the most part.

In a review of the classifications of the Basommatophorous group the change in number of families and genera reeognized is noteworthy. From one family in 1870 (Limnaeidae or Physilae) this grouping has grown to five at the present time, indicating a tendency to recognize smaller group differences and ako indieating advance in knowledge concerning these groups. Many generie and subgenerie names have been proposed during the past ninety or one hundred years but these were founded almost wholly on shell characteristies. No such analytical studies as those on the land mollusks by H. A. Pilsbry and by H. B. Baker were made until after the year 1920.

Studies of the anatomy of the Planorbidae began in Europe many years ago but were confined to only a few species. Most of the early papers or works on anatomy simply gave as illustration a familiar example, as, for example, Planorbis corneus and Limnaea stagnalis figured by MoquinTandon in 1855. Baudelot (1863) published good figures of the genitalia and other organs of Planorbis corneus (= Planorbarius). In 1867, Fieinus, an almost forgotten writer, published an article on the penis of Planorbiclae in which he divided the European speeies of Planorbis into two groups, (1) with a penial stylet, including Planorbis iortex, leneostoma, spirorbis, albus, and contortus, and (2) without a stylet, including Planorbis corneus, nitidus, and fontanus. He erected the genus Appendicularia for Planorbis 
nitidus and $P$. fontames because of the presence of the flagella on the penis. This is, as far as known to the writer, the first attempt to classify the Planorbiclae by reference to details of the anatomy.

In 1891, Buchner published the first comprehensive aceount of the genitalia of the family Planorbidae. He clivided the male organ into four types, (1) corneus with a small penis, (2) nitidus and complanatus with flagella and sperm outlet at the side, (3) marginatus and carinatus with sperm outlet in the center, and (4) contortus, vortex, rotundatus, and albus with a stylet. He did not distinguish the peeuliar gland of corneus from the penis. The difference between the prostate diverticula of Planorbis corneus and the smaller species, vortex, carmatus, nitidus, cte., was especially mentioned but no reference was made of the presence of a separate prostate duct. There was a good aceount of the excretory organ (kidney). Simroth's aceount (1912) of the genitalia of the Planorbidae was based on Buchmer's work and added nothing to our knowledge of the antomy of the group.

In 1917, L. Soos published a paper on the anatomy of the Hungarian Planorbidae, giving figures of the genitalia of Planorbis corneus, Tropidiscus planorbis, Segmentina nitida. Bathyomphalus contortus, Gyrorbis spirorbis, and Gyraulus albus. The radulae and the digestive system were also considered. This is the best work on the anatomy of the Planorbidae which had appeared up to this time.

During the decade from 1921 to 1930 , several notable papers appeared on the anatomy of the family. Ammandale (1922) and Annandale and Prashad 11919-1921) added to our knowledge of the anatomy of the Indian Planorbidae. In 1923, Rao published an exhaustive treatise on the anatomy of Ammandale's new genus Indoplanorbis. Connolly (1925) figured the genitalia and radula of Planorbis pfeifferi which indieated that it was related to the West Indian genus Tropicorbis. F. C. Baker, in 1926, published notes on the genitalia, jaws, and radulae of certain American Planorbidae and in 1928 (Moll. of Wis., I, pp. 306-387) presented descriptions and figures of the genitalia, jaws, and radulae of the species of Platnorbidae inhabiting the Middle West. The subfamily Helisominae (Helisomatinae) was proposed as new on page 309 of that work. The classification of the genitalia is based on that of Buchner with the addition of two types, one new and one following Annandale.

In 1929, Odhner published an account of the Mollusea of the Täkerns in which the genera were separated by characteristics of the genitalia, radulae, and other anatomical features. On page 22 a key appeared in which the groups were briefly diagnosed from the anatomical standpoint. This was the most modern treatment which the family had received and the key is the first attempt to separate the genera by the use of anatomical differences.

During the decade 1931 to 1940, several critical papers appeared on the anatomy of the Planorbidae, adding greatly to our knowledge and clearing up many doubtful points in the elassification based on the anatomy. In 1931, Germain issued his work on the land and fresh-water mollusks of France in which outline figures of the genitalia, and some of the radulae, were given. No attempt was made. however, to base a elassification on the anatomical data. Also in 1931, appeared F. C. Baker's paper 
on the elassification of the larger planorbes of Europe and America, in which Planorbis corneus and the American Helisoma species were discussed and the genitalia and radulae figured. The peculiar penial gland of the genus Helisome was discussed at length. The same author, in 1933, made a study of the peculiar genitalia of Indoplenorbis exustus of India adding some features to the previous paper by Rao. Later, the same author published short papers placing certain disputed species in their proper generic position, based on their anatony. Thus, in 1935, Planorbis umbilicatellus, long thought to be a Gyraulus, was shown to be a member of the genus Menetus and a new subgenus was proposed for Menetus exacuous (Promenetus). In 1936, Planorbis obstructus was shown to belong in the genus Tropicorbis and the true relationship of Parapholyx was indicated.

In 1935, A. Soos published a paper on the Planorbidae of Hungary which included good figures of the genitalia of the species inhabiting that country. In 1934, a paper from the pen of H. A. Pilsbry discuseed the planorbid fam of Florida, their genitalia were figured, and a new name (Seminolina) was proposed for the group which is not found outside of the Florida peninsula. The classification of other groups. Tropicorbis, Menetus, Carinifex, and Parapholyx was discussed and a new genus Australorbis was proposed for the large snails inhabiting South America and the West Indies. The European genus Anisus was ably discussed. A new subfamily, Planorbulinae, was establisher. Characteristic keys to the genera of American Planorbidae were given, based on anatomical features. It is not orerstating to say that this paper is the most comprehensive account of the family Planorbidae from a morern standpoint that has yet appeared.

From the foregoing summary it is plainly obrious that a detailed study of the classification of the family Planorbidae, based on anatomical information, comparable to the methods need by Pilsbry on the land mollusks, is still to be prepared. An attempt to supply this deficiency is the purpose of the present work. It is believed that a foundation has been laid upon which to build a natural classification of the fanily Planorbidae. 


\section{A NEW CLASSIFICATION OF THE FAMILY PLANORBIDAE}

\section{GENERAL DISCUSSION}

$\mathrm{D}$ URING THE PAST FIFTY YEARS, the elassifieation of the land shells (Stylommatophora), under the able leadership of Dr. Henry A. Pilsbry, of the Academy of Natural seiences of Philadelphia, has been brought to a high degree of accuracy and completeness. This has been aceomplished by the study of anatomical details of the genera and speeies, bringing together groups which are allied by features of the natural organization of the animal. While the shell has helped in many cases it has been the internal features, chiefly the genitalia, that have given criteria for generic and higher distinctions. The results obtained by these studies have been aceepted by nearly all malacologists and conchologists.

No such comparable work has been done on the fresh-water pulmonates (Basommatophora), and the few attempts to apply anatomical criteria for generie distinetions, as used in the Pulmonata, have met with more or less eriticism. It is obvious, however, that only by the careful study of the internal organs of the animal can a natural classifieation be secured. This was attempted by the writer for the Lymnaeidae in 1911 and some gratifying results were obtained. The family Planorbidae offers better characteristies for purposes of elassifieation than does the Lrmnaeidae. there being a greater diversity of structural features among the different genera.

For the data in the present work a large number of species of the family Planorbidae, from different parts of the world, were dissected. These represent a majority of the generic groups so far published, in addition to several new genera. As in the study of the land mollusks, the genitalia have been of the greatest assistanee. Few new groups were necessary because those already published, of which there were many, were adequate to represent the different anatomical features involved.

In the new elassification here presented, great stress is laid on the differences in the male genitalia. the size of the preputium and rergic sac; the characteristics of the prostate diverticula and the prostate duet; the presence or absence of a stylet on the verge; flagella present or absent on the vergie sac; a penial gland in the preputium and whether this has an internal or an external duet or none at all; the opening of the sperm eanal in the rerge. whether at the end or on the side; the number of letractor museles of the penial complex; and the nature of the orotestis, whether the diverticula are in a double series or are multiple.

Other anatomieal features also aid in classification, as the shape of the kidney, whether it is smooth or has a ridge; the condition of the jams. whether simple or fragmented; the form of the radula teeth; the shape of the stomach and the turns of the intestine from stomach to anus. The pseudobranch also offers some criteria although this organ is fairly uniform in the family. It does effectirely separate the Planorbidae from the Bulinidae, the pseudobranchs of the two groups being markedly different. For generic purposes, the shell offers less assistance than the organs of the animal, although the shell sometimes presents characteristies of generic importance. 
It has been possible to recognize four subfamilies of the family Planorbidae based on fundamental anatomical differences, and all of the genera, as far as they have been examined, reachly fit into this subfamily classification. A few groups, as Taphius, Biomphalaria, Platytaphius, and Trochorbis, are still mknown anatomically, but it is believed that when examined they will be found to fit into this classification. Many species of the family still remain of which the animal characteristics are unknown and it is possible that new genera or subgenera will need to be made for their inclusion. It is confidently believed that the classification herein presented will form a reliable foundation on which to build future knowledge which may be obtained concerning this interesting family.

\section{ANATOMICAL KEYS TO GROUPS*}

\section{Key to Subfamilie}

1a. Prostate a single row of diverticula usually placed on a separate prostate duct...2

b. Prostate with multiple diverticula nsually placed on the sperm duct..........

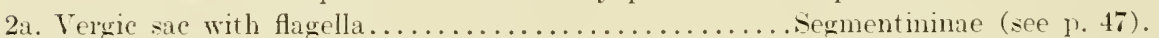

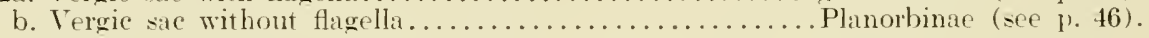

3a. Prostate forming a fan-shaped pattern in cross section, penial gland duct on ontside of preputium, orotestis consisting of several diverticula arranged

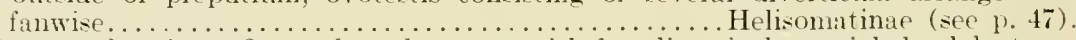

b. Prostate forming a finger-shaped pattern with few diverticula, penial gland duct inside preputium, orotestis with paired diverticula... Planorbulinae (see p. 48).

\section{Kes to Genera of Planorbinaet}

1a. Prostate direrticula on separate duct, simple, unbranched at end..........2

b. Prostate diverticula not on separate duet, branched at

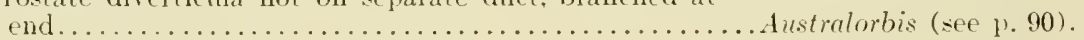

2a. Terge with stylet, outlet of sperm canal at side $\ldots \ldots \ldots \ldots \ldots \ldots \ldots \ldots \ldots \ldots$

b. Verge withont stylet, ontlet of sperm canal at end $\ldots \ldots \ldots \ldots \ldots \ldots \ldots \ldots \ldots \ldots$

3a. Shell with many closely coiled whorls not increasing greatly in diameter......4

b. Shell with few loosely coiled whorls rapidly increasing in diameter..........5

4a. Left side of shell flat without central depression.........Anisus s.s. (sce 1). 57 ).

b. Left side of shell with deeply excarated

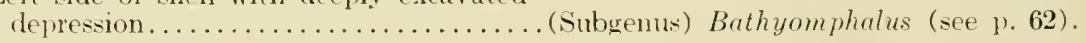

5a. Left side of shell with rounded whorls on a plane surface.. Cryraulus s.s. (see p.66).

b. Left side of shell with whorls depressed as though reamed

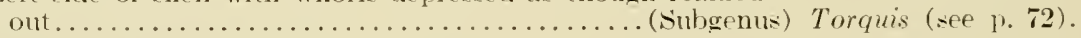

6a. Vergic sac less than one-fourth length of preputimm.......Planorbis (see 1). 51).

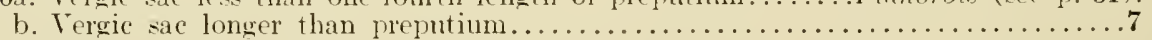

7a. Tergic sac about as long as preputium, shell $5 \mathrm{~mm}$. or more in diameter,

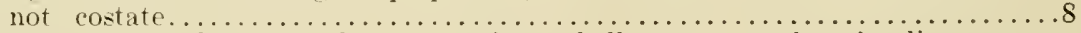

b. Vergic sac much longer than preputium, shell 3 mm. or less in diameter,

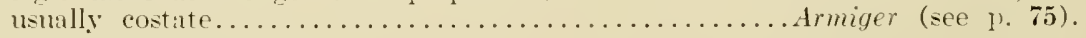

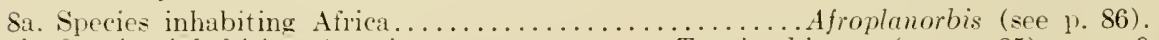

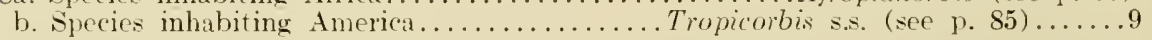
* In using this type of alternative key the options are always arranged in couplets, the contrasting
conditions being arranged as ' $a$ ' and ' $b$ ' under the same numeral. The reader always starts with la. If the description under la fits the specimen or concept under consideration, the numeral at the end of that line indicates the next couplet to be tried (except in those instances where la leads directly to an identification). If the statenent under la does not fit, the alternative under $1 \mathrm{~b}$ should, and so on through the kev until a group name is reached at the end of one of the options. This form of continuous and consecutive key is less confusing than the fype in which descriptions to be compared are widely separated from each other and does not offer the technical difficulties of composition inherent in the indented or step form of key.-H.J.V.C.

tsome subgenera which bave distinctive morphological characters are inctuded in this key and in all succeeding keys to genera. 
9a. Shell with closely coiled whorls slowly increasing in diameter, orbicular.......10

b. Shell with loosely coiled whorls rapidly increasing in

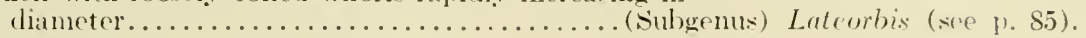

10ix. Aperture without internal lamellae at any stage of

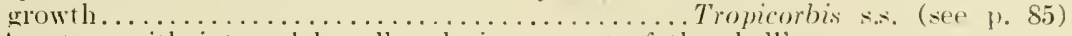

b. Aperture with internal lamellac during a part of the shell's

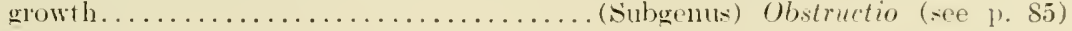

\section{Key to Genera of Segmentininae*}

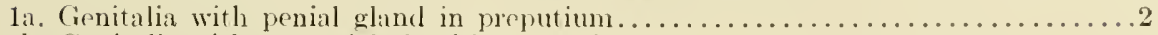

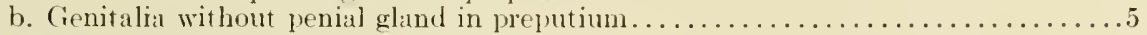

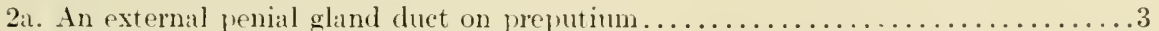

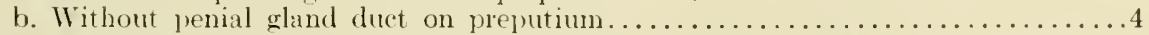

3a. External duct very short, half as long as preputium; penial gland a simple cup attached to wall of preputium; flagella more than twice as long as vergic sac, sausage-shaped, attached to short ducts......... Intha (see p.112).

b. External duct about four times as long as preputium; penial gland sac-like, bifurcated; flagella consisting of small cylindrical sacs attached to very

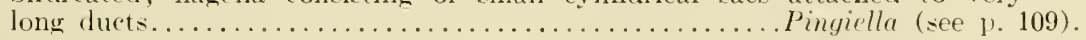

4a. Preputium narrow, ciub-shaped; vergic sac longer than preputium; verge sender with vergic appentage at end................mentina (see p. 96).

b. Preputium wide, peal-shaped; vergic sac shorter than preputium; rerge wide at uper part, without penial appendage............. Hippentis (sce p. 100).

5a. Flagellum long and narrow; rergic sac and preputium of about the same

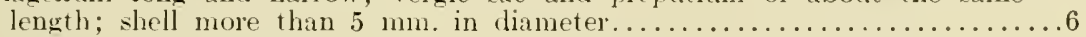

b. Flagellum wide and short; verwic sac about twice as long as preputium; shell very small, $1.5 \mathrm{~mm}$. in dianeter..........................

6a. Flagellum as long as penial complex, swollen or club-shaped at summit . . . . . . 104).

b. Flagellum shorter than penial complex, not swollen at summit, often bifid at the end.........................

7a. Shell with rounded peripherr............... Drepanotremu s... (see p. 118).

b. Shell with angulaterl or carinated periphery.. (Subgenus) Fossulorbis (see p. 118).

\section{Key to Genera of Helisomatinaet}

1a. Preputium with penial gland but without penial duct....Planorbarius (see p. 166).

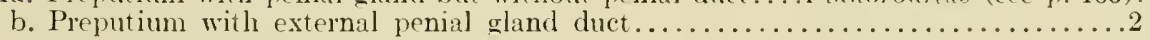

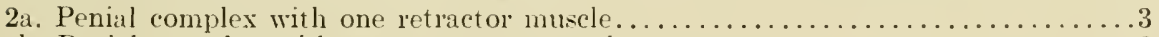

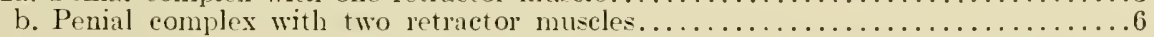

3a. Penial complex with but little constriction between vergic sac and preputium; penial gland duct about half as long as preputium...Helisomas.s. (see p. 124) ...4

b. Penial complex with notable constriction between vergic sac and preputium; penial glind duct as long as the preputium... (Subgenus) Siminolina (spe p.129).

4a. Penial complex with vergic sac and preputium equal in length, the preputium much wider than the rergic sac; penial gland duct several times as long as preputium, in a coil between vergic sac and preputium...............

b. Penial complex with rergic sac shorter than the preputium. which is elongate; penial gland short and thick, not longer than preputium............... 6

5a. Shell with simple aperture, not (ampanulate... (Subgenu*) Pierosoma (see p. 134).

b. Shell with campanulate or bell-shuped apertue (Subgenus) Planorbella (see p. 150).

6a. Penial duct on outside of preputium very short. slender, placed between vergic sac and preputium; penial gland an elongated cup with wide

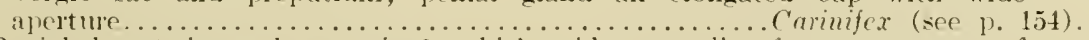

b. Penial duct twice as long as in 6 at thick, wide, extending from upper part of preputium to rergic sac; penial gland pipe-shaped, with a long "stem" at-

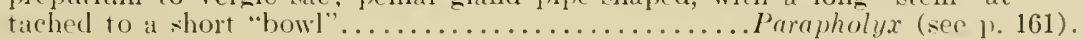

*One subgenus is included among the groups differentiated in this key.

theveral sulugenera are also differentiated in this key. 
Key to Genera of Planorbulinae*

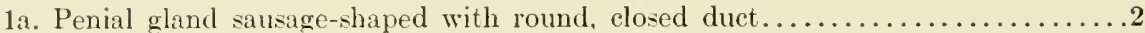

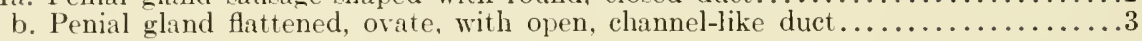

2a. Penial duct very short leading from gland direct to muscular collar or diaphragm........................... (see p. 183).

b. Penial duct long, extending up the side of the preputium to the muscular collar or diaphragm................. (Subgents) Micromenctus (see p. 187).

3a. Penial gland connected with muscular collar by an open duct as long as the gland, lying above a single diagonal projection of the left pilaster; seminal vesicle composed of many diverticula forming a mulberry appearance on

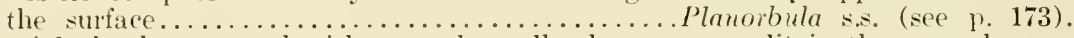

b. Penial gland connected with muscular collar by an open slit in the muscular wall of the preputium, the two pilasters sending branches from both sides to this slit; seminal vesicle consisting of many short diverticula stretched along a large part of the orisperm duct............. Promonetus (see p. 17S).

\section{SYSTEMATIC LIST OF GENERA AND SUBGENERA RECOGNIZED IN THIS WORK}

In the following list the genera and subgenera are arranged in the sequence which appears most in accord with their structural features. Several groups are unknown anatomically and these are marked by an asterisk. They are placed in the subfamilies and near the genera with which they appear to be affiliated. 'The fossil specics, it is obvious, can never be known anatomically and these are placed near those genera which they most nearly rescmble. The fossil groups are marked by a dagger. Two groups of uncertain affinities, one recent and one fossil, are placed at the end of the family sequence. The type species is indicated following the name of each gemus or subgenus.

Family PLANORBIDAE H. and A. Adams, 185.5

Subfamily Planorbinae Pilsbry, 1934

Genus Planorbis Geoffrov, $1767 \ldots \ldots \ldots \ldots$. . . . Helix planorbis Limn.

Genus Anisus Studer, 1820 (Gray, 1847)

Subgenus Anisus S. ................ Helix spin orbis Linn.

Subgemus Costorbis Lindholm, $\dagger 1926 \ldots \ldots \ldots$. . . . . . . . .

Suhgenus Bathyomphalus (Ag.) Charp., 1837.. It lix contorta Linn.

Genus Odontogyrorbis Lörenthey $\dagger 1906 \ldots \ldots \ldots$ Planorbis krambergeri Halaváts

Genus Gyraulus (Ag.) Charp., 1837

Subgenus Grraulus s. . ............... Planorbis albus Müller

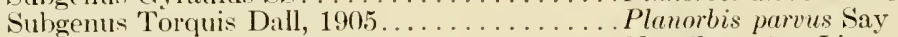

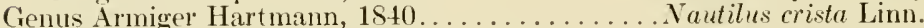

Genus Taphlius H. and A. Adams, $1855 \ldots . . \ldots \ldots$. Planorbis andecolus Orb.

Genus Tropicorbis Pilsbry and Brown, 1914

Subgenus Tropicorlis SS.

P. liebmanni Dunker $=$ orbiculus Morelet

Subgenus Obstructio Haas, 1939........... Planorbis jancirensis Clessin

Subgenus Lateorbis F. C. Baker (New)......... Planorbis pallidus C. B. Adams

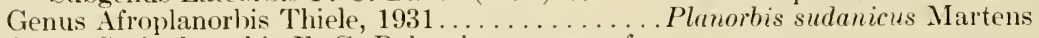

Genus Syrioplanorbis F. C. Baker, $\dagger$ new name for

Heterodiscus West., preoccupied........... Planorbis libanicus West.

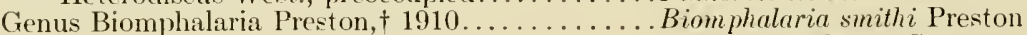

Genus Australorbis Pikbry, $1934 \ldots \ldots \ldots \ldots \ldots$ Planorbis glabratus Say

Genus Anisopsis Sandberger, $₫ 1875 \ldots \ldots \ldots \ldots \ldots$ Planorbis calculus Sandberger

*One subgenus is included in this key.

†The anatomy is not known for any nember of this group.

$¥$ A group represented by fossils only. 


\section{Subfamily SEGMENTININAE F. C. Baker (New)}

Genus Segmentina Fleming, $1817 \ldots \ldots \ldots \ldots \ldots$ Planorbis vitidus Müller

Genus Hippeutis (Ag.) Charp., 1837 . . . . . . . Planorbis complanatues Drap.

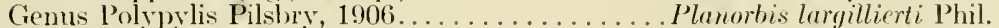

Genus Helicorbis Benson, $\dagger 1855 \ldots \ldots \ldots \ldots \ldots \ldots$ Planorbis umbilicalis Benson

Genus Trochorlois Benson, $†$ 185.5. . . . . . . . . . Trochorbis trochoidues Benson

Genus l'ingiella F. C. Baker (New) .......... Pyramidula peipinensis Ping and Yen Genus Intha Annandale, $1922 \ldots \ldots \ldots \ldots$. . . . . . Irtha capitis Annandale

Genus Drepanotrema Fischer and Crosse, 1880

Subgents Drepanotrema Ss...............Planorbis anatinum Orb.

(=yzabalensis C. and F.).

Sulggenus Fossulorbis Pilsbry, 1934 ........ Planorbis cultratus Orb.

Genus Paraplanorbis Hanna, $\ddagger 1922 \ldots \ldots \ldots \ldots \ldots$ Planorbis comdoni Hanna

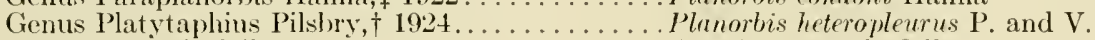

Genus Aerorlis Odhner, $1937 \ldots \ldots \ldots \ldots \ldots$. . . . . . .

\section{Subfamily HELISOMA'TINAE F. C. Baker, 1928}

Genus Helisoma Swainson, 1840

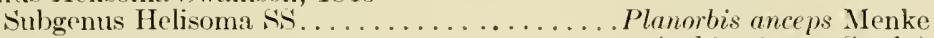

(=biearinatus Sowb.)

Subgenus Seminolina Pilsbry, 1934. . . . . . Physa scalaris Jay

Subgents Pierosoma Dall, $1905 \ldots \ldots \ldots \ldots$. . . . . . . . . . Phorbis trivolvis Say

Subgenus Planorbella Haldeman, is $12 \ldots . . . .$. Planorbis campanulatus Say

Genus Carinifex IV. G. Binney, 1863........... Planorbis newberryi Lea

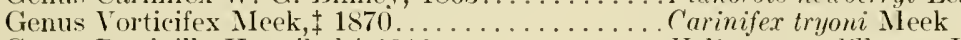

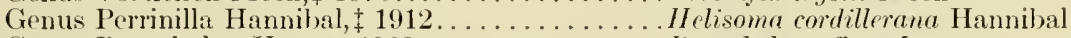

Genus Parapholyx Hanna, $1922 \ldots \ldots \ldots \ldots \ldots \ldots$. Pompholy.x effusa Lea

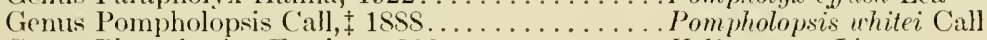

Genus Planorbarits Froriep, $1806 \ldots \ldots \ldots \ldots \ldots$. . . . . . . cornea Linn.

\section{Sulfamily PLANORBLLINAE Pilsbry, 1934}

Genus Planorbula Haldeman, 1840

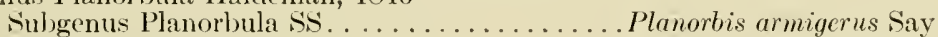

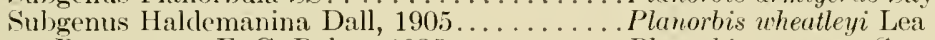

Genus Promenetus F. C. Baker, 1935.......... Plamorbis exacuous Say

Genus Menetus H. and A. Adams, 1855

Suljgenus Menetus S. . . . . . . . . . . . Planorbis opercularis Gould

Sulggenus Nicromenetus F. C. Baker (New)...PPlanorbis dilatatus Gould

Genus Planorbifex Pilsbry, $\ddagger 193 t \ldots \ldots \ldots \ldots \ldots$. . . . . . . . .

Groups of Uncertain Affinities

Genus Choanomphalus Gerstfeldt, $\uparrow 1859$. . . . . Choanomphalus maacki Gerstfeldt Genus Poecilospira Mörch, $\ddagger 1853 \ldots \ldots \ldots \ldots \ldots$ Valvata multiformis Zeiten.

tThe anatony is not known for any nember of this group.

¿A group represented by fossils only: 


\section{SYSTEMATIC ACCOUNT OF THE SUB- FAMILIES, GENERA, AND SUBGENERA RECENT AND FOSSIL}

$\mathrm{P}$ LANORBIDAE, together with the Phrsidae and Bulinidae, are animals with spiral shells; the genitalia and the respiratory and excretory organs are on the left side. The shell of Planorbidae is typically sinistral in some groups (Helisoma) and pseudodextral or ultradextral in many groups. The shell is carried almost vertically in the typically sinistral groups but leans toward the left in other groups, principally the smaller forms. In these groups the spire is beneath and the umbilievis is above, these being respectively the right and left sides of the shell. The central tooth of the radula is always bicuspid. In Physa it is multicuspid.

The chief feature scparating the Planorbiclae from the other nombers of the Limmophila is the presence of an accessory breathing organ, the pseudobranch, which takes over the office of a gill when the animal is submerged and can not obtain free air'. 'The flattened, 'planorboid' shell is, of course, another distinctive feature of the family.

The groups of genera related to Bulinus and Physopsis have in the past been included in the family Planorbidae because of the similarity of the radulae and the presence of a pseudobranch. But this organ in Bulinus is different from the pseudobranch in Planorbidae, being in the form of folds or ridges while in the Planorbirlae it is smooth and leaf-like. There are also differences in the genitalia, prineipally in the penial complex. These differences suggest that Butinus, Physopsis, and other related groups should form a separate family Bulinidae. This has been recognized by Germain in his mollusks of France (1931) and by Larambergue in a recent publication (1939). The Indian genus Indoplanorbis has been shown by the latter author to be related to Bulinus and its place appears to be with the Bulinidae.

\section{Subfamily PLANORBINAE H. A. Pilsbry, 1934}

The subfamily of $\mathrm{H}$. and $\mathrm{A}$. Adams is equiralent to the family Planorbidae as now recognized by systematists. In the Planorbinae the prostate direrticula are all simple saes placed in a single row along the whole length of a long prostate duet which is separated from the sperm duct into which it enters. The ovotestis has the diverticula arranged in a double row. An apparent exception is found in the genus Australorbis where the single row of glands is placed clirectly on the sperm duct and the ends of the prostate diverticula are branched. The kichey is usually rounded and without a superposed ridge. Here again Australorbis is an exception, having a ridged kidney as in Helisoma.

Trpe genus Planorbis Geoffroy.

There is considerable variation among the different genera grouped in Plamorbinae, principally in the jaws, the radulae, and the presence of a penial stylet. These differences may be tabulated as follows:

Rachula with serrated marginals placed high up on the reflection: Planorbis, Bathyomphalus, Anisus, Gyraulus, Armiger.

Radula with claw-like marginals on a long reflection: Australorbis, Tropicorbis. 
Radula with interstitial cusps on laterals or marginals: Australorbis, Tropicorbis. Jaw in three pieces, a slperior and two lateril jaws: Tropicorbis, Australorbis, Afroplanorbis.

Jaw fragmented with many plates: Planorbis, Bathyomphalus, Anisus, Gyraulus, Armiget.

Verge with stylet: Anisus, Bathyomphalus, Gyraulus.

Terge without stylet: Planorbis, Armiger, Tropicurbis, Afroplanorbis, Australorbis.

Several groups are unknown anatomically and hence their position in the system can not be definitely known until the animal has been exanined. such are Costorbis, Syrioplanorbis, Taphius, and Biomphalaria. The fossil group supposed to belong to this subfamily, Odontogyrorbis, can only be placed by shell resemblances and this points to the Planorbinae.

\section{Genus PLANORBIs Geoffroy. 1767}

Genotype by tiatonomy Helix planorbis Linn.

1767. Planorbis Geofror, Traité Coq., Paris. p. 12. No trpe designation.

174. Planorbis Müller, (part) Verm. Terr. Hist., II, p. 152. No type designation.

1833. Amisus Fitzizger, (part) Beitr. Lamlesk. Oester. III, p. 111 (Non Dejean, 1S21, Coleoptera).

1St7. Spromlina Hantiaxy, Hermannsen. Ind. Gen. Mal., II, P. 2S6. As synonym of Planorbis.

1850. Tropidiscus Steix, Schn. u. Museheln Berlins, p. 76. As subgenus. Type designated by Clessin, 1886 - Planorbis marginatus Drap.

1852. Anisus [Fitzixger] Herrmaxxsex, Ind. Gen, Mal., Suppl, p. 9. Type: Planorbis umbilicatus Miiller. As fixed by Gray, 1S47. Not Anisus Studer, $18 s s$.

185̃o. Gyrobis Moq.-Taxd., (part) Hist. Nat. Moll. Terr. et Fluv. France, II, 1.428. No type cited. As genus.

155̃. Omalodiscus Bexsox, Jour. Asiatic Soc. Bengal, XXIT, p. 127. Type designated by Kennard and Woodward, 1924, Omalodiscus marginatus Drap.

1S83. Tropidiscus Fischer, Man. Conch., p. 509. No type designation. As section.

1SS5. Tropidiscus Westerlicd, Fauna Palaearc. Reg.. T. p. 64. No type cited. As subgenus of Planorbis.

1856. Tropidiscus Clessix. Syst. Conch.-Cab., XVII, p. 34. Type Planorbis marginatus Drap. As subgenus.

1598. Planorbis (Geoffroy) vox Mantexs, Biol. Centr. Amer., Moll., p. 380. No type cited. As genus.

1902. Tropidiseus Westerltyd, Rad. Jugoslav. Akad., 151, p. 120. Genotype Helix planorbis Linn. As subgenus.

1905. Placorbis Draparxatd, Nat. Hist. Moll. France, p. 13S. (vide Lindholm, Archiv. fiir Mollusk., 5s year, Heft 6, p. 252).

1905. Tropidiscus D.tLl, Alaska Moll., p. S5. Type Planorbis umbilicatus Müller= Planorbis complanatus Stein.

1906. Omalodiscus Dall. Nautilus XIX, p. 105. Comments on nomenclatorial position but cites no type.

1917. Tropidiscus Soos, Ann. Musei Nat. Hungarici, XT, pp. 40, 141. Type Tropidiscus planorbis (Linn.). As genus.

1921. Tropidiscus Germax, Rec. Ind. Mus., XXI, p. 7. Type Planorbis planorbis (Linn.). As subgenus.

1923. Planorbis (of Müller 1774) Wexz, Fossil. Cat., Part, 22, p. 1523. Crenotype Planorbis planorbis (Linn.). As genus.

1926. Tropidiscus (of Stein) Lixdholm, Archir. für Mollusk., 5s year, Heft 6, p. 252. Ideogenotype Helix planorbis Linn. As genus.

1927. Planorbis Kexyard and Woodward, Syn. British Non-Marine Moll., p. 66. Type by tautonomy Hclix planorbis Linn. As genus. 
1929. Planorbis (of Mïller 1774) HAss, Trab. Mus. Cien. Nat. Barcelona, XIII, p. 379. Type evidently intended to be Planorbis planorbis (Linn.). As genus.

1930. Planorbis H. B. Baker, Oc. Papers, Mus. Zool. Univ. Mich., No. 210, p. 42. Type by absolute tautonomy Helix planorbis Linn. As genus.

1931. Planorbis Germax, Moll. Terr. et Fluv. France, II, pp. 516, 521. No type designation. As genus and subgenus.

1931. Tropidiscus Thiele, Handbuch, IV, Teil 2, p. 481. Type Planorbis planorbis (Limn.). As subgenus.

1935. Tropidiscus Soos, Allat. Kozlem., XXXI1, p. 29. Planorbis carinatus Mïller and Planorbis planorbis (Linn.) cited. As subgenus under genus Anisus.

1936. Planorbis (of Miiller 1774) HAds, Abh. Senckn. Natur. Gesell., No. 431, p. 25. Planorbis planorbis (Linn.) by absolute tautonomy. As genus.

Shell (plate 77, figs. 26-28) discoidal with few whorls, regularly increasing in diameter; upper and lower (left and right) sides flattened; a carina encircles the body whorl on the left side; aperture small, rounded, or oval, the right side in adrance of the left side.

Animal. External appearance. The body is small, the foot short. rouncled before and pointed behind; tentacles long and filiform; eyes sessile at the inner base of the tentacles; when removed from the shell the animal of Planorbis planorbis has a blackish or lead-colored mantle, a yellowish liver, and a pinkish ovotestis.

\section{ANATOMICAL CHARACTERISTICS}

\section{PLATE 1}

GENITALIA. Male Organs (fig. 1). Seminal resicle (sV) $3.5 \mathrm{~mm}$. long and $0.7 \mathrm{~mm}$. wide, elongate-cylindrical, covered for the most part by small pustule-like glands. Sperm duct (SPD) very long (14 mm.) adherent to the oviduct. The prostate (PRS) is about $5 \mathrm{~mm}$. long and consists of forty to forty-five diverticula placed in a single row on a long prostate duct (PD) which is separated from the sperm duct. Both sperm duet and prostate duct enter the smaller vas deferens near the ragina (fig. 1, VD, PD). The prostate diverticula are cylindrical in form and a trifie more than $0.5 \mathrm{~mm}$. in length. A cross section through the prostate and oviduct shows the relationship between the sperm duct and the prostate duet (fig. 7). The vas deferens is a long (12 mm.) narrow tube (VD).

The penial complex is elongated (fig. 2), the preputium (PR) is long (3 mm.), cylindrical, and the vergic sac (VS) is short $(0.7 \mathrm{~mm}$.) and somewhat less in diameter than the preputium. There is one long and narrow retractor muscle ( $R M$ ) attached to the rergic sae near the junction of the latter with the preputium. A group of five or more small muscles near the base of the preputiun and a longer, narrow muscle attached to the upper part of the preputium have been ealled supporting museles (SM). They are not attached to the columella muscle but to the fore part of the head. The long, narrow muscle may play a part in retracting the preputium after copulation.

Internally (fig. 4) the preputium has two vertical pilasters and a large number of longitudinal muscular ridges (PL). The walls of the preputium are thin but the walls of the vergic sac are thickened, especially at the summit where the vas deferens enters. The verge $(\mathrm{V})$ is short and wide in repose and nearly fills the vergic sac. A section through the verge and a 
part of the vas deferens shows the sperm eanal to be loeated in the center and to have a central exit (fig. 5). The absence of a distinct muscular ring or diaphragm is noteworthy.

Female Organs. The spermatheca (S) in the specimens examined is about $1.5 \mathrm{~mm}$. long and $1 \mathrm{~mm}$. wide, globular or pear-shaped, and attached to the uterus by a short, narrow duct about $1 \mathrm{~mm}$. long (SD). The ragina (VG) is very short (less than $0.5 \mathrm{~mm}$.) and wide. The uterus (U) is as wide as the vagina and is about $5 \mathrm{~mm}$. long. The nidamental gland (NG) is as long as the uterus and surrounds a large part of the oviduct isce fig. 1). It is greatly lobulated. The free oviduct (OD) is short (about 2 mm.) and about as narrow as the sperm duet. Beneath the albumen gland the sperm duct and the oviduct are joined to form the orisperm duct (fig. 6). The albumen gland is large $(3.5$ by $2 \mathrm{~mm}$. $)$ and is a mass of small sacs (AL). A small duet enters the earrefour (CF) which in turn enters the oviduet in front of the junction of that organ with the sperm duet.

Hermaphrodite Organs. The orotestis (OT) eonsists of many elubshaped divertieula placed in a double row (fig. 8). The ovotestis is buried in the cell-mass of the liver (fig. 9). The orisperm duct (SO) is divided into two external parts separated by the seminal resicle, through which it passes. One portion, about $5 \mathrm{~mm}$. long, extends back of the sperm duet at its junction with the oviduct and gradually enlarges as it enters the seminal vesicle. A smaller tube, about $3 \mathrm{~mm}$. in length, passes from the seminal vesicle to the orotestis.

The genitalia of Planorbis planorbis have been figured by several European conchologists. Cermain's figure (1931, 1). 523, fig. 533) is in general like the figures in this work, but there is lack of detail. The spermatheea is shown in a more elongated form, but this organ is subject to more or less variation. The large seminal vesicle is indicated by a swelling in the orisperm duet. L. Soos's figure $(1917$, p. 41) agrees in general with that shown in this work. The prostate shows relatively the same number of diverticula. The spermatheea is shown on a long duet and the spermatheca is pear-shaped, not rounded as was observed in all specimens personally examined. Crermain's figure is like Soos's in this respect. There appears to be some rariation in this organ perhaps due to seasonal or sex condition.

The penial complex in Soos's figure is not shown in suffieient detail, but the position of the retractor muscle indicates a short vergic sac. The seminal resicle shows an enlargement. A. Soos's figure $(1935$, p. 25$)$ appears more nearly correct, showing for the first time the separate prostate duct. The spermatheea, however, is shown of a pyriform shape and on a long duct. The figure of the related species carinatus Müller (p. 24) given by Soos is more like the Poland speeimens of planorbis personally examined. The duct of the prostate is shown as very short while in the Poland material the free portion of this duct is much longer before entering the vas deferens. The lower portion of the female complex is shown very mueh longer in Soos's figure than was observed in the Poland specimens.

Respiratory and Renal Systems. The pseudobranch (P. fig. 3 ) is leafshaped, flattened, about $2.5 \mathrm{~mm}$. long and $2 \mathrm{~mm}$. wide. The reetum (R) pierces it after bordering the columella muscle and the anus has its exit at the lower edge (A). The respiratory tube or pneumostome (PS) forms a 
short V-shaped lobe to the right of the pseudobranch. It is large and can be greatly expanded.

The kidney (plate 46, fig. 9) is very long and narrow (10 mm. long, $1 \mathrm{~mm}$. wide), the glandular portion occupying only about one-eighth of the length. The ureter is short $(1 \mathrm{~mm}$. long), narrowly tubular and turns sharply to the left into the mantle eavity. A cross section of the kidner at about midway of its length shows the lumen to be flattened and widened with a rein at each end (fig. 10). There is no ridge on the lower side. The pericardium is long-oval in shape, $2.5 \mathrm{~mm}$. long and $1.2 \mathrm{~mm}$. wide.

Digestive System. The stomach (plate 48, figs. 6, 7) is elongated and pyriform in shape, the blind sac about as long as the stomach. The intestine rums directly forward and does not make a backward loop as in Helisoma and some other groups. The stomach does not show distinct divisions into erop and gizzard. The bueeal sae is elongated and shortly pyriform in shape, the fore part near the mouth somewhat tubular. The radula sae is distinct and rounded. The salivary glands are much elongated, eylindrical, and joined behind.

The jaw (plate 50, fig. 21) is horseshoe-shaped and is eomposed of many small plates, about thirty on the upper or horizontal part, the lower or cutting edges $\mathrm{V}$-shaped.

The radulat (plate 67 , fig. 7 ) formula is $24-1-24,25-1-25$, or $26-1-26$ and the number of rows of teeth varied as follows: 175, 176, 205, and 209 . The central tooth is bicuspid with a wide base of attachment, the cusps long and spade-shaped; lateral teeth (1-10) tricuspid, the cusps large and spade-shaped, the mesocone largest and longest, the reflection reaching nearly to the lower edge of the base of attachment. Intermediate teeth (11-13) with the reflection reaching only about half way to the lower edge of the base of attachment, with four cusps, the ectocone split into two cusps. Marginal teeth (14-20) very narrow with the reflection placed high up on the tooth, with four cusps which become subequal toward the outer margin of the radula membrane. The outer marginals are very narrow, the width being about one-fourth of the height and there are four short, subequal cusps. In one membrane some of the marginal teeth $(20)$ had the entocone split into two sharp eusps. This was rare and oceurred only in atypical rows.

The central teeth varied somewhat in wilth in the same membrane. For example, in rows 1 to 156 the upper part of the central tooth measured 6 mierons and the lower part of the base of attachment measured 12 mierons in width. In rows 157 to 176 these measurements were 5 and 12 mierons respectively. In most membranes the central teeth were very uniform in width.

For the above anatomical data eight specimens were examined, collected by Mr. A. Jankowski from a pond in Swidry-Mate, $25 \mathrm{~km}$. southeast of Warsaw, Poland. No parasitic worms (cercariae) were observed in any of the speeimens examined.

Geographical Distribution. The genus Planorbis, as herein understood, is distributed throughout Europe from Sweden southward to the Mediterranean and from Great Britain eastward to western Russia. It is also found in northern Asia (siberia), Asia Minor, and northern Africa.

Species Considered as Valid. Although many species now assigned to other genera were originally placed in the genus Planorbis there are now 
but relatively few species which belong in this genus as now restricted. The best reeognized of these are:

Planorbis planorbis (Linn.) Planorbis carinatus Miiller Planorbis amouldi Germain Planorbis marmoratus. Michand
Planorbis atticus Bgt. l'lanorbis sieversi Mouss.

Planorbis antiochianus Locard

Geological Distribution. Oligocene to Recent time, according to Wenz. It is probable that some of the species included in this genus by paleontologists really belong to other groups.

Remarks. The genus Planorbis is peculiar anatomieally in the form of the prostate with many single diverticula and in the comparatively small size of the vergie sae as compared with the preputium. The verge, also, is rery small, short, and wide, differing markedly in this respect (as far as known) from any other group of planorbes in Europe. The nature of the genitalia and the form of the shell set this group apart as a distinct genus of the family Planorbidae.

For many rears, the author for this genus and the species for its trpe have been in dispute. Some authors (Tryon 1872, 1884, Fischel 1883, Baker 1902, Binney 1865, Dall 1870. Fischer and Crosse 1879) quote (iuettard as authority (Mem. Acad. Sci., p. 151, 1756). Other authors have cited the genus as of Mïller (Verm. Hist., p. 152, 1774) with Helix corneus Linn. as trpe (Dall 1905, Pilsbry and Bequaert 1927, Baker 1931). A few have used Guettard 1756 and Müller 1774 in combination with Helix corneus as genotype (Cermain 1921, 1931). Another group of authors have cited Geoffroy (Traité Coq., Paris, p. 12, 1767) with Helix planorbis Linn. as genotype i Kennard and Woodward, 1924, 1926).

Guettard 1756 is pre-Linnean and also non-binomial and would appear to be ruled out on these accounts. Geoffroy 1767 is post-Linnean but this author was not in all cases binomial and is rejected by some students for this reason. Kennard and Woodward (1924, p. 9), however, have presented very eonvincing arguments in faror of retaining the Planorbis of this author. The Planorbis of Müller (1774) is preferred by some late writers (Dall 1905. Pilsbry and Bequaert 1927), who cite the Helix corneus of Linnaeus as genotype, giving Montfort 1810 (Conch. Syst., II, p. 270) as the first author to select a genotrpe.

However, whether Geoffroy or Müller is selected, the genotype for both is Helix planorbis Linn., the selection of which is governed by the rules of tautonomy (see H. B. Baker, 1930). After reviewing the evidence very carefully there seems to be no valid reason why Planorbis Geoffroy, $176 \overline{7}$, should not be used, as adrocated by Kemmard and Woodward (1924). The Helix corneus Limn. is the genotype of Planorbarius Froriep, 1806. The name Tropidiscus Stein (1850) is in use by several European authors (Germain 1921, L. Soos 1917, A. Soos 1935, Thiele 1931) but this name is a symonym of Planorbis, having the same genotype. Helix planorbis Linn.

\section{Genus ANISUS Studer, 1820 (Cray, 1847)}

Type Helix spirorbis Linn. selected by Gray in 1847

1820. Anisus Studer, Naturwis. Anzeiger Allg. Schweiz. Ges. Gesimmt. Naturwiss., 3te Jahrg., Nr. 12, p. 91.

1840. Spirorbis Swaxsox, Treat. Malac., p. 337. Type Planorbis vulgaris Swain. Not Spirorbis Daudin, 1800 (Termes). 
1840. Spiralina Hartmax, Erd-und Süssw.-Gasterop., 'Syst. Lebersicht.' Nude name. 1813. Planorbina Haldenax, Mon. Freshwater Univalve Moll., Physidae, p. 14. Type designated by Pilsbry 1934. Planorbis spirorbis Linn. Not Planorbina Dall, 1905 .

1847. Anisus Studer, Grar, Proc. Zool. Soc, p. 180. Type Hclix spirorbis Linn.

1847. Spirorbis Herranaxsex, Ind. Gen. Mal., II, p. 492. Type Planorbis spirorbis (Linn.).

1850. Tropidiscus Stern (part), Lebend. Schneck. und Musch. Berlins, p. 76.

1855. Gyrorbis Moqun-Tandos, Moll. Ter. Flur. France, II, pp. 423, 428. Type designated by Lindholm, 1926. Planorbis rotundatus Poir. = Planorbis leucostoma Millet. Not Gyrorbis Fitz., 1833. As genus.

1870. Anisus Fitz. Dall, An. Lyc. Nat. Hist., N.Y., IX, p. 352. Type Anisus vortex (Linn.). As section of Planorbis.

1853. Gyrorbis Fischer, Man. de Conch., p. 507. Type Planorbis rotundatus Poir. As section of Planorbis.

1885. Gyrorbis Westerlund, Faima Palaeare. Reg., T, p. 64. No type cited. As subgenus of Planorbis.

1856. Gyrorbis Cuessin, Syst. Conch. Cub., XVII, p. 34. Type Planorbis rotundatus Poir. As subgenus.

1897. Diplodiscus Westerluxd, Act. Soc. Fauna Flora Fennica, XIII, p. 115. First species Planorbis vortex (Linn.). Not Diplodiscus Dies.. 1836. Trematodes.

1899. Spiralina Hartmann, yox Martexis, Biol. Cent. Amer., Moll., 1. 395. Type designated Planorbis vortex (Lim.), by Lindholm in 1922 and Kennard and Woodward in 1924.

1902. Diplodiscus Westerlund, Rad. Jugoslay. Akad., 151, p. 120. First species, Helix v'ortex Linn. As subgenus of Planorbis.

1905. Paraspira Dald, Alaska Moll., p1). 82, S6. Type by original designation Planorbis rotundatus Poir. = Planorbis lencostoma Millet. As section of Planorbis.

1909. IJ"̈̈stia Hoxmgunx. Zeitsch. f. Nisturw?, 81, p. 296. Type designated by Lindholm, 1926, Planorbis rotundatus Poir. As synonym of subgenus Anisus.

1917. Gyrorbis L. Soos, Ann. Musei Nat. Hungarici, XT, pp. 49, 143. Gyrorbis spirorbis first species (Anatomy). As genus.

1921. Diplodiscus Westerlund, Germas, Rec. Ind. Mus., XXI, p. 7. Type Planorbis vortex (Linn.). Non Dies. 1836. As subgenus.

1921. Paraspira Germaix, op. cit., p. 7. Type Planorbis rotundatus Poir. As subgenus. 1922. Sprialina (Hartmann) von Martens, Lixpholy. Ann. Musee Zool. L'Acad. Sci.. Russia, Tome XXIII, p. 320. Type designated by Lindholm Planorbis vortex (Limn.). As subgenus.

1923. Gyrostoma Hass, Archiv. f. Molluskund., LV, pp. 43, 45. Trpe designated Gyrostoma rotundatum Poir. = Planorbis leucostoma Millet. Not Gyrostoma Kirby and Spence 1828, Knietniewski 1897, or Hesse 1909.

1923. Spiralina ron Martens 1899, Wevz, Fossil. Cat., pars. 22, p. 1529. Genotype Spiralina vortex (Linn.). As genus.

1923. Paraspira Wexz, op. cit., p. 1530. Genotype Paraspira rotundata Poiret. As genus and subgems.

1926. Spiralina (Hartmann MS) von Martens, Kexward and Woodward, Syn. Brit. non-marine Moll., p. 68. Type Helix vortex Linn. As subgenus.

1926. Spiralina (Hartmann MS) von Martens, 1899, Lindhols, Arehiv. f. Mollusk. 58 year, Heft 6, p. 252. Ideogenotype Helix vortex Linn. As genus.

1926. Anisus (Studer, 1820) Lixphol, op. cit., p. 253. Ideogenotype Planorbis spirorbis (Linn.). As genus.

1926. Anisus (S. Str.) Lindholı, op. cit., p. 253. Monogenotype Spirorbis vulgaris (= Planorbis vortex var. of Drap.). As subgenus.

1929. Anisus (Studer, 1820) HaAs, Trab. Mus. Cien. Nat. Barcelona, XIII, p. 281. Type evidently Planorbis spirorbis (Linn.). As genus.

1929. Spiralina (von Martens, 1899) HAAs, op. cit., p. 381. Type evidently Helix vortcx Linn. As genus. 
1931. Spiralina (Hartmann, von Martens), Germax, Moll. Ter. Fluv. France, II, p. 526. Type rrobably intended to be Planorbis vortex (Linn.). As subgenus. 1931. Anisus (Studer, 1820) Thiele, Handbuch, iv teil, 1. 480. As genus.

1931. Anisus (SS) Thiele, op. cit., p. 481. Type Planorbis lcucostoma Millet. As subgenus of Anisus.

1931. Spiralina (Hartmann) Thuele, op. cit., p. 481. Type Planorbis vortex (Linn.). As subgenus of Anisus.

1934. Anisus Studer, 1820, Prusbry, Proc. Acad. Nat. Sci., LXXXVI, p. 62. Type Helix planorbis Linn. designated by Gray in 1847. As genus.

1935. Spiraliua (Hartmann) ron Martens, 1899, Soos, Allat. Kozlem., XXXII, p. 29. As subgents of genus Anisus.

1935. Anisus Studer, 1820, Soos, op. cit., p. 29. As genus.

\section{Subgenus ANISUS SS.}

Type Helix spirorbis Linn.

Shell (plate 77, figs. 20-22, Anisus spirorbis (Linn.), figs. 16-18, Anisus leucostomus (Millet), fig. 19, Anisus vortex (Limn.)) discoidal with many tightly coiled whorls rery slowly increasing in diameter, all of the whorls risible on both sides of the shell; whorls rounded or with a sharp carina at the periphery; aperture small, rounded or ovate, modified in carinate species by the peripheral carina.

Animal. Externally resembling that of Planorbis.

\section{ANATOMICAL C'HARACTERISTICS}

\section{PLATES 6-7}

GENITALIA. Male Organs (plate 6, fig. 12, spirorbis; plate 7, fig. 2, leucostomus; plate 7 , fig. 6, septemgyratus). Seminal vesiele (SV) long, eylindrical, convoluted, about three times the diameter of the ovisperm duct. sperm duet (SPD) very long and slender $(5 \mathrm{~mm}$. in spirorbis, $7 \mathrm{~mm}$. in septemgyratus, $3 \mathrm{~mm}$. in leucostomus, and $4 \mathrm{~mm}$. in vortex). The prostate is long in vortex and septemgyratus and short in spirorbis and leucostomus. The number of diverticula vary correspondingly, in vortex being about sixty, in septemgyratus fifty-seven, in spirorbis about twenty, and in leucostomus over twenty. The diverticula are sac-like, cylindrical, and are placed on a duet separated from the sperm duet which joins the latter some distance above the vagina to form the vas deferens. Cross sections through the oviduct and prostate show the separation of the two duets (plate 6 , fig. 3 vortex, fig. 8 spirorbis). The prostate duct varies in length in the different speeies. It is about $1 \mathrm{~mm}$. long in spirorbis, but only about $0.2 \mathrm{~mm}$. long in vortex, septemgyratus, and leucostomus. The diverticula of the prostate vary in length and diameter as shown in the figures (plate 6, fig. 12 ; plate 7 , figs. 2,6). The vas deferens is shorter than the sperm duct by about half its length, and, as usual, is a narrow tube.

The penial complex is greatly elongated in all species of the genus Anisus. It is about $3.5 \mathrm{~mm}$. long in vortex, $2 \mathrm{~mm}$. long in spirorbis and leucostomus. The preputium is always shorter than the vergic sac, which may be nearly twice as long in vortex as in spirorbis (figs. 1 and 13 on plate 6 ). The preputium is cylindrical, usually swollen at the upper part. The vergic sac is elongated, pyriform or club-shaped, narrowing greatly in diameter where it joins the preputium. There is one long, narrow retractor muscle and apparently no supporting museles. 
Internally the penial complex has certain distinctive features, as shown in fig. 10 on plate 6 (spirorbis). The preputium has two vertical ridges or pilasters. Between the preputium and the rergic sac there is a thick muscular ring which shows as a swelling on the exterior surface of the upper part of the preputium. A large papilla $(\mathrm{PP})$ is suspended between the walls of the muscular ring, the walls of which are very thick.

Below the large muscular swelling there is a second smaller ring which is here called the diaphragm (D). It is relatively thin and is capable of considerable contraction and expansion, which causes the hole or foramen in the middle, as viewed from above, to be small or large. Buchner shows this ring (Ringwulst) in his fig. 1 on plate 5 , but it is there shown in scetion as almost closed and is placed below the thick papilla. In those specimens of the four species examined the ring has been widely open and the papilla has been extended below the area of the ring (plate 6 , fig. 4 , vortex, fig. 10, spirorbis. The papilla is larger and somewhat differently shaped in the figures on plate 6 , varying in this respect from Buchner's figure. Possibly changes due to breeding condition may be the reason for this difference.

The verge is long, eylindrically pyriform in shape above and tapering rapidly below the midchle of its length to form a slender tube, at the end of which is a small, horny stylet. The sperm canal turns to the side just above the stylet where it has its exit on the side of the verge (plate 6 , figs. 4,5 ). The stylet is sharp and needle-like, bulbous at the upper part where it is attached to the rerge. There is a fine groove extending along one face of the stylet (plate 6 , figs. 2,5 ; plate 7 , fig. 5 ). The verge of vortex is much narrower than that of any other species examined. With the exception of the 'Ringwulst' the penial complex of the four species of the genus Anisus agrees with the description and figure of Buchner.

Female Organs. The spermatheca is much elongated and cylindrical in vortex, spirorbis, and septemgyratus with a spermathecal duct about as long as the spermatheca (plate 6, fig. 12). In leucostomus, howerer, the spermatheca is short and bulbous with a short, thick spermathecal duct (plate 7, fig. 2). In several specimens of septemgyratus the spermatheca was cylindrical and acutely pointed at the summit. One specimen contained a large spermatophore (plate 7, fig. 6). The spermatheca and its duct are over $1 \mathrm{~mm}$. long in spirorbis, but less than a millimeter in leucostomus.

The vagina (V) is very short (less than $0.3 \mathrm{~mm}$.) in all species. The uterus $(\mathrm{U})$ is long and cylindrical in vortex, septemgyratus, and spirorbis, but rather short and wide in leucostomus. The nidamental gland is long and cylindrical in v'ortex, spirorbis, and septemgyratus but large and swollen in leucostomus. The oviduct shows the same differences, being long and cylindrical in vortex, spirorbis (3 mm. long), and septemgyratus, but is short (about $2 \mathrm{~mm}$. long) and of larger diameter in leucostomus. The oviduct is always of greater diameter than the sperm duct (see figs. 2 and 6 , plate 7 , fig. 12 , plate 6 ). The albumen gland is elongated, narrow, and somewhat arched (plate 6 , fig. 9 ; plate 7 , figs. $2,6, \mathrm{AL}$ ).

Hermaphrodite Organs. The ovotestis is made up of many club-shaped diverticula arranged in a double row on the ovisperm duct (plate 6 , fig. 12; plate 7, fig. 2, OT, spirorbis and leucostomus). Two diverticula of leucostomus are shown on plate 6 , fig. 7 . Sereral diverticula of vortex had ripe ova. The ovisperm duct is divided into two parts separated by the 
seminal resicle, as in the genus Planorbis. The portion between the seminat vesicle and the ovotestis is enlarged in septemgyratus and leucostomus (plate 7 , figs. 2,6 ) but is of small diameter in spirorbis and vortex. In the first two species the enlargenent is of the same diameter as the seminal vesicle, of which it may be a part. The portion of the orisperm duct between the seminal resicle and the oviduct is a long, slender, smooth tube in leucostomus, but in vortex, septemgyratus, and spirorbis there are small pustule-like bulgings which appear to be glandular extensions of the sominal resicle.

The genitalia of the four species here recorded are in the main similar to Buchner's fig. 11, tafel 4, which is copied by simroth. Germain's figure of rotundatus $i=$ leucostomus) is similar but lacks detail (1931, pp. 527 , 539). The prostate is shown too long as compared with the Poland specimens personally examined. Soos's figure $(1917$, p. 50) is like those in this work, as is also the figure of vortex $(1,53)$.

Respiratory and Renal Systems. The pseudobranch is large, narrow, and flattened in all species examined. It is pierced by the rectum which is long and narrow. The pneumostome is eylindrical and in the specimens examined is rolled into a crlindrical tube with a large cleft extending its whole length. It varies in length in the different species (plate 6, fig. 6 rortex, fig. 11 spirorbis, and plate 7 , fig. 1 leucostomus).

The kidney (plate 47) is very long and narrow, the glandular portion occupying only a small part of the entire length. In spirorbis (fig. 13) it is $5 \mathrm{~mm}$. long and about $0.3 \mathrm{~mm}$. wide but in vortex it is $12 \mathrm{~mm}$. long and over $0.3 \mathrm{~mm}$. wide. The ureter is very short and is sharply bent upward into the mantle cavity. The pericardium is very short as compared with total length of the kidney. Cross sections show no evidence of a ridge. In i'ortex (fig. 14) the kidney is as thick as wide and the veins are placed at the base of the rounded lumen. In lencostomus (fig. 15) the kidney is wider than high with the reins lower on the lumen. In these species the kidney is somewhat triangular in shape to fit the sharp angle caused by the peripheral carina of the shell. In a cross section of spirorbis (fig. 16) the kidney is seen to be very wide and much flattened with the reins near the middle of the lumen. The kidney of Anisus does not differ in any essential way from that of Planorbis.

Digestive System. The stomach, buceal sac, and general digestive system are similar to these organs in Planorbis. The jaw (plate 50, fig. 25) is similar to that of Planorbis with about twenty plates on the upper part. The side jaws are also fragmented.

The radula (plate 67 , fig. 6, spirorbis) formula is 15-1-15 or 16-1-16. The numbers of rows of teeth vary from 185 to 195 . Central tooth with two spade-shaped cusps reaching nearly to the lower edge of the base of attachment. Lateral teeth (1-10) tricuspid, about as wide as high at first but becoming narrower toward the marginal teeth. There is but one intermediate tooth (11), four-cuspid, with the reflection short and wide. Marginal teeth (12-15) narrow, four-cuspid, the reflections very short and wide. The fourth cusp appears as a splitting of the ectocone. The formulae for the other species examined are as follows:

$$
\begin{aligned}
& \text { septemgyratus 16-1-16 with } 130 \text { rows } \\
& \text { vortex 16-1-16 with } 142 \text { rows } \\
& \text { leucostomus 16-1-16 with } 130 \text { rows }
\end{aligned}
$$


The teeth are all very uniform in form. Anisus has fewer teeth in a row than Planorbis, the formula of which is 25-1-25, but the teeth are similar in form and number of cusps.

For the anatomical information herein presented the following material has been available, all received from Mr. A. Jankowski, of Warsaw, Poland:

vortex, Eight examples from stream in meadow at Jab-Tonna, $18 \mathrm{~km}$. northeast of Warsaw, Poland.

spirorbis, Eight specimens from a trench in Struga, $12 \mathrm{~km}$. northeast of Warsaw, Poland.

septemgyratus, Three examples from turfy meadow in Drewnica, $4 \mathrm{~km}$. northeast of THarsaw, Poland.

leucostomus, Three specimens from small ponds in Bielany Park, Warsaw, Poland.

Geographical Distribution. The genus Anisus is distributed throughout Europe from Great Britain to Russia and Siberia and southward to Italy and Algeria. Thus the distribution is about the same as that of Planorbis. One species is reported from China (paratorter). This distribution may be enlarged when other species are examined anatomically.

Species Considered as Valid. The following speeies are understood to conform to the concept of Anisus.

$\begin{array}{ll}\text { Anisus spirorbis (Linn.) } & \text { Anisus johanseni (Mozley) } \\ \text { Anisus vortcx (Linn.) } & \text { Anisus perezi (Dupuy) } \\ \text { Anisus septemgyratus (Ziegler) } & \text { Anisus fragilis (Millet) } \\ \text { Anisus lcucostomus (Millet) } & \text { Anisus paravortex (Ping and Yen) } \\ \text { Anisus vorticulus (Troschel) } & \text { Anisus milleti (Ciermain) } \\ \text { Anisus villai (Adami) } & \text { Anisus charteus (Held.) } \\ \text { Anisus ressmannianus (West.) } & \text { Anisus centrogyratus (West.) } \\ \text { Anisus compressus (Michaud) } & \end{array}$

Geological Distribution. This genus begins about the middle of the Miocene period.

Remarks. The group of European planorbids under the name Anisus differs from the genus Planorbis notably in the form of the penial complex (compare fig. 4, plate 1, Planorbis, with fig. 10, plate 6, Anisus). In Planorbis the vergic sac is only one-fourth as long as the preputium while in Anisus this organ is always longer than the preputium and the verge is long and narrow and bears a stylet at the end, which is absent in Planorbis. The presence of the muscular ring and papilla in Anisus is also another striking difference. The seminal vesicle also differs markedly in the two genera. The shell is always flattened and many-whorled but from the shell alone the two groups could scarcely be separated generically.

The proper name for the group of European planorbids typified by Planorbis spirorbis, v'ortex, and leucostoms has been in considerable doubt. The name most commonly found in the literature, used by Germain, Lindholm, Soos, Kennard and Woodward, and others, is Spiralina, a nude name published by Hartmann in 1840. In 1899, von Martens used the name for the European Planorbis vortex and the American Planorbis cultratus and sumichrasti. The last two species are now members of the genus Drepanotrema. Thus the type of Spiralina becomes Planorbis vortex and this species was formally designated the type by Lindholm in 1922 (p. 320), and by Kennard and Woodward in 1924 (p. 68). But in 1847 Herrmannsen (Ind. Gen. Mal. II, p. 286) listed Spiralina Hartmann in the synonymy of typical Planorbis without comment or question, thus, as 
H. B. Baker remarks (1930, p. 49) 'effectually elothing and simultaneously killing the name Spiralina.' Thus no subsequent use of this name is permissible. Dall (1905) used the name Diplodiscus Westerlund and cited Planorbis vortex as type, this being the first speeies listed. But this name is preoceupied by Diesing in Trematodes.

In 1934 (Proe. Phil. Acad. Sei., p. 62), Pilsbry revived the early name Anisus Studer, 1820 and gave some very good reasons for accepting this name for the group typified by Planorbis iortex and spirorbis, accepting Gray's subsequent designation of Helix spirorbis Linn. as type. In this connection he remarks

Gray's type designation of ' $H$. spirorbis' is valid for Anisus only if the identity of spirorbis Studer and spirorbis Linn. is admitted. I see no sufficient reason for doubting it. A more serious question relating to Anisus is whether a generic name is valid when admitted by its author to be for a group formed by the union of two prior grenera, and containing nothing else. Unfortunately Opinion 9 of the International Commission on Nomenclature is not explicit on this point, but as Anisus has been widely used it had better be retained.

Other names have been proposed for this European group and would be available but for previous use in other groups. Spirorbis Swainson, Gyrorbis, Diplodiscus, Wrestia, and Gyrostoma are thus affected, as noted in the list of synonyms of Anisus.

The writer agrees with Pilsbry that, since the name Anisus has had wide use in the literature it had better be retained for this group, sinee it was properly clothed as a genus by Gray in 1847. Anisus is used by Thiele in his Handbuch, 1931. The best interest of nomenclature is served by the use of Anisus rather than by coining a new name.

\section{Subgenus COSTORBIS Lindholm, 1926}

Type by original designation Planorbis strauchianus Clessin

1926. Costorbis Lindholı, Archiv. für Mollusk., 58 year, Heft 6. pp. 253, 257. Monogenotype Planorbis strauchianus Clessin. As subgenus of Anisus.

1931. Costorbis Thuele, Handbuch. T. Teil 2, p. 481. Type A. (C.) strauchianus Clessin. As subgenus of Anisus.

Shell (plate 76, fig. 3). Differing from Anisus in being heavily transrersely costate, the body whorl angulated above and below, the aperture quadrate.

Animal. The group is anatomically unknown but the shape of the shell would inclicate that it should be grouped with Anisus.

Geographical Distribution. Russia.

Species Considered as Valid. The only species definitely referable to this subgenus is Anisus (Costorbis) strauchianus (Clessin).

Remarks. It is a question whether this group should be separated from Anisus. The shell of strauchianus is similar in form to that of Anisus scptemgyratus, differing principally in the costate seulpture. Clessin's figure (copied from Conch. Cab., XVII, plate 31, fig. 5) is reproduced on plate 76 , fig. 3 . The original description of the shell appears on page 204 of Clessin's work. 
Subgenus BATHYOMPHALCS (Agassiz MS) Charpentier, 1837

Type IIelix contorta Linn. designated by Hermannsen in 1852

1837. Bathyomphalus Agassiz (MS) Charpextier, Neue Denkechr. Allg. Schweiz. Gesell., I, no. 2, p. 20.

1847. Polygyrus Gray, Proc. Zool. Soc., p. 181. Type Planorbis contortus (Linn.) (not of Say, 1818, or Beck, 1837).

1850. Discoidina Sterx, Leben. Schneck. und Musch. Berlins, p. 82. Type Planorbis contortus (Linn.).

1852. Bathyomphalus Hernuaxsex, Ind. Gen. Mal., II, Suppl., p. 16. Type Planorbis contortus (Linn.).

1855. Bathyomphalus Moqun-Tandon, Hist. Nat. Moll. France, II, p. 443. As subgenus.

1870. Bathyomphalus Dalu, Ann. N.Y. Lyc. Nat. Hist., IX, p. 352. Type Planorbis contortus (Linn.). As subgenus.

1883. Bathyomphahus Fiscrier, Man. Conch., p. 507. Type Helix contorta Linn. As section of Planorbis.

1885. Bathyomphalus Westerluxd, Fauna Palaeare. Reg., V. p. 65. To type cited.

18s6. Bathyomphalus CuEssix, Conch. Cab., XTII, p. 34. Type Planorbis contortus (Linn.). As subgenus.

1902. Bathyomphalus Westeruuxd, Rad. Jugostar. Akad., 151, p. 120. Type Iclix contortus Linn. As genus of Planorbis.

1905. Bathyomphalus Dall, Alaska Moll., pp. 83, 86. Type Planorbus contortus (Linn.). As section of Planorbis.

1917. Bathyomphalus Soos, Ann. Musei Nat. Hungarici, XV, pp. 45, 142. Type Bathyomphalus contortus (Linn.). As subgenus.

1921. Bathyomphalus Cienuax, Ree. Ind. Mus., XXI, p. 7. Type Planorbis contortus (Limu.). As subgenus of Planorbis.

1923. Brthyomphalus Wexz, Fossil. Cat., Pars 22, p. 1633. Genotype Bathyomphalus contortus (Linu.). As genus.

1926. Bathyomphalus Lixdrow, Archir. für Mollısk., 58 year, Heft 6, p. 253. Monogenotype Planorbis contortus (Linn.). As genus.

1926. Bathyomphalus Kevxard and Woodward, Syn. British Non-marine Moll., p. 68. Type II lix contorta Lim. As subgenus of Planorbis.

1929. Bathyomphalus HAAs. Trab. Museo Cien. Nat. Barcelona, XII, P. 383. Type evidently Planorbis contortus (Linn.). As genus.

1931. Bathyomphalus Germax, Moll. Terr. Flur. France, II, p. 520. Type evidently Planorbis contortus (Linn.). As subgenus of Planorbis.

1931. Bathyomphalus Thiele, Handbuch. IV, Teil 2, p. 481. Tyre Anisus (B.) comtortus (linn.). As subgenus of Anisus.

1935. Bathyomphalus Soos, Allat. Kozlem., XXXII, p. 30. Planorbis contortus (Linn.) cited. As genus.

Shell (plate 77, figs. 23-25). Small, ultradextral with the whorls more numerous and more closely coiled than in Anisus, increasing very slowly in diameter, equally visible above and below, but the spire whorls left side) forming a wide depression, a false umbilicus, not present in Anisus.

Animal. Not differing in general characteristics from Anisus.

\section{ANATOMICAL, CHARACTERISTICS}

PIATE 3

GENITALIA. Male Organs (fig. 10). Seminal vesicle (SV) very long (3.5 $\mathrm{mm}$.), of larger diameter than the ovisperm duct with many small tuberculous glands protruding from the surface. Prostate long (about $3 \mathrm{~mm}$.) and composed of forty-eight to fifty relatively short and wide 
diverticula (fig. 10, PRS, fig. 8). The prostate duet is a narrow tube about $1.5 \mathrm{~mm}$. long from the prostate to its junction with the sperm duct to form the vas deferens (fig. 10, PD, SPD). In the natural position the prostate lies over the sperm duet and until separated from this organ the prostate diverticula appear to be directly attached to the sperm duct (see fig. 8, PD). This junction is placed higher up on the uterus than in Planorbis or Anisus. The ras deferens is a long $(4.5 \mathrm{~mm}$.) narrow tube which enters the vergic sac without enlargement.

The penial complex (fig. 9) is very long and narrow, the preputium (PR) being a little more than half the length of the vergic sac (preputium $1.3 \mathrm{~mm}$. vergie sac $2 \mathrm{~mm}$.). The narrow and eylindrical vergie sae is greatly contracted for about a third of its length near its connection with the preputium. There is one long and narrow retractor muscle attached to the summit of the preputium. Internally, the anatomy of the penial complex is the same as in Anisus.

Female Organs. The spermatheea is eylindrieal, $1 \mathrm{~mm}$. long, attached to the ragina by a narrow spemathecal duct a little more than $1 \mathrm{~mm}$. long. The vagina ( $\mathrm{V}$ ) is very short $(0.3 \mathrm{~mm}$.) and wide. The uterus $(\mathrm{U})$ is long (2 mm. long, $0.2 \mathrm{~mm}$. wide) and narrowly eylindrical. The nidamental gland (NG) is long (about $3 \mathrm{~mm}$.) and of larger diameter than the uterus (about $0.3 \mathrm{~mm}$.). The oviduet $(\mathrm{OD})$ is long (about $4 \mathrm{~mm}$.) and narrowly cylindrical. The albumen gland is about the shape of that organ in Anisus (see plate 7 , fig. 2 ).

Hermaphrodite Organs. The ovotestis is like that organ in Planorbis and Anisus. The diverticula are long and eylindrical and packed elosely on the orisperm duet (plate 3 , OT, fig. 7). The ovisperm duct lies at each end of the seminal resicle, of about the same length in each division, labout 2 mm.) and is a small, smooth tube (sO).

The figure in Germain $(1931$, pl. 521, 532) does not agree with the Poland specimens in all respects. The penial complex (p) shows the vergic sae as much swollen, while in the specimens examined it was long and narrowly eylindrical. The relative lengths of the female and male systems is shom much shorter than was observed in the Poland specimens. Details of the prostate and orotestis are not shown. The spermatheea in both figures is the same.

Soos's figure $(1917$, p. 47) is similar to the ones here presented and is somewhat clearer than those of Germain. The prostate shows the great number of short diverticula, the spermatheca is on a long duet, and the penial complex is like the Poland specimens here figured.

Respiratory and Renal Systems. The pseudobranch (plate 3. fig. 5, P) is about as in Anisus, but is smaller and narrower. The pneumostome (PS) is larger than in Anisus but is otherwise similar.

The kidney (plate 46. fig. 19) is long and narrow $(7 \mathrm{~mm}$. long, $0.5 \mathrm{~mm}$. wide) with a sharply reflected ureter. A cross section of the kidney ifig. 20) shows a laterally pyriform lumen with the veins at about the center of the section at each end. There is no ridge on the ventral side of the kidney but there is a rounder bulging on the left side that does not appear on the right sicle.

Digestive System. The stomach (plate 48, fig. 8) is greatly elongated, pear-shaped, with a large blind sae, two-thirds as long as the stomach. 
The intestine crosses orer the oesophagus and extends toward the forward part of the body, but there is no bending backward with a posterior loop as in the Helisomatinae. As in Anisus, there is no sharp division into crop, gizzard, and pyloris. The pyloric portion of the stomach appears to merge with the intestine. Germain states that it is absent. The buceal sac is as in Anisus.

The jaw is like that of Planorbis planorbis, the superior portion having about twenty plates.

The raclula (plate 68, fig. 1) formula is 15-1-15 with 140-145 rows of teeth. Central tooth bicuspicl, nearly reaches to the lower margin of the base of attachment. Lateral teeth (1-8) are tricuspid with a small additional cusp above the ectocone, placed high up on the reflection. The intermediate teeth (9-11) differ by having the reflection placed higher on the tooth, with four cusps, the ectocone split into three cusps. Marginals (1215) with five cusps are like the intermediate tecth, the reflection very high on the tooth. The outer marginal (15) is very narrow.

For the anatomical data herein presented, four specimens were dissected, collected by A. Jankowski, at Drewnica, a turfy ground $4 \mathrm{~km}$. northeast of IVarsaw, Poland.

Geographical Distribution. 'This group extends throughout Europe from the British Isles and Portugal castward to Russia and Siberia, as far east as Kamchatka (Everdam, 1928). Southward the distribution includes the eountries bordering the Mediterranean Sea and the Caspian Sea.

Species Considered as Valid. Apparently but two species are included in this group: Amisus (Bathyomphalus) eontortus (Limn.) of Europe and Asia, and Anisus (Bathyomphahus) dispar (Westr.) of Sweden and Russia.

Geological Distribution. From the Miocene perior to the Recent perioct.

Remarks. In anatomical features Bathyomphalus so nearly resembles Anisus that there scems little reason for recognizing the group as distinct. The genitalia strongly resemble those of Anisus septemgyratus. The internal structure of the penial complex is similar. The kidney shows some differences in cross section (compare plate 46 , fig. 20 , with plate 47 , figs. 14-16). However, the shell is distinctive and the name has been in use for so long a period that it should be retained as a subgenus of the old group Spiralina $(=$ Anisus $)$. It should be noted that the radula formula is the same as in Anisus and different from that of Planorbis.

\section{Genus ODONTOGYRORBIS Lörenthey, 1906}

Type by original designation Planorbis krambergeri Halaráts

1906. Odontogyrorbis Lörexthey, Beiträge zur Fauna und stratigraphischen Lage der pannonischen Schichten in der Ungebung des Balaton-Sees. Resultate d. wissenschaftl. Erforschung des Balatonsees, I, 1, Art. 3, p. 121. Genotype Planorbis krambergeri Halaváts.

1923. Odontogyrorbis Wexz, Fossil. Cat., Pars. 22, p. 1538. Genotype Paraspira (Odontogyrorbis) krambergeri Halavíts. As subgenus of Paraspira.

Shell (plate 76, figs. 1, 2). Tery small, discoidal, flattened, whorls relatively few, closely coiled, increasing very slowly in diameter, each sicle showing all of the volutions, right side slightly concave, left side almost flat; the aperture contains three lamellae, one on the base of the lip and 
two on the upper part of the aperture. The whole edge of the aperture is thickened.

Geological Distribution. Lower Pliocene. Fonyod, Kenese, and Nagyvazsong, Hungary.

Remarks. This group is noteworthy for the presence in the aperture of three folds or plicae, whence the gencric name Odontogyrorbis. In general form the shell is related to Anisus ivetex (Limn.), but is very much smaller. Halavíts original specimens (plate 76 , fig. 1) were broken and did not have the folds in the aperture. Lörenthey obtained specimens with the lip entire (plate 76, fig. 2). Wenz (1923, p. 1538) made Odontogyrorbis a subgenus of Paraspira $(=$ Anisus). While the shell does resemble the type of Paraspira (Planorbis leucostomus Millet) no member of the genus Anisus has as ret been recorded from the recent fauma with a dentate aperture. For the present Odontogyrorbis should be treated as an extinct genus related to Anisus.

Species Considered as Valid. Odontogyrorbis hrambergeri (Halaváts) is the only species here ascribed to the genus Odontogyrorbis.

It is of interest to note that the Pliocene planorbid fauna of the Lake Balaton region consist of sixteen species, all but onc of which are extinct, the Pleistocene fauna contains fifteen species and races all of which belong to the recent fauna. Some of the supposed extinct species are closely related to their recent allies and might be considered geologic variations of the recent forms, in fact, ancestral species.

\section{Genus GRAULL' (Agassiz MS') Charpentier, 1837}

Trpe Planorbis albus Miiller (= Planorbis hispidus Drap.)

Designated by Dall in 18;0. The first species originally included.

1827. Planaria (part) Brows, Illust. Conch. Britain, ed. I, explan. plate LI, firs. 48, 49. Non Mïiller 1886 and Golze 1782 (Vermes).

1837. Gyraulus (Aqasiz MS) Chanpextier, Neue Denkschr. Allg. Schweiz. Gesell. I, no. 2. p. 21.

1510. Gyraulus Hartuary, Syst. Uebers. Eurou. (Gattun. (Tableau).

1841. Trochlea Haldemax, Amer. Jour. Seı., Xlil, p. 216. New name for Planaria. Brown.

1S44. Gyraulus Hartusx, Erd und sïrsw. Gaster. der Schweiz. V. 1) S9.

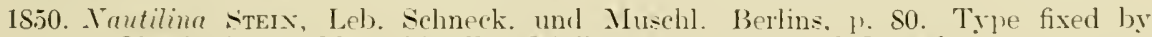
Clessin (1S86) Planorbis albus Müller. As synonym of Gyraulus.

1855. Gyraulus Moquix-Taxdox, Hist. Nat. Moll. France, II, p. 438. No type cited. As genus.

185̃. Giralus Moqun-Taxdox, op. eit., p. 423. Typographical error for Gyraulus.

1857. Gyraulus Girsy, Turton's Manual, 2nd Ed., p. 234. In synonymy.

155̃7. Gymulus Girar, op. cit., p. 234. Error for Gyraulus.

1565. Gyraulus W. G. Brxver, L. \& F-IV Sh. N. A., II, p. 128. No type cited. As subgenus of Planorbis.

1570. Gyraulus Dall, Ann. N. Y. Lye. Nat. Hist., IX, p. 351. Type Planorbis albus Müiller. As subgenus of Planorbis.

18S3. Gyraulus Fischer, Man. Conch., p. 507. Tỹpe Planorbis albus Müller. As section of Planorbis.

1SS3. Caillaudia Bourgutgst, Ann. Soc. Nat. Zool., (6), XV, p. 99. Monotype Caillaudia angulata Bourg. = Planorbis costulatus Krauss. (ville Pilsbry and Bequaert, 1927, p. 124). 
1884. Gyraulus Triox, S. \& S. Conch., III, p. 106. Example Planorbis deflectus Say. As subgenus or Planorbis.

1885. Gyraulus Westerluxb, Fauna Palaeare. Reg., V, p. 75. Type Plamorbis albus Miill. As subgenus of Planorbis.

1856. Gyraulus Clessix, Conch. Cab., XVII, p. 33. Type Planorbis albus Miiller. As subgenus of Planorbis.

1899. Gyraulus Martexs, Biol. Cent. Amer. Moll., p. 392. Type Planorbis albus Miiller. As subgenus of Planorbis.

1902. Gyraulus F. C. BAker, Moll. Chi. Area, II, p. 297. No type cited. As subgenus of Ilanorbis.

1902. Gyraulus Westerlusd, Rad. Jugoslav. Akad., 151, p. 121. Type Planorbis albus Miiller. As subgenus of Planorbis.

1905. Gyraulus DALl, Alaska Moll., Mp. S3, S6. Type Planorbis albus Mïller. As subgenus of Planorbis.

1912. Gyraulus Haxxibal, Proc. Mal. Soc. London, X, p. 154. Type Planorbis albus Miiller. As subgenus of Planorbis.

1915. Gyraulus Prestox, Fauna Brit. India, Moll., p. 118. Type Planorbis albus Miiller. As section of Planorbis.

1917. Gyraulus Soos, Ann. Musei Nat. Hungarici, XV, pp. 54, 144. Type Planorbis albus Miiller. As genus.

1918. Gyraulus Walker, Miscel. Pub., Mins. Zool.. Univ. Mich., No. 6, pp. 12, 94. Type Planorbis albus Miiller. As subgenus of Planorbis.

1919. Gyraulus Axxaxdate and Prashad, Rec. Ind. Mus., XVIII, p. 52. Type Planorbis albus Miiller. As gemus (genitalia and radula).

1921. Gymalus Germax, Rec. Ind. Mus., XXI, pp. S, 98. Type Planorbis albus Miiller. As subgenus of Planorbis.

1922. Gyraulus AnNandale, Rec. Ind. Mus., XXIT, p. 361. Type Planorbis albus Miiller. As genus.

1923. Gyraulus Wexz, Fossil. Cat., Pars 22, p. 1540. Genotype Gyraulus hispidus Drap. $=G$. albus Mïller. As genus.

1926. Gyraulus Kexxard and Woodward, Syn. British Non-Marine Moll., p. 67. Type Planorbis albus Muiller. As subgenus of Planorbis.

1926. Gyraulus F. C. BAker. Trans. Wis. Acad. Sci. Arts, XXII, p. 204. Type Planorbis albus Miiller. As genms.

1927. Gyraulus Pilsbry and Bequanrt, Bull. Amer. Mus. Nat. Hist., LIII, p. 124. Type Planorbis albus Miiller. As subgenus of Planorbis.

1928. Gyraulus F. C. Baker, F. W. Moll. Wis., I, p. 361. Type Planorbis albus Miiller. As genus.

1929. Gyraulus HAis, Trab. Museo Cien. Nat. Barcelona, XIII, p. 384. Type evidently Planorbis albus Mïller. As genus.

1931. Caillaudia Thiele. Handbuch, IV ${ }^{\top}$, 2nd Teil, P. 481. Type wrongly given as Anisus (C.) letourneuxi Bourg. (see Pilsbry and Bequaert, 1927, 1). 124). As section under subgenus Armiger which is a subgenus of Anisus.

1931. Gyraulus Thiels, Handbuch, IV, 2nd Teil, P. 481. Type Planorbis albus Mïller. As section under gemus Anisus.

1931. Gyraulus Germain, Moll. Tert. et Flur. France, II, p. 533. No type cited. As subgenus of Planorbis.

1935. Gyraulus Soos, Allat. Kozlem., XXXII, p. 30. No type cited. As genus.

\section{Subgenus GYRAULUS SS.}

Type Planorbis albus Mïll.

Shell (plate 77, figs. 1-3). Small, ultradextral, of comparatively few flattened whorls, equally visible above and below, usually rapidly enlarging in diameter; body whorl at aperture usually somewhat deflected, the aperture oblique; the periphery is usually median and in some species carinate; the 
shell in screral species is covered with short, hair-like projections of the periostracum (hirsute).

Animal. External appearance (plate 70, fig. 5). The head bears the long. filiform tentacles characteristic of the Planorbinae with the eres at the inner base. In general form the animal does not differ greatly from the figures of Tropicorbis on plate 78. No pigmentation, howerer, shows through the shell.

\section{ANATONICAL, CHARACTERISTICS \\ PLATE 14 (Gyraulus albus)}

GENITALIA. Male Organs (fig. 7). Seminal resicle (ST) less than 1 mm. long, eomposed of a few large diverticula or glands three or four times the diameter of the ovisperm duct. Sperm duet about $2 \mathrm{mmm}$. long, of small diameter. Prostate (PRS) relatively long $(1.5 \mathrm{~mm}$.) consisting of about 22 long (less than $0.5 \mathrm{~mm}$.) diverticula attached to a separate prostate duct which is more than twice the diameter of the sperm duct. The free portion of the prostate duet is very short $(0.2 \mathrm{~mm}$.) and is of the same cliameter as the sperm duct which it joins to form the rather short $(1.2 \mathrm{~mm}$.) ras deferens. A eross section through the prostate near the anterior end shows the sperm duet behind the prostate (fig. 9. SPD).

The penial complex (fig. 2) is eylindrieally elongated, a trifle more than $1 \mathrm{~mm}$. long, the rergie sac (VS) somewhat shorter than the preputium (PR). There is one long retractor musele (RMI). The vas deferens is not enlarged as it enters the vergic sac. Internally (fig. 1) the preputium has thick walls, two pilasters, a muscular ring or diaphragm (D), and a dependent papilla (PP). The vergic sae has thin walls which increase in thickness toward the preputium. The rerge $(\mathrm{V})$ is elongate-prriform, narrowed at the lower end where there is a stylet (ST). The stylet (fig. 8, ST) is dark brown, dagger-like with a ridge extending down the center. The opening of the sperm canal (SC) turns to one side above the stylet and has its exit on the side of the verge.

Female Organs. The spermatheca (fig. 7, S) is elongate-pyriform, about $0.5 \mathrm{~mm}$. long. It is joined to the ragina by a short, narrow duct about half as long as the spermatheea (SD). The vagina (VG) is very short and wide. The uterus $(\mathrm{U})$ is wider than the vagina and the nidamental gland is mide and made up of many large diverticula (fig. 6, NG). The uterus and gland are hidden in the figure by the large prostate. The free oviduet (fig: $6, \mathrm{OD})$ is a short and narrow tube, looped beneath the prostate. Figure 6 shows the relationship of the nidamental gland cliverticula, the oviduct, the prostate, the sperm duct, which forms a loop, and the method of junetion to form the orisperm duet. The narrow duct of the albumen gland and its connection with the oriduct is shown. The albumen gland is squarish or oral in shape and is composed of large gland cells. It contains eavities for the loop of the intestine, over which it lies (fig. 5).

Hermaphrodite Organs. The orotestis (OT) consists of a double row of prriform diverticula attached to a large orisperm duct (fig. 10). At the posterior end of the ovotestis the diverticula are crowded together (fig. 11). Several diverticula had developing egg eells. The ovisperm duct (SO) is divided into two parts, one at each end of the seminal resicle (fig. 7, SO).

The figures on plate 14 agree with that of Germain (1931, p. 533. fig. $545)$. His figure, however, is not very clear. Soos's figure $(1917$, p. 55$)$ is 
similar in general form. The prostate shows fewer diverticula, however, and the spermatheca is on a longer duet than in the specimens from Poland examined, and they are figured more irregularly than was observed in the specimens personally examined. A. Soos's figure of Gyraulus laevis (Ald.) $(1935$, p. 27) shows a smaller number of prostate diverticula than appears normal for the genus. The spermatheca is also on a longer duct than in those species of the genus personally examined. No separate prostate duct is indicated.

American species examined differ but little from the European Gyraulus albus. Gyraulus hirsutus (Gould), the nearest relative to albus, has from twenty to twenty-two diverticula on the prostate as in albus (plate 15. fig. 2). The seminal vesicle is practically the same. The penial complex has a much shorter preputium with a rergic sac one and one-half times as long as the preputium. This difference in form of the penial complex easily separates albus from hirsutus (compare fig. 2, plate 14, with fig. 2 . plate 15). In Gyraulus deflectus obliquus (DeKay) there are forty diverticula on the prostate which is much longer than either albus or hirsutus. The prostate diverticula are also longer and club-shaped tomard the end (plate 16, figs. 11, 12). Plate 16 fully illustrates the genitalia of obliquus. Gyraulus latestomus F. C. Baker (plate 19, fig. 9) has thirty-two diverticula on the prostate and the penial complex resembles that of obliquus. Gyroulus concexiusculus (Hutton) (plate 19, fig. 2) of India has about twenty-five prostate diverticula. The penial complex is rery long and narrow but generally resembles that of hirsutus. The figures on plate 19 agree with those by Annandale and Prashad (Ree. Ind. Mus., XVIII, p. 40 excent that the spematheea in the specimens examined is on a much longer tuct than is shown in their figure.

Respiratory and Renal Systems. The pseudobranch of Gryraulus albus (plate 14, figs. 3, 4) is broad, somewhat triangular, and flattened. The pneumostome is broad (fig. 3. Ps). Figure 4 shows the pseudobranch eut open to indieate the rascular network of blood ressels. The rectum passes through the pseudobranch, as in other genera of Planorbinae. In Gyraulus hirsutus (plate 15, fig. 3) the pseudobranch is as broad as in albus. In Gyraulus deflectus obliquus the pseudobranch was observed to be of several forms (plate 16, figs. 13, 14, 15). It is in each ease a broad, flattened organ. Figure 15 is an unusual form, possibly pathologic. In Gyraulus latestomus (plate 19, fig. 8) it is broad and flattened. In Gyraulus convexiusculus, from India (plate 19, fig. 3 ) it is flat and very thin and the pneumostome is very large. The pseudobranch appears to be similar in form in species from Europe, America, and Inclia.

The kidney (plate 48) is long and narrow in obliquus (fig. $4,9 \mathrm{~mm}$. long) and convexiusculus (fig. 17, $8.5 \mathrm{~mm}$. long). In hirsutus (fig. 18, 2.5 mm. long) and albus (which has the same form as hirsutus) the kidney is short and wide, quite unlike the kidney of the two species previously mentioned. It is similar to that of vermicularis (fig. 3). Sections through the kidneys at about the middle show this organ to be flattened, the lumen much wider than high, and the veins to be placed at each end at about the center. Convexiusculus (fig. 8), hirsutus (fig. 19), and latestomus (fig. 11) are similar in form, but obliquus (fig. 10) is higher in proportion to width showing that the kidney is thicker than in the other species. There is no ridge. The ureter is short in convexiusculus and obliquus but longer and more tube-like in hirsutus and albus. 
Digestive System. The stomach (plate 48, fig. 13) is eylinclrical with the erop, gizzard, and pyloris plainly inclieated. The intestine, after leaving the prloris, makes a loop orer the oesophagus which extends backwart, around the liver, and then loops forward to the reetum which has its exit on the pseudobranch. All species of typical Gyroulus examined have the same type of stomach and intestine. The buccal sac fof Gyraulus albus plate 70 , fig. 131 is pyriform with the radula sac greatly developed and protruding behind (RL). The salivary glands (SG) are elongated, cylindrical, and almost as long as the buceal sac. The ducts of these glands are long.

The jaw (plate 50) is horseshoe-shaped and fragmented as in Planorbis and Anisus. Gyraulus hirsutus (fig. 17) has large plates, about forty on the entire jaw. Gyraulus albus has the same number. In Gyraulus deflectus obliquus (fig. 18) the jaw is arched and consists of orer fifty plates which are narrower than those of albus and hirsutus. In latestomus the jaw is similar to that of obliquus and has over forty plates.

The radula formula of Gyraulus albus (plate 68, fig. 9) is 18-1-18 with 103 to 114 rows of teeth. The center tooth is bicuspid, the eusps long and narrow and reaching only about half way to the lower margin of the base of attachment. The laterals (1-9) are tricuspid mith long, narrow eusps. The cusps of intermediate teeth $(10-11)$ are short. placed high up on the reflection, and the ectocone is split into two sharp eusps. The marginal teeth (12-18) have the reflection high up on the tooth, are wirle and low and 6-euspid. The entocone is split into two small cusps, the mesocone is larger. and the ectocone eusps, three in number, are very small and sharp. In sereral membranes examined a rery small 4 th cusp appears on the 6 th tooth and continues to the intermediate teeth. The center tooth varies in size in the $43 \mathrm{r}$ t to 62 nd rows being a trifle wider at the top than in the first fortytwo lows. The 86 th to $103 \mathrm{rd}$ rows have a central tooth a little more than half the width of those in the 43rd to 62 nd rows.

The radula of $G$ yraulus hirsutus (plate 69 , fig. 1 ) is similar to that of albus. The formula is 19-1-19, with 1-9 lateral teeth, 10-11 intermediate teeth, and 12-19 marginal teeth. There are 130 l'ows of teeth. The radula of Gyraulus deflectus obliquus (plate 69, fig. 2) has a formula of 22-1-22. with 1-9 lateral teeth, 10-13 intermediate teeth, and 14-22 marginal teeth. There are 175 to 183 rows. Gyraulus latestomus has the formula 20-1-20. with 1-10 marginal teeth, 11-14 intermediate teeth, and 15-20 marginal teeth. There are 155 lows of teeth.

Gyraulus convexiusculus has the formula 20-1-20, with 1-9 lateral teeth, 10-13 intermerliate teeth, and 14-20 marginal teeth. The specimens examined differ from the figure by Anmandale and Prashad (Rec. Ind. Mus., XVIII, p. 55, fig. 8, B) where the inner laterals are shown as bicuspid, an unusual condition in the genus. Probably the entocones were not observerl, for they were present in all of the laterals of the teeth personally examined. The figure of the radula of Gyraulus euphraticus (C) by Annandale and Prashad is more correet in the tricuspid character of the lateral teeth. The radulae of all of the typieal Gyraulus examined have been similar in character.

For the above anatomical data the following material has been available:

G. albus, 25 specimens from park in Krolikarnia, a suburb of Trarsaw, Poland. Collected by Mr. A. Jankowski. 
G. hirsutus, 9 specimens from mouth of Bass Creek, Lake Nipissing, Ontario. Collected by Mr. A. La Rocque.

G. deflectus obliquus, 13 specimens from Lake Chetek, Wisconsin. Collected by F. C. Baker; 6 specimens from Taylors Lake, near Quebec, Canada. Collected by Mr. A. LaRocque.

G. latistomus, 3 specimens from Cedar Lake, Algonquin Park, Ontario. Collected by Mr. A. LaRocque.

G. convexiusculus, 3 specimens from Calcutta. India, collected by Dr. B. Prashad.

Geographical Distribution. The genus Gyraulus is practically worldwide in distribution, differing in this respect from all other genera of Planorbidae. Specifie regions include North Ameriea, parts of the Thest Indies and northern South America, Europe, Asia, Africa, Australia, Malaysia, Fiji, New Caledonia, Philippines, and other islands of the Pacifie Ocean.

Below is given a list of some of the species of Planorbids believed to belong in the genus Gyraulus." Some of these speeies may be found, on anatomical examination, to belong to other subgenera or genera. The list is probably not complete.

\section{Species of Europe and Western Asia}

albus Miiller

aeronicus Ferussic

ancylus West.

arcticus Möller

albopersicus Germain

borcalis Loven

bourguignati Moitessier

brondeli Raym.

capocestianis V. Brus.

crossei Bat.

devians Porro

drapanauldi Jeff. gredleri Bietz hebraicus ligt. infraliratus West. intermixtus Mouss. jaminensis Mouss. lacevis Alder limnophilus West. mumidicus Bet. miscinarum Bgt. polnris West. regulosus Lindholm socins 1 Test. tetragyrus West.

\section{Species of Australia and Tasmania}

essingtoncnsis Smith gilbcrti Dunker

\section{Species of Africa}

abyssinicus Jickeli adansonii J. E. Gray acthiopicus Bourg. agraulus Bourg. andersoni Ancey avakubicnsis Pils. and Beq. chedcaui Germain cockbrumi Godwin-Austen costulatus hrauss crawfordi Melville and Ponsonby fouladongouensis Germain gardei Germain meridionalis Brazier planissimus Mousson

gibbonsi Nelson kigeziensis Preston kisumiensis Prest on lamyi Germain leucochilus Melville and Ponsonby misellus Morelet natalensis Krauss spcrabilis Preston schueinfurthi Clessin tilhoi Germain toukotoensis Germain

*In this faunal list, which Mr. Baker had never fully edited, the author's name follows each specific name with disregard for use of parentheses to indicate change from original generic assignment.-H.J.V-C. 


\section{Species of Fiji Group \\ singularis Mousson}

\section{Species of New Caledonia}

montrouzicri Gassies rossiteri Crosse

Species of India and Asia

associatus Westerlund
acutus Clessin
barratiporensis Clessin
cantori Benson
cherraensis Godwin-Austen
compressus Hutton
concexiusculus Hutton
demissus Westerlund
elegantulus Dohrn
euphraticus. Mousson
himlayaensis Hutton
hohenacheri Clessin
huttomi Benson
hyptiocyclos Benson
infralincatus Martens
intermixtus Mousson
issytulensis Clessin

labiatus Benson

laidocensis Nevill

liratus Westerlund

malacaensis Germain pangongensis Nevill proclivis Martens rotula Benson

saigonensis Crosse and Fischer saltensis Germain sivalensis Hutton stelzneri Dohrn stewarti Germain sumatrames Martens tomdanensis Quoy and Gaimard velifer Annandale ycni Ping and Yen

Species of Japan

amplificatus Mori biuacnsis Preston hicmantium. Westerlund infirmus Mori iuaotakii Mori

\section{Species of the Philippines}

mindanensis Bartsch

quadrasi Mollendorff

$$
\begin{aligned}
& \text { japonicus Martens } \\
& \text { noziriensis Mori } \\
& \text { puleher Mori } \\
& \text { tokyoensis Mori }
\end{aligned}
$$

\section{areticus (Beck in Möller) \\ boetzhesi (Miller) \\ borealis Lovén cyclostomus F. C. Baker deflectus (Say)}

Species of America

deflectus obliquus (De Kay) hirsutus (Gould) homensis F. C. Baker latistomus F. C. Baker

Geological Distribution. According to Wenz the genus Gyraulus dates geologically from the Middle Eocene period.

Remarks. The genus Gyraulus is closely related to Anisus in its anatomical features, especially the genitalia. In faet, Gyraulus, Anisus, and Bathyomphalus form a natural group, based on their anatomy, particularly in the presence of a horny stylet on the verge. The shells of Anisus and Gyraulus, however, are quite unlike and the genera should undoubtedly be separated on conchologieal grounds alone.

More than ninety species of Gyraulus are listed on the previous pages (excluding those from America). Some of these may be found to belong in other genera, when examined anatomically. Also, it is probable that sereral additional species should be added to those listed. Completeness is not claimed. All of those listed have been included in the genus Gyraulus by competent conchologists. 
Subgenus TORQUIS Dall, 1905

Type by original designation Planorbis parvus Say

1899. Gyraulus (part) Martexs. Biol. Cent. Amer., Moll., p. 392. Includes Planorbis parvus Say.

1905. Torquis Dall, Alaska Moll., pp. 83, 86. Type Planorbis parvus Say. As section of subgenus Gyraulus.

1918. Torquis Walker, Miscel. Contr., Mus. Zool., Univ. Mich., No. 6, pp. 34, 94. Type Planorbis parvus Say. As section of subgenus Gyraulus.

1921. Torquis Germaix, Rec. Ind. Mus., XXI, pp. 8, 150. Type Planorbis parvus Sily. As subgenus of Planorbis.

1923. Torquis Wexz, Fossil. Cat. Pars 22, p. 1627. Genotype Gyraulus (Torquis) Say. As subgenus of Gyraulus.

1926. Torquis Kexxard and Woopward, British Non-Marine Moll., p. 67. As section of Gyraulus in synonymy.

1926. Torquis F. C. Baker, Trans. Wis. Acad. Sci. and Arts, XXI, p. 204. Type Planorbis parvus Say. As subgenus of Gyraulus.

1928. Torquis F. C. BAker, Fresh-Water Moll. Wis., I, N. 373. Type Planorbis parvus Say. As subgenus of Gyraulus.

Shell (plate 77, figs. 4-6). Ultradextral, smaller than Gyraulus, Ss, with the whorls less distinctly spirally striated, not hirsute, the bise (left side) more or less concave, or excavated (appearing as though reamed out), the lip often slightly thickened within.

Animal. Not differing from Gyraulus in general form.

\section{ANATONICAI, CHARACTERISTICS}

PLATE 17 (Gryraulus parus)

GENITALIA. Male Organs (fig. 6). Seminal resicle (ST) short $(0.5$ mm.) of the same diameter as the sper'm duct. There are a number of small glands which stand out like pustules. Sperm duct a trifle more than $1 \mathrm{~mm}$. in length. Prostate (PRS) more than half as long as the sperm duct with eleven long and cylindrical diverticula. The free portion of the prostate duct is very short (PD), joining with the sperm duct to form the ras deferens. A cross section through the prostate shows the crlindrical or pear-shaped diverticula on a separate duct which has a greater diameter than the sperm duct (fig. 10). The ras deferens is at first a large duet but becomes smaller in diameter toward the penial complex (VD). It is about $1 \mathrm{~mm}$. in length.

The penial complex (fig. 6. VS, PR) is very long (about $1.3 \mathrm{~mm}$.) and narrow, and cylindrical. The vergic sac is longer than the preputium. There is one large retractor muscle attached near the junction of the vergic sac with the preputium (fig. 12, RM). The vas deferens is not enlarged as it cnters the vergic sac. Internally (fig. 12) the preputium has two vertical pilasters. The rergic sac is long and cylindrical and is cnlarged at the upper end (VS). The verge $(\mathrm{V})$ is long and narrow, enlarged at the upper end, very narrow below where there is a horny stylet (ST). The opening of the sperm canal is on the side as in typical Gyraulus. Betreen the vergic sac and the preputium there is a large papilla and below this a swelling of the wall of the preputium representing the better-developed muscular ring or cliaphragm of typical Gyraulus (not shown in the figure).

Female Organs. The spermatheca (fig. 6, S) is small, pyriform, and connected with the ragina by a duct about as long as the spermatheca 
(SD). The ragina is narrow and about as long as the spermatheca and its duct. The uterus and nidamental gland are relatively short and wide (U). The oviduet is short (about $0.5 \mathrm{~mm}$.). The junetion of the ovicluat and sperm duct to form the ovisperm duet is shown in fig. 7. The albumen gland is squarish in form, longer than wide (about $1 \mathrm{~mm}$. long), and is composed of large diverticula. Its duct is long and looped (fig. 9, D)A).

Hermaphrodite Organs. The orotestis is rather short and is composed of but few club-shaped divertieula arranged in a double row (fig. 6, OT; fig. 11). The ovisperm duet is small and tube-like and is longer between the seminal resicle and the orotestis than between the seminal resicle and the ovidurt (fig. 6, SO). Several of the cliverticula of the orotestis were filled with ova ready for extrusion (fig. 11).

Sereral other species of the subgenus Torquis have been dissected and may be compared with parvus. Cryraulus circumstriatus (Tryon) (plate 17, fig. 1, also fig. 4) is similar in form. The prostate has tweive clivertieula. The spermatheca is the same. The duct to the albumen gland is not so long (fig. 2). The penial complex is the same in both species which are of about the same size. In Gyraulus vermicularis (Gould) there are sixteen diverticula in the prostate and ten chrerticula in the ovotestis (plate 15, fig. 10). The penial complex is somewhat different, the preputium being long and eylindrical and the vergie sac very short, only about half as long as the preputium. In Gyraulus similaris (F. C. Baker) (plate 18, fig. 1) there are nineteen diverticula on the prostate and the orotestis diverticula are few in number. In the penial complex the rergic sac is shorter than the preputium. There is a heary swelling at the upper part of the preputium where the papilla and museular ring are loeated. A section through the penial complex (fig. 3) shows the relationship between the several organs. The verge is very long and slender and has a large stylet (fig. 4). The junction of oviduet, slerm duet, and ovisperm duct is shown in fig. 2.

The genitalia of the subgenus Torquis differ from those of typical Gyraulus in the form of the seminal vesicle, the fewer diverticula of the prostate, and the rounder spermatheca on a shorter duet. In general, however. the two groups are very similar in the form and position of the genital organs. No figures of the genitalia of the Torquis group have been published previously; hence no comparisons can be made.

Respiratory and Renal Systems. The pseudobranch of Gyraulus parrus (plate 17, fig. 8) is flattened, wide, leaf-like, and is piereed by the rectum. The pneumostome is very large. In Gyraulus circumstriatus (fig. 3) the pseudobranch is much narrower (the animal was much contracted). In Gyraulus vermicularis (plate 15, fig. 8) it is flattened and somewhat triangular. In Gyraulus similaris (plate 18, fig. 5 ) it is like that of vermicularis but the rectum has a slight ridge which was not observed in any of the other species examined. In the four species of this group studied there was a large, flattened, muscular pad extending backward from the free portion of the pseudlobranch to the place where the rectum begins on the intestine. Figure 5 on plate 18 and fig. 8 on plate 15 show the form of this pad. The rectum pierces this pad as well as the pseudobranch and has its exit (A) above the leaf-like pseudobranch.

The kidney (plate 47, fig. 1, parvus) is very long and narrow (4 mm. long, $0.5 \mathrm{~mm}$. wide), the ureter short and recurved. In Gyraulus circum- 
striatus (fig. 2) the kidney is much shorter and wider (less than $2 \mathrm{~mm}$. long). In v'ermicularis it is short and wide as is also the case in similaris. Cross sections through the kidney of the four species show a similarity of conditions (fig. 5 parvus; fig. 6 circumstriatus; fig. 7 z'ermicularis; fig. 9 similaris). The kidneys in Gyraulus and Torquis differ little in structure.

Digestive System. The digestive tract shows division into crop, gizzard, and pyloris and there is a large blind sac. The intestine does not form a posterior loop, as in typical Gyraulus, but crosses orer the oesophagus and extends forward as in the genus Planorbis. The buccal sac is like this organ in trpical Gyraulus.

The jaw (plate 50, fig. 16, partus) is horseshoe-shaped with many small plates as in Gyraulus typical. There are approximately thirty-six to forty plates on the jaw of parrus and Gyraulus vermicularis has about forty-seven plates (fig. 19). Gyraulus circumstriatus (fig. 22) has a small, narrow jaw with about thirty-seren plates. The jaws of Gyraulus (figs. 17-18) are not as trpically horseshoe-shaped as in the subgenus Torquis.

The radula formula of Gyrculus parius (Say) is 14-1-14 with 105 rows of teeth (plate 69, fig. 3 ). The center tooth is bicuspid, the cusps not reaching the lower margin of the base of attachment. There are 1-6 lateral tecth, tricuspid, with spade-shaped cusps. Intemediate teeth (7-8) with the ectocone split into two small cusps. The 9 th tooth is also transitional with the ectocone split into three small cusps. Trpical marginal tecth (10-13) have the entocone split into two small cusps, the mesocone large and spade-shaped, and the ectocone split into three small cusps.

In Gyraulus vermicularis (Gould) (fig. 5) the formula is 15-1-15, with 1-6 laterals, 7-10 intermediates and 11-15 marginals. There are 120-125 rows of teeth. In Gyraulus similaris (F. ( . Baker) (fig. 4 ) the formula is 22-1-22 with 1-7 laterals, 8-10 intermediates, and 11-22 marginals. There are 130 rows of teeth. Gyraulus circumstriatus (Tryon) has the formula 14-1-14 with the same number and position of teeth as in parvus. The radula teeth of the subgenus Torquis do not differ in general characteristics from those of typical Gyraulus. Compare figs. 1, 2 with figs. 3, 4, 5 on plate 69 .

For the above anatomical data the following specimens were studied:

Gyraulus parvus (Say), 14 specimens from Winnebago Lake, Wisconsin, Henry Co., Illinois, and Meach Lake, Canada, collected by F. C. Baker and A. LaRocque. Gyraulus circumstriatus (Tryon), 17 specimens from Wainwright Park, Alberta, collected by Dr. Swales, and North Star Lake, Wisconsin, collected by F. C. Baker. Gyraulus rermicularis (Gould), 10 specimens from Mt. Lake, San Francisco, California, and Hat Creek, Bishop, California, both lots collected by Dr. G. D. Hanna.

Gyraulus similaris (F. C. Baker), 17 specimens from Smartweed Lake, Toland, Colorado, collected by Dr. Frank Smith.

Geographical Distribution. The subgenus Torquis is found throughout North America from Mexico northward. It is also apparently represented by Gyraulus santacruzensis Germain from the Island of St. Croix. West Indies. Gyraulus laevis Alder, a common suecies of Europe, also belongs to this subgenus. Some of the other species listed under the distribution of typical Gyraulus may belong to Torquis, but not enough material is available for study to confirm this suggestion. 
Species Considered as Valid. The Anerican species inclucled in this subgenus are:

Gyraulus (Torquis) acruginosus Morelet

Gyraulus ('Torquis) arizonensis Pilsbry and Ferriss

Gyrmulus (Torquis) altissimus ( F. C. Baker)

Gycaulus (Torquis) carus

Pilshry and Ferrise

Gyraulus (Torquis) circumstrintus (Tryon)

Gyraulus (Torquis) circumstriatus wallieri Tanatta

\author{
Gyroulus (Torquis) proreus (Sia) \\ Gyraulus (Torquis) sentucruzensis \\ (Germatio) \\ Gyraulus (Torquis) similaris \\ (F. C. Baker) \\ Gymanlus (Torquis) remicularis \\ (Gould) \\ Gyraulus (Torquis) vermicularis \\ hendrisomi Wilker
}

Geological Distribution. Torquis apparently dates geologically from the Oligocene period. Torquis silicens Pilsbry and Brown, Oligocene of Dry Hill, Antigua.

Remarks. Exeept for some small details in genitalia, referred to on a previous page, the subgenus Torquis is similar in anatomical details to typical Gyraulus. It is, however, a convenient name for the smaller species with 'reamed out' left side, like parvus and vermicularis, which have narrower and smoother whorls than the species of typical Gyraulus, like albus and deflectus.

\section{Genus ARMIIGER Hartmann, 1840}

Type by designation of Hartmann in 1812, Nautilus crista Linn.

1840. Armiger Hartataxx, Syst. ubers. Europ. Gatt., table.

1842. Armiger Hartuasx, Frd-und Siiss. Gasterop., V, pp. 172, 219. Tyje Armiger cristatus Drap. = Nautilus crista Linn.

1847. Nautilus Grar, Proc. Zool. Soc., p. 181. Type Turbo nautilus Linn.

1850. Nautilina Sterx, Leben. Schneck. und Musch. Berlins, 1. 81. Ideogenotype Planorbis nautilus Stein $=$ Planorbis cristata Drap. Type designation by Lindholm in 1926.

1885. Armiger Westerluxd, Fanna Palueare. Reg., V, p. 65. No type citerl. As subgenus of Planorbis.

1902. Armiger Westerluxd, Rad. Jugoslar. Akad, 151, p. 121. Type Turbo nautilus Linn. As subgenus of Planorbis.

1903. Spiniformis Germaix, Bull. Soc. Sci. Nat. Ouest France, ii, III, p. 204. Vicle Ciermain, 1931.

1905. Armiger DALl, Alaska Moll., pp. 83, 86. Type Planorbis crista (Linn.). As section of subgenus Gyraulus.

1918. Armiger Walker, Miscel. Contr., Mus. Zool., Univ. Mich., No. 6. pp. 13, 94. Type Planorbis crista (Linn.). As section of subgenus Gyraulus.

1923. Armiger Germatx, Rec. Ind. Mus., XXI, pp. 8, 153. Type Planorbis crista (Linn.). As subgenus of Planorbis.

1923. Armiger Wenz, Fossil. Cat., Pirs 22, p. 1625. Genotype Gyraulus (Armiger) crista (Linn.). As subgenus of Gyraulus.

1926. Armiger Lrvoholir, Arehiv, fïr Mollusk., 58 year, Heft 6, p. 253. Monogenotype Armiger cristatus Drap. = Planorbis crista (Linn.). As genus on conchological grounds.

1928. Armiger F. C. Baker, Fresh-water Moll. of Wisconsin, I, p. 385. Type Nautilus crista Linn. As subgenus of Gyraulus.

1929. Armiger HaAs, Trab. Museo Cien. Nat. Barcelona, XIII, p. 386. Type eridently Nautilus crista Linn. As genus. 
1929. Armiger Odhxer, Die Mollusk. Fauna Takern, p. 22. Type Armiger crista (Linn.). As genus on anatomical grounds.

1931. Armiger, Genmarx, Moll. terr. flur. de France, II, P. 540. Type Planorbis crista (Linn.). As subgenus of Planorbis.

1931. Armiger Thiele, Handbuch, IV, Teil 2, p. 481. Type Anisus (Armiger) crista (Linn.). As subgenus under Anisus.

1935. Armiger A. Soos, Allat. Kozlem., XXXII, p. 30. As subgenus of Gyraulus. No type indicated.

Shell (plate 76 , fig. 6). Ultradextral, small, with few rapidly increasing, costate whorls, the costae usually projecting at the periphery. The general form is like that of Gyraulus.

Animal. External form like that of Gyraulus.

\section{ANATOMICAL CHARACTERISTIC'S}

\section{PLATE IS}

GENITALIA. Male Organs (plate 18, fig. 7). Seminal vesicle (SV) with very few large glands or diverticula. Sperm duct $1.5 \mathrm{~mm}$. long, bent upon itself in a loop posterior to the prostate. Prostate $0.5 \mathrm{~mm}$. long, consisting of thirteen long, cylindrical diverticula placerl on a separate prostate duct. The free portion of the prostate duct is very short. Vas deferens a long (1 mm.), small duet.

Penial complex (fig. 7) with a rergic sac one and one-half times as long as the preputium. The vergic sac is enlarged at the end where the vas deferens enters it as an cnlarged tube. There is one retractor muscle (RM). The preputium is of larger diameter than the greater part of the length of the vergic sac.

Internally (fig. 9) the penial complex is formed like that of Gyraulus. There are two pilasters, a dependent papilla (D), and also a muscular ring or diaphragm (not shown in figure). The verge $(\mathrm{V})$ is elongated, cylindrical, tapering gradually to the end, which does not bear a horny stylet, as in Gyraulus, but a small, pointed fleshy papilla (fig. 10. PA, fig. 11, PA). The opening of the sperm canal is just above this papilla at the end of the verge, in the center and not at the side as in Gyraulus (figs. 10, 11, SC).

Female Organs. The spermatheca $(\mathrm{S})$ is long and pyriform in shape, tapering gradually to the short, wide ragina ( $\mathrm{V}(\mathrm{i})$, the duct being very short. The uterus (U) and nidamental gland are wide, the uterus short and the gland rather long. The oviduct (OD) is short and greatly swollen below the junction with the sperm duct to form the ovisperm duct. The albumen gland (fig. 8) is large (1 mm.), elongated and composed of large gland cells. It is joined to the large, bulbous carrefour $(\mathrm{CF})$ by a long, very fine duct (DA). The carrefour connects with the oviduct. The intestine $e x-$ tends the whole length of the albumen gland which covers the greater part of the intestine. The space occupied by this organ is shown in the figure (AL).

Hermaphrodite Organs. The orotestis (OT) consists of many clubshaped diverticula placed in a double row. The ovisperm duct (SO) is twice as long between the oviduct and the seminal resicle as between that organ and the orotestis.

No figure of the whole genitalia of Armiger was available before the publication of A. Soos's paper in 1935 . His figure $(1935$, p. 28) differs in several respects from the oncs here presented. The prostate has nine 
diverticula which appear widely spaced while there were thirteen crowded diverticula in the specimens personaly examined. 'The separate prostate duet is not shown in Soos's figure. The spermathera in Soos's figure is also on a longer duct. The penial eomplex differs in several respects.

In 1929 (p). 22, 30) Odhner called attention to the absence of a stylet in Armiger, figured the verge of Armiger crista to show the absence of the stylet and the presence of a small penial papilla. This is, apparently, the first indication of this anatomical difference between Armiger and Gyraulus. Odhner noted a difference in the size of the teeth and formula of crista, those from the Tikern having much smaller teeth than specimens from near Stockholm. The formula, also, was only 11-1-11 while the larger form has a formula of 14-1-14.

Germain (1931, p. 540) says 'Appareil génital comme rhez les espèces du sous-genre Gyraulus.' But this is not the ease. There is no stylet at the end of the verge and the opening of the sperm canal is at the center beside a small papilla and not at the side above a stylet as in Gyraulus. The seminal resicle is also different in form of glands. These differences in anatomy are sufficient to remove Armiger as a subgenus of Gyraulus and indicate its right to full generie rank. The genitalia of Armiger and Torquis may be compared on plate 18 , where the difference in the structure of the termination of the verge is plainly indicated.

Respiratory and Renal Systems. The pseudobranch (plate 18, fig. 6) is broadly triangular, leaf-like. The rectum is a large tube bordering the upper side of the pseudobranch and the anus is above the pseudobranch.

The kidney (plate 47, fig. 20) is short and wide, somewhat resenbling the kidney of Gyraulus vermicularis (fig. 3). A scetion through the kidney near the middle (fig. 21) shows it to be flattened, convex above, with the veins near the center of each side of the oval lumen. The seetion is also similar to that of Gyraulus vermicularis (fig. 7).

Digestive System. In the region of the stomach (plate 48 , fig. 15) there is a distinct division into crop, gizzard, and pyloris. The intestine makes a loop forward and then backward under the oesophagus. It bends around the liver and turns forward, ending in the rectum on the pseudobranch. The stomach region resembles that of Gyraulus (fig. 13). The buccal sac is like that of Gyraulus.

The jaw (plate 50, fig. 20) is narrow and characteristically horseshoeshaped with the lateral processes elongated. There are twenty-two plates in the upper or superior jaw and fourteen to sixteen plates in each of the side jaws. The jaw most nearly resembles that of Gyraulus circumstriatus (fig. 22 ) except that it bears a larger number of plates.

The radula formula is 16-1-16 with 150 rows of teeth. The center tooth is bicuspid and resembles that of Gyraulus iermicularis (fig. 5). The laterals are four-cuspid (1-9), the intermediate teeth (10-11) five-cuspid, and the marginals (12-13) six-cuspid. The outer marginals are vestigial. The teeth resemble those of Gyraulus except that there is always an accessory cusp above the ectocone, even in the lateral teeth.

For the above anatomical rata ten specimens were dissected, collected from a siramp on University Bay, Lake Mendota, near Madison, Wisconsin, by Dr. J. P. E. Morrison. These represent the variety imbricatus. Typical crista from a pond in Krolikarnia, a suburb of Wirsaw. Poland, collected by A. Jankowski, provided most of the anatomical data. 
Geographical Distribution. Armiger is Palearctic in distribution, occurring in the northern United States and Canada, northern Europe and Asia. Armiger crista is reported from the trans-Mediterranean region, from Algeria, Tunis, etc. A species (Armiger annandalei Germain) has been described from eastern Asia. The genus contains several forms which should probably rank as species.

Geological Distribution. Accorting to Wenz (p). 1632-1633) Armiger is first known from the Middle Miocene period.

Species Considered as Valid. The only species definitely assigned to this genus in the present volume are:

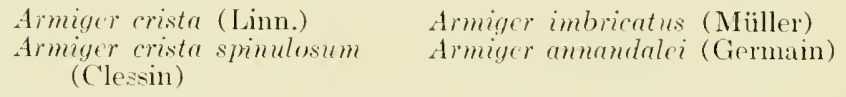

Remarks. By the form of the penial complex this group is distinct from Gyraulus and should be considered as of full generic rank. L. Soos (1917) and A. Soos (1935) list it as a subgenus of Gyraulus, but the lack of a penial stylet removes it from that group. Lindhohn (1926) considers it a genus. Thicle (1931) considers it a subgenus of Anisus. Othner 11929, p. 30 ) gives the group full generic rank on the basis of the lack of a stylet on the verge which is characteristic of Gyraulus. A good figure of the verge of Armiger crista, showing the small penial papilla at one side of the sperm outlet, is shown (fig. 10). Haas (1929, p. 386) considers Armiger a distinct genus.

Odhner (1929, pp. 20, 21, 30) states his belief that Armiger represents a stage in the crolution of Gyraulus. He found young Gyraulus borealis of two whorls without a stylet on the verge while those of three and one-half whorls had a well-developed stylet. Specimens of Gyraulus laevis of three whorls had a stylet. From these observations he concludes that the development of the stylet (penisstachel) may be checked in the later fall, possibly through some infavorable chmatic condition. Haas, in a review of this work $(1930$, p. 20) does not fully agree with Odhner, believing that more study should be given the subject before conclusions are made. This is undoubtedly true, but the subject is one of great interest and dissections should be made of many species at different ages to determine whether the stylet is absent in young and immature Gyraulus. It has becn present in all specimens personally examined, but these were either full grown or nearly full grown.

This group of small snails is highly rariable specifically and a number of names have been bestowed upon the variations. Two forms appear distinct enough to rank as species, crista (Linn.), with strong ribs projecting from the shell, and imbricatus (Müller), in which no ribs project from the shell. Armiger spinulosus (Clessin) is probably a race of crista Limm. Another species in eastern Asia has been named annandalei by Germain.

The value of recognizing subgenera for these variations may be questioned seriously. In 1922, Dybowski and Grochmalachi elected three subgenera based on spiny variation in Armiger: Nautiloarmiger, Cristoamiger, and Atropoamiger (vide Lindhohn, 1926, p. 24).

There appears to be some rariation in the genitalia and also in the radula. Odhner found the formula to be 11-1-11 and 14-1-14 in crista from two localities and the writer obtained the formula 16-1-16 from crista 
collected in Poland. These differences may all be individual. The group merits additional anatomical study.

\title{
Genus TAPHICS H. and A. Arlams, 1855
}

Type by original designation Planorbis andecolus Orb.

1855. Taphius H. and A. Adsurs, Genera, II, p. 262. Type Planorbis andecolus Orb. 1870. Taphius Dall, Ann. N. Y. Lyc. Nat. Hist., IX, p. 351. Type Planorbis andecolus (H. and A. Adlams, error for Orb.). As subgenus of Planorbis

18s3. Taphins Fischer, Man. de Conch., p. 507. Type Planorbis andecolus Orb. As section of Planorbis

18st. Taphius Tryox, S. and S. Conch., III, 1. 106. Type Planorbis andecolus Orb. As subgenus of Planorbis

1856. Taphius Clessix, Syst. Conch. Cab., XVII, p. 33. Type Planorbis andecolus Orb. As subgenus of Planorbis

1899. Taphius Martexs, Biol. Cent. Amel.. Moll., p. 396. Mentions Planorbis subpromus Martens. As subgenus of Planorbis

1905. Taphius Datl, Alaska Moll., p. S1. Type Planorbis andecolus Orb. As synonym of Helisoma

1921. Taphius Germain, Rec. Ind. Mus., XXI, pp. 7,62 . Type Planorbis andecolus Orb. As subgenus of Planorbis

1924. Taphius PILsbry, Proc. Acad. Nat. Sci. Phil., 86, p. 49, plate 4. Variation of Planorbis andecolus Orb.

1930. Taphius H. B. Baker, Oc. Papers, Mus. Zool. Univ, Mich., 210, p. 43. Monotype Planorbis andecolus Orb. As genus

1931. Taphizs Thiele, Handbuch, Part 2, p. 479. Type Planorbis andecolus Orb. As section of Planorbis

Shell (plate 77, figs. 13-15). Sinistral, whorls few, rapidly increasing in diameter, the body whorl wide and much enlarged; spire greatly depressed below the lerel of the body whorl, the spire whorls bluntly angulate; umbilical side flattened; all the whorls visible and nearly in the same plane; aperture large, expanded; no lamellae within the aperture.

Animal. The characteristic of the animal and its anatomy have not been described.

Geographical Distribution. South and Central America from southern Mexico to Peru and Bolivia.

Species Considered as Valid. Only five species are here referred to Taphius.

\author{
Taphius andecolus (Orb.) Lake Titicaca, Peru \\ Taphins montanus (Orb.) Lake Titicaca, Pern \\ Trphius titicacensis (Clessin) Lake Titicaca, Peru \\ Taphius pronus (Martens) Tenezuela \\ Taphius subpronus (Martens) Mexico
}

Geological Distribution. Not definitely known. Taphius pronus has been found fossil in Lake Valencia, Tenezucla, probably of Pleistocene age.

Remarks. The systematic position of the genus Taphius is greatly in doubt because its anatomy is unknown. Some of the species, as proms and subpronus, resemble certain species of Tropicorbis and Taphius may be another genus of Planorbidae peculiar to both ('entral and South America. Typical andecolus bears a striking resemblance to the typical group of Helisoma and Dall (1905) made Taphius a synonym of that group. Germain (1921) makes it a subgenus of Planorbis allied to Helisoma. 
Pilsbry (1934, p. 47) associates Taphius with Helisoma and refers Taphius pronus to Helisoma together with caloderma, but pronus certainly does not resemble any form of Helisoma, rather is it allied to Tropicorbis. What the group may be and where it may be placed can only be determined by an anatomical study. With our present limited knowledge, it seems best to regard Taphius as a genus related to Tropicorbis. An excellent account of the shell variation of Taphius andecolus, accompanied by a good plate, is given by Pilsbry (1924, p. 49, plate 4).

\section{(renus TROPICORBIS Pilsbry and Brown, 1914}

Trpe by original designation, Planorbis liebmanni

Dunker (= Planorbis orbiculus Morelet)

1880. Gyrorbis Fischer and C'rosse, Études Moll. terr-fluv. Mex. et Guat., II, p. 70 (non Gyrorbis Fitz., 1833). Example Planorbis orbiculus Morelet.

1884. Menetus Triox (non H. and A. Adams), S. and S. Conch., iii, 1. 106. Example Planorbis heloicus Orb.

1599. Planorbula Martexs (part), Biol. Cent. Amer., Moll., p. 398. Includes Planorbis obstructus Morelet and Planorbis denticns Morelet, now referred to Tropicorbis.

1899. Menctus Martexs (part) (non H. and A. Adams), op. eit., p. 390. Includes species now referred to Tropicorbis.

1914. Tropicorbis PiLsbri and Browx, Proc. Acad. Nat. Sci. Phil., 66, p. 212. Type Planorbis licbmanni Dunker. As section of Planorbis.

1921. Tropicorbis Germalx, Rec. Ind. Mus., XXI, p. 91. Type incorrectly given as Planorbis maya Morelet. As subgenus of Planorbis.

1923. Tropicorbis Wexz, Fossil. Cat., Pars 22, p. 1627. Genotype Gyraulus (Tropicorbis) liebmami (Dunker). As subgenus of Gyraulus.

1930. Tropicorbis H. B. Baker, Oc. Papers Mus. Zool. Univ, Mich., No. 210, p. 43. Type Planorbis licbmanni Dkr. As genus.

1931. Tropicorbis Thiele. Handbuch, IV. Teil 2. p. 480. Type wrongly stated to be Planorbis maya Morelet. As section of Planorbis.

1934. Tropicorbis Pilsbri, Proc. Acad. Tat. Sci. Phil., S6, p. 52. Type Planorbis liebmanmi Dunker. As genus. Anatomy described.

1936. Tropicorbis F. C. Baker, Nautilus, 49, 1. 104. Anatomy of Planorbis obstructus Morelet and Planorbis havanensis Orb. described. As genus.

1939. Obstructio HAss, Zool. Ser. Field Mus. Nat. Hist. XXIV, p. 99. Type by original designation Planorbis jancircnsis Clessin. As subgenus of Planorbis.

1940. Tropicorbis F. C. BaKer, Nautilus, LIII, p. 106. As genus.

1941. Obstructio HA.s. Nautilus, 55, p. 31.

Shell. Of medium size, ultradextral, orbicular, of few whorls which may increase regularly in diameter (plate 77, figs. 7-9 orbiculus) or the body whorl may inerease rapidly in diameter (plate 77, figs. 10-12, pallidus); whorls in view equally on both sides, somewhat overlapping on the left (spire) side; aperture unarmed or with one large parietal lamella with a small infraparietal below it, and four lamellae within the outer lip. The labial lamellae differ principally from those of the genus Planorbula in having the lower palatal lamella pointing slightly downward on the left side while in Planorbula this lamella always points upward, in the group Haldemanina the upward end forming a vertical and transwerse lamella combined. The basal lamella in Planorbula is normally more massive and is, in some species, distinctly curved (plate 76, figs. 7, 8, 9). 
Animal. When in locomotion the foot is rather long and narrow, rounded before and tapering to a point behind. The tentacles are very long and filiform and the eyes are large, black, and conspicuonsly placed at the imner base of the tentacles (plate 78 , figs. 3,4 ). The velar area is well developed. When at rest (plate 70, fig. 4, Tropicorbis havanensis) the foot may be hunched up, rounded, and even the tentacles may be drawn backward. The Tropicorbis group is noteworthy for the peculiar pigmentation observed in some species, this consisting of dark, blackish or brownish, markings which show plainly through the shell (plate 78, figs. 3, 4, Tropicorbis nigrilabris (Lutz), and are particularly plain when the animal is removed from the shell (plate 12, fig. 5. T. havanensis (Pfr.) ). These sometimes show on the base, through the shell, as dot-like markings (plate 70, fig. 4, T. hav'anensis).

\section{ANATOMICAL C'HARACTERISTICS}

PLATE 12 (Tropicorbis havanensis)

GENITALIA. Male Organs (fig. 11). Seminal vesicle (SV) of greater diameter than the ovisperm duct. It is beset with numerous protuberances or glands many of which have the form of club-shaped diverticula. They vary in size anteriorly, the larger vesicles being nearer the ovotestis. The whole seminal vesicle is about $2 \mathrm{~mm}$. long. The sperm duct is over $5 \mathrm{~mm}$. long and is very narrow. It is peculiarly enlarged at the junction of the oriduct and sperm canal and might be considered a carrefour, but that feature is attached to the female system and is a small swelling into which the albumen duet enters (fig. 11, CF). See figs. 7, 8, CF.

The prostate (PRS') is very long $13.5 \mathrm{~mm}$.) and bears about fifty short, sac-like diverticula. These are placed on a separate duct, the prostate duct, the free portion of which is very short and quickly joins the vas deferens. A cross section through the prostate (fig. 9, PD, SPD) shows the relationship between these two separate ducts. The ras deferens (VI) is moderately long $(3.5 \mathrm{~mm}$.) and is a small tube throughout its length except that it is slightly enlarged where it enters the vergic sac (fig. 1, VD).

The penial complex (fig. 11) is much elongated; the preputium (PR) is cylindrical and slightly longer than the vergic sac (VS). In another specimen (fig. 10) the preputium and vergic sac were more nearly equal in length and the upper part of the vergic sac was slightly enlarged. The vergic sac is always of less diameter than the preputium. The retractor muscles (RM) are somewhat complicated, there being three branches all connected by cross muscles. There are also several small muscles below the retractor muscles which are attached to the mantle and not to the columella muscle. These may be what we have called supporting muscles. There are several series of muscles on the opposite side of the penial complex which we have ealled supporting muscles (SM). These are attached to the upper part of the neck. The upper set, which have small branches, may also help in retracting the penial complex following coitus.

Internally (fig. 1) the preputium has two or more pilasters. There is a heavy muscular ring or diaphragm which separates the preputial cavity from the vergic space (fig: 1, D, fig. 2). This apparently takes the place of the papilla in Gyraulus, but there is no second ring below this ring, as there is in Gyraulus. The verge ( $\mathrm{T}$ ), very long and cylindrical, ends in a 
small papilla and the sperm canal has a central outlet (fig. 3). The walls of the rergic sac are thin but those of the preputium are rather thick.

Female Organs. The spermatheca (S) is pear-shaped and less than $1 \mathrm{~mm}$. long. The spermathecal duet is longer than the spermatheca, rery narrow, and enters the short ragina (VG) near the female opening. The uterus (U) is narrow and slightly longer than the spermatheea and its duet. The nidamental gland ( $\mathrm{NG}$ ) is long and narrow (about $3 \mathrm{~mm}$. long) and of larger diameter than the uterus. The oviduct (OD) is about $2 \mathrm{~mm}$. long and smaller in diameter than the nidamental gland but much wider than the sperm duet. The albumen gland is short, somewhat pear-shaped with large gland cells (fig. 6). It lies over the intestine, one loop of which passes through a trough-like space on the under side of the albumen gland. The junction between the oviduct, sperm duet, and ovisperm duet, together with the albumen gland connections, are shown in figs. 7 and 8 .

Hermaphrodite Organs. The ovotestis (OT) consists of many elubshaped diverticula placed in a double row. The ovisperm duet is very short between the seminal resicle and orotestis but three times this length between the seminal resicle and the oviduct. The duct is a narrow tube.

Two other species of Tropicorbis have been dissected by the writer. Tropicorbis riisci (Dunker) (plate 13, fig. 9 ) has twenty-four diverticula on the prostate and Tropicorbis obstructus (. Iorelet) has cighteen diverticula on its prostate. The penial complex is about the same in the three speeies. Some of the diverticula of the prostate are folded over at the end in riise (figs. 4,5 ). The retractor muscle complex is complicated in riisci but quite simple in obstructus. The spermatheea is rounder and less pyriform in riisci and obstructus and the ducts are longer than in havanensis (compare the figures). In obstructus a number of the diverticula of the orotest is contained eggs almost ready to be discharged (plate 13 , fig. 3 ). The junetion of the prostate duet and the sperm duct to form the ras deferens is shown in fig. 8 (riisei).

Pilsbry (1934, p. 53) has figured the genitalia of Tropicorbis pallidus (C. B. Adams), from Bolivar, near santa Marta, Colombia. This figure differs in a few respects from the genitalia of riisci, hatanensis and obstructus as figured in this volume. There are twelve long and somewhat irregular diverticula on the prostate. The penial complex shows a rery long and narrow vergic sac, considerably longer than the preputium. The rerge appears as in the other speeies studied. There is one retractor muscle as in obstructus.

It is evident from the knowledge afforded by the four species of which the anatomy is known that there is considerable variation in the details of strueture of the genus Tropicorbis. The prostate, particularly, may bear as many as fifty diverticula (havanensis) or as few as twelve diverticula (pallidus). The penial complex may have the vergic sac shorter than the preputium (havanensis) or much longer than the preputium tpallidus). There is complete agreement, however, in the long, narrow verge with terminal opening, the lobulate seminal resicle, the long and narrow oviduet, nidamental gland, and sperm duct, and the rounded or pear-shaped spermatheea on a long duct. It is desirable that the genitalia of the type species corbiculus=licbmanni) be known. It is believed to be like haranensis, a related speeies. Hundreds of shells of orbiculus have been seen but no material containing the animal has been arailable. 
Respiratory and Renal Systems. The pseudobranch fof hatanensis, plate 12, fig. 4 is a thin, leaf-shaped, fleshy organ doubled or folded upon itself. The rectum ( $\mathrm{R}$ ) lies above the pseudobranch and has a conspicuous crested ridge extending nearly its whole length, ending some distance above the anus. There is a large pmemostome (PS). In risei (plate 13, fig. 10) the folded nature of the pseudobranch is better shown as is also the erested ridge. The erest is present in all species examined. Pilsbry's figure of the pseudobranch of pallidus (1934, p. 53. B) shows a simple folded pouch. In his figure $\mathrm{C}$, the pseudobranch is figured as much elongated. This appears to be a pathologie condition.

The kidney (plate 46. fig. 11, rïsei) is rather long (about $2.5 \mathrm{~mm}$.), the ureter sharply reflected. A cross section near the middle (fig. 12 ) shows the kidney to be rounded with the lumen rounded, the two veins being at the lower comers of the seetion. There is no ridge on the kidney but there is a distinct vertical ridge in the mantle to the left of the kidner. A eross section of the kidney of havanensis (fig. 13) shows that in this species this organ is much more eompressed and much wider than in riisei; the central lumen is irregularly oral with the two veins placed below the lumen at the outer ends of the seetion. Of pallidus, Pilsbry says 'The kidney is long, band-like, and flat, with no trace of a superposed ridge' (p. 52).

Digestive System. Stomach region with distinet division into erop, gizzard, and pyloris. There is a large blind sae. The intestine makes a backward loop around the liver and extends forward, the rectum ending near the pseudobranch. The digestive organs are alike in all species examined. The buceal sac is pyriform with a large and conspieuous radula sac which protrudes from the posterior end of the buceal sae as a rounded projection. This sac is longer in obstructus than it is in rizsei. The salivary glands are erlindrieal, longer than the buceal sac, and joined behind, as in other groups of the Planorbinae.

The jaw of riisei (plate 50, fig. 12 ) is composed of three pieces, a wide and low superior part, finely striated along the face, and two lateral pices which assmue the form of a question mark. These are enlarged at their junction with the superior jaw and taper to a point at the lower end. The jaw of obstructus is similar to that of riisei (fig. 11). H. B. Baker has deseribed the jaws of pallidus and kühniamus (1930, pp. 47, 48). The jaws of Tropicorbis are unlike those of the other genera of Planorbinae (excepting Australorbis) and resemble those of the subfamily Helisomatinae.

The radula formula of havanensis (plate 68. fig. 8) is 19-1-19 or 20-1-20 with 109 to 112 rows of teeth. The central tooth has a broad base of attachment and is bicuspid, the eusps spade-shaped and reaching to the lower margin of the base of attachment. Laterals (1-6) squarish with three eusps, the entocone larger than the mesocone and ectocone. The 6th tooth has a small interstitial cusp on the entocone and two very small cusps above the ectocone. The 7 th tooth is an intermediate, the entocone broken up into four small cusps and the ectocone with two small cusps on the outer edge above. The 8 th to the 16 th or 17 th teeth are marginals $(8,10$, 12 , the reflections becoming very long and narrow, with an entocone of four or five small cusps, a single spade-shaped mesocone, and four to six or seren small cusps on the outer edge representing the ectocone. The marginal teeth become narrower toward the edge of the membrane. The outer three marginals are restigial and are without denticulations. The central teeth of the different rows vary in width at the upper 
part of the tooth. The first thirty-four rows measure 5.4 microns, rows 35 to 89 measure 6 microns and rows 90 to 109 measure 5.4 microns. All central teeth examined exhibited this variation in width.

In riisei (plate 68 , fig. 6) the formula is 18-1-18 with 105 rows of teeth. The center tooth is like that of hatanensis but the cusps do not reach the base of attachment. There are four lateral teeth. The 5th and 6 th teeth are intermediate with interstitial cusps between the entocone and ectocone and small cusps above the ectocone (figs. $7,5,6$ ). Seven to twelve are typical marginals with a variable number of small cusps, as in havanensis. The 15 th to 18 th teeth are vestigial. The center teeth vary in width as in hazanensis, but the teeth are somewhat smaller.

In obstructus (plate 68 , fig. 7 ) the formula is 19-1-19 and there are 124 rows of teeth. There are seven tricuspid laterals, the 8 th tooth is intermediate, modified only on the entocone, and there are nine marginals becoming narrower toward the edge of the membrane. The outer marginals are vestigial. The center tooth varies in width as in the other species.

H. B. Baker (1930, plate 28, fig. 8) figures the radula of pallidus from Bolivar, Colombia. The formula is 18-1-18 with five laterals and there are 106 rows of teeth. The rarlula of kïhncrianus is described on page 47 of the same paper. The formula is 19-1-19, with six laterals and 106 rows of teeth. Thus the radulae of five species of Tropicorbis are known; haz'anensis, which is nearest to orbiculus (=licbmanni), the type of the genus, obstructus, riisei, pallidus, and liühnerianus. These cover fairly well the different variations of the species of the genus.

The material personally examined is as follows:

havanensis. New Orleans. Collected by Dr. E. C. Faust; 10 specimens riisei. Barceloneta, Puerto Rico. Collected by Dr. W. A. Hoffman; 12 specimens obstructus. New Orleans. Collected by Dr. E. C. Faust; 10 specimens.

Geographical Distribution. The genus Tropicorbis is one of the most widespread of any group of Anerican Planorbidae. From Louisiana and Texas in the United States, it extends southward through Mexico and Central America into South America as far south as the Argentine Republic, a distance of about 7.000 miles. The group is also found in many of the islands of the Thest Indies. In number of species represented, it outranks any other group of the family found in America except Helisoma, upward of thirty-three species and races being now recognized (see a later page for the list of species).

Geological Distribution. Oligocene or Lower Miocene to Recent time.

Remarks. The genus Tropicorbis presents some puzzling features of its anatomy which render its systematic position debatable. The nature of the prostate, with many diverticula in a single row, on a separate prostate duct, places the genus in the subfamily Planorbinae. The kidney is also like other members of this subfamily. The penial complex differs from that of Anisus and Gyraulus in lacking a penial stylet. The jaw is quite different and resembles this organ in Helisomatinae and Planorbulinae. The teeth of the radula also differ in having interstitial cusps on the intermediate and marginal teeth. Pilsbry (1934, p. 53) remarks that the group resembles Gyraulus but differs in the unarmed verge and the different jaw and marginal teeth. All points considered, it would seem that its place is with the Planorbinae, the largest number of characteristics agreeing with those of this subfamily. 
Some of the species of Tropicorbis have been heretofore placed in the genus Planorbula because of the presence of lamellae within the aperture. These lamellae have the same general position in the two groups but the lower palatal lamella in Planorbula points upward while in Tropicorbis it points slightly downward. The basal lamella is also usually more massive in Planorbula than in Tropicorbis (plate 76, figs. 7, 8, 9). Planorbula, however, has a very different form of genitalia which removes it from the Planorbinae and places it, with Wenetus, in a separate subfamily, Planorbulinae.

The relationship between the South Ameriean Tropicorbis and certain species in Africa is quite remarkable and has been emphasized by Pilsbry (1934, p. 54). Two African species (adouensis and pfeifferi) have been dissected and the genitalia are very smimar to the same organs in Tropicorbis. The African forms may be placed in Afroplanorbis of Thiele, at least, until more is known about other species of the African fauna. This relationship is discussed at greater length under the description of the genus Afroplanorbis.

While the anatomy of the sereral group forms is similar, there are variations in the shell which seem to warrant a division of the genus into three subgenera or sections. These are indicated below.

\section{Subgenus TROPICORBIS SS.}

Type Planorbis orbiculus Morelet

Shell orbicular, the whorls increasing gradually in diameter, the last whorl not notably expanderl. Apertural lamellae nerer present at any stage of growth.

\section{Subgenus OBSTRUCTIO Haas, 1939}

Type by original designation, Planorbis jancircnsis Clessin

Shell orbicular, whorls increasing slowly in diameter. Aperture with lamellae during some stage of the growth of the shell (plate 76, fig. 7).

\section{subgenus LATEORBIS F. C. Baker, New Subgenus}

Type Planorbis pallidus C. B. Adans

Shell with whorls rapidly increasing in diameter, the body whorl notably enlarged. Aperture never with lamellae.

Species Considered as Valid. The species and races beliered to group under the three subgenera of Tropicorbis are tabulated below.

TROPICORBIS

orbiculus (Morelet)

mayn (Morelet)

haz'anensis (Pieiffer)

philippianus (Dunker)

heloicus (Orbigny)

tepicensis (Martens)

gracilentus (Gould)

peregrimus (Orbigny)

chilensis (Clessin)

meridaensis (Preston)

bourcardianus (Preston)

centimetralis (Lutz)

fieldi (Tryon)
OBSTRLCTIO

jantirensis (Clessin) dentiens (Morelet)

dentions connarum

( Morelet)

obstructus (Morelet)

obstructus donbilli

(Tristrans)

obstructus anodontus

(Pilsbi'y)

dentiferus (C. B. Adams)

declivis (Tite)

paparyensis (F. Baker)

nigrilabris (Lutz)

albicans (Pfeiffer)

\section{LATEORBIS}

pallidus (C. B. Adams)

riise $i$ (Dunker)

straminens (Dunker)

petcrensis (Morelet)

isthmicus (Pilsbry)

decipiens (C. B. Adams)

pedrinus (Miller)

canonicus (Cousin)

trigyrus (Philippi) 


\section{Genus AFROPLANORBIS Thiele, 1931}

Type by original designation Planorbis sudanicus Martens

1SS5. Henctus Westerluxd (non H. and A. Adans, 1S55), Fauna Palaearc. Reg., V, p. 64. No type cited. As subgenus of Planorbis.

1902. Menetus Westerlund, Rad. Jugoslav. Akad., 151, p. 120. Type Planorbis boissyi P. and M. (non Adams, 1S55).

1923. Planorbulina Germas, Rec. Ind. Mus., XXI, p. 179. Citation for Planorbulina Jickeli (1S74) Fauna der Land und Siisswasser Mollusk Nord-ost-Afrika. Dresden, p. 221 ("pour la Planorbis alexandrinus Ehrenberg (Segmentina sousgenre Planorbulina)').

1925. Planorbula Convolly, Trans. Royal Soc. S. Africa, XII, p. 195 (non Haldeman). Anatomy of Planorbis pfeifferi Krauss.

1931. Afroplanorbis ThIELE, Handbuch, Teil 2, p. 4S0. Type Planorbis sudanicus von Martens. As section of Planorbis.

1934. Afroplanorbis Pilsbry, Proc. Phil. Acad. Nat. Sci., S6, p. 55. Type Planorbis sudanicus von Martens.

1936. Afroplanorbis HAs, Abh. Sencken. Natur. Gesell., No. 431, p. 25. Type Planorbis sudanicus von Martens. As genus.

1939. Planorbulina Hass, Malac. Notes, Field Mus. N. H., Zool., XXIV, p. 100. Citation from Jickeli 1574, Nora Acta Acad. Leop. Carol., XXXTII, p. 221.

1939. Biomphalaria Coxyolly (part); Ann. South African Mus., XXXIII, part 1, p. 483 .

1940. Planorbulina HAss, Nautilus, 1. 33. States that citations from Jickeli's paper (1S74) are erroneous, there being no reference to this name in the work mentioned, the name used being Planorbula. Planorbulina was used by d'Orbigny in 1826 in Foraminifera.

Shell (plate 81, figs. 2, 31. Small to medium size, orbicular, of few or many whorls which may be closely coiled or rapidly increase in diameter; usually flattened on both sides; aperture rounded, usually in the same plane as the last whorl, lips sharp, the aperture with or without lamellae.

Animal. Not observed.

\section{ANATOMICAL CHARACTERISTICS}

\section{PLATE 71}

GENITALIA. Male Organs (fig. 9, Afroplanorbis pfeifferi (Krauss)). Seminal vesicle occupying about half the length of the ovisperm duct, the glandular follicles short and projecting from the side of the cluct. Sperm duct a narrow tube about as long as the ovisperm duct and seminal vesicle combined. Prostate short, composed of five main branches each of which branch again two to four times, thirteen direrticula showing at the upper or outer end of the prostate. From the figure the diverticula appear to be arranged in fan-like manner. There is but one series of diverticula but there is no indication of a separate prostate duct. The ras deferens is a long, fine duct, apparently as long as the sperm duct and ovisperm duct combined.

The penial complex has a sac-like preputium with a narrow retractor muscle attached to the summit near the junction of preputium and vergic sac. The vergic sac is a narrow tube, not much greater in diameter than the vas deferens. It is about as long as the preputium and appears from the figure to be slightly enlarged at the end. The features of the interior of the penial complex are neither figured nor described.

Female Organs. The spermatheca is an elongated pouch connected with the rather long ragina by a duct half as long as the spermatheca. The 
uterus swells behind the ragina to more than twice the rliameter of the vagina. The nidamental gland is about as long as the uterus and is swollen to twice the diancter of the uterus. The oviduct is shorter than the uterus and rapidly narrows to meet the sperm duet. The abmuen gland is a large, elongate-ovate organ, half as high as long.

Hermaphrodite Organs. Orotestis apparently a double series of elubshaped diverticula. The ovisperm luet is very narrow and its free portion is about as long as the sperm duct. The seminal vesicle is placed nearer the ovotest is than observed in the species of Tropicorbis examined.

Pilsbry's figures of Planorbis adowensis Bourguignat (plate 71, figs. 10-12) are essentially the same in general generic characters as in pfeifferi described above. The prostate (fig. 10) shows about sixteen short diverticula which are unbranched. The penial complex (fig. 11 ) shows a witle, saclike preputim and a slender vergic sac equal in length to the preputium. The retractor muscle is inserted at the junction of vergic sac and preputium. Internally (fig. 12) the preputium has three vertical pilasters and the verge is very long and slenter. The spermatheca (fig. 10) is more pyriform than that of peifferi and the duct is longer.

The pseudobranch of Planorbis pfeifferi (fig. 7 ) appears to be folded as it is in Tropicorbis. The figure of the digestive system (fig. 8) shows a wide gizzard, a narrow and elongated pyloris, a narrow blind sac, and the intestine looped about the stomach. The salivary glands form a short loop behind the buceal sac.

The above anatomical notes are drawn from the papers of Connolly (1925) and Pilsbry (1934).

Geographical Distribution. Afroplanorbis appears to be distributed over northern and central Africa and to include a number of species.

Species Considered as Valid. The following are the species believed to be referable to Afroplanorbis. Other species may be added when their anatomy becomes known.

Afroplanorbis sudanicus (von Martens)

Afroplanorbis pfeifferi (Krauss)

Afroplanorbis sudanicus tanganikanus (Boury.)

Afroplanorbis alexandriensis (Ebrenb.)

Afroplanorbis boissyi (Pot. and Mich.)

Afroplanorbis salinarum (Morelet)

Afroplanorbis bridouxianus (Bourg.)

Afroplanorbis adowensis (Bourg.)

Afroplanorbis pacteli. (Jickeli)

Geological Distribution. Not ascertained. The group is probably as old as Tropicorbis.

Remarks. The anatomy of Afroplanorbis sudanicus (von Martens) is unknown, but the shell so closely resembles that of Afroplanorbis adouensis (Bourg.) that they appear to be congeneric. Pilsbry $(1934$, p. 54 ) calls attention to the similarity of the shells. He also dissected Planorbis adouensis (his figures are copied on my plate 71 ) and found the anatomy to be very much like that of Tropicorbis. Comnolly (1925, plate 8) figures the genitalia of Planorbis pfeifferi Krauss and his figure differs little from that of Pilsbry except in specifie details. The branched diverticula of the prostate are believed to be attributed to faulty drawing rather than to real differences in structure. The chief difference between Tropicorbis and Afroplanorbis appears to be in the longer seminal resicle of the latter, the smaller number of prostate diverticula, the greater size of the uterus and nidamental gland, and the greater difference in diameter between the preputium and vergic sac. 
The African group would appear properly to take the name Afroplanorbis proposed by Thiele, preferably as a genus closely related to Tropicorbis. It has no relationship with Planorbula Haldeman which is purely an American genus belonging to a different subfamily. The close relationship between Tropicorbis of Central and South America and the African species here referred to Afroplanorbis is, as pointed out by Pilsbry (1934, p. 55), an interesting parallel in zoogeography. A similar relationship is found in the Ancylidae and in some groups of land shells.

In a recent work $(1939$, p. 483$)$ Connolly uses the generic name Biomphalaria Preston for all of the African species once referred to Planorbula. Howerer, the anatomy of the type of this genus, smithi Preston, is unknown and until that species has been examined anatomically it would seem unwise to use this name so inclusively. Should the anatomy prove to be like that of the two species here referred to the genus Afroplanorbis, Planorbis adowensis and P. pfeifferi, it would then take precedence over Afroplanorbis which would become a synonym of Biomphalaria. Tropicorbis appears to be generically distinct from the African species and can not be included in either Afroplanorbis or Biomphalaria, as suggested by Connolly (p. 484).

\section{Genus SYRIOPLANORBIS F. C. Baker}

New name for HETERODISCL's Westerlund, preoccupied. Type

Planorbis libanicus Westerlund, originally designated for HETERODISCUS

1902. Heterodiscus Westerluxd, Rad. Jugoslav. Akad., 151, p. 120. Type Planorbis libanicus Westerlund. As subgenus of Planorbis. Non Heterodiscus Sharp, Insecta, 1886.

1905. Heterodiscus Dall, Alaska Moll., p. S3. Type Planorbis libanieus Westerlund. As section of Planorbis.

1931. Heterodiscus Thiele, Handbuch, Teil 2, p. 479. Type Planorbis libanicus Westerlund. As section of Planorbis.

'Shell n: t. media (d. $14 \mathrm{~mm}$.), supra late profundeque concaro-unbilicata, subtus subplana, sub lente distincte spiraliter lineata, spira magna, utrinque orbiter subaequi, anfr. 5-6, primi lenti, ultimus subcylindraceus (typ. Pl. libanicus IV.).' Westerlund, p. 120.

Original description of Planorbis libanicus Westerlund: "Testa magnitudine mediocris, supra late profundeque concaro-umbilicata, infra subplana, nitida, cornea (subtus paullo pallidior'), firma. laevigata, sub lente forti densissime at distincte spiraliter lineata; anfr. 51/2-6, convexi, interiores utrinque verlente accrescentes, spiram magnum, subaequalem formantes, ultimus major, rotundatus, subcylindraceus, supra convexus, subtus pone suturam impressam obtusissime angulatus, extrorsum paullo planulatus; apertura oblique rotundito-Iunaris, marginibus distantibus, disjunctis, basili oblique surrecto. Diam. 14, alt. ad apert. $5 \mathrm{~mm}$.

Hab. Mons Libanon (legit beat. Evers, Harniensis).

'Haec species forte trpum nori subgeneris format, quod a subgen. Meneto differre videtur; Testa supra late concavo-umbilicata, infra subplana, sub lente tenue distincte spiraliter lineata, spira magna, utrinque subaeque lata.' Westerlund, Nach. Deutsch. Malak. Gesell., 1899, pp. 170-171.

Remarks. All of the information concerning this group name and its type species is given above. No specimens for figuring have been obtainable and no figure has been published, as far as known to the writer. Westerlund mentions in the description of the species (libanicus) that it differs from the subgenus Menetus and that it should become the type of a new subgenus, which he later calls Heterodiscus, which is unfortunately preoccupied. 
In Westerlund's list of the subgenera of Planorbis $(1902,1) .120)$, the type of Menetus is given as Planorbis boissyi P. and M., which is now placed in the genus Afroplanorbis, the type of Menetus being Planorbis opercularis Gould. The comparison of Heterodiscus with Menetus would indicate that the latter group was somewhat related to the African speeies and the Latin description would fit, in a measure, somespecies, as arlouensis and sudanicus. The habitat of Planorbis libanious is not so far removed from the African region as to preclude the possibility that this species might group with Afroplanorbis, hence the new name Syrioplanorbis (Heterodiscus) would beeome a synonym of Afroplanorbis. Only an examination of the animal of libanicus would positively settle this question.

Species Considered as Valid. Syrioplanorbis libanicus (Westerlund) is the only species attributable to this genus and, as indicated above, the validity of the generic concept is not wholly certain.

\section{Genus BIOMPHALARIA Preston, 1910}

Type by original designation Biomphalaria smithi Preston

1901. Planorbia J. E. S. Moore, To the Mountains of the Moon. p. 260. Monotype Planaria albertensis J. E. S. Moore (non Planaria Brown, 1827, or Mïiller, 1776).

1910. Biomphalaria Preston, Ann. Mag. N. H. (8), II, p. 535, plate ix, figs. 26, $26 a$. Type Biomphalaria smithi Preston. As genus.

1927. Planaria Pilsbry and Bequaert, Bull. Amer. Mus. N. H., LiII, p. 121. Monotype Planaria albertensis J. E. S. Moore.

1927. Biomphalaria Pilsbry and Bequaert, op. cit. p. 115. Monotype Biomphalaria smithi Preston. As synonym of Planorbis Müller.

1931. Biomphalaria Thiele, Handbuch, Teil 2, p. 479. As section of genus Planorbis. Type wrongly given as Planorbis choanomphalus von Martens.

1934. Biomphalaria Pilsbri, Proc. Phil. Acad. Nat. Sci., 86, p. 55. Type Biomphalaria smithi Preston.

1936. Biomphalaria Hass, Abh. Secken. Natur. Gesell., No. 431, p. 25. Type Biomphalaria smithi Preston. As genus.

Shell (plate 81, fig. 4). Subdiscoidal, planulate with coneave spire, last whorl very large; umbilieus open, but shallow; aperture gaping; labrum greatly receding below (Preston). The shell is ultradextral. Of this species Pilsbry says (1927, p. 120) 'The prominent character of this species is the deviation towards the left of the last half-whorl.' Viewed as a dextral species, the last part of the whorl drops below the periphery as in some specimens of Gyraulus deflectus.

Animal. The anatomy of the group is at present unknown.

Geographical Distribution. Lake Albert Edward, Belgian Congo, Africa. Only the type species is known. Planorbis ruppelli Dunker, Planorbis choanomphalus Martens and Planorbis katangae Haas, included in this genus by Haas (1936) appear to belong elsewhere. They do not have the characteristies assigned to Biomphalaria.

Species Considered as Valid. Biomphalaria smithi Preston is the sole representative of the genus here recognized.

Remarks. This genus is unknown anatomieally and its true position in planorbid nomenclature can not be definitely assigned until the animal has been dissected. Pilsbry (1927, p. 120) suggests that it is a modification of the Planorbis adowensis type and might be placed in the same section of 
the genus Planorbis. In a later publieation (1934, p. 55) this relationship is again emphasized. In both references by Pilsbry the suggestion is made that the shell might have been modified somewhat after the manner of Taphius. The shells as figured by Pilsbry $(1927$, p. 121, reproduced on plate 81 of this work) are strongly suggestive of Taphius, and Biomphalaria might bear the same relationship to Afroplanorbis that Taphius bears to Tropicorbis. Its best place in elassification at present appears to be near Afroplanorbis as a distinet genus.

\section{Genus ALsTRALORBIS Pilsbry, 1934}

\section{Type by original designation Planorbis guadaloupensis Sowb. = Planorbis glabratus Say}

1883. Menetus Fischer, Man. de Conch., p. 509. Type Pl. guadaloupensis Sowb. (non H. and A. Adams, 1855). As section of Planorbis

1899. Menctus Martexs, Biol. Cent. Amer., Moll., p. 390 (non H. and A. Adams, 1855). Martens gives no type but says subgenus is peculiar to South America and mentions Planorbis cumingianus Dki., and Planorbis guadaloupensis Sowb. as examples

1905. Planorbina DALL, Alaska Moll., pp. 81, \$1. Type by original designation Planorbis olivaceus Spix (non Planorbina Haldeman, 1813). As section of Planorbis

1918. Planorbina Walker, Miscel. Pub. Mus. Zool., Univ. Mich., No. 6, pp. 11, 94. Type Planorbis olvace spix (non Planorbina Hald, 1S43). As section of Planorbis

1921. Planorbina Geruan, Rec. Ind. Mus.. XXI. pp. 6, 41. Type Planorbis guadaloupensis Sowb. (non Planorbina Haldeman, 1843). As subgenus of Planorbis

1923. Planorbina Wexz, Fossil. Cat., pars 22, p. 14S2. Genotype Planorbis guadaloupensis Sowb. (non Planorbina Haldeman, 1843). As genus and subgenus

1930. Planorbina H. B. Baker, Oc. Papers, Mus. Zool., Univ. Mich., No. 210, p. 43. Type Planorbis olivaceus Spix (non Planorbina Haldeman, 1843). As genus

1931. Planorbina Thiele, Handbuch, Teil 2, p. 480. Type Planorbis olivaceus Spix (non Planorbina Haldeman, 1843). As section of Planorbis

1934. Australorbis Pilsbri, Proc. Acad. Nat. Sci. Phil., S6, p. 55. Type Planorbis guadaloupensis Sowb.(= Planorbis glabratus Say). As genus

1938. Australorbis Martiss, Contribuição ao estudo do genero Australorbis Pilsbry, 1934. On p. 47 lists Brazilian species of this and other genera. Some of the species listed belong to Tropicorbis

1940. Australorbis Scott, Notulae Naturae. No. 54, p. 9. As genus.

Shell (plate 77, figs. 29-31, Australorbis glabratus (Say)). Large, biconeave, smoothish, of slowly widening whorls which are rounded or angular laterally (Pilsbry, p. 55). The shell is sinistral.

Animal. Resembling Tropicorbis in general form. The color is grayish or blackish, the mantle mottled with brown or einnamon.

\section{ANATOMICAL CHARACTERISTICS}

PLATE 9 (Australorbis glabratus)

GENITALIA. Male Organs (fig. 10). The seminal vesiele (SV) is $3 \mathrm{~mm}$. long and is an enlargement of the orisperm duct on which there are many elongated follieles placed laterally. For a distance of $2 \mathrm{~mm}$. behind and 4 mm. in front of the seminal vesicle there are numerous nodes which are probably continuations of the seminal vesiele. The sperm duet (SPD) is a very long and narrow tube (29 $\mathrm{mm}$. Jong) of the same caliber throughout. The prostate is $8 \mathrm{~mm}$. long and is composed of twenty-three or twenty-four diverticula, the two or three anterior diverticula single and unbranched and the three posterior diverticula bifurcate. The others, eighteen in num- 
ber, have three main branches from a single stem, each branch again dividing two or three times, the secondary diverticula being of unequal length. All diverticula arise from the sperm duet in a single series, not in multiple series, as in Helisoma. A single brancherl diverticulum is shown in fig. 6. The diverticulum enters the sperm duct directly and is not placed on a separate duet as in Tropicorbis. The vas deferens (VD) is a narrow tube about $10 \mathrm{~mm}$. long, of less diameter than the sperm duct.

The penial complex (fig. 10) consists of an elongated, cylindrical, saclike preputium (PR), about $4 \mathrm{~mm}$. long and $0.7 \mathrm{~mm}$. wide and of about the same diameter throughout its length. The very narrow vergie sae (VS) is $3 \mathrm{~mm}$. long or slightly shorter than the preputium. It is not much greater in diameter than the vas deferens. There is a rounded enlargement of the vergic sac at the end receiring the ras deferens. There are several sets of muscles. A wide retractor muscle (RM) ('omposed of several smaller branches, is attached to the upper part of the preputium and to the columellar muscle. On the same side of the preputiun there is a wide muscle about midway of its length and two smaller muscles near the male opening which appear to be supporting muscles since they are attached to the mantle above the penial complex. On the opposite sirle of the preputium there is a narrow muscle attached to the upper part near the insertion of the vergic sac, and a very wide muscle or set of small muscles which are attached to the roof of the mantle cavity and are presumed to be supporting muscles (SM). Some of these may aid in retracting the penial complex after coitus.

Internally (fig. 9) there are two wide, heary pilasters in the preputium tapering to a point at the upper part of the preputial space. The space between the pilasters is marked by many cross muscles forming a reticulated pattern (PL). There is a flattened muscular ring or diaphragm (D). The verge $(\mathrm{V})$ is long and very narrow. It tapers to a point and the sperm canal is placed at the center (fig. 5 ). There is no penial papilla.

Female Organs. The spermatheca is pear-shaped (s) and the duet (SD) is narrow and as long as the spermatheea. Both gland and duct measure a trifle more than $3 \mathrm{~mm}$. in length. The vagina (VG) is very short and wide. The uterus is the same width as the vagina and gradually enlarges in diameter to meet the nidamental gland (NG) which is very long and wide (about $8 \mathrm{~mm}$. long, $1.5 \mathrm{~mm}$. wide). A part of the uterus projects behind the nidamental gland for several millimeters. The oviduct (OD) is a narrow tube extending from the ovisperm duet backward. It is about twice the diameter of the sperm duet and is about $18 \mathrm{~mm}$. in length. There is a rounded carrefour $(\mathrm{CF})$ extending from the oviduct to which the duet of the albumen gland is attached. The albumen gland (fig. 8) is rectangular in form and is composed of large follicles. The space for the passage of the intestine (IN) is quite conspicuous.

Hermaphrodite Organs. The ovisperm duct (SO) is very long (17 $\mathrm{mm}$.) and is a simple tube except for the portion oceupied by the seminal resicle. The orotestis is composed of multiple diverticula as seen in situ (fig. 10, OT). In cross section (fig. 4) the ovotestis appears to consist of a main diverticulum (fig. 1) upon which a number of short diverticula are attached (2). The organ is not multiple in the same sense that Helisoma is, which is observed to be fan-shaped in section. Several of the diverticula contained one large orum ready for expulsion. 
The above description agrees substantially with that of Pilsbry (1934, p. 55). The spermathecal duct in the specimens examined was not short, as Pilsbry found it, and, therefore, the spermatheca was not really adnate. The vergic sac, also, is almost as long as the preputium in the specimens examined. With these exceptions the genitalia of glabratus (guadaloupensis) here figured are like the figures of the race christopherensis given by Pilsbry on page 57. The figure by Scott (1940, p. 10$)$ agrees with the specimens personally dissected, especially in the form of the spermatheca.

Respiratory and Renal Systems. The pseudobranch is rather long and rounded. A frilled crest or ridge extends down the center of the rectum (R) which it crosses as a simple ridge to the anal opening (A) and extends across the pseudobranch to the lower edge. There is a large pneumostome (PS).

The kidney (plate 45, fig. 1) is long and nalrow (16 $\mathrm{mm}$. long, $2.5 \mathrm{~mm}$. wide). The ureter is nearly $2 \mathrm{~mm}$. long and is a narrow tube directed upward at a right angle from the kidney. The veins are very large. The pericardium is $3 \mathrm{~mm}$. long and $2 \mathrm{~mm}$. wide. A low, wide ridge extends from below the pericardium to the lower end of the kidney.

Cross sections show several interesting features. The position of each section is shown at $\mathrm{A}, \mathrm{B}, \mathrm{C}, \mathrm{D}, \mathrm{E}$, in fig. 1. Section $\mathrm{E}$ ( fig. 7) through the pericardium shows a large lumen nearly filling the entire section, containing many glandular diverticula. There are no veins. In section D ifig. 8) the lumen is smaller, rather squarish in shape, with the pulmonary vein (AP), large and round, on one side and the renal vein (RA), smaller and oviform, on the other side. The low ridge is seen at the left. In section C (fig. 9) the lumen is somewhat smaller and there is the same disparity in size between the two veins. The ridge ( $R K$ ), though wide, is higher than in section D. In section B (fig. 10) the lumen is much smaller, the veins still disproportionate in size and the ridge very wide, but low, and projecting over the left margin. In section A (fig. 11) near the base of the kidney, the whole organ is seen to be flattened, the lumen very small, the reins flattened, more nearly equal, and the ridge wide, flattenerl, and projecting over the left margin. The form of the long ridge to the left of the kidney is shown at the left in this section (RI)). The rirtge is a very characteristic feature in the kidney of Australorbis.

Digestive System. The stomach region (plate 48, figs. 9, 10) resembles that of Promenetus, the gizzard rather rounded, not flattened, the pyloris long and the blind sac rather short and placed as in Helisoma. The intestine makes a loop around the stomach and another loop around the liver, then rums forward to the rectum which bears a plaited crest or ridge (plate 48. fig. 9 ).

The buecal sac is short and high, not much elongated. The radula sac or pouch is large and rounded, somewhat as in Tropicorbis. The salivary glands are narrow and nearly three times as long as the buccal sac. They are joined behind as in Helisoma.

Jaws three in number as in Tropicorbis (plate 50, fig. 13). The superior jaw is very high, the length being abont three times the height. It is finely striated on its anterior face. The sicle jaws are much shorter than the width of the superior jaw and are very narrow. The side jaws are shorter in comparison with the length of the superior jaw than in most species 
of Planorbidae. The figure on plate 50 agrees with that by Pilsbry (1934, p. 57).

The radula formula is 31-1-31 to 33-1-33 with 182 rows of teeth (plate 68 , fig. 5). The eenter tooth $(60)$ is wider than high, the lower outer corners of the base of attachment expander to the extent that the base is twice as wide as the summit of the tooth. There are two sharp, spade-shaped cusps which extend below the lower margin of the base of attachment. Lateral teeth (1-13) asymmetrical, trieuspid, the eusps sharp, subequal, and extending below the base of attachment. The intermediate teeth (14-15) differ from the lateral teeth in having either an extra interstitial eusp between the ectocone and mesocone (14) or an interstitial cusp as in 14 and an extra cusp above the ectocone. Marginal teeth (16-26) elongated, oblique, the mesocone remaining a large sharp cusp, but the entoeone splitting into three to five small, subequal cusps arranged obliquely. The ectoeone continues as a large cusp but above it, on the margin of the tooth, there are three to six rery small eusps in addition. The ectocone is always separated from the mesocone by a distinet gap. The small eusps above the ectocone are placed higher up on the tooth than in other genera. The outer marginals are very narrow and oblique and the cusps appear as minute serrations. Even here, however, the two groups of cusps, mesocone and cetocone, are separated by a considerable space.

Pilsbry (1934, p. 55) figures the radula of the race christopherensis which agrees in all essential details with the figures on plate 68 . He gives the formula as 30-1-30 with seventeen laterals. In specimens personally dissected the marginals began on the 16th tooth in two specimens and on the 18 th tooth in one specimen, the 15 th to 17 th teeth being intermerliate in eharacter. These differences are unimportant.

Scott (1940, pp). 10-12) figures the radula of specimens from Caracas, Venezuela, and Puerto Rico, showing great variation in the form of the cusps. The Venezucla form with a formula of 45-1-45 may be representative of the race olizaceus.

The material used for this anatomical study was received from Dr. Wm. A. Hoffman and was collected at Lares, Puerto Rico.

Geographical Distribution. Except for its oceurrence in Haiti, Puerto Rico, and the Caribbean islands, Australorbis is a South Ameriean group (Pilsbry). It is known in South America from Venezuela southward to Argentine Republic.

Species Considered as Valid. Many names have been given to rariations within this genus and consequently there are many synonyms. The following species and races appear to be recognizable:

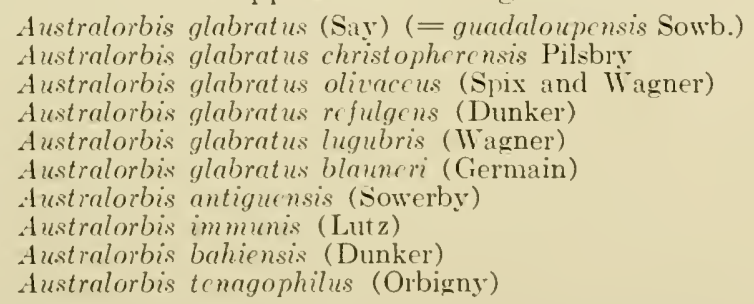

Geological Distribution. This genus probably dates from the Oligocene or Miocene period of the West Indies and South America. 
Remarks. Australorbis is so peculiar in certain of its anatomical characteristics as to puzzle the systematist regarding its proper position in the classification of the family Planorbidae. In its narrow penial complex without penial gland it is related to Tropicorbis. The prostate, however, is very different from any member of the Planorbinae and superficially resembles some of the Helisomatinae in the presence of multiform diverticula. The orotestis is also of a multiform nature. The prostate diverticula are also attached directly to the sperm duet instead of to a separate prostate duet as is the case in Tropicorbis. In this respect, the prostate of Australorbis resembles that of the genus Drepanotrcma, the few divertieula in this group being attached clirectly to the sperm duct. The kidney is of the Helisoma trpe, with a distinct ridge.

In spite of the multiple nature of the diverticula of the prostate and ovotestis, the group appears to be related to Tropicorbis and to be correctly placed in the subfamily Planorbinae. The absence of a penial gland removes it from Helisomatinae and Planorbulinae and the absence of a flagellum, and also the form of the shell (with overlapping whorls), excludes it from the subfamily Segmentininae. When the characteristics of the prostate are closely examined it is seen to be uniserial in form in spite of the branched nature of the diverticula. Each diverticulum arises from the sperm duet as a single tube, the branching taking place after the diverticula are above the sperm duet. so also in the ovotestis, each cliverticulum arises from the orisperm duct as a single tube, the branching being on one side only.

In the Helisomatinae, both the prostate and the ovotestis have the diverticula radiating from the ducts like the spokes of a wheel, in fanformation. The ridged kidney is an exeeption in the Planorbinae. This characteristic, as well as the apparent multiple appearance of the prostate and orotestis, may show ancient affinities with the Helisomatinae. Australorbis is apparently an aberrent genus of the family.

Pilsbry has suggested $(1934, p) 56$ t that it might be considered a subgenus of Tropicorbis but this procedure would appear untenable because of the peculiar prostate and orotestis as well as the ridge on the kidney. Pilsbry did not examine the orotestis or the kidney.

The name Planorbina Haldeman was used for this group by Dall in 1905, the Brazilian species Planorbis olizaceus spix and IV agner being designated as the type. Cermain, in 1921. selected Planorbis guadaloupensis sowb., as type of Planorbina. But as Pilsbry states in his rescription of Australorbis, neither olivaceus nor guadaloupensis answer to Haldeman's description 'whorls numerous, nearly equal,' the whorls in these species increasing in diameter to such an extent that the last whorl is notably widler than the precerling whorl. Haldeman's Planorbina is now considered a symonym of Anisus. Pilsbry's discussion of the reasons for rejecting the types proposed for Planorbina, for which no type was resignated by Halideman, by Dall or Germain are well stated and ro not need to be repeated here.

\section{Genus ANISOPSIS Sandberger, 1875}

Týpe herein nominated Planorbis calculus Sandberger

1875. Anisopsis Saxpberger, Land und Süssw. Conch. der Vorwelt, p. 958. No type cited

1905. Anisopsis Dall, Alaska Moll.. p. 81. Planorbis loryi Coq., and Planorbis calculus Sandb. cited as examples 
Shell (of Anisopsis calculus isandberger), plate 81, fig. 101. "Testa calculiformis, superne excarata, inferne latissime umbilicata. Anfractus 31/2. gracilis, quadrangulates, superne excarati, ad margineum superum neenon ad umbilicum carina eincta, suturis tenuibus profundis disjuneti, costulis transversalibus subtilibus ornati, ultinus permagnus, spiram eminens (Sandberger, p. 14). Taf. 1, fig. 7, 7a (stark vergrössert).'

The shell is ultradextral, with a distinct, sharp carina in the middle of the whorls on the right sirle. The left side also has carinated whorls. The whorls are few in number, increasing rather rapidly in diameter. From the figures there appeal's to be a carina at the periphery.

Horizon and Distribution. Middle or brown Jurassic period. Cajac, in lavers e and f. Very rare.

Remarks. The name Anisopsis appears to be a nude name, no type haring been formally designated for it, as far as the writer is aware. It also appears to have been comparatively unnoticed by recent students of the Mollusea. The only American reference observed is that by Dall in 1905. who cites Planorbis loryi Coq., and Planorbis calculus Sandb. as examples. The original reference is in a stratigraphic table on page 9.58 of Sandberger's work in which Anisopsis appears between Bathyomphalus and Anisus. The only valid reason for associating the two species mentioned above with Anisopsis is the presence of the stars in the Middle (Mittlerer) Jura and the Upper (Oberer) Jura in the table, indicating that these tro speeies are the ones intended for this group name, since no others from these horizons oecur in the body of this work.

Planorbis calculus Sandberger oceurs first on page 14 and should be taken as the type of Anisopsis. On page 15 Sandberger mentions the likeness of this species to the tricarinate Valvatas of North America typified by Talvata tricarinata. The figure of this species does look much like Valzata tricarinata on the right side but on the left side the figure is too wide, lacking the distinet earina and deep umbilicus of the Ameriean Valcata. Dall (1905, p. 81) suggests its relationship to Helisoma but the left side is different from any species of that genus known. The exact size is not given by Sandberger, who states that the figure is much enlarged.

The second species, Planorbis loryi Coquand (Sandberger, p. 41) is more planorboid in form and somewhat different in shape from calculus (see plate 81, fig. 11). It is also larger. Sandberger suggests its resemblance to Planorbis complanatus (Linn.) (= fontame Lightfoot) and Planorbis carinatus Müller, but the figures do not resemble either of these species. Sandberger's description of this species is as follows: 'Testa calculiformis, superne profunde exeavata, inferne depressa, latissime umbilieata. Anfractus quinque, gracilis, costulis transversalibus tenuibus muniti et carinis duabus acutis insignes, prima partem superam exeavatam, altera basin cingente. Apertura trapezoidea, valde iniquilateralis.'

The horizon and localities for this species are given as follows by Sandberger (p. 41): "Villers le Lae (physaschicht b), les Rousses. Charix bei Nantuar, Alfermé und Vigneules am Bieler See in den gleichen Schichten.' These localities are in the Lpper or White Jura.

The group Anisopsis, which may be resignated as a genus of the subfamily Planorbinae, may be retained to contain these early fossil species. The two species referred to this genus may not be congeneric, loryi appear- 
ing more like some of the species of Planorbis or Anisus. Many of the names of groups of the Planorbidae hare been used rather loosely by European writers. Sandberger, for example, lists the subgenera Menetus, Helisoma, and Carinifer among the European fossils, groups which we now know are confined to America and have no representatives outside the Western Hemisphere. All of the extinct Planorbidae, both American and European, are badly in need of a thorough taxonomic revision.

Species Considered as Valid. Anisopsis calculus (Sandberger), the genotype, is the only speeies unquestionably assigned here. The assignment of Planorbis loryi Coquand seems indefensible.

\section{Subfamily SEGMENTININAE F. C. Baker, New}

The prostate diverticula are simple saes placed in a single row along a prostate duct as in the subfanily Planorbinae. The penial complex has one or two flagella placed at the end of the rergic sac and in addition several genera have a penial gland in the preputium. The jaw is fragmented as in Planorbinae. The radula teeth are modified by additional eusps or by the presence of many interstitial cusps. The kidney is without a ridge.

Type genus Segmentina Fleming.

The groups included in this subfamily are as follows:

With penial gland but without duct: Segmentina, II ippeutis, Pingiella.

With penial gland and an external duct: Intha.

Without penial gland: Polypylis, Drepanotrema, Acrorbis.

With long flagella: Pingiella, Polypylis, Intha.

With short flagella: Segmentina. Hippeutis, Acrorbis.

With both long and short flagella: Drepanotrema.

With lamellae or barriers within the aperture: Segmentina, Polypylis, Trochorbis.

Without lamellae or barriers within the aperture: Hippeutis, Helicorbis, Pingia, Intha, Drepanotrema, Platytaphius, Aerorbis.

Several groups have not been examined anatomieally and their position is doubtful. Such are Helicorbis, Trochorbis, and Platytaphius. The fossil group Paraplanorbis must, of eourse, be placed by shell characters alone.

\section{Genus SEGAIENTINA Fleming, 1817}

Monotype Tautilus lacustris Lightfoot $=$ Planorbis nitidus O. F. Müller

1817. Segmentina Flemixg, Edinburgh Encyclopedia, Conchology, ed. VII, Vol. XII. Monotype, Nautilus lacustris Light foot = Planorbis nitidus O. F. Müller

1S18. Segmentina Flemixg, Supplement to 4-6th ed. Encye. Brit., III, 'Conchology,' p. 309. Type Nautilus lacustris Lightfoot

1819. Hemithalamus Leach, Moll. Brit. Synop. (proofs), p. 137

1831. Hemithalamus 'Leach' Turtox, Man. Land Fresh-water' Shells Brit. Isl., p. 116. In synonymy of Srgmentina nitida O. F. Mïller

1833. If mithalamus Fitzinger, Syst. Terz. p. 110

1S40. Segmentaria Swamsox, Treat. Malac., p. 337. Lapsus for Segmentina. As subgenus of Planorbis

1842. Segmentina Haldemax, Mon. Fresh-mater Univ. Moll., U. S., p. 14. No type cited. As subgenus of Planorbis

1S47. Segmentina Gray, Proc. Zool. Soc, p. 509. Type Nautilus lacustris Lightfoot. As genus

1817. Discus Gray, Proc. Zool. Soc., P. 509. No type cited. As synonym of Segmentina

1850. Segmentina (part) Sтегx, Schnecken u. Musch. Berlins, p. 7S. Segmentina $\mathrm{x}$ Hippe utis 
1855. Segmentina Moquix-Taxdox, Hist. Moll. Terr. Fluv. France, II, pp. 423, 424. Type Planorbis nitidus Miiller. As genus

1865. Segmentina Binner, L. and F-IT. Shells N. A., II, p. 136. No type cited. As genus:

1867. Appendienlaria (part) Ficinus, Zeits. für gesamm. Naturw., XXX, p. 363

1870. Segmentina Dall, Ann. N. Y. Lyc. N. H., IX, p. 352. Type Plamorbis laeustris Lightfoot. As genus

18S3. Segmentina Fiscier, Man. de Conch., p. 509. Type Planorbis nitidus Miill. As subgenus of Planorbis

18S4. Segmentina Tryox, S. and S. Conch., III, p. 107. Type Segmentina lacustris Lightfoot. As genus

18S5. Segmentina Westerluxd, Fauna Pal. Reg., V, p. 85. No type cited. As subgenus of Planorbis

1886. Segmentiua Cuessix, Syst. Conch. Cab., eal, 2, XVII, p. 34. Type Planorbis nitidus Müiller. As genus

1902. Segmentina Westerlund, Rad. Jugoslav. Akad., 151, P. 121. Type Planorbis nitidus Müller. As subgenus of Planorbis

1905. Segmentina DaLl, Alaska Moll., p. 97. Type Planorbis nitidus Müller. As genus

1912. Segmentina Haxiribal, Proc. Mal. Soc. Lond., X, p. 154. Type Planorbis nitidus Miiller. As subgenus of Planorbis

1915. Segmentina Prestox, Fauna Brit. India, Moll. FW. Gast. and Pelec., p. 124. Type Planorbis nitidus Müller. Includes species now referred to Helicorbis, Trochorbis, and Polypylis

1917. Segmentina L. Soos, Ann. Hist. Nat. Musei Hungarici, XV, pp. 140, 142. Type Planorbis nitida Miiller. As genus

1918. Segmentina Walker, Miscel. Pub., Mus. Zool., Univ. Mich., No. 6, p. 13. Type Nautilus lacustris Lightfoot. As genus

1919. Seqmentina Axxaxdale and Prashad, Rec. Ind. Mus., XVIII, p. 56. Type Planorbis nitidus Miiller. As genus

1921. Segmentina Germaix, Rec. Ind. Mus., XXI, p. 163. Type Planorbis nitidus Miiller. As genus

1923. Segmentina Wexz, Fossil. Cat., pars 22, p. 1661. Genotype Segmentina lacustris (Mantagu). As genus

1926. Segmentina Lixdholm, Archiv. für Mollusk., 58 year, Heft 6, p. 252. Monogenotype Nautilus lacustris Lightfoot (= Planorbis nitidus Mïller). As genus

1926. Segmentina Kexrard and Woodward, Syst. Brit. Non-Marine Moll., p. 89. Type Planorbis nitidus Mïller. As genus

1927. Segmentina Pilsbry and Bequaert, Bull. Amer. Mus. N. H., LIII, p. 12S. Type I'lanorbis nitidus Miiller. As genus

1929. Segmentina HaAs, Trab. Museo Cien. Nat. Barcelona, XIII, p. 38s. Type evidently Planorbis nitidus Mïller. As genus

1931. Segmentina Germax, Moll. Terr. Flur. France, II, P. 542. Type Segmentina nitida (Miiller). As genus

1931. Segmentina Thiele, Handbuch, Teil 2, p. 481. Type Anisus (S.) nitidus (Mijller). As subgenus of Amisus

1935. Segmentina A. Soos, Allat. Kozlen., XXXII, p. 29. As genus

Shell (plate 79, figs. 1-3). Small, ultradextral, smootl, and glossy; whorls few, notably overlapping the body whorl embracing most of the preceding whorls, causing the preceding whorl to project far within the width of the aperture; periphery rounded or carinaterl. Carity of the last whorl restricted by several barriers, each set usually composed of three large transverse lamellac, parietal, hasal, and palatal. There may be other smaller lamellae (plate 76, fig. 4). The internal lamellae are composed of enamel-like substance. The embryonic whorls have spiral rows of small pits. 
Animal. With a short foot, rounded in front, pointed behind; tentacles filiform, enlarged at the base, the eyes sessile at their inner bases. Erlge of mantle thickened. The color of the animal is brownish black much paler when immature.

\section{ANATOMICAL CHARACTERISTICS}

PLATES 2 and 3

GENITALIA. Male Organs (plate 3, fig. 2). Scminal resicle sac-like, about three times the diameter of the ovisperm duet with several protuberances near the posterior end. It is about $2 \mathrm{~mm}$. long. Sperm duct long $(4.5 \mathrm{~mm}$.) and of small diameter. Prostate moderately long $(1.7 \mathrm{~mm}$.) with twenty-two to twenty-five club-shaped diverticula of varying lengths, placed on a separate prostate duet, which joins the sperm duet to form the vas deferens. The free portion of the prostate duct is about $0.7 \mathrm{~mm}$. long and of larger diameter than the sperm duct. In the specimens examined the posterior end of the prostate duct is free of diverticula for about $0.3 \mathrm{~mm}$. The ras deferens is of medium length (about $3 \mathrm{~mm}$.) and of small diameter. A cross section through the prostate and sperm duet shows the relative position of these parts of the animal (plate 3 , fig. 3 ).

The penial complex (plate 3 , fig. 1 ) is very long (about $3 \mathrm{~mm}$.). The preputium (PR) occupies half of the length of the complex and is elongatepyriform in shape, the upper part swollen. The vergic sac (VS) is very long and narrow, almost tube-like, and is as long as the preputium. There are two short, narrow flagella (FL) at the end of the rergic sac at the point of insertion of the ras deferens. There is a single, rather wide retractor muscle, but no supporting muscles.

Internally (plate 2 , fig. 2 ) the preputium presents some striking features. There is a single heavy ridge on one side (plate 2, fig. 1) which extends vertically up a large portion of the preputium and is in the nature of a pilaster (PL). This ridge merges into a long, sac-like glandular organ which is reflected toward the base or opening of the preputium (SB). This penial gland has a shallow cup, the bottom of which is pared with small protuberances resembling parement (plate 2 , fig. 3 ), the fleshy sides rolled upward. In cross section this gland presents the appearance shown in fig. 4 of plate 2. On the right sicle of the preputium there is a long, very narrow pilaster which extends the whole length of the preputium from the external opening upward to the muscular ring (D) separating the preputium from the vergic sac. The large gland is free from attachment to the wall of the preputium and is connected only with the large left pilaster.

The verge ( $\mathrm{V}$ ) is long and very narrow. At its distal end it bears a fleshy papilla (plate 2, figs. 5, 6, PA) which is also long and narrow. This papilla is an extension of the rerge only from one side, the sperm canal (SC) being in the center of the rerge at the end, as shown in the figures.

Female Organs. The spermatheca (plate 3, fig. 2) is long and sac-like and is attached to the ragina by a long narrow duct which is somewhat longer than the spermatheea. The spermatheca is constricted about midway of its length. The ragina is narrow and about $0.5 \mathrm{~mm}$. in length. The uterus is about twice the diameter of the ragina and is a trifle over $1 \mathrm{~mm}$. in length. The nidamental gland is very long (about $3 \mathrm{~mm}$.), sac-like, and envelops the uterus. The oviduct is about half the cliameter of the 
nidamental gland and about $1.5 \mathrm{~mm}$. long. The albumen gland is rather small and oval in shape.

Hermaphrodite Organs. The ovotestis (plate 3, fig. 2) consists of relatively few (less than twenty) large elub-shaped diverticula. They are placed in a double row on the ovisperm duet. The ovisperm duct between seminal vesicle and orotestis is very short, but anteriorly, between the seminal resicle and the oviduct, it is a long (2 $11 \mathrm{~m}$.), narrow tube.

The figures on plates 2 and 3 agree in the main with those already published by European malacologists. L. Soos's figure (1917, p. 44, fig. 17) is the same, showing the few large orotestis diverticula, the elongated spermatheca and duct, and the few divertieula on the prostate. The flagella are shown somewhat longer than those in the figure on plate 3 . Germain's figure (1931, p. 543, fig. 56) is practically the same, the flagella being more like the figure on plate 3 .

Respiratory and Renal Systems. The pseudobranch (plate 3, fig. 4) is rather small. smooth, elongate-orate, and folded. The pneumostome is very large (fig. 4, PS).

The kidney (plate 47 , fig. 22 ) is very long $(8 \mathrm{~mm}$.) and narrow, ribbonlike, the short ureter reflected at right angles to the kidney. In eross section (fig. 23, below the middle) it is seen to be rounded, a trifle wider than high, with the reins placed at the upper eorners of the lumen, which is oral in shape. There is no superposed ridge.

Digestive System. The stomach region (plate 48, fig. 16) is very narrow, divided into erop, gizzard, and pyloris. There is a short blind sae. The intestine makes a sharp turn about the stomach and another around the liver, then runs forward to the rectum.

The buceal sae is much elongated, the salivary glands short, wide, and looped behind. There is a conspicuous radula sae which projeets notably from the rear end of the buceal sac.

The jaw (plate 50, fig. 24) is horseshoe-shaped, and composed of many small plates (about sixty). It is similar in form to that of Planorbis.

Radula (plate 69, fig. 7). The formula is 23-1-23 with 164 rows of teeth. The central tooth is wider at the lower edge of the base of attachment than at the upper margin of the tooth. The two short cusps do not reach the lower margin of the base of attachment. Lateral teeth (1-7) long and narrow, the reflection low and wide and placed high up on the tooth. There are seven cusps, dagger-like and subequal in size, the ectoconic eusps a trifle smaller. There are six teeth which may be called intermediate (8-13), since the cusps are a trifle smaller than those of the lateral teeth. Marginal teeth (14-21) with the reflection very low and wide, 7 euspid, the mesocone a trifle larger than the three cusps on each side. The outer marginals $(22,23)$ are vestigial. The teeth are all crowded on the membrane, some of them even overlapping. The teeth are very uniform in size and shape.

Twelve specimens of Segmentina nitida were dissected, collected from marshes in a meadow in Czerniakow, a suburb of Warsaw, Poland, by A. Jankowski.

Geographical Distribution. Typical Segmentina is distributed througlout Europe and northern Asia. A single species, S. nitida (Müller), is reeognized, with several races, by Westerlund and others. some small speeies, as 
kempi Preston and angusta Jiekeli, may be true Segmentina. Speeies quoted from northern Africa probably belong to other genera, as Afroplanorbis. South African species may belong to an undeseribed group. The Indian and Chinese speeies included by authors in Segmentina probably all belong to Polypylis, Pingiella, or Helicorbis. Only an anatomieal examination ean eorreetly place the many speeies referred to segmentina.

Geological Distribution. Oligocene period to Recent fauna.

Species Considered as Valid. Since the genus Segmentina is not found in Ameriea, it is extralimital to the seope of the present work. Segmentina mitida (Mïller), the genotype, is the only species definitely considered.

Remarks. The genus Segmentina is distinguished not only by its glossy shell with the embracing body whorl and intemal barricrs, but also by its genitalia witl the two short flagella on the verge, the few large ovotestis diverticula, the duetless penial gland in the preputium, and the papilla at the end of the verge. No mention is made of this peculiar gland in any work consulted. The prostate is on a separate duct as in the Planorbinae. These speeial features of the anatomy distinguish Segmentina from all other genera of Planorbidae.

The generic name has been used in a rather wide sense and has ineluded one group which belongs in another subfamily (Planorbula) and several other related groups which are separated generically from Segmentina (Popypylis, Pingiella, Helicorbis). As typified by Planorbis nitidus Müller it is a well characterized genus.

Segmentina nitida appears to be a favorite host for parasitic worms, all of the twelve speeimens examined being more or less heavily infested. The orotestis appeared to be most affected and in sereral specimens this organ was almost obliterated. The liver was also affected.

\section{Genus HIPPELTIS (Agassiz MS) Charpentier, 1837}

Type designated by Clessin in 1886, Planorbis complanatus Drap. (= Helix fontana Lightfoot), one of the two species originally included

1837. Hipprutis 'Agassiz' in J. de CH.ARPextuer, Neue Denksch. Allg. Schweiz. Natuw., I, No. 2. p. 22. As subgenus of Planorbis

1837. Hippeutis Gray, in Turton, Man. Land FIT. Shells Brit. Isl., Ed. 2, p. 243. As subgenus of Plamorbis

1844. Hippeutis Hartanx, Erd-und Süsswassser-Gast. der Schweiz., V, pp. 51, s7. As subgenus of Planorbis

1850. Hippeutes M. E. Grar, Fig. Moll. Anim., IV, Syst. Arrang., p. 119. Typographical error for Hippeutis

1850. Segmentina (part) Sters, Leben. Schneck. Muschl. Berlins, p. 78. Non Segmentina Fleming, 1S17. (Segmentina plus Hippentis)

1855. Hippeutis Moquin-Tandox, Hist. Moll., Terr. Flur. France, II, pp. 423, 426. Type Planorbis fontanus (Lightfoot). As genus

1855. Hippeutis Westerlund, Fauna Palearc. Reg. Binnen. Conch., Y, pp. 65, 84 . No type cited. As subgenus of Planorbis

1886. Hippeutis Cuessin, Syst. Conch. Cab., Ed. 2, XVII, p. 34. Type Planorbis complanatus Drap. As subgenus of Planorbis

1902. Hippeutis Westerlund, Rad. Jugoslar. Akad., 151, p. 121. Type Planorbis fontanus (Lightfoot). As subgenus of Planorbis

1905. Hippeutis Dal,, Alaska Moll., pp. 82, 86. Type Planorbis fontanus (Lightfoot). As subgenus of Planorbis

1912. Hippeutis Handibal, Proc. Mal. Soc. London, X, p. 154. Type Planorbis complanatus Drap. (= Helix fontana Lightfoot). As subgenus of Planorbis 
1915. Mippeutis Prestox, Fama Brit. India, Moll., FW. Gast and Pelec., p. 124. Type Planorbis fontanus (Lightfoot). As section of Planorbis

1918. Mippeutis Walker, Mis. Pub. Zool. Mus., Univ. Mich., No. 6, p. 94. Type Planorbis fontanus (Lightfoot). As subgenus of Planorbis

1923. Hippeutis Wexz, Fossil. Cat., Pars 22, p, 1633. Genotype Hippentis complanatus (Drap.) = Ilelix fontana Lightfoot. As genus

1923. Hippeutis Germax, Rec. Ind. Mus., XXI, pp. 8, 159. Type Planorbis fontanus (lightfoot). As subgenus of Plunorbis

1926. Hippeutis Livinow, Archiv. für Mollusk., 58 year, Heft 6, 1) 253. Ideogenotype Planorbis complanatus Drap. As genus

1926. Hippeulis Kexxard and Woodward, Syn. Brit. Non-Marine Moll., p. 69. Type Helix complanatus Linn. As subgenus of Planorbis

1927. Mippeutis Pulsbri and Bequaert, Bull. Amer. Mus. N. H., LIII, p. 128. Type Planorbis complanatus Drup. = Planorbis fontanus (Lightfoot). As subgenus of Planorbis

1929. Ihippeutis HAds, Trab. Museo Cien. Nat. Barcelona, XIII, p. 3s7. Type evidently Helix fontana Lightfoot. As genus

1931. Hippentis Germas, Moll. Terr. Flux. France, 11, ए. 541. Type not cited but Planorbis complanatus (Linn.) described. As subgenus of Planorbis

1931. Hippeutis Thiele, Handbuch, Teil 2, 1. 481. Type Anisus (II.) complanatus (Limn.). As subgenus under genus Anisus

1935. Hippeutis A. Soos, Allat. Kozlem., XXXII, p. 29. As subgenus of Segmentina. To type cited

Shell (plate 79, figs. 4-6). Small, ultradextral, lens-shaped, shining, the body whorl very wide and overlapping most of the inner whorls and forming a sharp keel at the periphery, the preceding whorl forming a sharp extended ridge on the parietal side of the aperture. Aperture triangular. outer lip thin. There are no barriers or lamellae within the aperture. The embryonie whorls have spiral punctures as in Segmentina.

Animal. Not differing from that of Segmentina in general form. The body of the animal is clear and translucent.

\section{ANATOMICAL CHARACTERISTICS}

PLATE 2 (llippentis complanatus (Limn.))

GENITALIA. Male Organs (fig. 15). Seminal vesiele ratler short (about $0.7 \mathrm{~mm}$.), placed midway between orotestis and oviduet, the diameter of the organ about the same as the ovosperm duct, with many pustule-like resieles. Prostate short (about $0.6 \mathrm{~mm}$.) with ten long and narrow diverticula. Free portion of prostate duet slort (fig. 8). Sperm duet (SPD) long (over $1 \mathrm{~mm}$.) and of large diameter. Vas deferens (VD) about as long as sperm duet, but of smaller diameter.

Penial complex (plate 2, fig. 14) less than $1 \mathrm{~mm}$. long. Preputium (PR) strikingly prriform, tapering to a narrow neek near the outlet. Vergic sac (VS) shorter than the preputium, sae-like, of mucl smaller diameter than the preputium. There are two short flagella (FL). There is a single wirle retractor muscle (RM) attached to the preputium at the lower part of the bulbous swelling.

Internally (fig. 12), the preputium has two large fleshy pilasters (PL), to the left one of which is attached a large, sae-like penial gland, which extends erosswise of the preputial eavity (SB). There is a depression at the end of the gland but apparently no eavity or eup. The square end of the gland is folded backward upon itself. It is shown folded in fig. 12 (SB) and with the end stretehed out in fig. 9 , where the small depression may be 
plainly seen. The retractor musele (RM) is attached to the preputium at the point where the gland joins the pilaster (fig. 12, SB).

The verge is swollen above and tapers to a narrow diameter for about half its length $(\mathrm{V})$. The sperm canal has a central outlet but there is no papilla. There is a narrow muscular ring or diaphragm (D) between vergic sac and preputium. The two short flagella (FL) are hollow and under high power show a minutely punctate surface at the upper rounded end (fig. 11).

Female Organs (fig. 15). The spermatheca (S) is long, ovate, sac-like and is joined to the short, wide ragina ( $\mathrm{T}$ ) by a long, tube-like duct, which is twice the length of the spermatheea. The utelus $(U)$ is trice as wide as the vagina, and shorter than the spermatheca and its duet. The nidamental ghand (NG) is longer than the uterus, much swollen and about half as wide as long. The oviduet (OD) is short (about $0.5 \mathrm{~mm}$.) and about the same diameter as the uterus. There is a large, bubous carrefour $(\mathrm{CF})$ which reecives the duct from the long and narrow abbumen gland (AL; also fig. 10).

Hermaphrodite Organs. The orotestis (OT) has about thirty clubshaped diverticula placed for the most part in a double row (fig. 7). The ovisperm duet (SO) is very long (about $2 \mathrm{~mm}$.) and of small diameter.

Odhner (1929, p. 32, fig. 13) figmes the genitalia of this species agreeing in most respects with the material personally examined. A few points, however, are figured differently from the position observed in the speeimens studied. The prostate is shom as having thirteen divertieula rather widely spaced on the sperm duet, quite different from the long, erowded diverticula personally observed see plate 2, fig. 15 , PRS). The ovotestis diverticula are shown extending in pairs from a short duct which enters the ovisperm duct. In this species, as well as others of this subfamily and of Planorbinae, the ovotestis diverticula arise in pairs direetly from the orisperm duet, each diverticulum entering the duct separately (see plate 2, fig. 7 ). No mention is made of a separate prostate duet or of a gland in the preputium. An elongated object in the upper part of the preputium is shown in Odhner's figure which might represent this organ.

Odhner's figure of the radula of Hippeutis complanatus differs somewhat from the radula as personally examined, there being no interstitial cusps between the larger eusps. The formulas of Odhner's speeinens agree exactly with ours.

Respiratory and Renal Systems. The pseudobraneh (plate 2, fig. 13) is small, rather narrow, and pierced above by the reetum (P). The pneumostome is very large.

The kidney (plate 46 , fig. 17$)$ is rather short $(1.5 \mathrm{~mm}$.) and wide, the greatest width being almost one thirct of the length. The ureter is not sharply reflexed as in Segmentina, but extends horizontally into the mantle eavity. A cross section below the middle (fig. 18) shows the kidney to be flattened, the lumen rounded with the veins placed at the upper corners of the lumen. There is no superposed ridge. The kidney of Hippeutis is quite different from that of Segmentina (compare fig. 17, plate 46, with fig. 22 , plate 47 ).

Digestive System. The stomach (plate 48, fig. 12) is elongated, as in Segmentina. The intestine loops around the stomach and liver, and there 
is a large blind sac. The buecal sae is elongated, narrowed in front with a large radula sac behind. The salivary glands are short and to not extend far beyond the posterior end of the buceal sac. They are joined behind as in Segmentina.

The jaw is fragmented as in Segmentina and is made up of many small plates.

The radula formula is 16-1-16, with 150 rows of teeth. The center tooth is higher than wide with two wide ensps which do not reach the lower margin of the base of attachment. The laterals (1-9) are squarish and trieuspid, the mesocone large and almost reaching the lower margin of the base of attachment. The entocone is shorter than the mesocone. The ectocone is shorter than the entocone and is placed high on the margin of the tooth. In the marginal teeth the reflection is wide and low and is placed high up on the tooth. The entocone and mesocone are of equal length and the ectocone is shorter with two small cusps above on the outer margin of the tooth. The radula teeth of Hippeutis resemble those of Bathyomphalus contortus shown on plate 68, fig. 1. They are not like those of Segmentina nitida figured on plate 69 , fig. 7 .

The above anatomical information was obtained from specimens collected in a pool on a meadow in Jabtonna, $16 \mathrm{~km}$. north of Warsaw, Poland. The specimens were obtained by Mr. A. Jankowski.

Geographical Distribution. Europe from Great Britain, Norway, and Sweden south to Portugal. Italy, and Albania. Eastward to northern Siberia. A palearetic group. It has been recorded from northern Africa and the group nay be circum-Mediterranean in distribution. As in Segmentina a number of species have been described with many varieties. The species eited from Soutl Africa, India, and China probably belong in other genera.

Species Considered as Valid. The following species are apparently referable to Hippeutis:
Hippeutis complanatus (Linn.)
Hippeutis riparius (Westerlund)
Hippeutis syraeusanus (Cafici)
llippentis diaphanellus (Bgt.)
Hippeutis raymondi (Bgt.)
IIippeutis junodi (Connolly)
IIippeutis benguelensis (Dunker)

Geological Distribution. From the Lower Eocene period (IVenz). Eighteen species and races of fossil Planorbis are referred to this genus by Wenz.

Remarks. Hippeutis complanatus resembles Segmentina nitida in its anatomy. The prostate, however, has fewer diverticula. The penial gland differs in shape but both are attached to the right pilaster. The whole genitalia of Segmentina are much elongated while these organs in Hippeutis are short and heary. Internally the penial complex of the two groups differs in details. The kidneys of the two genera are quite unlike. The radula resembles Bathyomphalus rather than Segmentina. The shell is wholly without barriers or lamellae of any kind within the aperture and this eharacteristic at once marks Hippeutis as a separate genus.

Species from northem Afriea and eastem Asia lave been assigned to Hippeutis but until these species have been examined anatomically this reference remains open to doubt. The Asiatic forms probably belong to Benson's genus Helicorbis. Parasites were not observed in any of the material examined. 


\author{
Genus POLYPYLIs Pilsbry, 1906 \\ Type by original designation Segmentina largillierti \\ (Dunker) $(=S$. hemisphaerula (Benson)
}

1906. Polypylis Pilsbri, Proc. Acad. Nat. Sci. Phil., LVIII, p. 166. Type Segmentina largillierti (Dunker). As subgenus of Segmentina

1921. Segmentiua (part) Prashad (non Fleming), Rec. Ind. Mus., XXII, p. 585. Ientions Segmentina calathus (Benson), included in Polypylis

1922. Segmentina Axxaxdale (non Fleming), Rec. Ind. MIus., XXIY, p. 362. Mentions Planorbis calathus Benson and Planorbis caenosus Benson, both included in Polypylis

1923. Polypylis Geruats, Rec. Ind. Mus. XXI, p. 164. As synonym of Segmentina 1939. Polypylis HAss, Field Mus. N. H., Zool., Miscel. Notes, XXIT, p. 96, fig. 8a. Type Segmentina largillierti (Dunker) $(=S$. hemisphaemla (Benson)). As subgenus of Segmentina

Shell (plate 79, figs. 7-9) less compressed than Segmentina (nitida) and not carinate, but glossy with deeply clasping whorls. The parietal lamina is obliquely transwerse, the others transverse, basal long, a shorter one in the outer wall, and one or two in the upper margin. There are several or many barriers (Pilsbry). The embryonic whorls are punctured.

Animal. Not examined.

\title{
ANATOMICAL CHARACTERISTICS
}

PLATE 5

GENITALIA. Male Organs (fig. 7). Seminal vesicle (SV) almost twice the diameter of the ovisperm duct, rather long $(2 \mathrm{~mm}$.) convoluted, with but few pustulose excrescences. The vesicle gradually decreases in diamcter to the ovisperm duct which is not sharply distinguished from the vesicle. Sperm duet (SPD) about $3 \mathrm{~mm}$. long, rather narrow. Prostate $1.3 \mathrm{~mm}$. long, on a separate prostate duct (PI)), consisting of twenty-eight to thirty-four long and narrow diverticula, the tip of which is bent over in most of the diverticula (fig. 4). Several of the diverticula are bifid at the end. The free prostate duct is very short. The vas deferene (VD) is a small, tube-like duct somewhat shorter than the sperm duct.

The penial complex (plate 8 , fig. 10$)$ is long and narrow $(0.5 \mathrm{~mm}$. long). The preputium (PR) is sac-like, rather narrow and elongated $(1 \mathrm{~mm}$. long). The vergic sac (VS) is two-thirds as long as the preputium and is very narrow. There is a single flagellum (FL) which is long (over $1 \mathrm{~mm}$.) and narrow and has a bulbous enlargement at the end which is almost half as long as the flagellum. The narrow part of the flagellum has about the same diameter as the vergic sac. The vas deferens enters the vergic sac at one side of the flagellum, as shown in the small figure in fig. 10. There is one large retractor muscle (RMI) which is attached to the preputium near the junction of this organ with the vergic sac.

In Polypylis calathus there are two short flagella and the vergic sac is longer than in hemisphaerula. The pilasters, also, are very thick pads in calathus. There are over thirty diverticula on the prostate of calathus and the seminal vesicle is very large with projecting vesicles.

Internally, in the penial complex of hemisphaerula (plate 8, fig. 9) the preputium has two pilasters extending the whole length of the sac. There is a small, narrow muscular ring or diaphragm (D) separating the preputial 
cavity from the rergic cavity. The verge (V) is long $(0.7 \mathrm{~mm}$.) and very narrow, tube-like and at the ent there is a fleshy papilla and the sperm canal has its outlet at the sicle of the verge just above this papilla cplate 5, fig. 6). There is no penial gland in the penial complex.

Female Organs (plate 5 , fig. 7 ). The spermatheca (S) is rather small and is attached to the long and narrow vagina by a narrow duet (SD) about $1 \mathrm{~mm}$. long. The ragina rapidy enlarges from its external opening to the point of jumeture of the spermathecal duct (VGi). The uterus ( $\mathrm{C}^{\mathrm{I}}$ ) is not much longer than the vagina. The nickamental gland is long $(2 \mathrm{~mm}$.) and much swollen (XC). The oviduet (OD) is short $11 \mathrm{~mm}$. long) and of about the same diameter as the uterus. There is a large carrefour (CF). The albumen gland is large $(1.7 \mathrm{~mm}$. long) and ovate in outline (fig. 2 ).

Hermaphrodite Organs. The orotestis (fig. 7, OT) consists of many very long and club-shaped diverticula placed in a double series. As many as thirty-eight pairs of diverticula were counter in one specimen. The ovisperm duet $(\mathrm{SO})$ is very short between the ovotestis and seminal vesicle and rery long $(2.5 \mathrm{~mm}$.) between the seminal vesicle and the oriduct.

Respiratory and Renal Systems. The pseudobranch (plate 5, fig. 3) is long and narrow and somewhat folded, squarely truncated at the lower margin. There is a large pneumostome.

The kidney of Polypylis hemisphaerula is rery $\operatorname{long}(7 \mathrm{~mm}$.) and narrow. It resembles the kidney of Polypylis calathus (plate 47, fig. 24) which is long and narrow and $9 \mathrm{~mm}$. in length. A cross section is similar to that of calathus (plate 47, fig. 25 ) which shows the kidney to be flattened, without a ridge, the lumen oval, wider than high with the two lateral reins of large diameter. In hemisphaemla the lumen is rounder and the reins relatively smaller. In outline the section of hemisphacmela more nearly resembles that of Segmentina nitida (plate 47, fig. 23) than that of calathus.

Digestive System. The stomach resembles that of Segmentina nitida (plate 48, fig. 16) but the blind sac is somewhat larger. The buecal sac is pyriform, with a large radula sac behind and two small salirary glands like those in Segmentina nitida.

The jaw is like that of Segmentina nitida, segmented with many plates (plate 50, fig. 24). Polypylis calathus has a similar jaw with many small plates.

The radula formula of hemisphaerula is 25-1-25 with over 200 rows of teeth. The teeth are like those of Polypylis calathus (plate 69, fig. 8). all 6-cuspid, the cusps short and the reflections wide and low and placed high up on the teeth. In calathus the formula is 26-1-1-26 with 205 to 210 rows of teeth. The rows of teeth are all in straight lines, as in Segmentina.

The above anatomical details were obtained from the following material: Folypylis hemisphacrula (Benson) from Peiping. Chinis, sent by the Fan Memorial Institute, Peiping, China. Four specimens.

Polypylis calathu (Benson), from weedy tank near inspection bungalow, Mongyai, N. Shan States, Burma. Collected by Dr. H. S. Rao and Mr. B. H. Chopus. One specimen examined.

Polypylis trin (Annandale and Rao), from below Machligaon. Port Blaie, Andamans. Collected by Dr. H. S. Rao. One specimen examined. 
Geographical Distribution. Polypylis is found throughout much of eastern China and India and on some of the islands lying off the coast of China and India. Its full distribution and the species belonging to it ean not be fully known until more of the speeies from Asia have been anatomieally examined.

Species Considered as Valid. The following species appear to be eorrectly placed in this genus:

Polypylis hemisphaerula (Benson)

Polypylis calathus (Benson)

Polypylis lucida (Gould)

Polypylis vitidella (Martens)

Polypylis swinhoci (H. Arlams) Polypylis taia (Annandale and Rao) Polypylis usta (Gould)

Geological Distribution. Not ascertained.

Remarks. Polypylis differs generieally from Segmentina and Intha in the absence of a penial gland in the preputium. There is some variation in the form of the flagella in the species examined. In hemisphaerula there is but one flagellum on a long duet, while in calathus and taia there are two short flagella as in Segmentina.

The shell of Segmentina differs notably from that of Polypylis, being flattened with an acute periphery, while the periphery of Polypylis is rounded and the shell is high. The lamellae within the aperture in Segmentina are three in number, parietal, basal, and upper labial, all transverse to the whorl (plate 76 , fig. 4 ). The space between the lamellae is narrow and three-eornered, quite unlike the wide space in the aperture of Polypylis (plate 76, fig. 5).

The difference between the form of flagellum in the type species and the flagella of the other speeies examined from India and China might indicate a division into two groups, as suggested below.

Group I. With one swollen flagellum on a long cluct.

Example: Polypylis hemisphaerula (Benson).

Group II. With two short, narrow flagella without swollen end.

Example: Polypylis calathus (Benson).

Polypylis taia (Annandale and Rao).

However, too few of the Asiatic speeies have thus far been examined anatomieally to warrant separation into subgenera at the present time.

\section{Genus HELICORBIS Benson, 1855}

1555. Helicorbis Bexsox, Jour. Asiatic Soc. Bengal, XXIV. p. 126. Subgenus of Planorbis. No type cited. The species Planorbis (Helicorbis) umbilicalis Benson, one of the original species listed, is here nominated as type of the genus.

1906. Helicorbis Dall, Nautilus, XIX, p. 105. Considers group equal to Hippeutis (Ag.) Charp., 1837.

1921. Hippeutis AxNandale and Prashad (non Charp., 1837), Rec. Ind. Mus., XXII, p. 584. Places Planorbis umbilicalis in this genus.

1922. Hippeutis Axvaxdale (non Charp., 1837). Rec. Ind. Mus., XXIV, p. 361. Mentions Planorbis umbilicalis Benson as belonging in genus Hippeutis.

1926. Helicorbis Kencard and Woodward, Syn. Brit. Non-Marine Moll., p. 69. Considered synonym of subgenus Hippeutis.

1931. Helicorbis Thiele, Handbuch, Teil 2, p. 481. Treated as synonym of Hippeutis.

Shell (plate 78, figs. 5-7). Ultradextral, the body whorl wide and overlapping or embracing the previous whorl, all whorls visible on upper (right) 
side, but mostly concealed on lower (left) side, the spire depression forming a false umbilicus. The whorls are rounded or at most only subangulate, not sharply carinate. Lips thin. There are no internal barriers or lamellae within the aperture. The embryonic whorls are marked as in other genera of the family.

The figure of Planorbis umbilicalis in Clessin, Conch. Cab., XVII, Taf. 15, fig. 6 does not represent that species but is a good representation of the new genus Pingiella F. C. Baker. Germain (1921, p. 177) has called attention to the discrepancy in Clessin's figure and gives good figures of umbilicalis on plate II, figs. 19,20 , and 21 . The periphery in these figures is rather well-rounded. The figures in Hanley and Theobald, Conchologia Indiea (1876), plate 40, figs. 7, 8, and 9 show the periphery as slightly earinated. Clench' and Bequaert (1939) give the best figures observed (plate 1, figs. 8, 9, and 10) showing well the slight angulation of the periphery. We can not agree, however, that Helicorbis mearnsi Bartsch is a synonym of umbilicalis (see plate 2, figs. 10-12); it is too sharply angulated on the periphery. It is evident that the species referred to the subfamily Segmentininae are in need of eareful revision.

Animal. "The external soft parts generally resemble those of Gyraulus except that the branchial process and the pulmonary siphon are a little better developed' (Ammandale and Prashad, 1921, p. 584).

\section{ANATOMICAL CHARACTERISTICS}

GENITALIA. 'The male genitalia generally approximate to Simroth's Typus I, but differ in details. The vas deferens is very long and coiled. The penis sac is a well-developed ovoidal structure with an elongated tubular preputium in continuation of the sac. The penis is massive with a lateral opening and without any stylet' (Ammandale and Prashad, 1921, p. 585 ).

Radula. "The radula is very minute and the dental formula is approximately 14-12-1-12-14(26-1-26): The central tooth is comparatively large and bicuspid with sharp cusps. The laterals and marginals both have a peculiar twinned structure, and the line of demarcation between the laterals and marginals is not very sharp. The laterals are tricuspid, the central cusp much the largest' (Ammandale and Prashad). The rarlula is figured on page 583 of the work eited (fig. 16B). The teeth are like those of Bathyomphalus and Hippeutis. The twinned nature noted for some of the teeth was not particularly apparent in the radula of Hippeutis complanatus examined.

Geographical Distribution. Not clearly known but including eastern and central China and India, the Philippines, and probably other islands off the cast coast of Asia.

Species Considered as Valid. Just what species may be included in this genus is not definitely known. The following are believed to belong here:
Helicorbis umbilicalis (Benson)
IIelicorbis mearnsi (Bartsch)
Helicorbis cacnosus (Benson)
Helicorbis papyraceus (Benson)

Geological Distribution. Not ascertained.

Remarks. The Segmentina-like shells of India and China referred to Hippeutis are apparently not like the type of that genus, Hippeutis complanatus (Linn.), at least as far as the shells are concerned. Both agree in 
lacking internal barriers or lamellac in the aperture. The shell of complanatus, however, is lenticular with a sharply angular peripheral keel and the aperture is longitudinally triangular, wirler than high. Helicorbis, on the contrary, has a higher shell with rounded or subangular whorls and the aperture is oblique and higher than wide.

The published description of the anatomy of this group (the type, Planorbis umbilicalis) is insufficient for the purpose of making comparisons with Hippeutis complanatus, as no mention is made of flagella, penial gland, or prostate. The penis (verge) is said to have its sperm canal opening on the side, which is like that of Hippeutis (see plate 2, figs. 5, 6). Until more is known of the genitalia of Planorbis umbilicalis, the group Helicorbis had better be considered a separate genus related to Hippeutis.

The name Helicorbis has been almost unnoticed since its publication in 1855. Dall (1905) overlooked it in his Alaska Mollusks but later (1906) he considered it equal to Hippeutis Agassiz, 1837. Germain (1921) onits all reference to it. Kemmard and Woodward make it a symonym of Hippeutis (1926), as does Thiele (1931). Bartsch, in a paper on Philippine mollusks $(1907$, p. 84), places a related species in Helicorbis, the latter treated as a subgenus of Planorbis. Bequaert and Clench in a later paper on Philippine Lrmmacidae and Planorbidae (1939, p. 16) place Planorbis umbilicalis in Hippeutis, which is recognized as a genus.

In Benson's paper (1855, p. 126) three species are mentioned under Helicorbis; hemisphaemla and nitida are ruled out by the remark in the paragraph above concerning Segmentina (of which nitida is the type) which refers to the internal divisions or barriers. Hemisphaerula, also, is the type of Pilsbry's Polypylis. There remains the species umbilicalis which has not previously been used as a type for any group and this is here nominated for the type of Helicorbis Benson.

Helicorbis may bear something of the same relationship to Hippeutis that Polypylis bears to Segmentina, although the anatomical differences between the last two groups are greater than appears to be the case of the first two groups.

\section{(ienus TROCHORBIS Benson, 1855}

Type by original designation Trochorbis trochoideus Benson

1855. Trochorbis Bexsox, Jour. Asiatic Soe. Bengal, XXIV, p. 126. Type Trochorbis trochoideus (Benson). As subgenus of Planorbis.

1906. Trochorbis Dall, Nautitus, XIX, p. 105. Type Planorbis trochoideus Benson. As subgenus of Planorbis.

1927. Trochorbis Kexyard and Woodward, Syn. Brit. Non-Marine Moll., p. 90. No type cited. Considered a synonym of Scgmentina.

Description of the type of the genus Planorbis trochoideus Benson: 'Testa vix perforata, diaphana, niticla, inconspicue radiato-striata, subtrochiformi, convexa; spira parvula, arcte convoluta, concava; sutura profunde impressa; anfractibus $3 \frac{1}{2} 2$, penultimo valde convexo, ultimo majori, versus suturam obtuse angulato, cxtus depresso, inferne acute carinato, intus laminis rarissinis pleurumque minuto, subtus plano, medio, versus umbilicum inconspicum, leviter excavato, versus periphaeriam vix declivi; apertura obliqua subsagittata, margine superiori arcuato, prominente, inferiori recidente. Diam. 3 mm., axis vel 2' (Benson, 1850, p. 352).

'The infrequency and irregularity of the internal laminae in this species, causing them to look more like accidental thickenings of the shell, made 
me overlook this structure in my original description. The species is singular from the nearly total absence of umbilicus' (Benson, 1850, p. 352). The shell is treated as dextral (ultradextral).

Animal. The anatomy of this species is at present unknown.

Geographical Distribution. Barrackpore, Bengal, India.

Species Considered as Valid. Trochorbis trochoideus Benson, the genotype, is the only species assigned to this genus.

Remarks. In 1850 (p. 352 ) Benson noted the trochoid form and small umbilicus of Planorbis trochoirteus and in 1855 (p. 126) ereeted the group Trochorbis for it. This name has been overlooked by most writers on Asiatic mollusks. Dall (1906, p. 105) considered Trochorbis a synonym of Segmentina. In Preston's Fauna of British India (1915, p. 125) the species appears as Planorbis (Segmentina) trochoideus without reference to its use as type of Trochorbis. Germain (1921, p. 175) does not mention the group name proposed by Benson and places the species trochoideus in the genus Segmentina. Fennard and Woodward (1926, p. 90) consider it an absolute synonym of Segmentina. Trochorbis is not recognized by Annandale and his co-workers in the studies of the mollusk fauna of the Indian Empire.

Typical Segmentina is not found in eastern Asia, the species previously referred to that genus now being placed in the genus Polypylis of Pilsbry. Trochorbis trochoideus greatly resembles Planorbis calathus Benson which belongs to the genus Polypylis and from the shell characters appears to be only specifically distinct from calathus, if one can judge from the very excellent figures of both speeies in Hanley and Theobald, Conchologia Indiea, plate 39, figs. 1-3 (calathus) and 4-6 (trochoideus).

The species trochoideus has a much smaller shell than calathus and the periphery is more acute. Aceording to Benson, the apertural lamellae are so weak that he overlooked them in his first description of the species. The Asiatic mollusks allied to Segmentina have shown such diversity in anatomical characteristics that until the animal of trochoideus is examined it seems best to treat Trochorbis as a separate genus. Its place, as far as can be judged at present, is near the group of shells called Polypylis, with the internal lamellae far within the aperture.

\section{Genus PINGIELLA F. C. Baker, New Genus \\ Type Pyramidula (Patula) peipinensis Ping and Yen}

1932. Pyramidula (Patula) peipinensis PINg and Yex, Bull. Fan Memorial Inst. Biol., III, p. 25, figs. 1-3. Wrongly interpreted as a land shell.

1938. Anisus (Hippentis) peipinensis Mon, Mem. Col. Sci., Kỹoto Imp. Univ., Ser. B, XIV, No. 2, p. 288 , plate 14 , fig. 6 .

Shell (plate 78, figs. 8-10). Ultradextral, lenticular, flattened, with sharp peripheral carina, the last whorl very large and strongly orerlapping or clasping the preceding whorls, the base flattened, with a narrow spire depression exhibiting all of the whorls, the depression about one third of the diameter of the shell. Aperture without internal lamellae. Major diameter of shell $7.8 \mathrm{~mm}$. to $8.6 \mathrm{~mm}$. The embryonic whorls are pitted.

Animal. Foot and pneumostome lead color, body yellowish finely mottled with black. Kidney pigmented (from aleoholic specimens). 


\section{ANATOMICAL CHARACTERISTICS}

\section{PLATE 4}

GENITALIA. Male Organs (plate 4, fig. 9). Seminal vesicle (SV) large, tortuous, more than double the cliameter of the ovisperm duct, with several vesicles, but mostly tubular. Sperm duct, long $(3.5 \mathrm{~mm}$.), narrow. Prostate (PRS) about $2 \mathrm{~mm}$. long with twenty to twenty-two long diverticula. Free portion of prostate duct very short. Tas deferens long $(4 \mathrm{~mm}$.) and tubular.

Penial complex (fig. 5) with a large, sae-like preputium (PR) and small, narrow, short (little more than $0.5 \mathrm{~mm}$.) vergic sae (VS). The vergie sac is placed on the side of the upper part of the preputium. There are two flagella, short and wide, placed on tube-like ducts longer than the whole penial complex. The sac-like flagella (FL, are turned horizontally to the tube-like duet. There is a very long and very fine, tube-like external penial duet (DC), about three times as long as the penial complex when stretehed to its fullest extent. There is a single, wide retractor musele (RII) attached about midway of the preputium at the point where the penial duet has its exit.

Internally (plate 4, fig. 6), there is a short, wide pilaster which bifurcates about midway of the preputial eavity, one branch forming a wide. flat gland (GL) which is doubled backward at the end (fig. 6). The other branch is short and narrow and ends above in a rounderl, disc-like organ (G). The very long duct (DC) which appears on the outsicle of the preputium, enters a canal in this small branch (fig. 2, C. fig. 7. C) which terminates on the underside of the reflexed end of the gland (fig. 7. GL,). The other end of the penial duet passes on the outside of the small pilaster and enters the round, turban-like termination of the small pilaster (figs. 2, 6, G and DC). There is a thickened museular ring or diaphragm between the vergie space and the preputial space (figs. $6,8, \mathrm{D})$. The retractor muscle is attached to the preputium near the small branch of the pilaster (fig. 6. RM).

The verge (fig. 8, V) is long and narrow. swollen or pear-shaped at the upper part but narrowed and tubular below. The lower end of the rerge is notably flattened and broad, with a small penial papilla at the end. just beside the sperm canal exit, which is in the center of the verge (figs. 3,4 ). The sac-like portion of the flagella is large and the carity is lined with elliptical cells which show on the exterior surface as small. rounded projeetions (fig. 5, PLi). The duet of the flagellum is narrow but is of greater diameter than the ras deferens.

Female Organs. The spermatheea is globe-shaped (S) with a short, narrow duct about as long as the greater diameter of the spermatheca (SD). Another specimen had a spermatheea long and sac-like (fig. 5. plate 5 ) attached to the ragina by a very short wide duct. This spermatheea contained a spermatophore and the specimen was evidently in gravid condition. The form of the spermatheea evidently varies with the breeding condition of the animal. Tagina rather short but longer than wide (VG). Uterus (U) short and as narrow as the vagina. Nidamental gland ( NC) very long $(3 \mathrm{~mm}$.) and much swollen. Oviduet (OD) short and narrow. Albumen gland (fig. 1) elongated, about twice as wide as long, placed over the stomach, the intestine looped beneath it. 
Hermaphrodite Organs. The orotestis (OT) consists of many long and narrow diverticula placed in a double series. The ovisperm duet (SO) is of small cliameter. The portion between the seminal vesicle and the ovotestis is very short (less than $1 \mathrm{~mm}$.) but the portion between the seminal resicle and the oriduct is rery long (about $3 \mathrm{~mm}$.).

An egg capsule on one of the shells, presumably of this species, contained eight eggs.

Respiratory and Renal Systems. The pseudobranch (plate 5, fig. 1, P) is small and inconspicuous, resembling that of Hippeutis.

The kidney is long and narrow, resembling that of segmentina, but not as long. The ureter is directed horizontally into the mantle cavity, not reflected. There is no superposed ridge. A seetion of the kidney near the middle shows a wide and low lumen about three times as wide as high with the veins at the upper corners. A section below the middle shows a flatter form with the lumen almost as high as wide and somewhat triangular, the reins at the upper part of the triangle. This triangular form is caused by the acute angle of the shell on the periphery.

Digestive System. The stomach is long and narrow as in Segmentina, the intestine making a loop around the stomach and another around the liver and then passing forward to the rectum and pseudobranch. The blind sae is rery short and pointed below.

The buceal sae is elongated, pear-shaped, the radula sac large and near the middle of the posterior end. The salivary glands extend considerably beyond the rear end of the buccal sae and are united behind; the ducts are small and tube-like.

The jaw is fragmented with about eighty plates. It is horseshoe-shaped as in the other groups of this subfamily.

Radula formula 26-1-26 with 160-170 rows of teeth. The teeth resemble those of Segmentina and Polypylis (see plate 69, figs. 7, 8). The laterals have six short, spade-shaped eusps and the marginals have seven short cusps.

The anatomical details have been obtained from three specimens from Peiping, China, received from the Fan Memorial Institute of Peiping, through the courtesy of Dr. Chi Ping.

Geographical Distribution. Northern and eastern China and Japan. It is probable that this distribution will be extended when more naterial has been examined from China and India.

Geological Distribution. Unknown.

Species Considered as Valid. Pingiella peipinensis (Ping and Yen), the genotype, is the only representative of this monotypie genus.

Remarks. This genus is remarkable for the peculiar characteristics of the penial complex, the penial gland, bifurcated into a large and a small branch, the latter with a turban-shaped termination, and the very long, tube-like external duct with its peculiar gland terminations. The terminal end of the rerge is also peculiar. The flagella are notable in having the long duets and the small, sac-like glands. These rlifferences are sufficient to stamp the species as belonging to a new and hitherto unknown generie group. It differs from Segmentina in the possession of an extemal duct and from Polypylis by having a penial gland which is absent in that genus. 
It is quite probable that other species belong in this genus and will be diseovered when examined anatomically.

Mori $(1938$, p. 288) has called attention to the fact that this species is a planorbid and not a land shell. He, however, places the species in the genus Anisus, subgenus Hippeutis, following the classification of Thiele. The anatomy, especially the genitalia, indicates that this species can not correctly be referred to either Anisus or Hippeutis, differing widely in its internal organization.

The genus is dedicated to Dr. Chi Ping, research professor in the Fan Memorial Institute of Biology, Peiping, China, an aceomplished student of the Asiatic molluscan fauna. Dr. Ping has supplied the author with a number of mollusks for anatomical study from near Peiping.

Genus INTHA Annandale, 1922

Type by original designation Intha capitis Annandale

1922. Intha Axxaxdule, Rec. Ind. Mus., XXIV, p. 361. Type Intha capitis Annandale. As genus.

1931. Intha Thiele, Handbuch, Teil 2, p. 482. Anisus (I.) capitis (Annandale). As subgenus under gemus Anisus.

Shell. 'In this genus the body-whorl, though relatively smaller than it is in Hippeutis, completely embraces and oceludes the rest of the shell in such a way that the spire is entirely concealed, except in so far as it can be detected by transpareney. The shell is very minute and has few whorls, which increase in size rapidly. Those of the spire are erlindrical, but the body whorl is flattened below and has the form of a flattened conoid slightly trumeate above. The outer lip arises in the middle of the upper surface and forms a small lobe at its point of origin. The aperture is large and very oblique but with a cordate outline. There is a well-developed simple eallus on the inner lip, but internal ridges are completely absent. The lower surface is narrowly umbilicate. The external surface is practically smooth' (Anmanclale, p. 361). The shell is ultradextral. No figure of the shell is arailable and the single specimen used for dissection had the shell badly broken which made it unfit for illustration.

Animal. 'The animal is remarkable externally for the large upper and lower lobes into which the mantle is divicled. The pseudobranch is poorly developed' (Annandale, p. 362). The head of the animal bears short, blunt tentacles (plate 8, fig. 3).

\section{ANATONICAL CHARACTERISTICS}

PLATE 8

GENITALIA. Male Organs (fig. 11). Seminal vesicle (SV) very large, about three tines the diameter of the orisperm duct, with a few irregular. pointed, glandular projections. It is less than $1 \mathrm{~mm}$. long. Sperm duct (SPD) long (slightly more than $1 \mathrm{~mm}$.) and of large dianeter. Prostate short, with six large, club-shaped diverticula. Prostate duct (free portion) about as long as the prostate. Tas deferens (VD) of small diameter and very long (about $5 \mathrm{~mm}$. when stretehed out).

The penial complex has a large, bulbous preputium (PR) and a small, slender vergic sac (TS), somewhat shorter than the preputium (fig. 6). Together both organs measure $1 \mathrm{~mm}$. in length. There is a short, narrow 
penial gland duet on the outside of the preputiun, emerging from the latter about midway between the outlet and the summit of the preputium. At the upper end of the vergie sac there are two very large flagella labout $1 \mathrm{~mm}$. long) which are sausage-shaped and are attached to the vergic sae by a very short duct, in faet they are almost sessile. Small glands on the interior of the flagella show through as white circles, as shown in the figure (fig. 11, FL). There is a wide retractor musele which is attached to the upper part of the preputium.

Internally (fig. 8), the preputim has a large penial gland (GL) which is attached to the preputium only at its base, the cup being free. It is more or less cireular in shape, depressed, with a wille cup-shaped depression in which the walls are ridged (probably glandular). There is a short cluet, external to the preputial ravity, which enters a round, fleshy ring or diaphragm between the vergic and preputial eavities (fig. 8, D). The relationship of the gland and duet to the preputial sac is well shown in fig. 7 . The verge ( $\mathrm{V}$ ) is narrow, tapering, with the exit at the end in the eenter. There is a very small papilla at one sicle of the opening (fig. 4). The two flagella are joined in one tube before they enter the vergie sac (fig. 11, VS; fig. 8, FL).

Female Organs (fig. 11). The spermatheca (S) is large and almost circular, and is joined to the short, wide ragina ( $\mathrm{V}$ ) by a duct which is shorter than the diameter of the spermatheea. The uteris (U) is wide and shorter than the spermatheea and its duet. The nidamental gland (NG) is very wide, sac-like, and about twice as long as the uterus. The oviduet $(O D)$ is short and wide, about as long as the preputium. There is a large carrefour $(\mathrm{CF})$. The albumen gland $(\mathrm{AL})$ is large, about $1 \mathrm{~mm}$. long, and has a space for the passage of the intestine (fig. 1).

Hermaphrodite Organs. The ovotestis (OT) is large with the diverticula long and club-shaped. They are placed in a double series. The ovisperm duet (OS) is very short between the seminal vesicle and the orotestis and about $1 \mathrm{~mm}$. long between the seminal vesiele and the oviduct. A spermatophore of peeuliar form was found in the spermatheea ( fig. 5) .

No figure or deseription has been published of the genitalia of this genus. Annandale says of the genitalia: "The male organ resembles that of Planorbis, except that the penial bulb is relatively very large' (op. cit., p. 362).

Respiratory and Renal Systems. The pseudobranch (fig. 2, P) is a flatly rounded, simple lobe, piereed above by the rectum. The kidney (plate 47. fig. 26) is wide and flattened and not as long as in Segmentina or Polypylis. There is no superposed ridge. In section (fig. 27) the lumen is long, oral in outline with the veins about in the center on each side.

Digestive System. The stomach is narrow as in Segmentina, the intestine making the same loops around the stomach and liver as in the genus Segmentina. The buecal sac resembles that of Segmentina. The jaw fplate 50. fig. 23) is fragmented as in Segmentina. There are more than sixty plates on the jaw.

The radula has the formula 15-1-15 with over 125 rows on a broken membrane (plate 69, fig. 9). Center tooth bicuspirl, the cusps not reaching the lower margin of the base of attachment. Lateral teeth (1-5) with two 
entocone cusps, a single mesocone, and three ectocone cusps, the mesocone a trifle larger than the other cusps. Marginal teeth 7 -cuspid $(6,8,11,12)$ with three small cusps on each side of a mesocone cusp. There are no intermediate teeth. The teeth are all in a straight row. They are very umiform in size and shape but become narrower toward the outer edge of the membrane. The teeth are essentially like those of segmentina.

For the above anatomical details a single specimen was dissected. received from Dr. H. S. Rao, collected by Dr. N. Anmandale in Inle Lake, southern Shan states, Burma.

Geographical Distribution. Known at present only from the type locality, He-Ho and Inle valleys (3000-3800 ft. alt.) southern Shan States. Burma. Recent and fossil.

Species Considered as Valid. Intha capitis Amnandale is the only species recognized for this monotypic genus.

Remarks. Intha is peculiar in the form of its shell and also in the characteristics of its genitalia, with the few prostate diverticula of large size, the two enormous flagella, and the striking penial complex with a penial gland which has a small, short duct entering the circular ring between the rergic sac and the preputium. In this respect it resembles some of the Helisomatinae (trpical Helisoma) but differs in the form of the prostate and ovotestis. It appears to be another peculiar variant of the Segmentina group of Planorbidae.

\section{Genus DREPANOTREגA Fischer and Crosse, 1880}

Monogenotype Planorbis yzabalensis C. and F. (= Planorbis anatinum d'Orbigny) 1850. Drepanotrema Fischer and Crosse, Miss. Scient. Mex., Moll., II, pp. 59, 75. Type Planorbis yzabalensis C. and F. As subgenus.

18S3. Drepanotrema Fisciler, Man. de Conch., p. 509. Type Planorbis yzabalensis C. and F. As section of Planorbis.

1854. Drepanotiema Trrox, S. and S. Conch., III, p. 107. Type Planorbis yzabalensis C. and F. As subgenus of Planorbis.

1884. Bathyomphalus Tryox (non Agassiz, 1837), S. and S. Conch., III, p. 106. Planorbis anatinus Orb., cited as example.

1854. Anisus Tryox (non Studer, 1820), S. and S. Conch., III, p. 106. Planorbis kermatoides Orb., cited as example.

1899. Drepanotrema Martexs, Biol. Cent. Amer., Moll., p. 397. As synonym of lippeutis.

1899. Spiralina Martexs, (part) op. cit., p. 395. Includes Drepanotrema cultratum and sumichrasti.

1899. Hippeutis Martexs (non Agassiz, 1837), op. cit., p. 397. Cites Planorbis yzabalensis, type of Drepanotrema.

1905. Drepanotrema Dall, Alaska Moll., p. 82. Type Planorbis yzabalensis C. and F. As section of subgenus Hippeutis.

1921. Drepanotrema German, Rec. Ind. Mus., XXI, p. 8. Type Planorbis yzabalcnsis C. and F. As subgenus of Planorbis.

1930. Drepanotrema H. B. BAker, Oc. Papers, Mus. Zool., Univ. Mich., No. 210, pp. 43, 38, 51. Type Planorbis yzabalensis C. and F. As genus.

1931. Drepanotrema Thiele, Handbuch, Teil 2, p. 481. Type Drepanotrema yzabalensis C. and F. Section of Gyraulus, subgenus of Planorbis.

1934. Drepanotrema Pilsbry, Proc. Acad. Nat. Sci. Phil., 86, p. 58. Type Planorbis yzabalensis C. and F. As genus. Figures genitalia of D. lucidum (Pfr.) and D. cultratum (O1b.). 
Shell (plate 79, figs. 16-18). Small, ult radextral, of few whorls, the body whorl large and expanded, embracing the previous whorl; whorls rounded or carinated; the right side with whorls sunken below the upper surface or showing a wide, slightly concave depression. There are no barriers or lamellae within the aperture. The embryonic shell is punctate.

Animal. The body is long and narrow, rounded before and sharply pointed behind. The tentacles are long and filiform, the cyes large and conspicuons, placed at the inner base of the tentacles. There may be two dark lines of color extending down the neek and top of the head. In some species (as melleus Lutz, plate 78, figs. 1, 2) the body is not mueh pigmented, but in some others (as hoffmani F. C. Baker, plate 10, fig. 1) the body is deeply pigmented with black.

\section{ANATOMICAL, CHARACTERISTIC'S}

\section{PLATES 9, 10, 11}

GENITALIA. Male Organs (plate 9. fig. 2; plate 10, fig. 2; plate 11, fig. 3, respectively anatinum, hoffmami, and lucidum). Seminal vesicle (ST) large, much elongated, swollen, two to three times the diameter of the orisperm duet, varying in length in the three species examined. It is about half the length of the orisperm duct region in hoffmani but only about a third of this length in lucidum. Anatimum is much like hoffmani. The prostate (PRS) varies greatly in the three speeies: in hoffmani it is 3.5 nmm. long and is made up of twenty-three short, elub-shaped, widely spaced diverticula; in lucidum, there are but eight diverticula on a prostate about $1 \mathrm{~mm}$. long; in anatinum, there are seven diverticula still more widely spaced and the prostate is about $1 \mathrm{~mm}$. long. All diverticula arise directly from the sperm duct and are not on a separate duct as in Segmentina and other members of the subfamily.

The sperm duct (SPD) also varies in length, being $5 \mathrm{~mm}$. in hoffmani, $2.3 \mathrm{~mm}$. in lucidum and a little over $1 \mathrm{~mm}$. in anatinum. These lengths do not include the sperm duet portion under the prostate diverticula. The vas deferens of the three species is always a long, narrow tube, varying in length in the different speeies.

The penial complex is much elongated in all species examined. In hoffmani (plate 10, fig. 5) the preputium is elongated, eylindrical, and about twice the diameter of the long and narrow vergic sac, which is nearly twice the length of the preputium. In lucidum, the preputium is about three times the diameter of the rergic sac, which is considerably longer than the preputium (plate 11, fig. 4). In another specimen, the preputium and the vergic sae were about equal in length (plate 11, fig. 5). In anatinum (plate 9, fig. 1), the vergie sae is shorter than the preputium, which forms a reversed cone, becoming smaller in diameter toward the upper part.

The flagella of the three speeies differ considerably. In hoffmani (plate 10 , figs. $6,7,81$, the flagellum is very short and is bifid at the end; in lucidum (plate 11 , figs. 4,5$)$, the flagellum is very long $(1 \mathrm{~mm}$. or more) and is not bifid at the end; in anatinum (plate 9, fig. 1), the flagellum is as long as the preputium $(0.6 \mathrm{~mm}$.) and is bifid at the end. A strong retractor muscle is attached to the end of the vergic sae near the insertion of the flagellum (plate 10, fig. 7). There is also a large nerve at this point $(\mathrm{N})$. 
Intermally, the penial complex is simple in all species studied and resembles the condition observed in hoffmani (plate 10, fig. 6). There are three rather heary pilasters, a small muscular ring or diaphragm between the preputium and the rergic sac, and a very long verge completely filling the vergic sac ( $V$ ). The verge is narrow at the end with a central sperm outlet (plate 10, fig. 9).

Female Organs. These also differ in the three species. In hoffmani (plate 10, fig. 2 ) the spermatheca is prriform and is joined to the long and narrow ragina by a duct twice as long as the spermatheca; in lucidum the spermatheca (plate 11, fig. 3) is globular, much wider than in hoffmani, and is comnected with the vagina (which is shorter than in hoffmani) by a cluct a trifle longer than the spermatheca; in anatinum (plate 9. fig. 2) the spermatheca is wider than in hoffmani but not as globular as in lucidum and is attached to the narrow vagina by a duct almost three times as long as the spermatheca. The uterus ( $\mathrm{C}^{*}$ ) is very long and narrow in hoffmani, shorter and wider in lucidum, and narrow in anatinum.

The nidamental gland is long and wider than the uterus in all three species. The oviduct (OD) is very long and narrow in hoffmani labout 5 mm. long), much shorter in lucidum (about $2 \mathrm{~mm}$.) and rery short in anatimm (less than $1 \mathrm{~mm}$.). There is a small and inconspicuons carrefour (C'F) in all species. The albumen gland is much elongated (plate 10, fig. 4).

Hermaphrodite Organs. The orotestis (OT) consists of a few clubshaped diverticula placed in a double series. The orisperm duct is much longer in lucidum than in either hoffmani or anatimum (see plate 9, fig. 2; plate 10 , fig. 2 ; plate 11 , fig. 3 ).

several specimens of hucidum had the male genitalia completely everted and lying on the body of the animal (sce plate 11). In fig. 1, the preputium is fully everted and the verge is extended to its fullest extent. In fig. 2, only the preputium is everted. In fig. 6. the organs are diagrammatically shown so that the relationship of the different parts may be seen under this condition. The flagellum, vergie sac, vas deferens, and retractor muscle remain in the body of the animal just behind the male opening. This is shown to better advantage in fig. 7 .

Pilsbry (1934, p. 59, fig. 6, F) figured the penial complex of lucidum (from sketches by H. B. Baker). This figure differs from the specimens here examined in having a shorter flagellum and in having the penial retractor attached to the preputium instead of to the vergic sac. In all specimens of Drepanotrema examined, the retractor muscle was inserted at the end of the vergic sac near the flagellum and not at the summit of the preputium. As shown in fig. 8 on plate 10 (hoffmani), the ras deferens, flagellum, and retractor muscle may be so closely pressed together and bent downward at the summit of the preputium that relationship of the muscle is difficult to see clearly unless the parts are separated, as shown in fig. 4, plate 11 (lucidum). All specimens were tom apart to insure accuracy in this statement.

Pilsbry also figured the penial complex of Drepanotrema cultratum (Orb.) (plate 76, fig. 10) which is similar to that of lucidum, the vergic sac being but a trifle shorter than the preputium. The flagellum is somewhat more than half as long as the rergic sac. Pilsbry's figures are the only ones previously published on the anatomy of Drepanotrema. 
Respiratory and Renal Systems. The pseudobranch (P) is a somewhat triangular process in lucidum (plate 11, figs. 1, 2) and anatimum (p)late 9, fig. 3 ) but in hoffmani appears to be narrower and more eylindrical (plate 10, fig. 3). The rectum is very large and the anus discharges just above the base of the pseudobranch. The puemostome is very large (PS).

The kidney of Drepanotrema hoffmani (plate 46, fig. 14) is very long and ribbon-like $(15 \mathrm{~mm}$. long). The ureter is very short and curves upward at right angles to the long axis of the kirney. A cross section neal the middle (fig. 15) shows the kidney to be much flattened, the lumen wider than high, and the veins flattened and elongated in section. The kidney of lucidum is shorter and a section near the middle shows it to be nore flattened than hoffmami, the lumen regularly long-ovate and the reins: smaller and more regular in form (fig. 16).

Digestive System. The stomach (plate 48, fig. 11 ) is pyriform, the pyloris tapering to the intestine, which forms a loop over the oesophagus and another loop around the liver as in other genera of the subfamily. The blind sac is tro-thirds as long as the stomach. The buceal sac is similar to that organ in Tropicorbis.

The jaw is horseshoe-shaped and is composed of many small plates arranged somewhat as in Planorbis. About seventy plates were counted on a jaw of lucidum (plate 50, fig. 27 ) and about as many on a jaw of hoffmami (plate 50, fig. 26 ).

The radula formula of anatimum (plate 68, fig. 3) is 18-1-18 with 158 rows of teeth. Center tooth squarish with two long, spade-shaped cusps reaching two-thirds of the way to the lower margin of the base of attachment. There is a very small cusp on each side of the center cusps high up on the reflection. Lateral teeth (1-6) very wide, with three long cusps, entocone, mesocone, and ectocone. Above the entocone there is a small additional cusp, and above the ectocone there is another small cusp on the first four laterals and two cusps on the 5th and 6th laterals. The intermediate teeth $(7-10)$ are very wide with the three main cusps well-developed and with a small cusp above the entocone and a small interstitial cusp between the mesocone and the ectocone. Above the ectocone there are four small cusps on the outer margin of the teeth. The marginal teeth (11-18) are narrower than the intermediate teeth; there is a long entocone and mesocone with a small cusp above the entocone, three cusps between the entocone and mesocone, and five small cusps on the outer margin of the tooth where the ectocone would normally be.

In lucidum (plate 68, fig. 2), the formula is 28-1-28 with 240 rows of teeth. The center tooth is like that of anatimum except that the large cusps are longer. The lateral and marginal teeth are similar to those of anatimum except that the cusps are longer.

In hoffmani (plate 68, fig. 4), the formula is 27-1-27 with 230 rows of teeth. The center tooth is as in lucidum and anatinum. The lateral and marginal teeth are similar to those of the other species figured.

Dr. H. B. Baker $(1930$, p. 50) has examined the radula of ahenum and says 'The radula and jaw of $D$. ahenum are also much as in $D$. lucidum. The radula formula is 30-1-30, with 194 transverse rows. The marginal teeth are slightly broader at the tip of the cusped reflection and may develop two interstitials between the entocone and mesocone.' 
The radula teeth of Drepanotrema are peculiar in the possession of the small interstitial eusps between the larger cusps. They somewhat resemble the multicuspid teeth of Segmentina, Hippeutis, Intha, ete., to which the genus is also allied by the presence of a flagellum. The radula of Drepanotrema is very uniform in the shape of the teeth, varying prineipally in the number of interstitial and accessory small eusps. The formulae, as well as the number of lateral and marginal teeth, vary in the different species.

For the above anatomieal data, three species have been examined:

Drepanotrema anatimum. (Orb.) Pueblo Viejo, Puerto Rico, collected by Dr. W. A.

Hoffman. Five specimens dissected.

Drepanotrema hoffmani F. C. Baker. Isabela, Puerto Rico, collected by Dr. W. A.

Hoffman. Eight specimens dissected.

Diepanotrema lucidum (Pfeiffer). Harana, Cuba. Received from Dr. C. G. Aguayo.

Five specimens dissected.

Geographical Distribution. This gents is found more or less abundantly from southem Texas southward through Mexico and Central America to Brazil, Bolivia, and the Argentine Republic. It it also found in many of the West Indies Islands. It is purely an Anerican genus and a number of speries are known, including some names now considered synonyms.

Pilsbry (1934, p. 59) divided the genus into three sections, Drepanotrema proper, Fossulorbis Pilsbry, and Platytaphius Pilsbry. In the writer's opinion, the last section should be regarded as a separate gemus until the type has been dissected and its anatomy made known. The other groups divide the genus Drepanotrema into two comprehensive subgenera.

\section{Subgenus DREPANOTREMA Fischer et Crosse, 1880}

Spire on the right side, narrow and deeply sunken; periphery broadly rounded (type Drepanotrema anatinum $(\mathrm{Orb})=$. Planorbis yzabalensis $\mathrm{C}$. and $\dot{\mathrm{F}}$. (Pilsbry)

\section{Species Considered as Valid.}

Drepanotrema anatiuum (Orbigny)

Plate 79, figs. 16-18

Drepanotrema lucidum (Pfeiffer) Plate 78, figs. 11-13

Drepanotrema hoffmani F. C. Baker

Plate 78, figs. 14-16

Drepanotrema chittyi Aguayo

Drepanotrema parapseide (Orbigny)

Drepanotrema ahenum H. B. Baker

Drepanotrema castaneonitens (Pils. and Van.)

Drepanotrema melleum (Lutz)

\section{Subgenus FOASULORBIS Pilsbry, 1934}

Haring a wide spiral on the right side, very slightly concave; the periphery from rounded to carinate. Type Diepanotrema cultratum (Oub.) Pilsbry.

\section{Species Considered as Valid.}

Drepanotrema (Fossulorbis) cultrutum (Orbigny) Plate 78 , figs. 17-19

Drepanotrema (Fossulorbis) e. anitense (Cooper)

Drepanotrema (Fossulorbis) e. duenasianum (Tristram)

Drepanotrema (Fossulorbis) c. labrosum Pilsbry

Drepanotrema (Fossulorbis) c. pamueo Pilsbry

Remarks. Diepanotrema differs in its genitalia and radula from all other Ameriean groups of Planorbidae. By its prostate, the diverticula
Dre panotrema (Fossulorbis) eimex (Moricand)

Drepanotrema (Fossulorbis) e. pistiae H. B. Baker

Drepanotrema (Fossulorbis) depressissimum (Moricand)

Drepanotrema (Fossulorbis) kermatoide (Orbigny)

Drepanotrema (Fossulorbis) sumichrasti (Crosse and Fischer) 
club-shaped and placed in a single row on the sperm duct, it is allied to the subfamily Segmentininae. The prostate differs from the members of both Planorbinae and Segmentininae in having the diverticula placed directly on the sperm duct instead of on a separate prostate duct. The presence of the flagellum on the rergic sac places Drepanotrema near the European and Asiatic groups Segmentina, Polypylis, Hippeutis, and Intha. The nature of the radula also indicates relationship with these groups. Although departing from these groups in having the diverticula of the prostate placed directly on the spern duct, the other characteristies place the genus in the subfamily segmentininae with little doubt.

The form of the shell of typical Drepanotrema bears close resemblance to the edentate Oriental groups of Segmentininae, such as Helicorbis, Intha, and Hippeutis, all having the peculiar embracing whorls so characteristic of Segmentina. This feature alone marks the assemblage of genera as of subgeneric solidarity.

\section{Genus PARAPLANORBIS Hanna, 1922}

Type by original designation Plamorbis condoni Hanna

1922. Paraplanorbis Haxxa, Univ. Oregon Pub., I, No. 12, p. 4. Type Planorbis (Paraplanorbis) condoni Hanni. As section of Planorbis.

1934. Paraplanorbis Pilsbry, Proc. Acad. Nat. Sci. Phil., 86, 1. 59. Type Planorbis condoni Hanna. As section or subgenus of Drepanotrema.

1935. Paraplanorbis Hexdersox. Non-Marine Moll. N. Amel', p. 245. Fossil. Type Planorbis condoni Hanna.

Shell (plate 81, fig. 5). Whorls rounded on the periphery as in Helisoma Swainson but aperture not expanded, umbilicus very narrow, and size minute (Hanna, 1922, p. 4, description of subgenus).

Hamna's deseription of the species Planorbis condoni is as follows: 'Shell ultradextral, planorboid, composed of about four and one-half regularly increasing whorls; apical cavity a cone of about 120 degrees. Last whorl slightly angulated about the upper margin and descending slightly at the aperture. Lines of growth fine and even, giving the shell a silky luster. Umbilicus deeply rimate $0.51 \mathrm{~mm}$. in diameter. Aperture roughly triangular but rounded on the outer lip; not expanded or thickened but a depression both above and below the periphery. Diameter $2.67 \mathrm{~mm}$; altitude $0.35 \mathrm{~mm}$.'

Geographical and Geological Distribution. Vicinity of Warner Lake, eastern Oregon, Hanna's locality No. 212. Pliocene period.

Species Considered as Valid. Paraplanorbis condoni (Hanna), genotype, is the unly species aseribed to this originally monotypic genus.

Remarks. This fossil genus is related to Drepanotrema and is consirlered a section or subgenus of the genus by Pilsbry (1934, p. 59). While the whorls are of a clasping or embracing nature, as is usually the case in Drepanotrema and its allies, the spire (left sicle) appears entirely different, the depression being narrow and the whorls deeply immersed. In view of the difficulty in this family of placing a group in its correct position in the classification by the shell alone, it would seem that the interest of nomenclature is best served by considering Paraplanorbis a separate genus of Segmentininae related to Drepanotrema. Its geographical location, also, so far removed from the present day distribution of Drepanotrema, is another reason for such procedure. 
Genus PLATYTAPHILS Pilsbry, 1924

Type by original designation Planorbis heteropleurus Pils. and Van.

1896. Planorbis heteropleurus Pilsbry and Vaxatta, Proc. Acad. Nat. Sci. Phil., 1896, 1). 562, plate 26 , figs. $1-3$.

1924. Platytaphius Pilsbry, Proc. Acad. Nat. Sci. Phil., 76, p. 51. Type Planorbis heteropleurus P. and V. As section of Planorbis.

1931. Platytaphius Thiele. Handbuch, Teil 2, p. 479. Type Planorbis heteropleurus Pils. and Van. As section of Planorbis.

1934. Platytaphius PILsbry, Proc. Acad. Nat. Sci. Phil., 86, p. 59. Type Planorbis heteropleurus Pils. and Van. As section of Dicpanotrema.

1934. Platytaphius Hexdersox and Roneck, Jour. Pal., VIII, p. 268. Type Planorbis heteropleurus Pils, and Van. As genus.

1935. Platytaphius Hexdersox, Non-Marine Moll. N. Amer., 1. 254. Fossil. Cites two fossil species from Oregon.

Shell (plate 79, figs. 10-12). Of medium size, ultradextral, moderately solid, corneous-white, rather opaque, the surface with fine, close growth lines; earlier whorls rather deeply and about equally sunken on the two sides; convex, and strongly angulate or keeled in the middle, on the right side; periphery conspicuously carinated on the left side, which is shallowly vortex-shaped, the whorls nearly flat. Last whorl slightly wider on the right than on the left side. Whorls three and one-half, all visible on both sides, the last wider than the spire. Aperture very oblique. rounded-pentagonal, the right margin produced forward (Pilsbry and Vanatta, 1896, p. 562). There are fine punctations on the embryonic whorls.

Animal. At present unknown anatomically.

Geographical Distribution. Lake Titicaca, Peru.

Geological Distribution. Pliocene to Recent fauna.

Species Considered as Valid. Platytaphius heteropleums (Pilsbry and Vanattal is the only recognized species.

Remarks. In describing this peculiar mollusk, Pilsbry says: 'This remarkable species is totally unlike $P$. titicacensis Clessin, $P$. montamus d'Orbigny, and $P$. andecola d'Orbigny, species already known from this Andean lake. It is most like $P$. andecola, but much flatter with differently placed keels, and in fact, so cliverse in characters that no profitable comparison can be made' (1896, p. 562). In 1924 (p. 51), this species was made the type of a section of Planorbis and in 1934 (p. 59), it was made a section of the genus Drepanotrema. In a paper by Henderson and Rodeck (1934, p. 268), the authors state that 'it is so distinct that it might be better' to consider it a genus. With this statement the present author is in complete agreement for the general form of the shell is so distinct from that of any other species of Drepanotrema that it does stand quite alone. What its real affinities are can not be known until its anatomy has been investigated. It may belong near Drepanotrema or it may belong elsewhere.

Henderson and Rodeck $(1934$, p. 268) have associated two extinet molluscan species from the Pliocene of Oregon with Platytaphius. The localities are sixteen miles southwest of Vale, Oregon. This locality is so far removed from Lake Titicaca, in Peru (more than 5000 miles), that it would seem impossible for species of any group without intermediate habitats to become established so far apart. Yet the two species from Oregon correspond fairly well with the diagnosis of the genus Platytaphius. Ad- 
ditional species, recent or fossil, may be found somewhere between these extreme points. At present there seems no alternative but to inclucte the Oregon fossils in Platytaphius, since no diagnosis could be made that would include the one and exclude the other. The two speeies of fossils from Oregon are Platytaphius malheurensis and P. milleri Henderson and Rorleck, figured on plate 37 of the publication eited, figs. 6, a, b, c and $9, \mathrm{a}, \mathrm{b}, \mathrm{c}$.

\section{Genus ACRORBIS Odhner, 1937}

Type by original designation Acrorbis petricola Odhner

1937. Acrorbis Odhner, Archiv, für Zoologi, Band 29B, No. 14, p. 1. Nov. 9, 1937. Type Acrorbis petricola Othner. As genus.

193S. Acrorbis P'llsbir, Nautilus, LI, p. 107 (review).

Shell (plate 72, figs. 1-3). Ultradextral, very small, thin, but firm, of circular form, with elevated spire, shell eovered with a shining cuticle, openly umbilicate; whorls slowly increasing, arehed, high, simple; aperture very oblique, broadly ovate; lips simple, very thin because of the lack of lime in the mouth-building; shell brown, dark and reddish above, underside more gravish; apex deep brown, globular, smooth, the following whorls with very weak spiral lines. Height of aperture same as height of whorl. Height $1.5 \mathrm{~mm}$.; diameter $2 \mathrm{~mm}$. (translated from Odhner).

Animal (plate 72, figs. 5, 6). Gray, the upper surface of the mantle flecked with black. The head is darker gray and neck blackish. The foot is broadly oval with thin borders and without any furrows on the sides. The tentacles are narrow; when fully extended, on the end obliquely truncated. The eyes are on the inner sicte of the base of the tentacles. The left tentacle differs from the right tentacle in being bifid at the end. The head is sharply pigmented between the eyes.

\section{ANATOMICAL CHARACTERISTICS}

\section{PLATE 72}

GENITALIA. Male Organs (fig. 10). No seminal vesiele is shown in the figure or mentioned in the description. The prostate is almost as long as the uterus and oviduct and has eight large diverticula in a single series. Neither description nor figure indicates the presence of a separate prostate duet. The vas deferens $(\mathrm{v})$ is a long and narrow tube. The penial eomplex (fig. 9) is elongated, the preputium, about one-third of the entire length, merging into the vergic sae without marked constriction between these sacs. There is a wide retractor muscle ( $\mathrm{rp}$ ) which appcars to be attacherl about midway of the length of the vergie sae. Above the vergie sac there is a wicle flagellum less than half as long as the vergic sac. Internally there is a long, tube-like verge and a diaphragm of fleshy ridge separating the preputium from the vergic sac. The upper end of the flagellum is said to have two carities, one on each sicle of a central tube (fig. 9 , a).

Female Organs (fig. 10). The spermatheca (b) is large and globular and is attached to the short, narrow vagina by a very short duet about one-third the length of the diameter of the spermatheca. The uterus (n) is at first as narrow as the vagina, but swells to several times this diameter posteriorly where it joins the nidamental gland. The oviduet is not shown clearly but evidently narrows to the point of junction with the ovisperm duet. The albumen gland is not figured. 
Hermaphrodite Organs. The ovotestis (go) is few-lobed, consisting of but five diverticula, which are smaller than the diverticula of the prostate. It is not stated whether the lobes of the orotestis are in a single or a double row. The ovispem duet (od) is almost as long as the uterus and oviduet combined and is a very narrow tube.

Respiratory System. The pseudobranch (figs. $5,6, \mathrm{k}$ ) is shown as bifid at the extremity. It is a narrow projeetion about twice as long as wide, and probably bears the anal outlet as in other Planorbidae. The kidney (fig. 5,11 ) is long and narrow without a superposed ridge.

Digestive System (fig. 8). There is a long and narrow oesophagus, an ovate stomach with a short pyloris and a very short blind sac (caecun, $e$ ). and a long intestine which makes a loop around the stomach and another around the liver, extending forward in the reetum $(r)$ to the outlet near the pseudobranch.

The buecal sac (fig. 7 ) is elongated, wide at the posterior end and much elongated at the anterior end. There is an unusually long radula sae (t) which forms a narrow tube as long as the whole radula sac. The salivary glands (s) are short, entering the radula sae by a fine tube. The jaw is said to be like that of Parapholyx (Pompholycordea).

The radula (fig. 4) formula is not given but sixteen teeth show in one row in the figure which would make the formula 16-1-16. The eenter tooth has two wide eusps which do not reach the lower margin of the base of attachment. The laterals are squarish with a long, spade-shaperl mesocone reaching the lower margin of the base of attachment, and a short entocone and cetocone about half as long as the mesocone. The intermediate teeth have the cusps more nearly equal in size. The marginals appear wide and low, the entoeone and ectoeone splitting into two smaller cusps.

The information conceming this genus has been drawn entirely from the original paper and figures by Odhner. His figures are reproduced on plate $\boldsymbol{7 2}$.

Geographical Distribution. State of Santa Catharina, Brazil. It lives in damp moss on rocks orer which water trickles.

Species Considered as Valid. Acrorbis petricola Odhner, type of the genus, is the only speeies recognized.

Remarks. Acrorbis is apparently a very distinet group of South Ameriean Mollusca. It is not related to Carinifex or Parapholyx (Pompholycodea) as indicated by Odhner, these two genera belonging to another subfanily, the Helisomatinae, in which there is a penial gland in the male complex. It searcely appears to belong with Choanomphalus. It is also eompared with Neoplanorbis Pilsbry, but that group is referable to the family Aneylidae, not Planorbidae.

Pilsbry has stated (1938, p. 107) that it is related to either Tropicorbis or Drepanotrema. The presence of a flagellum indicates a relationship with Drepanotrema and the few divertieula of the prostate in a single series indieates the same relationship, although the diverticula are more crowded than has been observed in species of Drepanotrema examined. Acrorbis differs from Drepanotrema in the wide form of the flagellum, the shape of the penial complex, wide for the whole length with no differentiation between preputium and vergie sae, the globular spermatheea on a very short duet, and the helicoid form of the shell, quite different from the 
overlapping whorls of Drepanotrema. The very long rachula sae is also a characteristic feature of the anatomy.

The radula appears very different from that of Drepanotrema isce plate 68) because of the apparent absence of interstitial cusps between the larger cusps. These might have been present but overlooked because of the small size of the radula teeth. The general shape of the mesocone in Odhner's figure (4) is suggestive of the same cusp in Drepanotrema, but the ectocone and entocone are much shorter. The radula is markedly different from that of Tropicorbis.

Acrorbis, therefore, appears to be another one of the peculiar groups of South American Planorbiclae, related to Drepanotrema, but distinet by both shell and anatony.

\section{Subfamily HELISOMATINAE F. C. Baker, 1928}

Prostate diverticula compound or multiple, consisting of a basal stem with branches grouping around a short prostate duct which is in intinate contact with the sperm duct. In cross section, the prostate exhibits a fanlike design. A penial gland is nearly always present with an external duct of greater or lesser length. The kidney is usually heavily ridged. The jaws are simple, of three pices, a superior and two lateral jaws.

Trpe genus Helisoma swainson.

The groups referred to this subfanily are noted below.

With one penial retractor muscle: Helisoma and subgenera Scminolina, Pierosoma and Planorbella.

With two penial retractor muscles: Carinifc $x$ and Parapholyx.

Without penial gland duct: Planorbarius.

The fossil groups Torticifex, Perrinilla, and Pompholopsis are included in this subfamily because of likeness of shell to Carinifex or Parapholyx.

With the exception of Planorbarius, which appears to have characteristics armitting it to this group, the subfamily is wholly American and is perhaps the most important planorbid element in the North Ameriean mollusean fauna. It is widespread throughout the northern part of North America and the species are numerous.

\section{Genus HELISOMA Swainson, 1840}

Type by original designation Planorbis bicarinatus Sowerby (=Planorbis bicarinatus Say = Planorbis anceps Menke)

1840. Helisoma Swansox, Treat. Malac., p. 337. Type Planorbis bicarinatus Sowb. As subgenus.

1846. If lisoma Herryanxsen, Ind. Gen. Mal. Prim., I, p. 516. Type Planorbis bicarinatus Say. As subgenus.

1865. Helisoma Brxyey, L. and FW. Sh. N. A., II, p. 112. No type cited. As subgenus.

1870. Helisoma Dall, Ann. N. Y. Lye. N. H., IX, p. 351. Type Planorbis bicarinatus Sowb. As subgenus of Planorbis.

1872. If lisoma Tryox, Mon. FW. Unir. Moll. U. S., pp. 188, 198. No type cited. As subgenus.

1880. IIclisoma Fischer and Crosse, Moll. Terr. Fluv. Mexico et Guat., II, p. 60. As subgenus.

1884. Helisoma Tryox, S. and S. Conch., III, p. 106. Type Planorbis bicarinatus Say. As subgenus.

1886. Helisoma Clessix, Syst. Conch., XV11, p. 33. Type Planorbis bicarinatus Sily. As subgenus. 
1899. If clisoma Martexs, Biol. Cent. Amer., Moll., p. 381. No type cited but includes Pierosoma. As subgenus.

1902. Helisoma F. C. Baker, Moll. Chi. Area, II, p. 287. No type cited. As subgenus.

1905. Helisoma Dall, Alaska Moll., pp. 81, 84. Type Planorbis bicarinaius Sowb. As subgenus.

1912. Helisoma Haxsibal, Proc. Mal. Soc. London, I. p. 157. Type Planorbis antrosus Conrad. As genus.

1918. Helisoma Walker, Miscel. Pub., Mus. Zool., Univ. Mich., No. 6, p. 11. Type Planorbis bicarinatus Say. As subgenus.

1921. Helisoma Germats, Rec. Ind. Mus., XXI, pp. 6, 64. Type Planorbis carinatus Say. As subgenus.

1923. Helisoma Wenz, Fossil. Cat., Pars 22, p. 1522. Genotype Helisoma bicarinata (Sowb.). As genus.

1926. Helisoma F. C. Baker. Trans. Wis. Acad. Arts and Sci., XXII, p. 201. Type Planorbis bicarinatus Sowb. As genus.

192S. Helisoma F. C. Baker, Fresh-water Moll. Wis., I, p. 311. Type Planorbis bicarinatus Sowb. As genus.

1929. If flisoma Chamberlin and Joxes, Bull. Univ. Utah, Biol. Ser., No. 1, p. 145. Genotype Planorbis biearinatus Sowb. As genus.

1930. It lisoma H. B. Baker, Oce. Papers, Mus. Zool., Univ. Mich., No. 210, p. 43. Planorbis bicainatus Say. As genus.

1931. Helisoma F. C. BAKer, Proc. Zool. Soc. London, p. 584. Type Planorbis bicarinatus Sowb. As genus.

1931. Helisoma Thiele, Handbuch, Teil 2, p. 479. Type Planorbis bicarinatus Say. As section of Planorbis.

1934. Helisoma Pilsbry, Proc. Acad. Nat. Sci. Phil., S6, p. 47. Type Planorbis bicarinatus Say. As genus.

\section{Subgenus HELISOMA SS.}

Tyre Planorbis anceps Menke

Shell (plate 80, figs. 1-61. Large, sinistral, of comparatively few whorls which rapidly increase in size, carinated; spire and umbilicus funicular; aperture expanded, outer lip thiekened.

Animal. Yellowish or brownish, flecked with whitish; there are spots of color near the eyes and between the tentacles, and the mantle is spotted with dark mottling, especially orer the kidney. The tentacles are long and filiform and the velar area is notably developed. The shell is carried almost perpendicularly.

\section{ANATOMICAL CHARACTERISTICS \\ PLATE 23. Helisoma anceps (Menke)}

GENITALIA. Male Organs (fig. 11). Seminal resicle (ST) short (about $1 \mathrm{~mm}$. long) and widely rounded, composed of many small follicles. Anterior to the seminal vesicte, for the space of $2.5 \mathrm{~mm}$, the ovisperm duct is bordered by many small follieles which may represent a portion of the seminal resicle (SO). The sperm duct (SPD) is about $6 \mathrm{~mm}$. long and is of wirle diameter, somewhat sausage-shaper, the tube about $0.3 \mathrm{~mm}$. in diameter. The prostate (PRS) is ovate in shape, about $2.5 \mathrm{~mm}$. long, $1 \mathrm{~mm}$. wide and less than $1 \mathrm{~mm}$. in height. It is composed of numerous diverticula forming a pavement-like pattern when viewed externally. In scetion (fig. 9) the prostate is fan-shaped, composed of six to eight diverticula each of which is branched two to four times toward the distal end. The prostate is placed on a short prostate duct which unites with the sperm duct to form the vas deferens (plate 22, fig. 12). The vas deferens (VD) 
is about $14 \mathrm{~mm}$. long, somewhat smaller in diameter than the sperm duet. It is still further diminished in diameter as it emerges from the muscular tissue to enter the penial eomplex (plate 23, fig. 3. V1)). Near the summit of the vergic sac the vas deferens enlarges to form an epiphallus (EPI).

The penial complex (plate 23. fig. 3 ) is a short, somewhat pyriform organ about $4 \mathrm{~mm}$. long. The preputium (PR) is very wide $(1.7 \mathrm{~mm}$.) and about $2.5 \mathrm{~mm}$. long. The rergie sae (VS) is somewhat bullet-shaped, 1.5 $\mathrm{mm}$. long and $1 \mathrm{~mm}$. wide. There is no marked constriction between the preputium and the vergie sac. There is a wide retractor muscle (RM) attached to the preputium just above the male opening. On the right side of the preputium there is a group of supporting muscles (sMI). This group may form a wide. solirl band or it may be broken up into ten or twelve smaller museular bands. The supporting muscles are attached to the roof of the mantle eavity. There is a short $(2 \mathrm{~mm}$. long), narrow, external tube or duct (DC) on the outside of the preputium and adherent thereto. This penial duct tapers to half its diameter as it enters the junction of the preputium with the vergic sac.

Internally (fig. 2 ) the penial complex shows two cavities, an upper vergic space and a lower preputial space, separated by a muscular ring or diaphragm (D) which is capable of great contraction and expansion (see fig. 5). In the preputial space there is one large, vertical fold or pilaster (PL) and several smaller vertical rirlges. Attached to the wall of the preputium at the upper end of the large pilaster is a roumled, cup-shaped penial gland (GL). In section (fig. 1) this gland is seen to have the eupshaped, bulbous termination divided into two parts, an upper portion with smooth or only slightly developed rertical folds (OC) and a lower portion (LC) lined with heary vertical folds (CF). The floor of this cup is eorered with pavement-like folds, from which a narrow duct (DC) extends through the neek of the gland and emerges through the borly wall of the preputium and becomes the external penial duct. A section through the region at the junction of the two spaces (fig. 6 ) shows the relationship of the museular ring or diaphragm (D) to the gland duct, the latter penetrating the thiek wall of the lower portion of the vergie sae and opening into this eavity just above the diaphragm. In fig. 11. plate 22 , the outer cup of the gland is turned back to expose more fully the folds of the inner cul) (Helisoma anceps percarinatum).

The verge (plate 23, fig. $2, V^{*}$ ) is normally short and wide and tapers abruptly to a narrow point. In fig. 1 on plate 22 (Helisoma anceps latchfordi) it is shown well-extended, exhibiting an elongated, eylindrical form, the supporting muscles (MS) plainly inclieated at the upper end near the top of the vergic sac. The enlarged epiphallus is also indicated. At the terminal end of the verge the seminal opening is placed in the center of the organ with a small, sharp appendage or papilla extending slightly below the end of the verge. In fig. 10 on plate 22 , the end of the verge is shown with this feature enlarged to show the pointed papilla and the centrally located seminal opening.

The penial complex may assume a number of shapes, depending upon the sexual condition of the animal. Often it is seen as shom in fig. 8 . plate 23. the penial gland pushed upward causing the complex to assume a bilobed aspect. The penial gland and the rerge may sometimes be seen protruding from the male opening and lying on the neck of the animal. 
The rerge is often extended into the preputial eavity as shown in figs. 2,3 , and 4 on plate 22 .

Female Organs (plate 23, fig. 11). The spermatheca (S) and its duct are $5 \mathrm{~mm}$. long, the spermatheea clongated, sausage-shaped and slightly less in length than the duet, which is rather wide and enlarged as it enters the long $(1.5 \mathrm{~mm}$.) and narrow vagina. The uterus $(\mathrm{C})$ is about $5 \mathrm{~mm}$. long, widening upward to the nidamental gland (NG), which is about $2 \mathrm{~mm}$. long and $1 \mathrm{~mm}$. wide. The oriduct $(\mathrm{OD})$ is about $4 \mathrm{~mm}$. long and $0.3 \mathrm{~mm}$. in diameter. There is a large earrefour (CF) into which the small, narrow duct of the albumen gland enters (DA). The albumen gland (fig. 7) is squarish in form, about $2.5 \mathrm{~mm}$. in diameter and is composed of small follicles. Near the albumen duet the lobules are much larger than in the body of the gland. A depression crosses the gland on the under side marking the space oceupied by the intestine.

Hermaphrodite Organs (fig. 11). The orotestis (OT) consists of many rows of elub-shaped diverticula having a pavement-like appearance from the surface of the gland. In section (fig. 10), the orotestis is seen to be composed of about a dozen diverticula extending fan-wise from the ovisperm duet. The free portion of the ovisperm duct (SO) is somewhat shorter, between the seminal vesiele and the orotestis, than between the seminal vesicle and the oviduet, but about $1 \mathrm{~mm}$. in both regions. The larger portion of the ovisperm duet is occupied by the seminal vesicle.

The genitalia of the races of Helisoma anceps, as far as they have been examined, are remarkably uniform. In specimens of Helisoma anceps percarinatum from Douglas Lake, Michigan, there was some variation in the form of the retractor muscle, this being often divided into several branches toward the columella muscle (plate 22 , figs. $2,3,4$ ). In one specimen (fig. 4) there were two muscles, an abnormal condition.

Respiratory and Renal Systems. The pseudobranch (plate 23, fig. 4, P) is squarish in shape, rounded below, pad-like, with a distinet ridge passing down the eenter from the rectal region. The pseudobranch is $2 \mathrm{~mm}$. wide and about $1 \mathrm{~mm}$. high. The rectum is very wide and there is an irregular erest or ridge extending down the center $(\mathrm{R})$. This ridge extends backward on the rectum about a quarter of a whorl. It narrows notably as it nears the anal end of the rectum. The pneumostome (PS) is not notably large.

The kidney (plate 44, fig. 1) is $7 \mathrm{~mm}$. long and $2 \mathrm{~mm}$. wide at the upper (pericardial) part, tapering to about $1 \mathrm{~mm}$. wide at the lower part. The ureter is less than $1 \mathrm{~mm}$. long and is sharply reflexed parallel to the long axis of the kidney. The pericardium is nearly $2 \mathrm{~mm}$. long and $1 \mathrm{~mm}$. wide. There is a large and conspicuous superposed ridge extending from just below the perieardium to the urethral portion of the kidney and going beyond the kidney almost to the mantle margin.

In cross section (fig. 7), this ridge, at the point in fig. 1 marked by the arrow, is seen to form a long fold which extends over the kidney causing it to appear rounded in a rentral view of the kichey, as shown in fig. 1. The lumen is regularly rounded and the two blood ressels appear on each side at the lower part of the section. A small ridge to the left of the lumen is shown in the figure. This ridge in the mantle is present in all species of the family.

A cross section of the kidney of Helisoma anceps latchfordi (fig. 8), taken at about the middle of the kidney, shows a less extensive ridge (RK) 
but is otherwise similar to typical anceps. The form of the section may vary when taken from different parts of the kidney, as is shown in sereral species of Helisoma.

Digestive System. The stomach is bulbous and tapers into the pyloris. The intestine loops around the stomach, passes over the oesophagus, tums backward in a long loop around the liver and then runs forward to the pseudobranch in the form of the rectum. The general form is like that of Helisoma trivolvis shown in fig. 1 on plate 48.

The buccal sac is short-orate. The salivary glands are narrow and about twice as long as the buccal sac. They are joined behind.

The jaw (plate 49, fig. 1). There is one wide, low, arehed superior jaw (about $1 \mathrm{~mm}$. wide) and two narrow, ribbon-like lateral jaws somewhat longer than the superior jaw. The superior jaw is finely striated on its anterior face.

The radula has the variable formula 22-1-22 to 30-1-30, with 150 to 193 rows of teeth. A rachla from specimens from Maple River, Michigan, is figured on plate 53, fig. 1. The center tooth is squarish with two short, wicle cusps. The lateral teeth (1-5) have a squarish reflection which extends well below the lower margin of the base of attachment. The eusps are spade-shaped, the mesocone the longest and the ectocone the shortest. The ectocone of the fourth tooth is split into four small cusps. The intermediate teeth (6-7) are narrower than the lateral teeth, the base of attachment very short. The entocone is broken up into two or three small cusps and several small cusps appear on the outer erlge of the tooth above the ectocone. The marginal teeth (8-14) are much narrower, this feature increasing toward the outer margin of the membrane where the tecth are very long and narrow (14). In the marginal teeth the entocone is broken up into fine serrations numbering from five to ten cusps, the number inereasing in the outer teeth (compare 8 and 14 ). The mesocone becomes somewhat smaller but is not modified. The ectocone is distinct in the 8th tooth with three small eusps above it. From the 10 th tooth this area changes to small serrations five to six in number. The outer marginal tecth appear like a saw, with one large tooth (the mesocone) in the center (see 14). The extreme outer marginals are vestigial.

The radulae of anceps and its races vary considerably, principally in the numerical formulae, but also in the number and position of the cusps. The table below indieates the extent of this variation. The columns are all as follows, reading from left to right: Locality, formula, lateral teeth, intermediate teeth, plate, and figure.

Helisoma anceps (Menke).

Maple River, Michigan . . . . . . . 23-1-23 to 24-1-24 1-5

Unionville, Connecticut . . . . . . . . . . 23-1-23 to 25-1-25 1-5

Chautauqua Lake, New York. . . . . . 22-1-22 to 25-1-25 $1-7$

Monse Ear Creek, Wiseonsin......... 26-1-26 to $27-1-2 \overline{7} \quad 1-6$

Cleveland, Oneida L., New York.... 25-1-25 to $27-1-27 \quad 1-6 \quad 7-8$

There are 150 to 160 rows of teeth.

Helisoma anceps sayi F. C. Baker.

Bayfield, Wisconsin.......... $27-1-2 \overline{7}$ to $2 \overline{7}-1-2 \bar{\tau} \quad 1-\overline{5} \quad 6-\bar{\tau} \quad$ Plate 53, fig. 4

Helisoma anceps percrininam (Walker).

Douglas Lake, Michigan. . . . . . 27-1-27 to 30-1-30 1-S 9-10 Plate 5t, fig. 1

There are 193 rows of teeth. 
Helisoma anceps royalense (Walker).

Bamiji Lake, Ontario. . . . . . . . 25-1-25 to $27-1-27 \quad 1-8 \quad 9 \quad$ Plate 5 t, fig. 2

There are 170 rows of teeth.

Hclisoma anceps cahni F. C. Baker.

Big Muskallonge Lake, Ontario. . . . 27-1-27 to 27-1-27 1-6 7-9 Plate 5t, fig. 3

There are 160 rows of teeth.

Hclisoma anceps latch fordi (Pilsbry).

Meach Lake, Quebec. ......... 27-1-27 to 30-1-30 1-6 7-9 Plate 5t, fig. 4

There are 190 rows of teeth.

For the above data more than forty specimens have been examined. In general form of teeth, there is complete agreement in all radulae examined, both from the same locality and from different places. The lormulae vary and along with this variation, the numbers of lateral and intermediate teeth likewise rary.

Abnomal teeth are common in radulae of Helisoma anceps. In a specimen from Maple Rirer, Michigan, the fourth lateral of the filteenth row had the ectocone broken up into four small cusps (plate 53, fig. 1). In a specimen from Chautauqua Lake, New York, the center tooth of the 118th row was broken up into three small cusps and one large cusp. In the first lateral of the same row, the entocone was split into two small cusps (plate 53, fig. 2). In a specimen from Unionville, Connecticut, the fifth lateral of the ninetieth row had a split ectocone. The 8 th and 9 th teeth of this row had the intermediate in unusual form. This row shows the shape of the teeth on the left side of the membrane (plate 53, fig. 3, lower row).

In the races of anceps, the same tendency to form abmormal teeth is observed. A specimen of sayi from Bayfield, Wisconsin, had the center tooth of the seventy-fifth row with three small cusps on the left side and one small cusp on the right sicle of a central cusp. All of the laterals in this row had the entocone broken up into two small cusps (plate 53, fig. 4, lower right row). In a radula of percarinatum from Douglas Lake, Michigan, the first and second laterals of the 100th row had the entocone split into two smaller cusps (plate 54, fig. 1, lower row). A specimen of latchfordi, in the sixtieth row, had the central tooth with an extra cusp on each side of two smaller central cusps (plate 54, fig. 4, 60). All of the teeth of this race examined had two rery small denticulations on the exlge of the reflection above the ectocones (plate 54, fig. 4).

Geographical Distribution. The species of trpieal Helisoma inhabit North America from British America (Hurlsons Bay) southward to Louisiana and Alabama and westward to the Rocky Mountains.

Species Considered as Valid. This, the trpical subgenus of the genus Helisoma, contains one species with many races and a second species with two recognizable races.

Helisoma anceps anceps (Menke) 1830

(= Planorbis bicarinatus Siy 1819

(preoccupied), P. antrosus Conrad, 1834)

Helisoma anceps sayi F. C. Baker

Helisoma anceps shellense F. C. Baker Helisoma anceps percarinatum. (IValker) Helisoma anceps royalense (Walker) Helisoma anceps rushi F. C. Baker Helisoma anceps jordanense (Winslow)
Helisoma anceps unicarinatum (Haldeman)

Helisoma anceps striatum (F. C. Baker)

II lisoma anceps cahni F. C. Baker

II lisoma anceps latchfordi (Pilsbry)

IIelisoma anceps portagensis (F. C. Baker)

Helisoma anceps aroostookense. (Pilsbry) Helisoma eucosmium (Bartsch)

Helisoma eucosmium vaughani (Bartsch) 
Geological Distribution. Miocene?, Pliocene to Recent fauna.

Remarks. Typical Helisoma is characterized by a short and wide, somewhat bulbous penial complex without a notable constriction between the preputium and the vergic sac. There is a cup-shaped penial gland with a short, narrow, almost straight penial gland duct. The prostate and ovotestis are made up of many small diverticula radiating from a duct in fanlike pattern when seen in eross scetion. Helisoma differs from Pierosoma in its shorter penial gland duet, wider and shorter vergie sac, and generally different penial complex. From Seminolina, which resembles Helisoma in its short penial gland duct, it differs by its shorter duct. The radular teeth also differ from Seminolina in having the cusps sharply aculeate instead of rounded. The shell of Helisoma is also quite different from Pierosoma and Seminolina in its general bicarinate form with the spire and unbilieus both deeply concave.

As a subgeneric name, Helisoma has been known in molluscan literature for many years. Binney (1865, p. 112). Tryon (1870, p. 188), and Dall $(1905$, p. 81$)$ cite the name, using, however, only characteristics of the shell for its distinction. In 1926 (p. 201) and in 1928 (I, p. 311), Baker elevated the group to generic rank, basing the distinction on the peculiar genital complex of the male organ. In 1931 (p. 584), the genus was diagnosed by Baker and the distinctions of the genitalia described and figured.

Authors generally have misquoted the type of the genus. The Planorbis bicarinatus of Sowerby, while with little doubt the same as Planorbis bicarinatus Say, has nothing to do with Say's species and Sowerby was probably not aware that there was another bicarinatus. Dall (1905, p. 84) cited the type as Planorbis bicarinatus (Say) Sowerby, which is incorrect, although the type is correctly eited on page 81 . The citation of Planorbis bicarinatus say, as has been made by some authors, is also incorrect. Say's species dates from 1817. Sowerby's from 1824.

A careful study of Sowerby's description and his two figures on plate elxxvii (fig. 4) leaves little doubt about the unity of his species with that of Say. Binney (1865, p. 124) thought it might be Planorbis campanulatus Say, but both figures and description point to bicarinatus. Binney based his opinion evidently on the lower fig. 4 of the plate, which is not elear, and might be mistaken for companulatus. There is little question about the upper figure being intended for bicarinatus. Unfortunately this appropriate name can not be used, as it is preoceupied for a Paris Basin fossil. Conrarl's Planorbis antrosus 1834 has been used in place of bicarinatus, but Menke's name precedes this by four years and must be accepted.

Regarding the name Hclisoma, it is a Greek noun in the neuter gender and all specific names must, of course, also be neuter (H. B. Baker, 1930, p. 139).

\section{Subgenus SEMINOLINA Pilsbry, 1934}

Type by original designation IIelisoma scalare (Jay)

1870. Ameria Dalu, Ann. N. Y. Lyc. N. H., IX, p. 356. Example Physa scalaris Jay (non H. and A. Adams, 1855).

1886. Thomsonin Axcey, Le Naturaliste, VIII, p. 358; not of Signoret, 1879 (Hemiptera).

1931. Thomsonia There, Handbuch, Teil 2, p. 479. Type Planorbis scalaris (Jay). As section of Planorbis.

1934. Seminolina Pilsbir, Proc. Acad. Nit. Sci. Phil., 86, p. 31. Type Helisoma scalare (Jay). Anatomy. As subgenus of Helisoma. 
Shell (plate 80, figs. 7-12). Large, sinistral, physa-shaped or planorboid, with every gradation between these forms, usually widely or deeply umbilicated; surface smooth, usually glossy, without the thread-like striae of Pierosoma.

Animal (plate 70, fig. 3 (adult), fig. 2 (young)). With large velar area and long tentacles as in Helisoma. Color variable. In scalare olivaceous, in duryi and varieties dark olivaceous in old specimens, purplish on top of head, flecked with white. Bottom of foot dark horn or purplish, flecked with fine light dots. Tentacles lead color. Mantle yellowish or gravish over lung and kidney, with few black or brown spots. Immature specimens are more yclowish with few or no dots. The young animal is hyaline and transparent, the internal organs yellowish or pinkish.

\section{ANATOMICAL C'HARAC'TERISTICS}

\section{PLATE 28}

GENITALIA. Male Organs (fig. 14). Seminal resicle (SV) about 2.5 mm. long, varying in width, but $1 \mathrm{~mm}$. wide at the center and about $0.5 \mathrm{~mm}$. wide anteriorly and posteriorly of this area. The seminal vesicle is composed of many small glands. The ovisperm duct bears many small vesicles along its side for over $1 \mathrm{~mm}$. below the scminal resicle. Sperm duct nearly $3 \mathrm{~mm}$. in length, of large diameter. Prostate (PRS) oblong, over $2 \mathrm{~mm}$. in length composed of many diverticula arranged in fanlike rows. A section of the prostate near the midlle shows sixteen rows of club-shaped divertieula (fig. 12). The prostate diverticulat discharge into a separate duct, the prostate duct, with which the sperm duct connects posteriorly and the ras deferens anteriorly (see fig. 14). The vas deferens (VD) is about $10 \mathrm{~mm}$. long, and is about half the diameter of the sperm duct. It is slightly enlarged repiphallus as it enters the vergic sac.

The penial complex (fig. 10) is about $3.5 \mathrm{~mm}$. long. The lower sac or preputium (PR) is pyriform, $1.3 \mathrm{~mm}$. wirle at the upper part and less than $0.5 \mathrm{~mm}$. wide at the male opening. There is one large retractor muscle (RM) which is split into four branches at the preputium and in some specimens (fig. 9) there may be one wide muscle of three branches with a narrow, separate muscle below. The muscles are attached to the upper part of the preputium. The supporting muscles (SM) usually form a wide band. split into three branches at the upper part of the preputium. In one specimen there were five narrow, separate supporting muscles, each with two branches, all placed near the lower end of the preputium (fig. 9).

The duet of the penial gland (DC) is rather short $(3.5 \mathrm{~mm}$. long) and tapers in diameter toward the end entering the vergie sac (fig. 6). The vergic sac is of about the same length as the preputium, ovate-pyriform in shape, about $1 \mathrm{~mm}$. wide near the upper part of the sac. In some specimens examined (fig. 9), the preputium was pushed upward and the rergie sac appeared as though attached to the lower part of the preputium. In this condition, the penial gland duct extends from the top of the preputium and enters the vergie sac below the level of the duct's exit. This condition is observed in specimens in breeding stage.

Internally (fig. 11), the preputial sac contains several (four or more) narrow, slight, vertieal ridges or pilasters (PL). The earity of the preputium is partly filled by an elongate-ovate (irregularly paralleliform) penial gland attached by a short neck of less diameter to the body wall 
of the preputium through which the penial duct extents (CL, DG). In section (fig. 7), this gland is seen to be composed of two eup-like cavities, one, the inner cup, has sereral large glandular folds ( $\mathrm{GF}$ ) and the other, the outer cup, has several smaller folds attached to the wall of the cup (OC). The larger folds extend transwersely across the eavity as shown in fig. 11, GL. The small eup is at the extreme end or tip of the gland. The gland duet enters the smaller eavity, as shown in fig. 7, DC. There is a narrow ridge or diaphragm which separates the vergie sac space from the preputial cavity. The gland duct enters the rergic space above this diaphragm as shown in fig. 11 . The verge $(\mathrm{V})$ is prriform or reversed conic $0.9 \mathrm{~mm}$. wide at the upper part and tapering to a point. The sperm eanal has a central outlet.

Female Organs (plate 28, fig. 14). The spermatheca (S) is bulbous, wide and about $1 \mathrm{~mm}$. long. Its duet (SPD) is $2 \mathrm{~mm}$. long, rather wide and increases notably in diameter at the lower end where it enters the short (1 $\mathrm{mm}$. long) ragina. The vagina narrows to about half its diameter at the female opening (VG). The uterus (U) is about $3 \mathrm{~mm}$. long and is as wirle as the diameter of the spermatheea. The nidamental gland (NG) is short (about $1 \mathrm{~mm}$. long) and sac-like. The oviduct $(\mathrm{OD})$ is about as long as the uterus, very wide, and bears the nidamental gland about midway of its length. The albumen gland (AL) is somewhat longer than wide and is composed of many small, gland-like resicles (fig. 14, AL).

Hermaphrodite Organs. The orotestis occupies the first and a part of the second whorls and is composed of ten or more rows of elub-shaped diverticula of unequal length (fig. 13. plate 28). The free portion of the orisperm duet is very short (about $0.7 \mathrm{~mm}$.) both anterior and posterior of the seminal vesicle.

The genitalia of Helisoma scalare examined agree perfectly with the figures published by Pilsbry (1934, fig. 1, b, e, d). The peculiarities are the wide and pyriform penial complex, the short gland duct, the elongated, two-cupped penial gland and the large, saceulated seminal resicle.

The several varieties under the name of Helisoma duryi (Wetherby) show some differences from scalare in their anatomy (plate 33). In Helisoma duryi normale Pilsbry, the genitalia are much elongated, due to the more widely-coiled shell (fig. 15). The seminal resicle (SV) is much shorter in comparison $(2 \mathrm{~mm}$. long) and the gland saes are larger. The sperm duet (SPD) is a long and narrow tube $(7.5 \mathrm{~mm}$. long). The prostate (PRS) is more elongated $(5.5 \mathrm{~mm}$. long) and contains a greater number of diverticula. The prostate duct is longer and the space between the entrance of the sperm duct and of the ras deferens is several times wider. The ras deferens (VD) is a long and narrow tube (over $20 \mathrm{~mm}$. long). The spermatheea (S) is much longer and larger $(3.5 \mathrm{~mm}$. long) and is more elongate-orate in shape. Its duct is longer $(5.5 \mathrm{~mm}$.) and much narrower. The uterus and nidamental gland are longer and narrower and the oviduct (OD) is narrow and much elongated. The free portion of the orisperm duct is also longer. The albumen gland (AL) is more irregular in shape.

The penial complex is usually short and wide but varies somewhat in this respect (see figs. $8,9,12,17,18$ ). Normally (figs. 17, 18), the preputial sac is as long as, or only a trifle longer than, the vergic sac, and is always 
wide. The penial gland duet is short, as in scalare. There is usually more of a constriction between the preputium and the vergie sae than in scalare. Figure 8 shows an abnormal form of penial eomplex and fig. 12 shows another in which the part of the preputial sae containing the penial gland has been pushed upward. In fig. 9, this feature is still further emplasizerl.

In Helisoma duryi (Wetherby), the preputial sac has been pushed up)ward as in normale. In Helisoma duryi eudiscus Pilsbry, there is considerable variation. In fig. 1, the gland duct is swollen in a bilobed form, while in fig. 2 it is very narrow. In fig. 7, the penial eomplex is very wile. Figure 5 shows the penial gland pushed upward in the preputial sae. Figure 6 shows the wider penial complex in an immature specimen with a shell 6.5 nmI. in diameter. In two specimens examined. the penial gland was extencled from the male opening and lay outside on the neek of the animal (fig. 13, duryi; fig. 16. H. d. normale). In fig. 16, it is shom just below the female opening.

The penial gland in the duryi eomplex is of about the same shape as that organ in scalare. In $H$. $d$. culdiscus, the external form is shown in fig. 4 and a section in fig. 3. There is the same division into an inner and an onter ('up) as in scalare. In 11 . d. nomale (fig. 10), a longitulinal scetion shows the same features. In Helisoma duryi, the penial gland is short and wide. The gland of a half-grown specimen is shown in fig. 19.

The figures of the duryi romplex agree with those by Pilsbry (1934, p. 34, fig. 1, f, g. h, i, j, k). As Pilsbry remarks on page 36 , the anatomical differences are sufficient to separate scolare from duryi and its races.

Respiratory and Renal Systems. The pseudolorineld (plate 28, fig. 8) is short and wide $(\mathrm{P})$. There is a large cremulated ridge on the reetmin ( $R$ ) which runs out on the pendoloranch in a curve, to the right of the anal opening (A). The pecuclobranch is $1.5 \mathrm{~mm}$. long and about 1 mum. high. It is eontractile and its size varies greatly in preserved speemens. There is a large puenmostome.

The kidney plate 44, fig. 4) of seculure is rather short (4 mm. long), wider at the upper part near the pericarlimm $11 \mathrm{~mm}$. widel. The ureter is directed diagonally backward. The pericarclimm is abont $1 \mathrm{~mm}$. long. A cross section of the kidney near the middle (fig. 25) shows a rather long. narrow crest or ridge, a small ovate lumen and two small veins placed just below the midclle of the lumen. The small ridge in the mantle is shown to the left in both figures.

In H. d. normale (fig. 5), the kiclney is longer $(17 \mathrm{~mm}$. long) and comparatively narrower $(3 \mathrm{~mm}$.) than in scalare. The ureter is about $2 \mathrm{~mm}$. long and is bent backward against the lower part of the kidney. A cross section of the kidney near the middle (fig. 26) shows it to be more compressed than that of sealare, the erest or ridge bent more to the left but of about the same form. The kumen is more elongated and about two and one-half times as wide as high. The two rems are placed near the lower border of the lumen. The kidney of Seminolina is more depressed than in Helisoma and the lumen is comparatively larger.

Digestive System. The stomach and intestine are as in Helisoma, as are also the bueeal sae and salivary glands.

Jaw (plate 49, fig. 4, scalare; fig. 14, H. duryi normale) as in Hclisoma, the superior jaw with vertical striations on the inner face. 
Radula (plate 64). In scalare, the eenter tooth (figs. 1, 89) is almost twice as wide at the base as at the summit of the reflection, the two broadly aculeate cusps of which reach the lower margin of the base of attachment. The lateral teeth (1-8) are about as broad as high and the reflection, which is trieuspid, extends below the base of attachment. The mesocone is roundly blunt, the entocone and ectocone broadly aculeate. The intermediate teeth (9-11) have the mesocone as in the lateral teeth, but narrower, the entocone as in the laterals. On the eleventh tooth, the entocone is split into two short, aculeate eusps. The ectocone in all intermediate teeth is split into two sharp cusps. The marginal teeth (12-21) are very long and narrow and elaw-like. The mesoeone is aculeate in all teeth but is always distinct. The entocone becomes very wicle and is split into from four to seven small eusps. The eetoconic region on the outer margin of the tooth bears three very small eusps.

In another specimen from the same loeality, the teeth are somewhat smaller (fig. 2). In $H$. duryi normale, from the Tamiami Trail (fig. 3), the teeth are all narrower than those of scalare, although the shell is mueh larger. The two cusps of the center tooth do not reach the lower margin of the base of attachment. The laterals (1-11) and the intermediate tooth (12) are narrow but the euspirlation is the same as in scalare. The marginal teeth (13-29) are similar to those of scalare differing only in being somewhat narrower. In a speeimen from Paines Prairie (fig. 4), the teeth are more like those of scalare. Two rows are figured, the 55th and the 140th. The number of intermediate teeth is smaller in normale than in scalare. The figures on plate 64 agree with those publishect by Pilsbry (1934, p. 34, fig. 1a).

The formula for scalare is 27-1-27 to 29-1-29 and there are 160 to 190 rows of teeth. Pilsbry gives 33-1-33 as the formula (1934, p. 35). A number of membranes were examined but none gave the larger formula. The outer teeth are small and vestigial.

The formula of normale from the Tamiami Trail is 28-1-28 to 31-1-31 with 175 rows of teeth. In speemens from High Springs several radulae gave 27-1-27 as the formula. These specimens vary toward the race intercalare. From Paines Prairie, several membranes gave 28-1-28 and 29-1-29 with 165 rows of teeth. H. d. cudiscus from Silver Springs gave a formula of 27-1-27 to 28-1-28 with 154 rows of teeth. The variation in formulae is from 27-1-27 to 31-1-31 for the complex of duryi and to 33-1-33 for scalare as examined by Pilsbry.

For the anatomical data herein presented thirty-five speeimens have been examined from the following loealities, all in Florida:

Helisoma scalare

Lake Butler. Collected by Dr. E. A. Andrews of the Johns Hopkins University

Helisoma duryi normale

Tamiami Trail, 40 miles west of Miami. Collected by Paul P. McGinty, Boynton, Florida

Canal west of Boynton, Palm Beach County. Collected by Paul P. McGinty, Boynton, Florida

Bridge No. 32, on canal west of Miami. Collected by W. F. Shay, St. Louis, Missouri

Paines Prairie, near Gainsville. Collected by T. van Hyning, Florida State Museum

Santa Fe River, High Springs. Collected by T. van Hyning 
H. duryi interenlare

Canal west of Boynton. Collected by IT. F. Shay

Santa Fe River, High Springs. Collected by T. van Hyning

II. duryi eudiseus

Silver Springs, Marion County. Collected by T, van Hyning

Geographical Distribution. As far as known, this group is found only in the peninsula of Florida north to Bradford County. It is particularly abundant in the Everglade region of southern Florida.

Species Considered as Valid. Three species are recognized, one with several races.

Helisoma (Seminolina) scalare (Jay)

Helisoma (Seminolina) duryi (Wetherby)

Hctisoma (Scminolina) duryi seminole Pilsbry

Helisoma (Seminotina) duryi normale

Pilsbry

II lisoma (Seminolina) duryi interealare (Pilsbry)

Inelisoma (Seminolina) duryi eudiseus Pilsbly

Helisoma (Seminolina) preglabratum (Marshall)

For an extended account of the speeies of this subgenus see Pilsbry 1934, p). 31-43.

Geological Distribution. Pliocene to Recent fauna.

Remarks. Seminolina is a characteristic group of Helisoma, differing from typical Helisoma in the presence of a physoid shell, not only in one distinct species, but in the rariations of the races of another species. In its anatomy, it differs from trpical Helisoma in the rounded mesocone of the lateral teeth which are distinetly aculeate in Helisoma. The duct of the penial gland is about trice as long as in Helisoma and the penial gland is more elongated, narrower, and less cup-shaped than in Helisoma.

Seminolina is a notable group of the subfamily Helisomatinae and one of the most variable genera as regards species. The physoid aspect of its type species, Paludina scalaris Jay. led the older concliologists to include it in Physe and in the genus Ameria of the family Bulinidae. The largest species, Helisoma duryi (Thetherby), is perhaps more variable than any other species found in America, its extremes being from typical Physashaped to flatly discoidal shell. The elongation of the spire always produces a physoid aspect. The races of dwryi blend into each other and often three forms will oceur in the same lot, as normale, intercalare, and duryi.

The Helisoma duryi complex includes several races more or less heavily infested with parasitic worms. These include normale, intercalare, eudiscus, and duryi. Many specimens were so badly infested that most of the organs, especially the genitalia and liver, were completely obliterated. Helisoma scalare was the least affected.

\section{Subgenus PIEROSOMA Dall, 1905}

Type by original designation Planorbis trivolvis Say

1865. Helisoma Bivney (non Swainson), Land and FW. Sh. N. A., II, p. 112. No type cited. Includes mostly species belonging to Pierosoma

1872. Helisoma Tryon (non Swainson), Mon. Univ. FW. Moll. U. S., pp. 188, 198. Includes mostly species of Pierosoma. As subgenus

1883. Helisoma Fischer (non Swainson), Man. de Conch., p. 509. Type Planorbis trivoliz Say. As section of Planorbis

1899. Helisoma Martens (non Swainson), Biol. Cent. Amer. Moll., p. 381. Inchudes species now referred to Pierosoma 
1905. Pierosoma Dall, Alaska Moll., pp. 81, 85. Type Planorbis trivolvis Say. As section under subgenus Hclisoma

1918. Picrosoma Walker, Miscel. Pub. Mus. Zool., Univ. Mich., No. 6, p. 11. Type Planorbis trivolvis Say. As section of subgenus Helisoma

1921. Picrosoma Germaix, Rec. Ind. Mus., XXI, pp. 6, 49. Type Planorbis trivolvis Say. As subgenus

1923. Picrosoma Wenz, Fossil. Cat., Pars 22, p. 1522. Genotype H. (Picrosoma) trivolvis (Say.) As subgenus.

1926. Picrosoma F. C. BAker, Trans. Wis. Acad. Arts and Science, XXII, p. 202. Type Planorbis trivolvis Say. As subgenus

1928. Picrosoma F. C. BAKer, Fresh-water Moll. Wis., I, p. 329. Type Planorbis trivolvis Say. Genitalia and radula. As subgenus

1931. Pierosoma F. C. Baker, Proc. Zool. Soc. London, p. 586. Type Planorbis trivolvis Say. Genitalia and radula. As subgenus

1931. Pierosoma Thiele, Handbuch, Teil 2, p. 479. Type Planorbis trivolvis Say. As section of Planorbis

1934. Pierosoma Pilsbry, Proc. Acad. Nat. Sci. Phil., 86, p. 30. As subgenus

Shell (plate 80, figs. 13-15). Large, sinistral, of few whorls, the last whorl large and capacious, the early whorls usually flattened and earinate above, widely umbilicate below; spire of the adult shell usually flattened and sunk below the level of the body whorl; aperture notably expanding, even flaring in some speeimens, the outer lip thickened within; seulpture of coarse growth lines and conspienous spiral lines; surface usually dull, never glossy as in Seminolina.

Animal (plate 70, fig. 7, H. trivolvis macrostomum; fig. 8, $H$. trivolvis fallax). Body long and somewhat narrow; rounded before, the foot narrowly pointed behind; velar area well-developed; tentacles long and filiform; eyes at base of tentacles as in other Planorbidae. Color usually dark horn, in some speeies reddish or yellowish, the body flecked with streaks or spots; mantle spotted, as in trivolvis, or without spots, as in pilsbryi; the head and foot are usually lead color. In the young, the tentacles are very long and slender, the body dark horn color flecked with white spots; the eyes black; viscera reddish through the shell; foot also somewhat reddish, especially on the front portion (plate 70, fig. 6).

\section{ANATOMICAL CHARACTERISTICS}

PLATE 24 (Planorbis trivolvis Say)

GENITALIA. Male Organs (fig. 15). Seminal vesicle (SV) elongated (3.5 mm. long, $0.5 \mathrm{~mm}$. wide) composed of many small vesicles. It occupies almost half of the length of the ovisperm duet. Sperm duct (SPD) long and narrow (about $4 \mathrm{~mm}$. long). Prostate (PRS) about $4.5 \mathrm{~mm}$. long and $1 \mathrm{~mm}$. wide, composed of fourteen rows of diverticula emptying into a short prostate duct which conneets with the sperm duet and from which the long (15 $111 \mathrm{~m}$.) vas deferens (VD) extends and passes to the vergic sae. There is only a very slight enlargement (epiphallus) of the vas deferens as it enters the vergic sac. A eross section of the prostate (fig. 13) shows the fourteen rows of diverticula to be of unequal length and the whole section to be fan-shaped.

The penial complex (fig. 11) is usually about $5 \mathrm{~mm}$. long. The preputium $(\mathrm{PR})$ is very wide $(1.5 \mathrm{~mm}$.) and cylindrical in shape. The vergic sac (VS) is of the same length as the preputium but is very narrow, the preputium rapidly narrowing as it receives the vergic sac. The vergic sac 
increases to double its diameter near the end where the vas deferens enters. There is a single, wicle retractor muscle (RM) which may be split into several branches (figs. 1, 5). The duct of the penial gland (I)C/ is rery long and narrow $(8 \mathrm{~mm}$. to $9 \mathrm{~mm}$. long) and extends from the upper part of the preputium to a point just above the diaphragn (see fig. 8). Normally the duet lies coiled on the preputimm just over the penial gland and adherent to the preputium, hound down by many small muscles covering the preputial sac. There is usually one wide band of supporting muscle (sil). The duct is shown in fig. 5 partly uncoiled.

Internally (fig. 8), the preputial cavity (PR) contains a number of small vertical folds or pilasters. There is a large, (up-shaped penial gland (GL) about $1 \mathrm{~mm}$. in diameter, which is eontlarted near its attalehment to the body wall of the preputium to form a narrow, rounded neck. The duct (I)(i) passes through the wall of the preputium and extends to the vergic sace where it enters just above the diaphragm (1)V I. A vortical seetion of the gland (fig. 4) shows the rireular (up) to be of ronsideralshe depth (about $1 \mathrm{~mm}$.), the imer walls lined with many rertical folds (ciF). The bottom of the cup contains many small folds placed lomgitudinally. The gland duet (D)C enters the bottom folds of the "up). The walls of the (up (BW) are very thick. Another form of glame is shown in fig. 14.

The rergie sate contains the clongated verge $(\mathrm{T})$ which is cnlarged at the upper end and tapers downwarl to a point. The seminal ranal has a central exit beyond which a small, triangular papilla extends, as show in fig. 10. There is a large muscular ring or diaphragm (I)) which is capable of eonsiderable extension and contration, callsing the diaphragm to be at narrow musculat ring or a rompalatively thin membrane which nearly ('loses the opening between the preputium and vergic sate. Figure 10, somewhat diagrammatic, shows the relationship betreen the diaphragm, the verge, and the entrance of the penial gland duct. which is a trifle too high in the figme.

The penial amplex often assumes a bilobate form, the preputim exteneling upward until it is higher than the vergic sare (fig. 1). A vertical sertion of such a condition (fig. 2) shows the penial gland to be placed at the summit of the preputial extension. The relationship of the verge and the penial gland duct is also shown in this section. In voumg sperimens of three and one-half whorls, the preputium and vergide sac form a single wile, elongate-pyriform penial complex with a short penial gland duet ifig. 3 ). This condition is suggestive of typical Helisoma, which has a wide penial complex and a short duct, and indicates, it would secm, a development of the Pierosoma group from the Helisoma group.

Female Organs (fig. 15). The spermatheea (S) is elongate-pyriform and about $2 \mathrm{~mm}$. long. The spermatheeal duct (SD) is $3 \mathrm{~mm}$. long, narrow, and somewhat enlarged at the lower end where it enters the short and wide ragina (VG). The uterus ( $\mathrm{C}$ ) is about $7 \mathrm{~mm}$. long, narrow at the vagina and widening to double this diameter near the prostate where it unites with the nidamental gland (NG), which is wide and bulbous. The oriduct (OD) is short and wide (about $3.5 \mathrm{~mm}$. long and $0.5 \mathrm{~mm}$. wide) and somewhat coiled. The albumen gland (fig. 7) is squarish and is composed of many small follieles. In side view, it is seen to be cleft to accommodate the passage of the intestine on its lower surface (fig. 6, IN). There is a large carrefour (fig. 15, CF) into which the duct of the albumen gland enters (DA). 
Hermaphrodite Organs (fig. 15). The ovotestis (OT) oceupies about one whorl of the shell. It is composed of about thirteen rows of divertieula which radiate from the orisperm duct. In a cross section near the anterior end (fig. 9), there are six diverticula entering the ovisperm duct, four of which branch twice, one is simple, unbranched, and one is branched four times. The branching is not miform throughout the ovotestis. The free portion of the ovisperm duct ( $\mathrm{SO}$ ) is short, that portion near the ovotestis being very short (about $1 \mathrm{~mm}$.). The end near the oviduct is longer (1.5 mm.). A portion of the duet beyond the seminal vesicle (for about $1.5 \mathrm{~mm}$.) is provided with small vesieles along the side which are probably to be considered as parts of the seminal vesicle.

No figures other than those by the writer $(1928,1931)$ have been published. The chief characteristie is the large, wide, and somewhat pyriform preputium and the very long penial gland duct. This duet is similar in mature specimens of the different races and species, but there is some variation in the details of the sexual organs, as would be expeeted.

The genitalia of the races of Helisoma trivolvis vary in minor details which are figured on plate 29. In H.t. pseudotrivolvis (=lentum, figs. 1-6), there is consiclerable variation. Figure 1 shows the penial complex a trifle wider than in typical trivolvis. In fig. 2, the penial complex is rertically sectioned showing a wider verge and a somewhat differently shaped penial gland. Figure 3 shows the manner in which the penial gland duct is coiled on the outside of the preputium (DC). In fig. 4, the penial gland is shown in rertical seetion, the cup being somewhat diagonal. As this gland is capable of some muscular contraction and expansion this variation in shape is of no taxonomic importanee. In fig. 5, the preputial sac has been pushed upward placing the vergie sae on the side of the preputium. The form of the penial gland, the verge, and the great length of the penial gland duct is indicated. In fig. 6 , the penial gland has been protruded from the male opening and is lying on the neek of the animal, near the female opening.

The genitalia of a race of trivolvis (lentum) from the type loeality, New Orleans, Louisiana, are shown in figs. 7-13. Figure 8 shows the general form of the penial complex. In fig. 11, the penial gland has been extended from the male opening, and is shown in its trpical eup-shaped condition. Figure 12 shows the gland exserted with the verge beside it, also exserted. In fig. 13, the shape of the entire verge of this speeimen is shown. It is peculiarly shaped at the distal end. In fig. 7 , the penial complex is shown in its typical position when the gland is exserted from the male opening. The cup-shaped gland (GL) is normal. Characteristies of the verge are shown in figs. 9 and 10 . Figure 9 shows the entire rerge which has been scetioned in two places to show the location of the sperm canal near the center of the verge. The waist-like constriction just above the middle of the verge shows where this organ was compressed when it was protruded through the museular ring or diaphragm. The shape and central position of the sperm eanal outlet is shown in fig. 10, from the front and from the side. The small papilla at the end of the verge is well shown. This feature is characteristic of all members of the group Pierosoma.

The large race of trivolvis (macrostomum) differs little from the typieal form. Figures 14 and 16 on plate 29 show the normal condition of the penial complex and fig. 15 a condition in which the preputium has been greatly pushed upward. 
In H. trivolvis fallax, a small race of trivolvis, a specimen was examined in which the penial complex had a very large, pyriform preputium and a small, eylindrieal vergic sae (fig. 17 ). The penial gland of this specimen was quite normal (fig. 18).

The great variation in the form of the retractor muscle is well shown on plate 29 , especially in figs. $1,2,3,5,7,8,14,15,16$, and 17 . It raries from a narrow band of muscle to a wide band with several branches.

\section{THE GENITALIA OF SPECIEN ALLIED TO TRIVOLYIS}

\section{Species East of the Rocky Molntains}

A closely related species. Helisoma chautauquense F. C. Baker (plate 29. figs. 19-22), differs from the trivolvis complex in the wider, more pyriform preputimm, shorter and wider vergic sac, and especially the much shorter penial gland duet (DC) which recalls the Seminolina group (fig. 22). The penial gland. however, does not differ from that of trivolits. In the immature stage of this species, the whole penial complex is wider, especially the vergie sac, and the gland duct is very short, the whole male organ resembling that of typical Helisome ( fig. 19).

In a rather distinct species. Hetioma truncatum (Niles), the genitalia are similar in general form but show some minor peculiarities (plate 26, fig. 13). The seminal resicle $\mathbf{S T}$ / is of greater diameter and less length, and the orisperm (luct is of slightly greater length $(4 \mathrm{~mm}$.). The prostate (PRS) is much shorter $(1.7 \mathrm{~mm}$.) and wider, and consists of fifteen diverticula, which are on a short prostate duct placed at the right erige of the group of diverticula (fig. 10). There are about eleven main diverticula, several of which are branched at the end. The cross section of the prostate of truncatum differs slightly from that of trivolvis. The duet of the spermathera is somewhat longer than in trivolvis. The penial complex is wider than in trivolvis and is similar to some of the races, lentum for example (figs. 6, 7, 12). The penial gland (fig. 9) does not differ from that of trivoleis.

A larger species, Helisoma pilsbryi (F. C. Baker), living in Wisconsin, Michigan, and the northern part of the United States and southern Canada, is figured on plate 25. The genitalia (fig. 4) are similar in general form to those of trivolvis, but there are some differences. The spermatheca (S) is narrower and shorter $(1.3 \mathrm{~mm}$.) but the duct is long. The prostate is shorter. The seminal resicle is shorter and wider. The ovotestis diverticula are very long. In the penial complex (fig. 5), the preputium is twice as long as the vergic sae and both are wider than in trivolvis. Tariations in shape and position of the rergic sac are shown in figures 1,6 , and 7 . In the penial gland, the eup is mueh shallower than in trivolizis (fig. 2). The genitalia are somewhat shorter than in Helisoma corpulentum.

A larger form than pilsbryi is known as $H$. pilsbryi infracarinatum F. C. Baker which is common in southern Canada. While regarded as a race of pilsbryi there are some features of the genitalia which indicate that is a very distinet race (plate 25 , fig. 13 ). The seminal resicle (SV) and orisperm duct (SO) are similar to these organs in pilsbryi, but the prostate (PRS) is twice as long $(5.7 \mathrm{~mm}$.) and much larger, comparatively. There 
is also a greater number of diverticula. The spermatheea is trice as long (3 mm.) and the duct is longer $(3.5 \mathrm{~mm}$.). A cross section of the prostate near the lower end shows seventeen rows of long, club-shaped diverticula (fig. 12). In the penial complex (fig. 8), the preputium is normally very wide, pyriform, with the vergic sac small and narrow and about half as long as the preputium. In fig. 9, a penial complex is shown with the preputium pushed upward. The immature penial complex (fig. 10) is rery wide with a short duct, as in other immature forms of Pierosoma.

Helisoma corpulentum (Say) and its races inhabit the northern part of the United States and southern Canada. The genitalia greatly resemble those of $H$. pilsbryi infracarinatum. The principal features of the genitalia are figured on plate 31 .

In corpulentum (fig. 3 ), the seminal vesicle (SV) is long and wide (4 $\mathrm{mm}$. long, $0.7 \mathrm{~mm}$. wide). The prostate is $5 \mathrm{~mm}$. long, $1.5 \mathrm{~mm}$. wide, and $1.5 \mathrm{~mm}$. high (fig. 2). In cross section, this is scen to be composed of twenty long diverticula arranged fan-rise. The ovotestis (OT) oceupies a trifle over one whorl and consists of about eighteen rows of long diverticula (fig. 1). The spermatheca (S) is $2 \mathrm{~mm}$. long and is placed at the end of a very long duct $(5 \mathrm{~mm}$.). In form, the spermatheea is more nearly like that of infracarinatum. The normal form of the penial complex is shown in fig. 5, the preputium and vergic sac being about equal in length. Figure 4 shows a specimen in which the rergic sac is shortened and the upper part of the preputium has been pushed upward, a common characteristic in Pierosoma. The form of the penial complex in immature individuals is shown in figs. 6 and 7 , fig. 6 being from a younger specimen.

A race of corpulentum, multicostatum F. C. Baker, has the genitalia much as in the typieal form. Figures 9 and 10 show the form of the penial complex in immature individuals. Figure 11 is from an immature individual in which the vergie sac has been lowered to the side of the preputiun. Figure 12 also shows an immature condition. In fig. 13, the penial complex of a fully mature individual is shown, the preputium pushed upward and the long penial gland duet uncoiled tit is $14 \mathrm{~mm}$. long). The penial gland is shown in section in fig. 8.

Another race found only in Lake Vermilion, Minnesota, H. c. vermilionense F. C. Baker, shows no essential differences in its genitalia. The penial gland is rather shallow (fig. 15) but this could be from contraction. Figure 14 shows one form of the penial complex when the preputium is pushed upward. The gland duct is partly uncoiled. Figures 16, 17, and 18 show the penial complex of immature inclividuals, progressively from 16 to 18 . The penial duct is short in figs. 16 and 17 but much longer in fig. 18, the latter nearer maturity. Two forms assumed by the verge are shown in figs. 17 and 18.

Helisoma whitearesi F. C. Baker, a related species, apparently rare in Canada, is similar in its genitalia to Helisoma corpulentum. The penial complex of an adult individual is shown in fig. 19. The vergic sae differs from that of the corpulentum group in being very long $(5.5 \mathrm{~mm}$.) and slender. It is about as long as the preputium. The gland duct is very long (24 mm.). Compare fig. 19 with fig. 13, the shells being of the same size and age.

A large Pierosoma, Helisoma magnificum (Pilsbry), living in Greenfield pond, near Wilmington, North Carolina, resembles the northern pilsbryi 
and corpulentum. The prostate is $7 \mathrm{~mm}$. long and more than $1 \mathrm{~mm}$. wide and high. There are thirteen rows of diverticula. The spermathecal duct is very long $(12 \mathrm{~mm}$.) and narrow, and the spermatheca is $3 \mathrm{~mm}$. long. The organs of the female system are long and narrow. The penial complex (fig. 20) has a pyriform preputium and a cylindrical vergic sac. The penial gland duct is very long. Internally, the complex shows a large gland and a eylindrical verge, both nearly filling their respective cavities (fig. 21). A cross section of the penial gland is shown in fig. 22 . It is much like that of trivoleis.

\section{Species of the Rocky Mountains and Westward}

Several species and races of Pierosoma oceur in the western part of the United States and Canada. One of the most abundant and widely distributed species is Helisoma subcrenatum (Carpenter), the genitalia of which are figured on plate 30 (specimen not quite mature). Figure 15 pictures the whole genitalia, the organs spread out. The seminal vesicle is $2 \mathrm{~mm}$. long and is notable for the number of rather long resicles, principally bordering the gland, which is much wider than the ovisperm duct. The sperm duct (SPD) is short $(2 \mathrm{~mm}$. long) and the vas deferens is narrow and about $7 \mathrm{~mm}$. long. The prostate is about $2 \mathrm{~mm}$. long and is composed of twenty-four rows of diverticula, arranged fan-wise when seen in section (fig. 12). There is a short prostate duct at each end of the prostate which joins the sperm duct beneath the prostate. The spermatheca $(\mathrm{S})$ is about $1 \mathrm{~mm}$. long and the duct is long and narrow and about $2 \mathrm{~mm}$. long. The uterus ( $\mathrm{U}$ ) is narrow anteriorly and widens posteriorly into the nidamental gland ( $\mathrm{N}(\mathrm{i})$, which is a large organ $1 \mathrm{~mm}$. wide. The oriduct $(\mathrm{OD})$ is a narrow tube about $2 \mathrm{~mm}$. long.

The penial complex is about $3.5 \mathrm{~mm}$. long in fully adult specimens (figs. $17,19)$. The vergic sac is slightly shorter than the preputimm. The preputium is widely pyriform while the vergic sac is narrow and cylindrical. The penial gland duet is not very long $(3$ to $4 \mathrm{~mm}$.) and is normally coiled on the preputium. In vertical section (fig. 13), the penial complex shows a large penial gland (GL), a rather thick diaphragm (1)), and a thick, somewhat sausage-shaped verge (V). In section, the penial gland (fig. 11) is similar to that organ in tricolvis. In immature individuals, the penial complex is very wide and the duct is very short (fig. 10). In fig. 15, the penial duct and complex is of a young specimen. In adult or old specimens, there is more difference between the preputium and vergic sac and the duct is always longer. These differences are shown in figs. 17 and 18 (compare with figs. 10 and 15 ).

The genitalia of subcrenatum differ from those of the trivolvis group in the greater number of prostate diverticula, shorter penial gland duct, when adult, and the presence of the aculeate resicles in the seminal resicle.

A relative of subcrenatum, H. plexatum (Ingersoll), is figured on plate 30, fig. 4 (genitalia). The general characteristics of plexatum are like subcrenatum. The seminal vesicle (ST), however, is different in the absence of the digitate resicles and is more like the seminal resicle in pilsbryi. The prostate is $5 \mathrm{~mm}$. long and more than $1 \mathrm{~mm}$. wide. The spermatheca (s) is very narrow, over $2 \mathrm{~mm}$. long, and the duct is $5 \mathrm{~mm}$. long or nearly three times the length of the spermatheca. It resembles the spermatheca of trivolvis. The vergic sac is small and less than half the length of the 
preputium (fig. 1). In vertieal seetion, the penial complex shows the penial gland to be compressed as in subcrenatum (fig. 31 and not globular as in trivolvis. The penial gland duet is longer than in subcrenatum (figs. 1, 2,3), resembling trivolvis in this respect (compare figs. 1 and 17). The penial gland is shown in section in fig. 5 . The verge $(\mathrm{V})$ is large and long orate in form when at rest (fig. 6). The shapes assumed during extension in to the vergie sae eavity are shown in figs. 7, 8, and 9 . The retractor museles are as in subcrenatum.

The penial complex of a form of subcrenatum from Pass Lake, Fidalgo Island, Puget Sound, Washington, is figured on plate 32 (fig. 8). It is similar in form to the penial complex of subcrenatum figured on plate 30 (fig. 17), the preputium, however, being more cylindrical and less pearshaped and the rergie sae is relatively longer. The presence of the two small and narrow retractor muscles is noteworthy.

Another form related to subcrenatum, but believed to be of spceific rank, is Helisoma horni (Tryon) from Paul Lake, British Columbia. The genitalia are different from both subcrenatum and plexatum (plate 26, fig. 3). The seminal vesiele is similar to that of plexatum. The prostate is about $3 \mathrm{~mm}$. long. and $1 \mathrm{~mm}$. wide and has thirteen rows of large, club-shaped diverticula (fig. 5). These are mueh wider and less in number than in subcrenatum. The spermatheea (S) is bulbous, about $1 \mathrm{~mm}$. in length and the duet is $3 \mathrm{~mm}$. long, widening as it enters the narrow vagina. The penial complex (fig. 11 has a long vergic sac enlarged at the outer end. The preputium is pushed upward. The gland duet is about as long as in plexatum. The penial gland (fig. 2) is like that organ in trivolvis. A section through the sperm duct, oviduet and nidamental gland (fig. 4) indieates the relationship between these organs.

Many years ago Tryon deseribed a small Planorbis from Pueblo Valley, Oregon, ealling it Planorbis oregonensis (now Helisoma oregonense). This species has been one of the rarities of western Planorbidae. Specimens collected in Tooele County, Utah, by Mr. J. Henderson belong to this species and the anatomy of this small planorbid is now arailable. On plate 28, fig. 2, the prineipal organs of the genitalia are shown.

The seminal vesiele is about $1 \mathrm{~mm}$. long and the ovisperm duet about $3 \mathrm{~mm}$. long. The latter bears short lateral vesicles for a large part of its length, as in plexatum. The prostate is short (about $2 \mathrm{~mm}$. long) and bears sixteen rows of long and narrow diverticula (fig. 3). The spermathera is bulbous, about $0.7 \mathrm{~mm}$. in length and connects with the long and narrow ragina by a duet slightly more than $1 \mathrm{~mm}$. in length. The shape of the spermatheca is like that of horni but the duct is shorter. The penial complex (fig. 1) has a large, pyriform preputium with the lower part lengthened. The rergie sae is short, swollen at the end, and almost half the length of the preputium. The penial gland duet is very long $(5 \mathrm{~mm}$.). There is one retractor muscle (sometimes split into two smaller muscles), attached to the lower part of the preputium, and one band of supporting musele. The penial gland (fig. 4) is round, rather short, and attached to the wall of the preputium by a short, wide neck. In rertical section (fig. 5), the eup is circular, with relatively few large vertical folds and a number of pavement-like folds in the bottom of the cup, to which the gland duct is connected (DC). 
A Helisoma abundantly distributed in California, and believed to be a race of the Mexican Helisoma tenue (Phil.), has been named H. temue californiense by F. C. Baker. The genitalia are shown on plate 32, fig. 1 . The seminal vesicle $(\mathrm{ST})$ is wide and long $(5 \mathrm{~mm}$.). It swells in the center and tapers at each end. It is made up of many small vesictes. The ovisperm duct is $5.5 \mathrm{~mm}$. long, narrow, and for two-thirds of its length is bordered, on one side only, by many small, rounded resicles. These are probably part of the seminal resicle system. The sperm duct (SPD) is $3 \mathrm{~mm}$. long and is very narrow. The prostate is short $(1.3 \mathrm{~mm}$. longl and wide $(1 \mathrm{~mm}$.) and has twelve rows of long, club-shaped diverticula (fig. 6 , the prostate in section). The vas deferens (VD) is a long, narrow tube $11 \mathrm{~mm}$. long. The spermatheca $(\mathrm{S})$ is pyriform, $1.5 \mathrm{~mm}$. long, with a long, narrow duet about 2.5 mm. long, enlarged as it enters the long and narrow vagina (VCi). The orotestis is made up of very large, club-shaped divertieula in eleven rows.

The penial complex (fig. 3) has a large, pyriform preputium $2.2 \mathrm{~mm}$. long and a eylindrical vergic sac $1.5 \mathrm{~mm}$. long. The penial gland (fig. 5) is short and eup-shaped with many rertical folds. Its duct is relatively short $(5 \mathrm{~mm}$.). Figure 2 shows the penial complex with the preputium pushed uprard, the vergic sac placed at the side. There is a wide, very muscular diaphragm. The verge (fig. 2, V) is wide above but tapers to a narrow point below. Figure 7 shows the penial complex of a specimen from Prospect Park, near Redlands, California. The preputium is priform and very wide at the summit. It is $3 \mathrm{~mm}$. long. The verge is $3 \mathrm{~mm}$. in length and is not as pyriform in shape as in the other Californian specimens examined. The gland duct is over twice as long $(14 \mathrm{~mm}$.) as in the shandon specimens. The Prospect Park specimens are very large, which probably accounts for the great length of the duct. There is one large retractor muscle and one or two supporting museles.

The genitatia of californiense are peculiar in the great length and size of the seminal resicle, in the rery short prostate, and in the sessile penial gland.

One of the largest of west American planorbios is Helisoma trastio (Lea). The genitalia of this species are shown in fig. 17 on plate 32 . The seminal vesicle is shaped like that organ in califormiense (see fig. 1) and is coiled in much the same manner. It is about $9 \mathrm{~mm}$. long (when extended) and $1 \mathrm{~mm}$. wide and is composed of many small vesicles. The orisperm duct $(\mathrm{SO})$ is very long $(16 \mathrm{~mm}$.) two-thirds of which bears small, widelyspaced resicles on the lateral margin. The sperm duct is $6 \mathrm{~mm}$. long and $0.5 \mathrm{~mm}$. wide for two-thirds of its length and tapers to about half this diameter near the point of contact with the prostate duct. The prostate (PRS, is very long $(6.5 \mathrm{~mm}$.) and about one-fourth as wide as long 11.5 mm. wide). There is a short prostate duct branch at each end of the sperm duct beneath the prostate. In section (fig. 12), the prostate shows fourteen rows of diverticula of varying length, umbranched. In the section, the nidamental gland (NG) is composed of several large diverticula. The vas deferens is a long, narrow tube $(25 \mathrm{~mm}$. long). The spermatheca (S) is of unusual length $(3.5 \mathrm{~mm}$.), is club-shaped and is placed at the end of a very long duct $(10 \mathrm{~mm}$.) which enlarges at its point of entrance into the short, narrow ragina (VG). The orotestis (OT) consists of large, clubshaped diverticula of varying length, thirteen rows being counted in a 
section at the proximal end of the orotestis (see fig. 17, OT). The albumen gland $(\mathrm{AL})$ is squarish and is made up of small follicles.

The penial complex (fig. 14) has a prriform preputim $4 \mathrm{~mm}$. long and a sausage-shaped vergic sac $3 \mathrm{~mm}$. long (PR, VS). The penial gland duct (DC) is of medium length $(9 \mathrm{~mm}$. long) and is a narrow tube. The retractor muscle (RM) is wide and is dividect into two main branches, united at their attachment near the upper part of the preputium. The supporting muscle (SM) is rather narrow and is branched sereral times in its attachment to the upper part of the preputium on the opposite side from the retractor muscle.

Internally (fig. 11), the preputium has a large penial gland (GL) which is attached to the. wall of the preputium by a thick neck or base. Sectioned rertically (fig. 13 I the penial gland is seen to have a large eup bordered by large rertical folds (GF). The base of the eup has many folds to which the penial gland duet is attached (DC). One speeimen of traskii had a bifid tentacle (fig. 16).

The genitalia of Helisoma traskii are peculiar in the large prostate, the elongated spermatheea on an unusually long duet, and in the generally long and narrow uterus and vas deferens. It is clifferent from californiense in the size of the prostate and in the size and length of the spermathecal duct. The shorter penial gland duct allies trastio with californiense and separates it from plexatum.

Another large species found in California is Helisoma occidentale (Cooper), living characteristically in Klamath Lake, Oregon. Unfortunately, the material had been preserved in formalin and the anatomy could not be worked out in a satisfactory manner. The penial complex is like that of califormiense figured on plate 32 , fig. 3 . The vergic sac, however, is more elongated at the distal end. The greater number of specimens examined had the penial complex as shown in fig. 10, the preputium pushed upward and the vergic sac attached to the side about halfway between the extremities of the penial complex. The penial gland was about as in traskit (fig. 13). The verge, coiled in the rergic sae, is shown in fig. 9 . Other details are not available from these specimens.

Respiratory and Renal Systems. The pseudobranch of Helisoma trivolvis (plate 24 , fig. 12 ) is very wide. somewhat bilobed, with a narrow erest or ridge extending down the rectum $(\mathrm{R})$ and over the pseudobranch at about the center. The anal opening is to the left of the ridge. There is a large pneumostome (PS).

The shape of the pseudobranch does not vary to any degree in the different species and races of Pierosoma, excepting in the general shape which in many eases is broadly rounded below and not bilobed (see plate 25, fig. 11). Several of these are figured on the following plates: pilsbryi, plate 25 , fig. 3 ; infracarinatum, plate 25 . fig. 11 ; truncatum, plate 26 , fig. 11 ; subcrenatum, plate 30 , fig. 16 ; californiense, plate 32 , fig. 4 ; trashii, plate 32 , fig. 15 .

The kirlney of Helisoma trivolvis (plate 44, fig. 2) is elongated, 12.5 $\mathrm{mm}$. long and $2 \mathrm{~mm}$. wide at the upper part near the pericardium. The ureter is $1 \mathrm{~mm}$. long and is clirected backward, parallel to the length of the kidney. There is a conspicuous crest or ridge extending down the eenter of the kidney from just below the pericardium to within $1 \mathrm{~mm}$. of the lower 
end of the organ. A cross section of the kidner made at about the middle portion (plate 44, fig. 9) shows the ridge to be rather short and narrow and placed at about the middle of the kidney. The lumen is rounded and the reins at each end are large and placed at the center of the margin of the lumen. In the race lentum (plate 44, fig. 11), a section near the lower end shows a large, ovate lumen with the veins at the lower comers. The ridge is approximately like that feature in trivolvis. In macrostomum, the largest race of trivoliz, a section made near the lower end shows a small, much-elongated lumen with the veins at the lower lateral corners (fig. 10). The whole kidney is much larger and much thicker with a relatively small ridge.

The species and races of Pierosoma show considerable variation in the form of the lumen, and especially in the form and position of the ridge, which is found in all species of Hetisoma and its subgenera. Several of these are figured on plate 44 and need no special comment. Those figured are: pilsbryi, section near middle, fig. 12; infracarinatum, near middle, fig. 17; magnificum, near middle, fig. 14; corpulentum, near middle, fig. 15; multicostatum, section near lower end, fig. 16; truncatum, near middle, fig. 13; subcrenatum, near middle, fig. 21; plexatum, section near lower end, fig. 22: (compare figs, 21 and 22 and note difference in ridges); hormi, near middle, fig. 23; occidentale, near mirldle, fig. 18; depressum, near mirldle, fig. 19 (note difference in two races); traskii, near middle, fig. 20; califomiense, near middle, fig. 24; oregonense, near lower end, fig. 6 .

The kidney of corpulentum (fig. 3) is somewhat shortened and bent toward the pericardium. The ridge is broad at the upper part and then narrowed for the greater part of its length. A cross section is shown in fig. 15. Compare this with the kirney of trivolvis, figs. 2 and 9.

The kirney of califormiense is figured on plate 45 (fig. 4). It is relatively short and rariable in width. A cross section made through the upper part (fig. 5, at $\mathrm{B}$ in fig. 4) shows the roundly-orate lumen occupying the greater part of the kidney, with the veins at the middle on each sicle. A sertion made near the lower end of the kirlney (fig. 6, at A in fig. 4) shows a very wide and flattened lumen with the veins at each end, and a high, pointed ridge. Compare with fig. 21 on plate 44.

Digestive System. The digestive system of Helisoma trivolvis (plate 48. figs. 1.2) is characteristic of that of all species of Pierosoma. The size of the organs differs in the various species. The oesophagus $(\mathrm{OE})$ is a narrow tube as it leaves the buccal sac, increasing several times in diancter as it passes to the crop portion of the stomach. It is about $10 \mathrm{~mm}$. long. The stomach is composed of a short erop (CR), a bilobed gizzard (GZ), and an elongated pyloris (PY). The intestine (IN) makes a complete turn over the oesophagus, extends backward alound the liver, performs another loop, and rums forward to the columella muscle. The intestine is $33 \mathrm{~mm}$. long from the end of the pyloris to the rectum. The rectum is $10 \mathrm{~mm}$. long, is larger in diameter than the intestine, and is particularly characterized by the presence of a frilled crest or ridge (RD) which extends the whole length of the rectum and ends over the pseudobranch. In fig. 2 , the stomach is seen from below showing the position and form of the blind sac or caecum (BS) which is attached to the pyloris just below the opening of the liver (OLV). This blind sac is present in all species of Pierosoma. 
The buceal sac (BP) is a pear-shaped organ, $2 \mathrm{~mm}$. long and $1.5 \mathrm{~mm}$. high. The oesophagus leaves the oral cavity near the upper posterior portion of the pouch. There are two strong buccal retractor muscles (BR). The salivary glands (SG) are two in number, $3 \mathrm{~mm}$. long, which enter the buceal cavity near the oesophagus by a long, narrow duct (1 $\mathrm{mm}$. long) on each side. The salivary glands form a loop, their posterior cnds connected.

There is not much rariation in the form of the buceal sac in Pierosoma. In some species, as pilsbryi, corpulentum, tenue californiense, and subcrenatum (plate 70 , fig. 12), the whole sac is a trifle more elongated, especially in the fore part. There is reason to believe, howerer, that the more elongated aspect may be due to distortion in the animal when killecl. At the back end of all sacs there is a rounded or elongated radula sac (plate 70 , fig. 13, RL) which has to do with the formation of the ractula membrane. This raries in form in some of the species.

The jaw in Pierosoma is always of three parts. The superior jaw is oblong, wide and low, sometimes somewhat arcuated. The face of the superior jaw is marked by fine striations which form a more or less denticulate border to the jaw when seen with high magnification. There are two long and narrow lateral jaws one on each side bordering the lips of the animal, and usually seen in the form of a question mark. The jaw of Helisoma trivolvis is shown on plate 49, fig. 2, and this is characteristic of all members of the subgenus. The jaws of some other species are figured as follows:

truncatum, plate 49, fig. 3 ; pilsbryi, fig. 5 ; infracarinatum, fig. 8; cormulentum, fig. 15; magnificum, fig. 16; oregonense, fig. 6 ; subcrenatum, fig. 7 ; homi, fig. 9; plexatum, fig. 10; traskii, fig. 12; occidentale, fig. 13; californiense, plate 50, fig. 1 .

Radula. The radula of Pierosoma is similar to that of Seminolina in the bluntly rounded mesocone of the lateral teeth. The radula of the type species, Helisoma trivolvis, is shown on plate 55, fig. 1.

The center tooth has two spade-shaped cusps which do not reach the lower margin of the base of attachment. The lateral teeth (1-10) have a quadrate reflection which is tricuspid, the entocone and cctocone sharp and spade-shaped, the mesocone rounded. The intermediate teeth (11-13) have the reflection somewhat narrower and more elongated than the lateral teeth, the entocone breaking up into three small, sharp cusps and the ectocone region developing two or three cusps above the ectocone on the outer margin of the tooth. Marginal tecth (14-18) still narrower, claw-like, with the entocone broken up into four to five small cusps and the ectocone into four or more small cusps on the upper, outer margin of the tooth. The extreme outer marginal teeth are small, very narrow, and with slight denticulations. There is some variation from the type described above, some of the lateral tecth dereloping two cusps in place of the one ectocone, as shown in fig. 4.

The radulae of the races of trivolvis differ little from the type species. On plate 55, several of these are shown. lentum (figs. 6, 7) and pseudotrivolvis (=lentum) figs. 2, 3. The radula of the large race, macrostomum, is shown on plate 56. fig. 2. In chautauquense (plate 55, fig. 5), the lateral teeth (1-11) are narrower than in trivoleis. In winslowi (plate 56, fig. 1), the 
lateral teeth are also narrower. In pilsbryi (plate 56, fig. 3) and infracarinatum (plate 56, figs. 4,5 ) the laterals are more quadrate, similar to those of trivolvis, but the marginals show some variation. In truncatum (plate 57, figs. 1,2) the laterals are narrower (as in chautauquense and winslowi). In several laterals of truncatum, there was observed to be considerable splitting of the entocone and ectocone cusps tsee fig. 2 , plate 57 , teeth 1, 5-10). In the large magnificum, the intermediate teetl are very long and narrow, the ectocone is placed high up on the margin, and the extra eusps of the entocone appear later in the series (plate 57, fig. 4, 21-26). The marginal teeth are also narrow and the cuspiclation is different from that in trivolvis and other species of Pierosoma (fig. 4, 27-41). In corpulentum, the teeth are arranged in a similar mannel to those of trivolvis (plate 57, fig. 3). The races vermilionense and multicostatum (plate 58, figs. 2, 3) are similar in form. In whiteavesi (plate 58, fig. 1), the teeth are similar in form to those of the corpulentum group.

In the western group of Pierosoma, Hetisoma plexatum has narrower lateral teeth than trivolvis (plate 59, fig. 1). In specimens from another locality, howerer, the early laterals are quadrate (fig. 2). In specimens of plexatum from Rexburg, Idaho, many of the laterals, and some of the marginals, in one specimen had the mesoeone broken and wary and otherwise modified (plate 58, fig. 4). Other individuals were normal i fig. 5). A lateral and two intermediate teeth of a speeinem from smartweed Lake. Colorato, are shown in fig. 6 on plate 58. A form of subcrenatum from Pass Lake, Puget Sound, Washington, has quadrate teeth, similar to those of trivolvis plate 59, fig. 5). Another form from Lost Lake, Puget Sound, had very wide, low laterul teeth (plate 60 , fig. 1). In one speeimen from this locality, the center tooth of the eighty-eighth row had seren small cusps and the fifth lateral had two sharp entoronic emsps (plate 60 , fig. 2). Specimens from Skagit Comnty, Washington, were normal, with quadiate laterals (plate 60 , fig. 2 ).

Typical subcrenatum from Cottonwood Pass, near Gypsum, Colorado, is shown on plate 61 , fig. 2. There are eight subquadrate lateral teeth and four intermediate teeth. The marginal teeth are normal as to cuspiclation. An allied species, horni, has á large, somewhat obliquely formerl mosocone on the lateral tecth, which are not as quachate as in subcrenatum (1-9), the intermediate teeth are narrow and the entocone and ectocone are not broken into smaller cusps (10-14). The marginal teeth (15-32) are less cuspirlate than similar teeth in subcrenatum. The outer marginals (32) are small and more or less vestigial (see plate 60 , fig. 7 ).

The large traskii from Kern Lake, California, is peculiar in several respects (plate 60, figs. 4-6). A nearly complete row (the ninetieth) is shown in fig. 5. In the center tooth, the two large cusps extend a considerable distance below the lower nargin of the base of attachment. The lateral teeth (1-8) are longer than wide and are unmodified tricuspirl. The intermerliate teeth $(9-10)$ have the entocone and ectocone split into small eusps. The marginal teeth $(11-22)$ are wide and the denticulation is very irregular, small interstitial cusps appearing among the larger cusps in some teeth (as 11, 13, 14, 17). In another row (eightieth), the last intermediate tooth and the first marginal tooth were peculiar in this respeet (fig. 6). In the eighty-second row of another speeimen, this feature was well marked (fig. 4). 
In another large species of Picrosoma from Klamath Lake. Oregon (occidentale, plate 61, fig. 1), the teeth are more uniform with but little splitting of the eusps. The radula differences between the two speeies occidentale and traskii are rery marked, as shown on plates 60 and 61.

In specimens of tenue californiense from shandon, California tplate 63, fig. 2), the center tooth has two wide, spade-shaped cusps extending below the base of attachment. The laterals (1-11) are at first wider than high, the eusps rather short, but toward the marginal teeth they become narrower. The entocone and the eetocone tend to split in some teeth (as 1,3 , 6. 7). There is one narrow intermediate tooth (12). The marginal teeth (13-19) are narrow, the entocones 4-6 euspidate. In the 100th row of the same membrane, the entocone and ectocone of the lateral teeth were largely modified by splitting (see fig. 2 ).

In a radula from a specimen living in the San Bernardino Mountains. there were eleven laterals, one intermediate tooth and nine or more marginals. No splitting was observed in this radula but in another menbrane all of the laterals were abmormal (plate 59, fig. 4) in the sixtieth row, small cusps appearing irregularly on the entoconic region. The entocone of the first lateral was broken up into four small eusps. The intermediate and marginal teeth were narrow and many of them abnormal in the splitting of the entocone (as $14,16,17$ ). The mesocone in all teeth was more or less irregular. In fig. 6, a very abnormal eleventh tooth from another specimen is figured. The relatively small species oregonense (plate 61, fig. 3) has narrow laterals (1-8) and intermediate teeth (9-10). The marginals are normal for the group.

The radula formulae of the different species vary more or less and the individual radulae may differ in number of teeth in a row. For comparison all of the species of Pierosoma which have been examined, together with all of the localities represented, are shown in the following table. This also indicates the material studied and the source from which the material was obtained. More specimens were dissected for the genitalia than for the radulae. From one to seven specimens of each were examined.

Species

trivolvis

trivolvis

trivolvis

trivolvis

trivolvis

pseudotrivolvis

(=lentum)

pseudotrivoliv

pseudotrivolis

pseudotrivolvis

pseudotricolvis

lentum

fallax

macrostomum

macrostomum

macrostomium

macrostomum

chautauquense

truncatum

uinslowi
Formulae

23-1-23 to 26-1-26

$23-1-23$ to $24-1-24$

$23-1-23$ to $24-1-24$

23-1-23 to 25-1-25

$23-1-23$ to $24-1-24$

23-1-23 to 24-1-24

24-1-24 to $25-1-25$

22-1-22 to $24-1-24$

$23-1-23$ to $24-1-24$

$24-1-24$.

$23-1-23$ to $25-1-25$

26-1-26 to 2S-1-2s

$26-1-26$ to $2 \mathrm{~s}-1-2 \mathrm{~S}$

$2 \overline{\mathrm{i}}-1-27$ to $30-1-30$

$27-1-27$.

$31-1-31$ to $32-1-32$

$37-1-37$ to $39-1-39$

$24-1-2$ to $26-1-26$

20-1-20 to 21-1-21

$27-1-27$ to $29-1-29$

\section{Locality}

Canandaigua L., New York

Green Lake, Wisconsin

Devils Lake, Wisconsin

Murphy Creek, Wisconsin

Sturgeon Bay, Wisconsin

St. Joseph, Illinois

Peoria, Illinois

Reelfoot L., Tennessee

Iammoth Spgs., Arkansas

Ada Lake, Oklahoma

Trinity R., Texas

New Orleans, Louisiana

Near Boston, Massachusetts

Barfield, Wiseonsin

Moose Ear Creek, Wisconsin

Saskatoon, Canada

L. Crauveau, Canada

Chautauqua L., New York

Wimmebago L., WVisconsin

Arbor Vitae L., Wisconsin
Rous

143-167

148

126

$150-152$

110-134

141-167 F. C. Baker

149 F. C. Baker

$180 \quad \mathrm{Mr}$. Firkins

131-15.5 C. A. Llorde

150-160 A. D. Buck

150-181 E. P. Cheatum

147-186 E. C. Faust

144-170 W. J. Clench

180 F. C. Baker

155 F. C. Baker

173 D. s. Rawson

154-210 A. LaRoeque

127

126-129 F. C. Baker

125
A. R. Cahn 
magnifieum

pilsbryi

pilsbryi

pilsbryi

pilsbryi

infracarinatum 32-1-32 to 37-1-37

infracarinatum 31-1-31 to 38-1-35

infracarinatum $25-1-25$ to $27-1-27$

infracarinatum $30-1-30$ to $37-1-37$

infracarinatum 32-1-32 to 35-1-35

corpulentum

corpulentum

corpulentum

multicostatum.

multicostatum

multicostatum

rermilionense

vermilionense

whitcaucsi

subcrenatum

suberenatum

var.

suberenatum

var.

subcrenatum

var.

subcrenatiom

plexatum

plexatum.

plexatum

plexatum.

plexatum

horni

oregonense

occidentale

traskii

ealiformiense

californiense

caleforniense
$42-1-42$ to $43-1-13$ 27-1-27 to 29-1-29 $27-1-27$ to $29-1-29$ 28-1-28 to 29-1-29 $36-1-36$ to $41-1-41$ $25-1-25$ to $25-1-28$ $32-1-32$ to $35-1-35$ $40-1-40$ to $4.5-1-4.5$

3S-1-3s to 41-1-41 $30-1-30$ to $37-1-37$ $30-1-30$ to $31-1-31$ $25-1-25$ to $27-1-27$ $36-1-36$ to $42-1-42$ $25-1-25$ to $27-1-27$ $29-1-29$ to $32-1-32$

$25-1-28$ to $29-1-29$

$28-1-2 S$ to $31-1-31$

$30-1-30$ to $32-1-32$ 26-1-26 to 30-1-30 $25-1-25$ to $30-1-30$ $26-1-26$ to $30-1-30$ $27-1-27$ to $2 \mathrm{i}-1-2 \mathrm{~s}$ $27-1-27$ to $31-1-31$ $32-1-32$

20-1-20 to 21-1-21

$31-1-31$ to $32-1-32$ 28-1-28 to $30-1-30$ $2+1-2+$ to $25-1-25$ $26-1-26$ to $27-1-27$ $24-1-24$ to $27-1-27$
Wilmington, North Carolina 180

Chetek L., Wisconsin

Prairie L., IVisconsin

Chetek L., Wisconsin

Basswood R., Ontario

Bimaji L., Ontario

As above (immature)

Nille Laes, Ontario

Rickeau R., Ontario

Lake La Croix, Ontario

As above (immature)

Knife Lake, Minnesota

Kahmipiminanikok L.,

$$
\text { Minnesota }
$$

Mille Lacs swamp, Ontario

As above (immature)

Vermilion L., Mimnesota

As above (immature)

Nille Lacs, Ontario

Gypsum, Colorado

Pass Lake, Washington

Lost Lake, Washington

Pondilla L., Washington

Me Murray, Washington

Columbine L., Colorado

Smartweed L., Colorado

Grand Mesa, Colorado

Crooseberry Creek, Utah

Rexburg, İlaho

Paul Lake, British Colmmbia

Tooele Co., Etah

Klamath L., Oregon

Kern Lake, California

Shandon, California

San Juan R., California

Near Redlands, Californi:
F. C. Bake

205 F. C. Baker

F. C. Baker

F. C. Baker

140-163 A. R. Cahn

140-151 A. R. Cahn

140-153 A. R. Cahn

140-15.5 A. R. Cahn

171-177 A. LaRorque

165-190 A. R. Cahn

109-117 A. R. C'ahn

140-150 A. R. Cahn

163-170 A. R. Cahn

145-150 A. R. Cahn

152 A. R. Cahn

120-123 F. C. Baker

119 F.C. Baker

139-15t A. R. Cahn

123-130 J. Henderson

150-160 J. Henderson

134-146 J. Henderson

175-1S0 J. Henderson

150-170 J. Henderson

140-173 J. Henderson

155-170 J. Henderson

15.5 J. Hender'son

150-165 J. Henderson

145-15.5 J. Henderson

110-114 D. s. Rawsol

111-117 J. Henderson

150-160 J. Hender'son

161-182 S. Siegfus

15.5-160 Hamna \& Chureh

150 J. D. Hamna

140-157 s. s. Berry

Table Showng Range of Formulae in Different Species

\begin{tabular}{|c|c|c|c|c|}
\hline 23 to $2 \gamma$ & 25 to $2 S$ & 20 to 21 & 28 to 32 & 32 to $4 \pi$ \\
\hline $\begin{array}{l}\text { inolvis } \\
\text { indotrivolvis } \\
\text { antanquense } \\
\text { liforniense }\end{array}$ & $\begin{array}{l}\text { fallux } \\
\text { lentum } \\
\text { suberenatum } \\
\text { plexatum }\end{array}$ & $\begin{array}{l}\text { truneatum } \\
\text { oregonense }\end{array}$ & $\begin{array}{l}\text { suberenatum var. } \\
\text { occidentale } \\
\text { traskiii }\end{array}$ & $\begin{array}{l}\text { infracarinatum } \\
\text { corpulentum } \\
\text { multicostatum } \\
\text { whiteavesi } \\
\text { horni }\end{array}$ \\
\hline
\end{tabular}

This table shows that, while there is wide variation in the formulae of the radulae in Pierosoma, the range within the species is fairly constant. The difference in many membranes is due to the presence of several extra marginal tecth on some radulae which do not appear on others. It is to be observed, also, that the immature animal usually has a smaller formula than the same species when adult. This is noted in the table under several species (infracarinatum, corpulentum, vermilionense, and multicostatum). Magnificum has the largest formula, 42-1-42 to 43-1-43.

Geographical Distribution. The subgenus Pierosoma is clistributed from Ungava, Labrador, Mackenzie, and Alaska southward to Georgia, Louisiana, Texas, and California, the whole of Mexico, and southward, on the west coast of South America, to Peru. In the West Indies, it is known 
from Cuba, Jamaica, Haiti, and other islands. The metropolis of the group is in North America, prineipally in southern Canada and northern United States, where the largest number of species and races is found. Southward the number of species rapidly decreases, only two speeies being known from South America and four from the West Indies. These appear to be species which have migrated southward in past geologieal time, possibly by the aid of migrating birds.

In the recent fauna, no member of the Helisoma group is found outside of North and South America. In Pleistocene deposits, however, a form of Helisoma allied to trivolvis has been reported by Lindholm (1933) from the Kolyma River in northeast Siberia beyond the Aretic Circle. It would appear that this planorbid is not referable to trivolvis but to some form like hormi or subcrenatum. The latter species is common in northwestem British America and also occurs in Alaska. The siberian form should probably be allied with subcrenatum. Lindholm ealled it Helisoma trivolvis kolymense but it might be better to designate it simply as Helisoma kolymense Lindholm until more is known about its affinities. As suggested by Pilsbry (1933, p. 137), it might represent a migration by the way of the old land bridge between Alaska and Siberia, used by both nan and other mammals during Pliocene and Pleistocene times.

Species Considered as Valid. The large number of species attributable to the genus Helisoma, subgenus Pierosoma, are listed below. The names Helisoma (Pierosoma) are understood to be prefixed before each specific name in the list.

ammon (Gould)

binneyi (Tryon)

calodermum (Pilsbry)

caribacum caribaeum (d'Orbigny)

caribacum guatemalense (Clessin)

chantauquense F. C. Baker

contrerasi (Pilsbry)

corpulentum corpulentum (Say)

corpulentum vermilionense F. C. Baker

costaricense (Preston)

equatorium (Cousin)

eyerdami Clench and Aguayo

foveale (Menke) (= affine C. B. Adams)

horni (Tryon)

kolymense Lindholm

magnificum (Pilsbry)

multicostatum multicostatum F. C. Baker

multicostatum whiteavesi F. C. Baker

occidentale occidentale (Cooper)

occidentale depressum F. C. Baker

oregonense (Tryon)

peruvianum (Brod.)

pilsbryi pilsbryi (F. C. Baker)

pilsbryi infracarinatum F. C. Baker

\author{
plexatum (Ingersoll) \\ salvini (Clessin) \\ subcrenatum subcrmatum (Carpenter) \\ subcrenatum disjectum (Cooper) \\ tenue tenue (Philippi) \\ teme boucardi (Fischer and Crosse) \\ tenue californiense $\mathrm{F}$. C. Baker \\ tenue chapalcnse (Pilsbry) \\ tenue exaggeratum (Martens) \\ tenue pertenue F. C. Baker \\ (= applanatus Martens preoccupied) \\ tenue simuosm (Bonnet) \\ tenue strebelianum (Fisch. and Crosse) \\ traskii (Lea) \\ trivolvis trivolvis (Say) \\ trivolvis fallax (Haldeman) \\ trivolvis lentum (Say) \\ trivolvis macrostomiom (Whiteaves) \\ trivolvis turgidum (Jeffreys) \\ (= intertrxtum (Sowb.)) \\ truncatum (Miles) \\ tumens (Carpenter) \\ winslowi (F. C. Baker) \\ wyldii (Tristram)
}

Remarks. Pierosoma is a very distinct group of Helisoma, distinguished from the subgenera Helisoma and Seminolina by peculiarities of genitalia and radula. The duct of the penial gland is always longer in adult animals than in the other groups mentioned. Some of the special anatomical features have been described and figured in the preceding pages. The shell is large and distinctly sinistral, especially in immature specimens. Pierosoma is the dominant planorbid group in North America north of Mexico. 


\section{Subgenus PLANORBELLA Haldeman, 1842}

Type by original designation Planorbis campanulatus Say

1542. Planorbella Haldemax, Mon. FW. Univ. Moll., Physidae, p. 14. Type Planorbis campanulatus Say (plate 1, figs. 7-11, 1844)

1861. Adula H. Adaus, Proc. Zool. Soc.. p. 145. Type Planorbis multivolvis Case. Non Adula H. and A. ADAMs, 1857

1865. Planorbella Brxwer, L. FW. Sh. N. A., II, p. 109. Type Planorbis campanulatus Siy. As subgenus

1865. Adula Bixver, op. cit., p. 111. Type Planorbis multivolvis Case. As subgenus

1869. Ancacus H. Adxus, Proc. Zool. Soc., p. 275. Non Ancacus Fauvel, 1863. In place of Adula, preoceupied

1870. Mlanorbclla Dall, Ann. Iye. Nat. Hist. N. Y., IX, p. 351. Type Planorbis campanulatus Sity. As subgenus

1570. Adula Dall, op. cit., p. 351. Tyge Planorbis multivolvis Case. As subgenus

1870. Plamorbella Tryox, Contr. Hald. Mon., pp. 188, 196. Type Planorbis campanulatus siay. As subgemus

1870. Adula Triox, op. cit., pp. 188, 197. Type Planorbis multivolvis Case. As subgentss

1883. Planorbclla Fisciner, Man. de Conch., p. 509. Type Planorbis campanulatus Say. As section of Plamorbis

1SS3. Adula Fischer, Man. de Conch., p. 509. Type Planorbis multivolvis Case. As section of Planorbis

1884. Planorbclla Tryox, S. and S. Conch., III, p. 106. Type Planorbis campanulatus Sily. As subgenus

1881. Adula Triox, op cit., p. 106. Type Mlanorbis multivolvis Case. As subgenus.

1886. Adula C'Lessix, Conch. Cab., XVII, p. 33. Type Planorbis multivolvis Case. As subgenus

1886. Manmbclla Clessix, op. cit., p. 33. Type Planorbis campanulatus Say. As subgenus

1902. Plamorbella F. C. BAкer, Moll. Chi. Area, II, p. 294. Type Planorbis campanulatus Say. As subgenus

1905. Mlanorbclla D.ıu, Alaska Moll., pp. 81, 85. Type Planorbis campanulatus Say. As section of subgenus Helisoma

1912. Planorbella Haxibal, Proc. Mil. Soc. London, X, p. 159. Type Planorbis campramulatus Siyy. As subgenus

1918. Mlanorbclla Walkir, Miscel. Pub. Mus. Zool., Univ. Mich., No. 6, pp. 12, 94. Type P'lanorbis compamulatus Say. As subgenus

1921. Manorbella Germaix, Rec. Ind. MIss, XXI, pp. 7,66 . Type Planorbis campanulatus siy. As subgenus

1926. Planorbclla F. C. B.tкer, Trans. Wis. Acad. Sci. Arts, XXII, p. 202. Type Planorbis campamulatus say. As subgenus

1927. Mypsogyra Lindiolu. Trav. Com. l'Etude Lac Baikal, II, p. 181. New name for Adula H. Adams, 1861, preocexpied

1928. Planorbella F. C. BAKer, Fresh-water Moll. Wis., I, P. 345. Type Planorbis campanulatus Say. Radula and genitalia. As subgenus

1931. Planorbclla F. C. BAker, Proc. Zool. Soc., P. 586. Type Planorbis campanulatus Say. Genitalia and radula. As subgenus

1931. Adula F. C. Baker, op. cit., p. 566. Type Planorbis multivolvis Case. As synonym of Planorbella

1931. Hypsogyra Tninele, Handbuch, Teil 2, p. 479. Type Planorbis multivolvis Case. As section of Planorbis

1931. Planorbclla Thiele, Handbuch, Teil 2, p. 479. Type Planorbis campanulatus Sily. As section of Planorbis

Shell. Sinistral, of medium size, resembling Pierosoma in general form but the last whorl notably restricted behind the aperture which is campan- 
ulate (plate 80, figs. 16-18, campanulatum (Say); figs. 19-21, multivolvis (Case)).

Animal (plate 70, fig. 1, campanulatum). With short, wide foot, oval in shape, otherwise like Pierosoma. Color dark reddish brown or blackish, bottom of foot very dark reddish with flecks of white, tentacles dark colored with indistinct white rings. There is some variation in the shades of color. The animal is usually very slow in movement.

ANATOMICAL CHARACTERISTIC'S

PLATE 27 (Helisoma campanulatum (Say))

GENITALIA. Male Organs (fig. 15). The seminal vesicle (SV) is short and wicle (about $2 \mathrm{~mm}$. long and $0.5 \mathrm{~mm}$. wide) and the vesicles are very large and comparatively few in number. They are mostly attached laterally. A few short resicles extend down the ovisperm duct for about $1 \mathrm{~mm}$. The sperm duct (SPD) is about $4 \mathrm{~mm}$. long and $0.3 \mathrm{~mm}$. wide. The prostate (PRS) is long $(4.5 \mathrm{~mm}$.) with a short prostate duct at each end which connects with the sperm duct and the vas deferens. There are fourteen rows of diverticula of rarying length, the median ones the largest, the outer ones the smallest. Some of the diverticula are branched toward the end, the section figured (fig. 12) showing four such branches. The section also shows the fan-like pattern of the diverticula. The ras deferens (VD) is a long and narrow duct $(16 \mathrm{~mm}$. long).

The penial complex (fig. 11) is much like that of Helisoma trivolvis. The preputium is distinctly pear-shaped, $1.5 \mathrm{~mm}$. long, the vergic sac (VS) smaller, shorter $(1.5 \mathrm{~mm}$. long) and club-shaped, and very narrow at its junction with the preputium. The penial gland duet (DC) is very long $(5.5 \mathrm{~mm}$.) and narrows considerably at each end where it enters the preputium and the rergie sac. Normally, the long penial gland duct is coiled on the preputium between this organ and the vergic sac, as shown in fig. 9, DC. Usually, there is one more or less branched retractor muscle (RM) but in some specimens two retractors were observed (fig. 9). There are several (1-3) narrow supporting muscles (figs. 5-8, 10, 11) or there may be one wide band with sereral smaller muscles. In fig. 9, two small muscles are shown below the retractor muscles. These are attached to the wall of the mantle cavity and not to the columella muscle.

Internally (fig. 10), the preputium has several vertical folds or pilasters and a muscular, eup-shaped penial gland (GL) which is attached by a small neck to the wall of the upper third of the preputium. In section (fig. 1), the gland is eup-shaped, one side of the cup being thicker than the other as shown in the figure (BIT). There are many vertical, thickwalled folds (GF) and a number of small, flat, pavement-like folds in the bottom of the cup from which the gland duct (DC) proceeds to the exterior of the preputium. The space between the preputium and the vergic sac is ahmost closed by a thick muscular ring or diaphragm (fig. 3. D) which is dependent between the walls of the preputium. The penial gland duct enters the vergic sac immediately above this diaphragm (DV). The verge (fig. $10, V$ ) is club-shaped, tapering rapidly toward the end.

In figs. 5 to 7 , the penial complex of $H$. campanulatum smithi is shown indicating how the preputium becomes pushed upward and the rergic sae 
appears to descend to the middle of the preputium. In fig. 8, the penial complex of $H$. campanulatum canadense is shown with the preputium notably pushed upward.

Female Organs (fig. 15). The spermatheca $(S)$ is very long $(2.5 \mathrm{~mm}$.), sac-like and tapers to the long $(5.5 \mathrm{~mm}$.), narrow spermathecal duet (SD). The ragina ( $\mathrm{VG}$ ) is $1 \mathrm{~mm}$. long and is very narrow. The uterus ( $U$ ) is long $(7.5 \mathrm{~mm}$.) and narrow. The nidamental gland (NG) is about $4 \mathrm{~mm}$. long. very wide, and sae-like. The free oriduct (OD) is about $2 \mathrm{~mm}$. long and is about twice as wicle as the sperm duet. There is a large, elongated earrefour (CF). The albumen gland (fig. 2) is orately rounded and is composed of many small follicles. The space for the passage of the intestine is conspicuous (fig. 2, IN).

Hermaphrodite Organs (fig. 15). The orotestis (OT) consists of eight or more rows of club-shaped diverticula, some of which may branch two or three times, as shown in the seetion fig. 4 (FOV), this branehing rendering the counting of rows difficult. The figure shows fourteen rows on the surface and but eight entering the ovisperm duet. The free portion of the orisperm duet $(\mathrm{SO})$ is $3 \mathrm{~mm}$. long near the oriduet but only $1 \mathrm{~mm}$. long near the orotestis.

The only previous deseription and figures of the genitalia of Helisoma campamulatum are by F. C. Baker (1931, p.585, plate iv) where the penial complex is shown (plate 27, figs. 10-11 of this work).

Respiratory and Renal Systems. The pseudobranch (plate 27, fig. 13) is leaf-shaped, broadly orate, with a ridge down the center which is a continuation of the ridge on the rectum $(R)$. The pneumostome is large.

The kidney (plate 45) is similar to that of Pierosoma as represented by Helisoma trivolvis. Sections through the kidney of $H$. campanulatum visconsinense are shown in figs. 15, 16, and 17. In fig. 15, the section through the upper part shows a large rounded lumen with a large vein on each sicle near the middle. The ridge does not begin until lower down on the kidney. Figure 16 shows a seetion through the middle of the kidney. The lumen is larger than in fig. 15, the veins are at the lower part on each side, and the ridge is just begimning to show. In fig. 17, taken through the lower part of the kichey, the lumen is smaller, the veins relatively larger. and the ridge forms a high erest. All rarieties of campanulatum show essentially this form of kidney.

Digestive System. The general digestive system does not differ from that of Helisoma trivolvis. The buceal sae is much elongated, differing in this respect from many of the species of Picrosoma.

The jaw (plate 49). The superior jaw (of smithi, fig. 11) is elongated and low, somewhat arched, its face covered with vertical striations as shown in fig. 20. The lateral jaws are about as in Pierosoma.

The radula (plate 62). Typical campanulatum (fig. 1) has a wide, bicuspid center tooth, the eusps not reaching the lower margin of the base of attachment. The lateral teeth (1-7) are squarish, tricuspid, with the mesocone bluntly rounded, the entocone and ectocone aculeate. The intermediate teeth (8-9) have smaller, sharper mesocones and the entocone and eetocone are modified by the addition of smaller cusps. The marginal teeth (10-13) are long and narrow, somewhat elaw-like, with the entocone wide and armed with from four to eight small eusps. The mesocone is small 
and spade-shaped. The eetocone is modified to form three small cusps. The outer marginal teeth $(20)$ are simply serrated and much smaller than the earlier marginal teeth.

The races wisconsinense and canadense (figs. 2, 3) differ little in their radulae from trpical campamulatum. H. campanulatum smithi is also similar (fig. 4), the lateral teeth showing a gractual change in the form of the mesocone. The teeth $6-9$ might all be called intermediate, since the mesueone is alike in all. Smithi has a larger tooth formula than any of the other races of campanulatum. The radulae of the subgenus Planorbella are in all respects like those of Pierosoma.

The formulae of the different races are shown in the table below:

Race

campenulatum 20-1-20 to 22-1-22

c. wisconsincuse $21-1-21$ to $22-1-22$

c. wisconsinense 21-1-21

c. canadense 21-1-21 to 23-1-23

c. corudense 21-1-21 to 23-1-23

c. smithi

\section{Locality}

Oneida Lake, New York

Muskellunge L., Wisconsin

North Star Lake, Wisconsin

Sturgeon L., Ontario

Basswood R., Ontario

Donglas L., Michigan

\begin{tabular}{ll}
\multicolumn{1}{c}{ Rows } & \multicolumn{1}{c}{ Collector } \\
120 & F. C. Baker \\
125 & A. R. Cahn \\
132 & F. C. Baker \\
$123-129$ & A. R. Cahn \\
139 & A. R. Cahn \\
$130-135$ & F. Smith
\end{tabular}

Helisoma campanulatum wisconsinense was also studied anatomically from Lake Nipissing, Ontario.

Geographical Distribution. Planorbella has been eolleeted from Great Slave Lake, Labrador, Quebee, and Ontario south to New York, Ohio, and Illinois. Westward it extends to North Dakota and Nebraska. It is essentially a group of the northern part of the United States and Canada. In this area it varies considerably and several races have been reeognized. These appear to be mostly local races, not geographieal, possibly environmental variations.

Species Considered as Valid. The following species and races are recognized:

Helisoma (Planorbclla) campanulatum campanulatum (Siay)

Helisoma (Planorbella) campanulatum wisconsinense (Winslow)

Hclisoma (Planorbclla) campanulatum davisi (Winslow)

Helisoma (Planorbella) campanulatum canadense F. C. Baker

Helisoma (Planorbella) campanulatum collinsi F. C. Baker

Hrlisoma (Planorbclla) campanulatum michigancnse F. C. Baker

Hclisoma (Planorbclla) campanulatum mudentis (Dall)

Hctisoma (Planorbella) campanulatum smithi (F. C. Baker)

Ilelisoma (Planorbella) multivolvis (Case)

Geological Distribution. Pleistocene to Recent fauna.

Remarks. Exeept for the campanulate aperture of the shell there is nothing in the anatomy to separate Planorbella from Pierosoma. The genitalia, with the long penial gland duct and the eup-shaped penial gland, the pseudobranch, and the kidney are all like these organs in Pierosoma. The radula is also the same. The shape of the shell, with its closely-eoiled whorls and particularly the bell-shaped form of the aperture, may be features characteristic enough to retain Planorbella as a subgenus of Helisoma.

H. Adams has ereeted the group Adula (preoceupied) to admit the very peeuliar Planorbis multivolvis Case, a species living in Howe Lake, Michigan. As the race collinsi of Helisoma campanulatum approaches this species in the form of the shell, it would appear that the group name is without value in nomenelature. Lindholm (1927) coined a new name, 
Hypsogyra, in place of the preoceupied names Adula and Ancacus. Should this species prove, after anatomical investigation, to have characteristics different from Planorbella, it should bear Lindholn's name. It is very rare and the animal is wholly unknown. It seems, from the features of the shell, perfectly safe to merge the group with Planorbella (see plate 80 , figs. 19-21).

\section{Genus CARINIFEX IV. G. Bimey, 1863}

Type by original designation Planorbis newberryi Lea

1863. Carinifex Brxxey, Smith. Check-List of Shells. Type Planorbis newberryi Lea. As genus

1864. Megasystropha LEA, Proc. Acad. Nat. Sci. Phil., p. 5 (footnote). Type Planorbis neuberryi Lea. As gents

1865. Carinifex Brxyey, L. and FW. Sh. X. A., II, p. 74. Type Camifex newbermi (Leil). As genus

1865. Carinifex, Amer. Jour. Conch., I, p. 50, plate vii, figs. 6-7

1870. Megasystropha Tryox, Con. Hald, Mon., 1) 84

1870. Carinifex Tryos, Con. Hald. Mon., P1. 187, 214. Type Carinifex newberryi (Lea). As genus

1870. Carinifex Dall, Ann. N. Y. Lyce. Nat. Hist., IX, pp. 344, 353. Type Planorbis newbermi Lea. As genus

1883. Carinifex Fischer, Man. de Conch., N. 508. Type Carinifex newberryi (Lea). As subgenus of Choanomphalus

1884. Carimifex Tryox, S. and S. Conch., III, p. 105. Type Carmifex newberryi (Lea). As genus

1912. Carinifex Haxxibal, Proc. Mal. Soc. London, X, p. I62. Type Carinifex newberryi (Lea). As subgenus of Pompholyx

1918. Carinifex Walker, Miscel. Pub. Mus. Zool. Univ. Mich., No. 6, pp. 15, 106. Type Planorbis neuberryi Lea. As genus

1923. Carimifex Germaix, Rec. Ind. Mus., XXI, p. 18s. Type Carinifex newberryi (Lea). As genus

1923. Carinifex Wenz, Fossil. Cat., Pars 22, p. 1671. Genotype Carinifex newberryi (Lea). As genus

1924. Carinifex Datu, Prof. Pajers U. S. Geol. Surv. No. 132 (G) p. 112. As synonym of Ilegasystropha Lea

1924. Megasystropha Dall, op. cit., p. 112. Type Planorbis newberryi Lea. As genus 1925. Megasystropha LeA, Smith. Miscel. Coll., LXXIII, No. 3, Dec. 16. Opinion 87, Int. Com. on Zool. Nomenclature

1926. Carinifex Pilsbry, Science, LXIV, p. 248, Sept. 10. Defending use of this name instead of Megasystropha Lea

1929. Carinifex J. Henderson, Unir. Col. Studies, Xili, No. 2, p. 143. Type Carinifex neuberryi (Lea). As genus

1929. Carinifex Chamberdix and Jones, Bull, Univ. Utah, XIX, No, 4, p. 155. Biol. Series I, No. 1. Genotype Planorbis newberryi Lea. As genus.

1931. Carinifex Thiele, Handbuch, Teil 2, p. 480. Type Carinifex newberryi (Lea). As genus

1934. Carinifex Pilsbry. Proc. Acad. Nat. Sci. Phil., 86, p. 48. Type Planorbis newberryi Lea. As genus. Figures genitalia of Carinifex ponsonbyi and C. newberryi subrotunda

1935. Carinifex J. Henderson, Non-Marine Moll. N. A., p. 255. Disenssion of genus and listing of fossil species $C$. malheurensis Henderson and Rodeck

Shell (plate 78, figs. 23-25). Medium to large, ultradextral, body whorl angulated; spire depressed or elevated, the whorls terraced and angular; base funieular; last whorl broad at the periphery, rapidly attenuated below; aperture triangular, outer lip thin; inner lip with slight eallus. 
When the spire of Carinifex becomes elongated the shell is dextral although anatomically the animal is sinistral like that of Helisoma.

Animal. Resembling Helisoma in general form, but the tentacles are shorter (see plate 34 , fig. 1).

\section{ANATOMICAL CHARACTERISTI('S}

\section{PLATE 34 (Carinifix ponsonbyi E. A. Smith)}

GENITALIA. Male Organs (fig. 4). Seminal resicle (SV) represented by many short resicles bordering the orisperm duct for a length of $4.5 \mathrm{~mm}$. Sperm duet (SPD) long and nalrow $(2.5 \mathrm{~mm}$. long), diminishing to less than half its diameter as it joins the vas deferens, which is a tube of fine diameter, 14-15 mm. long. The prostate (PRS) is elongated $(3.5 \mathrm{~mm}$. long). A section, through the prostate and uterus (fig. 7) shows that the prostate is peculiar in having the diverticula (14 in this section) oecurring laterally from a main pouch into which they empty and which, in turn, empties into the sperm duct. There appears to be no special prostate duet at each end, as in Helisoma. A section through the upper end of the prostate (fig. 8) shows only 11 diverticula but the arrangement is the same.

Penial complex (fig. 2). The preputium (PR) is elongated and sac-like, $4.5 \mathrm{~mm}$. long and about $1 \mathrm{~mm}$. wide at its greatest diameter. The vergic sac (VS) is short $(1.5 \mathrm{~mm}$. in length) and there is no marked constriction between the two sacs, as in Pierosoma. The musculature is lifferent from that feature in Helisoma. There are two sets of retractor muscles (RMI), one set, composed of two main branches with several small branches, is attached to the vergic sae and the upper part of the preputium; the other set, composed of two or more branching divisions, is attached to the upper part of the vergic sac, with one branch connecting with a branch of the first set. The vas deferens passes under this branch. There are three sets of supporting muscles (SII) attached to the preputium. These are dirided several times in their attachment to the preputim and to the roof of the mantle carity. Several small muscles appear on the base of the preputium below the first set of retractor muscles.

Another specimen of ponsonbyi (plate 35 , fig. 1) had a variation of this musculature, there being but one main retractor in the first set, and several narrow muscles, much branched, in the second set. The supporting muscles (SM) were also somewhat different. All specimens have a very short (about $0.5 \mathrm{~mm}$. long) penial gland duet on the outside of the penial complex between the vergic sac and the preputium (DC). This duct does not vary in any of the specimens examined.

Internally (plate 34 , fig. 3), there are two fleshy pilasters in the preputiom (PL). These are shown in section in fig. 12. The penial gland (GL) is an elongated, somewhat pyriform sac, narrowed at its junction with the body wall of the preputium and enlarged at the eup-shaped eavity. A section of the gland (fig. 10) shows many vertical glandular folds on the wall of the cup and a number of parement-like folds in the bottom of the cup (IC). The gland duet (DC) extends into the emp and connects with the vertical and parement-like folds. The verge $(\mathrm{V})$ is short and thick. There is a muscular ridge or diaphragm (D) separating the carity of the vergic sac from the preputial cavity.

Female Organs. The spermatheea (S) is about $1 \mathrm{~mm}$. long, long-ovate in shape and has a narrow duct (SD) almost $2 \mathrm{~mm}$. in length, which enters 
the short ragina ( $\mathrm{VG}$ ) without marked swelling. Another form of spermatheca and duet, from another specimen, is shown in fig. 11. The uterus (U) is tough and leathery, long and wide $(6 \mathrm{~mm}$. long and $1 \mathrm{~mm}$. wide), and is covered with wart-like prominenees. The nidamental gland (NG) is wide and somewhat globular, covered with small follicles. The oviduet (OD) is much narrower than the uterus and is about $3 \mathrm{~mm}$. long and $0.3 \mathrm{~mm}$. wide. There is a large, swollen carrefour (CF). The relationship of the organs near the junction with the ovisperm duct is shown in fig. 6. The albumen gland (fig. 5) is about twice as long as wide and lies erosswise of the body. The space for the passage of the intestine is shown near the center of the figure.

Hermaphrodite Organs (fig. 4). The orotestis (OT) is composed of large club-shaped cliverticula. A scetion of this organ near the front end is shown in fig. 9. Six rows of liverticula of varying length are to be seen. The sections vary in different parts of the orotestis. There may be only six unbranched rivertieula of large size, or there may be six or seven main branches, each branch subdivided two or three times to form a surface aspect of fourteen, fifteen, or eighteen diverticula. The free ovisperm duct $(\mathrm{s} O)$ is very short and appears only between the oviduet and the seninal resicle.

In another species, Carinifex jacksonensis (plate 35, fig. 5), there is some deviation from the structures as seen in ponsonbyi. The seminal vesicle (SV) forms a grape-like bunching just beyond the ovotestis labout $1 \mathrm{~mm}$. long and $0.7 \mathrm{~mm}$. wide) with lateral vesicles on the ovisperm duet as in ponsonbyi, and for the suceeeding $2 \mathrm{~mm}$. with rery small resicles which appear as fine erenulations on one side only. The prostate (PRS) is shorter (only $3 \mathrm{~mm}$. long) and is connected with the sperm cluct in the same manner as in ponsonbyi. The diverticula are of the same form and condition as in ponsonbyi. The spermatheca and its duet are also of about the same form (see fig. 9). In figs. 6 and 7 , the features near the junction of the ovisperm duct are shown. There is a large carrefour (CF). The albumen gland (fig. 8) is relatively shorter than in ponsonbyi.

The penial gland is of the same form as in ponsonbyi (fig. 3) and has the same short gland duct. The retractor muscles (RMI), however, are much more complicated in form and position. They are much smaller, narrower, and more mumcrous. The supporting muscles (S.II) are small and numerous and are attached to both vergic sac and preputium. Small muscles on the retractor muscle side of the preputium and on its lower half, are attached to the wall of the mantle cavity. These are believed to be supporting muscles. The attachment of the retractor muscles to the vergic sac is shown in fig. 2, which is the reverse of fig. 3 .

Pilsbry (1934, p. 50) figured the genitalia of Carinifex ponsonbyi differing in some respects from the drawings on plate 34 . The musculature is nearly the same but is not shown in as great detail as in the figures on plate 34 . The spermatheea is more nearly spherical in Pilsbry's figure. The seminal resicle is shown as a mass of small vesicles, much as seen in Carinifex jacksonensis on plate 35 ( fig. 5). The penial complex and penial gland in $C$. newberryi subrotunda are figured. It is probable that the sex organs vary somewhat in form, especially those that are evertible. Also, the condition of the preserved material will make a great difference, espe- 
eially in those organs like the nidamentat gland, the uterus and the oriduet, which may become swollen and thus alter the true form of these organs.

Three species of Carinifex have been dissected by Pilsbry and the writer, ponsonbyi, jacksononsis, and newberryi subrotunda, and all show the homogeneity of the group and its distinctness from Helisoma.

Respiratory and Renal Systems. The pseudobranch (płate 34, fig. 1) of ponsonbyi is a rounded extension from the rectal region, in form like that in Helisoma, inchuding the rectal ridge which extends over the pseudobranch. In jacksonensis (plate 35, fig. 4), the pseudobranch is narrower. In the specimen figured, the pseudobranch was folded in such a manner as to make the ridge appear on the left margin of the organ.

The kidney (plate 45 , fig. 2 ) is long and narrow $(15 \mathrm{~mm}$. long, 1 to 1.2 $\mathrm{mm}$. wide) and the ureter is reflexed at right angles to the kidney. A section of the kidney near the middle (fig. 12) shows it to be much flattened, with a bottle-shaped lumen and roundly elongated and flattened reins. There is no superposed ridge like that in Helisoma. The ridge on the mantle to the left of the kidney is seen in the seetion to be flattened and wide.

Digestive System. The digestive system is similar to that of Pierosoma. The stomach region is shown on plate 48 , fig. 3 . The intestine is looped about the stomach and liver. The buceal sac is similar to that organ in Helisoma.

The jaw is peculiar. There is but one jaw which is horseshoe-shaped, narrow, eomposed of many small, vertical plates which produce a saw-like edge. In ponsonbyi (plate 49, fig. 19), there are spiral striae on the jaw plates. In jacksonensis this striation is not visible (plate 49. fig. 18). The jaw is attached to a very large cartilage which has the relative shape and size shown in fig. 17. In fig. 19, the jaw is somewhat distorted. The jaw of Carinifex bears some resemblance to the fragmented jaw of the Planorbinae, but the general form is different.

Radula. The radula of Carinifer ponsonbyi (plate 67. fig. 8) has a square, bicuspid center tooth, the spade-shaped cusps extending below the lower border of the base of attachment. The lateral teeth (1-6) are trieuspid, all cusps sharply spade-shaped, inchding the mesocone. In some rows, single cusps may become bifid, as the ectocone in the fifth lateral tooth in fig. 8. The intermediate teeth $(7-8)$ differ only in the splitting of the ectocone into two sharp cusps. The marginal teeth $19-27$ ) are long and narrow, the entocone remaining unchanged at first $(9-10)$ but the ectocone undergoing additional splitting. On the elerenth tooth the entoeone begins to split, developing three small. sharp cusps. In the outer part of the membrane, the marginal teeth become narrower and the entocone splits into seven very small, sharp cusps and the ectoconic area becomes simply serrated along the outer margin. The mesocone remains unchanged throughout the entire row.

In Carinifex jacksonensis (plate 65 , fig. 4 ), the teeth have practically the same shape, but are smaller. There are ten lateral teeth and two intermediate teeth. In the splitting of the marginal teeth, the inner cusp of the entocone is larger than the four eusps on the inner side of the mesocone. This feature persists throughout the radula. The radula formulae of the two species are as follows:
ponsonbyi
$32-1-32$
Klamath Lake, Oregon jacksonensis
$25-1-25$
Jackson Lake, Wyoming 
The data for the specimens examined are as follows: ponsonbyi, from lower end of Upper Klamath Lake, Klamath Falls, Oregon, collected by Mr. and Mrs. J. Henderson, August 7, 1931; ten specimens dissected. Jacksonensis, from Jackson Lake, at Moran, Wyoming, in shallow water just above dam at very low water stage, eollected by Mr. and Mrs. Henderson, August 20, 1931; eight speeimens dissected.

Geographical Distribution. Carinifex is a purely American group found only in westem America from California eastward to Wyoming. Pilsbry believes that all of the deseribed speeies and races of Carinifex are subspecies of a single stock comparable to the subspecies of Helisoma anepps (Menke). There are, indeed, comparable characteristies between these two groups, although the anceps group is much more widely distributed, both in latitude and area, and is subject to more diverse environmental influences than is Carinifex.

Species Considered as Valid. A eareful study of all species, many speeimens from the type lots, learls the writer to the following eonclusion eoncerning the specific range of the genus. There are doubtless anatomical characteristies which separate some of the species as has been noted in ponsonbyi and jacksonensis.

Carinifex newberryi newberryi (Lea) Carinife $x$ ncwberryi minor Cooper Carinifex newberryi malleata Pilsbry Carinifex newberryi subrotunda Pilsbry

Carinifex occidentalis Hanna Carinifex ponsonbyi E. A. Smith

Carinifex jactisonensis J. Henderson

Geological Distribution. Pliocene to Recent fanna. The genus may extend as far back as the Miocene period.

Remarks. Carinifex has been thought to be closely allied to Helisoma and Pilsbry states $(1934$, p. 48) that there is very little structural difference between the two groups. There are, however, characteristics of both shell and anatomy which, in the judgment of the writer, are sufficient to mark Carmifex as of generic rank. The ultradextral shell bears some resemblance to certain forms of typical Helisoma but the anatomy, especially the genitalia, exhibits features of importance. The external penial gland duet is shorter than in any form of Helisoma and is of different form. The prostate, when seen in section, shows the diverticula to be formed in a totally different manner from those of Helisoma. The musculature of the penial complex is far more complex with two distinet retractor museles. The jaw is also of entirely different shape and nature. The radula teeth have the mesocone as it is in typieal Helisoma. The kidney is without a superposed ridge.

By a ruling of the International Commission on Zoologieal Nomenclature (Opinion 87), the name Carimifex of $\mathrm{W}$. G. Binney has been ruled out of systematic nomenclature because of its publication in what is termed a 'proof sheet' and therefore not usable as a nomenclatorial referenee. Proof sheets are obviously not to be quoted as systematie references to publication, but the example chosen to sustain this ruling was most unfortunate, since the publication in which the name Carinifer appeared (Smithsonian Miscellaneons Collections), is an oetaro pamphlet of twelve leaves, printed on one side (the left) for corrections. This pamphlet was widely distributed among conchologists and is even now available among seconthand book dealers. The contention that this pamphlet is merely a 
'proof sheet' seems unwarranted and the writer fully agrees with Pilsbry (1926, p. 248) that Carinifex was sufficiently 'published' by Bimey and that this name should be used in place of Megasystropha Lea, which is ruled by the Commission to be used instead of carinifex.

Dall (1870) says (in footnote under Carinifex) "Megasystropha Lea. Neither genus was characterized by the author, and the former is in general use and has priority.' In 1924, however, Mall reversed this opinion (Prof. Papers, p. 112) and used Megasystropha as the name for this group, contending that the earlier 'proof sheets' of 1863 were simply proofs and should not he quoted. However, in a general review of the literature of this genus, it is evident that the name Carinifex has been almost universally used, as noted in the bibliography of the genus on a previous page of this volume. Henderson $(1929$, p. 143$)$ well states the situation in the following words. 'It must not be forgotten that the purpose of rules of nomenclature is to insure, so far as possible, stability of names and certainty in their use in the designation of species, etc., which purpose would be defeated rather than accomplished by this proposed substitution.' The name Carinifex is, therefore, adopted in this work.

\section{Genus VORTICIFEX Neek, 1870}

Type by original designation Carinifex tryoni Meek

1870. Vortifex Mеeк, Proc. Acad. Nat. Sei. Phil., p. 59. Type Carinifex (Vortifex) tryoni Meek, new species. Proposed as subgenus of Carinifex Binney

1870. Vorticifex D.tL, Ann. N. Y. Lye. Nat. Hist., IX, p. 353. Correction of Vortifex, originally misspelled. Type Carinifex tryoni Meek.

1871. Vorticifex Meek, Tryon, Amer. Jour. Conch., VI, p. 285, April, 1871. Review of Meek's paper. Vortifex corrected to Vorticifex and Carinife $x$ tryoni stated to be the type

1877. Vorticifex MeEk, U. S. Geol. Surv. 40th Parallel, IV, p. 187. Subgenus described and Carinifex bimeyi and tryomi both placed therein

1883. Vorticifex Fischer, Man. de Conch., p. 508. Type Carinifex tryoni Meek. As subgenus of Carinifex

1884. Vorticifex Tryox, S. and S. Conch., III, p. 105. Type wrongly stated to be Carinifex bimeyi Meek. As subgenus of Carimifex

1888. Vorticifex Call, Amer. Geol., I, p. 148. Genus formally described and Carinifex bimneyi Meek wrongly designated as type

1922. Vorticifex Haxsa, Univ. Oregon Pub., I, No. 12, p. 7. Type Carinifax tryoni Meek. As genus

1924. Paradines Dall, U. S. G. S., Prof. Papers, No. 132, p. 112. Type by original designation Carinifex binneyi Meek. As section of genus Megasystropha

1935. Torticifex Henderson, Fossil Non-Marine Moll. N. A., p. 255. Type Carinifex tryoni Meek. As genus

Shell (plate 76, fig. 12 tryoni; fig. 13, binneyi). Large, ultradextral, of few rapidly enlarging, rounded whorls, the body whorl very large, rounded, and sculptured with distinct, rib-like striae parallel with the lines of growth; right side flatly convex; left side with deep 'umbilical' depression almost completely obscuring the inner whorls; aperture large, rounded.

'The chief clistinguishing features of the genus are (1), lack of carinae, either at periphery, suture or around umbilieus; (2), much rounder body whorl than Carinifex: and (3), much less triangular aperture than Carinifex' (Hanna, 1922, p. 7). 
Geological Horizon and Distribution. Eocene. Truckee Lake beds, Nevada; Payette Lake beds, Idaho; Fossil Hill. Kawsoh Mits., Nevada; Pliocene, Cache Valley, Mendon, Collinston, Utah; Tulare formation, Kettleman Hills, Califomia; Warner Lake beds, eastern Oregon. A single speeies, Torticifex stcarnsii (White) has been reported from the Morrison formation in Wyoming, belonging in the upper. Jurassic or Lower Cretaceous period.

Species Considered as Valid. The following species and races have been referred to this genus.

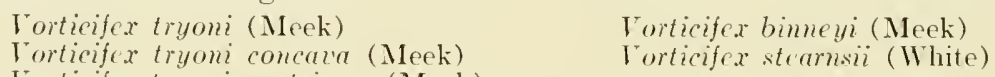

Remarks. Torticifer appears to be a rather distinet genus related to both Carinifex and Parapholyx. The wide body-whorl with its distinct costae is quite characteristic. The name Paradines Dall (1924, p. 112) founded upon the larger species Carinifex binneyi Meek does not appear more than specifically distinct from the smaller Carinifex tryoni Meek. Both speeies seem, from the published figures, to be generically elosely related and to be distinet from the genus Carinifex.

Several species referred to Torticifex appear to belong elsewhere. Torticifex sanctacclarae Hamibal and $T$. sanctaeclarae marshalli Arnold seem rather to belong in Camifex as originally deseribed rather than in Torticifex as listed by Henderson (1935, p. 257). They were placed in Carinifex by Pilsbry (1934, 1). 567). The Torticifex larus of Chamberlin and Berry i Nautilus. XLVIJ, p. 26, 1933) does not appear to fit into the genus Torticifex, but might be included in the genus Carinifex. It appears to be an internal cast and the external characteristics would not show clearly in such a condition.

\section{Genus PERRINILLA Hamibal, 1912}

Type by original designation Helisoma cordillerana Hamnibal

1912. Perrinilla Haxvibal, Proe. Mal. Soc. London, X, p. 159. Type Helisoma cordillerana Hannibal. As subgenus of Helisoma

1923. Perrinilla Wexz, Fossil. Cat., Pars 22, p. 1518. Genotype Planorbina (Perrinilla) cordillerana (Hannibal). As subgenus of Planorbina Haldeman

1934. Perrinilla Pussery, Proc. Acad. Nat. Sci. Phil., 86, p. 48. Type Helisoma cordillerana Hannibal. Presumably considered as genus

1935. Perrinilla J. Hexpersox, Fossil Non-Marine Moll. of N. A., p. 246. Type Helisoma cordillcrana Hannibal

Shell (plate 79, figs. 31-32). "Similar to Planorbella, except that it is totally ultra-sinistral; spire-pit deep and narrow, umbilieus but slightly excavated, superior and inferior peripheries subangular' (Hannibal for subgenus).

Shell of considerable size. whorls large, somewhat compressed, and strongly ultrasinistral, the umbilicus barely concave, superior and inferior peripheries subangular in young stages, becoming rounded in adult, growth striae strong, spiral striae oceasionally preserved, aperture expanded somewhat in adult; habitat apparently lacustrine. Diameter 22, alt. 9, diameter of aperture $12 \mathrm{~mm}$.' (Hamnibal, p. 161, description of Helisoma cordillerana). 
Geological Horizon and Distribution. Eocene period. Truckee Lake beds. Nevada, several localities. Miocene. Contra Costa Iake beds, California, Planorbis pabloanus .J. G. Cooper, 1894, is believed by Hannibal to be eongeneric.

Species Considered as Valid. Perrinilla cordillerana (Hamibal), the genotype, is the only recognized species of the genus.

Remarks. Perrinilla appears to be more elosely related to Carinifex than to Helisoma, as suggested by Pilsbry $(1934$, p. 49), who says

Perrinilla Hannibal, 1912 . . . seems to stand near the form of the Carinifex phylum to be expected in the Eocene, and it may possibly belong in the ancestral line of Carinifex.

The best disposition of the group in planorbid classification appears to be as a distinct genus near Carinifex.

Genus PARAPHOLYX Hanna, 1922

Type by original designation Pompholyx effusa Lea

1856. Pompholyx Les, Proc. Acad. Nat. Sci. Phil., VIII, p. S0. Type Pompholyx effusa Lea. Not Pompholyx Goose, 1851, Rotifera. As genus

1857. Pompholyx Lea. Journ. de Conch., VI, p. 208. As genus

1865. Pompholyx W. G. Binver, L. and FW. Sh. N. A., II, p. 73. Type Pompholyx effusa Lea. As genus

1866. Pompholyx Dall, Proc. Cal. Acad. Sci., III, pp. 265, 268. Description of subfamily Pompholiginae

1868. Pompholyx J. E. Grar, Ann. Mag. Nat. Hist., (4) II, p. 387. As genus

1870. Pompholyx: Dald, Ann. N. Y. Lyc. Nat. Hist., IX, pp. 334, 344, 353. Type Pompholyx effusa Lea. As genus. Anatomy imperfectly described

1870. Pompholyx Trrox, Con. Hald. Mon., pp. 83, 174. Type Pompholyx effusa Lea. As genus

1883. Pompholyx Fischer, Man. de. Conch., 507. Type Pompholyx effusa Lea. As genus

1884. Pompholyx Tryos, S. and S. Conch., III, p. 105. Type Pompholyx effusa Lea. As genus

1856. Pompholyx Cuessix, Conch. Cab., XVII, p. 226. Type Pompholyx effusa Lea. As genus

1912. Pompholyx Haxisal, Proc. Mal. Soc. London, X, p. 162. Type Pompholyx effusc Lea. As genus

1918. Pompholyx Walker, Miscel. Pub. Mus. Zool., Unir. Mich., No. 6, pp. 14, 105. Type Pompholyx effusa Lea. As genus

1922. Pompholyx Germaix, Rec. Ind. Mus., XXI, p. 185. Type Pompholyx cffusa Lea. As genus

1922. Parapholyx Haxxa, Univ. Oregon Pub., I, No. 12, p. 5. New name for Pompholyx Lea, 1856, non Goose, 1851

1927. Pompholyeodea Lixdholi, Proc. Commission for study of Lake Baikal, II, p. 180. New name for Pompholyx Lea, not Goose

1929. Parapholyx J. Hexnersox, Univ. Col. Studies, XVII, No. 2, p. 145. Type Pompholyx effusa Lea. As genus

1931. Pompholycodea Thiele, Handbuch, Teil 2, p. 480. Type Pompholyx effusa Lea. As genus

1934. Parapholyx Plusbry, Proc. Acad. Nat. Sci. Phil., 86, pp. 46, 51. Trpe Pompholyx effusa Lea. As genus

1935. Parapholyx J. Hexdersox, Fossil Non-Marine Moll. N. A., p. 254. As genus

1936. Parapholyx F. C. Baker, Nautilus, L, pp. 30-31. Notes on anatomy 
Shell (plate 78, figs. 20-22). Of medium size, ultradextral, globose, the spire short and but little raised above the body whorl which is ventricose and embraces most of the shell; aperture wide, greatly expanded; outer lip thin, acute, somewhat reflexed in adult or old specimens; inner lip more or less thickened; base convex or conical, imperforate or with but a small chink.

Animal (plate 36, fig. 1). Foot short, about half as broad as long. Telum as in Helisoma. Tentacles short, eylindrieal, blunt at the end, not tapering. Eyes sessile at the inner base of the tentacles. The eyes are not conspieuous in some preserved speeimens. The body is darkly pigmented, the pigmented areas extending to the head and sometimes forming streaks on the tentacles. The posterior portion of the body is light gray. The ovotestis area is yellowish.

\section{ANATOMICAL CHARACTERISTICS}

PLATE 36 (Parapholyx effusa kilamathensis F. C. Baker)

GENITALIA. Male Organs (fig. 3). Seminal vesiele (ST) about 4 mm. long, swollen, with many small resicles projecting from the otherwise smooth surface. The sperin duct (SPD) is about $3 \mathrm{~mm}$. long and of large diameter $(0.4 \mathrm{~mm}$.). The prostate (PRS) is long $(3.5 \mathrm{~mm}$.) and wide and is composed of many smahl diverticula. In section (fig. 4), these diverticula are seen to be composed of about a dozen irregular follicles linked together like sausages. From the outside of the prostate, these diverticula appear to be covered with small tubercles irregularly placed. These follicles enter the sperm duct at a common center, shown at $\mathrm{X}$ in the figure. The vas deferens is about half the diameter of the sperm duet and is $11 \mathrm{~mm}$. long.

The penial eomplex (fig. 7 ) is sac-like and is nearly $4 \mathrm{~mm}$. in length. The preputium is $1 \mathrm{~mm}$. wide and oceupies most of the length of the penial complex. The vergic sae (VS) is $1 \mathrm{~mm}$. long and $0.7 \mathrm{~mm}$. wide. There is only a slight constriction between the preputium and the rergic sae. The penial gland duet is relatively short (about $1.5 \mathrm{~mm}$. long) and rather thick. It extends from the preputium near its upper third and enters the vergie sae at the eonstricted area. The portion of the duct entering the vergic sac and the preputium is very small and narrow, the duet swelling greatly in dianeter on the surface of the preputium. There are two scts of retractor muscles, each set eonsisting of two main branches which subdivide several times at the penial sac insertions and at the connections in the columella muscle. All insertions are on the preputium, none on the vergie sac. There are several narrow supporting museles (SM) attached to the preputium.

Internally (fig. 9), the preputium has two large, fleshy folds or pilasters (PL). There is a much elongated, cylindrical penial gland (1.7 mm. long) which resembles a pipe-stem, with a eup-shaped or bowl-shaped gland (about $0.5 \mathrm{~mm}$. in diameter placed at the lower end (CI.). The duct (DC and $\mathrm{X}$ ) enters the cylindrieal portion of the gland and extends through this stem-like portion, then enters the bowl-like eup of the gland where it is enlarged into a bulb-like body (fig. 11, X). The cup-shaped gland resembles the bowl of a pipe. In scetion (fig. 11), the eup shows a shallow area at the top and the sicles are lined with wide, thick folds (GF). The bottom of the bowl-like eup is covered with small follicles which are 
placed at the upper end of the rounded enlargement of the penial gland duet. The right pilaster is attached to the gland at its upper end, curring towarl the gland beneath the gland duet.

There is a thick ring or diaphragm (D) which separates the carity of the preputium from the rergic carity. This diaphragm has a circular canal into which the upper end of the penial gland duct, which is greatly diminished in diancter, enters. This feature is shown in fig. 10. The rerge (T) is narrowly pyriform, tapering to a point at its lower end. The sperm canal extends through the center of the verge and has a central outlet (fig. 12). A large nerve and blood ressel supply the penial complex (fig. 8).

Female Organs (fig. 3 ). The spermatheca (S) is large and egg-shaped, almost globular. It is connected with the short, narrow ragina ( $\mathrm{VG}$ ) by a narrow duct shorter than the length of the spermatheca (SD). The uterus ( $\mathrm{C}$ ) is narrow as it passes upward from the vagina but increases abruptly in diameter to three times the width of that region, combining with the nidamental gland. This region is concealed by the prostate in fig. 3. The oviduct (OD) contracts in diameter to form a sac-like organ of small diameter. There is a large carrefour (CF). The albumen gland (AL) is 4 mmln. long and is longer than wide. The duct of this gland is $\operatorname{long}(0.5 \mathrm{~mm}$.).

Hermaphrodite Organs. The orotestis (OT) is long and sac-like and is composed of screral club-shaped diverticula. A section near the middle of the orotestis (fig. 5) shows eight rather long diverticula, the longest follicles being in the center. A section near the posterior end (fig. 6) shows six diverticula in less fan-like pattern. Sections from the middle to the anterior end show eight diverticula all in fan-shaped pattern, but scetions made toward the posterior end show but six diverticula which are more or less irregularly arranged. The ovisperm duct is rery short in the portion betreen the orotestis and the seminal resicle. The free portion near the oviduct is somewhat longer. The seminal resicle (SV) occupies about twothirds of the length of the ovisperm duct.

The genitalia of Parapholyx effusa diagonalis Henderson, also dissected, do not differ from the figures and descriptions herein presented.

In 1870. Dall dissected Pompholyx solida and published descriptions and sereral figures of the genitalia. These are not in sufficient detail and embrace some errors, such as the presence of a distinct testicle on the male srstem. This might have been the albumen gland. As far as can be seen. the anatomy of solida is similar to that of the species personally examined and herein figured.

Respiratory and Renal Systems. The pscudobranch (fig. 2) is a triangular appendage extending from the rectal region. There is a distinct lidge cxtending over the rectum in a broad curve, ending above the anus.

The kidney (plate 46, fig. 1) is short and wide (about $3 \mathrm{~mm}$. long and $1 \mathrm{~mm}$. wide); the ureter is large and sharply reflexed. directed upward into the mantle carity. The pericardium is also large (about $1 \mathrm{~mm}$. long). A cross section of the kidney near the middle (fig. 2 ) shows a much flattened form with a wide lumen, the veins orate and flattened, and placed at the lower lateral sides of the lumen. There is no ridge and the scetion resembles that of Carinifex.

Digestive System. The stomach is like that of Carinifex and essentially as described by Dall for Pompholyx solida. The oesophagus is short 
and is enlarged just behind the buecal sae. The salivary glands form a loop. The bueeal sac is short, high and prriform, as in Carinifex.

The jaws are three in number, differing markedly from the single horseshoe-shaped jaw of Carmifex. The superior jaw is low and about three times as wide as high. The side jaws are as in Hclisoma. The face of the superior jaw is striated rertically. There is little difference between the jaws of hlamathensis and diagonalis. Dall says there are no accessory plates (side jaws) but they oecurred in all speeimens personally examined. The jaw figured by Dall (his plate 2, fig. 11a) is different from the jaws found in the two races examined.

The radula of $P$. effusa klamathensis (plate 65 , fig. 3 ) has a squarish center tooth, the bicuspid refleetion not reaching the lower margin of the base of attachment. The lateral teeth (1-8) are squarish and tricuspid, all cusps being sharp and spade-shaped. The intemediate teeth (9-11) are narrow, the ectocone splitting into two sharp cusps as long as, or nearly as long as, the mesocone. There are two small eusp on the outer border of the tooth, above the ectocone. The marginal teeth (13-15) are narrow, the entocone with four to fire small cusps, the ectoconie region with three cusps. The onter marginal teeth (16-19) are very narrow and are simply serrated on the eetoconic side, there being no dirision into entocone, mesocone, and eetocone. Dall's figure of the radula of solida (his plate 2, fig. 9) shows the lateral teeth with a rounded mesocone and all cusps appear too blunt. The marginal teeth are too wide and the small cusps are not shown.

Radela Formela or Parapholyx

\begin{tabular}{lllll}
\multicolumn{1}{c}{ Speeies } & Formula & \multicolumn{1}{c}{ Locality } & Rows & \multicolumn{1}{c}{ Collector } \\
klamathensis & $19-1-19$ & Klamath Lake, Oregon & 125 & J. Henrlerson \\
diagonalis & $21-1-21$ & Crater Lake, Oregon & $100-114$ & J. Henclerson \\
solida & $22-1-22$ & White Pine, Nevada & 150 & Dall's paper
\end{tabular}

The following material has been examined for the anatomical data contained in this work. P. effusa klamathensis from outlet of Upper Klamath Lake, (Oregon, eight specimens examined. P. effusa diagonalis from Crater Lake, Oregon, eight specimens examined. Both lots eolleeted by J. Henderson.

Geographical Distribution. Parapholyx is purely an American genus confined to the west coast of Ameriea from Washington southward to California and eastward to Nevada. Pompholyx leana H. and A. Adams was described from 'West Columbia,' but no speemen of this genus has been seen from British Columbia and it is very doubtful that the genus is found north of the United States. A number of species and races have been deseribed and the same opinion expressed for the division of Carinifex may also apply to this genus.

\section{Species Considered as Valid.}

Parapholyx effusa effusa (Lea)

Parapholyx effusa eostata (Hemphill)

Parapholyx effusa diagonalis

$$
\text { J. Henderson }
$$

Parapholyx effusa klamathensis F. C.

Baker

$$
\begin{aligned}
& \text { Parapholyx nevadensis J. Henderson } \\
& \text { Parapholyx mailliardi Hanna } \\
& \text { Parapholyx solida solida (Dall) } \\
& \text { Parapholyx solida optima (Pilsbry) } \\
& \text { Parapholyx leana (H. and A. Adams) } \\
& \text { Species practically unknown }
\end{aligned}
$$

Geological Distribution. Parapholyx is eertainly known from the Pliocene to the Recent fauna. It may oceur in earlier deposits. One extinet 
species is known, Parapholyx packardi Hanna, from Warner Lake deposits in eastern Oregon.

Remarks. Parapholyx is a very distinet genus both in shell and anatomy. The shell is depressed and almost neritaeform. The anatomy is peculiar in several respects. The prostate is not composed of distinet clubshaped diverticula, but of small gland-like bodies arranged like a string of sausages. The penial gland is not a short, (up)-shaped organ, as in Carinifer, but an elongated, pipe-shaped body with a eup-like termination, with a long duet passing through the center of the longitudinal, sac-like 'stem' of the gland. The termination of the duct is swollen and bulb-like, expanding in the bottom of the penial gland cup. The penial gland duct is external as in Carinifex, but it is somewhat longer and of greater diameter. The jaw is like that of Helisoma and is not fragmented like that of Carinifex. The genus stands out as one of the most distinct among American planorbids.

In 1866. Dall instituted a subfamily Pompholiginae for Pompholyx effusa, basing the separation on the supposition that there were two pairs of eres. one at the inner base of the tentacles and one at the end of the tentacles. The fact of this peculiar condition was positively stated by Mr. William M. Gabb, who made drawings of the animal. Dr. J. E. Cray (1868, p. 387) questioned this statement. In 1870, D)all obtained speeimens of a Pompholyx (Parapholy $x^{\circ}$ ) different specifieally from the known species, which he ealled solida. An examination of the tentacles of this speeies at once cleared up the anomaly of the four eyes, the supposed eyes on the end of the tentacles being simply an aggregation of pigment. Only one pair of eyes is present, at the inner base of the tentacles. as is the case in other species of Planorbidae.

Dall still retained the subfamily Pompholiginae (1870, p. 352 ) although the chief reason for its adoption, the four eyes, had been found to be invalid. The subfamily has been used by most writers on fresh-water Mollusca, including Fischer (1883, p. 507). Tryon (1884, p. 105). Walker (1918, p. 14), Germain (1922, p. 185), Henderson (1929, p. 143), and Chamberlin and Jones (1929, p. 155). Hannibal (1912, p. 161) elevated it to fanily status as Pompholigidae. Dall has also used the name Pompholiginae for a section of the marine genus Divarieella (Proe. U. .. Nat. Mus., XXIII, p. 814, 1901).

The study of the animals of Carinifex and Parapholyx shows that they have no general anatomical characteristies not shared by Helisoma and the subfamily Pompholiginae must therefore be abandoned. This course was inclicated by Pilsbry in 1934 (p. 46). In 1936 (Nautilus, L, p. 30), the writer indicated the general anatomical features of Parapholyx', showing its general relationship to Helisoma and Carinifex and stating that the old subfamily Pompholiginae was without anatomical distinction.

\section{Genus POMPHOLOPSIS Call, 1888}

Type by original designation Pompholopsis whitei Call

18ss. Pompholopsis Call, Amer. Geol., I, No. 3, p. 147. Type Pompholopsis whitei Call. As genus

1935. Pompholopsis J. Hendersox, Fossil Non-Marine Moll. N. A., p. 255. Type Pompholopsis whitci Call. As genus 
Shell (plate 76. fig. 11). 'Dextral, globose, rather solid, deeply unbilicated; whorls three to three and one-half, convex, body-whorl very large; spire short, apex obtuse; aperture roundly ovate; peritreme continuous, forming a heary callus on the parietal wall of the body-whorl. Growth lines ineonspicuous, surface of the shell smooth; sutures rather irregularly impressed. Length $7.26 \mathrm{~mm}$.; diameter $8.13 \mathrm{~mm}$.' (Call, 1888, p. 147).

Geological Horizon and Distribution. Post-plioeene (Pleistocene). Tassajara Lake beds, California.

Species Considered as Valid. Pompholopsis whitei Call is the only species assigned to this genus.

Remarks. Pompholopsis differs from Parapholyx in being deeply unbilicated and in haring a high spire and smaller, rounder aperture. It is related to Parapholyx but appears sufficiently distinct to justify a genus. A series of shells might add greatly to our knowledge of the relationship of this species.

\section{Genus PLANORBARIUS Froriep, 1806}

Type by original designation Helix comea Limn.

1806. Planorbarius Froniep, in Duméril, Analyt. Zool., p. 165. Type Ilelix cornea Linn. As genus

1810. Planorbis Moxtfort, Conch. Syst., II, 1. 270. Type Planorbis corncus (Linn.). Non Geoffroy or Iü̈ller. As genus

1840. Planorbis Swarcox, Treat. Malac., p. 337. Type Planorbis corneus (Linn.). As genus

1817. Corctus (Adanson, 1757) Grar, Proc. Zool. Soc. London, p. 180. Type Planorbis eorneus (Linn.). As genus

1850. Spirodiscus Sterx, Schn. u. Muscheln Berlin, p. 73. Type (1st species): Planorbis corncus (Linn.)

1855. Corctus Moquin-Taxdox, Hist. Moll. Terr. Flur. France, II, pp. 424, 445. Type Planorbis eorneus (Linn.)

1870. Plamorbis Dall, Ann. N. Y. Lyc. N. H., IX, p. 351. Type Planorbis corneus (Linn.). As genus

1883. Spirodiscus Frscher, Min. de Conch., p. 509. Type Helix corneus Linn. As section of Planurbis

1884. Planorbis Tryox, S. and S. Conch., III, p. 106. Type Planorbis comeus (Linn.). As genus

1885. Coretus Westerluxd, Fauna Pal. Reg., V, p. 64. No type cited. As subgenus of Planorbis

1886. Coretus Clessix, Conch. Cab., XVII, p. 32. Type Planorbis eorneus (Linn.). As subgenus

1902. Spirodiseus Westerlund, Rad. Jugoslar. Akad., 151, p. 120. Type Helix comea Linn. As subgenus

1905. Planorbis D.tL, Alaska Moll., p. S1. Type Planorbis eomeus (Linn.). As genus 1917. Planorbis Soos, Ann. Musei Nat. Hungarici, XT, pp. 37, 140. Type Planorbis corneus (Linn.)

1918. Planorbis Walker, Miscel. Pub. Mus. Zool., Univ. Mich., No. 6, p. 94. Type Planorbis corneus (Linn.). As subgenus of Planorbis

1921. Planorbis Germaix, Rec. Ind. Mus., XXI, pp. 6, 9. Type Planorbis comeus (Linn.). As subgenus of Planorbis

1923. Corctus (Gray 1847) Wenz, Fossil. Cat., Pars 22, p. 1421. Genotype Corctus comeus (Linn.). As genus

1924. Planorbarius Kexpard and Woodwand, Proc. Mal. Soc. London, XVI, p. 10. Type Helix cornea Linn. 
1926. Planorbarius Kennard and Woopward, Syn. Brit. Non-Marine Moll., p. 67. Type Helix comea Linn. As subgenus

1926. Planorbis Lisdrolm, Archiv, für Mollusk., Heft 6, year 58, p. 252. Ideogenotype II lix cornea linn. As genus, type by Montfort

1927. Planorbis Pilsbry and Bequaert, Bull. Amer. Mus. N. H., LIII, pp. 115, 116. Type Planorbis cornens (Linn.). As genus

1929. Coretus (Gray 1847) Hass, Trab. Museo Cien. Nat. Barcelona, XIII, p. 378. Tyue evidently Helix eomen Linn. As genus

1931. Planorbis F. C. Baren, Proc. Zool. Soc., London, p. 583. Genotype Helix cornea Linn. As gents

1931. Corctus (Andanson, 1757) Germaln, Moll. Terr. Flur. France, II, p. 517. No type cited but Planorbis corneus (Linn.) described. As subgenus of Planorbis

1931. Planorbis Thiele, Handbuch, Teil 2, p. 479. Type Planorbis corneus (Linn.). Subgenus of Planorbis Miiller, 1774

Shell (plate 80 , figs. 22-24). Large, sinistral, discoidal, rather solid, of few gradually enlarging whorls, equally visible above and below; aperture slightly enlarged, in the same plane as the whorls; lips sharp, not thickened.

Animal. With short, wide foot, rounded before, tapering behind, the vela area large; tentacles long, wide at the base, and tapering to a point, eyes sessile at their inner bases. Color of living animal lead, sometimes nearly black tinged with brown; tentacles bluish black. Sometimes the whole body is reddish.

The young snail of two whorls, recently hatched from the egg capsule, is very translucent, the organs plainly visible through the hyaline shell. The body shows pinkish through the shell, head and foot with border of white on edge. The radula sac may be seen working backward and forward, when feeding, as in the adult animal. The heart may be observed beating rapidly. The young snails are distinctly physoid in form and glide about like Physa. Specimens of the young with bifid tentacles are not uncommon.

\section{ANATOMICAL CHARACTERISTICS}

\section{PLATE 20 (Planorbarius corneus (Linn.))}

GENITALIA. Male Organs (fig. 13). The seminal vesicle (SV) is about $4 \mathrm{~mm}$. long and $1 \mathrm{~mm}$. wide, narrowing at the anterior end to the diameter of the ovisperm duct. This organ is a rounded mass of small vesicles. A number of small vesicles continue down one side of the ovisperm duet. The sperm duct (SPD) is about $10 \mathrm{~mm}$. long. Where it leaves the ovisperm duct it is of small diameter, but it gradually enlarges to twice this diameter near the prostate where it abruptly expands to several times the first diameter, and then suddenly diminishes again to almost its original diameter. The prostate (PRS) is elongated and somewhat fan-shaped, $4.5 \mathrm{~mm}$. long. The duct of the prostate is a continuation of the vas deferens and is about $1 \mathrm{~mm}$. long. It lies over the sperm duct with which it is connected, the prostate diverticula radiating from this duct. The ras deferens (VD) is a narrow tube about $12 \mathrm{~mm}$. long.

The prostate in section (fig. 4) is radiate or fan-shaped in form, the seven to nine main diverticula branching several times (usually four) toward the outer part of the section. Figure 4 also shows the relationship between the uterus, the nidamental gland, and the prostate, the figure being a cross section cutting through these organs. The prostate diverticula may be noted to enter the prostate duct directly. 
The penial complex (fig. 12) consists of a very large, pyriform preputium (PR), $3.5 \mathrm{~mm}$. long and $2 \mathrm{~mm}$. wide at the upper part, tapering to $0.5 \mathrm{~mm}$. wide at the male opening. The vergie sac (VS) is very small (about $1 \mathrm{~mm}$. long) and is placed at the summit of the preputium, lying on that organ. There are two retractor muscles (RMI), an upper one attached to the preputium near the vergic sae by two branches, one branch on each sicle of the vergic sac, and a lower muscle attached at about midway of the preputium. There are four or five supporting muscles (N)II on the opposite side from the lower retractor muscle. In some specimens, the two retractor muscles are placed one above the other attached to the preputium near the upper part, with smaller muscles joining the two larger muscles and a small muscle extending to the vas deferens (fig. 7. RMI. VMI). This form of musculature was more common than the one shown in fig. 12. The vergic sac and a part of the vas deferens are attached to the surface of the preputium, as shown in fig. 12 .

Internally (fig. 11), the large preputial cavity has two heavy, vertical pilasters (PL). In the upper part of the preputium, there is a peculiarly shaped penial gland (Cil, . It is shown somewhat restrieted in fig. 11 and drawn upward in the preputial sac. There is a conspicuous ghand appendage ( it). The verge (V) is rery small $(0.7 \mathrm{~mm}$. long) and rery narrow and is attached to the vas deferens at about the apex of the preputial sac. When fully extended, the penial gland has the form shown in fig. 1. The gland becomes a rosette surrounding the opening into the vergic sac $(\mathrm{X}$ in figure). and the gland appendage (GA) extends forward for downwarl) in the preputial cavity, ending in two lateral swellings which notably resemble the glans penis of the buman genitalia. There is a narrow canal or channel which extends down the center of the appendage for its entire length $(\mathrm{C})$. A cross section of the appendage indicating the position of this canal is shown in fig. 2 (C).

The verge (highly magnified) is shown in fig. 6. It is short and narrow, somewhat enlarged toward the lower end, with a centrally located sperm canal and exit. There is a narrow rergic sae cavity (VO). The channel which extends down the center of the penial gland appendage is seen to extend upward and into the vergic sac cavity (C). There is a small penial appendage beside the sperm canal outlet of the verge which is flattened and extcuds diagonally from the end of the rerge, as shown in fig. 8 (PA).

Female Organs. The spermatheca (S) is large and pyriform in general shape (fig. 13), about $1.5 \mathrm{~mm}$. long and $1 \mathrm{~mm}$. wide. The duct (SO) is $2.5 \mathrm{~mm}$. long and is a narrow tube. The vagina ( $\mathrm{VG}$ ) is narrow, a trifle more than $1 \mathrm{~mm}$. long and less than $0.5 \mathrm{~mm}$. wide. The uterus (U) begins with the same diameter as the vagina but rapidly enlarges to about $1 \mathrm{~mm}$. wide. It is about $8 \mathrm{~mm}$. long. The nidamental gland (NG) is a large saclike organ $3.5 \mathrm{~mm}$. long and about $2 \mathrm{~mm}$. in diameter (see fig. 4 , NG). The oviduet (OD) is over $4 \mathrm{~mm}$. long and is a large flattener tube about $0.5 \mathrm{~mm}$. in diameter. There is a large carrefour (CF). The albumen gland (fig. 9) is squarish in shape and is composed of many small follicles.

Hermaphrodite Organs (fig. 13). The orotestis (OT) is very long and occupies a little more than one whorl. It is composed of many diverticula which form a pavement-like pattern on the surface of the ovotestis. In section (fig. 5), the organ shows seven main diverticula each of which is 
divided into four secondary branches. In fig. 3, a single ripe orum is shown in the diverticulum. The free portion of the ovisperm duct $(\mathrm{SO})$ is about $5 \mathrm{~mm}$. long between the seminal vesicle and the oriduet and only $1 \mathrm{~mm}$. long between the resiele and the orotestis.

The published figures of the genitalia of Planorbams corneus vary considerably. That of simpoth (1912, tafel 26. fig. 3 ) is one of the best and agrees with our fig. 13 on plate 20 in general gross anatomy. LacazeDuthier's figures are also aceurate as regards general anatomy and nerve organization $(1872$, plate 20$)$. L. Soos's figure (1917, p. 37) lacks detail. Germain's figure of the genitalia of Planorbis corneus (1931, p. 518) lacks details of structure and is less clear than that of simroth.

The published figures of the external and internal aspects of the penial complex lave been inaccurate, either in figuring or in the interpretation of parts of the organs. Moquin-Tandon (1855) on his plate 32, fig. 3, shows the gland of comeus which is ealled the penis (verge), the lower part being designated as a dilation and the end of the groove is said to represent the stylet. Buchner (1891, tafel 5, fig. 1, copied by simroth, 1912, p. 502) shows the penial complex incorrectly. Internally, the first type of the penis (penis complex) of corneus is an error of interpretation, the penis of Buchner not being the true verge but the gland appendage, which has a channel down the center, thought to be the sperm canal by Buchner. F. C. Baker (1928. I, p. 308, has copied these figures and has erroneously accepted the division into types of the male organ in Planorbis. Other authors, as Annandale $(1922 i$, have also used these penial subdivisions. Baudelot (1863, plate 4$)$ correctly figures the eylindrical appendage and gland but the appendage is erroneously called the penis. Taylor $(1900$, p. 366) figures the terminal bulbous portion, calling it the vibratile stimulating appendage, which it probably is.

The true nature of the gland and its appendage and the very small true verge have not been recognized and figured until F. C. Baker's paper appeared in 1931 (p. 579, plate 1 ). The small verge appears to be an enlargement of the ras deferens and has been completely overlooked.

Respiratory and Renal Systems. The pseudobranch (plate 20, fig. 10) is an oval, elongated body extending from the anal region. It is usually somewhat leaf-like but, as in the figure, it may often be folded forming a rounded tube $(\mathrm{P})$. The rectum $(\mathrm{R})$ is large, rounded, and bears a simple, rounded crest or ridge, which does not extend over the psendobranch as in Helisoma. The anal opening is above the pseudobranch (A). There is a large pneumostome (PS).

The kiclney is in general like that of Helisoma corpulentum (plate 44. fig. 31 except that it is longer and wider $(14 \mathrm{~mm}$. long and $4 \mathrm{~mm}$. wide at the upper part). The portion of the kidney bordering the pericardium is flattened or even a trifle concave, the lower part is rounderl and lobate on both margins, the lobations being more numerous than in Helisoma corpulentum. There is a large ridge extending down the center of the kidney. A cross section of the kidney near the lower end (plate 45, fig. 181 shows a rounded lumen (TK) with a vein on each side at the lower angle of the lumen (RA, AP). There is a high, sharp crest or ridge ( $\mathrm{RK}$ ) causing the section to be higher than wide. The ridge on the mantle, to the left in the section, is wide, high, and curved (RD). 
Digestive System. The digestive system is like that of the Helisomatinae in general. The stomach region is rather narrow and resembles that of Promenetus exacuous figured on plate 48 (figs. 4, 5). There is a large blind sac or eaecum. The intestine makes a coil about the stomach and another around the liver. The buceal sae is prriform, elongated, with a short, rounded radula sae. The salivary glands are short and are composed of large branched follicles, in this respect differing from the salivary glands of Helisoma.

The superior jaw (plate 50, fig. 14) is wide and low, convex, the ends attenuaterl and bent downard. The face of the jaw is heavily vertieally striated. The side jaws are very narrow and as long as the width of the superior jaw.

Radula (plate 66 , fig. 2 ). Center tooth higher than wide, the two spadeshaped eusps not reaching the lower margin of the base of attachment. Lateral teeth (1-9) squarish, tricuspid, the eusps sharply pointed, the mesocone larger than either the entocone or ectocone. Intermediate teeth (10-14) narrower than the lateral teeth, the entocone breaking up into two to four sharp, pointed cusps, the ectocone becoming bicuspid. Marginal tecth 15-38) narrow, the entocone breaking up into five to six subequal cusps, all in a straight row, the ectocone beeoming tricuspid, the eusps very small. The mesocone remains large in all teeth with but little modification. The outer marginals (39-42) are very narrow, mueh smaller than the other marginals, the cusps becoming very small and forming a serrated outer margin of the teeth.

Germain (1931, p. 518) figures the radula of cornews as having interstitial eusps, but such were not observed in the material personally examined. Taylor $(1900$, p. 270$)$ figures the laterals as bicuspid and in this he is followed by simroth $(1912$, ). 316). All specimens studied have had trieuspid lateral teeth, as has been noted for every genus in the family as yet examined. Taylor also figures thirty-three teetl in a row while in speeimens personally examined the number has been from forty-two to forty-five. In some specimens from Gemany, there were odd teeth (72nd row, 12-15, marginal, in which the cusps of the endocone were uneven and the smaller ones might be assumed to be interstitial eusps. some outer marginals $(17,20,22)$ were of a like nature.

The following radulae have been examined:

\section{Locality}

Poland, near Warsaw

Germany

Florida (aquarium specimen)

$\begin{array}{cc}\text { Formula } & \text { Rows } \\ 42-1-42 & 200-217 \\ 45-1-45 & 170-210 \\ 45-1-45 & 200-218\end{array}$

Source

MIr. A. Jankowski

Dr. F. Haas

Mr. Roger P. Gray

Material from the following sources has been used for the above data: Branch of Wista River at Morysinek, $5 \mathrm{~km}$. south of Warsaw, Poland, collected by Mr. A. Jankowski; Germany (loeality unknown) from Dr. F. Haas; Ojus, Florida; Copenhagen red snails, bred for aquaria, Mr. Roger P. Gray, sent by Mr. T. Tan Hyning.

Geographical Distribution. Great Britain and Europe east to northern and western Asia, south to Portugal and Italy. It has been introduced into New Jersey, Puerto Rieo, and probably other places. Whether the larger species found in northern Africa are referable to Planorbarius ean only be detemined by an antomical examination. 
Just how many speeies may be inclucled in Planorbarius is somewhat of a question. Germain $(1921,1931)$ includes one species with several varieties. In the eatalogue of Planorbidae in the Indian Museum, Germain includes in Planorbis (= Planorbarius) several species which belong in other genera, prineipally Afroplanorbis.

Species Considered as Valid. Since the members of this genus are extralimital, the species listed by Westerlund which appear to be referable to Planorbarius are cited here.
Planorbarius corneus (Linn.)
Planorbarius elophilus (Bgt.)
Planorbarius metidjensis (Forbes)
Planorbarius stenostoma (Bgt.)

Planorbarius kabylianus (Let.)

Geological Distribution. According to Wenz (1923, p. 1481), the genus Corneus (= Planorbarius) begins in the late Eocene period.

Remarks. The genus Planorbarius is at once distinguished from all other groups of Planorbidae by characteristies of the genitalia. The very large preputium and rery small rergic sac are particularly noteworthy, and the form of the penial gland with its elongated appendage and the very small verge are unique features of the genus. The two retractors of the penial complex are also diagnostic features. The strueture of the prostate and orotestis is likewise distinctive. No specimens with everted gland or verge have been observed and one ean only surmise that the gland is everted as an excitatory organ and probably the small vergic sae and rerge are extended from the male opening, as has been observed in Helisoma.

Almost all writers on European fresh-water Mollusea have mistaken the penial gland appendage for the true penis (verge) and have completely missed the small, vestigial true penis. Other authors have ignored all details of the internal anatomy of the penial complex, simply figuring the large preputium and the vas deferens as directly entering this organ.

The systematic position of Planorbarius is without doubt in the subfamily Helisomatinae. The presence of the penial gland and the multiple character of the diverticula of both prostate and ovotestis indicate this relationship. The strongly ridged kidney is also another evidence of this kinship. It is the only group of the subfamily thus far known outsicle of Ameriea. The large shell resembles that of Helisoma especially the subgenus Pierosoma.

The proper genus for the reception of the Helix comea of Limn. has been in some dispute. Many authors have considered it the type of the genus Planorbis of Müller. Dall (1905) considered it the type of Planorbis, dating it from Montfort, 1810, who definitely established cornea as the type of the genus. This procedure has been followed by Germain (1921), Pilsbry and Bequaert (1927), Lindholm (1926), Baker (1931), and Thiele (1931). Dall's conclusions were questioned by Kennard and Woodward (1924) who maintained that the type of the genus Planorbis is the Helix planorbis of Limm. by absolute tautonomy. H. B. Baker (1930) has also expressed the same opinion. Germain, in a later work (1931), eites the Helix planorbis of Linn. as the type of Planorbis Guettard 1756 and Geoffroy 1767.

The generie name Coretus is in current use by many European conchologists. Some of these use the Coretus of Adanson 1757 (as Clessin 1886 and Germain 1931) but that author was non-binomial and pre- 
Limnean, furthermore, he applied the name to a minute species about an eighth of an inch in cliameter. In 1847, Gray (P.Z.S., p. 508) used the name Coretus, as of Adanson, but definitely cited the Helix cornea of Limnaeus as the type. Later authors (Wenz, 1923, Haas, 1929) use Coretus Cray, 1847, with the type Helix cornea.

In 1806, Duméril (Zool. Analyt., p. 164) coined the name Planorbarius for a group of mollusks, without an operculum, inhabiting fresh water. Except for the name, which suggests Planorbis, the groun might pass for anything among fresh-water puhmonates and the name is absolutely useless for purposes of nomenclature. In a Cerman erlition of Duméril's work. however, Froriep used this name and supplied a troe, the Helix cornea of Linnaeus which, according to Opinion 46 of the International Code, becomes the monogenotype of the genus Planorbarius of Froriep. This anteclates Montfort's use of corneus as a genotype by four years.

Froriep says of Planorbarius in his German translation (p. 165):

Die Scheibenschnecken (Planorbarius) unterscheiden sich (die Schaele uberriicksichtiget) ron den rorigen nur durch den mangelnden Schliessdeckel. Es sind dies Flussechnecken. Z.B., Helix comera.

The case is much better than that of Coretus Gray and there appears to be no reason why Planorbarius, as published by Froriep, should not be used for the large European snail previously known as Planorbis corneus. The rarity of Froriep's translation in libraries has doubtless been the eause of its being omitted in most previous discussions of planorbid nomenclature.

\section{Subfamily PIANORBLLINAE Pilsbry, 1934}

Prostate diverticula compound but not fan-like in section, there being a main division from which branch, on one side, several (four to six) smaller diverticula. The ovotestis diverticula are placed in pairs. There is a penial gland but no external duct, which is ahays placed inside of the preputium. The jaws are as in Helisomatinae.

Type genus Planorbula Halcleman.

The few groups belonging in this subfimily are noted below:

With short, tube-like duct: Planorbula, Promenetus.

Without distinct duct but with open channel: Menetus, Micromenctus.

The fossil group Planobifex Pilsbry doubtless belongs in this subfamily.

\section{Genus PLANORBLLA Haldeman, 1840}

Type by original designation Planorbis armigerus Say

1840. Discus Haldevax, Mon. Limn. Part I, p. 4 of cover, July, 1840. Non Fitzinger, 1833, a land genus. Type Planorbis armigerus Say. As subgenus

1840. Planorbula Haldemax, op. cit.. Suppl. to Part I, p. 2 (Oct. 1840). New name for Discus Haldeman. preoccupied

1842. Planorbula Haldemax, Mon. Limn., Part IV, Physidae, p. 14. Monotype Planorbis armigerus Say. As subgenus

1847. Dentatus Gray, Proc. Zool. Soc. London, p. 181, non Beck, 1837. Type Planorbis armatus. Gray, supposed to be the same as Planorbis armigerus Say. As subgenus of Coretus

1855. Planorbula H. and A. Anaws, Genera of Rec. Moll., II, p. 265. Type Planorbis armigerus Say. As subgenus

1865. Planorbula Bixyey, L. and FIT. Sh. N. A., II. p. 136. No type cited, but Planorbis armigerus Say by assumption. As subgenus of Segmentina 
1870. Planorbula Dall, Ann. N. I. Ixyc. N. H., IX, p. 352. Type Planorbis armigerus Say. As subgenus of Segmentina

1870. Segmentina Tryox, Con. Hald. Mon., p. 213 (non Fleming). No type cited but Planorbis armigerus Say, listed.

1883. Planorbula Fischer. Man. de Conch., p. 509. Type Planorbis armigerus Say. As subgenus of Planorbis

1S84. Planorbula Triox, S. \& S. Conch., III, p. 107. Type Segmentina armigera (Say). Subgenus of Segmentina

1S86. Planorbula Clessix, Conch. Cab., X VII, p. 35. Type Planorbula armigera (Say). As genus

1899. Planorbulina Mantexs, Biol. Cent. Amer., Moll., p. 400. Clerical error for Planorbula. May equal Tropicorbis in part. For group of Planorbis armigerus Say

1902. Planorbula F. C. BAker, Moll. Chicago Area, Part II, p. 300. Radula figured. As subgenus of Segmentina

1905. Planorbula Dall, Alaska Moll., p. 97. Type Planorbis armigerus Say. As subgenus of Segmentina

1906. Planorbula Pilsbry and Ferriss, Proc. Acad. Nat. Sci. Phil., p. 166. As subgenus of Segmentina

1909. Planorbula Pallary, Mem. Inst. Egypt, VI, p. 59. As genus. Doubts that Planorbula of America is found in Egypt

1912. Segmentina (part) Haxnibal, Proc. Mal. Soc. London, X, p. 154. A group mixture, but includes Planorbula of Haldeman.

1918. Planorbula Walker, Miscel. Papers Mus. Zool., Tniv. Mich., No. 6, pp. 14, 104. Type Planorbis armigerus Say. Shell and radula. As subgenus of Segmentina

1923. Planorbula Germaix, Rec. Ind. Mus., XXI, p. 179. Type Planorbis armigerus Say. As genus

1926. Planorbula F. C. B.tker, Trans. Wis. Acad. Sci., Arts, and Lett., XXII, p, 203. Type Planorbis armigerus Say. As genus

1926. Planorbula Lixdholı, Archiv. für Mollusk., 58 year, Heft 6, p. 258. Thinks it should be separate genus

1927. Planorbula Pilsbry and Bequaert, Bull. Amer. Mus. N. H., LIII, p. 131. Monotype Planorbis armigerus Say. As genus

1928. Planorbula F. C. BAker, Fresh-water Moll. Wis., I, p. 353. Type Planorbis armigerus Say. Genitalia, jaw and radula figured. As genus

1930. Planorbula H. B. Baker, Occ. Papers Mus. Zool., Univ. Mich., No. 210, p. 43. Monotype Planorbis armigerus Say. As genus

1931. Planorbula Thiele, Handbuch, 2 Teil, p. 480. Type Planorbis armigerus Say. As genus

1934. Planorbula Pilsbri, Proc. Acad. Nat. Sci. Phil., 86, p. 54. Form of prostate and presence of penial gland indicated

1934. Planorbulina Pilsbry, loc. cit.. p. 54. Typographical error of ron Martens for Planorbula. Type designated by Pilsbry Planorbis armigerus Say

1940. Planorbula Haldeman, Morrison, Nautilus, LIV, p. 65. Notes correct date of publication, Oet. 1840

\section{Subgenus PLANORBULA SS.}

Type by original designation Planorbis armigurus Say

Shell (plate 79, figs. 25-27). Small, ultradextral, of few closely coiled whorls, slowly increasing in diameter, with flatly rounded whorls above and a wide ilepression below, the body whorl usually carinate in the middle; lips more or less thickened by a varix. Aperture with six lamellae situated well within, placed as follows: a large parietal lamella, somewhat sigmoid, obliquely transverse, with a small tubercular lamella below, at the left end of the parietal lamella; four palatal lamellae (plate 76, fig. 8), a large slightly transverse basal (4), a large lower palatal (3) which is 
always directed upwark, an upper palatal above and smaller than the lower palatal (2), also pointed upward, and a suprapalatal (1) which is usually in a transverse position. This lamella may be restigial or absent in some forms of Planorbula. Only one set of lamellae oeeurs in each shell although the lamellae are found at a very early period in the age of the individual, the old set appearing to be absorbed before the new one is formed as the shell increases through growth.

Animal (plate 70, fig. 11). The living animal of Planorbula jenksii from Lake Wentworth, New Hampshire, is almost black, the foot with lightel edges. The tentacles are long and tapering, blackish in eolor with a light zone near the head; a blackish band borders the head and neek above the foot and velar area; the top of the head is wine-colored or reddish, the sides of the body lighter; the black eves are placed at the inner bases of the tentacles. The mantle is blotehed with dark gray dots. The stomach region is pigmented. The liver and orotestis are yellowish. The velar area is very wide and extends beyond the foot when the animal is in motion. The shell is earried tilted to the left, at an angle of about forty-five degrees. It is sometimes carried flat, the left sicle lowermost.

\section{ANATOMICAL CHARACTERISTICS}

PLATE 37 (Planorbula armigera (Say))

GENITALIA. Male Organs (fig. 4). The seminal resiele (SV) is about $1 \mathrm{~mm}$. long and $0.5 \mathrm{~mm}$. wide and is composed of a cluster of small glands or follicles. The sperm duet (SPD) is romdly enlarged at its distal end (about $0.5 \mathrm{~mm}$. long and wide) tapering anteriorly to les than half this diameter under the prostate. The prostate (PRSi is about $1.5111 m$. in length and less than $0.5 \mathrm{~mm}$. in height. In scetion (figs. 1, 2), the prostate is seen to be composed of a long diverticulum to which are attached, on one side only, five or six smaller and shorter diverticula, several of which may be branched two to four times. There are about thirty rows of diverticula in the prostate. The ras deferens is of smaller dimmeter than the sperm duct, for the most part about half this diameter, and is $6 \mathrm{~mm}$. long.

The penial complex (fig. 9) has a strikingly pyriform preputium, narrowing anteriorly to a round tube of small diameter. The preputium is less than $1 \mathrm{~mm}$. long and a trifle more than $0.5 \mathrm{~mm}$. in diameter at its greatest width. The vergie sac is cylindrical in form, about $0.3 \mathrm{~mm}$. in diameter and as long as the preputium. There is only a slight constriction between the preputiun and the vergic sae. There is one heavy retractor muscle (RMI) attached to the summit of the preputium near the vergic sac. Three wide supporting muscles are attached to the upper and middle area of the preputium. There is no external penial gland duct. The penial complex of another specimen shows a more swollen preputim and a wider vergic sac (fig. 10).

Internally (fig. 11), the preputium has two heavy vertical pilasters (PL) the left one sending a transverse, thick, rounded fold or ridge across the upper part of the preputial sac to the right pilaster. There is a rounded, basin-shaped penial gland (GL), with a shallow eup, the walls of which have many vertieal folds (fig. 6, GF). There is no external gland duet, but a shallow ehannel, open above (DC), conneets the penial gland with a circular space bordering externally the high, thick, fleshy museular ling or diaphragm between the ring and the body wall of the preputium 
(fig. 11, D). The verge (V) is sac-like, about $1 \mathrm{~mm}$. long, and tapers to a point at its lower end (fig. 12). The sperm canal exteuds through the center of the verge and has a central outlet bordered by a small penial papilla (fig. 8).

Female Organs (fig. 4). The spermatheca (S) and spermathecal duet (SD) are about $1.3 \mathrm{~mm}$. long, the duct and gland of equal length and the gland swollen to more than twice the diameter of the duct. The vagina (VCi) is $0.8 \mathrm{~mm}$. long and $0.3 \mathrm{~mm}$. wide the spermathecal duct entering it rather high. The uterus (U) is about $2 \mathrm{~mm}$. long and is but little wider than the vagina. The nidamental gland is slightly wider than the uterus and is loeated beneath the prostate. The oviduet (OD) is over $2 \mathrm{~mm}$. long and is of the same diameter as the sperm duet. It is somewhat convoluted at the upper end. where there is a large carrefour $(\mathrm{CF})$ which receives the long duct from the albumen gland (fig. 3, DA, AL). The albumen gland (AL) is large, about $1 \mathrm{~mm}$. in diameter, somewhat triangular in shape, and is folded for the passage of the intestine.

Hermaphrodite Organs. The ovotestis (fig. 4, OT) occupies a little more than one whorl and is composed of long, club-shaped diverticula arranged in pairs (fig. 7), each pair bending to right or left or placed in the center. There is a very short free ovisperm duet between the ovisperm duct and the seminal vesicle, and a longer, narrow duct $(2 \mathrm{~mm}$. long) between the seminal vesicle and the oviduct. A few resicles extend down a part of the ovisperm duct from the seminal vesicle.

The genitalia of Planorbula jenksii are in most respects like those of armigera. The prostate has about twenty-five rows of diverticula while in armigera there are thirty rows.

No figures of the genitalia of Planorbula have been published previously, except those by F. C. Baker (1928, p. 356, figs. 153, 154). The figure of the entire genitalia (1928, fig. 153) is incorrect in several particulars, especially in the form of the prostate and the seminal vesicle. The diagrammatic figure of a secion of the penial complex (1928, fig. 154) is more nearly correct, but does not show the details of the penial gland.

Respiratory and Renal Systems. The pseudobranch (plate 37, fig: $5, \mathrm{Pl}$ is rounded and has a ridge extending down the middle which conneets with a crest-like ridge on the rectum $(R)$. The ridge on the pseudobranch is heavy and when bent over (as shown in the figure) causes the pseudobranch to appear folded. There is a large pmemostome (PS). The pseudobranch of jenksii is like that of armigera.

The kidney (plate 45, fig. 3) is long and narrow $(5.5 \mathrm{~mm}$. long, $1 \mathrm{~mm}$. wide at the pericardium). The ureter is sharply recurved and is directed upward into the mantle cavity. The pericardium is about $1 \mathrm{~mm}$. long. In section (fig. 13, near midclle), the kidney is seen to be much flattened, with the lumen twice as wide as high and with a vein at each end. There is no ridge on the kidney.

Digestive System. The digestive organs (narrow stomach, crop, and pyloris, are similar to those in C'arinifex and Parapholy.x. The intestine makes a loop around the stomach, passes backward to the liver, makes another loop and runs forward to the rectum, ending in the anus over the pseudobranch. There is a conspicuous blind sac or eaecum. Both jenksii and armigera have the same type of digestive system. The buecal sac is of 
the same form as that of Carinifex. The salivary glands extend half their length behind the buceal sac and form a loop.

The superior jaw of armigera (plate 50, fig. 2) is slightly arched, about four times as wide as high and finely, vertically striated on the anterior face. The side jaws are about as long as the width of the superior jaw and are shaped as in Parapholyx. The jaws of jenksii (fig. 3) are the same as those of amigera.

Radula of armigera (plate 65, fig. 1). The center tooth is slightly higher than wide with a bicuspid reflection which does not reach the lower margin of the base of attachment. The lateral teeth (1-8) are squarish with three long, spade-like cusps of the same shape. The intermediate teeth (9-11) have the ectocone split two or three times, the cusps sharp. The marginal tecth (12-19) are long and narrow with eusps at the lower end. The endocone at first is split into two cusps about as long as the mesocone (12-13); they then become split into four small, equal cusps (14-16). The ectoconic margin has three to four small cusps. The outer marginal teeth are shorter than the earlier marginals but have the same form (19). The radula of jenksii has the same form of teeth.

Radula Data for Planorbula

$\begin{array}{lclcc}\text { Species } & \text { Forumla } & \text { Locality } & \text { Rous } & \text { Source } \\ \text { armigera } & 18-1-18 & \text { Murphy Creek, Wisconsin } & \mathbf{1 6 0 - 1 6 5} & \text { Dr. C. Juday } \\ \text { armigera } & 24-1-24 & \text { Snodgrass Lake, Ontario } & \mathbf{1 6 0 - 1 6 5} & \text { Dr. A. R. Cahn } \\ \text { armigera } & 18-1-18 & \text { Devil's Lake, Wisconsin } & 125-140 & \text { F. C. Baker } \\ \text { armigera } & 19-1-19 & \text { Douglas Lake, Michigan } & \mathbf{1 2 5 - 1 4 0} & \text { Dr. F. Smith } \\ \text { jenksii } & 19-1-19 & \text { Tnionvile, Connecticut } & 145-150 & \text { F. C. Baker }\end{array}$

The data for the material examined anatomically are as follows: armigera, Murphy Creek, near Madison, Wisconsin; Snodgrass Lake, Ontario; Devil's Lake, Wisconsin; Douglas Lake, Mich.; jenksii, Roaring Brook, Unionville, Connecticut. Five specimens from each lot of armigera were examined and about fifteen specimens of jenkisii.

Geographical Distribution. Planorbula is wholly an American genus distributed from Great Slave Lake and Fort Smith, Mackenzic River, south to Georgia and Louisiana, and from the New England states west to Nebraska.

Species Considered as Valid. The following are recognizable as belonging to this genus:

Planoibula armigera armigera (Say) Planorbula armigera palustris Baker Planorbula crassilabris (Walker)

Geological Distribution. Pleistocene to Recent fauna.

$$
\begin{aligned}
& \text { Planorbula jenksii (H. F. Carpenter) } \\
& \text { Planorbula campestris (Dawson) } \\
& \text { (= = christyi Dall) }
\end{aligned}
$$

Remarks. Planorbula is a distinct and characteristic genus of American Planorbidac. The name has been used to cover many dentate planorbids, such as Tropicorbis of the tropics and certain forms of north Africa belonging to Afroplanorbis. It is in no way related to these groups, which belong in the subfamily Planorbinae. Planorbula of Haldeman belongs in a scparate subfamily related to Helisomatinae, having a distinct penial gland and multiform prostate and ovotestis diverticula.

The lamellae within the aperture are also different in the two groupsin Tropicorbis the large lower palatal lamella is always pointed downward 
while in Planorbula this lamella points upward. In Planorbula, the plicae are always present but in Tropicorbis they may be absorbed late in life and the aperture become edentulous (see remarks under Tropicorbis).

Planorbula has also been suborlinated to Segmentina as a subgenus but it has no relationship to that genus, the internal organs being of a totally different character. Segmentina is the type genus of the subfamily Segmentininae.

The chicf characteristies of the genus Planorbula are the orate or rounded penial gland without an external duet but with a canal-like duet within the preputium, and the prostate with small, branched divertieula on one side of a main diverticulum. Its nearest relative is Promenetus, with which it agrees in general in the form of prostate and penial gland. These genera and their relatives constitute a subfamily Planorbulinae, as suggested by Pilsbry in 1934 (p. 47).

\section{Subgenus HALDEMANINA Dall, 1905}

Type by original designation Planorbis wheatleyi Lea

1905. Haldemanina D.slu, Alaska Moll., p. 97. Type Planorbis wheatleyi Lea. As section of subgenus Planorbula Haldeman

191S. Haldemanina Walker, Miscel. Pub. Mus. Zool., Univ. Mich., No. 6, p. 105. Type Planorbis wheatleyi Lea. Synonym of Planorbula

1923. Haldemanina Germaix, Rec. Ind. Mus. XXI, p. 181. Type Planorbis wheatleyi Lea. Considered srnonym of Planorbula

1931. Haldemanina Thiele, Handbuch, Teil 2, p. 480. Type Planorbis wheatlcyi Lea. As synonym of Planorbula

Shell (plate 79, figs. 28-30). As in Planorbula but with the aperture notably thickened, the lower palatal lamella within the aperture very long and curved upward as far as the upper palatal lamella.

Animal. The animal is unknown anatomically.

Geographical Distribution. Not at present known outside of the state of Alabama.

Species Considered as Valid. Planorbula (Haldemanina) wheatleyi (Lea), type of this subgenus, is the only species ascribed to it.

Remarks. In 1905 (p. 97). Dall instituted a section Haldemanina to contain the Planorbis wheatleyi of Lea. No particular characteristics different from Planorbis armigera appear in his diagnosis, except the statement 'lamellae complex.' Upon examining the lamellae of wheatleyi, the complexity is at once seen. The lower palatal lamella is about twice as long as in armigera and the upper part is bent upward almost at right angles to the transverse lower part, so that this end is on a line with the upper palatal lamella, the whole lamella being bent like an Australian boomerang (see plate 76 , fig. 9, wheatleyi; fig. 8, armigera).

Authors, generally, have considered Haldemanina an absolute synonym of Planorbula, but the differenee in the lower palatal lamella is persistent in all specimens of wheatleyi here examined and is not found in any other species or race of Planorbula. The writer, therefore, is disposed to accept Haldemanina as a subgroup under Planorbula. The thickening of the lip has no spceial significance, as this is found in several specics of Planorbula. 
Genus PROMENETUS F. C. Baker, 1935

Type by original designation Planorbis exacuous Say

1928. Menetus F. C. Baker, Fresh-water Moll. Wis., I, pp. 357, 360, 362 (non H. and A. Adams). Genitalia of Planorbis exacuous Say

1935. Promenetus F. C. Baker, Nautilus, XLIX, p. 48. Type Planorbis exacuous Say. As new group

Shell (plate 79, figs. 19-21). Ultradextral with a small number of whorls rapidly increasing in diameter, carmated or rounded; left side with broad spire depression exhibiting all of the whorls; right side flat, also exhibiting all of the whorls; aperture wider than high; outer lip thin.

Animal. External features similar to those of Planorbula. Foot very short and rounded. Color blackish.

\section{ANATOMICAL CHARACTERISTICS \\ PLATE 41 (Promenetus exacuous (Say))}

GENITALIA. Male Organs (fig. 10). The seminal vesicle (SV) is about $2 \mathrm{~mm}$. long, is nearly three times the diameter of the ovisperm duct and has many small diverticula or vesicles, about as long as the diameter of the seminal vesicle, projecting from one side of the organ. The sperm duct (SPD) is about $1.5 \mathrm{~mm}$. long and $0.3 \mathrm{~mm}$. in diameter and appears sausage-shaperl. The prostate (PRSi) is $1.5 \mathrm{~mm}$. long and is composed of thirteen multiple diverticula. In section (fig. 5) the prostate is seen to have four supplementary diverticula projecting from the sicle which lies next to the oviduct. An unusual form of prostate is shown in fig. 11, plate 42 (P. exacuous megas) in which the three supplementary diverticula are each branched three times at the extremity. The ras deferens (VD) is about 7 $\mathrm{mm}$. long and about one third the diameter of the sperm duct, which, itself, also diminishes greatly in diameter beneath the prostate.

The penial complex (plate 41, fig. 2) is $3 \mathrm{~mm}$. long, the pyriform preputium occupying half of the length, the much narrower vergic sac the other half. There is no sharp constriction between the upper and lower sacs, the preputium simply narrowing as it joins the vergic sac. There is one narrow retractor muscle (RM) and a wide group of three to five supporting muscles (SM) forming a lattice-like pattern. The vas deforens enlarges only slightly as it enters the vergic sac (VD). In fig. 1, a penial complex is shown in which the preputim is much swollen by the enlarged penial gland. The penial complex of variety megas does not differ from that of exacuous.

Internally (fig. 3), the preputium has two heavy pilasters (PL) to the upper part of the left one of which the penial gland is attached (GI,). The gland appears sac-like as seen from the sicle and is bent crosswise in the cavity of the preputium. There is a wide projection at the end of the gland in which there is an open groove (DC) or channel connecting the gland with the muscular ring or diaphragm (D) and separating the upper from the lower cavity. In fig. 3 on plate 42 , the penial gland is shown from above, the pilasters separated to show the ovate cup of the gland and the glandular folds lining the walls of the cup. A longitudinal section of the gland (plate 42, fig. 7) shows the arrangement of the vertical folds within the gland.

The verge (V) is long and narrow, usually filling the vergic sac (plate 41, fig. 3) and protruding from the diaphragm into the preputial cavity. 
In fig. 12, plate 42, the verge is shown in this condition, with the penial gland (GiL) extended crosswise of the preputial carity. The end of the verge of variety megas is shown in fig. 13, plate 42, indicating the centrally loeated opening of the sperm eanal with a small penial papilla placed just below and to one side of the opening. A circular ridge near the end of the verge was observed in this specimen which did not appear in others examined.

In a speeimen of rariety megas (fig. 4 , plate 42 ), the gland was somewhat contracted but showed well the trough-like canal or channel conneeting the gland with the eircular eanal near the diaphragm. In this speeimen, the side ridges or bands of muscle connecting the two pilasters with this eanal are well shown. A specimen from Wimebago Lake had the verge and penial, gland extended from the male opening and lying on the neck of the animal (plate 41, fig. 9 ).

Female Organs (plate 41, fig. 10). The spermatheca (S) is irregularly ovate, bulging in the center. with a wide duet (SD) about as long as the spermatheea, the two parts together measuring about $2 \mathrm{~mm}$. The ragina (TG) is wide and a trifle more than $1 \mathrm{~mm}$. in length. The uterus ( $\mathrm{C}$ ) is the same width as the ragina and narrows only at the upper part of the oriduct (OD). The uterus and oviduct combined are about $4 \mathrm{~mm}$. long. The nidamental gland $(\mathrm{NG})$ is about $1.5 \mathrm{~mm}$. long. The relationship of the sperm duct, oviduct, orisperm duct. carrefour, and albumen gland duct is shown in fig. 10 , plate 42 of rariety megas). The duet of the albumen gland is quite long and folded in an $\mathrm{S}$ form. The albumen gland (plate 41, fig. 7 ) is about $2 \mathrm{~mm}$. long and half as wide.

Hermaphrodite Organs. The orotestis OT, (plate 41, fig. 10) occupies a little more than one whorl (fig. 6). In section (fig. 4), it is seen to be composed of twin, elub-shaped diverticula, both glands entering the ovisperm duet. Sections of rariety megas are shown on plate 42 , one near the middle of the orotestis ( fig. 8) and one near the posterior end (fig. 9). The orisperm duct (free portion) extends about $1 \mathrm{~mm}$. on each side of the seminal vesicle and is without glandular projections or swellings.

A related species. Promenetus umbilicatellus, formerly known as Gyraulus umbilicatus, shows some differences and the anatomy of this species is shown on plate 43 . The seminal vesicle is about twice the diameter of the ovisperm duet (fig. 1) and is bordered on both sides by several more or less sharply pointed gland-like protuberances. Smail resicles project from the orisperm duet for a long distance (over $1 \mathrm{~mm}$.) below the seminal resicle. The sperm duet (SPD) is short and narrow (less than $1 \mathrm{~mm}$. long) and is a small tube. The prostate (PRS) is about $1 \mathrm{~mm}$. long and is composed of twenty diverticula which appear very long and narrow when the prostate is in its natural position lying against the uterus. A section about midway of its length (fig. 6) shows five supplementary diverticula or six including the termination of the main divertieulum. The ras deferens (VD) is a narrow tube about $3 \mathrm{~mm}$. long.

The penial complex (fig. 4) is about $1.5 \mathrm{~mm}$. long and the preputium and the rergic sae are of about equal length. The rergie sae is not much narrower than the preputium, the latter having a swelling or ridge at the upper part indicating the position of the diaphragm. There is one narrow retractor muscle (RM) attached to the upper part of the preputium and a ride band of supporting musele (S.MI) attached to the middle portion of 
the preputium. A small supporting muscle may be present on the preputium below the retractor muscle.

Internally, the penial complex is like that of exacuous (fig. 3). There is a large penial gland (GL) which may be folded back as shown in fig. 10. In section (fig. 11), it is like that of exacuous. There is an open, canallike duct (see fig: 9). The verge ( $\mathrm{V}$ ) is short and wide, with a central opening of the sperm canal bordered by a distinct penial papilla (fig. 12).

In the female system (fig. 1), there is a short spermatheea (S) with a wide duet twice as long as the spermatheca (SD). The ragina (V) is wide but shorter than in cxacuous. The uterus ( $\mathrm{U}$ ) is wide and short and there is a swollen nidanental gland (NG). The oviduet $(O D)$ is longer than in exacuous. The relationship of the oviduct, sperm duet and ovisperm duet is shown in fig. 7. The albumen gland is somewhat quadrangular in form and is composed of large vesicles (fig. 5).

Of the hermaphrodite organs, the orotestis is composed of paired diverticula. In the specimens examined, many of the diverticula were gravid (plate 43, fig. 1, OT; fig. 8). The ovisperm duet differs from that of exacuous by having a number of small swellings on one side of the duet for half the length of the portion between the seminal vesicle and the oviduet. A portion of the orisperm duct between the seminal vesicle and the ovotestis is without gland-like swellings.

The penial complex of Menetus cxacuous is figured by Baker (1928, p. 357, fig. 1541. The retractor nusele is shown with an attachment to both the preputium and the vergie sae. This feature was not observed in any specimens more recently examined and this figure must be eonsidered abnormal. All material studied, of exacuous and umbilicatellus, had a single retractor without two branches for the vergie sae and the preputium. The same eriticism extends to fig. 157 on p. 362 of the work mentioned.

Respiratory and Renal Systems. The pseudobranch appears somewhat variable in form, the variation being largely due to the amount of expansion of the organ. In specimens of exacuous from Winnebago Lake, Wisconsin (plate 41, fig. 8), it is large and leaf-like. In an example from Wainwright Park, Alberta (plate 42, fig. 1), it is fully expanderl, wide and romeded below, with the anal opening conspieuously placed on one side within the area of the pseudobranch. It is somewhat folded in the middle. In a specimen of variety megas from Paul Lake. British Columbia (plate 42, fig. 2), the pseudobranch is rounded, and there is a smooth ridge extending over a part of the reetum and forming a thickened border to the pseudobranch. In umbilicatcllus (plate 42, fig. 6), the pseudobranch is rounded in one specimen and folded in another (plate 43, fig. 2). In these examples, the anal region is outside of the area of the pseudobranch. There is no decided ridge on any specimen examined and the ridge on the rectum is not like that in Helisomatinae.

The kidney (plate 46, fig. 3 ) of exacuous is $3.5 \mathrm{~mm}$. long and about $0.5 \mathrm{~mm}$. wide, rather long and narrow. The ureter is a long tube and turns at right angles to the long diameter of the kidney. It borders the thickened mantle margin on the inside. The pericardium is less than $1 \mathrm{~mm}$. long. A cross section of the kidney near the middle (plate 46, fig. 4) shows an ovate lumen with a small vein on each side. There is no superposed ridge. The kidney of umbilicatellus is of the same shape and general nature as 
that of exacuous, but the ureter bends backward at a sharper angle and is directed upward into the mantle carity.

Digestive System. The stomach is elongated with the gizzard longer than wide and with a rounded pyloris (plate 48 , figs. 4,5 ). There is a long blind sac or caecum (BS). The intestine (IN) makes a tight loop around the stomach, extends backward to the liver and then makes another loop and runs forward to the rectum. The buccal sac is elongated, with a rounded radular sac. The salivary glands are narrow, looper, and as long as the buccal sac.

The superior jaw is arched, wide, and low, with the face vertically striated, as in other members of the group (plate 50, fig. 8, cxacuous). In umbilicatellus (plate 50, fig. 15$)$, there is a sharp median projection on the lower edge of the superior jaw. In exacuous, there is only a rounded bulge at this point. The side jaws are as in other species of the subfamily.

The radula of exacuous has a squarish center tooth with expanded lower margins, the two wide, spade-shaped cusps not reaching the lower border of the base of attachment. The lateral teeth (1-6) are squarish, tricuspid, the mesocone longer and larger than the entocone and ectocone. All cusps are sharply pointed. The sixth lateral has a small cusp above the ectocone. Intermediate teeth begin on the seventh tooth, the entocone splitting into two long, sharp cusps and one or two small cusps appearing on the outer margin of the tooth above the ectocone (9-10). Marginal teeth (11-15) long and narrow, the entocone splitting into three to four small cusps and the outer margin of the teeth having two to three small cusps above the ectocone. The outer marginals are almost restigial. The radula of umbilicatellus (fig. 2 ) is similar in form to that of exacuous.

The radula data for Promenetus are as follows, two to four specimens of each having been examined:

\begin{tabular}{lcccc}
\multicolumn{1}{c}{ Species } & Formula & Locality & Rours & Collector \\
exacuous & $17-1-17$ & Winnebago Lake, Wisconsin & $110-112$ & F. C. Baker \\
exacuous & $16-1-16$ & Wainwright Park, Alberta & 115 & Dr. Swales \\
umbilicatellus & $17-1-17$ & Wainwright Park, Alberta & $138-140$ & Dr. Swales \\
umbilicatellus & $18-1-18$ & Vermilion Lake, Minnesota & 140 & F. C. Baker
\end{tabular}

The material examined for the anatomical data described and figured in the preceding pages is listed below. Figures in parenthesis indicate number of specimens studied.

exacuous: Winnebago Lake, Wisconsin, collected by F. C. Baker (4); Lake Nipissing. Ontario, reccived from the Canadian National Museum (5); Mott Lake, Wainwright Park, Alberta, collected by Dr. Swales (4);

exacuous megas: Paul Lake, British Columbia, collected by Prof. D. S. Rawson $(2)$.

umbilicatellus: Mott Lake. Wainwright Park, Alberta, collected by Dr. Swales (8); North Star Lake, Minnesota, collected by F. C. Baker (1); Vermilion Lake, Minnesota, collected by F. C. Baker (2).

Specimens of exacuous from Wainwright Park, Alberta, were hearily infested with cercariae, more abundant in the ovotestis and liver. In several specimens both of these organs were almost obliterated.

Geographical Distribution. The genus Promenetus has a wide distribution. It has been recorded from Maine west to Washington and Oregon and from Hudson Bay and Alaska south to New Mexico and Alabama. A single species (imus) is known from Bermuda. 
Species Considered as Valid. Five species, in one of which two races are recognized, are attributable to Promenetus.

Promenetus exacuous exacuous (Say)

Promenetus exacuous megas (Dall)

Promenetus umbilicatellus (Cockerell)
Promenetus rubellus (Sterki)

Promenctus hudsonicus (Pilsbry)

Promenetus imus (Tanatta)

Geological Distribution. Pliocene to Recent fauna.

Remarks. Promenetus, first described as a group of the genus Menetus, differs so radically from Menetus in the form of the penial gland that it is deemed necessary to raise the group to generic rank. Its gland resembles Planorbula in the lack of a distinct duct and in the opening of the gland which is lengthwise instead of at the end of a cylindrical sac-like gland, as in typical Menetus and its subgenus Micromenetus. The form of the penial complex is also more like that of Planorbula than like this organ in Menetus. In other respects, the genus Promenetus conforms to the general characteristics of the subfamily.

The discovery that the species long known as Gyraulus umbilicatellus is a Menetus closely related to exacuous (Baker, 1935, p. 46) was a surprise and shows that the group Promenetus includes species with both rounded and sharply carinated whorls. The ras deferens in trpical Menetus enlarges as it enters the rergic sac to form an epiphallus. In Promenetus and Planorbula, there is no such enlargement.

\section{Genus MENETLS H. and A. Arlams, 1855}

Type designated by DALL in 1S70. Planorbis opercularis Gould

1855. Wenetus H. and A. Adsus, Genera of Rec. Moll., II, p. 262. Includes several unrelated species among which is Planorbis opercularis Gould. (Non Menetus of Chenu, 1869, P. Fischer, 1883, Tryon, 1884, C. A. Westerlund, 1885, or von Martens, 1899)

1S65. Henetus W. G. Bixvey, L. and FW. Sh. N. A., II, p. 125. No type cited but includes Planorbis opercularis and P. exacuous (- exacutus). As subgenus of Planorbis

1870. Menetus Triox, Con. Hali. Mon.. pp. 1S8, 206. No type cited but includes both Planorbis opereularis and $P$. exacutus. As subgenus

1870. Menetus Dali, Ann. N. Y. Lyc. N. H., IX, p. 351. Type designation, Planorbis opercularis Gould. As subgenus

18s6. Menetus Clessin, Syst. Conch. Cab., XVII, p. 33. Type Planorbis opercularis Gould. As genus

1905. Henetus Dall, Alaska Moll., pp. 82, 86. Type Planorbis opercularis Gould. Section of subgenus Hippeutis Agassiz

1918. Menetus Walker, Miscel. Pub. Mus. Zool., Univ. Mich., No. 6, pp. 12, 94. Type Planorbis opereularis Gould. Section of subgenus Hippeutis Agassiz

1923. Menetus Wexz, Fossil. Cat., Pars 22, p. 1650. Genotype Hippeutis (Menetus) opercularis (Gould). Few of the species listed are true members of the genus Menetus, which is not found in Europe. They might belong in the genus Anisus. Subgenus of genus Hippeutis

1923. Menetus Germax, Rec. Ind. Mus., XXI, pp. S, 156. Type Planorbis opercularis Gould. As subgenus of Planorbis

1926. Wenetus F. C. BAKer, Trans. Wis. Acad. Sci., Arts and Lett., XXII, p. 203. Type Planorbis opereularis Gould. Anatomy. As genus

1928. Menetus F. C. Baren, Fresh-water Moll. Wis., I, p. 360. Type Planorbis opercularis Gould. Anatomy. As genus

1929. Menctus J. Hexdersox, Univ. Col. Studies, XVII, No. 2, pp. 140-141. As subgenus of Planorbis 
1931. Menetus Thiele, Handbuch, p. 481. Type Planorbis opereularis Gould. As section under II ippeutis, subgenus of Anisus

1934. Menetus Pilsbry, Proc. Acad. Nat. Sci. Phil., 86, p. 63. Type Planorbis opereularis Gould. Anatomy. As genus

1935. Menetus F. C. BAker, Nautilus, XLIX, p. 47. Type Planorbis opercularis Gould. Anatomy. As genus

\section{Subgenus MENETU'S SS. \\ Type Planorbis opereularis Could}

Shell (plate 79, figs. 22-24). Small, ultraclextral, of few rapidly enlarging whorls, the body whorl of large dianeter compared with the immer whorls; right side flat, left side with the spire whorls deeply immersed; periphery or shoulder of body whorl more or less earinated; aperture wide, more or less expanded; outer lip usually thin.

Animal. The foot is comparatively short, the tentacles long and filiform. Color generally blackish. In general features the animal is like that of Planorbula.

\section{ANATOMICAL CHARACTERISTICS}

PLATES 38 AND 39

GENITALIA. Male Organs. Menetus opercularis, type of the genus, plate 38 , fig. 1). Seminal vesicle (ST) about $0.5 \mathrm{~mm}$. long, twice the diameter of the orisperm duct and about the same length. The resicle proper has a few wide lobes, but the lower part (the ovisperm duet) is lined with small resicles on the side. Sperm rluet (SPI)) about $1 \mathrm{~mm}$. long, rather thick. Prostate (PRS) about $0.5 \mathrm{~mm}$. long with about a dozen main diverticula. In section (fig. 2 ), the prostate shows several small diverticula projecting from a single, vertical diverticulum, there being usually five branches, one or more of which may be divided two or three times at the end (as in figs. 2, 3), or all may be single, long and club-shaped, as in cooperi (fig. 14). The ras deferens is $3 \mathrm{~mm}$. long, about half the diameter of the sperm duet, and slightly enlarged as it enters the vergie sac.

The penial complex (fig. 10) is elongated and sac-like, about $1.5 \mathrm{~mm}$. long, of which the preputium, narrowed at the male genital opening, occupies $1 \mathrm{~mm}$. or two-thirds of its length. There is a slight constriction between the preputium and the vergic sae (VS). There is one narrow retractor muscle (RM) attached to the base of the vergic sac. There are four sets of supporting museles (SM) attached to the preputium. Most of these are branched several times.

Internally (fig. 8), the preputium has two pilasters (PL). At the upper part of the preputium, there is a short penial gland which is doubled over in the normal position (GL). When expanded (fig. 6), this gland is trumpet-shaped, the bell-like eup flaring. The eup cavity is provided with vertical folds, as in other Planorbidae. There is a dependent ring or diaphragm between the preputiun and the vergic sac cavity (D in fig. 8). The verge $(\mathrm{V})$ is elongated and tapering and normally as long as the vergic sac.

Female Organs (fig. 1). The spermatheea (S) is orate, about $0.3 \mathrm{~mm}$. long and has a very narrow duct (SD) almost $1 \mathrm{~mm}$. long, which enters the short and narrow ragina (VG). The uterus (U) is about $0.2 \mathrm{~mm}$. wide and $1 \mathrm{~mm}$. long. The oviduct (OD) is rery short (about $0.4 \mathrm{~mm}$.) and enters the ovisperm duet without notable decrease in size. There is a large 
earrefour (CF). The albumen gland (fig. 7) is about $1 \mathrm{~mm}$. long and about half as wide as long. The resicles are relatively large. The position of the albumen gland in relation to the other organs is shown in fig. 9.

Hermaphrodite Organs. The orotestis (OT) is composed of rather long, club-shaped diverticula. In section (fig. 5), they are seen to be in pairs, unbranched. The orisperm duct is not free at any portion of its length, as is the ease in cooperi and $c$. callioglyptus and other members of the Planorbulinae, but is lined with small, rounded vesicles (SO, fig. 1).

A related, but distinct variety, $c$. callioglyptus, shows some noteworthy differences (plate 39, fig. 1). The seminal resicle is twice the cliameter of the ovisperm duct but the resicles are longer and digitiform (ST). This is better shown in a California specimen (fig. 6), where the glands are in groups and branched. Rounded swellings or vesicles extend down the orisperm duet some distance, but do not cover the entire length as in opereularis. The prostate (PRS) has 15-17 diverticula (see also fig. 13 in plate 38 , a British Cohmbia specimen). In section, the prostate is similar to that of opercularis (fig. 3, plate 38 ) or it may be unbranched, as in fig. 14 , plate 38 (British Columbia specimen).

The penial complex (plate 38, fig. 11. California specimen) is rather broader than that of opercularis, but the relative length of preputium and vergic sac is the same. In specimens from British Cohmbia (plate 38, fig. 12 ; plate 39, fig. 9), there is a decided enlargement at the summit of the vergic sac forming an epiphathe (FPI) as in some land snails. This was only slightly developed in opercularis (plate 38 , fig. 10). There are five sets of supporting muscles in a California specimen (plate 38 , fig. 11) but a lesser number in a specimen from British Colmmbia (plate 39, fig. 9). There is but one retractor muscle (R.MI). A penial complex from a specimen collected in British Columbia, badly infested with flukes, is shown in fig. 10 , plate 39 .

Internally (plate 39, fig. 7, Menetus cooperi), the preputium has two large vertieal pilasters (PL). There is a large, sac-like penial gland (GL) with a short, narrow, tube-like internal duet (I)C) which enters a eanal in the nusculal ring or diaphragm (D)). In section (fig. 8), the gland shows a shallow eup (OC) at the outer end, lined with many vertical folds. A long duct runs through the fleshy part of the gland and connects with the short duet which emerges from the base of the gland. The penial gland of a Californian specimen of cooperi callioglyptus is shown in fig. 5 . In this specimen, the gland was bent upward and somewhat contracter. The verge (plate 39 , fig. 7, V) of cooperi is wide with thick walls. In section, it shows a large cavity connecting with the enlarged vas deferens (epiphathes) which narrow notably at the entrance of the ras deferens (fig. 7, EPI, VD). The end of the rerge is shown in fig. 15, plate 38 , indicating the centrally located exit of the spern canal. The natural position of the penial complex beneath the female organs (ragina and uterus) is shown in fig. 3 , plate 39 . In the female organs, the spermatheca (plate 39, fig. 1,S) is much elongated and sac-like and the duct is narrow, widening somewhat as it enters the vagina. The duct is about as long as the spermatheca. The other organs are similar to those of opercularis.

Pilsbry (1934, p. 64, fig. 7a) figures the penial complex of Menetus cooperi callioglyptus (Vanatta) and this is similar to the figures in the 
present work. The rerge is figured rather longer than was observed in specimens personally eximined, but this organ is variable in form under different conditions. The peculiar epiphallic enlargement of the ras deferens is shown in Pilsbry's figure. 'The statement that the prostate alveoli (diverticula) are in a single series needs emendation, for while they appear to be in a single series when viewed in position over the nidamental gland, in a cross section they are seen to be composed of several branches, as figured on plate 38 (figs. 2, 3). The divertienla in the natural position are hidden beneath the large direrticulum (as in fig. 1 in both plates 38 and 39 ) and the series appears simple.

There is eonsiderable difference between the genitalia of Menetus opercularis and $M$. cooperi, particularly in the penial complex, in which the form of the penial gland and the size of the epiphallus differ. This difference indicates that the two forms are distinct species. There is some slight variation between specimens from British Columbia and California, but in general the anatomical features are similar.

Respiratory and Renal Systems. The pseudobranch of opercularis is wide, somewhat folded or lobed and the reetum extends through the middle, the anus opening at the lower edge (plate 38 , fig. $4, \mathrm{P}, \mathrm{A}, \mathrm{R}$ ). There is a large pneumostome. In cooperi callioglyptus (plate 39, figs. 2, 4), the pseudobranch is rounded, somewhat lobed, and with a high ridge extending orer the length of the rectum (R) and running down the midde of the pseudobranch as a low ridge. The anal opening is placed at the left side of the pseudobranch. This ridge is also found in opercularis, but is not indieated in the figure. The two forms of pseudobranch shown in figs. 2 and 4 on plate 39 indieate the amount of variation that may take place in two individuals of the same species.

The kidney (plate 46, fig. 7) of Menetus cooperi callioglyptus is short and rery wide (about $2 \mathrm{~mm}$. long and $1 \mathrm{~mm}$. wide). The ureter is a rather long, narrow tube reflexed abruptly and directed upward into the mantle cavity. The pericardium is about $1 \mathrm{~mm}$. long. The lower part of the kidney is very close to the mantle margin, the ureter being in contact with it. A cross section of the kidney near the middle (fig. 8) shows the lumen to be large, ovate, somewhat wider than high, the vein leading to the pericardium much greater in diameter than the renal vein. There is no superposed ridge.

Digestive System. The stomach region is elongated, the oesophagus enlarged to form a crop, the gizzard rounded, and the pyloris rounded and diminishing to the intestine which forms a complete loop around the stomach, extends backward in the body, makes another loop around the liver, and runs forward to the rectum, ending over the pseudobranch. There is a long and narrow blind sac or eaecum. The stomach region is like that of Promenetus exacuous which is figured on plate 48, figs. 4, 5 .

The buceal sae is pyriform, with a large, rounded extension of the radula sac at the lower, posterior part. The salivary glands are about trice as long as the buceal sac and are much enlarged at the posterior end where they are attached, the whole apparatus forming a loop. The oesophagus is enlarged to twice its diameter posterior to the buccal sae.

The superior jaw of cooperi callioglyptus (plate 50, fig. 7 ) is arched, the ends attenuated. There is a central rounded bulge on the lower margin. The jaw is hearily, vertically striated. The side jaws are normal except 
that at the point of attachment to the superior jaw they are bent backward more than usual. The jaw of Menetus opercularis is similar.

The radula of Menetus cooperi callioglyptus (plate 67, fig. 3, from British Columbia) has a large center tooth, higher than wide, the two wide, sparle-shaped eusps not reaching the lower border of the base of attachment. The lateral teeth (1-8) are squarish and tricuspid, the cusps long and spade-shaped, the mesocone the longest. The intermediate teeth $(9-10)$ are narrower than the laterals and have one or two additional eusps above the ectocone. The entocone, mesocone, and ectocone become more nearly equal in length. The marginal teeth (11-15) are very narrow, elongated, the entocone is split into from two to four small cusps and the ectocone splits into three to four small eusps. The outer marginal teeth are very narrow and appear to be serrated with small eusps. The mesocone persists throughout the entire series of teetl and may always be identified.

Data For Radela

Name Formula Locality Rours Collector

$\begin{array}{lllll}\text { cooperi callioglyptus } & 20-1-20 & \text { Quatsino, British Columbia } & 144-145 & \text { Mr. Arthur Peake } \\ \text { cooperi } & 20-1-20 & \text { Oreas Island, Washington } & 155-161 & \text { Dr. T. D. Foster }\end{array}$

The material for the study of Menetus was received from the following sources: opercularis from Mountain Lake, near San Francisco, California, collected by Mr. H. Walton Clark, two specimens examined; cooperi callioglyptus, Quatsino sound, Taneouver Island, British Columbia, collected by Mr. Arthur Peake, eleven speeimens examined; mill pond at Crescent City, California, received from Dr. G. D. Hanna, four specimens studied; cooperi, from Oreas Island. Puget sound, small mountain lake on Mt. Constitution, Washington, eollected by Dr. T. D. Foster, fifteen specimens examined.

Specimens of cooperi callioglyptus from Quatsino Sound, Vaneouver Island, were largely infested with cereariae of trematode worms, as many as 200 Jarrae oceurring in one specimen. All organs were affected but the orotestis and albumen gland were more often attacked. The parasites were most numerous over the stomach region. specimens of cooperi from Oreas Island, Puget sound, had parasites in liver, ovotestis, albumen gland, and over the stomach. In some specimens from both Washington and British Columbia all of the organs were obseured by a thick coating of mueus.

Geographical Distribution. Typical Menetus is distributed over the Pacific coast region from Vancouver Island south to northern California. The group does not extend far inland to the east. It is distinetively a genus of the coast region. Only a few species are known. Opercularis appears to be confined to California, but cooperi $(=$ planulatus $)$ is found from northern California northward to Vaneouver Island, and within this area is quite variable. There are a number of local forms of limited distribution.

Species Considered as Valid. The following species and races are at present known for the typical subgenus of Menetus.

Menetus opercularis (Gould)

Menetus cooperi F. C. Baker, new name

for planulatus Cooper, 1859, not planulatus Deshayes, 1824, a fossil species.
Menetus cooperi callioglyptus (Vanatta) Henetus cooperi multilincatus (Vanatta) Henetus centervillensis (Tryon) 
Geological Distribution. Pliocene to Recent fauna. Little is definitely known concerning the geological ancestry of this genus.

Remarks. Typical Menetus is a very distinct genus characterized by noteworthy anatomical features, chief among which are the sac-like penial gland with its short, narrow, internal duct and the epiphallus-like enlargement of the vas referens as it enters the vergic sac. The prostate resembles that of Planorbula which has the same structural arrangement of diverticula. The ovotestis is also like that of Planorbula. The penial gland, however, is quite unlike either that of Planorbula or Promenetus. The duct is also different. The radula and jaw are like these organs in Promenetus and Planorbula.

Menetus has been subordinated to several groups as a section or subgenus. Thiele places it under Anisus (1931, p. 481), Dall as a section under subgenus Hippeutis $(1905$, p. 82). Germain as a subgenus of Planorbis (1923, p. 156). Von Martens $(1899$, p. 390$)$ includes in it species now referred to Tropicorbis. The Adams brothers indicated no type, though one was definitely proposed by Dall in 1870 (p. 351 ).

F. C. Baker (1928, p. 360 ) and Pilsbry (1934, p. 64) have shown definitely that the group should rank as a genus. The anatomical figures herein published support this conclusion.

\section{Subgenus MICROMENETLS F. C. Baker, New Subgenus Genotype Planorbis dilatatus Gould}

Shell (plate 79, figs. 13-15). Very small, ultradextral, of few rapidly enlarging whorls; right side flat or convex, left side with inner whorls submerged by the body whorl; body whorl with a more or less well-developed carina. usually placed just below the top of the right side; aperture large, somewhat dilated; lips thin.

Animal. Foot short, wide, oral on base, bluntly rounded before and behind; tentacles long and filiform, enlarged somewhat at base, attached far back on the head; eyes on small swellings at inner base of tentacles; color mottled brown and cream, whole back dark, two black lines extending down middle of head; bottom and sides of foot yellowish; tentacles transparent. Shape of foot varies during locomotion. The shell is carried at an angle of thirty to forty-five degrees or it may lie flat on the body of the animal. It is seldom carried erect as in Helisoma (plate 70, fig. 9).

\section{ANATOMICAL CHARACTERISTICS}

PLATE 40

GENITALIA. Male Organs (fig. 12). Seminal vesicle (ST) of $\boldsymbol{M}$. dilatatus made up of a small number of relatively large vesicles placed on each sirle of the ovisperm duct. Anterior to the seminal vesicle, the ovisperm duct is bordered by a number of widely spaced resicles for a distance three times the length of the seminal vesicle. Sperm duct (SPD) of small diameter. not much greater than that of the ovisperm duct. The combined free portion and that part beneath the prostate measure about $1 \mathrm{~mm}$. in length. the sperm duct being a trifle longer than the prostate portion. Prostate (PRS) with relatively few diverticula, eight or nine. In cross section, the prostate shows the same multiplication of smaller diverticula on the under side as is present in Menetus opercularis. In an immature specimen of 
cooperi, the prostate had but five rows of diverticula. The vas deferens is a narrow tube almost as long as the sperm duet. It is slightly enlarged near the vergic sac. In Menetus sampsoni, the seminal vesicle (fig. 1) differs from that organ in cooperi in being composed of four rounded swellings. Only a few rather large vesicles occur on the ovisperm duct.

The penial complex (fig. 12) is about $0.5 \mathrm{~mm}$. long, the preputium (PR) is sac-like or elongate-pyriform and is about twice as long as the orate vergic sac (VS). In sampsoni (fig. 11), the vergic sac is longer and wider. There is one retractor muscle (RM) which is usually attached to the constriction between the preputium and the vergic sac (fig. 11). There are several small supporting muscles on both sides of the preputium. The penial complex was observed in several different forms in the material examined. In one (fig. 3), the rergic sac was placed on the side of the preputium, the gland being pushed upward, as occurs so frequently in the genus Helisoma. In another specimen (fig. 4), the preputium was much swollen and the retractor muscle was attached to the preputium some clistance below the vergic sac.

Internally (fig. 5), there is a sac-like penial gland with a rather long duct. This is shown to better advantage in Menetus sampsoni (fig. 10), where the gland (GL) is much elongated and gradually diminishes in diameter to the round duct, which follows the wall of the preputium (DC) to the muscular ring or diaphragm separating the preputial sac from the vergic cavity. The cup containing the vertical folds is small and is placed at the end of the penial gland. There is a central duet rumning through the gland as in Menetus cooperi callioglyptus. In a Texas specimen (fig. 2), the gland was somewhat different, resembling a pipe or trumpet. This might have been abnormal. The verge (fig. 10, $\mathrm{V}$ ) is elongated, narrowing to a point at the lower end. The sperm canal has a central outlet. See also fig. 5 .

Female Organs. The spermatheca (fig. 12, S) is short and sac-like and is connected with the very wide ragina ( $\mathrm{VG}$ ) by a wide duct twice as long and half as wide as the spermatheca. The uterus $(U)$ is wide, increasing to about twice the diameter of the vagina in the region of the prostate, where the still wider nidamental gland (NG) appears. The oviduct (OD) is short and gradually narrows to meet the sperm duct. There is a carrefour which lies between the oriduct and the albumen gland (not shown in the figure). The albumen gland (AL) is very large and wide (almost half as wide as long) and is composed of large vesicles. The intestine makes a loop beneath the albumen gland (IN).

Hermaphrodite Organs. The ovotestis (OT) is composed of relatively few large, somewhat club-shaped diverticula arranged in pairs. A single diverticulum filled with developing ova is shown in fig. 6. The diverticula vary in form, being more swollen when filled with ova ready for discharge.

Respiratory and Renal Systems. The pseudobranch of dilatatus (plate 40, figs. 7,9 ) is about twice as long as wide and extends below the margin of the foot in preserved specimens. It is somewhat folded on the side and in a Texas specimen (sampsoni, fig. 8) formed a hollow cylinder. There is a fluter crest on the rectum $(\mathrm{R})$ which, however, does not appear on the pseudobranch in the specimens examined. The anal opening (A) is placed at the upper end of the pseudobranch. 
The kidney (fig. 5) is rather short, about $1 \mathrm{~mm}$. long and $0.3 \mathrm{~mm}$. wide. The ureter is very long and is folded baek tightly against the lower part of the kidney. A cross section near the middle of the kidney (fig. 6) shows an oblong or ovate lumen with a small vein at each end. There is no superposed ridge. The kidney is wider than that of exacuous but narrower than that of cooperi or c. callioglyptus. The perieardium is very wide.

Digestive System. The digestive system is similar to that of exacuous (sce plate 48, figs. 4, 5). The radula sae is essentially the same as in Menetus.

The superior jaw (plate 50, fig. 9) of dilatatus is wide and low with vertically striated face. The side jaws are as long as the width of the superior jaw. The jaws of sampsoni (fig. 6) are similar, but larger. There is a slight bulging in the center of the lower eutting erge of the superior jaw in both dilatatus and sampsoni.

The radula (plate 67 , fig. 4 , dilatatus). Center tooth squarish, not as wide as in typieal Menetus. Lateral teeth (1-7) squarish, trieuspid, the mesocone longest, all eusps sharp and spade-shaped. Intermediate teeth (8-10) becoming narrower and developing a split entocone and one or two small cusps above the ectocone. Marginal teeth (11-14) long and narrow, the entocone with three to four small subequal cusps, the ectocone with several small cusps on the outer edge of the teeth. The marginal teeth become much smaller toward the edge of the membrane. The radula of sampsoni is practically of the same type as that of dilatatus (fig. 5).

\begin{tabular}{|c|c|c|c|c|}
\hline \multicolumn{5}{|c|}{ Radula Data } \\
\hline Name & Formula & Locality & Rours & Collector \\
\hline $\begin{array}{l}\text { dilatatus } \\
\text { dilatatus }\end{array}$ & $15-1-15$ & Unionville, Connecticut & 125 & F. C. Baker \\
\hline $\begin{array}{l}\text { dilatatus } \\
\text { sampsoni }\end{array}$ & $\begin{array}{l}15-1-15 \\
15-1-15\end{array}$ & $\begin{array}{l}\text { Hyannis, Massachusetts } \\
\text { Merrimec } R \text { Missouri }\end{array}$ & $\begin{array}{l}125 \\
125\end{array}$ & $\begin{array}{l}\text { F. C. Baker } \\
\text { Leslie Hubricht }\end{array}$ \\
\hline sampsoni & $15-1-15$ & Dallas, Texas & 120 & E. P. Cheatum \\
\hline
\end{tabular}

The material examined for anatomical data has been as follows: dilatatus, near Unionville, Connecticut, twelve miles west of Hartford, collected by F. C. Baker (16); near Hyamnis, Cape Cod, Massachusetts, eolleeted by F. C. Baker (2); sampsoni, Merrimee River, near Stanton, Franklin County, Missouri, collected by Mr. Leslie Hubricht (14); small ereek, six miles northeast of Dallas, Texas, collected by Dr. E. P. Cheatum (4) ; slough, near Trinity River, twelve miles southeast of Dallas, Texas, collected by Dr. Cheatum (2); small lake, near Hutchins, Dallas County, Texas, collected by Dr. Cheatum (2).

The cercariae or rediae of trematode worms were found in some of both species of Micromenetus. Of dilatatus, near Unionville, Connecticut, one specimen infested; sampsoni, Merrimec River, Missouri, nearly all speeimens examined, many of the specimens being badly diseased.

Geographical Distribution. The speeies belonging to the subgenus Micromenctus are distributed over the eastern part of North Ameriea from Massachusetts west to Iowa and Missouri, and from Maine and Michigan southward to Alabama, Florida, and Texas. It is a group found east of the Rocky Mountains. One speeies, Menetus uliginosus Vanatta, is found in Bermuda. 
Species Considered as Valid. There are several distinet species and races of the subgenus Micromenetus recognizable within the genus Menetus, as follows:

Henetus (Mieromenetus) dilatatus dilatatus (Gould)

Menetus (Mieromenetus) dilatatus pennsyluanicus Pilsbry

Menetus (Mieromonetus) dilatatus buchancnsis (Lea)

Menetus (Micromenetus) alabamensis alabamensis Pilsbry
Menetus (Micromenetus) alabamensis
avus Pilsbry
Menetus (Micromenetus) brogniartianus
(Lei)
Menetus (Micromenetus) sampsoni
(Ancey)
Menctus (Micromenetus) uliginosus
Vanatia

Geological Distribution. Not exactly known but certainly from the Pliocene to Recent fauna.

Remarks. The group here separated as Micromenetus differs from typical Menetus in the size of the shell which is always much smaller, none exceeding $4 \mathrm{~mm}$. in diameter. The form of the shell is lenticular and there is usually a peripheral carina more or less well developed. The penial gland has a duct which is almost three times as long as the gland and is attached to the inner wall of the preputium for the greater part of its length (plate 40, fig. 10). In typical Menetus, this duet is short and enters the diaphragm directly without being attached to the wall of the preputium (plate 39 , fig. 7). The pseudobranch in Micromenetus is also very long and narrow while in typical Menetus it is short and wide (compare plate 38, fig. 14, with plate 40, fig. 9). These are small differenees, perhaps, but they appear constant. Micromenetus differs from both Promenetus and Planorbula in the shape of the penial gland. As far as examined the radulae of the two groups differ in formulae, that of Menetus being 20-1-20 while in Micromenetus it is 15-1-15.

\section{Genus PLANORBIFEX Pilsbry, 1934}

Type by original designation Planorbis vanvlecki Arnold

1934. Planorbifex Pilsbry, Proc. Acad, Nat. Sci. Phil., 86, p. 568. Cienotype Planorbis vanvlecti Amold. As subgenus of Menetus

1935. Menetus (Planorbifex) vanulecti Pilsbry, J. Hexdersos, Fossil Non-Marine Moll. N. A., p. 252.

Shell (plate 81, fig. 6). Discoidal, dextral in appearance, the right side moderately convex, with the last whorl carinate, the periphery rounded; left side deeply umbilicate, the last whorl more or less flattened. Sculpture of fine, elose, hair-like striae. Aperture strongly oblique, its outline excised by the preceding whorl, the receding left margin thickened within (Pilsbry).

Geological Horizon and Distribution. Basal part of the Tulare formation, Pliocene. North clome, Kettleman Hills, Kings County, California.

Species Considered as Valid. The fossil species Planorbifex v'anvlecki Arnold, as genotype, is the only species known for this genus.

Remarks. 'Except for the narrow umbilicus, the absence of a peripheral keel, and the thickened peristome, this form resembles Platytaphius Pilsbry, a much larger planorb from Lake Titicaca, which has similar sculpture. Paraplanorbis Hanna resembles Planorbifex in being small and 
narrowly umbilicate, but it has a spire of closely coiled whorls like Drepanotrema. The small size and umbilieate left side are like Menetus, which, as Amold thought, is probably its nearest relative; but in carinate speeies of Menetus the keel is peripheral' ( Pilsbry, 1934, p. 568).

'The shell of the type species, Planorbifex ianilecki, varies in the amount of flattening of the base; sometimes it is scarcely noticeable. The species was referred by Dr. Cooper to Taluata virens, a very different shell. It has certain resemblances to such forms as Taleata bicarinata Lea, but the excised outline of the strongly oblique aperture, and the thickened peristome, exclude a reference to the Valvatidae, some of which have a similar sculpture' (Pilsbry, 1934, p. 569).

As remarked under the genus Paraplanorbis, it appears better to regard Planorbifex as a separate genus related to Wenetus rather than as a subgenus of Menetus. The earma in the middle of the whorl of the right side is distinctive, and is different from any known species of Menetus or Promenetus, where the earina is peripheral or just below the margin of the left side. 


\title{
VIII. \\ GROUPS OF UNCERTAIN AFFINITIES
}

\author{
Subfamily CHOANOMPHALINAE Germain, 1923
}

Character's those of the genus Choanomphalus Gerstfeldt

\section{Genus CHOANOMIPHALTS Gerstfeldt, 1859}

Type by original designation, Choanomphalus maachi Gerstfeldt

1859. Choanomphalus Gerstfeldt, Ueber Land und Süsswasser-mollusken Siberiens, 1. 527. Type Choanomphalus maachi Gerstfeldt. As genus

1870. Choanomphalus D.tu, Ann. N. I. Lye. N. H., IX, pp. 353, 358. Type Choanomphalus maachi Gerstfeldt. As genus

1875. Choanomphalus IV. Drвowsi, Die Gasteropoden Fauna Baikal-see. Men. Acad. Sci., St. Petersbury, Ser 7, XX, 1. 52. Type Choanomphalus maacki Gerst. As genus

1879. Choanomphalus Crosse and Fischer, Jour. de Conch., XXVII, p. 160. Type Choanomphalus mancki Gerst. As genus

1883. Choanomphalus Fiscrer, Man. de Conch., 1. 508. Type Choanomphalus maachi Gerst. As genus

1SS4. Choanomphalus Tryon, S. and S. Conch., III, P. 105. Type Choanomphalus manchi Gerst. As genus

1SS5. Choanomphalus Westerluxd, Fauna der paläarct. Region Binnenconchỵlien, I. P. 63. Type Choanomphalus manchi Gerst. As genus

1856. Choanomphahes Clessix, Syst. Conch. Cab., XVII, P. 232. Type Choanomphalus manchi Gerst. As genus

1909. Choanomphalus Lixdrolir, Mollusken, in Korotneff, Wissens. Ergebn. Zool. Exped. Baikal-See, IV, pp. S, 93. Type Choanomphalus maachi Gerst. As genus

1923. Choanomphalus Germaix, Rec. Ind. Mus., XXI, p. 190. Type Choanomphalus maachi Gerst. As genus

1925. Choanomphalus Drbowski and Gracharalichi, Kosmos, L. p. 877. As genus

1931. Choanomphalus Thiele, Handbuch, p. 482. Type Choanomphalus maacki Gerst. As genus

Shell (plate 81, figs. $7,8,9)$ small, pseudoclextral, turbinate, of few whorls rather rapidly increasing in diameter, the spire depressed but not flat, base wickely umbilicated or with a small chink; aperture rounderl. The shell resembles some species of Talcata in form.

Animal. Similar to Planorbis in tentacles, jaw, and radula. Respiratory and genital openings on the left side (see Dybowski and Grachmalichi, p. 870). The eggs are laid in eapsules with four to five eggs in each eapsule. The jaws are three in number with a large, half-moon-shaped superior jaw and two small lateral jaws.

The radula plate measures $1.6 \mathrm{~mm}$. in length and $0.3 \mathrm{~mm}$. in width, and carries 175 rows of teeth. The formula of Choanomphalus maacki is (4)9-5-16-1-16-5-9-(4) (69 teeth in row) or sixteen lateral teeth, five intermediate teeth, nine marginal teeth, and four outer marginal teeth without distinct form. In ('hoanomphalus valvatoides the formula is 13)-10-5-10-110-5-10-(3) $(57$ teeth in row). In Choanomphalus bicarinatus the formula is 4-6-20-1-20-6-4 (61 teeth in row). Choanomphalus cryptomphalus has the formula 5-6-20-1-20-6-5 (63 teeth in row). The smallest formula is borne by Choanomphalus schrenchi which is 4-7-1-7-4 (23 teeth in row), 
the outer marginals indistinct and uncountable (op. cit., p. 871). No mention is made of the cusps of the teeth. There seems to be great uniformity in the total number of teeth but some variation in the number of lateral teeth.

The published information concerning the anatomical details is wholly insufficient for purposes of classification.

Geographical Distribution. Lake Baikal, Siberia. The different species oceur at varying depths, thus mackit occurs at great depths, principally between 150 and 350 meters. Taliatoides, on the other hand, occurs in comparatively shallow water, from two to ten meters. One species is found in the Angara River, near Lake Baikal (amauronicus). Another species is found in Japan (japonicus). Testerlund includes Europe, Thessalia, between Greece and Turkey, in the distribution of the genus. This range needs confirmation.

Remarks. The genus Choanomphalus is a group of mollusks probably related to the Planorbidae but of uncertain status as to its proper position in the classification of the fresh-water pulmonates. Dall (1870) and Tryon (1884) placed the genus in the subfanily Pompholiginae with Pompholyx (Parapholy $x^{2}$ and Carinifex. Crosse and Fischer in 1879 compared the genus with the American group Carinifex and suggested its group relationship with the fossil Valvata multiformis (=trochiformis). The resemblance to Carinifex in both Choanomphalus and the Steinheim fossil Itrochiformis) is superficial. Choanomphalus not having the same characteristies of anatomy found in Carinifex and Parapholyx. Westerlund, in 1902 (p. 1201, placed Choanomphalus in the subfamily Planorbinae.

In 1909 , IT. A. Lindholn made a study of the Lake Baikal fauna and divided Choanomphalus into three subgenera, as noted below.

1. Choanomphalus Sensu Stricto. Type Choanomphalus maacki Gerstfeldt

2. Achoanomphalus Lindholn. Type Choanomphalus amauronius Bourguignat

3. Sulcifer Iindholm. Type Choanomphalus schrencki IT. Dybowski

The Japanese species is placed in a separate section by Lindholm, Choanomphalodes, 1927; type Choanomphalus japonicus Preston.

Germain (1923) places the group in a subfamily Choanomphalinae. Dybowski and Grachmalichi (1925, pp. 819-881), in an exhaustive monograph, review all of the species of ('hoanomphalus, some twentr-five in number, of which fifteen are considered valid. The peculiar Planorbis paradoxus sturany, from Lake Ochrida near the city of Ochrida, in European Turker, is discussed, but its relationship to Choanomphalus is questioned. It has been thought to be related to Choanomphalus by sturany and other European conchologists. It probably represents another peculiar form of Planorbidae and its anatomy should be examined.

The suggestion in the foregoing reference (p. 835), that Segmentina may be related to Choanomphalus is obviously erroneous because that genus has been shown to be the trpe of a distinct subfamily not known to have any affinities with the Baikal Lake group. A form of Segmentina nitida is found in Lake Baikal and is giren the name of angarensis by these two authors.

On pages 877 to 880 , Drbowski and Grachmalicki present a new arrangement of Choanomphalus which is made a separate family. Wladislaviidae. Six genera and some twenty-three lesser groups are designated. 
The subgeneric names proposed by Lindholm in 1909 are ignored. These six genera, as listed by Thiele (1931, p. 482) with the earlier names of Lindholm and the new names proposed by Tomlin for the preoceupied names, are tabulated below.

1. Choanomphalus (SS). Type Choanomphalus mancki Gerst.

2. Talvatomphalus D. and G. (= Achoanomphalus Lindholm, 1909). Type C. amauronicus Bourg.

3. Cryptomphalus D. and G. (non Charpentier, 1837)=Omphalocrypta Tomlin, 1929. Type C. cryptomphalus IV. Dybowski

4. Biangulatus D. and C. Type Choanomphalus bicarinatus Dybowski

5. Anomphalus D. and G. (non Meek and Worthen, 1866)= Anomphalodes Tomlin, 1929. Type $C$. anomphalus W. Dybowski

6. Platybasalis D. and G. (= Sulcifor Lindholm, 1909). Type C. schrencti IV. Dybowski

The value of these generic and group names is debatable. The plate of species in the Dybowski and Crachmalicki monograph does not show rariation enough to warrant any such minute division, and many of the figures suggest individual rariation, such as is common anong many of our North American species of Helisoma. Possibly the few groups and species enumerated by Lindholm can be recognized, judging from the figures in Fischer's paper (1879, plate 4, figs. 8-10) which are reproduced on $m y$ plate 81 . Just why all of the Lake Baikal species of Choanomphalus should not be included in the one genus is not apparent from a study of the shells and what little is known about the animals.

The name Wladislaviidae can not be used because Germain in 1923 (1). 190) proposed the subfanily name Choanomphalinae two years earlier. On this page Germain also questions the ralue of recognizing subgenera for the different species.

Until the details of the genitalia are known, particularly the form of the orotestis, prostate, and the internal conditions of the penial complex, it will be impossible to determine the true position of this group in the classification of the fresh water pulmonates. For the present, the group designation of Germain as a subfamily of Planorbirlae should be retained. It is possible, of course, that when the anatomy is known the group might be found to be of family rank, but in that ease the name of Crermain must be used because it was given at an earlier date than Wladislavidae of Dybowski and Grachmalicki.

\section{Genus POECILOsPIRA Mörch, 1853}

Type by original designation Valvata multiformis Zeiten

1853. Poccilospira Mörch, Cat. Conch. Yoldi. Type Valvata multiformis Zeiten (= Helicites trochiformis Stahl, 1824)

1879. Poccilospira Crosse and Fischer, Jour. de Conch. XXVII, p. 160. Type Valvata multiformis Zeiten. As genus

1884. Poccilospira Trrox. S. and S. Conch., III, p. 105. Type Planorbis multiformis (Zeiten). As subgenus of Choanomphalus

Shell (plate 81, fig. 1). Dextral, varying from flat with depressed spire. discoidal, to trochiform with greatly elevated spire, the last whorl rounded and in the same plane as the body whorl or greatly deflected. Whorls earinated, the carina placed at the upper side of the whorl in planorboid forms and forming a peripheral ridge in the forms with elevated spire. Umbilicus large and conspicuous. Aperture round or lunate, entire and 
separated from the body whorl, a thick callus on the parietal wall and the outer lip thickened in many specimens.

Horizon and Distribution. Miocene period. Steinheim near Heidenhein, Württenberg, Germany.

Remarks. The planorbid fauna at Steinheim has become classical for studies of variation, not only as individuals in a fauna, but also in time between the earlier and later strata. Perhaps Hyatt's studies in 1880 (pp. 1-114, plates 1-91 are the best known and show in large measure the great amount of variation which has taken place during the life of these mollusks while the Tertiary strata were being formed in the old lake bed and on its shores. Hyatt refers all species to the genus Planorbis.

In a later paper (1920. pp. 155-216, Taf. 10-12), Gottschick reviews what is known concerning the fossils of this locality. He postulated a coldwater fauma and a warm-water fauna, as we sometimes find in the Pleistocene faunas of the middle west. This paper is well illustrated and shows the great variation in the group of shells known as Planorbis multiformis. TVenz (1923, p. 1601) includes all of the Steinheim fossils in the genus Gyraulus. The work of Wenz also brings out clearly the fact that the fossils of this and nearby regions have been very much overnamed, for between 1824 and 1920 no less than forty-five names have been given to variations of this group.

A careful study of the works of Hratt, Gottschick, and others shows that, while many of the so-called speeies appear to be referable to the genus Gyraulus, the forms grouped around multiformis (trochiformis) appear different from the Gyraulus-like shells, approaching Valcata in form, and apparently should be segregated in another group. Mörch, in 1863, recognized this difference and gave the assemblage the name of Poecilospira. Later authors appear to have overlooked this name which does not appear in recent monographs or check lists. It is not mentioned by Wenz (1923) in the list of fossils related to trochiformis.

To what group Poecilospira is related is not definitely clear. It is certainly not near Gyraulus and apparently does not belong in the subfamily Planorbinae. Also, it is not related to Carinifex or to any of the fossil relatives of this group. There are some features in common between Poecilospira and Choanomphalus and its true position may be with the latter group, as suggested by Tryon in 1884. 


\section{IX.}

\section{FAMILY BULINIDAE}

This group has almost universally been considered a subfamily of Planorbidae. It is so treated by Pilsbry (1927, p. 132). More recently sereral authors have considered the group as of family rank, distinct from the Planorbidae (Germain, 1931, p. 514; Larambergue, 1939). The shell is of Physoid shape but the radula is like that of Planorbis. Two characteristic features of the group separate it from any known division of the Planorbidae, the fluted or lobular pseudobranch and the shape of the penial complex in the genitalia. These are so different that they would appear to be characteristics of family rank. The family is mostly exotie, distributed as far as known in Austratia, Oeeania, New Cninea, Celebes, Japan, India, the Ethiopian and Malagasy regions, the Merliterranean subregion as far east as Mesopotamia, and the Antilles (vide Pilsbry, 1927, p. 132). (Mnly one species occurs in the Antillean region.

The present work was prepared to include only the groups properly belonging to the family. Planorbidae, but as one species previously referred to the Planorbidae has recently been placed in Bulinidae, space is given to a discussion of this speeies and the data for its inclusion in a family to which it was not previously believed related.

\section{Genus INDOPLANORBIs Amandale and Prashad, 1920}

Type by original designation, l'lanorbis exnstus Deshayes

1920. Indoplanorbis Axraxdate and Prasilad, Jour. Med. Res., VIII, p. 112. Type Planorbis exustus Deshates. As genus

1921. Indoplamorbis Pr.sis.uD, Ree. Ind. Mus. XXII, p. 471. Type Planorbis exustus Desh. As genus

1921. Indoplanorbis Axxavidie and Prismad, Ree. Ind. Mus., XXII, p. 57S. Type P'lanorbis (xustus Desh. As genus

1921. Planorbis (Planorbis) exustus Germax, Ree. Ind. Mus., XXI, 1). 26-41. Exhaustive account of rariation and synonymy

1922. Indoplanorbis Axyxdate and Prasitad, Rec. Ind. Mus., XXIV, p. 360. Type Planorbis rxustus Desh. As genus

1923. Indoplanorbis R.to, Ree. Ind. Mus.. XXY, pp. 199-219. Type Planorbis exustus Desh. Description of anatomy. As genus

1926. Indoplanorbis THIELE, Handbuch, p. 479. Type Planorbis exustus Desh. As section of Planorbis

1933. Indoplanorbis F. C. Bıker, Jour. Morph., LT, No. 1, pp. 1-12, plate 1-2. Type Planorbis cxustus Desh. Account of anatomy, especially genititia and radula. As genus

1934. Indoplanorbis Pilsbry, Proc. Acad. Nat. Sei. Phil., 86, p. 54. Remarks on taxonomic position

1939. Indoplanorbis cxustus Larambergue, Bull. Soc. Zool. de France, LXIV, No. 5, pp. 286-295. Anatomy and family position. As genus

Shell (plate 79, figs. 33-35). Of medium size, sinistral, with few rapidly inereasing whorls, the body whorl large and greatly increasing in diameter toward the aperture; spire whorls flat, depressed below the level of the body whorl; base with small umbilieal opening, the inner whorls eoneealed by the last two whorls; aperture usually oblique, lips simple, sharp.

Animal (plate 21, fig. 2). The animal is sinistral. Its foot is relatively broad and short, leaf-shaped, broadly rounded in front and pointed behind. 
The head is very broad and has its lower margin expanded and flattened. The tentacles are elongate and filiform. The eyes lie at the immer base of the tentacles and are eompletely sessile. The mouth opens on the lower surface of the head in front of the foot' (Annandale and Prashad, 1921. p. 578). See Rao, 1923, p. 200, for a more extended account of external characteristics.

\section{ANATOMICAL CHARACTERISTICS}

GENITALIA (plate 21, fig. 3). Male Organs. The seminal resicle (ST) is about $4 \mathrm{~mm}$. long and nearly $1 \mathrm{~mm}$. wide and is composed of small lobes or tubereles surrounding the orisperm duet. The sperm duct (SPD) is a small tube $7 \mathrm{~mm}$. long, the portion near the ovisperm duet folded or eoiled. The prostate (PRS) is $3.5 \mathrm{~mm}$. long and nearly $2 \mathrm{~mm}$. wide, its lower end broadly rounded, its upper end narrowed to half the diameter of the lower lobe. The prostate is composed of many long, branched diverticula, all of which radiate fan-wise from the common meeting place of the sperm duet and ras deferens. In a eross section near the middle (fig. 8), there are shown eight primary divertieula each of which is branched three or four times toward the outer end, eausing the outer surface of the prostate to show twenty-four or more rounded projections. Each diverticulum is branched as shown in fig. 9 . The sperm duct and vas deferens meet on the lower side of the prostate, the prostate diverticula radiating outward from this jumetion. The prostate diverticula enter the sperm duct from which the ras deferens proceeds as a small tube less than half the diameter of the sperm duct. This condition is indieated in fig. 10 .

Both Rao and Larambergue describe the prostate as ellipitical in form. but it was of the shape figured in all but one of the specimens examined and the exception was regularly elliptical. There may, obriously, be some rariation in the shape of this organ. In its natural position, the prostate lies against the uterus below the nidamental gland. The vas deferens is a very long, narrow tube (about $12 \mathrm{~mm}$. long) .

The penial complex (fig. 3 ) is made up of a short, eylindrical preputium (3.5 $\mathrm{mm}$. long) and a very long (17 $\mathrm{mm}$.), narrow tube-like vergic sae (VS), which is fire times the length of the preputium. In the figure of Larambergue (1939, fig. 3, the vergie sae is shown four times the length of the preputium. In Rao's figure $(1923$, p. 215$)$, the vergie sae and the ras deferens are confused and the enlarged vergic sac is entirely too short. The figure by Larambergue (fig. 1) shows the vergie sae too short and the preputium too long as compared with the specimens personally examined.

There is a single retractor musele (RMI) attached to the vergie sae near the summit of the preputium. A heary nerve $(\mathrm{N})$ innervates this musele. Bands of supporting muscles (SM) are attached to the preputium on both sides. In Rao's figure $(1923$, p. 215), the retractor muscle is shown as attached to the vergie sac far above the preputium, which position was not observed in any specimen examined. Larambergue's figure $(1939$, p. 288) shows the muscle attached to the rergic sac just above the preputium, which appears to be its natural position.

Internally (plate 21, fig. 1), the preputium contains two long, rertical. muscular pads or pilasters (MP) which extend the whole length of the preputial eavity. There is a small museular ring or diapliragm between the vergic eavity and the preputial earity. The verge (V) is a very long, nar- 
row tube freely movable within the rergic sac (VS). This organ was entirely misunderstood by Rao and was not fully comprehended by the writer (Baker, 1933). Larambergue (1939, p. 288) correctly figures the relationship between the vergie sae (poche de pénis) and the verge (tube pénial), the latter being much longer than figured by Baker and extending the whole length of the rergie sac.

The writer figured and described a bulbous swelling within the vergic sac (plate 21 , fig. $1, B$ ) which was thought to be the termination of the verge, the tube behind this swelling being considered as a part of the ras deferens. Larambergue's figure 2 (reproduced as fig. 2 on plate 73 of this work) shows that this is not the ease and that the whole tube must be considerert the verge. However, this bulbous portion of the verge was present in all specimens examined and a swelling of this region is shown in the figure of Larambergue where the long line for the symbol pe is directed. It seems probable that this bulbous portion (use unknown) is found in all examples of Indoplanorbis but in the specimens examined by Larambergue there was less contraction than in the specimens examined by Baker. In other words, the differenees may be attributable to methods of preservation.

Two speeimens examined by Baker had the preputium completely everted from the male opening, the sac lying on the body of the animal, as shown in fig. 2 of plate 21. One of these specimens is shown in optical section in fig. 7 of plate 22 . In this speeimen, the preputium was greatly flattened so that the pilasters (MP) became two flattened muscular pads, filling the greater part of the preputial eavity. The verge $(V)$ and vergic sae (VS) extend through the preputium nearly to the opening of the preputium (PR). The bulbous portion of the verge is conspicuous and has moved downward. The retractor muscle is attached to the vergie sac near its distal end and the large nerve lies beside it (RM, N). It is elearly evident that this muscle pulls back the male intromittent organ after copulation. A eross section of the preputium near its widest part is shown in fig. 6. The branching of the retractor muscle and the comnections of the nerve are shown in fig. 5, greatly enlarged. The so-ealled supporting muscles of the preputium apparently become retractor muscles when the verge and the preputium are everted (fig. 5, plate 21 ).

Larambergue (1939, p. 293) deseribes and figures the penial complex in the everted position (see plate 74 , fig. 6 ). The rergic sae is shown extended from the everted end of the preputium. The everted copulatory organ is enlarged at the distal end, being almost twice the diameter of the proximal end near the preputium. A trifle more than half of the length of the vergic sac is everted, the shorter portion remaining within the preputium and body during eversion. These drawings of Larambergue were made from freshly anesthetized specimens taken in coitus.

Observations on the specimens dissected by the author do not entirely agree with those of Larambergue. In several specimens, the verge extended from the vergic sac and protruded into the perputium for some distance (plate 21, fig. 1). Rao (1923, p. 215) figures the verge (penis) as protruding from the rergic sae into the preputial eavity. He also figures the retractor muscle as attached to the vergic sac and not to the preputium.

It has been the writer's opinion that only the verge was protruded from the end of the preputium when the latter was everted from the male opening. The retractor muscle is shown by Larambergue as attached to the upper end of the preputium, while in all specimens personally examined 
this muscle, distally branched, was attached to the end of the vergic sac, as shown in plate 22 , fig. 7 . There are muscles on the preputium which probably aid in its retraction (plate 21, fig. 5). The writer believes that the bulbous swelling (shown at B in fig. 1, plate 21, and at B in fig. 7, plate 22) has some significance, for it is also shown, although in a more lengthened condition, in Larambergue's figure on page 288. It might be that it marks the limit of the copulatory portion of the verge, as suggested by the writer in a previous paper $(1933, p .4)$. The schematic figures 8 and 9 in Larambergue's paper (eopied on plate 74, figs. 8, 91 suggest such a condition. As observed by Larambergue, however, these differences may be largely due to the preservation of the material examined.

Female Organs (plate 21, fig. 3). Spermatheca (S) small (about $1 \mathrm{~mm}$. long) pyriform, attached to the long, narrow vagina (2 $\mathrm{mm}$. long) by a very short duet. The spermatheea is, in fact, almost sessile. The uterus $(\mathrm{U})$ is about $5 \mathrm{~mm}$. long and nearly four times as wide as the vagina. The large nidamental gland (NG) is $6 \mathrm{~mm}$. long, is about as wide as the uterus and is curved about the uterus and oviduct. The ovirluet (OD) is about as long as the uterus and vagina combined (about $9 \mathrm{~mm}$. long). It is $1 \mathrm{~mm}$. wide at the uterus end but decreases in diameter toward the albumen gland where it joins the sperm duct to form the ovisperm duct. There is a small carrefour. The albumen gland (AL), a flattened, more or less heart-shaped organ, is convex above and concave below. It has a narrow duet which enters the earrefour. The ovisperm duet $(\mathrm{SO})$ is a narrow tube about $3 \mathrm{~mm}$. long between the seminal vesicle and the oriduet. In the specimens examined it was entirely smooth, but Larambergue figures it as having lateral swellings, as was observed in some species of Planorbidae. A small, smooth duct about $1 \mathrm{~mm}$. long joins the seminal resicle to the ovotestis. The female organs are as figured in Larambergue's paper and also as deseribed by Rao.

The ovotestis (OT) appears on the surface as a multilobed organ. In cross section (near the anterior end) it is seen to be made up of seren or more main diverticula which branch twice at the outer end (plate 21. fig. 7). They radiate fan-wise from the ovisperm duct. Several branched diverticula contained ripe ova at their distal ends. The ova were dark gray in color and with these there were several small, rounded bodies which were red in color, evidently undeveloped ora.

Respiratory and Renal Systems. The pseudobranch (figs. 4, 6, plate 21 ) is large and conspicuous and is not simply folded or leaf-like, as in all of the Planorbidae examined, but on the upper and lower surfaces of a leaf-like base are developed a number of projections with broad lobes, plaits, or folds (fig. 4) grouped together in series of three to six folds, each group of folds being separated from the other folds by a distinet depression or gap. The base of attachment of the folds is not modified by the folded series (see fig. 6). In the living animal, the folded portion of the pseudobranch is turned back against the mantle edge. The rectum $(R)$ is on the side above the pseudobranch and the anal opening is between the pseudobranch and the pneumostome.

Rao (1923, p. 208) deseribes the lobes as occurring in groups of three or four, but in the specimens examined there were two groups of six each on the under side of the base and two groups of three lobes and two groups of two lobes on the upper side, as shown in fig. 6. The pneumostome (PS) 
is a large, thin lobe and is capable of considerable extension (fig. 4, Ps). In fig. 2, it is shown turned back and spread open.

The pseudobranch is highly vaseular, well-supplied with blood ressels, reins, and muscles. It more nearly resembles the mollusean branchimn than the pseudobranch of any of the other fresh-water pulmonates.

The kidney is long and narrow (12 $\mathrm{mm}$. long, 1.5 to $3 \mathrm{~mm}$. wide). The ureter is $1.5 \mathrm{~mm}$. long and is sharply reflexed against the lower part of the kidney, pointing backward and upward into the mantle eavity. In form, the kidney resembles that of Helisoma trivolvis figured on plate 44 (fig. 2 ). The reflexed ureter in the specimens examined is not so long as figured by Rao (1923, p. 206). A eross section near the middle (plate 45, fig. 19) shows a high, thick, wide ridge. The lumen is rounded and shows internal folds or septa. A large vein lies on each side of the lumen. The cross section somewhat resembles that of the kidney of Planorbarius corneus (plate 45, fig. 18). The kidney of Indoplanorbis is noteworthy for the size and width of the superposed ridge, which resembles some of the large Helisoma species (as Helisoma pilsbryi, plate 44, fig. 12 ).

Digestive System. The stomach resembles that organ in Australorbix glabratus (plate 48, figs. 9, 10). The intestine first makes a loop around the stomarh, passes backward to the posterior part of the liver, then makes another loop and passes forward to the enlarged reetum, which has it: exit in the anus above the pseudobranch. There is a narrow, low rilge on the reetum which ends near the pseudobranch. There is a large eaccum or blind sac near the pylorie portion of the stomach.

The buecal sae is short, wide, and high. Viewed from above, it is roughly heart-shaped. The radula sac is represented by a wide. flatly rounder bulge at the lower posterior extremity of the buceal sac. The two salivary glands are rather long, about one and a half times as long as the buccal sac when fully extended. In the natural position, the posterior portion of the salivary glands (somewhat less than half the length) is doubled backward beneath the anterior portion, which is wider with larger glandular lobules. The ducts are short and narrow. The salivary glands are joined behind as in Helisoma and other planorbids.

The jaws (plate 50, fig. 10) consist of a wide and low superior jaw, striated on its outer face, slightly bent clownward at the ends. The lateral jaws are in the form of a question mark, are very narrow and about as long as the width of the superior jaw. The jaws of Indoplanorbis do not differ notably from the jaws of the subfamily Helisomatinae.

The center tooth of the radula (plate 66 , fig. 1) is higher than wide, rather narrow, the reflection broadly bicuspid and reaching nearly to the lower margin of the base of attachment. Lateral teeth (1-5), squarish, tricuspid, the mesocone the longest, the ectocone the shortest and placed high up on the reflection, all eusps wide and spade-shaped. Intermediate teeth (6-11) narrower, differing from the typical laterals in having a second small eusp above the ectocone. The tenth intermediate tooth has two small cusps above the ectocone. Marginal teeth (12-26) narrow, about three times as long as broad. The entocone is split into three to five small, subequal eusps, the mesocone is larger and distinet, and the ectocone is smaller with two to three small cusps above it on the outer margin of the tooth. The outer marginal teeth $(27,32)$ are still narrower and the lower edge of the reflection is minutely denticulated. The extreme outer marginal teeth are very small (33). 
The radula formula of Indoplanorbis is 33-1-33 with 140 to 150 rows of teeth. There is some variation among the clifferent rows of teeth, principally in the number of accessory cusps in the narginal teeth. The radulae eximined were remarkably uniform. The radula figured on plate 66 agrees with that described by Rao (1923, p. 204$).$

The material examined consisted of six specimens from Hsipaw, North Shan state, Burma, collected by Dr. B. N. Chopra and Dr. H. S. Rao. The specimens were received from Dr. B. Prashad of the Zoological Survey of India.

Geographical Distribution. The genus as represented by the type species, Planorbis exustus Desh., occurs throughout the plains of the Inclian Empire east of the Indus, in Siam, the Malay Peninsula, French Indo-China, and Sumatra vide Ammandale). For a more detailed account of the distribution of this group see Germain (1921, pp. 28, 29).

The number of species or races referable to Indoplanorbis is in doubt. Germain (1921, p. 27) places almost everything under exustus as synonyms of that species. Planorbis coromandelicus Sowerby and Planorbis indicus Clessin have been thought to be distinct by some conchologists. A careful study of all names in connection with a large series of specimens from various localities might establish several recognizable forms.

Remarks. The systematic position of Deshayes' Planorbis exustus has been a matter of interest for a number of years. It is the largest planorbid in India and the shell closely resembles certain species of the American genus Helisoma. An examination of its anatomy led Annandale and Prashad $(1920)$ to consider it a new genus and Rao's investigations (1923) strengthened the view of its distinetion as a generic group. Baker (1933) stated that it was 'one of the most distinct groups of the Planorbidae, its male complex exhibiting characters not shared by any other group at present known.' Pilsbry $(1934$, p. 54) suggests its resemblance to Tropicorbis, particularly in the form of the penial complex.

More recently Larambergue $(1939, \mathrm{pp} .291,294)$ argues that the genus Indoplanorbis is a group of the family Bulinidae. Little is known concerning the anatomy of the majority of the species of this family. Two species have been rather carefully studied, Bulimus contortus of Europe by Larambergue (1939) and Isidora globosa from Portuguese East Africa by Connolly. In both of these species, the genitalia are similar to those of Indoplanorbis, especially in the form of the penial complex and the prostate (see plate 71 , fig. 3 and plate 75 of this work). The most convineing characteristic is the pseudobranch, which is lobed in Bulinidae /Germain. 1931. p. 514). In Isidora globosa the lobed condition is well shown in Connolly's figure (plate 71 , fig. 5 , of this work.)

The anomaly of a distinctly planorboid shell in a group made up ahmost exclusively of physoid shells is no greater than is shown in the American subgenus Seminolina where one species, Helisoma duryi seminolina, contains all shapes of shell from distinctly physoid to normally planorboid. The shell of Indoplanorbis exustus is distinetly sinistral, particularly so in the young and immature stages of growth.

The writer agrees with Larambergue in the statement that the group Indoplanorbis is a distinct genus of the family Bulinidae, the deciding features being the lobulated pseudobranch and characteristics of the male genitalia, particularly the penial complex. 


\title{
GENERA WRONGLY REFERRED TO PLANORBIDAE
}

\author{
Genus NAUTILINUS Mousson, 1872
}

Type by original designation, Hyalina clymene Shuttleworth

1872. Nautilinus Moussox, Neue Denksch. Allg. Schweiz. Gesell., XXV, p. 19. Type Hyalina clymene Shuttl. As subgenus of Hyalina

1921. Nautitinus Thiele, Archiv. für Mollusk., LIII, p. 111. Type Hyalina clymene Shuttl. Radula and generic position

1931. Nautilinus Thuele, Hamlbuch, Teil 2, p. 481. Type A. (N.) clymene (Shuttl.). As subgenus of Anisus

This genus, based on a supposed land snail from Garachico, Ténérife, Canary Islands, is searcely a member of the family Planorbidae, although so considered by Thiele. The figures given by Mousson this plate 1 , figs. 28-30, natural size, figs. 31-33 enlarged) do resemble some forms of Gyraulus. The shell is very small, only $2 \mathrm{~mm}$. in diameter. Tryon (in Man. Conch., II, p. 172, 1886) places it in Zonitidae and says 'Its habitat is different from the Hyalininae generally, living in wet moss, associated with Physa, Ancylus, and Hydrocena, ete.' Pilsbry (Man. Conch. IX, p. 24) lists it among the land shells. Wollaston 11878 , p. 324) says 'I am extremely doubtful whether this curious little Planorbis-like shell should be associated with Hyalina.'

In 1921 (p. 111), Thiele extracted a dried radula from a shell of this species and briefly described the teeth. The formula is 20-1-20. The center tooth is small and has one indistinet cusp. The side teeth (laterals and marginals) have four sharp cusps. The single cusp of the center tooth removes clymene from the Planorbidae in which the center tooth always has two eusps. The form of the shell is distinetly unlike any form of the family Lymmacidae, in which the center tooth of the radula is unicuspid. The radula resembles some groups of Anerlidae and Nautitinus might prove to be related to this family, perhaps in a similar manner to the American genus Neoplanorbis Pilsbry, in which the shell is particularly Planorbislike. Only an examination of the anatomy of the animal, especially the genitalia, will definitely settle the question of the taxonomic position of Nautilinus.

\section{Genus PALAEORBIS Beneden and Coemans, 1867}

1867. Palaeorbis Bexeden and Commaxs, Bull. Acad. Belgique, ser. ii, XXII, pp. 385, 390

The only recent reference to this group, so far as known to the writer, is in Zittel's Grundzüge der Palaontologie (Palaozoologie), Abth. I, Invertebrata, p. 424, where the following comment is made: 'Hierher dïrfte wohl auch die Planorbis sehr ähnliche Gattung; die zierliche Palaeorbis Bened. et Coemans em. Reis aus oberkarbonischen und permischen Ablagerungen von Europa und Nordamerika gehören.' The name does not occur in any other edition of Zittel's work.

The group is beheved to include fossil Vermes, possibly Polychaetes. It does not appear to be referable to any mollusk, centainly not to the Pla- 
norbidae, which are unknown in both the Carboniferous (Mississippian and Pennsylvanian) and Permian periods of America. The generic name does not appear, as far as known to the writer, in any American work on fossil pulmonates. It is probable that some Planorbidae will eventually be found in Palaeozoic strata, since the family is so well developed in Mesozoic time. 


\section{XI. BIBLIOGRAPHY}

Adans, Charles C. (1909). Isle Royale as a biotic environment. Report Geol. Surv, Michigan, 1908, pp. 1-53.

Adars, H. (1861). Descriptions of a new genus and some new species of shells from the collection of Hugh Cuming. Esq. Proc. Zool. Soc. London, 1861, pp. 143-145.

AdAus, H. and A. (1853-1858). The genera of recent Mollusca; arranged according to their organization. 3 vols. London. Planorbidae in Vol. 2, 1855.

Aguro. C. G. (1938). Los Moluseos fluriatiles Cubanos. Mem. Sociedad de Hist. Nat., XII, pp. 203-242, 3 maps, 4 figs. in text.

Axcr, C. F. (1886). Note sur certains Sections du genre Physa et diverses forms de ce genre. Le Naturaliste, VIII, pp. 357-358.

Axsandale, N. (1922). Materials for a generic revision of the fresh-water gastropod molluses of the Indian Empire. No. 5. The Indian Planorbidae. Records Indian Mus., XXIT, pp. 357-363.

Axcandale, N., and Prashad, B. (1919). The Mollusca of the inland waters of Beluchistan and of Seistan. Records Indian Mus., XVIII, pu. 17-64, plates 3-8. (1921). The aquatic and amphibious Mollusca of Manipur. Records Indian Mus., XXIl, pp. 529-633, plates 4-8, 36 figs. in text.

Baher, Fraxk Collixs (1902). The Mollusca of the Chicago area. Part II. Gastropoda. Bull. Nat. Hist. Surr., Claicago Acarl. Sci., III, pp. 131-410, plates 28-36, text figs. 13-138.

(1910). The ecology of the Skokie Marsh area; with special reference to the Mollusea. Bull. Illinois State Lab. Nat. Hist., V1l1, pp. 437-499.

(1911a). The molluscan fauna of Tonahawk Lake, Wisconsin. Trans. Wisconsin Acarl. Sci. Arts and Lett., XVII, pp. 200-246, plates 11-17.

(1911b). The Lymnaeidae of North and Middle America, recent and fossil. Spec. Pub. Chicago Acad. Sci.. 3, pp. i-xvi, 1-539, plates 1-58. 51 text figs.

(1916). The relation of mollusks to fish in Oneida Lake. Tech. Pub., New York State Col. Forestry, Syracuse Unir.. No. 4, pp. 15-366, 50 figs., 1 map.

(1918). The productivity of invertebrate fish food on the bottom of Oneidla Lake, with special reference to mollusks. Op. cit.. No. 9, 1p. 1-264, 44 text figs., 2 plates.

(1920). The effect of sewage and other pollution on animal life in rivers and streams. Trans. Illinois State Acad. Sci., XIII, pp. 271-279.

(1922a). Fluke infections and the destruction of the intermediate host. Jour. Parasitol., VIII, pp. 145-147.

(1922b). The mollusean fauna of the Big Vermilion River. Illinois, with special reference to its modification as a result of pollution by sewage and manufacturing wastes. Illinois Biol. Mon., VII, No. 2, 1p. 1-126, plates 1-15.

(1924). The fauna of the Lake Winnebago region. A quantitative and qualitative survey, with special reference to the Mollusca. Trans. Wisconsin Acad. Arts, Sci. and Lett., XXI, pp. 109-146, 1 map.

(1926). Nomenclatorial notes on American fresh-water Mollusea. Op. cit., XXII, pp. 193-205.

(1928). The fresh-water Mollusea of Wisconsin. Bull. Wisconsin Geol. and Nat. Hist. Surr., LXX, Part I, Gastropoda, pp. ixx, 1-507, plates 1-28, 202 text figs.

(1931). The classification of the large planorboid snatils of Europe and America. Proc. Zool. Soc. London. 1931, pp. 575-592, plates 1-6.

(1933). The genitalia of the Indian mollusk Indoplanorbis exustus. Jour. Morph., LY. Xo. 1, pp. 1-13, plates 1-2, 1 text fir.

(1935). The generic position of Planorbis umbilicatellus with the description of a new group of Planorbidae. Nautilus, XLIX, pp. 46-48.

(1936a). The generic position of Planorbis obstructus Morelet. Nautilus, XLIX, p. 104. 
(1936b). The relationship of Parapholyx. Nautilus, L, pp. 30-31.

1). 106 .

(1940). South American species referred to Planorbula. Nautilus, LIII,

(1941). A new species of Drepanotrema and some preoccupied planorbid names. Nautilus, LIV, pp. 96-97.

Baker, H. Burrivgtox (1930il). The Mollusea collected by the University of Michigan - Williamson expedition to Venezuela. Part vi. Occ. Papers Mus. Zool. Univ. Michigan, No. 210, pp. 1-94, plates 27-33.

- (1930b). Gender in generic names. Nautilus, XLIII, pp. 139-140.

Bartach, Paul (1907). The Philipuine mollusks of the genus Planorbis. Proc. United States Nat. Mus., XXXII, pp. 83-85, 2 text figs.

Baddelot, M. (1863). Recherces sur l'appareil générateur des Mollusques gastéropodes. Ann. des Sci. Nat., Ser. 4, Zool., NIX, pp. 135-222, 268-294, plates 2-5.

Bequaert, J. C., and Clesch, W. J. (1939). Philippine Lymnaeidae and Planorbidae. Philippine Jour: Sci., LXIX, No. 1, pp. 1-21, plates 1-2.

BExsox, W. H. (1850). Characters of nine new or imperfectly described species of PJanorbis inhabiting India and China. Ann. and Mag. Nat. Hist., Ser. 2, V, pp. $348-352$.

(1855). Chusan shells ... collected by Dr. J. Cantor. Jour. Asiatic Soc. Bengal, XXIV, No. 2, pp. 119-140.

Binvey, William G. (1865a). Land and fresh-water shells of North America. Part II. Pulmonata Limnophila and Thalassophila. Smithsonian Miscel. Coll., No. 143, pp. i-ix, 1-161, 261 text figs.

(1865b). Descriptions of new species of North American land and freshwater shells. American Jour. Conch., I, pp. 49-51, plate 7.

Bourguignat, J. R. (1883). Histoire malacologique de l'Abyssinie. Ann. Sci. Nat., Ser. 6 (Zool.) Tom. XV, art. 2, pp. 1-162, 5 plates.

Brooks, W. K. (1880). Observations upon the early stages in development of the fresh-water pulmonates. Stud. Biol. Lab., Johns Hopkins Univ., Baltimore. I, pp. 73-104, 4 plates.

Brown, T., Capt. (1827). Illustrations of the conchology of Great Britain and Ireland, etc. $P_{1}$. (iii), $V^{\top} ; 52$ plates col., with descript. Letterpress. 4to. London. In the article 'Conchology,' Encye. Brit., ed. 6, vi, 1823, p. 405, the figures in this edition are cited. (Copied from Kennard and Woodward, 1927, p. 370).

Brumpt, E. (1936). Schistosoma bovis et Sch. mansoni ne sont pas transmis par Planorbis (Indoplanorbis) exustus: observations biologiques concernant ce Planorbe. Ann. Parasitol., Paris, XIV, p. 464.

Buchiser, O. (1891). Beiträge zur Kenntnis des Baues der einheimischen Planorbiden. Jahreshefte des Vereins für Vaterländische Naturkunde Württemberg, XLVII, pp. 35-118, Tafeln iv-ri.

Call, R. Ellsworth (1888). On a new Post-Pliocene limnaeid. American Geologist, I, No. 3, pp. 146-148, 6 text figs.

('наршіск, W. H. (1903). Self-fecundation in Planorbis vortex. Jour. of Conch., I, p. 265.

Chamberlin, Ralph, and Jones, David T. (1929). A descriptive catalog of the Mollusea of Utal. Bull. Univ. Utah, XIX, No. 4 (Biol. Bull. Series, I, No. 1), pp.1-203, 86 text figs., 1 map.

Chamberlin, Ralph, and Berry, Eluer (1933). Mollusks of the Pliocene deposits at Collinston, Utah. Nautilus, XLVII, pp. 25-29, plates 4, 5 .

Chaxder, Asa C. (1920). Control of fluke diseases by destruction of the intermediate host. Jour. Agricult. Research, XX, No. 3, pp. 193-208.

Chinplextier, J. de (1837). Catalogue des Mollusques terrestres ef fluviatiles de la Suisse. Neue Denkschr. Allg. Schweiz. Gesell., Band I, No. 2, pp. 1-28, 2 plates (publishes MS names of Agassiz).

Clessix, S. (1886). Die Familie der Limnaeiden, enthaltend die Genera Planorbis, Limnaeus, Physa und Amphipeplea. In Martini und Chemnitz, Syst. Conchyliencabinet, ed. 2, XVII. Nïrenbery. 
Coltox, Harold S. (1912). Lymnaea columella and self-fertilization. Proc. Acad. Tat. Sci. Philadelplia, j]). 173-183.

(1918). Self-fertilization in the air-breathing pond snails. Biol. Bull., XIXT, 15-19.

Conyolty, M. (1925). The non-marine Mollusca of Portuguese East Africa. Trans. Rotal soc. South Africa. XII, pp. 105-220, plates 3-S, 30 text figs.

(1939). A monograplic surver of South African non-marine Mollusca. Ann. South African Mus.. XXXII, Part 1, pl. 660, plate 19. 5s text figs.

CrABB, EDW ARD D. (1927). The fertilization proces in the snail, Lymmaea stagnalis apuressa Say. Biol. Bull.. LIII, pp. 67-106, plates $1-5$.

Crosse. H., et Fincher, P. (1579). Faune malacologique de Lac Baikal. Jour. de Conch.. XITII. mi. 143-168, plate 4

(1SSS). Etudes sur les Mollusques terrestres et fluviatiles de Mexique et du Guatemala. Mission scient. du Mexique et dans l'Anerique Centrale. Recherches Zool., TII, Part 2

Dall. Mnlam H. (1S66). On a new subfamily of fluviatile Mollusca. Proc. California Acad. Sci. (i), II. Part 3, 1, 26 s.

- (18;0). On the genu= Pompholrx and its allies, with a revision of the Limnaeidae of autliors. Ann. Lyc. Na1. His. N. ... IX, pp. 333-361, plate 2.

(1905). Land and fre-h-water mollusks. Harriman Alaska Exped., IIII, 17). i-ix, 1-171, plites 1, 2. 118 text figs. 101-105.

(1908). Totes on Planorbis and its subdivisions. Proc. Mal. Soc. London, TIII, p. 141 .

(1924). Discorery of a Balkan fresh-rater fauna in the Idaho formation of Snake River Talley, Idaho. Prof. Pajers, [nited States Geol. Surv., No. 132 (G), pp. 109-115.

Duméril, A. M. C. (1806a). Zoologie analytique, ou méthode naturelle de Classification des Animeaux, rendue plus facile a l'aide de tableaux synoptiques. Paris. Pp. i-xxxii. 1-314

(1806b). C Duméri]: ... Analytische Zoologie. Aus dem Französizchen mit Zusätzen ron L. F. Froner. Pr. 314. Meimar. (Froriep added type specie:to many of the new genera.)

Drвowski. Mi (1575). Die Gasteropoden-fauna des Baikal-Seer. Memoirs Acad. Sci. st. Petersburg, ser. 7. XI.

(1903). Bemerhungen über die gegenwärtige sistematik der SüswasserSchnecken. Nach. Deut-ch. Mal. Gesell.. XXIT, Ip. 130-144.

Drвow-Ki. B., and Grochmalickl. J. (1925). Przỵezýnhi do znajomósej mięczahów jeziora Bajkalshiego (Contribution- à lid connain-ance de: mollusques du lac Baical). Fosmos, L, ro. 819-851, 1 plate.

ExtrDam. W. J. (1935). A collection of fresh-water shells from Kamchatka. Nautilus, LII, y. 5. 56-59.

Fatst. Erxest C. (1917). Noter on the Cercariae of the Bitter Root Talley, Montana. Jour. Parasitol., III, ]'p. 105-123.

(1918). Btudies in Illinois Cercariae. Jour. Parasitol., IV, pp. 93-110.

(1919i). Notes on South African Cercariae. Jour. Parasitol., T. pp. 161-175.

(1919b). A biblionsaphical surver of described Cereariae in the United States. Amer. Nat., LIII, pJ. 85-92.

- (1920: A surrey of Cawston:- specie- of South African Cercariae. Parasitology (Cambridge), XII. Tp. 212-216.

(1920b). Pathological changes in the gasteropod liver produced by fluke infection. John- Hopkins Hosp. Bull., XIXI, No. 319, pp. 79-81, plates 32-33, test firs. 1-4. Reprint pp. 1-16.

(1932). The rôle of aquatic molluses in the spread of human trematode infections. China Jour., XYI. No. 6. pp. 350-353. 
(1933a). Investigations in Puerto Rico on Manson's blood-fluke infection (Schistosomiasis mansoni). Science, LXXVIII, pp. 62-63.

(1933b). Studies on Schistosomiasis mansoni in Puerto Rico. I. The history of Schistosomiasis in Puerto Rico. Puerto Rico Jour. Pub. Health and Trop. Med., IX, \o. 2, pp. 15t-168.

Fatst, Erxest C.. Joxes, Chirles A., and Hoffmax. Wrllaw A. (1934). Studies on Schistosomiasis mansoni in Puerto Rico. III. Biological studies. 2. The mammalian phase of the life cycle. Op. cit., X, No. 2, pp. 133-196, figs. 1-9.

Ficrits. H. D. A. (186\%). Der penis der einheimischen Planorbiden. Zeitschr. für die gesammten Taturwissen., XIX. pp. 363-36i.

Fischer, Patr H. (18S0-1S87). Manuel de Conchyliologie et de Palèontologie conchy-liologique; ou histoire naturelle des Mollusques rirants et tossiles suivi d'un appendice sur les Brachiopodes par D. P. Oehlert. Paris. Pp. xxir-1369, 23 plates, 1138 figs, in text. Planorbis published in 1883.

Fitzisagr, L. J. E. J. (1833). Systematisches Verzeichniss der im Erzherzogthume Oesterreich vorkommenden Weichthiere, etc... Beiträge zur Landeskunde Oesterreich's unter der Enns. Band III, pp. SS-122.

Flemixg, J. (1S1S). Conchology. Supplement to the 4th, 5th, and 6th ed. of Encyclopaedia Britannica. Vol. iii, pp. 2S4-316 (pp. 1-316 of Vol. iii published in 1818, the whole volume in 1824. Vide Kennard and Woodward, 1926, p. 379).

Forbes, Edward, and Haxley, Sylvanes (1S4S-1853). A history of British Mollusca and their shells. London. 4 volumes. Gastropoda in Vol. 4, 1852.

Forel. F. A. (1869). Introduction a létude de la faune profonde de Lac Léman. Bull. Soc. Vaudoise Sci. nat. Tome X, pp. 217.

(1574). Matériaux pour servir a l'étude de la Faune profonde du Lac Léman. Op. cit., Tome IIII, pp. 201-364, 3 plates.

Froriep. L. F. (1906). See Duméril, 1906.

Cieofrroy. E. L. (176i). Traité sommaire des Coquilles tant fluriatiles que terrestres, qui trouvent aux environs de Paris. Pp. ix +143.

Germaix. Lotis (1903). Étude sur les Mollusques terrestres et fluriatiles vivants des environs d'Angers et du département de Maine-et-Loire. Bull. Soc. Sci. Nat. Ouest France, Sér. 2. Tome III. pp. 238.

(1921-24). Catalogue of the Planorbidae in the Indian Museum (NaturaI History) Calcutta. Rec. Indian Mus.. XII, pp. 1-210, plates 1-1. 21 text figs.

(1931). Mollusques terrestres et fluviatiles. Part 2. In Faune de France, 22. Paris. Pp. 479-897, plates 14-26, text figs. 471-\$60.

Gerstfeldt, G. (1859). Teber Land-und Süswasser - Mollusken Siberiens und des Amur-gebietes. Mem, des sarants étrangers, IX, pp. 507-j4s. Imp. Acad. Sci. St. Petersbury.

Gotтsсніск. F. (1920). Die Lmbildung der sïswasserschnecken des Tertiärbeckens ron Steinheim a. A. unter dem Einflusse heisser Quellen. Jenais. Zeitschrift Naturwissensch., LTI. pp. 15j-216, tafeln 10-12.

Gray, J. E. (1S47). A list of the generu of recent Mollusca, their syonyms and types. Proc. Zool. Soc. London, XV, pp. 129-206.

(1S6S). Note on Pompholyx Lea. A new family of Auriatile Mollusca. Ann. and Mag. Nat. Hist. Ser. 4. II, p. 3S\%.

GraY, M. E. (1S50). Figures of molluscous animals, etc. 5 vols. London. 1842-1S57.

HuAs. Frutz (1929). Fauna Malacologica terrestre $Y$ de agua dulce de Cataluña. Trabajos Museo de Ciencias Laturales de Barcelona. XIII, pp. 491, 18 i text figs. (1930). Reriew of Odhner's 'Die Molluskntauna des Takern' Archiv. Molluskenkunde. L.III, p. 20.

(1936). Binnen-mollusken aus Inner-Afrika, hauptsächlich gesammelt ron Dr. F. Haas während der schomburgh-Expedition in den Jahren 1931-1932. Abhand. der Senckenbergischer Naturforsch. Gesellsch. No. 431, pp. 156, \& Tafeln, 17 text figs.

(1939). Malacological notes. The South Americun species of Planorbula. Zool. Series, Field Mus. Nat. Hist., XIIV, No. S. pp. 93-103, figs. 7-9. 
p1). $33-34$.

1940). Planorbulina not a generic name in the Mollusca. Nautilus, LIV,

(1941). Obstructio rersus Tropicorbis. Niutilus, 55, pp. 31-32.

Halaváts, G. v. (1902). Die Fauna der Pontischen Schichten in den Ungebung des Balatonsees. Resultate 1. Wissensch. Erforsch. Balatonsees, Erster Band, Erster Teil, Art. II, pp. 1-8, plates 1-3, 7 text figs.

Haldeman, S. S. (1841-1845). A monograph of the Limniades, or fresh-water univalve shells of North America. Continued as A monograph of the fresh-water univalve Mollusea of the United States, including notices of species in other parts of North America. Philadelphia, Pa. Published in nine numbers.

No. 2, p. 216.

HaxNA, G. D. (1922). Fossil fresh-water mollusks from Oregon contained in the C'ondon Museum of the University of Oregon. Univ. Oregon Pub., 1, No. 12, p). 1-22, plates 1-4.

Haximal, Harolo (1912). A synopsis of the recent and Tertiury fresh-water Mollusca of the Californian Prorince, based uyon an ontogenetic classification. Proc. Mal. Soc. London, X, pl. 112-166 (Part 2), pp. 167-211 (Part 3), plates 5-8.

Hanley, Srlvanus, and Theobald, Willay (1867). Conchologia Indica: Illustrations of the land and fresh-water shells of British India. Pp. i-xriii, 1-65, plates $1-160$.

Haktanx, J. D. W. (1840-1844). Erd-und Sïsswasser Gasteropoden beschrieben und abgebildet ron... St. Gallen. Published in 8 fascicles, 1, 1840; 1I-IV, 1841 ; V-VI, 1842; VII, 1843; VIH, 1844. The Systematisches Chersicht der EuropaFwehen Gattungen' was probably published with the first part of this work.

Hexdersox, Juxius (1929). Non-marine Molluscil of Oregon and Washington. Univ. Colorado Studies, XVII, No. 2, pp. 47-190, 186 text figs.

(1935). Fossil non-marine Mollusea of North America. Geol. Soc. America, Special Papers No. 3, pp. 313.

Hexperson, Junits, and Ropeck. Hugo G. (1934). New species of Pliocene Mollusar from Eastern Oregon. Jour. Paleont., VIII, pp. 264-269, plate 37.

Herruaxisex, A. N. (1846-1852). Indicis generum Malacozoorum primordia, etc. Vol. I, 1846; Vol. II. 1847-49. Supplements et corrigenda, 1852.

Hoffuax, Williay A., and Faust, E. C. (1934). Studies on Schistosomiasis mansoni in Puerto Rico. II. The epidemiology and geographical distribution of Schistosomiasis in Puerto Rico. I. Epidemiology of the infection on the istand. Puerto Rico Jour. Pub. Health and Trop. Medl., IX, No. 3, pl. 228-282, 13 figs.

Holmes, SAuUEL J. (1900). The early development of Planorbis. Jour. Morph., XVI, l'p. 369-458, plates 17-21.

Hoxiguaxy, H. L. (1909). Terzeichniss der im Zoologischen Museum der Universität Halle befindlichen Coldfussschen Mollusken-Lokalsammlung. Zeitschr. für Naturw, LXXXI, lp. 287-300.

Hyatt, Alphets (1880). The genesis of the Tertiary species of Planorbis at Steinheim. Mem. Boston Soc. Nat. Hist., Anniversary Volume, pp. 1-114, plates 1-9.

Jickeli, C. F. (1874). Fauna der Land-11nd Siisswasser-Mollusken Nord-ost-Afrika's. Tova Acta Acad. Caes. Leop.-Carol. Nat. Cur., XXXYI, No. 1, pp. 352, plate 11.

Kexcard, A. S. (1908). Notes on Planorbis rorticulus, Troschel, and Pl. laevis, Alder; also on some proposed subdivisions of the genus. Proc. Mal. Soc. London, VIII, pp. 46-49.

Kexpard, A. S. and Woodward, B. B. (1924). Nomenclatorial notes relating to British non-marine Mollusca. II. Proc. Mal. Soc. London. XVI, pp. 7-14.

(1926). Srnonymy of the British non-marine Mollusea (recent and postTertiary). London. Trustees of British Museum, pp. xxiv, 447.

I acaze-Duthiers, Henri de (1872). Du système nerveux des Mollusques Gastéropodes pulmonés aquatiques et d'um nouvel organe d'innervation. Archiv. Zool. Exper. et Génélale, I, pp. 437-500, plates 17-20. 
LAMARCK, J. B. P. A. DE M. DE (1799). Prodrome d'une nouvelle Classification des Coquilles, ete. Mém. Soc. Hist. Nat. Paris, i, Prairial, An VII, pp. 63-91.

(1815-1822). Histoire naturelle des Animaux sans vertèbres, etc. 7 Tom. Paris. (Mollusca in tom. V-VTI, 1818-1822).

LANKEster, E. RAY (1874). Observations on the development of the pond-snail (lymnaeus stagnalis) and on the early stages of other Mollusea. Quart. Jour. Micr. Sci., N.S., XIV, pp. 365-391, plates $16,17$.

Larambergue, Marc de (1939a). Étude de l'autofécundation chez les gastéropodes pulmonés recherches sur l'aphallie et la fécondation chez Bulinus (Isidora) contortus Michaud. Bull. Biol., France et Belgique, Tome LXXIII, fasc. 1-2, pp. 19213, plates 3-5, 46 text figs.

(1939b). Remarques sur l'appareil gènital de l'Indoplanorbis exustus affinités de cette espéce arec les Bulimidés. Bull. Soc. Zool. France, Tume LXIV, No. 5, pp. 286-295, 6 text figs.

LEA, IsAAC (1864). Description of and remarks on Planorbis newberryi. Proc. Acad. Nat. Sci. Philadelphia, 1864, p. 5.

LEACH, W. E. (1852). Molluscomm Britanniae Snyopsis. A synopsis of the Molluscae of Great Britain, etc. (Edited by J. E. Gray). Pp. xri, 376, plate 13. London. "The first 116 pages were in proof and partly circulated in 1819.' (Vide Kennard and Woodward).

Lixinoli, W. A. (1909). Die Mollusken der Baikal-Sees (Gastropoda et Pelecypoda). Korotneff, Wissensch. Ergebn. Zool. Exped. Baikal-See, IV, pp. 104, plate 2, 3 text figs.

(1922). Miscellaneous notes on palaearctic land and fresh-water mollusks. Ezheghol. Zool. Mus. Ross. Akad. Nauk., XYIII, pp. 304-320, 1918-1922.

(1926). Beiträge zur Kenntniss der palärktischen Planorbidae. IV. Zu Systematik der Europäischen Planorbidae. Archiv. Molluskenkunde, Heft 6, 58 year, pp. 241-258.

(1927). Kritische Studien zur Molluskenfauna des Baikalsees. Trav. Com. l'étude Lac Baikal, Leningrad 2, pp. 139-186.

(1933). Ein Vorkommen des Amerikanischen Helisoma trivolvis Say im Pleistocene des Flusses Kolyma (Nordost Siberien). Acad. Sci., U.S.S.R. Work of the Council and the Study of Natural History, No. 11, p. 65.

Linne (Linnaeus). Carl vos (1758). Systema Naturae, seu Regna tria Naturae systematica proposita, per classes, ordines, genera et species. Ed. X, 2 rols. Holmine, $1758-1759$.

Lörexthey, E. (1906). Beitrïge zur Fauna und stratigraphischen Lage der pannonischen Schichten in der Ungebung des Balatonsees. Resultate d. wissenchaftl. Untersuch. des Balatonsees. Erster Band, erster Teil, art. 3, pp. 216. Taf. 3, text figs. 12 .

Lowraxce, EDward (1934). On the early development of Stagnicola kingi (Meek). Bull. Univ. Utah, XXIV. No. 5, Biol. Series, II, No. 5, pp. 21, plates 3.

Lutz, Adolpr (1918). On Brazilian fresh-water shells of the genus Planorbis. Memorias Inst. Oswaldo Cruz, X, pp. 45-61, plates 15-18.

Martexs, E. C. yon (1890-1901). Biologia Centrali-Americana. Land and Fresh-water Mollusca. Pp. xxviiit 706, 44 plates. London.

Martixs, A. Thaxxa (1938). Contribucáo ao estudo do genero Australorbis Pilsbry, 1934. Trabalho do Instituto Biologico Ezequiel Dias. Tése de livre docencia por A. Vianna Martins. Pp. 66, plate 6 .

Matrox, Normax T. (1937). Oogenesis of Campeloma rufum, a parthenogenetic snail. Zeits. fïr Zellforsch. u. mikroskop. Anat., Band XYVII, Heft. 4, pp. 455-461, 30 text figs.

(1938). Morphology of Campeloma rufum, a parthenogenetic snail. Jour. Morph., LXII, No. 2, pp. 243-261, plates 1, 2.

(1940). Two new snails of the genus Campeloma from Ontario. Nautilus, LIT, No. 1, pp. 12-17.

McCormck, Robert N. (1923). The comparative parasitization of certain freshwater snails. Ohio Jour. Sci., XXIII, No. 4, pp. 163-180. 
MeEK, F. B. (1870). Descriptions of fossils collected by the United States Geological Survey under the charge of Clarence King, esq. Proc. Acad. Nat. Sci. Philadelphia, XXII, pp. 56-64.

(157\%). Paleontology. United States Explor. 40th Parallel (King Survey), IV, Part 1, pp. 197.

Miller, Edwix L. (1936). Stulies on North American Cercariae. Illinois Biol. Monographs, XIT, No. 2, pp. 125, plate 8 .

Montfort, P. Dexrs de (1810). Conchyliologie systématique et Classification méthodique des Coquilles. Tomes 2, Paris 1808-1810.

Moore, J. E. S. (1901a). To the Mountains of the Moon. Cited from Pilsbry, 1927, p. 121 .

(1901b). Further researches concerning the molluses of the Great African Lakes. Proc. Zool. Soc., London, pp. 461-470.

Moquin-Tandos, A. (1855). Histoire naturelle des Mollusques terrestres et fluriatiles de France. Two tomes, Illustrated. Paris, 185̃5-1856.

Mörch, O. A. L. (1852-1853). Catalogus Conchyliorum quae reliquit ... Comes de Foldi. Two fascicles. Hafniae (quoted from Kennard and Woodward).

Mori, S. (1938). Classification of the Japanese Planorbidae. Mem. Coll. Sci., Kyoto Imp. Univ., B 14, pp. 279-300, plates 12-18.

Morrison, J. P. E. (1940). Haldeman's 1840 supplement. Nautilus, LIV, pp. 64-66.

Moussox, J. R. A. (1872). Révision de la Faune Malacologique des Canaries. Neue Denkschr. Allg. Schweiz. Gesell., .XXT, No, 1, pp. 176, plate 6.

Müller, O. F. (1774). Vermium terrestrium et fluviatilum seu animalium infusorium helminthicum et testaceum, non marinorum, suceincta historia. Tol. II, pp. xxxri+214 (10). Havinae and Lipsiae.

Odhxer, Nils H. (1929). Die Molluskenfauna des Tơkern. Sjön Tokkerns Fauma och Flora, utgiven ar $\mathbf{K}$. Srenska Tet.-Akad., VIII, pp. 129, Taf. vii, text fig. 89 .

(1937). Acrorbis petricola n. gen. n. sp., eine merkliche Süisswasser-schnecke aus Brasilien. Archir. Zoologi, Band 29 B, M. 14, pu. 1-S, 10 figs. in text.

O'Roke, Earl C. (1917). Larval Trematodes from Kansas fresh-water snails. Kansas Eniv. Sci. Bull.. X, No. 7 , pp. 161-180, plates 1-7.

Pallari, P. (1909). Catalogue de la faune Malacologique d'Égrpte. Mém. Inst. Égypte, VI, pp. 1-92, 177-182, 5 plates.

Pulsbry, Hexry A. (1896). New species of fresh-water mollusks from South America. Proc. Acad. Nat. Sci. Philadelphia, pp. 561-565, plates 26-27.

(1924). South American land and fresh-water mollusks: notes and descriptions. Op. cit., LXXVI, lp. 49-66. plate 4.

(1926). What constitutes publication? A question concerning nomenclature. Science, N.S. L.TIT, pp. 248-249. use of name.)

(1934). Review of the Planorbidae of Florida, with notes on other members of the family. Proc. Acad. Nat. Sci. Philadelphia, LXXXVI, pp. 29-66, plates 7-11, 7 text figs.

(1935). Mollusks of the fresh-mater Pliocene beds of the Kettleman Hills and neighboring oil fields, California. Op. cit., LXXXVI, pp. 541-570, plates 18-23, 9 text figs.

(1938). Acrorbis petricola. Review. Nautilus, LI, p. 107.

Pilsbri, H. A., and Bequakrt, J. (1927). The aquatic mollusks of the Belgian Congo, with a geographical and ecological account of Congo malacology. Bull. American Mus. N. H., LIII, art. ii, pp. 69-602, plates x-lxxvii, 93 text figs., 15 maps.

Pllsbry, H. A., and Ferriss, J. H. (1906). Mollusca of the southwestern states, II. Proc. Acad. Nat. Sci. Philadelphia, pp. 123-175, plates 5-9, 37 text figs.

Ping, Chi, and Yex. Texg-Chiex (1932). On five new species of non-marine Gastropods from North China. Bull. Fan Memorial Inst. Biol., III, pp. 25-34, 14 text figs.

Prashad, B. (1921). Report on a collection of Sumatran molluses from fresh and brackish water. Rec. Indian Mus., XXII, pp. 461-507, plate 14 . 
Prestox, H. B. (1910). Additions to the non-marine Molluscan fauna of British and German East Africa and Lake Albert Edward. Ann. and Mag. Nat. Hist., Ser. S, VI, pp. 526-536, plates 7-9.

(1915). The fauna of British India, including Ceylon and Burma. Mollusca (Fresh-water Gastropoda and Pelecypoda). London. Pp. xix, 244, 29 text figs.

Rao, H. SRinivasa (1923). On the anatomy of Indoplanorbis exustus (Mollusca, Pulmonata). Rec. Indian Mus., XXV, pp. 199-219, 14 text figs.

Saxpberger, C. I. F. vox (1875). Die Land-und Süsswasser-Conchylien der Vorwelt. Pp. viii $+1000,36$ plates. Wiesbaden, 1870-1875.

Scott, J. Allex (1940). Venezuelan snails of the genus Australorbis. Notulae Naturae, Philadelphia Acad. Sci., No. 54, 13 pp. 4 figs.

Simroti. H. R. (1912). Mollusca. In Bronn and Keferstein, Klassen und Ordnungen der Weichthiere. III, pr. 700, 44 plates, many figs. in text.

Soos, A. (1935a). A Magrarországi Planorbis-Félék warkészülékének Alak-és Szövett:ına. Állattani Közlemények, 32 Kötet, 1-2 Füzet, pp. 21-42, 4 figs. in text.

(1935b). Morphologie und Histologie des Geschlechtsapparates der ungarischen Planorbis-Arten. Állat. Közlem. XXXII, pp. 21-46, 2 Tafeln.

Soos, Lajos (1917). Zur srstematischen Anatomie der Ungarischen Pulmonaten. Ann. Musei Nat. Hungarici, XV, pp. 165, 100 text figs.

Sterx, J. P. E. F. (1850). Die lebenden Schnecken und Muscheln der Umgegend Berlins, etc. Berlin. Pp. viii $+120,3$ plates.

Studer, S. (1S20). Kurzes Verzeichniss der bis jetz in unserm Taterlande entdeckten Conchylien. Naturw. Anzeiger Allg. Schweiz. Gesell. Gesammt. Naturwiss., III, No. 12 , pp. $83-90$.

Swarsox, W. (1840). A treatise on Malacolory. Pp. viii+419, many text figs. London.

Tarlor, Johx II. (1894-1900). Monograph of the land and fresh-water Mollusca of the British Isles. Structural and general volume. Leeds, pp. 454, plate vi, 743 text figs. ру. $97-116$.

(1928). Mutations of land and fresh-water Molluska. Jour. Conch., XVIII,

Thiele, Johaxies (1921). Leber die Radula und systematische Stellung ron Nautilinus clrmene Shuttl. Archiv. für Mollusk., LIII, pp. 111-112.

(1931). Handbuch der systematischen Weichtierkunde. Jena. Erster Band, Erster und Zweiter Teil, pp. vi+778, 752 figs. in text.

Trrox, George W. (1870). A monograph of the fresh-water univalve Mollusca of the United States (in continuation of Prof. S. S. Haldeman's work published under the above title). Pp. 238, plates irregularly numbered.

(1871). Review of Meek's paper in Proc. Acad. Nat. Sci. Phil., 1870, p. 59. American Jour. Conch., VI, p. 285.

(1884). Structural and systematic Conchology. An introduction to the study of the Mollusea, III, 453 pp., plates 92-140. Philadelphia.

Turtos, II. (1831). A manual of the land and fresh-water shells of the British Islands. Pp. viii $+150,16$. 10 colored plates. London.

(1857). A manual of the land and fresh-water shells of the British Islands. New edition by J. E. Gray. Pp. xvit335, 12 colored plates, many text figs. London.

VaxCleave, H. J. (1932). Statistical analysis of quantitative collections as a means of interpreting life histories. Trans. Illinois St. Acad. Sci., Vol. 24, No. 2, pp. 228-234.

(1934). The seasonal life history of an amphibious snail, Fossaria modicella, living on sandstone cliffs. Ecology, Vol. 16, No. 1, pp. 101-10S.

YaxCleate, H. J., and Altrixger, D. A. (1937). Studies on the life cycle of Campeloma rufum, a fresh-water snail. American Nat., LXXI, pp. 167-184.

TaxCleave, H. J., and Lederer. L. G. (1932). Studies on the life cycle of the snail, Tiviparus contectoides. Jour. Morph., Tol. 53, No. 3, pp. 499-522.

WALKER. BRYANt (1918). A srnopsis of the classification of the fresh-water Mollusca of North America, north of Mexico, and a catalogue of the more recently described species, with notes. Miscel. Pub., No. 6, Mus. Zool., Univ. Michigan, pp. 213, 1 plate, 233 text figs. 
Ward, Hexry B., and Whipple, Geo. C. (1918). Fresh-water Biology. New York. (Chapter XIII, Parasitic flatworms, pp. 365-424, by Henry B. Ward.)

Menz, W. (1923). Gastropoda extramarina tetiaria. In Fossilium Catalogus I: Animalio, Pars 22, pp. 1421-1734. Edited by C. Diener. Berlin.

White, C. A. (1883). The Molluscan fauna of the Truckee group, including a new form. Proc. United States Nat. Mus., V, pp. 99-102, plate 5.

Westerlund, C. A. (1885). Fauna der in der Paläarctischen Region ... lebenden Binnenconchylien. Lund, Fascicle V, pp. $135+14$.

(1899). Planorbis libanicus n. sp. Nachrbl. Deutsch. Mal. Ges., pp. 170-171.

(1902). Methodus dispositionis Conchyliorum extramarinum in regione palaearctica viventium, familias, genera, subgenera, et stirpes sistens. Rad. Jugoslav. Akad., CLI, pp. 82-139. (1-58).

Wollaston, T. V. (1878). Testacea Atlantica, etc. Pp. xi+588. London.

Woodward, S. P. (1851-1856). A manual of the Mollusea. Published as follows: Pt. 1, pp. 1-158, 1851; Pt. 2, pp. 159-330, 1854; Pt. 3, pp. 331-486, 1856 . Several subsequent editions. (Ralph Tate has an appendix in 1869 in which Pompholyx appears.)

Zittel, Karl A. von (1910). Grundzüge der Paläontologie (Paläozoologie). I. Abteilung Invertebrata. Neubearbeitet von Dr. Ferdinand Broili. München und Berlin. $\mathrm{x}+607$ pp., 1414 text figs. 


\title{
THE MOLLUSCAN FAMILY PLANORBIDAE
}

\author{
PART II \\ THE PLANORBIDAE INHABITING NORTH AND SOUTH \\ AMERICA AND THE WEST INDIES*
}

\footnotetext{
*It was Mr. Baker's plan that Part II should contain full morphological and taxonomic descriptions together with comprehensive illustrations of the shells of all species of the Planorbidae known for North and South America and the West Indies. His voluminous working notes were not near enough objective organization at the time of his death to permit their being edited for publication. Any attempt at preparation of these notes by another hand could not ensure the reflection of Mr. Baker's matured judgment and ultinate intent in the casting of specific descriptions, in the portrayal of individual variability, and in the discussion of geographical distribution and ecological relationships. However, at the time of his death, he had completed fifty-four of the plates intended for this section and had prepared typewritten copy for them. In his desk were found plainly-marked photographic prints of other species sufficient to prepare six additional plates and pencil manuscript for descriptions of the figures had been written out. The entire group of sixty plates (82-141) is included as a supplement to Part I, even though the six plates at the end of this series represent working copy in which he night have desired to make some final alterations. For convenience of arrangement and reference, the plates of Parts I and II are presented in a single undivided series at the end of this monograph.

In addition to the plates for Part II, descriptions have been prepared for nine new species and seventeen new varieties.

The foreword was written by Professor Harley Jones Van Cleave, who also assembled and edited the descriptions of the new forms and edited the explanations of the plates.-H.E.C.
} 



\section{XII. FOREWORD}

$\mathrm{F}$ OR ALMOST A QUARTER OF A CENTURY, Frank Collins Baker had been engaged in the preparation of detailed descriptions of the species and eritical evaluation of the synonymy of the Planorbidae of the Western Hemisphere. This study was the natural outgrowth of the long vears of detailed morphological studies which led him to the evaluation of anatomical detail as expressed in the broader phases of taxonomy in the main body of the present volume. The second volume in this series was to have treated the species of the Planorbidae in a manner similar to his treatise on another large and important family of fresh-water snails, the Lymnaeidae. Though published in 1911, his volume on the Lymnaeidae of North and Middle America after more than thirty years still stands as the leading taxonomic and distributional study of the lymnacid snails of the Western Hemisphere.

Though such a program of study involved intimate familiarity with the voluminous, seattered literature and wise interpretations of matters of disputed priority and synonymy, these labors paled into insignificance when compared with the self-imposed task of dissecting and microscopically studying representatives of all the species available through the wellrecognized repositories of collections. To these customary sources were added large quantities of material from individuals throughout the world with whom kindly cooperation had established intimate personal and professional contacts. Large numbers of dissections and long series of shells gave opportunity for bridging the gap between the earlier field of Conchology and the newer seience of Malacology to both of which Mr. Baker had made notable contributions. As he reached final decisions on the validity and synonymy of the species in the various genera, he prepared photographs of the shells or of original drawings of the type specimens when shells were not available. These photographs he arranged as plates and for each he prepared a detailed deseriptive legend. He had completed plates illustrating the shells of the genera Helisoma, Carinifex, Parapholyx, Planorbula, Menetus, Drepanotrema, Tropicorbis, and Taphius. In his office at the time of his death were hundreds of photographic prints of other genera and species intended for use in this monograph. Some of these he had so marked and keyed with numbers that it has been possible to assemble six additional plates which are included at the end of the series. With this inclusion, all of the genera which he apparently intended to figure are included though many of the species are not portrayed in the detail which he established in those earlier parts which he had completed. The explanations of plates 136 to 141 are compiled from rough peneil notes and must be accepted as the author's tentative arrangement of work in progress which might have been ehanged somewhat in the final editing.

Some of the species not included in the plates of the appendix have representative shells figured on plates 72 to 81 of the illustrations for the body of the monograph. However, these figures are usually of only the type species in each genus and do not carry out the plan of comprehensive comparisons set for the second section of the monograph as originally projected by the author. 
In the sixty plates included in this appendix (plates 82 to 141 ), many trpe specimens and other eritically determined materials are figured, and information as to the present whereabouts of these eritical materials is made available. In the members of the family Planorbiclae, where synonymy has been so involved and where intergradations in shell characters have been so confusing, the interpretation of range of individual variability by one who has devoted rears to the study and had the singular advantage of access to all the important collections, will be appreciated by all naturalists who have the need for studying snails.

For convenience of reference, the plates in the appendix are numbered in direct eontinuation with the series of plates in the body of the monograph. In the explanation of the plates, the repository of the figured specimens is usually indieated by the following abbreviations:

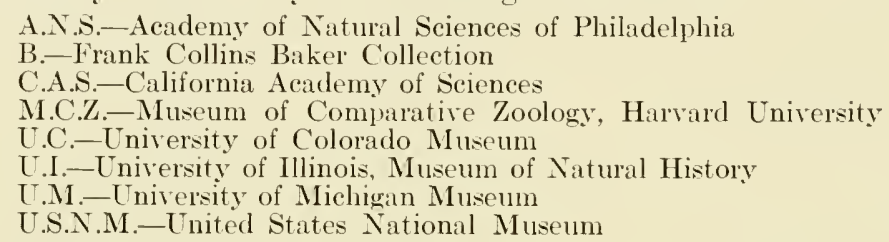

In connection with the foregoing list of repositories, it should be here recorded that the Frank Collins Baker collection of fresh-water snails and the specialized library accompanying it, after his death, was deposited in the United States National Museum. This was in keeping with his expressed desire. It should be further explained that the collections attributed to the University of Illinois are designated by two series of letters. Those 'U.I.' entries having the letter ' $Z$ ' preceding the accession numeral are in the zoological research collections of the Museum of Natural History in the University of Illinois. Paleontologieal specimens, indicated by insertion of the letter ' $\mathrm{P}$ ' immediately before the aceession number, are now deposited in the Paleontological Collections of the Illinois State Geological Survey, in Urbana, Illinois.

Citations of magnification in the explanation of the plates are usually only approximate. In final preparation of the euts, it was in many instances unavoidably necessary to make slight modification of the author's indieated amount of reduetion from the original plates so as to conform to the available page size.

In listing the names of the species in the explanation of plates in the appendix, Mr. Baker placed the name of the author of the species immediately after the specific name and frequently gave no indication by the use of parentheses in instances where the specifie name was recombined with a generie name other than that to which the species was originally ascribed. It should be recalled that the preliminary draft which he prepared was never finally edited by him. Through the very generous cooperation of a number of the most widely recognized Ameriean authorities in the study of the Mollusea, the use of parentheses for author names has been carefully ehecked. Some errors or inconsistencies may yet be found because the literature is extremely scattered and there are no comprehensive check lists of the species of Planorbiclae.

As previously explained, the manuseript for the section in which Mr. Baker harl expected to provide full descriptions of all species and varieties 
of the Planorbidae of the New World had never been completed. In the voluminous long-hand notes which he left in unfinished form, there were ineluded the preliminary drafts of descriptions of many new speeies and new varieties intended for ineorporation in Part II. After it had been decided that the plates for Part II should be included as an appendix to the morphologieal studies, it was discovered that the legends for these plates made frequent reference to previously unpublished speeific and rarietal names. His manuscript clescriptions for many of the new speeies and new varieties were so well organized that there could be no doubt regarding his intention. Consequently, his preliminary descriptions have been edited and are included as a separate section of Part II. A few of the rarieties and species which he tentatively considered as new could not be found in his files. For these it is assumed that he had never prepared definite descriptions. In order to avoid nomenelatorial difficulties, these names have been deleted to prevent their becoming nomina nuda. In each such instance the undeseribed and unnamed form has been referred to under its proper genus as a questioned species or questioned rariety. 


\section{XIII.}

\section{DESCRIPTIONS OF NEW SPECIES AND NEW VARIETIES}

A EXPLAINED in the foreword, the following technical descriptions of new species and new rarieties were edited from longhand notes prepared by $\mathrm{Mr}$. Baker. During the past quarter of a century he examined every important collection of Planorbidae housed in the museums of America and received extensive field collections from many private eollectors as well. In the handling of this lunge quantity of material he came to recognize fundamental likenesses and differenees at rarying levels. In addition to his study of the shells, his intensive work on the morphology of the snails gave him a broad background for the recognition of natural groups. On the one sicle, he expressed his conclusions in the broad new classification of the Planorbidae as set forth in Part I of this rolume. There he evaluated the characteristies on which families, subfamilies. genera, and subgenera may be recognized with safety. On the other side, his attention to the limits of individual variation in characteristies of the shell furnished the basis for the detailed recognition of specifie and varietal boundaries. The descriptions of new forms and the redescription of all known species were to have been the final goal of Part II of this study.

From lis incomplete notes the following deseriptions include only those for which he had prepared tentative definitions. On other speeies and varicties, which he obriously thought of as new, he had not committed himself through the preparation of manuscript notes and in the assembly of illustrations.

The descriptions of nine new species and seventeen new varieties are arranged in the same sequenee of genera and subgenera as outlined in Part I (see pages xir and xr of the Contents).

All tabular arrangements of shell measurements are expressed in millimeters.

\section{GENUS Tropicorbis}

\section{Tropicorbis shimeki, New Species}

Plate 134, figs. 12-14, 28

Shell solid, small, of three and one-half whorls. Upper surface showing three and one-half whorls which are subangulate above, sutures very deep. Lower surface showing three and one-half whorls which are subangulate in the middle, sutures very deep. Whorls rounded on the periphery. Apical whorls sunken on botl surfaces. Whorl slightly deflected at aperture. Aperture lunately rounded, outer lip thick with eallus. A callus on parietal wall connecting the extremities of the outer lip. Seulpture of coarse growth lines with fine spiral lines. Apertural lamellae six, those of sigmoid form extremely short and thick, only slightly more than half the length of those found in obstructus.

$\begin{array}{cccccc}\begin{array}{c}\text { Shell } \\ \text { Height }\end{array} & \begin{array}{c}\text { Greater } \\ \text { Diameter }\end{array} & \begin{array}{c}\text { Lesser } \\ \text { Diameter }\end{array} & \begin{array}{c}\text { Aperture } \\ \text { Height }\end{array} & \begin{array}{c}\text { Aperture } \\ \text { Diameter }\end{array} & \\ 1.5 & 4.0 & 3.2 & 1.1 & 1.0 & \text { Holotype } \\ 1.6 & 3.8 & 3.1 & 1.1 & 1.1 & \text { Paratype } \\ 1.5 & 3.4 & 2.8 & 1.1 & 1.0 & \text { Paratype }\end{array}$


Type Locality. Ometope, Niearagua.

Type Material. Collected by B. Shimek in 1893. Four specimens deposited in United States National Museum. Accession no. 534290. The holotype is shown on plate 134 as fig. 12 ; figs. 13,14 are paratypes.

Tropicorbis shimehi resembles albicans but is smaller, has a greater axial height, and has subearinate whorls. The parietal lamellae are distinetly shorter and thicker than in other forms of the genus. T. shimeki is smaller than declivis and its axial height is greater; it also has deeper sutures than are found in declivis.

Additional representatives of $T$. shimehi were eolleeted by Oreutt in Coatzocoales, Mexico (United States National Museum, Aceession no. 219696).

This species is named in honor of Professor B. Shimek.

\section{GENUS Helisoma}

\section{Helisoma anceps anticostianum, New Variety}

Plate 96, figs. 18-22

Shell differs from typical anceps in the low axial height, the wide and shallow spire depression with bluntly angular carina, and the shallow and wide umbilical region of the new variety. The aperture is but slightly expanded. Whorls about four, evenly and regularly coiled, with faint spiral lines.

$\begin{array}{ccccc}\begin{array}{c}\text { Shell } \\ \text { Height }\end{array} & \begin{array}{c}\text { Greatest } \\ \text { Diameter }\end{array} & \begin{array}{c}\text { Aperture } \\ \text { Height }\end{array} & \begin{array}{c}\text { Aperture } \\ \text { Diameter }\end{array} & \\ 4.7 & 10.0 & 3.7 & 3.0 & \text { Holotype } \\ 6.0 & 12.5 & 4.8 & 3.6 & \text { Paratye } \\ 4.8 & 9.5 & 3.7 & 2.9 & \text { Paratye }\end{array}$

Type Locality. English Bay, Anticosti Island, Quebee. Canada.

Type Material. Collected by II. S. Brooks, September 15. 1919. The holotype is shown on plate 96 as fig. 18 ; paratypes as figs. 19 to 22 . Deposited in the collection of the Museum of Comparative Zoology, Harvard University. Accession no. 48285.

$H$. anceps anticostianum, a Pleistocene fossil, is similar in appearance to striatimum from Milwaukee, but differs in the fact that the new rariety has wider and shallower spire depression, has general lower axial height. and lacks distinet angulations above and below. All of these features are marked in striatinum. The whorls are likewise flatter above in the new form than in striatinum. Spiral lines are not notably distinct. Some specimens have evidence of a former campanulate lip.

\section{Helisoma anceps bartschi, New Variety}

Plate 83, figs. 19-22

Shell compressed, with four whorls. Periphery rounded. Spire depression wide, a wide cone with flat sides; shallow, bordered by a well defined carina. Base with flattened whorls, the carina sharp and placed near the outer edge. Surface of shell shining, growth lines very fine; occasionally white varices on whorls. Seulpture of rery faint spiral lines. Aperture inverted ear-shaped, forming a sharp $\vee$ above and a broad $\vee$ below. Outer 
lip thickened and expanded, white, bordered by reddish band inside. Parietal wall with white callus.

$\begin{array}{ccccc}\begin{array}{c}\text { Shell } \\ \text { Height }\end{array} & \text { Maximum } & \text { Aperture } & \text { Aperture } & \\ \text { Diameter } & \text { Height } & \text { Diameter } & \\ 6.5 & 11.7 & 5.5 & 3.3 & \text { Holotype } \\ 6.1 & 12.0 & 5.1 & 3.0 & \text { Paratype } \\ 6.6 & 11.6 & 5.5 & 3.3 & \text { Paratype }\end{array}$

Type Locality. Brook at Great Falls, Virginia. Collected by Soelner.

Type Material. Holotype and seven paratypes, deposited in the United States National Museum, Accession no. 227858. Holotype figured on plate 83, fig. 19 ; paratypes figs. $20-22$.

This variety may be distinguished by its small axial height, depressed shape, wide and shallow spire depression, flat basal whorls with carina near periphery. It resembles the variety politum from Canada, but that variety has rounded basal whorls without marked carina, its spire depression is wide with more flat-sided whorls, and dorsal carina is more acute. The basal part of the aperture is rounded or almost flat in politum, but has sharp, wide angle in bartschi.

Bartschi differs from sayi in lower axial height, less sharply angled basal whorls (with carina not near edge as in sayi); shallow and wide spire depression.

Bartschi differs from anceps in lower relative axial height (compared with (liameter); wider spire depression; basal whorls flatter; carina nearer periphery (near center in anceps).

Helisoma anceps bartschi is apparently a common form in the Potomac drainage.

\section{Helisoma anceps idahoense, New Variety}

Plate S4, figs. 26-2S

Plate 101, figs. 11, 12

Spire with carina in center. Base concave, basal whorls flat to sutures which are well marked. Whorls four. Spire depression deep and fumnelshaped, the whorls flat-sided. Carina well marked. Whole shell is coneshaped, the whorls sloping upward to the spire carina. Color yellowish horn. Sculpture of regular growth ribs crossed by distinct spiral lines. Aperture auriform (reversed), sharply angled above, flat or flatly-rounded below. Lip sharp. Distinct columellar callus. Color of aperture whitish or shightly purplish. A callus often within the lip edge.

$\begin{array}{cccc}\text { Shell } & \text { Maximum } & \text { Aperture } & \text { Aperture } \\ \text { Height } & \text { Diameter } & \text { Ileight } & \text { Diameter } \\ 11.0 & 15.0 & 9.5 & 6.0 \\ 8.5 & 15.6 & 7.5 & 6.0 \\ 9.5 & 15.5 & 8.6 & 6.2\end{array}$

There is considerable variation in width and depth of spire depression. Base rarely rounded, without carina. Carina always near center of base. Some variation in shape of aperture. It may form a sharp $V$ below (as in the holotype) or it may be rounded and flattened at this point. This variety is nearest to latchfordi, differing in the less angular basal portion of the aperture and also in the more distinct and heavier spiral sculpture in irlahoense. 
Type Locality. Pend Oreille River, Sand Point, Idaho.

Type Material. Holotype (plate 84, fig. 26) and paratypes in F. C. Baker Collection, no. 1863, now deposited in United States National Museum.

H. anceps idahoense is apparently common in Idaho and Montana. In some places it oceurs on muddy sand or on old logs.

\section{Helisoma anceps politum, New Variety}

Plate 83, figs. 16-18

Shell flattened, wider than high, spire deeply sunken, showing three and one-half to four whorls, the depression widely cone-shaped rising to a vaguely defined, rounded carina. Umbilical region flattened, showing three and one-half to four whorls, the front half of the bodr whorl with a faint ridge about in the center of the whorl. Ridge disappears on the last third of the body whorl which is rounded. Sculpture of fine, thread-like riblets, often raised into slight ridges, especially toward the aperture. Color of shell pale yellowish to dark brown. Surface polished in living specimens. Fine impressed spiral lines present in all specimens examined. Aperture ovate, higher than wide, obtusely angled above, straight or but slightly eurved below. Outer lip thickened, bordered within by a reddish-brown band. The lip erlge is white on the outside.

$\begin{array}{ccccc}\begin{array}{c}\text { Shell } \\ \text { Height }\end{array} & \begin{array}{c}\text { Maximum } \\ \text { Diameter }\end{array} & \begin{array}{c}\text { Aperture } \\ \text { Height }\end{array} & \begin{array}{c}\text { Aperture } \\ \text { Diameter }\end{array} & \\ \text { S.1 } & 15.0 & 7.0 & 4.4 & \text { Holotype } \\ \text { S.1 } & 14.0 & 7.0 & 4.0 & \text { Paratype } \\ \text { S.0 } & 14.2 & 7.0 & 4.0 & \text { Paratype }\end{array}$

Type Locality. Honeywell Creek, Carleton Co., Ontario, Canada. Collected by F. R. Latehford.

Type Material. Deposited in United States National Museum, Accession no. 367426. Holotype figured on plate 83, fig. 16; figs. 17, 18 are paratypes.

H. anceps politum is related to unicostatum but the new variety has a wider and shallower spire depression, a more compressed shell, and a distinct carina on the basal whorl, besides having the surface of the shell polished. Latchford identified this material as unicarinatum.

\section{Helisoma binneyi randolphi, New Variety}

Plate 94, figs. 1-S

Shell differing from typical bimneyi in being of less axial height, the carina surrounding the spire depression is obsolete or faintly developed; the basal whorls are rounded, not angulated. Sculpture is fine with the ribs close together, both being very much finer and closer together than in binneyi. The lip is only slightly expanded. Mature shells have four whorls.

$\begin{array}{ccccc}\begin{array}{c}\text { Shell } \\ \text { Height }\end{array} & \begin{array}{c}\text { Maximum } \\ \text { Diameter }\end{array} & \begin{array}{c}\text { Aperture } \\ \text { Ieight }\end{array} & \begin{array}{c}\text { Aperture } \\ \text { Diameter }\end{array} & \\ \mathbf{1 1 . 8} & 20.8 & 10.2 & 7.3 & \text { Holotype } \\ 11.0 & 20.8 & 10.3 & 6.5 & \text { Paratype } \\ 9.1 & 17.1 & 8.5 & 5.0 & \text { Paratype } \\ 9.2 & 15.9 & 8.2 & 5.5 & \text { Paratype } \\ 7.6 & 12.4 & 7.0 & 4.1 & \text { Immature }\end{array}$


Type Locality. Lake Washington, Scattle, Washington.

Type Material. Collected by P. B. Randolph, deposited in United States National Muscum, Shimek Collection, Accession no. 504360. Holotype figured on plate 94, fig. 1 ; paratypes, figs. $2-4$; immature, fig. 5.

\section{Helisoma caribaeum cubense, New Variety}

Plate 119, figs. 22-25

Shell differing from that of typical caribacum in having the spire depression much narrower, the whorls, especially the borly whorl, increasing more rapidly in diameter. Five full whorls. Sutures not impressed as in caribacum, the spire whorls flattened, not rounded, and there is often a carina at the edge of the whorls. Nuclear and first whorl rounded as in caribaeum and of the same size. Basal whorts rounded, the umbilical region concave, umbilical opening distinct. Axial height somewhat greater than in typical caribaeum, the body whorl flattened near the spire depression, not evenly rounded as in typical caribacum. Aperture more nearly auriculate than in caribaeum, the lip sometimes (as in the holotyje) thickened by a heary callus. Sculpture as in caribaeum.

$\begin{array}{cccccc}\begin{array}{c}\text { Shell } \\ \text { Height }\end{array} & \begin{array}{c}\text { Greater } \\ \text { Diameter }\end{array} & \begin{array}{c}\text { Lesser } \\ \text { Diameter }\end{array} & \begin{array}{c}\text { Aperture } \\ \text { Height }\end{array} & \begin{array}{c}\text { Aperture } \\ \text { Diameter }\end{array} & \\ 8.7 & 19.1 & 16.0 & 6.0 & 4.0^{*} & \text { Holotype } \\ 7.0 & 16.0 & 13.5 & 6.2 & 4.0 & \text { Paratype } \\ 6.1 & 14.0 & 12.0 & 4.5 & 3.0 & \text { Paratype } \\ 6.0 & 14.1 & 11.1 & 4.3 & 3.1 & \text { Paratype }\end{array}$

*Aperture contracted in holotype by thickened lip.

The form of the whorls increases like that of tenue, especially like that of tenue sinuosum, but inner whorls are like those of caribacum in that they are rounded, and are not like those of temue which are flat and carinated at the edges. Some living Cuban specimens have a somewhat narrower spire than the typical form here figured but these lack the greatly increased diameter of the borly whorl characteristic of cubense and the aperture is not auriculate or thickened by a callus as in mature and nearly mature specimens of cubcnse. The basal whorls are more concave than in caribacum. Sutures are not as deep as in caribaeum. Evidently a Pleistocene fossil.

Type Locality. Zapata Swamp, Cuba, in marl between layers of peat.

Type Material. Eight specimens, collected April 19, 1927, by H. H. Bennett, are deposited in the Tnited States National Nuseum, Accession no. 404719. Of these. the holotype is figured on plate 119 as fig. 22, and three of the paratypes are shown as figs. 23-25.

\section{Helisoma columbiense, New Species}

Plate 119, figs. 16-21

Shell with four to four and one-half whorls, rapidly enlarging. Spire depression flattened, the inner whorls bordered by a sharp carina which becomes distinctly central in position on the last whorl. The sides of the depression slope sharply downward. Base of shell concave, broadly funnelshaped, the last whorl with a more or less sharp carina or rirlge. Sutures well marked. Sculpture of coarse riblets, widely spaced, as in typical sub- 
crenatum. Aperture ovately rounded, the lip rim thiekened and broadly reflected. A eallus on the parietal wall renders the aperture continuous. There is usually a border of dark chestnut or reddish brown within the aperture. The aperture may be rounded above or there may be a sharp V-shaped angle, depending upon whether the dorsal carina is sharp or rounded. There is normally an indication of angulation at this point. The basal part of the aperture is flaty rounded. several old lip expansions may show on the body whorl back of the aperture. Color whitish, tinged with chestnut in some specimens.

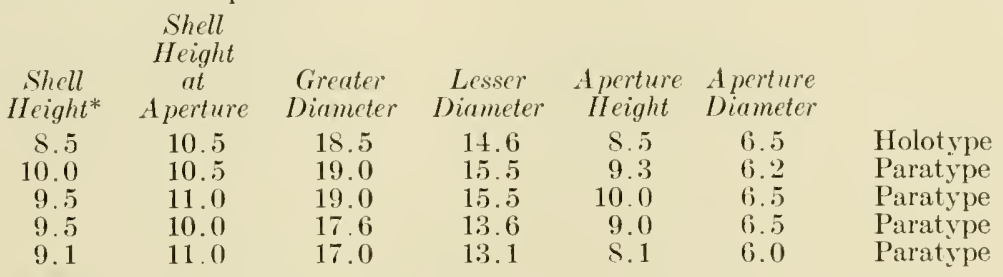

* Measurement taken belind the expanded lip.

Type Locality. Lac La Hache, Cariboo Distriet, British Columbia.

Type Material. Fifteen speeimens, colleeted by H. and R. D. Svihla, are deposited in the Museum of Comparative Zoology of Harrard University, Accession no. 93710. The individual selected as holotype is shom on plate 119 as fig. 16 ; paratypes as figs. 17-21.

Helisoma columbiense shows relationship to the binneyi group in its sculpture and the earination of its whorls. It differs from the members of that group in that it is of smaller size, has less relative axial height, its rib striae are less widely spaced and the whorls are usually more angulate.

It differs from the subcrenatum group in having more regular and less widely spaced rib striae, in its angulated base and spire depression, and in the shape of the aperture.

\section{Helisoma kennicotti, New Species}

Plate 89, figs. 13-17

Shell in four whorls, rapidly increasing in diameter. Borly whorl axially very high. Sculpture of evenly spaced, rather heary, rib-like growth lines becoming more widely spaced on the last half of the body whorls. Spire depression concave, widely cone-shaped, flat-sided, bordered by a strong, sharp earina, extending to the aperture. Base showing three whorls, the umbilicus deep, with a small perforation; only slight indication of a carina in adult, but distinet and sharp in immature speeimens. Aperture auriform, sharply angled above, flatly rounded and effuse below, the outer lip expanded. Parietal wall with a thin wash of eallus which connects the extremes of the lip. Color light, yellowing horn, brownish or bluish in some specinens.

$\begin{array}{cccccc}\text { Shell } & \begin{array}{c}\text { Greater } \\ \text { Expanded }\end{array} & \begin{array}{c}\text { Expanded } \\ \text { Liameter }\end{array} & \text { Lip } & \text { Aperture } & \text { Aperture } \\ \text { Height } & \text { Diamht } & \text { Diameter } \\ 12.5 & 19.0 & 14.2 & 20.2 & 12.0 & 6.6 \\ 12.0 & 17.1 & 14.0 & 18.5 & 11.5 & 6.5 \\ 12.5 & 18.1 & 14.2 & 19.4 & 12.0 & 5.5 \\ 7.5 & 11.0 & 9.0 & 12.0 & 7.0 & 4.0 \\ \text { S.0 } & 11.0 & 9.0 & 12.0 & 7.0 & 4.1\end{array}$

Holotype
Paratype
Paratype
Immature
Immature


Helisoma kennicotti is a very distinet species. It differs from infracarinatum in its smaller size, greater relative axial height, as compared with diameter. Expressed in pereentages of height to diameter, kennicotti is sixty-five per cent and infracarinatum, fifty-six per cent. The spire depression is much smaller, narrower, and deeper in kennicotti, the shell forming an inverted cone. The base of the new species is likewise narrower, and the whorls dip into the umbilicus at a sharper angle, only one and one-half turns before entering the umbilicus. In contrast, in infracarinatum there are two full turns visible.

Type Locality. Lake Isle la Crosse, English River, Canada.

Type Material. Deposited in United States National Museum, Aceession no. 29231, bearing the label of the old Binney collection no. 9272 and there recorded as Planorbis trivolvis. Figures on plate 89; holotype as fig. 15 ; paratypes as figs. 16,$17 ; 13,14$ immature shells.

\section{Helisoma pilsbryi preblei, New Variety}

Plate 91, figs. 6 to 8

Helisoma pilsbryi preblei differs from typical pilsbryi in its greater relative height in comparison with dianeter of the shell. The whorls in preblei are more tightly coiled, the body whorl increasing more rapidly in cliameter, causing the spire depression and umbilical region to appear smaller than in pilsbryi in which the whorls are rounded more regularly. The aperture is widely expanded to form a reflected lip. This is not true of pilsbryi. Whorls, four and one-half. Sculpture as in pilsbryi. H. p. preblei differs from subcrenatum in absence of all indication of a carina on the umbilical side. The whorls of the spire depression are subangulated, not sharply angled as in infracarinatum.

\begin{tabular}{|c|c|c|c|c|c|c|}
\hline $\begin{array}{l}\text { Shell } \\
\text { Height }\end{array}$ & $\begin{array}{l}\text { Greater } \\
\text { Diameter }\end{array}$ & $\begin{array}{c}\text { Height } \\
\text { at } \\
\text { Exprended } \\
\text { Lip }\end{array}$ & $\begin{array}{l}\text { Diameter } \\
\text { at } \\
\text { Expanded } \\
\text { Lip }\end{array}$ & $\begin{array}{c}\text { Aperture } \\
\text { Height }\end{array}$ & $\begin{array}{l}\text { Aperture } \\
\text { Diameter }\end{array}$ & \\
\hline 14.0 & 24.5 & 17.0 & 27.0 & 13.0 & 7.0 & Holotype \\
\hline 14.0 & 25.0 & 16.0 & 26.0 & 13.0 & 7.5 & Paratype \\
\hline 11.5 & 19.0 & $\ldots{ }^{*}$ & $\ldots$ & 9.5 & 5.6 & Paratype* \\
\hline
\end{tabular}

Type Locality. Knee Lake, Manitoba, Canada.

Type Material. Three specimens, collected by E. A. Preble in the 'North West 'Territory, Knee Lake, Keewatin,' depositerl in United States National Museum, Accession no. 180279. Figured on plate 91, holotype as fig. 6; paratypes as figs. 7,8 .

The type material was previously called infracarinatum but it is nearer to pilsbryi. It differs from the latter in its expanded lip and more tightly coiled whorls of the umbilical region. Differs from infracarinatum in the absence of a basal carina and in having a narrower and more sumken spire depression.

\section{Helisoma subcrenatum perdisjunctum, New Variety}

Plate 96, figs. 13-17

Shell small, horn colored; whorls three and one-half to four, discoidal, evenly rouncled; 3 whorls below. Whorls slowly increasing in dianeter, rounded above and below, not carinated. Sculpture of distinet growth lines, 
finer than in disjunctum. Aperture rounded above and below, slightly expanded where it joins the body whorl. A distinct eallus on the parietal wall, often making the aperture and lip continuous. A slight thickening inside outer lip, bordered by brown band.

$\begin{array}{cccccc}\begin{array}{c}\text { Shell } \\ \text { Height }\end{array} & \begin{array}{c}\text { Greater } \\ \text { Diameter }\end{array} & \begin{array}{c}\text { Aperture } \\ \text { Ineight }\end{array} & \begin{array}{c}\text { Aperture } \\ \text { Diameter }\end{array} & \begin{array}{c}\text { Number } \\ \text { of Whorls }\end{array} & \\ 4.0 & 5.5 & 3.7 & 2.6 & 4.0 & \text { Holotype } \\ 4.6 & 9.2 & 4.1 & 3.0 & 33 / 4 & \text { Paratype } \\ 5.0 & 9.0 & 4.7 & 3.2 & 31 / 2 & \text { Paratype } \\ 5.2 & 10.5 & 4.9 & 3.2 & 4.0 & \text { Paratype }\end{array}$

Type Locality. Yellowstone Lake, Wyoming.

Type Material. Five specimens, collected by 1)r. Curtis, deposited in the United States National Museum, Aceession no. 30207a. Holotype here shown as fig. 13 on plate 96 ; paratypes as figs. $14-17$ on same plate.

H.s. perdisjunctum is similar to disjunctum but is much smaller, about the size of oregonense, but lacks the characteristic shape of the aperture of the last named form. The dorsal carina and the more uniformly and evenly coiled whorls, without rapid inerease in size distinguish it from oregonense. Appears at first like immature disjunctum but is uniformly smaller; never has the axial height of disjunctum. Many specimens have lost the epidermis, exposing white, chalky shell.

\section{Helisoma trivolvis marshalli, New Variety}

Plate 87, figs. 11-15

Shell compressed. whorls four and one-half, rapidly increasing in diameter, the borly whorl notably expanding toward the aperture. Sutures well marked above and below. Sculpture of coarse lines of growth, thread-like; spiral lines very indistinct or wanting. Spire depression small, narrow, shallow (less than one-half the width of whorli, its border rounded, without earina in adult specimens, carina slightly developed in young and immature specimens. Spire flat in young individuals. Ventral surface flattened, the whorls coiled in one plane in mature specimens, three whorls visible, the umbilical whorls with a more or less acute carina. Sutures deep. In young and immature individuals the carina is sharp and the basal whorl about the umbilicus is raised to form an inverted $V$; whorls rounded ventrally in half grown and immature specimens. Aperture wider than high, long oval, the dorsal margin forming an inverted $V$ near junction with body whorls; the rentral margin flat, straight, extending well beyond the position of the dorsal margin on the body whorl. Outer lip sharp, with slight thickening within, margined by reddish line. Surface of shell light or dark horn.

$\begin{array}{cccccc}\begin{array}{c}\text { Shell } \\ \text { Height }\end{array} & \begin{array}{c}\text { Gieater } \\ \text { Diameter }\end{array} & \begin{array}{c}\text { Lesser } \\ \text { Diameter }\end{array} & \begin{array}{c}\text { Aperture } \\ \text { Height }\end{array} & \begin{array}{c}\text { Aperture } \\ \text { Diameter }\end{array} & \\ 5.9 & 14.8 & 11.5 & 5.0 & 4.7 & \text { Holotype } \\ 6.0 & 13.0 & 10.5 & 5.0 & 4.1 & \text { Paratype } \\ 5.8 & 14.0 & 11.9 & 4.9 & 4.5 & \text { Paratype } \\ 5.4 & 11.0 & 8.6 & 4.8 & 3.5 & \text { Immature } \\ 4.9 & 10.2 & \text { S.0 } & 4.2 & 3.3 & \text { Immature }\end{array}$

Helisoma trivolic marshalli differs from fallax in that the new variety has the body whorls more expanded toward the aperture; the dorsal depression is smaller; color is light or dark horn, not greenish; the aperture is wider and more ovate. 
Type Locality. Washington, D. C.

Type Material. Colleeted by Foreman, deposited in Lnited States National Museum, Accession no. 124989. Holotype on plate 87 as fig. 13; paratypes as figs. 11 and 12 ; figs. 14 and 15 of immature shells.

In addition to the type locality, H.t. marshalli has been identified in collections from rarious loealities in Maryland, New York, New Jersey, and Virginia.

\section{Helisoma campanulatum dalli, New Variety}

Plate 111, figs. 12, 13, 15, 16

Shell resembling michigancnse in the low axial height, but the body whorl is irregularly coiled and overlaps the penultimate whorl. Five whorls, upper whorls irregular; blunt carina on upper whorls. Four whorls showing on base, base 'reamed out' similar to that of rudentis, and whorls irregular. Umbilieus much smaller than in rudentis and also smaller than in michiganense. Lower whorls rounded. Sculpture and aperture as in michiganense.

$\begin{array}{cccccc}\begin{array}{c}\text { Shell } \\ \text { Height }\end{array} & \begin{array}{c}\text { Moximum } \\ \text { Diameter }\end{array} & \begin{array}{c}\text { Lesser } \\ \text { Diameter }\end{array} & \begin{array}{c}\text { Apertwre } \\ \text { Height }\end{array} & \begin{array}{c}\text { Aperture } \\ \text { Diameter }\end{array} & \\ 6.2 & 15.0 & 11.6 & 5.5 & 4.0 & \text { Holotype } \\ 5.4 & 14.1 & 11.0 & 4.7 & 4.0 & \text { Paratype } \\ 5.5 & 11.1 & 11.5 & 5.0 & 3.6 & \text { Paratype } \\ 6.1 & 14.9 & 11.6 & 5.3 & 4.0 & \text { Paratype }\end{array}$

Type Locality. Anticosti Island, Quebee, Canada.

Type Material. Collected by Dr. J. Schmitt, deposited in United States National Museum. Accession no. 162724. Holotype, plate 111, fig. 12 ; paratypes, figs. $13,15,16$, five others not figured.

Differs from other varieties in irregularly coiled borly whorl which conspieuously overlaps the preceding whorls. Base is not excavaterl, but whorls are irregularly coiled as in spire. Axial height less than in rudentis.

Helisoma campanulatum dalli is known only from marl deposits.

\section{Helisoma campanulatum pleistocenicum, New Variety}

Plate 110, figs. 21-26

Shell small, whorls four, the inner spire whorls tightly coiled and gradually increasing in diameter, the last whorl rapidly inereasing in diameter. The spire depression oecupies about thirty per cent of the greater diameter of the shell while in campamulatum campanulatum it oeeupies about forty per cent of the greater diameter of the shell. Sutures well impressed. Base with two to two and one-half whorls visible, the whorls tumid. Cmbilieus large for the size of the shell. Aperture strongly campanulate, the eampanulation beginning a considerable distance back of the aperture.

The small dianeter of the spire depression and the rapidly enlarging body whorl serve to distinguish this variety from all other forms of campanulatum. This form is distinetly different from the Pleistocene campamilatum of the middle west.

Type Locality. White Pond, Marlsboro, Warren Co., New Jersey.

Type Material. Holotype (figured on plate 110, fig. 21) and eight paratypes (five shown on plate 110, figs. 22-26) are in the Lea Collection in the United States National Museum, Aceession no. 121195. 


\section{Helisoma campanulatum rideauense, New Variety}

Plite 109, figs. 21-24

Shell very large, of five whorls, spire flattened, the inner whorls raisect slightly above the body whorl; sutures deeply marked. Base with three to four whorls visible, rounded, in same plane, not reamed out as in dalli and rudentis; sutures well marked and whorls rounded. Tmbilicus small, deep. Aperture as in campanulatum. Sculpture of heary, evenly spaced riblets, but not as heary as in wisconsinense; about as in some indiridual shells of campanulatum. In the following table the measurements were taken just behind the aperture, which is constricted and then dilated.

$\begin{array}{cccccc}\begin{array}{c}\text { Shell } \\ \text { Height }\end{array} & \begin{array}{c}\text { Greater } \\ \text { Diameter }\end{array} & \begin{array}{c}\text { Lesser } \\ \text { Diameter }\end{array} & \begin{array}{c}\text { Aperture } \\ \text { Height }\end{array} & \begin{array}{c}\text { Aperture } \\ \text { Diameter }\end{array} & \\ 6.5 & 19.6 & 15.0 & 6.5 & 6.0 & \text { Holotype } \\ 7.0 & 18.5 & 14.1 & 6.5 & 5.1 & \text { Paratype } \\ 7.0 & 18.0 & 14.0 & 6.3 & 5.1 & \text { Paratype } \\ 6.8 & 17.5 & 13.0 & 6.3 & 5.4 & \text { Paratype }\end{array}$

H. c. rideauense differs from michiganense in the former's larger size, smaller umbilical opening, and greater axial height. Surface is dull, not shiny, caused by the heary seulpture. Color bright horn. The aperture is more distinctly campanulate than in michiganense.

Type Locality. Rideau River, Ottawa. Canada.

Type Material. Five specimens, collected by F. R. Latchford, deposited in the United States National Museum, Accession no. 346627. The holotype is shown on plate 109, fig. 21 ; paratypes, figs. 22-24.

\section{GENUS Parapholyx}

\section{Parapholyx effusa dalli, New Variety}

Plate 115, figs. 27-30

Three whorls, rounded. Color greenish horn. Spire slightly raised, sutures well marked, deep on last whorl. Sculpture of strong, erect, membranous ribs, thirteen to fifteen on body whorl, equidistant or widely spaced. Very fine lines of growth between ribs, spiral lines obsolete. Ribs usually absent on spire whorls. The ribs produce spaced, vertical depressions inside aperture. Aperture rounded, acute below. Columella narrow, concave, either completely closing the umbilieus or leaving a small narrow and long chink. A thin wash of eallus on the parietal wall.

$\begin{array}{cccccc}\text { Shell } & \begin{array}{c}\text { Greater } \\ \text { Height }\end{array} & \begin{array}{c}\text { Lesser } \\ \text { Diameter }\end{array} & \begin{array}{c}\text { A Diameter } \\ \text { Height }\end{array} & \begin{array}{c}\text { Aperture } \\ \text { Diameter }\end{array} & \\ 4.9 & 5.0 & 4.8 & 3.9 & 3.3 & \text { Holotype } \\ 5.0 & 5.0 & 5.0 & 4.0 & 3.3 & \text { Paratype } \\ 5.0 & 6.0 & 5.0 & 4.1 & 3.2 & \text { Paratype }\end{array}$

Parapholyx effusa dalli differs from all other forms of the genus in the presence of nembranous ribs which stand up, either at an angle or vertically, as leaf-like frills, very thin and easily broken off. The ribs in costata and other costate forms of the genus (as costate specimens of klamathensis from Klamath Falls) are simply rounded ribs, enlargements of the lines of growth. These do not affect the inside of the aperture. In dalli, on the contrary, the ribs appear as vertical creases on the inside of the aper- 
ture. Some individuals of costata may have slightly membranous ribs, but these are never like those of dalli.

Type Locality. Klamath Falls, Oregon.

Type Material. Serenteen specimens, collected by Henshaw, are deposited in the United States National Museum, Aceession no. 219749. The holotype is figured on plate 115 as fig. 27 ; paratypes as figs. 28-30.

\section{Parapholyx klamathensis sinitsini, New Variety}

Plate 123, figs. 2-10

Shell similar to that of klamathensis but smaller, more globose; the shell thicker and more solid. Spire more elevated than in typical Klamathensis; aperture rounder, not as effuse; columella eallus heavier, more tightly appressed to the columella. The umbilieus usually elosed, rarely having a small chink. Color brownish horn, never greenish. Sculpture heavier than in lilamathensis, growth lines more distinet, in a few specimens rib-like. Interior of aperture reddish-brown. Lip bordered internally by a white margin which in old specimens forms a thickened eallus. In contrast, klamathensis of trpical variety has a thin lip without a callus. Columellar callus white. Whorls three. some speemens with diagonal markings like pores. Aperture angulate below, as in kilamathensis, but not markedly angular in some specimens.

$\begin{array}{cccccc}\begin{array}{c}\text { Shell } \\ \text { Height }\end{array} & \begin{array}{c}\text { Greater } \\ \text { Diameter }\end{array} & \begin{array}{c}\text { Lesser } \\ \text { Diameter }\end{array} & \begin{array}{c}\text { Aperture } \\ \text { Height }\end{array} & \begin{array}{c}\text { Aperture } \\ \text { Diameter }\end{array} & \\ 6.4 & 7.0 & 5.0 & 4.5 & 4.0 & \text { Holotype } \\ 5.6 & 7.1 & 4.4 & 4.3 & 4.3 & \text { Paratype } \\ 7.1 & 8.2 & 6.0 & 5.0 & 4.8 & \text { Paratype } \\ 5.6 & 6.8 & 4.5 & 4.0 & 3.6 & \text { Paratype } \\ 5.6 & 6.6 & 5.4 & 3.8 & 3.8 & \text { Paratype }\end{array}$

Type Locality. Bereley Spring, fourteen miles north of Klamath Falls, Oregon.

Type Material. Five specimens, of which one is designated as holotype and the four others as paratypes, are deposited in the United States National Muscum, Aecession no. 531029. The holotype is shown on plate 123 as fig. 2; two paratypes on the same plate as figs. 3 and 4 . A series of specimens from the same locality, collected by Mrs. L. Sinitsin, are accessioned in the United States National Museum, no. 531064. The individuals of this last named series are designated as locotypes of the new variety.

Parapholyx klamathensis sinitsini is a form smaller than the typical klamathensis. The two forms have the same columella and angular base of aperture. The new variety has a higher spire than the typical form and the shell is more globose. Some individuals with diagonal ridges resemble diagonalis from Crater Lake but in that form the columella is wider, more concave and flatter and the aperture is more effuse. The spire of the new variety varies from flat to elevated depending upon the deflection of the aperture. Sinitsini has about the same size as Parapholyx solida optima but that form has a flat spire and a different aperture, especially in the region of the columella.

This variety is named for Mrs. L. Sinitsin. 


\section{Parapholyx pusilla, New Species}

Plate 117, figs. 1-6

Shell small, with three whorls, sealariform, the second whorl standing on the body, turban-shaped; sutures clistinct. Aperture roundly orate, lips simple, lower lip rounderl at base. (columella callus narrow, not expanded, separated from the columella region where it often projects leaving a distinet umbilieal ehink. Aperture continuous by the presence of a parietal callus. Sculpture coarse, often costate.

$\begin{array}{ccccc}\text { Shell } & \text { Maximum } & \text { Aperture } & \text { Aperture } & \\ \text { Height } & \text { Diameter } & \text { Meight } & \text { Diameter } & \\ 4.0 & 5.0 & 2.3 & 2.3 & \text { Holotype } \\ 4.5 & 4.3 & 2.5 & 2.1 & \text { Paratype } \\ 4.5 & 4.5 & 2.4 & 2.4 & \text { Paratype }\end{array}$

Type Locality. Six miles west of Pyramid Lake, Washoe County, Nevada.

Type Material. One hundred twenty-five specimens taken from a Pleistocene deposit by Elbert Howard, are deposited in the United States National Museum, Aceession no. 308925. The indiridual from this lot chosen as holotype is shown on plate 117 as fig. 1. Figures 2 to 5 on the same plate are of paratypes.

Parapholyx pusilla differs from Parapholyx nevadensis in that the new speeies has a more rounded shell, with elevated and turban-shaped second whorl and the lower portion of the aperture lacks the sharp angle caused by the columellar callus in nevadensis. The new species differs from $P$. solida in the form of the spire, aperture and base of lip.

This is apparently an extinct species.

\section{GENUS Planorbula}

\section{Planorbula smithii, New Species}

Plate 118, figs. 11-12; plate 119, figs. 10-12

Shell resembling that of wheatleyi but larger, of five whorls, the spire whorls in the same plane and not so sunken toward the nueleus as in wheatleyi; no dorsal riclge as is developed in wheatleyi; umbilical opening with the whorls rounded, not flat sided and without the sharp earina distinetive of wheatleyi. Crest behind aperture not as heary or as thickened as in wheatleyi. Seulpture of distinct spiral lines. Apertural lamellae as in armigera not as in wheatleyi.

$\begin{array}{cccccc}\text { Shell } & \begin{array}{c}\text { Creater } \\ \text { Height }\end{array} & \begin{array}{c}\text { Deswer } \\ \text { Diameter }\end{array} & \begin{array}{c}\text { Aperture } \\ \text { Height }\end{array} & \begin{array}{c}\text { Aperture } \\ \text { Diameter }\end{array} & \\ 3.0 & 7.1 & 5.5 & 2.0 & 1.3 & \text { Holotype } \\ 2.5 & 7.0 & 5.0 & 1.7 & 1.0 & \text { Paratype } \\ 2.9 & 6.9 & 5.5 & 1.5 & 1.0 & \text { Paratype }\end{array}$

Type Locality. Jackson County, Alabama.

Type Material. Fifteen speeimens, collected by H. H. Snith, are deposited in the United States National Museum. Accession no. 321196. The holotype is figured on plate 119 , as fig. 10 ; paratypes on the same plate as figs. 11 and 12 .

Externally Planorbula smithii resembles wheatleyi but the newly reeognized species is readily distinguishable by the absence of the L-shaped 
second labial lamella. Smithii is larger than crassilabris and has a much heavier lip eallus. It somewhat resembles indianensis but lacks the axial height of that race and the latter also lacks the lip eallus of smithii.

Planorbula smithii is named for Herbert H. Smith.

\section{GENUS Menetus \\ Menetus coloradoensis, New Species}

Plate 122, figs. 23-25

Shell aeutely lenticular, flattened, with three whorls. Color blackish brown. A rounded earina on the periphery which is impressed both above and below the periphery a short distance from the edge. The earina is not acute (excepting in immature specimens) but is bluntly rounded. Upper surface flattened, with deeply inpressed sutures. The whorls tumid near the sutures. Base convex near the suture but flattened toward the periphery. Basal whorls separated by deep sutures. Seulpture ranging from coarse growth lines to evenly spaced ribs, spiral lines very fine. Some specimens begin with eoarse growth lines and end with ribs. Aperture triangular, upper and lower lips arehing downward and upward to meet the periphery which is not sharp but is narrowly rounded. Upper lip projects just above the periphery and is flat. but lower hip has a long columellar region and is convex. Aperture much wider than high, purplish within and somewhat pearly. Umbilieus rather wide and deep.

$\begin{array}{cccccc}\begin{array}{c}\text { Shell } \\ \text { Height }\end{array} & \begin{array}{c}\text { Greater } \\ \text { Diameter }\end{array} & \begin{array}{c}\text { Lesser } \\ \text { Diameter }\end{array} & \begin{array}{c}\text { Aperture } \\ \text { Height }\end{array} & \begin{array}{c}\text { Aperture } \\ \text { Diameter }\end{array} & \\ 1.1 & 4.0 & 3.6 & 1.0 & 1.6 & \text { Holotype } \\ 1.0 & 4.6 & 4.0 & 0.9 & 1.8 & \text { Paratype } \\ 1.0 & 4.1 & 3.6 & 0.9 & 1.5 & \text { Paratype }\end{array}$

Type Locality. Swamp at head of Eldora Lake, near Eldora, Colorado.

Type Material. Deposited in the University of Colorado Museum, Accession no. 10114. Holotype shown as fig. 25 on plate 122 ; two paratypes as figs. 23 and 24 on same plate.

Menetus coloradoensis differs from exacuous in the pinched nature of the periphery, the swollen or tumid base near the suture, and the heary (in some instances, costate) sculpture. Wenetus exacuous megas has a pinched periphery, but in this variety the base and sculpture are as in typical exacuous. The new speeies is nearest to kansasensis but differs in having a more tumid base and a different type of rib-sculpture.

\section{Menetus cooperi crassilabris, New Variety}

Plate 121, figs. 19-21; plate 122, fig. 13 ; plate 123, fig. 26

Specimens like cooperi but with heavy callus just within lip. Shell of four whorls. Heary spiral sculpture. Whorls usually rounded but with slight indieation of earina at shoulder as in cooperi. Several spiral ridges below shoulder, and base often malleated as in cooperi. Umbilieus with rounded edges. Aperture rounded, not usually modified by earina. Most shells are smaller than cooperi.

$\begin{array}{cccccc}\text { Shell } & \text { Greater } & \text { Lesser } & \text { Aperture } & \text { Aperture } & \\ \text { Height } & \text { Diameter } & \text { Diameter } & \text { Height } & \text { Diameter } & \\ 2.1 & 5.4 & 4.0 & 1.6 & 2.0 & \text { Holotype }\end{array}$


Type Locality. Seattle, Washington.

Type Material. Twenty-four specimens are in the United States National Museum bearing Aecession no. 214590, one of which is seleeted as holotype and the remaining specimens become paratypes. Holotype is shown on plate 121 as fig. 20 ; and one paratype as fig. 19.

Of the twenty-four speeimens in the type lot all but one had a callus, this one being doubtfully referred to cooperi. The original labels of some lots in the National Museun earried identifieation as oregonensis. Evidently this was based upon the presence of a lip callus. However, crassilabris lacks a peripheral earina and eannot be allied with oregonensis. Other collections have been determined as centervillensis, but the umbilieus is distinctly different in crassilabris.

Menetus cooperi crassilabris has been identified in collections from Colna, San Mateo County, California; Oakland, California; Portland, Oregon; Lake Washington at Seattle, Washington; and mountain swamps at Olga, Washington. The last named were erroneously identified as Menetus cooperi calioglyptus. One collection from Oakland was associated with typical cooperi.

\section{Menetus cooperi planospirus, New Variety}

Plate 122, figs. 3-6

shell with three whorls, of vellowish horn color. Tpper surface flat, the whorl bordered by a raised revolving ridge at the edge. Spire whorls sunken below general level. Base convex. Umbilicus deep, about one-fourth the diameter of the shell. Peripheral ridge stands out and elevated above the shell as a cord. Aperture modlified by carina. Sculpture of rather coarse growth lines, crossed by heary spiral lines.

$\begin{array}{cccccc}\text { Shell } & \begin{array}{c}\text { Greater } \\ \text { Height }\end{array} & \begin{array}{c}\text { Liamer } \\ \text { Diamer }\end{array} & \begin{array}{c}\text { Diameter } \\ \text { Aperture } \\ \text { Ileight }\end{array} & \begin{array}{c}\text { A perture } \\ \text { Diameter }\end{array} & \\ 3.3 & 5.0 & 7.0 & 3.0 & 3.0 & \text { Holotype } \\ 3.0 & 6.5 & 5.6 & 2.6 & 3.0 & \text { Paratype } \\ 2.6 & 5.9 & 5.0 & 2.0 & 2.0 & \text { Paratype } \\ 2.5 & 5.9 & 5.0 & 2.2 & 2.4 & \text { Paratype }\end{array}$

Type Locality. Orcas Island, Puget Sound, Washington.

Type Material. A eollection of thirty-six speeimens, taken by $\mathrm{W}$. H. Souther, is deposited in the Museum of Comparative Zoology, Harvard University, Accession no. 31583. One of these, designated as holotype, is shown on plate 122 as fig. 5 , and three paratypes are shown on the same plate as figs. 3,4 , and 6 .

Menetus cooperi planospirus is characterized by its very flat spire and the presence of a raised carina placed at the upper edge of the whorl. It cliffers from Menetus cooperi multilineatus in the position of the earina, and in having a flat rather than a convex spire.

\section{Menetus dalli, New Species}

Plate 140, figs. 22-24

Shell small, lenticular, with a bluntly angular periphery. Upper surface flatly convex, three whorls visible, sutures deeply incised. Lower surface flatly convex, the umbilical or spire region small, occupying one-sixth of the diameter of the shell. The lower surface is swollen over the umbili- 
cus. The lower surface has a somewhat pinched appearance, with an indistinct, impressed line bordering the periphery. Seulpture of coarse growth lines radiating from the periphery. At regular intervals there are larger rib-like projections, with four to six of the smaller ribs between. All the ribs extend into the spire carity, which is deep. The seulpture is more conspicuous on the base of the shell. The umbilieal (upper) side has the fine riblets more regularly spaced without the larger ones. This sculpture is most apparent on the large holotype specimen. There are likewise fine, impressed spiral lines. Aperture triangular, wider than high. Columella almost vertical. Lip thickened by callus, which includes the columellar and parietal walls. The right side of the aperture is acute and pinched.

$\begin{array}{cccccc}\text { Shell } & \begin{array}{c}\text { Greater } \\ \text { Height }\end{array} & \begin{array}{c}\text { Lesser } \\ \text { Diameter }\end{array} & \begin{array}{c}\text { Aperture } \\ \text { Diameter }\end{array} & \begin{array}{c}\text { Aperture } \\ \text { Diameter }\end{array} & \\ 1.5 & 1.0 & 3.2 & 1.1 & 1.6 & \text { Holotype } \\ 1.4 & 3.2 & 2.7 & 1.0 & 1.5 & \text { Paratype } \\ 1.2 & 2.9 & 2.2 & 0.9 & 0.9 & \text { Paratype }\end{array}$

Type Locality. Caloosahatchie River, Florida.

Type Material. Pliocene fossils, collected by W. H. Dall, deposited in the United States National Museum, Aceession no. 112556. Holotrpe figured on plate 140 as Fig. 22; paratypes as figs. 23, 24.

Menetus dalli differs from alabamensis in the former's smaller and deeper spire depression and its heavier growth lines forming riblets. It was identified by Dall (after whom the new species is mamed) as exacuous. It was associated with dilatatus and alabamensis anus.

\section{Menetus dilatatus floridensis, New Variety}

Plate 123, figs. 20-22

Shell small, of three whorls, slow increasing in diameter. Color light horn. Body whorl forms a rounded obtuse angle as in dilatatus. Base flatly rounded. Spire depression wide, shallow, showing all of the whorls. Seulpture of fine growth lines crossed by fine spiral lines. Aperture rounded, not flaring. Outer lip thin. No callus on parietal wall.

\begin{tabular}{|c|c|c|c|c|c|}
\hline Shell & Greater & Lesser & Aperture & A perture & \\
\hline Iteight & Diameter & Diameter & IFeight & Diameter & \\
\hline 0.9 & 2.5 & 2.1 & 0.8 & 1.0 & Holotype \\
\hline 0.8 & 2.3 & 2.0 & 0.7 & 0.8 & Paratype \\
\hline 0.8 & 2.0 & 1.6 & 0.7 & 0.7 & Paratype \\
\hline
\end{tabular}

Type Locality. St. Johns River, Palatka, Florida.

Type Material. Collected by W. H. Dall. Deposited in the United States Tational Muscum, Accession no. 37585. Holotype shown on plate 123 as fig. 20 ; paratypes as figs. 21 and 22 .

Menetus dilatatus floridensis differs from typical dilatatus in the fact that the new variety has a smaller aperture which is rounded, not flaring; has rounded body whorl, without trace of angulation; and has wider, shallower spire depression, showing all of the whorls.

\section{Menetus labiatus, New Species}

Plate 121, figs. 9-11

Whorls three, rounded. Spire flattened, apex sunken. Base rounded, umbilicus broad and shallow, one-sixth the diameter of the shell. Whorls and 
umbilieus rapidly increasing in diameter. Aperture orately rounded, the lip with a heavy internal rim of callus which joins a distinet parietal eallus, making the lip in some specimens continuous. Unbilieus varies in depth. Sculpture of fine growth lines, crossed by fine spiral lines, although the latter may be absent in some specimens.

$\begin{array}{cccccl}\begin{array}{c}\text { Shell } \\ \text { IIeight }\end{array} & \begin{array}{c}\text { Greater } \\ \text { Diameter }\end{array} & \begin{array}{c}\text { Lesser } \\ \text { Diameter }\end{array} & \begin{array}{c}\text { Aperture } \\ \text { Ieight }\end{array} & \begin{array}{c}\text { Aperture } \\ \text { Diameter }\end{array} & \\ 1.0 & 2.6 & 2.1 & 0.5 & 0.5^{*} & \text { Holotype } \\ 0.9 & 2.3 & 2.0 & 0.5 & 0.5 & \text { Paratype } \\ 1.1 & 3.1 & 2.6 & 0.6 & 0.5 & \text { Baker Coll., 2100 } \\ 1.2 & 3.0 & 2.3 & 0.8 & 0.8 & \text { Baker Coll., 2100 } \\ \text { *t heavg callus reduces the size of the aperture. } & & \end{array}$

Type Locality. Terminal Island, Los Angeles County, California.

Type Material. Three sperimens, colleeted by Eastman, are in the United States National Museum, Aceession no. 190021. Designated holotype and paratypes illustrated on plate 121 as figs. 11 and 9,10 , respectively.

The type material was labelled as centervillensis. Taken in various southern California localities. Some large individuals of this species were collected from peat deposits by S. S. Berry, in Orange County, California. Two of these individuals, which have a heary lip eallus, are inclurled as the third and fourth items in the above tabulation of shell characters (Baker Coll., no. 2100).

Menetus labiatus cliffers from centervillensis in the shape of the umbilieus and the aperture.

\section{Menetus portlandensis, New Species}

Plate 121, figs. 12-18

Shell less elevated than in centervillensis, the body whorl depressed, rounded on the periphery, not angled as in centervillensis. Spire flat, three and one-half whorls, sutures impresserl. Color blackish to light horn, usually in the same shell. Base flatter than in centerillensis; the umbilicus wider, about one-fourth of the diameter of the shell. Aperture transwersely orate. wider than in centervillensis and not as nearly round. Slight eallus on parietal wall. Seulpture of coarsely impressed spiral lines, distinet in all specimens examined.

$\begin{array}{cccccc}\text { Shell } & \begin{array}{c}\text { Greater } \\ \text { Height }\end{array} & \begin{array}{c}\text { Lesser } \\ \text { Diameter }\end{array} & \begin{array}{c}\text { Diameter } \\ \text { Derture } \\ \text { Height }\end{array} & \begin{array}{c}\text { Aperture } \\ \text { Diameter }\end{array} & \\ 1.4 & 4.0 & 3.3 & 1.1 & 1.2 & \text { Holotype } \\ 1.3 & 3.5 & 3.0 & 0.8 & 1.0 & \text { Paratype } \\ 1.1 & 3.3 & 2.6 & 0.5 & 1.0 & \text { Paratype }\end{array}$

Type Locality. Tanner Creek, Portland, Oregon.

Type Material. A large collection of one hundred shells, collected by J. E. Benedict, is deposited in the United States National Museum, Aceession no. 184182. The holotype is shown on plate 121 as fig. 12 ; six paratypes on the same plate as figs. 13 to 18 .

The chief distinguishing characteristies of Menetus portlandensis are that the umbilieus is wider and shallower and the spiral lines on the shell are heavier than in other species of the genus.

This new species has also been taken in the ricinity of San Francisco, California, and at Astoria, Oregon. In the latter instance it was associated with specimens of cooperi. 

ILLUSTRATIONS OF THE ANATOMY AND OF SHELLS 



\section{ANATOMICAL SYMBOLS USED ON THE PLATES}

A, anus

AG, abdominal ganglion

$\mathrm{Al}$, albumen gland

AO, aortis

$A P$, pulmonary vein

ARMI, anterior retractor muscles

$A L$, anricle

13, bulbous termination of rerese

BG, bnecal ganglion

BP, buccal pouch

$B R$, buccal retractor ususcle

13S, blind sac or caecum

$\mathrm{BV}$. blood ressel

BII, body wall of gland

C. canal

CF, carrefour

CG, cerebral ganglion

CL, cilia

CM, columella muscle

CMIC, eut portion of mantle collar and columella muscle

CR, crop

D, diaphragm

DA, duct from albumen gland

DC, duct of gland

DG, duct of preputium

DV, duct entering vergic sac

E. ere

EPI, epiphallus-like swelling

EUD, external opening of ras deferens

F. foot

FL, flagellum

FO, female opening

FOY, diverticula of ovotestis

FPR, diverticula of prostate

G, accessory gland

GA, gland appendage

GF, folds in wall of gland cavity

GI, penial gland

(i), ganglion

GR, growth lines

GIV, wall of preputial sac

GZ, gizzard

$H$, head

HT, heart

IC, carity of gland connecting with gland duct

$\mathrm{IN}$, intestine or space for intestine J, jaw on surface of albumen gland

$\mathrm{K}$, kidney

L. ling

LJ, lateral jaw

$\mathrm{LV}$, liver

M. mantle

MC, mantle collar

MO, nale opening

MN, muscle of neck

MP, muscular pads or pillars in preputium (pilasters)

MR, muscular ridge or diaphragm

MS. suspensary muscles of verge

NT, mouth

$\mathrm{N}$, nerve
NA, section through neck

NG, nidamental gland

NS, new shell forming

OC, outer cup of gland

$\mathrm{OD}$, oviduct

OE, oesopliagus

OLV, opening of liver duct into stomach

OT, ovotest is

$P$, pseudobrauch

PA, rergic appendage

$P C$, pericardium

PD, duct of prostate

PF, prostate diverticula

PC, pedal ganglia

PL, pilasters

$P P$, yarilla in preputium

PR, preputium

P'RM, posterior retractor muscle

PRS, jrostate

PS, pneumostome

PY, pyloris

$R$, rectum

$R A$, renal vein

$\mathrm{RD}$, ridge

$\mathrm{RK}$, ridge on kidney

$\mathrm{RL}$, radula

$R M$, retractor muscle

$S$, spermatheea

$\mathrm{SB}$, sarcobelum

SC, sperm canal

SD, spermathecal duct

SG, salivary gland

$\mathrm{SCO}$, opening of sperm canal

SJ, superior jaw

SH, shell

SK, saccular part of kidney

SM, supporting muscle

SO, orisperm duct

SP. spermatophore

SPD, sperm duct

ST, stylet

STM, stomach

ST, seminal resicle

$\mathrm{T}$, tentacle

TK, tubular part of kidney

$\mathrm{U}$, uterus

UO, external opening of ureter

UR, ureter

$\mathrm{V}$, verge

$\mathrm{TC}$, vergic sac

YD, ras deferens

YDV, ras deferens in rergic sac

$\mathrm{VF}$, folds in vergic sac

$\mathrm{rG}$, ragina

VGL, visceral ganglion

V'L, velum

VM, muscle to vergic sac

TN, vein

TO, opening between rergic sac and preputium

$\mathrm{VP}$, vergic papilla

VS, vergic sac

VT, rentricle

$\mathrm{I}$, canal in penial gland 


\section{PLATE 1}

\section{Planorbis planorbis (Linn.)}

From a pond 25 miles southeast of Warsaw, Poland; from A. Jankowski.

1. Entire genital system spread out. The dark spaces are folds in the anatomical preparation.

2. Penial complex with muscles.

3. Head and foot showing form of pseudobranch.

4. Vertical section through penial complex to show small size of verge.

5. Section through rerge and ras deferens.

6. Junction of oviduct and ras deferens to form orisperm duct and connection with albumen gland and carrefour.

7. Section through prostate, oviduct, and vas deferens showing a prostate canal separated from the vas deferens.

8 . Section through orotestis.

9. Section through orotestis showing diverticula embedded in the liver cells.

Line near figure indicates $1 \mathrm{~mm}$. in length 

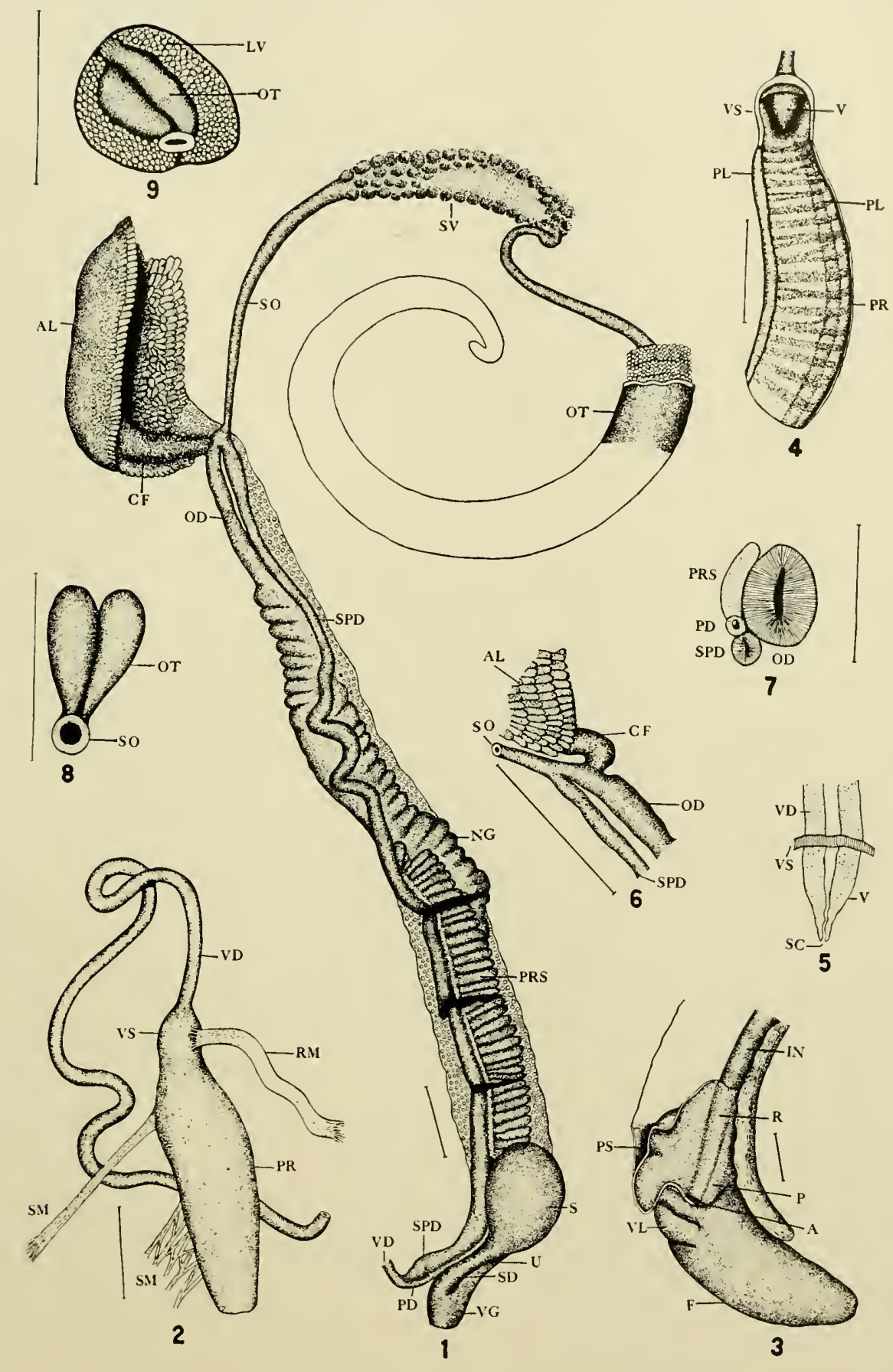

PLATE 1 


\section{PLATE 2}

\section{Segmentina and Hippeutis}

1-6. Segmentina nitida (Miiller). From swamps on a meadow near Warsaw, Poland; from A. Jankowski.

1. Cross section of pilaster to which appendage is attached.

2. Vertical section of preputium showing position of gland-like appendage.

3. Upper view of cup of gland or appendage.

4. Tertical section of gland or appendage.

5. End of verge showing position of vergic appendage.

6. End of verge showing vergic appendage and outlet of sperm canal.

7-15. Hippeutis complanatus (Linn.). From pool in meadow in Jabtonna, $16 \mathrm{~km}$. north of Warsaw, Poland; collected by A. Jankowski.

7. Two diverticula of ovotestis.

8. Cross section of prostate showing two canals, one for prostate (PD) and one for sperm duct (SPD).

9. Gland or appendage in preputium.

10. Outline of albumen gland (from above).

11. Upper part of vergic sac showing two flagella and the vas deferens.

12. Tertical section of penial complex showing relationship of verge, gland, or appendage, and flagella.

13. Head of animal showing form of pseudobranch and pneumostome.

14. Penial complex from the ontside.

15. General dissection of genitalia omitting the penial complex.

Line near figure indicates $1 \mathrm{~mm}$. in length. Line at leit of fig. 12 also indicates size of figs. 3, 4, 5, 8 , and 9. Figures 6 and 11 are greatly enlarged. Figure 14 has same magnification as fig. 15. 
Illustrations of the Anatomy and of Shells

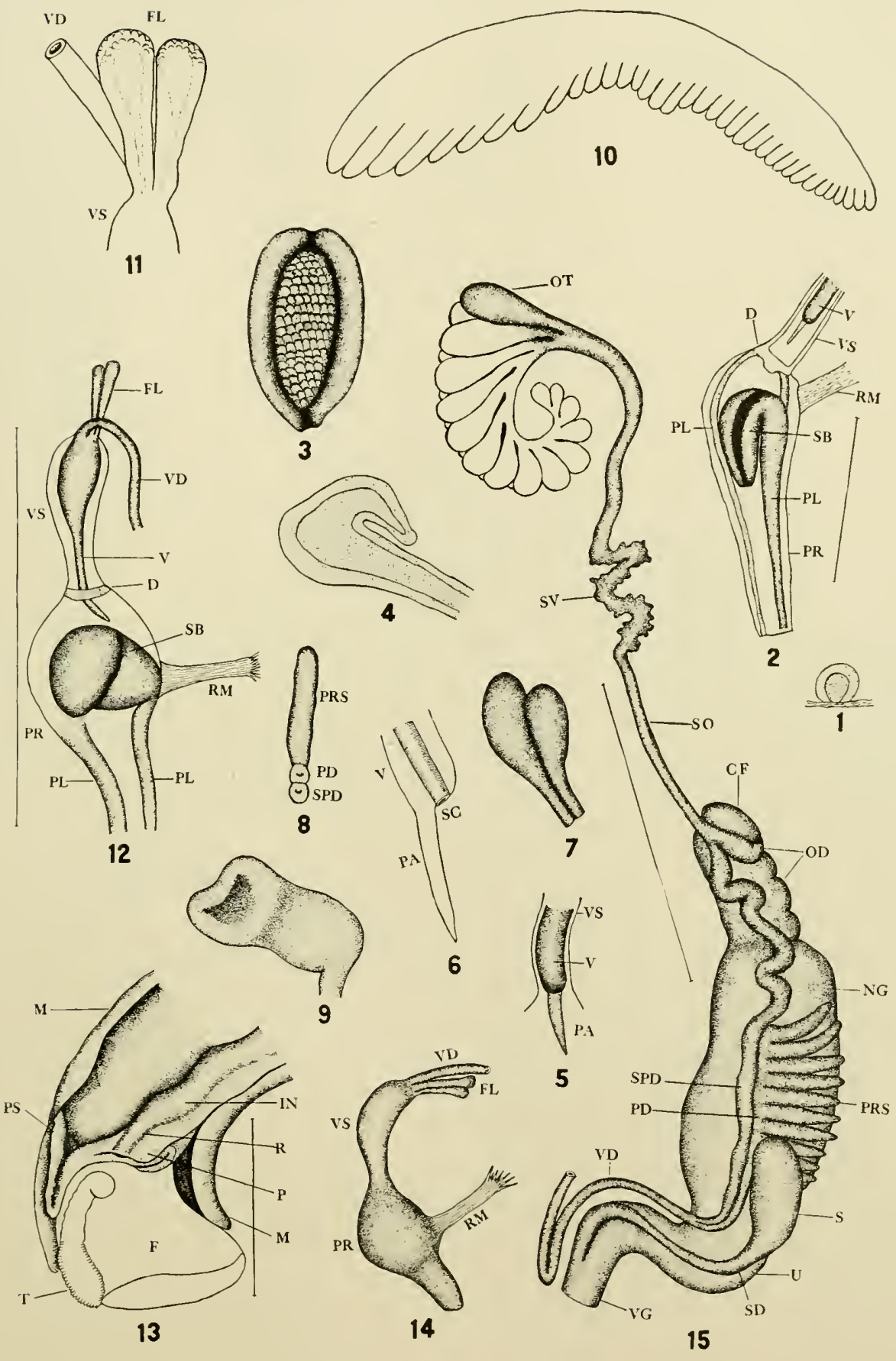

PLATE 2 


\section{PLATE 3}

\section{Segmentina and Bathyomphalus}

1-4. Segmentina nitida (Müller). From meadow near Warsaw, Poland; from A. Jankowski.

1. External riew of penial complex.

2. Hermaphrodite complex.

3. Cross section of prostate and ducts of prostate and ras deferens.

4. Head showing position and form of pseudobranch.

5-10. Bathyomphalus contortus (Linn.). From Drewnica, a turfy ground $4 \mathrm{~km}$, northeast of Warsaw, Poland; collected by A. Jankowski.

5. Head showing position and form of pseudobranch.

6. Pseudobranch showing position of rectum.

7. Cross section of orotestis.

8. Cross section of prostate showing prostate duct separate from sperm duct.

9. Penial complex from the outside.

10. Hermaphrodite complex dissected and spread out.

Line near figure indicates $1 \mathrm{~mm}$. in length. Line at left of fig. 7 also represents size of figs. 3 and 8 . Figure 9 is same magnification as fig. 10. 
Illustrations of the Anatomy and of Shells
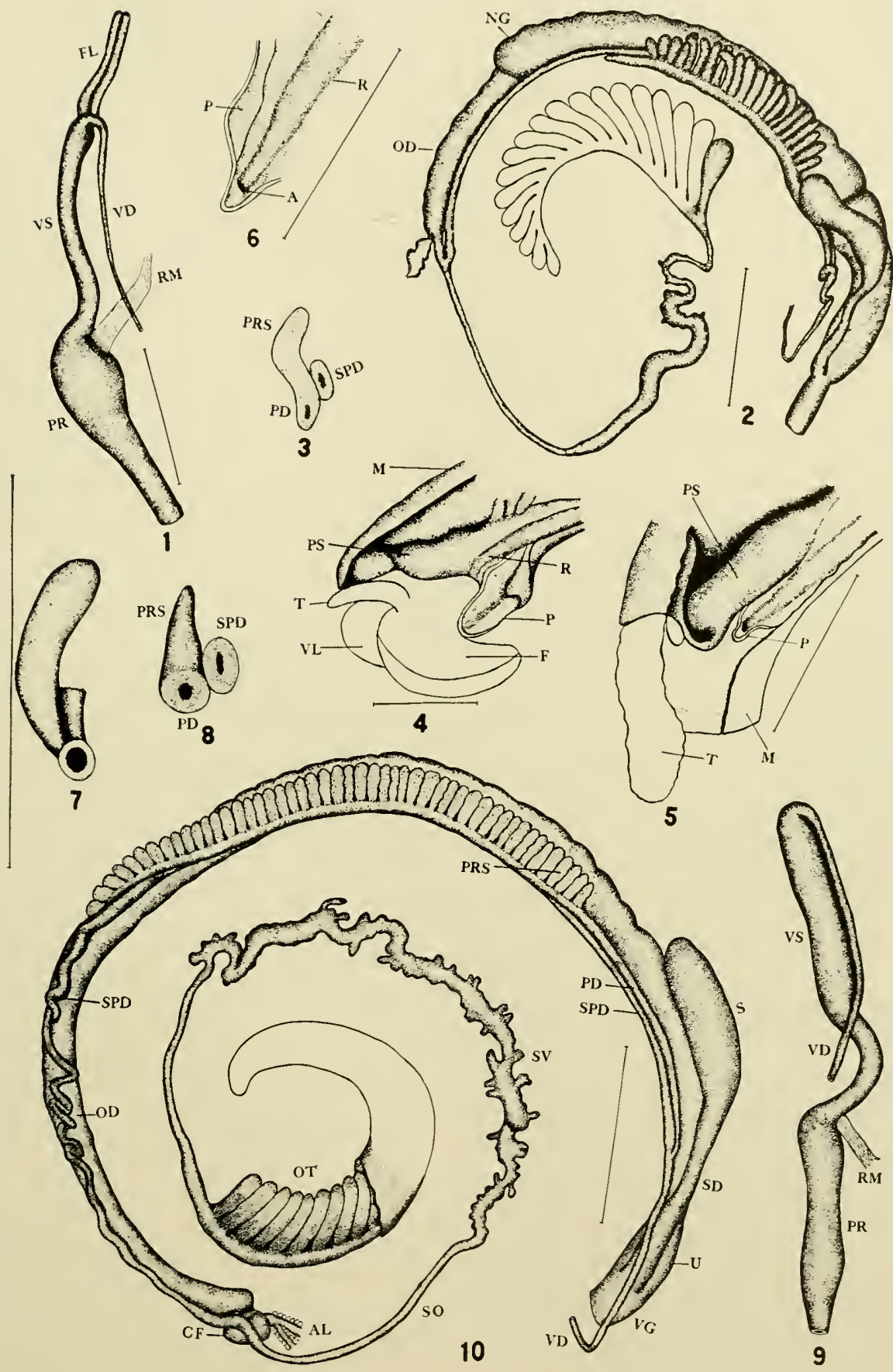

PLATE 3 


\section{PLATE 4}

Pingiella peipinensis (Ping and Yen). New genus

Peiping, China; from Fan Memorial Institute, Peiping, China.

1. Albumen gland showing position of stomach.

2. Portion of penial gland showing position of ducts.

3. Terminal end of penial gland, under side.

4. Teminal end of penial gland, view from side showing internal canal.

5. Penial complex showing long duct of penial gland and long and peculiarly formed appendages.

6. Preputium cut open to show penial gland.

7. Preputium cut open to show penial gland and relationship of long duct.

$\mathrm{S}$. Verge in vergic sac.

9. General dissection of genitalia, the organs separated and extended.

Line near figure indicates $1 \mathrm{~mm}$. in length. Figures 3 and 4 are greatly enlarged. 
Illustrations of the Anatomy and of Shells

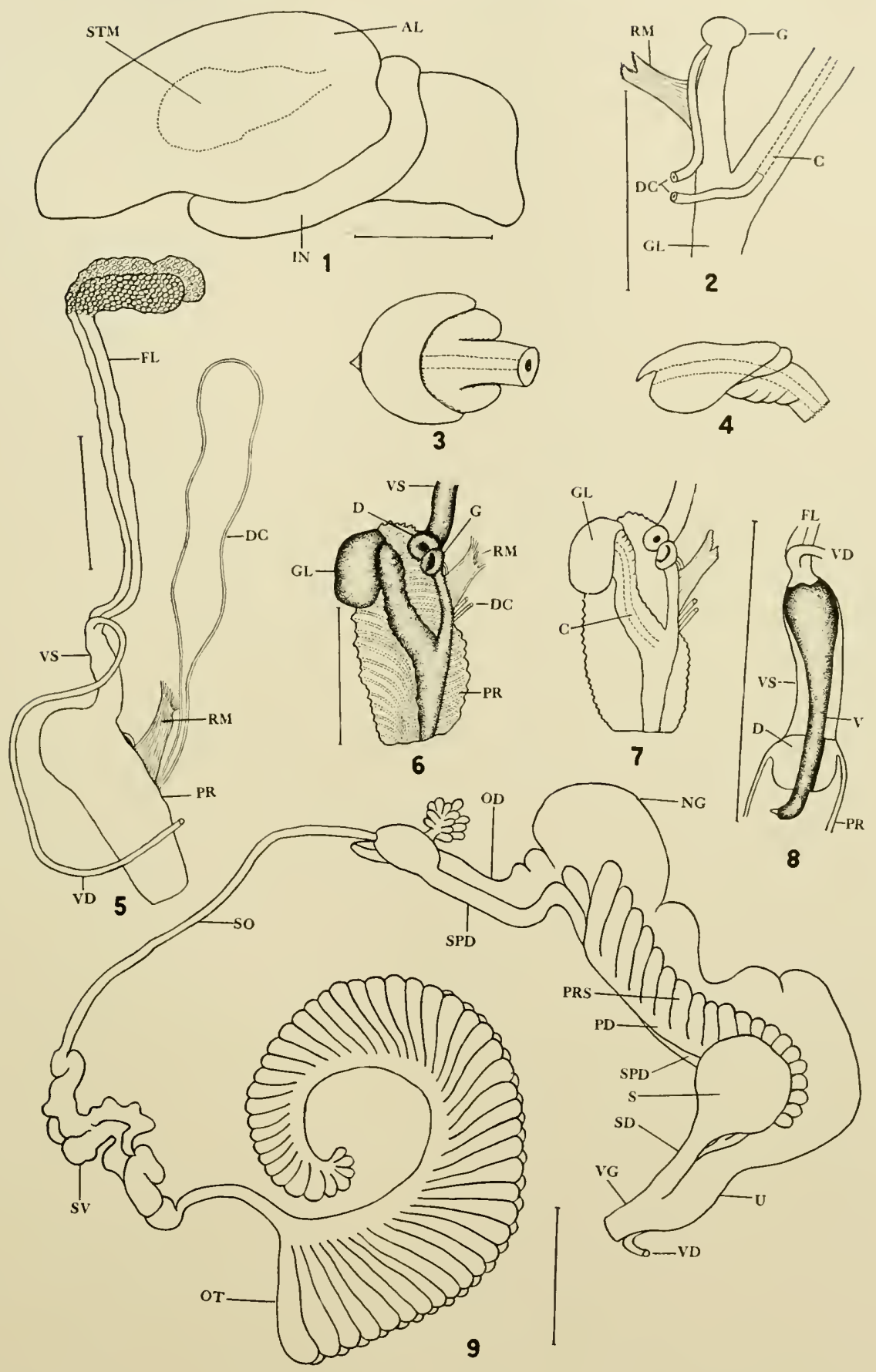

PLATE 4 


\section{PLATE 5}

\section{Pingiella and Polypylis}

1,5. Pingiella peipinensis (Ping and Yen), new genus. Peiping, China.

1. Region of the pseudobranch.

5. Spermatheca of different shape.

2-4,6,7. Polypylis hemisphaerula (Benson). Peiping, China; from Fan Memorial Institute.

2. Outline of albumen gland.

3. Region of the pseudobranch.

4. Section through prostate and ducts.

6. Distal end of verge showing outlet of canal at the side.

7. Entire genitalia dissected and organs separated.

Line near figure indicates $1 \mathrm{~mm}$, in length. Figure 6 is greatly enlarged. 

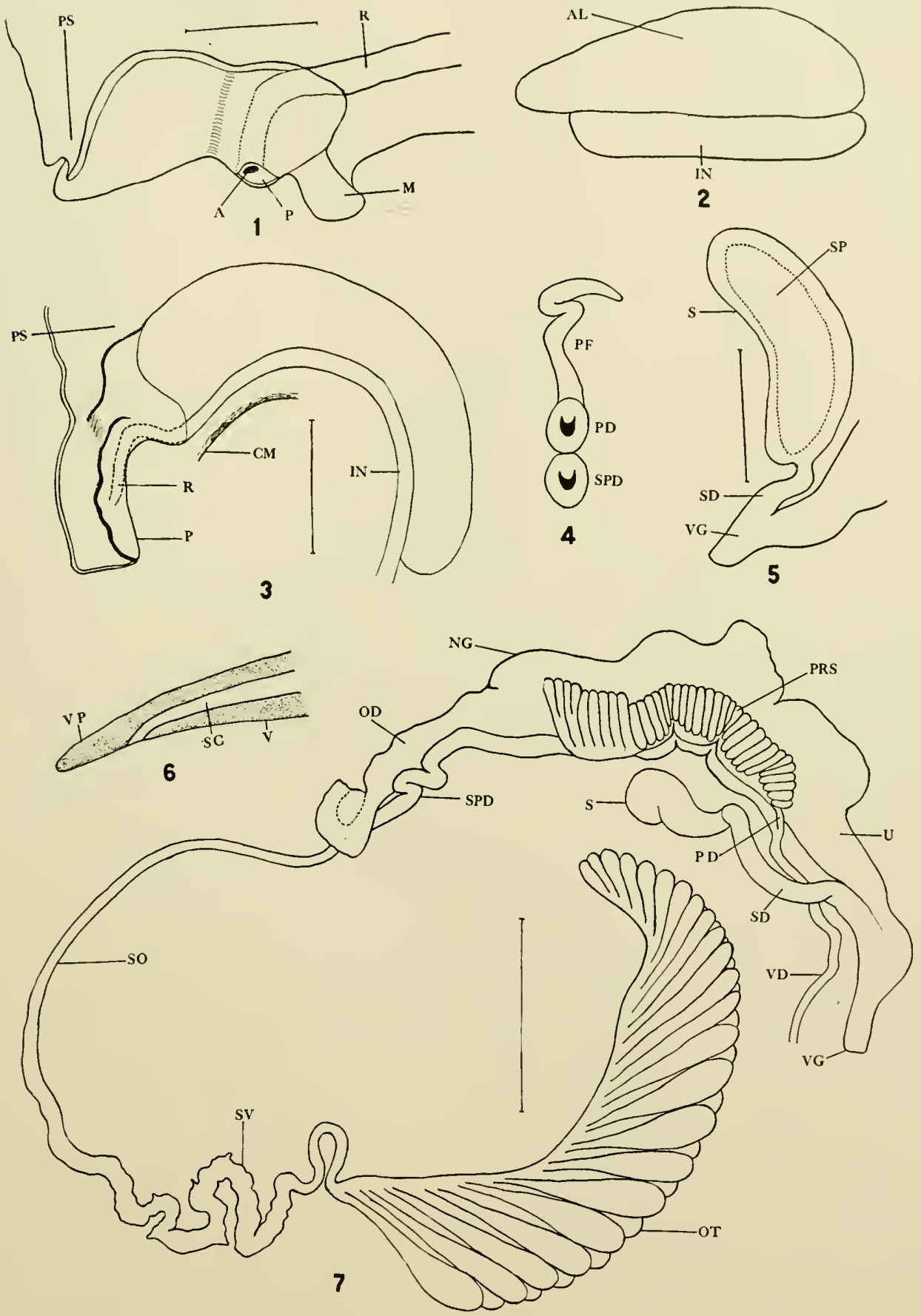

PLATE 5 


\section{PLATE 6}

\section{Anisus vortex and Anisus spirorbis}

1-4,6. Anisus vortex (Linn.). From stream in meadow in Jabtonna, 18 km. northeast of Warsaw, Poland; collected by A. Jankowski.

1. Penial complex showing long and narrow vergic sac.

2. Stylet, dry and somewhat crushed.

3. Section through prostate and sperm canal showing two ducts.

4. Section through upper portion or preputium and vergic sac, showing papilla in preputium, stylet and outlet of sperm canal at the side of the verge.

6. Pseudobranch showing relationship to rectum.

5, 7-13. Anisus spirorbis (Linn.). From a trench in Struga, $12 \mathrm{~km}$. northeast of Warsaw, Poland; collected by A. Jankowski.

5. Stylet at end of verge with outlet of sperm canal at side of verge.

7. Two diverticula of ovotestis.

S. Cross section through prostate and oviduct.

9. Albumen gland, upper part.

10. Penial complex in vertical section showing stylet, muscular papilla, and pilasters.

11. Foot, pseudobranch, and pneumostome.

12. Entire genitalia dissected and separated.

13. Penial complex of specimen with vergic sic shortened and club-shaped.

Line near figure indicates $1 \mathrm{~mm}$. in length. Figures 2 and 5 are greatly enlarged. 
Illustrations of the Anatomy and of Shells
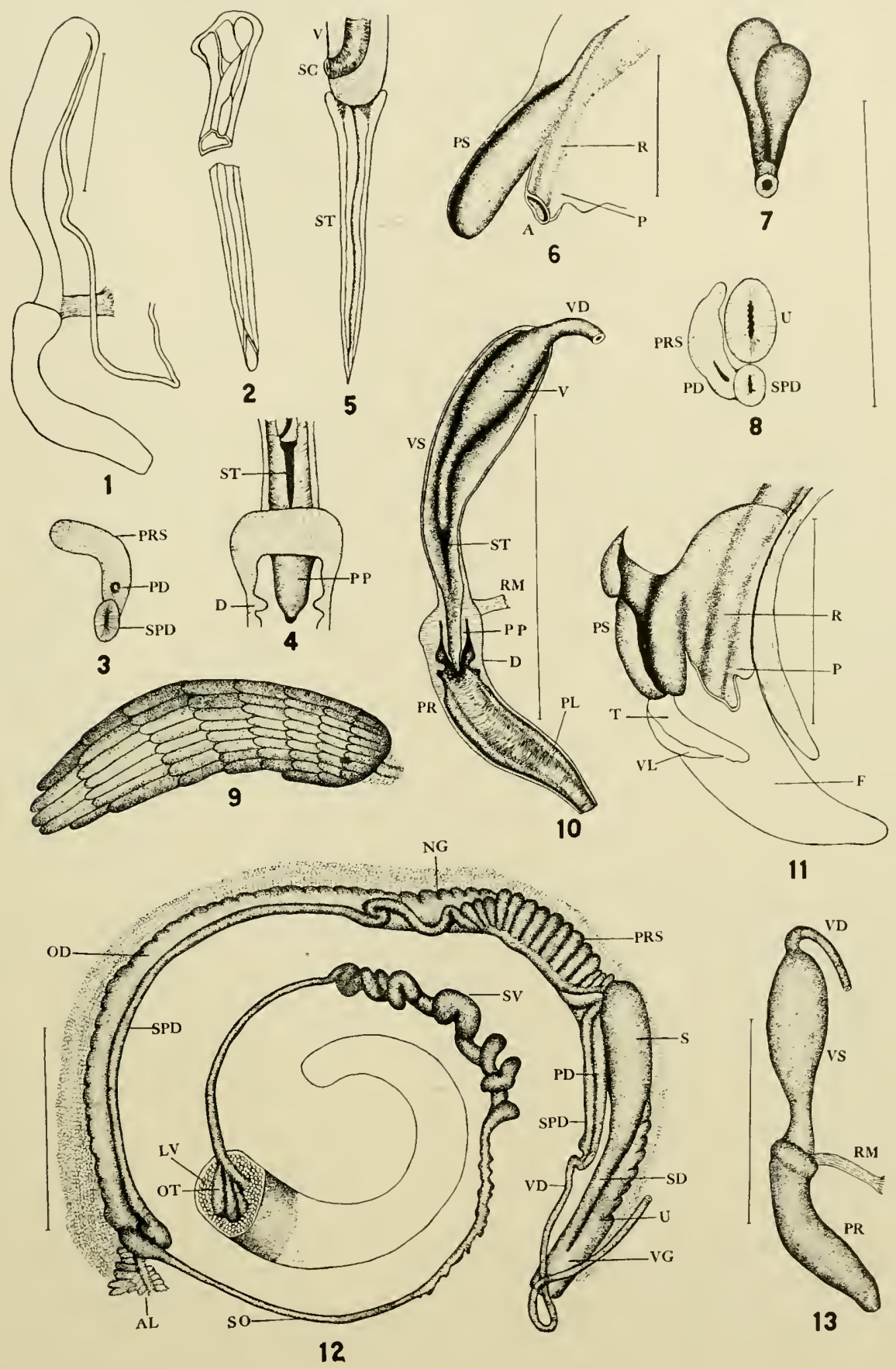

PLATE 6 


\section{PLATE 7}

Anisus leucostomus and Anisus septemgyratus

1-5. Anisus leucostomus (Millet). From small pond in Bielany Park, Warsaw, Poland; collected by A. Jankowski.

1. Foot, pseudobranch, and pneumostome.

2. Crenitalia dissected and the organs separated. Figure under seminal vesicle shows this organ stretched out.

3. Muscular ring or diaphragm in upper part of preputiun showing papilla with stylet protruding.

4. End of oriduct and ras deferens showing where ovisperm duct joins the oviduct and ras deferens.

5. Stylet.

6. Anisus septemgyratus (Ziegler). From turfy meadow in Drewnica, $4 \mathrm{~km}$. northwest of Warsaw, Poland; collected by A. Jankowski.

6. Outline of genitalia exchusive of the penial complex.

Line near figure indicates $1 \mathrm{~mm}$. in length. Line at left of fig. 5 is only for size of figs. 3 and 4. 

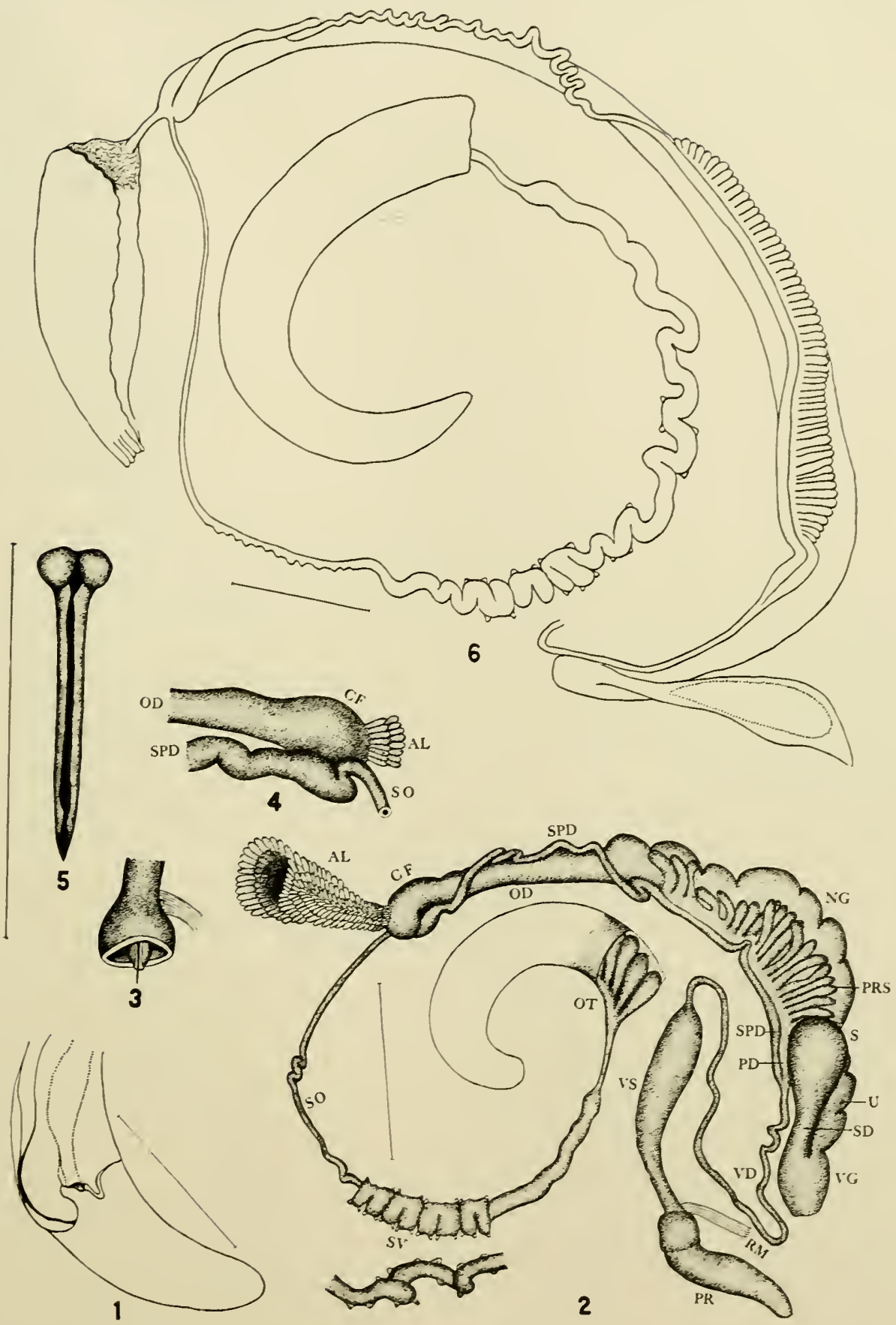

PLATE T 


\section{PLATE $\&$}

\section{Intha and Polypylis}

1-S. 11. Intha capitis Amnandale. From Inle Lake, South Shan State, Burma, India; collected by Dr. N. Annandale.

1. Outline of albumen gland.

2. Pseudobranch and rectum.

3. Head of animal showing tentacles and eyes.

4. Distal end of verge.

5. A spermatophore.

6. Penial complex, dorsal view.

7. Cross section of penial gland.

8. Vertical section of penial complex showing verge, gland, and duct.

11. Tentral view of entire genitalia, showing the large size of the flagella.

9.10. Polypylis hemisphaerula (Benson). Peiping. China; from Fan Memorial Institute.

9. Section of penial complex cut open to show verge, diaphragm and pilasters.

10. Penial complex, rentral riew. Small figure at right shows insertion of vas deferens at junction of vergic sac and flagellum. Dorsal view.

Line near figure indicates $1 \mathrm{~mm}$, in length. Figures $1,5,6$, and 7 have same magnification as fig. 11. Figure 4 is greatly enlarged. 


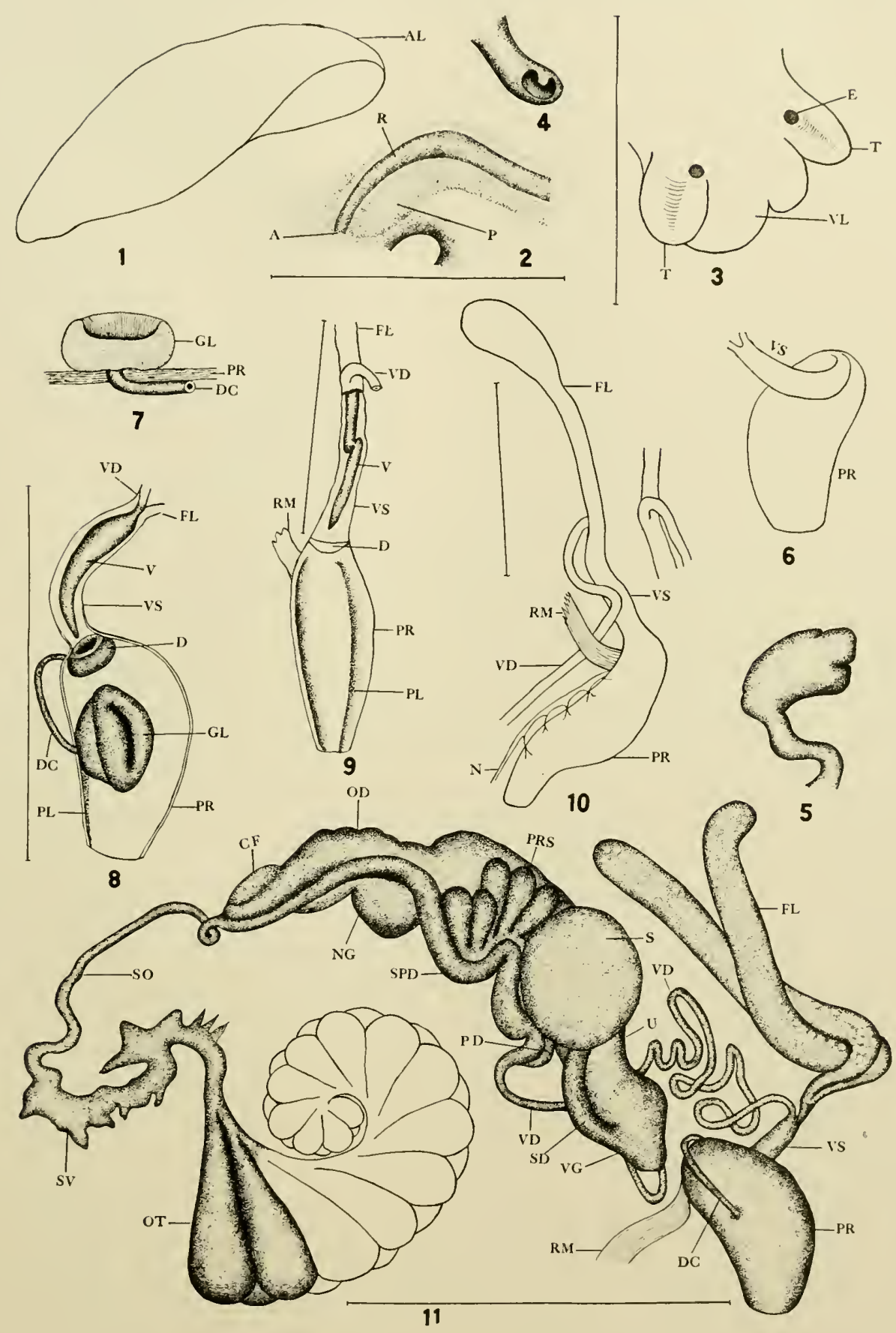

PLATE 8 
PLATE 9

\section{Drepanotrema and Australorbis}

1-3. Drepanotrema anatinum (Orbigny). From Viejo, Puerto Rico; from Dr. IV. A. Hoffman.

1. Penial complex showing form of flagellum.

2. Cenitalia dissected and organs separated. Note the small number of prostate diverticula.

3. Head and foot showing form of pseudobranch.

4-10. Australorbis glabratus (Say). From Lares, Puerto Rico; from Dr. W. A. Hoffman.

4. Cross section of portion of orotestis to show multiple branched diverticula.

5. Distal end of verge showing opening at center.

6. One diverticulum of prostate showing multiple branching at end.

7. Pseudobranch and pneumostome.

8. Outline of albumen gland showing depression occupied by intestine.

9. Section of penial complex showing long and narrow verge and vergic sac.

10. Entire genitalia dissected and organs separated. Note branched form of prostate diverticula and multiple nature of orotest is diverticula.

Line near figure indicates $1 \mathrm{~mm}$. in length. Line near left of fig. 1 is also for fig. 3 . 
Illustrations of the Anatomy and of Shells
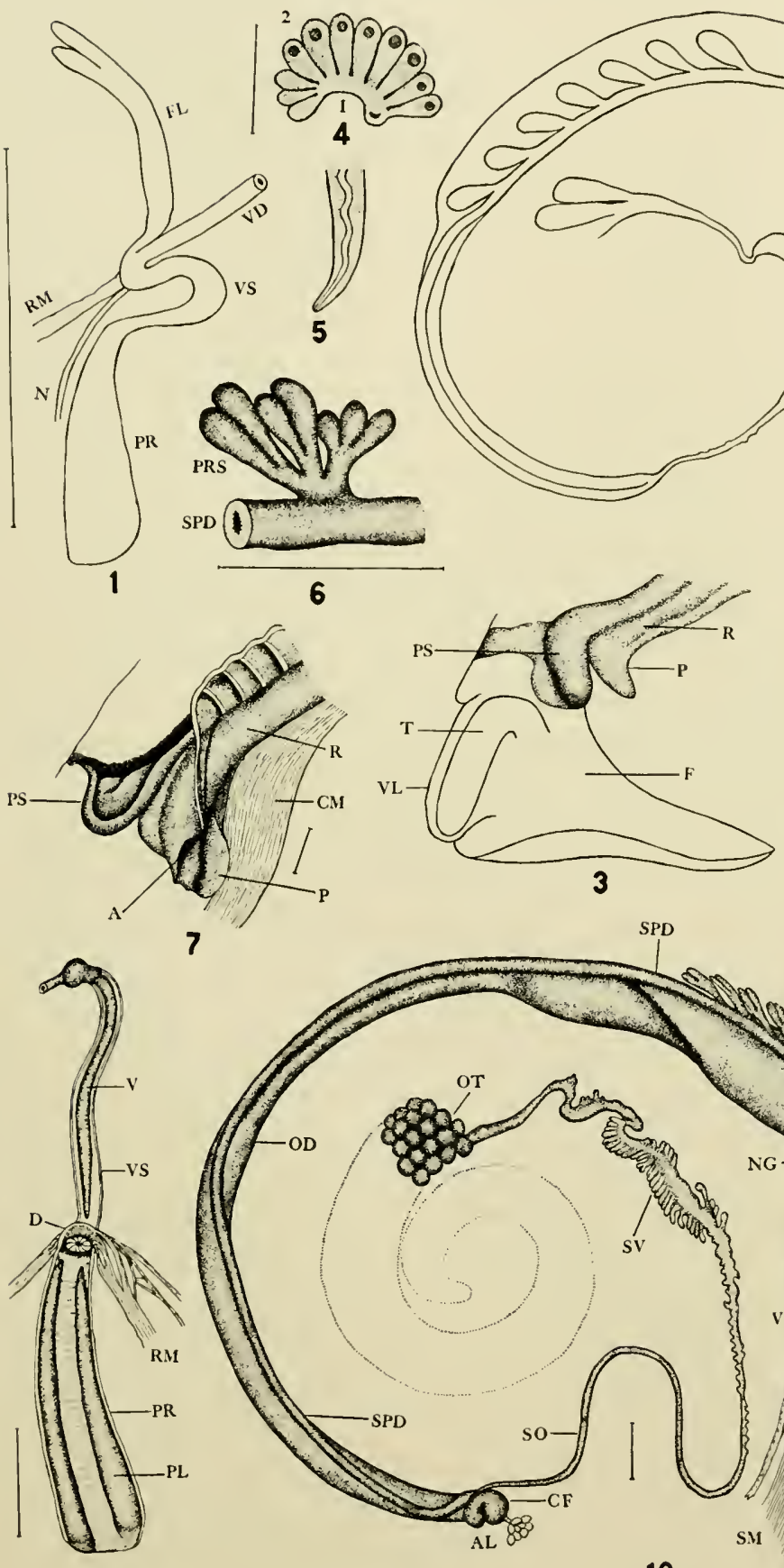

9

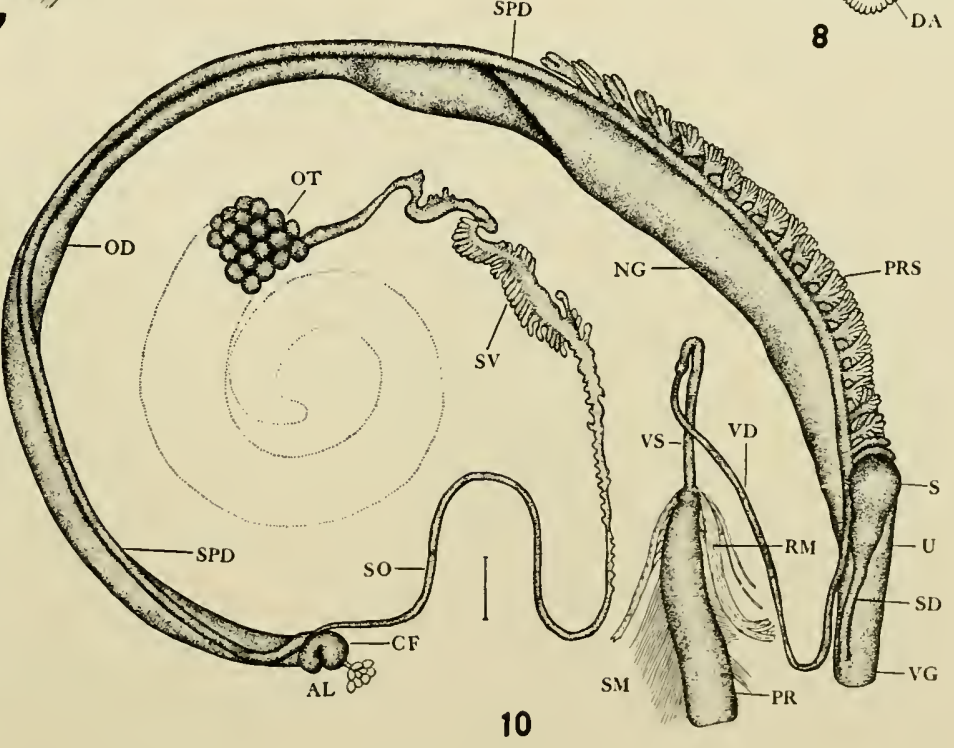

PLATE 9 
PLATE 10

\section{Drepanotrema hoffmani F. C. Baker}

From Isabela, Puerto Rico; collected by Dr. W. A. Hoffman.

1. Animal removed from shell showing pigmentation of mantle, shape of head and tentacles, and position of stomach (STM) in body.

2. Genitalia dissected and organs separated.

3. Fore part of body showing head, pseudobranch, etc.

4. Albumen gland showing attachment of ducts.

5. Penial complex showing attachment of short flagellum, vas deferens, etc.

6. Section of penial complex showing verge, pilasters, vas deferens, flagellum, etc.

7. Upper part of penial complex showing relationship of flagellum, vas deferens, vergic sac, retractor muscle, etc.

8. Penial complex of another specimen.

9. Distal end of verge showing central outlet of sperm canal.

Line near figure indicates $1 \mathrm{~mm}$. in length 

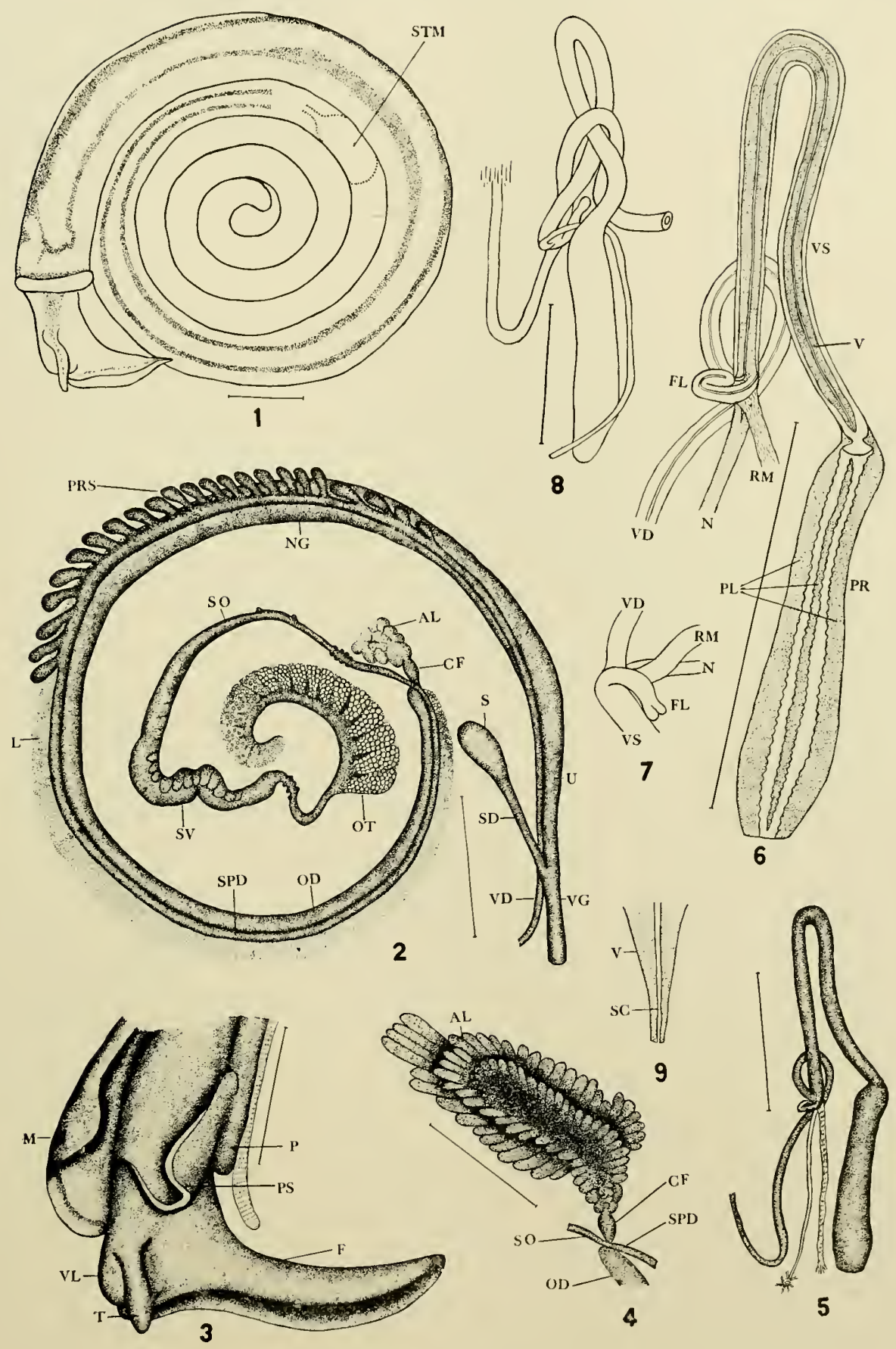

PLATE 10 


\section{PLATE 11}

\section{Drepanotrema lucidum (Pfeiffer)}

From Havana, Cuba; collected by Dr. C. G. Aguayo.

1. Head and foot with preputium and verge extended from male genital opening. The pseudobranch and rectum are also shown.

2. Head and foot with only preputium extended from male genital opening.

3. Genital system dissected and organs separated.

4. Penial complex showing flagellum, vas deferens, etc.

5. Penial complex with very long flagellum.

6. Diagram of penial complex showing preputium and verge extended from male genital opening.

7. Relationship of vas deferens, flagellum, retractor muscle in body of animal in specimen with preputium and verge extended from male opening.

Line near figure indicates $1 \mathrm{~mm}$. in length 

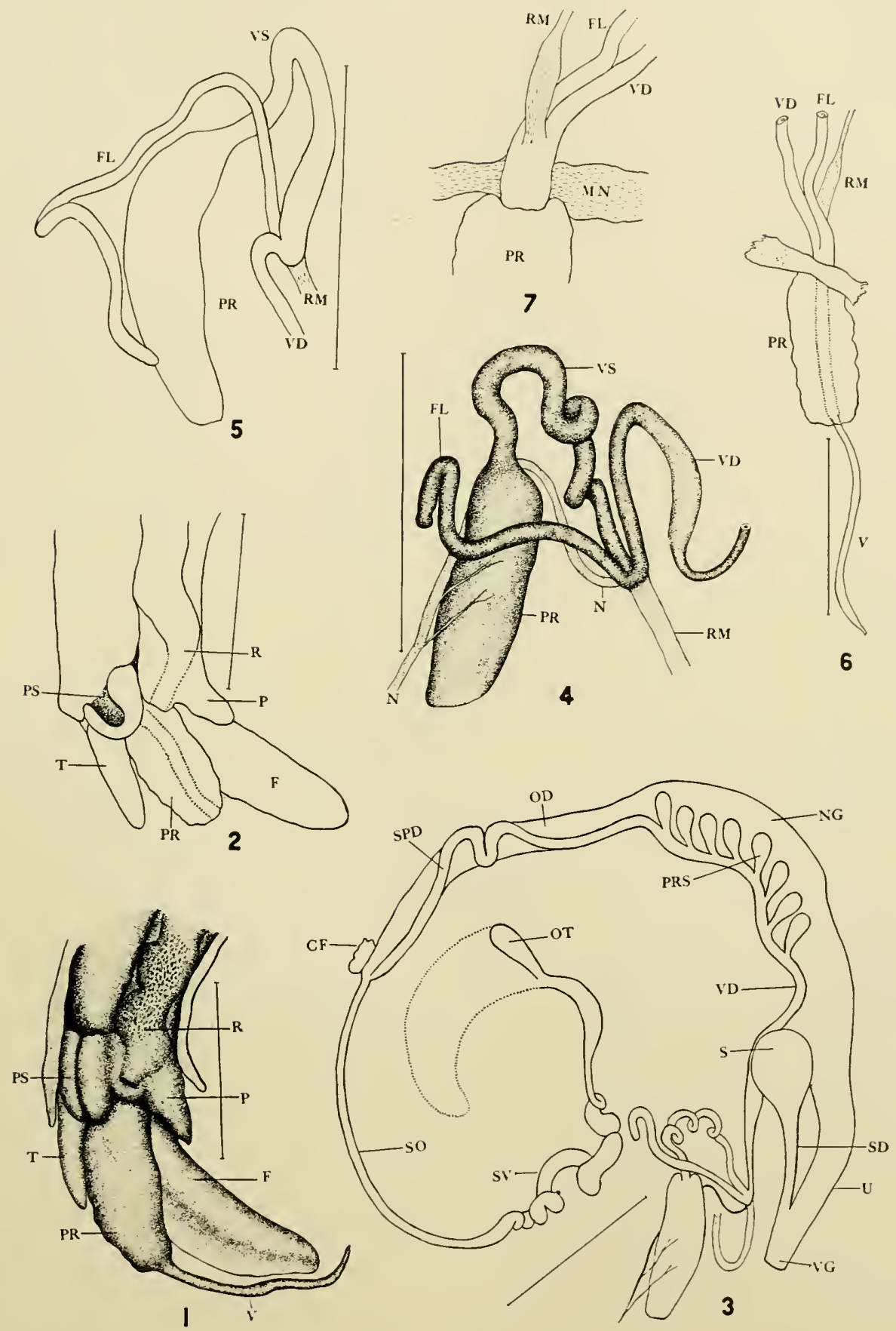

PLATE 11 


\section{PLATE 12}

\section{Tropicorbis havanensis (Pfeiffer)}

From New Orleans, La.; collected by Dr. E. Carroll Faust.

1. Penial complex in section to show verge and pilasters in vergic sac.

2. Muscular ring or ridge between vergic sac and preputium (diaphragm).

3. Distal end of rerge showing central opening of sperm canal.

4. Borly of snail showing pseudobranch, pnemmostome, rectum, and frilled ridge or crest over rectum.

5. Body of snail showing jigmentation of mantle.

6. Albumen gland from above.

7. Portion of genitalia at junction of oviduet and sperm duct with ovisperm duct. Also entrance of albumen duct into carrefour and thence to oviduct. From below.

S. Same as fig. 7 , from above.

9. Single diverticulum of prostate showing canal distinct from that of sperm duct.

10. Penial complex showing enlargement of preputial sac.

11. Genitalia dissected and the organs separated, showing relationship of all organs.

Line near figure indicates $1 \mathrm{~mm}$. in length. Line at left of fig. 1 is also for figs. 7,8 , and 9 . Line at left of fig. 11 is also size for fig. 6 . 


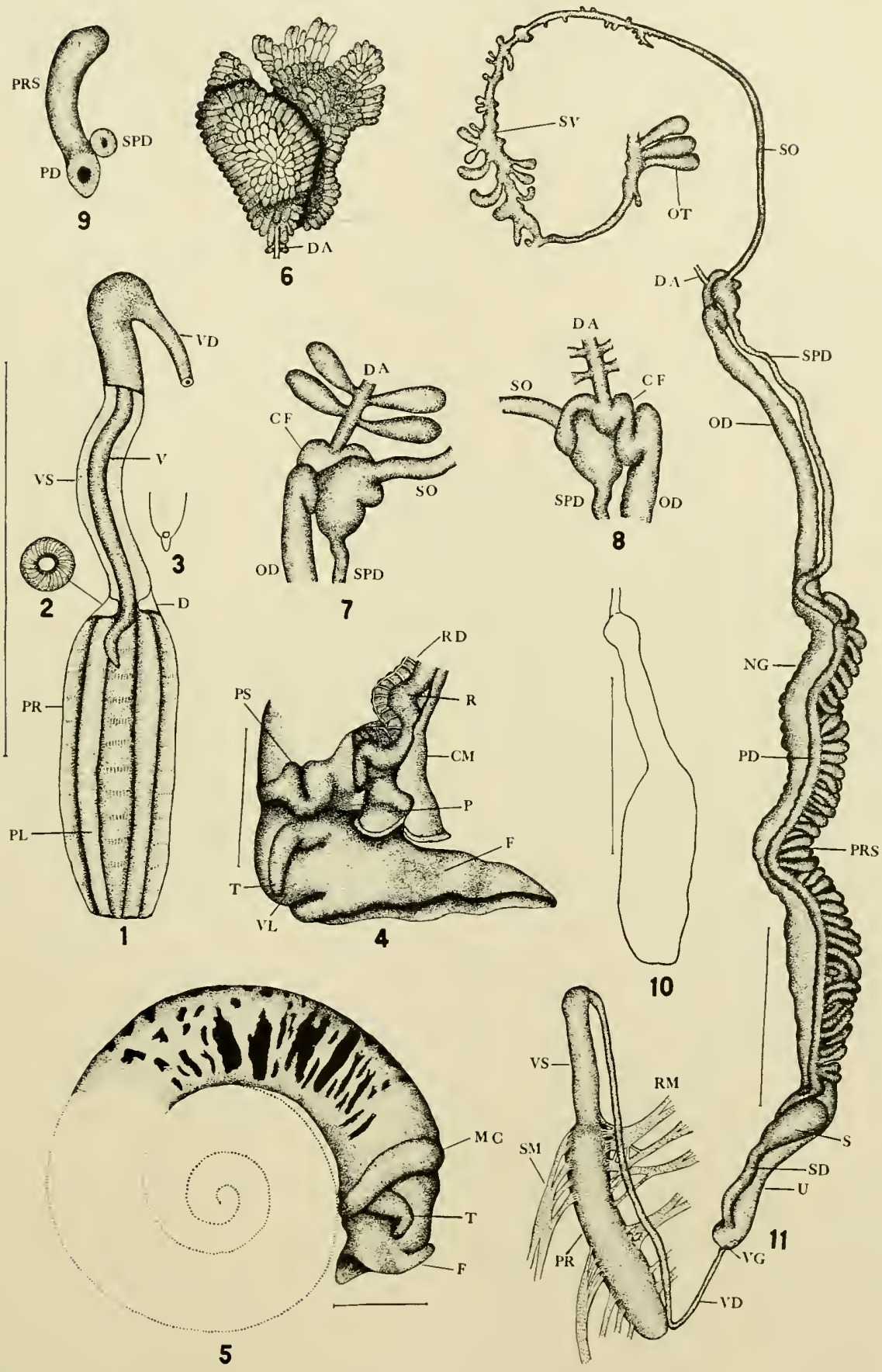

PLATE 12 


\section{PLATE 13}

\section{Tropicorbis}

1-3. Tropicorbis obstructus (Morelet). From New Orleans, La.; collected by Dr. E. C. Faust.

1. Genitalia dissected and organs separated.

2. Cross section of orotestis in non-gravid stage.

3. Cross section of ovotestis in gravid stage with ova in diverticula. Line at right indicates $0.5 \mathrm{~mm}$. in length.

4-10. Tropicorbis rïsei (Dunker). From Lares, Puerto Rico; from Dr. W. A. Hoffman.

4,5. Cross sections of prostate diverticula showing bending at end. Also presence of prostate duct distinct from sperm duct.

6. Penial complex, external riew.

7. Albumen gland from below showing duct (DA).

8. Vas deferens showing branching to form sperm duct and prostate duct (greatly enlarged).

9. Portion of genitalia dissected and organs separated. Organs as in fig. 1.

10. Head of animal showing pseudobranch and pneumostome as well as ridge over rectum.

Line near figure indicates $1 \mathrm{~mm}$. in length. Line at left of figs. 4 and 5 is for both figures. 
Illustrations of the Anatomy and of Shells

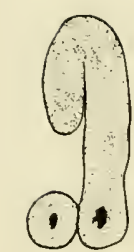

4

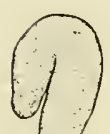

1. $\mathrm{PD}$

- ${ }_{\mathrm{SPD}}^{\mathrm{PD}}$

5
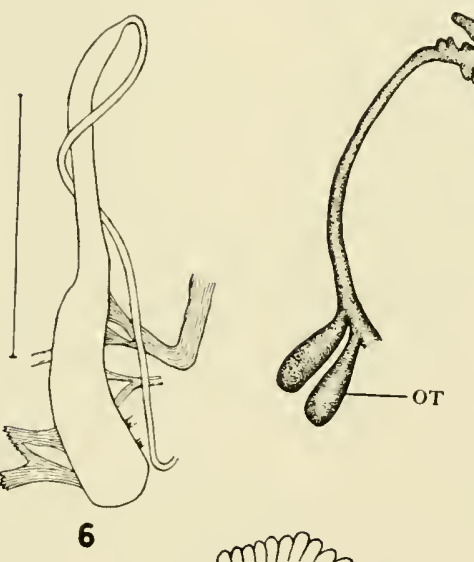
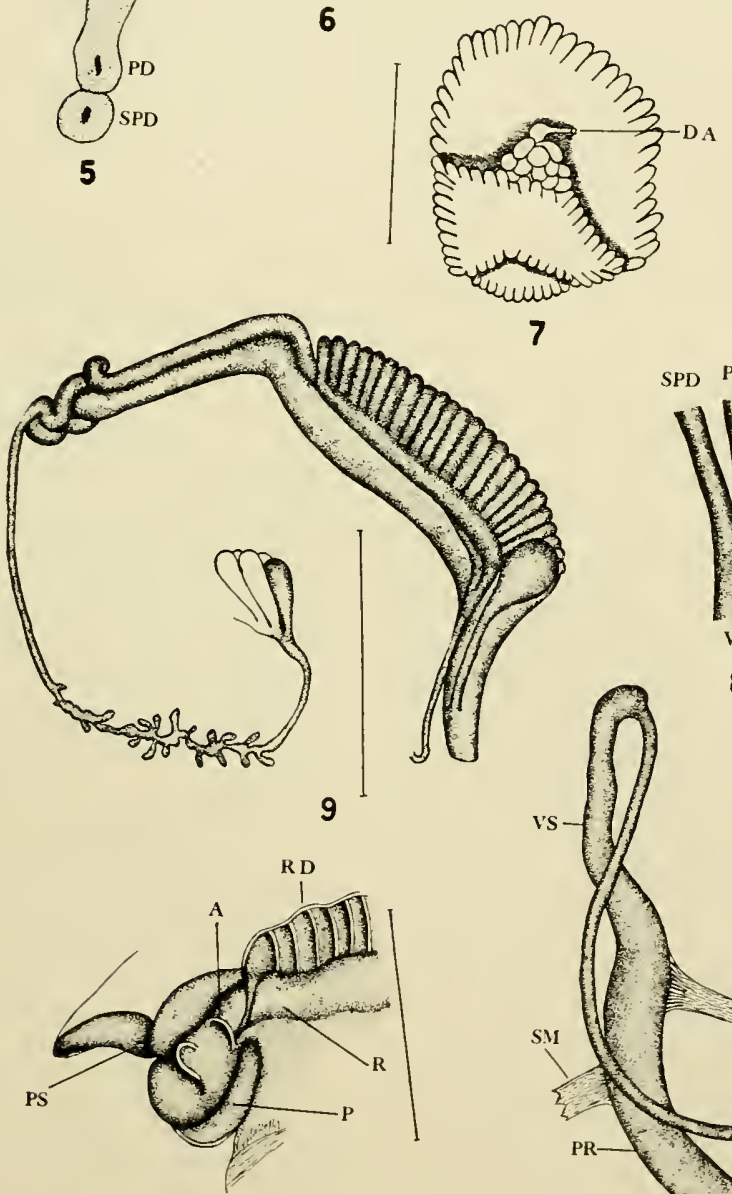

10

SPD PD
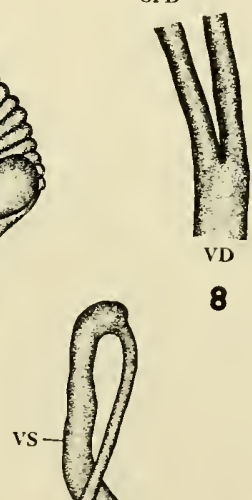
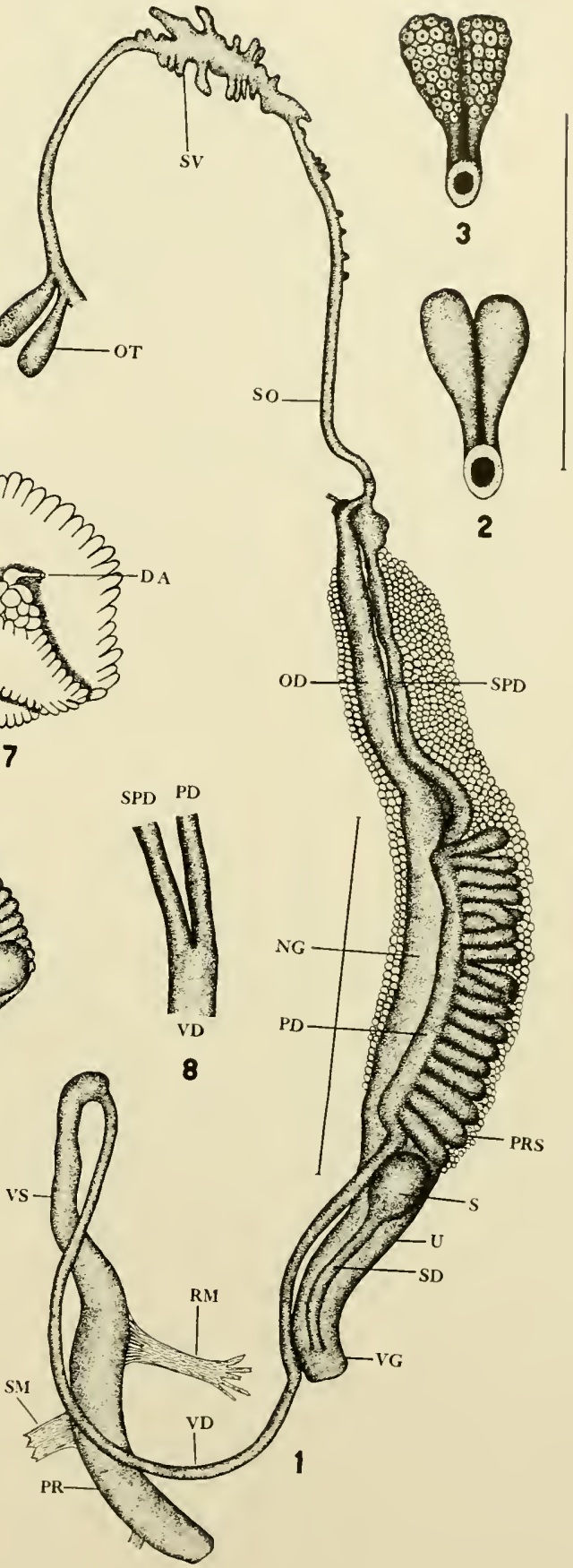

PLATE 13 
PLATE 14

\section{Gyraulus albus (Müller)}

From pond in Krolikania, a suburb of Warsaw, Poland; from A. Jankowski.

1. Penial complex sectioned to show verge, stylet, etc.

2. Penial complex, external riew.

3. Fore part of animal showing pseudobranch and pneumostome.

4. Fore part of animal showing pseudobranch, pneumostome, and renation of some of these organs.

5. Albumen gland from below.

6. Portion of genitalia showing attachments of albumen gland duct, oviduct, sperm duct, and general relationship of these and other organs.

7. Cienitalia dissected and organs separated.

8. Stylet at end of verge with sperm canal outlet at side of verge.

9. Section of prostate showing distinct canals for prostate and sperm duct. Three diverticula are shown.

10. Section through orotestis near front end.

11. Distal end of orotestis showing grouping of diverticula.

Line near figure indicates $1 \mathrm{~mm}$. in length. Line at lower right corner of plate is for figs. 5, 6, 7, 9, 10, and 11. Figure 8 line is one-sixth of $1 \mathrm{~mm}$. in length. 


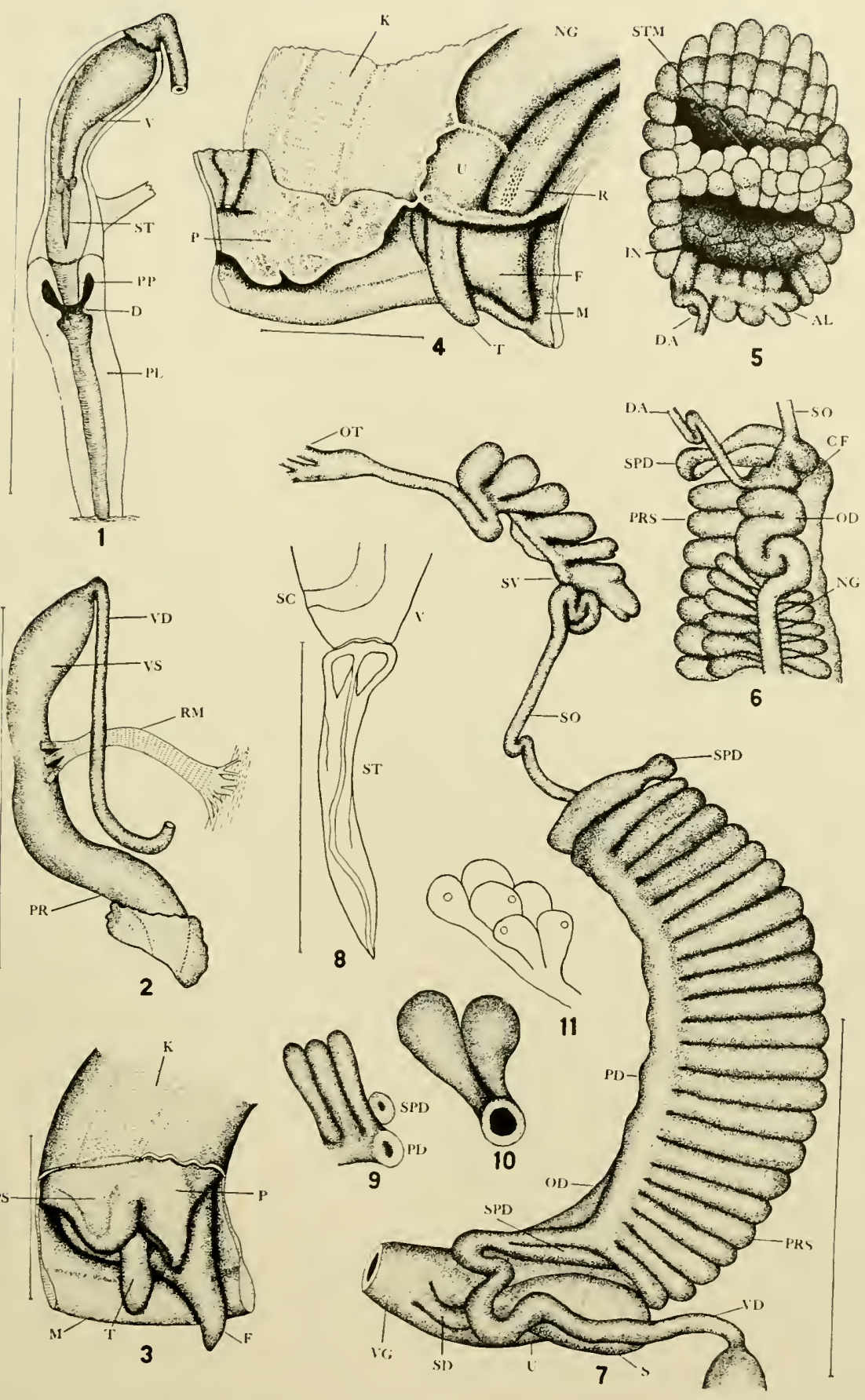

PLATE 14 


\section{PLATE 15}

\section{Gyraulus}

1-7. Gyraulus hirsutus (Gould). From Bass Creek, Lake Nipissing, Ontario, Canada; received from A. LaRocque.

1. Genitalia dissected and organs separated. A portion of the intestine is slown beneath the albumen gland.

2. Penial complex, external view.

3. Fore end of body showing pseudobranch, pneumostome, rectum, etc.

4. Distal end of genitulia showing connection of various ducts. From right side.

5. Same as fig. 4, from left side.

6. A single diverticulum of the prostate with duct separate from the sperm duct.

7. Two diverticulil of the orotestis.

8-10. Gyraulus vermicularis (Gould). From Stone Lake, Golden Gate Park, San Francisco, California; from Dr. G. D. Hanna.

8. Fore end of body showing pseudobranch.

9. Distal end of genitalia showing relationship of ducts.

10. Genitalia dissected and organs separated.

Line near figure indicates $1 \mathrm{~mm}$. in length. Line in upper left corner of plate is for figs. $4,5,6$, and 7 . 
Illustrations of the Anatomy and of Shells
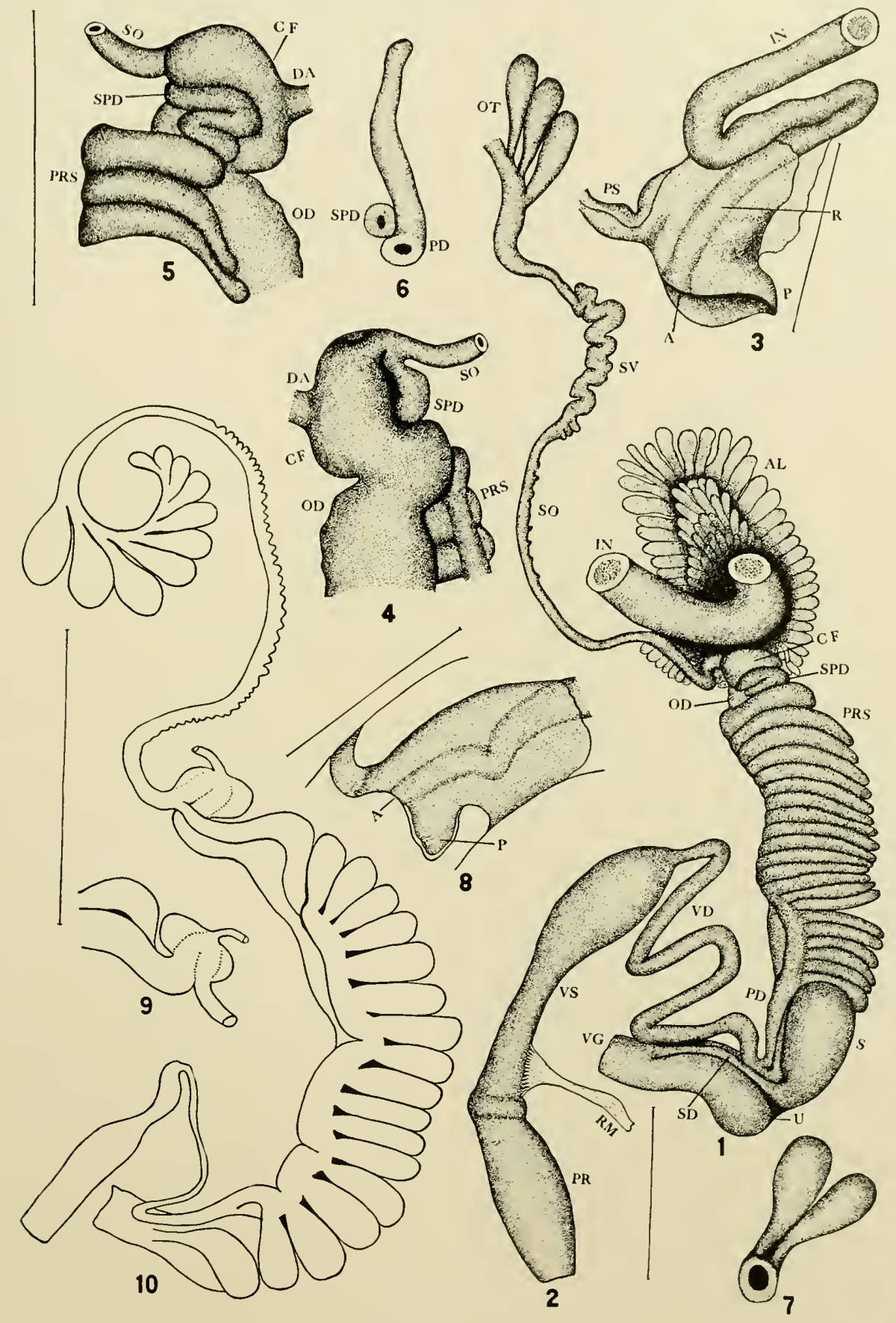

PLATE 15 
PLATE 16

\section{Gyraulus deflectus obliquus (DeKay)}

From Taylor Lake, Masham. Quebec. Canada; collected by A. LaRocque.

1. Penial complex in vertical section.

2. Penial complex of specimen with bulbous termination of vergic sac.

3. External view of penial complex showing relationship of parts. Also male opening behind tentacle.

4. Genitalia dissected and organs separated.

5. Section through portion of penial complex at junction of rergic sac and preputial sac to show thickened portion with papill:ı.

6. Stylet. Distal end of rerge shows sperm canal outlet at side.

7. Terminal diverticula of ovotestis, showing developing ora.

8. Terminal diverticula of orotestis from left side.

9. Section through diverticulit of orotestis.

10. Distal end of genitalia showing position of sperm duct, oviduct, albumen duct, ete.

11. Section of prostate near middle.

12. Section of prostate six diverticula from front end.

13. Body and foot of animal showing pseudobranch, ete.

14. Pseudobranch showing network of blood vessels.

15. Another form of pseudobranch.

Line near figure indicates $1 \mathrm{~mm}$. in length. Line at middle left of plite indicates size of figs. $5,6,7,8,9,11$, and 12 . 


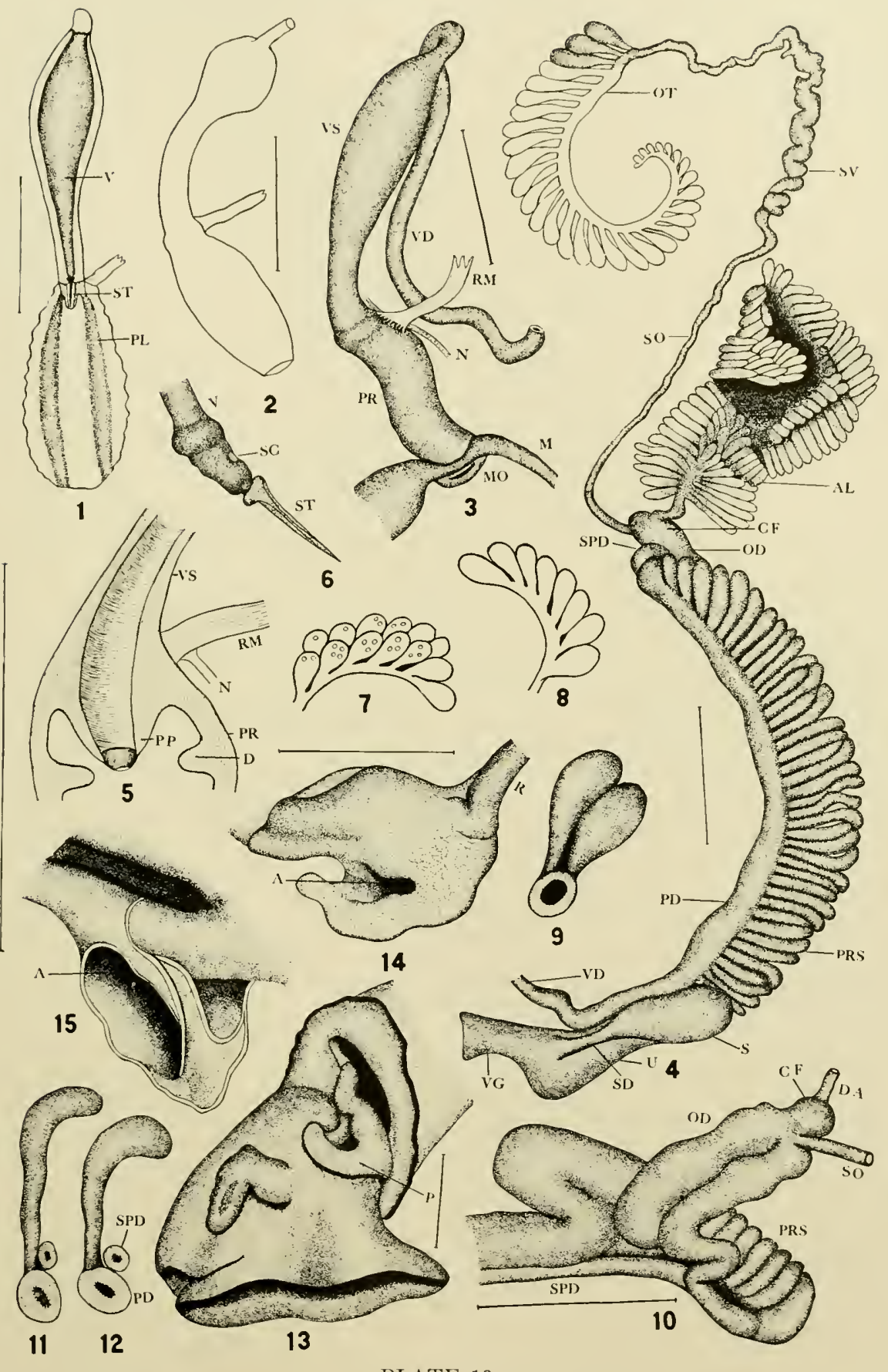

PLATE 16 


\section{PLATE 17}

\section{Gyraulus}

1-5. Gyraulus circumstriatus (Tryon). From Wainwright Park, near Mott Lake, Alberta, Canada; collected by Dr. Swales.

1. Genitalia dissected and organs separated. Outline. Penial complex in natural position.

2. Distal end of genitalia showing duct connections. From left side.

3. Pseudobranch and pneumostome.

4. Animal removed from shell showing position of several organs.

5. Two diverticula of ovotestis in gravid condition.

6-12. Gyraulus parvus (Say). From Winnebago Lake, neal Oshkosh, Wisconsin; collected by F. C. Baker.

6. Genitalia dissected and organs separated.

7. Distal end of genitalia, from left side.

8. Portion of fore end of animal showing pseudobranch, etc.

9. Albumen gland showing attachment of oviduct.

10. Three diverticula of prostate with prostate duct below and sperm duct at the side.

11. Two diverticula of orotestis.

12. Penial complex opened to show verge, stylet, papilla, etc.

Line near figure indicates $1 \mathrm{~mm}$. in length. Figures 5, 10, and 11 have same magnification as fig. 12. 
Illustrations of the Anatomy and of Shells

271

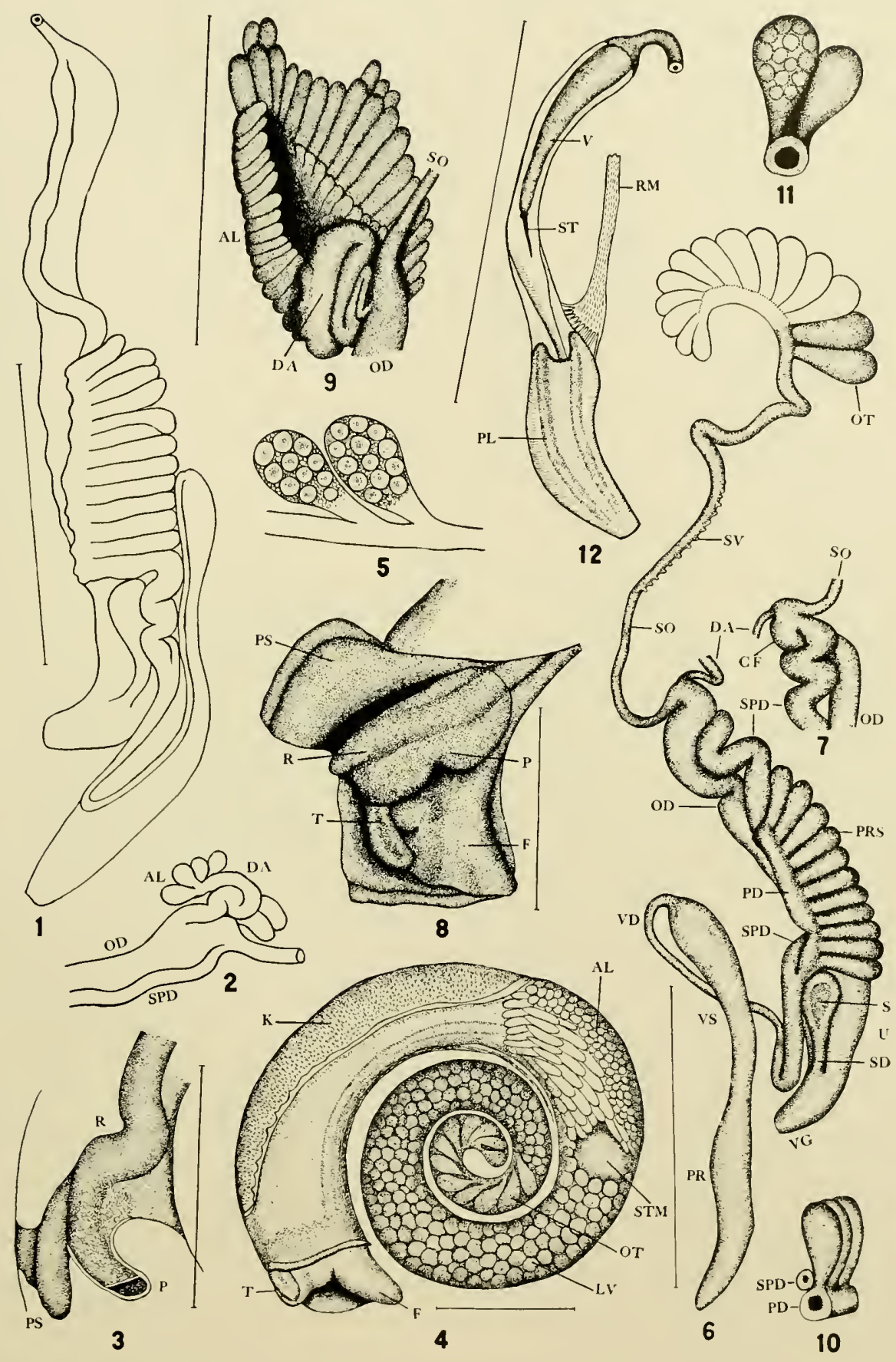

PLATE 17 


\section{PLATE 18}

\section{Gyraulus and Armiger}

1-5. Gyraulus similaris (F. C. Baker). From Smartweed Lake, near Tolland, Colorado; collected by Dr. Frank Smith.

1. Genitalia dissected and organs separated.

2. Distal end of genitalia showing arrangement of ducts.

3. Penial complex in section showing verge, stylet, and preputium.

4. Stylet. Outlet of sperm canal is shown at side of verge.

5. Head and foot of animal showing psendobranch.

6-11. Armiger crista (Linn.). From pond in Krolikarnia, a suburb of Warsaw, Poland; collected by A. Jankowski.

6. Head showing form of pseudobranch.

7. Genitalia dissected and organs separated.

8. Albumen gland from side.

9. Penial complex in section showing verge without stylet.

10. Fnd of verge showing absence of stylet and presence of a fleshy papilla. Sperm canal with outlet in center of verge.

11. End of verge from side showing relationship of papilla and canal.

Line near figure nsually indicates $1 \mathrm{~mm}$. in length. Line at left of fig. 4 measures one-fifth of $1 \mathrm{~mm}$. Line in center of fig. 7 is also for fig. S. Same line equals $0.5 \mathrm{~nm}$. for fig. 9 .

Fiqures 10 and 11 are much enlargerl. 


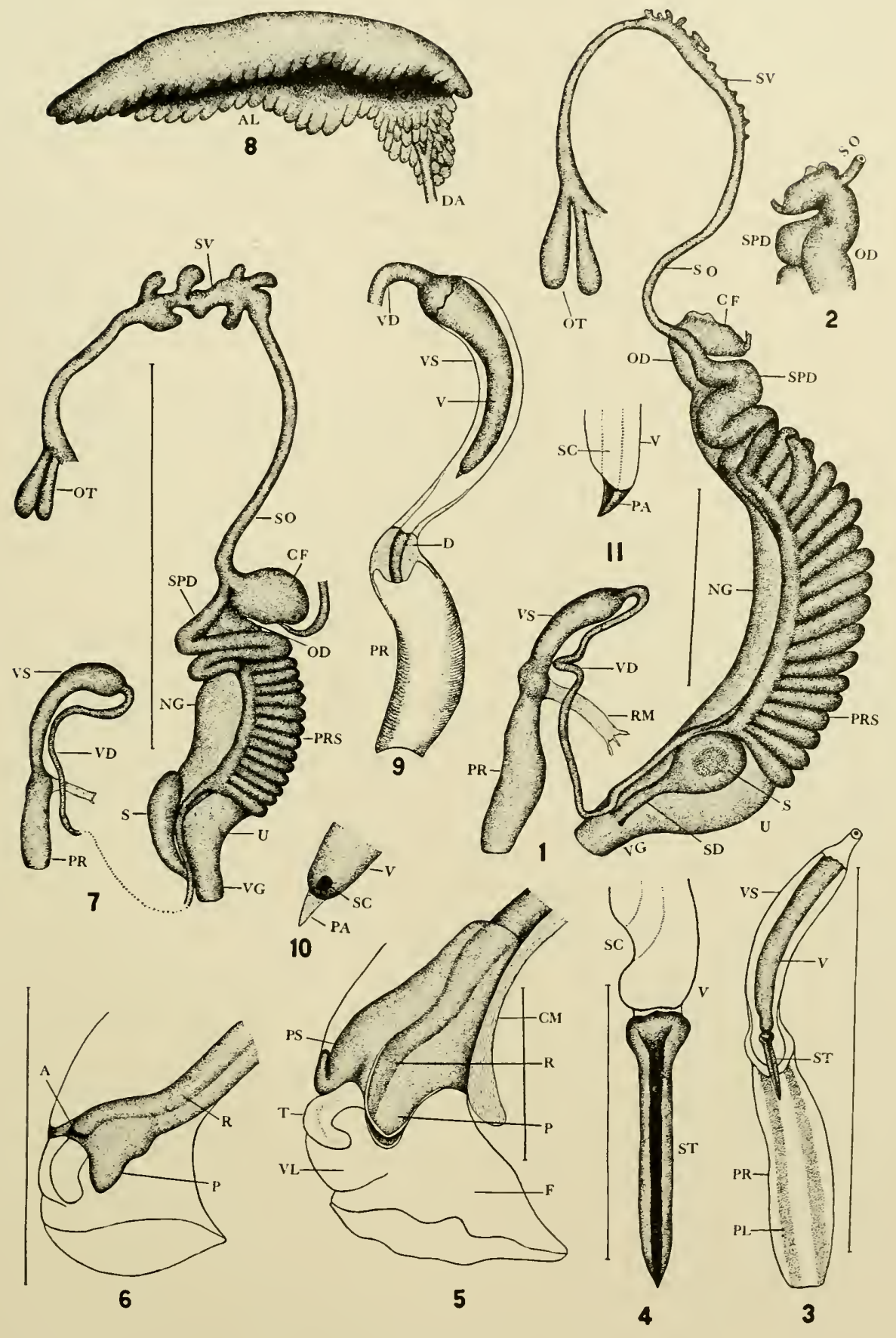

PLATE 18 
PLATE 19

\section{Gyraulus}

1-3. Gyraulus convexiusculus (Hutton). From Calcutta, India; from Dr. B. Prashad.

1. Cross section of one diverticulum of prostate showing separate canals for prostate duct and sperm duct.

2. Genitalia dissected and organs separated.

3. Pseudobranch and pneumostome.

4-9. Gyraulus latestomus F. C. Baker. From Cedar Lake, Algonquin Park, Ontario, Canada; collected by A. LaRocque.

4. Distal end of genitalia from left side.

5. Albumen gland from below, showing loop of intestine.

6. Penial complex.

7. Cross section of one diverticulum of prostate.

S. Anterior end of body showing pseudobranch and pneumostome.

9. Genitalia dissected and the organs sepramed.

Line near figure indicates $1 \mathrm{~mm}$. in length. Figures 1 and 7 are greatly enlarged. 


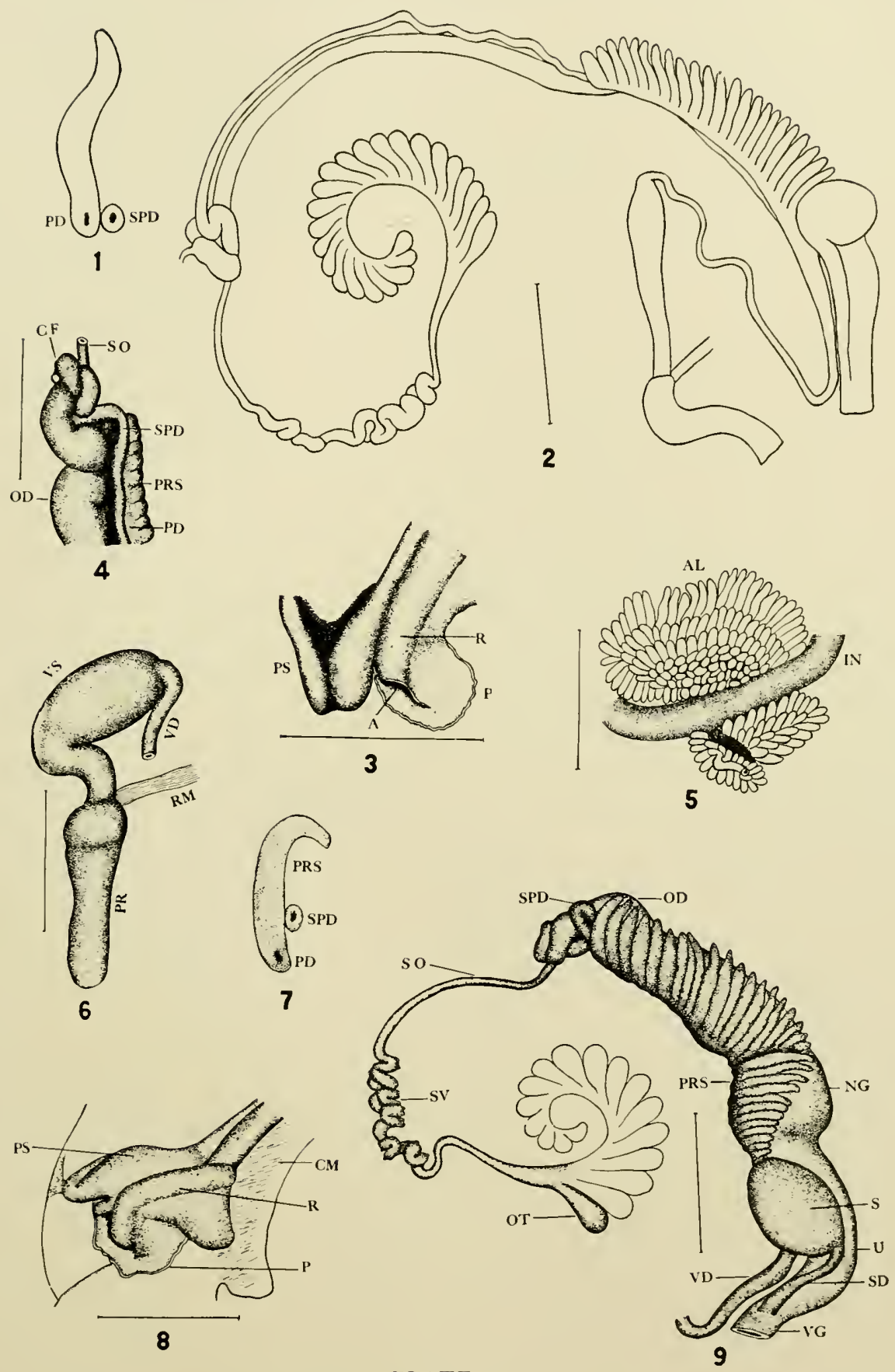

PLATE 19 


\section{PLATE 20}

\section{Planorbarius corncus (Limn.).}

From branch of Wista River at Morysinek, $5 \mathrm{~km}$, south of Warsaw, Poland; collected by A. Jankowski.

1. Penial gland and appendages in extended position.

2. Section through appendage at $\mathrm{C}$ in fig. 1.

3. One diverticulum of orotestis with ripe orum (greatly enlarged).

4. Cross section through prostate, nterus, and nidamental gland.

5. Cross section of ovotest is in gravid specimen.

6. Vergic sac opened to show verge and canal in gland.

7. Retractor muscles in typicul specimen.

s. End of verge showing penial appendage.

9. Albumen gland.

10. Portion of head showing psendobranch, pnemostome, and rectum with ridge.

11. Penial complex opened to show position of penial gland, verge, pilasters, etc. Penial appendage is retracted.

12. Penial complex from outside showing muscles.

13. Cienitalia dissected and organs separated, showing particulary the form of prostate and its junction with the vas deferens and sperm duct.

Line near figure indicates $1 \mathrm{~mm}$. in length. Line at right of fig. 1 is also for fig. 2. Line at left of fig. 6 represents $0.5 \mathrm{~mm}$. in length. 
Illustrations of the Anatomy and of Shells

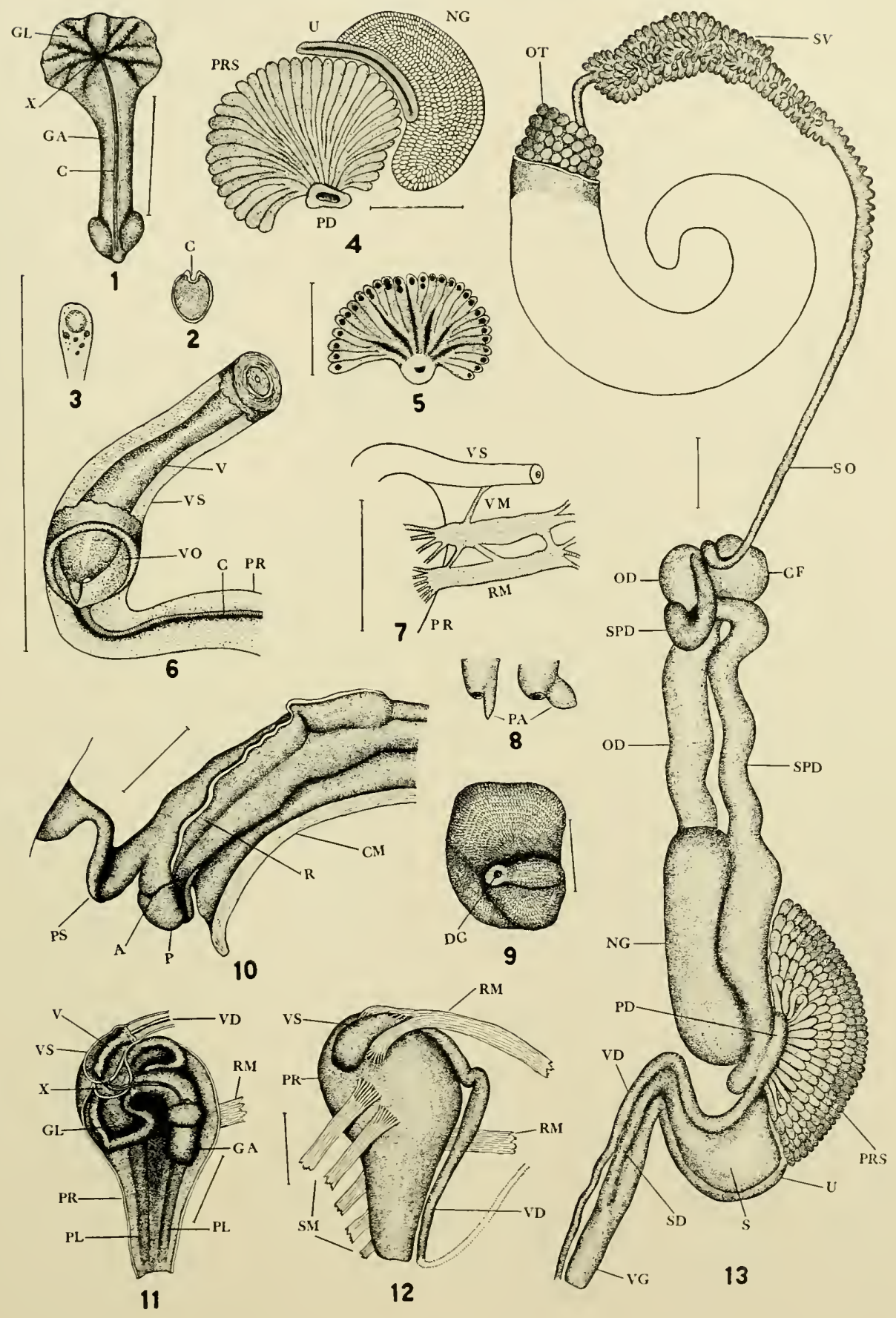

PLATE 20 


\section{PLATE 21}

\section{Indoplanorbis exustus (Deshayes)}

From Hsipaw, North Shan State, Burma, India; collected by Dr. B. N. Chopra and Dr. H. S. Rao; contributed by Dr. B. Prashart.

1. Penial complex in natural position.

2. Fore part of animal showing pseudobranch and pneumostome, with preputium protruded from male opening and lying on the neck of the animal.

3. Genitalia dissected and organs separated.

4. Pleated pseudobranch and pneumostome.

5. Unter side of preputium everted through male opening in the neck of the animal.

6. Pseulobranch from side showing branched or lleated condition.

7. ('ross section of orotestis showing sereral gravid diverticula.

8. Cross section of prostate.

9. Two diverticula of prostate.

10. Portion of prostate showing relationship of ras deferens, sperm duct, and diverticula of gland.

Line near figure indicates $1 \mathrm{~mm}$. in length. Figures 9 and 10 are greatly magnified. Figures 1, 2, 3, and 10 were published in Jour. Morph., LV, plates 1 and 2. 
Illustrations of the Anatomy and of Shells

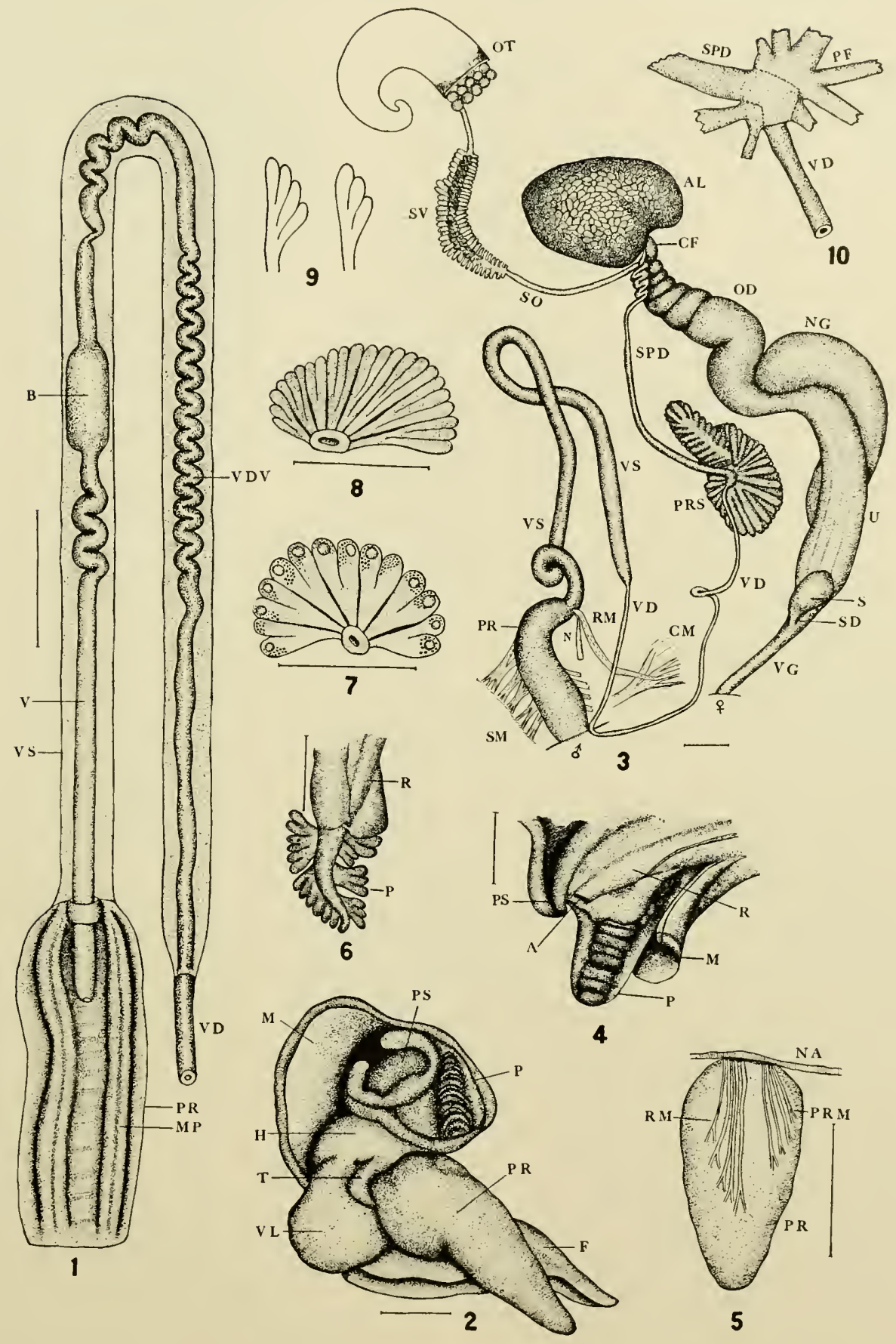

PLATE 21 


\section{PLATE 22}

\section{Indoplanorbis and Helisoma}

5-9. Indoplanorbis exustus (Deshayes). Continued from plate 21.

5. Retractor muscle of verge showing branching to vergic sac. Also nerve connection.

6. Cross section of preputium in extended condition as shown in fig. 7 .

7. Penial complex of specimen in breeding condition with preputimm extended from male opening in neck. Compare with fig. 1 on plate 21.

S. Section of vergic suc through bulbous termination of verge.

9. Section of rergic sic through rerge.

Line near figure inticates $1 \mathrm{~mm}$. in length. Figure 5 is enlarged. Figure 6 has sime magnification as fig. 7 . These figures were published in Jour. Morph.

1. Helisoma anceps latchfordi (Pilsbry).

1. Verge. Also enlarged portion of ras deferens (epiphallus).

2-4, 11. Hetisoma anceps perearinatum (Walker).

2-4. Variation in form of muscles and in position of rerge in preputium. Greatly enlarged.

11. Penial gland with cup turned back to show folds in inner cup.

10, 12. Helisoma anceps: (Menke).

10. Fnd of verge showing papilla and sperm canal outlet.

12. Prostate showing attachment of prostate duct to sperm duet.

Line near figure indicates $1 \mathrm{~mm}$, in length 

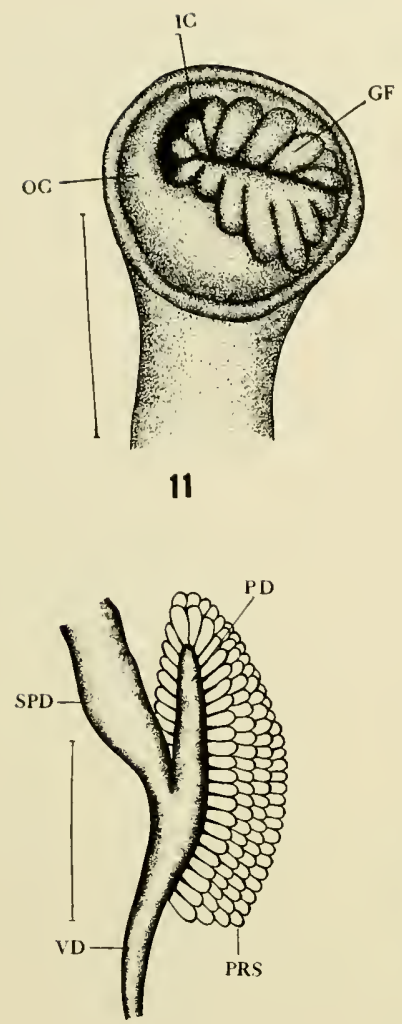

12
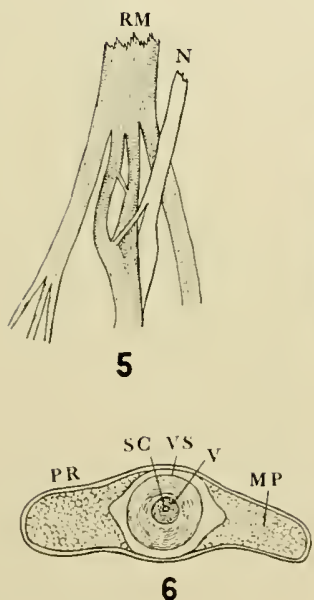

6

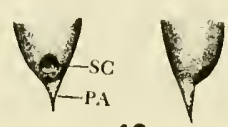

10
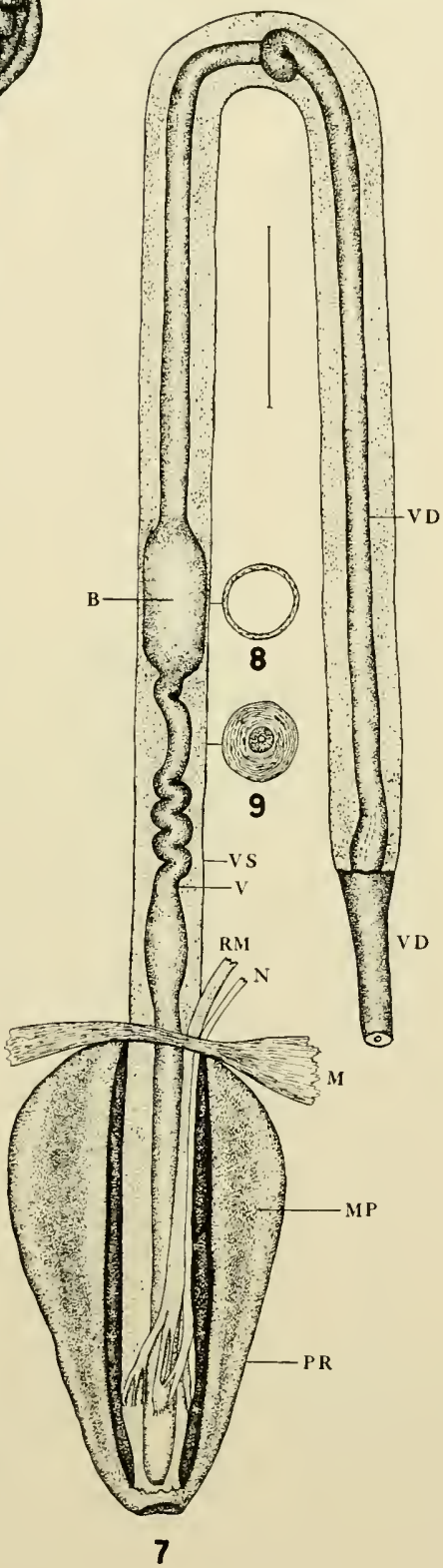

7
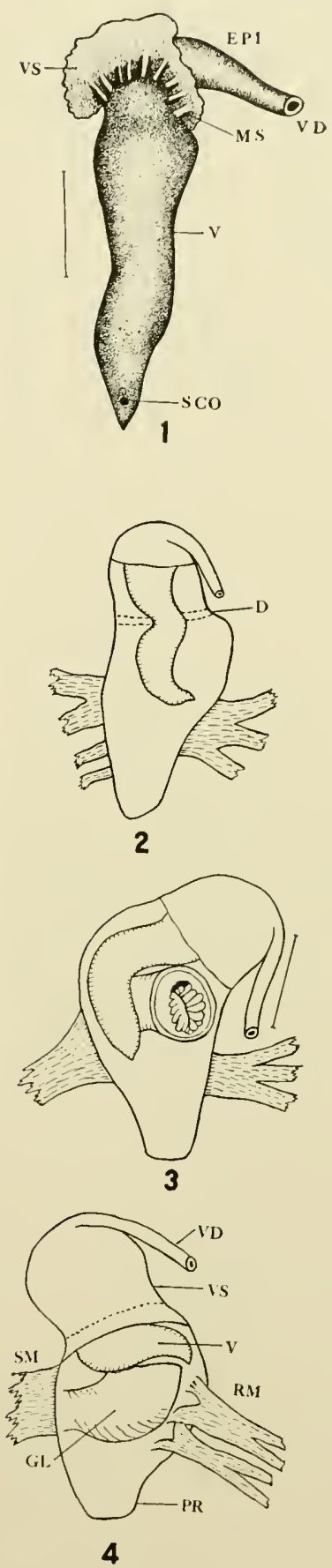

PLATE 22 


\section{PLATE 23}

\section{Helisoma anceps (Menke)}

1-4, 7-11. Helisoma aneeps (Menke). From Gillespies Pond, Collinsville, Connecticut; collected by F. C. Baker and Leslie Brewer.

1. Cross section of penial gland showing cup, folds, and duct.

2. Section of penial complex to show position of gland in preputium.

3. Exterior view of penial complex showing short duct on outside of preputium.

4. Region of the neck showing pseudobranch, pnenmostome, and rectum.

7. Albumen gland from below.

8. Penial complex of specimen in which gland in preputium has been pushed upward.

9. Cross section of prostate showing multiple form of diverticula.

10. Cross section of orotestis.

11. Genitalia dissected and organs separated.

5,6. Helisoma anceps latchfordi (Pilsbry). From Meach Lake, Quebec, Canada; collected by A. La Rocque.

5. Diaphragm in preputial sac view from below.

6. Section through diaphragm showing entrance of gland duct into rergic sac eavity just above diaphragm.

Line near figure indicates $1 \mathrm{~mm}$. in length 

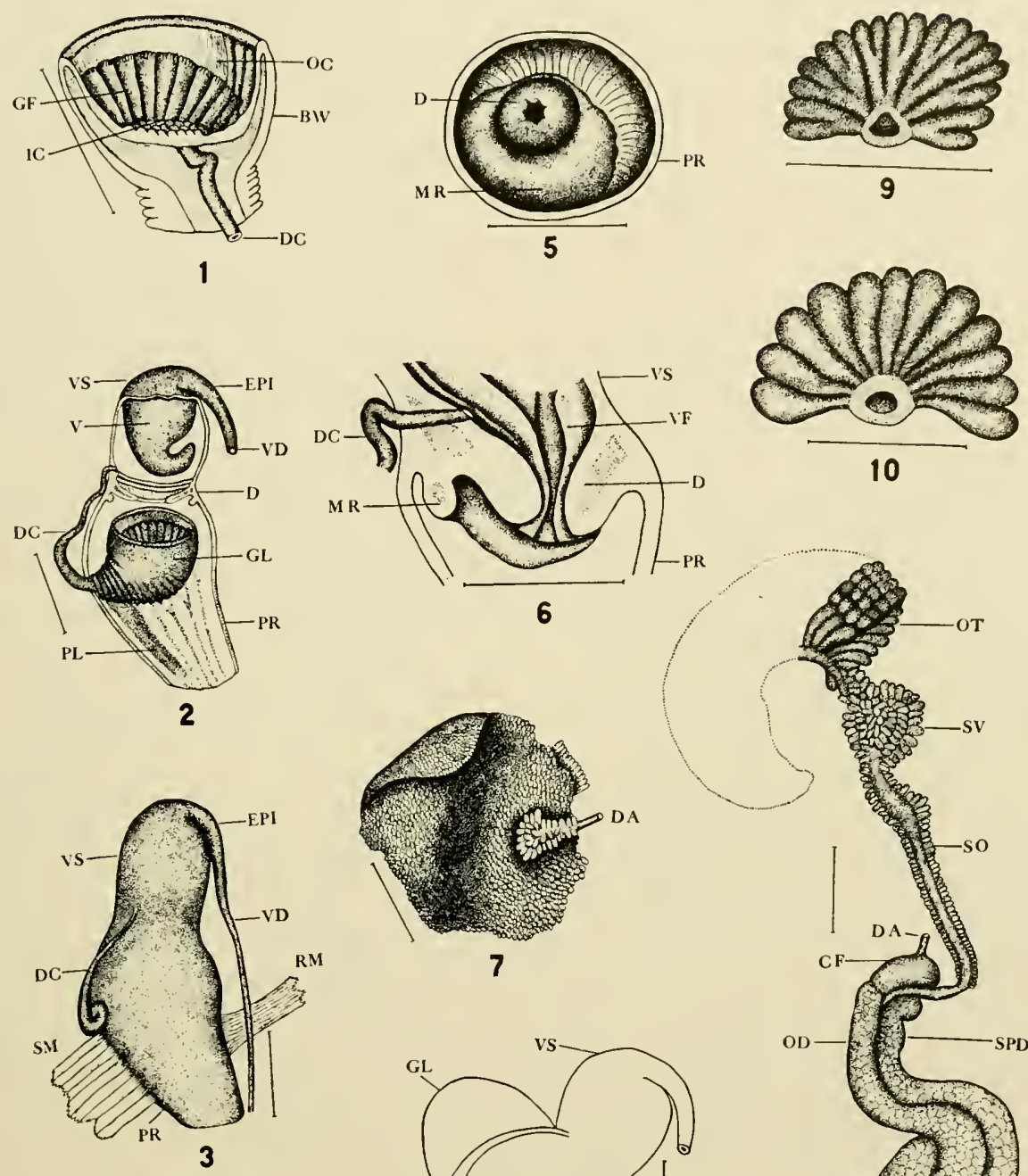

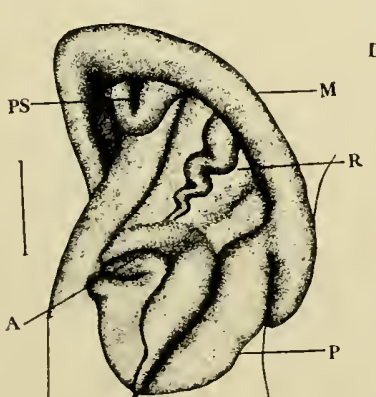

4
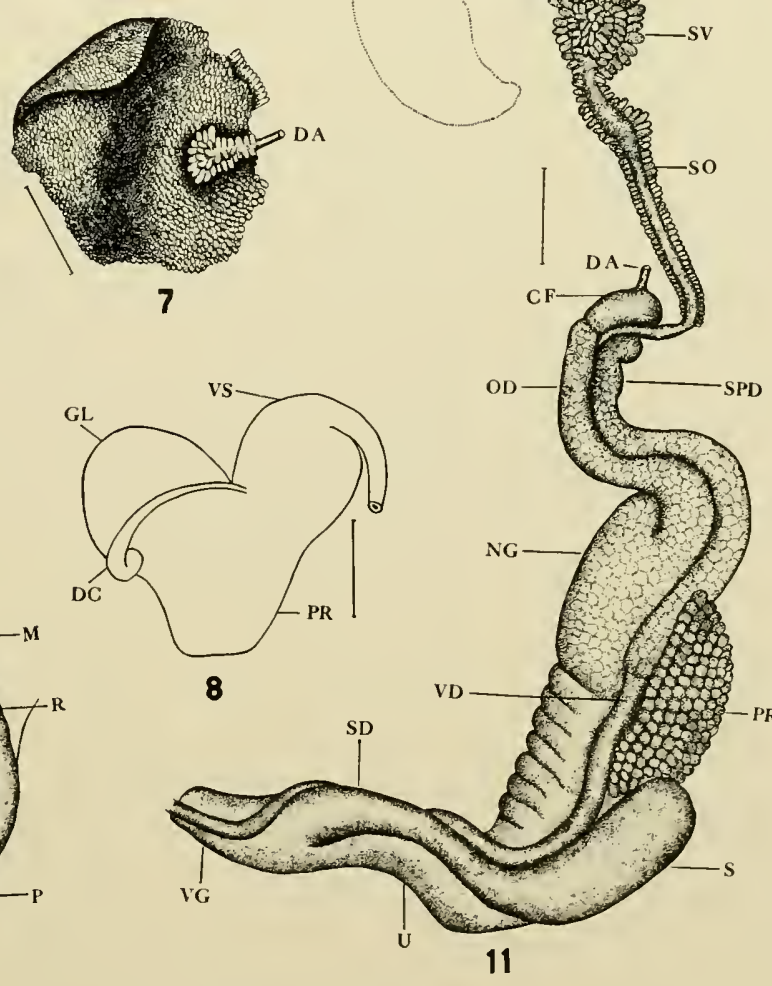

PLATE 23 


\section{PLATE 24}

\section{Helisoma trivolvis (Say)}

Collected from Oncida Lake, New York, by F. C. Baker, except where otherwise stated.

1. Penial complex. Specimen with portion of preputium containing gland pushed upward. Pool near Green Lake, Wisconsin.

2. Penial complex in vertical section. Specimen with preputium pushed upward. Illinois River, near Peoria, Illinois.

3. Penial complex. Young specimen with $3 \frac{1}{2}$ whorls. Devils Lake, Wisconsin.

4. Section through penial gland showing folds in cup.

5. Penial complex in immature specimen. Pond near Sturgeon Bay, Wisconsin.

6. Side view of albumen gland.

7. Albumen gland from below.

S. Section through penial gland in specimen in normal, non-breeding condition.

9. Section through ovotest is near anterior end.

10. Section through penial complex in region of diaphragm.

11. Extemal view of penial complex showing duct uncoiled and stretched out, indicating great length.

12. Region of neck showing pseudobranch, pneumostome, rectum, ete.

13. Section through prostate and uterus near middle of gland.

14. Penial gland somewhat contracted at cup end.

15. Genitalia dissected and organs separated.

Line near figure indicates $1 \mathrm{~mm}$, in length 

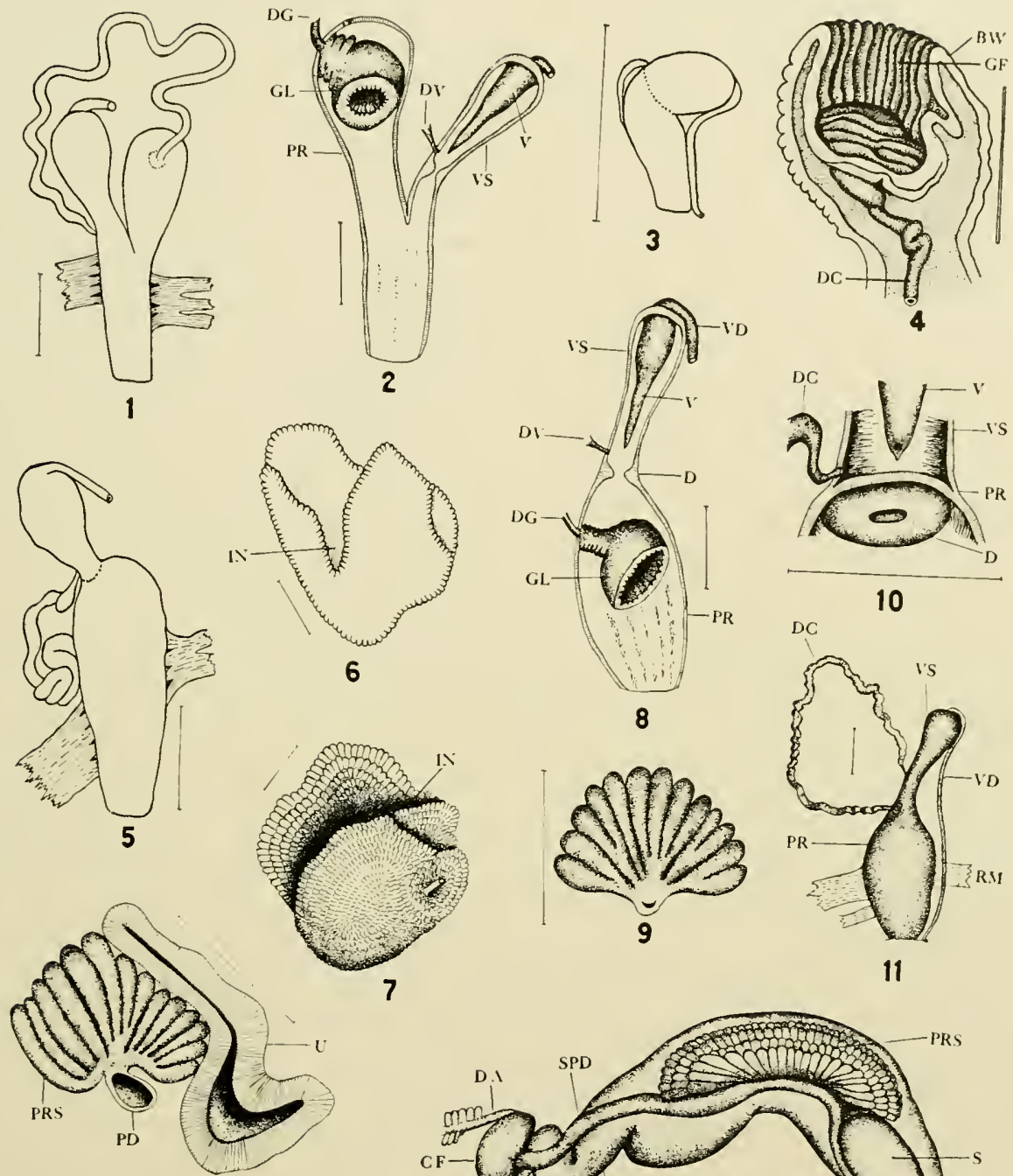

13

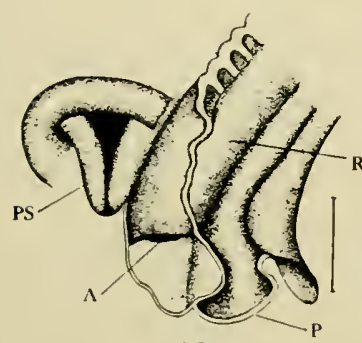

12
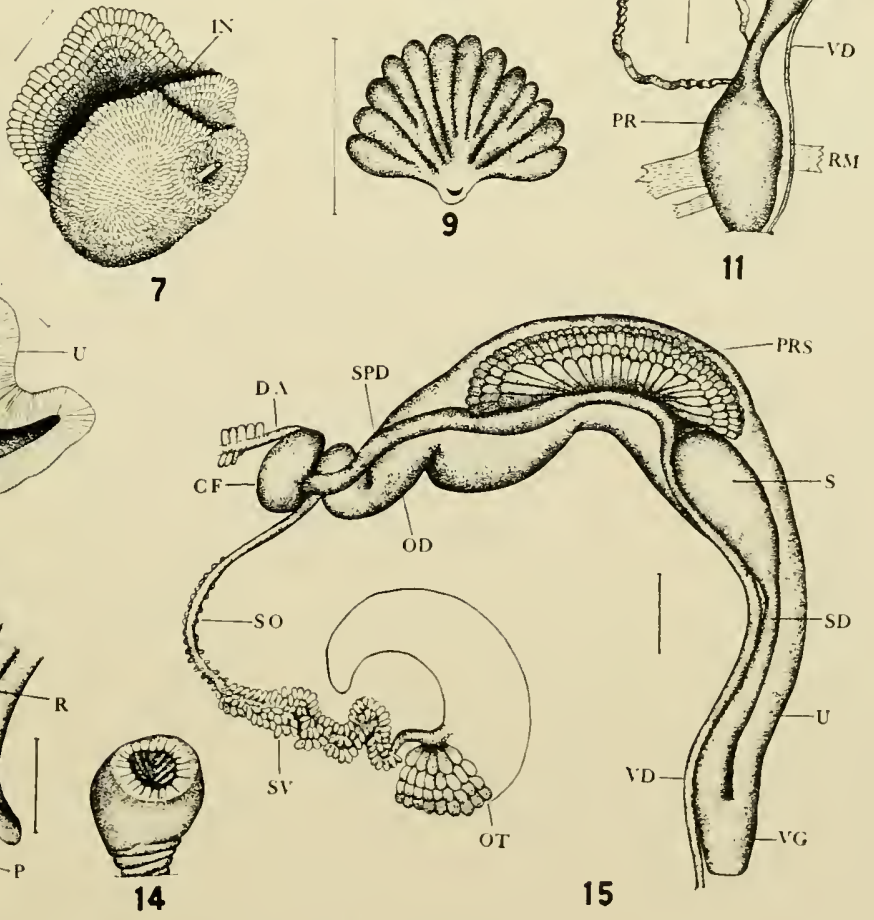

PLATE 24 


\section{PLA'TE 25}

\section{Helisoma pilsbryi (F. C. Baker)}

1-7. Helisoma pilsbryi (F. C. Baker). From Chetek Lake, Barron County, Wisconsin; collected by F. C. Baker.

1. Penial complex with vergic sac drawn to side of preputium.

2. Cross section of penial gland.

3. Pseudobranch and pneumostome.

4. Outline of genitalia with organs separated.

5. Penial complex from outside, in normal position.

6. Penial complex of specimen with preputium pushed upward.

7. Penial complex showing great length of penial gland duct.

8-13. Helisoma pilsbryi infracarinatum F. C. Baker. Unless otherwise stated specimens are from Basswood River Rapids, Ontario, Canada; collected by A. R. Cahn.

8. Penial complex of specimen with large preputium. Fron Rideau River Rapids, Ottawa, Canada; collected by A. LaRocque.

9. Penial complex with preputium pushed upward, showing length of penial gland duct.

10. Penial complex of imnature specimen. From Bamiji Lake, Ontario, Canada; collected by Dr. A. R. Cahn.

11. Pseudobranch and adjacent organs.

12. Section through prostate and uterus.

13. Outline of genitalia dissected and organs separated.

Line near figure indicates $1 \mathrm{~mm}$. in length 
Illustrations of the Anatomy and of Shells
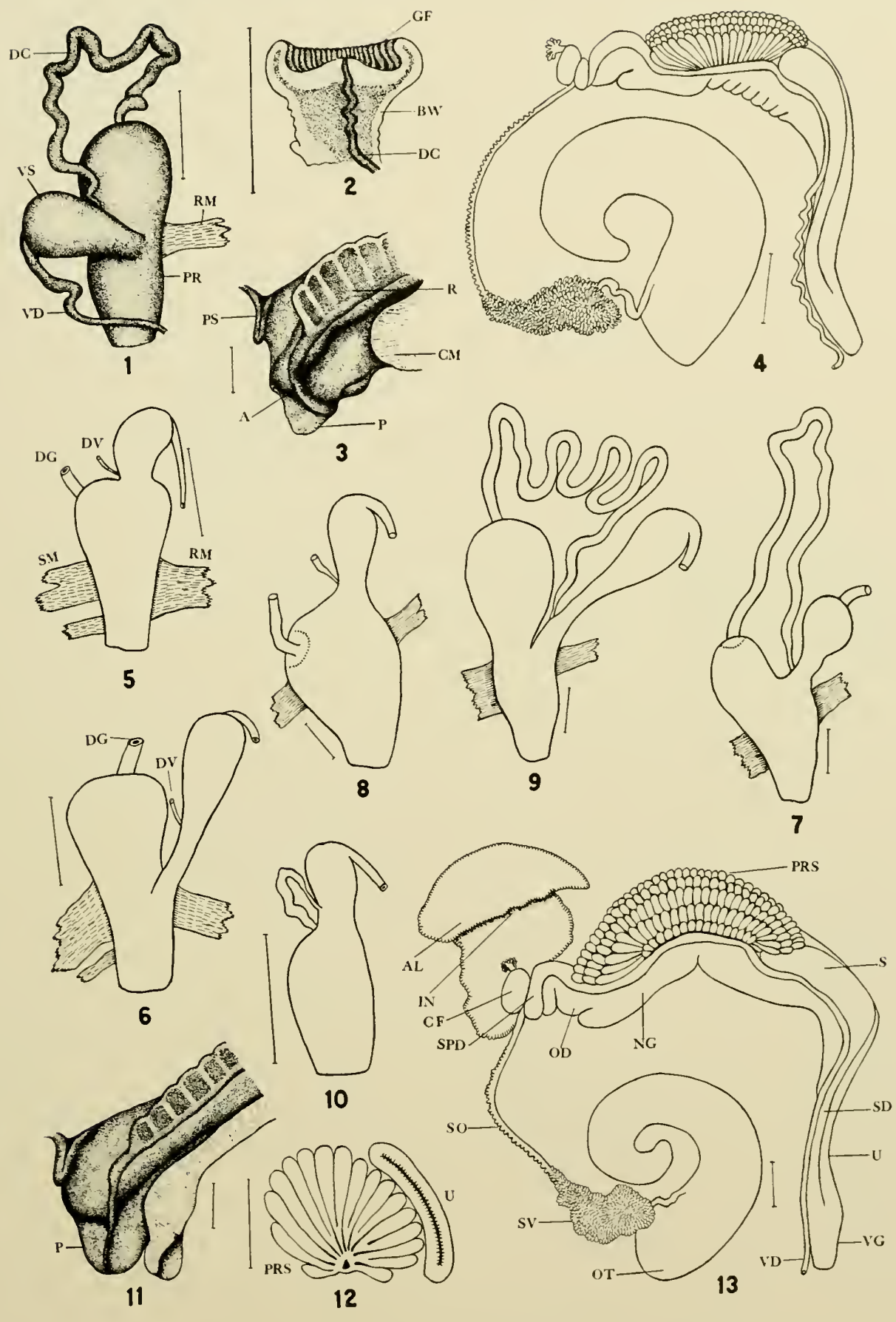

PLATE 25 


\section{PLATE 26}

\section{Helisoma}

1-5. Helisoma horni (Tryon). From Paul Lake, British Columbia; collected by Prof. D. S. Rawson.

1. Penial complex in breeding condition, the preputium pushed upward.

2. Outline of penial gland.

3. Outline of genitalia dissected and organs separated.

4. Cross section through oviduct, sperm duct, aud nidamental gland.

5. Cross section throngh prostate and oviduct, near middle of gland.

6-13. Helisoma truncatum (Miles). From Winnebago Lake, near Oshkosh, Wisconsin; collected by F. C. Baker.

6. Penial complex with penial gland duct in normal position coiled on surface of preputium.

7. Penial complex with penial gland duet pulled out to show great length.

8. Cross section of ovotestis near anterior end.

9. Cross section of penial gland.

10. Cross section of prostate and oviduct near anterior end.

11. Head showing position of pseudobranch, pneumostome, and rectum.

12. Penial complex with penial gland duct sprearl out. Preputium is partly pushed питаrd.

13. Genitalia dissected and organs separated.

Line near figure indieates $1 \mathrm{~mm}$. in length 
Illustrations of the Anatomy and of Shells
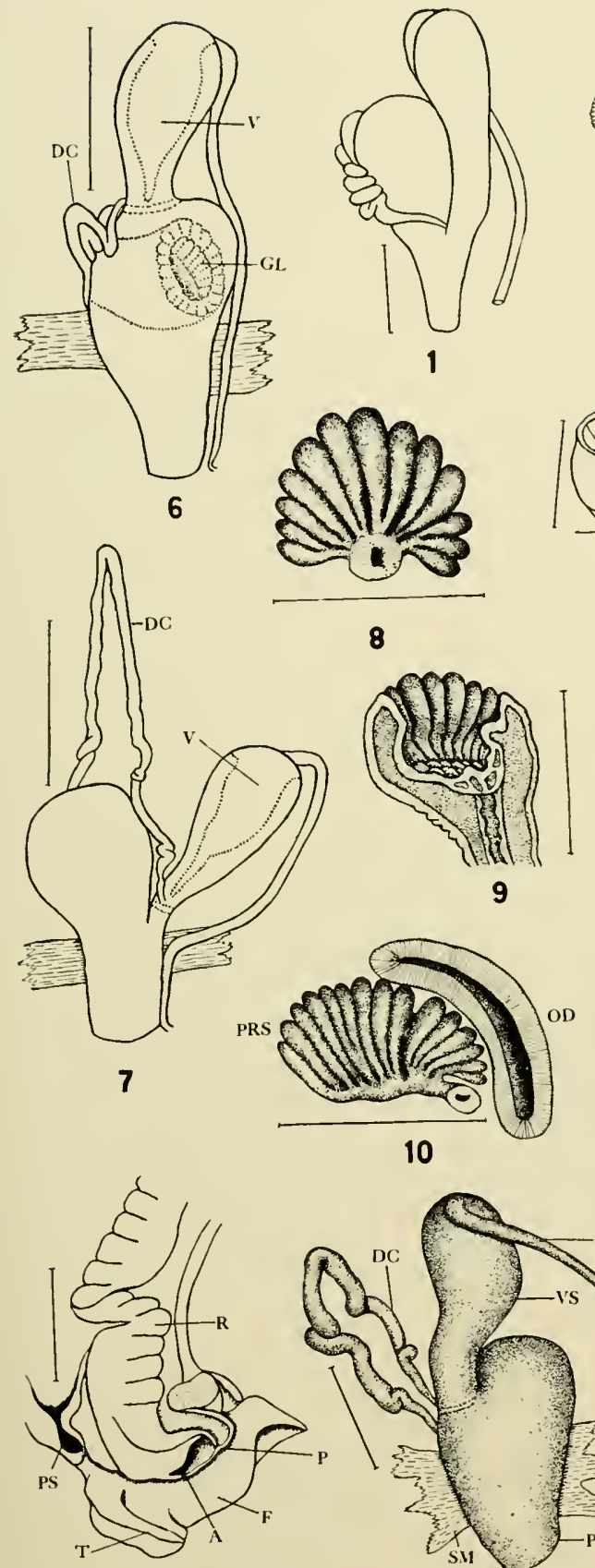

11

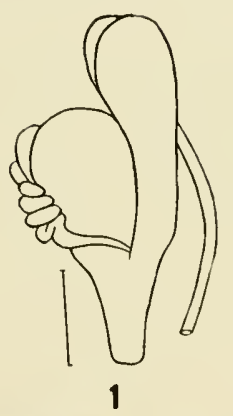

的

8
2
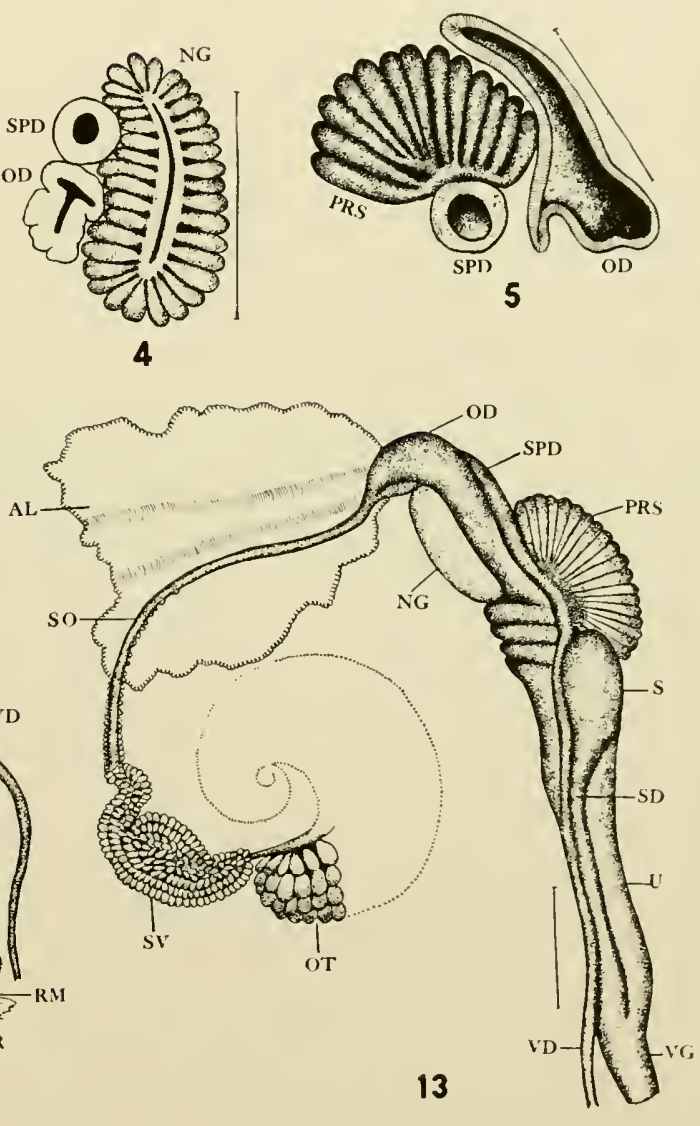


\section{PLATE 27}

\section{Helisoma campanulatum (Say)}

From Oneida Lake, New York, near Brewerton; collected by F. C. Baker.

1. Section through penial gland.

2. Albumen gland from below.

3. Section through diaphragm showing relationship of penial gland duct to vergic sac.

4. Section through orotestis near anterior end.

5-7. Penial complex of Helisoma campanulatum smithi (F. C. Baker), from Douglas Lake, Michigan, showing rariation in form, especially the preputium.

8-14. If lisoma campanulatum canadense F. C. Baker. From Sturgeon Lake, Ontario, Canada; collected by Dr. A. R. Cahn.

8. Penial complex.

9. Penial complex showing penial gland duct coiled between preputium and vergic sac. Also variation in muscles.

10. Section of penial complex showing relationship of penial gland to verge.

11. Penial complex with penial gland duct uncoiled to show length.

12. Section through prostate near middle of gland.

13. Pseudobranch, pneumostome, and rectum.

14. Genitalia dissected and organs separated.

Line near figure indicates $1 \mathrm{~mm}$. in length 
Illustrations of the Anatomy and of Shells
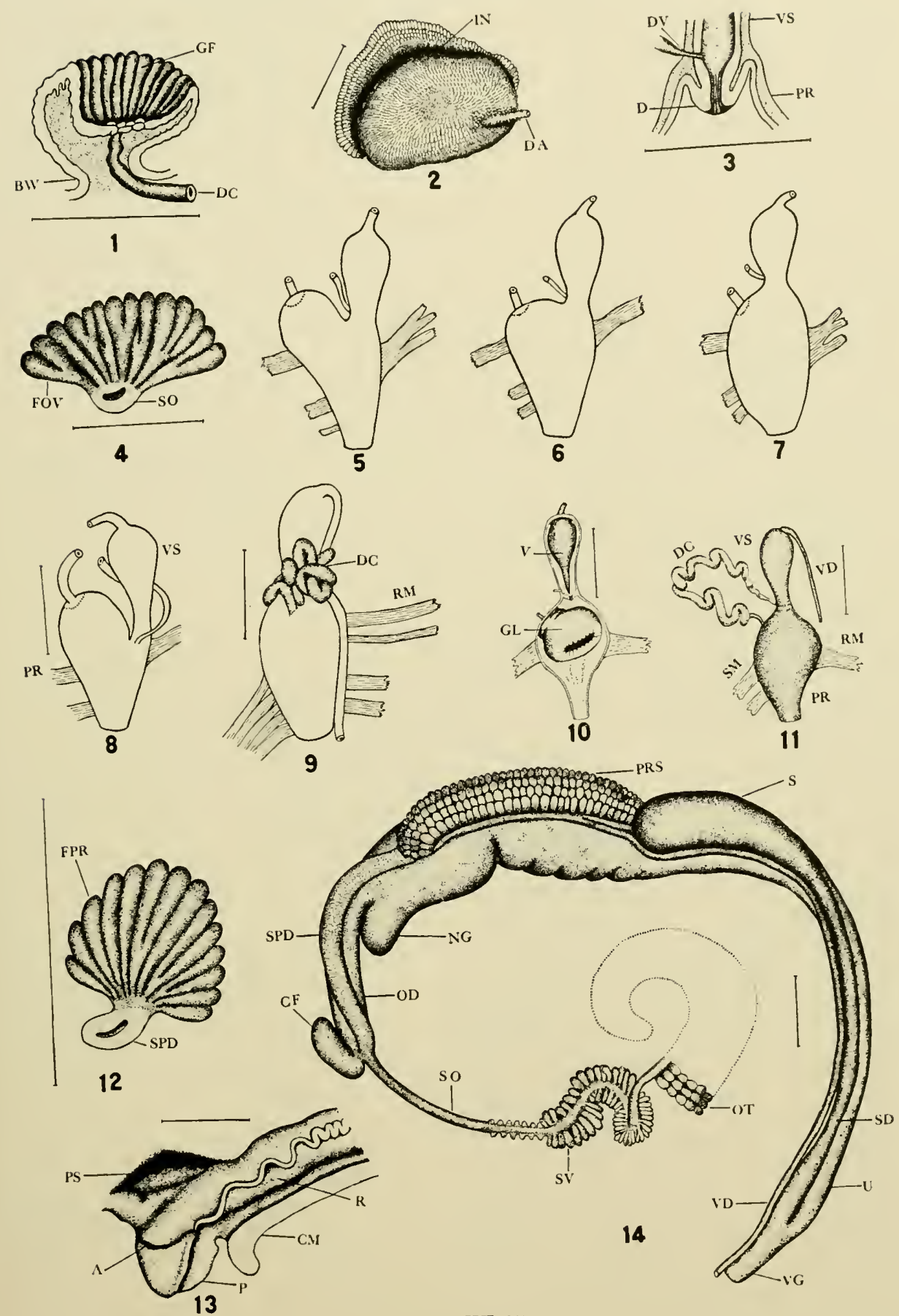

PLATE 27 
PLATE 28

\section{Helisoma}

1-5. Helisoma oregonense (Tryon). From Tooele Co., Utah; collected by J. Henderson.

1. Penial complex showing long penial gland duct.

2. Genitalia dissected and organs separated.

3. Cross section of prostate near middle of gland.

4. Penial gland viewed from above.

5. Section through penial gland.

6-14. Helisoma scalare (Jay). From Lake Butler, Florida; receired from Dr. E. A. Andrews.

6. Entrunce of penial gland duct into vergic sac.

7. Section through penial gland.

8. Psendobranch and pneumostome.

9. Penial complex with preputium pushed upward.

10. Penial complex in normal position, the penial gland duct extended.

11. Penial complex in section to show relationship of organs.

12. Section through prostate near middle.

13. Section through orotestis near anterior end.

14. Genitalia dissected and organs separated.

Line near figure indicates $1 \mathrm{~mm}$. in length 
Illustrations of the Anatomy and of Shells
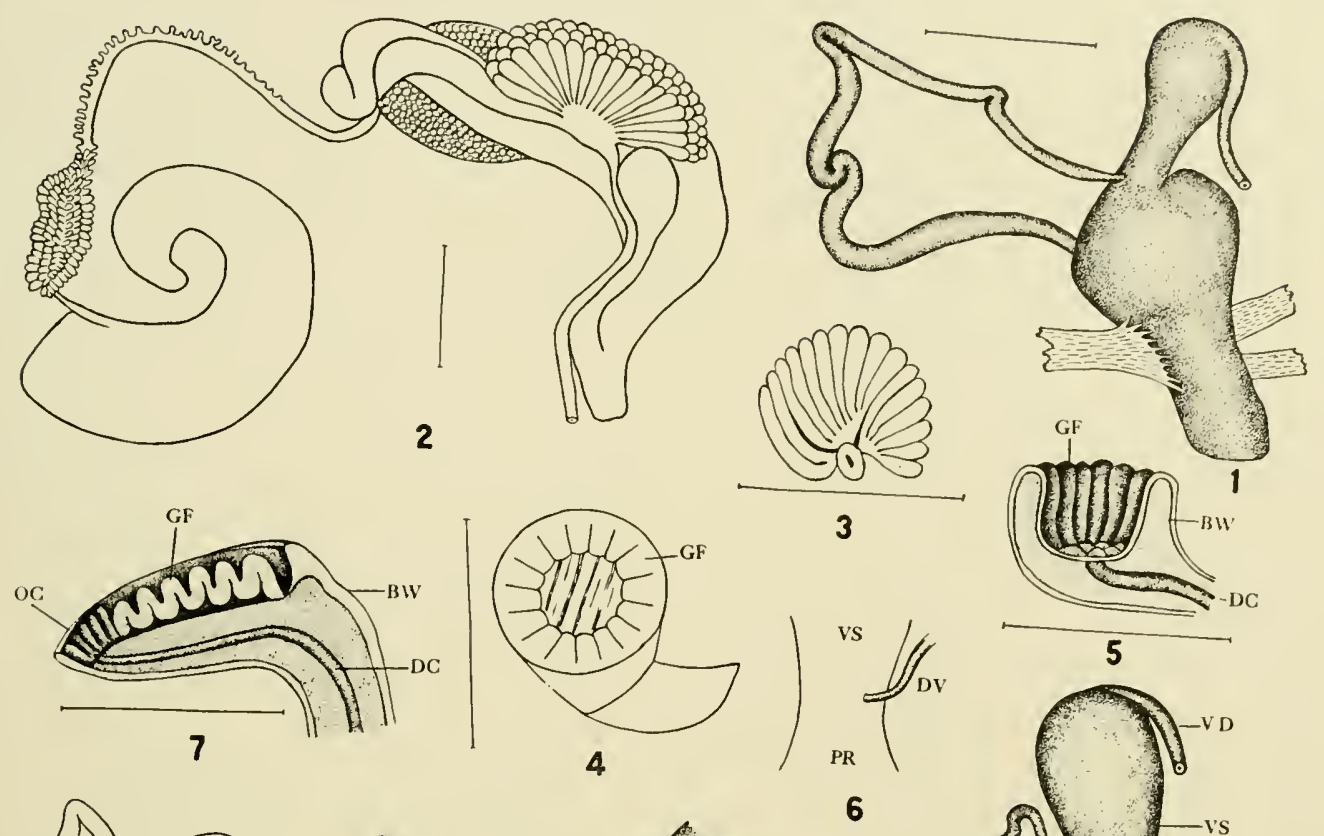

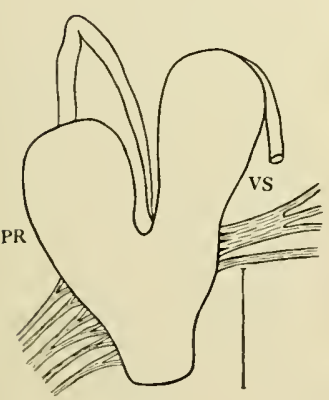

9

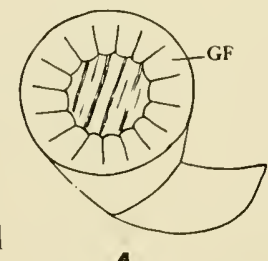

4

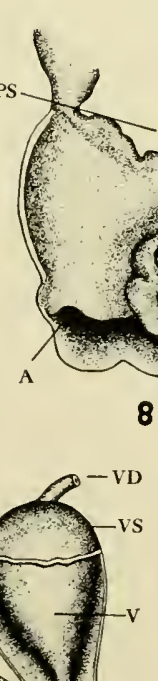

12
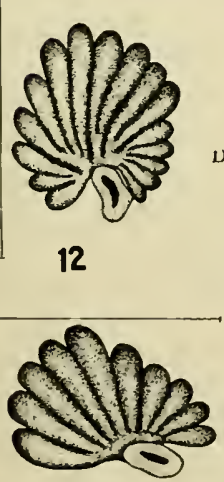

13

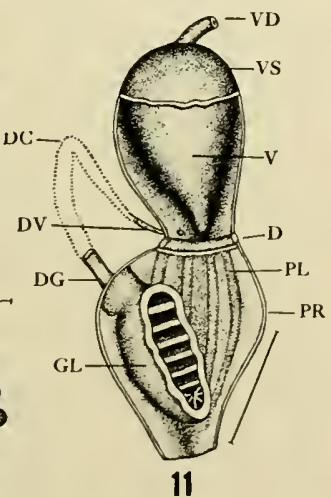

8
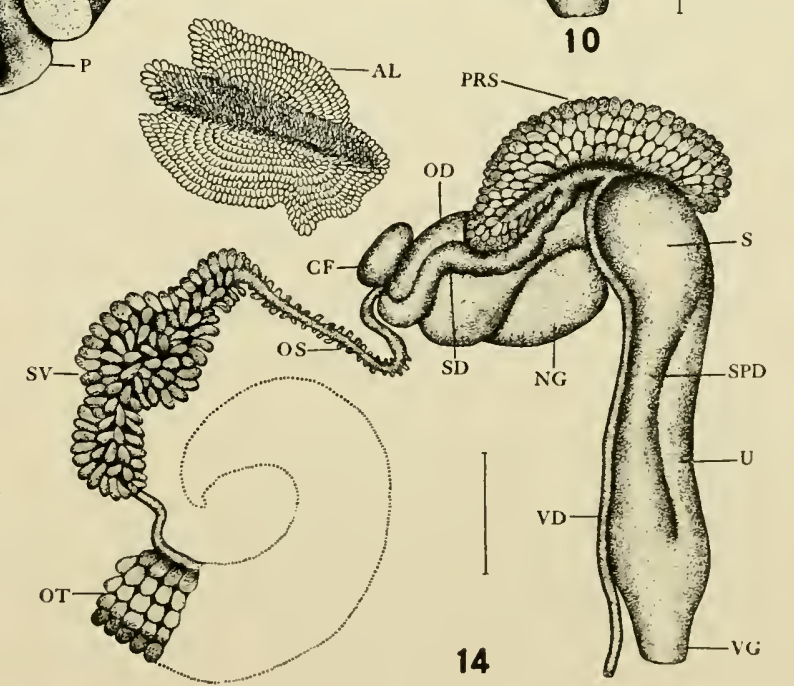

PLATE 28 


\section{PLATE 29}

\section{Helisoma}

1-6. Helisoma trivolvis pseudotrivotvis (F. C. Baker) =lentum Say. From St. Joseph, Champaign Co., Illinois; collected by F. C. Baker.

1. Penial complex with penial gland duct spread out to show length.

2. Penial complex in section showing penial gland in natural position in preputium.

3. Penial complex with penial gland duct coiled on preputium.

4. Penial gland in section.

5. Penial complex in section showing preputium pushed upward and penial gland duct uncoiled. From Illinois River, Peoria, Illinois.

6. Neck of animal showing penial gland everted. From Reelfoot Lake, Tennessee.

7-13. Helisoma trivolvis lentum (Say). From New Orleans, Louisiana; collected by E. C. Faust.

7. Penial complex with penial gland everted.

8. Penial complex with penial gland duct uncoiled.

9. Terge fully extended with sections in two places as indicated.

10. End of verge showing exit of sperm canal with small, lip-like processes surrounding the opening.

11. Head and neck of animal showing penial gland and rerge everted.

12. Penial complex with penial gland and verge everted.

13. Verge in fig. 12 removed from penial complex.

14-16. If clisoma trivolvis macrostomum (Whiteares).

14. Penial complex. From Bayfield, Wisconsin; collected by F. C. Baker.

15. Penial complex with preputium pushed upward. Same locality as fig. 14.

16. Penial complex with penial gland duct uncoiled. From Lake Gaurreau, Canada; collected by A. LaRocque.

17, 18. Helisoma trivolvis fallax (Haldeman). From Cambridge, Massachusetts; collected by W. J. Clench.

17. Penial complex showing large size of preputium.

18. Exterior view of penial gland.

19 22. Helisoma chautanquense F. C. Baker. From Chantauqua Lake, New York; collected by F. C. Baker.

19. Penial complex of immature specinen.

20. Exterior view of penial gland.

21. Verge much retracted.

22. Penial complex of adult specimen in normal condition.

Line near figure indicates $1 \mathrm{~mm}$. in length. In fig. 10 line equals $0.5 \mathrm{~mm}$. 
Illustrations of the Anatomy and of Shells
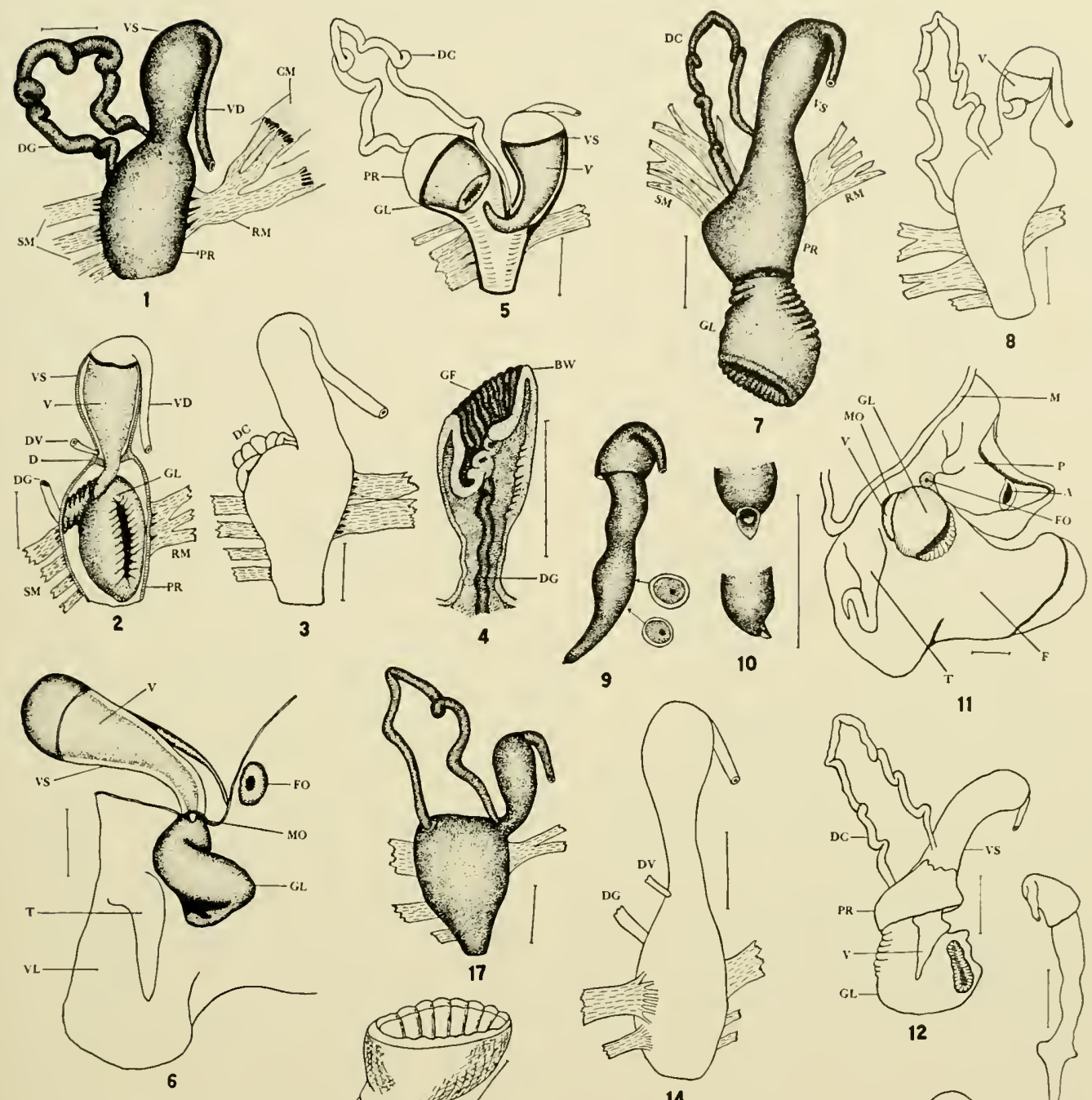

10
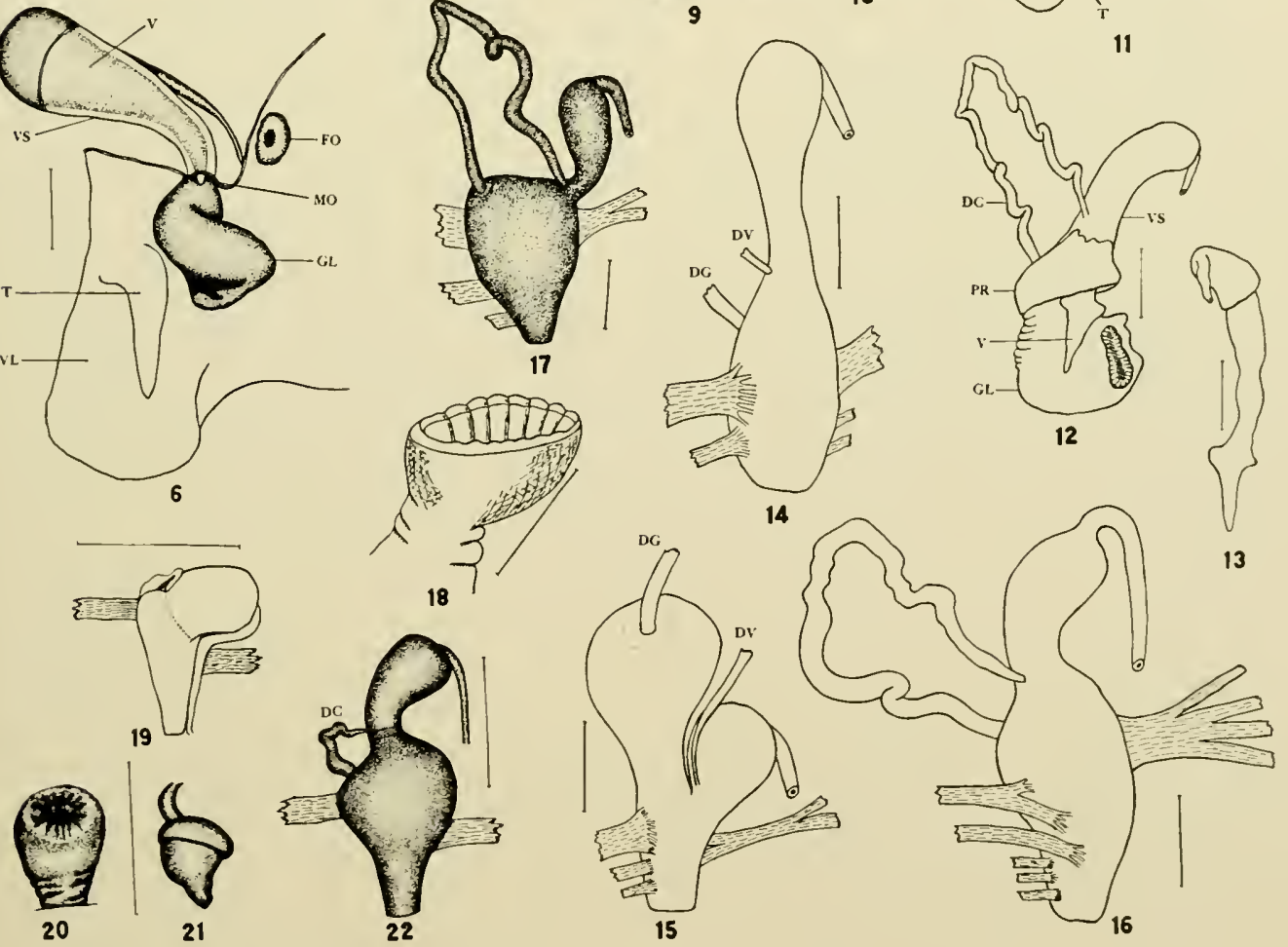

PLATE 29 


\section{PLATE 30}

\section{Helisoma}

1-9. Helisoma plexatum (Ingersoll). Collected by J. Henderson.

1. Penial complex with penial gland duct uncoiled. From Columbine Lake, Coloriado.

2. Penial complex with vergic sac cut open to show form of verge.

3. Penial complex in section to show form of gland. From Columbine Lake, Colorido.

4. Genitalia dissected and organs separated. From Smartweed Lake, Colorado.

5. Cross section of penial gland. From Lower Los Lagos, near Smartweed Lake.

6-8. Section of vergic sac showing form of verge in different individuals. From Teton River, north of Rexburg, Idaho.

9. Form of verge in a specimen from Smartweed Lake, Colorado.

10-19. Helisoma subcrenatum (P. P. Carpenter). From one nile west of Devon, Montana; collected by J. Henderson.

10. Penial complex showing short penial gland duct in immature specimen.

11. Section of penial gland.

12. Cross section of prostate about midway of its length.

13. Section through penial complex showing verge and penial gland.

14. Albumen gland from below.

15. Genitalia dissected and organs separated.

16. Head showing pseudobranch, pneunostome, and rectum.

17. Penial complex with penial gland duct uncoiled.

18. Penial complex in section showing form of penial gland and verge.

19. Penial complex with vergic sac cut open to show verge. Figures 17-19 are from specimens collected at Cottonwood Pass, near Gypsum, Colorado.

Line near figure indicates $1 \mathrm{~mm}$. in length 

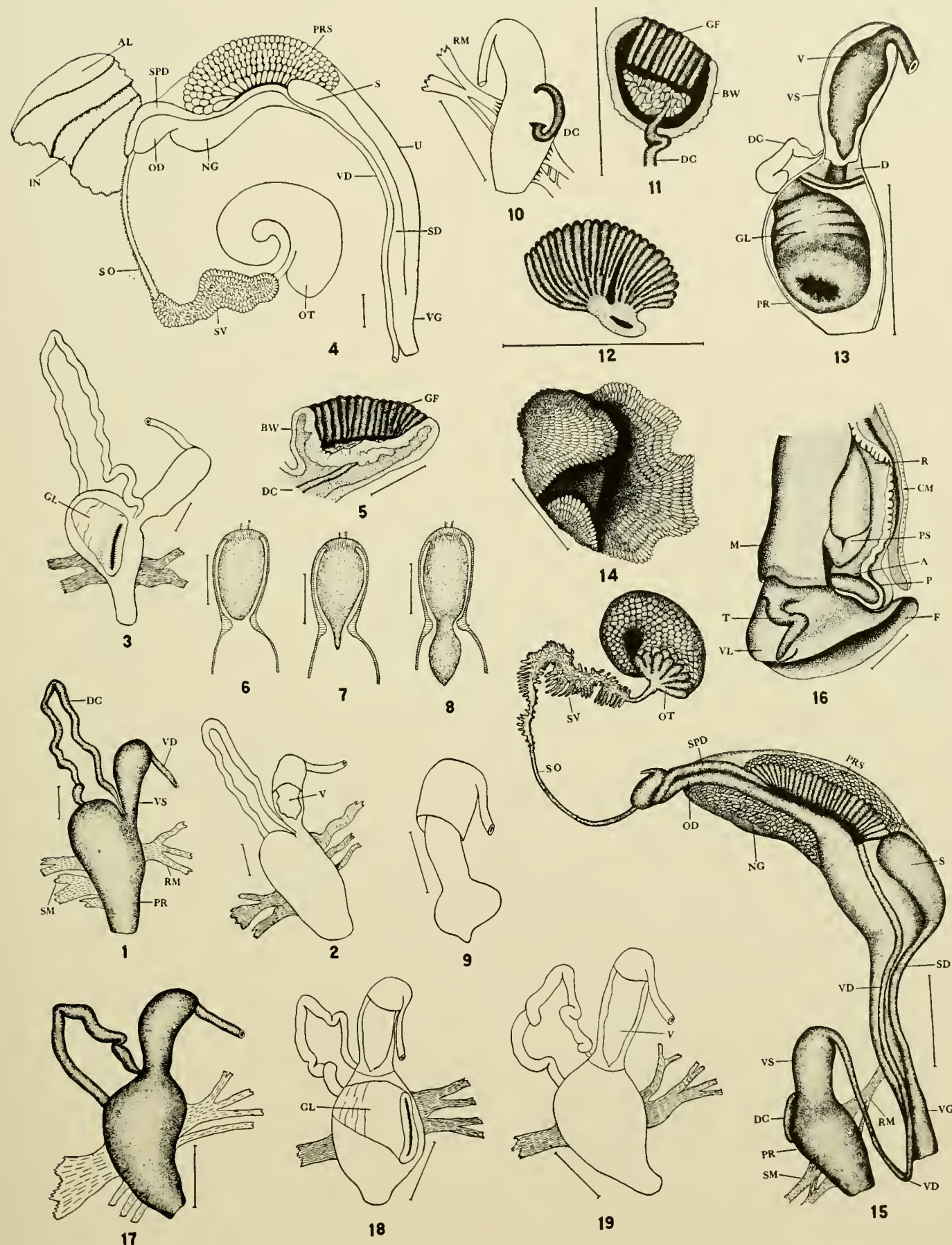

PLATE 30 
PLATE 31

\section{Helisoma}

1-7. Helisoma corpulentum (Say). From Knife Lake, Minnesota and Lalie La Croix, Ontario; collected by Dr. A. R. Cahn.

1. Cross section of orotestis. From Knife Lake.

2. Cross section of prostate and uterus at $\mathrm{X}$ in fig. 3. From Knife Lake.

3. Genitalia dissected and organs separated. From Knife Lake.

4. Penial complex with preputimm pushed upward and penial gland duct uncoiled.

5. Penial complex and penial gland duct in natural position. From Knife Lake.

6. Penial complex of immature specimen, shell $12 \mathrm{~mm}$. in diameter. From Lake La Croix.

7. Penial complex of specimen with shell $14 \mathrm{~mm}$. in diameter. From Lake La Croix.

8-13. Helisoma cormulentum multicostatum F. C. Baker. From Kahnipiminanicock Lake, Onturio, Canada; collected bỵ Dr. A. R. Cahn.

8. Cross section of penial gland. Duct not shown.

9. Penial complex of immature specimen, shell $5.5 \mathrm{~mm}$. in diameter. Duct short.

10. Penial complex of half-grown animal, shell $14.5 \mathrm{~mm}$. in dianeter.

11. Penial complex of another half-grown specimen, shell $14.5 \mathrm{~mm}$. in diameter.

12. Penial complex of specimen almost adult, shell $16 \mathrm{~mm}$. in diameter.

13. Penial complex of adult animal, shell $23 \mathrm{~mm}$, in diameter. Duct long, uncoiled.

14-18. Helisoma corpulentum vermilionense F. C. Baker. From Lake Vermilion, Minnesota; collected by F. C. Baker.

14. Penial complex showing preputim pushed upward. Duct uncoiled.

15. Section of penial gland showing eup and penial gland duet.

16. Penial complex, specimen about one-fourth grown.

17. Penial complex in specimen somewhat older than fig. 16.

18. Penial complex of animal about half-grown. Verge of different shape.

19. Helisoma whitearesi F. C. Baker. From Mille Lacs, Ontario, Canada; collected by A. R. Cahn.

19. Penial complex with small vergic sac, the penial gland duet uncoiled.

20-22. Helisoma magnificum (Pilsbry). From Greenfield Pond, 1 mile south of Wilmington, North Carolina; collected by Dr. Paul Bartsch.

20. Penial complex with penial gland duct uncoiled.

21. Penial complex in section.

22. Penial gland in section.

Line near figure indicates $1 \mathrm{nmm}$. in length 
Illustrations of the Anatomy and of Shells
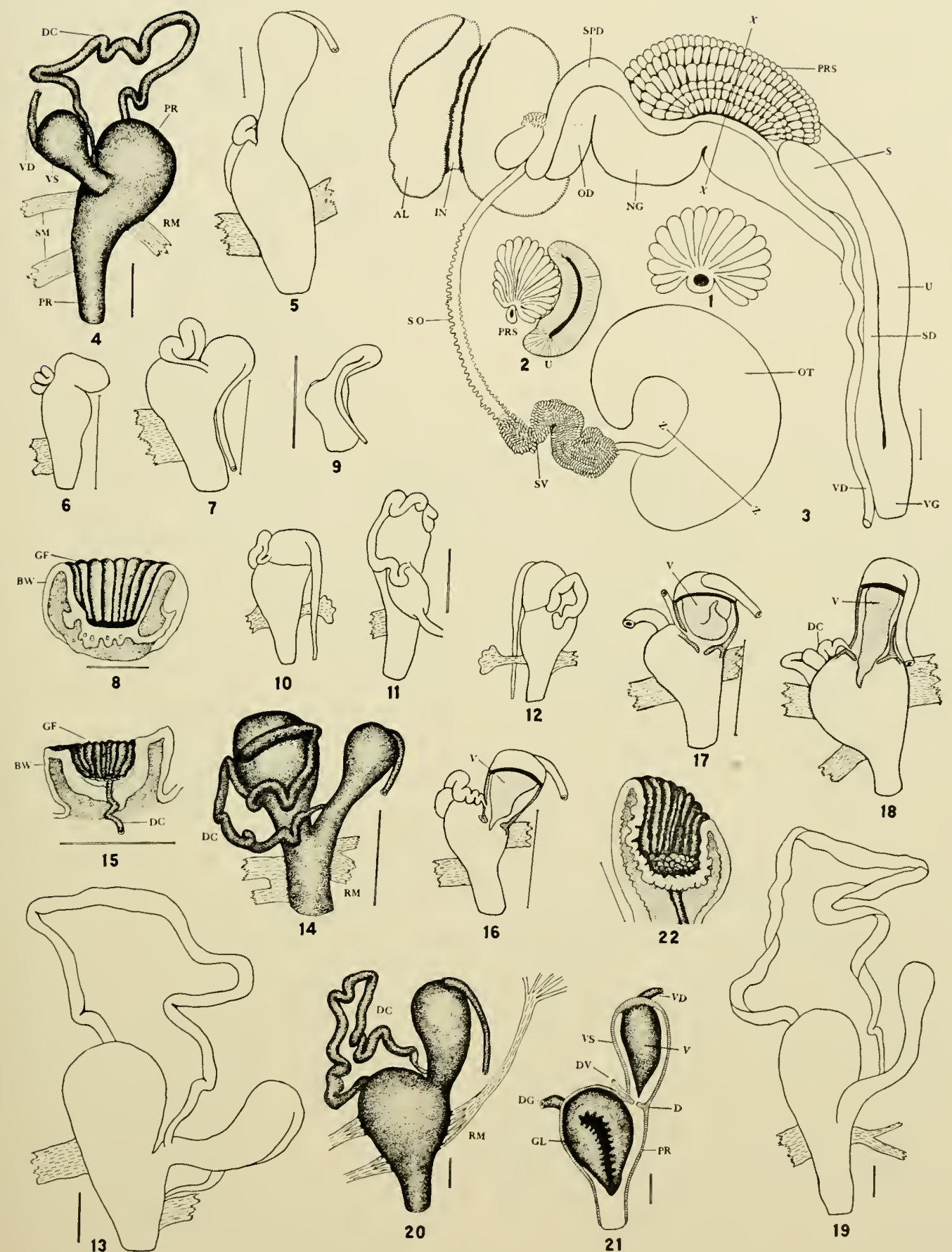

4
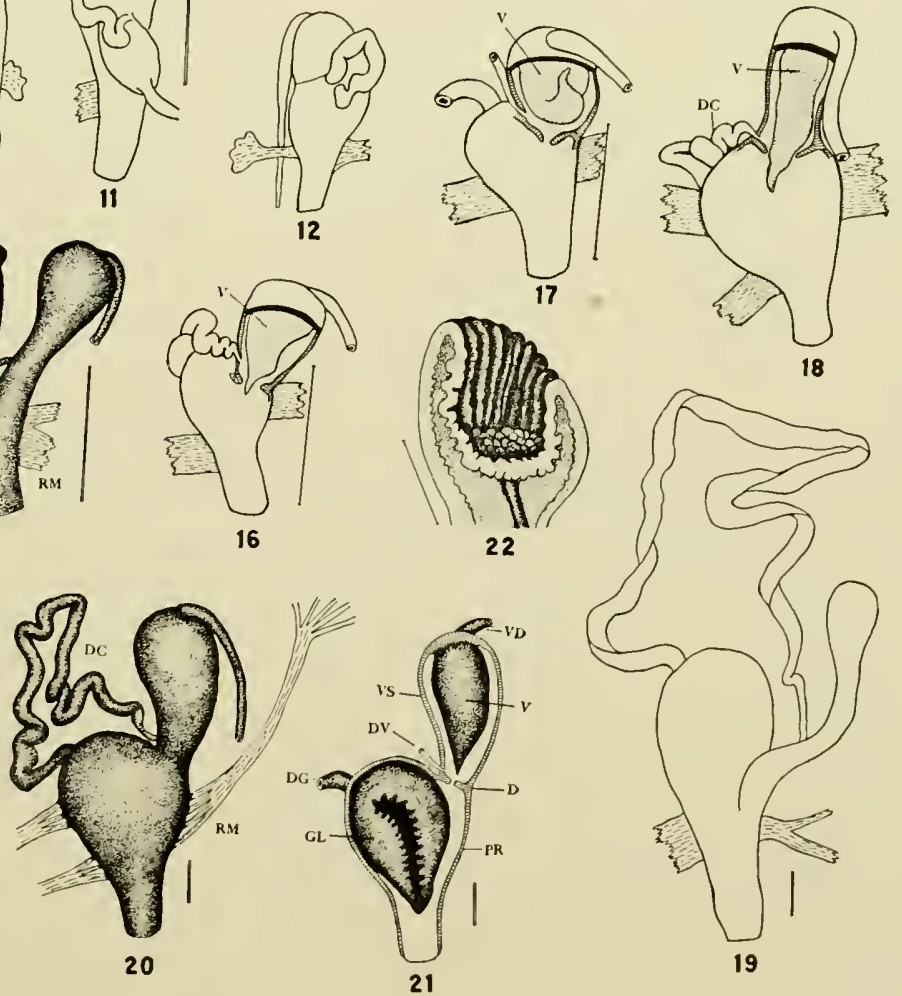

16
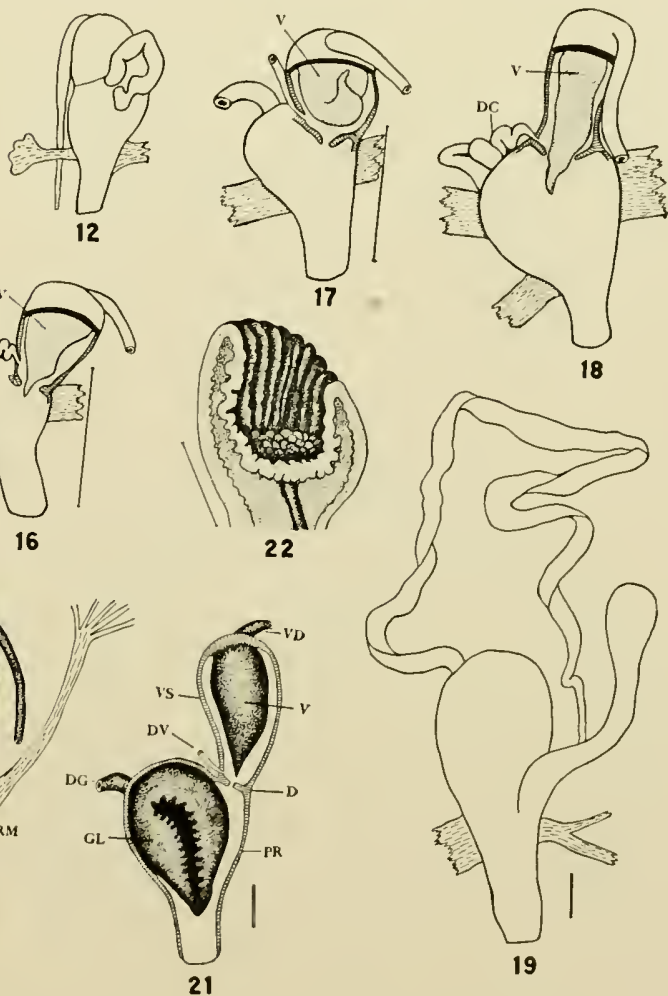

PLATE 31 


\section{PLATE 32}

\section{Helisoma}

1-7. Helisoma tenue californiense F. C. Baker. Fron pools from artesian wells, near Shandon, California; collected by Dr. G. D. Hanna.

1. Genitalia dissected and organs separated.

2. Penial complex cut open to show rerge.

3. Penial complex with rergic sac at summit of preputium.

4. Pseudobranch, pneumostome, and rectum.

5. Penial gland viewed from the outside.

6 . Section of prostate and uterus.

7. Penial complex with penial gland duct uncoiled. From Prospect Park, Redlands, California; collected by Dr. s. s. Berry.

8. Ifelisoma suberenatum (P. P. Carrenter). Variety. From Pass Lake, Fidalgo Island, Puget Somal. Washington; collected by J. Henderson.

8. Penial complex with preputium puked upward.

9, 10. Helisoma occidentale (Cooper). From Wacos Bay, Kilamath Lake, Oregon; collected by J. Henderson.

9. Position of verge in vergic sac.

10. Penial complex with preputium pushed upward.

11-17. Helisoma traskii (Lea). From slough near Kern River, three miles northeast of Bakersfield, California; collected by L. G. Ingles.

11. Penial complex cut open to show form of penial gland.

12. Cross section through prostate, uterus, and nidanental gland.

13. Section through penial gland.

14. Penial complex in normal position with penial gland duct uncoiled.

15. Pseudobranch, pneumostone, and rectum.

16. Bifid tentacle.

17. Genitalia dissected and organs separated.

Line near figure indicates $1 \mathrm{~mm}$. in length 
Illustrations of the Anatomy and of Shells
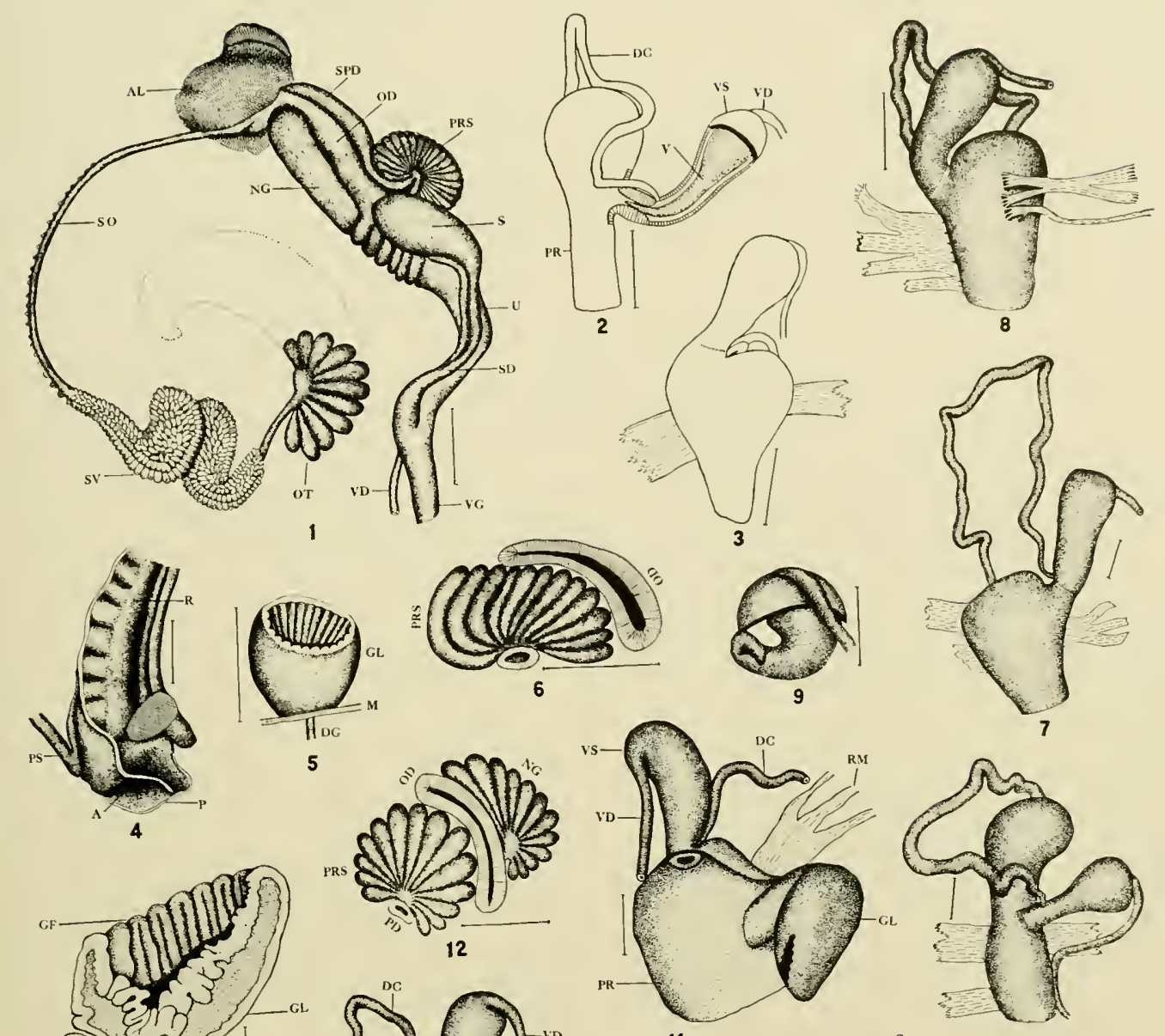

5
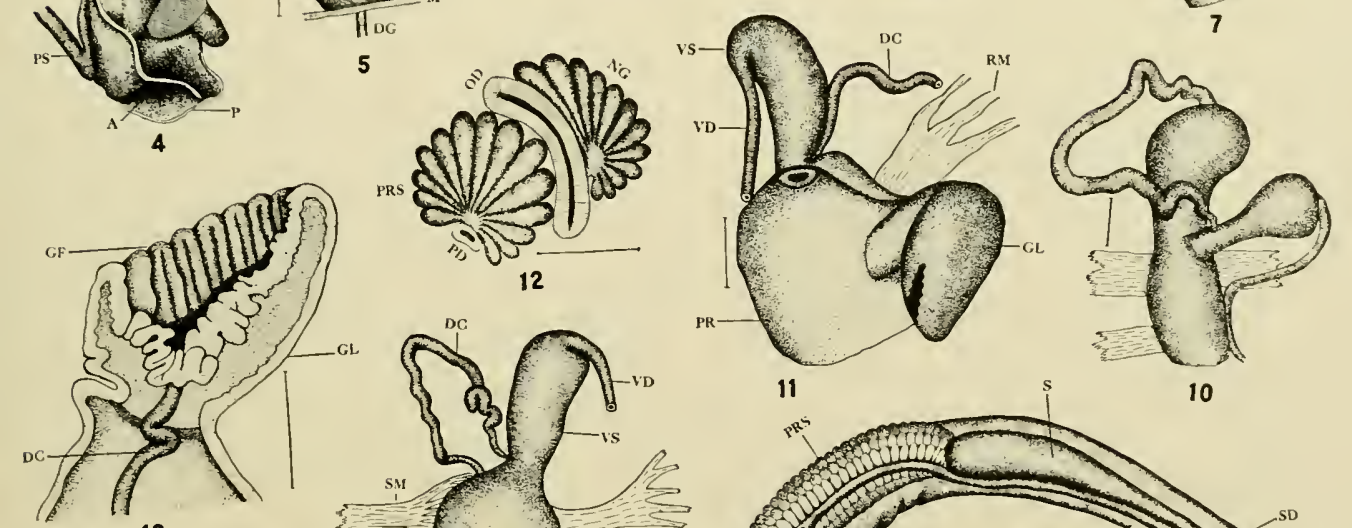

13

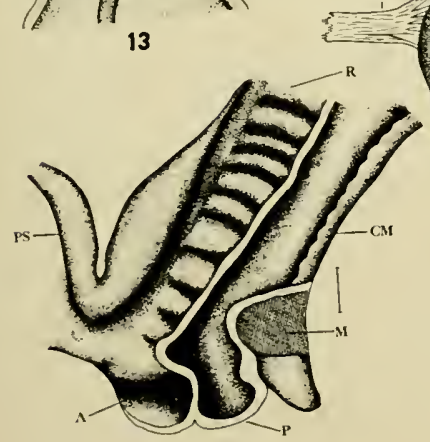

15
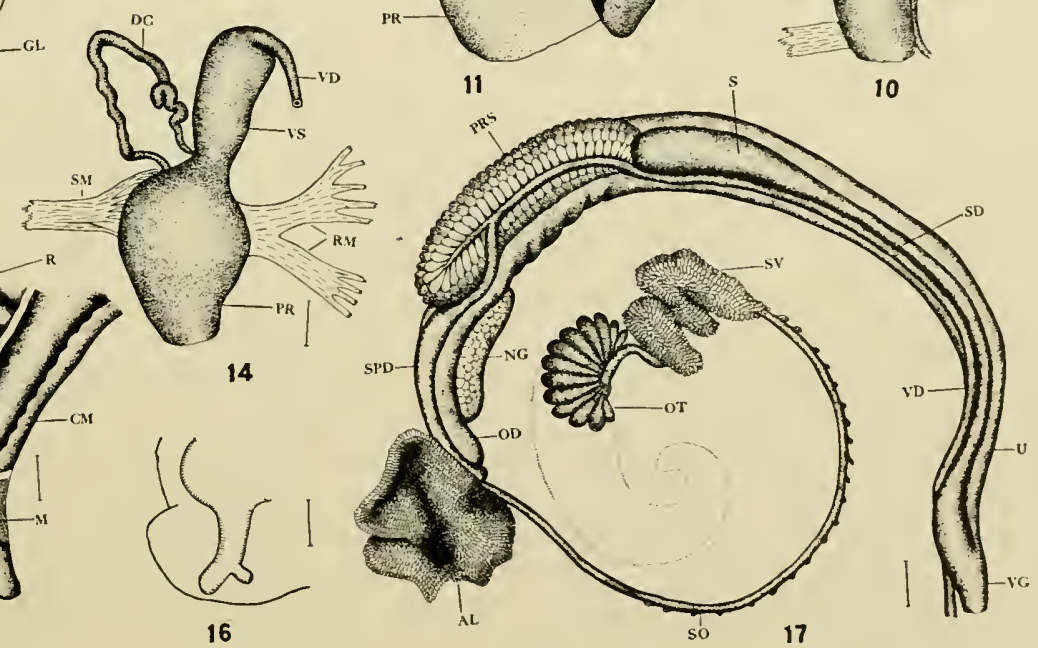

PLATE 32 


\section{PLATE 33}

\section{Helisoma}

1-7. Helisoma duryı eudiscus Pilsbry. From Silver Springs, Florida; collected by T. Van Hyning.

1. Penial complex showing swollen duct of penial gland and position of verge in vergic sac.

2. Penial complex from exterior with penial gland duct uncoiled.

3. Penial gland in section showing the long, shallow cup.

4. Exterior view of penial gland.

5. Penial complex with preputium pushed upward.

6. Penial complex of immature specimen, shell $6.5 \mathrm{~mm}$. in diameter.

7. A very wide example of penial complex.

8-10, 12, 16-19. Helisoma duryi normale Pilsbry.

8. Penial complex. From near Paines Prairie, Gainesville, Florida; collected by T. Van Hyning.

9. Penial complex with swollen preputium. From Santa Fe River, High Springs, Alachua Co., Florida; collected by T. Van Hyning.

10. Penial gland in section. Same locality as fig. 9 .

12. Penial complex. Variation in form. From Tamiami Trail, 40 miles west of Miami, Florida; collected by W. F. Shay.

16. Head and neck with penial gland protruding from male opening. Same locality as fig. 12.

17. Penial complex. A normal form showing short penial gland duct. Same locality as fig. 12 .

18. Penial complex. A very wide example. Same locality as fig. 12.

19. Penial gland of half-grown specimen. From near Gainesville, Florida.

11, 13, 14. Helisoma duryi (Wetherby), near typical form. Same locality as fig. 12 .

11. Penial gland, partly contracted.

13. Penial complex with penial gland protruding from male opening.

14. Penial complex of normal specimen.

15. Helisoma duryi normale Pilsbry, varying toward interenlare (Pilsbry).

15. Genitalia dissected and organs separated. From canal at Boynton, Florida; collected by W. F. Shay.

Line near figure indicates $1 \mathrm{~mm}$. in length 
Illustrations of the Anatomy and of Shells
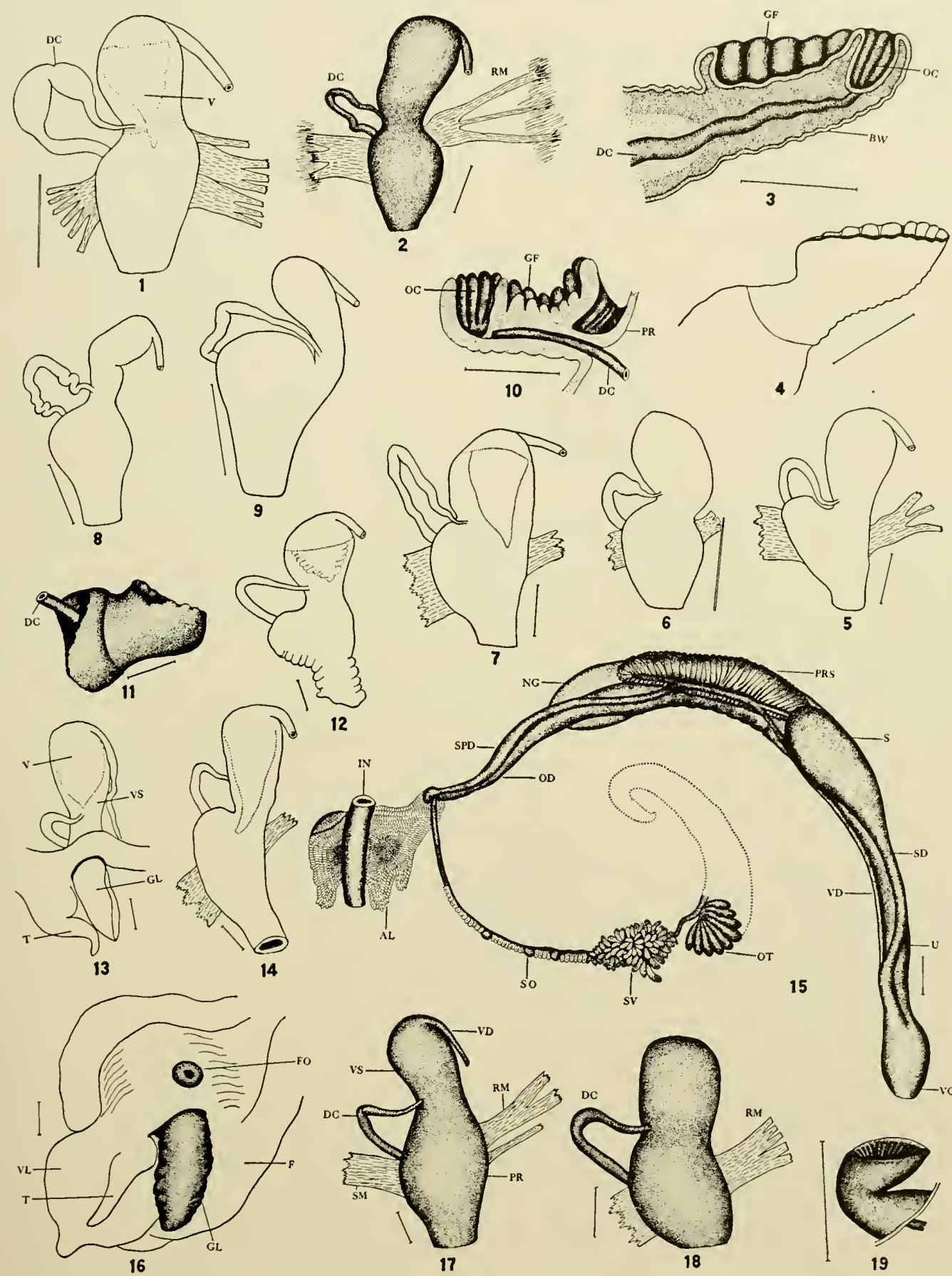

15

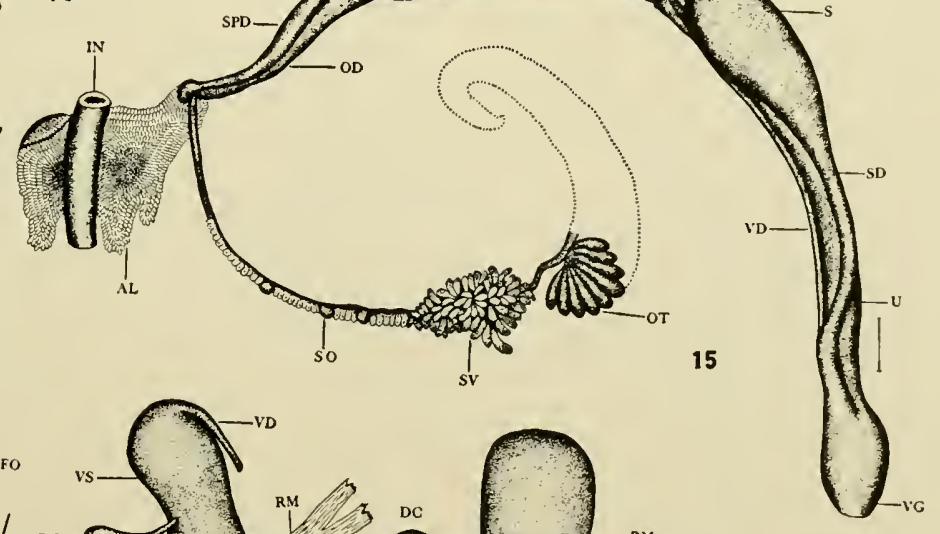

PLATE 33 


\section{PLATE 34}

\section{Carinifex ponsonbyi E. A. Smith}

From Upper Klamath Lake, Oregon; collected by J. Henderson.

1. Head and foot showing pseulobranch and pnemmostome.

2. Penial complex showing muscle system and short penial gland duct.

3. Penial complex ent open to show verge and penial gland.

4. Genitalia dissected and organs separated. Shows umsual position of spermatheca.

5. Albumen gland from below.

6. Portion of genitalia showing relationship of oriduct, sperm duet, ovisperm duct. and duct to albumen gland.

7. Cross section of prostate and uterus.

S. Cross section of prostate near distal end.

9. Cross section of orotestis near proximal end.

10. Section through penial gland to show duct and folds.

11. Tingina and spermatheca of different form.

12. Cross section of preputial sac to show vertical ridges or pilasters.

Line near figure indicates $1 \mathrm{~mm}$. in length. Figure 12 has same magnification as fig. 2 . 

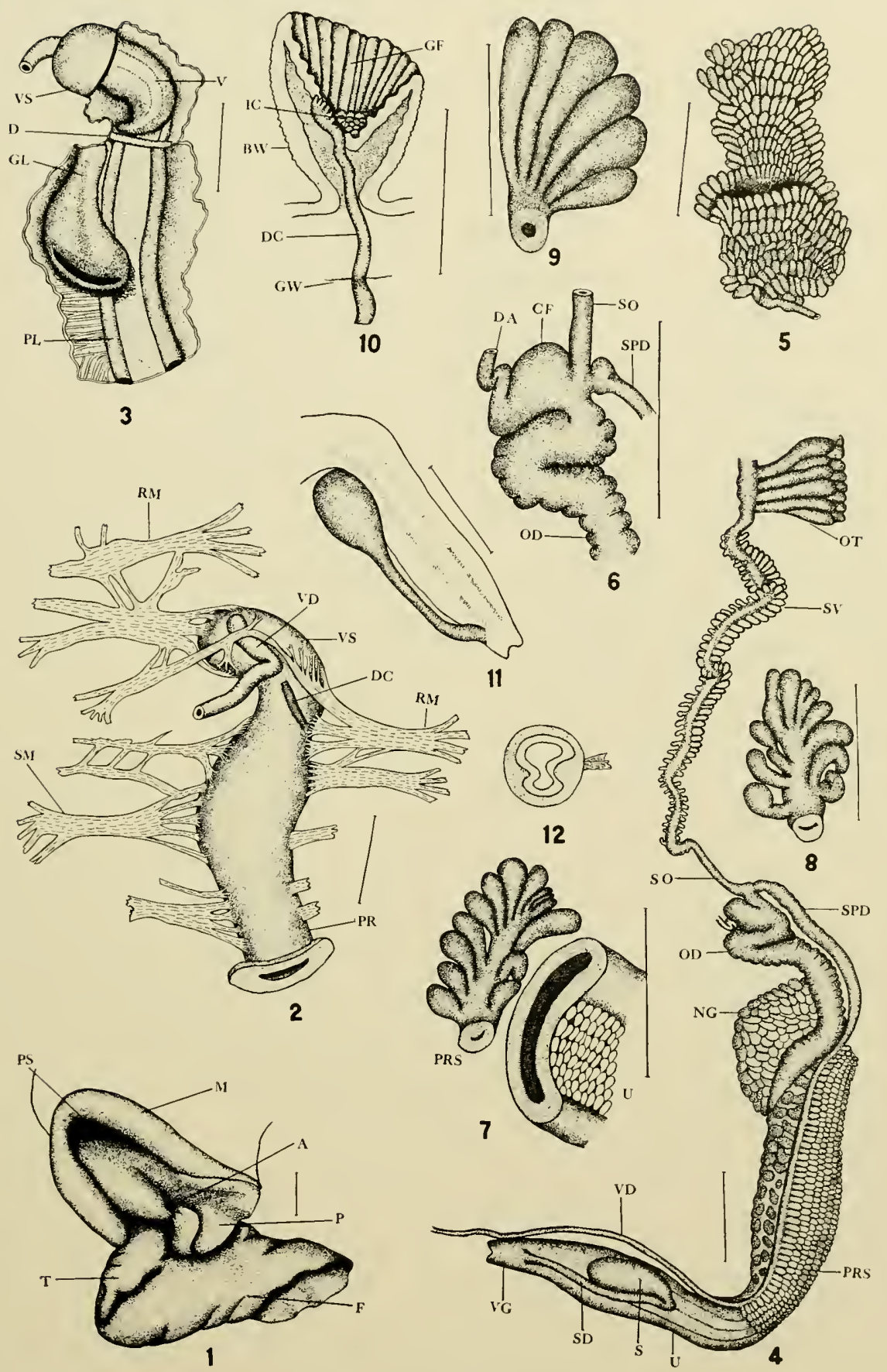

PLATE 34 


\section{PLATE 35}

\section{Carinifex}

1. Carinifex pousonbyi E. A. Smith. From Upper Klamath Lake, Oregon.

1. Penial complex showing variation in muscle system.

2-9. Carinifex jacksonensis J. Henderson. From Jackson Lake, Wyoming; collected by J. Henderson.

2. Summit of verge showing attachment of retractor muscles.

3. Penial complex showing multiplication of retractor muscles and short penial gland duct.

4. Pseudobranch and pneumostome.

5. Genitalia dissected and organs separated.

6. Portion of genitalia showing relationship of oviduct, sperm duct, ovisperm duct, etc.

7. Same organs as in fig. 6 , from above.

8. Albumen gland.

9. Another form of spermatheca.

Line near figure indicates $1 \mathrm{~mm}$. in length 

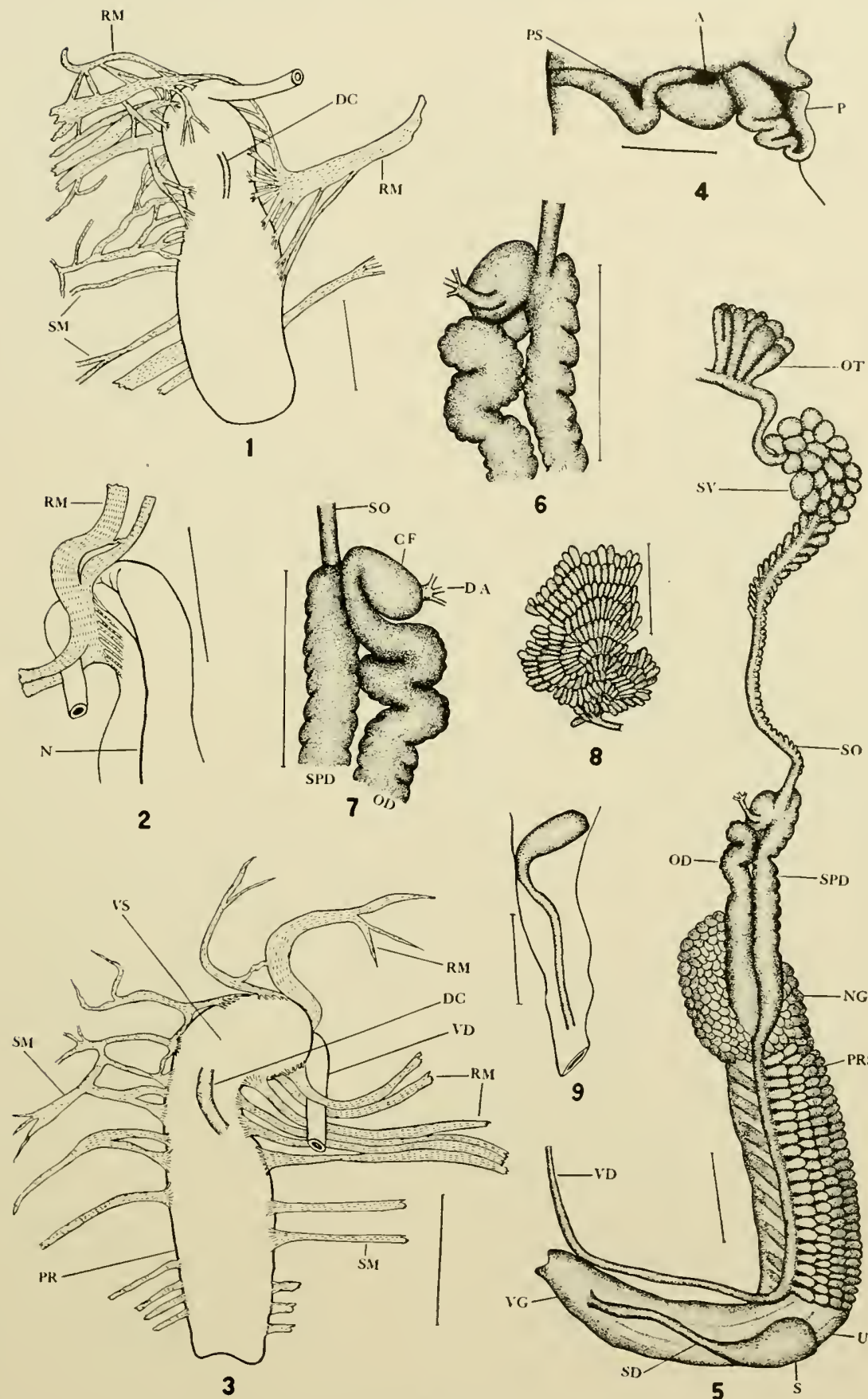

PLATE $3 \tilde{5}$

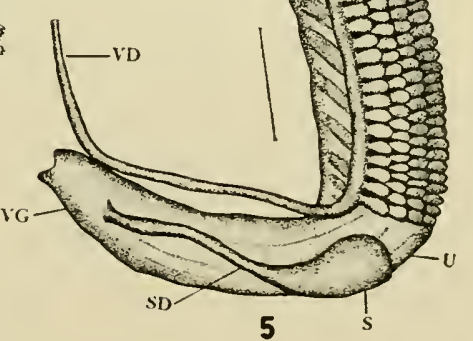




\section{PLATE 36}

\section{Parapholyx}

1-9, 11, 12. Parapholyx rffusa klamathensis F. C. Baker. From Upper Klamath Lake, Oregon; collected by J. Henderson.

1. Whole animal removed from shell.

2. Pseudobranch and related organs.

3. Genitalia dissected and organs separated.

4. Cross section of prostate, uterus, and nidamental gland.

5. Cross section of ovotestis about midway of its length.

6. Cross section of ovotestis toward posterior end.

7. Penial complex showing retractor muscles and short penial gland duct.

8. Penial complex showing nerve and blood vessels.

9. Penial complex cut open to show verge and penial gland with its short duct. At $\mathrm{I}$ gland is cut open to show canal.

11. Section of penial gland showing pipe-like cup and canal.

12. Verge showing central position of exit for the sperm canal.

10. Parapholyx cffusa diagonalis J. Henderson. From Crater Iake, Oregon; collected by J. Henderson.

10. Vergic sac and upper part of preputium showing verge, muscular ring or diaphragm, and entrance of penial gland duct into diaphragm.

Line near figure indicates $1 \mathrm{~mm}$. in length 

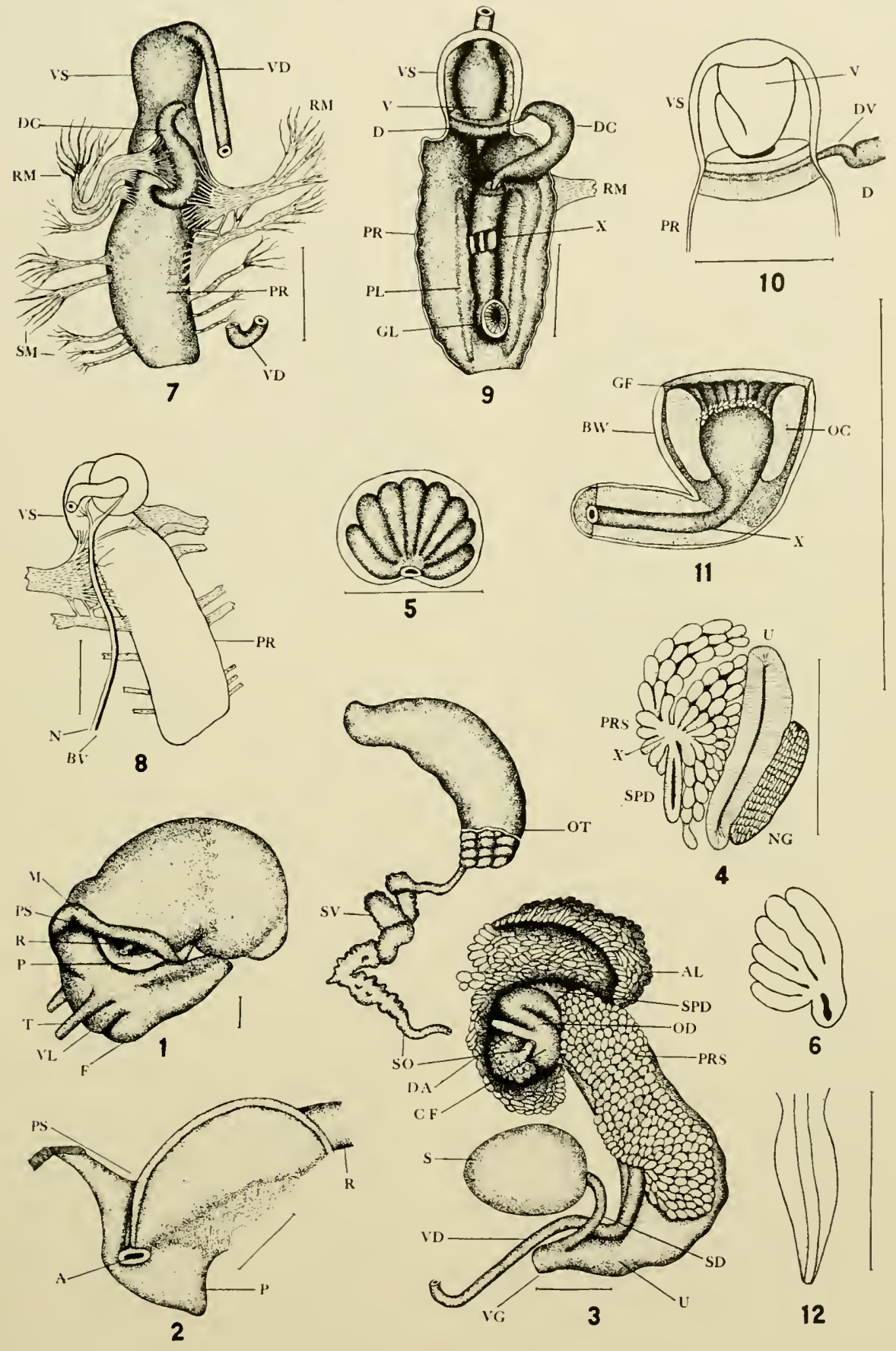

PLATE 36 
PLATE 37

\section{Planorbula armigera (Say)}

From Murphy Creek swamp, near Madison, Wisconsin; collected by J. E. Morrison.

1. Section of prostate near middle of gland.

2. Section of prostate near middle.

3. Portion of genitalia showing relationship of oviduct, sperm duct, ovisperm duet, and carrefour.

4. Genitalia dissected and organs separated, with abumen gland in natural position.

5. Head and foot showing pseulobranch and pneumostome.

6. Section of penial glanul.

7. Section of orotestis to show paired condition of diverticula, which are extended laterally, appearing as thongh digitate.

8 . End of verge to show outlet of sperm canal.

9. Penial complex showing muscles and general form of vergic sac and preputium.

10. Penial complex of small, immature specimen showing wide form of preputium.

11. Section of penial complex showing penial gland spread out and opened, with a short, internal duct.

12. Verge in vergic sac.

Line near figure indicates $1 \mathrm{~mm}$. in length. Long line at left of plate is for figs. 6,7 , and 8 . Long line at right of plate is for figs. 1 and 2 . 
Illustrations of the Anatomy and of Shells

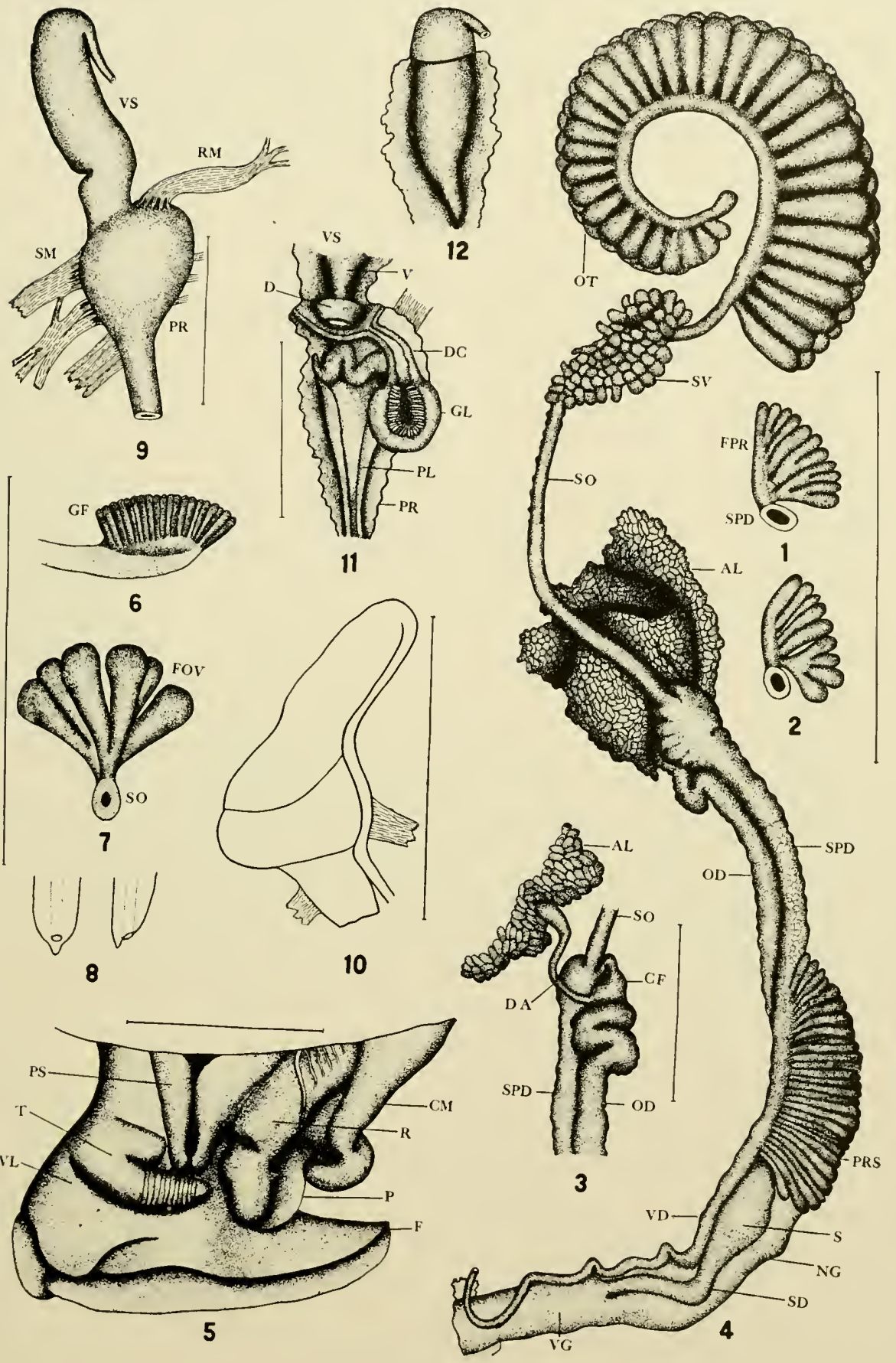

PLATE 37 
PLATE 38

\section{Menetus}

1,2,4-10. Menctus opercularis (Gould). From Mountain Lake, San Francisco, California; collected by H. Walton Clark.

1. Genitalia dissected and organs separated.

2. Section of prostate near distal end.

4. Head showing position of pseudobranch.

5. Section of orotestis.

6. Penial gland with cup expanded.

7. Albumen gland.

8. Section through penial complex showing natural position of penial gland.

9. Albumen gland in natural position orerlying stomach.

10. Exterior view of penial complex.

3,11-15. Menctus cooperi callioglyptus (Vanatta). From Crescent City, California ; received from Dr. G. D. Hanna. Also from Quatsino Sound, British Columbia; collecterl by A. Peake.

3. Section of prostate about midway of its length. California specimen.

11. Penial complex from the outside. California specimen.

12. Penial complex. British Columbia specimen.

13. Entire prostate. British Columbia specimen.

14. Cross section of prostate and uterus near front end. British Columbia specimen.

15. End of rerge showing central outlet of sperm canal. British Columbia specimen.

Line near figure indicates $1 \mathrm{~mm}$. in length. Iine at left of fig. 10 is also for figs. 7 and 8 . Line at left of fig. 14 is also for figs. $2,3,5,6,14$, and 15 . 
Illustrations of the Anatomy and of Shells
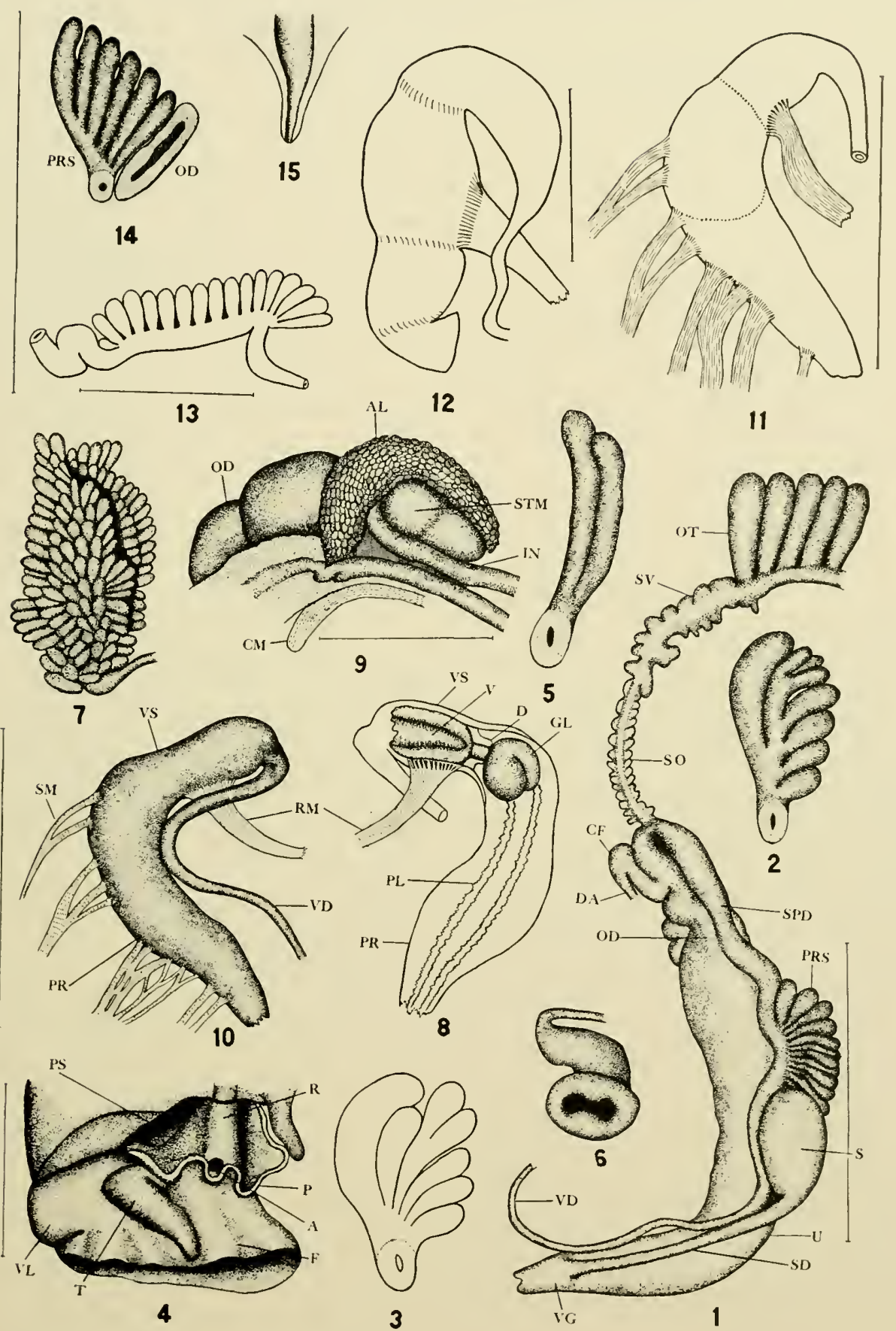


\section{PLATE 39}

\section{Menetus}

1-6, 9, 10. Menetus cooperi callioglyptus (Vanatta). From Quatsino Sound. Vancouver Island, British Columbia; collected by Arthur Peake. Also from Crescent City, California. See plate 38.

1. Genitalia dissected and organs separated. California specimen.

2. Hear showing form of pseudobranch. California specimen.

3. Penial complex in natural position under female complex. British Columbia specimen.

4. Hearl showing pseudobranch. California specimen.

5. Penial gland attached to wall of preputium. California specimen.

6. Seminal resicle and ovisperm duct. California specimen.

9. Penial complex showing enlargement of ras deferens as it enters the rergic sac to form an epiphallus. Also form of pental gland in preputium.

10. Penial complex of specimen badly infested with Trematode worms (flukes). Note peculiar form. British Columbia specimen.

7,8. Menetus cooperi F. C. Baker (= planulatus Cooper, preoceupied). From Oreas Island, Puget Sound, Washington; collected by Dr. T. Dale Foster.

7. Penial complex cut open to show verge, penial gland with its short, internal duct, enlargement of vas deferens (epiphallus), and position of retractor muscle.

8. Penial gland in section.

Line near figure indicates $1 \mathrm{~mm}$. in length. Line above fig. 6 is also for figs. 5 and 8 . Line near fig. 9 is also for fig. 7 . 

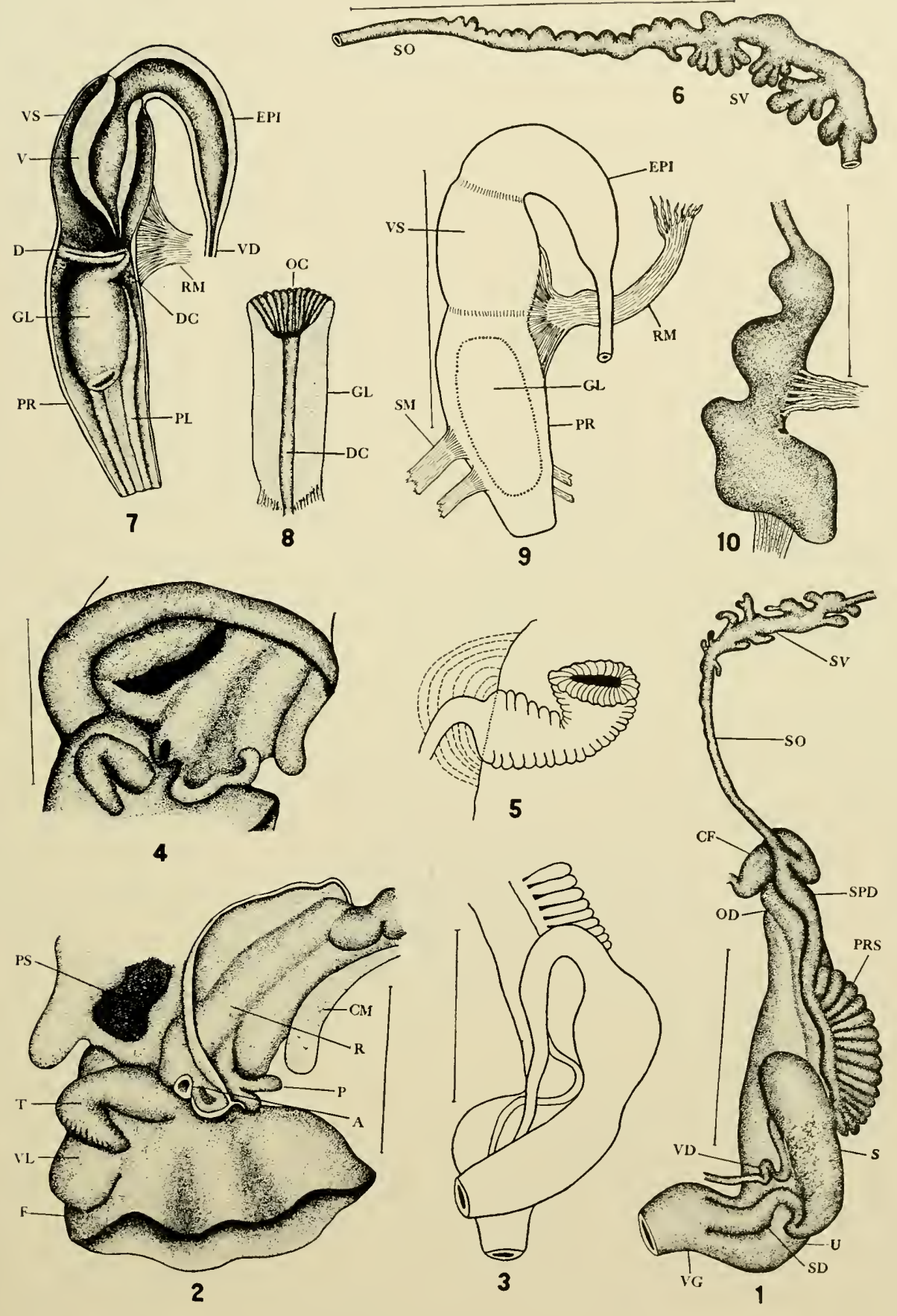

PLATE 39 
PLATE 40

\section{Menetus}

3-5, 7, 9, 12. Henetus dilatatus (Gould). From pond in field near Unionville, Connecticut; collected by F. C. Baker and Leslie Brewer. Also from Hyamnis, Massachusetts; collected by F. C. Baker.

3. Penial complex with preputium pushed upward.

4. Penial complex in natural position, the preputium inflated.

5. Penial complex shown in fig. 4 cut open to show position of rerge and penial gland.

7. Psendobranch of specimen from Hyamnis, Massachusetts. A broad form.

9. Pseudobranch of specimen from Unionville.

12. Genitalia dissected and organs separated. Snall specimen shows reverse side of prostate and vas deferens.

1,2,6, 8, 10, 11. Menetus sampsoni (Ancey). From six miles northeast of Dallas, Texas; collected by Dr. E. P. Cheatum. Also from Meremac River, near Stanton, Missouri; collected by Leslie Hubricht.

1. Orisperm duct and seminal vesicle. Missouri specimen.

2. Penial gland. Texas specimen.

6. Diverticulum of orotestis with ora in upper part. Texas specimen.

8. Pseudobranch in cylindrical form. Texas specimen.

10. Penial complex cut open to show verge and form of penial gland. Texas specimen.

11. External view of penial complex. Texas form.

Line at left of fig. 12 equals $1 \mathrm{~mm}$. in length. Line at right of fig. 10 equals $0.5 \mathrm{~mm}$. in length. All figures are greatly enlarged. 

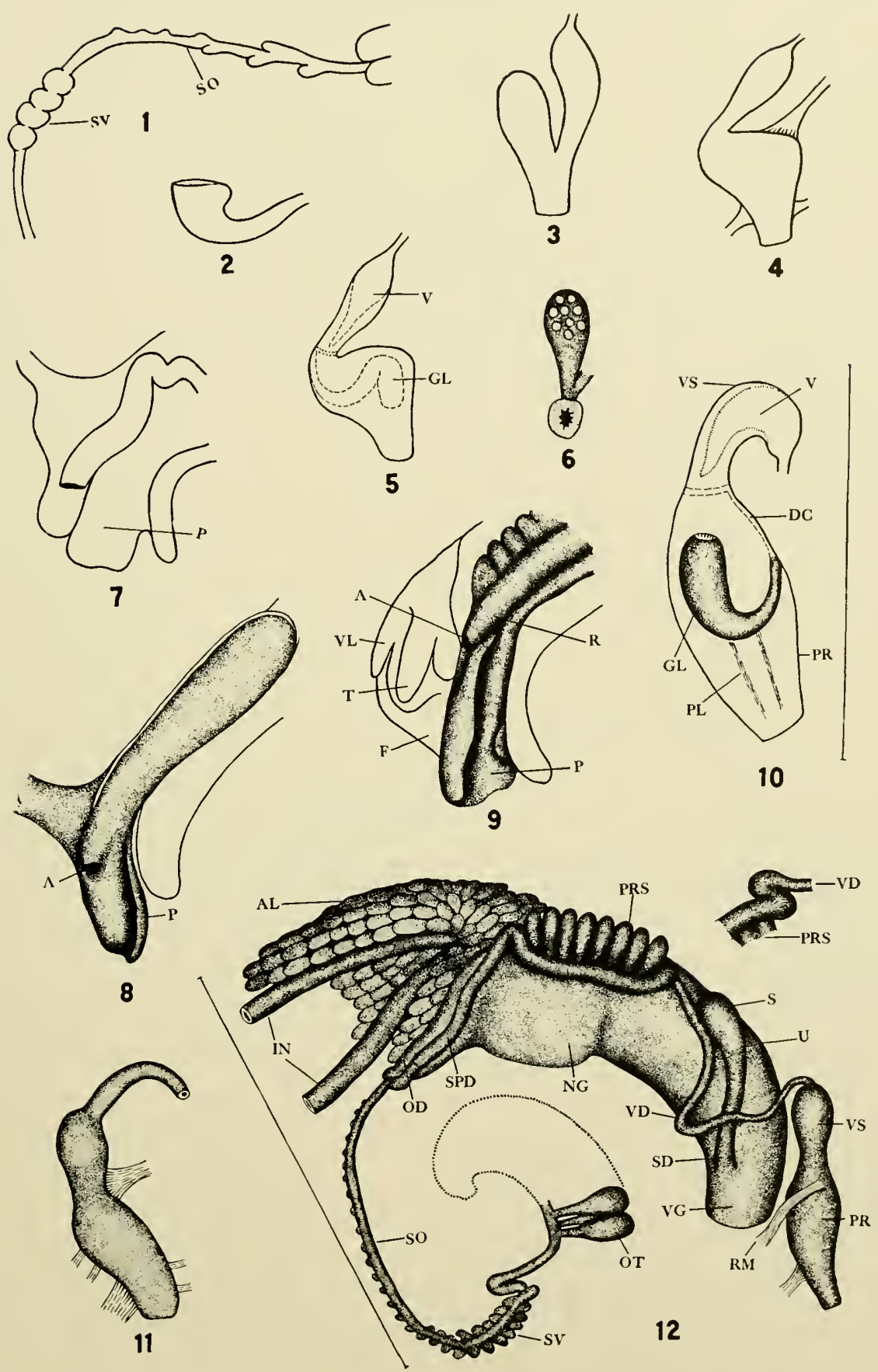

PLATE 40 


\section{PLATE 41}

\section{Promenetus exacuous (Say)}

From Winnebago Lake, near Oshkosh, Wisconsin; collected by F. C. Baker.

1. Penial complex. Swollen gland causing bulge in preputium.

2. Penial complex, external riew, showing a single retractor muscle.

3. Penial complex opened to show rerge and penial gland.

4. Cross section of orotestis about midway of its length.

5. Cross section of prostate near anterior end.

6. Orotestis viewed from left side of animal, showing diverticula.

7. Albumen gland from the side.

8. Head and neck of animal showing pseudobranch.

9. Head of animal showing verge and penial gland projecting from the male genital opening.

10. Genitalia dissected and organs separated.

Line near figure indicates $1 \mathrm{~mm}$. in length. Line at left of figs. 4 and 5 is for both of these figures. Figure 7 has the same magnification as fig. 10 . 

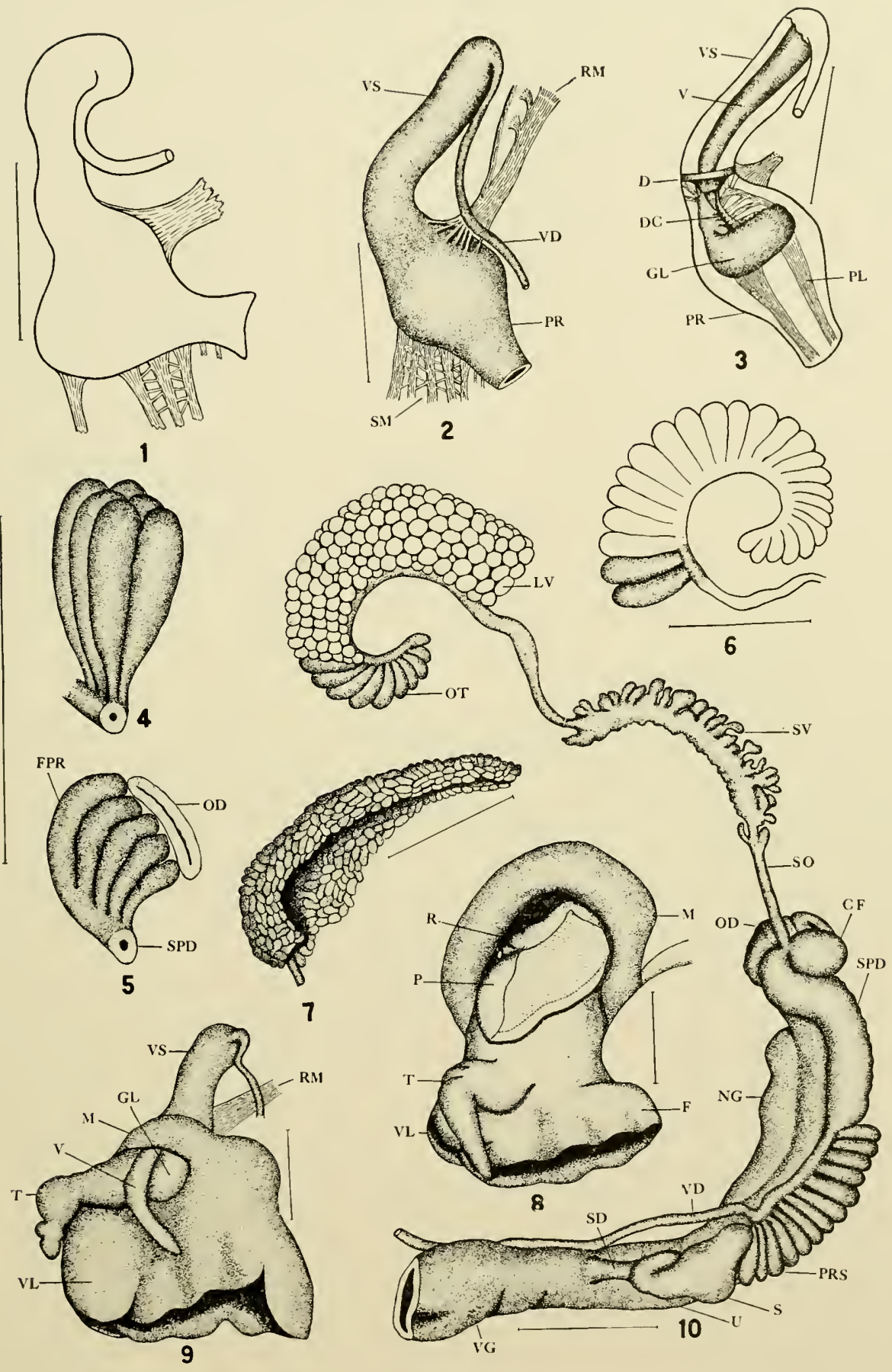

PLATE 41 


\section{PLATE 42}

\section{Promenetus}

1,3,7,12. Promenetus exacuous (Say). From Mott Lake, Wainwright Park. Alberta; collected by Dr. Stiles. Received from Canadian National Museum.

1. Pseudobranch fully expanded.

3. Penial gland in preputium which has been cut open and the pilasters separated.

7. Section of penial gland.

12. Side view of preputium showing penial gland and end of verge passing through the diaphragm.

2, 4,5, 8-11, 13. Promenctus exacuous megas (Dall). From Paul Lake, British Columbia; collected by Dr. D. S. Rawson.

2. Head of animal showing pseudobranch.

4. Penial gland from above showing trough-like duct leading to muscular ring or diaphragm at upper part of preputium.

5. Penial complex in natural position.

8. Cross section of orotest is near middle.

9. Cross section of ovotestis near posterior end.

10. Portion of genitalia showing relationship of ducts.

11. Cross section of prostate. An unusual form with split diverticula.

13. Terminal end of verge showing central exit for sperm canal, small fleshy appendage, and peculiar ring near end.

6. Promenctus umbilicatellus (Cockerell). From Wainwright Park, Alberta; collected by Dr. Stiles. Received from Canatian National Museum.

6. Pseudobranch and pneumostome.

Line near figure indicates $1 \mathrm{~mm}$. in length. Vertical line bordering figs. 8,9 , and 13 is also for figs. 7,10 , and 11 . 

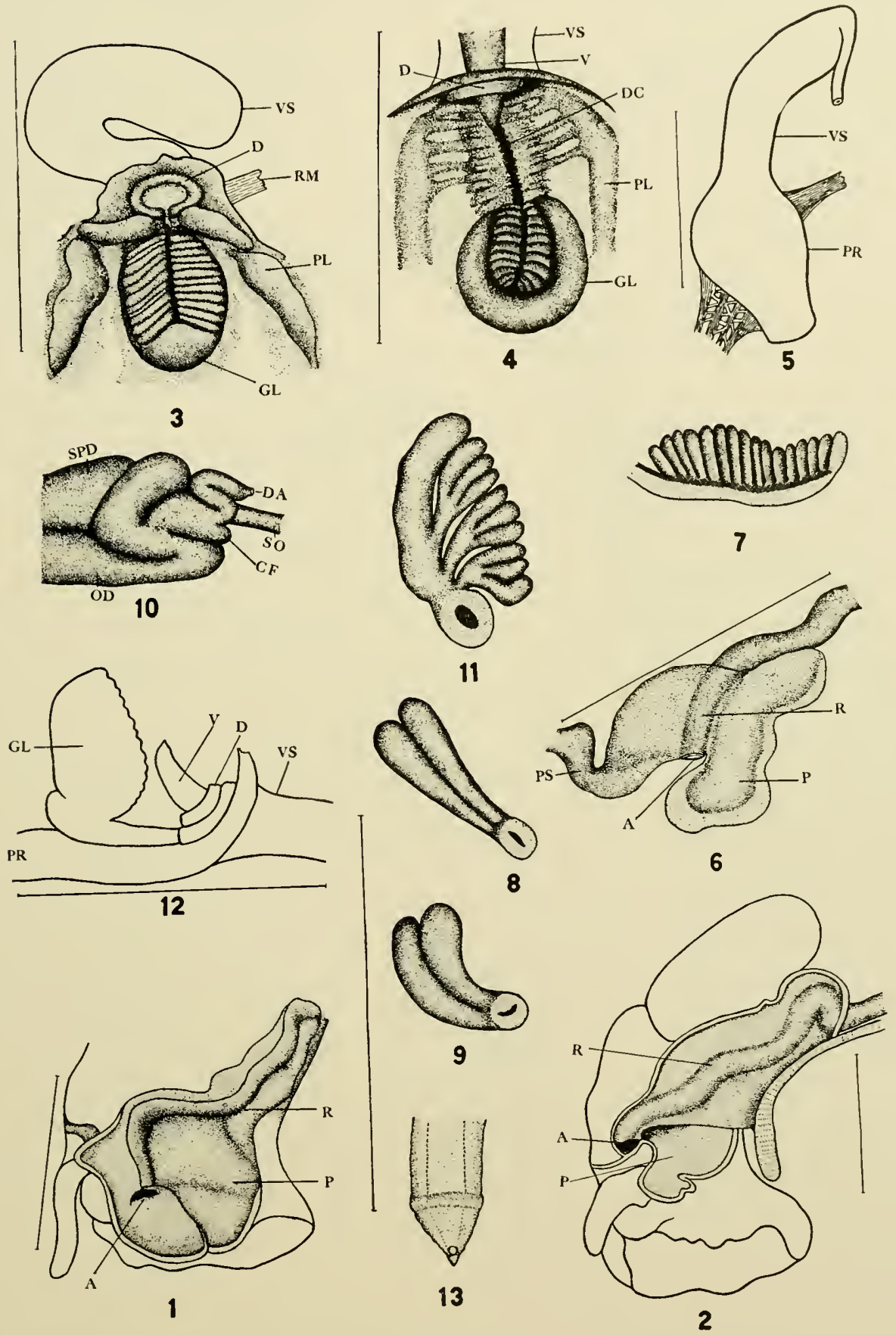

PLATE 42 


\section{PLA'TE 43}

\section{Promenetus umbilicatellus (Cockerell)}

From lake southwest of Mott Lake, Wainwright Park, Alberta; collected by Dr. Stiles. Received from the Canadian National Museum.

1. Genitalia dissected and organs separated.

2. Head showing pseudobranch and pneumostome.

3. Penial complex opened to show penial gland, verge, diaphragm, etc.

4. Penial complex in natural position.

5. Albumen gland from below.

6. Cross section of prostate and uterus about midway of length.

7. Portion of genitalia showing union of oriduct and sperm duct, also carrefour.

8. Cross section of orotestis. Note developing ova.

9. Penial gland showing channel-like duct, viewed from above.

10. Penial gland riewed from the side showing how gland is folded and base attached to preputium at lower end.

11. Section of penial gland.

12. Termination of verge showing small fleshy appendage at end.

Line near figure indicates $1 \mathrm{~mm}$. in length. Figures 5, 6, 7 , and 8 have same measurements as fig. 1 . Figures $9,10,11$, and 12 have same measurements as fig. 3 . 


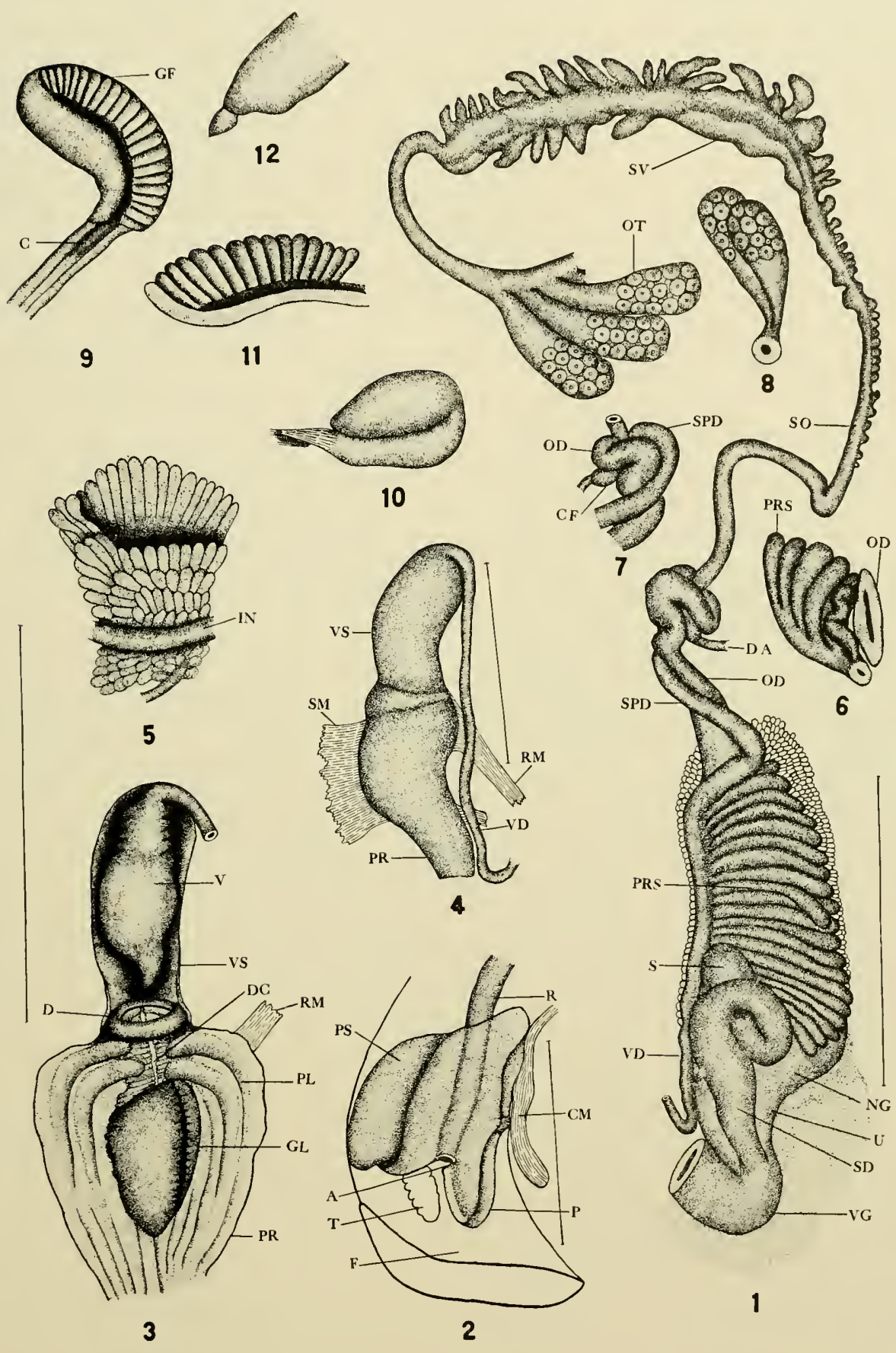

PLATE 43 
PLATE 44

\section{Kidney of Helisoma}

1. II. anceps (Menke). Gillespies Pond, Collinsville, Connecticut.

2. H. trivolvis (Say). Oneida Lake, New York.

3. H. corpulentum (Say). Lake of the Woods, Ontario, Canada.

4. H. scalare (Jay). Lake Butler, Florida.

5. H. duryi normale Pilsbry. Canal at Boynton, Florida.

\section{Sections of kidneys}

6. H. oregonense (Tryon). Tooele Co., Oregon. Near lower end of kidney:

7. H. anceps (Menke). Gillespies Pond, Collinsville, Connecticut. Above middle.

S. H. a. latchfordi (Pikbry). Meach Lake, Quebec, Canada. Near middle.

9. H. trivolvis (Say). Oneida Lake, New York. About middle.

10. H. t. macrostomum (Whiteaves). Bayfield, Wisconsin. About middle.

11. H. t. lentum (Say). New Orleans, Lonisiana. Lower end.

12. H. pilsbryi (F. C. Baker). Lake Chetek, Wisconsin. Near Middle.

13. If. truncatum (Miles). Winnebago Lake, Wisconsin. Tear middle.

14. H. magnificum (Pilsbry). Near Wilmington, North Carolina. Near middle.

15. H. corpulentum (Say). Lake of the Woods, Ontario. Near middle.

16. H. c. multicostatum F. C. Baker. Crooked Pine Lake, Ontario. Lower end.

17. H. p. infraearinatum F. C. Baker. Basswood River Rapids, Ontario. At middle.

1S. H. occidentale (Cooper). Klamath Lake, Oregon. Near middle.

19. H. o. depressum F. C. Baker. Klamath Lake, Oregon. Near middle.

20. If. traskï (Lea). Buena Vista Cunal, California. Near middle.

21. If. suberenatum (P. P. Carpenter). MeMurray, Skagit Co., Mashington. Near middle.

22. H. plexatum (Ingersoll). Columbine Lake. Colorado. Lower end.

23. H. horni (Tryon). Paul Lake, British Columbia. Near middle.

24. II. tenue californiense F. C. Baker. Shandon, California. Tear middle.

25. H. scalare (Jay). Lake Butler, Florida. Near middle.

26. H. duryi normale Pilsbry. Canal at Boynton, Florida. Near middle.

Line near figure indicates $1 \mathrm{~mm}$. in length. Arrow indicates point at which section was made. 
Illustrations of the Anatomy and of Shells
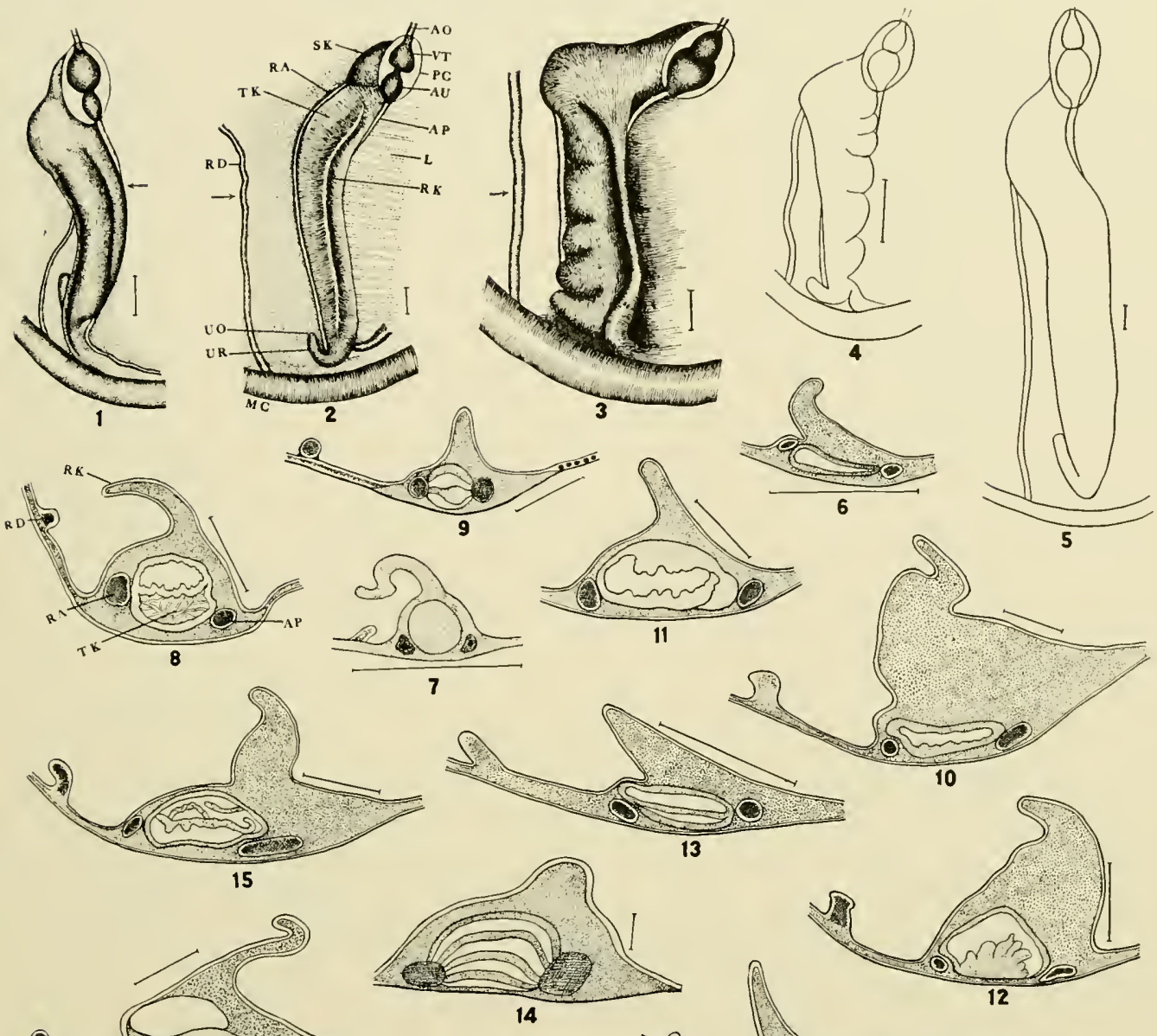

s
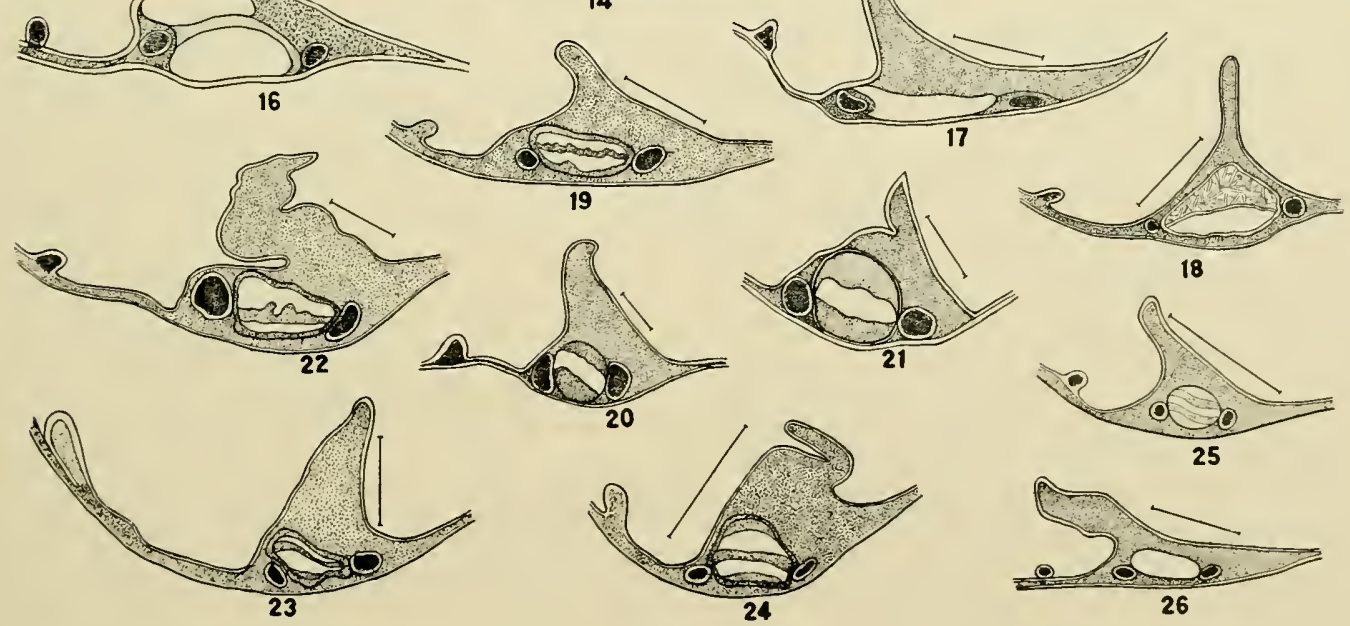

PLATE 44 


\section{PLATE 45}

\section{Kidneys of Planorbidae}

1. Australorbis glabratus (Say). Puerto Rico.

2. Carinifex ponsombyi E. A. Smith. Klamath Lake, Oregon.

3. Planorbula armigera (Say). Near Oshkosh, Wisconsin.

4. H. temue califormiense F. C. Biker. Near Redlands, Catifornia.

5. II. tenue califormiense F. C. Baker. Section at B in fig. 4.

6. H. temue ealiforniense F. C. Baker. Section at A in fig. 4.

7. Australorbis glabratus (Say). Section at $\mathrm{E}$ in fig. 1.

8. Australorbis glabratus (Say). Section at D in fig. 1.

9. Australorbis glabratus (Say). Section at C in fig. 1.

10. Australorbis glabratus (Say). Section at B in fig. 1.

11. Australorbis glabratus (Say). Section at A in fig. 1.

12. Carinifex ponsonbyi E. A. Smith. Section near middle.

13. Planorbula armigera (Say). Section near middle.

14. Four spherical bodies from ridge of kidney. Greatly enlarged.

15. Helisoma campanulatum wisconsinense (Winslow). Section through upper part.

16. H. campanulatum wisconsinense (Winslow). Section through middle.

17. H. campanulatum wisconsincnse (Winslow). Section through lower end.

18. Planorbarius corneus (Linn.). Section through lower end. From Poland.

19. Indoplanorbis exustus (Deshayes). Section near middle. From India.

Line near figure indicates $1 \mathrm{~mm}$. in length. Letters $\mathrm{A}, \mathrm{B}, \mathrm{C}, \mathrm{D}$, E, etc., indicate points of kichey through which sections have

been made and are figured. 
Illustrations of the Anatomy and of Shells
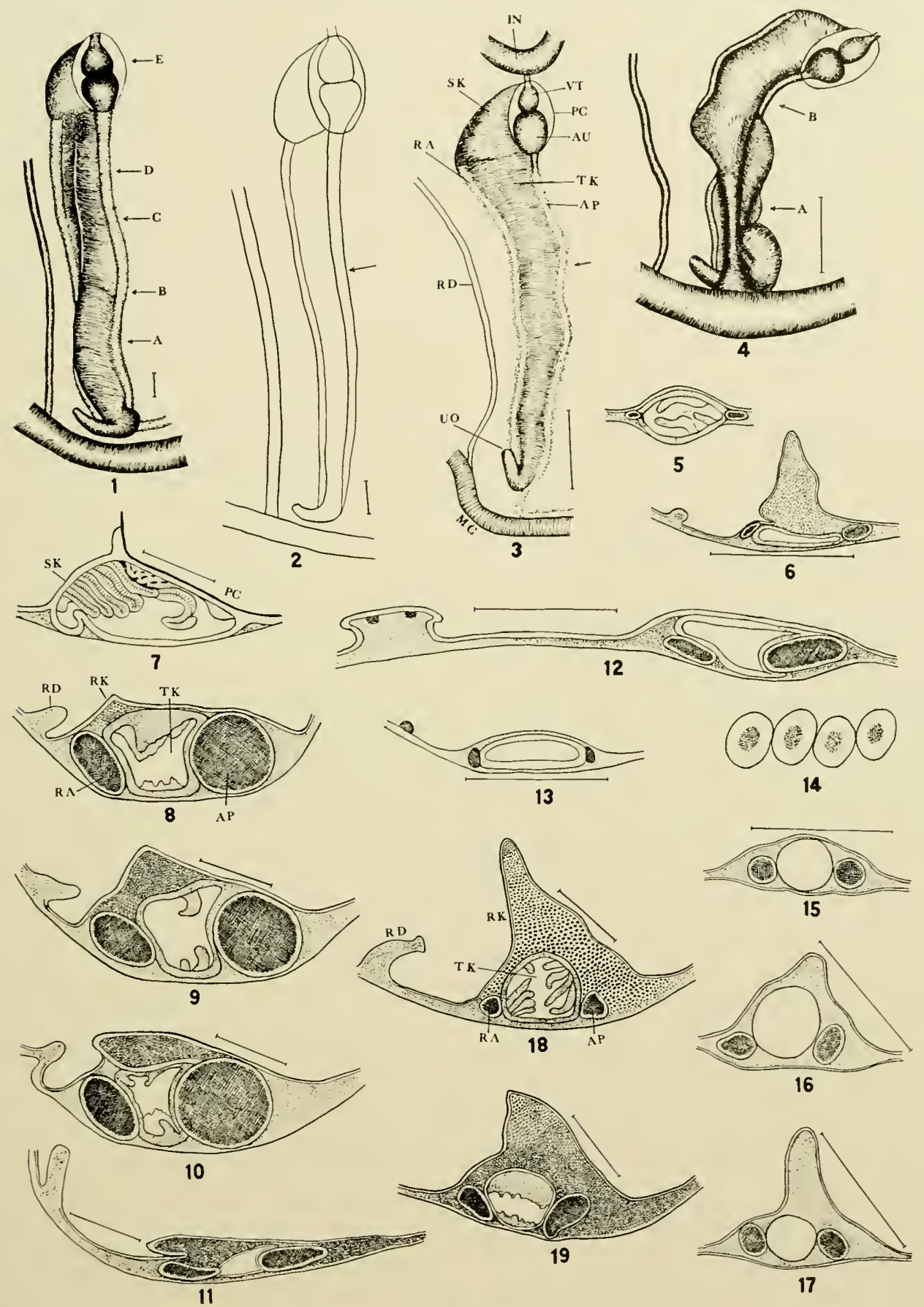

PLATE 45 


\section{PLATE 46}

\section{Kidneys of Planorbiclae}

1. Parapholyx effusa klamathensis F. C. Baker. Klamath Lake, Oregon.

2. P. cffusa klamathensis F. C. Baker. Section near middle.

3. Promenetus cacuous (Say). Winnebago Lake, near Oshkosh, Wisconsin.

4. Promenctus exacuous (Say). Section near middle. Line is $0.3 \mathrm{~mm}$. long.

5. Menctus dilatatus (Gould). Unionville, Comnecticut.

6. Menetus dilatatus (Gould). Section near middle. Line is $0.3 \mathrm{~mm}$. long.

7. Menctus cooperi eallioglyptus (Vanatta). Vancouver Island, British Columbia.

8. H. eooperi callioglyptus (Vanatta). Section near middle.

9. Planorbis planorbis (Linn.). Near Warsaw, Poland.

10. Planorbis planorbis (Linn.). Section near middle.

11. Tropicorbis riisei (Dunker). Puerto Rico.

12. Tropieorbis riisci (Dunker). Section near middle.

13. Tropieorbis havanensis (Pfeiffer). Section near midclle.

14. Dre penotrema hoffmani F. C. Baker. Isabela, Puerto Rico.

15. Dicpanotrema hoffmani F. C. Baker. Section at point indicated by arrow.

16. Diepanotrema lucidum (Pfeiffer). Section near middle.

17. Hippeutis complanatus (Linn.). Near Warsaw, Poland.

18. Hippeutis complanatus (Linn.). Section at point indicated by arrow. Line equals $0.5 \mathrm{~mm}$. in length.

19. Bathyomphalus contortus (Lim.). Near Warsaw, Poland.

20. Bathyomphalus contortus (Limn.). Section at point indicater by arrow. Line equals $0.5 \mathrm{~mm}$. in length.

Except where otherwise mentioned the line near the figure indicates $1 \mathrm{~mm}$. in length. 
Illustrations of the Anatomy and of Shells
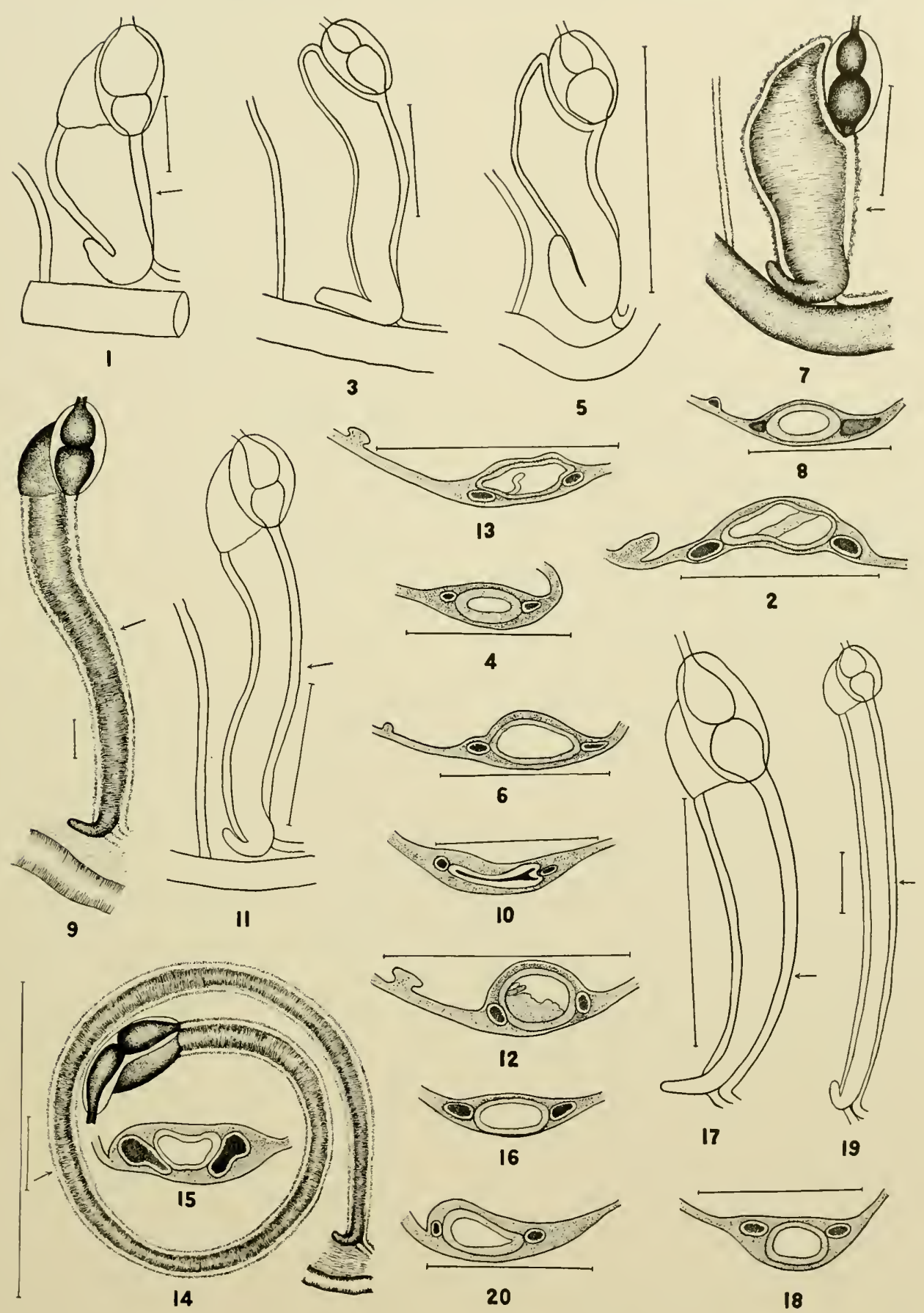

PLATE 46 


\section{PLATE 47}

\section{Kidneys of Planorbidae}

1. Gyraulus parvus (Say)). Winnebago Lake, Wisconsin.

2. Gyraulus circumstriatus (Tryon). Wainwright Park, Alberta.

3. Gyraulus deflectus obliquus (Dehay). Near Quebec, Canarla.

4. Gyraulus vermicularis (Gould). Near San Franciseo, California.

5. Gyraulus parvus (Say). Section near middle. Line equals $0.5 \mathrm{~mm}$.

6. Gyraulus circumstriatus (Tryon). Section near middle. Line equals $0.5 \mathrm{~mm}$.

7. Gyraulus vermicularis (Could). Section near middle. Line equals $0.5 \mathrm{~mm}$.

8. Gyraulus convexiusculus (Hutton). India. Section near middle.

9. Gyraulus similaris (F. C. Baker). Section near niddle.

10. Gyraulus deflectus obliquus (DeKay). Section near middle.

11. Gyraulus latestomus F. C. Baker. Section below middle.

Figures 6 to 11 have same magnification as fig. 5 .

12. Anisus vortex (Linn.). Near Warsaw, Poland.

13. Anisus spirorbis (Linn.). Near Warsaw, Poland.

14. Anisus vortrx (Linn.). Section near middle. Line equals $0.5 \mathrm{~mm}$.

15. Anisus lencostomus (Millet). Section near midclle. Line cquils $0.5 \mathrm{~mm}$.

16. Anisus spriorbis (Linn.). Section near middle. Line equals $0.5 \mathrm{~mm}$.

17. Gyraulus comvexiusculus (Hutton). Inclia.

18. Gyraulus hirsutus (Gould). Canada.

19. Gyraulus hirsutus (Could). Section below midulle.

20. Armiger crista (Linn.). Wisconsin.

21. Armiger crista (Linn.). Section near middle. Line equils $0.5 \mathrm{~mm}$.

22. Segmentina nitrda (Mïller). Near Warsaw, Poland.

23. Segmentina nitida (Mïler). Section below mirldle. I ine equals $0.5 \mathrm{~mm}$.

24. Polypylis hemisphacrula (Benson). Peiping. China.

25. Polypylis hemisphaerula (Benson). Section near midelle. Line oquals $0.5 \mathrm{~mm}$. 26. Intha capitis Annundale. South Shan State, Burma.

27. Intha capitis Annandale. Section below middle. Line equal: $0.25 \mathrm{~mm}$.

Inless otherwise stated the line near the figure indieates 1 mun. in length. 
Illustrations of the Anatomy and of Shells
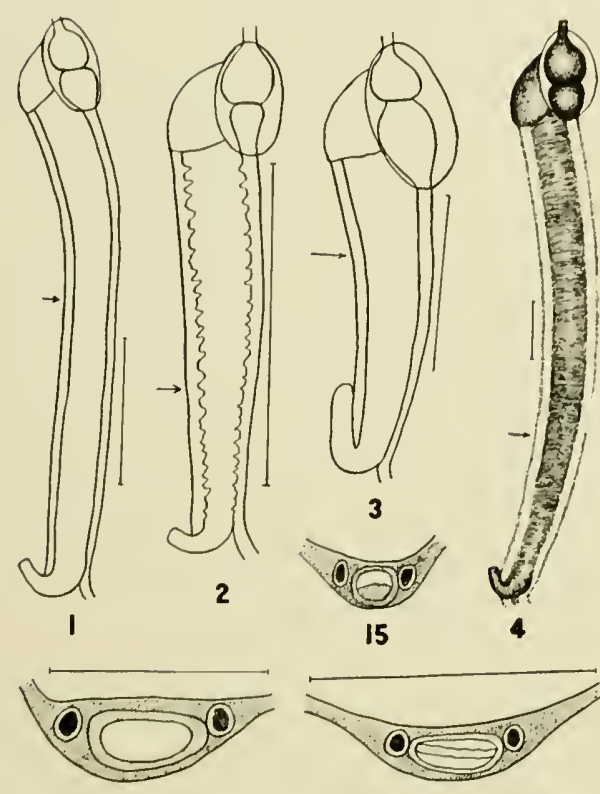

5

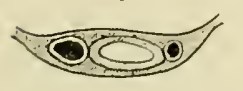

6
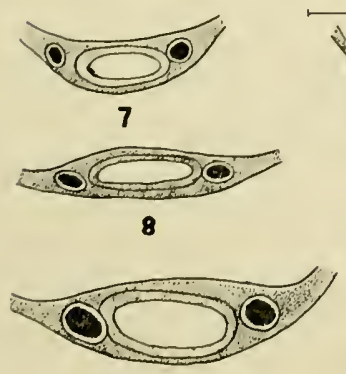

9
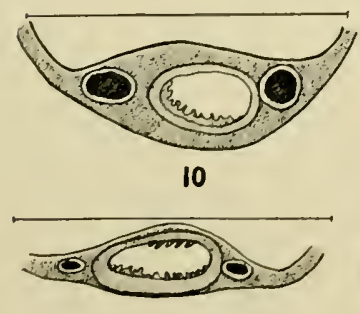

II
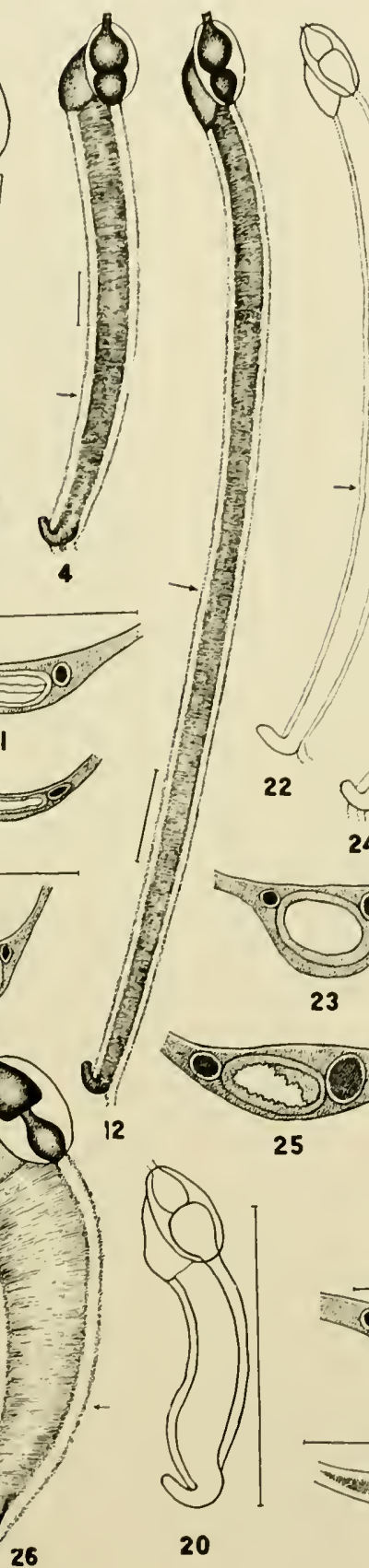

40
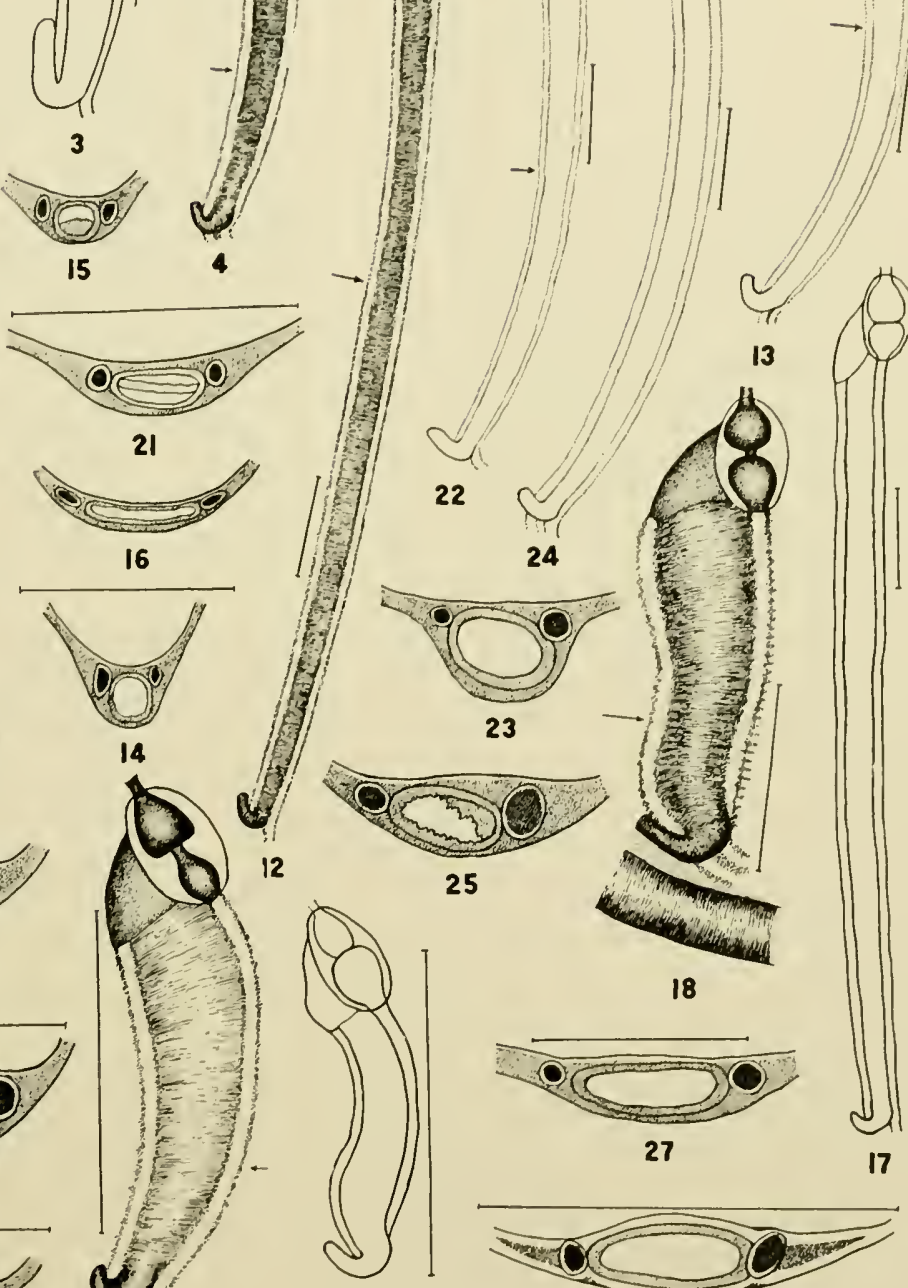

25
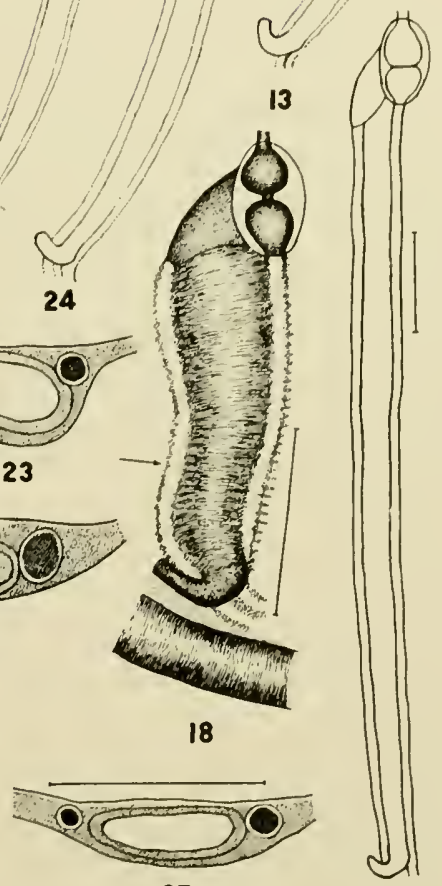

17

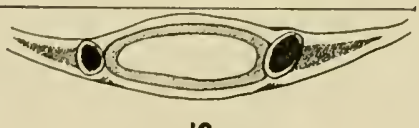

19

PLATE 47 


\section{PLATE 4S}

\section{Digestive System of Planorbidae}

1. Helisoma trivolvis (Say). Entire digestive system except liver. From above.

2. Helisoma trivolvis (Say). Region of the stomach from below.

3. Carimifex ponsonbyi E. A. Smith. Region of stomach from below.

4. Promenetus exacuous (Say). Region of stomach from above.

5. Piomenetus exacuous (Say). Region of stomach from below.

6. Planorbis planorbis (Linn.). Region of stomach from above.

7. Planorbis planorbis (Linn.). Region of stomach from below.

8. Bathyomphalus contortus (Linn.). Portion of digestive system from above.

9. Australorbis glabratus (Say). Region of stomich from above.

10. Australorbis glabratus (Say). Region of stomach from below.

11. Drepanotrema lucidum (Pfeiffer). Region of stomach from above.

12. Hippentis complanatus (Linn.). Region of stomach from above.

13. Gyraulus albus (Mïller). Region of stomach from above.

14. Gyraulus parvus (Say). Region of stomach from above.

15. Armiger crista (Linn.). Region of stomach from above.

16. Segmentina nitida (Miiller). Region of stomach from above.

17. Helisoma anceps (Menke). Nerves and blood ressels to penial complex. Nerve from left cerebral ganglion.

1S. Nerve ring of Helisoma trizolize (Siy), from above.

Line near figure indicates $1 \mathrm{~mm}$. in length 
Illustrations of the Anatomy and of Shells
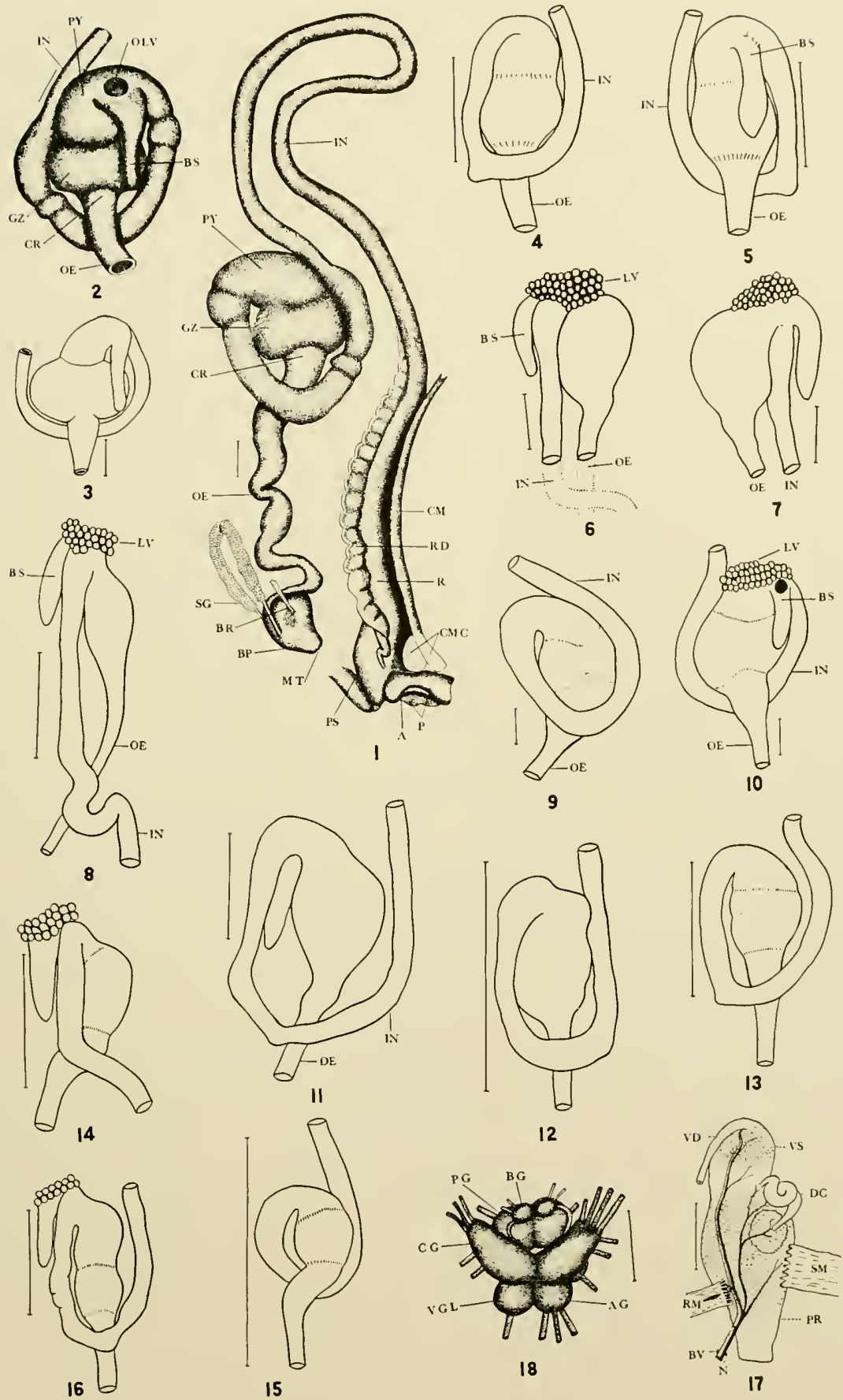

PLATE 48 
PLATE 49

\section{Jaws of Planorbidae}

1. Helisoma anceps (Menke). Chetek Lake, Wisconsin.

2. If elisoma trizolvis (Say). Devils Lake, Wisconsin. Small fig. indicates striation.

3. Helisoma truncatum (Miles). Oshkosh, Lake Winnebago, Wisconsin.

4. Helisoma scalare (Jay). Lake Butler, Florida.

5. Helisoma pilsbryi (F. C. Baker). Chetek Lake, Wisconsin.

6. Helisoma oregoncuse (Tryon). Tooele Co., Utah.

7. Helisoma subcrenatum (P. P. Carpenter). Ciypsum, Colorado. Superior jaw.

8. H. pilsbryi infracarinatum F. C. Baker. Rideau River, Ontario. Superior jaw.

9. Helisoma homi (Tryon). Paul Lake, British Columbia.

10. Helisoma plexatum (Ingersoll). Grand Mesa, Colorado. Superior jaw.

11. H. campanulatum smithi (F. C. Baker). Douglas Lake, Michigan.

12. Helisoma traskii (Lea). Outlet of Kern Lake, California. Superior jaw.

13. Helisoma occidentale (Cooper). Klamath Lake, Oregon. Superior jaw.

14. H. duryi normale Pilsbry. Forty miles west of Miami, Florida. Superior jaw.

15. Helisoma corpulentum (Say). Bamiji Lake, Ontario, Canada.

16. Helisoma magnificum (Pilsbry). Near Wilmington, North Carolina.

17. Carinifex jaeksonensis J. Henderson. Jackson Lake, Wyoming. Jaw and cartilage from the side.

18. Carinifex jacksonensis J. Henderson. Jaw from abore.

19. Carinifex ponsonbyi E. A. Smith. Klamath Lake, Oregon. Jaw and cartilage from below.

20. Helisoma campanulatum smithi (F. C. Baker). Douglas Lake, Michigan. Vertical striation on jaw. Highly magnified.

Line at right of fig. 1 indicates $1 \mathrm{~mm}$. in length. Line at lower extreme left is for figs. 18 and 19 and represents $0.5 \mathrm{~mm}$. in length. Middle line is for fig. 6 . Line at right is for figs. $2,3,4,5$, and

7 to 16 . Figure 17 is diagrammatic. 
Illustrations of the Anatomy and of Shells
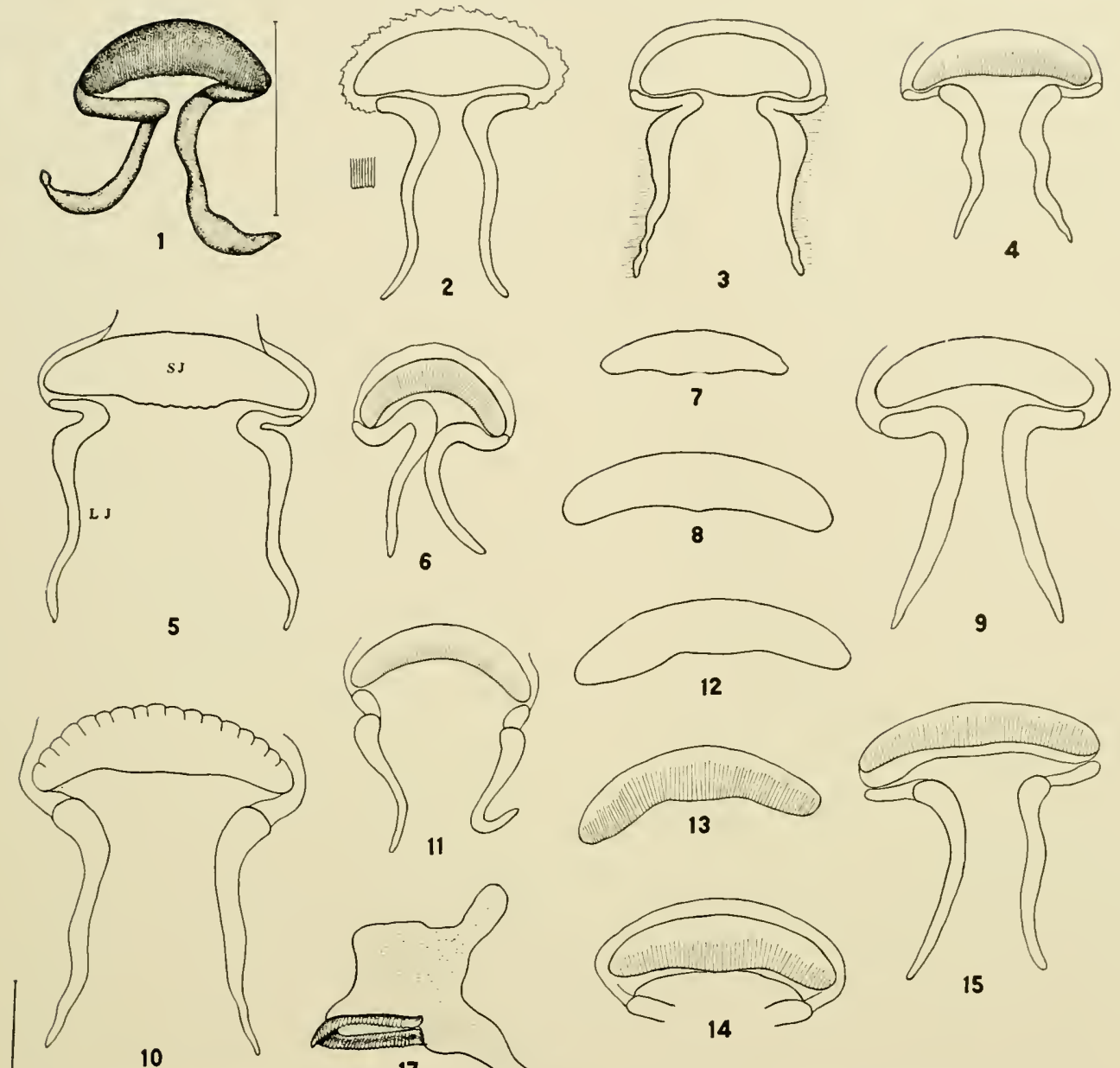

9
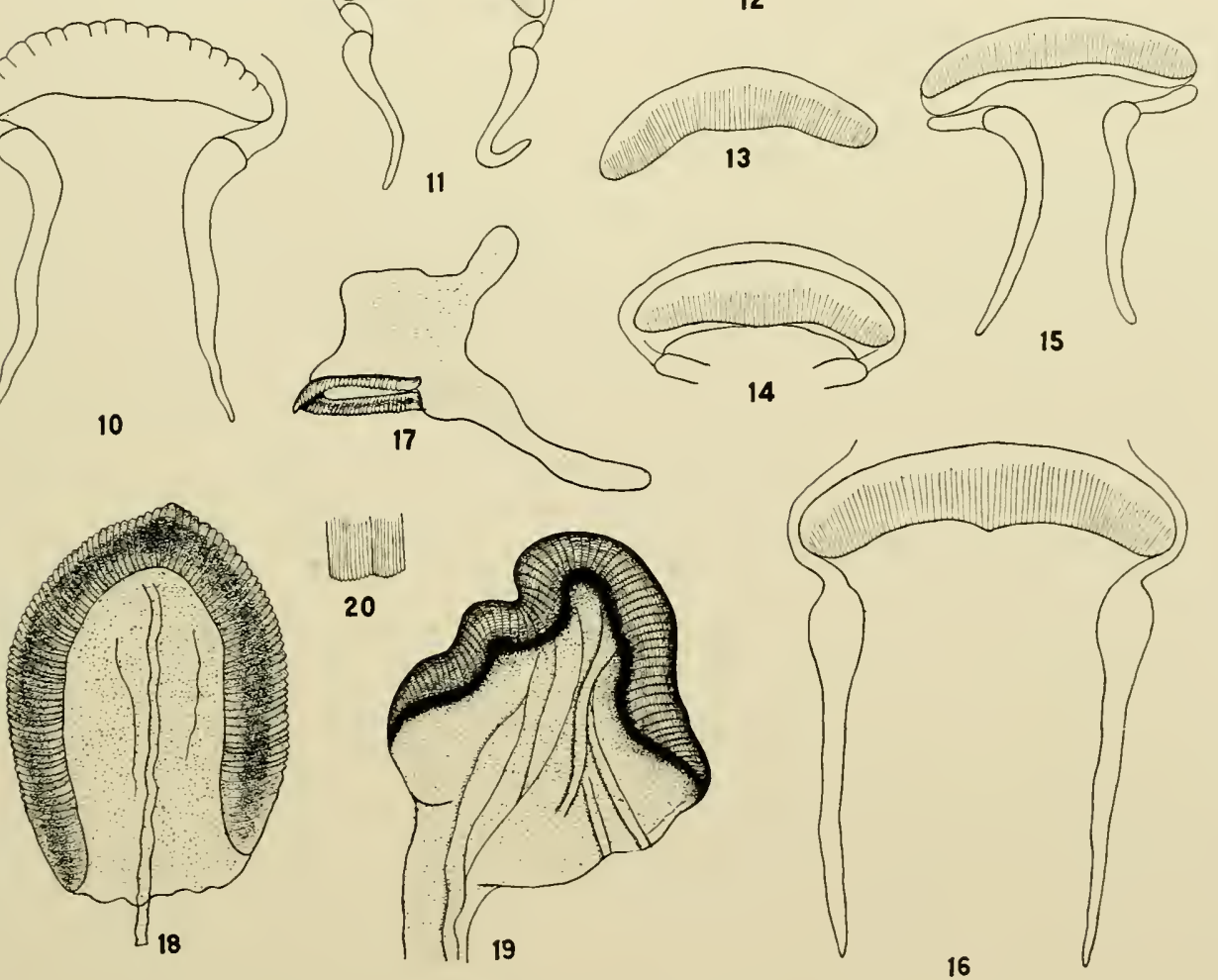

PLATE 49 


\section{Jaws of Planorbidae}

1. Ilelisoma tenue califomiense F. C. Baker. Shandon, California.

2. Planorbula armigcra (Say). Murphy Creek, near Madison, Wisconsin.

3. Planorbula jenksii (H. F. Ciurpenter). Unionville, Connecticut.

4. Parapholyx effusa klamathensis F. C. Baker. Klamath Lake, Oregon.

5. Parapholyx effusa dingonalis J. Henderson. Crater Lake, Oregon.

6. Menetus sampsomi (Ancey). Near Stanton, Missouri.

7. Wenetus cooperi callioglyptus (Vinatta). Vancouver Island, British Columbia.

8. Promenctus exncuous (Say). Winnebago Lake, Wisconsin.

9. Wenetus dilatatus (Gould). Unionville, Connecticut.

10. Indoplanorbis ciustus (Deshayes). North Shan State, Burnat.

11. Tropicorbis obstructus (Morelet). New Orleans, Louisiana. Superior jaw.

12. Tropicorbis rïsci (Dunker). Puerto Rico.

13. Australorbis glabratus (Say). Puerto Rico.

14. Plenorbarius corneus (Linn.). Near Warsaw, Poland.

15. Promenctus umbilicatellus (Cockerell). Wainwright Park, Alberta.

16. Gyraulus parvus (Say). Winnebago Lake, Wisconsin.

17. Gyraulus hirsutus (Gould). Lake Nipissing, Ontario, Canada.

18. Gyraulus deflectus obliquus (DeKaỵ). Taylor Lake, Quebec, Canada.

19. Gyraulus vermicularis (Gould). Near San Francisco, California.

20. Armiger crista (Linn.). Wisconsin.

21. Planorbis planorbis (Linn.). Near Warsaw, Poland.

22. Gyraulus circumstriatus (Tryon). Wainwright Park, Alberta.

23. Intha capitis Annundale. Burma.

24. Segmentina nitida (Miiller). Near Warsaw, Poland.

25. Anisus spirorbis (Linn.). Near Warsaw, Poland

26. Drepanotrema hoffmani F. C. Baker. Puerto Rico.

27. Drepanotrema lucidum (Pfeiffer). Cuba.

28. Gyraulus albus (Müller). Near Warsaw, Poland.

Figures are greatly enlarged. Sizes are disproportionate. 
Illustrations of the Anatomy and of Shells
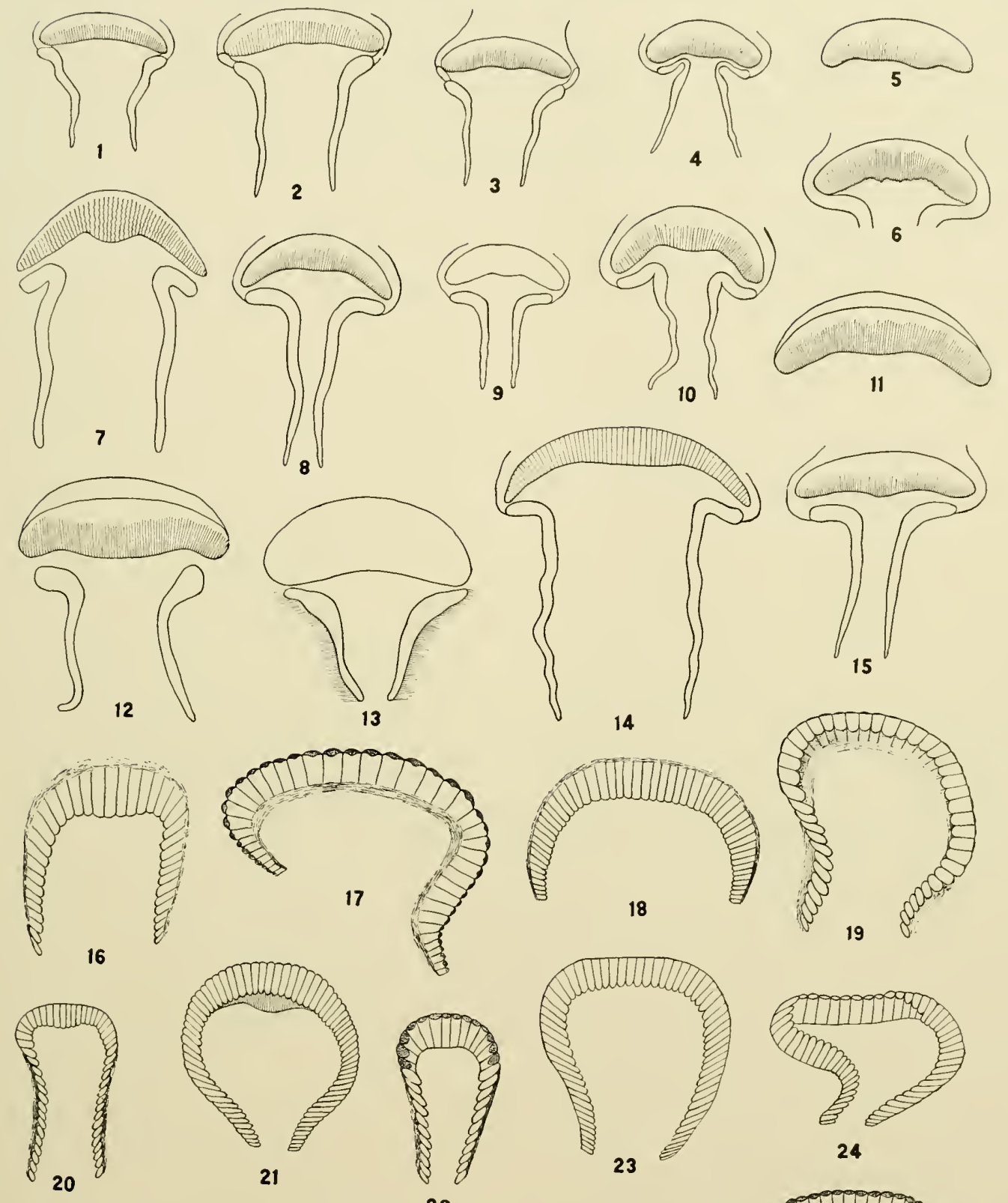

20

22

p
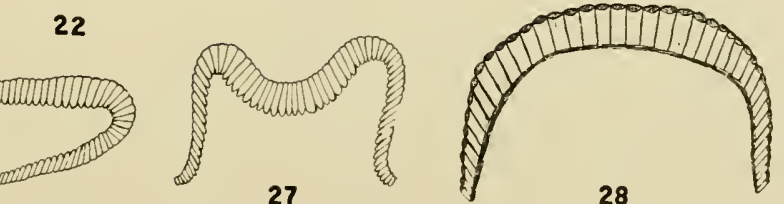

PLATE 50 


\section{PLATE 51}

\section{Development of Helisoma scalare (Jay)}

1. Egg capsule containing 28 eggs, observed on March 1, 1932. Each egg is marked to correspond with the numbered figures below. Line near figure indicates $1 \mathrm{~mm}$. in length.

2. The 24-cell stage of segmentation in egg No. 7. Mareh 7.

3. Gastrula stage of segmentation in egg No. 7. March 8.

4. Post-trochophore stage in egg No. 11. March 4.

5. Post-trochophore stage in egg No. 11. March 5.

6. Veliger stage of embryo in egg No. 11. March 9.

7. Veliger stage of embryo in egg No. 8. Front view. March 9.

8. Veliger stage of embryo in egg No. 8. Side view. March 9.

9. Veliger stage of embryo in egg No. 8. Top view. March 10.

10. Embryo in egg No, 3. March 12.

11. Embryo in egg No. 1 showing heart and stomach. March 11.

12. Young snail in egg No. 3. March 14. A similar young snail was observed in egg No. 20 on March 14. Shell growth distinct.

13. Young snail just out of egg No. 1. March 15.

14. Young snail two days out of egg No. 1. March 16. Shell now shows both growth lines and spiral striae.

Line at lower left indicates $1 \mathrm{~mm}$. in length 

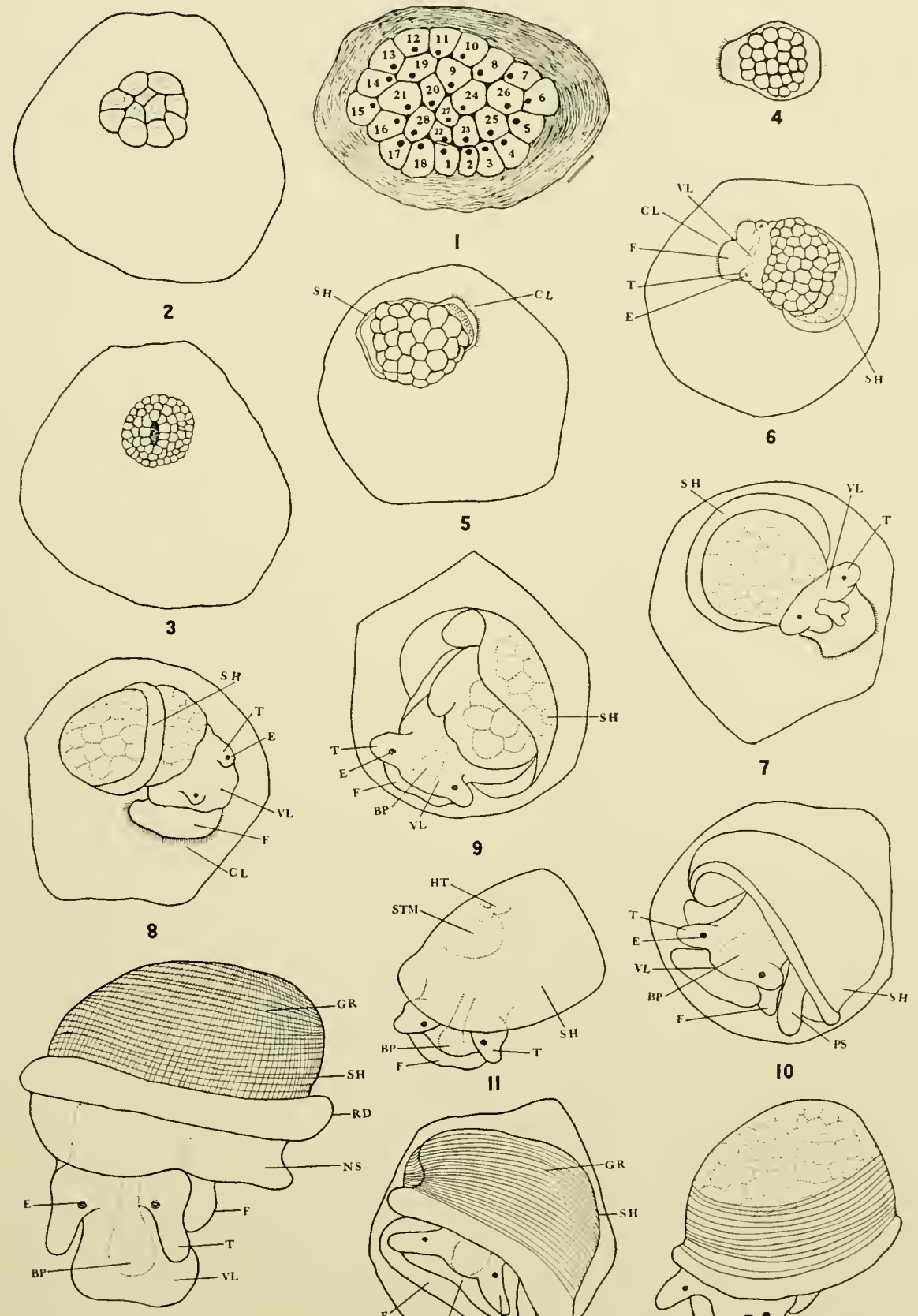

14
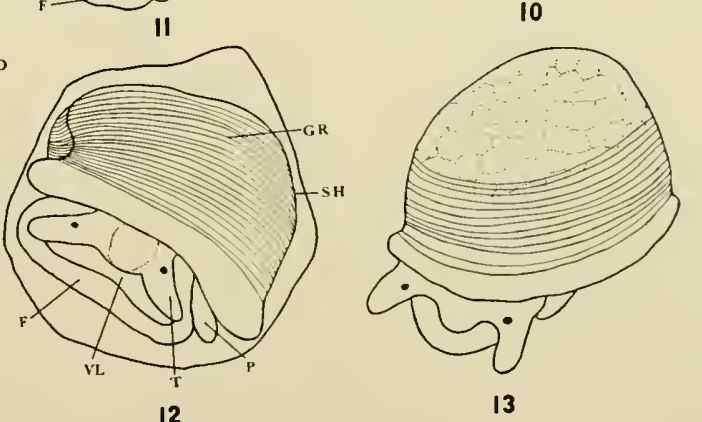

PLATE 51 
PLATE 52

\section{Nidification in Planorbirlae}

1-3. Helisoma scalare (Jay). Lake Butler, Florida.

1. Five eggs laid March 13, 1931.

2. Fourteen eggs laid April 1, 1931.

3. Ten eggs laid April 2, 1931.

4-5. Helisoma trivolvis lentum (Say). New Orleans, Louisiana.

4. Twenty eggs laid June 5, 1933.

5. Ten eggs laid May 27, 1933.

6-S. Helisoma duryi normale Pilsbry. Gainesville, Florida.

6. Two eggs laid Dec. 25, 1931.

7. Three eggs laid Dec. 26, 1931.

8. Four eggs laid Jan. 17, 1932.

9-11. Helisoma duryi eudiscus Pilsbry. Silver Springs, Florida.

9. Five eggs laid Dec. 13, 1931.

10. Nine eggs laid Feb. 6, 1932.

11. Twelve eggs laid Feb. 10, 1932.

12. Helisoma duryi normale Pilsbry. Tamiami Trail, 40 miles west of Miami, Florida. 12. Sixteen eggs laid Jan. 17, 1932.

13. Helisoma traskii (Lea). Buena Vista Canal, outlet of Kern Lake, California.

13. Alcoholic specimen with 50 eggs laid on adult shell.

14-16. Gyraulus circumstriatus (Tryon). Wainwright Park, Alberta.

14. Nucleated orum from orotestis.

15. Spermatozoa from orotestis. Typical (eupyrene) spermatozoa as seen in active group.

16. Eupyrene spermatozoa from the side and from abore.

Line near figs. 1-13 indicates $1 \mathrm{~mm}$. in length. Line near figs. 14-16 indicates 25 microns in length. 


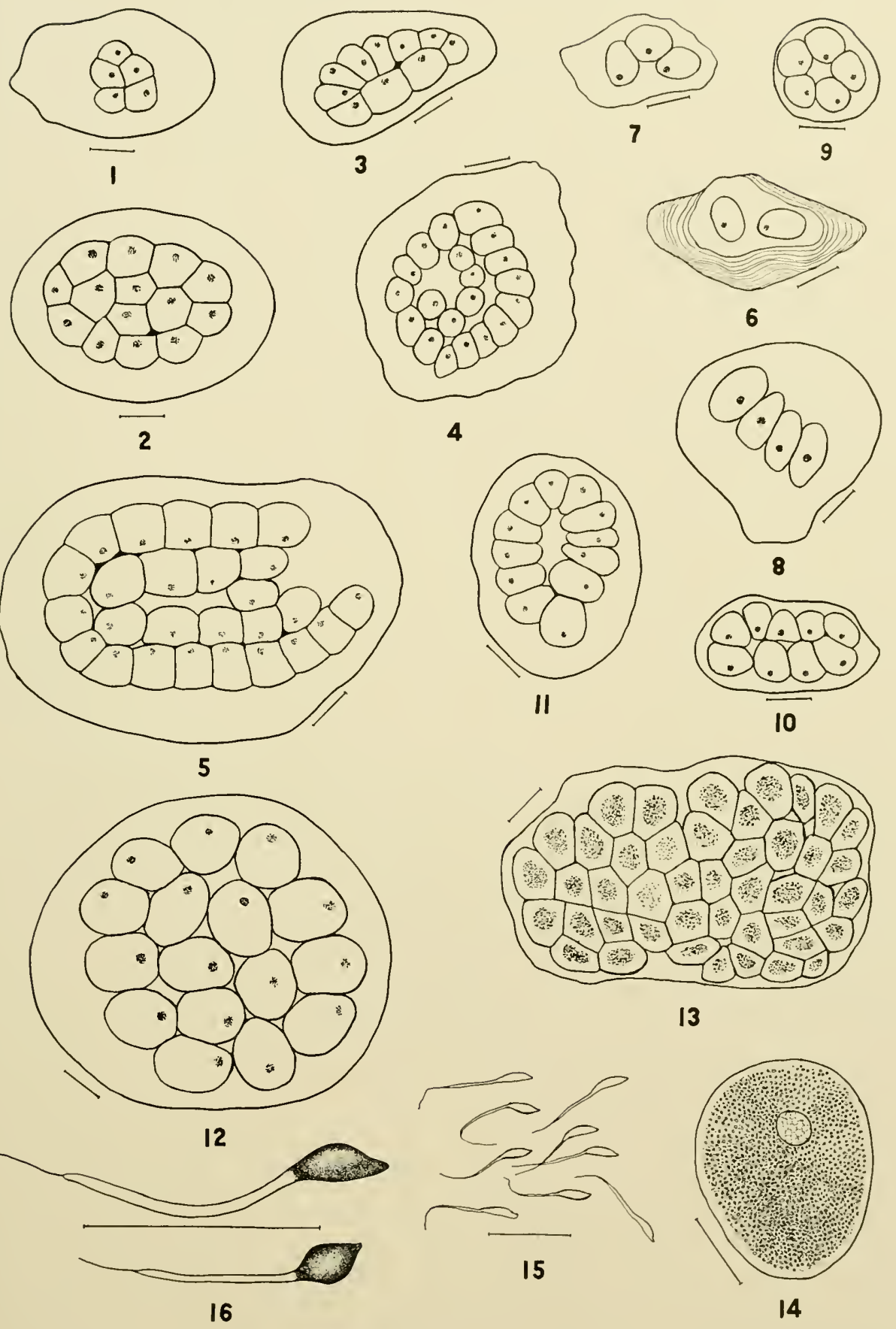

PLATE 52 


\section{PLATE 53}

\section{Radulae of Helisoma}

In the plates of radulae, the number under the central tooth (as $15,80,98,50$, and 75 on this plate) indicates the number of the transverse row, counting from the front end of the radula. The numbers following indicate the number of the tooth in this row, counting from the central tooth, the first lateral tooth being number 1 . The line at the lower part of the plate indicates 25 microns.

1. Helisoma anceps (Menke). Maple River, Michigan.

15, center tooth; $1-5$, lateral teeth; 6 , 7 , intermediate teeth; 8 -14, marginal teeth.

2. Helisoma anceps (Menke). Chautauqua Lake, New York.

80 , center tooth; $1-5$, lateral teeth; $6-8$, intermediate teeth; 9 -13, marginal teeth. 118 , center tooth (of 118th row) with first left marginal beside it.

3. Helisoma aneeps (Menke). Unionville, Connecticut.

98 , center tooth; 1,2 , lateral teeth; 6,7 , intermediate teeth; 8,9 , marginal teeth on right side; 11-16, marginal teeth on left side of row. 90 , 90th row, center tooth; 5, lateral tooth with two ectocones; 8 , intermediate tooth; 9,10 , marginal teeth.

4. Helisoma anceps sayi F. C. Baker. Bayfield, Wisconsin.

50 , center tooth in 50th row; $1-5$, lateral teeth; 6,7 , intermediate teeth; $8-14$, marginal teeth. 75, 75th row. pathologic center tooth; 1-5, pathologic lateral teeth. 

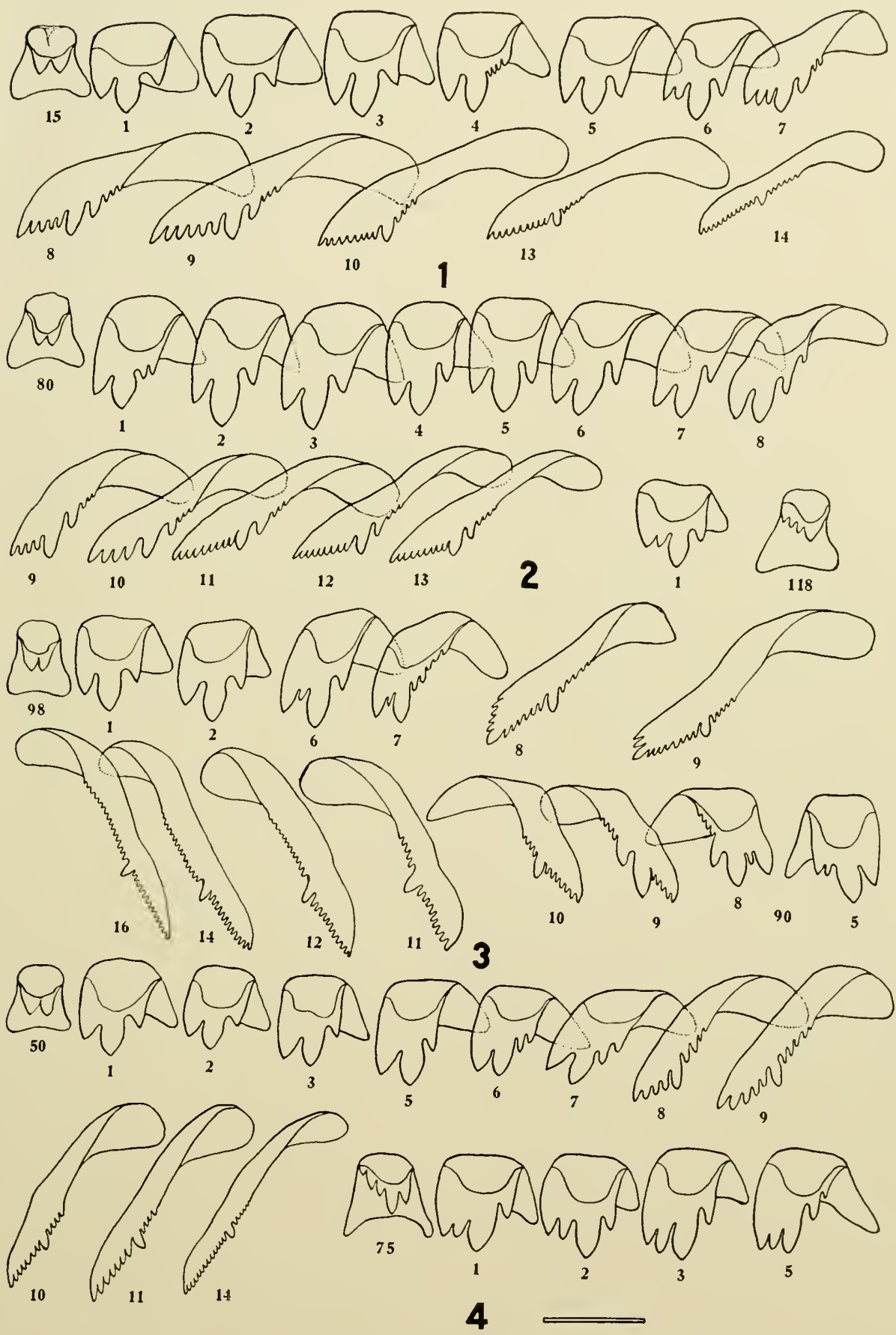

PLATE 53 


\section{PLATE 54}

\section{Radulae of Helisoma}

See remarks on plate 53. Line at bottom of plate indicates 25 microns in length.

1. Helisoma anceps percarinatum (Walker). Douglas Lake, Michigan.

85, center tooth; 1-6, lateral teeth; 7-9, intermediate teeth; 10-23, marginal teeth. 100 , 100th row, center tooth; 1-3, lateral teeth, pathologic (2 entocones); 9 . intermediate tooth; 10 , marginal tooth.

2. Helisoma anccps royalense (Walker). Bamiji Lake, Ontario, Canada.

60 , center tooth; 1-6, lateral teeth; $7-9$, intermediate teeth; 10-19, marginal teeth.

3. Helisoma anceps cahni F. C. Baker. Big Muskallonge Lake, Wisconsin.

60 , center tooth; $1-6$, lateral teeth; $7-9$, intermediate teeth; 10-18, marginal teeth.

4. Helisoma anceps latchfordi (Pilsbry). Meach Lake, Quebec, Canada.

51 , center tooth; $1-6$, lateral teeth; $7-9$, intermediate teeth; 10-26, marginal teeth. 60 , an abnormal center tooth from another nembrane, with accessory lateral cusps above the normal center cusps. 
Mand and
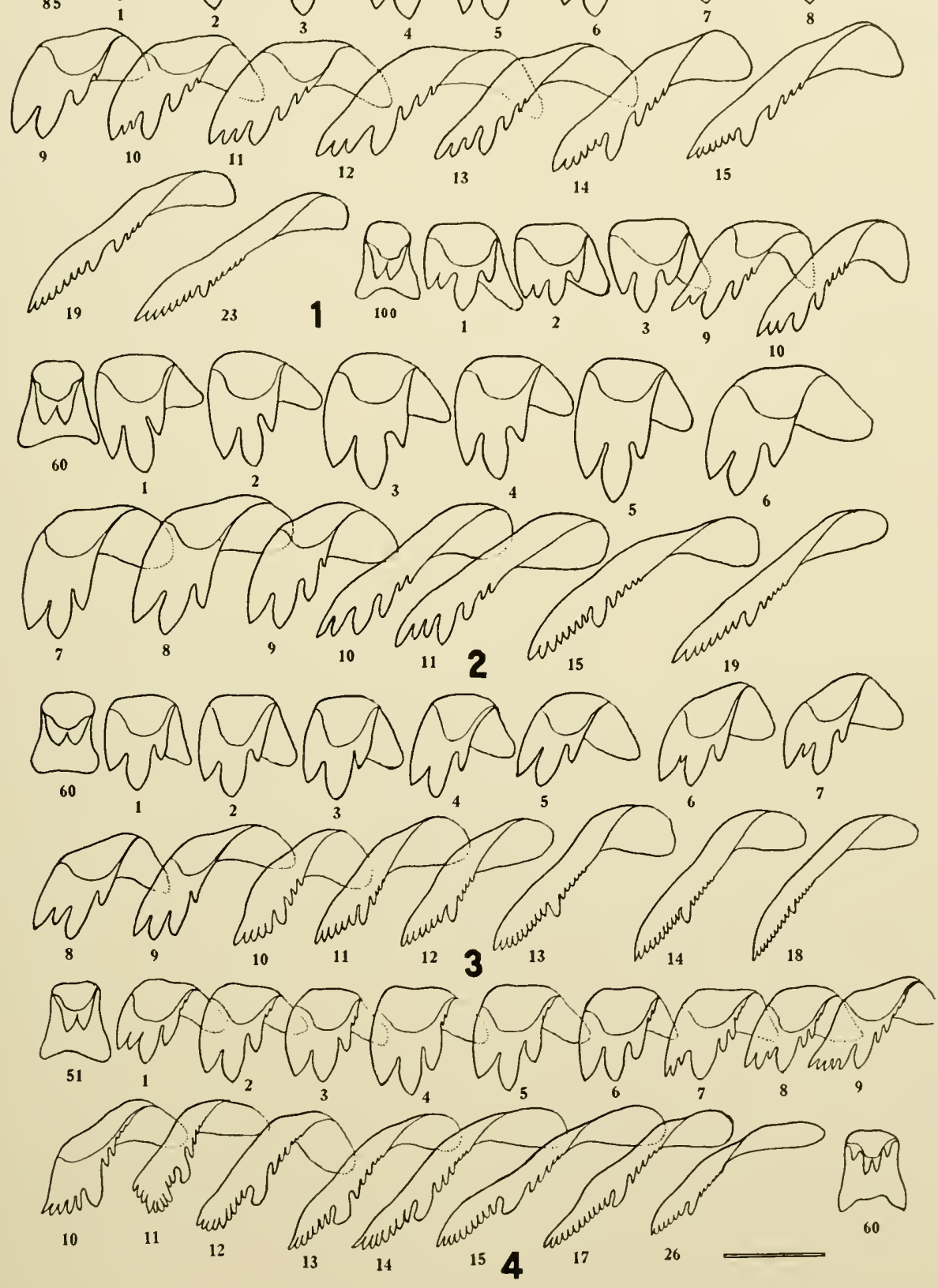

PLATE 54 


\section{PLATE 5j}

\section{Radulae of Helisoma}

See remarks on plate 53 . Line at bottom of plate indicates 25 microns in length.

1. Helisoma trivolvis (Say). Oneida Lake, New York.

60 , center tooth; $1-7$, lateral teeth; 8-10, intermediate teeth; 11-18, marginal teeth.

2. Helisoma trivolvis (Say) $=$ pseudotrivolvis F. C. Baker, near lentum Say. From Reelfoot Lake, Tennessee.

150, center tooth; $1-\overline{7}$, lateral teeth; 8-10, intermediate teeth; 11-13, marginal teeth.

3. Helisoma trivolvis lentum (Say) $=$ pseudotrivolvis F. C. Baker. Reelfoot Lake, Tennessee.

107 , center tooth; $1-\overline{7}$, lateral teeth; $8-10$, intermediate teeth; $11-14$, marginal teeth; 50,50 th center tooth of another row.

4. Helisoma trivolvis (Say). Sturgeon Bay, Wisconsin.

70, center tooth; 1-6, lateral teeth; $\mathbf{7}-11$, intermediate teeth; 13,14 , marginal teeth.

5. Helisoma chautauquense F. C. Baker. Chautauqua Lake, New York.

102 , center tooth; 1-7, lateral teeth; 8-11, intermediate teeth; 12-15, marginal teeth.

6. Helisoma trivolvis lentum (Say). New Orleans, Louisiana.

96, center tooth; 1-8, lateral teeth; 9-11, intermediate teeth; 12-15, marginal teeth.

7. Itelisoma trivolvis lentum (Say). New Orleans, Louisiana.

16-25, marginal teeth; 4, 4th lateral tooth from another row, with two entoconic cusps. 


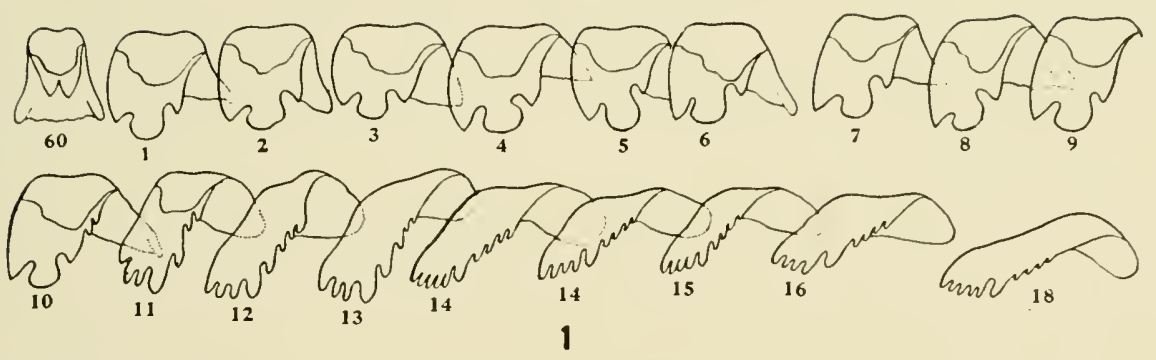

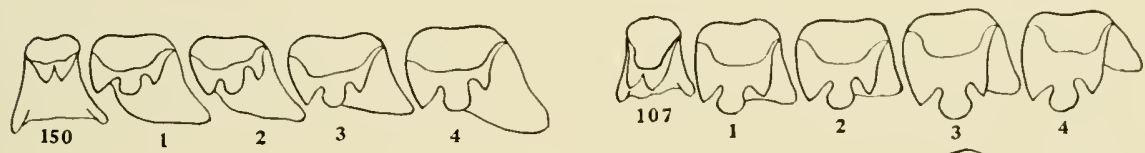

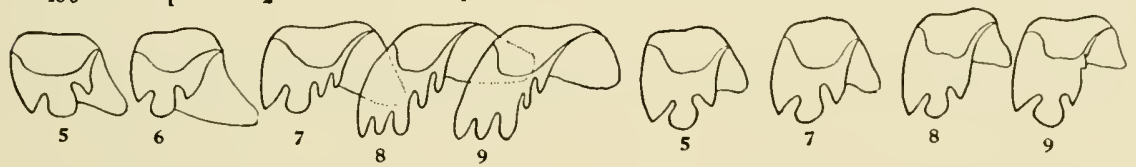

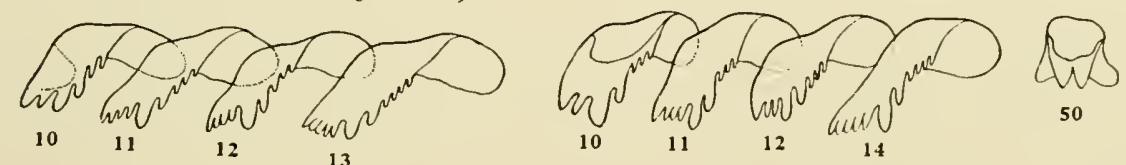

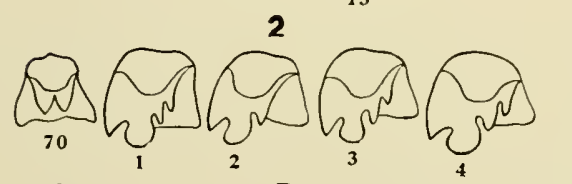

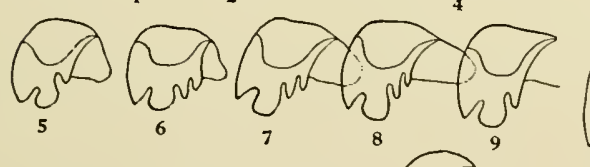
PRAR

4

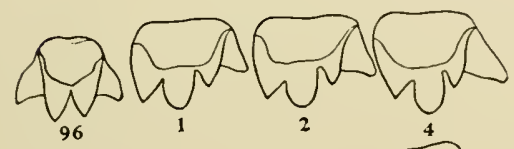
añána

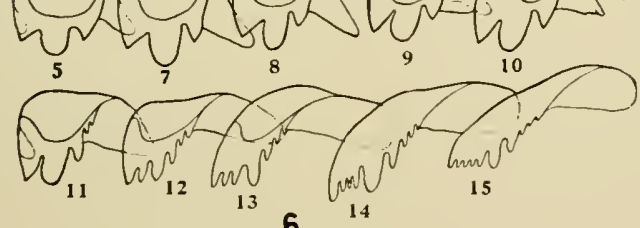

PLATE 55
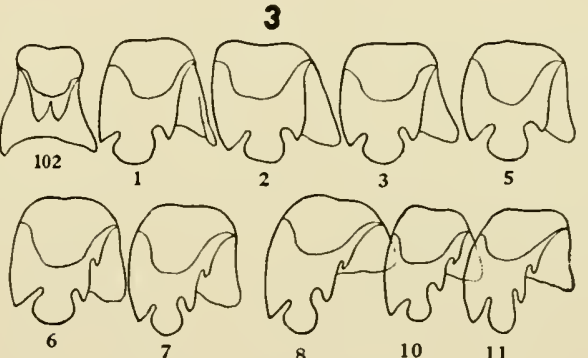

$\cos \operatorname{lo}^{N} \operatorname{lon} N^{N} \ln N^{N}$

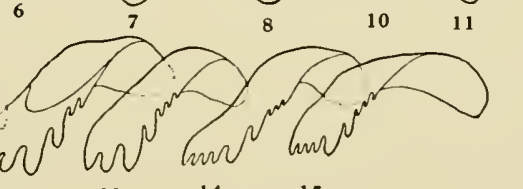

$12 \quad 13 \quad 14 \quad 15$

\section{5}

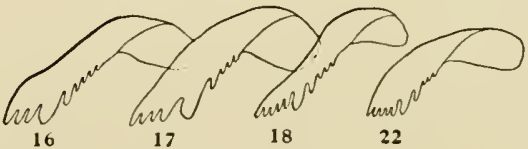




\section{PLATE 56}

\section{Radulae of Helisoma}

Sce remarks on plate 53 . Line at bottom of plate indicates 25 microns in length.

1. Helisoma winslowi (F. C. Baker). Little Arbor Vitae Lake, Wisconsin.

70, center tooth; $1-13$, lateral teeth; 14,15 , intermediate teeth; $17-19$, marginal teeth.

2. Helisoma trivolvis macrostomum (Whiteares). Bayfield, Wisconsin.

53, center tooth; 1-8, lateral teeth; 9-13, intermediate teeth; 14-23, marginal teeth.

3. Helisoma pilsbryi (F. C. Baker). Chetek Lake, Wisconsin.

100 , center tooth; 1-8, lateral teeth; 10-12, intermediate teeth; 13-23, marginal teeth.

4. Helisoma pilsbryi infracarinatum F. C. Baker. Basswood River Rapids, Ontario.

132, center tooth; 1-9, lateral teeth; 10-14, intermediate teeth; 15-21, marginal teeth.

5. Helisoma pilsbryi infracarinatum F. C. Baker. Rideau River, Ontario.

Varying toward pilsbryi. 115, center tooth; 1-13. lateral teeth; 14, 15, intermediate teeth; 16-29, marginal teeth. 


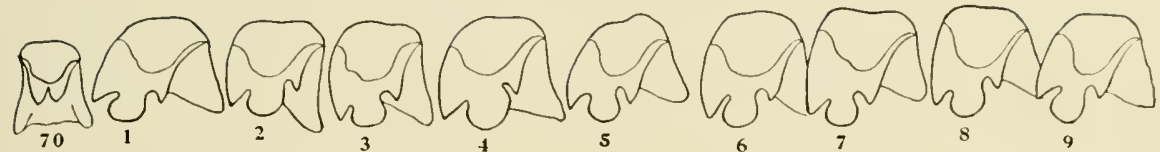
arparan on Q9

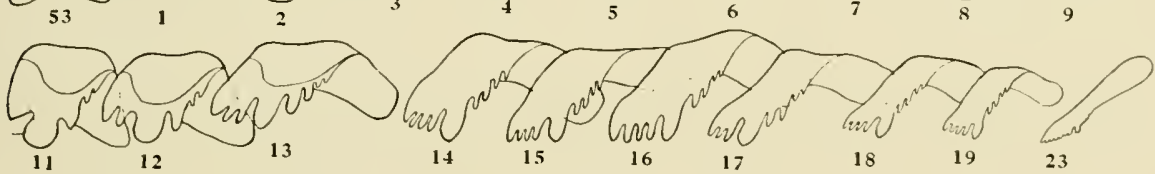
2

g日a

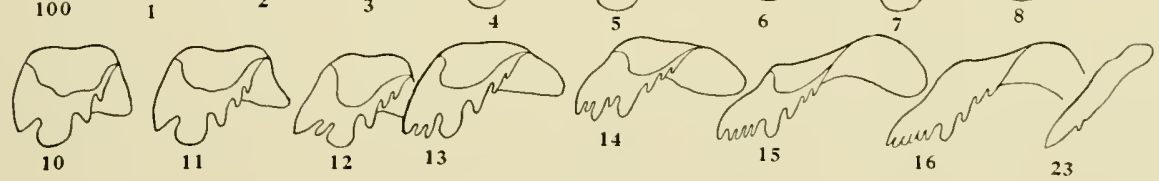

3

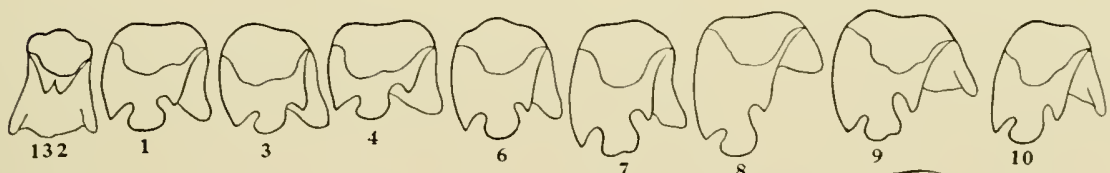
ara

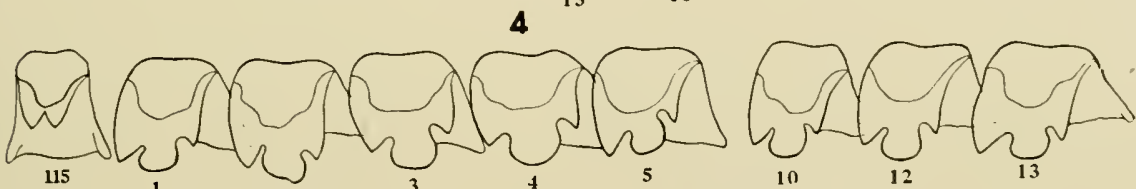
(2) 5

PLATE 56 


\section{PLATE 57}

\section{Radulae of Helisoma}

See remarks on plate 53. Line at bottom of plate indicates 25 microns in length.

1. Helisoma truncatum (Miles). Winnebago Lake, near Oshkosh, Wisconsin.

Normal mentbrane. 85, center tooth; $1-\boldsymbol{7}$, lateral teeth; 9-11, intermediate teeth; 13-20, marginal teeth.

2. Helisoma truncatum (Miles). Winnebago Lake, Wisconsin.

Abnormal nembrane, with many split cusps on teeth. 90, center tooth; 1-8, lateral teeth, 6 and 7 with bifich entoconic cusps and 5, 6, and 7 with sphit ectoconic cusps; 9-11, intermediate teeth with modified ectocones; 12-21, marginal teeth.

3. Helisoma corpulentum (Say). Lac la Croix, Ontario, Canada.

48, center tooth; 1-8, lateral teeth; 9-12, intermediate teeth; 13-25, marginal teetb.

4. Helisoma magnificum (Pilsbry). Near Wilmington, North Carolina.

90 , center tooth; 1-14, lateral teeth; 16-23, intermediate teeth; $24-41$, marginal teeth.

The snall numerals on the first lateral of fig. 1 indicate the following parts of the tooth: 1, entocone or inner cusp; 2, mesocone or middle cusp; 3 , ectocone or outer cusp; 4, base of attachment to radula membrane. In 16 of fig. 1, the small numeral 2 indicates the position of the mesocone in a marginal tooth. 

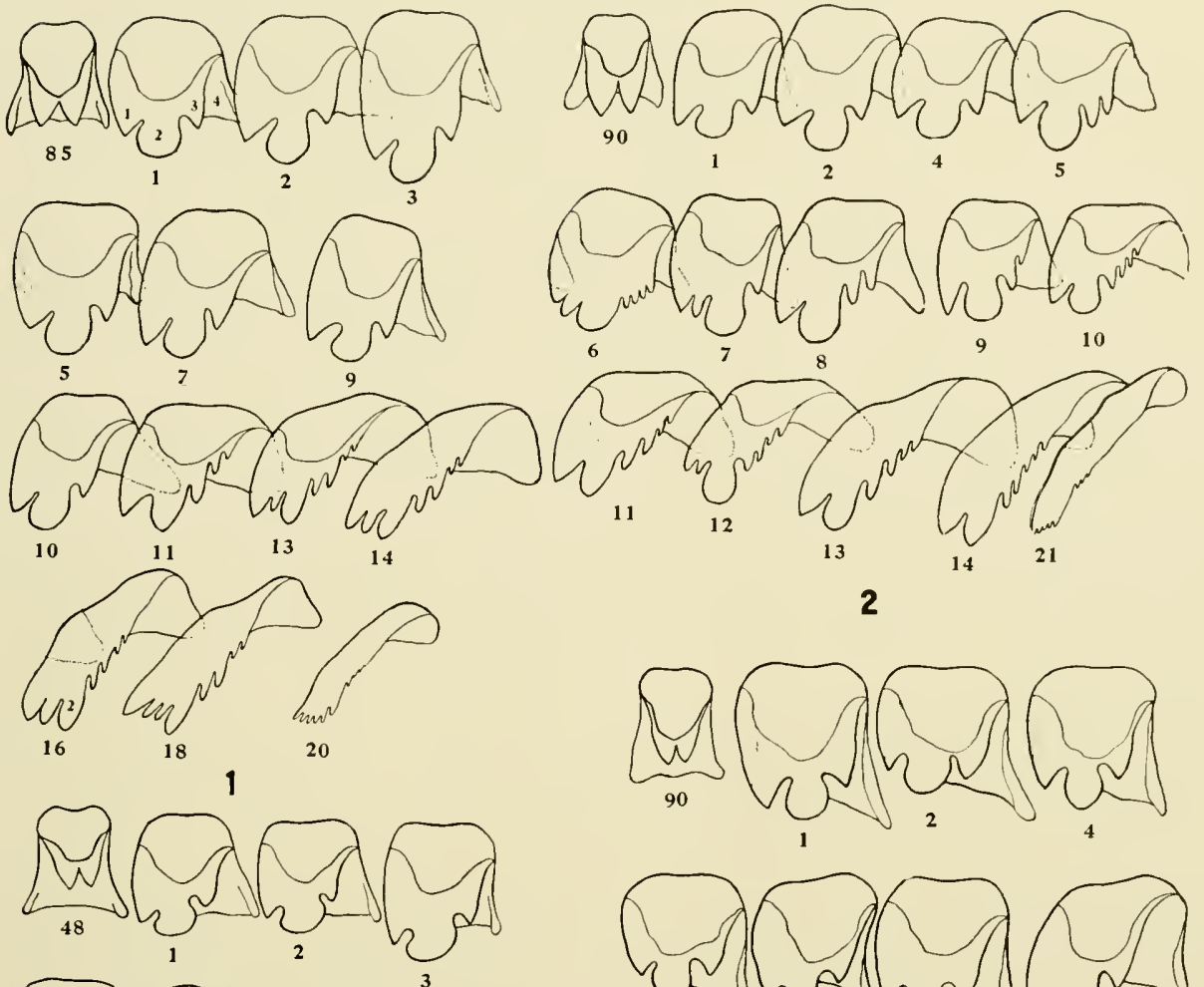

Arasia
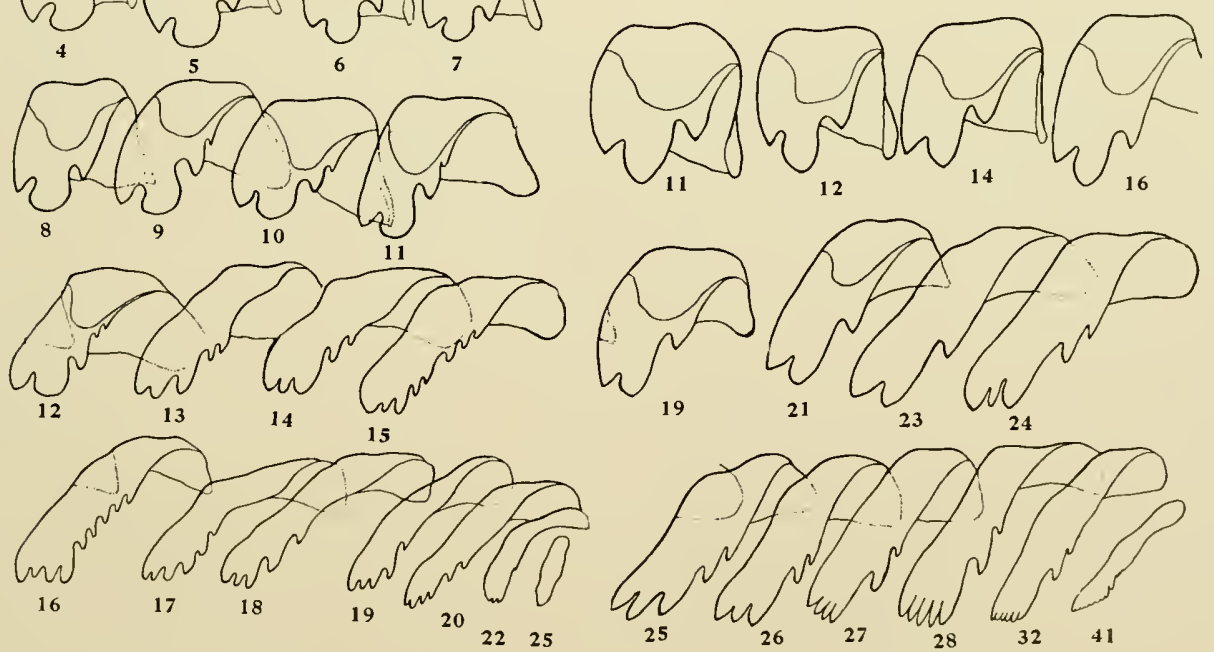

3
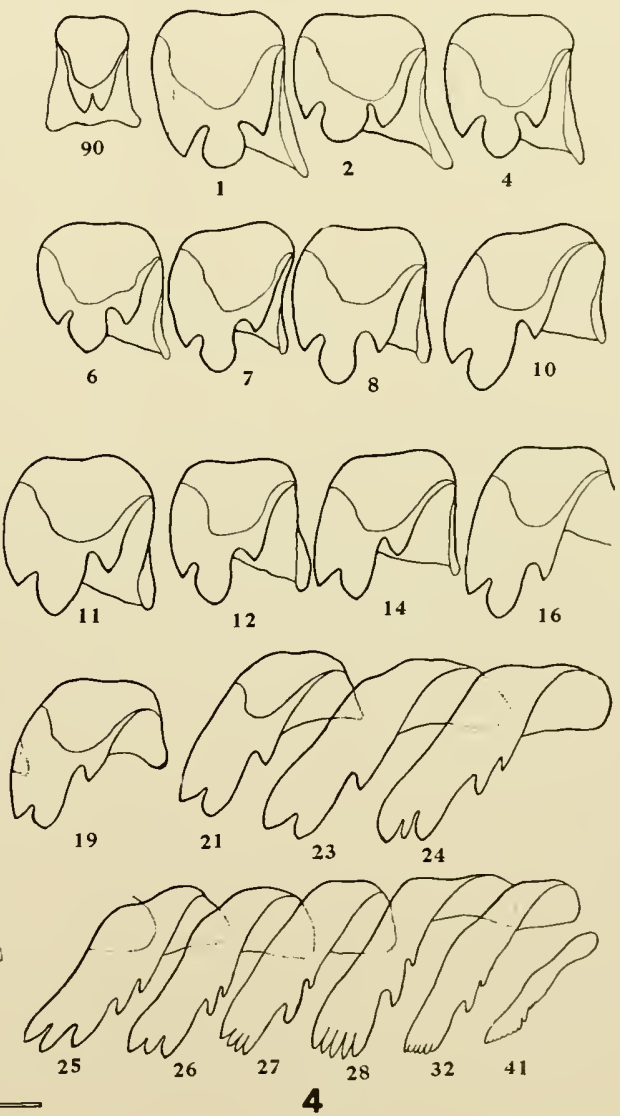

PLATE 57 


\section{PLATE 58}

\section{Radulae of Helisoma}

See remarks on plate 53 . Line at bottom of plate indicates 25 microns in length.

1. Helisoma whiteavesi F. C. Baker. Mille Lacs, Ontario, Canada.

105, center tooth; 1-16, lateral teeth; 17-19, intermediate teeth; 20-35. marginal teeth. 23, a pathologic tooth in another row. 12, a lateral tooth on the left side with split cusps.

2. Helisoma corpulentum vermitionense F. C. Baker. Vermilion Lake, Minnesota.

101, center tooth; 1-7, lateral teeth; 9-12, intermediate teeth; 13-21. marginal teeth.

3. Helisoma corpulentum multienstatum F. C. Baker. Kahnipiminanikok Lake, Ontario, Canada.

60, center tooth; 1-7, lateral teeth; 11-14, intermediate teeth; 15-41, marginal teeth.

4. Helisoma plexatum (Ingersoll). Teton River, near Rexburg, Idaho.

44 , center tooth; 1-8, lateral teeth, 1 and 4 with mesocones worn or pathologic; 10-13, intermediate teeth; 13-16, marginal teeth. The two 13 figures show how this tooth differed in two rows, being an intermediate tooth in one row and a marginal tooth in another row.

5 Ile lisoma plexatum (Ingersoll).

The 120th row in another membrane from a Teton River specimen. 16-1s, modified marginal teeth.

6. Helisoma plexatum (Ingersoll). Smartweed Lake, Colorado.

13, a lateral tooth; 14-15, malginal teeth. 

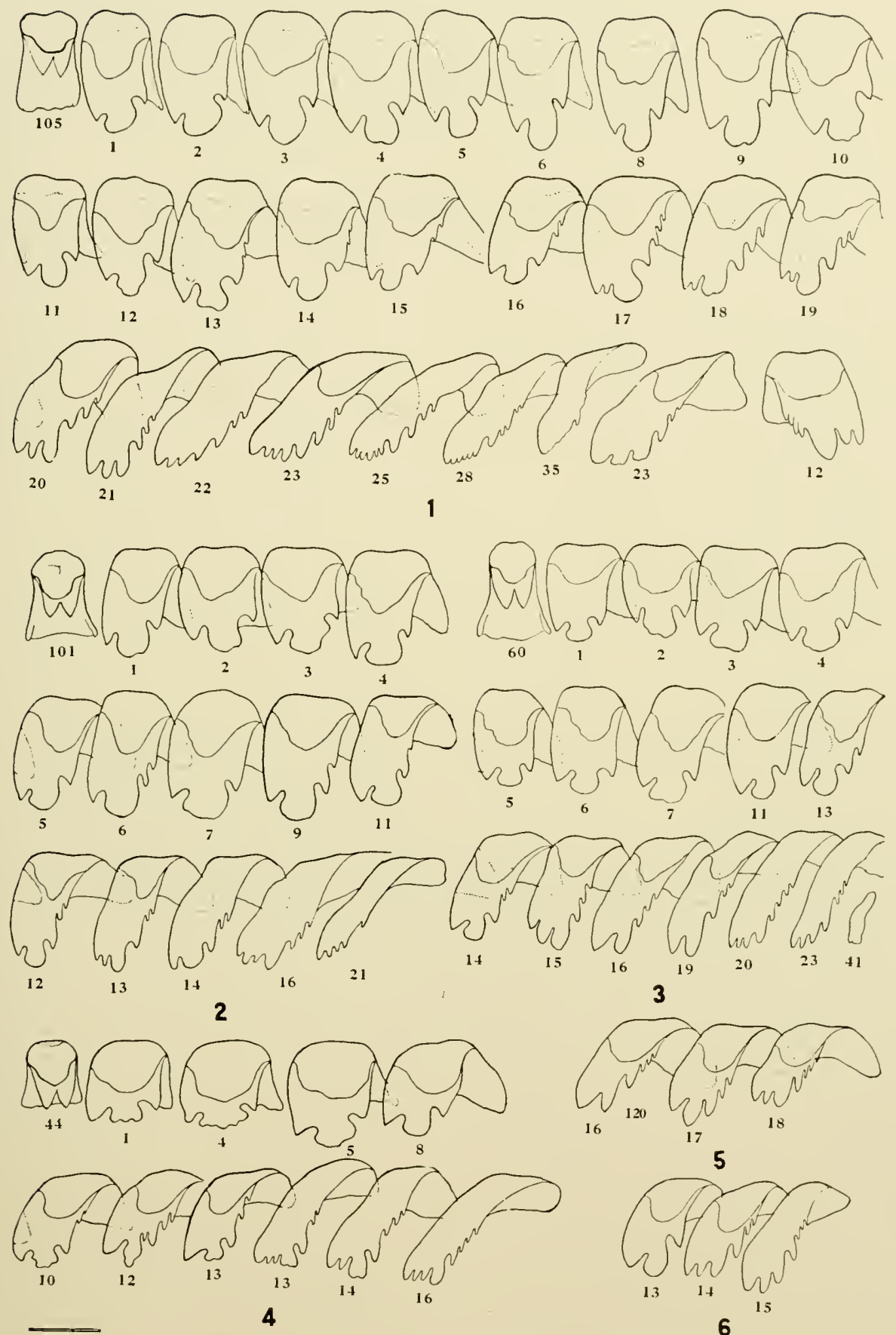

PLATE 58 


\section{PLATE 59}

\section{Radulae of Helisoma}

See remarks on plate 53 . Line at bottom of plate indicates 25 microns in length.

1. Helisoma plexatum (Ingersoll). Grand Mesa, Colorado.

60 , center tooth; $1-12$, lateral teeth; $13-17$, intermediate teeth; 18-22, marginal teeth.

2. Helisoma plexatum (Ingersoll). Columbine Lake, Colorado.

95 , center tooth; 1-10, lateral teeth; 11-12, intermediate teeth; 13-15, marginal teeth.

3. Helisoma tenue californiense F. C. Baker. San Bernardino Mts., California.

Normal teeth. 60, center tooth; 1-11, lateral teeth; 12, 13, intermediate teeth; 14-21, marginal teeth.

4. Helisoma tenue ealiforniense F. C. Baker. San Bernardino Mts., California.

Abnormal teeth, the lateral teeth with extra cusps on both entocones and ectocones and with mesocone much modified. 60 , center tooth; 1-10, lateral teeth; 11, 12, intermediate teeth; 12-17, marginal teeth.

5. Helisoma suberenatum (P. P. Carpenter). Variety. Pass Lake, Puget Sound, Washington.

96. center tooth; 1-15, lateral teeth; 16-18, intermediate teeth; 19-28, marginal teeth.

6. Helisoma tenue californiense F. C. Baker. San Bernardino Mts., California.

An abnormal 11th lateral tooth. 
Mas

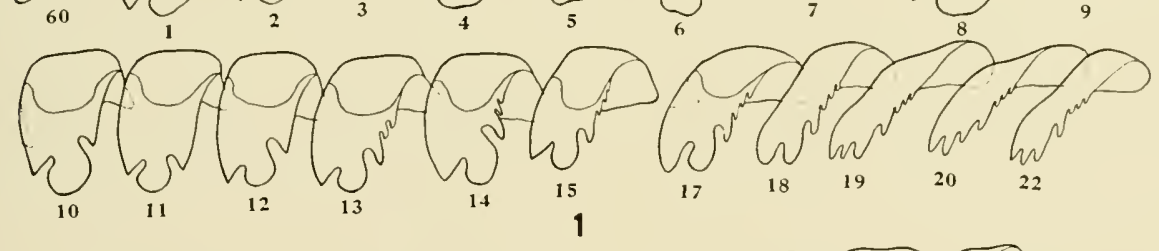

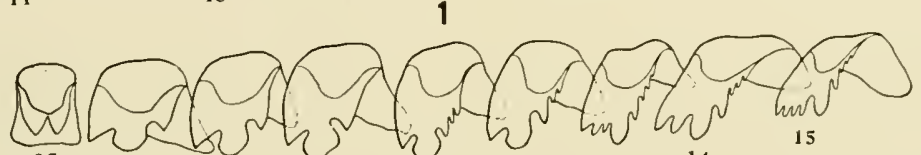

as an

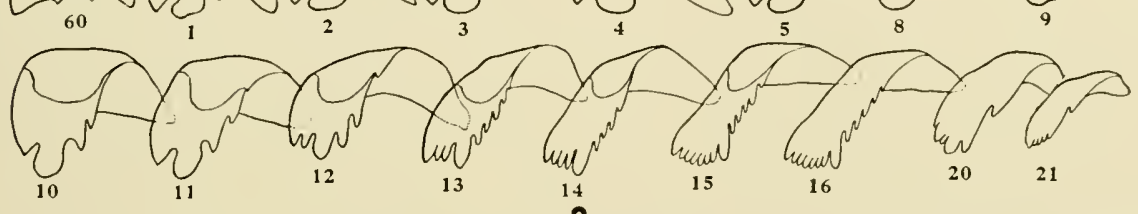

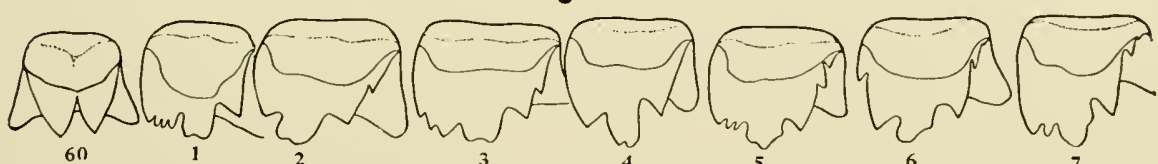
GPA

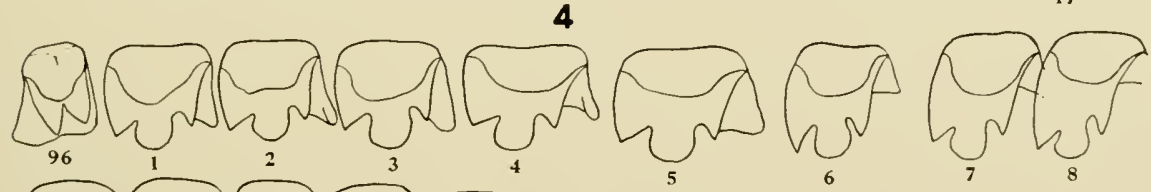

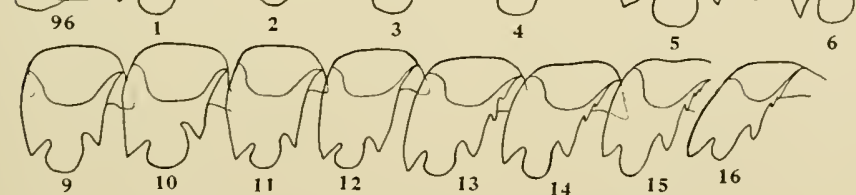
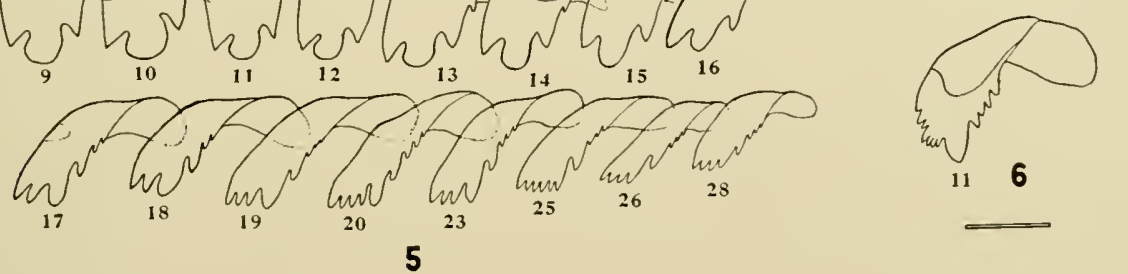

PLATE 59 


\section{PLATE 60}

\section{Radulae of Helisoma}

See remarks on plate 53 . Line at lower right of plate indicates 25 microns in length.

1. Helisoma subcrenatum (P. P. Carpenter). Variety. Lost Lake, Puget Sound, Washington.

73, center tooth; 1-7, lateral teeth; 12,13 , intermediate teeth; $15-20$, marginal teeth.

2. Helisoma subcrenatum (P. P. Carpenter). Variety. Lost Lake, Puget Sound, Washington.

SS, abnormal center tooth; 5 , lateral tooth with bicuspid entocone.

3. Helisoma suberenatum (P. P. Carpenter). Skagit Co., Washington.

90 , center tooth; 1 , 7 , lateral teeth; 12 , intermediate tooth; 17,20 , marginal teeth.

4. Helisoma traskii (Lea). Outlet of Kern Lake, California.

82nd row, 9, intermediate tooth; 10,11 , marginal teeth.

5. Helisoma traskii (Lea). Outlet of Kern Lake, California.

90 , center tooth; 1-9, lateral teeth; 10, 11, intermediate teeth; 12-22, marginal teeth.

6. Helisoma traskii (Lea). Outlet of Kern Lake, California.

80th row, 9 , intermediate tooth; 10 , first marginal tooth.

7. Helisoma horni (Tryon). Paul Lake, British Columbia.

60 , center tooth; 1-9, lateral teeth; 10-14, intermediate teeth; 15-32, marginal teeth. 4 , fourth tooth in another row. 
73, and

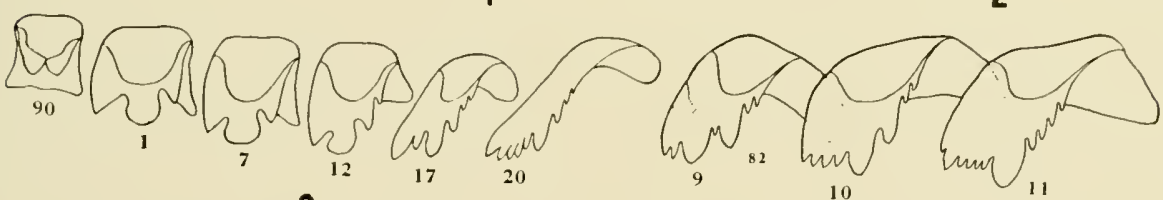

3

${ }^{10} 4$

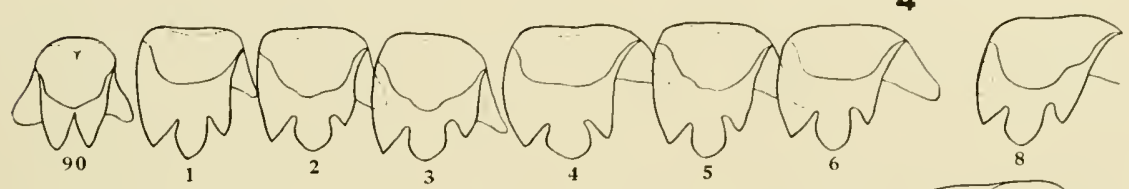

(2)
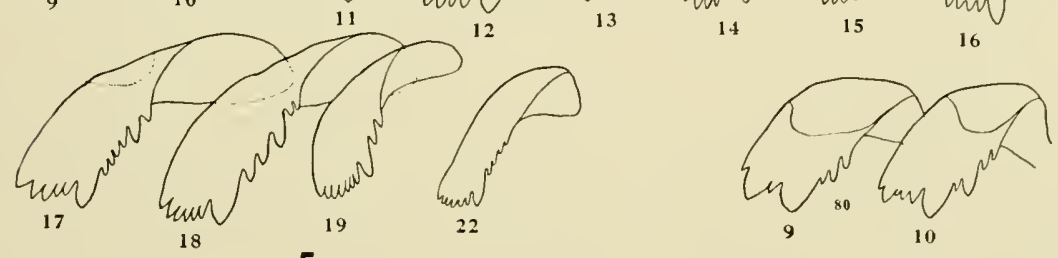

5

6
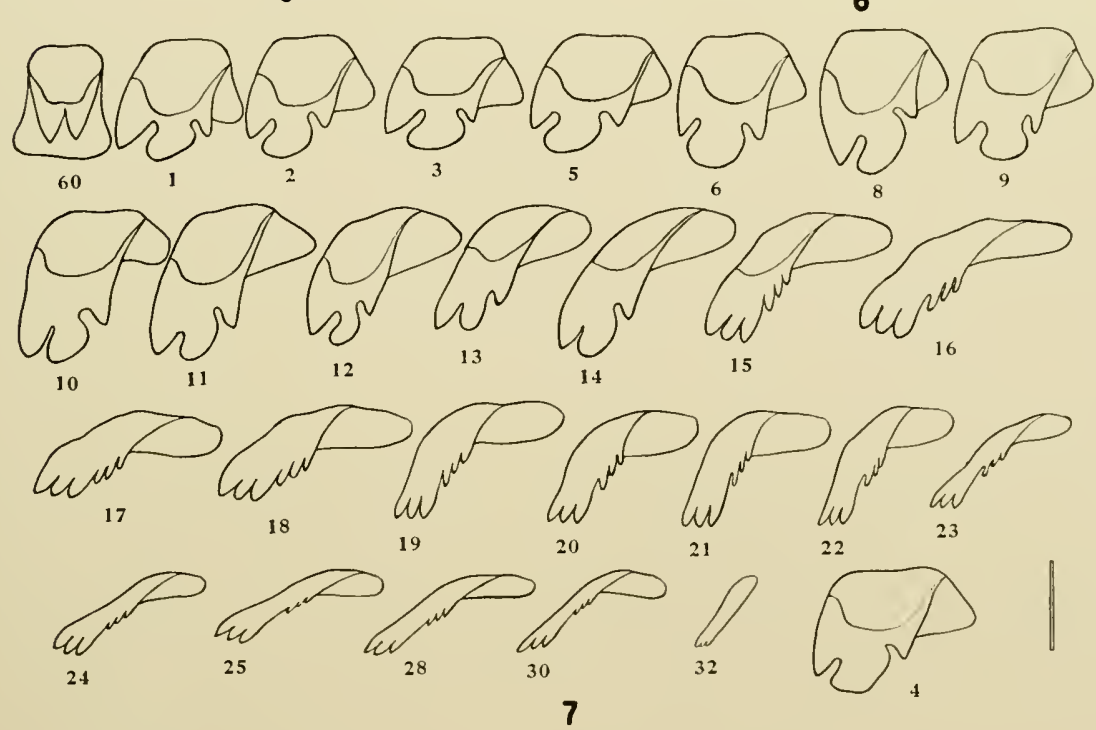

PLATE 60 


\section{PLATE 61}

\section{Radulae of Helisoma}

See remarks on plate 53. Line at lower right of plate indicates 25 microns in length.

1. Helisoma occidentale (Cooper). Klamath Lake, Oregon.

45, center tooth; 1-8, lateral teeth; 9-12, intermediate teeth; 13-23, marginal teeth.

2. Helisoma subcrenatum (P. P. Carpenter). Cottonwood Pass, Gypsum, Colorado.

95 , center tooth; $1-8$, lateral teeth; $9-12$, intermediate teeth; 13-20, marginal teeth.

3. Helisoma oregonense (Tryon). Tooele Co., Utah.

58 , center tooth; $1-8$, lateral teeth; 9,10 , intermediate teeth; $11-21$, marginal teeth. 


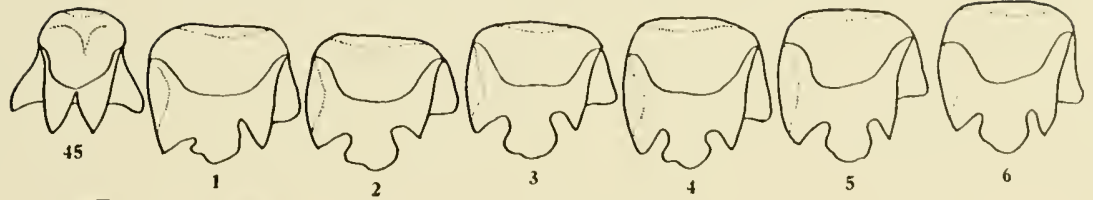
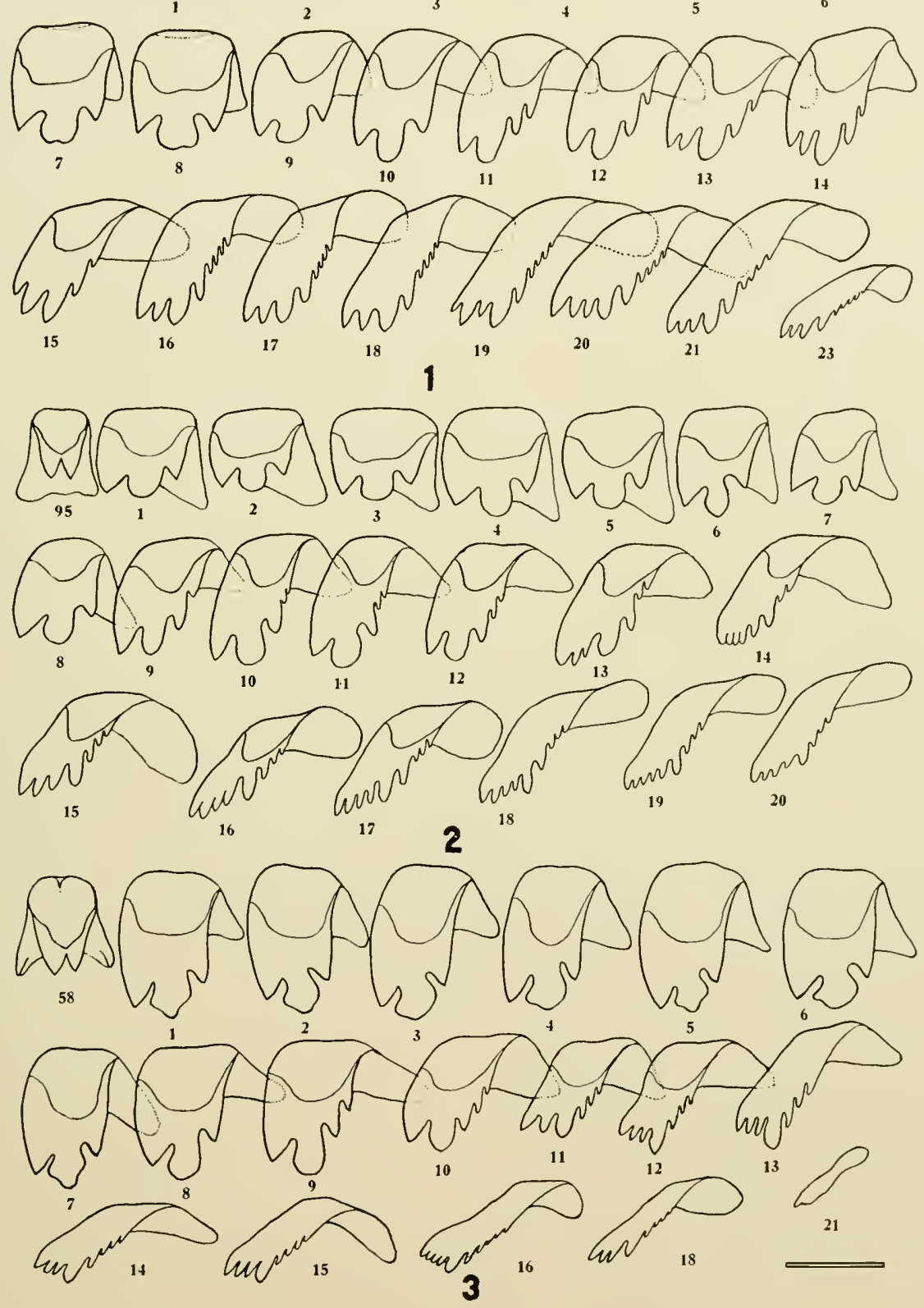

PLATE 61 


\section{PLATE 62}

\section{Radulae of Helisoma}

See remarks on plate 53 . Line at lower right of plate indicates 25 microns in lengtl.

1. Helisoma campanulatum (Say). Oneida Lake, New York.

60 , center tooth; $1-7$, lateral teeth; 8,9 , intermediate teeth; $10-20$, marginal teeth.

2. Helisoma campanulatum wisconsinense (Winslow). Little Arbor Vitae Lake, Wisconsin.

50 , center tooth; $1-8$, lateral teeth; 9,10 , intermediate teeth; 11-15, marginal teeth.

3. Helisoma campanulatum canadense F. C. Baker. Bamiji Lake, Ontario, Canada.

52 , center tooth; $1-8$, lateral teeth; 9,10 , intermediate teeth; 11-20, marginal teeth.

4. Helisoma campanulatum smithi (F. C. Baker). Douglas Lake, Michigan.

60 , center tooth; $1-8$, lateral teeth; 9,10 , intermediate teeth; 11-19, marginal teeth. 

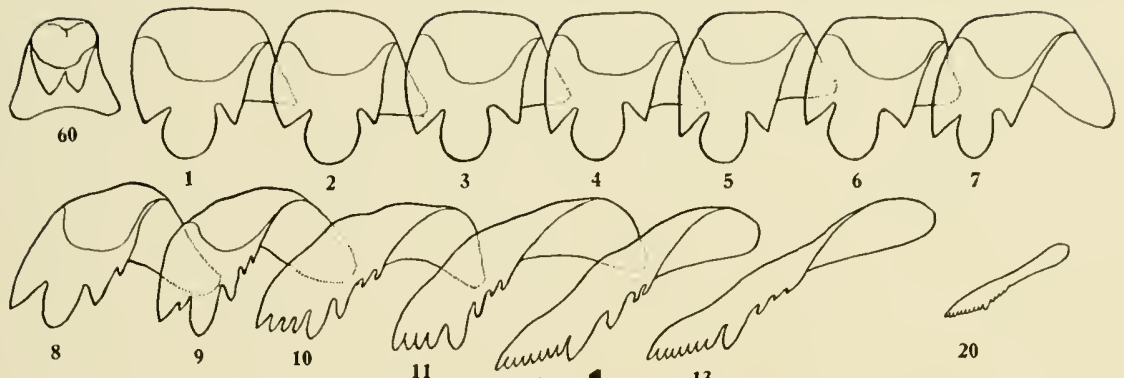

(n)
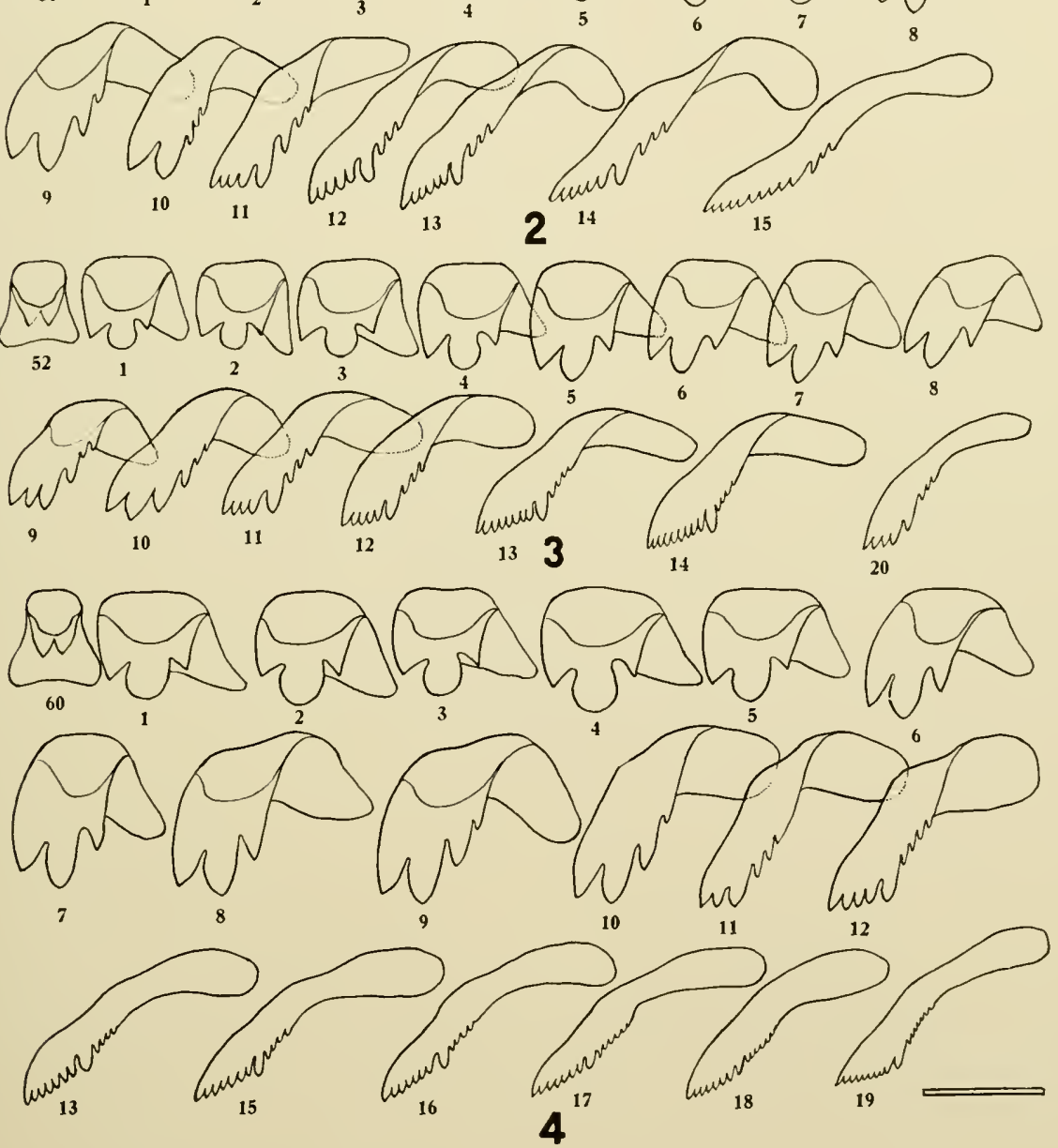

PLATE 62 


\section{PLATE 63}

\section{Radulae of Helisoma}

See remarks on plate 53. Line at lower right of plate indicates 25 microns in length.

1. Helisoma trivolvis fallax (Haldeman). Cambridge, Massachusetts.

60 , center tooth; 1-7, lateral teeth; 10 , intermediate tooth; 11-23, marginal teeth.

2. Helisoma tenue ealiforniense F. C. Baker. Shandon, California.

77, center tooth; 1-11, lateril teeth; 12, intermediate tooth; 13-19. marginal teeth. 100th row. Numerals 1-11, lateral teeth with multiple cusps on entocone and ectocone.

3. Helisoma trivolvis lentum (Say). New Orleans, Louisiani.

60 , center tooth; 1-9, lateral teeth; 10. 11, intermediate teeth; 12-20, marginal teeth.

4. Helisoma duryi eudiscus Pilsbry. Silver Springs, Floridi.

84 , center tooth; 1-10, laterial teeth; 11,12 , intermediute teeth; 12-22, marginal teeth. 
Illustrations of the Anatomy and of Shells
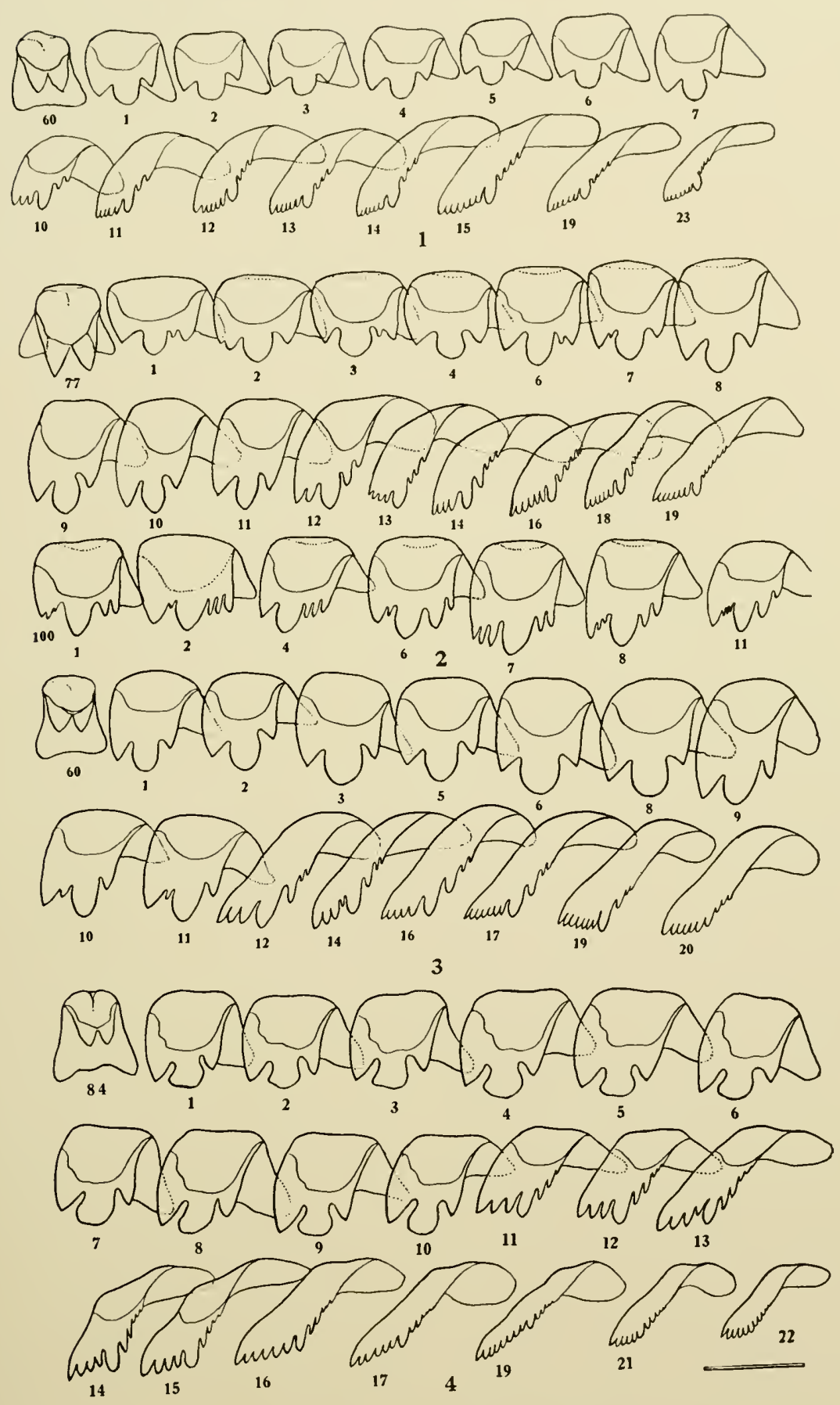

PLATE 63 


\section{PLATE 64}

\section{Radulae of Helisoma}

See remirks on plate 53. Line at lower right of plate indicates 25 microns in length.

1. Helisoma scalare (Jay). Lake Butler, Florida.

89 , center tooth; $1-8$, lateral teeth; 9 -11, intermediate tceth; 12-21, marginal teeth.

2. Helisoma scalare (Jay). Lake Butler, Florida.

86 , center tooth of another specimen; 1-6, lateral teeth.

3. Helisoma duryi normale Pilsbry. Tamiami Trail, 40 miles west of Miami, Florida.

110 , center tooth; 1-11, lateral teeth; 12, intermediate tooth; 13-29, marginal teeth. 12, lower right, 12 th tooth (marginal) in another row of teeth.

4. Helisoma duryi normale Pilsbry. Paines Prairie, Florida.

55, center tooth; 1-9, lateral teeth; 10 , intermediate tooth; 11-26, marginal teeth. 140 , center tooth; $1-10$, lateral teeth; 11 , intermediate tooth; $12-20$, marginal teeth. 

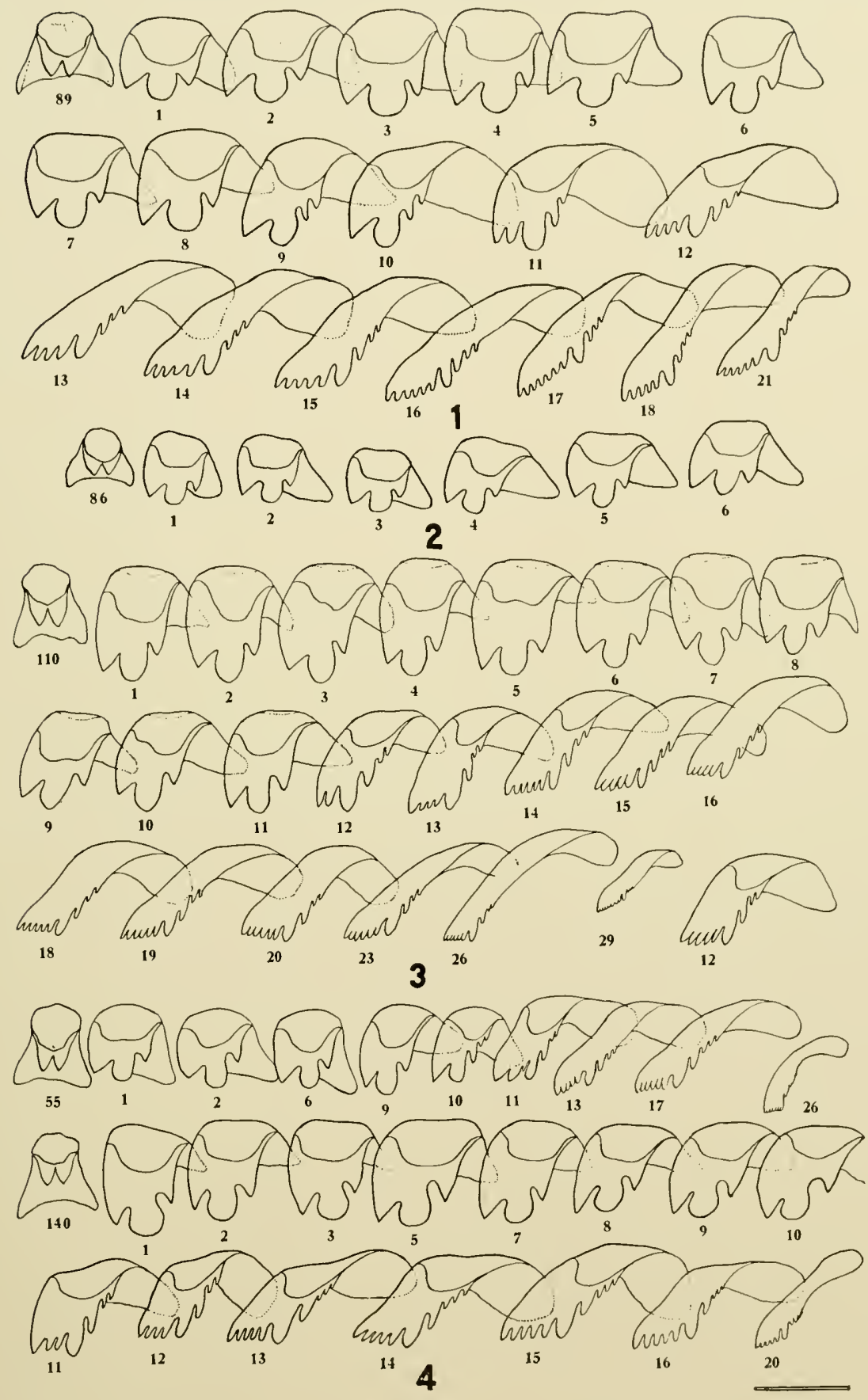

PLATE 64 
PLATE 65

\section{Radulae of Planorbula, Parapholyx, and Carinifex}

See remarks on plate 53 . Line at lower left of plate indicates 25 microns in length.

1. Planorbula armigera (Say). Murphy Creek, near Madison, Wisconsin.

128, center tooth; 1-6, lateral teeth; 9,11 , intermediate teeth; 12-19, marginal teeth.

2. Planorbula jenksii (H. F. Carpenter). Unionville. Connecticut.

105 , center tooth; 1-5, lateral teeth; 9 , 11, intermediate teeth; 12-19, marginal teeth.

3. Parapholyx effusa klamathensis F. C. Baker. Klamath Lake, Oregon.

60, center tooth; 1-8 lateral teeth; 9-11, intermediate teeth; 13-19, marginal teeth.

4. Carinifex jacksonensis J. Henderson. Jackson Lake, Wyoming.

120, center tooth; $1-10$, lateral teeth; 12 , intermediate tooth; 13-24, marginal teeth. 

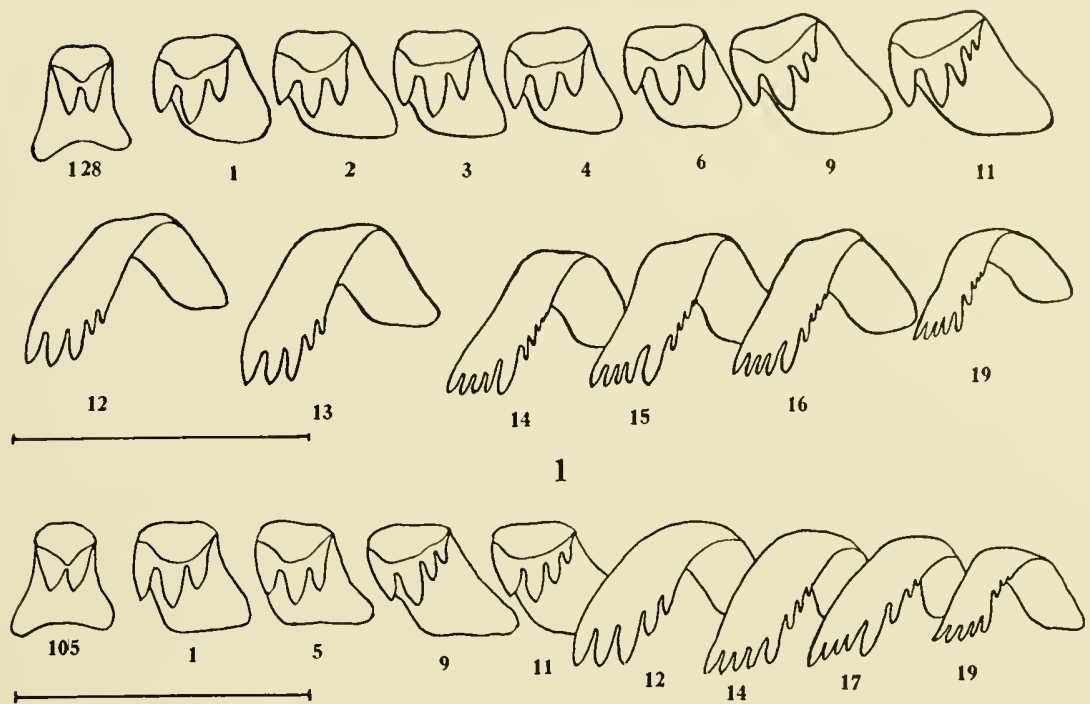

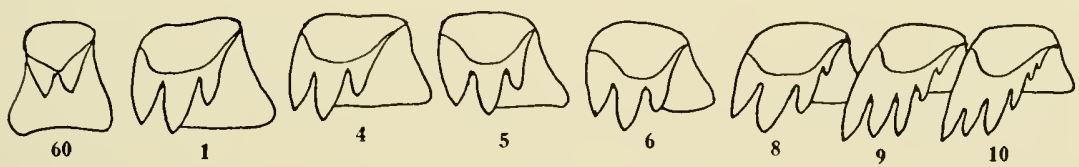

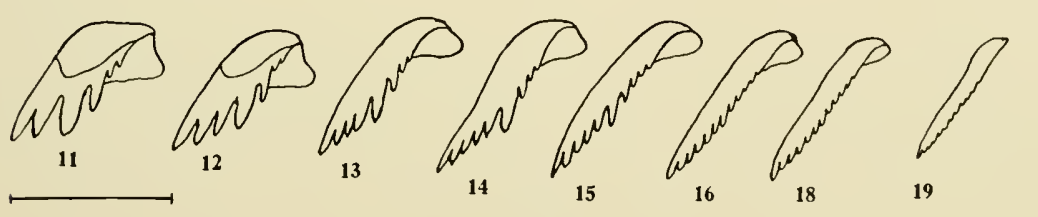

3

Magn an as as as
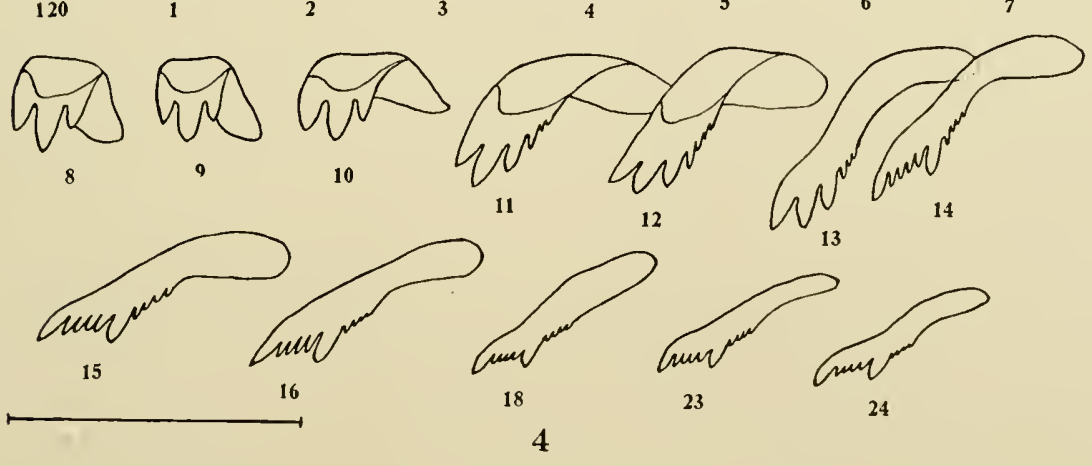

PLATE 65 


\section{PLATE 66}

\section{Radulae of Indoplanorbis and Planorbarius}

See remarks on plate 53 . Line at lower right of plate indicates 25 microns in length.

1. Indoplanorbis exustus (Deshayes). North Shan State, Burma.

60, center tooth; 1-5, lateral teeth; 6-10, intermediate teeth; 16-21, marginal teeth; 11, last intermediate tooth in another row; $12-15$, marginal teeth in same row; 23-26, marginal teeth in same row: $27,32,33$, outer marginal teeth in same row.

2. Planorbarius corneus (Linn.). Near Warsaw, Poland.

60, center tooth; 1-9, lateral teeth; 10-14, intermediate teeth; 15-38, marginal teeth; 39-42, outer marginal teeth. 

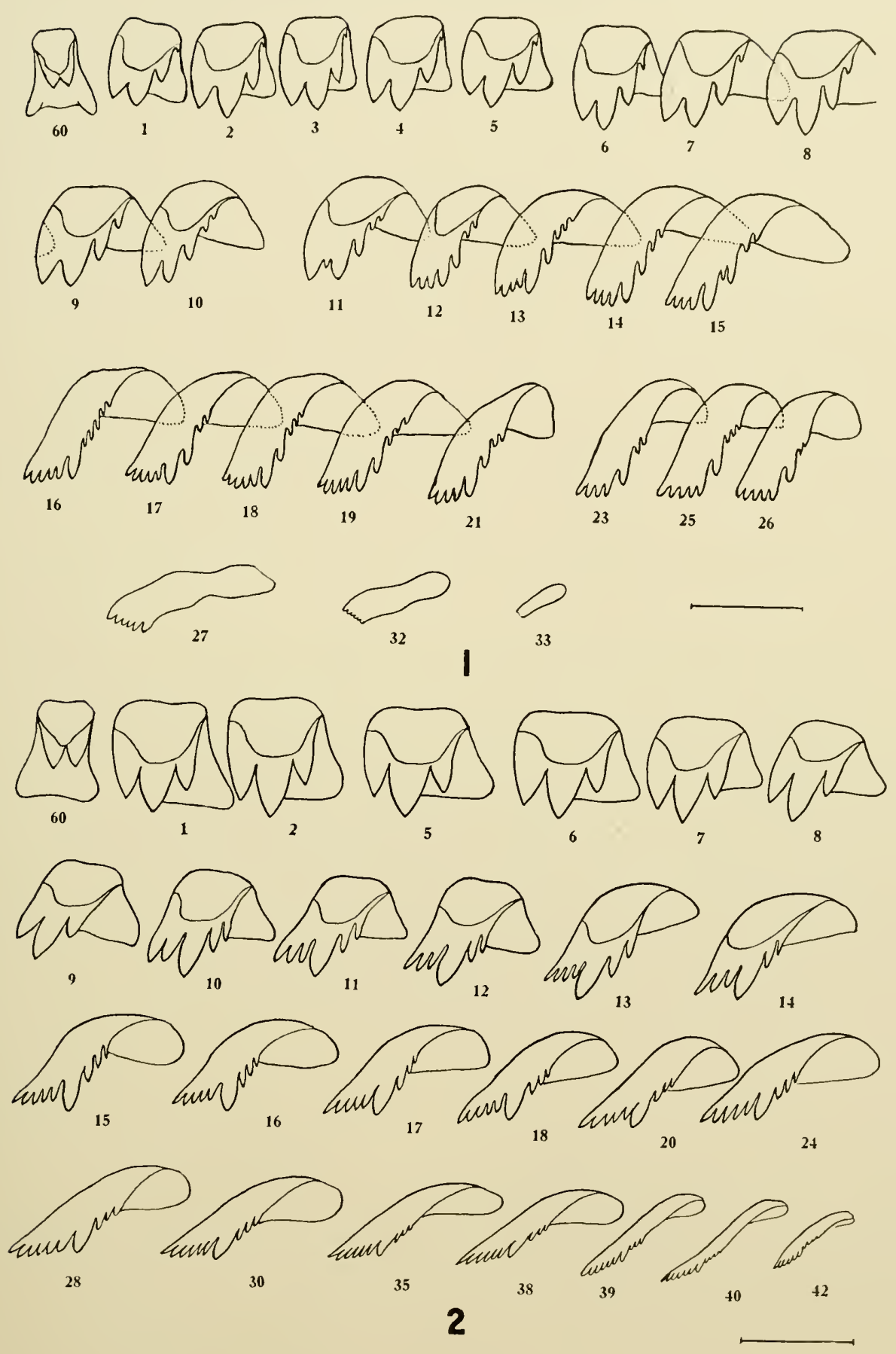

PLATE 66 


\section{PLATE 67}

\section{Radulae of Planorbidae}

See remarks on plate 53. Line at lower right of plate indicates 25 microns in length. Line under fig. 6 is also for figs. 1 to 5 .

1. Promenetus exacuous (Say). Wainwright Park, Alberta.

50, center tooth; 1-6. lateral teeth; 9, 10, intermediate teeth; 11-15, marginal teeth.

2. Promenetus umbilicatellus (Cockerell). Wainwright Park, Alberta.

60 , center tooth; 1-6, lateral teeth; 9-11, intermediate teeth; 12-15, marginal teeth.

3. Menetus cooperi callioglyptus (Vanatta). Vancouver Island, British Columbia.

55 , center tooth; 1-8, lateral teeth; 9 , 10, intermediate teeth; 11-15, marginal teeth.

4. Menetus dilatatus (Gould). Unionville, Connecticut.

60 , center tooth; $1-7$, lateral teeth; 8-10, intermediate teeth; 11-14, marginal teeth.

5. Menetus sampsoni (Ancey). Stanton, Missouri.

50 , center tooth; 1-7, lateral teeth; 8,10 , intermediate teeth; 11-14, marginal teeth.

6. Anisus spirorbis (Linn.). Near Warsaw, Poland.

45 , center tooth; $1-10$, lateral teeth; 11 , intermediate tooth; 12-15, marginal teeth.

7. Planorbis planorbis (Linn.). Near Warsaw, Poland.

60 , center tooth; $1-9$, lateral teeth; 11 , intermediate tooth; 14-20, marginal teeth.

8. Carinifex ponsonbyi E. A. Smith. Klamath Lake, Oregon.

115 , center tooth; 1-6, lateral teeth; 7-10, intermediate teeth; 11-27, marginal teeth. 


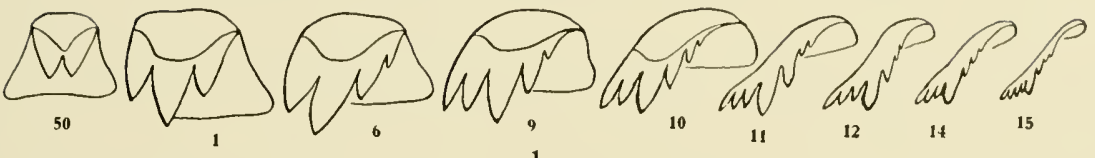

Q

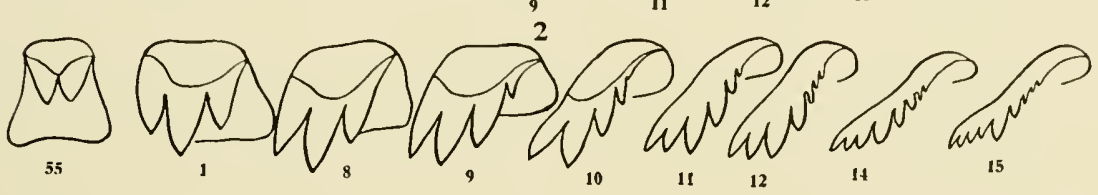

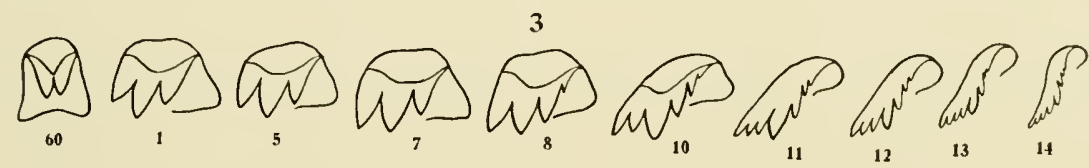

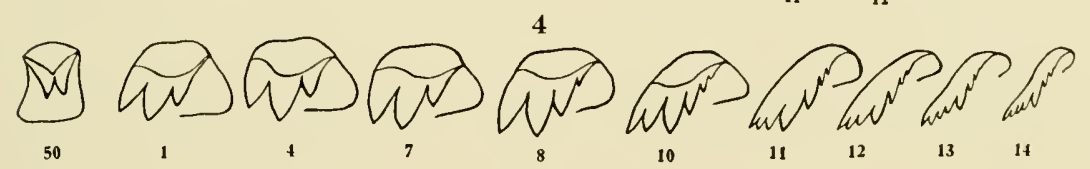

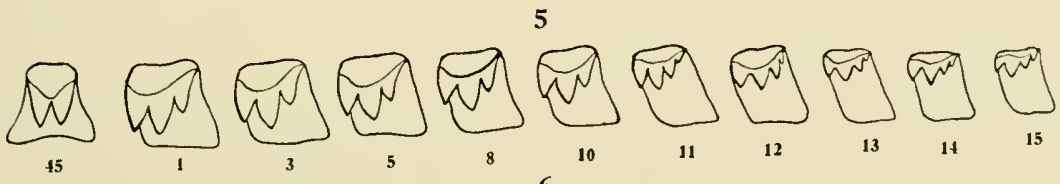

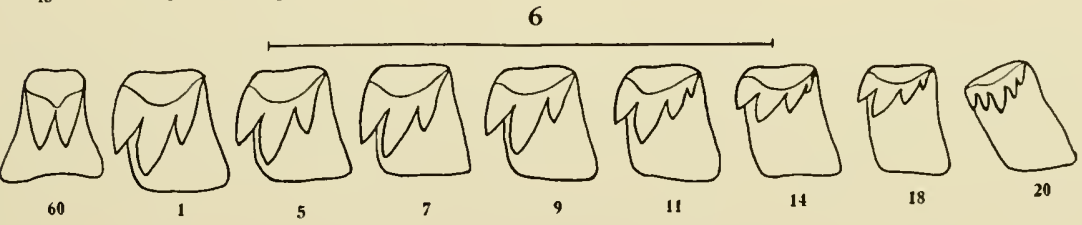

(n)
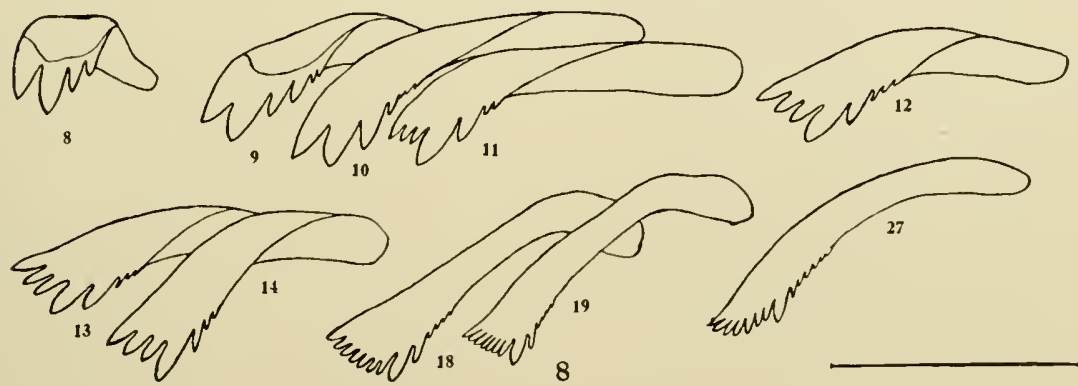

PLATE $6 \pi$ 


\section{PLATE 68}

\section{Radulae of Planorbidae}

See remarks on plate 53 . Line at lower right of plate indicates 25 microns in length for figs. $5-9$; lines for figs. 1-4 are 10 microns in length.

1. Bathyomphalus contortus (Linn.). Near Warsaw, Poland.

60 , center tooth.

2. Drepanotrema lucidum (Pfeiffer). Havana, Cuba.

50 , center tooth; $1-8$, lateral teeth; 13,14 , intermediate teeth; 15 , marginal tooth.

3. Drepanotrema anatinum (Orbigny). Puerto Rico.

50 , center tooth; 1-5. lateral teeth; 7.9 , internediate teeth; 13 , marginal tooth.

4. Drepanotrema hoffmani F. C. Baker. Puerto Rico.

52 , center tooth; 1-6, lateral teeth; 8 , intermediate tooth; 11-21, marginal teeth.

5. Australorbis glabratus (Say). Puerto Rico.

60 , center tooth; 1-13, lateral teeth; 14, 15, intermediate teeth; 16-26, marginal teeth.

6. Tropicorbis rïsei (Dunker). Lares, Puerto Rico.

50 , center tooth; 1 , lateral tooth; 5,6 , intermediate teeth; $7-12$, marginal teeth.

7. Tropicorbis obstructus (Morelet). New Orleans, Louisiana.

60 , center tooth; 1-7. lateral teeth; 8,9 , intermediate teeth; 11-14, marginal teeth.

8. Tropicorbis havanensis (Pfeiffer). New Orleans, Louisiana.

55 , center tooth; 1, lateral tooth; 6 -8, intermediate teeth; 10 , 12, marginal teeth.

9. Gyraulus albus (Müller). Near Warsaw, Poland.

60 , center tooth; $1,5,8$, lateral teeth; 10 , intermediate tooth; 12,13 , marginal teeth. 


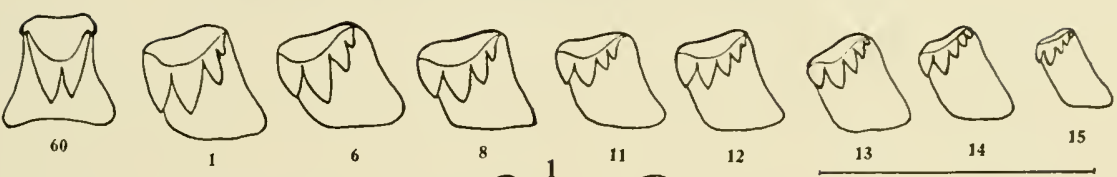

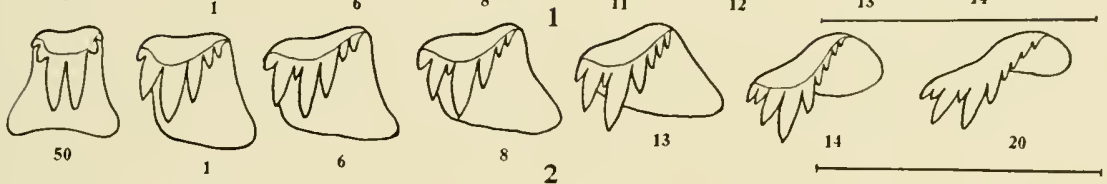

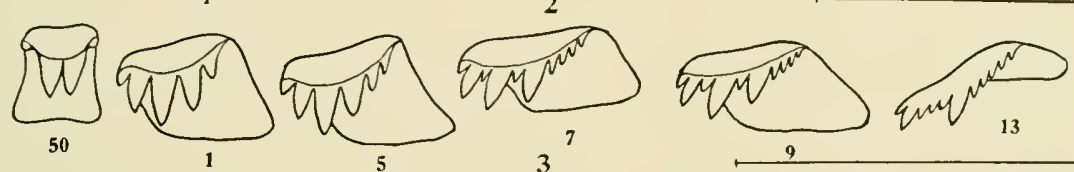

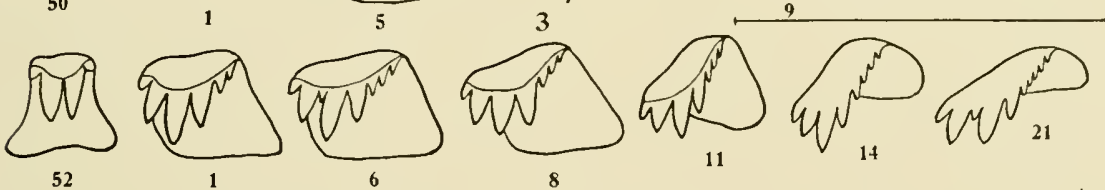

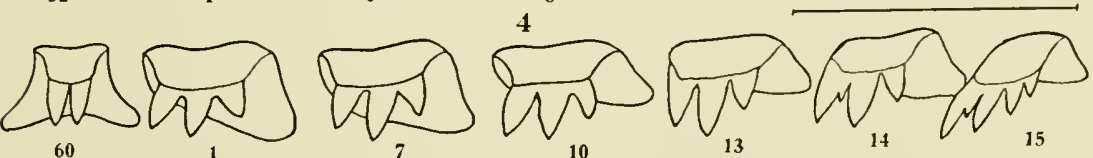

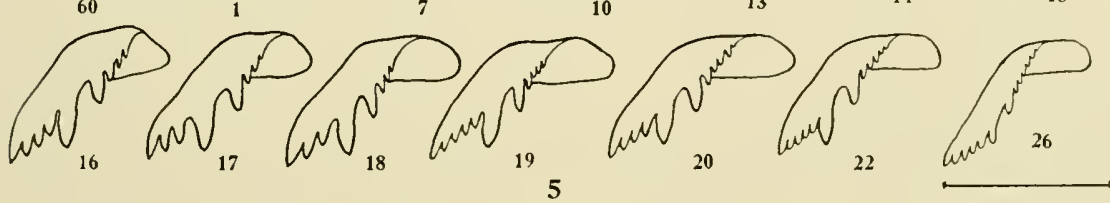

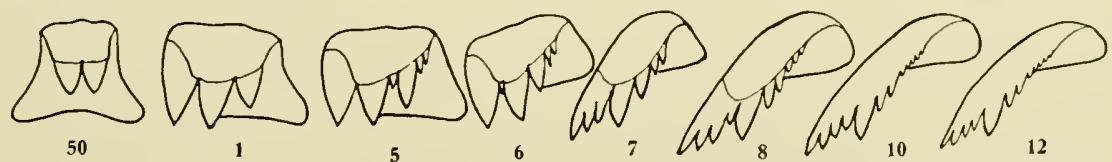

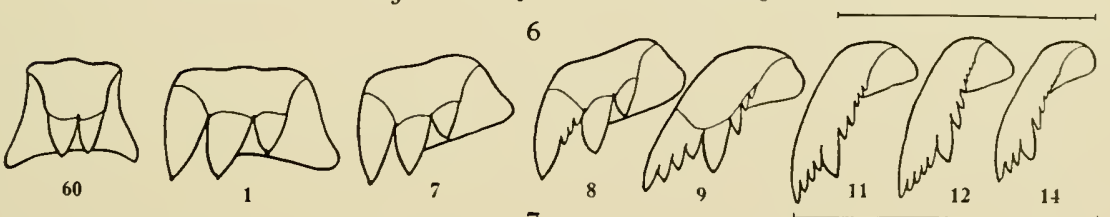

0000000000000

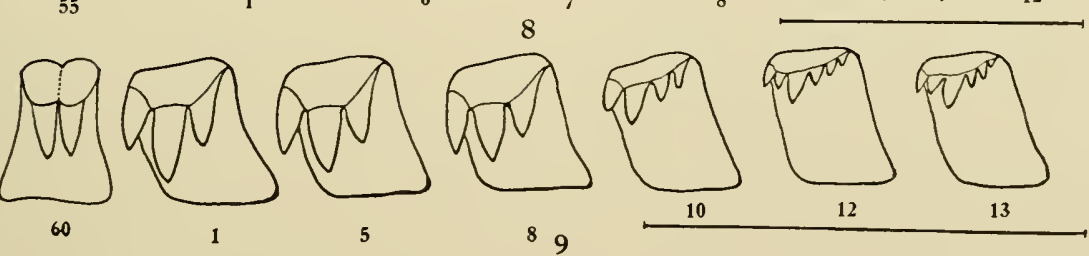

PLATE 68 
PIATE 69

\section{Radulae of Planorbidae}

See remarks on plate 53. Lines near figs. 1 to 5 indicate 25 microns in length; lines near figs. 6 to 9 indicate 10 microns in length.

1. Gyraulus hirsutus (Gould). Lake Nipissing, Ontario, Canada.

50 , center tooth; 1 , lateral tooth; 9 , 11, intermediate teeth; $12-16$, marginal teeth.

2. Gyraulus deflectus obliquus (DeKay). Taylor Lake, Quebec, Canada.

60 , center tooth; 1 , lateral tooth; $9-11$, intermediate teeth; 13-18, marginal teeth.

3. Gyraulus parvus (Say). Winnebago Lake, near Oshkosh, Wisconsin.

55 , center tooth; 1, 5, lateral teeth; 6 , intermediate tooth; $7-10$, marginal teeth.

4. Gyraulus similaris (F. C. Baker). Tolland, Colorado.

60 , center tooth; 1, 6. lateral teeth; S, 10, intermediate teeth; 13, 15, marginal teeth.

5. Gyraulus vermicularis (Gould). Near San Francisco, California.

50 , center tooth; 1-6, lateral teeth; 7-10, intermediate teeth; 11 , marginal tooth.

6. Armiger imbricatus (Müller). Michigan.

55 , center tooth; 1-6, lateral teeth; 8, 10. intermediate teeth; 12,13 , marginal teeth.

7. Segmentina nitida (Müller). Near Warsaw, Poland.

60 , center tooth; 1-S, lateral teeth; 13-16, marginal teeth.

S. Polypylis calathus (Benson). North Shan State, Burma.

50 , center tooth; $1-8$, lateral teeth; 13-18, marginal teeth.

9. Intha capitis Annandale. North Shan State, Burma.

60 , center tooth; $1-S$, lateral teeth; 11,12 , marginal teeth. 


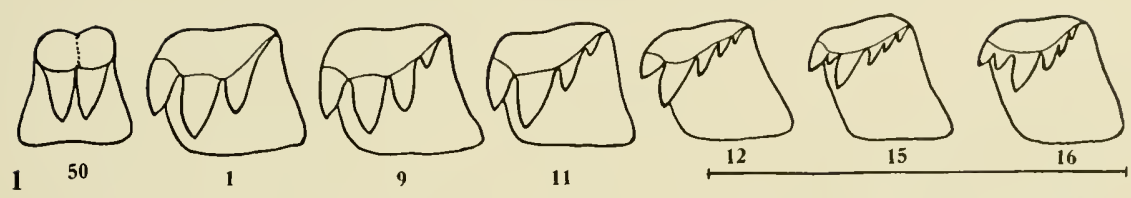

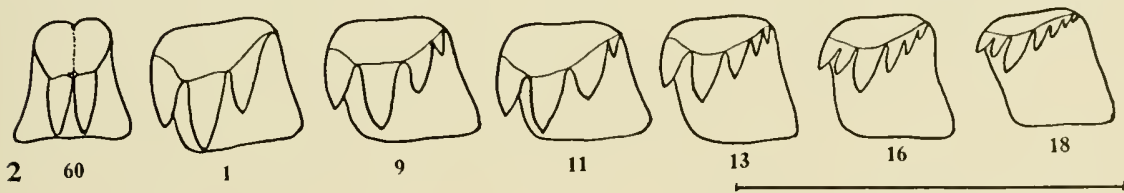

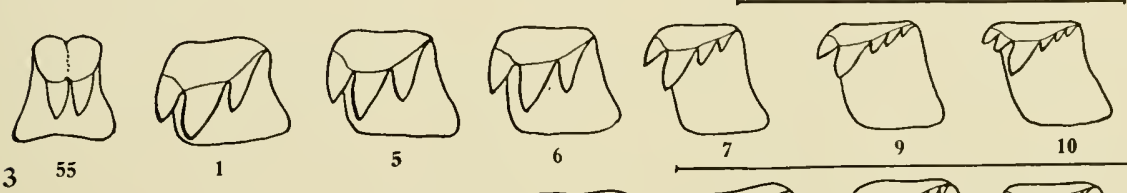

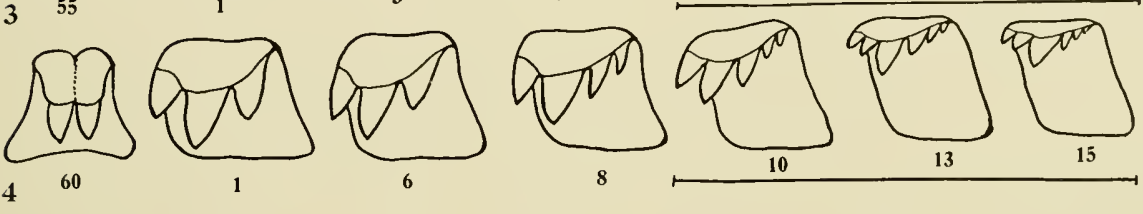

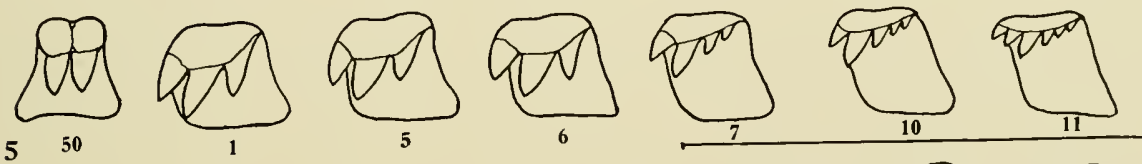

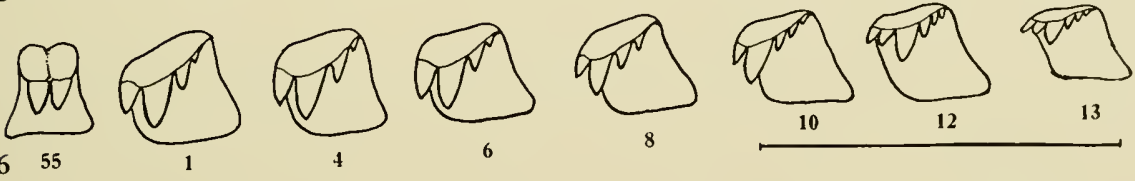
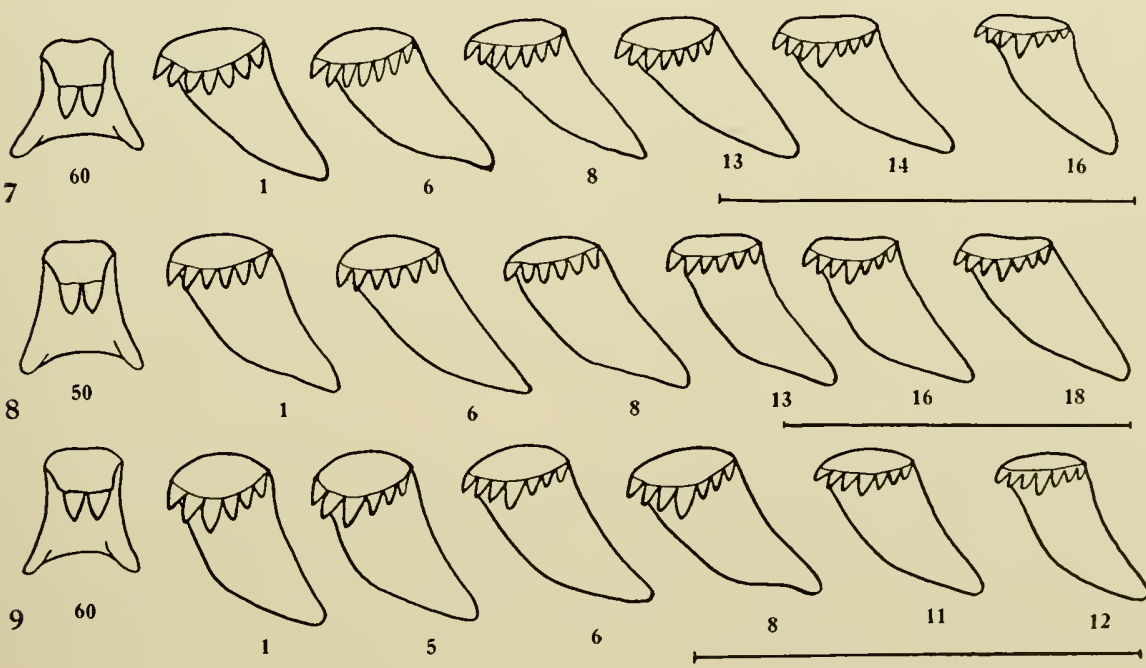

PLATE 69 


\section{PLATE 70}

\section{Animals of Planorbidae}

1. He lisoma campanulatum (Say). Canadian specimen. View as seen crawling up side of aquariun jar.

2. Helisoma sealare ( $\left.\mathrm{Jay}_{\mathrm{y}}\right)$. March 13. Twelve hours out of egg.

3. Helisoma secalare (Jay). Lake Butler, Florida. Adult with shell $10 \mathrm{~mm}$. long. Drawn from aquarium specimen.

4. Tropicorbis havanensis (Pfeiffer). New Orleans, Louisiana. Drawn fron aquarimn specimen. Shows pigmentation of mantle through shell.

5. Gyraulus hirsutus (Gould). Halfmoon Pond, near Alton Bay, Lake Winnipesaukee, New Hampshire. Head and tentacles of crawling animal.

6. Helisoma trivolvis (Say). Oneida Lake, New York. Young Animal.

7. Hclisoma trivolvis macrostomum (Whiteaves). Near Bayfield, Wisconsin. Side view of crawling animal with parts indicated.

8. II clisoma trivolvis fallax (Haldeman). Cambridge, Massachusetts. Animal crawling up side of aquarium jar.

9. Menetus dilatatus (Gould). Unionville, Connecticut. Aninal crawling on stick in aquarium jar. Side view.

10. Uenetus dilatatus (Gould). Unionville, Connecticut. Top view of animal.

11. Planorbula jenksii (H. F. Carpenter). From pool near Lake Wentworth, New Hampshire. Animal crawling on bottom of aquarium jar.

12. Helisome suberenatum (P. P. Carpenter). Buccal sac with parts indicated.

13. Gyraulus albus (Müller). Buccal sac. The outline of the radula is shown in the radular sac and the buccal sac.

Lme near figure indicates $1 \mathrm{~mm}$. in length 
Illustrations of the Anatomy and of Shells
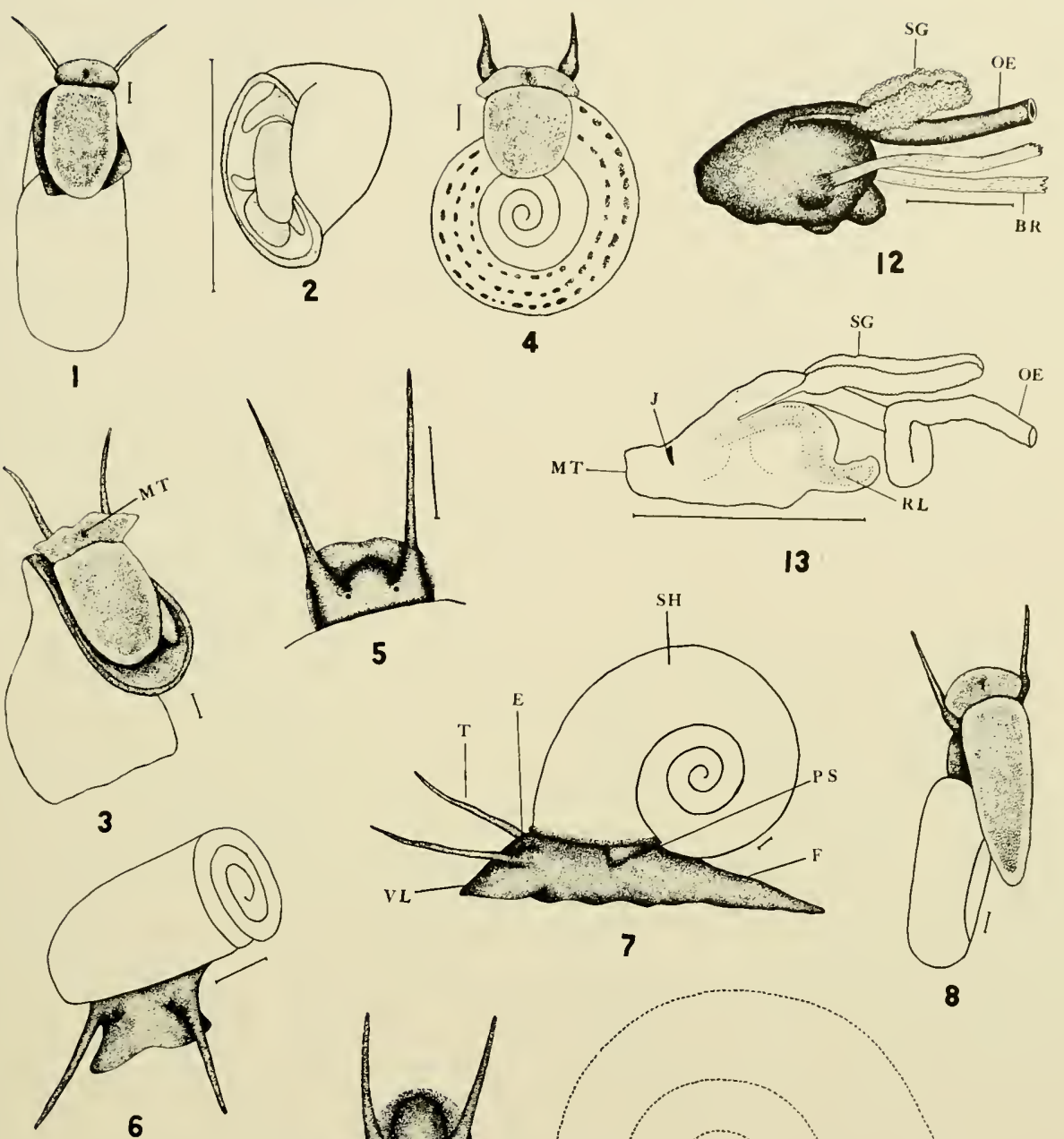

13
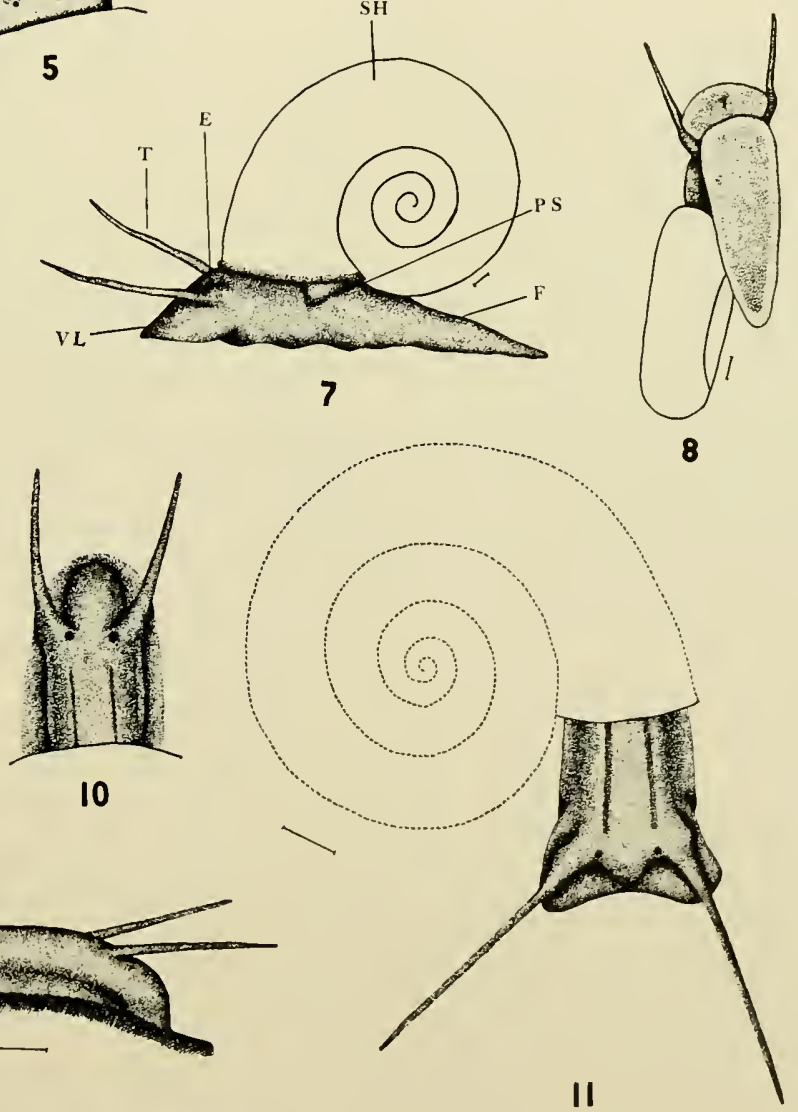

PLATE 70 


\section{PLATE 71}

\section{Isidora and Afroplanorbis}

I-6. Isidora globosa (Morelet). Copied from Connolly, Trans. Royal Soc. South Africa, XII, plate 8 .

1. Posterior end of penis (verge) with its sheath split open, showing the junction of the vas deferens with the penis (rerge). Fig. 11. $\times 11$.

2. Alimentary canal and salivary glands seen from above. Fig. $12, \times 6$.

3. Reproductive organs (genitalia). Fig. 14. $\times 5$.

4. Animal without its shell, seen from the left side. Fig. 13. $\times 3$.

5. Pulmonary orifice, with the folded branchial tube, anus, etc, on the right of it. Fig. 8. $\times \mathbf{5}$.

6. Posterior end of penis (rergic sac) showing penis papilla, this specimen exhibiting a different condition from that seen in fig. 1. Fig. 15 . $\times 12$.

7-9. Planorbis pfeifferi Krauss (=Afroplanorbis pfeifferi (Krauss)). Copied from Connolly; as noted above, plate 8 .

7. Lobes beneath the pulmonary orifice, seen from above. Fig. $17 . \times 8$. Includes pseudobranch and rectum.

8. Buceal mass, salivary glands, oesophagus, stomach, caecum, and first loop of intestine. Fig. 19. $\times 6$.

9. Reproductive organs (genitalia). Fig. 18 . $\times 8$.

10-12. Planorbis adowensis Bourg. (= Afroplanorbis adourusis (Bourg.)). Copied from Pilsbry, Proc. Acad. Nat. Sci. Phil., LXXXY, p. 53.

10. Genitalia showing spermatheca, prostate, uterus, etc. Fig. G.

11. Nale organ (penial complex) showing preputium and verge. Fig. F.

12. Preputium cut open to show pilasters and end of rerge, the rerge indicated by dotted lines. u. s. upper sac (vergic sac). Fig. H.

Figures are greatly enlarged 
Illustrations of the Anatomy and of Shells
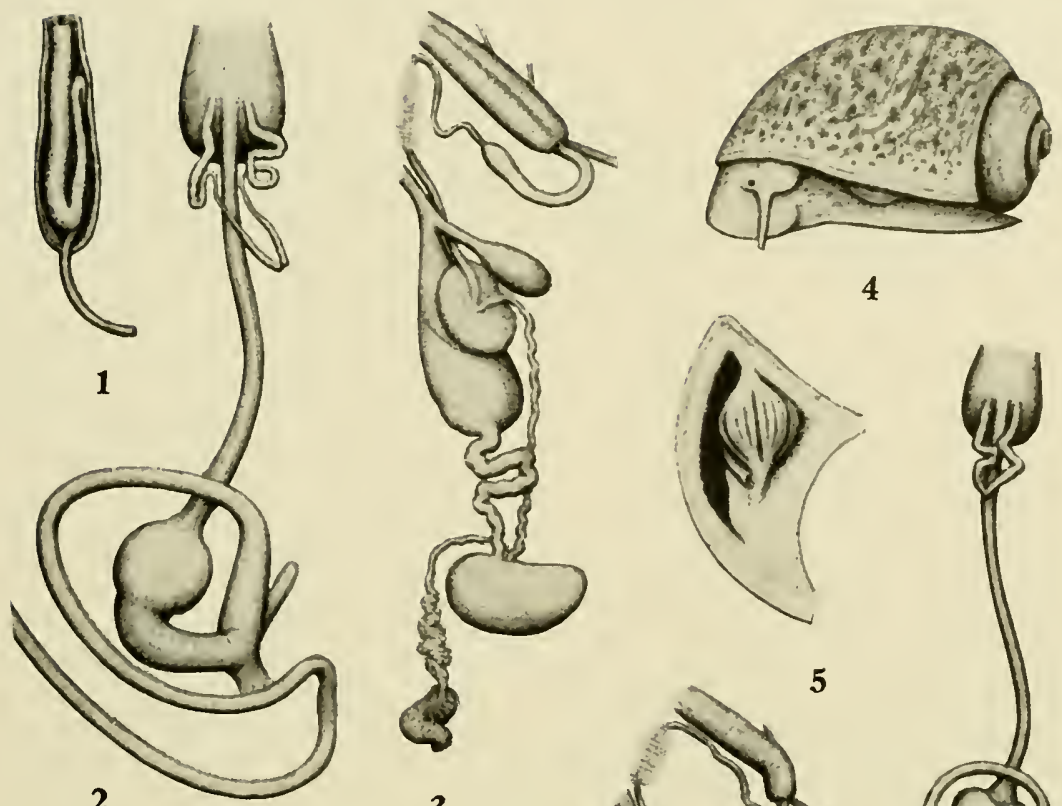

4
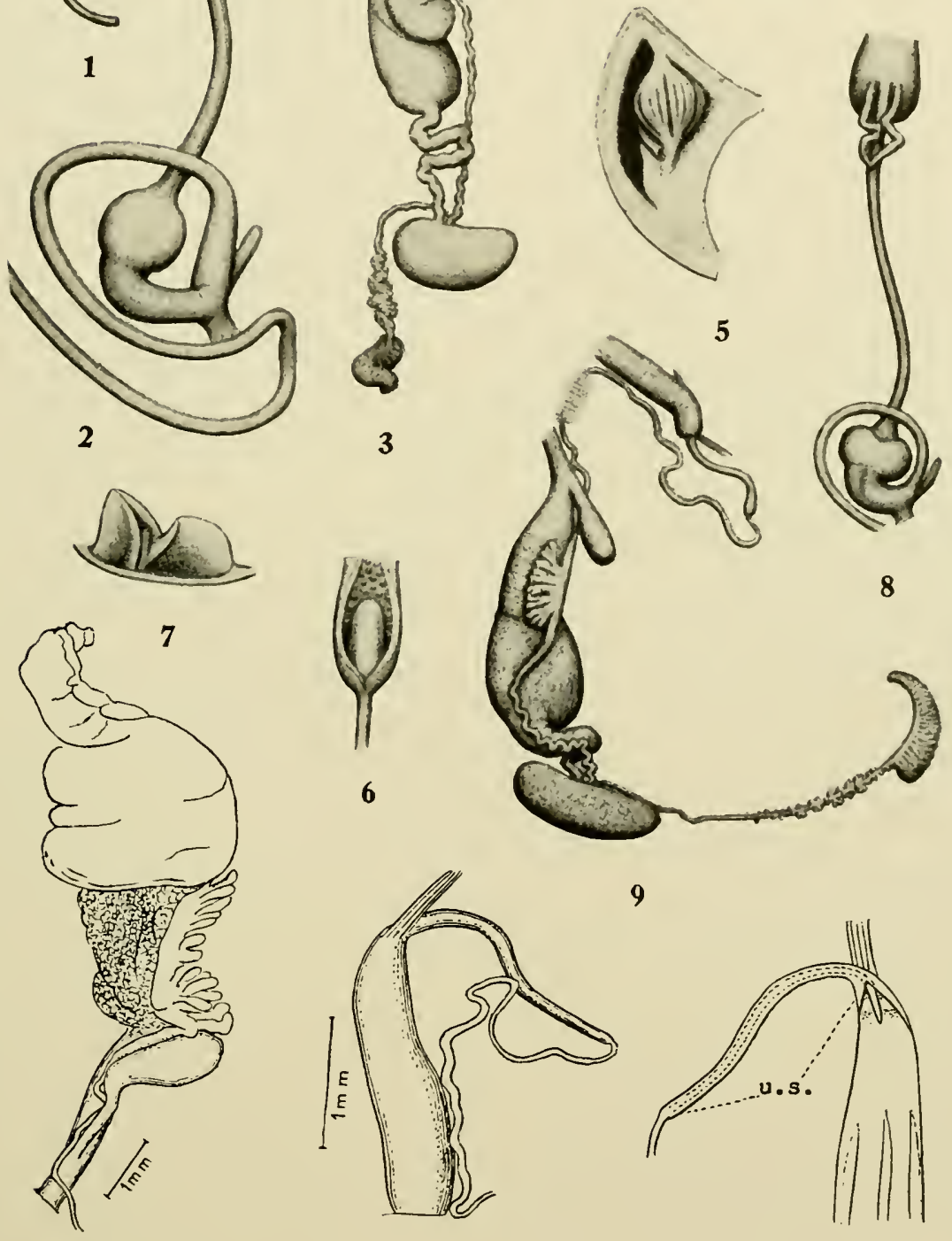

10

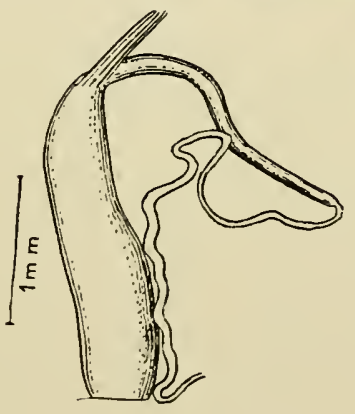

11

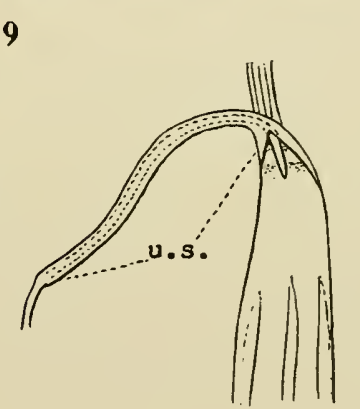

12

PLATE 71 


\section{PLATE 72}

\section{Acrorbis petricola Odhner}

Copied from Odhner's paper in Arkiv. för Zoologi, Band 29B, No. 14, two plates reduced to one plate in this volume.

1-3. Acrorbis petricola Odhner. Shell from below, front view, and from above.

4. Radula, one-half row on left side. $\times 1000$.

5. Animal removed from shell to show organization, from above.

6. Head and foot of animal, fore view.

7. Buccal sac.

8. Digestive system, from above.

9. Penial complex.

10. Portion of genitalia.

Description of symbols used on this plate: a, flagellum (anhangsdrüse); b, spermatheca (bursa copulatrix); c, caecum, a blind sac; $d$, intestine; f, tentacle; g, ganglia in nerve collar; go, orotestis (gonad); l, heart in pericardium; j, jaw; k, pseudobranch (kiemen falte) ; l, liver; m, stomach; $\mathrm{n}$, kidney (niere); o, oesophagus; od, oviduct (in the figmre this refers to the ovisperm duct); p, prostate; ph, buccal sac; ps, preputium (penissack, here including the whole penial complex, preputium and rergic sac); $\mathrm{r}$, rectum; re, penial retractors; s, salirary glands (speichel drüsen); t, radula sac (radula tasche); u, uterus; r, vas deferens. 


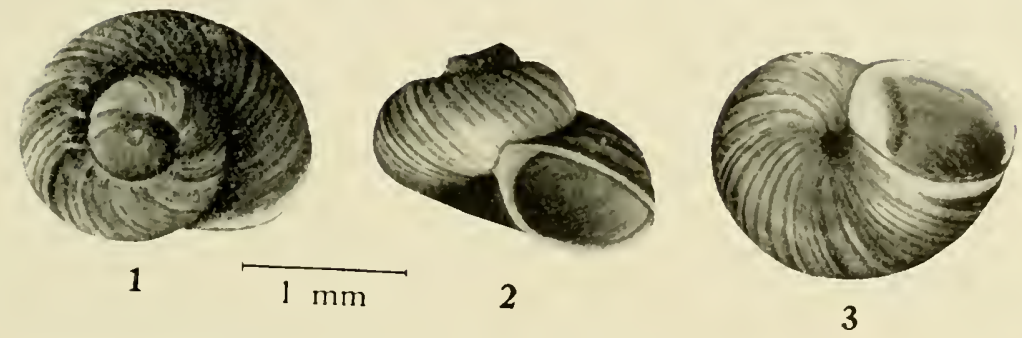

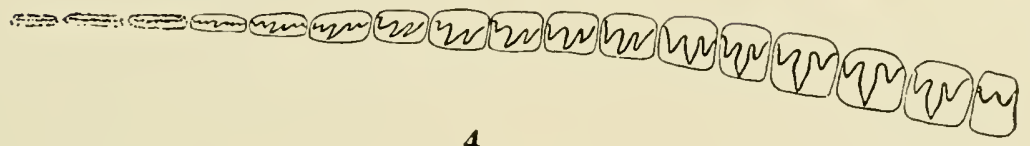
4

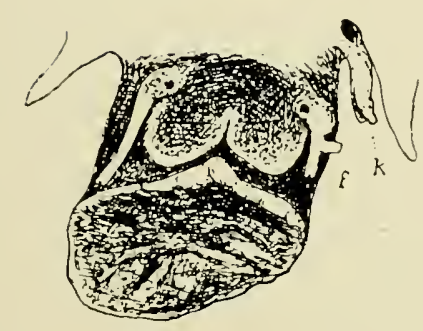

6
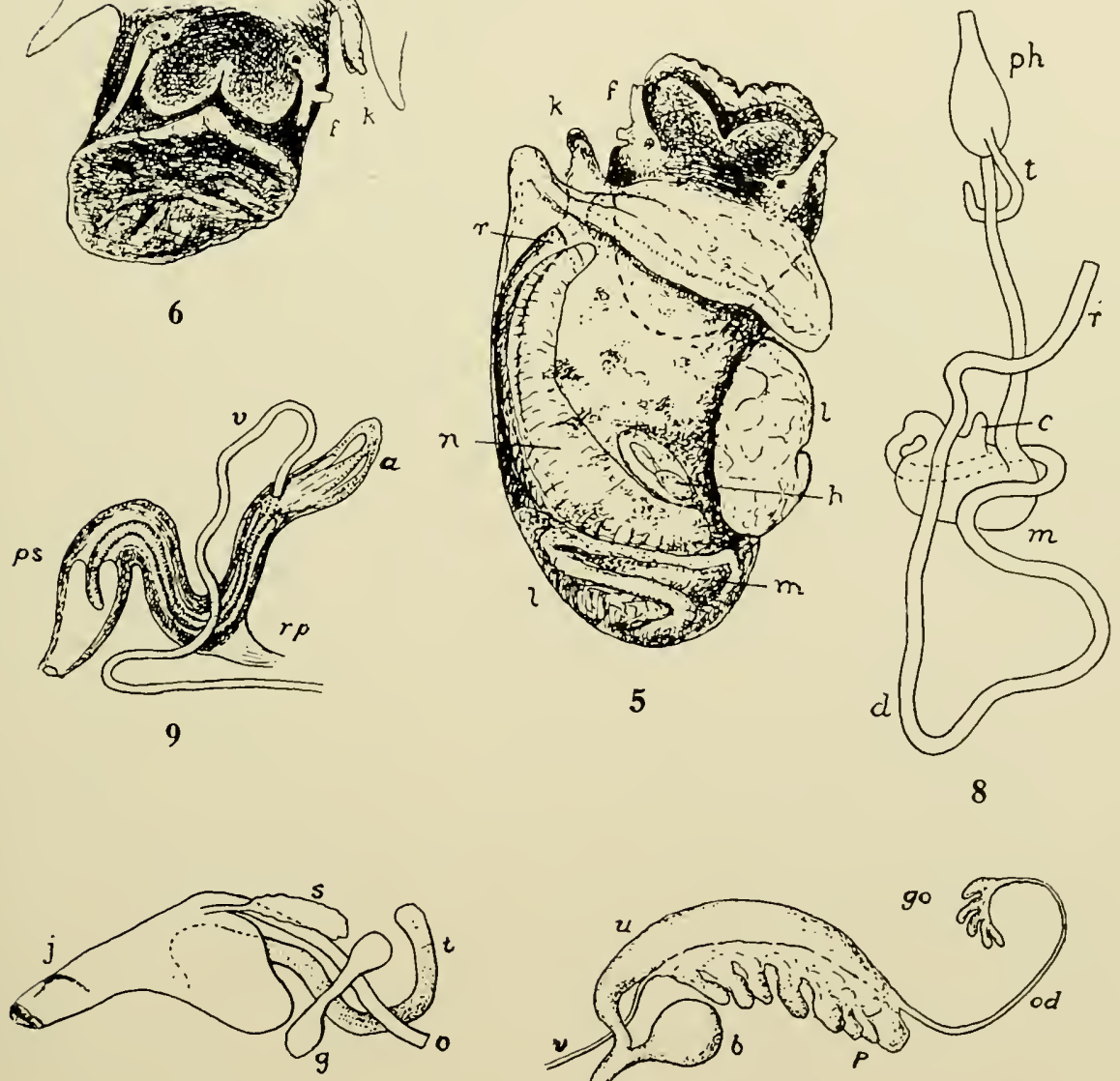

7

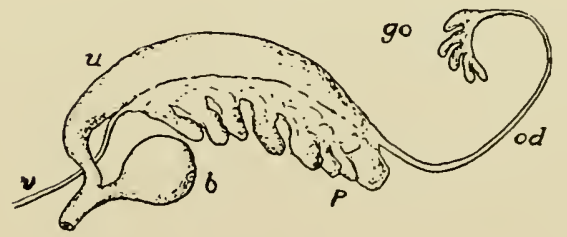




\section{PLATE 73}

\section{Indoplanorbis exustus (Deshayes)}

Genitalia copied from Larambergue, 1939b, p. 288

1. General view of genitalia (in French works the figures of both the animal and the shell are in reverse as compared with the position of American figures).

2. Penial complex (appareil copulateur) with vergic sac cut open to show length and nature of verge.

3. Transverse section of vas deferens (canal déférent).

Explanation of symbols used on the plates: Al, albumen gland; Bf, buceal sac; $\mathrm{C}$, junction of preputium with vergic sac $(\mathrm{col})$; $\mathrm{C} \stackrel{\sigma^{7}}{+}$, ovisperm duct (canal hermaphrodite); Cd, vas deferens (canal déférent); G, preputium (gaine); G o $^{7}$, ovotestis (glande hermaphrodite); Gu, nidamental gland (glande utérines); Od, oviduct; $\mathrm{P}$, pilasters (piliers musculaires); Pc, spermatheca (poche copulatrice); Pe, verge (tube pénial); Pp, vergic sac (poche du jénis); $\mathrm{Pr}$, prostate; $\mathrm{R}$, retractor muscle (muscle retractéur); compare the insertions of this figure with the figures on plate 22 of this work; Sp, sperm duet (spermiducte); Ut, uterus; Va, ragina.

Vertical line indicates measurements in millimeters; horizontal line in microns. 

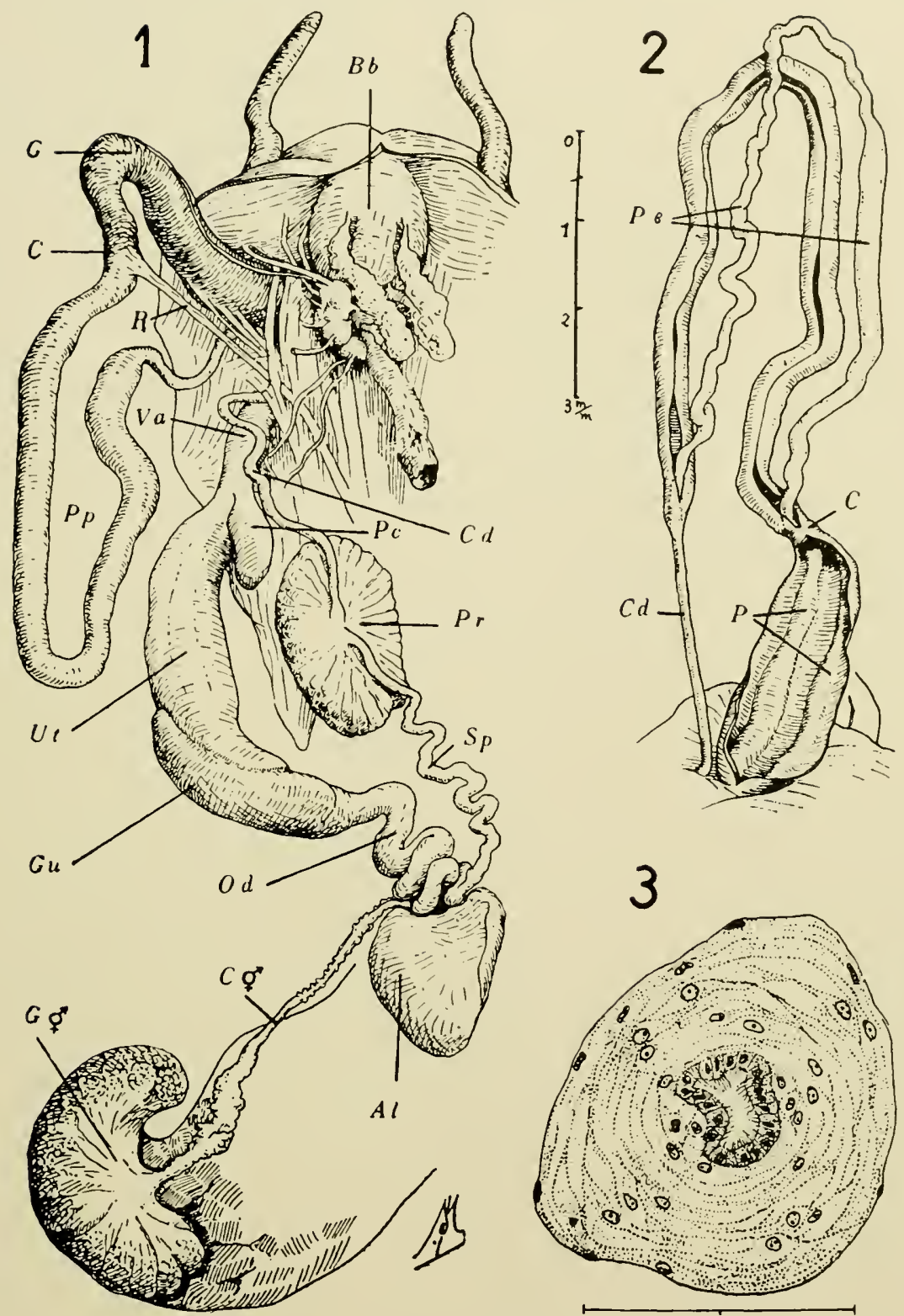

PLATE 73

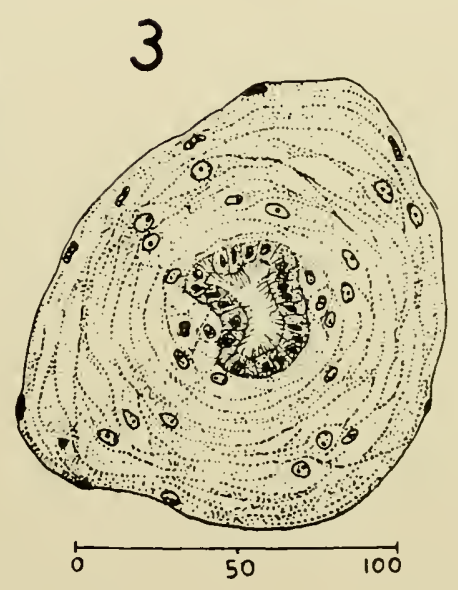




\section{PLATE 74}

\section{Indoplanorbis exustus (Deshayes)}

Genitalia copied from Larambergue, 1939b, p. 293

6. Individual with verge and preputium protruded from male genital opening, the latter cut open to show portion of verge not everted.

7. Two individuals of Indoplanorbis in coitus showing the extension of the penial complex from the body of the animal acting as male. Specimens anesthetized.

8. Schematic figure of penial complex retracted within the body of the animal.

9 Schematic figure of penial complex everted during copulation.

Explanation of symbols on the plate: Cd, ras deferens; $\mathrm{C}$, preputium (gaine); Pe, verge (tube pénial); Pp, vergic sac (poche du pénis).

Tertical line indicates size in millimeters 
Illustrations of the Anatomy and of Shells

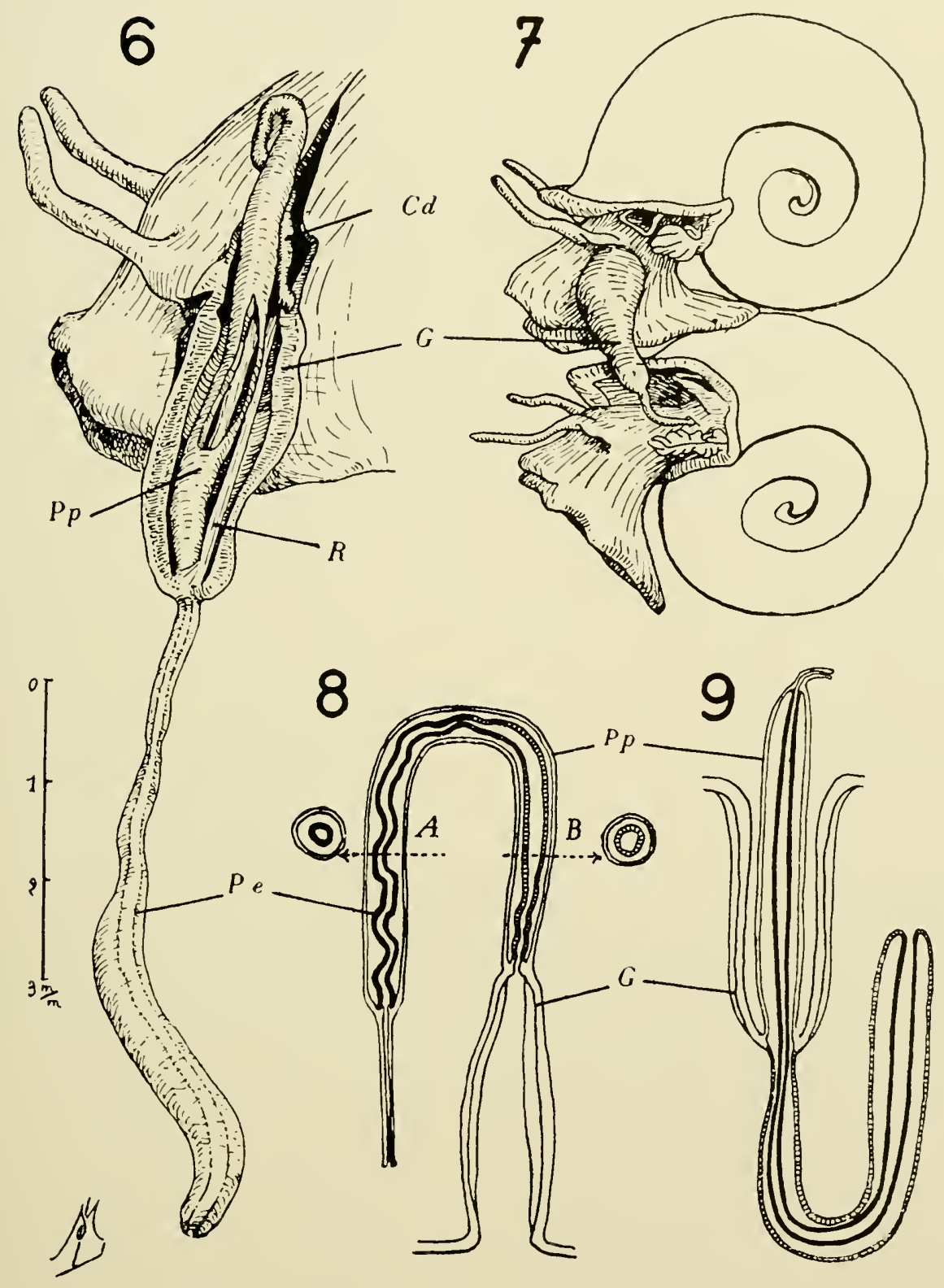

PLATE 74 


\section{PLATE 75}

\section{Bulinus contortus (Michaud)}

Genitalia copied from Larambergue, 1939a, p. 93

4. General dissection of genitalia and fore part of body.

5. Penial complex cut open to show characteristics.

6. Carrefour of the genitalia.

Explanation of symbols on the plate: A, atrium; Al, albumen gland; $\mathrm{Bb}$, buccal sac; $\mathrm{C}$, junction of preputium with rergic sac $(\mathrm{col})$; $\mathrm{C}$ 索, ovisperm duct (canal hermaphrodite); C Al, duct of albumen gland; $\mathrm{Cd}$, vas deferens (canal déférent); G, preputium (gaine); $\mathrm{G} \underset{+}{0^{7}}$, orotestis (glande hermaphrodite); Od, oviduct; P, pilasters (piliers musculaires); $\mathrm{Pc}$, spermatheca (poche copulatrice); Pe, verge (pénis); $\mathrm{Pp}$, vergic sac (poche du pénis); Pr, prostite; $R$, retractor muscle; Sp, sperm duct; It, uterus; Va, vagina.

Vertical line indicates size in millimeters 


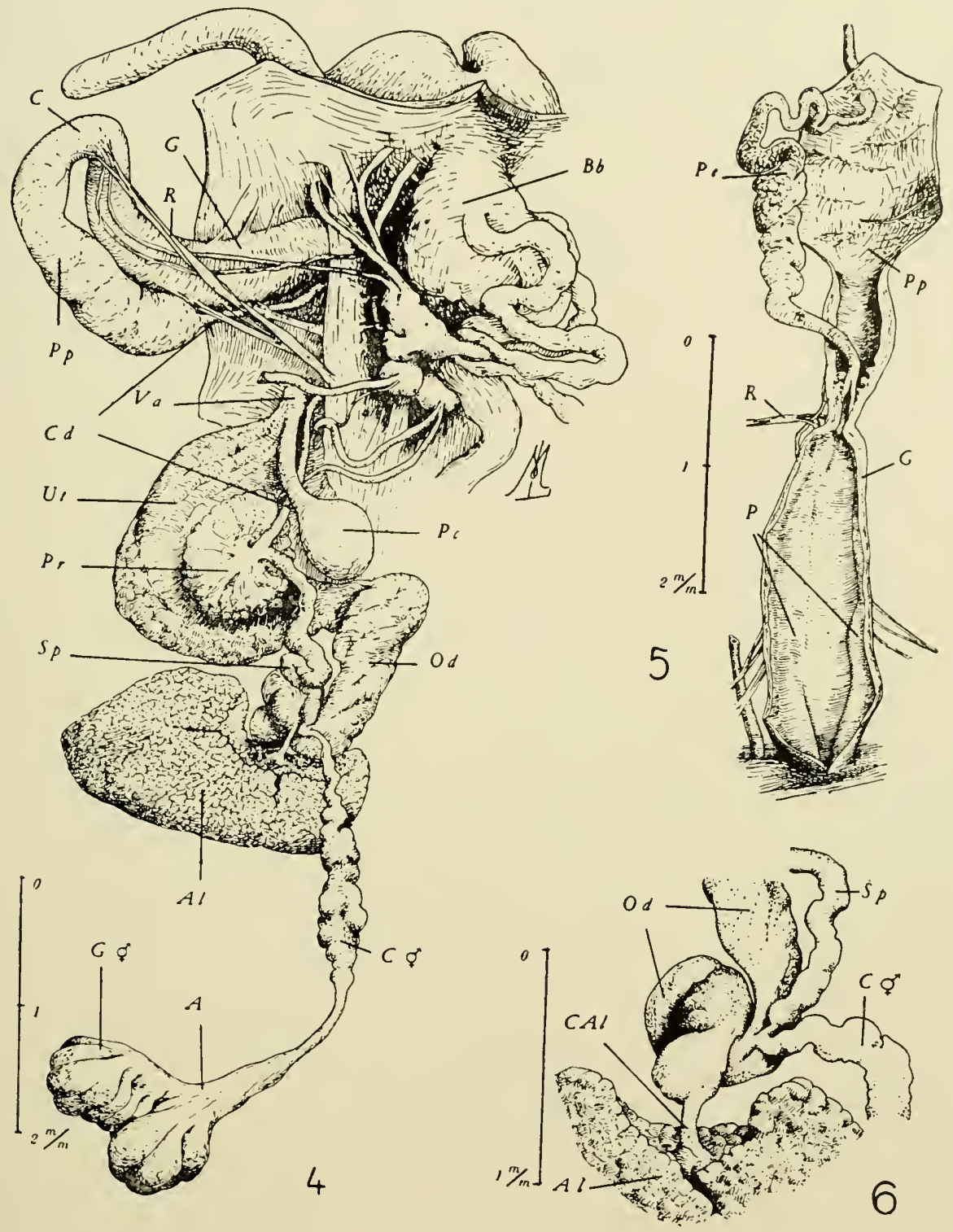

PLATE 75 


\section{PLATE 76}

\section{Shells of Planorbidae}

1. Planorbis krambergeri Halaváts. Resultate d. Wissens. Erforsch. des Balatonsee, plate 3 , figs. $3 \mathrm{a}, 3 \mathrm{~b}, 3 \mathrm{c} . \times 6$.

2. Odontogyrorbis krambergeri (Halaváts). Lörenthay, op. cit., Art. 3, plate 2, fig. 17. About $\times 5$.

3. Costorbis strauchianus (Clessin). Conch. Cab., XVII, plate 31, fig. 5. $\times 3$.

4. Segmentina nitida (Müller). Apertural lamellae. Greatly enlarged.

5. Polypylis hemispherula (Benson). Apertural lamellae. Greatly enlarged.

6. Armiger crista (Linn.). Forbes and Hanley, Hist. Brit. Moll., IV, plate 126, figs. 6, 7. About $\times 4$.

7. Tropicorbis obstructus (Morelet). Lamellae on outer lip. Enlarged.

8. Planorbula armigera (Siy). Lamellae on outer lip. Cireatly enlarged.

9. Planorbula wheatleyi (Lea). Lamellae on outer lip. Cireatly enlarged.

10. Drepanotrcma cultratum (Orbigny). From Bolivar, Colombia. Penial complex. Pilsbry, 1934, fig. 6. E (after H. B. Baker); fl, flagellum; vd, vas deferens; pr, penial retractor, vide Pilsbry.

11. Pompholopsis whitci Call. Amer. Geol., I, p. 147, figs. 5-7.

12. Vorticifex tryoni (Meek). White, Proc. U.S. Nat. Mus., V, plate 5, figs. 5-7.

13. Torticifex binneyi (Meek). Op. cit., figs. 8, 9.

Figures 11 to 13 are natural size 

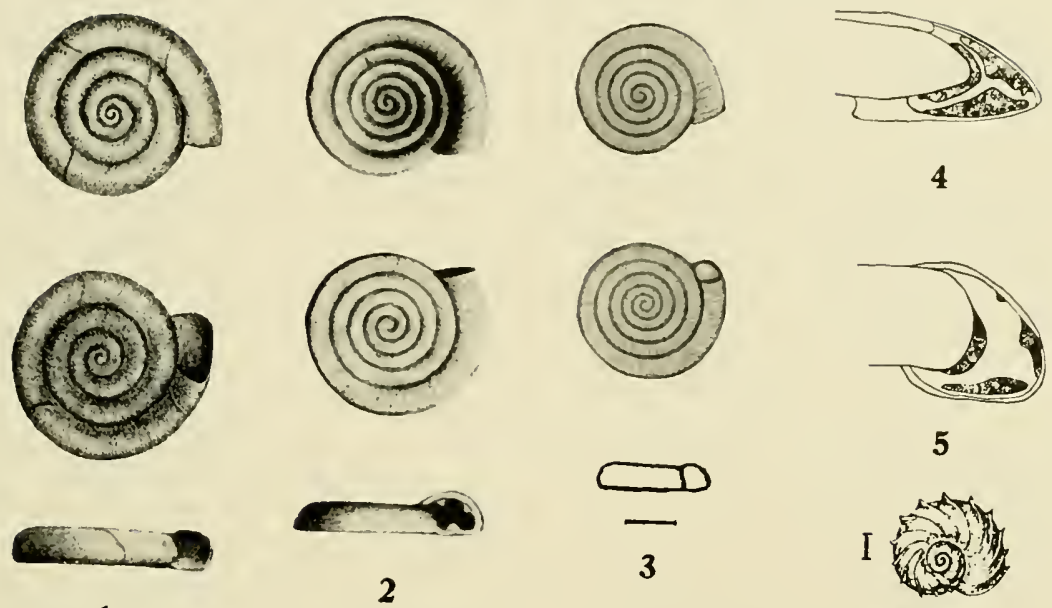

1
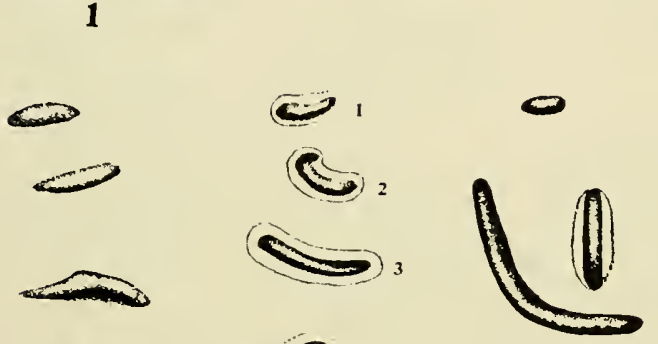

1

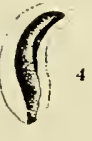

7

8

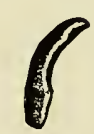

9

6

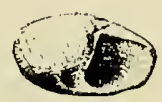

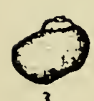
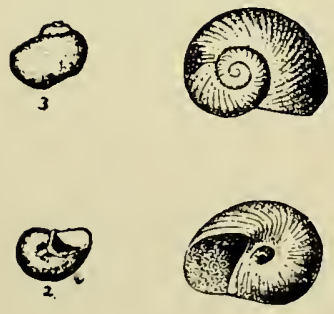

11

12
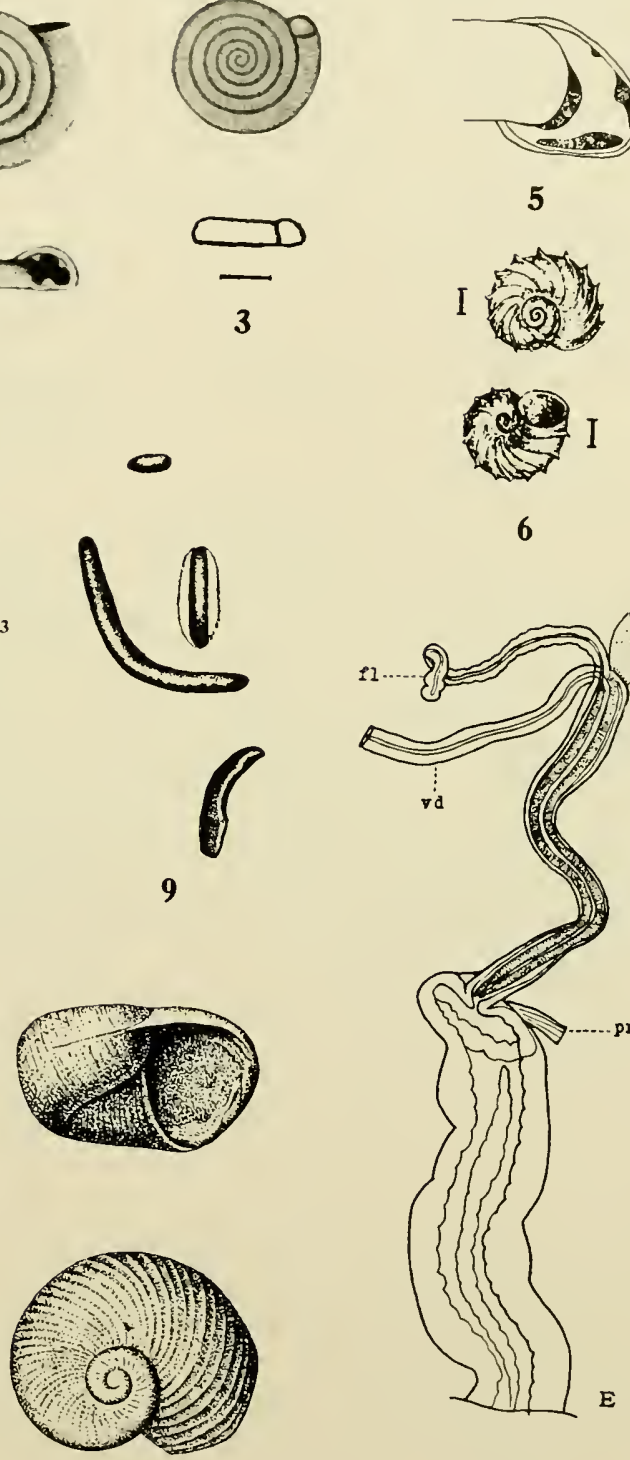

6

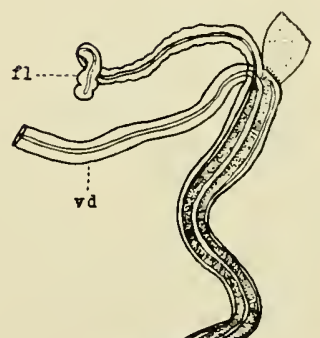

13

10

PLATE 76 


\section{PLATE 77}

\section{Shells of Planorbidae}

1-3. Gyraulus albus (Miiller). Pond in park in Kròlikarnia, a suburb of Warsaw, Poland. Baker coll., 3968. $\times 4$.

4-6. Gyraulus parvus (Say). Blue Pond, Wheatland Center Road, Monroe Co., New York. U.I., 41369. $\times 4$.

7-9. Tropicorbis orbiculus (Morelet). Drift at falls, Valles, Mexico. U.I., 28525. $\times 2$. 10-12. Tropicorbis pallidus (C. B. Adams). Kingston, Jamaica. U.I., 40466. $\times 4$.

13-15. Taphius andecolus (Orb.). Lake Titicaca, Peru. U.1., 40595. ×11/2.

16-18. Anisus leucostomus (Millet). Small pond in Bielany Park, Warsaw, Poland. Baker coll., 3969. $\times 4$.

19. Anisus vortex (Linn.). Stream in meadow in Jab-Tonna, $18 \mathrm{~km}$. northeast of Warsaw, Poland. Baker coll., 3971. $\times 2$.

20-22. Anisus spirorbis (Linn.). Pond at Scarborough, England. Baker coll., 1234. $\times 4$.

23-25. Bathyomphalus contortus (Linn.). Drewnica, $4 \mathrm{~km}$. northeast of Warsaw, Poland. Baker coll., 3972. $\times 4$.

26-28. Planorbis planorbis (Linn.). A pond $25 \mathrm{~km}$. southeast of Warsaw, Poland. Baker coll., 3970. $\times 2$.

29-31. Australorbis glabratus (Say). San Juan, Puerto Rico. M.C.Z., 65218. ×11\%2. 

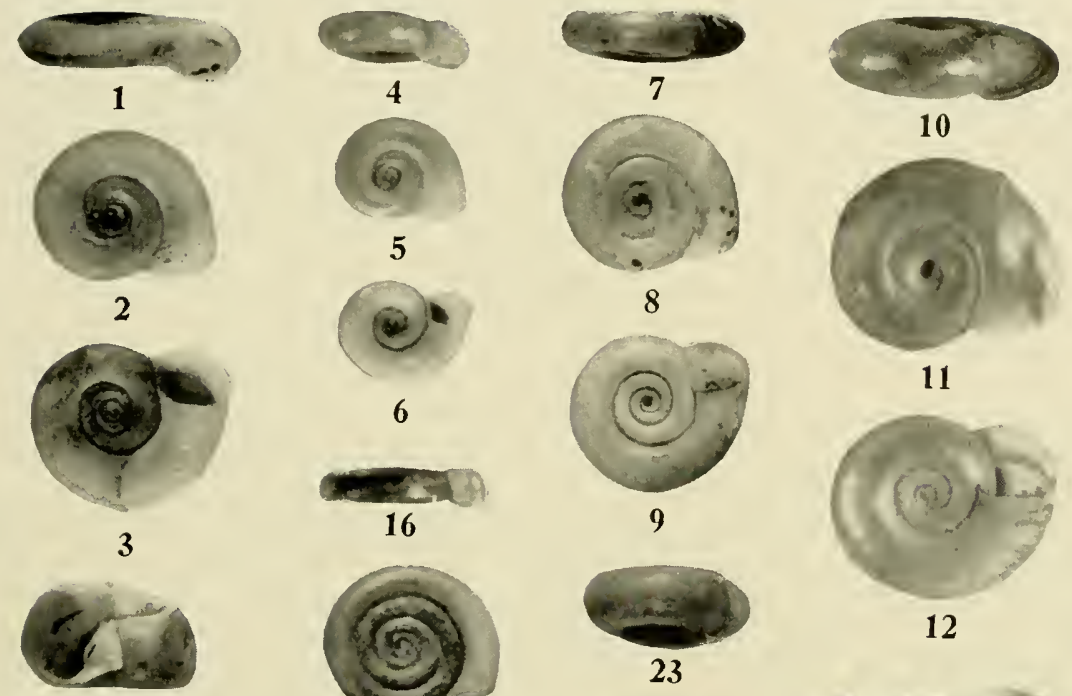

13

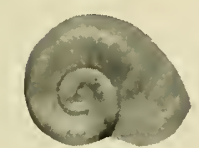

14

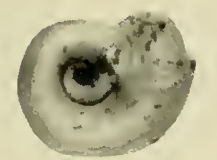

15
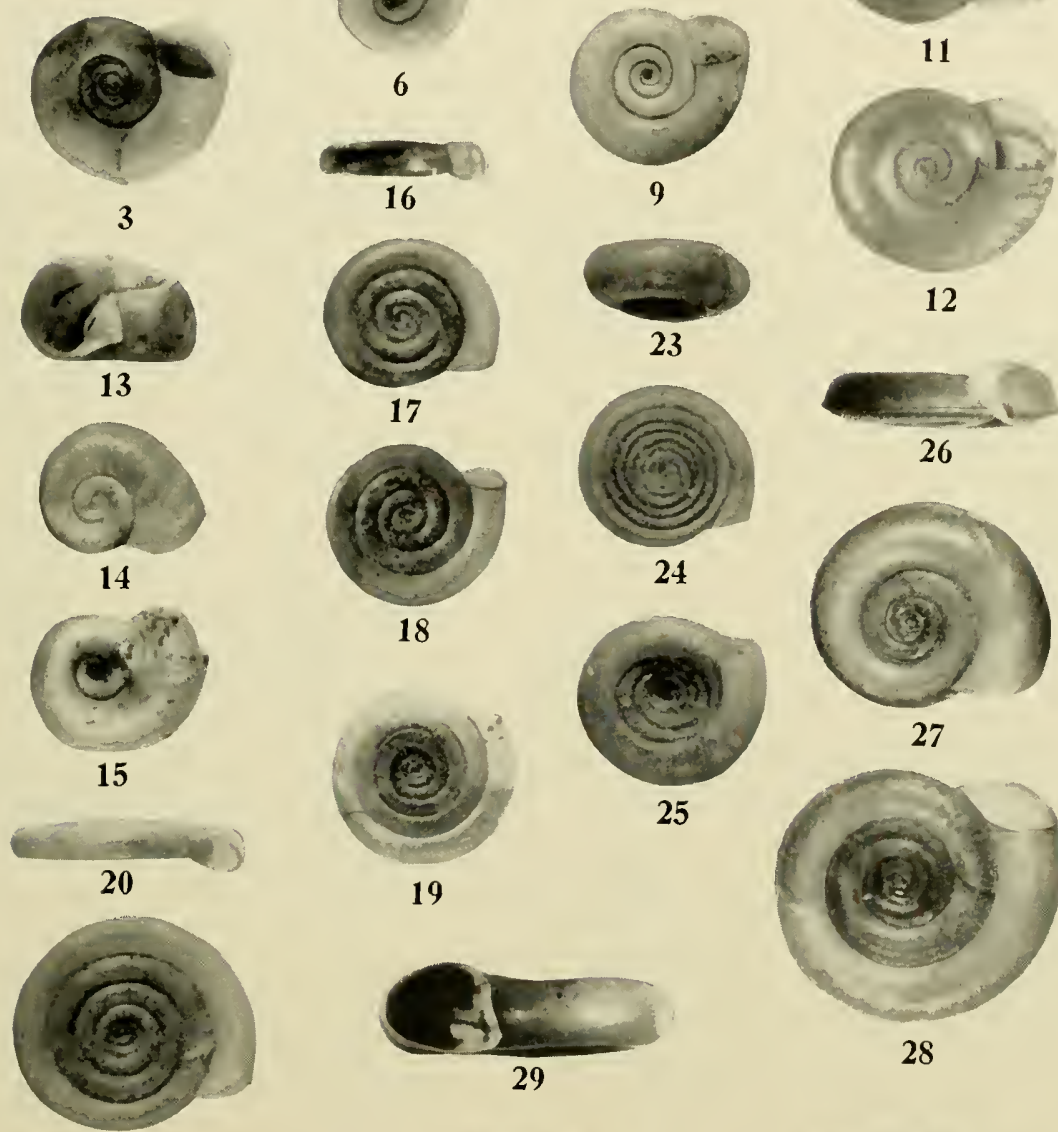

23
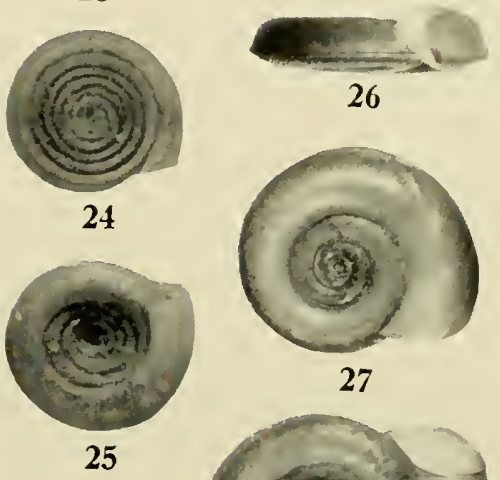

21

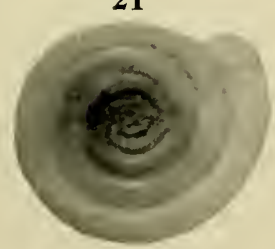

22
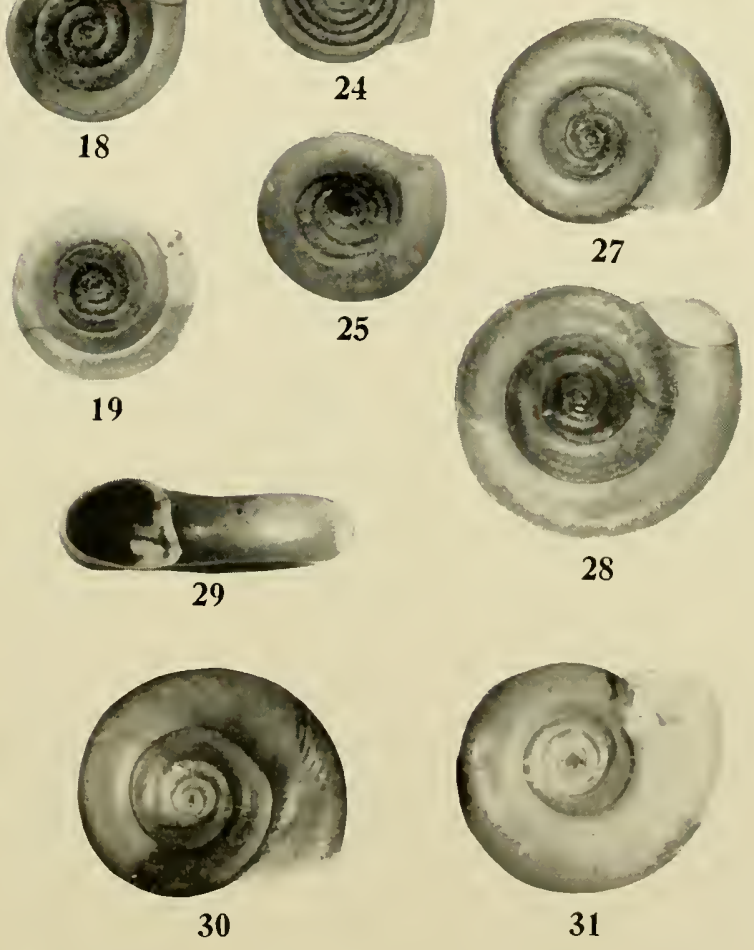

PLATE 77 


\section{PLATE 78}

\section{Shells of Planorbidae}

1,2. Tropicorbis molleus (Lutz). Upper and under side of animal. From Lutz, fig. 5, a, c.

3. Tropicorbis nigrilabris (Lutz). Animal from above. Lutz, fig. 4, c.

4. Tropieorbis nigrilabris (Iutz). Animal from above, lighter in pigmentation than fig. 3. From Lutz, fig. 6, c, mislabeled Planorbis nigricans by Lutz. Figures 1-4 from Mem. Inst. Oswaldo Cruz, rol. 10, plate 16. Figures greatly enlarged.

5-7. Helicorbis umbilicalis (Benson). Figures 5. 6. Hongkong. China. Baker coll., 2756; fig. 7, Canton, China. Baker coll., 2751. $\times 3$.

8-10. Pingiella peipinensis (Ping and Yen). Peiping, China. Bakel coll., 3975. $\times 3$.

11-13. Drepanotrema lucidum (Pfi.). Laguna del Bili, Alacranes Mts., Cuba. M.C.Z., 129991. $\times 3$.

14-16. Drepanotrema hoffmani F. C. Baker. Isabela, Puerto Rico. Types. Baker coll., $3976 . \times 3$.

17-19. Drepanotrema cultratum (Orb.). Painters Pond, Painters, Antigua. U.S.N.M., $272282 . \times 3$.

20,21. Parapholyx effusa (Lea). Sucramento River, California. Probably type lot. Lea coll., U.S.N.M., 121167. $\times 3$.

22. Parapholyx effusa (Lea). Sacramento River, California. Lea coll., U.S.N.M., 121133. $\times 3$.

23. Carinifex newberryi (Lea). Canoe Creek, California. U.S.N.M., 56405. $\times 3$.

24. Carinifex newberyi (Lea). Canoe Creek, California. Type. Lea coll., U.S.N.M., $9256 . \times 3$.

25-26. Carinifex newberyi minor Cooper. Clear Lake, California. Lea coll., U.S.N.M., 121025. $\times 3$. 


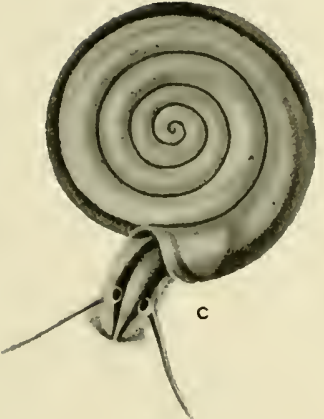

1
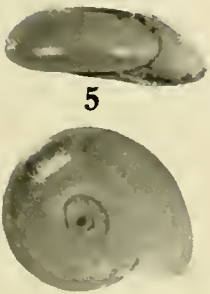

6
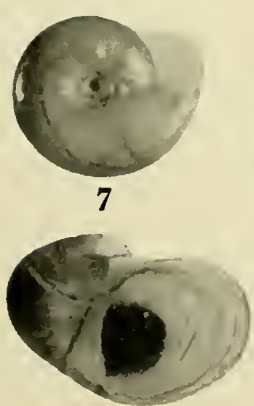

20

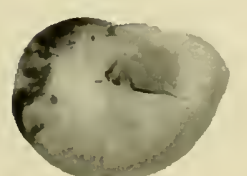

21

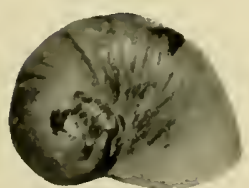

22

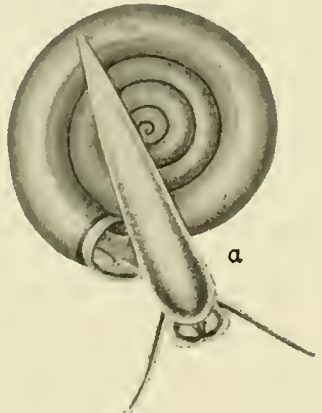

2
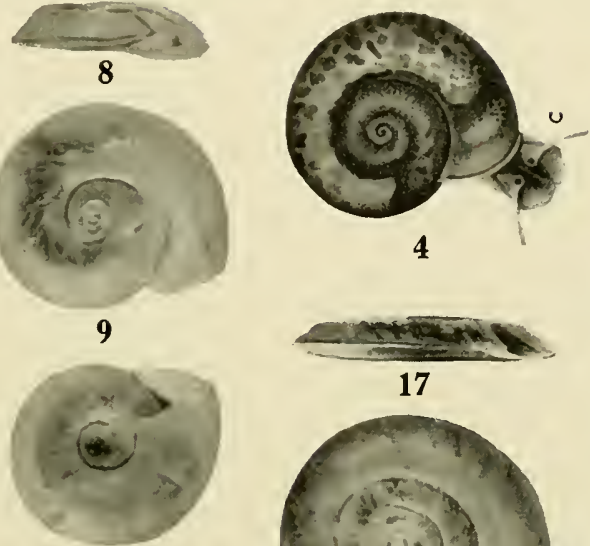

10

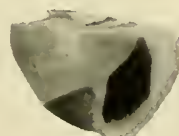

23

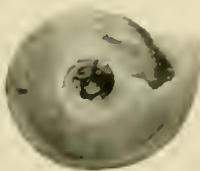

24

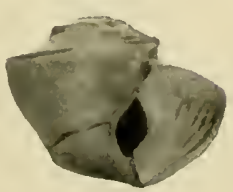

25

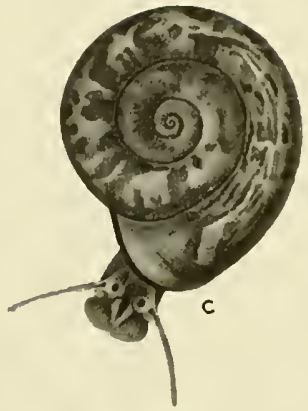

3

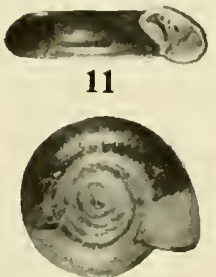

12

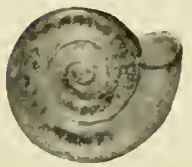

13

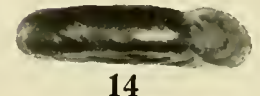

14

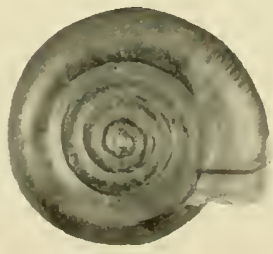

15

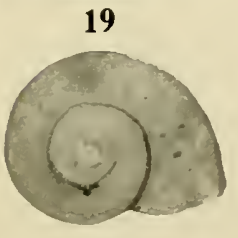

26

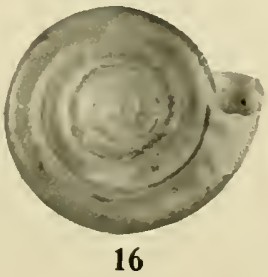

PLATE 78 


\section{PLATE 79}

\section{Shells of Planorbidae}

1-3. Segmentina nitida (Müller). Swamp on a meadow in Czerniakow, a suburb of Warsaw, Poland. Baker coll., 3972. $\times 4$.

4-6. Hippentis fontamus (Lightfoot) = complanatus (Linn.). Damsells Mill Pond, Painswich, West Strand, England. Baker coll., 1256. $\times 6$.

7-9. Polypylis largilliarti (Phil.) =hemisphacrula (Benson). Peiping, China. Baker coll., 5973. $\times 4$.

10-12. Platytaphius heteropleurus (Pils. \& Van.). Lake Titicaca, Peru. Baker coll., $3974 . \times 2$.

13-15. Menetus dilatatus (Gould). Wrights Dike, Duxbury, Massachusetts. Baker coll., 3978. $\times 4$.

16-18. Drepanotrema anatinum (Orb.). Figures 16, 17, Para, Brazil. U.S.N.M., 348535; fig. 18, Para, Brazil M.C.Z., 72832. $\times 5$.

19-21. Promenctus exacuous (Say). Small brook west bank Cayuga Lake, near Cayuga, New York. Baker coll., 1140. $\times 4$.

22-24. Menetus opereularis (Gould). San Francisco, California. U.S.N.M., 227303. $\times 4$.

25-27. Planorbula armigera (Say). Thief River Falls, Minnesota. U.I., 27093. $\times 4$.

28-30. Planorbula wheatleyi (Lea). Boligee, Alabama. Baker coll., 1140. $\times 4$.

31,32. Perrinilla cordilleriana (Hannibal). Truckee Lake Beds, Nevada. Hill near Hawthorne, on Belmont Stage Road, Nevada. Hannibal, Proc. Mal. Soc., X, plate 6, fig. 16, plate 8 , fig. 34 . About natural size.

33-35. Indoplanorbis cxustus (Desh.). Figures 33, 34, Bombay, India. Baker coll., 1231 ; fig. 35 , Calcutta, India, Baker coll., 2229. $\times 11 \% 2$. 

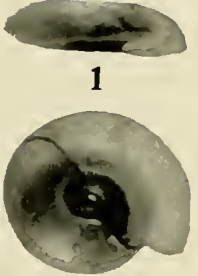

2

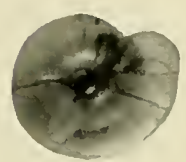

3

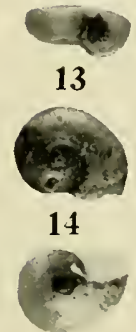

15

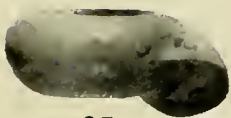

25

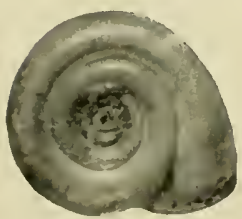

26

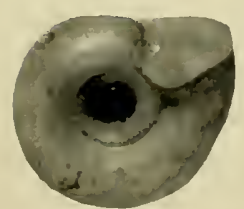

27
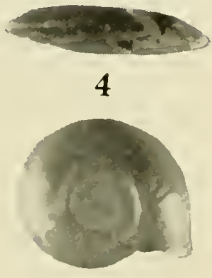

5

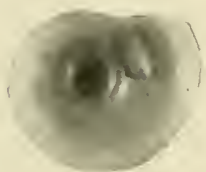

6
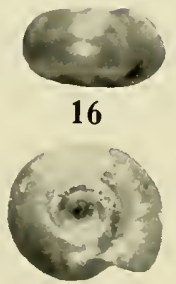

17

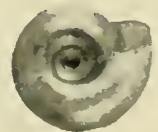

18

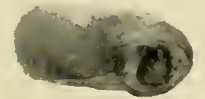

28

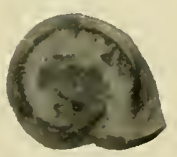

29

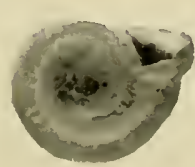

30

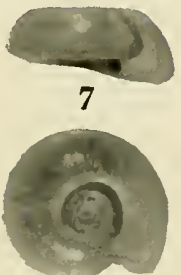

8
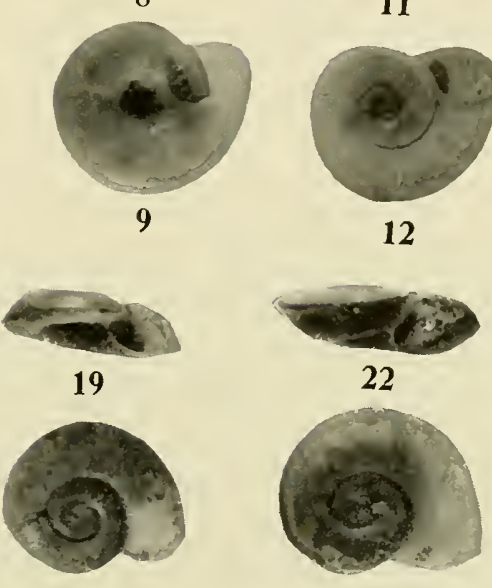

20

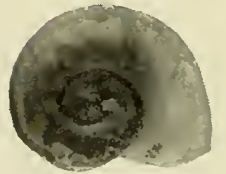

23

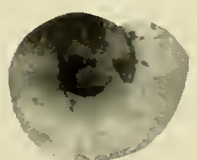

21
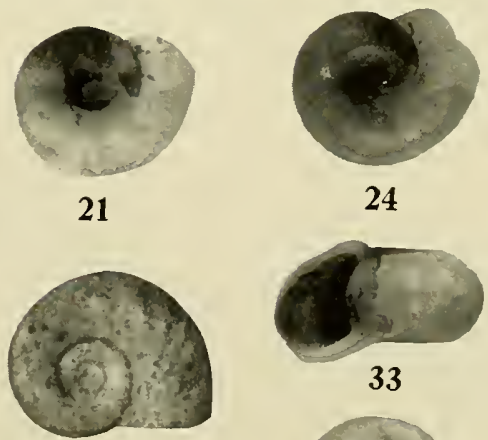

31

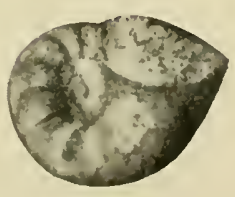

32

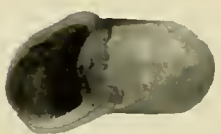

33

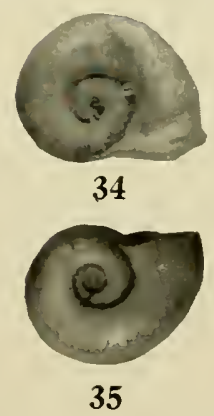

PLATE 79 
PLATE 80

\section{Shells of Planorbidae}

1-3. Helisoma anceps (Menke) = Planorbis bicarinatus Sowb. and P. bicarinatus Say. From Delaware River 11/2 miles above Plum Point, New Jersey. Like Say's figures. U.I., /25738. $\times 2$.

4-6. Helisoma anceps (Menke). South Street Brook, Auburn, New York. Strongly carinated form. U.I., Z25934. $\times 2$.

7-8. Hctisoma scalare (Jay). Everglades, head of Miami River, Dade Co., Florida. Baker coll., 2371. $\times 2$.

9. Helisoma duryi seminole Pilsbry. Lake Eustis, Floricla. Physoid shell. Baker coll., 3977. $\times 2$.

11-12. Ilelisoma duryi nomale Pilsbry. Lake Pinsett. Florida. Typically planorboid shell. U.I., 41489. $\times 11 \frac{1}{2}$.

13-15. Helisoma trivolvis (Say). Braddocks Bay, near Rochester, New York. Lake Ontario. U.I., 29789. $\times 1 \frac{1}{2}$.

16-18. Helisoma campanulatum (Say). Thousand Island Park, St. Lawrence River, New York. U.I., 27112. $\times 1$ 1/2.

19-21. Helisoma multivolvis (Case). Howe Lake, Marquette Co., Michigan. Baker coll., $1962 . \times 2$.

22-24. Planorbarius corneus (Iinn.). Rhone River, France. U.I., 25740. $\times 11 \frac{2}{}$. 

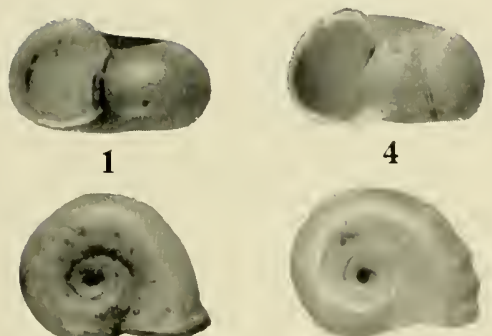

5

2

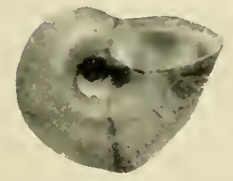

3

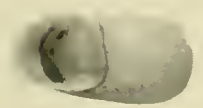

16

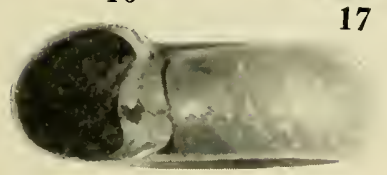

22

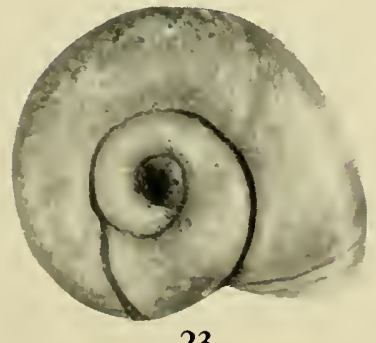

23

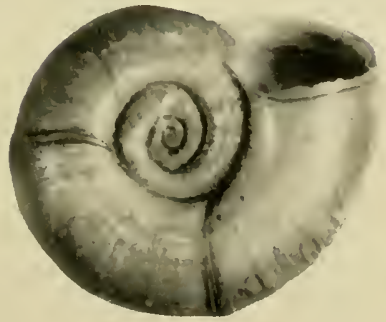

24
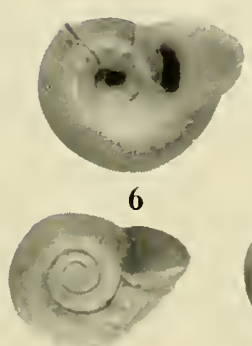

17

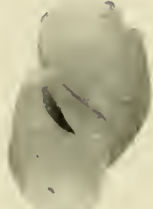

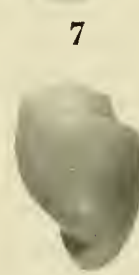

8

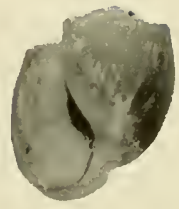

9

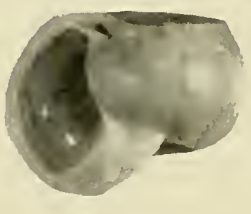

10

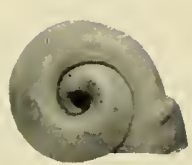

18
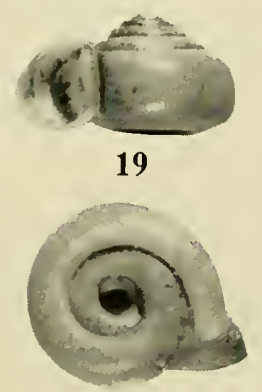

20
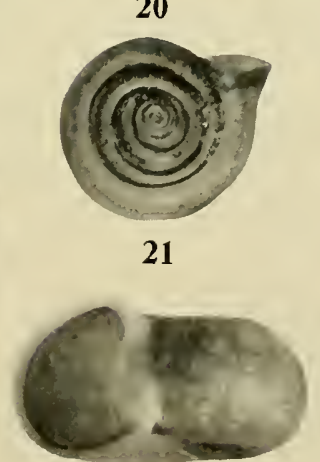

15

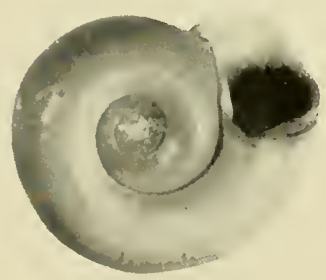

12

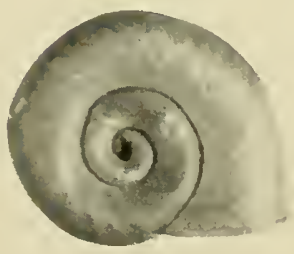

13

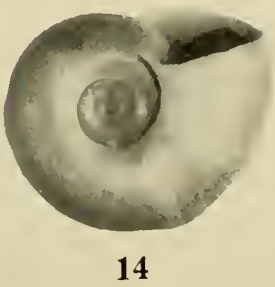

PLATE 80 


\section{PLATE 81}

\section{Shells of Planorbidae}

1. Poecilospira trochiformis (Stah1). Steinheim, Germany. Showing extreme range of rariation from short, flattened spire to long, conical spire. M.C.Z. $\times 2$.

2. Afroplanorbis adowensis (Bourg.). Belgian Congo, Africa. Pilsbry and Bequaert, Bull. Amer. Mus. N.H., LIII, fig. 4, p. 118 . $\times 11 \frac{1}{2}$.

3. Afroplanorbis sudanicus (Martens). Bahr-el-Ghazal, Africa. U.S.N.M., 215381. Pilsbry and Bequaert, op. cit., fig. 7, p. 122 . $\times 1 \frac{1}{2}$.

4. Biomphalaria smithi Preston. Upper figures, specimen from Kabare, Lake Edward, Africa; lower figures, paratypes from Lake Edward. Pilsbry and Bequaert, op. cit., fig. 6, p. $121 . \times 1 \frac{1}{12}$.

5. Paraplanorbis condoni (Hanna). Vicinity of Wamer Lake, eastern Oregon. Pliocene period. Hanna, Univ. Oregon Pub., I, No. 12, plate 1, figs. 1-3. About $\times 7$.

6. Planorbifex vanvlecti (Arnold). North dome Kettleman Hills, King Co., California. Pliocene. Pilsbry, Proc. Acad. Nat. Sci. Phil., 86, plate 21, fig. 9, a, b, c. Reduced one-half from Pilabry's figure. Line indicates $1 \mathrm{~mm}$.

7. Choanomphalus mancki Gerstfeldt. Crosse and Fischer, Jour. de Conch., XXVII, plate 4 , fig. 9 .

8. Choanomphalus valvatoides Dybowski. Op. cit., plate 4, fig. 8 .

9. Choanomphalus schrenchii Dybowski. Op. cit, plate 4, fig. 10. Line near figures 8-10 indicates natural size.

10. Anisopsis calculus (Sandberger). Land und Suiss.-Conch. Vorwelt, taf. 1, figs. 7, 7a. (stark vergrössert).

11. Anisopsis loryi (Coquand). Op. cit, taf. 1, figs. 28, 28a, 28b. 

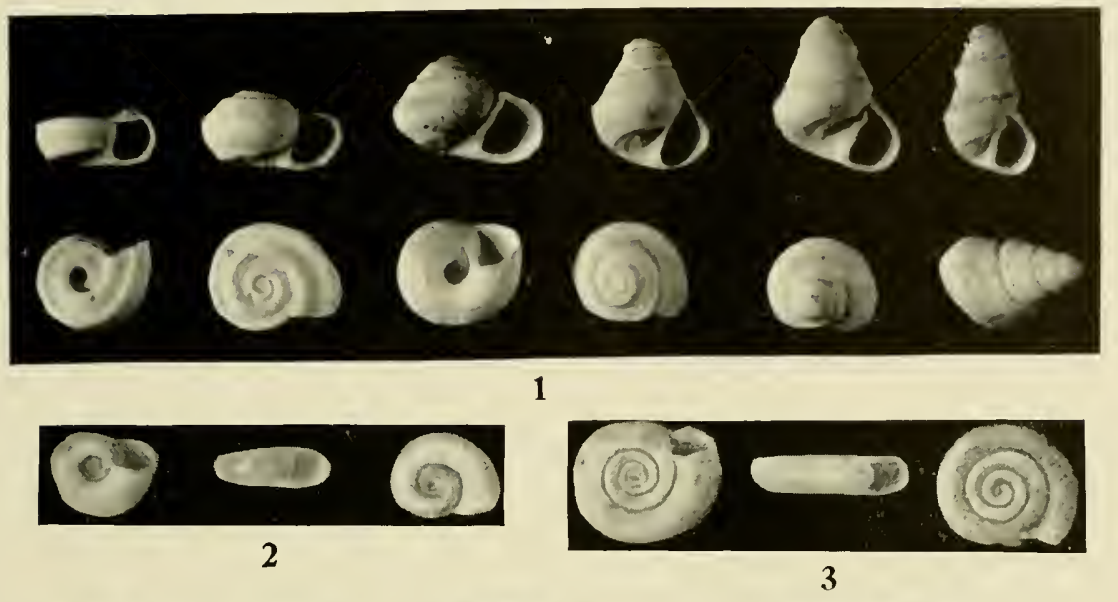

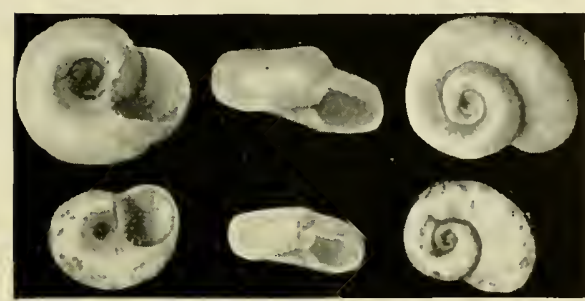

4

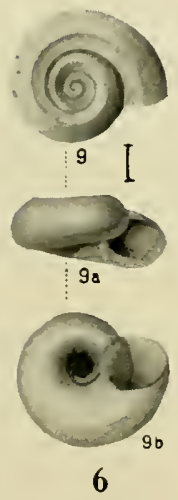

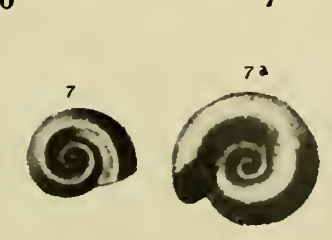

10
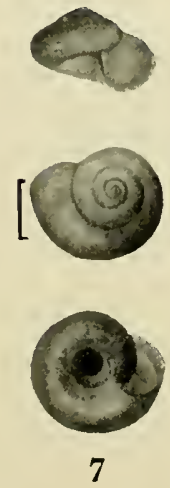

7

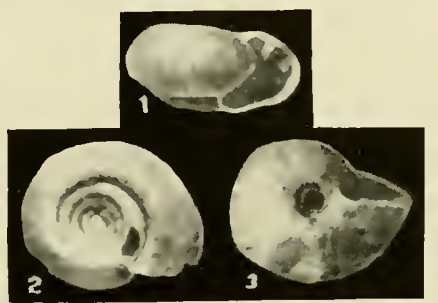

5
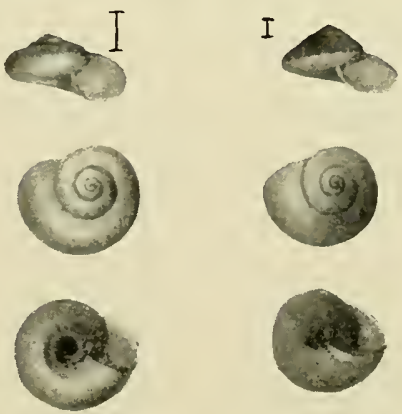

8

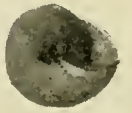

9

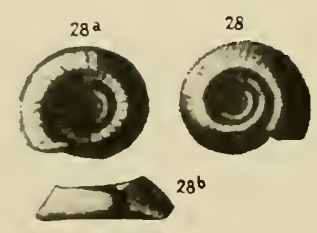

11

PLATE 81 


\section{PLATE 82}

\section{Shells of Planorbidae}

1,2. Helisoma anceps (Menke). Ashland, Tirginia. Resembling Menke's figure. B999. 3-5. Helisoma anceps (Menke). Below dam at Lake Junalaska, North Carolinar. B1s19.

6-8. Ilelisoma aneeps (Menke). Long Lake, Alpena, Michigan. Resembling Rackett's figure of Helix angulata. B1001.

9-11. Helisoma anceps (Menke). Spring Grove, Dove Co., Alabama. Walker coll. Resembling Conrad's Planorbis antrosa. U.M., 67401.

12-15. Helisom aneeps (Menke). Potomac River, Fort Washington, Maryland. 14, resembling unicarinatum; 15, resembling sayi. U.S.N.M., 364718.

16, 17. Helisoma anceps (Menke). Blue Creek, Coenr l'Alene Mts., Idaho. U.M., S1780

18, 19. Helisoma anceps (Menke). Portland, Oregon. Hemphill coll. C.A.S., 6875.

20-22. Helisoma anceps striatum (F. C. Baker). Bay View, Milwankee, Wisconsin. From marl bed. B2S51.

23-25. Helisoma anceps shellense F. C. Baker. Shell Lake, Washburn Co., Wisconsin. 23, paratype, U.I., Z19354; 24-25, type locality, U.I., Z13474.

26. Helisoma anceps (Menke). Portland, Oregon. I.C.M., 23143.

27-29. Helisoma aneeps minnesotense (F. C. Baker). Frontenic, Minnesota. Types. B1002.

30. Helisoma anceps (Menke). Priests Lake, Bonnar Co., Idaho. U.M., 81798.

31. Helisoma anceps corrugatum (Currier). Nortluern part of Minnesota. B985.

32-34. Helisoma anceps sayi F. C. Baker. East Lake Okoboji, Iowa. Shinek coll., U.S.N.M., 476580.

Figures are enlarged approximately two diameters 


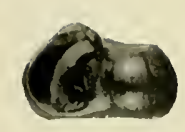

1

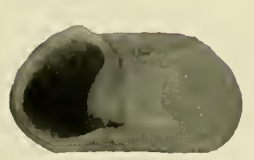

6

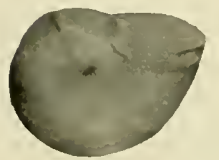

10

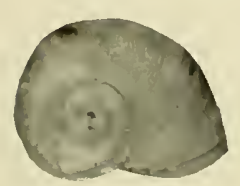

14

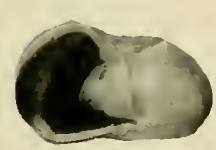

18

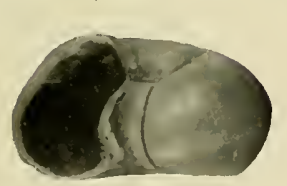

23

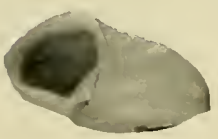

27

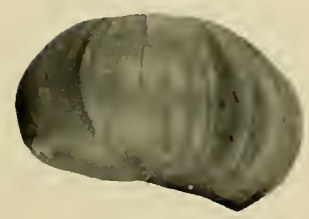

31

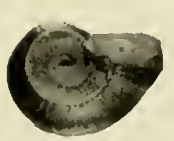

2

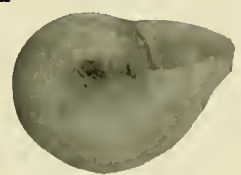

7

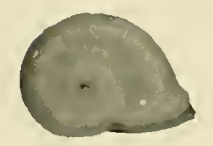

11

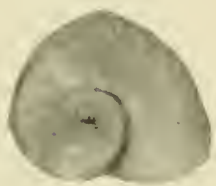

15

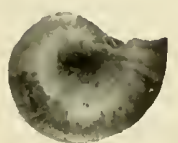

3

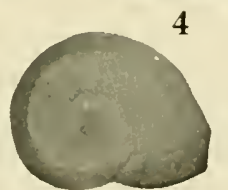

8

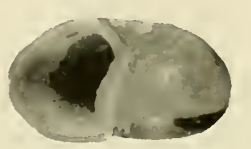

12

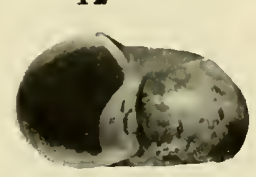

16

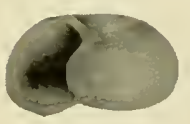

20

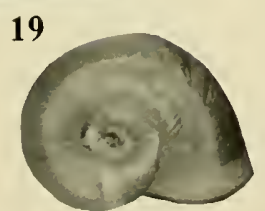

24

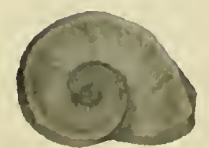

28

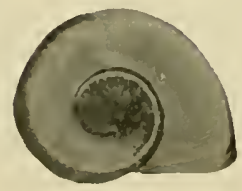

32

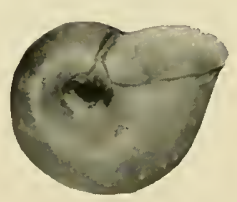

25
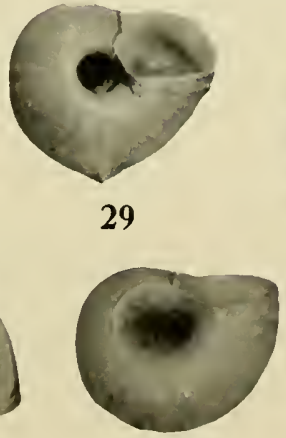

33

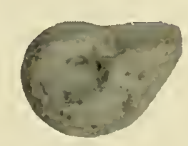

21

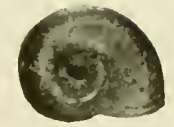

5
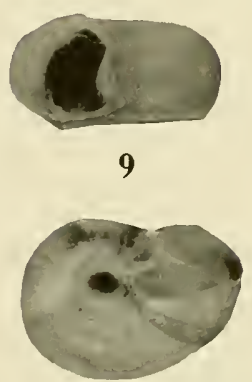

13

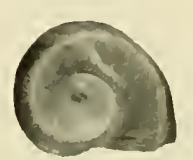

17

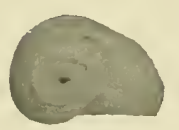

22

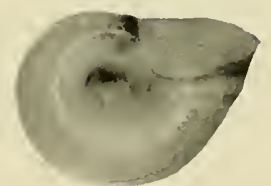

26
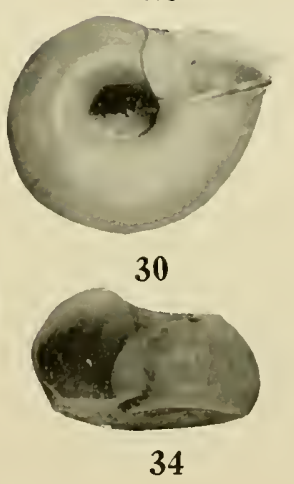

PLATE 82 


\section{PLATE 83}

\section{Shells of Planorbidae}

1-3. Helisoma anceps sayi F. C. Baker. Tomahawk Lake, Oneida Co., Wisconsin. Type locality. U.I., Z25736.

4-6. Helisoma anceps sayi F. C. Baker. West Lake Okoboji, Iowa. Shimek coll. Varying toward anceps. U.S.N.M., 475945.

7-9. Helisoma anceps unicarinatum (Haldeman). Plum Point, Delaware River, above Riverton, New Jersey. U.I., Z25938.

10-12. II lisoma anceps unicarinatum (Hald.). Cherokee River, Little River Station, Alabama. U.I., Z41055.

13-15. Helisoma anceps unicarinatum (Hald.). Blackstone River', above Courtland, West Virginia. Figure 13 resembles Haldeman's angistomum. U.S.N.M., 109888.

16-18. Helisoma anceps politum F. C. Baker. Honeywell Creek, Carleton Co., Ontario, Canada. F. R. Latchford coll. Holotype, fig. 16; paratypes, figs. 17, 18. U.S.N.M., 367426.

19-22. Helisoma anceps bartschi F. C. Baker. Brook at Great Falls, Virginia. Holotype, fig. 19; paratypes, figs. 20-22. U.S.N.M., 227858.

23-25. Helisoma anceps (Menke). Variety? Mouth of Yaqui River, Northwest Mexico. U.S.N.M., 53677.

26. Helisoma anceps (Menke). Variety? Potomac River. U.S.X.M., 36471s.

27-29. Helisoma anceps aroostookense (Pilsbry). Woodland, Aroostook Co., Maine. Type locality. U.I., Z21015.

Figures are enlarged approximately two diameters 

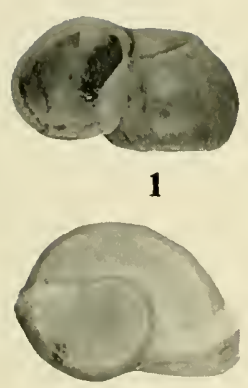

6

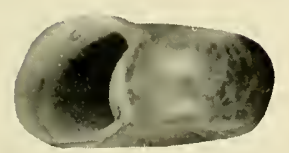

11

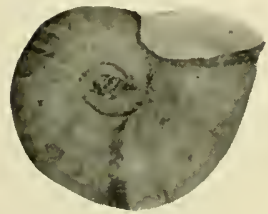

15

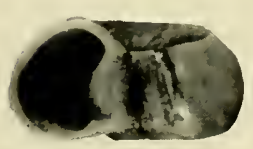

19

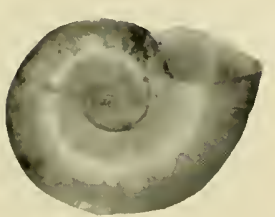

23

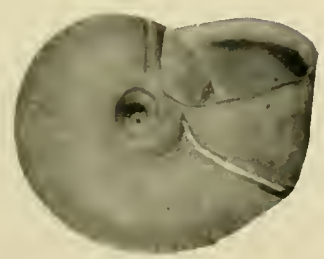

27

2

7
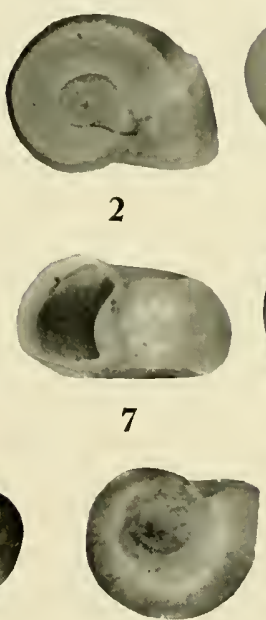

12

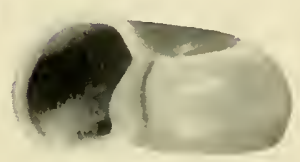

16

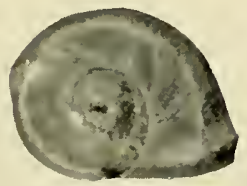

20

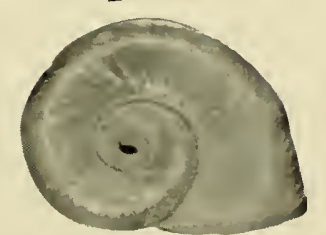

24

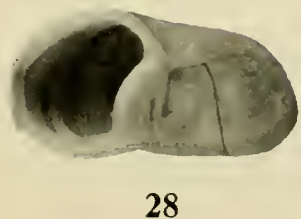

PLATE 83

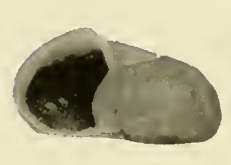

4

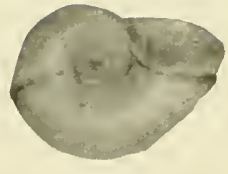

5
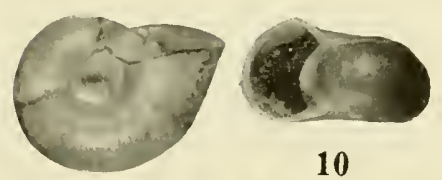

9

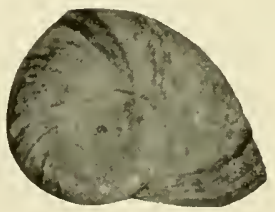

13

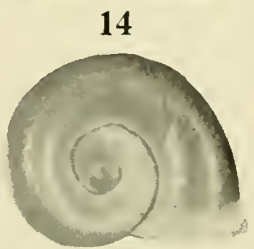

18

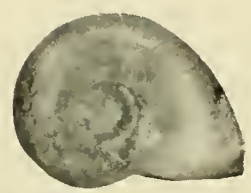

22

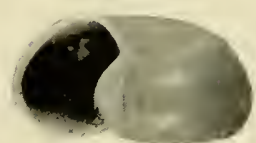

25
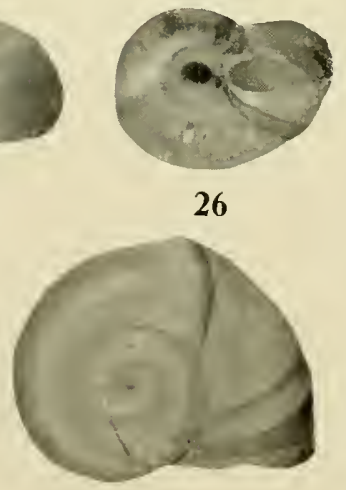

29 


\section{PLATE 84}

Shells of Planorbiclae

1. Hetisomn anceps (Menke). Immature shell. $\times 3 \frac{1}{2}$.

2. Helisoma anceps percarinatum (Walker). Immature shell. $\times 31 / 2$.

3. Hclisoma ance ps: portagense (F. C. Baker). Immature shell. $\times 3 \frac{1}{2}$.

4. IIclisoma anceps royalcnse (Walker). Immature shell. $\times 33_{2}$.

5. Helisoma anceps sayi F. C. Baker. Immature shell. $\times 3 \frac{1 / 2}{2}$.

6-8. Helisoma anceps jordanense (Winslow). Lake (harlevoix, NE of Jordan, Charlevoix Co., Michigan. Topotypes. U.M., 61589.

9. Helisoma anceps royalense (Walker). Isle Royale, Michigan. Cotype. B. Walker. B995.

10-12. Hclisoma anceps rushi F. C. Baker. Toad Island, Georgian Bay, Ontario. 10 holotype; 11-12 paratypes. U.I., Z25239.

13, 14. Helisoma anceps royalense (Walker). St. Joselh Latke. Onturio. T'.I., Z30853.

15-17. Hctisoma anceps royalense (Walker). Bamiji Lake, Ontario. U.I., Z30844.

18-20. Helisoma fucosmius (Bartsch). Types. Bull. L.S.N.M., 33, plate 57, figs. 1-3. $\times 4$.

21. Helisoma cucosmius (Bartzch). Greenfield Pond, North Carolina. Paratype. U.S.N.M., 193890, $\times 3 \frac{1}{1} 2$.

22-24. Helisoma eucosmius vaughani (Bartsch). Types. Bull. U.S.N.M., 33, plate 57, figs. $4-6 . \times 4$.

25. Helisoma encosmius erenghani (Bartach). Burke's Place, Louisiana. Paratype. U.S.X.M., 125719. $\times 31 \%$.

26-28. Helisoma anceps idahoense F. C. Baker. Pend Oreille River, Sand Point, Itaho. Holotype. B1863.

All figures are enlarged about twice excepting those otherwise listed 


$$
\text { Illustrations of the Anatomy and of Shells }
$$

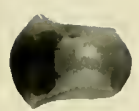

1

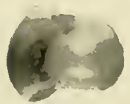

2
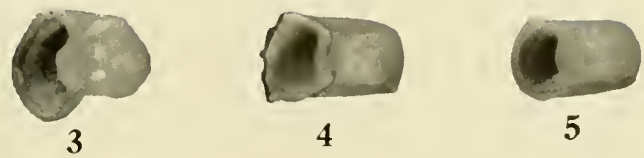

5

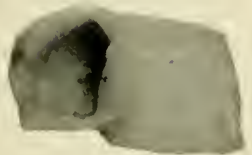

6 .

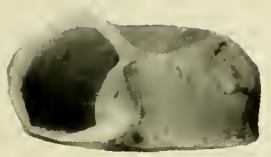

10

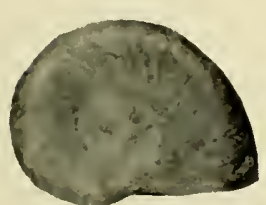

14

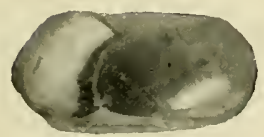

18

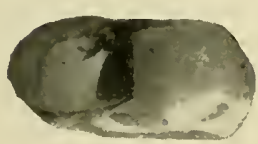

22

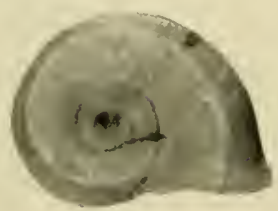

26

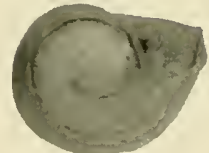

7

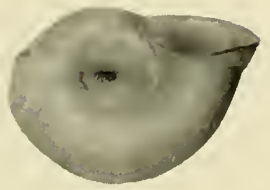

11

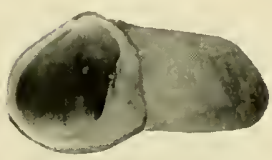

15

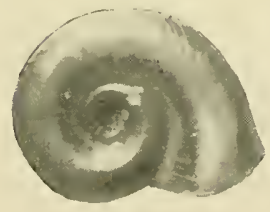

19

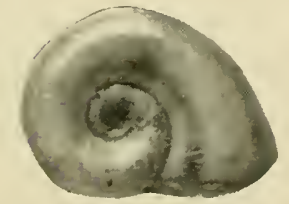

23

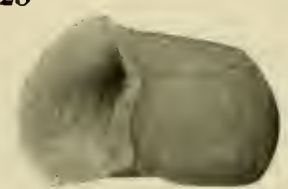

27

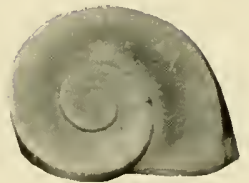

12

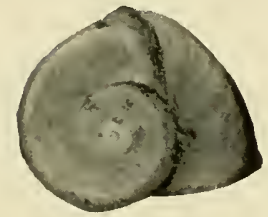

16

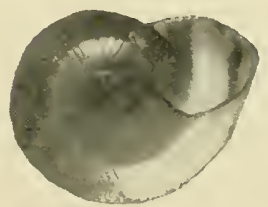

20

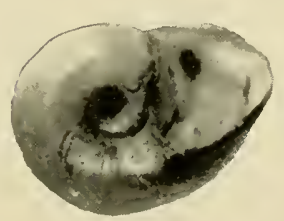

24
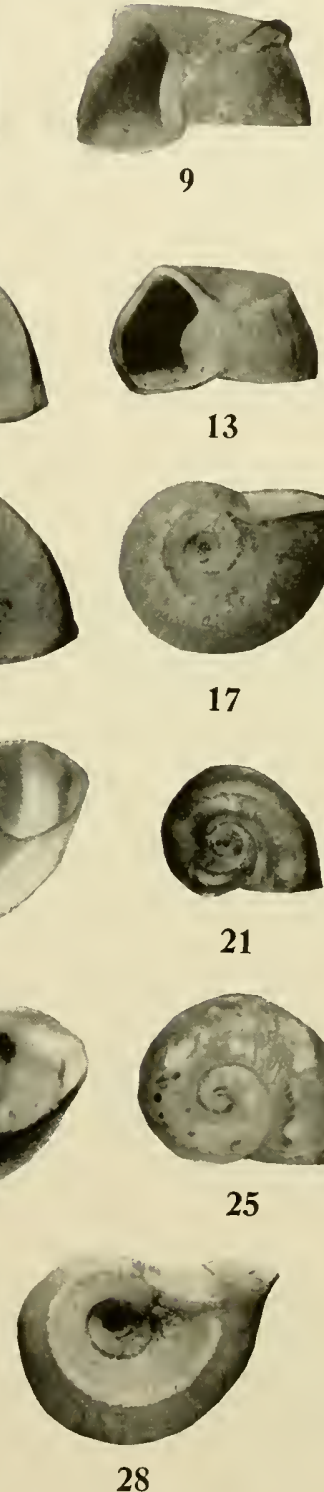

27

28

PLATE 84

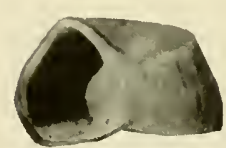

13

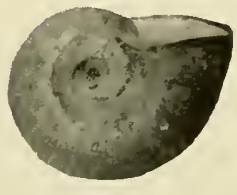

17

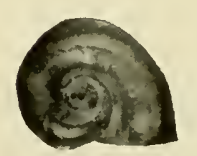

21

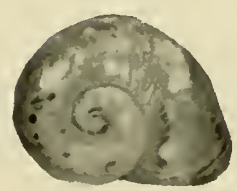

25 


\section{PLATE 85}

\section{Shells of Planorbidae}

1-3. Helisoma anceps portagense (F. C. Baker). Poltage Lake, Aroostook Co., Maine. Type locality. B988.

4. Helisoma anceps portagense (F. C. Baker). Meach Lake, Quebec, Canada. B3686.

5-7. Helisoma anceps latehfordi (Pilsbry). Meach Lake, Quebec, Canada. Type locality. Collected by Latchford. U.I., Z37203.

8-10. Helisoma anceps percarinatum (Walker). Crystal Lake, Benzie Co., Michigan. Type locality. B986.

11-13. Helisoma anceps perearinutum (Talker). Douglas Lake, Michigan. 12 ridged shell. U.I., Z26276.

14-16. Helisoma aneeps cahmi F. C. Baker. Big Muskallonge Lake, Vilas Co., Wisconsin. Types. U.I., Z21124.

17-19. Helisoma trivolvis (Say). Immature shells. $\times 3$.

20-24. Helisoma trivolvis (Say). Showing regular increase in growth of shell. U.I., Z29134.

25-29. Helisoma trivolvis (Say). Braddock's Bay, near Rochester, New York. U.I., Z29789.

30. Helisoma trivolvis (Say). Elmira, Chemung Co., New York. I'I., Z34976.

All figures excepting $17-19$ are enlarged about $1 \% 3$ diameters 


\section{PLATE 86}

\section{Shells of Planorbidae}

1. Helisomn trivolvis (Say). Indian River, Cheboygan Co., Michigan. (= Planorbis. imegastoma DeKay.) U.I., Z32472.

2,4. Itelisoma trivolicis (Say). Salt Fork, near Urbana, Champaign C'o., Illinois. (=Planorbis pseudotrizolitis F. C. Baker. 2, paratype; 4, holotype). U.I., Z11292.

3. Helisoma trivolvis (Say). Salt Fork, near Urbana, Hlinois. (= Planorbis pseudotrizolics F. C. Baker. Type locality.) B930.

5-S. Helisoma trivolizs lentum (Say). New Orleans, Louisiana. Type locality. U.I., Z3053s.

9, 10, 13. Iclisoma trivolvis intertextum (Sowerby). Manatee River, Florida. U.I., Z32367.

11, 12, 15. If elisoma trivolies intertextum (Sowb.). Shoal Creek, Alabama. U.I., Z32365.

14. Helisoma trivolizis intertextum (sowb.). Manatee River, Florid.a. Biosj.

16. If lisoma tricolvis chautauquense F. C. Baker. Chautauqua Assembly, Chautauqua Lake. New York. Type locality. U.I., Z27S42.

17. Ilelisoma trizolvis chautauquense F. C. Baker. Chautauqua Lake, New York. Holotype. U.I., Zi237S0.

18, 19. Helisoma trizolvis chautauquense F. C. Baker. Chautauqua Lake, New York. Paratypes. U.I., Z237S0.

20. Helisoma trizolvis (Say). Enlargement of whorls on base. B3914. $\times \mathbf{7}$.

21. In lisoma trivolvis (Say). (= Planorbis pscudotrivolvis F. C. Baker). Enlargement of whorls on base. B3915. $\times \mathbf{i}$.

22. Helisoma trivolizis lentum (Say). Enlargement of whorls on base. B3916. X7.

23. Ifrlisoma trivolvis intertextum (Sowb.). Enlargement of whorls on base. B3917. $\times 7$.

All figures, excepting those indicated otherwise, are enlarged about $1 \% 3$ diameters 

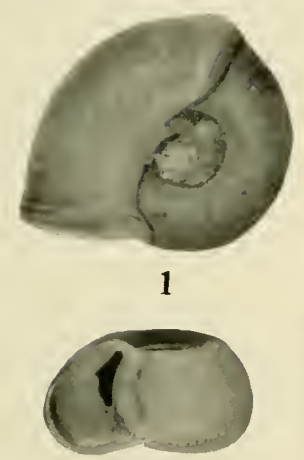

5

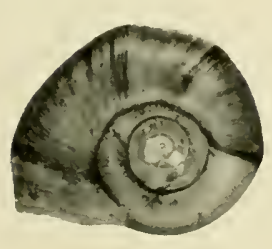

9

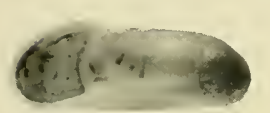

13

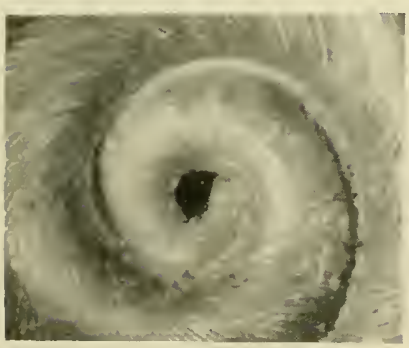

20

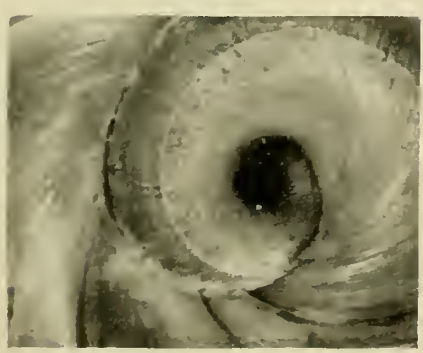

22
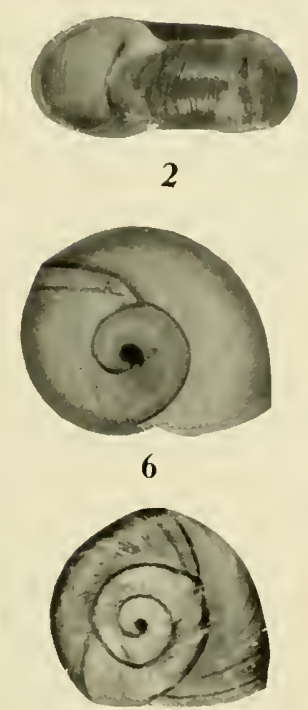

10

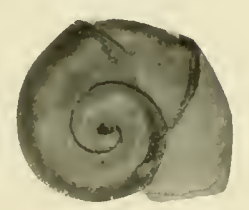

3
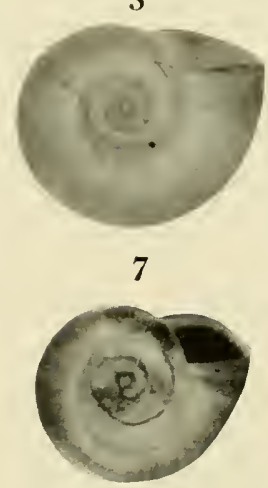

11

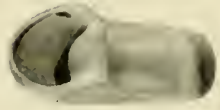

15

14

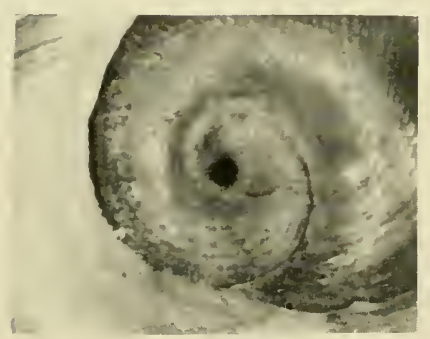

21

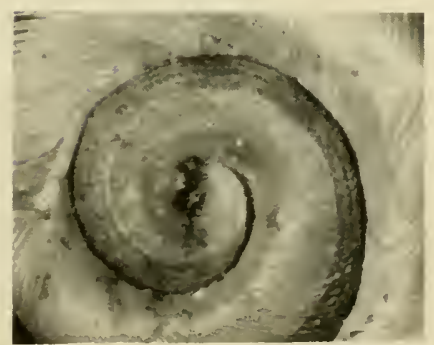

23
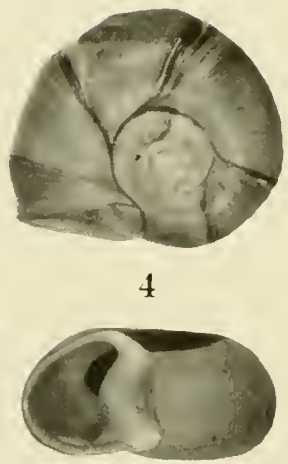

8

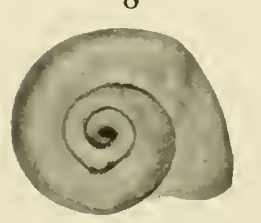

12

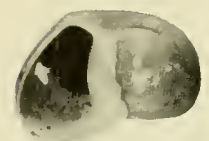

16

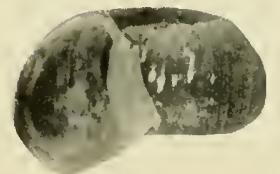

17

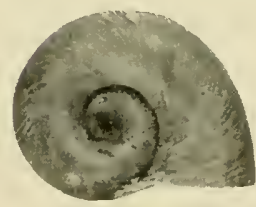

18

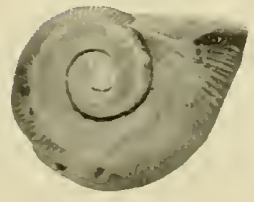

19

PLATE 86 


\section{PLATE 87}

\section{Shells of Planorbiclae}

1-4. Helisoma trivolvis fallax (Haldeman). Milton Mills, Milton, Massachusetts. U.l., Z4110s.

5-7. Helisoma trivolvis fallax (Haldeman). Green Lodge, Neponset, Massachusetts. B904.

S, 9. Helisoma trivolvis fallax (Haldeman). Fresh Pond, Cambrilge, Massachusetts. U.S.N.M., 336571.

10. Helisoma trivolvis fallax (Haldeman). Port Elizabeth, Maine. U.S.X.M., 26449.

11-15. II elisoma trizolitis marshalli F. C. Baker. Washington, D.C. 13, holotype; 11-12, paratypes; 14-15, immature. U.S.N.M., 124989.

16. Helisoma trivolvis marshalli F. C. Baker. New Jersey. U.S.N.M.. 504153.

17-20. Helisoma trivolvis holstonense F. C. Baker. Holston River, Smith Co., Virginia. 17 , holotype; 1S-20, paratypes. T.I., Z 41443.

21. Helisoma trivolvis lentum (Say). New Orleans, Louisiana. Immature. Aquarium specimen. B3918.

22. Helisoma trivolvis holstonense F. C. Baker. Holston River, Virginia. Immature. U.I., Z41444.

23, 24. Helisoma trivolvis holstonense F. C. Baker. Holston River, Virginia. Tariation in color. U.I., Z41444.

All figures are enlarged about two diameters 


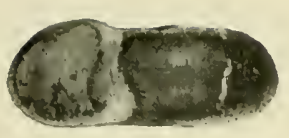

1

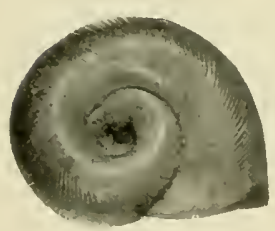

5

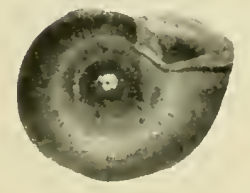

9

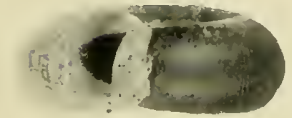

13

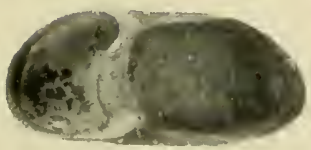

17

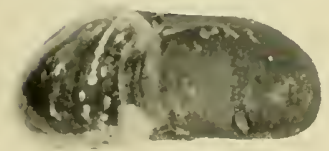

18

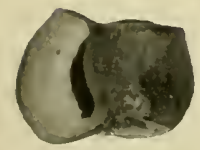

21
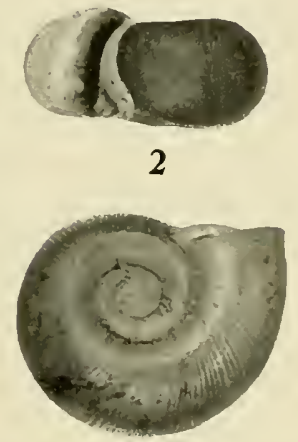

6

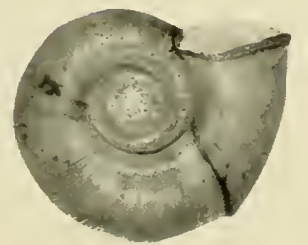

10

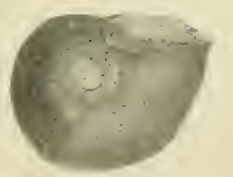

14

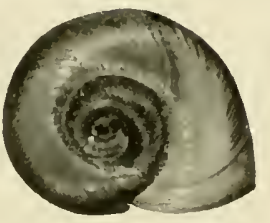

3

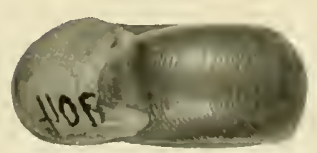

7

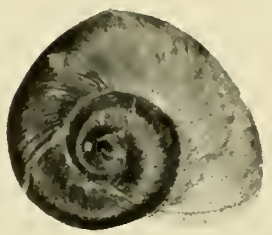

11

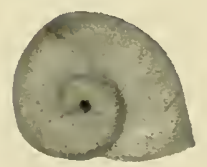

15

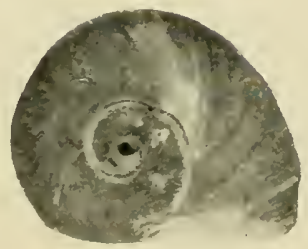

19

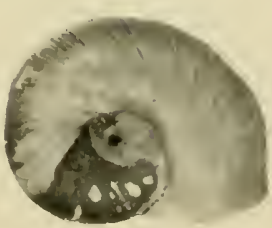

23

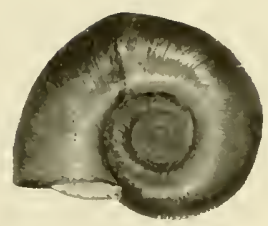

4

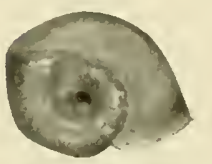

8

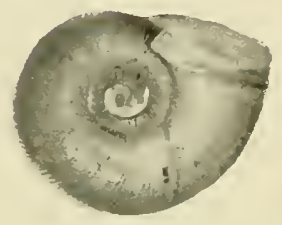

12
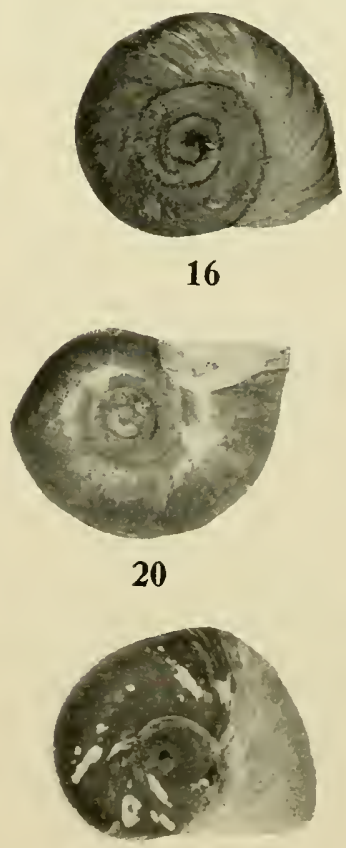

24

PLATE 87 


\section{PLATE SS}

\section{Shells of Planorbidae}

1. 2. Inclisoma trivolvis trivolvis (Say). Presque Isle, Michigan. Transition form toward macrostomum. U.I., Z26268.

3. Helisoma trivolvis trivolvis (Say). Winnebago Lake, near Oshkosh, Wisconsin. Large form, but typical. U.I., Z12791.

4-6. Hclisomn trivolvis macrostomum (Whiteaves). Mile End Gate, near Montreal. Canada. National Museum of Canada. 4, lectotype, 3869; 5-6, paratypes, B3870.

7. IJ -7isoma trivolvis macrostomum (Whiteaves). Bayfield. Wisconsin. In beach pool. U.I., 'L13677a.

8-10. Helisoma pilsbryi (F. C. Baker). Tomahawk Lake, Oneida County, Wisconsin. Type loculity. B843.

11-13. Helisoma pilsbryi infracarinatum F. C. Baker. Ridean River, near Ottawa. Canadit. B3715.

14, 15. Hclisoma pilsbryi infracarinatum F. C. Baker. Basswood River Rapids, Rainy River District, Ontario. 14, holotype. U.I., Z32361 ; 15 . paratype. B2986.

16. Helisoma pilsbryi infracarinatum F. C. Baker. Basswood Latke, Ontario, Canada. U.I., Z41268.

All figures enlarged abont $1 \frac{1 / 2}{2}$ diameters 
Illustrations of the Anatomy and of Shells
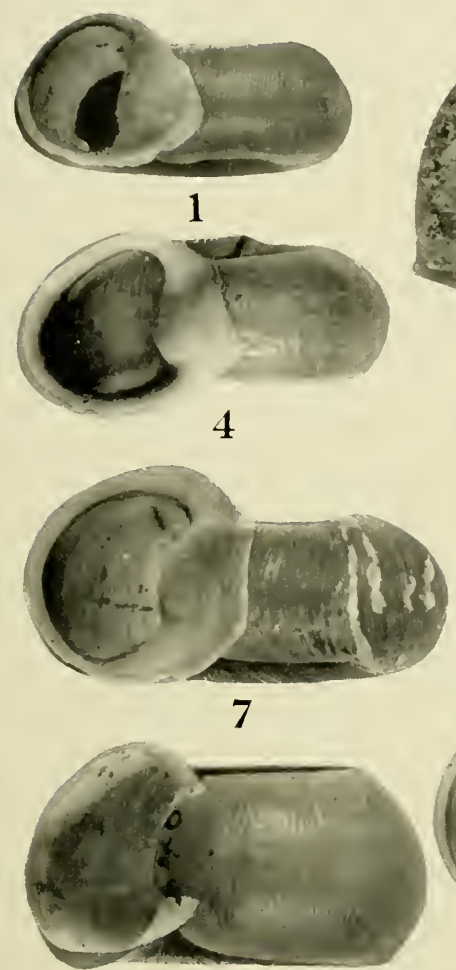

8

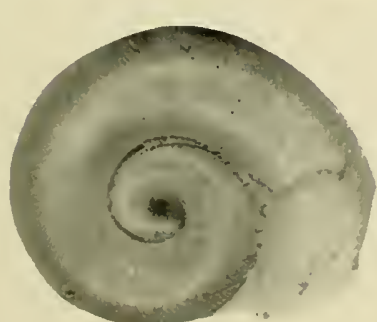

9

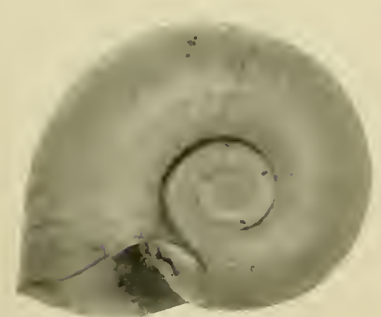

10

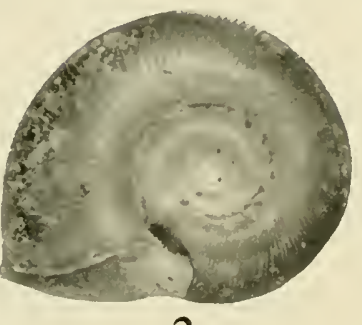

2

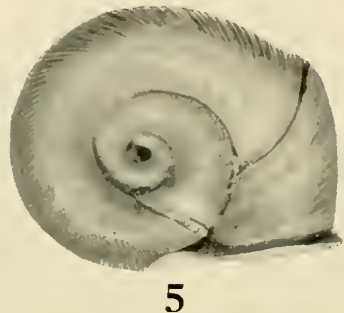

5
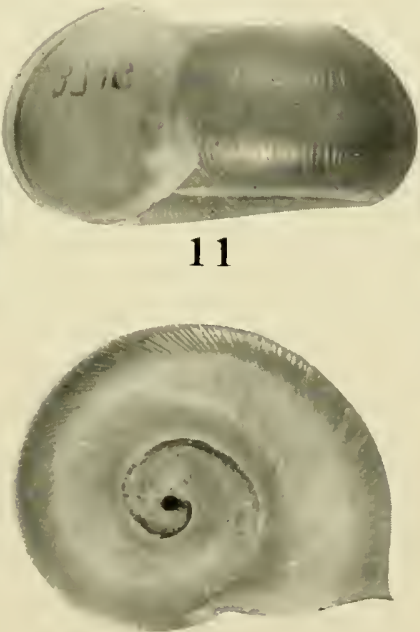

12

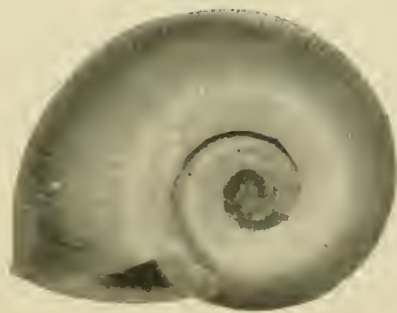

13
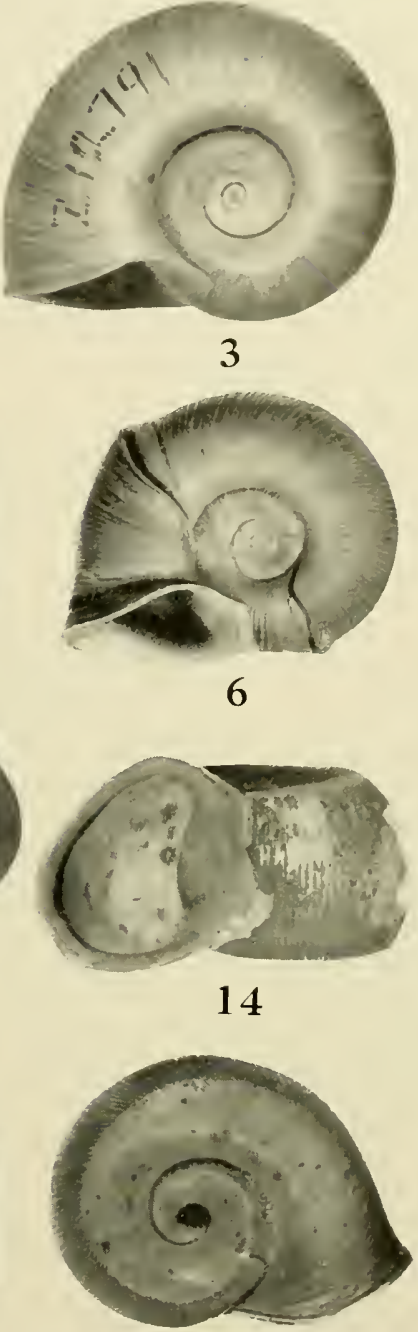

15

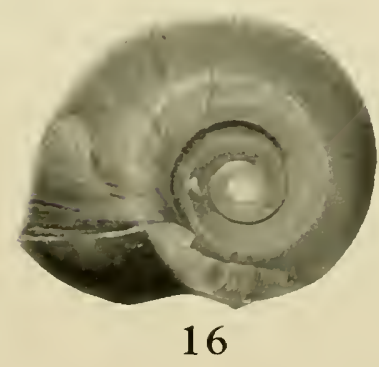

PLATE 88 


\section{PLATE 89}

\section{Shells of Planorbidae}

1-4. Helisoma trivolide Ientum (Say). Austin, Texas. Figure 3 varies toward intertextum. T.S.N.M., 252256.

5,6. Helisoma trivolvis intertextum (Sowb.). Fort Smith, Arkansas. Variation toward lentum (fig. 6). U.S.N.M.. 120965.

7. Helisoma trivolizs intertextum (Sowb.). South Carolina? Binney's fig. 179 of Planorbis glabratus (not of Say). U.S.N.M., 29219.

8. Helisoma trivolies intertextum (Sowb.). Leon, Texas. U.S.N.M., 28210.

9, 10. Helisoma trivolvis reticulatum (Dall) (=intertextum Siy). Salt Lake, Hilsborough Co., Florida. Types. U.S.X.M., 75421.

11. Helisoma truncatum (Miles). Saginaw Bay, Michigan. Type. Binney's fig. 202. U.S.N.M., 9010.

12. Planorbis bellus Lea (= Helisoma trivolvis lentum (Say)). Type. Tennessee. Lea Coll., U.S.A.M., 121178.

13-17. Helisoma kemicotti F. C. Baker. Lake Isle la Crosse, English River, Canada. 15, holotype; 16, 17, paratypes; 13, 14, immature. U.S.N.M., 29231 (old 9272).

18. Helisoma subcrenatum (Cyr.). Reservoir near Floweree, Montana. B3792.

19. Helisoma subcrenatum (Cpr.). Wainwright Park, Alberta. U.I., Z34689.

20. Helisoma suberenatum (Cpr.). Fort Yukon, Alaska. U.S.N.M., 218908.

21. Helisoma subcrenatum disjectum (Cooper). Boise, Idaho. U.I., Z36335.

22. Helisoma suberenatum plexatum (Ing.). Sagnache, Colorado. U.S.N.M., 535328.

23. Helisoma occidentale (Cooper). Klamath Falls, Oregon. U.S.N.M., 219750.

24. Helisoma occidentale (Cooper). Tule Lake, California. U.S.N.M., 160839a.

25. Helisoma ammon (Gould). Daggett, California. U.S.N.M., 349083.

26. Helisoma ammon (Gould). Spring Valley, San Mateo Co., California. U.M., 84105.

27. Helisama ammon (Gould). Clear Lake, California. U.M., $\$ 1743$.

28, 29. Helisoma trivolvis (Say). Aquarium specimens raised by Di. E. G. Berry. Note resemblance to Helisoma duryi seminole. B3796.

Figures 18-29, immature.

All figures are enlarged a trifle less than two diameters 

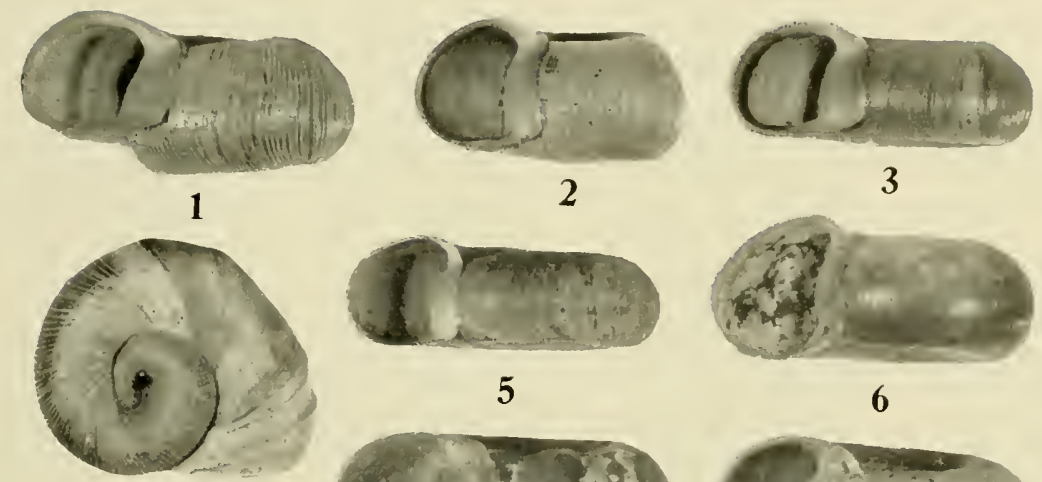

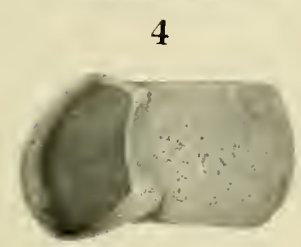

11

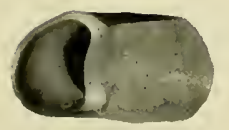

12
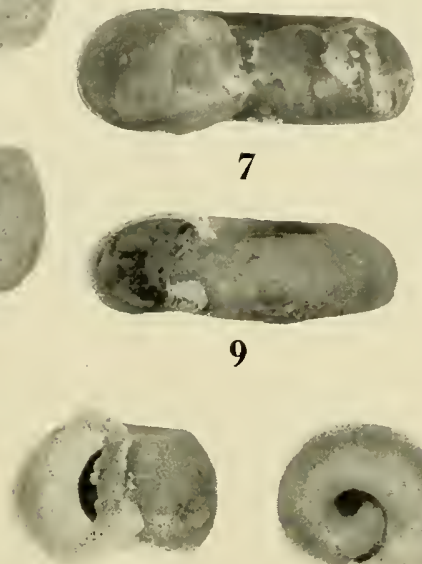

13
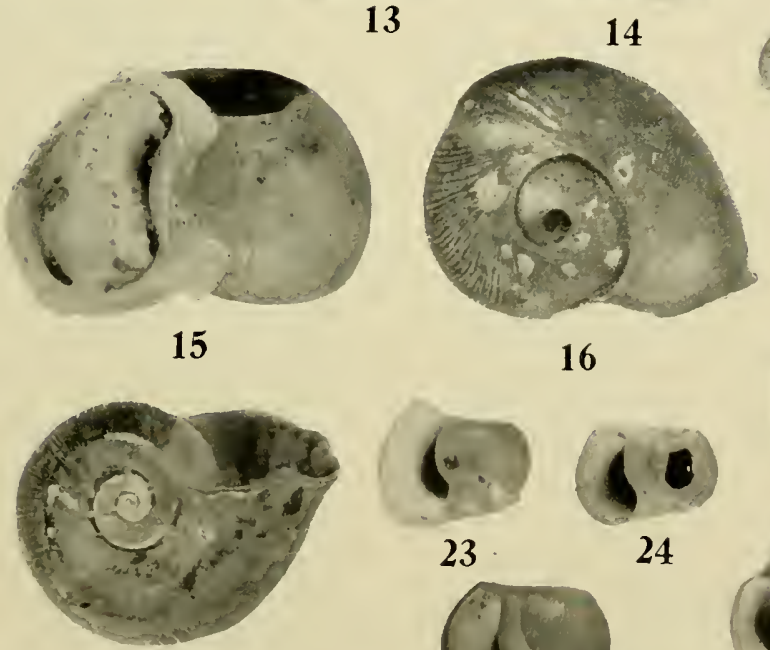

17

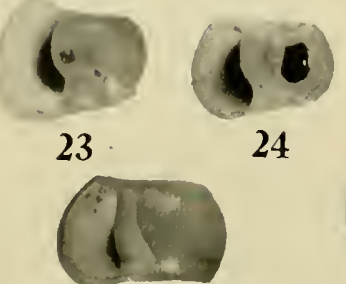

27
7

9

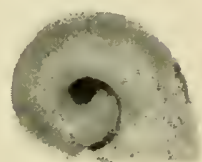

16

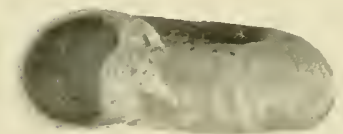

8
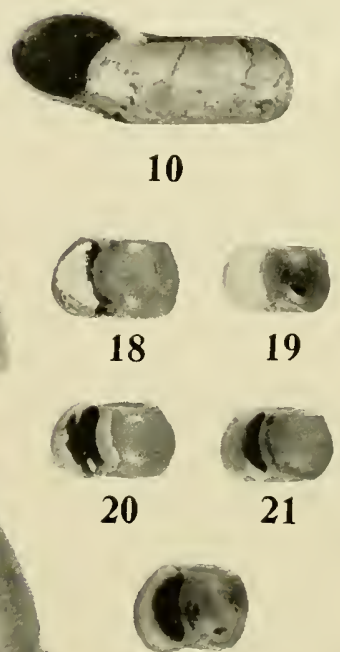

22

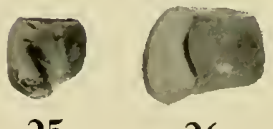

$25 \quad 26$

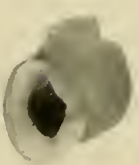

28

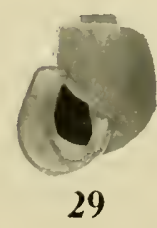

PLATE 89 
PLATE 90

\section{Shells of Planorbidae}

1-4. Helisoma truncatum (Miles). Saginaw Bay, Michigan. Type locality. U.I., Z32515.

5-8. Helisoma truncatum (Miles). Spirit Lake, Iowa. U.S.N.M., 476566.

9. Helisoma truncatum (Miles). Spirit Lake, Iowa. U.S.N.M., 505817.

10. Helisoma truncatum (Miles). Sturgeon Bay, Door Co., Wisconsin. U.I., Z1S455.

11, 12. Helisoma truncatum (Miles). Winnebago Lake, Wisconsin. U.I., Z12805.

13-15. Helisoma subcrenatum disjectum (Cooper). Tuolumne, California. B1090.

16-1S. II tisoma subcrenatum disjectum (Cooper). Boise, Idaho. U.I., Z36335.

19-21. Helisoma subcrenatum horni (Tryon). Paul Lake, British Columbia. B3148.

22-24. Helisoma subcrcnatum variety? Quamichan Lake, British Columbia. B1973.

All figures are enlarged a little less than two diameters 
Illustrations of the Anatomy and of Shells

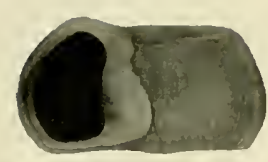

1

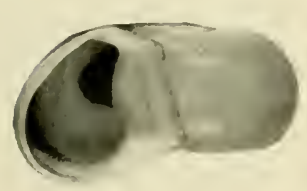

5

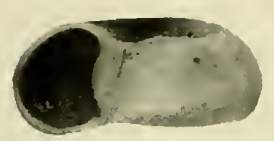

9

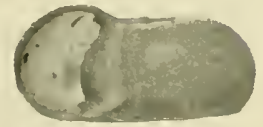

13

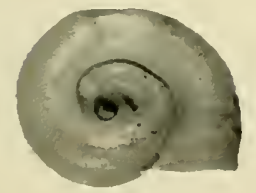

14

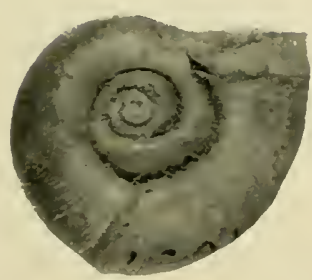

15

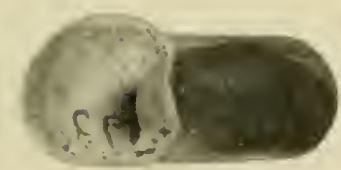

22
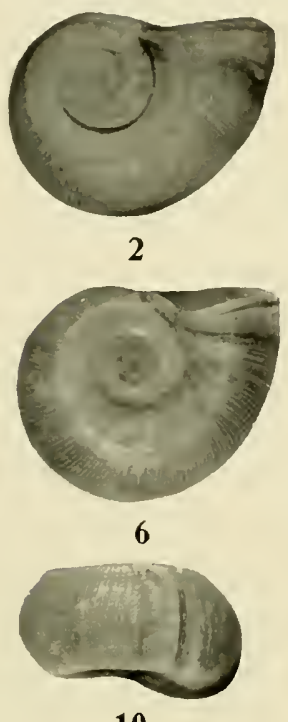

10

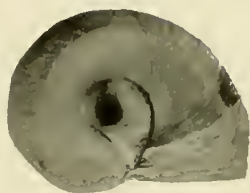

3

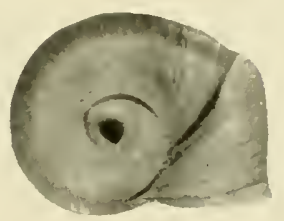

7

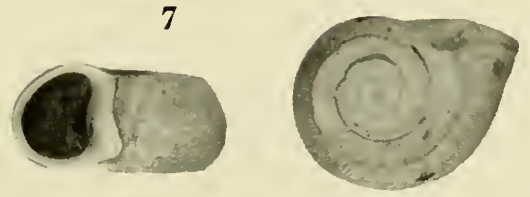

11
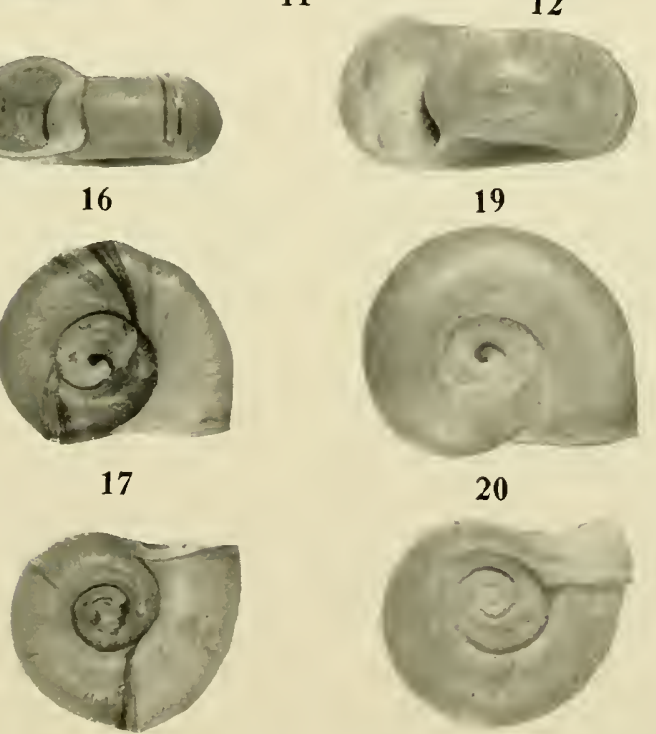

18

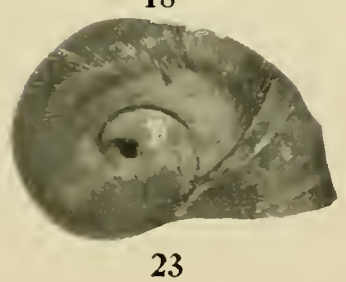

23
19

20

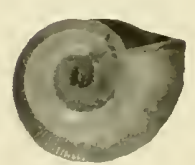

8

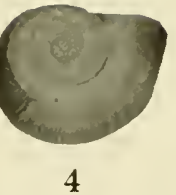

12

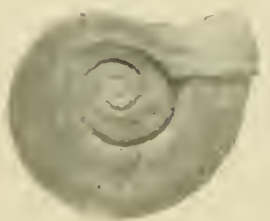

21

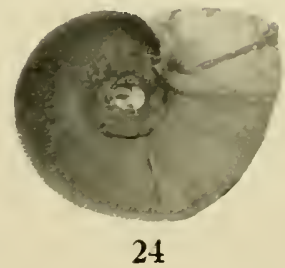

PLATE 90 
PLATE 91

\section{Shells of Planorbidae}

1-4. Helisoma wimslowi (F. C. Baker). Little Arbor Vitae Lake, Vilas Co., Wisconsin. Paratyes. Figure 4, immature. $\times$ 31\%. T.I., Z18637, Z19398.

5. Hclisoma pilsbryi (F. C. Baker). Chetek Lake. Barron Co., Wisconsin. B.

6-8. Helisoma pilsbryi preblei F. C. Baker. Knee Lake, Manitoba. Figure 6, holotype; 7-8, paratypes. U.S.N.M., 180279.

9-12. Helisoma subcrenatum (Carpenter). Idaho. Shimek Coll., T'S.X.M., 504310.

13. Helisoma subcrenatum (Cpr.). Third Vermilion Lake, below warm sulphur cave, Alberta. Pathologic specimen. U.S.T.M., 272105.

14. Helisoma subcrenatum (C'rr.). Lake La Hoche, British Columbia. U.S.N.M., 43346.

15. Itelisoma subcrenatum (Cpr.). Locomotive Springs, Kelton, Utah. T.S.N.M., 308926.

16. 18, 19. Helisoma subcrenutum variety? Ttah Lake, 2 miles south of Lehi, Utah. B1894.

17. Ifelisoma suberenatum variety? Same locality as above. Variation toward subcrenatum. 131894.

All figures, excepting 4 , are enlarged about $11 / 2$ diameters 
PLATE 92

\section{Shells of Planorbidae}

1. 2. Melisoma subcrenatum (Cpr.). Newton, Utah. B3046.

3. Helisoma suberenatum (Cpr.). Stewart River, Yukon Dist., Alaska. L.S.N.M., 180281.

4. II lisoma suberenatum (Cpr.). Cleary. Alaska. Fossil pits. U.S.N.M., 381941.

5. Helisoma suberenatum (Cpr.). Great Slave Iake. Kennicott Coll., U.S.N.M., 9275.

6,7. Helisoma subercnatum (Cyr.). Wainwright Park, Aberta. B3919.

S-10. II clisoma suberenatum (Cyr.). Fort Simpson, Mackenzie District, Canadı. Kennicott Coll., U.S.N.M., 2837 .

11, 12. Helisoma subcrenatum (Cpr.). Creek one mile west of Devon, Montana. Immature. B3793.

13-15. Helisoma subernatum horni (Tryon). Fort Yukon, Alaska. U.S.N.M., 218908.

16. II lisoma suberenatum horni (Tryon). Dall River, Alaska. Varying toward suberenatum. U.S.N.M., 180280.

17-22. Helisoma suberenatum plexatum (Ingersoll). St. Mary Lake, Mineral Co., Colorado. Figure 17, lectotype, U.S.N.M., 420210; figs. 18-22, paratypes. U.S.N.M., 125130 .

23. Helisoma suberenatum plexatum (Ing.). Signache, Colorado. Immature. U.S.N.M., 535328

All figures are enlarged about $1 \frac{1}{2}$ diameters 

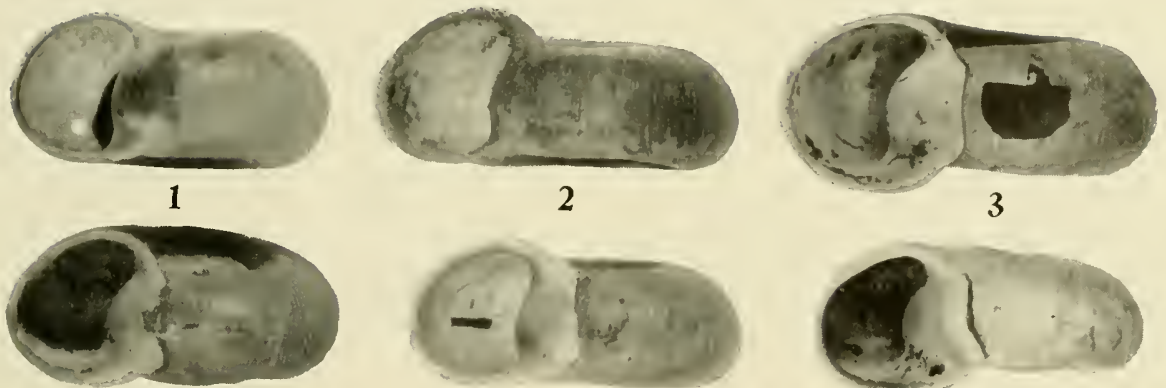

4

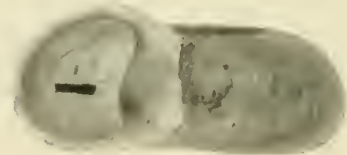

5
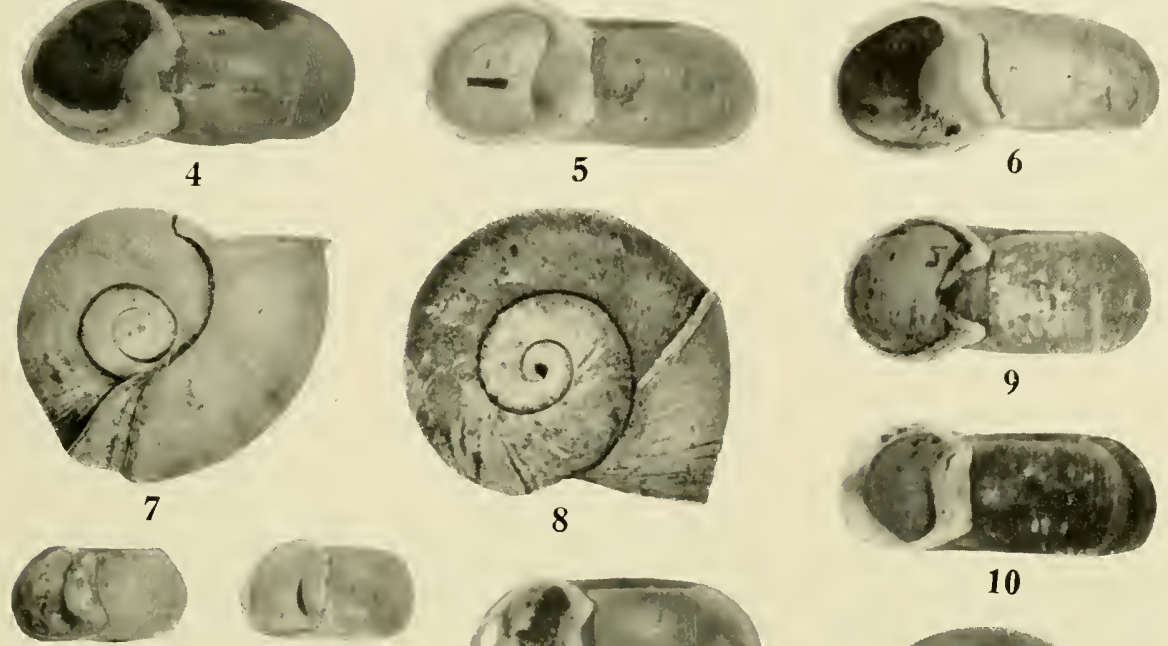

12
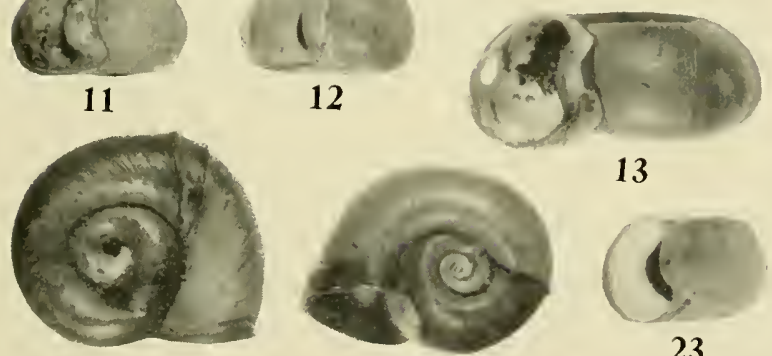

14

15

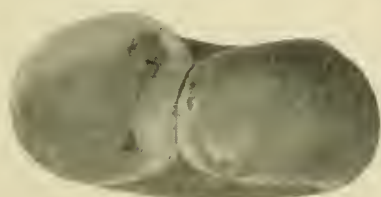

17

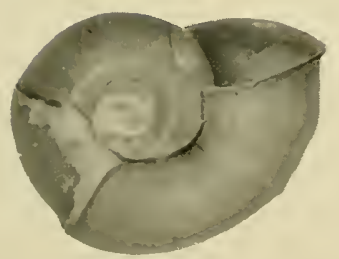

20

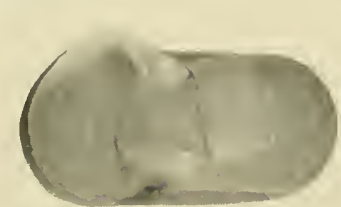

18

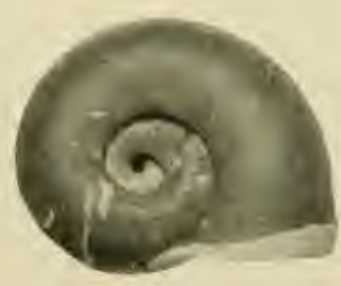

21
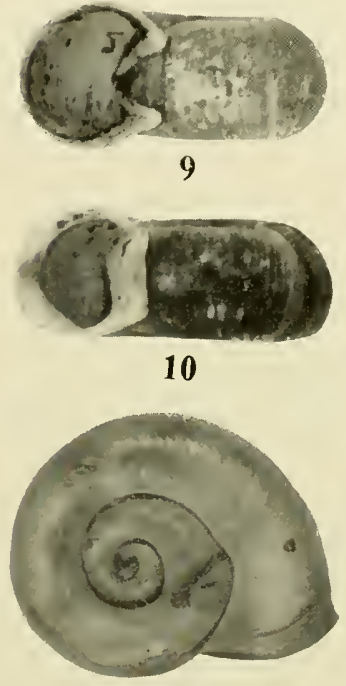

16
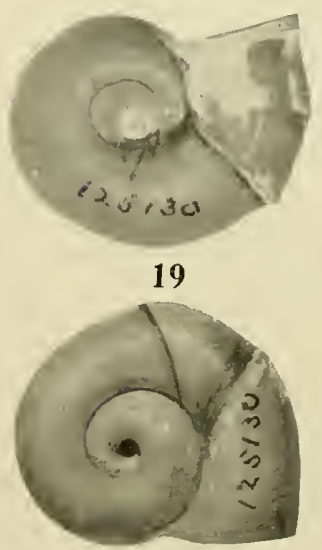

22

PLATE 92 
PLATE 93

\section{Shells of Planorbidae}

1-3. Helisoma subcrenatum plexatum (Inq.). Great Falls. Montana. C.S.N.M., 183037.

4. Hetisoma occidentale (Cooper). Tule Lake, California. U.S.X.M., 160839a.

5. Helisoma occidentale (Cooper). 'Washington Territory' Binney's fig. 193. T.S.X.M., 9120.

6. Helisoma occidentule (Cooper). Klamath Falls, Oregon. U.S.X.M.. 219750.

7.S. If lisoma oceidentale (Cooper). Epper Klamath Lake, south boundary of reservation, Oregon. U.M., 62741.

9. 10. Helisoma occidentale (Cooper). Lower end [uprer Klamath Lake. Oregon. B3246.

11, 12. Helisoma occidentale (Cooper). Slough at Wiacos Bay. Klamath Lake, Oregon. B3069.

13. 14. Hetisoma occidentale (Cooper). Eluer Flamath Lake. Oregon. B3011.

15. Helisoma occidentale (Cooper). Upper Klamath Lake, south boundary of reservation. U.M., 62741.

16. Hetisoma occidentale depressum F. C. Baker. Lower Klamath Lake, Oregon. Holotype. B3239.

17, 18. Helisoma occidentale depressum F. C. Baker. Lower Klamath Lake, Oregon. Paratypes. B3240.

19. 20. Helisoma binn yi (Tryon). Portland, Oregon. stanford Eniv.. B3220.

21.22. Hetisoma binneyi (Tryon). Lake Whatcom, Washington. BS53.

23-26. Helisoma bimnyi (Tryon). Holders Lake, Nanamo, British Columbia. T.M., \$1750.

All figures are enlarged about 11,2 diameters 

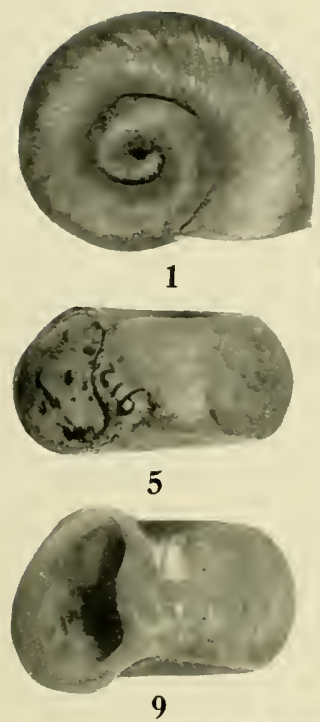

9

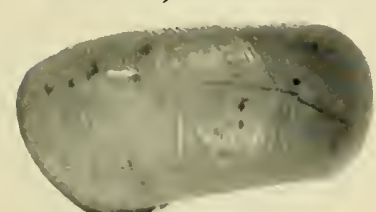

12

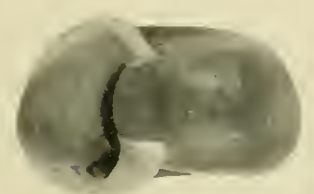

15
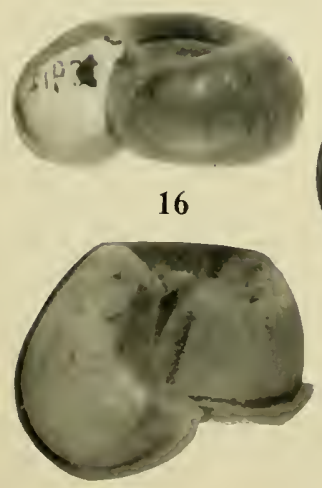

24
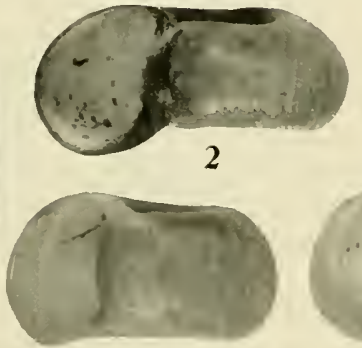

6
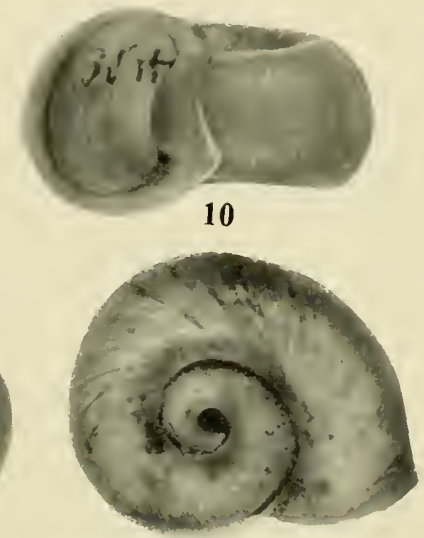

13
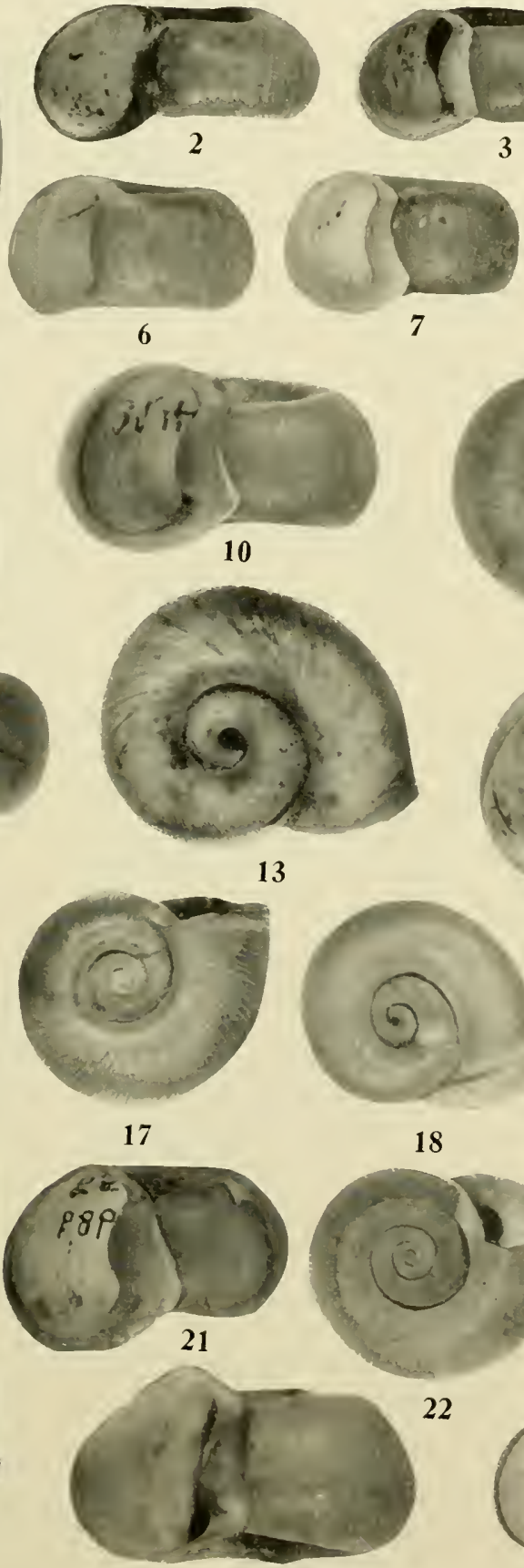

25
7
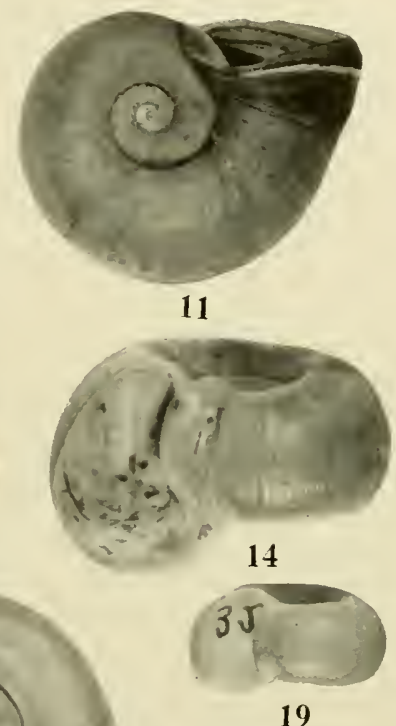

(2)

19

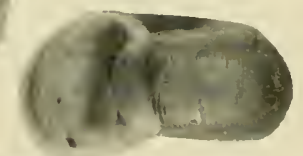

18

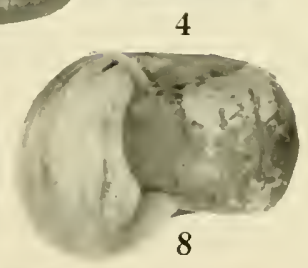

20

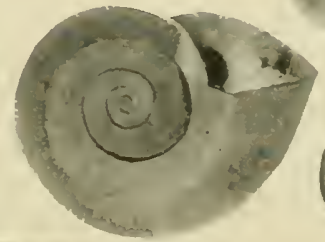

22

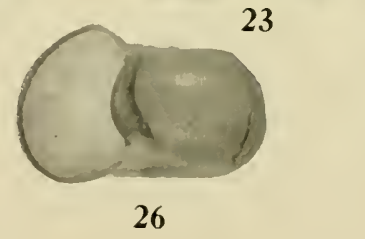

PLATE 93 
PLATE 94

Shells of Planorbidae

1-5. Helisoma binne yi randolphi F. C. Baker. Seattle. Washington. Figure 1, holotype; 2-4, paratypes; 5, immature. T.S.T.M., 504360.

6-S. Helisoma binneyi randolphi F. C. Baker. Green Lake, Seattle, Washington. About lalf grown. U'.S.N.M., 474779.

9-11. Helisoma binneyi (Tryon). Astoria, Oregon. B1Ss8.

12, 13. Helismme bimeyi (Tryon). Portland, Oregon. Immature. C'.I., Z35295.

14. Helisoma ammom (Gould). Spring Valley, San Mateo Co., California. Immature. U.M., 84105 .

15. Helisoma ammon (cionld). Near Cerritos, Los Angeles Co., California. Immature. U.S.N.M., 174051.

16. Helisoma bimeyi (Tryon), Astoria, Oregon. Back view of shell. U.I., Z1S459.

17. Helisoma ammom (Could). Monterey, Monterey Co., California. Back riew of shell. T.M., S1746.

18. Helisoma binneyi (Tryon). Oregon. Type. Gould's figure of Plamorbis corpulentum Sty, U.S. Ex. Experl., plate S. fig. 130. I S.X.M., 5530.

19. Helisoma binneyi (Tryon). Columbia River, Oregon. Binney's fig. 191 of Planorbis corpulentum Say. U.S.X.M., S119.

20.21. Ilclisoma ammon (Could). Hollister, San Benito C'o., C'alifornia. U.M., 81748. 22-21. Helisoma ammon (Gould). Stockton, Sinn Joarhin Co., Californial. B3246.

25, 26. Helisoma ammon (Gould). San Joachin River, California. [..M.. S1749.

27. Mrlisema rmmon (Could). San Diego, California. T.M., 35676.

28. Helisoma ammon (Gould). Stockton, Sin Joachin ('o., California. Inmature. U.M., $\$ 1571$.

All figures are enlarged about 1/\%2 diameters 
Illustrations of the Anatomy and of Shells
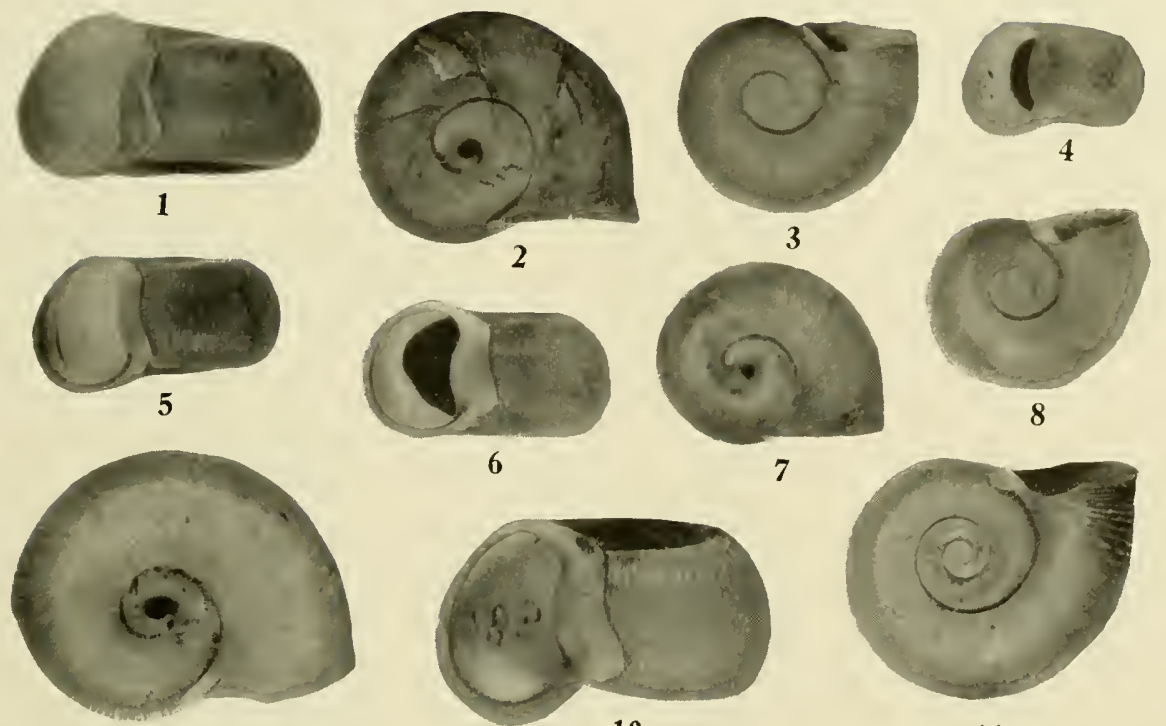

9
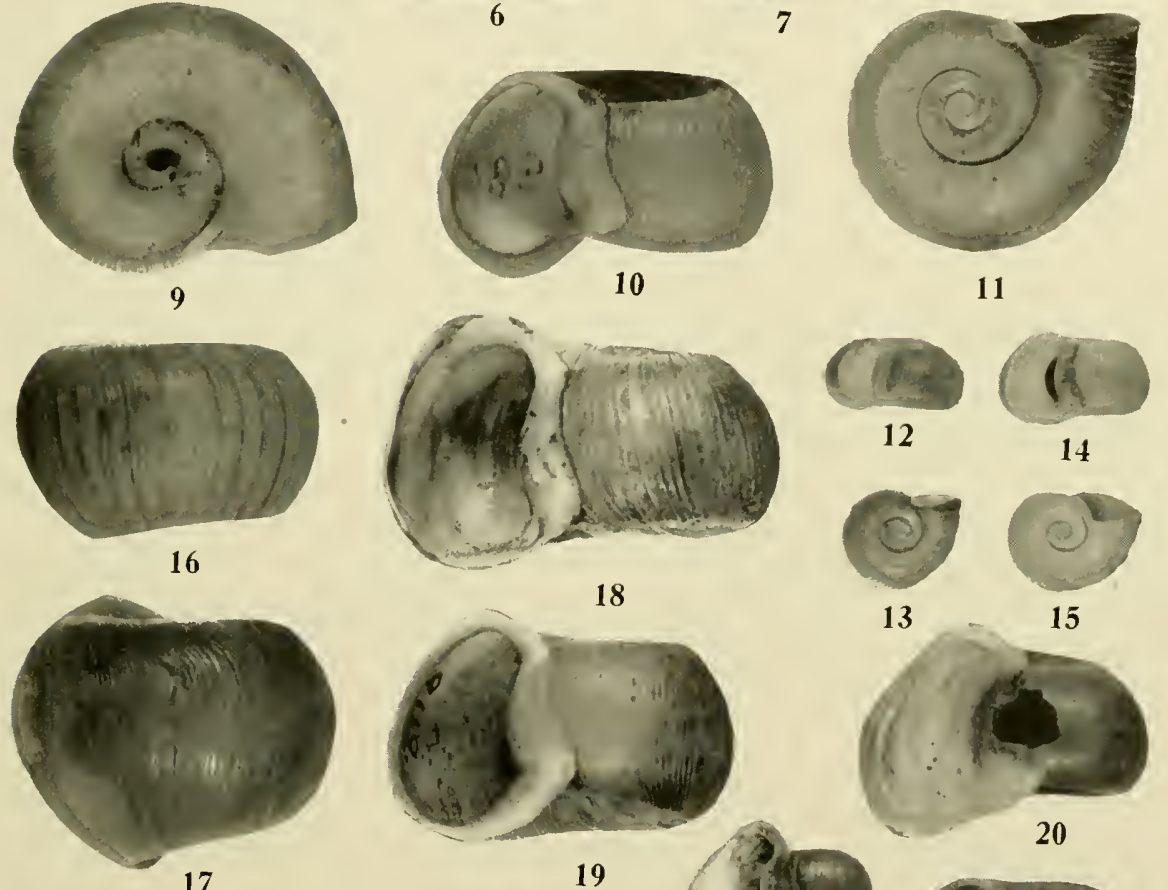

17
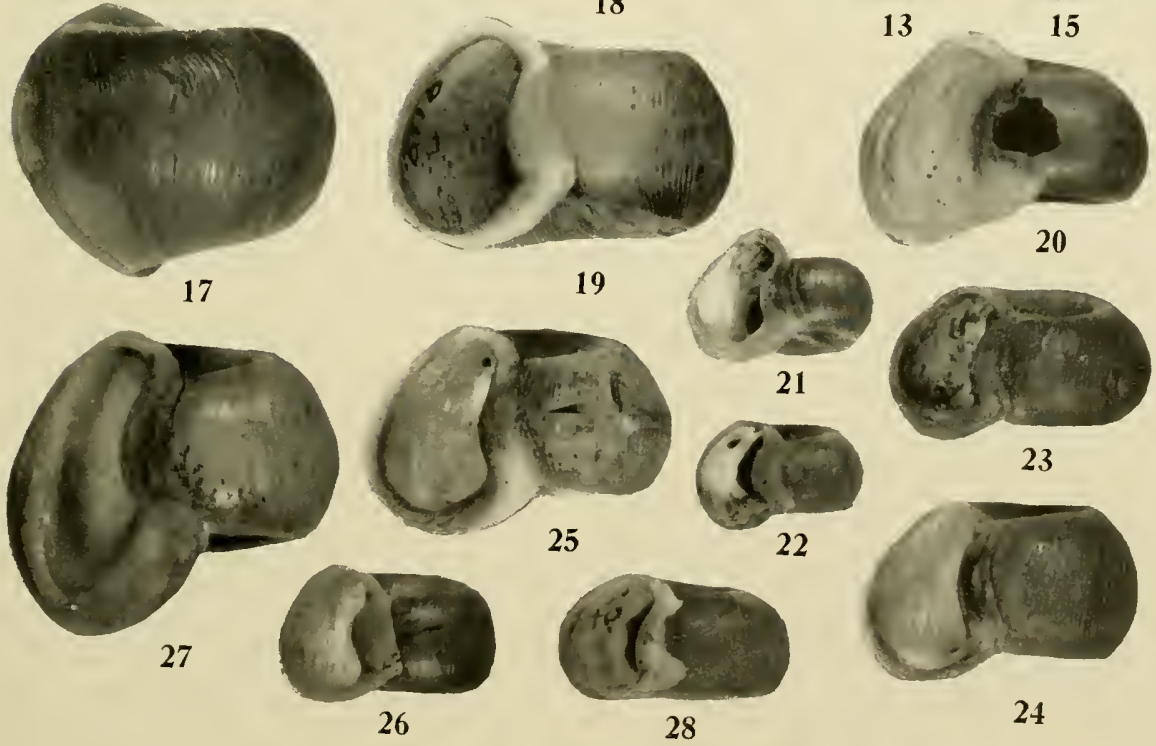

PLATE 94 


\section{PLATE 95}

\section{Shells of Planorbidae}

1-5. Helisoma ammon (Gould). Mountain Lake near San Franciseo, California. Immature form. B32Ss.

6-9. Helisoma ammon (Gould). Clear Lake, California. Stages of growth. U.M., S1743.

10, 11. Ilelisoma ammon (Gould). Clear Lake, California. U.MI., S1752.

12-14. Ifelisoma ammon (Gould). Watsonville, Santa Cruz Co., California. U.MI., \$1747.

15. Helisoma ammon (Gould). Kiern Lake. Tulare Co., California. Cooper Coll., B9124.

16. Helisoma ammon (Gould). Point Happy, Indio, California. U.I., Z35624.

17-19. Helisoma traskii (Lea). Bakersfield, Tiern Co., California. Immature. U.M., \$1754.

20,21. Itelisoma traskiz (Lea). Tiern Lake, Tulare Co., California. Type of Lea, figured by Binney. 1SS. Lea Coll., U.S.X.M., 121000.

22. Helisoma traskii (Lea). California? U.S.X...I., 47616.

23-25. II lisoma traskï (Lea). Buena Vista Canal, draining Buena Vista Lake, which drained Kern Lake, California. More depressed than Lea s type. B3066.

All figures are enlarged about 1/2: diameters 
Illustrations of the Anatomy and of Shells
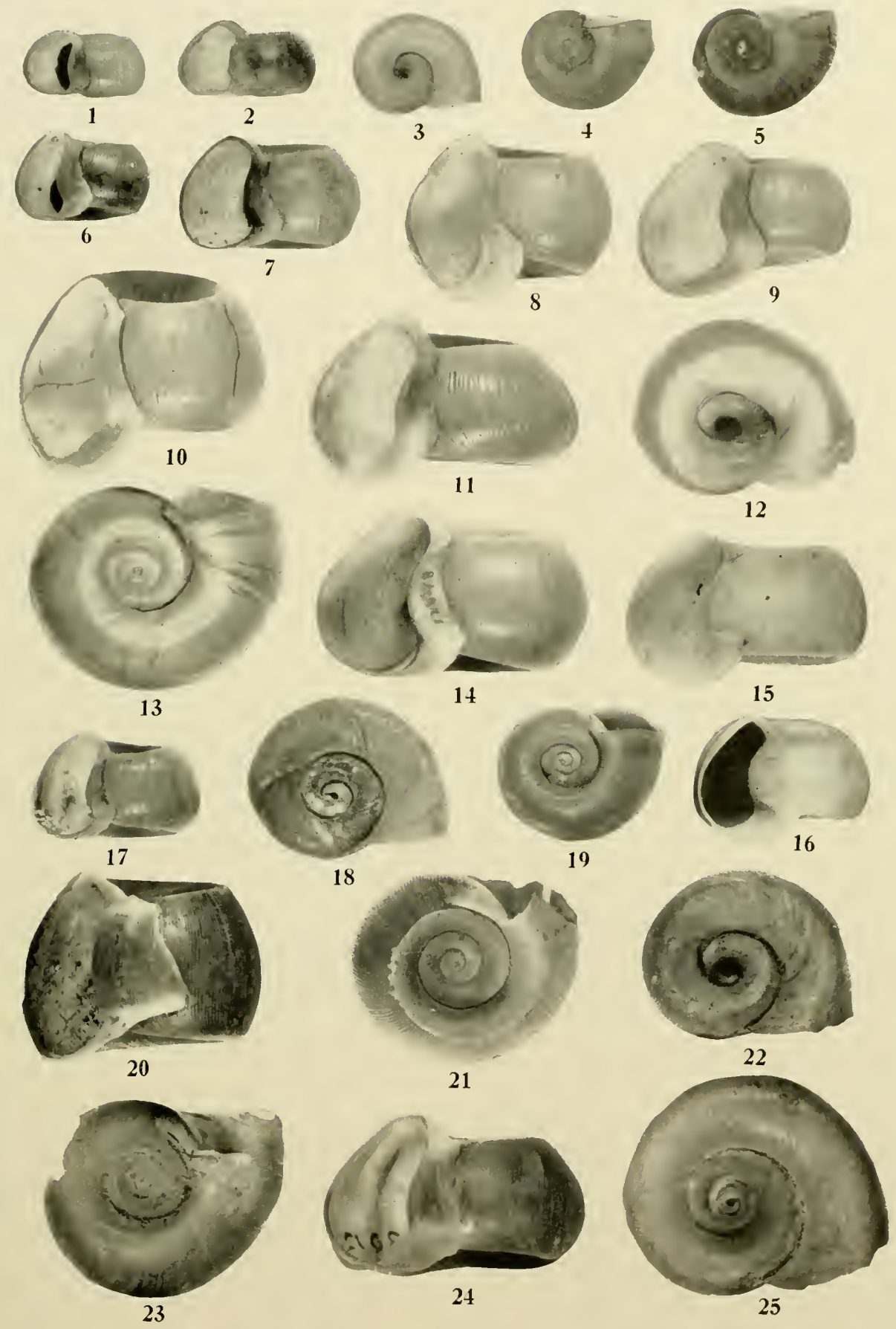

PLATE 95 
PLATE 96

\section{Shells of Planorbidae}

1-3. Helisoma oregonense (Tryon). Pueblo Valley on boundary of Oregon, sixty miles west of east boundary. Type locality. B1096.

4,5. Helisoma oregonense (Tryon). Nevada. Stearns Coll. U.M., 35679.

6-8. Helisoma oregomense (Tryon). Sixteen miles northwest of Gerbach, Neviula. M.C.Z., 92410.

9-12. Helisoma oregonense (Tryon). Variation. Tooele Co., Utah, in salt spring. B3920.

13-17. Helisoma subcrenatum perdisjectum F. C. Baker. Yellowstone Lake, Wyoning. Figure 13, holotype; 14-17, paratypes. L.S.N.M., 30207a.

18-22. Helisoma anceps anticostianum F. C. Baker. English Bay, Anticosti Fsland. Fig. 18, holotyle; 19-22, printypes. M.C.Z., 48285.

23-30. Helisoma anceps (Menke). Cheramm Pond, nortl of Kinoxrille, Tennessee. Figures 24, 25, 29, normal anceps; figs. 26, 27, 28, 30, the angistomus form of Haldeman; fig. 23, immature. M.C.Z., 46502.

31-34. Helisoma magnificum (Pilsbry). Greenfield Pond, near Wilmington, North Carolina. Type locality. Bartich's figs. Proc. [T. S. Nat. Mus., 33, plate 57, figs. 7-9. U.S.N.M., 193321.

Figures 1-30 are enlarged about two diameters; figs. 31-34 are about natural size. 


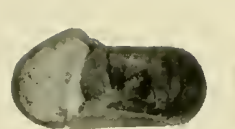

1
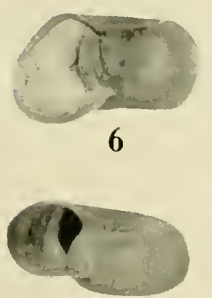

11

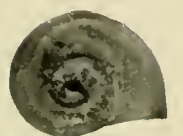

16

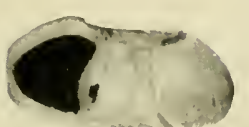

21

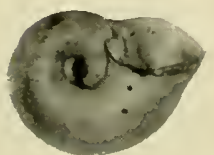

25

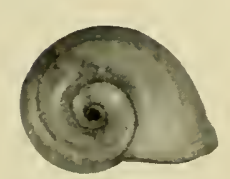

29

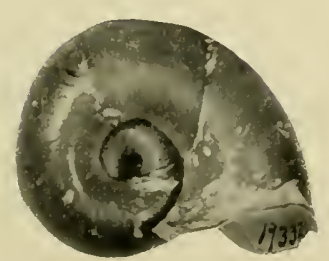

32

2

17
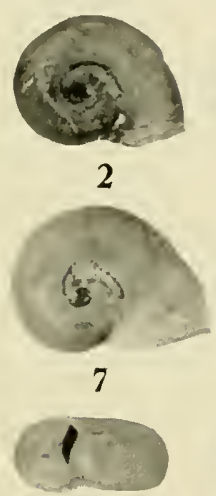

12
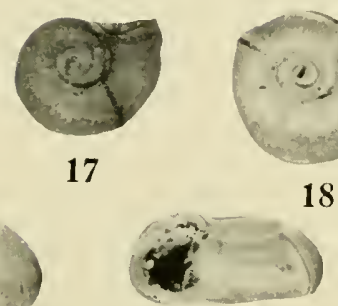

22
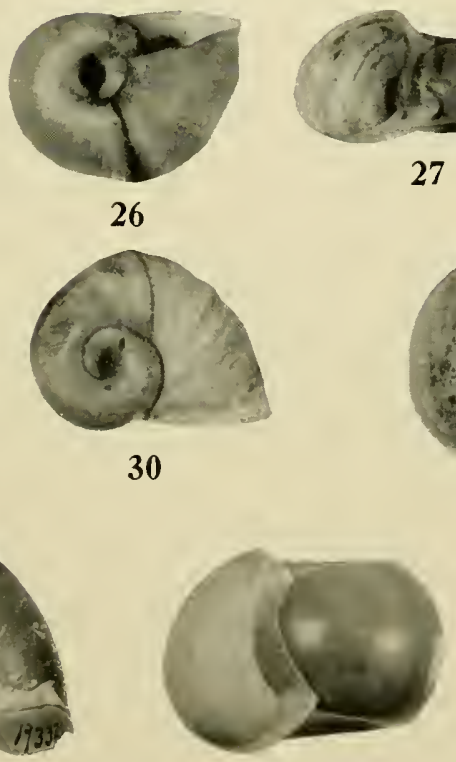

33

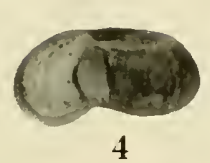

4

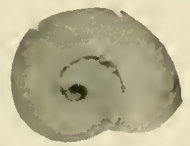

9

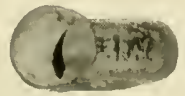

14

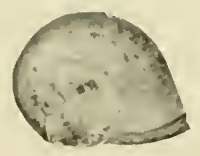

19
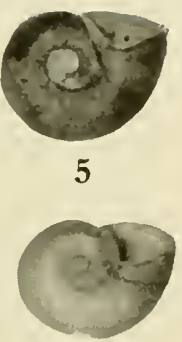

10

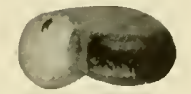

15
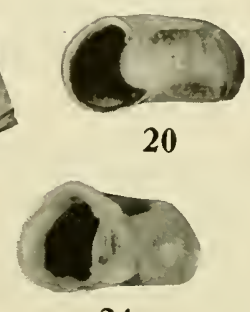

23

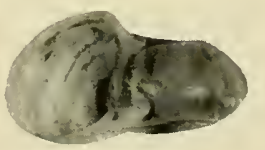

27

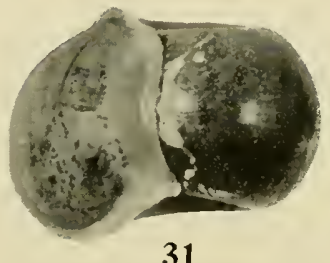

31

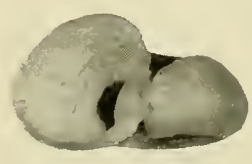

28

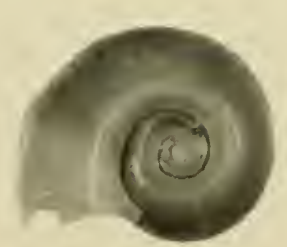

34

PLATE 96 
PLATE 97

\section{Shells of Planorbiclae}

1-4. Helisoma tenue (Philippi). Platpa near City of Mexico, Mexico. Type locality. U.S.N.M., 160175.

5. Itelisoma tenue (Philipni). Laguna de Tamos, near Tampico, Vera Cruz, Mexico. U.S.N.M., 467437.

6. Helisoma temue (Philippi). Toluca, Mexico. U.S.N.M., 185942.

7. S. Helisoma tenue (Philippi). Lake Texcoco, near City of Mexico, Mexico. M.C.Z.

9. II tisoma tenue (Philipri). Vera Cruz. Strebel Coll. U.S.N.M., 10585.

10. Helisoma tenue (Philippi). Sources of Rio Lelma, Valley of Tohea, Mexico. U.S.X.M., 467433.

11. Helisoma tenue (Philippi). Orizaba, Mexico. U.S.A.M., 22009.

12. Ifelisoma tenue bourcardi (C. and F.). City of Mexico, Mexico. U.S.N.M., 8506.

13-17. Helisoma tenue bourcardi (C. and F.). City of Mexico, Mexico. U.S.N.M., 26453.

18-25. Ifelisoma tenue rxaggeratum (ron Martens). Lake Patzcuaro, State of Michoacan, Mexico. Type locality. U.S.N.M., 467462.

26-28. Helisoma tenue applanatum (ron Martens). Lanos River, Chichuachua, Mexico. U.S.N.M., 16252.

All figures are enlarged about $1 \frac{1}{2} 2$ diameters 
Illustrations of the Anatomy and of Shells
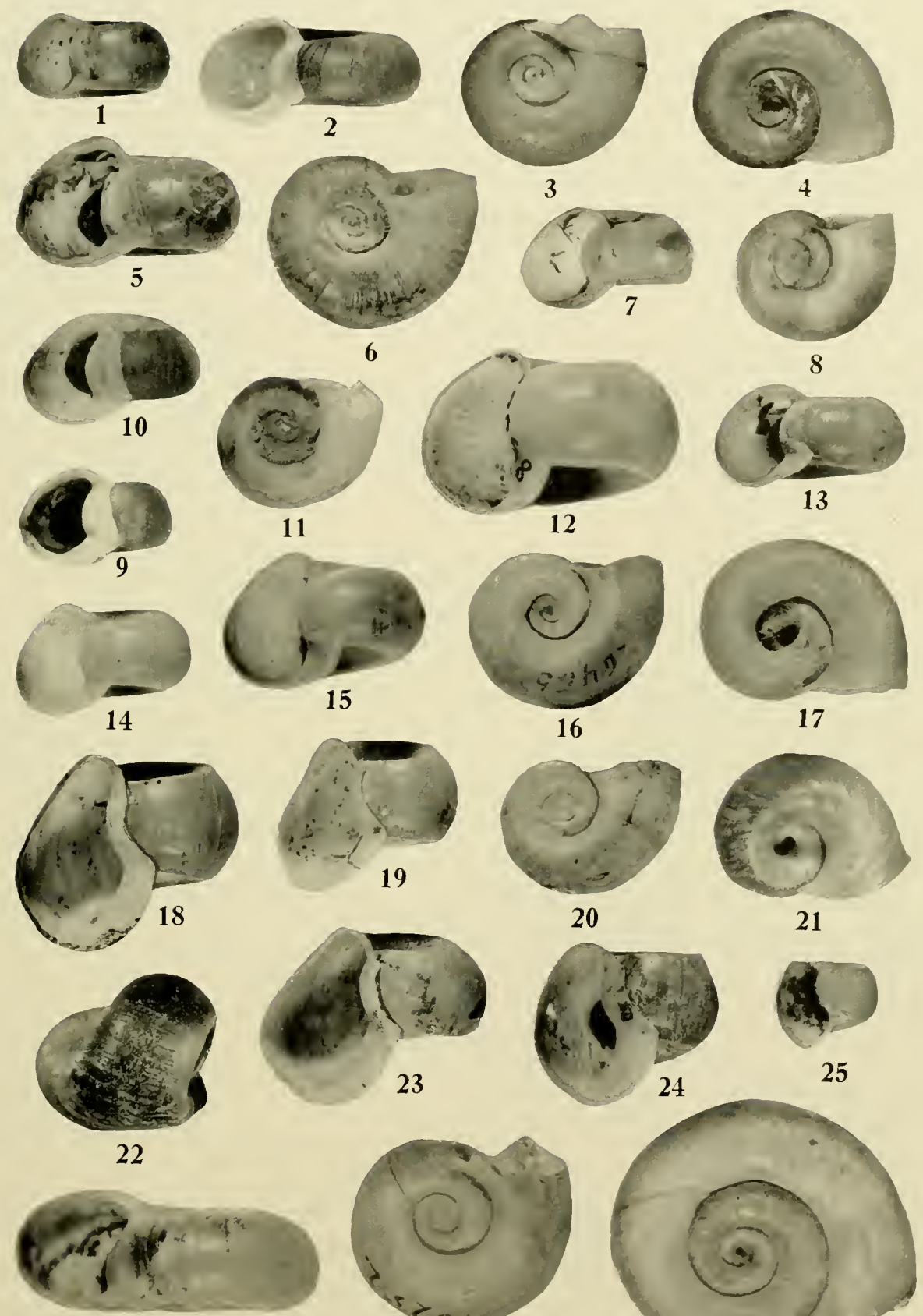

26

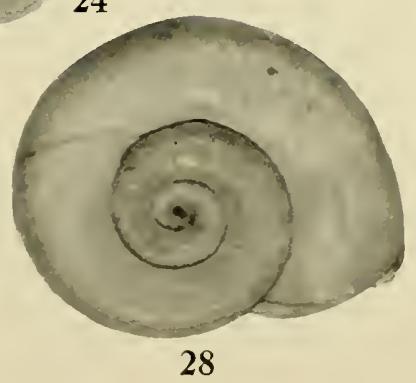

PLATE 97 
PLATE 98

\section{Shells of Planorbidae}

1. Helisoma tenue applanatum (ron Martens). Orizaba, Mexico. Strebel Coll. IT.S.N.M., 10538.

2-6. Helisoma tenue applanatum (ron Martens). Yaqui River, near Cindad Obregon, Sonora, Mexico. U.S.N.M., 467429.

7.S. IIelisoma tenue applanutum (ron Martens). Mazatlan, Mexico. Lea Coll. U.S.N.M., 121192.

9-13. Helisoma tenue sinuosum (Bonnet). Sinta Cruz River, Tueson, Arizona. In stream bed. U.S.N.M., 130237.

14. II elisoma temue sinuosum (Bonnet). Soroyta Creek, Sonora, Mexico. U.S.N.M., 130229.

15. Helisoma tenue simuosum (Bonnet). Albuquerque, New Mexico. $5000 \mathrm{ft}$ altitude. U.S.N.M., 134552 .

16,17. Iletisoma tenue califomiense F. C. Baker. Santa Cruz, California. U.S.N.M., 47571 .

18. Helisoma tenue califomiense F. C. Baker. Santa Cruz, California. U.S.N.M., 47572.

19-21. Helisoma temue californiense F. C. Baker. Crystal Creek, San Jose, California. U.S.N.M., 32111.

22. Helisoma tenue californicnse F. C. Baker. Santa Cruz Mts., 4 miles from Los Catos, California. U.S.N.M., 75437.

23, 24. Helisoma tenue califormiense F. C. Baker. Cimadeloupe Creek, San Jose, California. Paratypes. B3262.

25. Helisoma tenue simuosum (Bonnet). Rio Grande, El Paso, Texas. Immature. T.S.N.M., 130239.

26. Hchisoma temue califomiense F. C. Baker. Bixby, Los Angeles C'o., California. Immature. B3227.

Figmes 25 and 26 show differences in spire whorls and sculpture of the two varieties

All figures are enlarged about $1 \frac{1}{2}$ diameters 


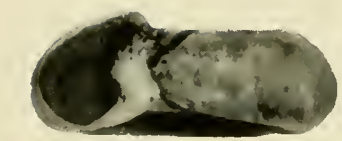

1
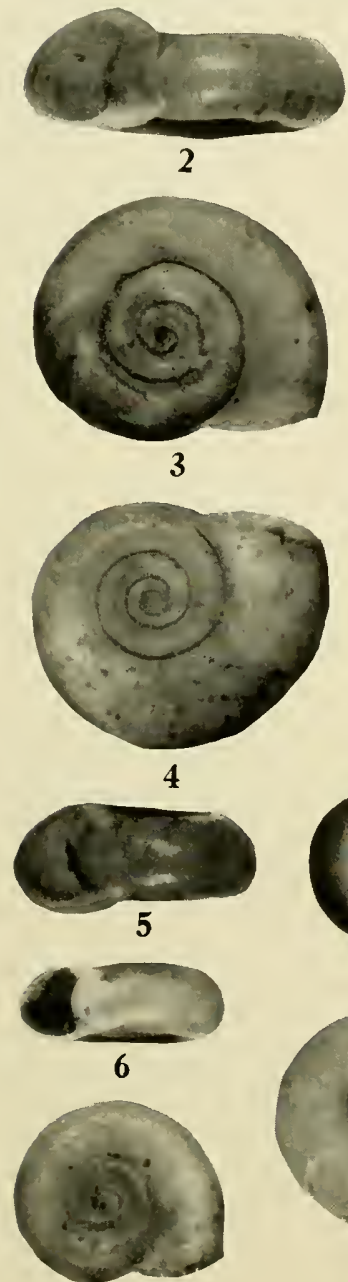

7

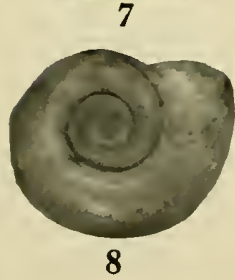

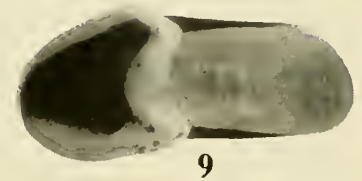

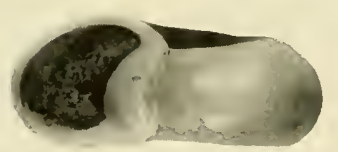

10

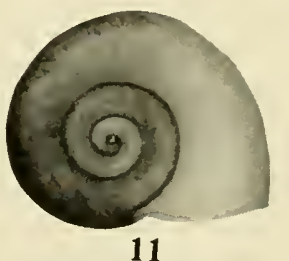

11

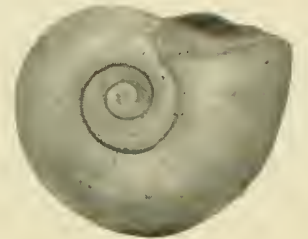

12
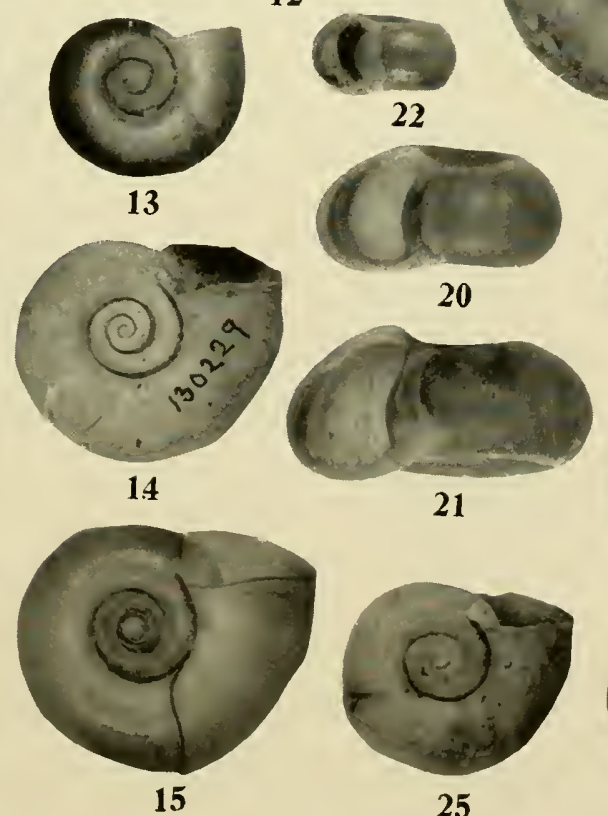

15

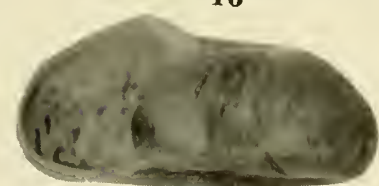

17

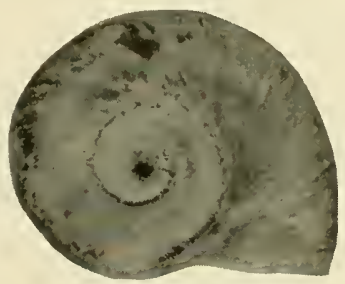

18
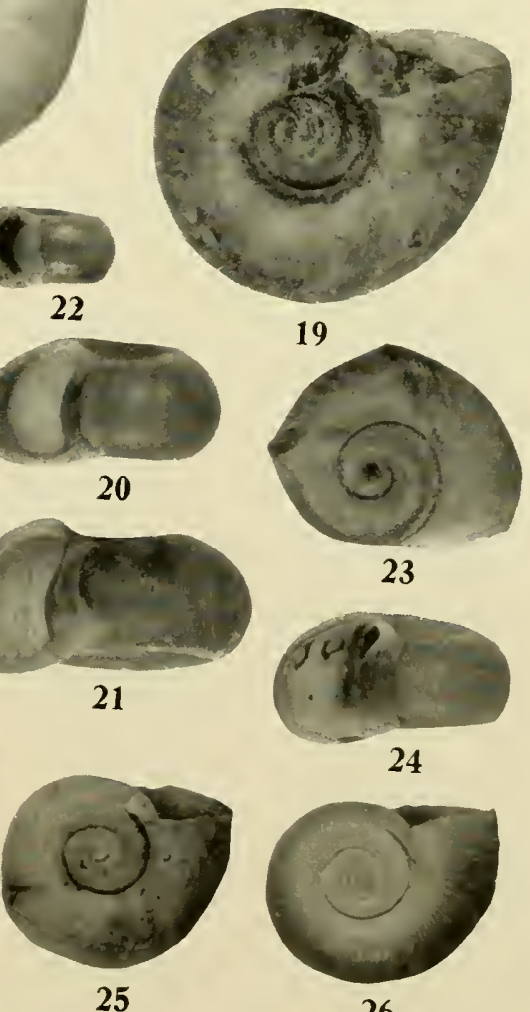

25

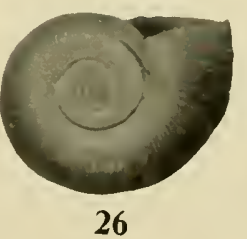

PLATE 98 


\section{Shells of Planorbidae}

1. Helisoma tenue applanatum (ron Martens). Near Vallecitos, Lower California. Immiture. U.S.N.M., 162654.

2.3. Helisoma tenue applanatum (von Martens). Yaqui River, near Ciudad Obregon, Mexico. Immature. U.S.N.M., 467429.

4-8. Helisoma tenue sinuosum (Bonnet). Santa Cruz River, Tucson, Arizona. Immature. U.S.X.M1., 130237.

9, 10. If elisoma tenue simuosum (Bonnet). Rio Grande, El Paso, Texas. Immature. U.S.N.M., 130239

11-15. Helisoma teme califormiense F. C. Baker. Bixby, Los Angeles Co., California. Immature. U.S.N.M., 174048.

16-19. Helisoma teme strebelianum (F. and C.). Penasco, 5 miles north of San Luis Potosi, Mexico. Immature. U.S.X.M., 251815.

20-24. Helisoma caribaenm guatemalense (Clessin). Reservoirs 4 miles north of Ginatemala City, Guatemala. U.M., 83490.

25. Helisoma tenue strebelianum (F. and C.). Tamaulipus, Mexico. U.S.N.M., 109916.

26. Helisoma temue strebelianum (F. and C.). Coy River, San huis Potosi, Mexico. B3921.

27-30. Helisoma tenue strebolianum (F. and C.). Alta Mira, Tamaulipus, Mexico. U.S.N.M., 251807.

31. Helisome earibatum (Orb.). Naranjo, Guatemala. Varying toward Helisoma caribacum guatemalense. I.M., 83487.

32-36. Helisoma earibaeum guatemalense (Clessin). Nicaragua. U.M., 83485.

All figures are enlarged about $1 \frac{1}{2}$ diameters 
Illustrations of the Anatomy and of Shells

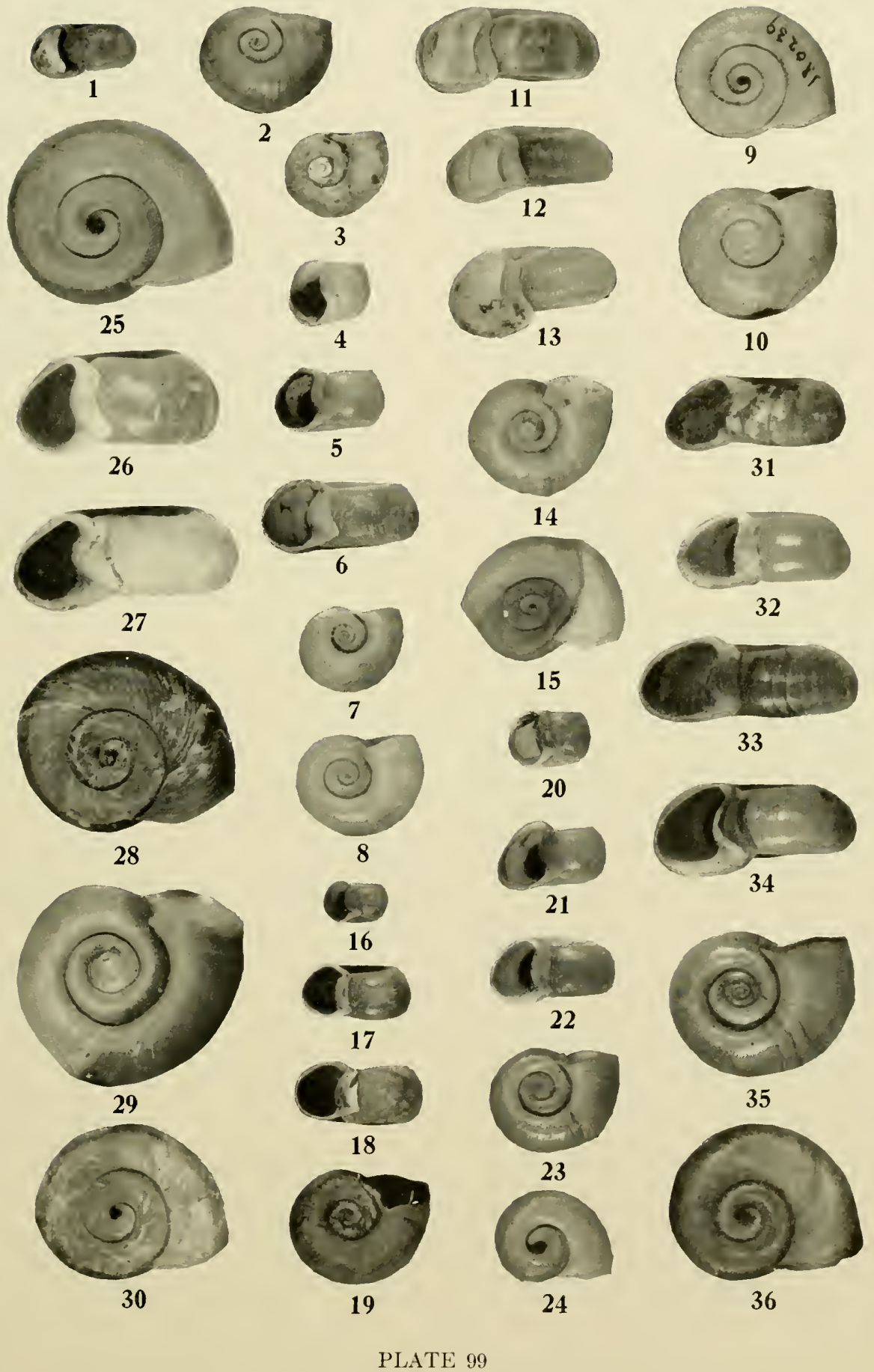


PLATE 100

Shells of Planorbidae

1,2,5. Helisoma caribatum (Orb.). Cuba. C'.M., S3491.

3.4. Helisoma caribaeum (Orb.). Punta de la Junta, Cuba. T.S.X.M.. 11204.

6-10. Helisoma caribaeum (Otb.). Panama. I'.M., 83492.

11-13. Helisoma caribaeum (Orb.). Somorrostro, Havana. Cuba. B3075.

14-17. Helisoma caribacum (Orb.). Vera ('ruz, Mexico. T.S.N.M., 210852.

18-20. Helisoma wyldii salvimi (Tristram). Guatemalı. T.S.N.M., 121023.

21-24. Helisoma wyldii (Tristram). San Carlos, Nicaragua. C.S.N.M.. 354295.

25-27. Helisoma wyldii (Tristram). Lake Olomega, Sun Sialvador. T.S.X.M., 360392

28. Helisoma wyldii (Tristram). Lake Metapan, San Salvador. T.s.N.M., 360391. 29, 30. Helisoma uyldii (Tristram). Lake Guija, San Salvador. C.S.N.M.. 360390.

31. Helisoma tumens (Clu.). Mazatlan, Mexico. T.S.X.M., 46967.

32.33. Helisome tumens (Cpr.). Mazatlan, Mexico. T'S.X.M., 47517.

34-37. Helisoma tumens (C'pr.). Mazatlan, Mexico. B22s4.

All figures are enlarged about $1 \frac{1}{2}$ diameter 


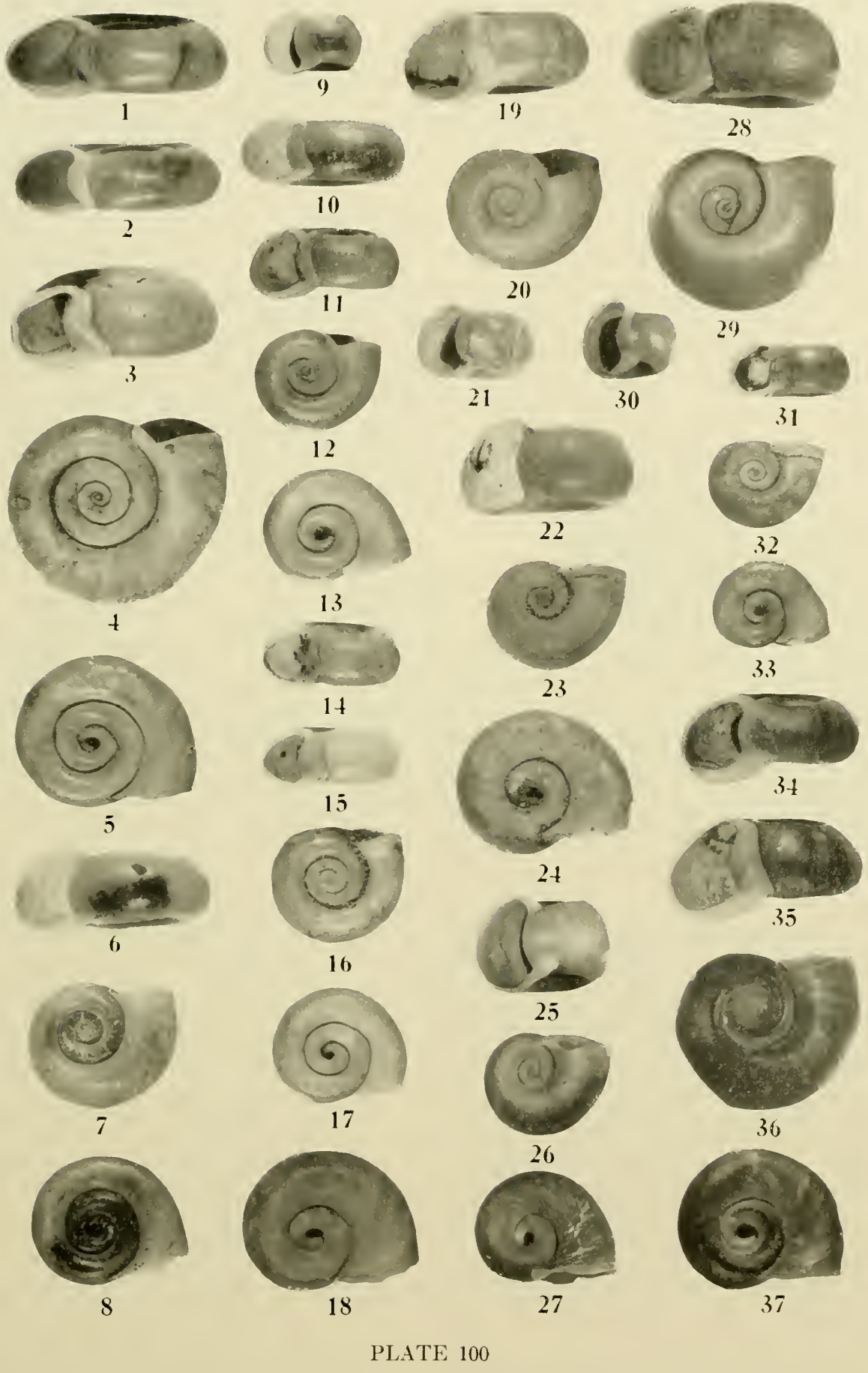


PLATE 101

Shells of Planorbidae

1. Ilelisoma foveale (Menke). Jamaica. U.S.N.M., 74762.

2. Helisoma foveale (Menke). Jamaica. U.S.Y.M., 90479.

3.4.6. Helisoma foveale (Menke). Kingston, Jamaica. U.S.N.M., 454058.

5. Helisoma foveale (Menke). Kingston, Jamaica. U.S.X.M., 74762.

7. Helisoma magnificum (Pilsbry). Joung, born in captivity. Parent from type locality. U.S.N.M.

8.9. Helisoma costaricense (Preston). Catalina, Guanacaste, Costa Rica. Cotype. B2132.

10. Ielisoma costaricense (Preston). Catalina, Guanacaste, Costa Rica. Figured type. U.S.N.M., 202522.

11, 12. Helisoma anceps idahoense F. C. Baker. Foot of Elbow or Lindbergh Lake, Mission Mts., Montana. M.C.Z.

13. II lisoma suberenatum variety? Utah Lake, Utah. U.S.N.M., 29332.

14. Helisoma subcrenatum (Cpr.). Oregon. From Nuttall in Lea Coll. U.S.N.M., 120986.

15. Helisoma caribacum (Orb.). Cuba. To show rounded inner whorls. U.M., 83491. X6.

16. If tisoma tenue applareatum (von Martens). To show flat inner whorls. U.S.N.M., 10538.

All figures, excepting 15 and 16 , are enlarged about $1 \frac{1}{2}$ diameters 
Illustrations of the Anatomy and of Shells
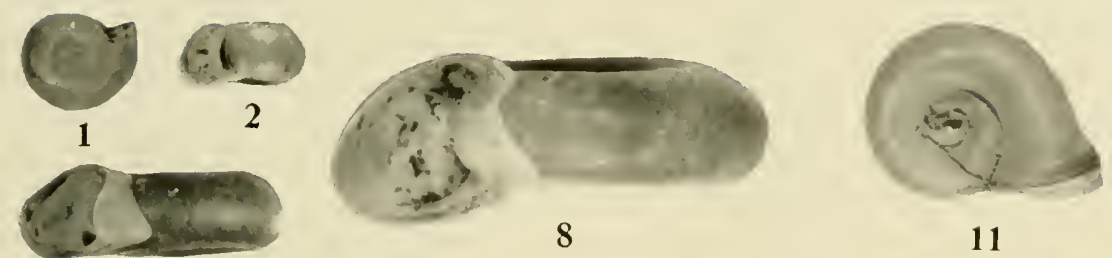

3
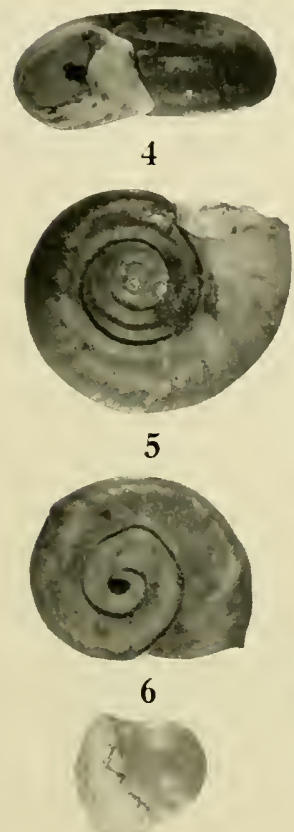

7
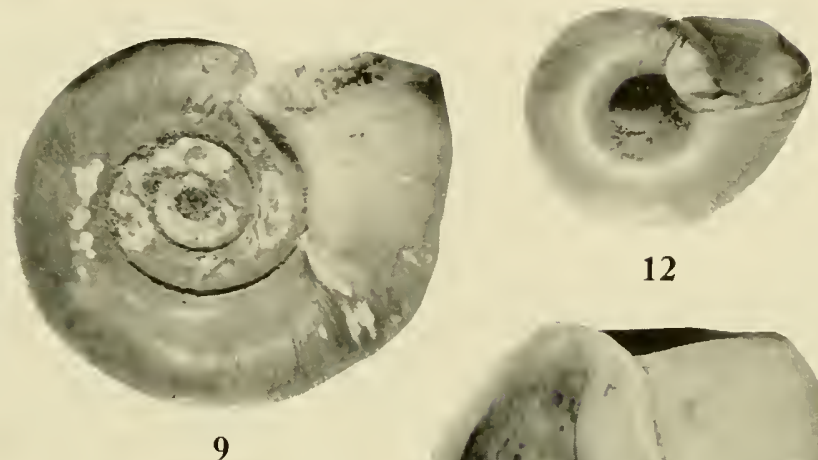

12

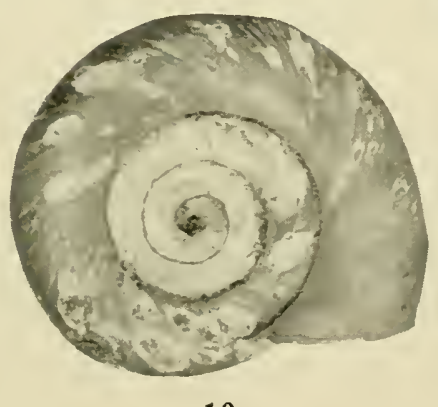

10

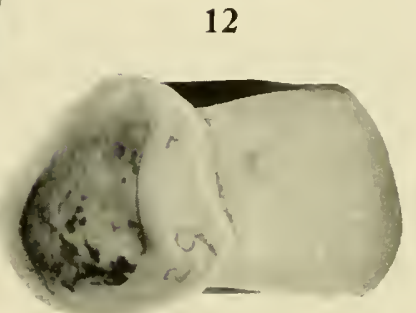

13

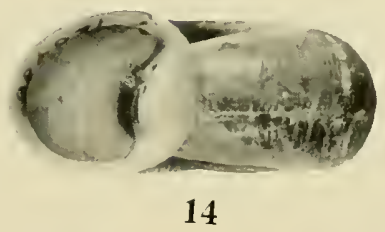

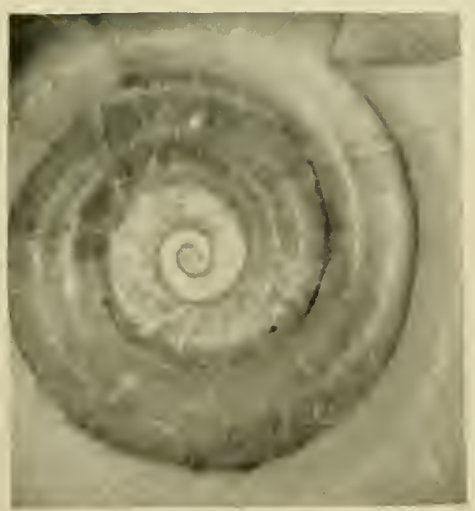

15

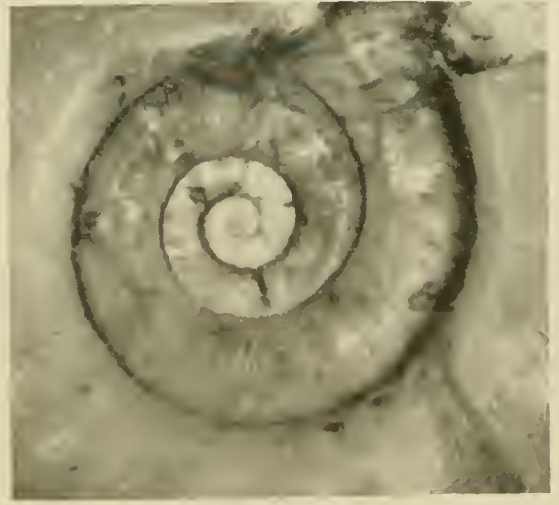

16

PLATE 101 


\section{PLATE 102}

\section{Shells of Planorbidae}

1. Helisoma te nue chapaltnse (Pilsbry). Proc. Acarl. Sci. Phil., 1920, p. 193, fig. 1. Enlarged.

2. Hetisoma contrerasi (Pilsbry). Proc. Acad. Sci. Phil., 1920, 1. 193, fig. 2. Enlarged. 3, 4. Helisoma contrerasi (Pilsbry). Lake Chapala, near Guadalajara, Mexico. L.S.N.M., 225863.

5-10. Helisoma tenue chapalense (Pilsbry). Oaxaca, Mexico. U.S.N.M., 117952.

11, 12. Helisome sealare (Jay). Caloosatchee Pliocene formation, Florida. B1106.

13, 14. Helisoma sealare (Jay). Lake Griffin, near Leesburg, Florida. B1438.

15-18. II tisoma scalare (Jay). Head of Miani River, Everclades, Dade Co., Florida. B2969.

19, 20. Helisoma sealare (Jay). Everglades, Florida. B3002.

21. Helisoma duryi seminole Pilsbry. Everglades, Florida. B2962.

22, 23. Helisoma duryi seminole Pilsbry. Sunter Co., Florida. B2965.

All figures, excepting 1 and 2 , are enlarged about two diameters 
Illustrations of the Anatomy and of Shells
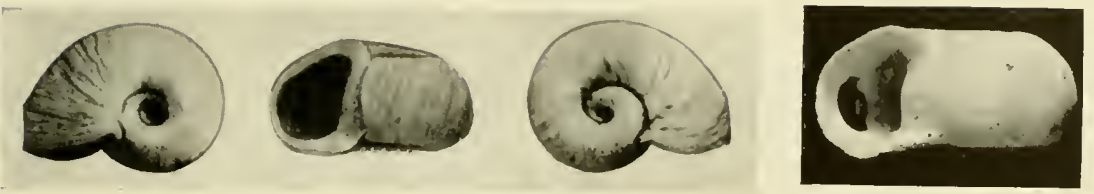

3
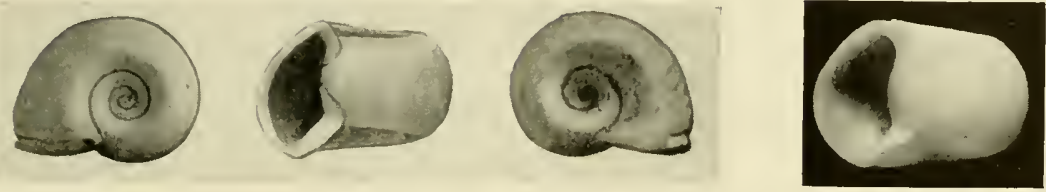

4

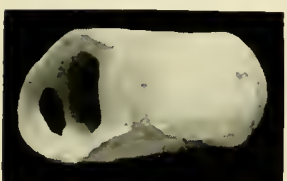

5

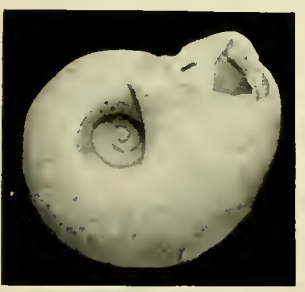

9

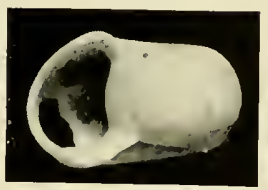

6

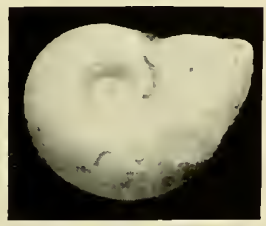

10

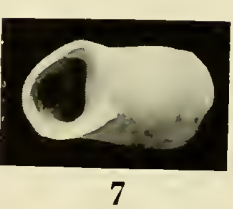

7

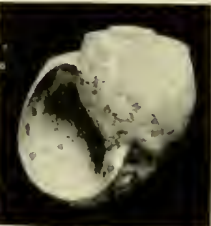

11

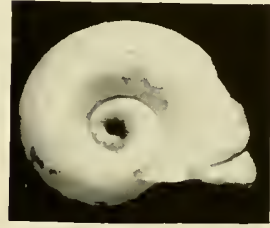

8

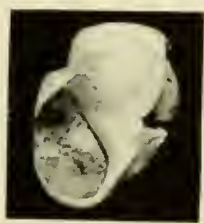

12

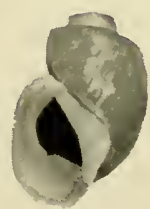

17

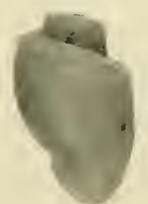

18

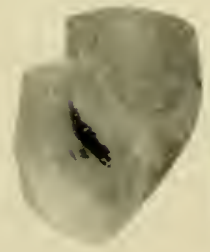

19

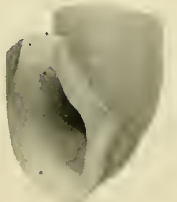

14

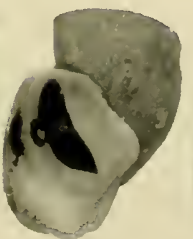

20

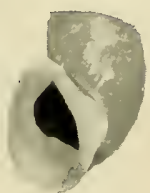

15

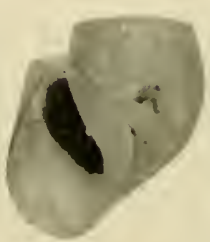

21

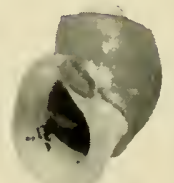

16

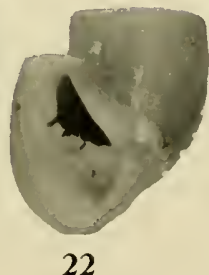

22

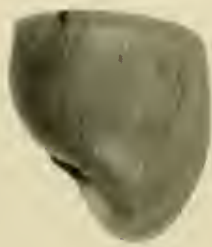

23

PLATE 102 


\section{PLATE 103}

\section{Shells of Planorbidae}

1.2. Helisoma duryi seminole Pilsbry. Ererglates, Florida. B2962.

3-5, 8, 9. Helisoma duryi seminole Pilsbry. Lake Eust is, Lake Co., Florida. Paratrpes. B2960.

6.7. Helisoma duryi seminole Pilsbry. Lake Eustis, Lake Co., Florida. U.I., Z32368.

10, 11. Helisomn duryi seminole Pilsbry. Okechobee Lake, near More Haven, Florida. M.C.Z., 43311.

12. Helisoma duryi seminole Pilsbry. Lake Apopka, Florida. M.C.Z., 71599.

13. Helisoma duryi seminole Pilsbry. Lake Apopka, Florida. M.C.Z., 71598.

14-18. Helisoma duryi se minole Pilsbry. Survey, Lee C'o., Florida. M.C.Z., 68236.

19. Helisoma duryi seminole Pilsbry. Sumter Co., Florida. U.I., Z32364.

20-30. Helisoma duryi (Wetherby). Near West Pam Beach, Floricla. M.C.Z., \$2856.

31. Helisoma duryi (Wetherby). Miami, Florida. [.S.N.M., 153412.

These figures show the great variation in form of spire and shape of shell of the duryi complex, especially the form seminote.

All figures are enlarged about $1 \frac{1}{1 / 2}$ diameters 
Illustrations of the Anatomy and of shells
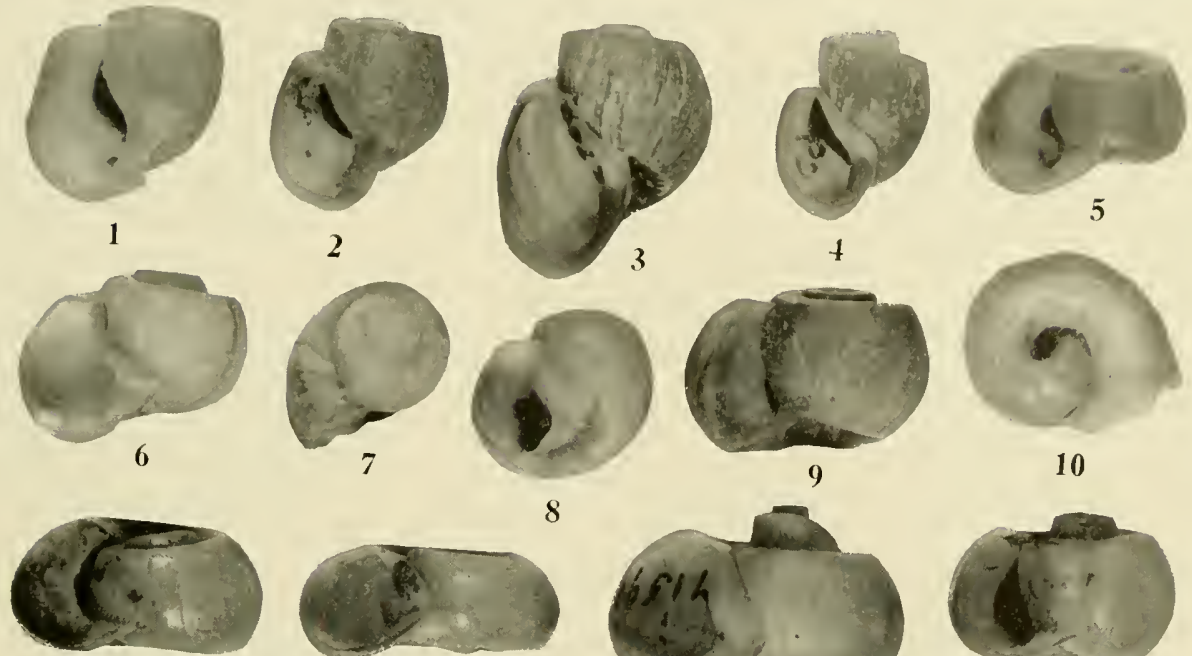

11
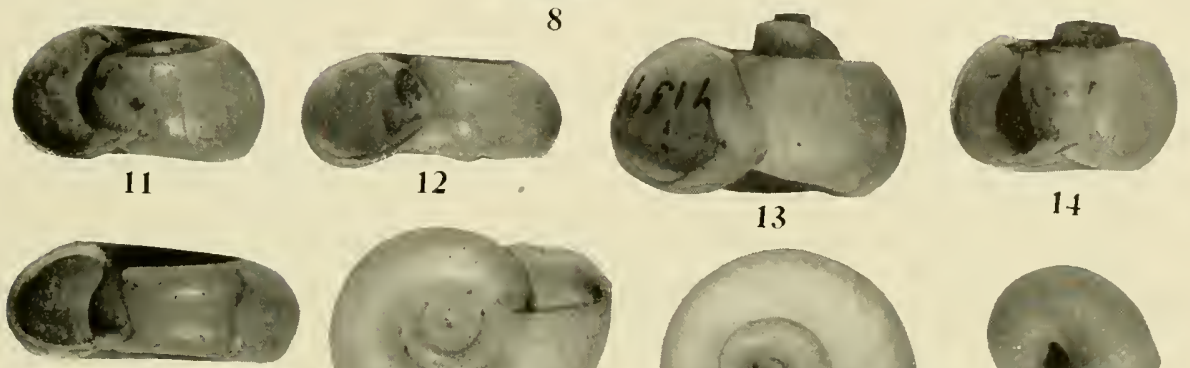

15

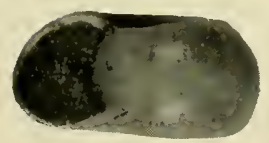

16
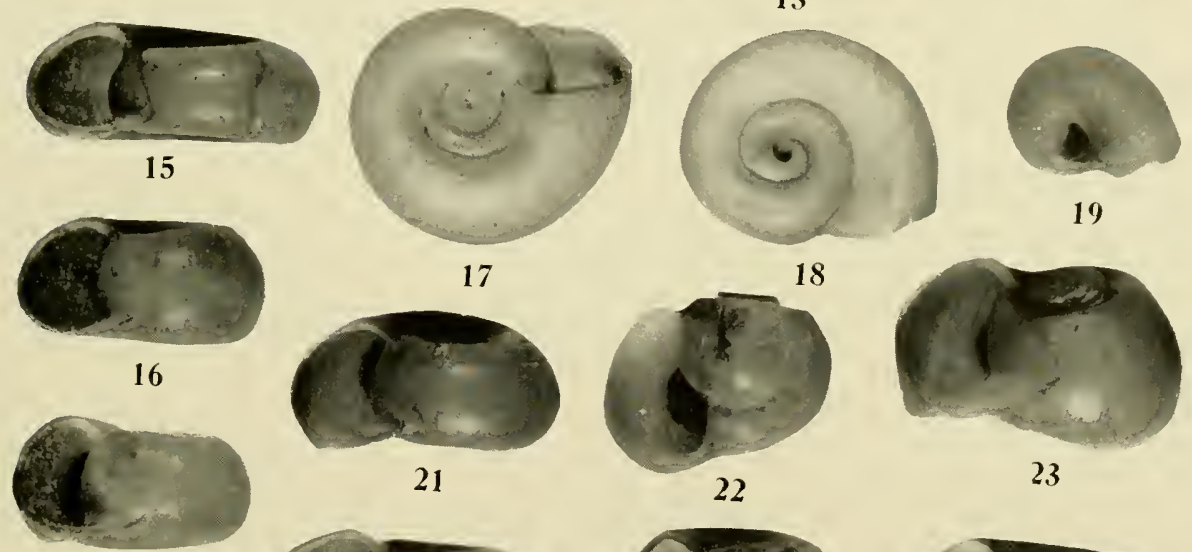

21
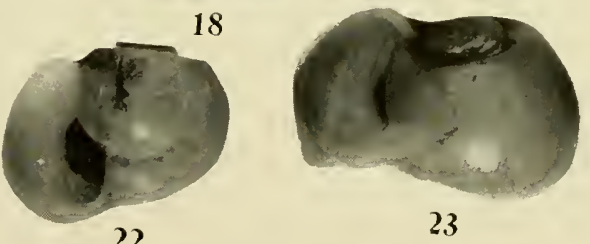

20

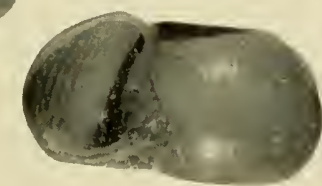

25

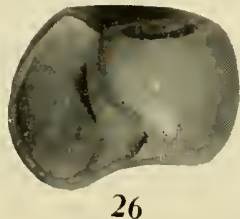

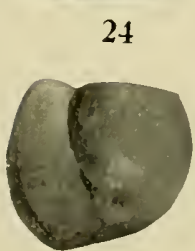

28

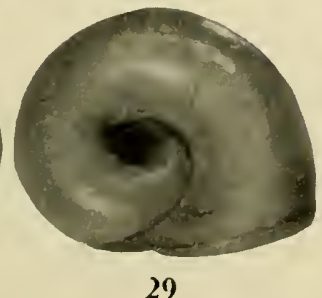

29

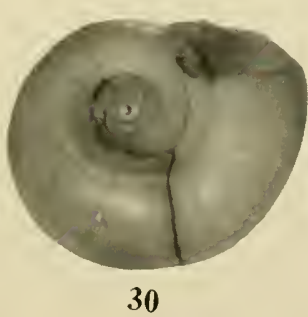

30

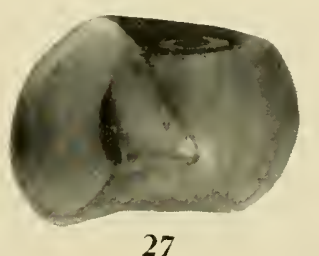

27

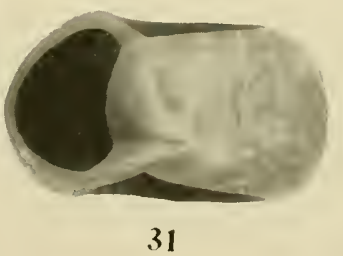

PLATE 103 


\section{PLATE 104}

Shells of Planorbirlae

1-3. Helisoma duryi (Wetherby). Kissimmee River, Florida. Valdiation toward variety normale. U.S.N.M., 168921.

4-7. Helisoma duryi (Wetherby). Near West Pahm Beach, Patm Beach Co., Floricla. Variation toward variety normale. M.C.Z., 45103.

S-16. Helisoma duryi normale Pilsbry. One mile north of Oil well, Pinecrest, Everglades, Florida. U.I., Z34637.

17. Helisoma duryi normale Pilsbry. Canal west of Boynton, Palm Beach Co., Florida. Malleated base. M.C.Z., 76659.

18-22. Helisoma duryi normale Pilsbry. Magnolia, Florida. M.C.\%., \$7505.

All figures are enlarged about 11/2 diameters 

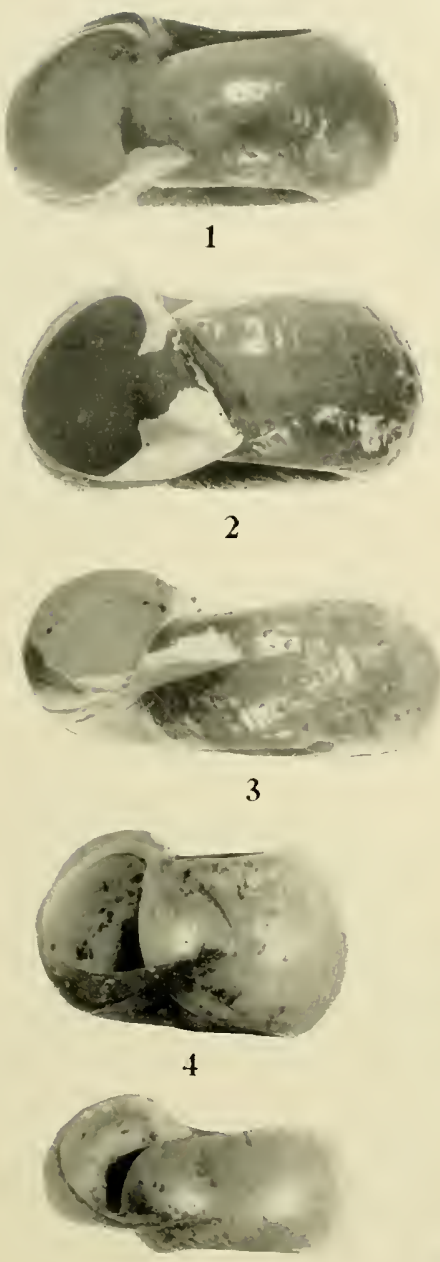

5
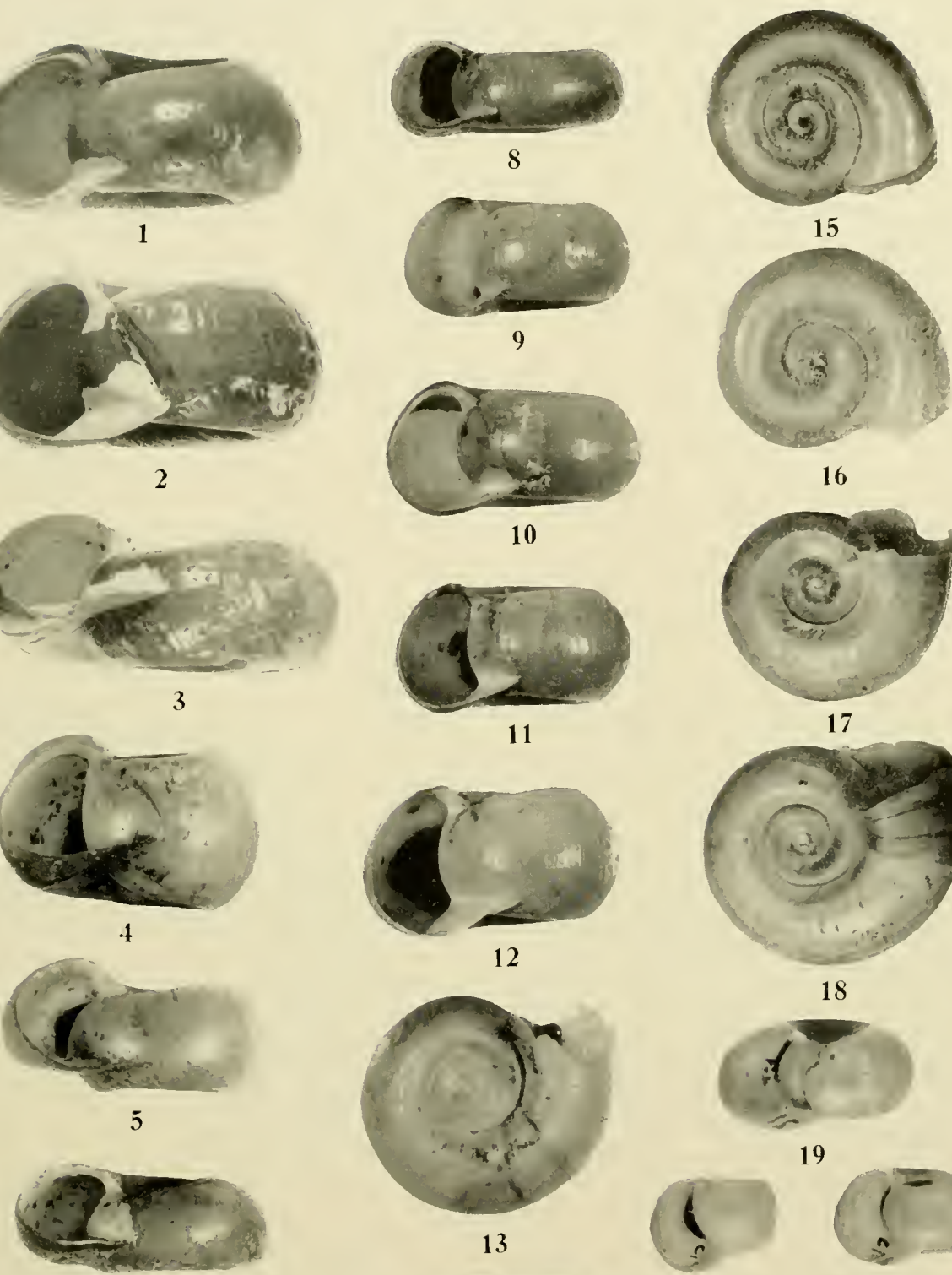

15

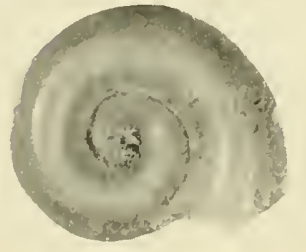

16

10
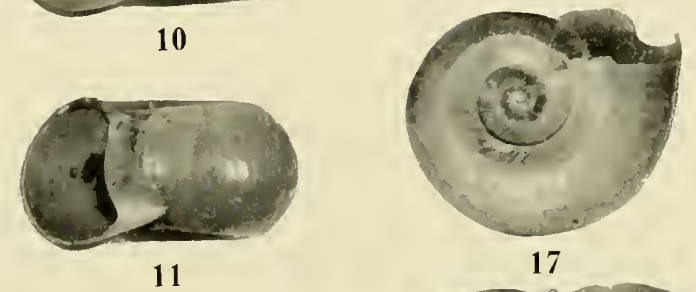

17
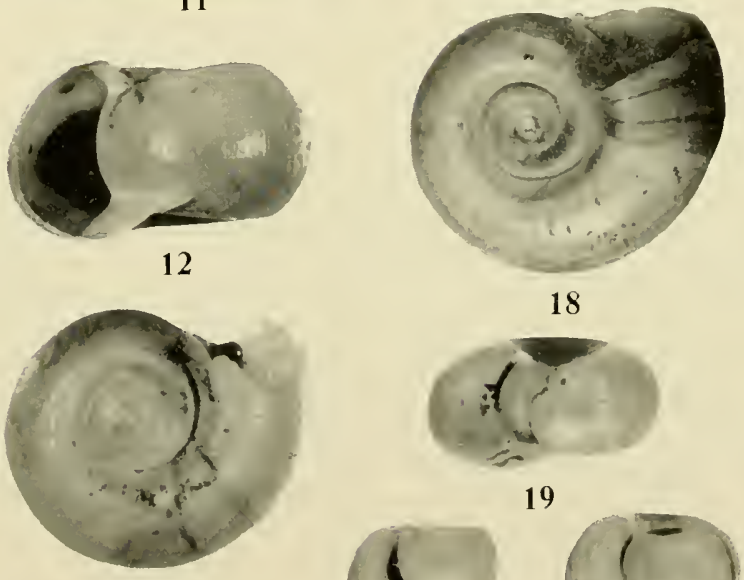

13

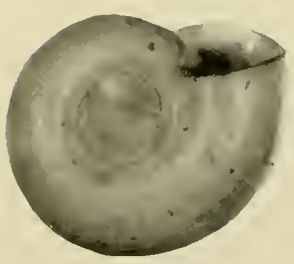

14
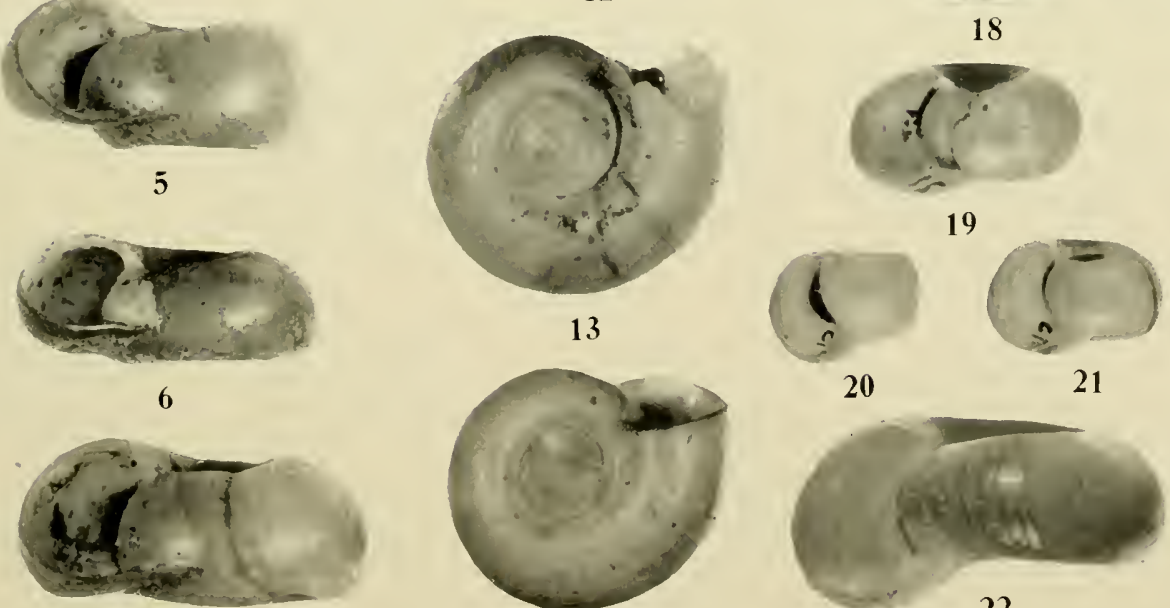

7

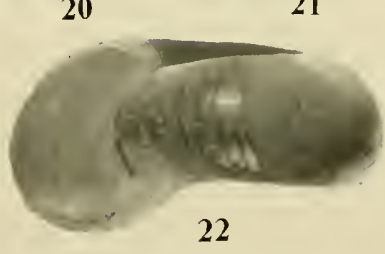

PLATE 104 


\section{PLATE 105}

\section{Shells of Planorbidac}

1-3. Helisoma duryi nomale Pilsbry. Everglades 40 miles from Ft. Meyers, Florida. M.C.Z., 71020.

4-8. Helisoma duryi intercalare (Pilsbry). East shore Lake Okeechobee, Palm Beach Co., Florirla. M.C.Z.

9. Ifelisoma duryi intercalare (Pilsbry). Beecher Spring, Wakulla, Wakulla Co., Florida. I'.S.N.M., 153079.

10, 11. Helisoma duryi intercalare (Pilsbry). Lake Jessup, Florida. U.S.X.M., 167040.

12, 13. Helisoma duryi intercalare form alternatum Pilsbry. Blne Creek, Lake Co., Florida. Type tocality. M.C.Z., S3729.

14-16. Helisoma duryi eudiscus Pilsbry. Head of Minmi Rirer, near Miami, Dade Co., Floridat. Paratypes. B3074.

17-19. Hclisomn duryi culiscus Pilsbry. Silver Springs, Marion Co., Florida. Varying toward intercalare. B3073.

20-27. II elisoma duryi preglabratum (Marshall). Canal, Palm Beach Co., Florida. Type locality. M.C.Z., 46572.

All figures are enlarged about $11 / 2$ diameters 

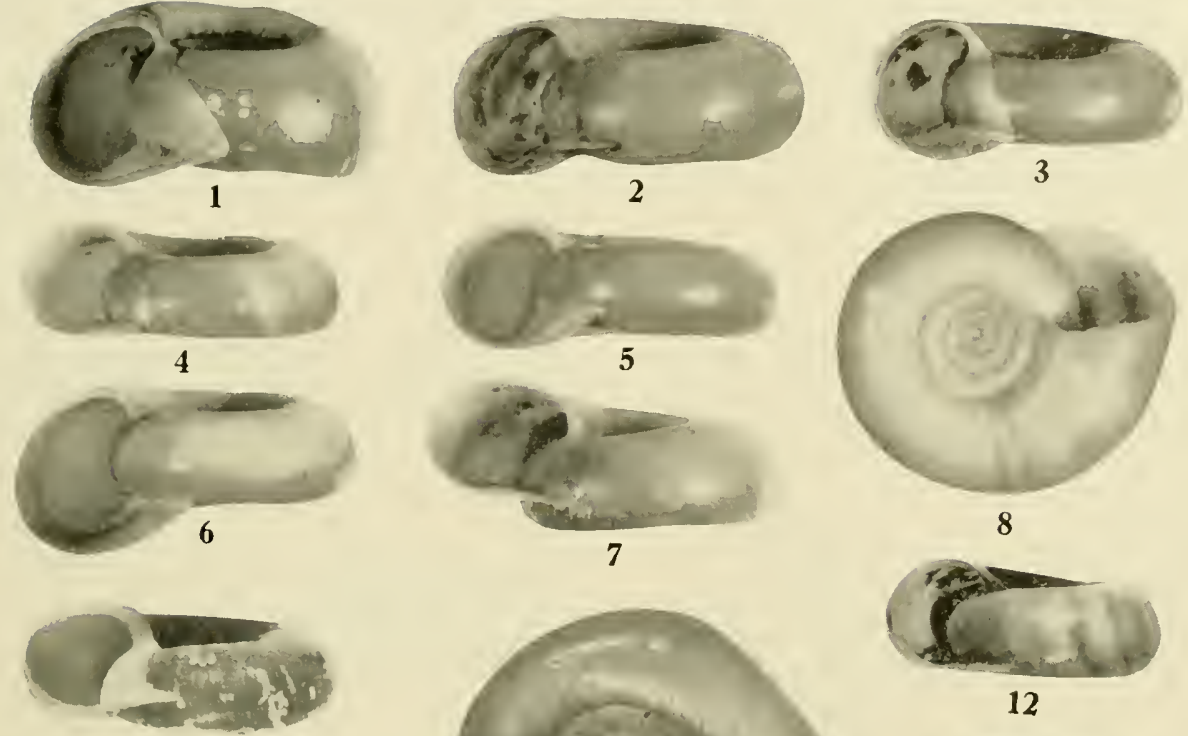

9

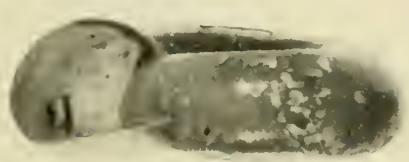

10

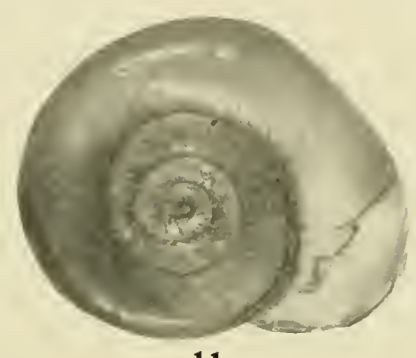

11

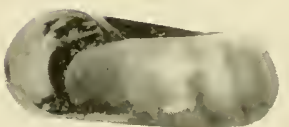

12

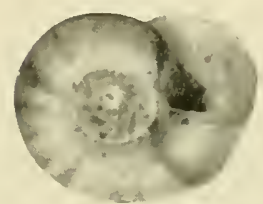

13

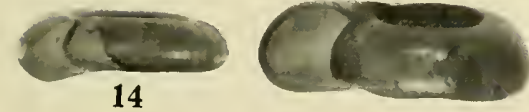

18
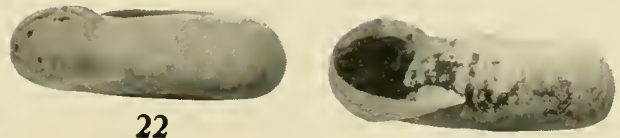

25
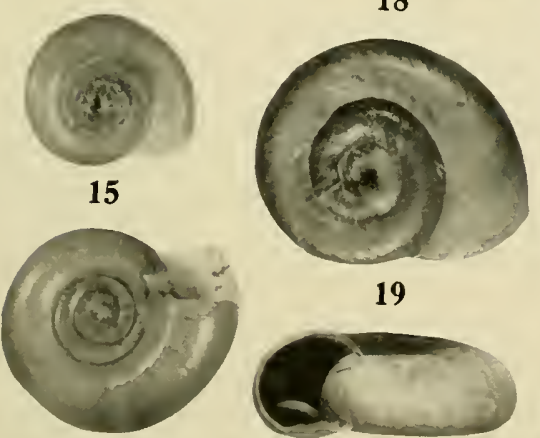

19
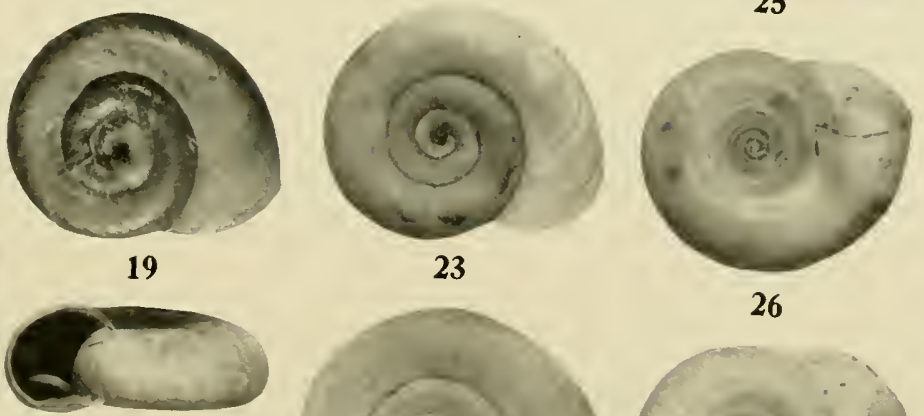

16
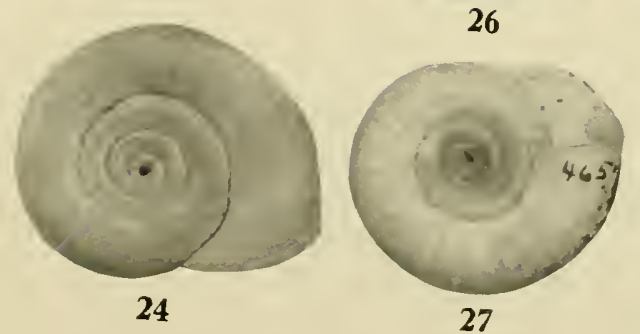

PLATE 105 
PLATE 106

Shells of Planorbidae

1-3. Helisoma duryi seminole Pilsbry. Florida. U.S.N.M.. 99301.

4. Helisoma conanti Dall. Caloosahatchee River, Florida. U.I., Z40z̃o.

5-7. Helisoma conanti Dall. Caloosihatchee River, Florida. B1107.

8. Itelisoma disstoni (Dall). Vero, St. Lucia Co., Florida. C.S.X.M., 331971.

9-11. Helisoma species? Asecibo, Puerto Rico. U.S.T.M.., 535394.

12-15. Helisoma disstoni (Dall). Canal, Palm Beach Co., Floridit. M.CZ., 99182.

16. Hclisoma corpulentum multicostatum F. C. Baker. Lake Kahnipiminanikok, Ontario, Canadia. Young. U.I., Z3262S.

17. Helisoma corpulentum (Siy). Lac la croix, Ontaria, ('anadia. Young. L.I., Z32626.

18. Hclisoma whiteavesi F. C. Baker. Lac des Mille Lacs, Ontario, Canada. Holotype. U.I., Z32311.

19, 20. Hclisoma whitcavesi F. C. Baker. Lac des Mille Lacs, Ontario, Canadi. Paratypes. U.I., Z32312.

21. Helisoma whitcavesi F. C. Baker. Lac des Mille Lacs, Ontario, Canada. Paratype, Immature. U.I., Z32313.

22. Helisoma corpulentum (Say). Kettle Falls, Raing River Distriet, Ontario, Canada. Began as a corpulentum and on last whorl changed form of shell toward that of multicostatum. U.S.N.M., 361737.

All figures are enlarged about $1 \frac{1}{2}$ diameters 


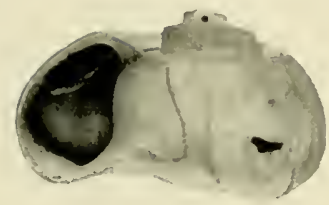

1

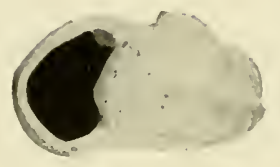

2
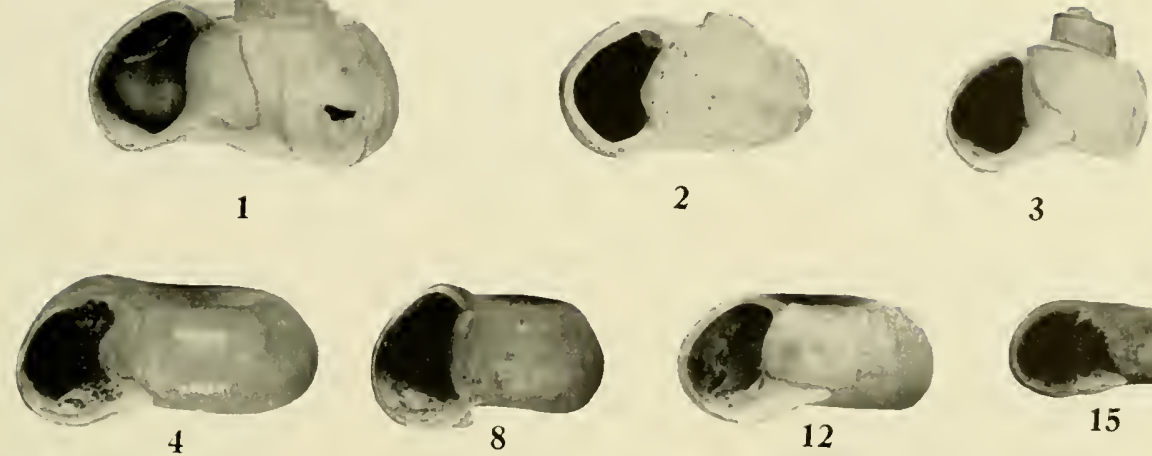

12

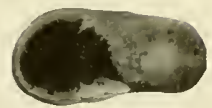

15

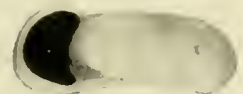

5

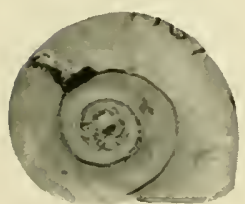

6

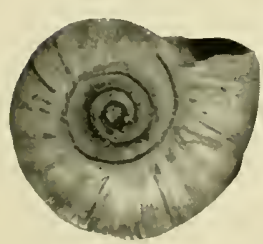

.9

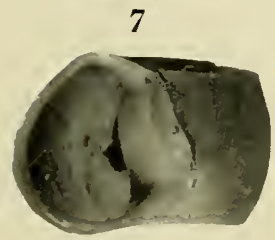

21
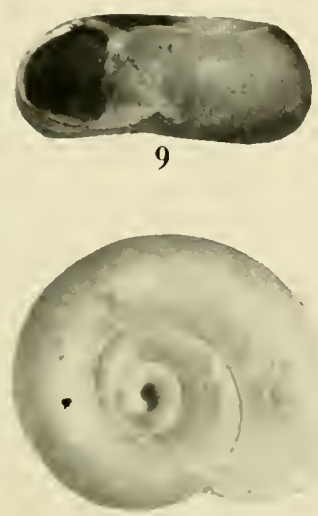

10
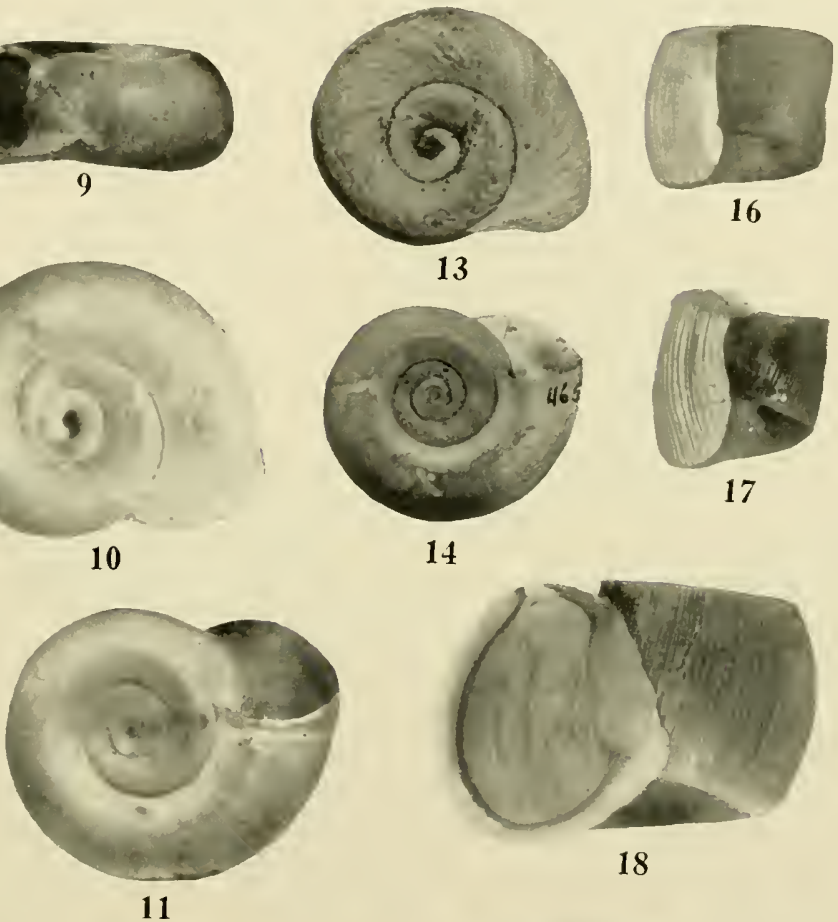

13
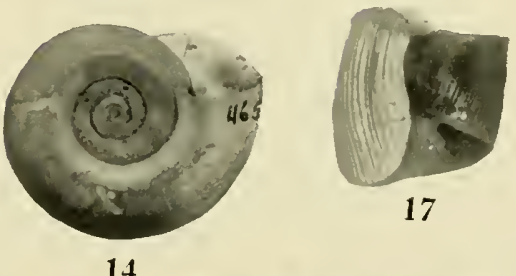

17

14
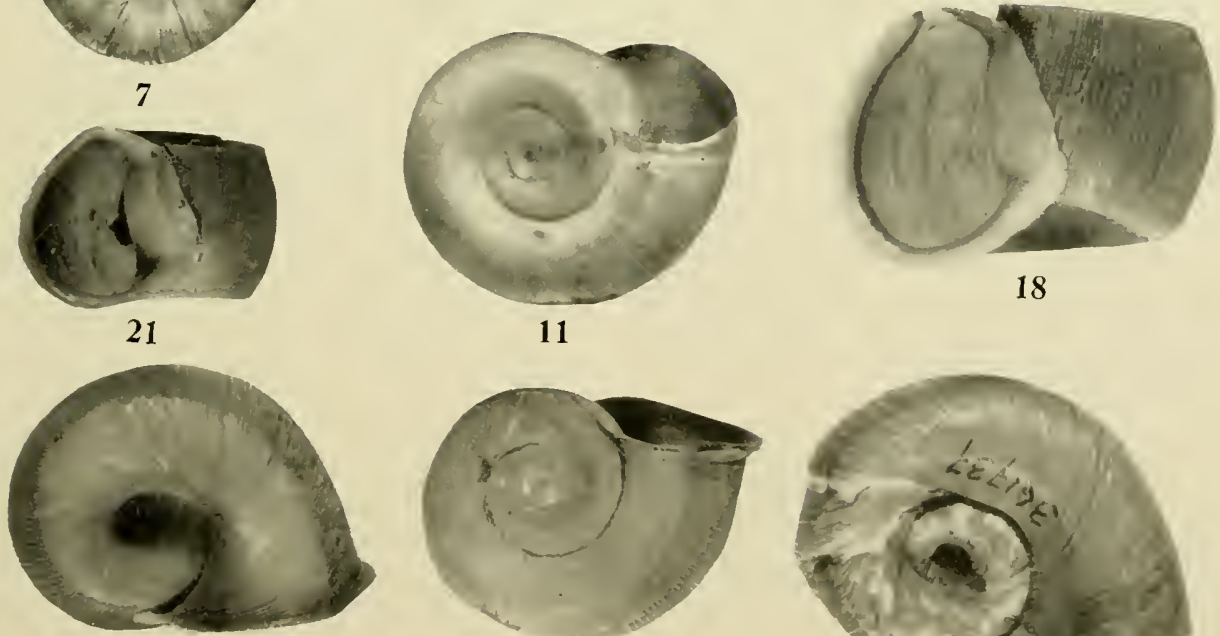

19

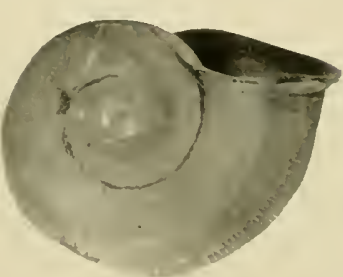

20

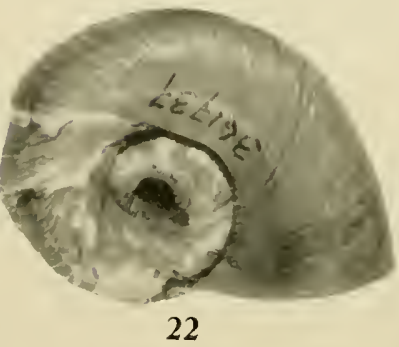

PLATE 106 


\section{PLATE 107}

\section{Shells of Planorbidae}

1-4. If elisoma corpulentum (Say). Lac la Croix, Ontario, Canada. C.I., Z32296.

5. Ilelisome (ompulentum (Siy). Rainy Lake, Ontario, Canada. A type locality. B1101.

6. Helisoma corpulentum (Say). Rabbit Point, west of Sabaskong Bay, Lake of the Woods, Canada. A type locality. Resembles Say's figure. U.I., Z41286.

7. Ifelisoma corpulentum (Sity). Lae la Croix, Ontario, Canada. U.I., Z32626.

S. II lisoma corpulentum z'rmilionense F. C. Baker. Vermilion Lake, St. Louis Co., Minnesotil. Holotype. B3021.

9, 10. Helisoma corpulentum t'ermilionense F. C. Baker. Termilion Lake, Minnesota. Paratypes. B3014.

11. Hetisoma corpulentum vermitionense F. C. Baker. Vernilion Lake, Minnesota. Paratype, immature. U.I., Z32518.

12. Hclisoma corpulentum multicostatum F. C. Bakes. Iake Kahnipiminanikok, Ontario, Canadil. Holotyre. U.I., Z32308.

13. Helisoma corpulentum (Siy). Lac la Croix, Ontario, Canada. Young. U.I., Z32626.

14. Helisoma corpulentum vcrmilionense F. C. Baker. Vermilion Lake, Minnesota. Young. U.I., Z32627.

15. IIclisoma whitearesi F. C. Baker. Lac des Mille Lacs, Canada. Young. U.I., Z32312.

16-18. Helisoma corpulentum multicostatum F. C. Baker. Kahnipiminanikok Lake, Ontario, Canadia. Paratypes. C.I., Z32307.

19. Helisoma corpulentum multicostatum F. C. Baker. Knife Lake, Minnesota. U.I., Z29828.

20. Helisoma corpulentum multicostatum F. C. Baker. Bemidji Lake, Beltrami Co., Minnesota. U.I., Z32475.

21. Helisoma corpulcntum multicostatum F. C. Baker. Kahnipiminanikok Lake, Ontario, Canida. Immiture. U.I., Z32628.

All figures are enlarged about $1 \frac{11 / 2}{2}$ diameters 
Illustrations of the Anatomy and of Shells
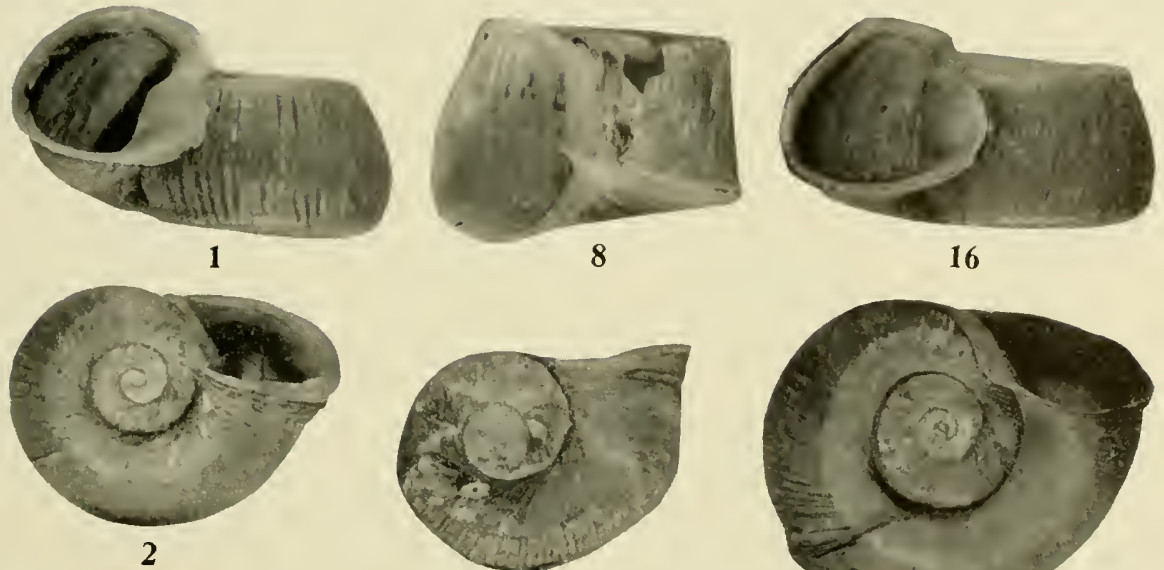

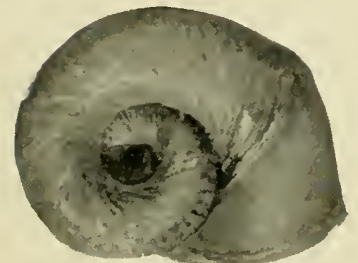

3
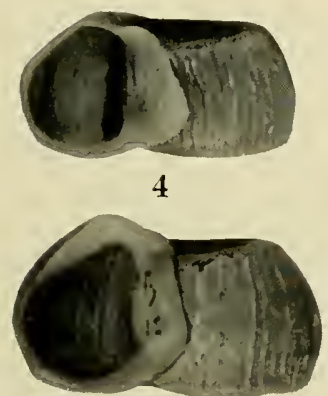

5
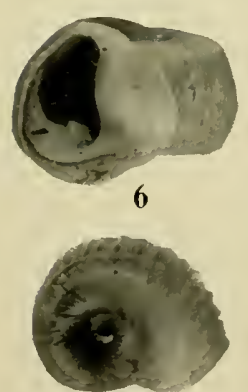

7
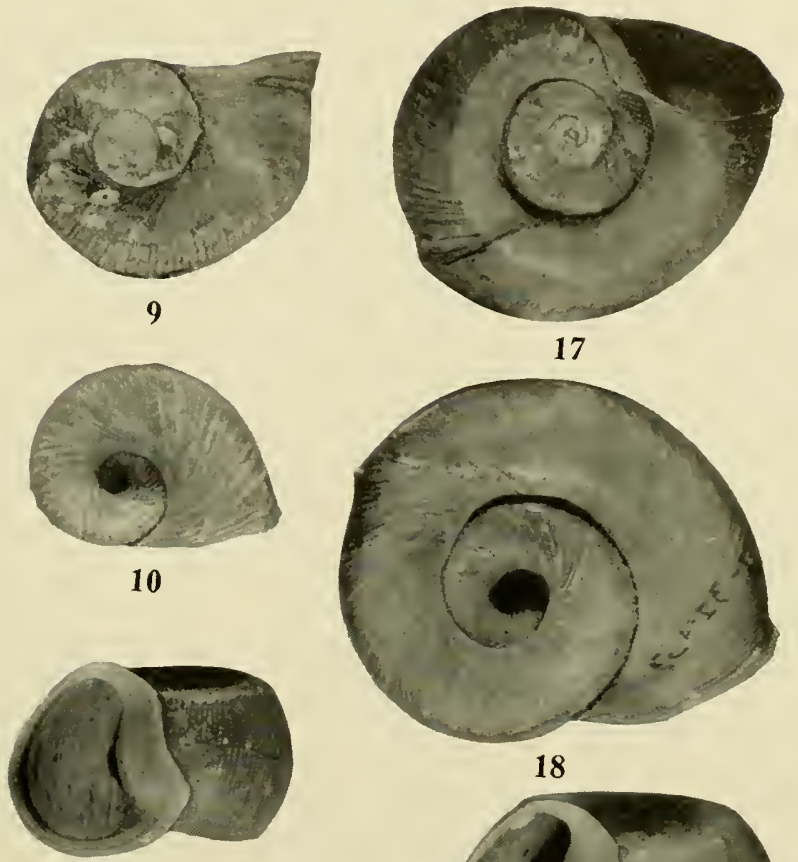

12

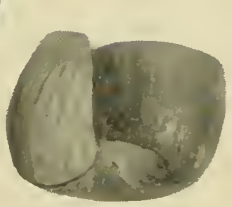

13

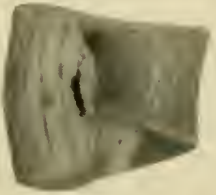

14
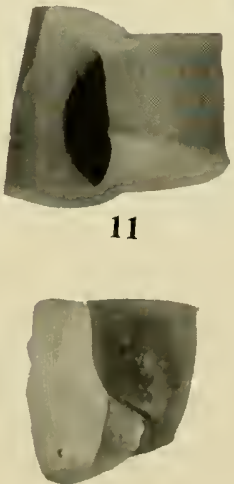

15

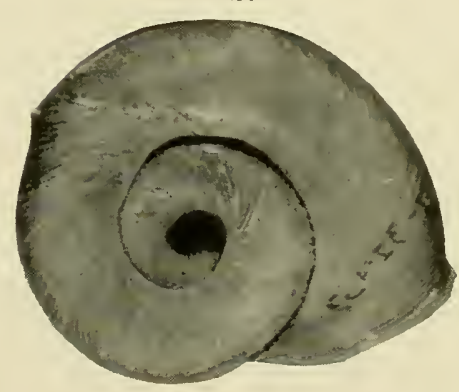

18

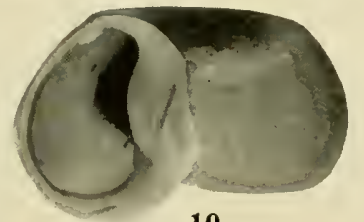

19

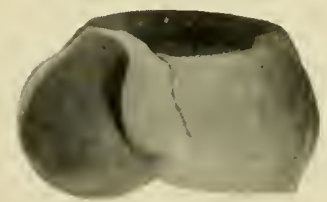

20

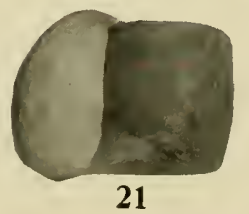

PLATE 107 
PLATE 108

Shells of Planorbiclae

1-6. Helisoma campanulatum (Say). Caynga Lake, New York. Type locality. U.S.N.M., 212700.

7-9. Helisoma campanulatum (Say). North end Cayuga Lake, New York. Probable type locality. B1043.

10, 11. Helisoma companulatum (Say). Ottawa, Ontario, Canada. U.S.N.M., 120985.

12-14. Helisoma compamulatum (Say). North end Canandaigua Lake, New York. 133859.

15-17. Helisoma campanulatum (Siy). Crooked Lake, Oden, Michigan. Variation in size. U.I., Z19877.

18. II lisoma campanulatum ferrissi F. C. Baker. Marl Lake, Fair Grounds, Joliet, Will Co., Illinois. Holotype. C.I., P1068a.

19. Helisoma companulatum ferissi F. C. Bakel. Same locality as above. Paratype. U.I., P1068b.

20-25. Helisoma campanulatum ferrissi F. C. Baker. Same locality as above. Paratypes. U.I., P1068.

26-28. Helisoma campanulatum ferrissi F. C. Baker. White Lake, Oakland Co., Michigian. U.I., Z2090S.

29-31. Helisoma companulatum ferrissi F. C. Baker. Interior Charity Island, Michigan. B3860.

32-34. Helisoma companulatum ferrissi F. C. Baker. Lermond, Bonne Bay, Newfoundland. B3858.

All figures are enlarged about two dianeters 


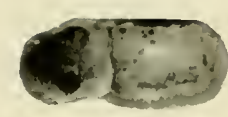

1

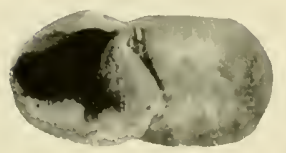

5

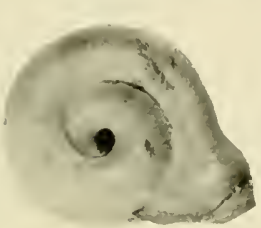

10

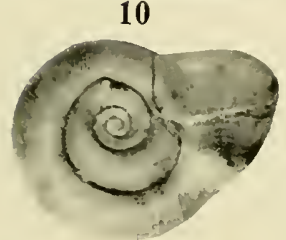

14
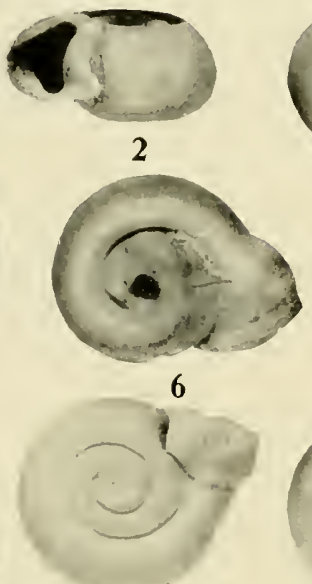

11
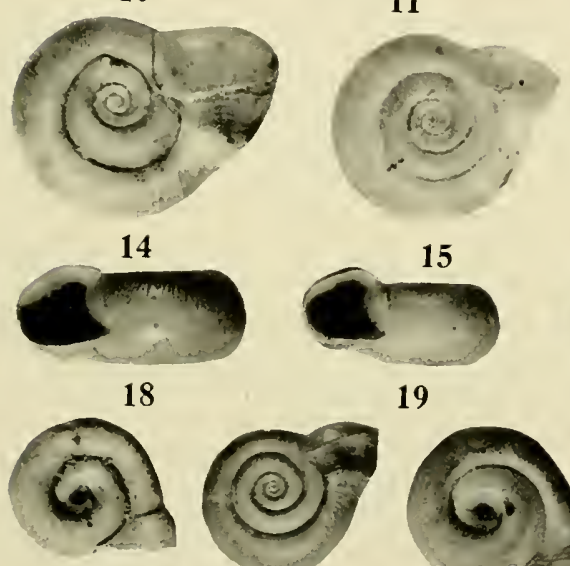

22

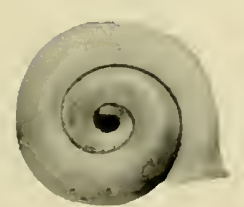

27

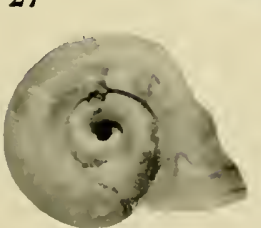

32

29
2

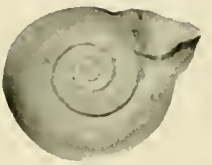

3

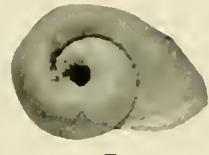

7

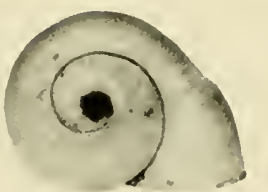

12

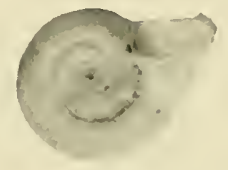

16
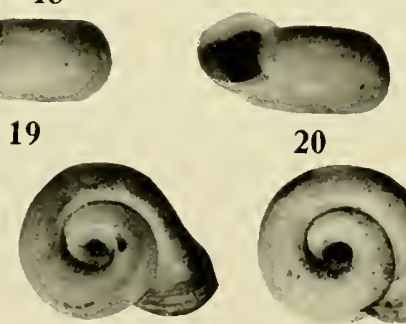

24

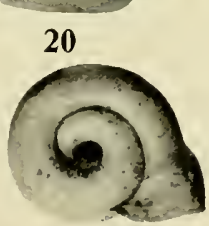

25

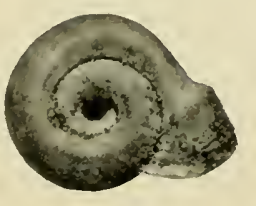

30
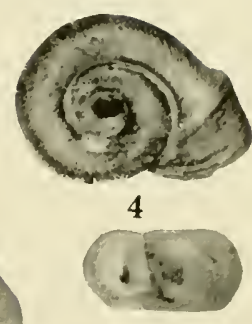

8
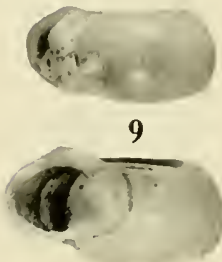

13

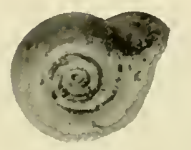

17

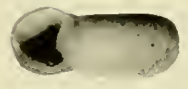

21

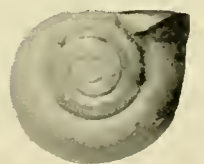

26

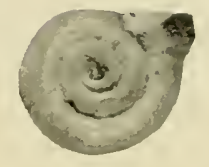

31

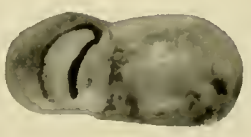

33

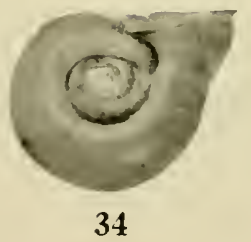

PLATE 108 
PI.ATE 109

\section{Shells of Planorbidac}

1-6. Helisoma campanulatum (Say). Pine Island Lake. Kent Co., Michigan. Exaggerated campanulate lip. B3922.

7. Helisoma campanulatum wisconsinense (Winslow). Little Arbor Vitate Lake, Vilas Co., Wisconsin. Type locality. U.I., Z1S121.

S. II lisoma campanulatum wisconsinense (Winslow). Tomahawk Lake, Wisconsin. B1718.

9. Helisoma exmpamulatum wiseonsinense (Trinslow). Tomabawk Lake, Wisconsin. B1719.

10, 11. Helisoma campanulatum wisconsinense (Winslow). Tomahawk Lake, Wisconsin. $\mathrm{B} 1725$.

12, 13. Intisoma campanulatum wisconsinense (Winslow). Tomahawk Lake, Wisconsin. B3857.

14. Helisoma campanulatum smithii (F. C. Baker). Douglas Lake, Michigan. Holotype. B1054.

15,16. Helisoma campanulutum smithui (F. C. Baker). Douglas Lake, Michigan. Paratypes. B1728.

17-20. Helisoma campanulatum smithii (F. C. Baker). Donglas Lake. Michigan. Type locality. B3861.

21. Ictisoma campanulatum ridcauense F. C. Baker. Rideau River, Ottawa, Canada. Holotype. T.S.X.M., 346627.

22-24. Helisoma campanulatum rideaucnse F. C. Baher. Rideau River, Ottawa, Canada. Paratypes. U.S.N.M., 346627.

25. Hetisoma campanulatum smithii (F. C. Baker). Douglas Lake, Michigan. Small form. B1056.

26-28. Helinoma multivoleis (Case). Howe Lake, Marquette Co., Michigan. C.I.. Z23192.

29. Helisoma multivolvis (Case). Howe Lake. Marquette Co., Michigan. U.A.M.M., 272274 .

All figures are enlarged about $1 \frac{1 / 2}{2}$ diameters 
Illustrations of the Anatomy and of Shells
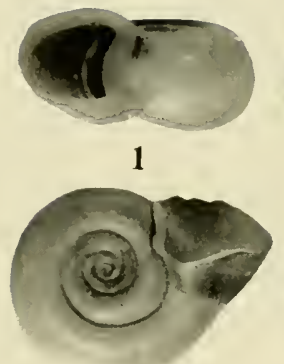

5

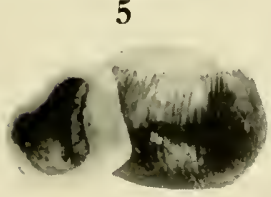

9

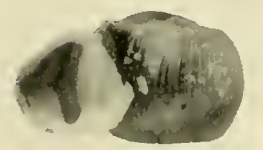

13

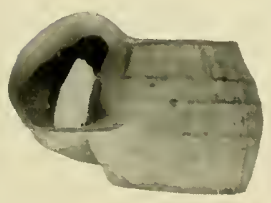

17

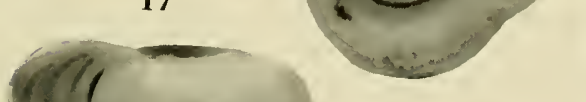

18

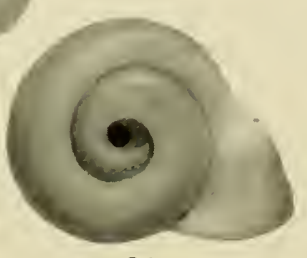

23

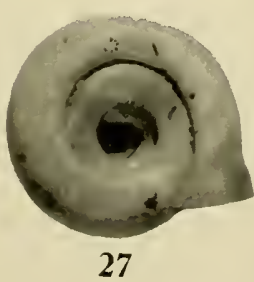

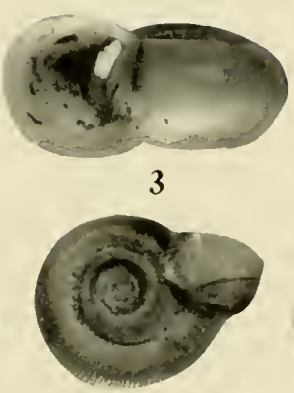

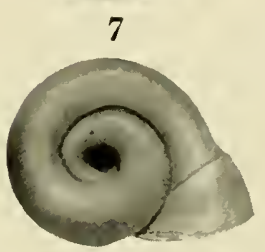

11

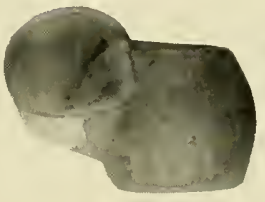

15

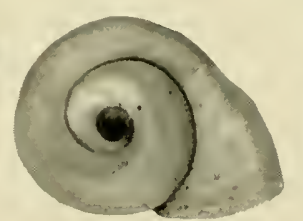

19

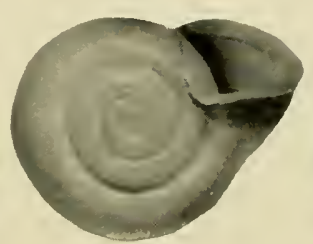

24

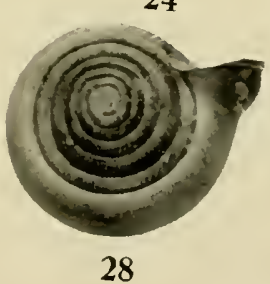

28
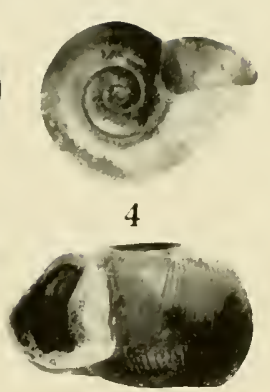

8

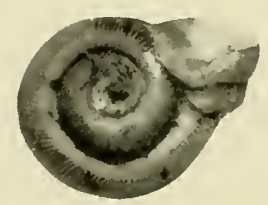

12

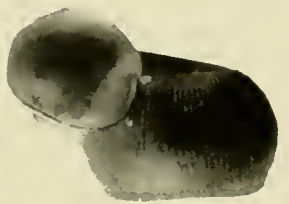

16

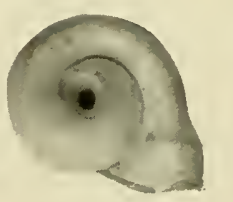

20

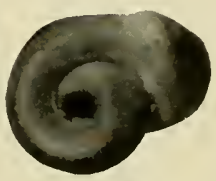

25

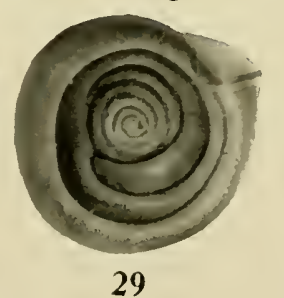

PLATE 109 


\section{PLATE 110}

\section{Shells of Planorbidae}

1-4. Ilelisoma campanulatum wisconsinense (Winslow). Tomahawk Lake, Wisconsin. 1. 2. Inmature. 3, 4, Small form. T.I., Z29858.

5-7. Helisoma campamlatum near variety smithii (F. C. Baker). Douglas Lake. Michigan. U.I., Z13957.

8-10. If lisoma campanulatum smithii (F. C. Baker). Donglas Lake, Michigan. Small form. B1056.

11. Helisoma campanulatum crnadense F. C. Baker. Bamiji Lake, Ontario, Canada. Holotype. U.I., Z30721.

12, 13. Helisoma campanulatum canadense F. C. Baker. Bamiji Lake, Ontario, Canada. Paratypes. T.1., Z30721.

14. Helisoma companulatum canadonse F. C. Baker. Brent Lake, Ontario, Canada. U.I., Z41303.

15-17. Hclisoma enmpanulatum canadense F. C. Baker. Lake near Lake Merentio, Ontario, Canada. Variation in size. T.I., Z40064.

18-20. Ilelisoma campanulatum canadensc F. C. Baker. Sturgeon Lake, Ontario, Canada. Variation in size. U.I.. Z32331.

21. Itclisoma campamulatum pleistocenicum F. C. Baker. White Pond, Marlboro, New Jersey. Holotype. U.S.N.M., 121195.

22-26. Helisoma campanulatum pleistoccnicum F. C. Baker. White Pond. Marlboro, New Jersey. Paratypes. U.S.N.M., 121195.

27-35. Helisoma campanulatum collinsi F. C. Baker. Cameron Lake. Lake of the Woods, Canada. Variation in size. U.I., Z41297.

All figures are enlarged about two diameters 
Illustrations of the Anatomy and of Shells

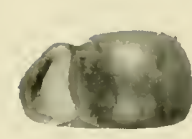

1

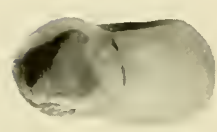

5

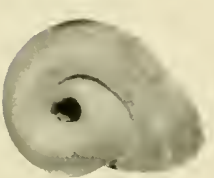

9

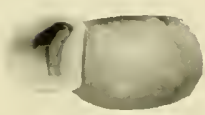

14

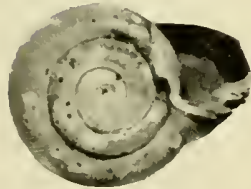

19

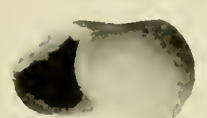

23

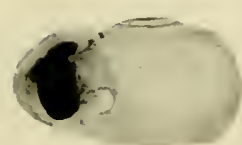

28

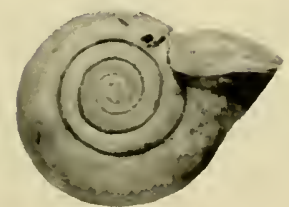

32
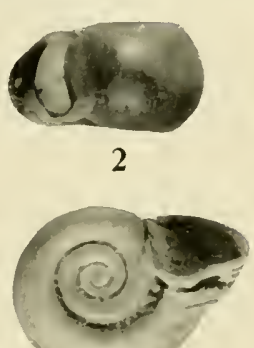

6

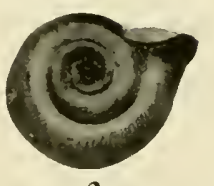

3

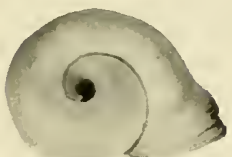

7

12

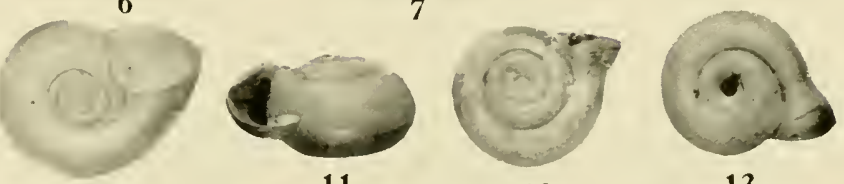

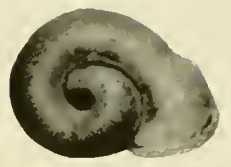

4

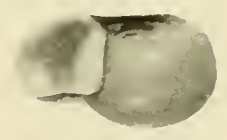

8
13

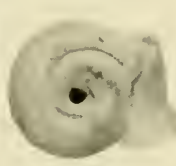

17

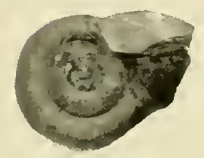

18
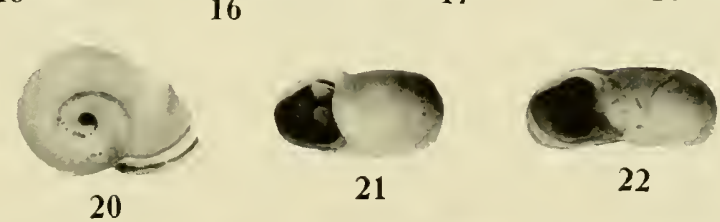

22
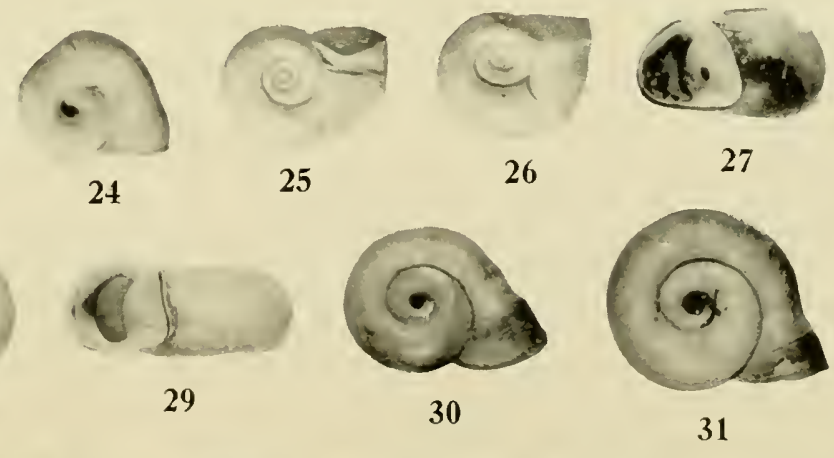

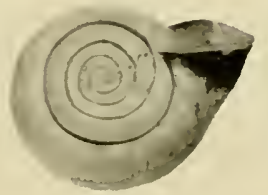

33

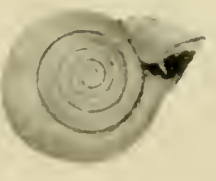

34

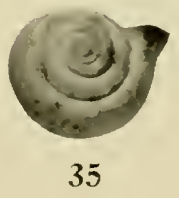

PLATE 110 


\section{PLATE 111}

\section{Shells of Planorbidae}

1-5. Helisoma campanulatum rudentis (Dall). Tinee Lake, Manitoba, Canala. Paratypes. U.S.N.M., 365574.

6.7. Helisoma campanulatum michigancnse F. C. Baker. Marl Lake, Roscommon Co., Michigan. 6, holotype, B1809; 7 , paratype, B1809a.

8,9. Ifelisoma campanulatum michiganense F. C. Baker. Marl Lake, Roscommon Co., Michigan. U.S.N.M., 173102.

10,11. Helisoma companulatum michiganense F. C. Baker. Marl Lake, Michigan. U.S.N.M., 173102 .

12, 13. Helisoma campanulatum dalli F. C. Baker. Anticosti Island, Canadis. 12, holotype; 13, paratype. U.S.I.M., 162724.

14. Hclisoma campanulatum michiganense F. C. Baker. Marl Lake, Michigan. Abnormal. U.S.N.M., 173102.

15, 16. Helisoma campamulatum dalli F. C. Baker. Anticosti Island, Canada. Paratypes. U.S.N.M., 162724.

17-19. Helisoma campanulatum collinsi F. C. Bakel. Cameron Lake, Lake of the Woods, Ontario, Canada. 17, holotype; 18, 19, paratypes. U.I., Z41297.

20. Hclisoma campanulatum collinsi F. C. Baker. Cameron Lake, Lake of the Woods, Canada. Paratype. A small specimen. U. I., Z41297.

21,22. Helisoma campanulutum (Say). Crooked Lake, Emmet Co., Michigan. Young. B3S6S. $\times 3 \frac{1}{12}$.

23-31. Helisoma scalare (Jay). Ererglades, Florida. Marl bed 10-15 ft. under weat. Variation toward seminole form. U.S.N.M., 345566.

32. II lisoma duryi seminole Pilsbry. Lake Apopka, Florida. Showing advanced lower part of aperture in contrast with the receling aperture of scalare (fig. 31 ). U.S.N.M., 566570.

All figures, excepting 21 and 22 , are enlarged about $1 \% \frac{1}{4}$ diameters 
Illustrations of the Anatomy and of Shells

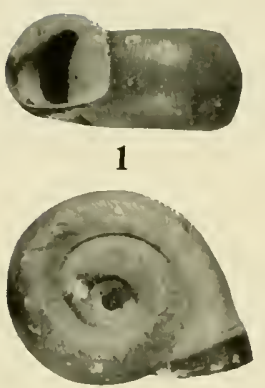

5

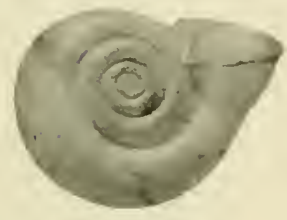

10

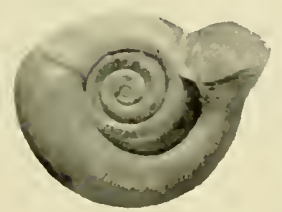

14

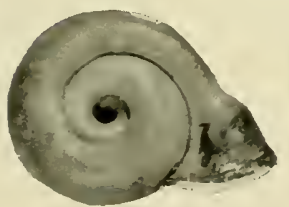

18

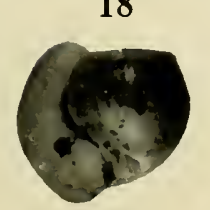

22

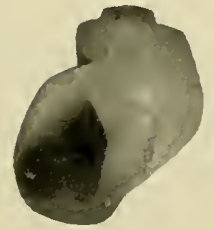

27
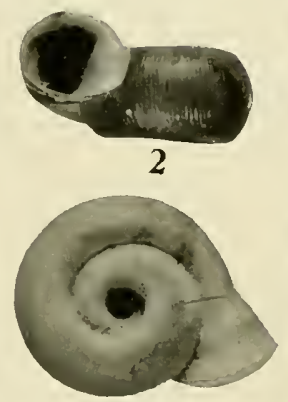

6
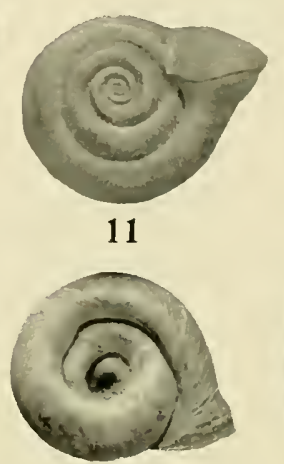

15

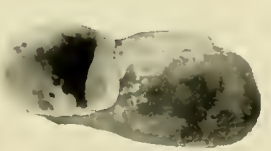

19
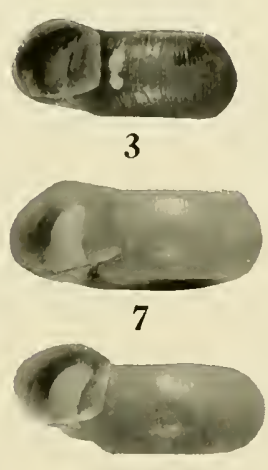

8

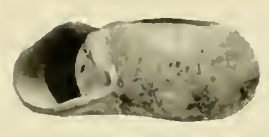

12

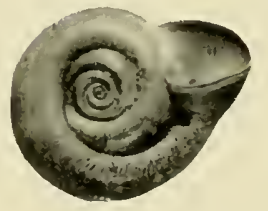

16

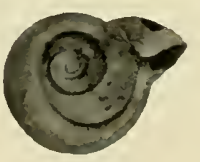

20

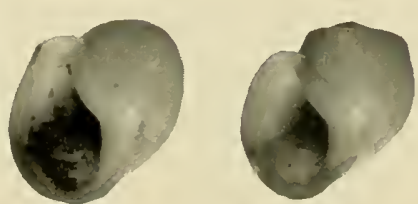

25

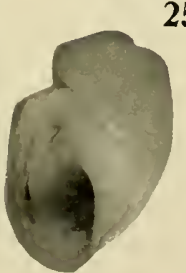

30
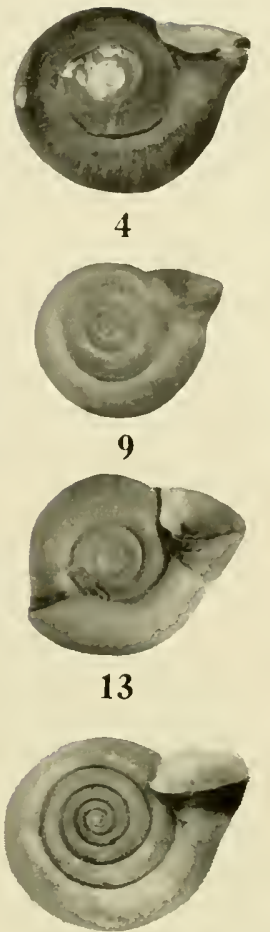

17
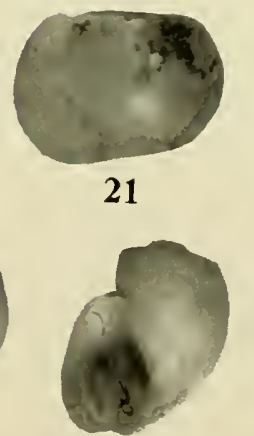

26

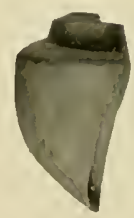

31

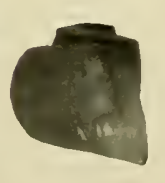

32

PLATE 111 


\section{PLATE 112}

Shells of Planorbidae

1-6. Ilclisoma duryi seminole Pilsbry. Lake Apopka, Florida. Range of variation. L.S.N.M., 50686S.

7. S. Ifelisoma duryi seminole Pilsbry. Lake Apopkia, Florida. scalare-like forms. T.S.T.M., 506870 .

9-11. Carinif $x$ newberryi (Lea). Owens Lake, Califolnia. U.S.N.M., 251516.

12-14. Carmifex occidentalis Hanna. Eagle Lake, Lasen Co., California. U.S.N.M., 120331.

15. Carinifex oceidentalis Hanna. Fagle Lake, California. U.S.N.M., 120333.

16-21. Cariniff $x$ occidentalis Hannit. Eagle Lake, California. U.S.N.M., 120331.

Figures 12-21 show range of rariation

All figures are enlarged about 11/2 times 
Illustrations of the Anatomy and of Shells
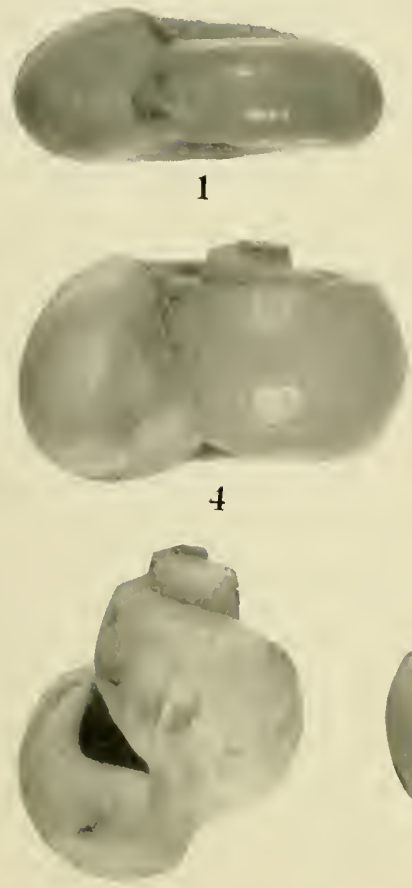

6

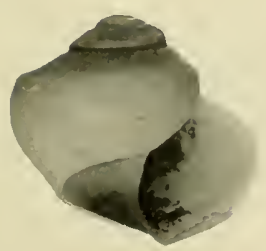

11

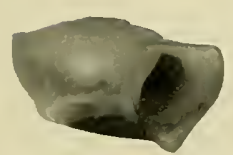

15

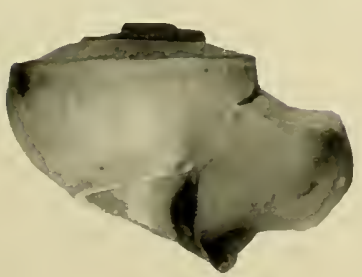

19
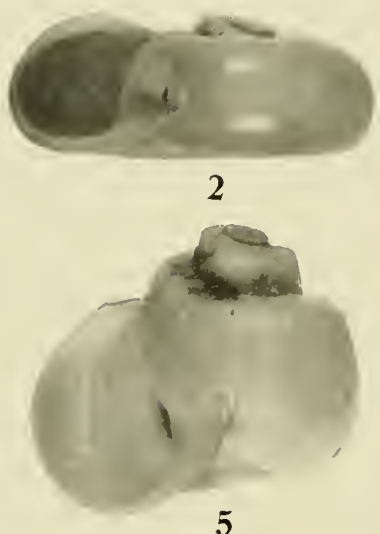

5

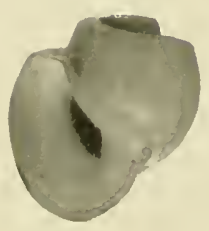

7

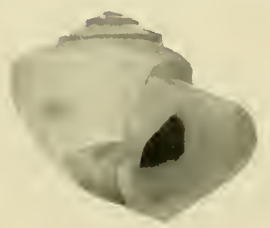

12

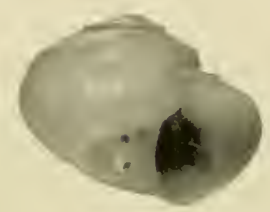

16

13

17
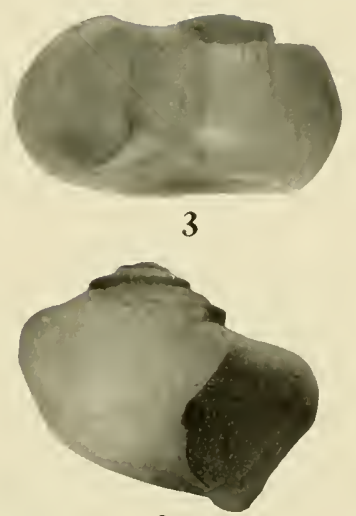

9

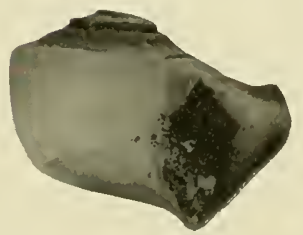

10
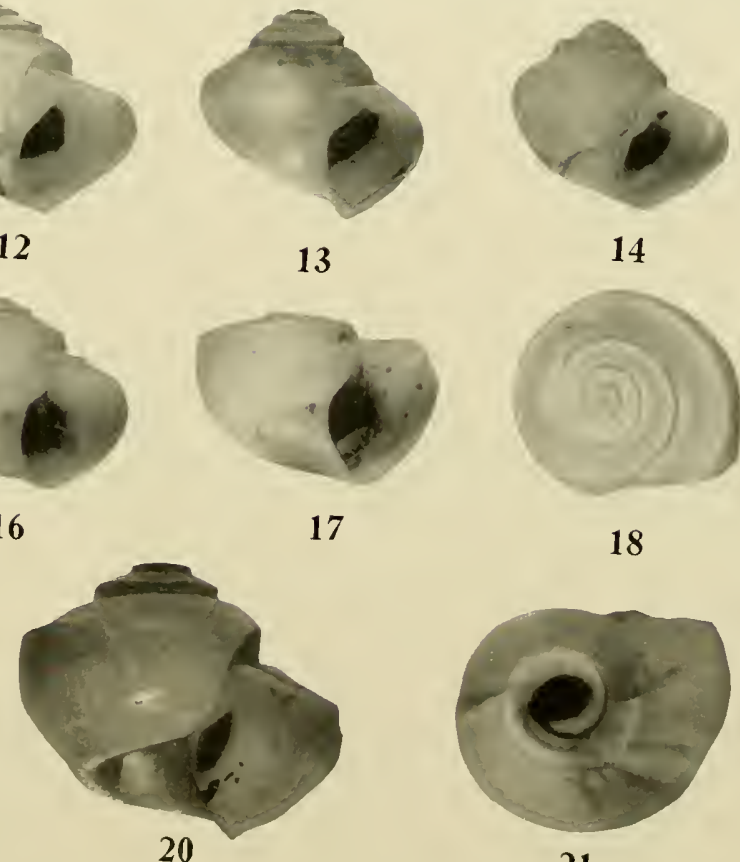

18

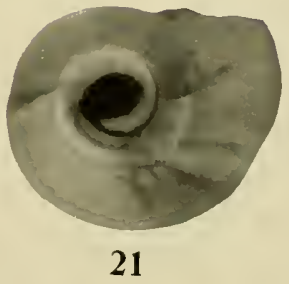

PIATE 112 
PLATE 113

Shells of Planorbidae

1-4. Carinifex newborryi (Lea). Canoe Creek, California. Type locality. U.S.I.M., 9254.

5,6. Carinifex newberryi (Lea). Canoe Creek, California. Said to be types. See Binney, p. 75. U.S......., 9256.

7,8. Carinifex newberyi (Lea). Canoe Creek, California. Lea Collection, probably types. See Binney fig. 120. [.S.N.M., 120991.

9. Carinifex newberyi (Lea). Canoe Creek, California. Similar in form to malleata. U.S.N.M., 2954.

10, 11. Carinifex newberyi (Lea). Canoe Creek, California. U.S.N.M., 56405.

12-15. Carinifex newberryi (Lea). Walker Lake, Nevala. U.S.N.M., 349132.

16-23. Carinifex newberryi (Lea). Lakota Resort, Bear Lake, Ttah. B3877.

24-25. Carinifex newberryi malleata Pilsbry. Pitt River, California. U.S.N.M., 9341.

29. Carinifex newberyi malleata Pilsbry. Pitt River, Califomia. U.S.N.M., 170772.

30. Carinifex newberryi malleata Pilsbry. Pitt River, California. Binney's fig. 122. U.S.N.M., 9342 .

All figures are enlarged about $13 \%$ diameters 
Illustrations of the Anatomy and of Shells
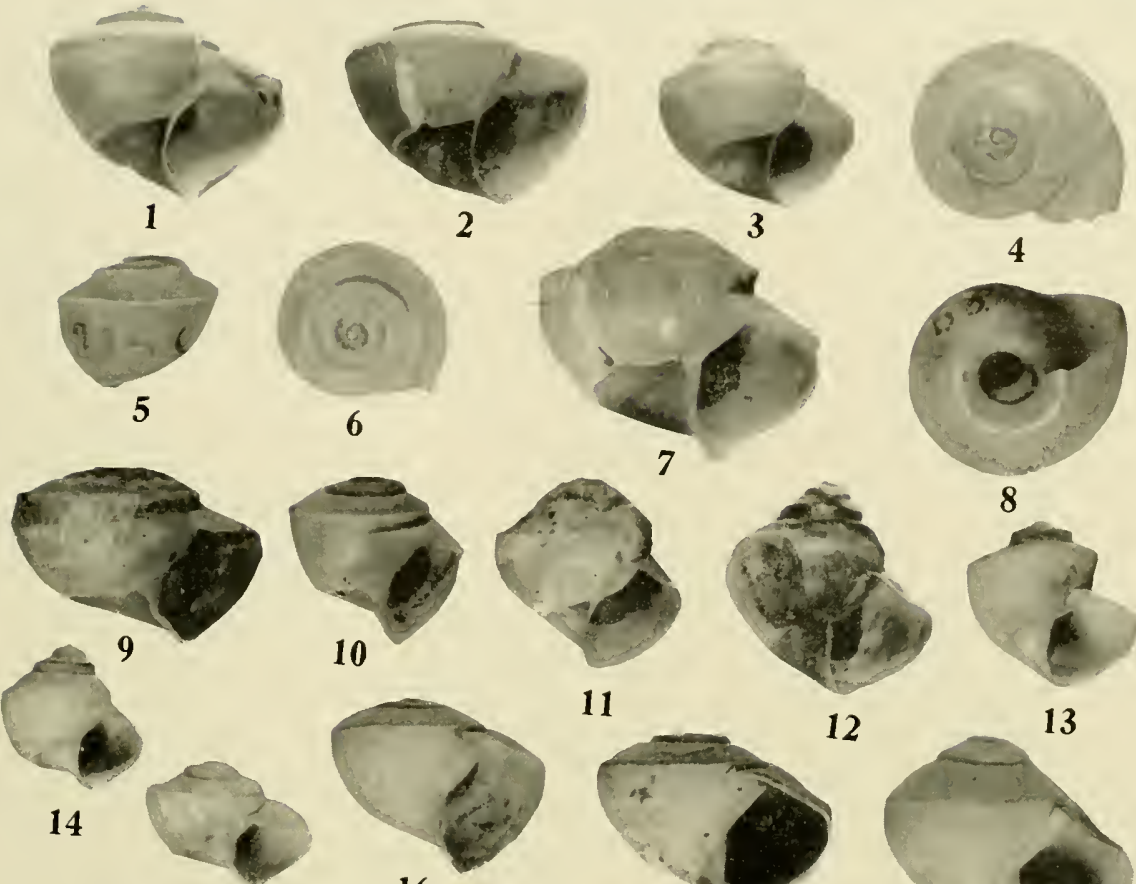

15
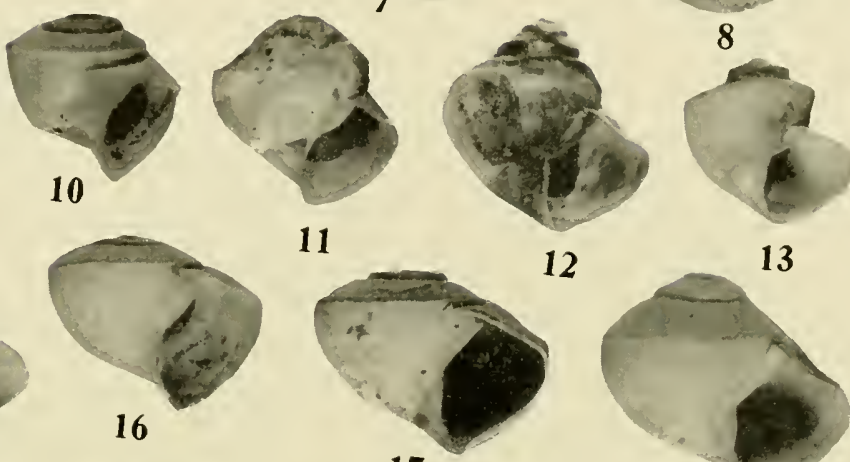

17
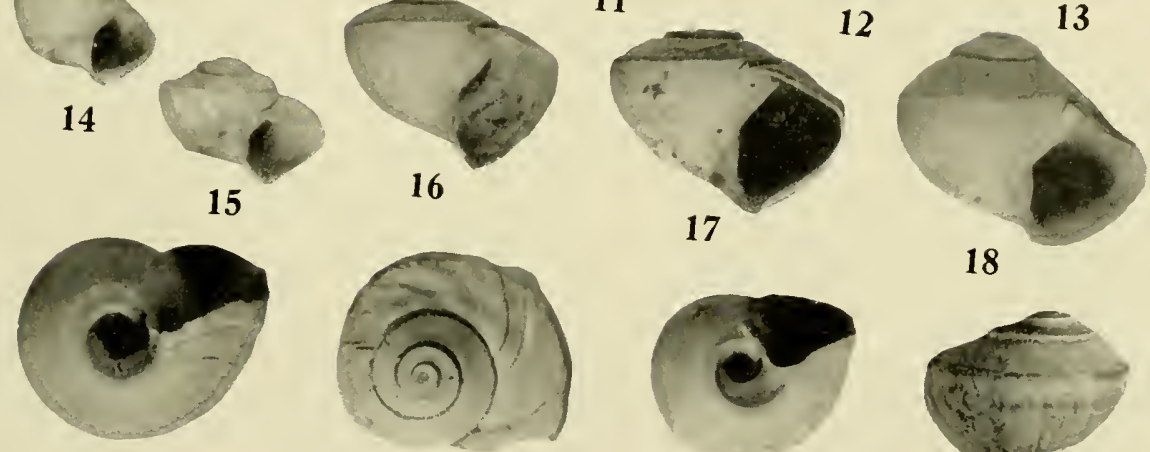

19

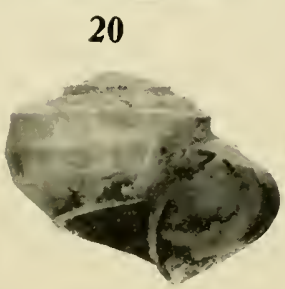

24

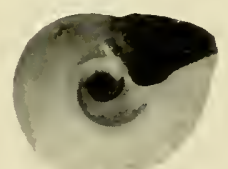

21

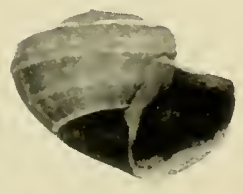

25

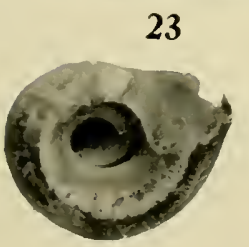

27

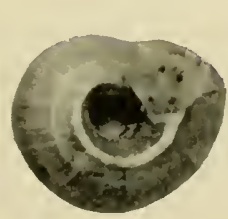

28

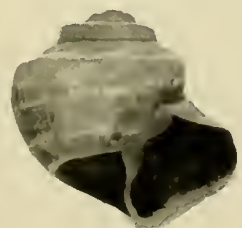

29

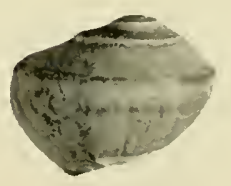

22

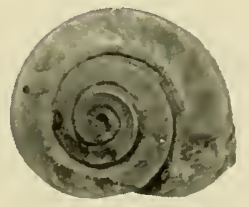

26

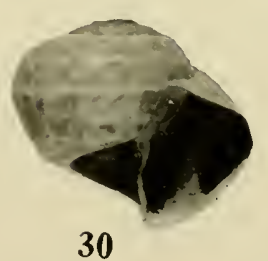

PLATE 113 


\section{PLATE 114}

\section{Shells of Planorbidae}

1. Carinifex ponsonbyi E. A. Snith. Lower Kilamath Lake. Kilamath Falls, Oregon. U.S.N.M., 334389.

2. Carinifex ponsonbyi F. A. Smith. Lower Klamath Lake, Kilamath Falls, Oregon. U.S.N.M., 219749.

3.4. Carinifex ponsonbyi E. A. Snith. South end Upper Kilamath Lake, Oregon. B3924.

5.6. Carinifex ponsonbyi E. A. Smith. South end Upuer Kilamath Iake, Oregon. 5, immature. B3924.

7-9. Carinifex ponsonbyi E. A. Smith. Lower Klamath Lake, Oregon. IT.S.N.M., 337022.

10,11. Carinifex ponsonbyi E. A. Smith. Upper Kilunath Lake, Oregon. U.S.N.M., 380807 .

12.13. Carinifex ponsonbyi E. A. Smith. Lower Klamath Lake, Oregon. U.S.N.M., 334387 .

14, 15. Carinifex newbrryi (Lea). Canoe Creek, California. Immatue. U.S.M.M.. 9256.

16. Carmifer newberryi (Lea). Canoe Creek. California. Immature. C.S.N.M., 56405.

17. Carinifex accidentalis Hanna. Eagle Lake, California. Immature. U.S.N.M., 120333.

18. Carimifex ponsonbyi E. A. Smith. Klamath Falls. Lower Kilanath Lake, Oregon. Immature. U.S.N.M., 510024.

19-24. Carinifex newberyi minor Cooper. Clear Lake, California. From Lea coll. C.S.N.M., 121025.

25-25. Carinifex newberryi subrotunda Pilsbry. Proc. Acad. Nat. Sei. Phil., S6, nlate 11, figs. 2, 2a, 2b, type; 3 , paratype.

Figures 1-13, 25-2S are enlarged abont 11/2 diameters; figs. 17-24 are enlarged 3 diameters. 
Illustrations of the Anatomy and of Shells

465

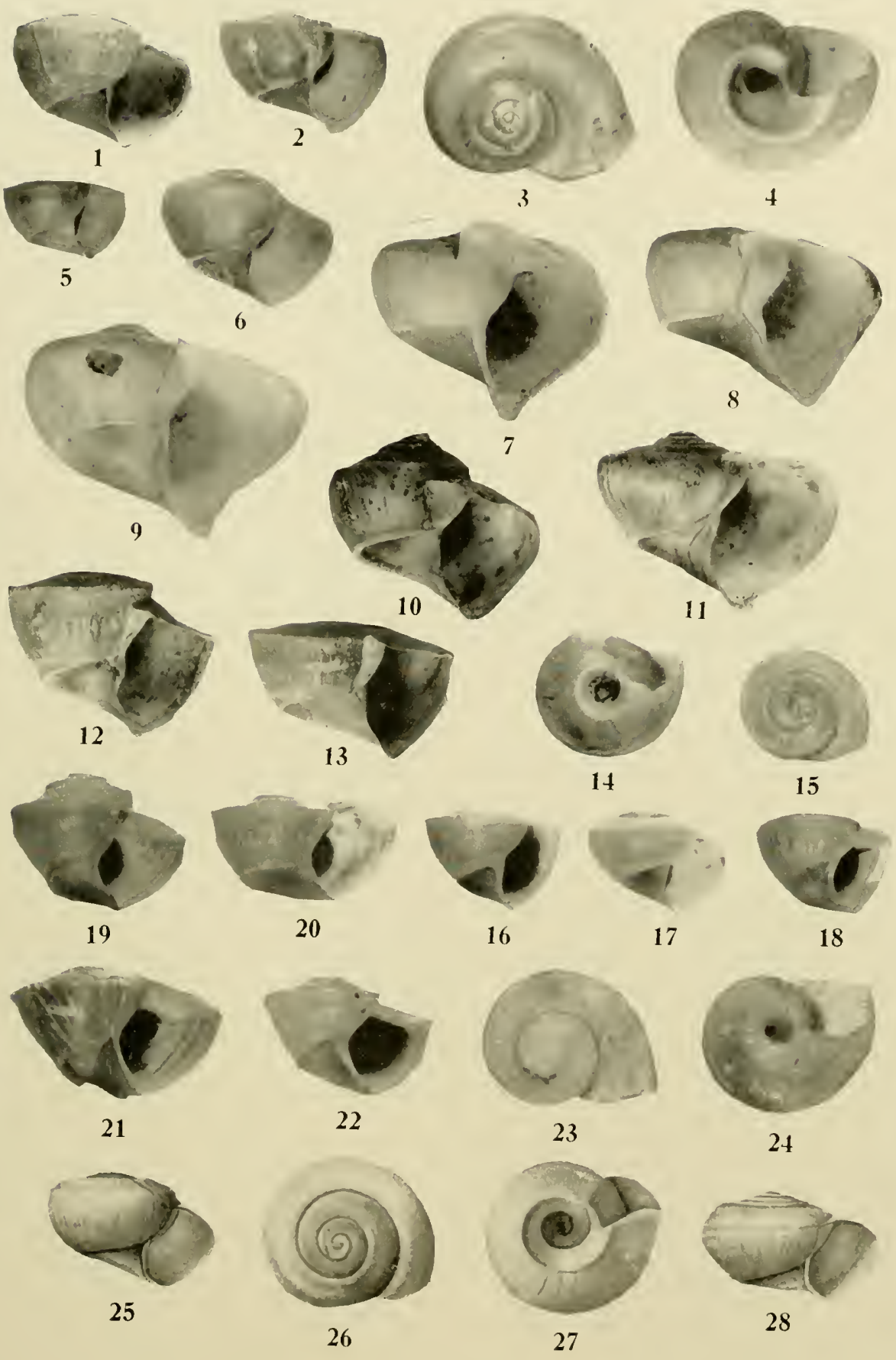

PLATE 114 
PLATE 115

\section{Shells of Planorbidae}

1. Helisoma caribacum (Orb.). Jocolo, Guatemala. Immature. B3S69.

2-4. Helisoma caloderma (Pilsbry). Esmeralda, Cinatemala. Cotypes. U.I., Z28577.

5-7. Helisoma eyerdami Clench and Aguayo. Lake Miragoane, 2 miles southeast of Miragoane, Haiti. Paratypes. M.C.Z., 83888.

8,9. Carinifex jacksonensis J. Henderson. Jackson's Lake, Wyoming. From type lot. B3925.

10-13. Carinifex jacksonensis J. Henderson. Jackson's Lake, Wyoning. From type lot. U.S.N.M., 510045.

14. Parapholyx klamathensis F. C. Baker. East side Upper Klamath Lake, 13 miles north of Kilamath Falls, Oregon. Holotype. U.S.N.M., 406024.

15-17. Parapholyx klamathensis F. C. Baker. Same locality as above. Paratypes. U.S.N.M., 406024.

18. Parapholyx klamathensis F. C. Baker. Same locality as above. From type lot. U.S.N.M., 406024.

19. Parapholyx klamathensis F. C. Baker. Same locality as above. From type lot; slightly costate. U.S.N.M., 406024.

20. Parapholyx liamathensis F. C. Baker. Same locality as above. From type lot; with diagonal grooves. U.S.N.M., 406024.

21-23. Parapholyx klamathensis F. C. Baker. Klamath Falls, Oregon. Small form. No. 23, costate. U.S.N.M., 219748.

24-26. Parapholyx effusa costata (Hemphill). Dilles of the Columbia River, Oregon. Type locality. U.S.N.M., 47520.

27. Parapholyx effusa dalli F. C. Baker. Klamath Falls, Oregon. Holotype. U.S.N.M., 219747.

28-30. Parapholyx effusa dalli F. C. Baker. Klamath Falls, Oregon. Paratypes. U.S.N.M., 219747.

Figures 1-7, 24-30 are enlarged about four diameters; figs. 8-23 are enlarged about two diameters. 

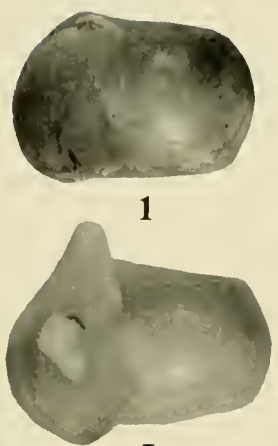

5
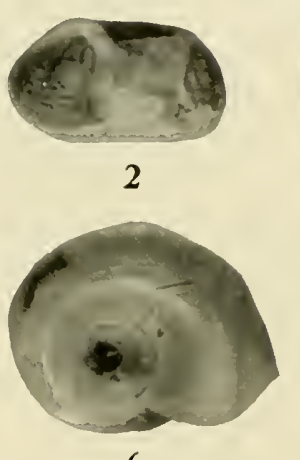

6

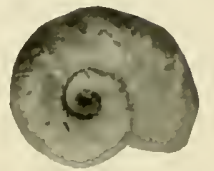

3

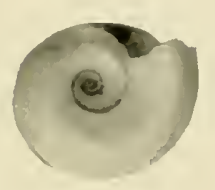

7
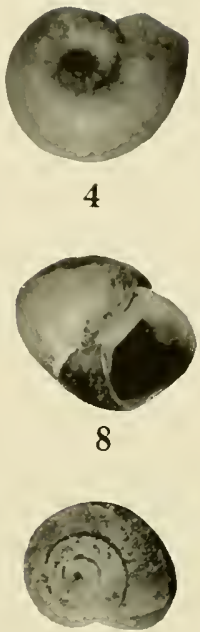

13

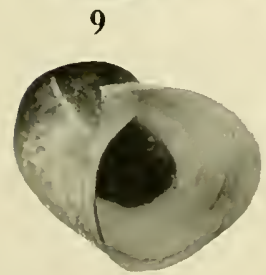

14

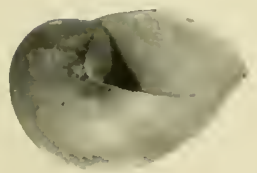

18

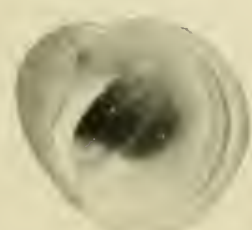

24

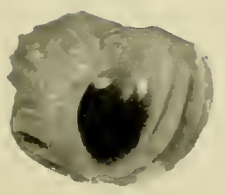

27

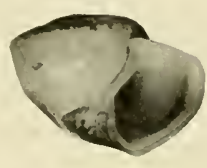

10

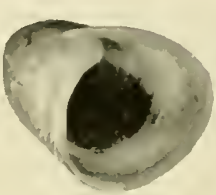

15

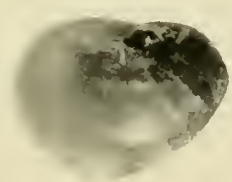

19

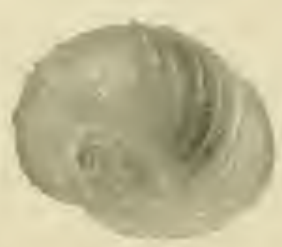

25

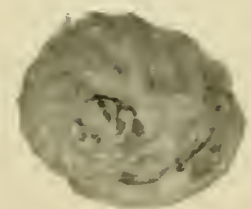

28
11

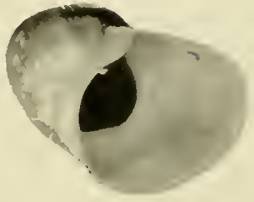

16

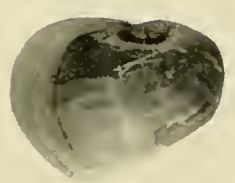

20

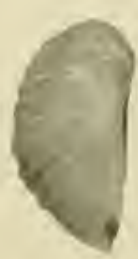

26

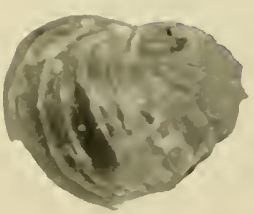

29

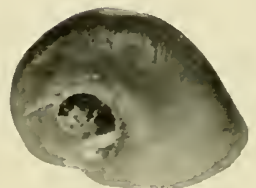

17

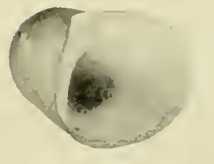

21
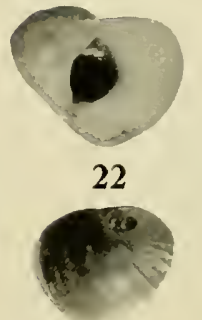

23

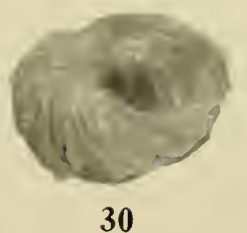

PLATE 115 


\section{PLATE 116}

\section{Shells of Planorbidae}

1, 2. Parapholyx effuse (Lea). Sacramento River, California. Type locality. Probably type lot. U.S.N.M., 121167.

3. Parapholyx effusa (Lea). Sacramento River, California. Type locality. U.S.N.M., 121133.

4-6. Parapholyx effusa (Lea). Oregon City, Oregon. U.S.X.M., 520085.

7.8. Parapholyx effusa neritoides (Hemphill). Dalles of the Columbia River. Oregon. Type locality. U.S.N.M., 36615.

9-11. Parapholyx effusa neritoides (Hemphill). Dalles of the Columbia River, Oregon. Trpe locality. U.S.N.M., 37518.

12. 13. Parapholyx rffusa costata (Hemphill). Dalles of the Colmubia River, Oregon. Smooth form. U.S.X.M., 47519.

14. Parapholyx effusa costata (Hemphilb). Dalles of the Colmmbia River, Oregon. Smooth form. U.S.N.M., 36617.

15-17. Parapholyx effusa diagonalis J. Henderson. Crater Lake, Oregon. Type locality. B3926.

18. Parapholyx solida (Dall). White Pine, Nevada. Lectotype. U.S.N.M.. 56409. 19, 20. Parapholyx solida (Dall). White Pine, Nerada. Paratypes. I.S.N.M., 56409.

21. Parapholyx solida (Dall). White Pine, Nerada. U.S.X.M., 75438.

22, 25, 26. Parapholyx solida (Dall). White Pine, Nevada. T.S.N.M., 24839.

23,24. Parapholyx solida (Dall). White Pine, Nevada. 24, slightly costate. U.S.N.M., 56410 .

27-30. Parapholyx mailliardi Hanna. Fagle Lake, California. Type locality. U.S.N.M., 47652 .

All figures are enlarged about three diameters 
Illustrations of the Anatomy and of shells
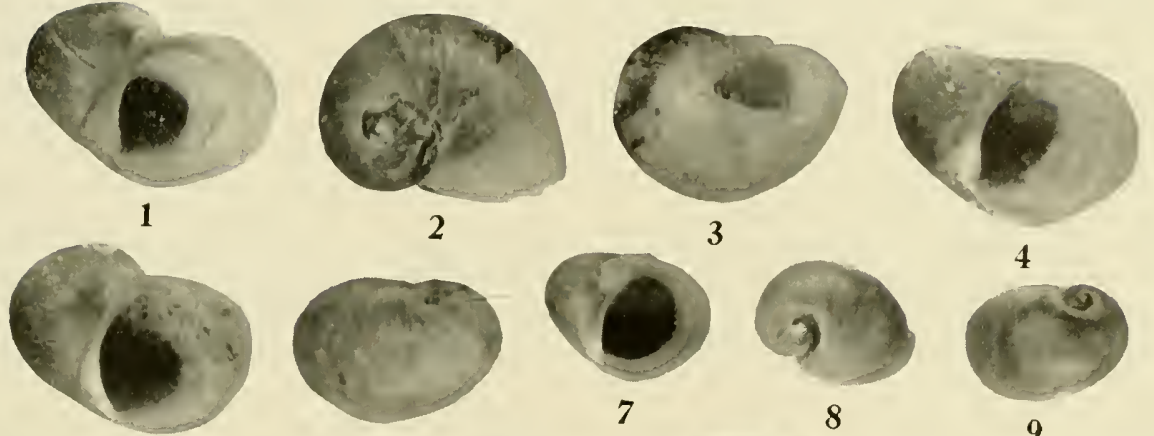

7

8
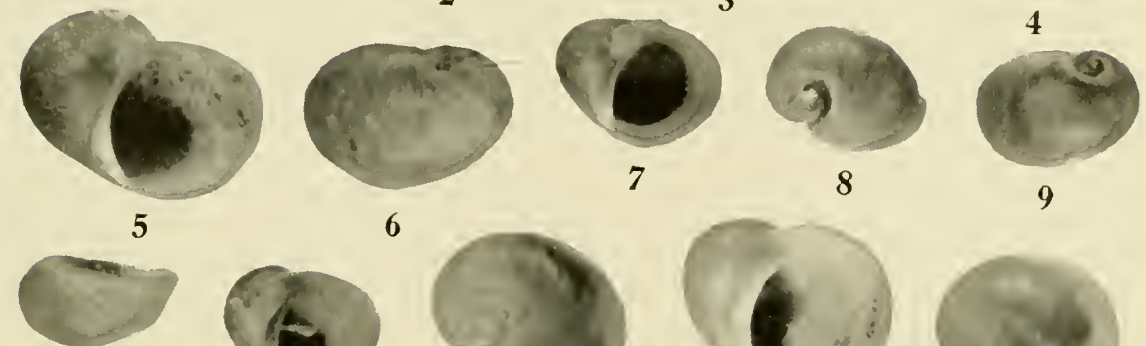

10
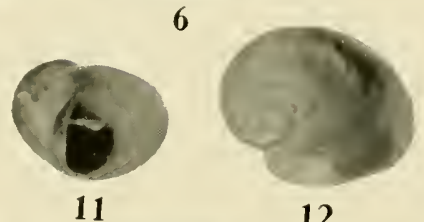

12

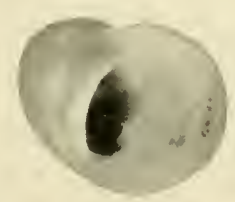

13
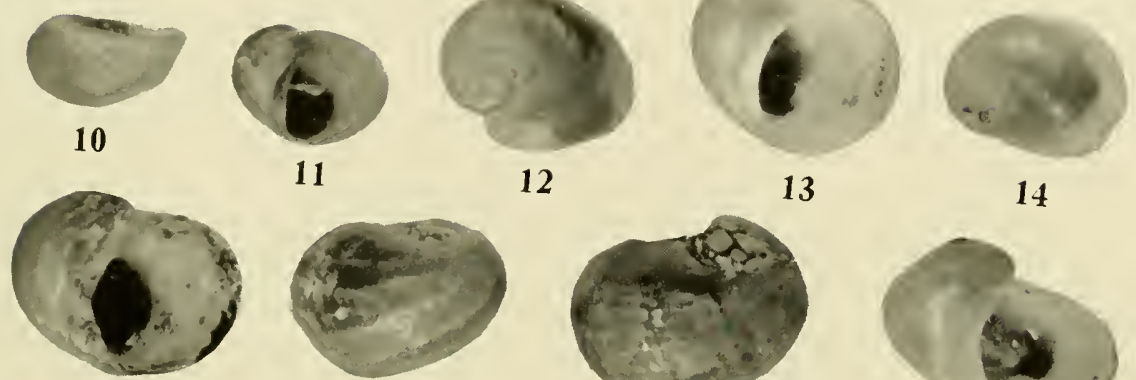

15

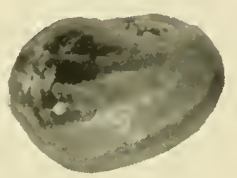

16

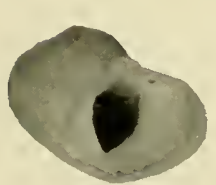

19
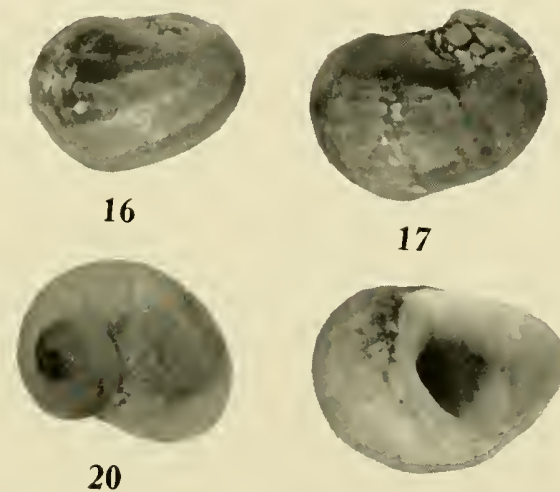

17

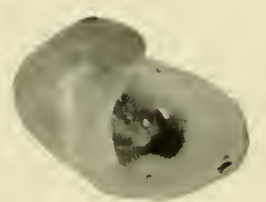

18

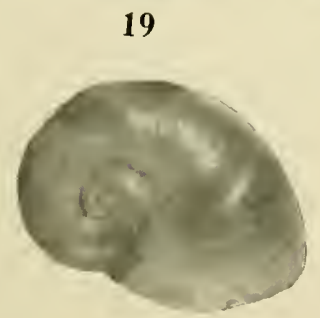

23

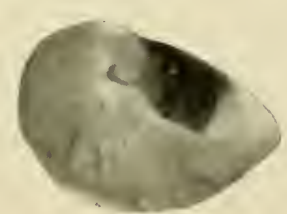

24
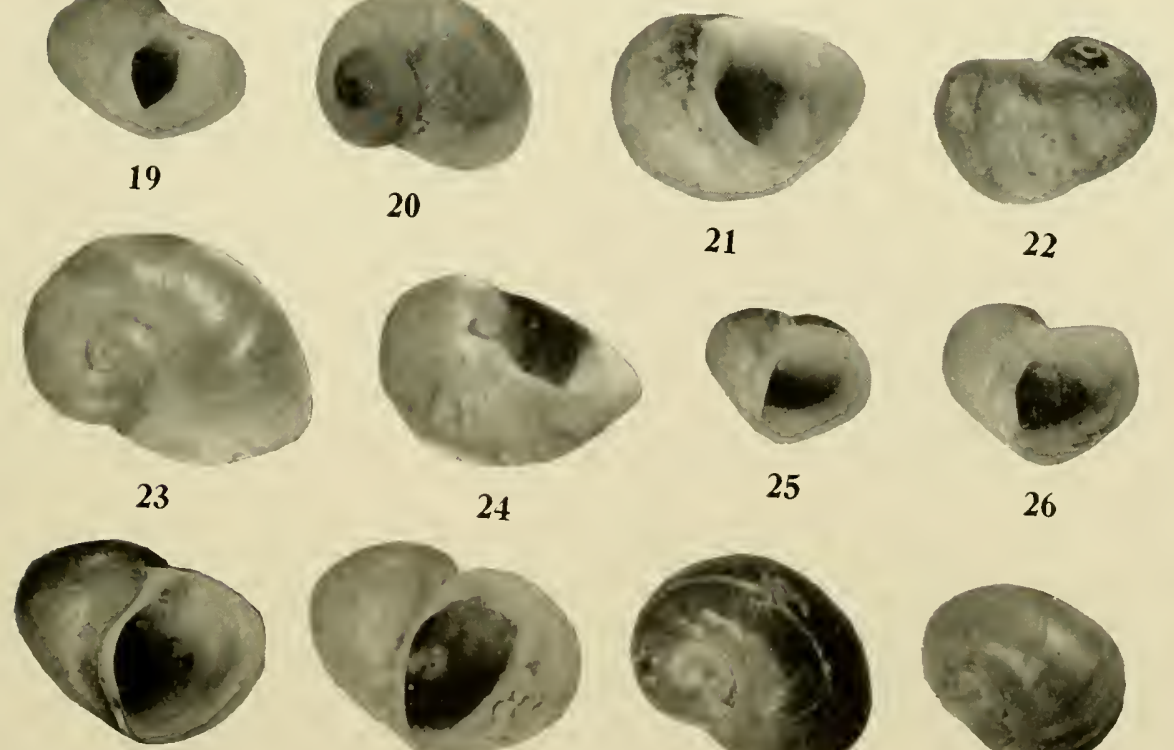

27

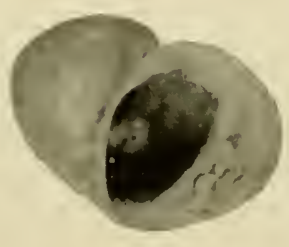

28

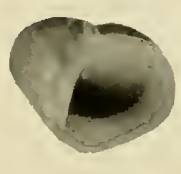

25

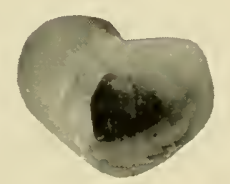

26

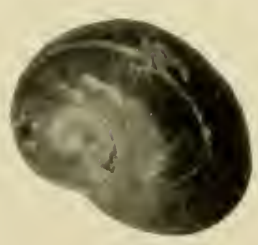

29

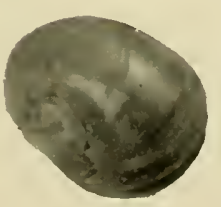

30

PLATE 116 


\section{PLATE 117}

\section{Shells of Planorbidae}

1-6. Parapholyx pusilla F. C. Baker. Six miles west of Pyramid Lake, Nevada. Figure 1, holotype: 2-5, paratypes; 6, costate specimen. I.S.X.M., 308925.

7-14. Parapholyx neradensis J. Henderson. Pyramid Lake, Nevada. U.S.N.M., 75440. 15. Parapholyx nevadensis J. Henderson. Pyramid Lake, Nerada. Sealariform specimen. U.S.N.M., 126765 .

16. Parapholyx novadensis J. Henderson. Pyramid Lake, Nevada. U.S.N.M., 75439.

17-26. Parapholyx nevadensis J. Henderson. Pramid Lake, Nevada. Variation in form, neritoid to bulmoid. U.S.N.M., 63493.

27-30. Parapholyx mailliardi Hanna. Eagle Lake, California. From type lot. C.A.S., 23040.

All figures are enlarged about $31 \frac{1}{2}$ diameters 

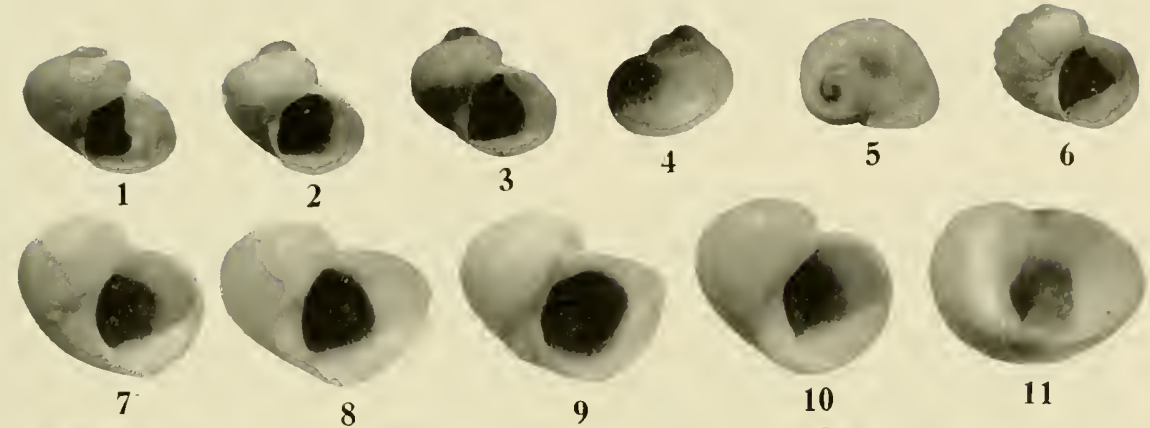

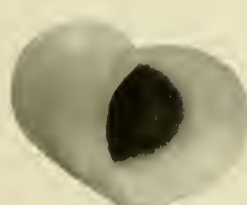

12

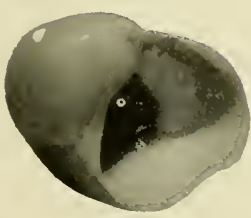

17

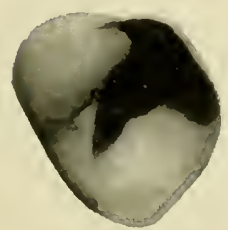

21

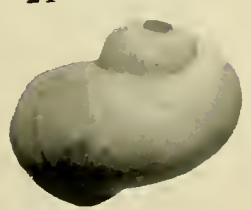

25

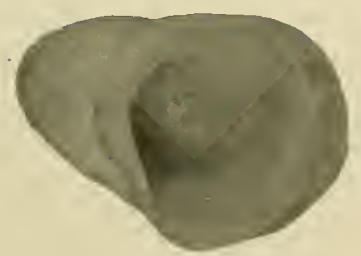

28

13
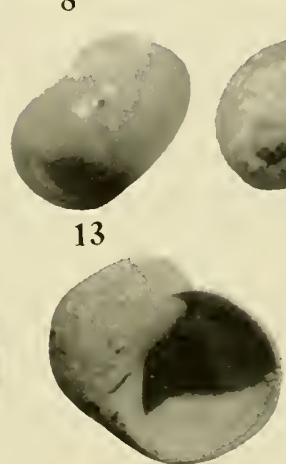

18

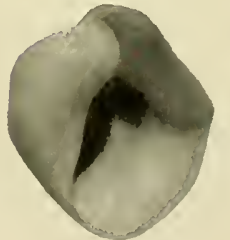

22
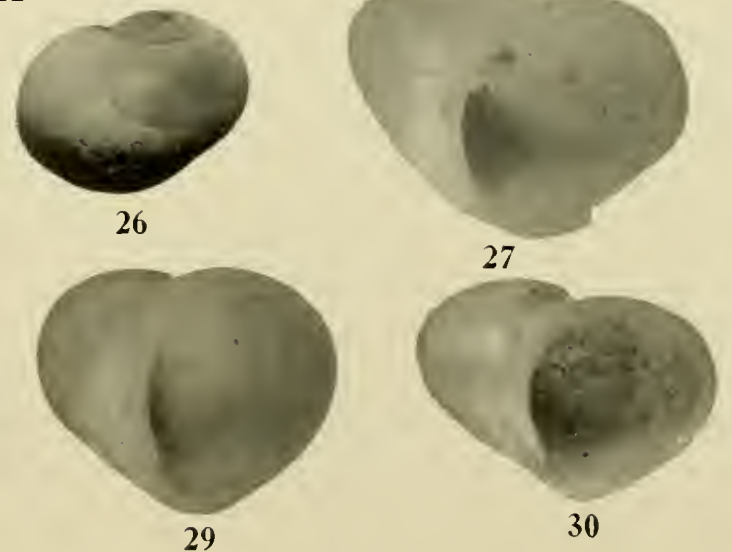

PLATE 117

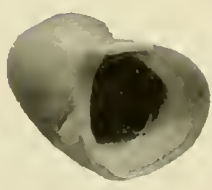

16

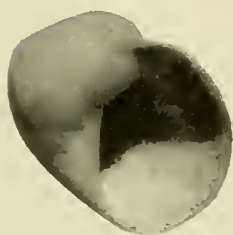

20

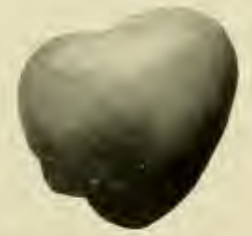

23

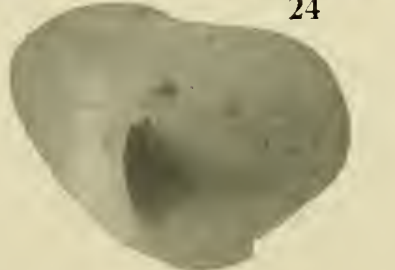




\section{PLATE 118}

\section{Shells of Planorbidae}

1. Planorbula armigera (Say). East Nebraska. U.S.N.M., 526054.

2. Planorbula armigera palustris F. C. Baker. Mason City, Iowa. U.S.N.M., 527656.

3. Planorbula crassilabris (Valker). Douglas Lake, Michigan. U.S.N.M., 251213.

4. Planorbula armigera indianensis F. C. Baker. Mt. Vernon, Indiana. U.I., Z2891.

5. Planorbula jenksii (H. F. Carpenter). Nayat, Rhode Island. B1195.

6. Planorbula smithi F. C. Baker. Stevenson, Alabama. U.S.N.M., 321196.

7. Planorbula wheatleyi (Lea). Boligee, Alabama. B1194.

8. Planorbula eampestris (Dawson). High Bluff, Manitoba. U.S.N.M., 63393.

Figures 1- $\delta$ show the folds within the aperture of each species

9. Planorbula armigera (Say). East Nebraska. U.S.N.M., 526054.

10. Planorbula jenksii (H. F. Carpenter). Medford, Massachusetts. U.S.N.M., 41411.

11. Planorbula smithi F. C. Baker. Stevenson, Alabama. U.S.N.M., 321196.

12. Planorbula smithi F. C. Baker. Sterenson, Alabama. Specimen with double parietal lamella. U.S.N.M., 321196.

Figures 9-12 show the form of the parietal lamella in three species

13-15. Planorbula armigera (Say). East Nebraska. U.S.N.M., 526054.

16. Planorbula armigera rariety? Camp Colfax, La Porte Co., Indiana. U.I., Z27094a. 17-19. Planorbula armigera variety? Camp Colfax, Indiana. U.I., Z27094b.

20-22. Planorbula crassilabris (Walker). Hamtramck, Wayne Co., Michigan. Type Jocality. B1200.

23-25. Planorbula erassilabris (Walker). Carr's Slough, Brookston, White Co., Indiana. U.I., Z27086.

26. Planorbula armigera variety? Big slough near Mason City, Iowa. Pathologic. U.S.N.M., 527656.

27-30. Planorbula jenksii (H. F. Carpenter). Nayat, Rhode Island. B1195.

31. Planorbula armigera (Say). East Nebraska. U.S.N.M., 526054.

32. Planorbula erassilabris (Walker). Brookston, Indiana. U.I., Z27086.

33. Planorbula wheatleyi (Lea). Boligee, Alabama. B1194.

Figures 31-33 show condition of crest behind aperture

All figures are enlarged about four diameters 


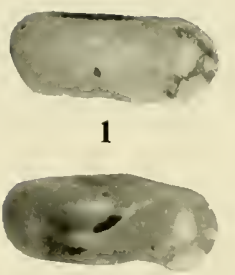

5

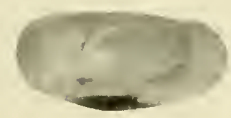

9

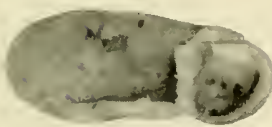

13

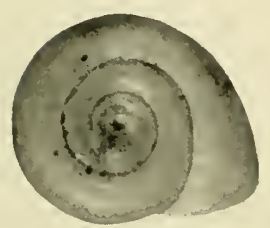

14

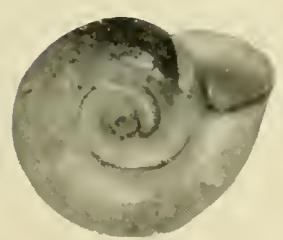

15

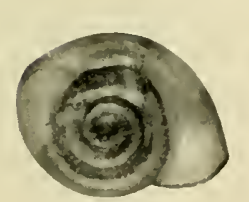

26

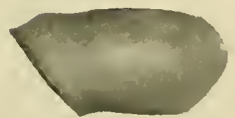

31
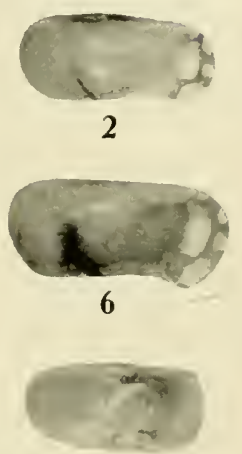

10

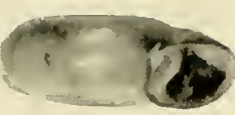

16

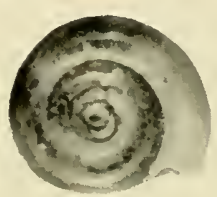

17

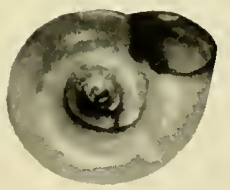

18

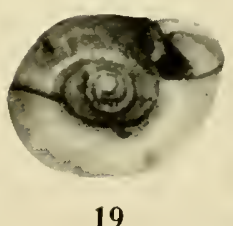

19

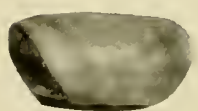

32

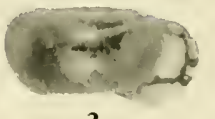

3
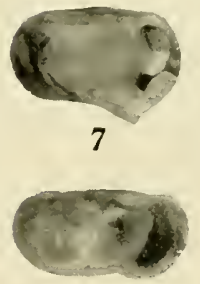

11

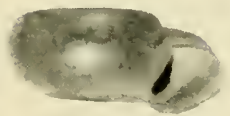

20
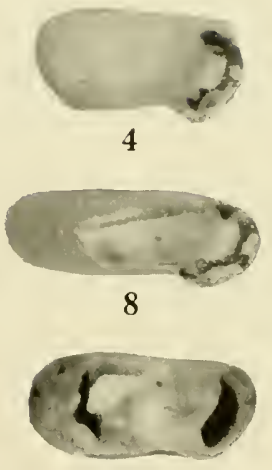

12

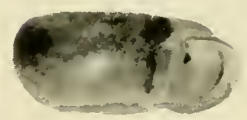

23
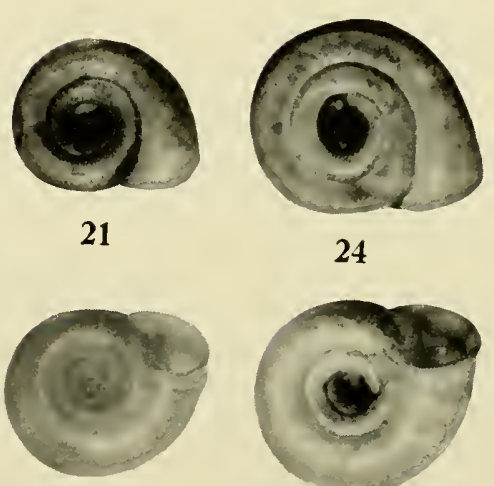

22

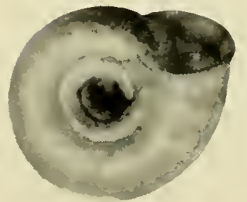

25

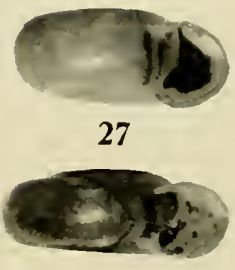

28

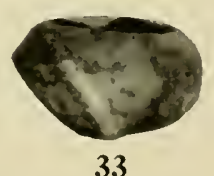

33

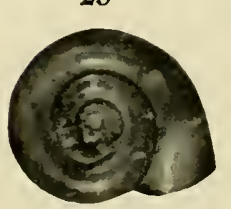

29

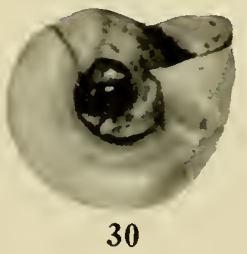

PIATE 118 


\section{PLATE 119}

\section{Shells of Planorbidae}

1-3. Planorbula armigera indianensis F. C. Baker. Uniontown Road, 2 miles southwest of Mt. Vernon, Indiana. 1, holotype; 2, 3, paratypes. U.I., P2833.

4-6. Planorbula jenksii (H. F. Carpenter). Medford, Massachusetts. U.S.N.M., 41411.

7, 8. Planorbula wheatlyi (Lea). Catoma, Montgomery Co., Alabama. Type. U.S.N.M., 29292.

9. Planorbula wheatleyi (Lea). Catoma Creek, Montgomery Co., Alabama. I.S.X.M., 120929.

10. Planorbula smithi F. C. Baker. Sterenson, Alabana. Holotype. U.S.N.M., 321196.

11, 12. Planorbula smithi F. C. Baker. Sterenson, Alabama. Paratypes. U.S.N.M., 321196.

13. Planorbula christyi (Dall) (= campestris Dawson). High Bluff, Manitoba. Figured type, Alaska Moll., plate ii, figs. 10, 11. U.S.N.M., 63393.

14, 15. Planorbula christyi (Dall). High Bluff, Manitoba. Paratypes. I.S.N.M., 63393.

16-21. Helisoma columbiense F. C. Baker. Lake La Hache, Caribou Dist., British Columbia. 16, holotype; 17-21, paratypes. M.C.Z., 93710.

22-25. Helisoma caribatum cubense F. C. Baker. Zapata Swamp, Cuba. Mar between Jayers of peat. 22, holotype; 23-25, paratypes. U.S.N.M., 404719.

Figures I-15 are enlarged about 31/2 diameters; figs. 16-25 are enlarged about $13 ;+$ diameters. 
Illustrations of the Anatomy and of Shells
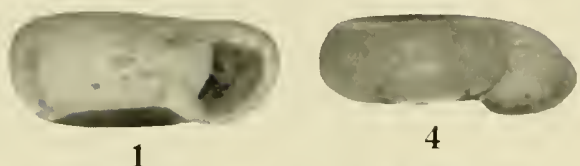

4
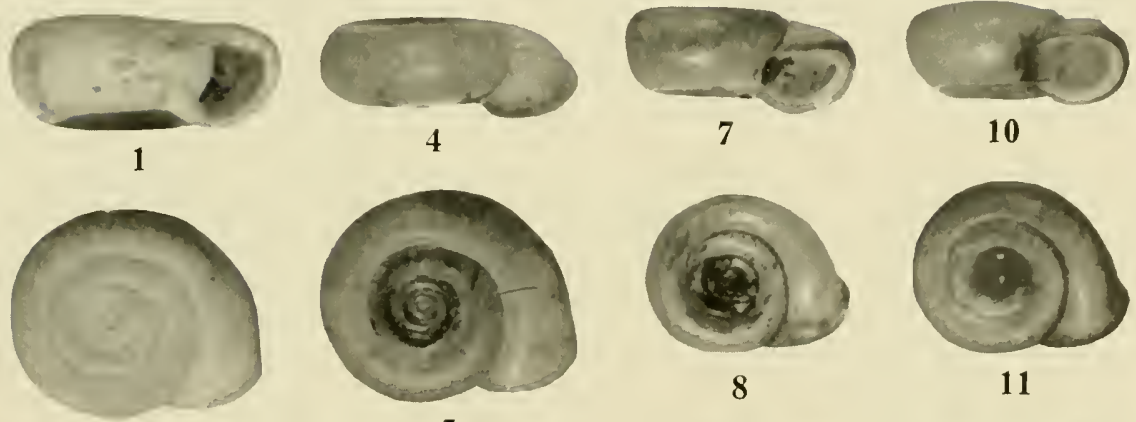

5

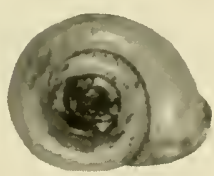

8

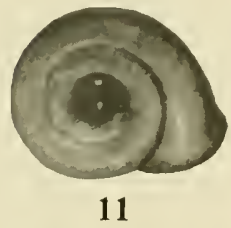

2
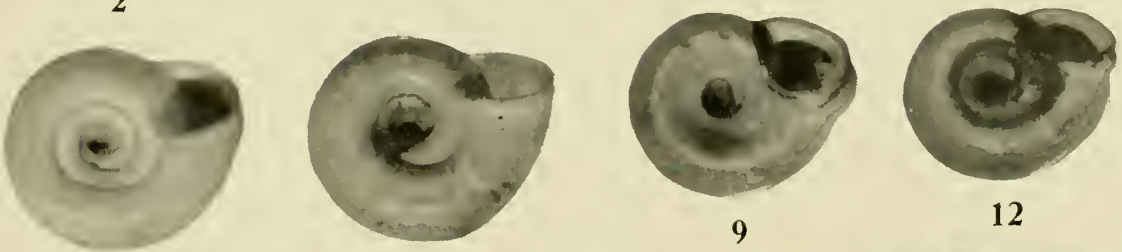

3

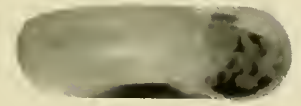

13

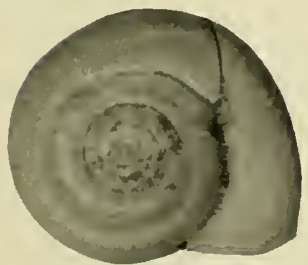

6

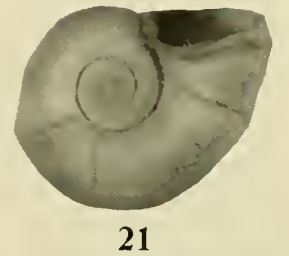

17
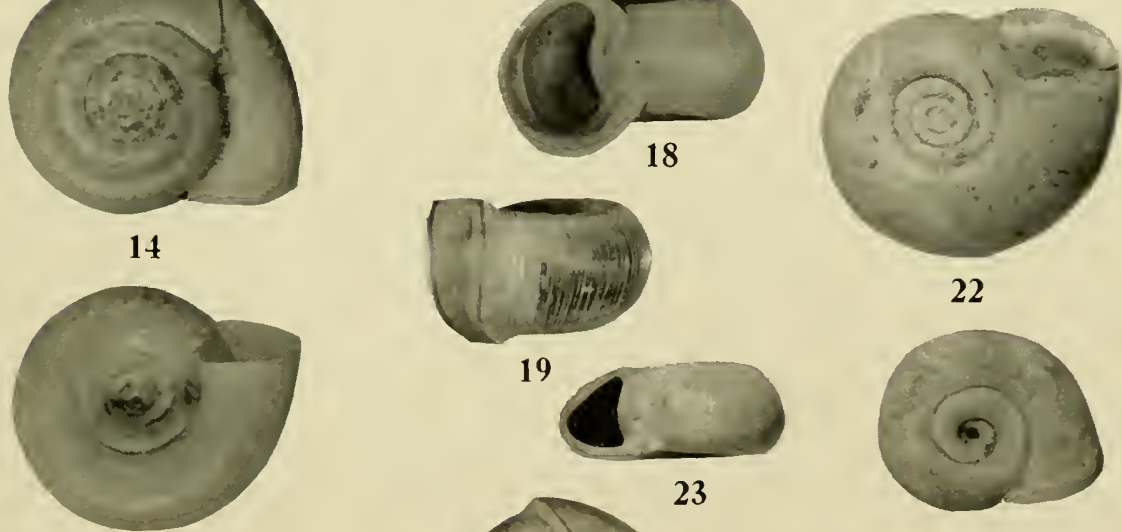

15

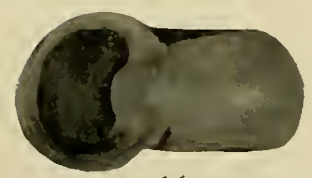

16
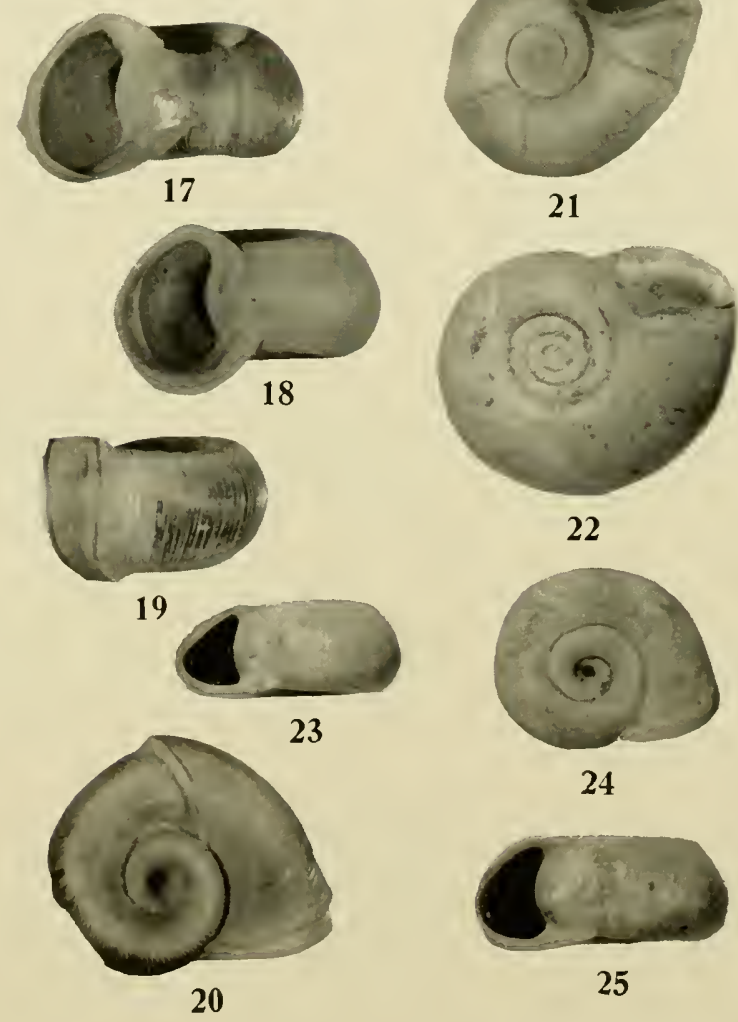

PLATE 119 


\section{PLATE 120}

\section{Shells of Planorbidae}

1-10. Menetus operenlaris (Crould). Mountain Lake, San Francisco, California. U.S.N.M., 47627.

11, 12. Menetus cooperi F. C. Baker (= plamulatus Cooper). Whidby's Island, Puget Sound, Washington. Type locality. U.S.N.M., 152185.

13. Wenetus cooperi F. C. Baker. Whidby's Island, Puget Sound, Washington. Holotype of W. planulatus. Binney's fig. 209 (No. 9118). U.S.Y.M., 29280a.

14. Menetus cooperi F. C. Baker. Whidby's Island, Puget Sound, Washington. Cotype of M. planulatus. U.S.N.M., 29280.

15-18. Wenetus cooperi F. C. Baker. Lake Union, Washington. U.S.N.M., 253617.

19-21. Menetus cooperi callioglyptus (Vanatta). Freeport, Washington. Cotypes. Hemphill coll. U.S.N.M., 47630.

22. Menetus cooperi F. C. Baker. Olga, Washington. U.S.N.M., 216936.

23-26. Menetus cooperi multilineatus (Vanatta). Pass Lake, Fidalgo Island, Washington. U.S.N.M., 346742.

27. Menetus cooperi F. C. Baker. Bellingham, Washington. Very flat spire. U.S.N.M., 525100 .

28. Menetus cooperi F. C. Baker. Lake Washington, Seattle, Washington. I.S.N.M., 169070.

29-31. Menetus cooperi multilincatus (Tanatta). Salem, Oregon. Type locality. B3927.

32. Parapholyx solida optima (Pilsbry). Lake Bigler, Nevada. Paratye. A.N.S.P.. 125363.

Figures 1-31 are enlarged about four dianeters; fig. 32 is enlarged two diameters. 


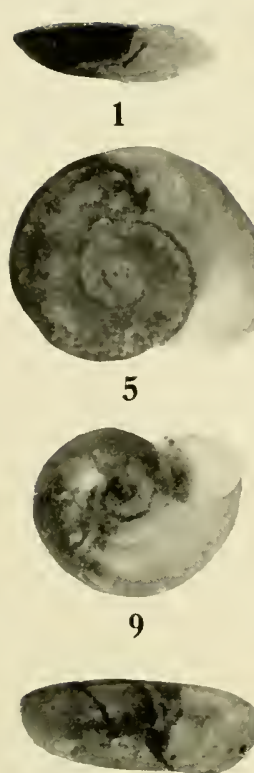

13

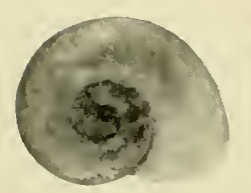

17

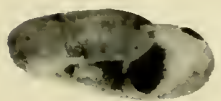

21

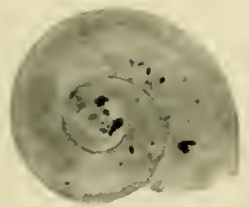

25

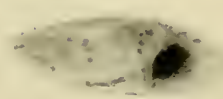

29

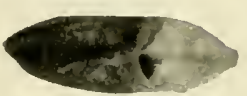

2

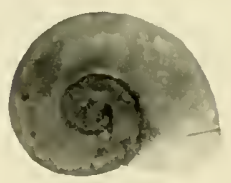

6

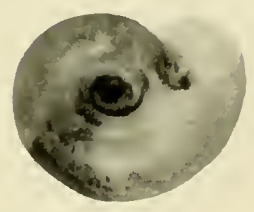

10

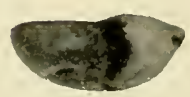

14

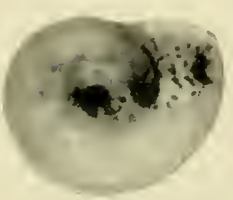

18

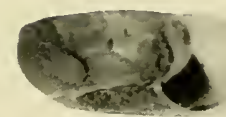

22
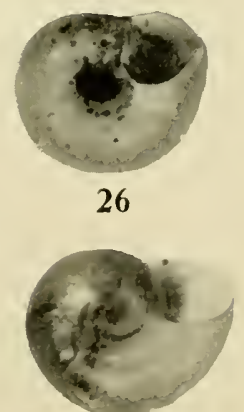

30

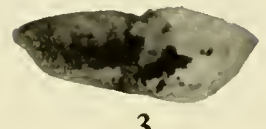

3

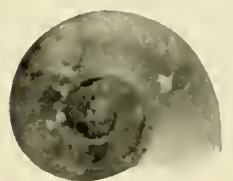

7

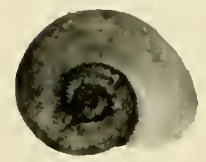

11

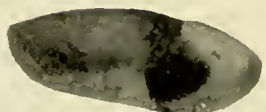

15

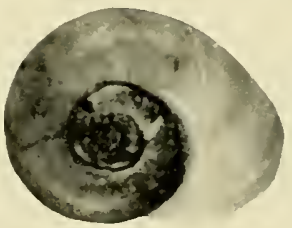

19

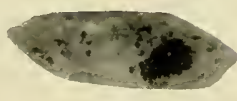

23

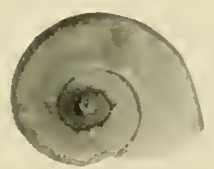

27

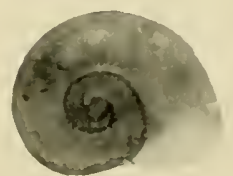

31
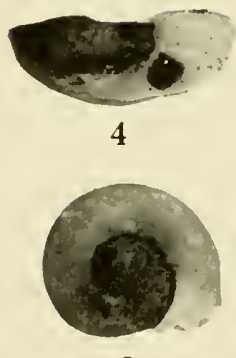

8
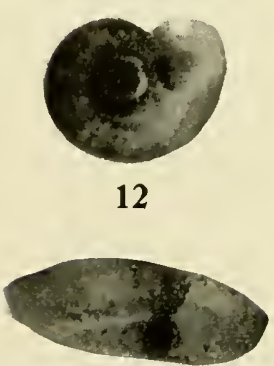

16
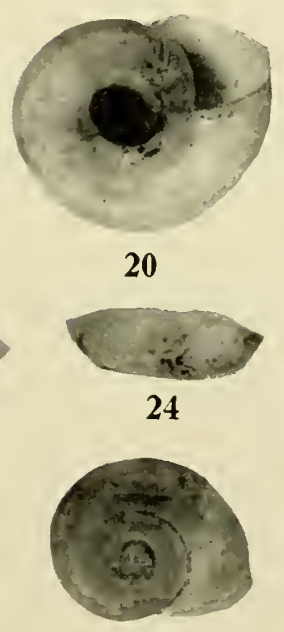

28

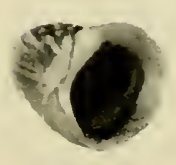

32

PIATE 120 


\section{PLATE 121}

\section{Shells of Planorbidae}

1-5. Menetus eenterillensis (Tryon). Noyo, California. U.S.N.M., 47639.

6-8. Menetus centerillensis (Tryon). Bear Lake, San Bernardino Mls., California. U.S.X.M., 175089.

9, 10. Menetus labiatus F. C. Baker. Terminal Island, Los Angeles Co., California. Puratyes. C.S.N.M., 190021.

11. Menetus labiatus F. C. Baker. Terminal Island, Los Angeles Co., California. Holotype. U.S.N.M., 190021.

12-1S. Menetus portlandensis F. C. Baker. Tanmer Creek, Portland. Oregon. 12, holotype: 13-18, paratypes. L.S.N.M., 184182.

19.20. Menetus cooperi erasilabris F. C. Baker. Seattle, Washington. 20, holotype; 19, paratye. U.S.N.M., 214590.

21. Henetus eooperi erassilabris F. C. Baker. Portland, Oregon. U.S.N.M., 99302.

22.25. Menetus dilatatus (Gould). Hingham, Massachusetts. Lea coll. Type locality. U.S.N.M., 121002

23,27, 25. Me'netus dilatatus buchanensis (Lea). Cincinnati, Ohio. Lea coll. Types. U.S.N.M., I2094S.

24,30. Menctus dilatatus buchanensis (Lea). Half mile west of Luray, Virginia. Variation toward dilatatus. U.S.N.M., 473961.

26. Menetus dilatutus (Gould). Medford, Massachusetts. U.S.N.M., 41725.

29. Menetus dilatatus buchanensis (Lea). Near Luray, Vinginia. Pathologic. U.S.N.M., 473961.

31. Menetus dilatatus buehanensis (Lea). Mt. Pleasant, District of Columbia. U.S.N.MI, 227832 .

32, 35, 36. Menetus dilatatus pennsylzanieus Pilsbry. Three and one-half miles southwest of Cambridge, Maryland. B168.

33. Menetus dilatatus buehemensis (Lea). Harbert, Berrien Co., Michigan. U.MI., S8030.

34. Menetus alabamensis (Pilsbry). Woodville, Jackson Co., Alabama. Type locality. U.M., 85913.

37. Menetus alabamensis (Pilsbry). Woodville, Alabama. Part of type lot. B392s.

35. Menetus alabamensis (Pilsbry). Woodville, Alabama. Type locality. U.M., S5913.

39. Menetus alabamensis (Pilsbry). Woodville, Alabama. Paratyne. U.S.N.M., 129005.

40.41. Menetus alabamensis avus (Pilsbry). Hammock near St. Johns River, Florida. U.S.N.M., I0169S.

42-44. Menetus brogniortianus (Lea). Cincinnati, Ohio. Lea coll. 42, lectotype; 43-44, paratypes. U.S.N.M., 120981. 

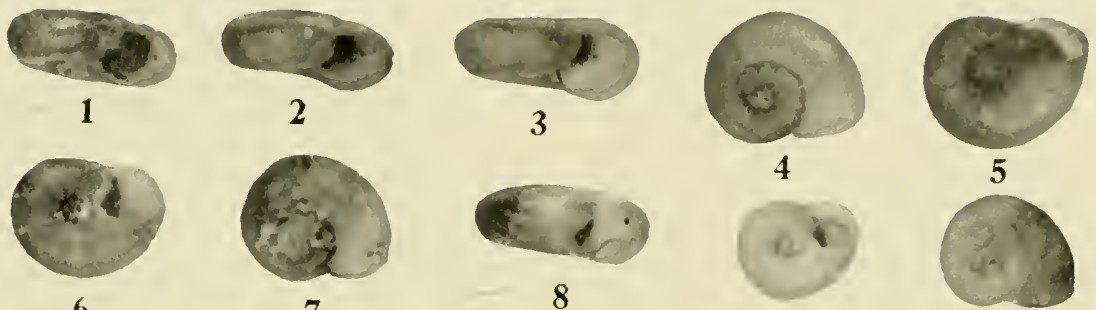

8
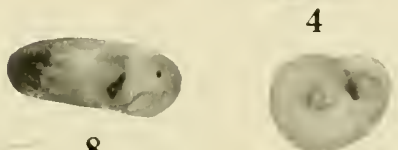

7
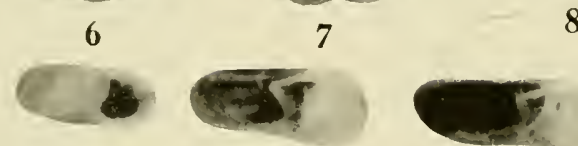

11

12

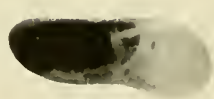

13

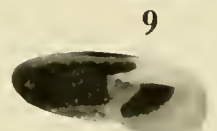

14

10

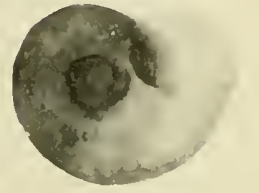

16

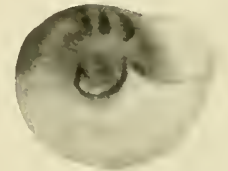

17

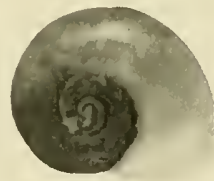

18

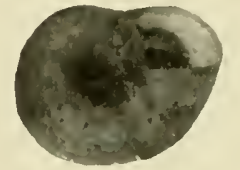

19

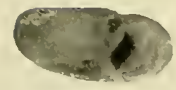

20
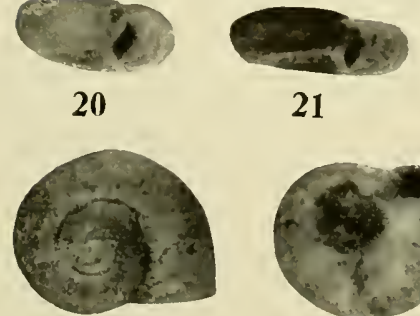

25

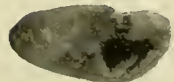

30

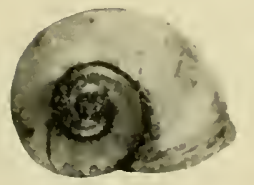

35

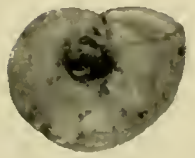

40

$$
36
$$

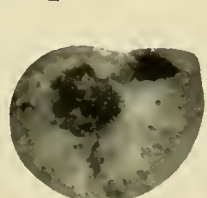

26

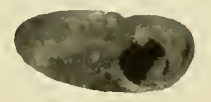

22

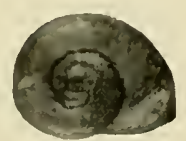

27
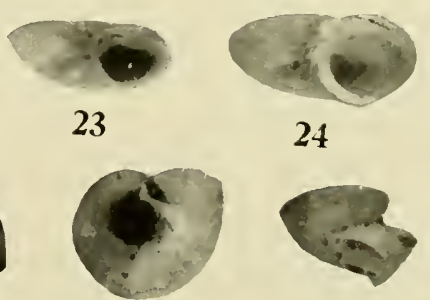

28
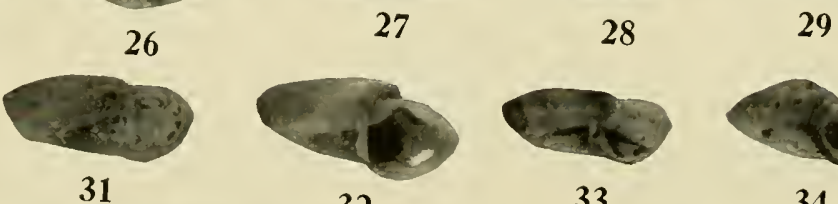

33
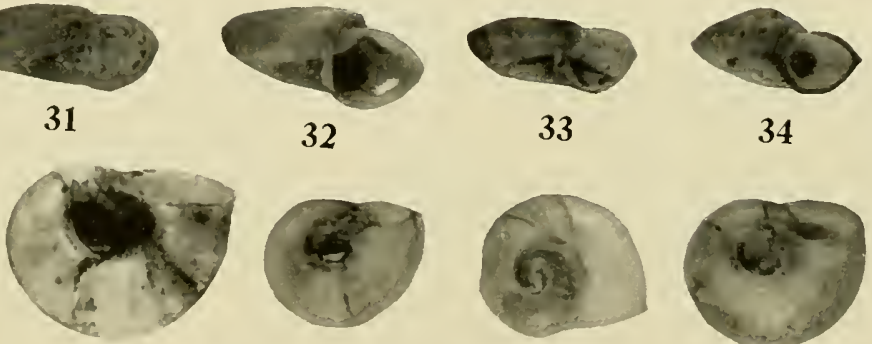

37

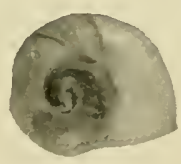

38

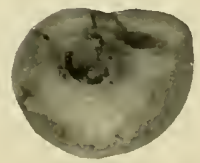

39
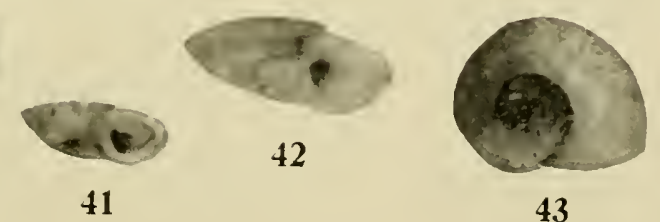

43

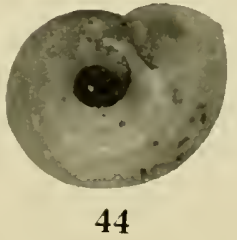

PLATE 121 


\section{PLATE 122}

\section{Shells of Planorbidae}

1.2. Menetus cooperi F. C. Baker. Blue Lake, Grand Coulee, Washington. B3935.

3-6. Menetus cooperi planospirus F. C. Baker. Orcas Island, Puget Sound, Washington. Figure 5, holotype; 3, 4, 6, paratypes. Figure 5 shows well the very flat spire. M.C.Z., 31583 .

7. Menetus cooperi F. C. Baker. Two miles north of Petaluma, California. U.S.N.M., 531171.

S. Menetus cooperi callioglyptus (Vanatta). Quamichan Lake, British Columbia. $\mathrm{B} 2030$.

9-12. Mcnetus eooperi multitineatus (Vanatta). Salem, Oregon. Type locality. B3929.

13. Menctus cooperi crassilabris F. C. Baker. Colma, San Mateo Co., California. U.S.N.M., 525095.

14. Promenetus exaeuous (Say). Chimney Point, Hospital Creek, Lake Champlain, Vermont. U.S.N.M., 336591.

15-18. Promenetus exacuous (Siyy). New York, New York. 133930.

19. Promenctus cxacuous (Say). West Lake Okoboji, Iowa. U.S.N.M., 475975.

20-22. Promenctus cxacuous megas (Dall). Birtle, Manitoba. Types. U.S.N.M., 63391.

23-25. Henctus coloradocnsis F. C. Baker. Swamp, head of Eldora Lake, near Eldora, Colorado. Figure 25, holotype; 23, 24, paratypes. U.C., 10114.

26-28. Promenctus exacuous rariety? Gresham Lake, between Gresham and Ward. Boulder Co., Colorido. ['.C., 526.

All figures are enlarged about four diameters 
PLATE 123

\section{Shells of Planorbidae}

1. Menetus alabamensis aurs (Pilsbry). South end Lake Panasofflee, Sumter Co., Florida. U.S.N.M., 211002.

2-10. Parapholyx klamathensis sinitsini F. C. Baker. Bercley Spring, 14 miles north of Klamath Falls, Oregon. Figure 2, holotype; 3, 4, paratypes; U.S.N.M., 531029. Figures 5-10, locotyes: U.S.N.M., 531064.

11. Menetus sampsomi (Ancey). Pond in Flat Creek bottom, near Sedalia, Missouri. Part of type lot. B166.

12. 13. Wenetus alabamensis (Pilsbry). Temporary pond half mile south of Fountain, Illinois. B3923.

14-16. Menetus sampsoni (Aneey). Pond in Flat Creek bottom, near Sedalia, Missouri. Type locality. M.C.Z., 4900.

17-19. Promenetus hudsomicus (Pilsbry). Four miles southeast of Canandaigua, in beach pond, east side Canandaigua Lake, New York. B2904.

20-22. Menetus dilatatus floridensis F. C. Baker. St. Johns River, Palatka, Florida. Figure 20. holotype; 21, 22, paratypes. U.S.N.M1, 37585.

23-25. Menetus uliginosus (Vanatta). Deronshire Swam1), near Hamilton, Bermuda. M.C.Z., 108996.

26. Menetus cooperi crassilabris F. C. Baker. Colma, San Mateo Co., California. U.S.N.M., 525095.

27,28. Menetus uliginosus (Vanatta). Proc. Phil. Acad. Sci., Vol. 62, p. 669, fig. 2. Pembroke Marsh, near Hamilton, Bermuda. Types.

29,30. Promenetus imus (Vanatta). Proc. Phil. Acad. Sei., Vol. 62, p. 669, fig. 3. Bermuda. Types.

31-33. Menetus sampsoni (Ancey). Meredosia, Illinois. B201S.

34,35. Promenetus umbilicatellus (Ckll.). Plummers Point, Lake Butte des Morts, Wisconsin. B2101.

36. Promenctus umbilicatellus (Ckll.). Upper Dells, Kilbourn, Wisconsin. B2102.

37-39. Promenctus rubcllus (Sterki). Ditch south of New Philadelphia, Ohio. Cotypes. B160.

Figures 2 to 10 are enlarged about two diameters; figs. 1, 11 to 26,31 to 33 , 37 to 39 , six diameters; figs. 34 to 36 , four diameters; figs. 27 to 30 , one-half size of original figures, but enlargement of shells is about five diameters. 


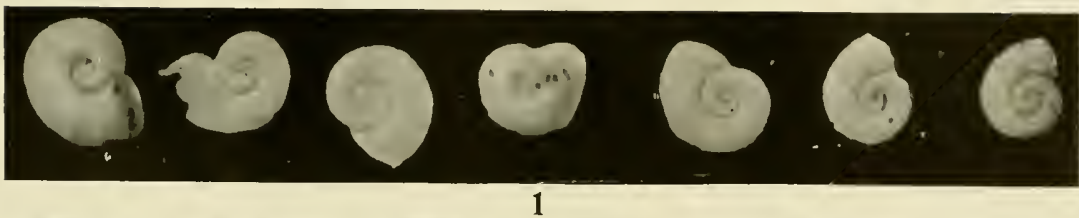

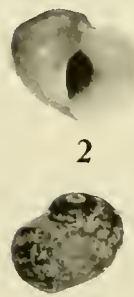

8

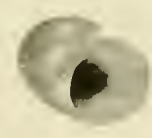

3

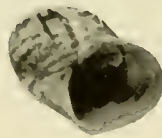

4

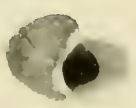

5

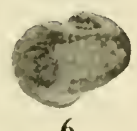

6

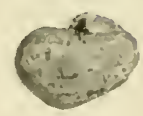

7

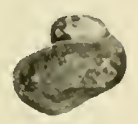

9

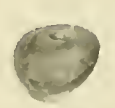

10

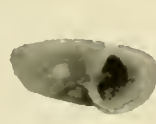

11

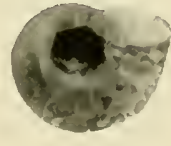

12
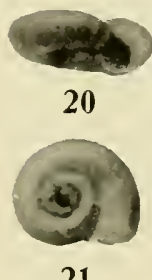

18

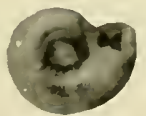

19

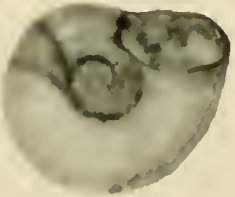

32
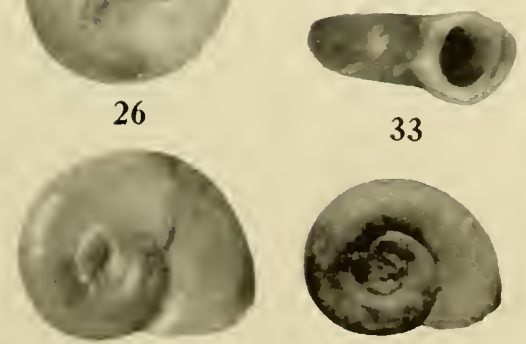

31
33

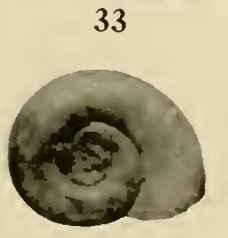

34
20
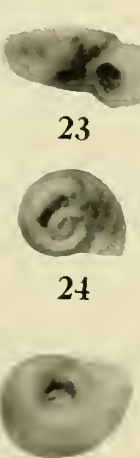

25

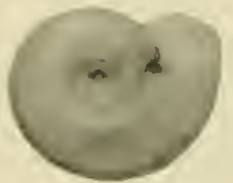

35
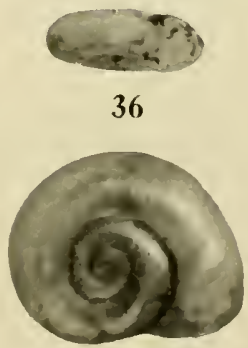

37
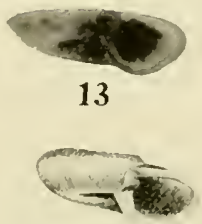

27
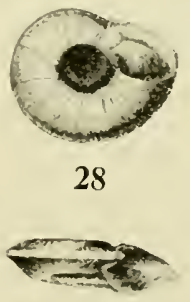

29

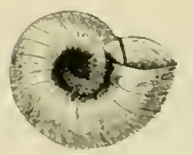

30
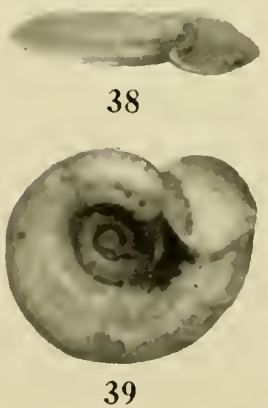

PLATE 123 


\section{PLATE 124}

Shells of Planorbidae

1, 2. Drepanotrema anatimum (Orb.). Para, Brazil. U.S.N.M., 348535.

3. Drepanotrema anatinum (Orb.). Para, Brazil. M.C.Z., 72832.

4-6. Drepanotrema anatinum (Orb.). Lake Miragoane, two miles SE of Miragoane, Haiti. M.C.Z., 83729.

7. Drepanotrema anatinum (Orb.). Jamaica. (= Planorbis haldemani C. B. Adams.) Lea Collection, probably part of original lot of haldemani. U.S.N.M., 94758.

8-10. Drepanotrema anatinum (Orb.). Esperanza, Cuba. Tyve locality of Planorbis esperanzensis Tryon. M.C.Z., 85875.

11-13. Drepanotrema anatinum (Orb.). Baron Hills, Trelawny, Jamaica. (= Planorbis haldemani C. B. Adams.) M.C.Z., 65839.

14-20. Drepanotrema parapseide (Orb.). Buena Vista, Santa Cruz, Bolivia. T.M., \$7196.

21-28. Drepanotrema ahenum H. B. Baker. Tuceas, Venezuela. Type lot, showing age variation in shell. U.M., S7164.

29,31,32. Drepanotrema lucidum (Pfr.). Juninaguas, Dept. Loreto, Peru. U.S.N.M., 381510.

30. Drepanotrema anatinum (Orb.). Juninaguas, Dept. Loreto, Peru. U.S.N.M., with 381510.

All figures are enlarged about four diameters 

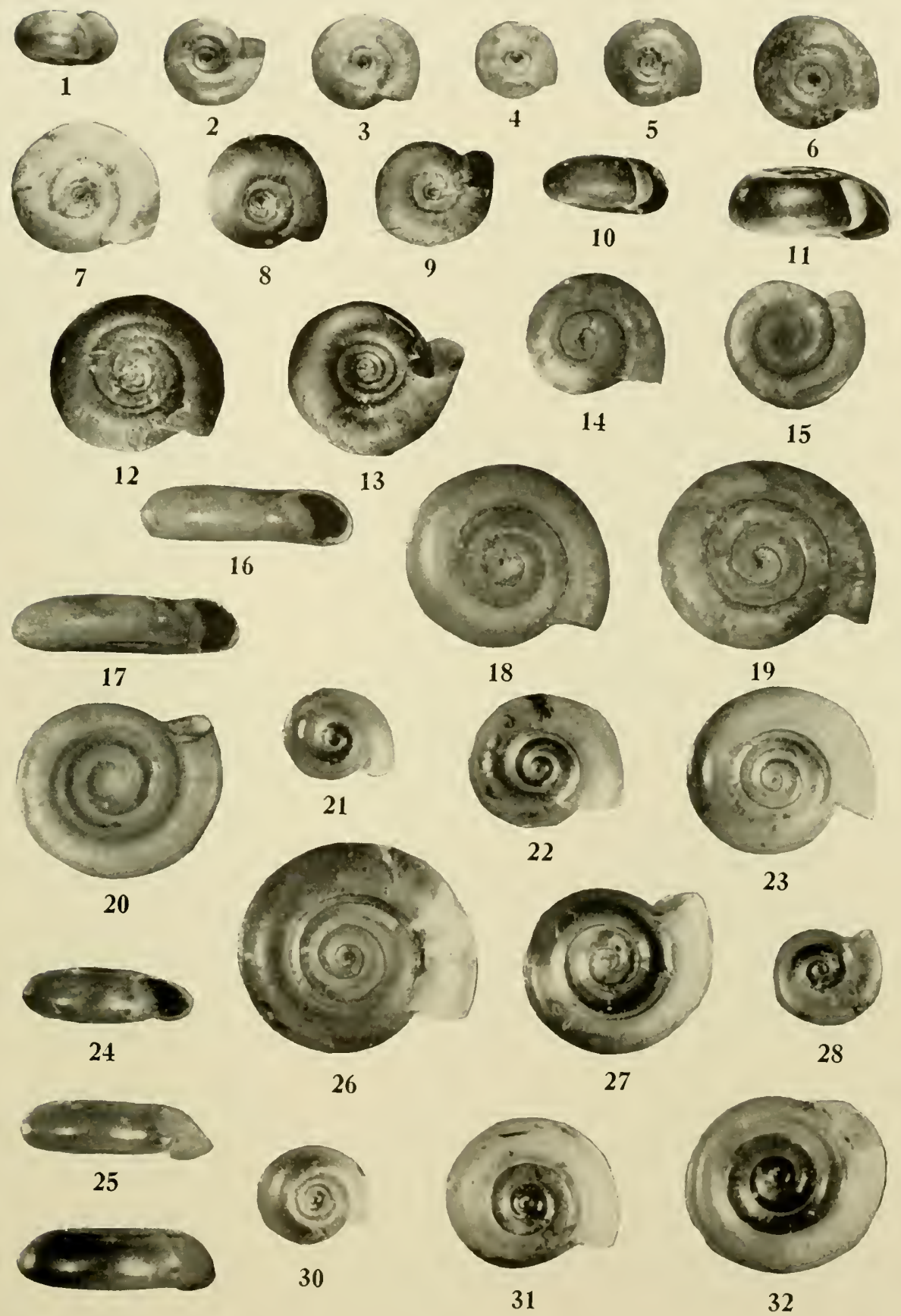

29

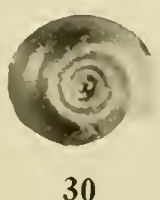

PLATE 124 


\section{PLATE 125}

\section{Shells of Planorbidae}

1, 4,6,7. Drepanotrema lucidum (Pfeiffer). Laguna del Bili, Alacranes Mts., Cuba. M.C.Z., 129991.

2.3. Drepanotrema lucidum (Pfeiffer). St. Louis, Dept. du Sud, Haiti. Immature shells. U.S.N.M., 402809.

5. Drepanotrema lucidum (Pfeiffer). Maggoty, St. Elizabeth, Jamaica. U.S.N.M., $37608 s$.

S. Drepanotrema lucidum (Pfeiffer). Jamaica. (=Planorbis redfieldi C. B. Adams.) Lea Collection. Possibly part of original lot of redfieldi. U.S.Y.M., 94757.

9. 10. Drcpanotrema lucidum (Pfeiffer). Jealousy Stream, St. Croix. U.S.N.M., 423966.

11-17. Drcpanotrema lucidum (Pfeiffer). Large variety with closely coiled whorls. Half mile NE of Orange Creek, Cat Island, Bahamas. M.C.Z., 107179.

1S-21. Drepanotrema mellezm (Lutz). Rio de Janeiro, Brazil. U.S.N.M... 53591S.

All figures are enlarged about four diameters 
Illustrations of the Anatomy and of Shells
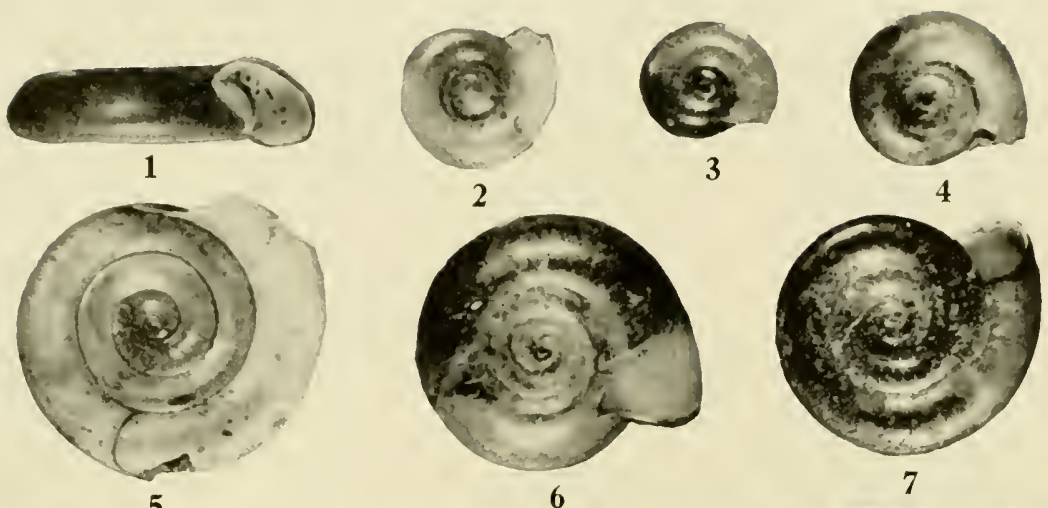

5

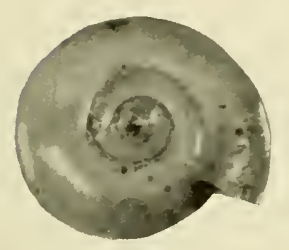

8
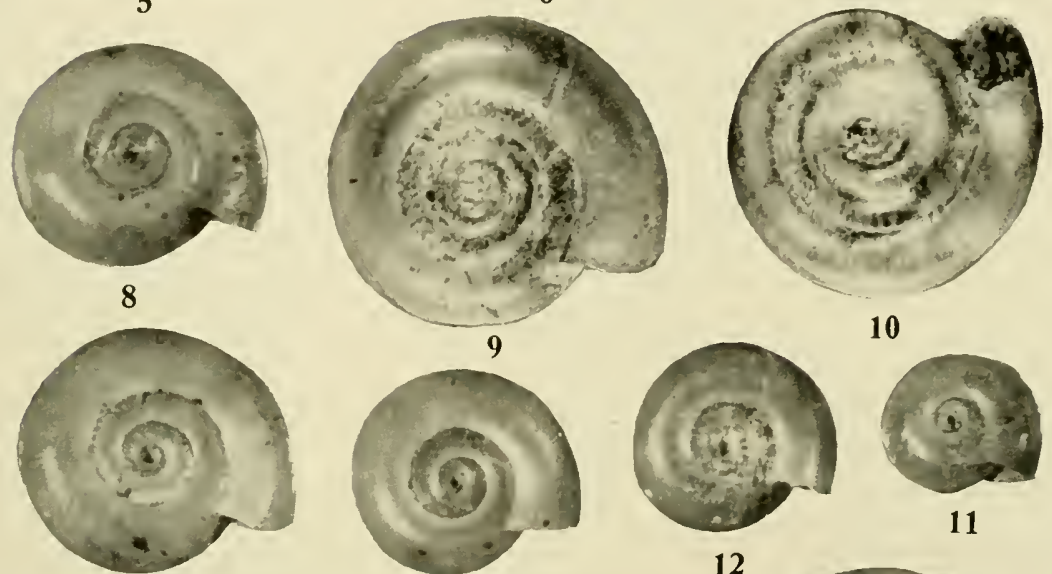

10
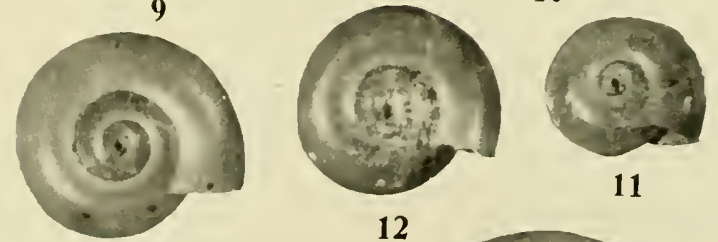

11

12
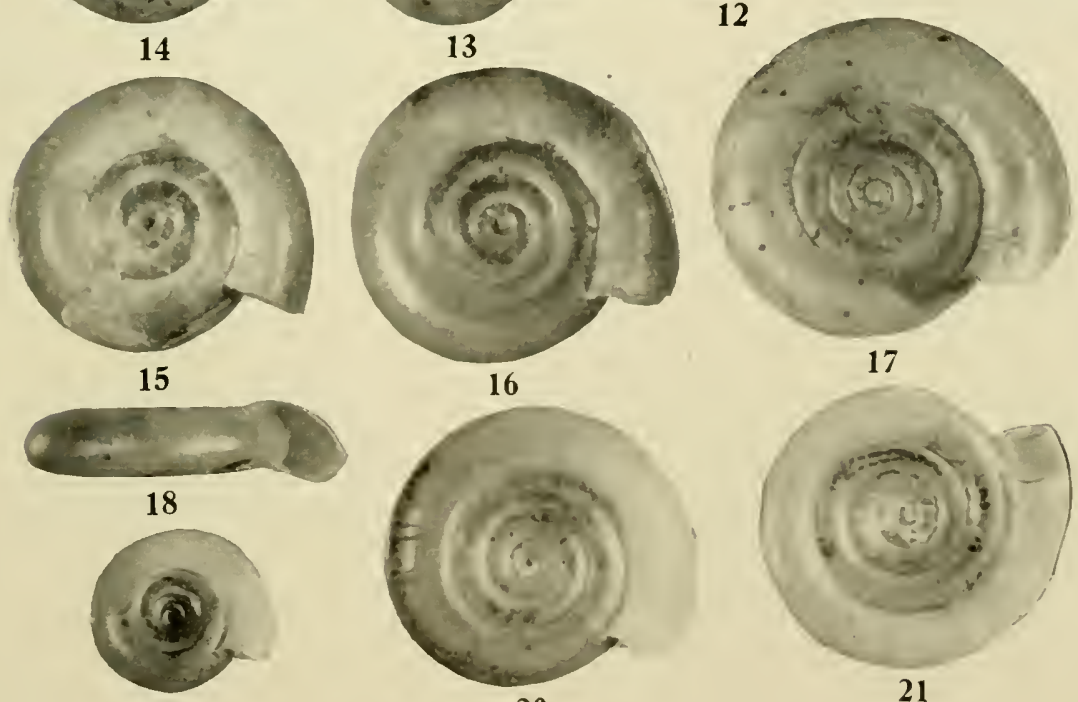

19
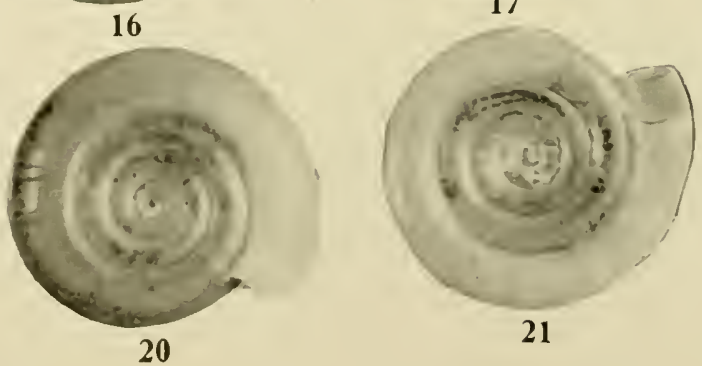

PLATE 125 


\section{PLATE 126}

\section{Shells of Planorbidae}

1-5. Drepanotieme castanemitens (Pils. and Tan.). Near Maldonado. Uruguay. Type locality. U.S.N.M., 151668.

6. Drepanotrema hoffmanni F. C. Baker. Isabela, Puerto Rico. Holotype. B3952.

7-9. Drepanotrema hoffmami F. C. Baker. Isabela, Puerto Rico. Paratypes. B3953.

10-12. Drepanotrema hoffmanmi F. C. Baker. Near San Juan, Puerto Rico. Age variation. L.S.N.M., 420573.

13. Drepanotrema liermatwide (Orb.). Puerto Haberton, Argentina. U.S.N.M., 362857.

14-16. Dre panotrema hermatode (Orb.). Lima, Peru. Type locality. Figure 14 shows an immature specimen. U.S.N.M., 20705.

17-19. Drepanotroma cultratum anitense (Cooper). Laguna, Santa Rita, Lower California. U.S.N.M., 129292.

All figures are enlarged about four diameters 


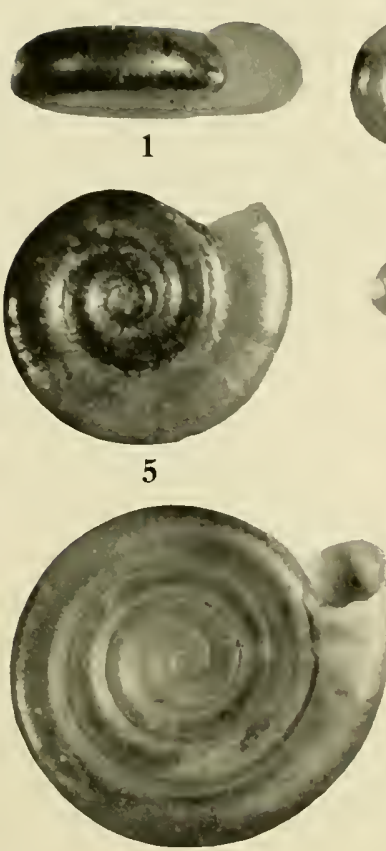

8

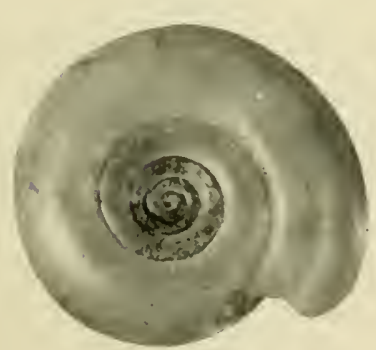

15

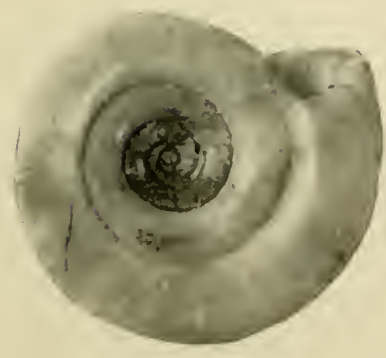

16
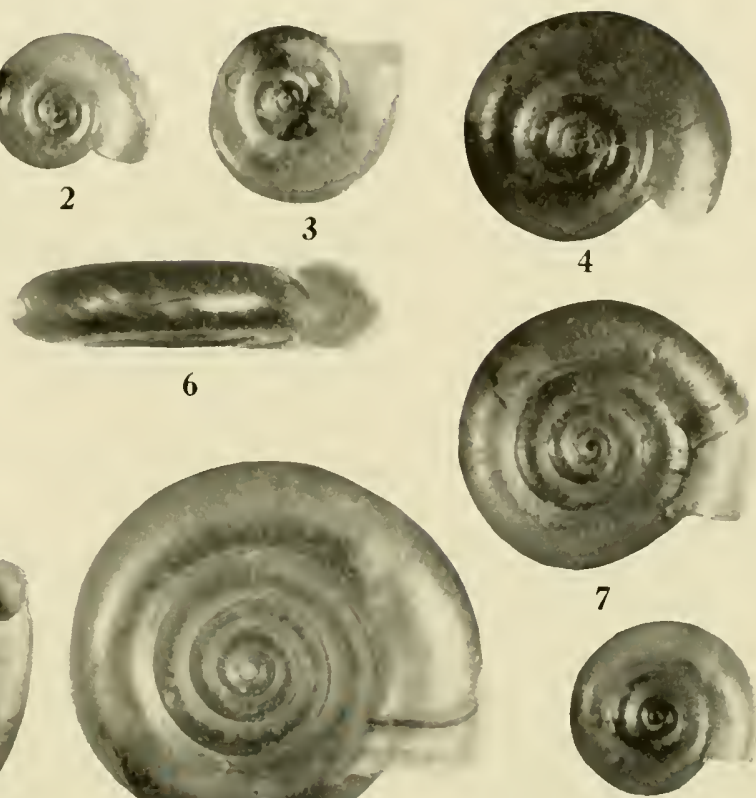

10

9

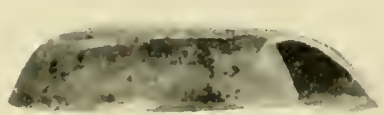

13

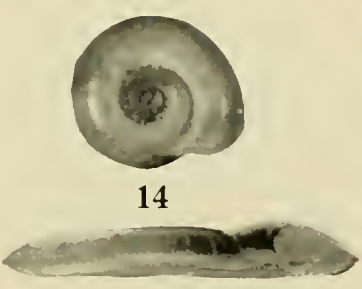

17

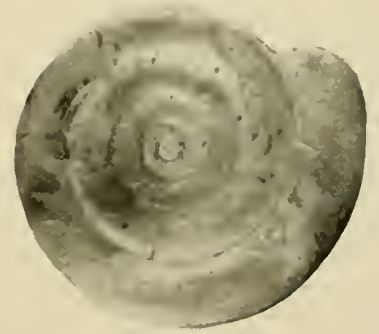

18
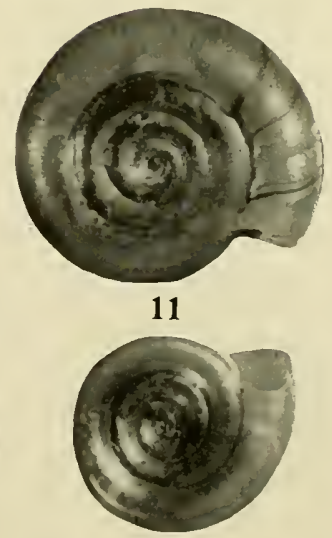

12

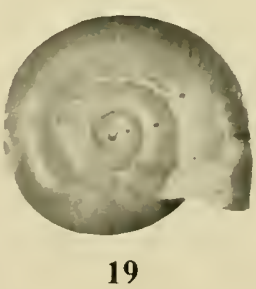

PLATE 126 


\section{PLATE 127}

Shells of Planorbidae

1-3. Drepanotrema cimex (Moricand). Valle de Yumuri, Matanzas, Cuba. M.C.Z., 129995.

4-6. Drepanotrema cultratum (Orb.). Painters Pond, Painters, Antigua. U.S.N.M., 272282.

7.S. Drepanotrema cimex (Moricand). Hunts Bay, St. Andrew, Jamaica. U.S.N.M., 378054 .

9-12. Drepanotrema cultratum duenasianum (Tristram). Pools along railway near Lake Amatitan, Guatemala. B125s.

13-15. Drepanotrema cimex pistiae H. B. Baker. Rincon del Valle, near Caracas, Venezuela. U.S.N.M., 362133.

16. Drepanotrema cimex (Moricand). Jamaica. (=Planorbis maenabianus C. B. Adams.) Lea Collection, probably part of original lot. U.S.N.M., 94756.

17-19. Drepanotrema depressissimum (Moricand). Bahia, Brazil. Paratypes. M.C.Z., 31432.

All figures are enlarged about four diameters 

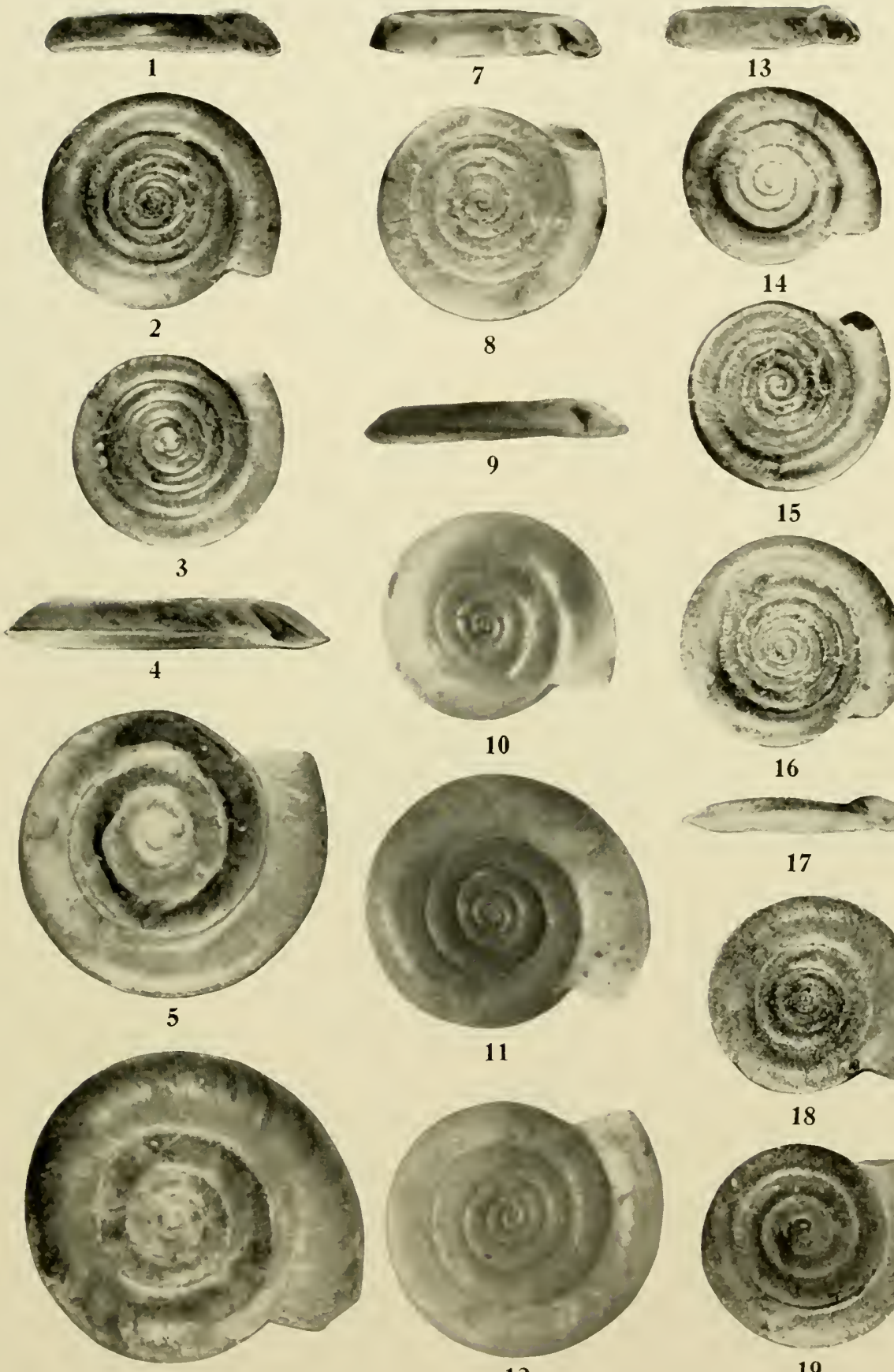

6
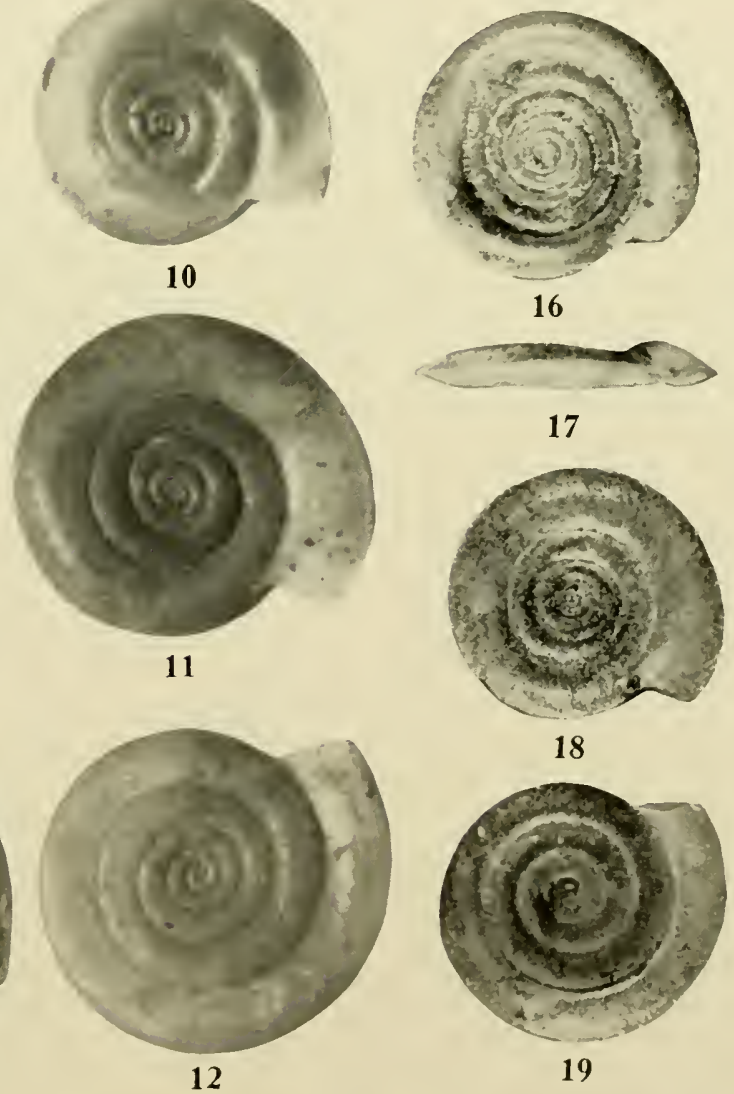

PLATE 127 


\section{PLATE 128}

Shells of Planorbidae

1.2. Drepanotrema cultratum panuco Pilsbry. Tampico, Mexico. B1183.

3-5. Drepanotrema cultratum panuco Pilsbry. Pasture west of San Dieguito, San Luis Potosi Co., Mexico. Locotypes. B2124.

6. Drepanotrema cultratum labrosum Pilsbry. Brownsville. Texas. U.S.N.M., 273933.

7-10. Drepanotrema cultratum labrosum Pilsbry. Brownsille, Texas. Locotyues. B1192.

11-16. Drepanotrema sumichrasti (Crosse and Fischer). Barbour Lathrop Trail, Barro Colorarlo Island, Gatun Lake, Canal Zone. B3967.

17-19. Drepanotrema cimex (Moricund). Brazil. U.S.X.M1., 121018.

20-22. Drepanotrema cimex (Moricand). Anapolis, Guyoz, Brazil. M.C.Z., 65716.

23-25. Drepanotrema peninsularis (Cooper). (= Drepanotrema anatinum). Sinta Anita, Lower California. U.S.N.M., 129291.

26-30. Tropicorbis obstructus (Morelet). Tampico, Mexico. U.I., Z28550.

31-33. Tropicorbis obstructus (Morelet). Lake Amatitan, Guatemala. B2125.

Figures 1 to 30 are enlarged about five diameters; figs. 31 to 33 are enlarged about four diameters. 
Illustrations of the Anatomy and of Shells
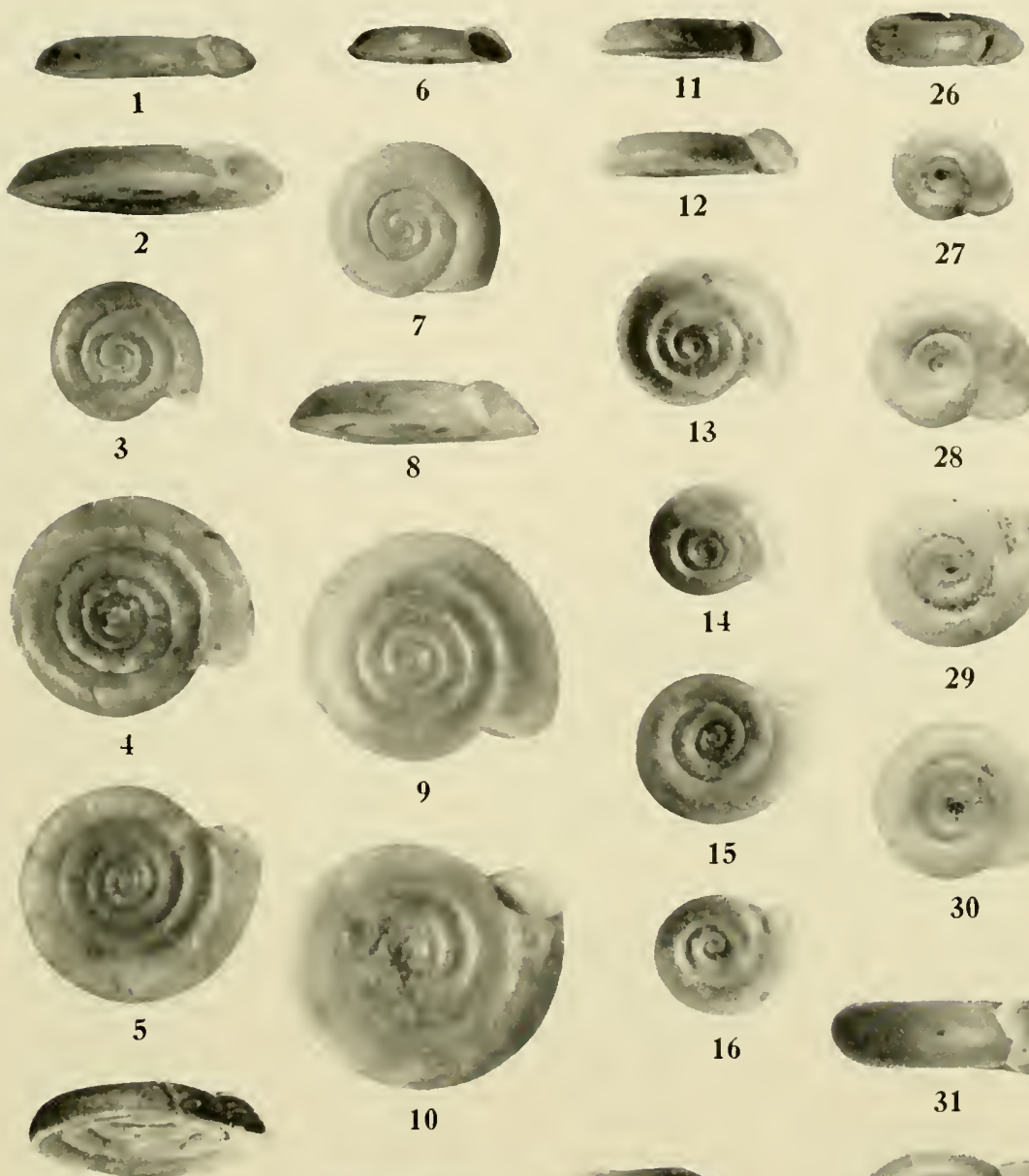

15
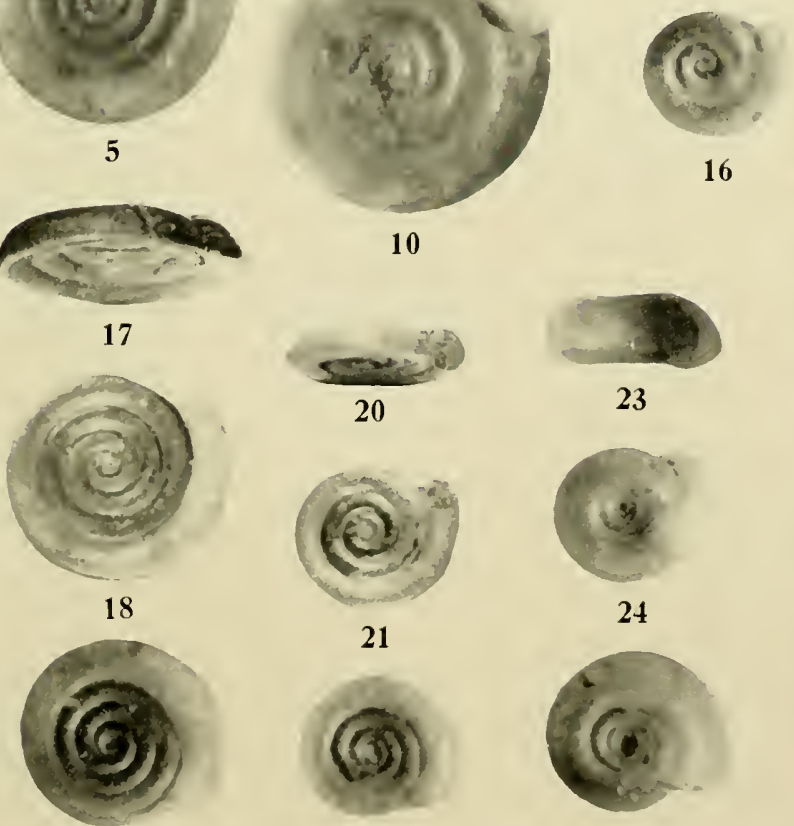

22

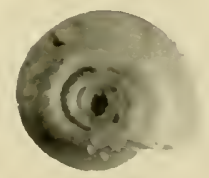

25
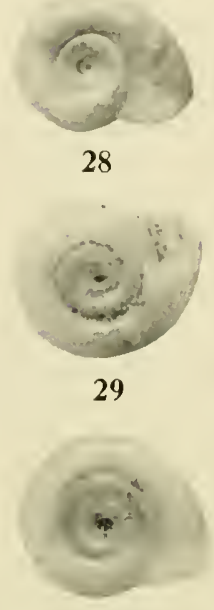

30
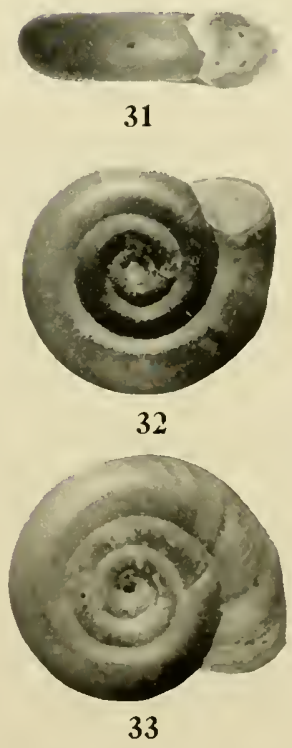

PLATE 128 


\section{PLATE 129}

\section{Shells of Planorbidae}

1-3. Tropicorbis orbiculus (Morelet). Near San Miguel. Cozumel Island, Quintana Roo, Mexico. M.C.Z., 75102.

4. Tropicorbis obstructus (Morelet). Sume as above. M.C.Z., 75102.

5-7. Tropicorbis orbiculus (Morelet). (= Planorbis liebmanni Dunker). Vera Cruz, Mexico. U.S.N.M., $2108 s 1$.

S.9. Tropicorbis obstructus (Morelet). Same locality as above. U.S.N.M., 210881.

10-15. Tropicorbis orbiculus (Morelet). Chamiai Creek, below Valles, Mexico. U.I., Z2S528.

16. Tropicorbis orbiculus (Morelet). Catanas Lake, El Abra, Mexico. B1191.

17-22. Tropicorbis obstructus donbilli (Tristram). Edentate. Guadalupe River, Victoria Co., Texas. U.S.Y.M., 464970.

23-25. Tropicorbis obstructus donbilli (Tristram). Edentate. Brownsville, Texas. B1187.

26-31. Tropicorbis orbiculus dunkeri F. C. Baker. New name. Dry pool near Tampico, Mexico. B1184.

32-36. Tropicorbis orbiculus dunkeri F. C. Baker. Los Canoas, Mexico. B2113.

37-42. Drepanotrema heleropleurus Pilsbry and Vanatta. Lake Titicaca, Peru. Topotypes. Agassiz Expedition.

All figures are enlarged about two diameters 
Illustrations of the Anatomy and of Shells

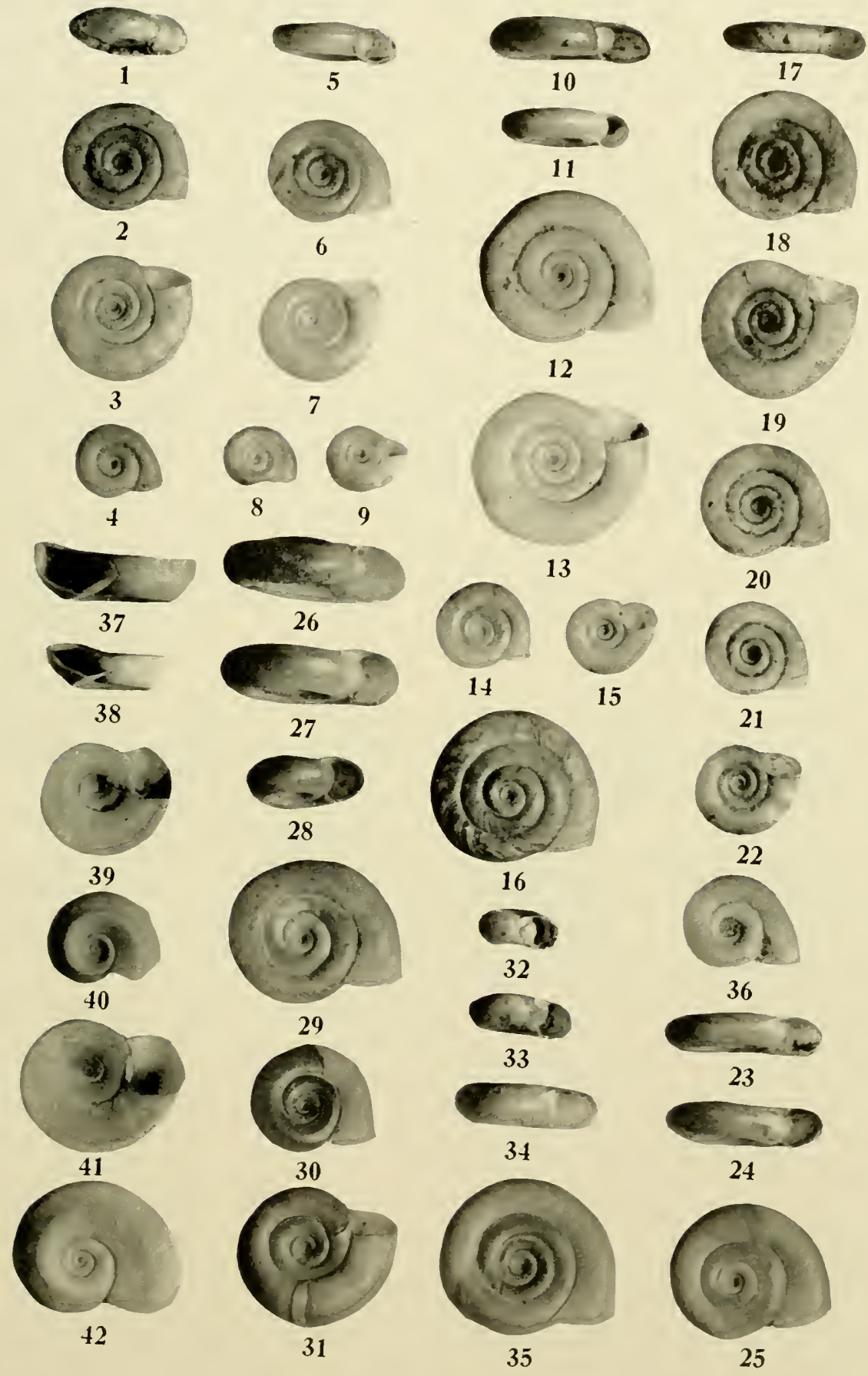

PLATE 129 


\section{PLATE 130}

\section{Shells of Planorbidae}

1-3. Tropicorbis gracilentus (Gould). Colorado Desert. Binney's fig. 183, p. 108. Holotype. U.S.N.M., 26477.

4-12. Tropicorbis gracilentus (Gould). San Marcos, Texas, in drift adjoining fish hatchery. Figure 10 shows closely coiled whorls like those of Tropicorbis orbiculus. B3298.

13-17. Tropicorbis maya (Morelet). Merida, Yucatan. M.C.Z., 59646.

18 20. Tropicorbis havamensis (Pfeiffer). Havana, Cuba. Type locality. U.M., 84039.

21-25. Tropicorbis hazanensis (Pfeiffer). New Orleans, Lousiana. A small variety. 133954 .

26. Tropicorbis hatunensis (Pfeiffer). Guayos, Santa C'lan Pror., Cuba. U.M., 84038.

27-2S. Tropicorbis haranusis (Pfeiffer). New Braunfels, Texas. M.C.Z., 13622.

29-32. Tropicorbis philippiamus (Dunker). Asuncion, Paraguay. Figure 31, loosely coilet. M.C.K., 62490.

33, 34. Tropicorbis phitippiamus (Dunker). Esperanza de Santa Fe, Argentina. M.C.Z.. 64963.

35-37. Tropicorbis centimetralis (Lutz). Ceará Mirim, Rio Grande do Norte, Brazil. Type locality. M.C.Z., 92825.

38-41. Tropicorbis peregrimus (Orbigny). Rio Grande de Sul, Brazil. M.C.Z.. 75376.

All figures are enlarged about two diameters 

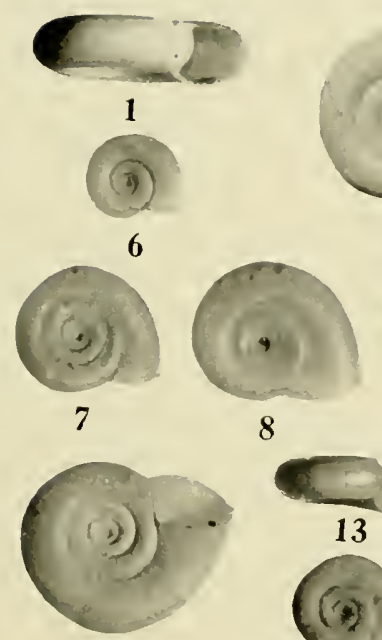

12
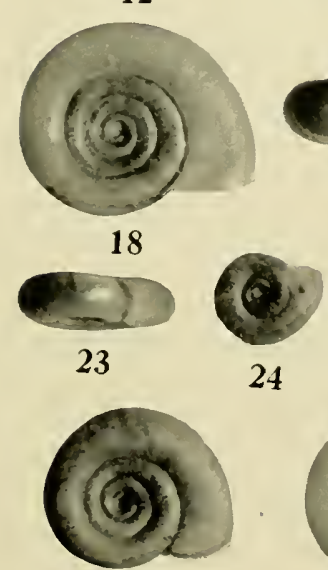

29

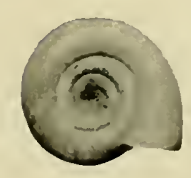

33

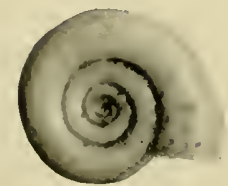

38
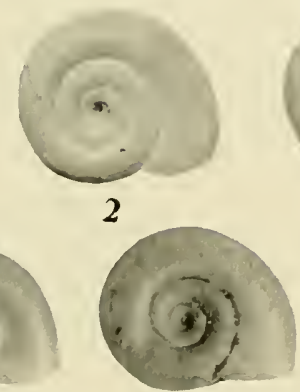

9

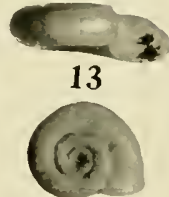

14

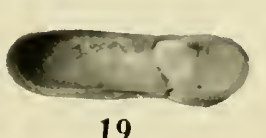

19

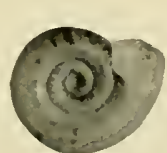

25
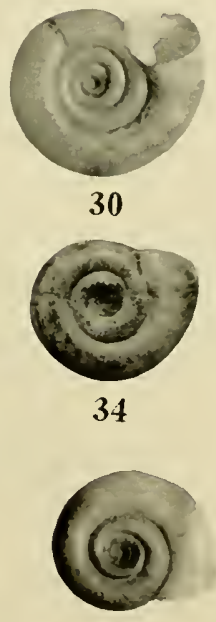

39

15
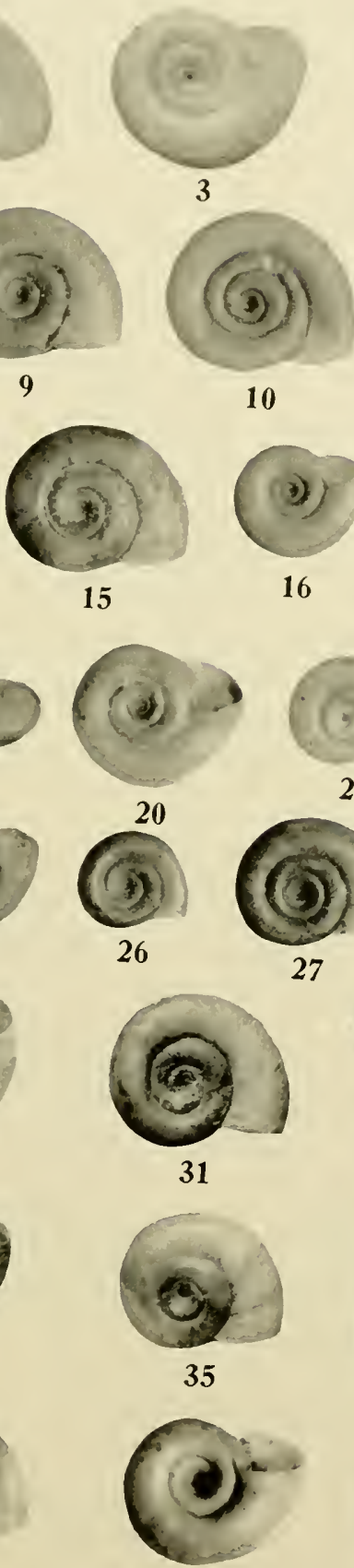

40
10

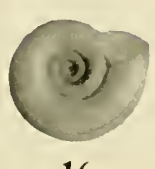

16
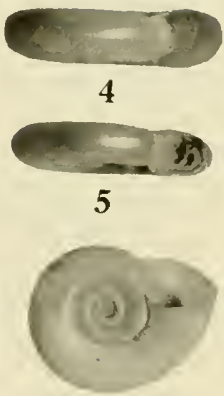

11
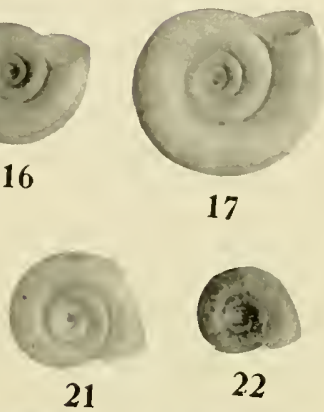

22
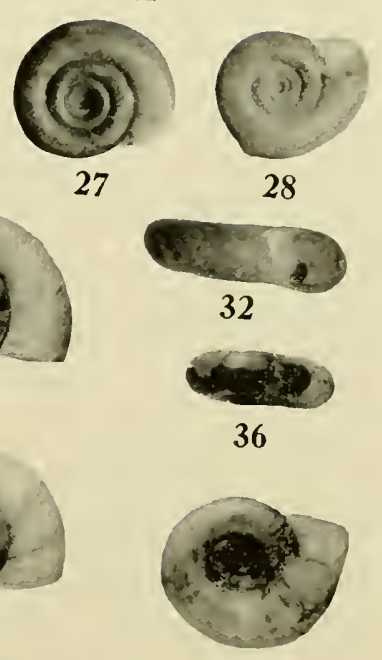

37

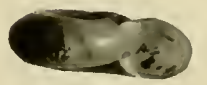

41

PLATE 130 


\section{PLATE 131}

\section{Shells of Planorbidae}

1-4. Tropicorbis isthmicus (Pilsbry). Panama City, Panama. Type locality. U.M., 88180.

5-7. Tropicorbis isthmicus (Pilsbry). Miraflores Lake, Panana. L.M., S8181.

8-10. Tropicorbis decipiens (C. B. Adams). Rockport, Jamaica. B3966.

11. Tropicorbis decipiens (C. B. Adams). Puerto Rico. U.I., Z40460.

12-14. Tropicorbis chilcnsis (Clessin). Valparaiso, Chile. M.C.Z., 74655.

15-24. Tropicorbis obstructus dombilli (Tristram). Dry pool in Tampico, Mexico. B1189.

25, 26. Tropicorbis obstructus donbilli (Tristram). Brownsrille, Texas. B127.

27-31. Taphius andecolus montanus (Orbigny). Tanja (Oroya), Peru. M.C.Z., 36702.

32-35. Taphius andecolus (Orbigny). Puoa, Peru. U.I., Z40575.

36-40. Taphius subpronus (ron Martens). Terrialba, Costa Rica. U.S.X.M., 162827.

Figures 1 to 35 are enlarged about two diameters; figs. 36 to 40 , four diameters. 
Illustrations of the Anatomy and of Shells
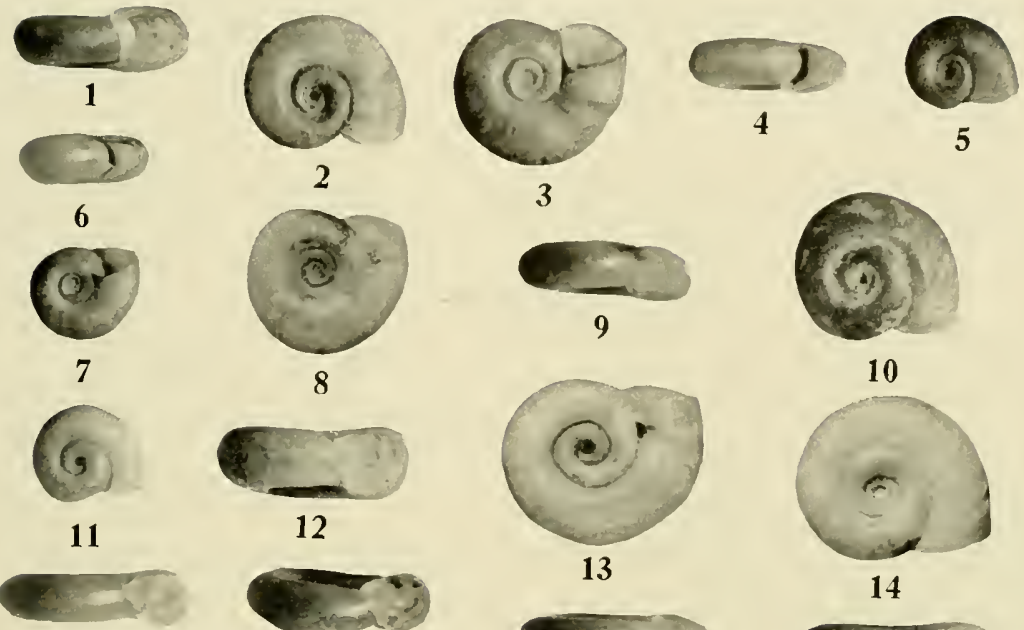

15
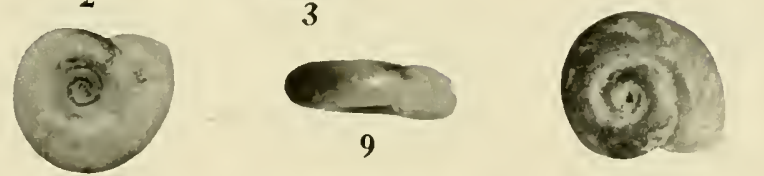

8
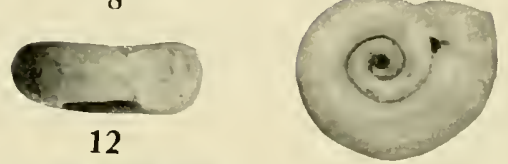

13
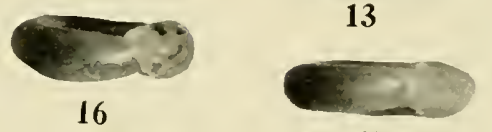

17

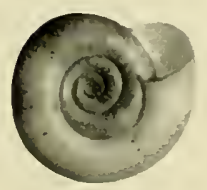

16

19

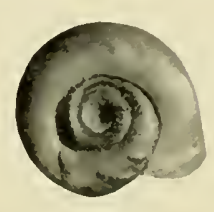

20

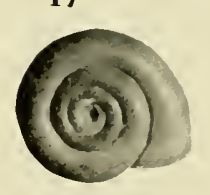

21

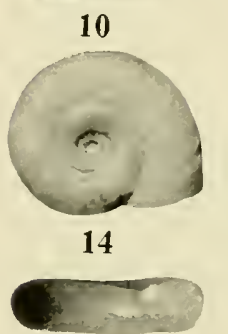

18

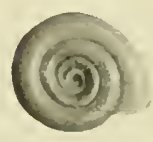

22
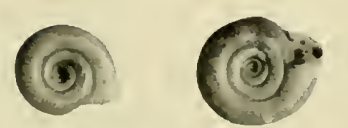

23
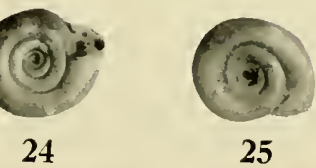

25
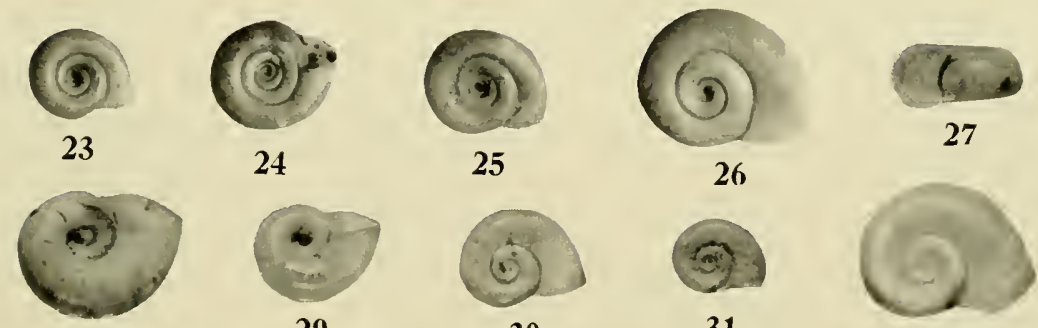

28

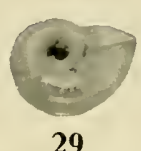

29

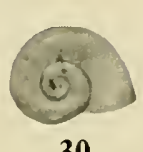

30

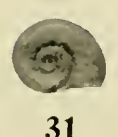

31

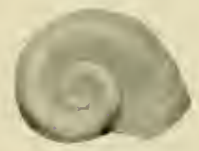

32

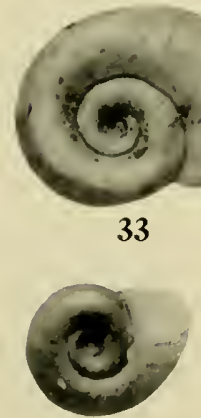

36

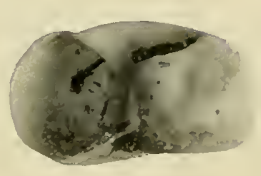

34

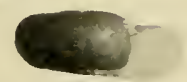

37
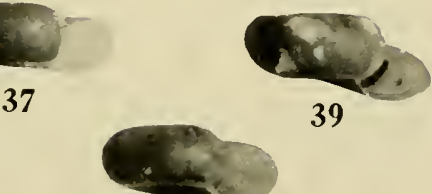

39

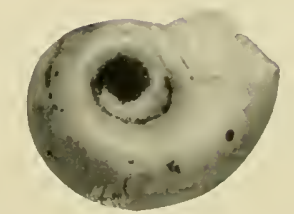

35

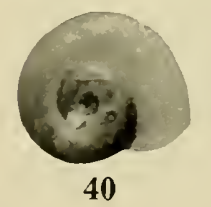

PLATE 131 


\section{PLATE 132}

\section{Shells of Planorbidae}

1-3. Tropicorbis pallidus (C. B. Adams). Kingston, Jamaica. U.I., Z40466.

4,5. Tropicorbis pallidus (C. B. Adams). Tucaras, Venezuela. U.M., $\$ 9990$.

6 9. Tropicorbis kuhrianus (Dunker). Bejuma, Venezuela. I.M., S9991.

10-12. Tropicorbis stramineus (Dunker). Venezueli. Paratypes. Ex Dunker. M.C.Z., 74654.

13, 14. Tropicorbis stramincus (Dumker). Lagoa Giboia, Municipio de Aquriz, Ceara, Brazil. M.C.Z., 65720.

15 21. Tropicorbis rïsti (Dunker). Lares, Pnerto Rico. B3955.

22, 23. Tropicorbis meridacnsis (Preston). Merida, Venezmela. U.I., Z40463.

24-28. Tropicorbis fieldi (Tryon). Catun, Panama Cinal. Tỵe locality. M.C.Z., 21187.

29,30. Tropicorbis fieldi (Tryon). Near Granada, Niculagua. M.C.Z.. 4534.

31,32. Tropicorbis bourcardianus (Preston). Mexico. L.S.N.M., 202523.

33-35. Tropicorbis gundlachi (Dunker) (= stramincus). Trinidad. U.I., Z40461.

All figures are enlarged about three diameters 


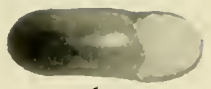

1
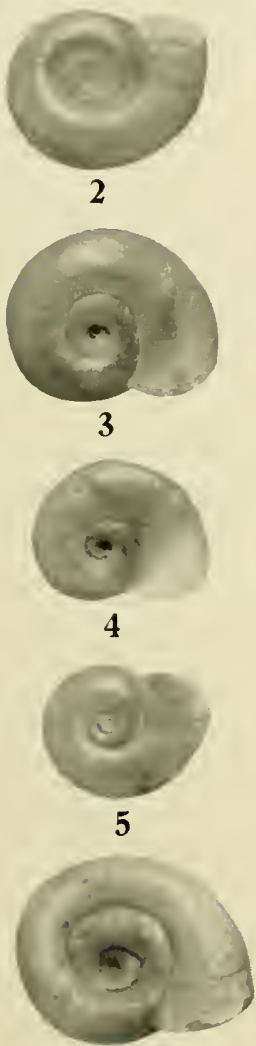

28

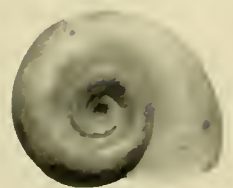

29

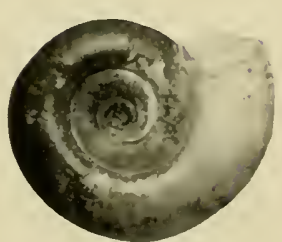

30
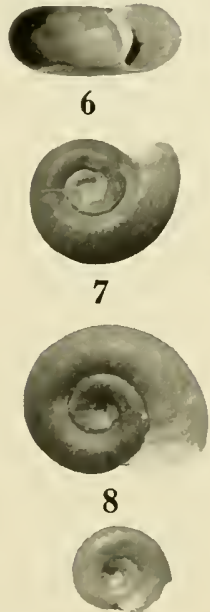

9

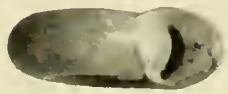

24

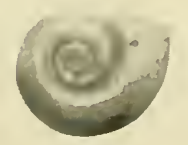

25

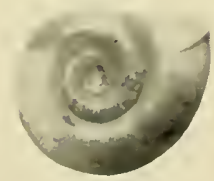

26

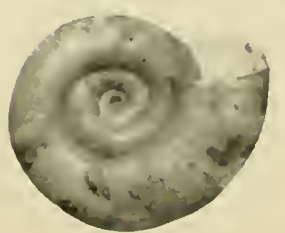

27

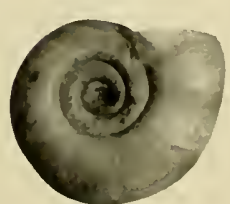

31

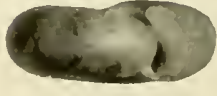

10
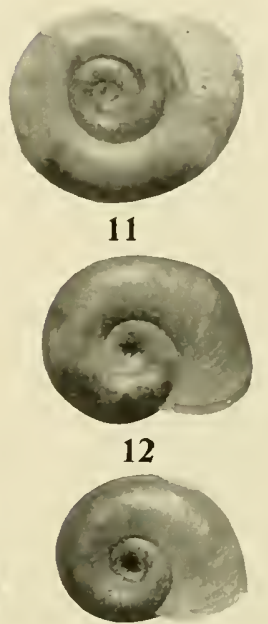

13
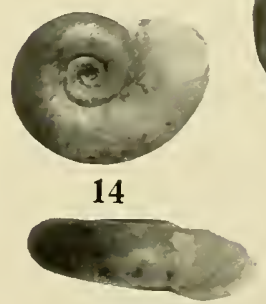

32

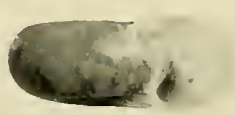

33

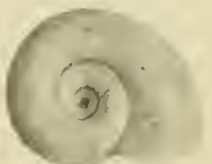

34

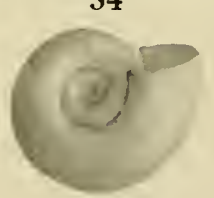

35

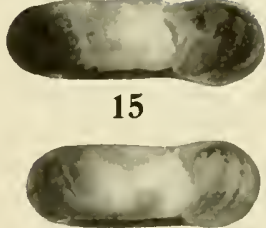

16

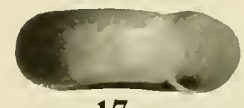

17

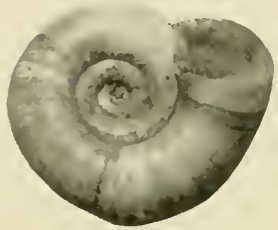

18

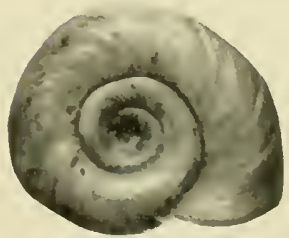

19
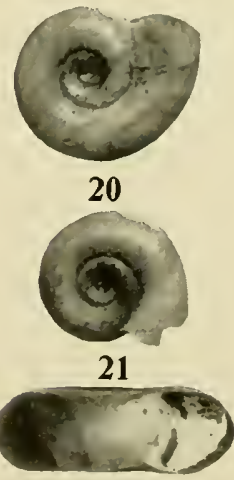

22

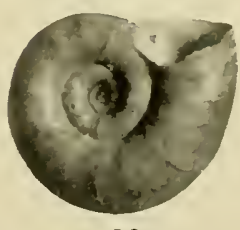

23

PLATE 132 
PLATE 133

\section{Shells of Planorbidae}

1-3. Tropicorbis petenensis Morelet. Tehauntepee, Mexico. M.C.Z., 64995.

4-9. Tropicorbis tepicensis (Martens). Tepic, Guadalajara, Mexico. U.S.N.M., 102211.

10-13. Tropicorbis heloicus (Orbigny). In small creek back of the Cerro, Montevideo, Uruguay. Type locality. U.S.N.M., 535720.

14-17. Tropicorbis nigrilabris (Lutz). Rio de Janeiro, Brazil. Type locality. U.S.N.M., 535713.

1S-21. Tropicorbis janeirensis (Clessin). Bahia. Brazil. U.S.N.M., 152677.

22. Tropicorbis schrammi (Crosse). Martinique. M.C.Z., 113883.

23. 24. Tropicorbis schrammi (Crosse). Antigua. U.I., Z40465.

25-27. Tropicorbis declivis (Tate). Nicaragua. U.S.N.M., 24006.

28-33. Tropicorbis obstructus (Morelet). Pool at Piste, Yucatin. M.C.Z., 59754.

34,35. Tropicorbis obstructus (Morelet). Falls of the Valles River, Valles, Mexico. B2117.

36 40. Tropicorbis obstructus anodontus (Pilsbry). Reservoir north of Guatemala City, Guatemala. Type locality. B2061.

All figures are enlarged about three diameters 

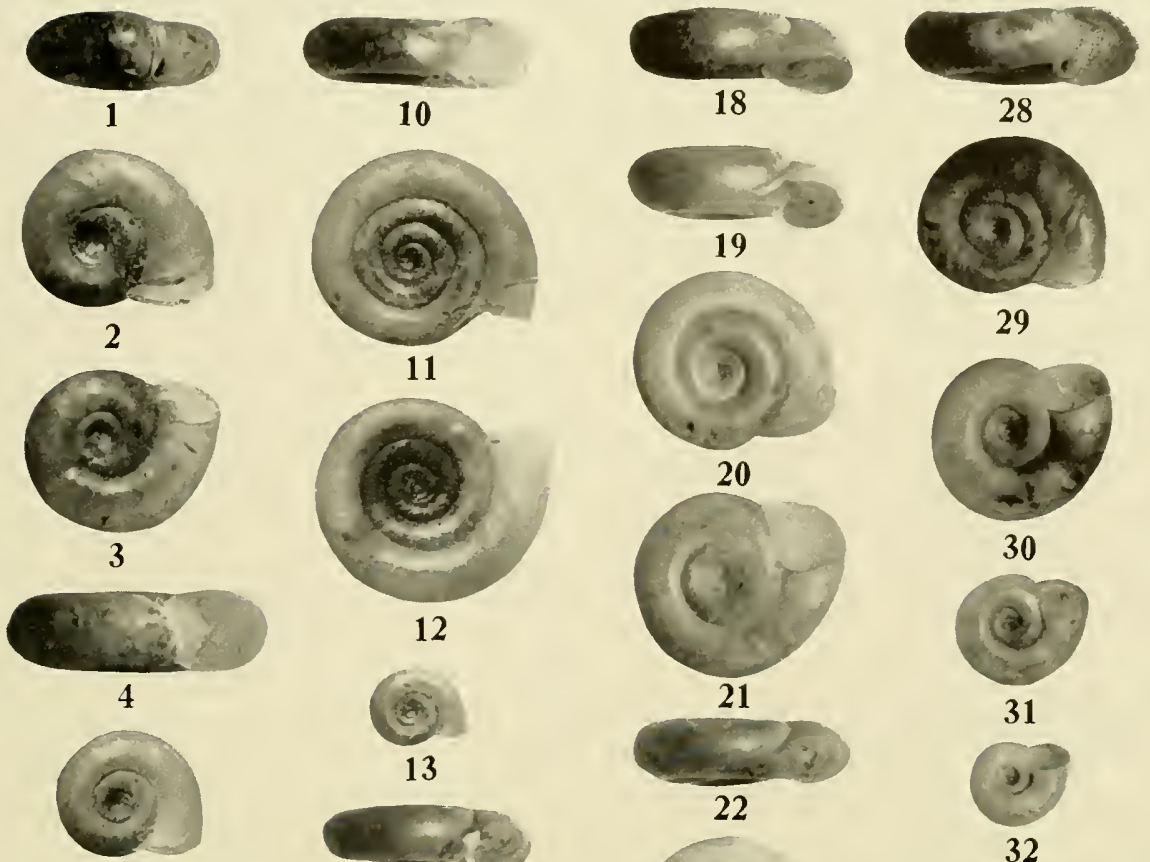

5
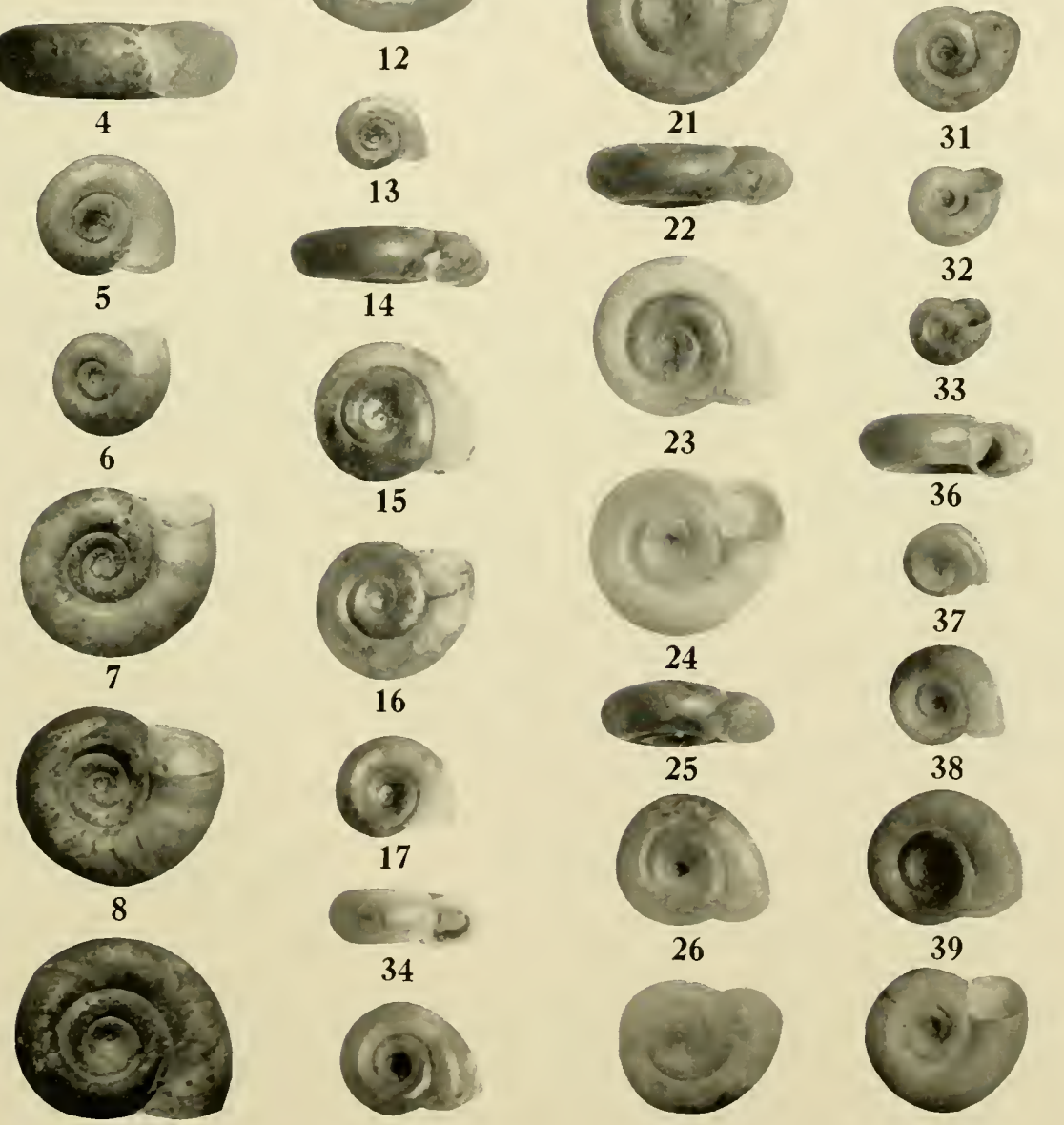

9
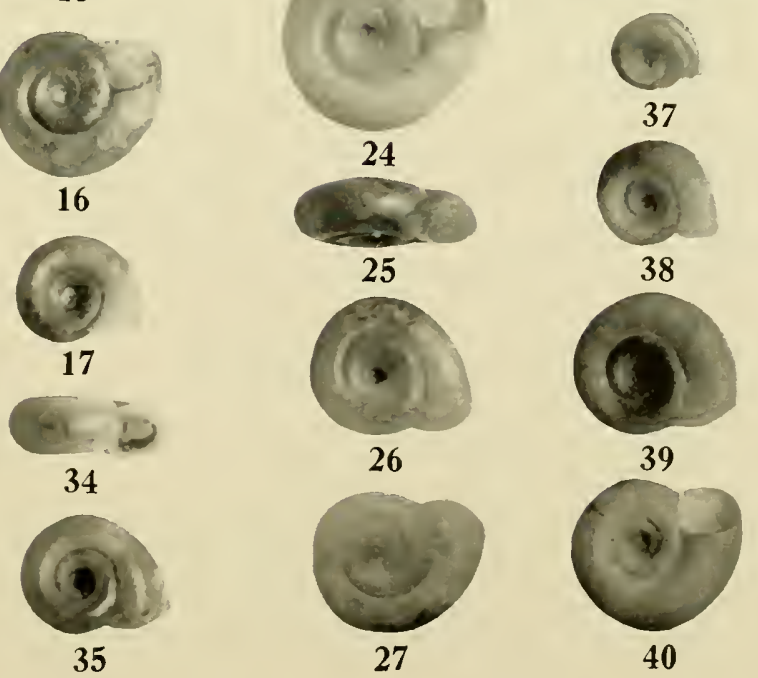

PLATE 133 


\section{PLATE 134}

\section{Shells of Planorbidae}

1-3. Tropicorbis paparyensis (F. Baker). Anapolis, Goyaz, Brazil. M.C.Z., 65717.

4-6. Tropicorbis albicans (Pfr.). Cuba. U.I., Z40459.

7. Tropicorbis schrammi (Crosse). Antigua. U.I., Z40465.

8, 9. Tropicorbis dentiferus (C. B. Adams). Bog Walk, St. Catherine, Jamaica. M.C.Z., 65838.

10, 11. Tropicorbis obstructus (Morelet). Catamas Lake, El Abra, Mexico. B1218.

12. Tropicorbis shimeti F. C. Baker. Onetope, Nicaragua. Holotype. U.S.N.M., 534290.

13, 14. Tropicorbis shimski F. C. Baker. Ometope, Nicaragua. Paratypes. U.S.N.M., 534290 .

15-18. Tropicorbis albicans (Pfr.). Mangrove Cay, along Kings Road, Lisbon Point, Andros Island, Bahamas. U.S.N.M., 270084.

19. Tropicorbis albicans (Pfr.). Cuba. U.I., Z40459.

20. Tropicorbis paparyensis (F. Baker). Anapolis, Brazil. M.C.Z., 65717.

21. Tropicorbis obstructus donbilli (Tristram). Tamosopo, Mexico. U.I., Z28545.

Figures 18 to 21 illustrate form of lamellae in aperture

22. Tropicorbis obstructus (Morelet). Pistae, Yucatan. M.C.Z., 59754.

23. Tropicorbis obstructus donbilli (Tristram). Tamosopo, Mexico. U.I., Z28545.

24. Tropicorbis jancircnsis (Clessin). Bahia, Brazil. U.S.N.M., 152677.

25. Tropicorbis nigrilabris (Lutz). Brazil. U.S.N.M., 535713.

26. Tropicorbis paparyensis (F. Baker). Anapolis, Brazil. M.C.Z., 65717.

27. Tropicorbis schrammi (Crosse). Martinique. U.I., Z40464.

28. Tropicorbis shimcki F. C. Baker. Coatzocoalcos, Mexico. U.S.N.M., 219696.

29. Tropicorbis albicans (Pfr.). Mangrove Cay, Andros, Bahamas. U.S.N.M., 270084.

Figures 22 to 29 illustrate lamellae on parietal wall

Figures 1 to 11 are enlarged about four diameters; figs. 12 to 29 , six diameters. 


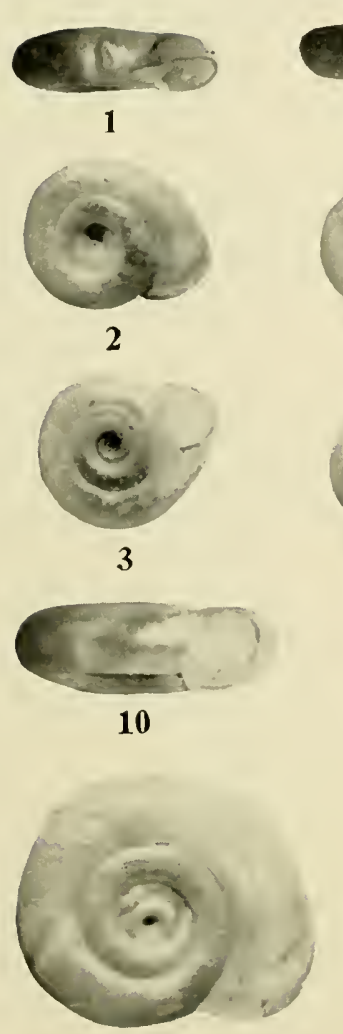

11

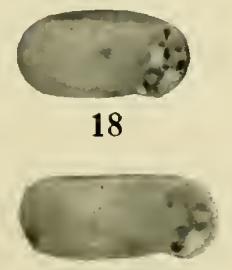

19

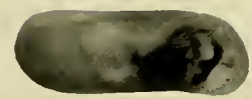

20

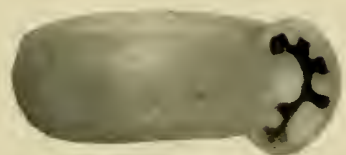

21

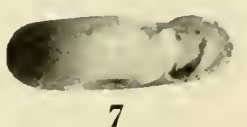

4
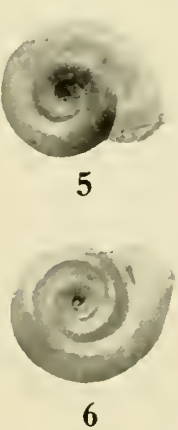

6
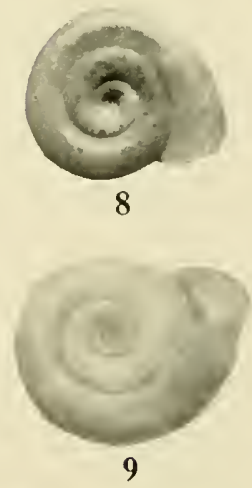
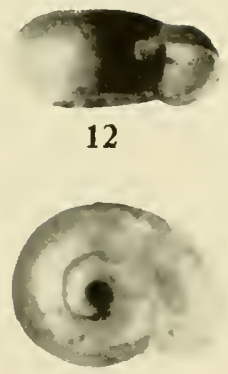

13

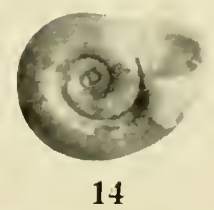

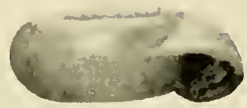

15
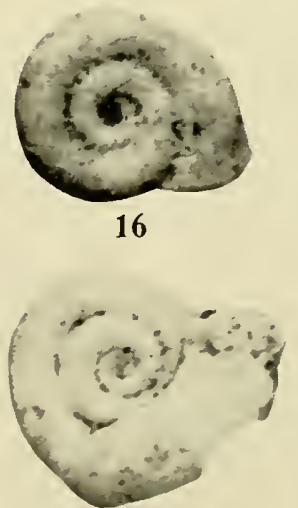

17
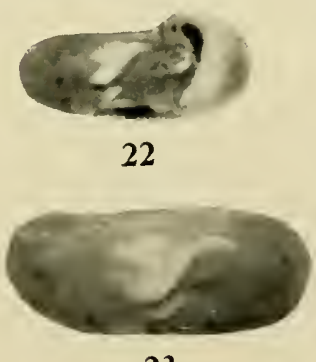

23

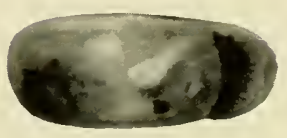

24
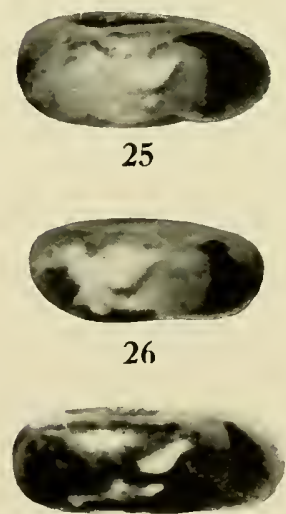

27
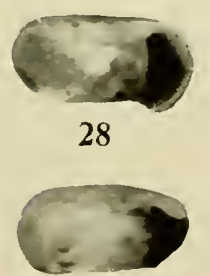

29

PLATE 134 


\section{PLATE 135}

\section{Shells of Planorbidae}

1-3. Tropicorbis peregrimus (Orbigny). Montevideo, Uruguay. U.S.X.M., 535952.

4. Tropicorbis peregrinus (Orbigny). Arroyo de Solon. Uruguay. U.S.N.M., 380999. 5-8. Tropicorbis centimetralis (Lutz). From Lutz. U.S.N.M., 535956.

9-11. Tropicorbis chilensis (Clessin). Peru. Lea Coll. from Paris Museum. U.S.N.M., 126412.

12, 13. Tropicorbis philippianus (Dunker). Lake near Coma de Ipaguaza, Boliria (15 mi. N.E. of Yacuiba). U.S.T.M., 341049.

14-16. Tropicorbis meridacusis (Preston). Ruicon de Valle, near Caracas, Tenezuela. U.S.N.M., 362132.

17-19. Tropicorbis bourcurdianus (Preston). Manzanello, Mexico. U.S.X.M., 219755.

20.21. Tropicorbis cononicus (Cousin). Soacha, near Bogata, Colombia. M.C.Z.

22, 23. Tropicorbis canonicus (Cousin). 'La Picata' near Bogata, Colombia. M.C.Z.

24-27. Tropicorbis canonicus (Cousin). Ibarra, Ecuador. M.C.Z., 64967.

28-31. Tropicorbis trigyrus (Philippi). Small lake near Titicaca, Peru. (14,000 feet elevation). U.S.N.M., 271591.

32-35. Tropicorbis gracilentus (Could). 30 miles S.W. of Santiago. Mexico. U.S.N.M., 28384.

All figures are enlarged about $2 \frac{1}{2}$ diameters 
Illustrations of the Anatomy and of Shells

507

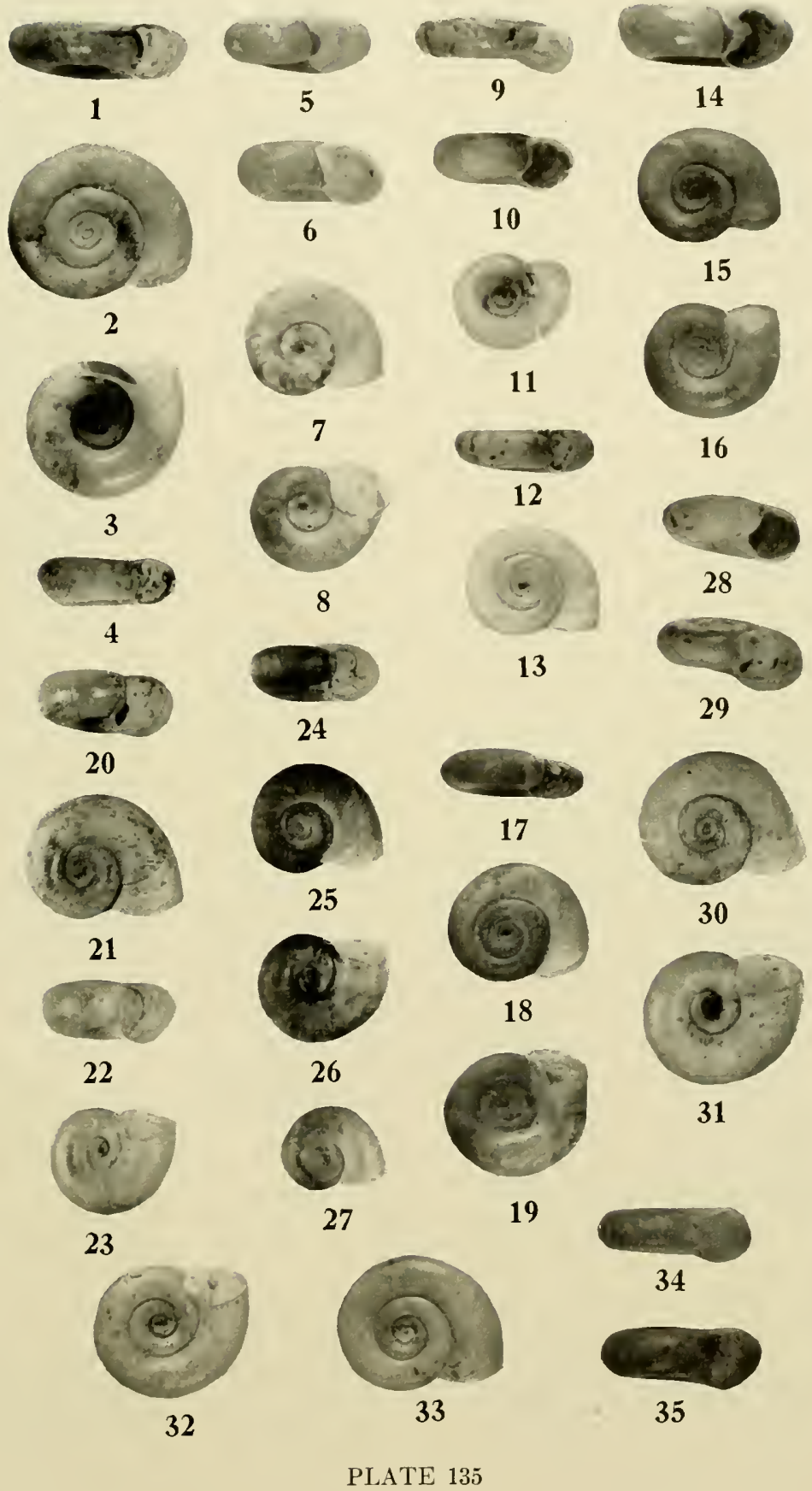




\section{PLATE 136}

\section{Shells of Planorbidae}

1-3. Gyraulus albus (Müller). Scaly Beck, near Scarborough, England. No. 3 shows fine spiral sculpture. Baker coll., 2768.

4-7. Gyraulus hirsutus (Crould). Lỵnnfield, Massachusetts. M.C.Z., 34915.

S-10. Gyraulus hirsutus (Gould). Lynnfield, Massachusetts. M.C.Z., 34915.

11. Gyraulus hirsutus (Could). Lynnfield, Massachusetts. Base of shell showing rounded whorls. M.C.Z., 34915.

12. Gyraulus hirsutus (Gould). Lynnfield, Massachusetts. Hirsute shell showing larger and less numerous rows than in albus, fig. 3 .

13-15. Gyraulus deflectus (Say). Miller Bay, Lake Winnebago, Wisconsin. Baker Coll., 2036.

16, 17. Gyraulus deflectus (Say). Lake Maxinkuckee, Indiana. Baker Coll., 127.

18-20. Gyraulus deflectus (Say). Miller Bay, Lake Winnebago, Wisconsin. Baker Coll. 2036.

21. Gyraulus deflectus (Say). Harbor Island, Lake George, New York. U.S.N.M., 426560. Showing hirsute periostracum.

22. Gyruulus deflectus obliquus (DeKay). Okoboji Lake, Iowa. Showing hirsute epidermis. U.S.N.M., 525319.

23. Gyraulus deflectus (Say). Lake Maxinkuckee, Indiana. Immature specimen with hairy periostracum. Baker Coll., 127.

24. Gyraulus deftectus (Siy). Harbor Island, Lake George, New York. Specimen with very acute periphery and hairy periostracum. U.S.N.M., 426560.

25, 26. Gyraulus deflectus (Say). Lake Maxinkuckee, Indiana. Immature. Baker Coll., 127.

27-31. Gyraulus deflectus obliquus (DeKaỵ). Round Pond, Charlotte, near Rochester, New York. Baker Coll., 1120.

32-37. Gyraulus borealis (Westerlund). Tanana River, Chena, Alaska. U.S.N.M., 193289.

38. Gyraulus borealis (Westerhund). Popoff Island, Shumigins Group, Alaska. T.S.Y.M., 180292.

39. Gyraulus borcalis (Westerlund). Saigan, Siberia. From Zool. Mus. Russia. Named by Westerlund. U.S.I.M., 15248.

All specimens are enlarged four diameters 


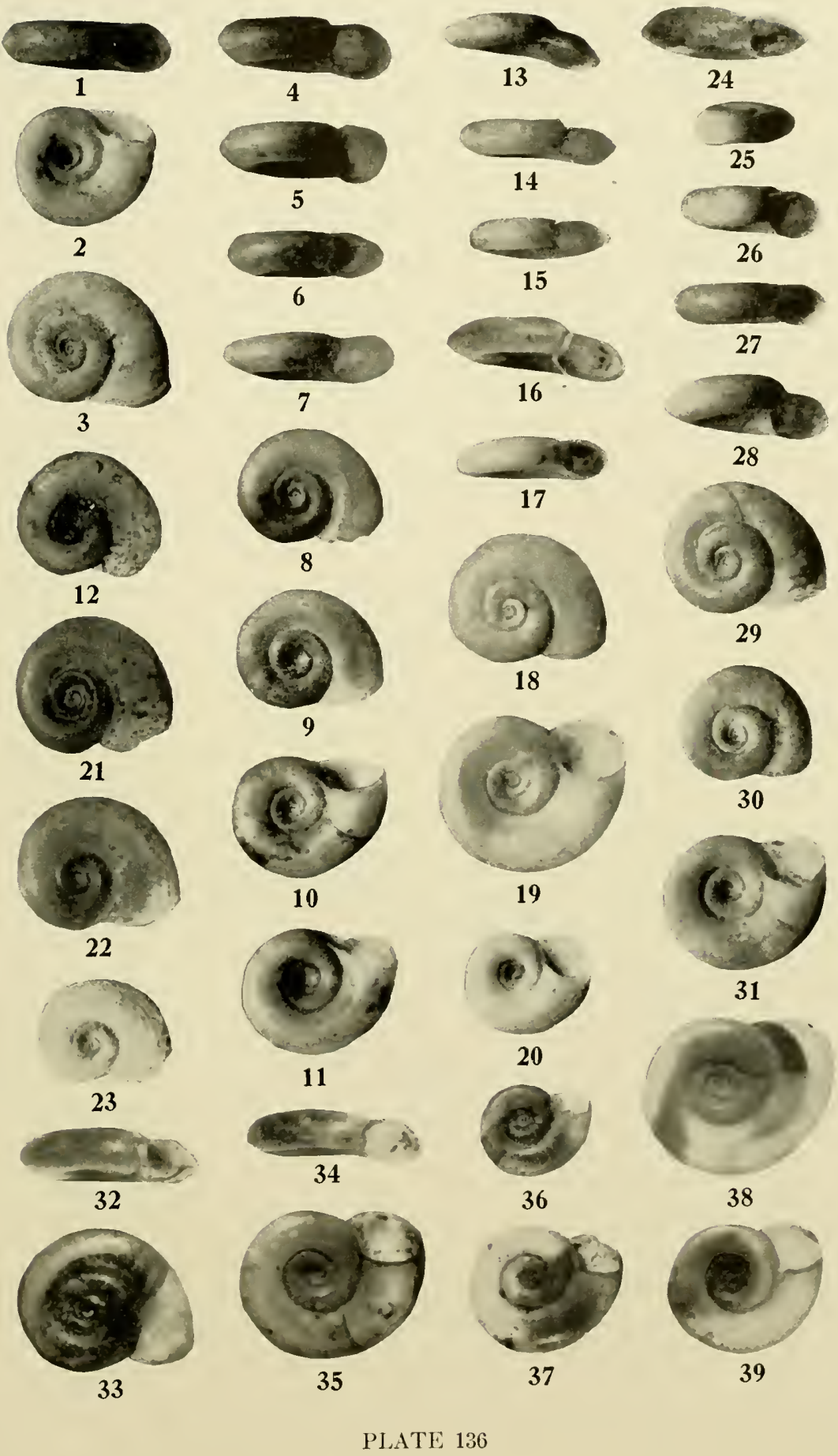




\section{PLATE 137}

\section{Shells of Planorbidae}

1-13. Taphius andecolus (Orb.). Duli, Lake Titicaca, Peru. U.S.X.M., 251596.

14, 15. Taphius pronus (Martens). From Lutz. U.S.N.M., 535957.

16.17; 19-21. Taphius promus (Martens). Penninsula de Cobrera, Lake Valencia, Venezuela. M.C.Z., 111649.

1S, 22-24. Taphius pronus (Martens). (Fossil, $110 \mathrm{ft}$. .) Lake Valencia, Venezuela. B3382.

25-27. Taphius montanus (Orb.). Duli, Lake Titicaca. Perı. C. Brües. T.S.M.M., 27159 S.

28. Australorbis immunis (Lutz). Immature. Rio de Janeiro, Brazil. M.C.Z., 7457S.

29.30. Australorbis immunis (Lutz). Rio de Janeiro, Brazil. M.C.Z.. 7457s.

31-34. Australorbis immumis (Lutz). (From Lutz) Rio de Janeiro, Brazil. U.S.N.M., 535953.

35, 36. Australorbis guadeloupensis (Sowb.). Cuadeloupe. Salle Coll. U.S.M.M., 151238. 
Illustrations of the Anatomy and of Shells

511

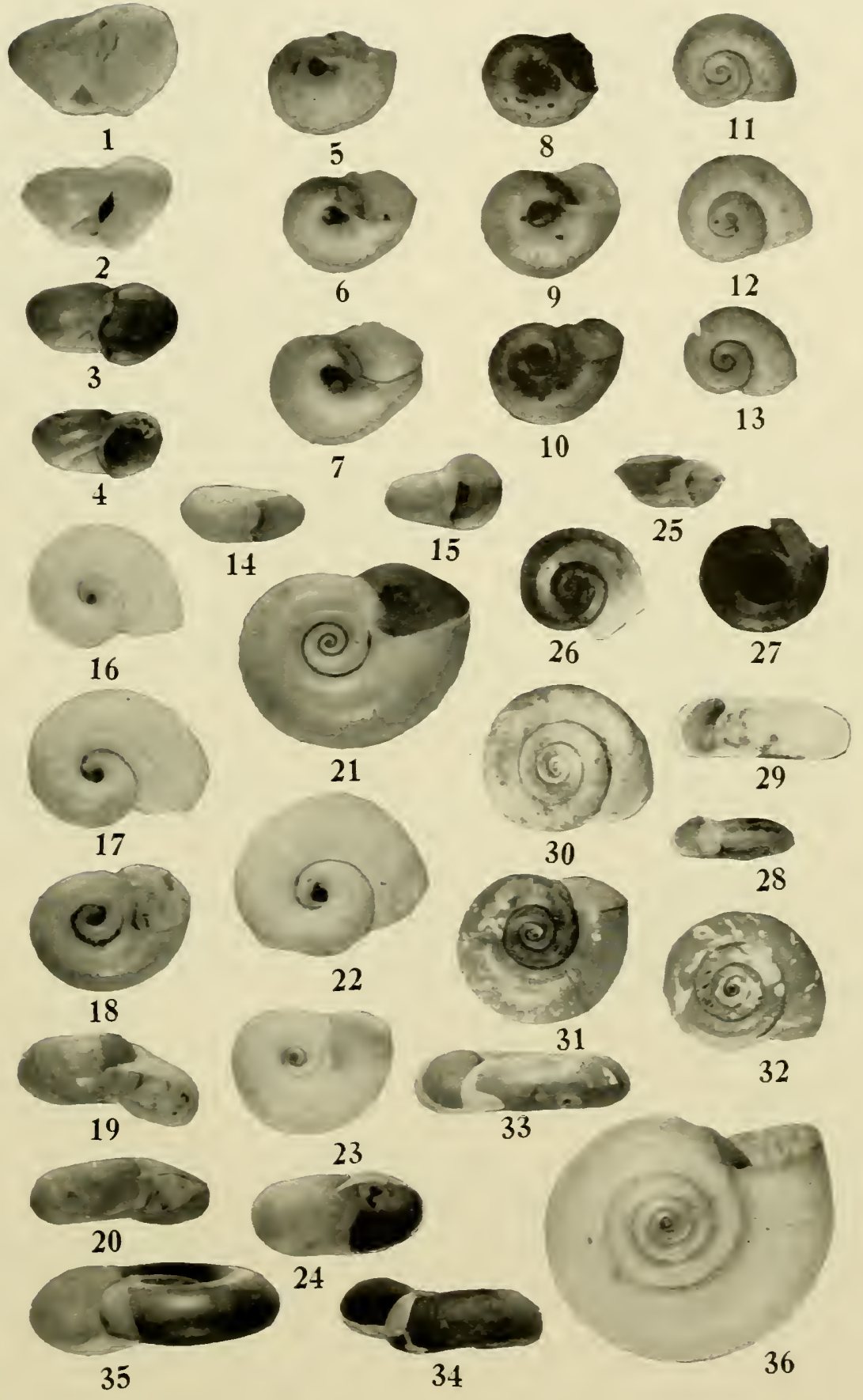

PLATE 137 


\section{PLATE 138}

Shells of Planorbidae

1,2. Australorbis lugubris (Wagner). Caracas, Venezuela. Lea Coll. U.S.N.M., 126406.

3.4. Australorbis lugubris (Wagner). Between Caracas and Puerto Cabello, Venezuela. Salle Coll. U.S.N.M., 336132.

5-7. Australorbis lugubris (Wagner). San Domingo, Brazil. M.C.Z., 74588.

8.9. Australorbis lugubris (Wagner). Near Caracas, Venezuela. U.S.N.M., 426247.

10. Australorbis lugubris (Wagner). Brazil. Lea Coll. U.S.N.M., 121006.

11, 12. Australorbis blauneri (Germain). Isle Vieques, Puerto Rico. Webb Coll. U.I., Z40479.

13-15, 19. Australorbis bahiensis (Dunker). Montevideo, Uruguay. U.S.N.M., 124592.

16, 18. Australorbis bahiensis (Dunker). Campos, Brazil. M.C.Z.. 74584.

17. Australorbis bahiensis (Dunker). Campos, Brazil. M.C.Z., 74585.

20. Australorbis bahiensis (Dunker). (nigricans, from Lutz). U.S.N.M., 535955.

21-23. Australorbis bahicnsis (Dunker). Victoria, Brazil. M.C.Z., 74586.

24, 25. Australorbis bahiensis (Dunker). San Domingo, Brazil. M.C.Z., 74588.

26, 27. Australorbis bahionsis (Dunker). Bahia, Brazil. M.C.Z., 74587. 

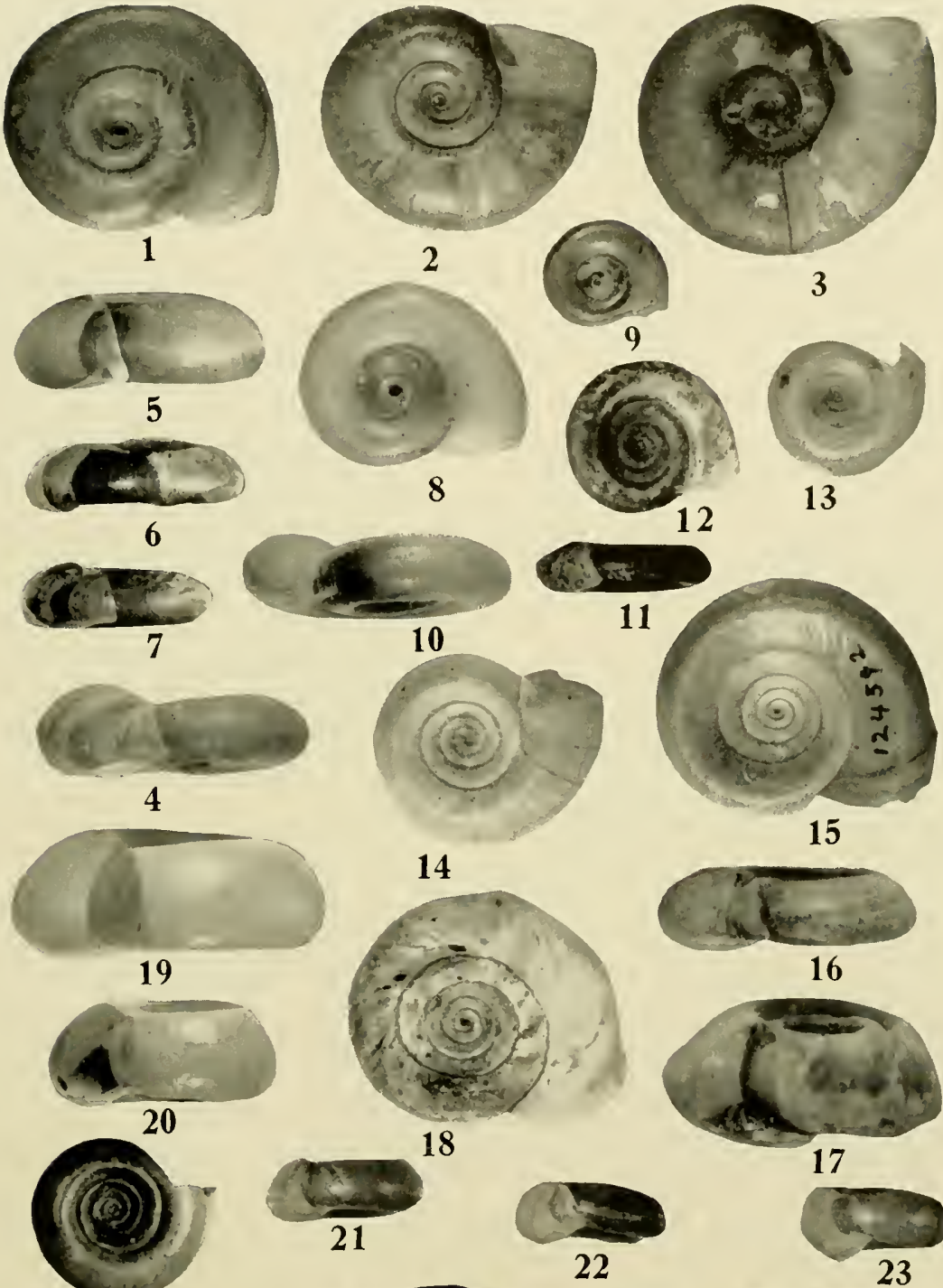

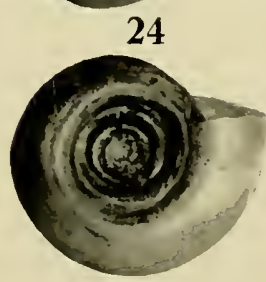

25

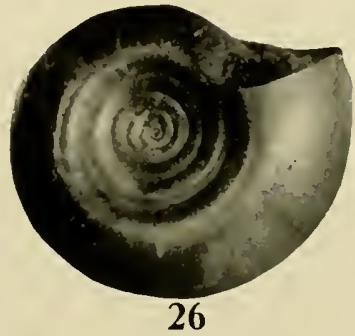

PLATE 138
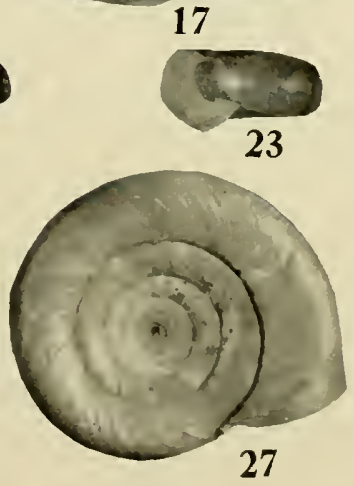

27 


\section{PLATE 139}

Shells of Planorbidae

1,2. Australorbis paysanduensis (Marshall). (Figured type). Paysandu, Uruguay. U.S.N.M., 380693.

3, 4. Australorbis paysanduensis (Marshall). (Paratype). Paysandu, Uruguay. U.S.N.M., 380694.

5. Australorbis paysanducnsis (Marshall). Paysandu, Uruguay. F. Felippo Coll. U.S.N.M., 322385.

6, 7. Australorbis tenagophilus (Orb.). Corrientes, Brazil. M.C.Z., 104573.

8-10. Australorbis tenagophilus (Orb.). Montevideo, Uruguay. U.S.N.M., 380522.

11, 12. Australorbis tenagophilus (Orb.). Young. Arroyo Jurical, Dept. San Jose, Uruguay. U.S.N.M., 380746.

13, 14. Australorbis tenagophilus (Orb.). Arroyo Jurical, Dept. San Jose, Uruguay. U.S.N.M., 346818.

15, 16. Australorbis tenagophilus (Orb.). Arroyo de Solon, Dept. Duragno, Uruguay. U.S.N.M., 380997.

17, 18. Australorbis tenagophilus (Orb.). Rio Couraguam, Brazil. Ton Ihering Coll. U.S.N.M., 122309.

19-25. Australorbis glabratus christopherensis Pilsbry. St. Kitts. West Indies.

26-28. Australorbis antignensis (Sowb.). Near Quebradillas, Puerto Rico. Pilsbry Coll. M.C.Z., 103302.

29,30. Australorbis antiguensis (Sowb.). St. Kitts. M.C.Z., 74651.

31. Australorbis glabratus refulgens (Dunker). Cotye. Santo Domingo. M.C.Z., 83890.

32. Australorbis glabratus olivaceus (Spix and Wagner). Immature. Januaria, Brazil. M.C.Z., 74577.

33. Australorbis glabratus olivaceus (Spix and Wagner). Immature. Brazil. M.C.Z., no number.

34,35. Australorbis glabratus olivaeeus (Spix and Wagner). Januaria, Brazil. M.C.Z., 74577.

36. Australorbis glabratus olivaceus (Spix and Wagner). St. Laurent du Maroni, French Guiana. Bequaert Coll. M.C.Z., 102281. 
Illustrations of the Anatomy and of Shells

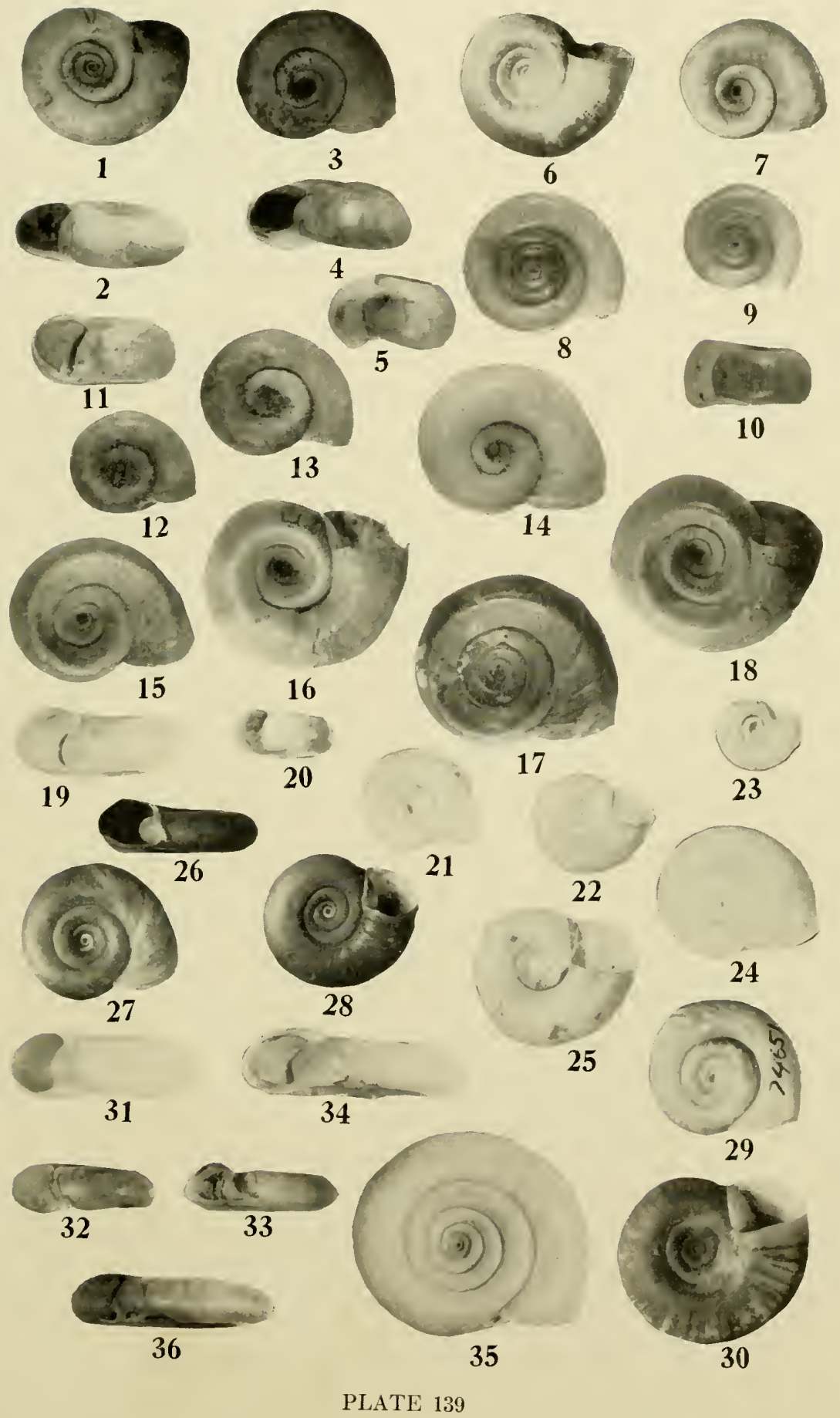


PLATE 140

\section{Shells of Planorbidae}

1-3. Australorbis glabratus olivaceus (Spix and Wagner). Brazl. Lea Coll. U.S.NM., 121204.

4. Australorbis glabratus olivaceus (Spix and Wagner). Near Maracay, Arugua State, Venezuela. U.S.N.M., 349069.

5,6. Australorbis glabratus (Say). San Juan, Puerto Rico. Bequaert. M.C.Z., 65218.

7,8. Australorbis glabratus (Say). Guadeloupe Island. Bequaert. M.C.Z., 64969.

9. Australorbis glabratus (Say). Immature. Cinadeloupe Island. Bequaert. M.C.Z., no number.

10-12. Australorbis glabratus (Say). Inmature. Castres, St. Lucia, II.I. M.C.Z., 72552.

13, 14. Australorbis glabratus (Say). Young. Ia Juria, Tortuoguera, Puerto Rico. Henderson Coll. U.S.N.M., 535961.

15-17. Australorbis glabratus (Say). Antigua. Th. Gill Coll. U.S.N.M., 454061.

18. Australorbis glabratus (Say). Immature. Puerto Rico. U.S.N.M., 535961.

19,20. Australorbis glabratus christopherensis Pilsbry. Marie Galante. U.S.N.M., 390137.

21. Australorbis glabratus christopherensis Pilsbry. Franklin Fstate. St. Christopher. U.S.N.M., 390136.

22. Menetus dalli F. C. Baker. Holotype. Pliocene. Caloosahatchie River, Florida. IT. H. Dall Coll. U.S.N.M., 112556.

23, 24. Menetus dalli F. C. Baker. Paratypes. Pliocene. Caloosahatehie River, Florida. II. H. Dall Coll. U.S.N.M., 112556.

25. Menetus alabamensis arus (Pilsbry). Caloosahatchie River, Florida. W. H. Dall Coll. U.S.N.M., 112556.

26. Menetus kansasensis F. C. Baker. Paratype. (90 feet deep in cliy). Mearle County, Kansas. U.I., P6778.

27. Menctus kansasensis F. C. Baker. Holotype. (90 feet deep in clay). Meade County, Kansas. U.I., P6778.

28, 29. Menetus kansasensis F. C. Baker. Paratypes. U.I., P6rz8. 
Illustrations of the Anatomy and of Shells
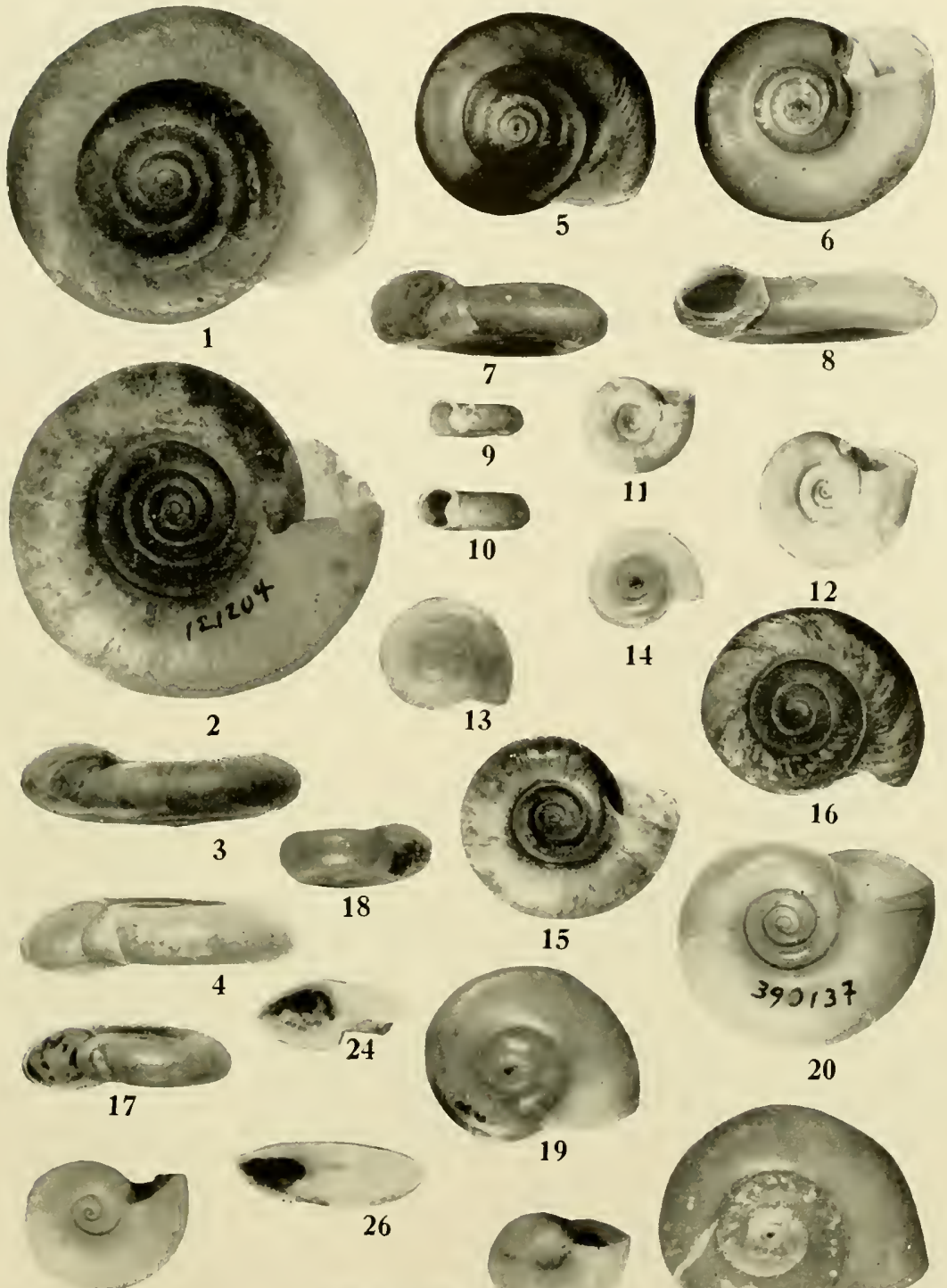

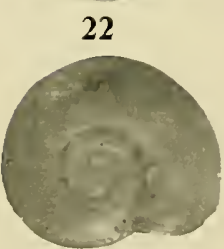

23

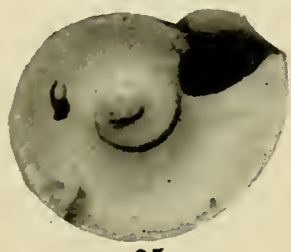

25
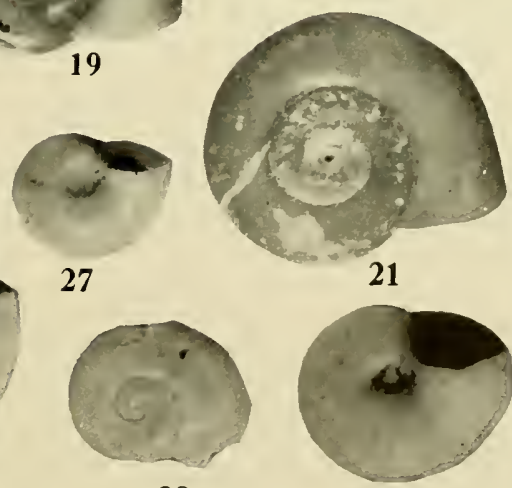

28

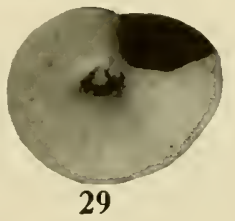

PLATE 140 


\section{PLATE 141}

\section{Shells of Planorbidae}

1. Tropicorbis pedrinus (Miller). Rio Lope Castro, Parana, Brazil. W. L. Schmidt Coll. U.S.N.M., 365157 .

2-4. Tropicorbis petcnensis Morelet. Laguna de Peten. Remate, Guatemala. U.S.N.M., 382775.

5-7. Tropicorbis denticus (Morelet). Belize, Honduras. A.N.S.P., 123897.

8-11. It clisoma affine. Young. Hents Bay, St. Andrew, Jamaica. U.S.N.M., 378049.

12. Ilelisoma foveale (Menke). U.S.N.M., 378040.

13-18. Helisoma foveale (Menke). Frankfield, Clarendon, Jamaica. U.S.X.M., 400632.

19. Helisoma equatorium (Cousin). (Beach) Eben, Peru. U.S.N.M., 347900.

20,21. Melisoma equatorium (Cousin). Milagis. Ecuardor. U.I., Z405z2.

22, 23. Ilelisoma equatorium (Cousin). (Labelled habirnsis). Ecuador. Lea Coll. U.S.N.M., 126411.

24.25. Helisoma equatorium (Cousin). Quito, Ecuador. Bequacrt. M.C.Z.. 64965.

26-28. Planorbis turgidus Jeffr. 'Type. 'Georgia.' (Britain in error). U.S.N.M., 65265.

29, 30. Ilelisoma perurianum (Brod.). Callao, Peru. (Like Clessin's figures). U.I., Z40593.

31.32. Helisoma peruviamum (Brod.) (= moricandi Beck.). Brazil. U.S.N.M., 20702. 33,31. Planorbis pedrimu Miller (= Tropicorbis). Moll. Blatt. n.s. 1. Plate 7.

35. Planorbis boetzkesi Miller (=Gyraulus). Moll. Blatt. n.s. 1. Plate 7. 
Illustrations of the Anatomy and of Shells

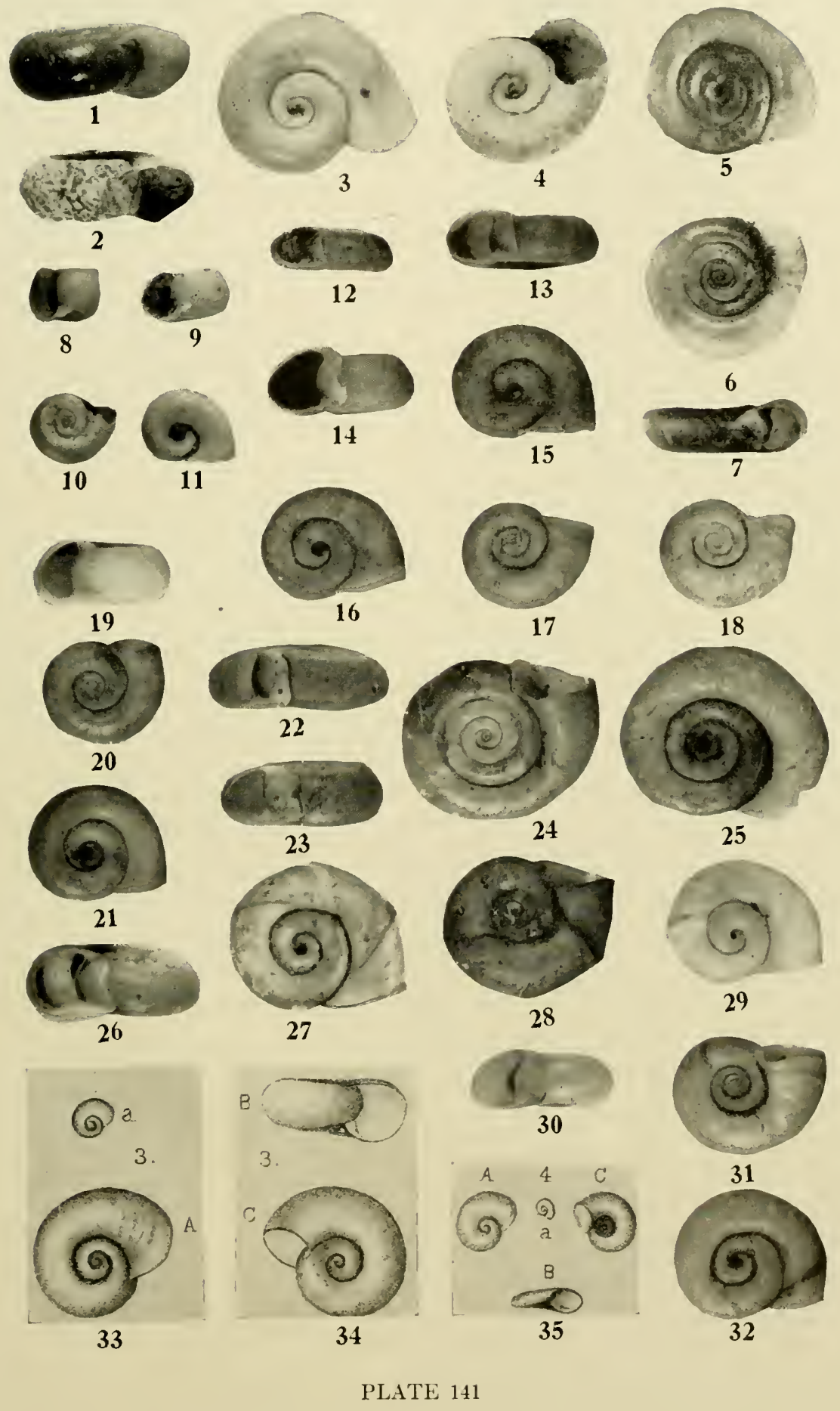



INDEXES 



\section{INDEX TO TEXT}

Since in the text of this volume all anatomical features, synonymy, distribution, and lists of ralid species are treated in full for each genus and subgenus, references to these details are not cited in the index. Similarly, the inclusion of all taxonomic names, morphologieal terms, and names of authorities where these appear in descriptions and comparisons would extend the size of the index unreasonably without adding value to the reader, hence these items are likewise omitted. A list of the more important synonyms is conveniently available in the text in a chronological list following the heading for each group; consequently these names are not repeated in the index.

For each seientifie name the chief reference to the full taxonomic and morphologieal treatment is eited in boldface type.

To avoid confusion of numerals for page, plate, and figure numbers, a separate index to the illustrations has been prepared wherein all figures are listed under the respective generic and specific names used in the explanation of the plates.

abdominal ganglia 14

accessory cusps 11

acknowledgments is

Acrorbis $47,49,121$

affinities uncertain 192

Afroplanorbis $21,46,48,86$

Aguayo 22

albumen gland 6

anatomical keys 46

anatomy, internal 4

Andrews 25

Anisopsis 48, 94

Anisus 9, 46, 48, 55

anticostianum, II lisoma anceps, n. var.

$$
219
$$

aorta 13

Armiger 46, 48, 75

arteries 13

arterioles 13

Atropoarmiger 78

auricle 13

Australorbis 21, 46, 48, 90

aut ofecundation 29

Baker, Frank Collins

biographical contributions xxxy

book notices and reviews xxy.

memorial to xvii

scientific publications $\mathrm{xxy}$

bartsehi, Helisoma anceps, n. var. 219

Bathyomphalus 46, 48, 62

bibliography 204

biographical sketch xvii

Biomphalaria 48, 89

blood flukes 21

blood sinuses 13

Boycott 29

buccal ganglia 14

buecal sac 9

Bulinidae 196

Bulinus 21, 50, 196 callus 15

Campelona 29

Carinifex 47, 49, 154

carrefour 6

Castalia 19

central tooth 11

cephalic artery 13

cercariae 21

cerebral ganglia 14

Chadwick 29

Choanomphalus 49, 192

circulatory system 13

Clapp 7

classification,

history of 41

new 45

Clonorchis 21

color of shell 16

coloradoensis, Menetus, n. sp. 230

Colton 29

columbiense, IIclisoma, n. sp. 222

costae 16

Costorbis 48, 61

Crabb $7,27,29,30,31$

crassilabris, Menetus eooperi, n. var. 230

Cristoarmiger $7 \mathrm{~S}$

crop 9

erystalline style 10

cubense, Helisoma caribneum, n. var. 222

cusps, accessoly 11

central 11

dalli, Helisoma campanulatum, n. var. 226

Uenetus, n. sp. 231

Parapholyx effusa, n. var. 227

derelopment 25

dextral 3

diaphragm 7

digestive system 9 
dispersal of species 39

distribution 37

Drepanotrema 21, 47, 49, 114

ecology 17

egg gland 6

embryological development 25 et seq.

envilonmental conditions 17

error in generic reference 202

eupyrene spermatozoa 7

excitatory organ 8

eyes 3

\section{Fasciola 22}

Fasciolopsis 22

Faust 21, 22, 24, 31

figured specimens, repositories of, 216

foridensis, Menetus dilatatus, n. var. 232

flukes 21

food, for other animals 19

habits 19

foot 3

foreword to Part II 215

Fossaria 22

Fossulorbis 47, 49, 118

ganglia 14

genera recognized 48

wrongly referred 202

genus new in this volume

Pingiella 109

geographical distribution 38

geological history 37

gizzard 9

groups of uncertain affinities 192

growth lines 16

Gyraulus 17, 22, 46, 48, 65

haemocyanin 13

haemoglobin 13

haemolymph 13

Haldemamina 49, 177

head 3

Helieorbis 22, 49, 106

Helisoma 47, 49, 123

anceps anticostianum, n. var. 219

anceps bartschi, n. var. 219

anceps idahoense, n. var. 220

anceps politum, n. var. 221

binneyi rondolphi, n. var. 221

campanulatum dalli, n. var. 226

campanulatum pleistocenicum, n. var. 226

campanulatum rideauense, n. var. 227

caribaenm cubense, n. var, 222

columbiense, n. sp. 222

kemicotti, n. sp. 223

pilsbryi preblei, n. var. 224

subcrenatum perdisjunctum, n. var. 224

trivolvis marshalli, n. var. 225

Helisomatinae 5, 123

key to genera of, 47

hermaphrodite duct 5
Heterodiscus 48, 88

Hippeutis 47, 49, 100

history of classification 41

Hoffnan 22, 23

Holmes 25

hosts 21

idahoense, Helisoma anceps, n. var. 220

Indoplanorbis 196

intermediate teeth 11

internal anatomy 4

intestine 9

Intha 47, 49, 112

Jankowski 23, 54, 60, 69

jaw 10

kennieotti, Hclisoma, n. sp. 223

kers to groups 46

to genera 46 et seq.

to subfamilies 46

kidney 12

Krull 31

labiatus, Menetus, n. sp. 232

lacunae 13

Lankester 25, 28

Lurambergue 5, 29

Lateorbis, n. subgen. $47,48,85$

lateral teeth 11

length of life 20

life, length of 20

lines of growth 16

lingual ribbon 11

liver 9

liver fluke 22

locomotion 19

Lowrance 25, 28

Lutz 24

Lymnaea 22

Lymnaeidae, monograph of, ix, 16. 18, 19

male organs 4

mantle collar 3

marginal teeth 11

marshalli, Iletisoma trivolvis, n. var. 225

Martins 24

Mattox 12,29

memorial to Baker xrii

Henetus 17, 23, 48, 49, 182

Menetus coloradoensis, n. sp. 230

cooperi crassilabris, n. var. 230

cooperi planospirus, n. var. 231

dalli, n. sp. 231

dilatatus floridensis, n. var. 232

labiatus, n. sp. 232

portlandensis, n. sp. 233

mesometamorphosis 11

Metagonimus 21

Mieromenetus, n. subgen. 48, 49, 187

migration 40

migrat ory birds 40

Miller 22

miracidium 21

morphology 3 
muscular system 15

museums as repositories 216

\section{Nautilinus 202}

Nautiloarmiger 78

nephridium 12

nervous system 14

new classifieation 45

new genus in this rolume

Pingiclla 109

new species and rarieties listed 218

new speeies in this rolume

Helisoma columbiense 222 kennicotti 223

Henetus coloradoensis 230 dalli 231

labiatus 232

portlandensis 233

Parapholyx pusilla 229

Planorbula smithii 229

Tropicorbis shimeki 218

new subfamily in this rolume

Segmentininae 96

new subgenera in this rolume

Latcorbis 85

Hicromenctus 187

new subgeneric nime

Syrioplanorbis 88

new varieties in this volume

IIelisoma anccps anticostianum 219 anceps bartschi 219

anceps idahoense 220

anceps politum 221

binneyi randolphi 221

campanulatum dalli 226

campanulatum pleistoccnicum 226

companulatum rideauense 227

caribacum cubcnse $\mathbf{2 2 2}$

pilsbryi preblei 224

subcrenatum perdisjunctum 224

trivolvis marshalli 225

Mcnctus cooperi crassilabris 230 cooperi planospirus 231

dilatatus floridensis $\mathbf{2 3 2}$

Parapholyx effusa dalli 227

klamathensis sinitsini 228

nidamental gland 6

nidifieation 25

Obstructio 47, 48, 85

Odontogyrorbis 48, 64

oesophagus 9

Oncomelania 21

orientation of shell 15,50

oviduct 5

ovisperm duct 5,6

orotestis 6

Palaeorbis 202

Parapholyx 47, 49, 161

effusa dalli, n. var. 227

lilamathensis sinitsini, n. var. 228

pusilla, n. sp. 229
Paraplanorbis 49, 119

parasitic worths 21

pedal ganglion 14

penial complex 4,7

gland 8

gland duet 5

penis 7

perdisjunctum, Helisoma subcrenatum, n. var. 224

pericardium 13

periostracun 16

Perrimilla 160

Physa. 22

Physopsis 21, 50

Pierosoma 47, 49, 134

pilatsters 7

Pilsbry ix, 11, 45, 196

Pingiella, n. gen. 22, 47, 49, 109

Plrnorbarius 47, 49, 166

Planorbclla 47, 49, 150

Planorbidae ix, $3,17,21,37,41,45.48$ as hosts 21

Planorbifex 49, 190

Planorbinae 50

key to genera of, 46

Planorbis 22, 46, 48, 50, 51

Planorbula 17, 48, 49, 172

smithii, n. sp. 229

Planorbulinae 172

key to genera of. 48

planospirus, Mcnetus cooperi, n. var. 231

Platytaphizes 49, 120

pleistocenicum, Helisoma campanulatum, n. var. 226

pleural ganglia 14

jneumostome 3,14

Poccilospira 49, 194

politum, Helisoma anceps, n. vall. 221

Polypylis 22, 47, 49, 104

Pompholopsis 49, 165

portlandensis, Menetus, n. sp. 233

Potamogeton 19

preblei, Hclisoma pilsbryi, n. var. 224

preputium 4, 7

Promenetus 48, 49, 178

prostate 5

jseudoblanch $3,14,50,196$

Pseudosuccinea 22

mublications of F. C. Baker xxy

pulmonary siphon 14

pusilla, Parapholyx, n. sp.

229

pyloris 9

Radix 22

radula 11,50

randolphi, Helisoma binneyi, n. var. 221

receptaculum seminis 6

rectum 9

rediae 21

renal organ 12

lepositories of specimens 216 
reproductive system 4

respiratory srstem 14

rideauense, Helisoma campanulatum, $\mathrm{n}$. var. 227

Rothschild 24

salivary glands 9

sarcobelum 8

Schistosoma 21

sculpture 16

Segmentina $22,47,48,96$

Segmentininae, key to genera of, 47 new subfamily 96

self fertilization 29

seminal resicle 5

Seminolina 47, 49, 129

shell 15,50

shimeki, Tropicorbis, 11. sp. 218

Simroth 5

sinistral 3

sinitsini, Parapholy, klamathensis, n. var. 228

sinuses 13

siplion, pulmonary, 14

size of shell 15

smithii, Planorbula, n. sp. 229

species, dispersal of, 39

new in this volume 218

Helisoma columbiense 222

kennicotti 223

Henctus coloradoensis 233

dalli 231

labiatus 232

portlandensis 233

Parapholyx pusilla 229

Planorbula smithii. 229

Tropicorbis shimeti 218

specimens figured. repositories of, 216

sperm duct 5

spermatheca 6

spermatophrore 6

gland 8

spermatozoa 7

sporocysts 21

Stagnicola 22

Sterki 11, 19

stomach 9

strle, crystalline, 10

stylet 7

stylotheca 10

subfamily new in this rolune

Segmentininae 96 subgenera new in this volume Lateorbis 85

Mieromenetus 187

subgeneric name new in this volume Syrioplanorbis 88

Syrioplanorbis, new name 48, 88

systematic account 50 list 48

Taphius 48, 79

Tarlor 5. 6

tentacles 3

Torquis 46, 48, 72

trematode worms 21

trivolvis, species allied to, 138

Trochorbis 108

Tropicorbis $17,21,46,47,48,49,80$

shimeti, n. sp. 218

nmbilicus 50

uncertain affinities 192

ureter 12

uterus 6

vagina 6

Van Cleave 29

variations 18

varieties, new 218

Helisoma anceps anticostianum 219 anceps bartschi 219

anceps politum 221

binne yi randolphi 221

campanulatum dalli 226

campanulatum pleistocenicum 226

campanulatum rideauense 227

caribaenm cubense 222

pilsbryi preblei 224

subcrenatum perdisjunetum 224

Menetus cooperi planospirus 231 dilatatus foridensis 232

Parapholyx effusa dalli 227

Flamathensis sinitsini 228

vas deferens 4

velum 3

ventricle 13

verge 7

vergic sac 4,7

risceral artery 13

ganglia 14

Torticifex 49, 159

IV ard 22

Wenz 37

Wesenburg-Lund 24

worms, parasitic, 21 


\section{INDEX TO ILLUSTRATIONS}

In this index, boldface type is used to refer to plate numbers; figure numbers are in regular type.

Acrorbis petricola $72: 1-10$

Afroplanorbis adowensis $71: 10-12 ; 81: 2$ pfeifferi $71: 7-9$ sudanicus $81: 3$

Anisopsis calculus $81: 10$ loryi $81: 11$

Anisus leucostomus $7: 1-5 ; 47: 15$; $77: 16-18$

septemgyratus $7: 6$ spirorbis $6: 5,7,13 ; 47: 13,16 ; 50: 25$; $67: 6 ; 77: 20-22$ vortex $6: 1-4,6 ; 47: 12,14 ; 77: 19$

Armiger crista $18: 6-11 ; 47: 20,21 ; 48: 15$; $50: 20 ; 69: 6 ; 76: 6$

Australorbis antiguensis 139:26-30 bahiensis 138:13-27

blauneri 138: 11-12

glabratus $9: 4-10 ; 45: 1,7-11 ; 48: 9,10$; $50: 13 ; 68: 5 ; 77: 29-31 ; 140: 5-18$ glabratus christopherensis 139:19-25; $140: 19-21$

glabratus olivacens $139: 32-36 ; 140: 1-4$ glabratus refulgen. 139:31

guadcloupensis $137: 35,36$

immunis $137: 28-34$

lugubris 138:1-10

paysanduensis 139:1-5

tenagophitus $139: 6-18$

Bathyomphalus contortus $3: 5-10 ; 46: 19$, $20 ; 48: 8 ; 68: 1 ; 77: 23-25$

Biomphalaria smithi $81: 4$

Bulinus contortus 75:4-6

Carinifex jacksonensis $35: 2-9 ; 49: 17,18$; $65: 4 ; 115: 8-13$

newberiyi $78: 23,24 ; 112: 9-11 ; 113: 1$ $23 ; 114: 14-16$

newberryi malleata $113: 24-30$

newberryi minor $78: 25,26 ; 114: 19-24$

newberryi subrotunda $114: 25-28$

occidentalis $112: 12-21 ; 114: 17$ ponsonbyi $34: 1-12 ; 35: 1 ; 45: 2,12$;

$48: 3 ; 49: 19 ; 67: 8 ; 114: 1-13,18$

Choanomphalus maachi $81: 7$

schrenchii $81: 9$

valuatoides $81: 8$

Costorbis strauchianus $76: 3$

Drepanotrema ahenum $124: 21-28$ anatinum 9:1-3; 68:3; 79:16-18; $124: 1-13,30$

eastaneonitens $126: 1-5$

cimex $127: 1-3,7,8,16 ; 128: 17-22$

cimex pistiae $127: 13-15$

cultratum $76: 10 ; 78: 17-19$

cultratum anitense 126:17-19 cultratum duenasianum $127: 9-12$

cultratum. labrosum 128:6-10

cultratum panueo $128: 1-5$

depressissimum 127:17-19

he teropleurus $129: 37-42$

hoffmani $10: 1-9 ; 46: 14,15 ; 50: 26$;

$68: 4 ; 78: 14-16 ; 126: 6-12$

kermatoide $126: 13-16$

lucidum $11: 1-7 ; 46: 16 ; 48: 11 ; 50: 27$; $68: 2 ; 78: 11-13 ; 124: 29,31,32$; $125: 1-17$

melleum 125:18-21

parapseide $124: 14-20$

peninsularis 128:23-25

sumichrasti 128:11-16

Gyraulius albus $14: 1-11 ; 48: 13 ; 50: 28$;

$68: 9 ; 70: 13 ; 77: 1-3 ; 136: 1-3$

borealis $126: 32-39$

circumstriatus $17: 1-5 ; 47: 2,6 ; 50: 22$; $52: 14-16$

convexiusculus $19: 1-3 ; 47: 8,17$

deflectus 136:13-21, 23-26

deflectus obliquus $16: 1-15 ; 47: 3,10$; $50: 18: 69: 2 ; 136: 22,27-31$

hirsutus $15: 1-7 ; 47: 18,19 ; 50: 17$;

$69: 1 ; 70: 5 ; 136: 4-12$

latestomus $19: 4-9 ; 47: 11$

parvus $17: 6-12 ; 47: 1,5 ; 48: 14 ; 50: 16$; $69: 3 ; 77: 4-6$

similaris $18: 1-5 ; 47: 9 ; 69: 4$

vermicularis $15: 8-10 ; 47: 4,7 ; 50: 19$; $69: 5$

Helicorbis umbilicalis 78:5-7

Helisoma affine 141:8-11

ammon $89: 25-27 ; 94: 14,15,17,20-28$; $95: 1-16$

anceps $22: 10,12 ; 23: 1-4,7-11 ; 44: 1,7$; $48: 17 ; 49: 1 ; 53: 1-3 ; 80: 1-6$;

$82: 1-19,26,30 ; 84: 1 ; 96: 23-30$

anceps anticostianum $96: 18-22$

anceps aroostookense $83: 27-29$

anccps bartschi $83: 19-22$

anceps eahni $54: 3 ; 85: 14-16$

anceps corrugatum $82: 31$

anceps idahocnse $84: 26-28 ; 101: 11,12$ anceps jordanense 84:6-8

anceps latchfordi $22: 1 ; 23: 5,6 ; 44: 8$; $54: 4 ; 85: 5-7$

anceps minnesotense $82: 27-29$

anceps percarinatum $22: 2-4,11 ; 54: 1$;

$84: 2 ; 85: 8-13$

anceps politum $83: 16-18$

anceps portagense $84: 3 ; 85: 1-4$

anceps royalensc $54: 2 ; 84: 4,9,13-17$

anceps rushi $84: 10-12$ 
Helisoma (continued)

anceps sayi $53: 4 ; 82: 32-34 ; 83: 1-6$; $84: 5$

anceps shellense $82: 23-25$

anceps striatum 82:20-22

anceps unicarinatum $83: 7-15$

binneyi 93:19-26; $94: 9-13,16,18,19$

binneyi randolphi $94: 1-8$

caloderma $115: 2-4$

campanulatum 27:1-14; 62:1; 70:1; $80: 16-19 ; 108: 1-17 ; 109: 1-6$; $111: 21,22$

campanulatum canadense $62: 3$; $110: 11-20$

campanulatum collinsi 110:27-35; $111: 17-20$

campanulatum dalli $111: 12,13,15,16$ campanulatum ferrissi 108:18-34

campanulatum michigancnse 111:6-11, 14

campanulatum pleistocenicum 110:2126

campanulatum rideauense 109:21-24

campanulatum rudentis $111: 1-5$

campanulatum smithi $49: 11,20$; $62: 4$; $109: 14-20,25 ; 110: 5-10$

campamulatum wisconsincnse 45:15-17; $62: 2 ; 109: 7-13 ; 110: 1-4$

caribreum 99:31; 100:1-17; $101: 15$; $115: 1$

caribaeum cubense 119:22-25

caribacum guatemalense 99:20-24, 3236

chautauquense $29: 19-22 ; 55: 5 ; 86: 16$ 19

columbiense 119:16-21

conanti $106: 4-7$

contrerasi $102: 2-4$

corpulcutum $31: 1-7 ; 44: 3,15 ; 49: 15$.

$57: 3 ; 106: 17,22 ; 107: 1-7,13$

corpulcntum multicostatum 31:8-13;

$44: 16 ; 58: 3 ; 106: 16 ; 107: 12,16-21$ corpulentum vermilionense $31: 14-18$; $58: 2 ; 107: 8-11,14$

costaricense $101: 8-10$

disstoni $106: 8,12-15$

duryi $33: 11,13,14 ; 103: 20-31 ; 104: 1-7$

duryi cudiscus $33: 1-7 ; 52: 9-11 ; 63: 4$; 105:14-19

duryi intercalare $105: 4-13$

duryi normale $33: 8-10,12,15-19$.

$44: 5,26 ; 49: 14 ; 52: 6-8,12$;

$64: 3,4 ; 80: 11,12 ; 104: 8-22$;

$105: 1-3$

duryi preglabratum 105:20-27

duryi seminole $80: 9 ; 102: 21-23$;

$103: 1-19 ; 106: 1-3 ; 111: 23$;

$112: 1-8$

equatorium 141:19-25

eucosmius $84: 18-21$

eucosmius vaughani $84: 22-25$

eyerdami 115:5-7

fovcale $101: 1-5 ; 141: 12-1 S$ hormi $26: 1-5 ; 44: 23 ; 49: 9 ; 60: 7$;

$90: 19-21 ; 92: 13-16$

kennicotti $89: 13-17$

magnificum $31: 20-22 ; 44: 13 ; 49: 16$;

$57: 4 ; 96: 31-34 ; 101: 7$

multivolvis $80: 19-21 ; 109: 26-29$

occidentale $32: 9,10 ; 44: 18 ; 49: 13$.

$61: 1 ; 89: 23,24 ; 93: 4-15$

occidentale depressum $93: 16-18$

oregonense $28: 1-5 ; 44: 6 ; 49: 6$;

$61: 3 ; 96: 1-12$

peruvianum 141:29-32

pilsbryi $25: 1-7 ; 44: 12 ; 49: 5 ; 56: 3$; $88: 8-10 ; 91: 5$

pilsbryi infracarinatum $25: 8-13 ; 44: 17$; $49: 8 ; 56: 4,5 ; 88: 11-16$

pilsbryi preblei $91: 6-8$

plexatum $30: 1-9 ; 44: 22 ; 49: 10$;

$58: 4-6 ; 59: 1,2 ; 89: 22$;

$92: 17-23 ; 93: 1-3$

scalare $28: 6-14 ; 44: 4,25 ; 49: 4 ; 51: 1$ -

$14 ; 52: 1-3 ; 64: 1,2 ; 70: 2,3 ; 80: 7$,

$8 ; 102: 11-20 ; 111: 23-31$

subcrenatum $30: 10-19 ; 32: 8 ; 44: 21$;

$49: 7 ; 59: 5 ; 60: 1-3 ; 61: 2 ; 70: 12$.

$89: 18-20 ; 91: 9-19 ; 92: 1-12$;

$101: 13,14$

subcrenatum disjectum $89: 21$; 90:13-18 subcrenatum perdisjunctum 96:13-17

tenue $97: 1-11$

tcnue applanatum 97:26-28; 98:1-13; $99: 1-3 ; 101: 16$

tenue bourcardi $97: 12-17$

tenue californiense $32: 1-7 ; 44: 24$;

$45: 4-6 ; 50: 1 ; 59: 3,4,6 ; 63: 3$;

$98: 16-24,26 ; 99: 11-15$

tenue chapalense $102: 1,5-10$

teune exaggratum 99:18-25

temue sinuosum $97: 14,15,25 ; 99: 4-10$

tenue strebelianum 99:16-19, 25-30

traskii $32: 11-17 ; 44: 20 ; 49: 12 ; 52: 13$; $60: 4-6 ; 95: 17-25$

trivolvis $24: 1-15 ; 44: 2,9 ; 48: 1,2,18$; $49: 2 ; 55: 1,2,4 ; 70: 6 ; 80: 13-15$; $85: 17-30 ; 86: 1-4,20,21 ; 88: 1-3$; $89: 28,29$

trivolvis fallax $29: 17,18 ; 63: 1 ; 70: 8$; $87: 1-10$

trivolvis holstonense $87: 17-24$

trivolvis intertextum 86:9-15, 23;

$89: 5-8$

trivolvis lentum 29:7-13; $44: 11 ; 52: 4$, $5 ; 55: 3,6,7 ; 63: 3 ; 86: 5-8,22$; $89: 1-4,12$

trivolvis macrostomum 29:14-16;

$44: 10 ; 56: 2 ; 70: 7 ; 88: 4-7$

trivolvis marshalli $87: 11-16$

trivolvis pseudotrivolvis 29:1-6

trivolvis reticulatum $89: 9,10$

truncatum $26: 6-13 ; 44: 13 ; 49: 3 ; 57: 1$, $2 ; 89: 11 ; 90: 1-12$

tumens $100: 31-37$ 
IIelisoma (continued)

whiteavesi $31: 19 ; 58: 1 ; 106: 18-21$; $107: 15$

winslowi $56: 1 ; 91: 1-4$

wyldii $100: 21-30$

wyldii salvini $100: 18-20$

IIippeutis complanatus $2: 7-15 ; 46: 17$, $18: 48: 12 ; 79: 4-6$

fontanus $79: 4-6$

Indoplanorbis exustus 21:1-10; 22:5-9; $45: 19 ; 50: 10 ; 66: 1 ; 73: 1-3 ; 74: 6-9$; $79: 33-35$

Intha capitis $8: 1-8,11 ; 47: 26,27$; $50: 23 ; 69: 9$

Isidora globosa $71: 1-6$

Menetus alabamensi.s $121: 34,37-39$; $123: 12,13$

alabamensis avus 121:40, 41; 123:1; $140: 25$

brogniartianus 121:42-44

centervillensis $121: 1-8$

coloradoensis 122:23-25

cooperi $39: 7,8 ; 120: 11-18,22,27,28$; $122: 1,2,7$

cooperi callioglyptus $38: 3,11-15 ; 39: 1$ $6,9,10 ; 46: 7,8 ; 50: 7 ; 67: 3 ; 120$ : $19-21 ; 122: 8$

cooperi crassitabris $121: 19-21 ; 122: 13$; $123: 26$

cooperi multilineatus $120: 23-26,29-31$; $122: 9-12$

cooperi planospirus $122: 3-6$

dalli $140: 22-24$

dilatatus $40: 3-5,7,9,12 ; 46: 5,6 ; 50: 9$; $67: 4 ; 70: 9,10 ; 79: 13-15 ; 121: 22$, 25,26

dilatatus buchanensis $121: 23,24,27-31$, 33

dilatatus floridanus $123: 20-22$

dilatatus pennsyleanicus $121: 32,35,36$

kansasensis 140:26-29

labiatus $121: 9-11$

opercularis $38: 1,2,4-10 ; 79: 22-24$; $120: 1-10$

portlandensis $121: 12-18$

sampsomi $40: 1,2,6,8,10,11 ; 50: 6$; $67: 5 ; 123: 11,14-16,31-33$

uliginosus $123: 23-25,27,28$

Odontogyrorbis krambergeri $76: 1,2$

Parnpholyx effusa $78: 20-22 ; 116: 1-6$ effusa costata $115: 24-26 ; 116: 12-14$ effusa dalli $115: 27-30$

cfusa diagonalis $36: 10 ; 50: 5 ; 116: 15-17$

effusa klamathensis $36: 1-9,11,12$; $46: 1,2 ; 50: 4 ; 65: 3 ; 115: 14-23$ effusa neritoides $116: 7-11$ klamathensis sinit.sini $123: 2-10$ mailliardi $116: 27-30 ; 117: 27-30$ nevade usis $117: 7-26$

pusilla $117: 1-6$

solida 116:18-24

solida optima 120:32

Paraplanorbis condoni $81: 5$

Perinilla cordilleriama $79: 31,32$

Pingiella peipinensis $4: 1-9 ; 5: 1,5$; $78: 8-10$

Planorbarius corneus 20:1-13; 45:18; $50: 14 ; 66: 2 ; 80: 22-24$

Planorbifex vanvlecki $81: 6$

Planorbis adowensis $71: 10-12$

boetzhesi $141: 35$

pfeifferi $71: 7-9$

krambergeri $76: 1$

planorbis $1: 1-9 ; 46: 9,10 ; 48: 6,7$; $50: 21 ; 67: 7 ; 77: 26-28$

turgidus $141: 26-28$

Planorbula armigera $37: 1-12 ; 45: 3,13$; $50: 2 ; 65: 1 ; 76: 8 ; 79: 25-27 ; 118: 1$, $9,13-15,16-19,26,31$

armigera indinensis $118: 4 ; 119: 1-3$

armigera palustris 118:2

christyi 119:13-15

crassilabris $118: 3,20-25,32$

jenksii $50: 3 ; 65: 2 ; 70: 11 ; 118: 5,10$, $27-30 ; 119: 4-6$

smithi 118:6,11, 12; 119:10-12

wheatleyi $76: 9 ; 79: 28-30 ; 118: 7,33$; $119 \cdot 7-9$

Platytaphius heteropleurus 79:10-12

Poecilospira trochiformis $81: 1$

Polypylis calathus 69:8

hemisphaerula $5: 2-4,6,7 ; 8: 9,10$; $47: 24,25 ; 76: 5 ; 79: 7-9$

largilliarti $79: 7-9$

Pompholopsis whitei $76: 11$

Promenetus exacuous $41: 1-10 ; 42: 1,3$. 7,$12 ; 46: 3,4 ; 48: 4,5 ; 50: 8 ; 67: 1$; $122: 14-19,26-28$

exrcuous megas $42: 2,4,5,8-11,13$; $79: 19-21 ; 122: 20-22$

hudsonicus 123:17-19

imus $123: 29,30$

rubellus $123: 37-39$

umbilicatellus $42: 6 ; 43: 1-12 ; 50: 15$; $67: 2 ; 123: 34-36$

Segmentina nitida $2: 1-6 ; 3: 1-4 ; 47: 22$, $23 ; 48: 16 ; 50: 24 ; 69: 7 ; 76: 4 ; 79: 1-3$

Taphius andecolus $77: 13-15 ; 131: 32-35$; $137: 1-13$

andecolus montrmus $131: 27-31$

montanus $137: 25-27$

promes $137: 14-24$

subpronus $131: 36-40$

Tropicorbis albicans $134: 4-6,15-19,29$ bourcardianus $132: 31,32 ; 135: 7-19$ canonicus $135: 20-27$ centimetralis $130: 30-37 ; 135: 5-8$ chilensis $131: 12-14 ; 135: 9-11$ 
Tropicorbis (continued)

decipiens $131: 6-11$

declivis $133: 25-27$

dentiens $141: 5-7$

dentiferus $134: 8,9$

fieldi $132: 24-30$

gracilentus $130: 1-12 ; 135: 32-35$

qundlachi $132: 33-35$

hovanensis $12: 1-11 ; 46: 13 ; 68: 8 ; 70: 4$; $130: 18-28$

heloicus 133:10-13

isthmicus 131:1-7

juneirensis $133: 18-21 ; 134: 24$

kuhnianus $132: 6-9$

maya 130:13-17

melleus $78: 1,2$

meridaensis $132: 22,23 ; 135: 14-16$

nigrilabris $78: 3,4 ; 133: 14-17 ; 134: 25$

obstructus $13: 1-3 ; 50: 11 ; 68: 7 ; 76: 7$; $128: 26-33 ; 129: 4,8,9 ; 133: 28-35$; $134: 10,11,22$ obstructus anodontus $133: 36-40$ obstructus dombilli $129: 17-25 ; 131: 15-$ $26 ; 135: 21,23$

obstructus dunkeri 129:26-36

orbiculus $77: 7-9 ; 129: 1-3,5-7,10-16$

pallidus $77: 10-12 ; 132: 1-5$

paparyensis $134: 1-3,20,26$

pedrinus $141: 1,33,34$

peregrinus $130: 38-41 ; 135: 1-4$

petenensis $133: 1-3 ; 141: 2-4$

philippianus $130: 29-34 ; 135: 12,13$

riisei $13: 4-10 ; 46: 11,12 ; 50: 12 ; 68: 6$; $132: 15-21$

schrammi $133: 22-24 ; 134: 7,27$

shimeki 134:12-14, 28

stramineus 132:10-14

tepicensis $133: 4-9$

trigyrus $135: 28-31$

Vortieifex binneyi $76: 13$

tryoni $76: 12$ 









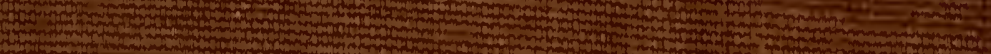

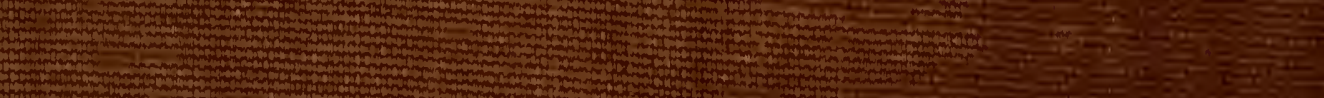

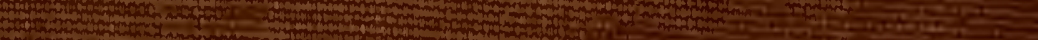
whoth

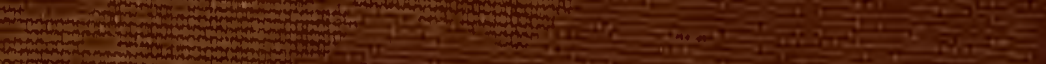

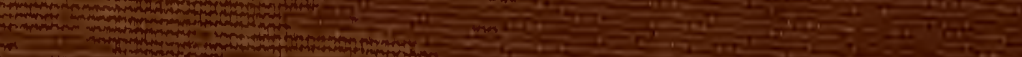

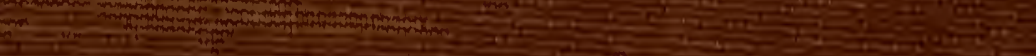

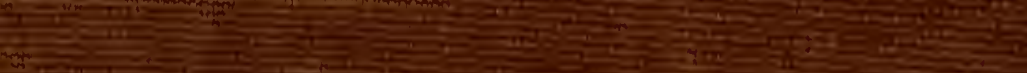
M.

in

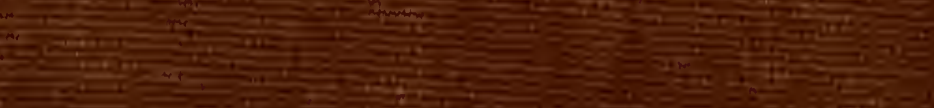

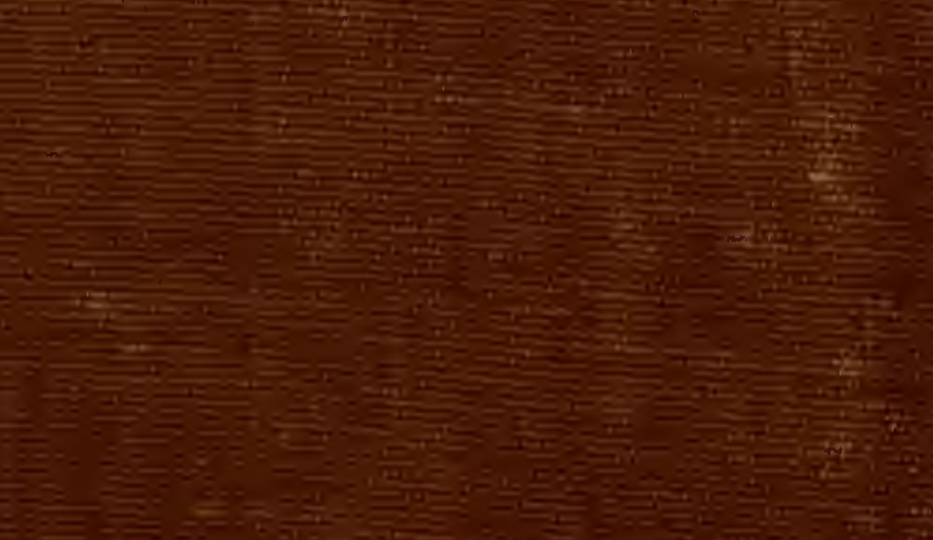

